\title{
De kapitaalverschaffer zonder stemrecht in de BV
}

Citation for published version (APA):

Wolf, R. A. (2013). De kapitaalverschaffer zonder stemrecht in de BV. [Doctoral Thesis, Maastricht University]. Kluwer. https://doi.org/10.26481/dis.20130531rw

Document status and date:

Published: 01/01/2013

DOI:

10.26481/dis.20130531rw

Document Version:

Publisher's PDF, also known as Version of record

\section{Please check the document version of this publication:}

- A submitted manuscript is the version of the article upon submission and before peer-review. There can be important differences between the submitted version and the official published version of record.

People interested in the research are advised to contact the author for the final version of the publication, or visit the DOI to the publisher's website.

- The final author version and the galley proof are versions of the publication after peer review.

- The final published version features the final layout of the paper including the volume, issue and page numbers.

Link to publication

\footnotetext{
General rights rights.

- You may freely distribute the URL identifying the publication in the public portal. please follow below link for the End User Agreement:

www.umlib.nl/taverne-license

Take down policy

If you believe that this document breaches copyright please contact us at:

repository@maastrichtuniversity.nl

providing details and we will investigate your claim.
}

Copyright and moral rights for the publications made accessible in the public portal are retained by the authors and/or other copyright owners and it is a condition of accessing publications that users recognise and abide by the legal requirements associated with these

- Users may download and print one copy of any publication from the public portal for the purpose of private study or research.

- You may not further distribute the material or use it for any profit-making activity or commercial gain

If the publication is distributed under the terms of Article $25 \mathrm{fa}$ of the Dutch Copyright Act, indicated by the "Taverne" license above, 
DE KAPITAALVERSCHAFFER ZONDER STEMRECHT IN DE BV 
SERIE VANWEGE HET

VAN DER HEIJDEN INSTITUUT TE NIJMEGEN

ONDER REDACTIE VAN

PROF. MR. G. VAN SOLINGE

PROF. MR. M. VAN OLFFEN

PROF. MR. M.P. NIEUWE WEME

PROF. MR. C.D.J. BULTEN

DEEL 116 


\title{
DE KAPITAALVERSCHAFFER ZONDER STEMRECHT IN DE BV
}

\author{
The provider of capital without voting rights of the Dutch private \\ company with limited liability
}

\section{PROEFSCHRIFT}

ter verkrijging van de graad van doctor aan de Universiteit Maastricht, op gezag van de Rector Magnificus, Prof. dr. L.L.G. Soete volgens het besluit van het College van Decanen, in het openbaar te verdedigen op vrijdag 31 mei 2013 om 14.00 uur

door

Rogier Anton Wolf 


\title{
Promotor:
}

prof. mr. C.A. Schwarz

\section{Copromotor:}

\author{
mr. dr. J.J.A. Hamers
}

Beoordelingscommissie:

prof. mr. B.T.M. Steins Bisschop, voorzitter

prof. mr. G.R. de Groot

mr. dr. M. Olaerts

prof. mr. G. van Solinge (Radboud Universiteit Nijmegen)

prof. mr. I.S. Wuisman (Universiteit Leiden)

Omslagontwerp: Bert Arts bNO

ISBN 9789013116274

ISBN 9789013116281 (e-book)

NUR $827-715$

(C) 2010-2013, R.A. Wolf

Alle rechten voorbehouden. Niets uit deze uitgave mag worden verveelvoudigd, opgeslagen in een geautomatiseerd gegevensbestand, of openbaar gemaakt, in enige vorm of op enige wijze, hetzij elektronisch, mechanisch, door fotokopieën, opnamen, of enige andere manier, zonder voorafgaande schriftelijke toestemming van de uitgever.

Voor zover het maken van kopieën uit deze uitgave is toegestaan op grond van artikel $16 \mathrm{~h} \mathrm{t} / \mathrm{m} 16 \mathrm{~m}$ Auteurswet jo. het Besluit van 27 november 2002, Stb. 575, dient men de daarvoor verschuldigde wettelijke vergoeding te voldoen aan de Stichting Reprorecht (Postbus 3051, 2130 KB Hoofddorp).

No part of this book may be reproduced in any form, by print, photoprint, microfilm or any other means without written permission from the publisher.

Hoewel aan de totstandkoming van deze uitgave de uiterste zorg is besteed, aanvaarden de auteur(s), redacteur(en) en uitgever(s) geen aansprakelijkheid voor eventuele fouten en onvolkomenheden, noch voor gevolgen hiervan.

Op alle uitgaven van Kluwer zijn de algemene leveringsvoorwaarden van toepassing. Deze kunt u lezen op www.kluwer.nl. 


\section{WOORD VOORAF}

Op 31 mei 2013 is Rogier Wolf aan de Universiteit Maastricht gepromoveerd. De titel van zijn proefschrift luidt De kapitaalverschaffer zonder stemrecht in de $B V$. Promotor was prof. mr. C.A. Schwarz. Copromotor was mr. dr. J.J.A. Hamers.

Directe aanleiding voor dit proefschrift was de introductie van het stemrechtloze aandeel in het Nederlandse vennootschapsrecht als gevolg van de Wet vereenvoudiging en flexibilisering bv-recht. Rogier Wolf bespreekt de rechtspositie van de stemrechtloze aandeelhouder en betrekt daarbij de positie van houders van andere rechtsfiguren zonder stemrecht: de houder van een certificaat van aandeel met en zonder vergaderrecht, de houder van een participatiebewijs en de houder van een aandeel waarbij het stemrecht is overgedragen aan de vruchtgebruiker of pandhouder. Zodoende worden in dit onderzoek vijf kapitaalverschaffers zonder stemrecht in de BV met elkaar vergeleken. Het onderzoek wordt gesteund door een zeer uitgebreid en actueel literatuur- en jurisprudentieonderzoek. Daarbij is ook de parlementaire geschiedenis van de Wet vereenvoudiging en flexibilisering bv-recht en de Invoeringswet vereenvoudiging en flexibilisering bv-recht betrokken. De regeling van het stemrechtloze aandeel en het certificaat met en zonder vergaderrecht alsmede het daarbij behorende overgangsrecht zijn kritisch tegen het licht gehouden.

Centraal staat in dit proefschrift de verhouding van de kapitaalverschaffers zonder stemrecht tot de vennootschap, het bestuur van de vennootschap en de andere kapitaalverschaffers van de vennootschap met stemrecht in de algemene vergadering. De auteur onderzoekt door welke rechten, verplichtingen en normen die verhoudingen worden ingevuld en op welke wijze de kapitaalverschaffers zonder stemrecht voor hun belangen kunnen opkomen dan wel hun rechten kunnen afdwingen.

Het proefschrift bevat negen hoofdstukken. Na de inleiding wordt de voorgeschiedenis en de introductie van het stemrechtloze aandeel in het Nederlandse vennootschapsrecht besproken. Daarna worden de mogelijke kapitaalparticipaties zonder stemrecht in de BV geïnventariseerd en volgt een verhandeling over de daaraan verbonden rechten. De hoofdstukken 5, 6 en 7 gaan in op het eerdergenoemde, centrale thema. Hoofdstuk 5 stelt de interne verhoudingen van de BV aan de orde en daarmee het spanningsveld waarin de kapitaalverschaffer zonder stemrecht zich bevindt. Hoofdstuk 6 behandelt de rechten van de kapitaalverschaffer zonder stemrecht. In hoofdstuk 7 komt de open norm van de redelijkheid en billijkheid en de zorgplichten in relatie tot de kapitaalverschaffer zonder stemrecht aan de orde. 
$\mathrm{Na}$ dit drieluik komt in hoofdstuk 8 de afdwingbaarheid van de rechten van de kapitaalverschaffer zonder stemrecht aan bod.

Een van de conclusies van het onderzoek van Rogier Wolf is dat het stemrechtloze aandeel geen gemakkelijke rechtsfiguur is vanwege de vele regels ten behoeve van de bescherming van de stemrechtloze aandeelhouder. In voorkomend geval zal moeten worden teruggevallen op de open norm van de vennootschappelijke redelijkheid en billijkheid en de in acht te nemen zorgplicht jegens de kapitaalverschaffer zonder stemrecht. De invulling van die open norm en de inhoud van die zorgplicht is afhankelijk van de omstandigheden van het geval en de aard van de rechtsfiguur zonder stemrecht. Niet uit te sluiten is dat indien in de flex-BV van de kapitaalparticipaties zonder stemrecht gebruik gemaakt wordt, in de rechtspraak meer nadruk op de vennootschappelijke redelijkheid en billijkheid en zorgplicht jegens de kapitaalverschaffer zonder stemrecht komt te liggen, zo volgt uit dit proefschrift. De conclusies en samenvatting van het onderzoek bevatten ook 22 aanbevelingen tot wijziging of interpretatie van de wet.

In de bijlagen zijn overzichten van de voor- en nadelen van de diverse rechtsfiguren zonder stemrecht en aanbevelingen voor de praktijk opgenomen. Ook elders in het boek komt de koppeling tussen wetenschap en praktijk terug. Daarmee is deze goed leesbare, wetenschappelijke studie ook voor de rechtspraktijk zeer relevant. Met de inwerkingtreding op 1 oktober 2012 van de Wet vereenvoudiging en flexibilisering bv-recht is bovendien de actualiteit van dit boek een gegeven. Niet alleen de wetenschapper, maar ook de praktijkjurist zal in dit proefschrift een schat aan overzichtelijke informatie vinden. Wij zijn verheugd dat dit proefschrift als deel 116 in de Serie vanwege het Van der Heijden Instituut verschijnt.

G. van Solinge

M. van Olffen

M.P. Nieuwe Weme

C.D.J. Bulten 
"Het recht vraagt uit zijn aard om gezag. Als er niet is een gezag, dat geëerbiedigd wordt in de gemeenschapsorganisatie als dat van wetgever of rechter, maakt het de beschrijving van wat is, de wetenschap, tot gezag voor wat zijn moet. De aard der rechtswetenschap, tegelijk beschrijving en voorschrift van regels, maakt dat mogelijk."

Asser-Scholten (Algemeen deel) 1974, p. 96. 



\section{INHOUDSOPGAVE}

Woord vooraf $\quad$ V

Inhoudsopgave IX

$\begin{array}{ll}\text { I. Voorwoord } & \text { XIX }\end{array}$

II. Lijst van gebruikte afkortingen $\quad$ XXI

Hoofdstuk 1. Inleiding 1

1.1 Aanleiding tot onderzoek 1

1.2 Onderzoeksonderwerp en -vragen 3

1.3 Relevantie van onderzoek 4

1.4 Onderzoeksmethode 4

1.5 Plan van behandeling 5

1.6 Tot slot 6

Hoofdstuk 2. Voorgeschiedenis en introductie van het stemrechtloze aandeel

2.1 Inleiding 7

2.2 Het pleidooi voor het stemrechtloze aandeel 8

2.3 Het stemrechtloze aandeel in andere landen 17

2.4 Uitgangspunten bij de herziening van het BV-recht en de
totstandkoming van de wet

2.5 Het ambtelijk voorontwerp van het wetsvoorstel en de uiteindelijke $\begin{array}{ll}\text { keuze voor het stemrechtloze aandeel } & 23\end{array}$

$\begin{array}{lll}2.5 .1 & \text { Inleiding } & 23\end{array}$

2.5.2 Het ambtelijk voorontwerp en de aanbevelingen van
de Expertgroep

2.5.3 Reacties uit de rechtspraktijk op het ambtelijk voorontwerp $\begin{array}{ll}\text { van het wetsvoorstel } & 26\end{array}$

2.5.4 Reacties in de literatuur op het ambtelijk voorontwerp van $\begin{array}{ll}\text { het wetsvoorstel } & 27\end{array}$

2.5.5 Uiteindelijke keuze van de wetgever: wél een

$\begin{array}{ll}\text { 2.5.6 Samenvatting en commentaar } & 29\end{array}$ 
2.6 Het stemrechtloze aandeel op hoofdlijnen 29

2.7 Geen stemrechtloos aandeel in het NV-recht 36

2.8 Samenvatting en conclusie 36

Hoofdstuk 3. Kapitaal, aandelen en verwante rechtsfiguren 39

$\begin{array}{lll}3.1 & \text { Inleiding } & 39\end{array}$

$\begin{array}{lll}3.2 & \text { Het kapitaal van de BV } & 39\end{array}$

3.3 De dualistische structur van de BV 41

3.4 Eigen en vreemd vermogen 43

3.5 Het begrip 'effecten' 45

3.6 Het begrip 'aandeel' 46

3.7 Soorten aandelen en verwante stukken 48

$\begin{array}{lll}3.7 .1 & \text { Inleiding } & 48\end{array}$

3.7.2 Gewone aandelen 49

3.7.3 Aan gewone aandelen verbonden rechten 49

3.7.4 (Cumulatief) preferente aandelen 49

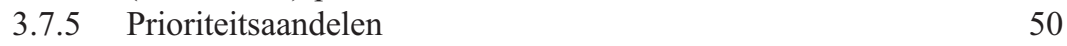

3.7.6 Oprichtersaandelen $\quad 50$

3.7.7 Bonusaandelen 51

3.7.8 Certificaten van aandelen $\quad 51$

3.7.9 Oprichters- en winstbewijzen $\quad 52$

3.7.10 Letteraandelen 53

3.7.11 Tracking stock 54

3.7.12 Loyaliteitsaandelen $\quad 54$

3.7.13 Participatiebewijzen 54

3.7.14 (Converteerbare) obligaties 56

$\begin{array}{lll}3.8 & \text { Samenvatting en conclusie } & 57\end{array}$

Hoofdstuk 4. Kapitaalparticipatie zonder stemrecht 59

4.1 Inleiding 59

4.2 Het stemrechtloze aandeel $\quad 59$

4.2.1 Inleiding $\quad 59$

4.2.2 Commentaar op de wettekst 61

4.2.3 Kwalificatie van het stemrechtloze aandeel 61

4.2.4 Mijn definitie van het stemrechtloze aandeel 63

4.2.5 Het stemrechtloze aandeel met beperkt recht op winst
en/of reserves

4.2.6 'Bepaalde soort of aanduiding' 67

4.2.7 De vergadering van stemrechtloze aandeelhouders 73 
4.2.8 Vastlegging van besluiten van de vergadering van houders van stemrechtloze aandeelhouders

4.2.9 Het stemrechtloze aandeel en het aandeel met een gedifferentieerd stemrecht

4.3 Het stemrechtloze aandeel bezien in het licht van enkele wettelijke bepalingen

4.3.1 Inleiding

4.3.2 De berekening van meerderheden en quora (art. 2:24d BW)

4.3.3 Het begrip 'dochtermaatschappij' (art. 2:24a BW)

Het begrip 'groepsmaatschappij' (art. 2:24b BW) 83

4.3.5 Het begrip 'deelneming' (art. 2:24c BW)

4.3.6 Het begrip 'afhankelijke maatschappij' (art. 2:63a, 2:152 en 2:262 BW)

4.3.7 Het verzwakte structuurregime van art. 2:265a BW 86

4.3.8 De uitzondering op het toestemmingsvereiste van art. 1:88 lid 5 BW

4.3.9 De Wet ter voorkoming van witwassen en financieren van terrorisme (Wwft) en de Wet toezicht trustkantoren (Wtt) 100

4.3.10 De faillissementspauliana (art. 42 Fw) 106

4.3.11 Het begrip 'in overwegende mate bij machte' in Boek 1 BW 107

4.3.12 Publiekrechtelijke wetgeving 111

4.3.13 Overige wijzigingen in de wet 112

$\begin{array}{ll}4.3 .14 \text { Overgangsrecht } & 113\end{array}$

$\begin{array}{lll}4.4 & \text { Certificaten van aandelen } & 113\end{array}$

$\begin{array}{lll}4.4 .1 \quad \text { Inleiding } & 113\end{array}$

$\begin{array}{ll}\text { 4.4.2 Wat zijn certificaten? } & 114\end{array}$

$\begin{array}{ll}\text { 4.4.3 Certificaten met of zonder vergaderrecht } & 117\end{array}$

4.4.4 Niet-royeerbare, beperkt royeerbare en royeerbare certificaten 121

4.4.5 Levering van een certificaat van aandeel (met vergaderrecht) 122

$\begin{array}{ll}4.4 .6 & 123 \\ & \text { Overgangsrecht }\end{array}$

$\begin{array}{lll}\text { 4.4.6.1 Inleiding } & 123\end{array}$

4.4.6.2 Overgangsrecht algemeen $\quad 124$

$\begin{array}{ll}\text { 4.4.6.3 Overgangsrecht specifiek } & 125\end{array}$

4.4.6.4 Conclusie 135

4.5 Het aandeel waarbij het stemrecht is overgedragen aan de
vruchtgebruiker

4.6 Het aandeel waarbij het stemrecht is overgedragen aan de pandhouder 139

$\begin{array}{lll}4.7 & \text { Het participatiebewijs } & 144\end{array}$

$\begin{array}{lll}4.8 & \text { Belang van de kwalificatie van de rechtsfiguren zonder stemrecht } & 146\end{array}$

$4.9 \quad$ Verdere afbakening 146

4.9.1 Inleiding en algemene opmerkingen 146

$\begin{array}{ll}\text { 4.9.2 Beslag op aandelen } & 148\end{array}$

$\begin{array}{ll}\text { 4.9.3 Opschorting van stemrecht } & 148\end{array}$ 
4.10 Terminologie: de kapitaalverschaffer zonder stemrecht 150

4.11 Het aandeelhoudersregister (art. 2:194 BW) 150

4.12 Vermelding in de jaarrekening en het jaarverslag (art. 2:392 lid 1 sub $f$ BW)

4.13 Samenvatting en conclusie 154

Hoofdstuk 5. Interne verhoudingen in de BV 159

$\begin{array}{lll}5.1 & \text { Inleiding } & 159\end{array}$

5.2 Principal-agent theory 159

$\begin{array}{ll}5.3 & \text { De beslotenheid van de BV } \\ & 162\end{array}$

$\begin{array}{lll}\text { 5.3.1 Inleiding } & 162\end{array}$

5.3.2 Aard van de samenwerking in de BV 162

5.3.3 Beslotenheid van de (flex-)BV 166

$\begin{array}{lll}\text { 5.3.4 Conclusie } & 168\end{array}$

5.4 Het vennootschappelijk belang 168

$\begin{array}{lll}\text { 5.4.1 Inleiding } & 168\end{array}$

$\begin{array}{ll}\text { 5.4.2 De holistische opvatting } & 169\end{array}$

5.4.3 De resultante-benadering 170

5.4.4 De gecombineerde opvatting 170

5.4.5 De leer van de leegte 171

5.4.6 Functie van het vennootschappelijk belang 171

5.4.7 Het vennootschappelijk belang in de flex-BV 171

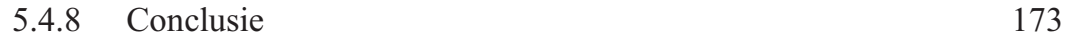

5.5 De dualistische structuur van de BV en de instructiebevoegdheid
van de algemene vergadering

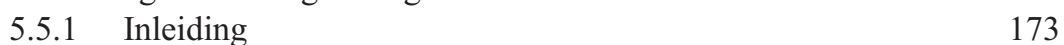

5.5.2 Bestuursautonomie 174

5.5.3 Instructiebevoegdheid van de algemene vergadering 175

5.5.4 Instructiebevoegdheid en het orgaanbegrip van
art. 2:189a BW

5.5.5 Conclusie 180

5.6 De grens van het dienen van het eigen belang door de aandeelhouder 181

5.7 Samenvatting en conclusie 184

Hoofdstuk 6. De rechten van de kapitaalverschaffer zonder stemrecht 187

$\begin{array}{lll}6.1 & \text { Inleiding } & 187\end{array}$

$\begin{array}{lll}6.2 & \text { De stemrechtloze aandeelhouder } & 187\end{array}$

$\begin{array}{lll}6.2 .1 & \text { Inleiding } & 187\end{array}$

6.2.2 Aard van de rechtsfiguur 188

6.2.3 Rechten van de stemrechtloze aandeelhouder 189

$\begin{array}{lll}\text { 6.2.3.1 Algemeen } & 189\end{array}$ 
6.2.3.2 Recht op winst en/of reserves

6.2.3.3 Benoeming, schorsing, ontslag en de vaststelling van de bezoldiging van (een) bestuurder(s) door de vergadering van stemrechtloze aandeelhouders

6.2.3.4 Benoeming, schorsing, ontslag en de vaststelling van de bezoldiging van (een) commissaris(sen) door de vergadering van stemrechtloze aandeelhouders

6.2.3.5 Het voorkeursrecht van de stemrechtloze aandeelhouder

6.2.3.6 Bescherming van de stemrechtloze aandeelhouder bij bepaalde besluiten 207

6.2.3.7 Enkele beschermingsregels nader bezien 209

6.2.3.8 Besluitvorming buiten vergadering 220

6.2.3.9 De statutaire verplichtingen van art. 2:192 BW 223

6.2.3.10 Aanbiedingsregeling 228

6.2.3.11 Uitkoopregeling 228

6.2.3.12 Conversie van het stemrechtloze aandeel 229

6.2.3.13 Omzetting van de BV in een andere rechtspersoon 230

6.2.3.14 'Omzetting' (inbreng) van de BV in een personenvennootschap en andersom 242

6.2.3.15 Fusie: de stemrechtloze aandeelhouder in de verdwijnende vennootschap

6.2.3.16 Splitsing en de positie van de stemrechtloze aandeelhouder

$\begin{array}{ll}\text { 6.2.3.17 Enquêtebevoegdheid } & 258\end{array}$

$\begin{array}{ll}\text { 6.2.3.18 Geschillenregeling } & 259\end{array}$

6.2.3.19 Redelijkheid en billijkheid en vernietiging van besluiten 259

6.2.4 Slotopmerking 260

6.3 De houder van certificaten met en zonder vergaderrecht 260

$\begin{array}{lll}6.3 .1 & \text { Inleiding } & 260\end{array}$

6.3.2 Aard van de rechtsfiguur 260

6.3.3 Rechten van de certificaathouder $\quad 262$

6.3.3.1 Algemeen 262

$\begin{array}{lll}\text { 6.3.3.2 Het stemrecht } & 267\end{array}$

$\begin{array}{lll}\text { 6.3.3.3 Het vergaderrecht } & 267\end{array}$

$\begin{array}{ll}\text { 6.3.3.4 Het ontnemen van het vergaderrecht aan } & \\ & \text { het certificaat }\end{array}$

6.3.3.5 Besluitvorming buiten vergadering 271

6.3.3.6 Het wettelijk pandrecht ex art. 3:259 BW 271 
6.3.3.7 Royeerbaarheid van certificaten 274

6.3.3.8 Omzetting van de BV in een andere rechtspersoon 275

6.3.3.9 'Omzetting' (inbreng) van de BV in een personenvennootschap en andersom

6.3.3.10 Fusie

6.3.3.11 Splitsing

6.3.3.12 Recht van enquête 280

6.3.3.13 Geschillenregeling 281

6.3.3.14 Redelijkheid en billijkheid en vernietiging van besluiten

6.4 De aandeelhouder wiens stemrecht is overgedragen

aan de vruchtgebruiker of de pandhouder 282

6.4.1 Inleiding 282

6.4.2 Aard van de rechtsfiguur 282

6.4.3 Rechten van de aandeelhouder wiens stemrecht is
overgedragen aan de vruchtgebruiker of de pandhouder

6.5 De houder van een participatiebewijs 282

6.5.1 Inleiding 282

6.5.2 Aard van de rechtsfiguur 283

6.5.3 Rechten van de houder van een participatiebewijs 284

6.5.3.1 Algemeen 284

6.5.3.2 Uitgifte van het participatiebewijs en de grondslag voor de (winst)uitkering 285

6.5.3.3 Het recht op winst en/of uitkering 287

6.5.3.4 Het recht op liquidatieoverschot 288

6.5.3.5 Het vergaderrecht 288

6.5.3.6 Het recht van instemming 289

6.5.3.7 Het voorkeursrecht 289

6.5.3.8 Inkoop en intrekking 290

6.5.3.9 Omzetting, fusie en splitsing 290

6.5.3.10 Recht van enquête en geschillenregeling 291

6.5.3.11 Redelijkheid en billijkheid en vernietiging
van besluiten

6.6 Aansprakelijkheid van de kapitaalverschaffers zonder stemrecht ex art. 2:216 lid 3 BW 292

6.7 Het afzien van de uitoefening van het vergaderrecht 298

$\begin{array}{lll}6.8 & \text { Samenvatting en conclusie } 302\end{array}$

Hoofdstuk 7. Redelijkheid en billijkheid en zorgplichten in de BV 313

$\begin{array}{lll}7.1 & \text { Inleiding } & 313\end{array}$

$\begin{array}{lll}7.2 & \text { Principal-agent theory } & 314\end{array}$ 
$\begin{array}{lll}\text { 7.3 De vennootschappelijke redelijkheid en billijkheid } & 314\end{array}$

7.4 De kring van betrokkenen in de zin van art. 2:8 BW 321

$\begin{array}{lll}\text { 7.4.1 Algemeen } & 321\end{array}$

7.4.2 Welke kapitaalverschaffers zonder stemrecht behoren tot de kring van betrokkenen? 322

7.5 Thema's in de vennootschappelijke redelijkheid en billijkheid 327

$\begin{array}{lll}7.5 .1 & \text { Inleiding } & 327\end{array}$

$\begin{array}{lll}\text { 7.5.2 Het gelijkheidsbeginsel } & 329\end{array}$

7.5.3 Bescherming van minderheidsaandeelhouders 333

$\begin{array}{ll}\text { 7.5.4 Besluiten die de rechten op winst en/of reserves raken } & 340\end{array}$

$\begin{array}{lll}\text { 7.5.4.1 Inleiding } & 340\end{array}$

$\begin{array}{lll}\text { 7.5.4.2 Winstreservering } 340 & 340\end{array}$

7.5.4.3 Besluiten omtrent de bezoldiging van bestuurders en commissarissen $\quad 350$

7.5.4.4 Overige besluiten die de rechten op winst en/of de reserves aantasten $\quad 352$

7.5.5 Verhouding tussen aandeelhouders onderling 354

7.5.6 De zorgplicht van (het bestuur van) de vennootschap jegens de kapitaalverschaffer zonder stemrecht 358

7.5.7 Het recht op informatie van de kapitaalverschaffers zonder stemrecht $\quad 360$

7.5.8 De zorgplicht van de kapitaalverschaffer met (doorslaggevend) stemrecht jegens de kapitaalverschaffer zonder stemrecht

Hoofdstuk 8. Rechtsvorderingen van de kapitaalverschaffer zonder stemrecht

$\begin{array}{lll}8.1 & \text { Inleiding } & 377\end{array}$

$\begin{array}{lll}\text { 8.2 Agenderingsrecht } & 378\end{array}$

$\begin{array}{lll}\text { 8.3 Verzoek tot bijeenroepen algemene vergadering } & 380\end{array}$

$\begin{array}{ll}\text { 8.4 Afdwingen van het recht van inlichtingen } & 382\end{array}$

8.5 Vordering tot medewerking tot het nemen van een besluit 387

8.6 Vernietiging van besluiten ex art. 2:15 lid 1 onder b jo. 2:8 BW 389

$\begin{array}{lll}8.7 & \text { Gebod of verbod in kort geding } & 394\end{array}$

$\begin{array}{lll}8.8 & \text { Enquêterecht } & 395\end{array}$

8.9 Geschillenregeling 403

8.10 Herleven van stemrecht? 407

8.11 Restcategorie van middelen, niet zijnde rechtsvorderingen 411

$\begin{array}{ll}8.12 & \text { Samenvatting en conclusie } \\ & 412\end{array}$ 
$9.1 \quad$ Inleiding

9.2.1 Wat is de verhouding van de kapitaalverschaffer zonder stemrecht tot de vennootschap, haar bestuur en de kapitaalverschaffers van de vennootschap met stemrecht?

9.2.2 Door welke rechtsnormen wordt de verhouding van de kapitaalverschaffer zonder stemrecht tot de vennootschap, haar bestuur en de kapitaalverschaffers van de vennootschap met stemrecht ingevuld?

9.2.3 Hoe kan de kapitaalverschaffer zonder stemrecht op de interne verhoudingen in de $\mathrm{BV}$ invloed uitoefenen en zijn rechten waarborgen?

9.3 Aanbevelingen tot wijziging of interpretatie van de wet

III. Summary, conclusions and recommendations

9.1 Introduction 441

9.2 Conclusions 442

9.2.1 What is the relationship between the provider of capital without the right to vote and the company, its management board and the company's providers of capital with voting rights?

9.2.2 Which are the legal standards governing the relationship between the provider of capital without the right to vote and the company, its management board and the company's providers of capital with voting rights?

9.2.3 How can the provider of capital without the right to vote influence internal relationships within the $\mathrm{BV}$ and safeguard his rights?

9.3 Recommendations for amendment or interpretation of the law

IV. Bijlage 1: Aan gewone aandelen verbonden rechten 469

V. Bijlage 2: Wetteksten Boek 2 oud BW 473

VI. Bijlage 3: Voor- en nadelen van het stemrechtloze aandeel en aanbevelingen

VII. Bijlage 4: Voor- en nadelen van het certificaat van aandeel en aanbevelingen 
VIII. Bijlage 5: Voor- en nadelen van het participatiebewijs en aanbevelingen

IX. Lijst van geraadpleegde en aangehaalde literatuur

X. Lijst van geraadpleegde en aangehaalde parlementaire en overige stukken

XI. Rechtspraak

523

XII. Over de promovendus 



\section{VOORWOORD}

Na mijn afstuderen in 1997 heb ik altijd in mijn achterhoofd gehouden dat ik 'nog wel eens' wilde promoveren. De wetenschap heeft mij altijd getrokken. Door mijn werk als advocaat en het leven van alledag werd die gedachte naar de achtergrond gedreven. Het zou iets voor later zijn. Wanneer dat 'later' zou zijn, was niet duidelijk. En nu is het dan zover: mijn proefschrift is af! Het was geen sinecure, doch ook een 'weg' vol uitdagingen, zowel op wetenschappelijk als op persoonlijk vlak (en dat laatste vlak met name op het gebied van 'doorzetten', 'time management' en de combinatie gezin-werk-promotieonderzoek).

Dit proefschrift is ook een van de resultaten in het kader van de samenwerking tussen het Institute for Corporate Law, Governance and Innovation Policies (ICGI) van de Universiteit Maastricht en TeekensKarstens advocaten notarissen, aan welk kantoor ik thans als partner en advocaat ondernemingsrecht verbonden ben. Die samenwerking is de directe aanleiding geweest dat de naar de achtergrond gedreven wens plots heel concreet op de voorgrond kwam te staan.

Op deze plaats past een woord van dank. Hoewel het schrijven van een proefschrift een tamelijk eenzame bezigheid is en ik vele uren in mijn studeerkamer heb doorgebracht (en soms aan de keukentafel tijdens een vakantie als de kinderen sliepen), zou dit eindresultaat niet mogelijk zijn geweest zonder hulp van anderen. Ik heb met veel mensen over mijn onderzoek gesproken. Vaak gaf dat andere gezichtspunten, nieuwe ideeën of invalshoeken. Een aantal personen wil ik in het bijzonder bedanken.

In de eerste plaats dank ik mijn promotor Kid Schwarz en copromotor Jos Hamers voor hun deskundigheid, begeleiding en hun kritische, doch immer positieve en opbouwende feed back. Mijn gesprekken met hen waren, naast zeer gezellig, bijzonder inspirerend en gaven me altijd weer positieve energie om het volgende stapje te nemen en nog eens met een frisse, doch kritische blik naar eerdere concepten te kijken.

Ik dank bovendien de leden van de beoordelingscommissie, prof. mr. B.T.M. Steins Bisschop, prof. mr. G.R. de Groot, mr. dr. M. Olaerts, prof. mr. G. van Solinge en prof. mr. I.S. Wuisman, voor hun bereidheid het manuscript te beoordelen en hun deskundige en waardevolle commentaar.

Ik ben ook dank verschuldigd aan mijn meelezers, Anne Bekkering, Har Hendriks, Françoise Niessen en Samantha Renssen voor hun feed back en scherpe, taalkundige blik op concepten van het manuscript. 
Mijn dank gaat tevens uit naar (mijn kantoorgenoten bij) TeekensKarstens advocaten notarissen voor het mogelijk maken van en de ondersteuning tijdens mijn promotieonderzoek.

Verder dank ik mijn familie en vrienden voor hun ondersteuning en begrip. Ze hebben mij tijdens mijn onderzoek wat moeten missen.

Niet in het minst geldt dat voor mijn echtgenote Joke. Aan haar ben ik veel, heel veel dank verschuldigd voor de ruimte en ondersteuning die zij mij heeft gegeven. Vaak lagen alle taken in ons jonge gezin, naast haar werk, op haar goede en brede schouders. Zonder haar had ik dit 'project' niet kunnen afronden.

De aanvang van mijn promotieonderzoek viel min of meer samen met de geboorte van mijn zoon. Tijdens mijn onderzoek werd ook mijn dochter geboren. Zij gaven mij, naast Joke, (onbewust) de meeste support. Aan Joke, Jelle en Ilse draag ik mijn proefschrift dan ook op!

Rogier Wolf

Bleiswijk, 7 maart 2013 


\section{LIJST VAN GEBRUIKTE AFKORTINGEN}

\begin{tabular}{|c|c|}
\hline$A A$ & Ars Aequi \\
\hline aant. & aantekening(en) \\
\hline AK & administratiekantoor \\
\hline A-G & advocaat-generaal \\
\hline$A R O$ & Actuele Rechtspraak Ondernemingspraktijk \\
\hline art. & $\operatorname{artikel(en)}$ \\
\hline$B b$ & Bedrijfsjuridische berichten \\
\hline BV & besloten vennootschap \\
\hline BW & Burgerlijk Wetboek \\
\hline concl. & conclusie \\
\hline c.s. & cum suis \\
\hline diss. & dissertatie \\
\hline dr. & doctor \\
\hline e.a. & en anderen \\
\hline e.v. & en volgende \\
\hline$f t V$ & fiscaal tijdschrift Vermogen \\
\hline $\mathrm{FW}$ & Faillissementswet \\
\hline Hof Amsterdam (OK) & Ondernemingskamer bij het Gerechtshof te Amsterdam \\
\hline $\mathrm{HR}$ & Hoge Raad der Nederlanden \\
\hline HvJ EG & Hof van Justitie van de Europese Gemeenschappen \\
\hline$J B N$ & Juridische Berichten voor het Notariaat \\
\hline$J I N$ & Jurisprudentie in Nederland \\
\hline jo. & juncto / junctis \\
\hline JOR & Jurisprudentie Onderneming \& Recht \\
\hline Kamerstukken I & Kamerstukken (Eerste Kamer) \\
\hline Kamerstukken II & Kamerstukken (Tweede Kamer) \\
\hline KNB & Koninklijke Notariële Beroepsorganisatie \\
\hline$K G$ & Kort Geding \\
\hline$L J N$ & Landelijk Jurisprudentie Nummer \\
\hline 1.k. & linkerkolom \\
\hline Losbl. & losbladige uitgave \\
\hline MvA I & memorie van antwoord (Eerste Kamer) \\
\hline MvA & memorie van antwoord (Tweede Kamer) \\
\hline MvT & memorie van toelichting \\
\hline m.nt. & met noot van \\
\hline$M v V$ & Maandblad voor Vermogensrecht \\
\hline$N b B W$ & Nieuwsbrief $B W$ \\
\hline NBW & Nieuw Burgerlijk Wetboek \\
\hline
\end{tabular}




\begin{tabular}{|c|c|}
\hline NJ & Nederlandse Jurisprudentie \\
\hline NV II & nota naar aanleiding van het verslag (Tweede Kamer) \\
\hline nr. & nummer(s) \\
\hline NV & naamloze vennootschap \\
\hline De NV & De naamlooze vennootschap \\
\hline OK & Ondernemingskamer bij het Gerechtshof te Amsterdam \\
\hline$O \& F$ & Onderneming en Financiering \\
\hline ORP & Tijdschrift Overeenkomst in de rechtspraktijk \\
\hline p. & pagina('s) \\
\hline par. & paragraaf/paragrafen \\
\hline Parl. Gesch. & parlementaire geschiedenis \\
\hline $\mathrm{P}-\mathrm{G}$ & procureur-generaal \\
\hline Pres. & president \\
\hline$P b$. & Publicatieblad \\
\hline$P b E G$ & Publicatieblad van de Europese Gemeenschappen \\
\hline$P b E U$ & Publicatieblad van de Europese Unie \\
\hline $\mathrm{Rb}$. & Rechtbank \\
\hline r.k. & rechterkolom \\
\hline RMThemis & Rechtsgeleerd Magazijn Themis \\
\hline r.o. & rechtsoverweging \\
\hline red. & redactie \\
\hline Rv & Wetboek van Burgerlijke Rechtsvordering \\
\hline STAK & stichting administratiekantoor \\
\hline Stb. & Staatsblad \\
\hline$S \& V$ & Stichting \& Vereniging \\
\hline$S V \& V$ & Stichting Vereniging \& Vennootschap \\
\hline TOP & Tijdschrift voor de Ondernemingsrechtpraktijk \\
\hline$T R V$ & Tijdschrift Rechtspersoon en Vennootschap (België) \\
\hline$T v O B$ & $\begin{array}{l}\text { Tijdschrift voor Ondernemingsbestuur / Tijdschrift voor } \\
\text { vennootschaps-en rechtspersonenrecht }\end{array}$ \\
\hline$T V V S$ & $\begin{array}{l}\text { TVVS. Maandblad voor Ondernemingsrecht en } \\
\text { rechtspersonen }\end{array}$ \\
\hline vgl. & vergelijk \\
\hline VV I & voorlopig verslag (Eerste Kamer) \\
\hline Vzr. & voorzieningenrechter \\
\hline$V \& O$ & Vennootschap \& Onderneming \\
\hline WPNR & Weekblad voor Privaatrecht, Notariaat en Registratie \\
\hline$W F R$ & Weekblad Fiscaal Recht \\
\hline Wtt & Wet toezicht trustkantoren \\
\hline Wwft & $\begin{array}{l}\text { Wet ter voorkoming van witwassen en financieren van } \\
\text { terrorisme }\end{array}$ \\
\hline
\end{tabular}




\section{Hoofdstuk 1}

\section{INLEIDING}

\subsection{Aanleiding tot onderzoek}

Sinds het begin van de jaren zeventig van de vorige eeuw is in Nederland discussie gevoerd over het nut en de noodzaak van een stemrechtloos aandeel in het vennootschapsrecht. Met de inwerkingtreding op 1 oktober 2012 van het nieuwe BV-recht ${ }^{1}$ is het stemrechtloze aandeel er gekomen. Andere landen - zoals Duitsland, Frankrijk, Spanje, België, Zwitserland, Italië, de (voorheen geheten) Nederlandse Antillen, ${ }^{2}$ het Verenigd Koninkrijk, de Verenigde Staten en Japan - kennen al een stemrechtloos aandeel in diverse verschijningsvormen.

Het stemrechtloze aandeel ${ }^{3}$ biedt de houder van dat aandeel in het nieuwe BV-recht alle rechten die een 'gewone' aandeelhouder ook toekomen. Alleen het stemrecht ontbreekt aan zijn aandeel.

Het nieuwe BV-recht wordt algemeen gedragen en ook het stemrechtloze aandeel wordt positief ontvangen. Anders dan het oude BV-recht biedt het nieuwe BV-recht enorme flexibiliteit. Zo kan niet alleen het stemrecht op aandelen worden beperkt, maar nu ook geheel worden uitgesloten. Daartussen zijn er vele mogelijkheden tot variatie. In de rechtspraktijk zal het stemrechtloze aandeel zijn weg moeten vinden. Het nieuwe BV-recht en het stemrechtloze aandeel in het bijzonder bieden de

1 Bestaande uit:

- Wet van 18 juni 2012 tot wijziging van Boek 2 van het Burgerlijk Wetboek in verband met de aanpassing van de regeling voor besloten vennootschappen met beperkte aansprakelijkheid (Wet vereenvoudiging en flexibilisering bv-recht). Kamerstukken 31 058. Stb. 2012, 299;

- Wet van 18 juni 2012 tot aanpassing van de wetgeving aan en invoering van de Wet vereenvoudiging en flexibilisering bv-recht (Invoeringswet vereenvoudiging en flexibilisering bv-recht). Kamerstukken 32 426. Stb. 2012, 300;

- Besluit van 29 juni 2012 tot vaststelling van het tijdstip van inwerkingtreding van de Wet vereenvoudiging en flexibilisering bv-recht en de Invoeringswet vereenvoudiging en flexibilisering bv-recht. Stb. 2012, 301.

2 Sinds 3 september 1987. Zie Burgers 1987. Ter zijde: De Nederlandse Antillen waren van 15 december 1954 tot 10 oktober 2010 een land binnen het Koninkrijk der Nederlanden. In 2010 gingen Curaçao en Sint Maarten als onafhankelijke landen binnen het Koninkrijk verder, terwijl Saba, Sint Eustatius en Bonaire als speciale gemeenten werden opgenomen bij Nederland.

3 Art. 2:228 lid 5 BW. 
ondernemer meer mogelijkheden zijn BV naar wens en op maat in te richten. Zo kunnen in de flex-BV naast stemrechtloze aandelen ook winstrechtloze aandelen ${ }^{4}$ en aandelen met flexibel stemrecht ${ }^{5}$ worden uitgegeven. In dit onderzoek staat onder meer het stemrechtloze aandeel centraal.

In de discussie over de invoering van het stemrechtloze aandeel zijn ook de reeds bestaande instrumenten van certificaten van aandelen en statutaire winstrechten betrokken. Het zou daarom te beperkt zijn alleen te kijken naar stemrechtloze aandelen. Een 'aandeel' is een soort effect. 'Effect' is het verzamelbegrip voor - al dan niet via de effectenbeurs - verhandelbare waardepapieren, zoals bijvoorbeeld aandelen en obligaties. Het stemrechtloze aandeel is in zekere zin te vergelijken met andere effecten, zoals bijvoorbeeld certificaten van aandelen en participatiebewijzen. De certificaathouder komt immers wel het winstrecht toe, maar niet het stemrecht. Houders van participatiebewijzen hebben wel financiële rechten of aanspraken jegens de vennootschap, maar geen zeggenschap in de vennootschap. In dit onderzoek wordt ook op deze rechtsfiguren zonder stemrecht ingegaan. Onderzocht zal worden wat de gelijkenis is, maar ook wat de verschillen tussen die rechtsfiguren zijn.

Effecten in al hun soorten zijn een juridische vertaling van een economische werkelijkheid of structuur. In het algemeen worden aandelen aangemerkt als een vorm van eigen vermogen. Immers, bij oprichting van een vennootschap wordt

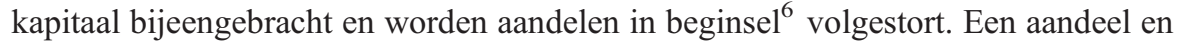
zijn aandeelhouder staan in de regel dicht bij de BV. Door het scheiden van winsten zeggenschapsrechten komt die aandeelhouder al wat minder dicht bij de vennootschap te staan. Ingeval van een stemrechtloos aandeel kan de houder van dat aandeel geen zeggenschap uitoefenen. De certificaathouder staat weer wat verder van de vennootschap. Daargelaten het onder het oude recht bestaande verschil tussen een certificaat dat met of zonder medewerking van de vennootschap uitgegeven is en thans het verschil tussen een certificaat met en zonder vergaderrecht, ${ }^{7}$ staat de certificaathouder in een rechtstreekse verhouding tot het administratiekantoor en (daarmee) in een indirecte verhouding tot de vennootschap. Participatiebewijzen ${ }^{8}$ zijn geen aandelen. Houders van dergelijke bewijzen zijn in feite schuldeisers van de vennootschap. Dat raakt het vreemd vermogen van een vennootschap. Toch wordt het participatiebewijs als eigen vermogen gezien.

Het nieuwe BV-recht stelt flexibilisering voorop en het neemt belemmeringen weg. De vrijheid van inrichting van een BV en haar statuten is vergroot. Raakt dat de interne verhoudingen in de BV? Verandert het besloten karakter van de BV en haar

4 Art. 2:216 lid $7 \mathrm{BW}$

5 Art. 2:228 lid $4 \mathrm{BW}$.

6 Art. 2:191 lid 1, tweede volzin, BW bepaalt dat - in afwijking van de hoofdregel van volstorting bedongen kan worden dat het nominale bedrag of een deel daarvan eerst behoeft te worden gestort na verloop van een bepaalde tijd of nadat de vennootschap het zal hebben opgevraagd.

7 Art. 2:227 lid 2 BW.

8 Zie over participatiebewijzen bijvoorbeeld Galavazi \& Van Wilsum 1988, p. 131 e.v. 
dualistische structuur? Meer vrijheid heeft vaak ook een keerzijde; althans meer vrijheid schept ook meer verantwoordelijkheid. Waar normen niet concreet vastgelegd zijn, komt de vraag op wat redelijk en billijk is. Niet alleen in het vermogensrecht (art. 3:12 BW) en in het verbintenissenrecht (art. 6:2 en 6:248 BW), maar ook in het vennootschapsrecht (art. 2:8 BW). Diverse schrijvers verwachten een toename van het aantal rechtszaken waarin een beroep op de vennootschappelijke redelijkheid en billijkheid van art. 2:8 BW wordt gedaan. ${ }^{9}$ Niet alleen vanwege de flexibilisering van het BV-recht in algemene zin, maar ook vanwege procedures ingesteld door de stemrechtloze aandeelhouder. Op welke wijze wordt de vennootschappelijke redelijkheid en billijkheid ten aanzien van deze aandeelhouder ingevuld? Is die invulling anders voor met het stemrechtloze aandeel vergelijkbare rechtsfiguren? In hoeverre veranderen de interne verhoudingen in de $\mathrm{BV}$ indien gebruik gemaakt wordt van het stemrechtloze aandeel? Al deze vragen zijn reden voor dit onderzoek.

\subsection{Onderzoeksonderwerp en -vragen}

Dit onderzoek richt zich op de kapitaalverschaffer zonder stemrecht in de BV. Dat zijn bijvoorbeeld de eerder genoemde stemrechtloze aandeelhouder en de certificaathouder met of zonder vergaderrecht. Het perspectief van het onderzoek is vanuit de rechthebbende, de kapitaalverschaffer als rechtssubject.

De hoofdvragen van dit onderzoek zijn:

1. Wat is de verhouding van de kapitaalverschaffer zonder stemrecht tot:

a. de vennootschap;

b. het bestuur van de vennootschap;

c. andere kapitaalverschaffers van de vennootschap met stemrecht in de algemene vergadering?

2. Door welke rechten, verplichtingen en normen worden die verhoudingen ingevuld?

3. Hoe kan de kapitaalverschaffer zonder stemrecht invloed op die verhoudingen uitoefenen en zijn rechten waarborgen?

De eerste twee vragen raken ook de in de rechtseconomie ontwikkelde principalagent theory. ${ }^{10}$ Deze theorie heeft onder meer haar neerslag gevonden in de vennootschappelijke redelijkheid en billijkheid. Bij de eerste twee vragen is een deelvraag welke factoren in die verhouding en bij die rechtsnormen een rol spelen. In dit onderzoek zullen die factoren worden benoemd.

9 Timmerman 2004, p. 30; Van der Sangen 2008, p. 3; Stokkermans 2008 (2), p. 118 en Roest 2012, p. 106.

10 Zie over de principal-agent theory: Kraakman e.a. 2009, p. 35 e.v. en De Kluiver 1994, p. 175 en de aldaar vermelde literatuur. 
De derde vraag ligt in het verlengde van het thema 'meer vrijheid, meer verantwoordelijkheid'. Daarbij speelt ook de eigen verantwoordelijkheid van de kapitaalverschaffer zonder stemrecht een rol. Dat vergt proactiviteit van die kapitaalverschaffer. Als mondige persoon (natuurlijk of rechtspersoon) zal hij dat in veel gevallen ook willen. Hij zal zelf waar mogelijk invloed willen uitoefenen en voor zijn belang willen opkomen. Welke middelen staan hem hiertoe ten dienste?

\subsection{Relevantie van onderzoek}

De relevantie van het onderzoek is gelegen in de introductie op 1 oktober 2012 van het stemrechtloze aandeel in het BV-recht. Dit nieuwe fenomeen roept, zoals geschetst, vragen op. Het antwoord op die vragen is, naar ik meen, niet alleen van wetenschappelijke waarde, maar ook relevant voor de rechtspraktijk. Daarbij speelt bijvoorbeeld de vraag wanneer en waarom voor welke rechtsfiguur zonder stemrecht (onder meer het stemrechtloze aandeel, het certificaat van aandeel met vergaderrecht of het participatiebewijs in de zin van een statutair winstrecht) wordt gekozen. Ook op die vraag zal ik een antwoord formuleren.

\subsection{Onderzoeksmethode}

Voor dit onderzoek is als onderzoeksmethode voor een literatuur- en rechtspraakonderzoek gekozen. Ik raadpleeg de literatuur en rechtspraak over de BV, de kapitaalverschaffers zonder stemrecht en de vennootschappelijke redelijkheid en billijkheid. Daarbij betrek ik vele deelthema's, zoals kapitaal, aandelen, aan aandelen verbonden rechten, beslotenheid van de BV, aard van de samenwerking in de BV, vennootschappelijk belang, principal-agent theory, dualistische structuur van de BV, instructiemacht, rechten van de kapitaalverschaffers zonder stemrecht, gelijkheidsbeginsel, bescherming van minderheidsaandeelhouders, besluiten die de rechten op winst en/of de reserves raken, zorgplichten in de BV, recht op informatie van de kapitaalverschaffers zonder stemrecht en rechtsvorderingen van de kapitaalverschaffers zonder stemrecht. Uiteraard worden bij dit onderzoek alle parlementaire stukken met betrekking tot de Wet vereenvoudiging en flexibilisering bv-recht ${ }^{11}$ en de Invoeringswet vereenvoudiging en flexibilisering bv-recht ${ }^{12}$ geraadpleegd, alsmede de vele literatuur en rapporten die over en de reacties die op de wetsvoorstellen zijn verschenen.

11 Wet van 18 juni 2012 tot wijziging van Boek 2 van het Burgerlijk Wetboek in verband met de aanpassing van de regeling voor besloten vennootschappen met beperkte aansprakelijkheid (Wet vereenvoudiging en flexibilisering bv-recht). Kamerstukken 31 058. Stb. 2012, 299.

12 Wet van 18 juni 2012 tot aanpassing van de wetgeving aan en invoering van de Wet vereenvoudiging en flexibilisering bv-recht (Invoeringswet vereenvoudiging en flexibilisering bv-recht). Kamerstukken 32 426. Stb. 2012, 300. 


\subsection{Plan van behandeling}

De opzet van mijn onderzoek is als volgt. In hoofdstuk 2 schets ik de voorgeschiedenis, de discussie en opvattingen in de literatuur over het stemrechtloze aandeel en de uiteindelijke introductie daarvan in het (nieuwe) BV-recht. In hoofdstuk 3 ga ik in op het begrip 'kapitaal' en bespreek ik de meest gangbare aandelen en aanverwante rechtsfiguren in de BV. Gevolg van deze analyse is dat rechtsfiguren zonder stemrecht in het (nieuwe) BV-recht worden geïdentificeerd. In hoofdstuk 4 bespreek ik de aard van de rechtsfiguren zonder stemrecht, baken ik die rechtsfiguren verder af en definieer ik het begrip 'de kapitaalverschaffer zonder stemrecht in de BV'. Vervolgens stel ik in hoofdstuk 5 de interne verhoudingen in de BV aan de orde. Ik ga in op de principal-agent theory, de aard van de samenwerking in de BV en de beslotenheid van die rechtsvorm. Ook sta ik stil bij het vennootschappelijk belang en de instructiebevoegdheid. De interne verhoudingen en de daarin door mij te onderscheiden thema's geven het kader, of beter gezegd, het spanningsveld weer, waarin de kapitaalverschaffer zonder stemrecht zich bevindt. Daarna bespreek ik in hoofdstuk 6 de rechten van de kapitaalverschaffer zonder stemrecht. Dat zijn de - hard law - rechten die aan de kapitaalverschaffer zonder stemrecht zijn toegekend om voor zijn belangen in dat spanningsveld op te komen. In hoofdstuk 7 komen - als soft law - de redelijkheid en billijkheid en zorgplichten in de BV vanuit de invalshoek van de kapitaalverschaffer zonder stemrecht aan de orde. Ik stel in dat hoofdstuk onder meer de vraag welke kapitaalverschaffers zonder stemrecht tot de kring van betrokkenen in de zin van art. 2:8 BW behoren. Daarnaast komen bijvoorbeeld thema's als het gelijkheidbeginsel, bescherming van minderheidsaandeelhouders, besluiten die de rechten op winst en/of reserves raken en het recht op informatie van de kapitaalverschaffer zonder stemrecht aan de orde. In hoofdstuk 8 staan de rechtsvorderingen van de kapitaalverschaffer zonder stemrecht centraal. Welke middelen heeft de kapitaalverschaffer zonder stemrecht om zijn in het drieluik van hoofdstuk 5, 6 en 7 geschetste recht af te dwingen?

Het sluitstuk van dit onderzoek vormt hoofdstuk 9. Daarin geef ik een samenvatting en formuleer ik mijn conclusie. Ik geef antwoord op de hoofdvragen van dit onderzoek. Daarnaast doe ik een aantal aanbevelingen, zowel voor de kapitaalverschaffer zonder stemrecht zelf als voor wijziging van de bestaande wetgeving. Ook geef ik antwoord op de eerder gestelde vraag wanneer en waarom voor welke rechtsfiguur zonder stemrecht gekozen (kan) word(t)(en). In dat laatste hoofdstuk komen wetenschap en praktijk (weer) bij elkaar.

Gelet op het (relatief) nieuwe fenomeen van het stemrechtloze aandeel zal in de genoemde hoofdstukken uitgebreider bij dat aandeel dan bij de andere rechtsfiguren zonder stemrecht worden stilgestaan.

In hoofdstuk 4, 5 en 6 staat de eerste hoofdvraag centraal. Wat is de verhouding van de kapitaalverschaffer zonder stemrecht tot de vennootschap, haar bestuur en de andere kapitaalverschaffers van de vennootschap met stemrecht? In hoofdstuk 7 
staat de tweede hoofdvraag centraal. Door welke rechtsnormen worden die verhoudingen ingevuld? Meer in het bijzonder: hoe wordt de vennootschappelijke redelijkheid en billijkheid ten aanzien van de kapitaalverschaffer zonder stemrecht ingevuld? Hoofdstuk 8 beantwoordt de derde hoofdvraag: hoe kan de kapitaalverschaffer zonder stemrecht invloed op die verhoudingen uitoefenen en zijn rechten waarborgen?

\subsection{Tot slot}

Dit onderzoek is een nationaalrechtelijk onderzoek. Daarom komen rechtsvergelijking of vragen van internationaal privaatrecht niet aan de orde. Alleen het BV-recht kent het stemrechtloze aandeel. Daarom beperk ik dit onderzoek tot de BV, meer in het bijzonder tot de BV waarin sprake is van een zekere mate van scheiding van zeggenschap en kapitaal en waarin sprake is van kapitaalverschaffers met en zonder stemrecht. Wel sta ik in hoofdstuk 2 kort stil bij het stemrechtloze aandeel dat in de ons omringende landen reeds (lang) bekend is.

Tenzij anders vermeld, worden de artikelen uit Boek 2 van het Burgerlijk Wetboek, zoals in werking getreden op 1 oktober 2012, bedoeld. Bij verwijzing naar het oude BV-recht wordt de aanduiding (oud) gebruikt. Onder de wet en wetsvoorstel(len) worden verstaan de Wet vereenvoudiging en flexibilisering bv-recht en de Invoeringswet vereenvoudiging en flexibilisering bv-recht.

Ik heb het onderzoek afgesloten op 16 december 2012. In een enkel geval is nadien verschenen jurisprudentie of literatuur verwerkt. 


\section{Hoofdstuk 2}

\section{VOORGESCHIEDENIS EN INTRODUCTIE VAN HET STEMRECHTLOZE AANDEEL}

\section{$2.1 \quad$ Inleiding}

In dit hoofdstuk schets ik de voorgeschiedenis en de introductie van het stemrechtloze aandeel in het BV-recht. Ik begin met de discussie die sinds de jaren zeventig van de vorige eeuw in de literatuur is gevoerd als pleidooi voor de invoering van het stemrechtloze aandeel. Diverse schrijvers hebben voor een dergelijk aandeel in diverse vormen, al dan niet in het NV- en/of BV-recht, gepleit (paragraaf 2.2). Daarna ga ik kort in op het stemrechtloze aandeel zoals diverse landen dat kennen (paragraaf 2.3). Vervolgens schets ik als achtergrond de uitgangspunten van de herziening van het BV-recht (paragraaf 2.4). In de daaropvolgende paragraaf bespreek ik het ambtelijk voorontwerp van het wetsvoorstel en de uiteindelijke keuze van de wetgever tot invoering van het stemrechtloze aandeel (paragraaf 2.5). Dat aandeel bespreek ik vervolgens op hoofdlijnen (paragraaf 2.6). In die paragraaf schets ik de rechtsfiguur van het stemrechtloze aandeel en geef ik weer welke plaats het in het BV-recht heeft gekregen. Vervolgens ga ik kort in op de redenen waarom het stemrechtloze aandeel, ondanks het geschetste pleidooi daartoe, niet in het NVrecht is geïntroduceerd (paragraaf 2.7). Ik rond af met een samenvatting en conclusie (paragraaf 2.8).

Dit algemene, (vooral) beschrijvende hoofdstuk is relevant, omdat het inzicht geeft in de redenen waarom de wetgever het stemrechtloze aandeel in het BV-recht heeft geïntroduceerd en welke keuzen de wetgever daarbij, mede aan de hand van het pleidooi voor het stemrechtloze aandeel, heeft gemaakt. In zijn overwegingen heeft de wetgever ook andere kapitaalverschaffers zonder stemrecht, zoals houders van (onder het oude recht) bewilligde certificaten en statutaire winstrechten, betrokken. Het is in het kader van dit onderzoek van belang ook van die overwegingen kennis te nemen, zodat op de onderzoeksvragen antwoord kan worden gegeven. 


\subsection{Het pleidooi voor het stemrechtloze aandeel}

$\mathrm{Al}$ ruim veertig jaar hebben diverse schrijvers gepleit voor invoering van het stemrechtloze aandeel in het Nederlandse vennootschapsrecht. Gepleit is voor diverse soorten stemrechtloze aandelen, al dan niet in het NV- of BV-recht. In min of meer chronologische volgorde verliep het pleidooi voor het stemrechtloze aandeel als volgt.

Van der Grinten startte het pleidooi. ${ }^{1}$ Het pleidooi van Van der Grinten ziet op de NV. Hij stelt aan de orde dat het functioneren van de algemene vergadering van de beursgenoteerde $\mathrm{NV}$ met een sterk gespreid aandelenbezit een probleem is, omdat voor de aandeelhouder van die vennootschap het aandeel dient als belegging van vermogen. Die aandeelhouder zou slechts geïnteresseerd zijn in rendement (dividend) en groei (waardeontwikkeling van het aandeel zelf). Hij ziet de aandeelhouder meer als belegger dan als 'vennoot' volgens de meer traditionele gedachte van de lidmaatschapsverhouding tussen aandeelhouder en vennootschap. Diezelfde aandeelhouder bezoekt niet of nauwelijks de algemene vergadering. ${ }^{2}$ Als die aandeelhouder die vergadering wel bezoekt, is het volgens Van der Grinten ongewenst dat slechts een kleine minderheid van toevallig aanwezigen belangrijke besluiten zou kunnen nemen. De besturen van die NV's hebben daarom als oplossing voor deze problematiek de wettelijke macht en bevoegdheid van de algemene vergadering overgebracht naar bestuur en commissarissen. Van der Grinten noemt dat uitschakelingspolitiek. In zijn betoog stelt hij dat dit echter niet tot een principale oplossing leidt. Daarom pleit hij voor het (omwisselbare) aandeel zonder stemrecht. De aandelen zonder stemrecht zijn toonderaandelen. De aandelen met stemrecht zijn aandelen op naam, zodat iedereen aan de hand van een openbaar register weet wie stemgerechtigd in de vennootschap is. Deze stemrechtloze toonderaandelen zijn omwisselbaar in aandelen met stemrecht op naam, zodat de echt bij de vennootschap betrokkenen invloed kunnen uitoefenen. De zeggenschapsrechten kunnen in dit

1 Van der Grinten 1971 (1), p. 296-304.

2 Daarover is een aantal onderzoeken verschenen. Zie bijvoorbeeld het onderzoek verricht door de Stichting Maatschappij en Onderneming (SMO), Machtsverdeling in de Naamloze Vennootschap, Den Haag 1971. Bij 62 procent van de onderzochte beursgenoteerde ondernemingen bedroeg het opkomstpercentage 20 procent of minder. Zie ook N. Lemmers, 'Aandeelhoudersvergaderingen in Nederland 1998-2002', Ondernemingsrecht 2004-6, p. 217-220. Lemmers bespreekt het in oktober 2003 verschenen onderzoeksrapport 'Aandeelhoudersvergaderingen in Nederland 1998-2002' van A. de Jong, G.M.H. Mertens en P.G.J. Roosenboom (faculteit Bedrijfskunde, Erasmus Universiteit Rotterdam). Een van de conclusies van dat onderzoek is dat bij beursgenoteerde vennootschappen op de algemene vergadering van aandeelhouders gemiddeld twee derde van de aandeelhouders niet vertegenwoordigd is; zie A. de Jong, G.M.H. Mertens en P.G.J. Roosenboom, 'Hoe actief zijn aandeelhouders in Nederland? Een empirische analyse van opkomst en stemgedrag', Maandblad voor Accountancy en Bedrijfseconomie 2005, p. 97-107. Voor een meer recente beschouwing zie R. Abma, 'Ontwikkelingen in het aandeelhoudersvergaderingenseizoen 2008', TvOB 2008-5, p. 109-117. Zie verder Voogd 1989, p. 389; Schwarz 1990, p. 8 en noot 25 en C.A. Schwarz, Groene Serie Rechtspersonen, art. 2:119 BW, aant. 4, Deventer: Kluwer. 
model bij de actieve personen in de vennootschap liggen, die invloed in de algemene vergadering wensen uit te oefenen om hun belangen te waarborgen. Van der Grinten acht de omstandigheid dat de belegger/aandeelhouder zijn zeggenschapsrecht niet uitoefent op zich als argument niet voldoende voor de invoering van het aandeel zonder stemrecht. ${ }^{3}$ Later is Van der Grinten voorzichtiger in zijn pleidooi voor het stemrechtloze aandeel geworden. Het winstbewijs als middel om het eigen vermogen te verkrijgen, is volgens hem attractiever dan het stemrechtloze aandeel, omdat dat aandeel bij gebreke van stemrecht gedenatureerd zou worden. ${ }^{4}$

Het is niet helemaal fair de start van het pleidooi voor het stemrechtloze aandeel aan Van der Grinten toe te schrijven. Treurniet heeft de suggestie van het stemrechtloze aandeel reeds in 1959 gedaan, ${ }^{5}$ maar is daarop later teruggekomen. ${ }^{6}$ Stemrechtloze aandelen zijn naar zijn mening uit den boze, omdat goede vennootschappelijke verhoudingen meebrengen dat de verschaffer van risicodragend kapitaal direct of indirect een zekere zeggenschap in de vorm van stemrecht heeft.

Bloemsma plaatst het stemrechtloze aandeel in het kader van beschermingsconstructies. Met certificering wordt in feite een stemrechtloos aandeel gecreëerd. ${ }^{7}$

Slagter verwelkomt het idee van het stemrechtloze aandeel van Van der Grinten en stelt dat de stemrechtloze aandeelhouder ook de weg terug moet hebben, gelijk de houder van royeerbare certificaten. Het gevolg is een vast geplaatst kapitaal met een steeds wisselend bedrag van aandelen met en zonder stemrecht. ${ }^{8}$

Galavazi \& Van Wilsum hebben de mogelijkheid tot het invoeren van het stemrechtloze aandeel naar aanleiding van de introductie daarvan in het Antilliaanse vennootschapsrecht gesignaleerd. ${ }^{9}$

Wachter stelt dat tegen stemrechtloze aandelen geen wezenlijke bezwaren bestaan. $^{10}$

3 Van der Grinten 1971 (2), p. 107

4 Van der Grinten 1991, p. 125. Van der Grinten lijkt van zijn pleidooi voor het stemrechtloze aandeel zelfs terug te komen: "Stemrechtloze aandelen zijn niet logisch onmogelijk; er zijn rechtstelsels die zulke aandelen kennen. Met de Nederlandse traditie verdragen echter zulke aandelen zich slecht."

5 Treurniet 1959, p. 165 , voetnoot 11.

6 Treurniet 1968 , p. 204, rechterkolom.

7 Bloemsma 1973 , p. 226

8 Slagter 1977 , p. $127-128$.

9 Galavazi \& Van Wilsum 1988, p. 130. Het stemrechtloze aandeel naar Antilliaans recht heeft zijn grondslag in de Landsverordening van de 29ste december 2003 houdende vaststelling van de tekst van Boek 2 van het Burgerlijk Wetboek, $P b$. 2004, nr. 6, in werking getreden op 1 maart 2004. Art. 200 lid 2 van deze Landsverordening bepaalt onder meer dat bij de oprichting van de besloten vennootschap ten minste één aandeel met volledig stemrecht, dat deelt in de winst, dan wel één aandeel met volledig stemrecht en één aandeel dat deelt in de winst, bij een oprichter of een derde wordt geplaatst. Art. 200 lid 3 bepaalt: "Rechten die stemrecht noch aanspraak op winstuitkering omvatten, worden niet als aandeel aangemerkt." Op grond van art. 209 wordt in het aandeelhoudersregister bijgehouden of aan het aandeel stemrecht is verbonden. Zie voor de rechten van de stemrechtloze aandeelhouder art. 227 e.v. van de Landsverordening.

10 Wachter 1988, p. 136 
Noordraven pleit ook voor het stemrechtloze aandeel in de NV en ziet een rol voor dat aandeel in het kader van beschermingsconstructies weggelegd. Hij ziet het stemrechtloze aandeel als een beter alternatief dan constructies als certificering en de uitgifte van preferente beschermingsaandelen. Zodoende worden overvallen bemoeilijkt en ligt de zeggenschap over het beleid slechts bij een gedeelte van de verschaffers van het kapitaal. Het verschil met constructies als certificering en de uitgifte van preferente beschermingsaandelen is dat bij het stemrechtloze aandeel aan een groot deel van de kapitaalverschaffers hun stemrecht wordt ontnomen, terwijl bij de andere constructies het stemrecht op een ander (orgaan of een buitenstaander) overgaat, aldus Noordraven. ${ }^{11}$

Van Schilfgaarde ${ }^{12}$ ziet ook een rol weggelegd voor het stemrechtloze aandeel als alternatief voor beschermingsconstructies in de NV. Als bezwaar tegen het stemrechtloze aandeel noemt hij "dat bij ongelimiteerde toepassing de vennootschap tot een kapitaal aantrekkende stichting wordt gereduceerd." Hij onderkent echter ook de bezwaren van certificering, gelijk Noordraven. ${ }^{13}$ Het stemrecht gaat bij certificering immers op een derde over. Desondanks acht Van Schilfgaarde certificering 'subtieler' dan het stemrechtloze aandeel, omdat het als beschermingsconstructie afgeschaft of onbruikbaar kan worden gemaakt.

Slagter heeft de ontwikkeling in het eigendomsrecht van aandelen geschetst. ${ }^{14}$ Hij schetst een verdere afbrokkeling van dat recht met als logisch eindpunt het stemrechtloze aandeel. Hij is niet tegen die ontwikkeling en bepleit evenmin de aandeelhouder meer rechten toe te kennen. Hij constateert dat aandeelhouders niettemin met hun resterende bevoegdheden nog vrij veel macht kunnen uitoefenen gebaseerd op feitelijke factoren.

Ook Faasen heeft gepleit voor de introductie van het stemrechtloze aandeel in het Nederlandse recht. ${ }^{15}$ Zijn pleidooi blijft beperkt tot de NV, omdat hij het stemrechtloze aandeel zich voor de BV niet vindt lenen, onder andere vanwege de beslotenheid van die rechtsvorm en de verplichte aandelen op naam en blokkeringsregeling. ${ }^{16}$ Ook volgens Faasen liggen de voordelen van het stemrechtloze aandeel op het gebied van het verbeteren van het functioneren van de algemene vergadering. Veel aandeelhouders zien het aandeel slechts als beleggingsinstrument en zijn niet of minder geïnteresseerd in de aan het aandeel verbonden zeggen-

11 Noordraven 1988, p. 180 en 182.

12 Van Schilfgaarde 1988, p. 35.

13 Noordraven 1988, p. 180.

14 Slagter 1988, p. 12-13.

15 Faasen 1989, p. 455, 456 en 465. Faasen zet vanuit historisch perspectief enige vraagtekens bij de introductie van stemrechtloze aandelen, zie p. 465. Die vraagtekens zijn met name ingegeven door de traditionele gedachte dat sprake is van een lidmaatschapsverhouding van aandeelhouders met de vennootschap. De vraagtekens worden voor Faasen geen uitroeptekens, omdat het aandeel als beleggingsfunctie meer op de voorgrond is getreden en niet alle zeggenschapsrechten ontbreken aan een stemrechtloos aandeel.

16 Faasen 1989, p. 456 en 497. 
schapsrechten met als gevolg absenteïsme op de algemene vergadering. ${ }^{17}$ Daarnaast ziet Faasen om diverse redenen het stemrechtloze aandeel als alternatief voor beschermingsconstructies. ${ }^{18}$ Faasen plaatst bij de introductie van het stemrechtloze aandeel echter ook kanttekeningen. Met Van der Grinten ${ }^{19}$ en Van Schilfgaarde ${ }^{20}$ is hij tegen een ongelimiteerde uitgifte van aandelen zonder stemrecht. De vennootschap zou in dat geval slechts een kapitaal aantrekkende stichting zijn of daartoe verworden. Faasen pleit voor een stelsel van gewone aandelen en stemrechtloze aandelen. Aan de gewone aandelen is stemrecht verbonden en deze luiden op naam. Die aandelen worden gehouden door de ondernemers als beleidsbepalers van de vennootschap. Met ondernemers bedoelt Faasen kennelijk degenen die in de vennootschap het beleid bepalen en controle uitoefenen, zijnde de twee pijlers van de zeggenschap. Daarmee wordt tevens voldaan aan het door de wetgever voorgestane, dualistische systeem van de vennootschap. ${ }^{21}$ De aandelen op naam worden in een register ingeschreven. Dat komt de rechtszekerheid en overzichtelijkheid ten goede. ${ }^{22}$ De stemrechtloze aandelen luiden aan toonder en hebben extra vermogensrechten ter compensatie van het verlies van de zeggenschapsrechten. Bij het niet uitkeren van dit preferente dividend, zou het stemrecht moeten herleven, aldus nog steeds Faasen. ${ }^{23}$

Voogd ziet het stemrechtloze aandeel als een belangrijk middel voor de beveiliging van vennootschappen tegen een overval of een onvriendelijke overname. Ook hij ziet het stemrechtloze aandeel als een statutair beschermingsmiddel. ${ }^{24}$ Voogd vindt het stemrechtloze aandeel een figuur die in zekere zin te vergelijken is met het (winstgevende) participatiebewijs, waartoe KLM destijds de statutaire mogelijkheid heeft gecreëerd ${ }^{25}$ en zoals reeds bekend is in Zwitserland. ${ }^{26}$

17 In de literatuur wordt dit argument veelvuldig gebruikt in het pleidooi voor het stemrechtloze aandeel. Het is maar de vraag of dat argument in alle gevallen op gaat. Zo was het hedgefund The Children's Investment van mening dat het aandeel ABN AMRO begin deze eeuw te weinig rendement liet zien in vergelijking tot concurrenten van de bank. Het hedgefund zette de bank onder druk en noemde overname van ABN AMRO door een bank die wel waarde wist te creëren als alternatief. Het bestuur van ABN AMRO kwam met Barclays als mogelijke koper. Het hedge fund eiste echter dat ook andere banken een bod op ABN AMRO konden uitbrengen. Uiteindelijk kochten Fortis, Royal Bank of Scotland en Banco Santader ABN AMRO tegen een hoger bod dan Barclays, hetgeen uiteraard in het voordeel was van het hedgefund. Tijdens de kredietcrisis van 2008 is ABN AMRO uiteindelijk genationaliseerd

18 Faasen 1989 , p. 459 e.v.

19 Van der Grinten 1971 (1), p. 303

20 Van Schilfgaarde 1988, p. 35

21 Faasen 1989, p. 463.

22 Faasen 1989, p. 463 en 464.

23 Faasen 1989, p. 501.

24 Voogd 1989, p. 99.

25 Zie ook Eisma 1991, p. 28 en Van der Grinten 1991, p. 122 en 127-128

26 Voogd 1989, p. 99. Zie ook Galavazi \& Van Wilsum 1988, p. 131 e.v. 
Ook Van Groeningen plaatst het stemrechtloze aandeel op de kaart in de discussie over alternatieven voor beschermingsconstructies. ${ }^{27}$

Schwarz refereert in zijn oratie ${ }^{28}$ aan het feit dat vooral kleine aandeelhouders in publieke vennootschappen niet betrokken zijn. Omdat daardoor besluitvorming in de algemene vergadering wordt gefrustreerd of omdat slechts een klein deel van de aandeelhouders de belangrijke besluiten neemt, zijn er oligarchische regelingen opgetuigd. In deze regelingen wordt de macht van de aandeelhouders beperkt en meer macht aan het bestuur of aan een met het bestuur verbonden groep toebedeeld, bijvoorbeeld als beschermingsconstructie tegen (vijandige) overnames. Vaak wordt van prioriteitsaandelen gebruik gemaakt. Schwarz is voorstander van het dualistische systeem van de vennootschap, waarin het bestuur onder toezicht staat van de algemene vergadering en/of de raad van commissarissen. Dat systeem zou beter functioneren indien er een nauwere band tussen aandeelhouder en vennootschap bestaat. Het zou er ook toe leiden dat oligarchische regelingen minder worden toegepast en aldus het dualistische systeem niet verstoren. Tegen deze achtergrond pleit Schwarz voor de introductie van een stemrechtloos aandeel - door hem het 0-aandeel (nul-aandeel) genoemd - in het Nederlandse vennootschapsrecht, waarbij aangesloten zou kunnen worden bij de reeds bestaande stemrechtloze aandelen in de EU-landen. Schwarz ziet alleen plaats voor het 0 -aandeel in de publieke NV (al dan niet beursgenoteerd) en niet in de BV, omdat hij het 0 -aandeel als financieringsinstrument ziet. Het 0 -aandeel luidt aldus aan toonder. Ter compensatie van het ontbreken van stemrecht aan het 0 -aandeel stelt hij een laag cumulatief preferent winstdelend aandeel van ten minste drie procent van de nominale waarde van het aandeel voor. Naast het ontbreken van stemrecht hebben de 0 -aandeelhouders ook geen voorkeursrecht op nieuw uit te geven aandelen van welke soort dan ook, tenzij het de emissie van 0 -aandelen betreft. Het ontbreken van het stemrecht ziet Schwarz als voorwaardelijk. In het geval dat het minimale dividend op de 0 -aandelen in enig jaar niet zou worden uitgekeerd, zou op verzoek van de 0 -aandeelhouder het stemrecht weer herleven en zou dat stemrecht aan het 0 -aandeel verbonden blijven tot het moment dat het totale preferente dividend is uitgekeerd. Schwarz stelt voorts voor dat een besluit waarbij afbreuk gedaan kan worden aan de financiële rechten van de 0 -aandeelhouder de voorafgaande goedkeuring van de vergadering van 0 -aandeelhouders behoeft. Te denken valt daarbij aan besluiten tot ontbinding van de vennootschap, tot emissie van aandelen, tot vermindering van kapitaal, tot fusie en - in algemene zin - een besluit tot wijziging van de statuten van de vennootschap in de gevallen waarin door de wijziging van de statuten afbreuk aan de rechten van de 0 -aandeelhouders wordt gedaan. Schwarz wenst uitgifte van 0-aandelen mogelijk te maken tot zeventig procent van het totale, geplaatste aandelenkapitaal. Het 0 -aandeel zou ook een functie als beschermingsconstructie hebben. Gelet op het feit dat het 0 -aandeel een echt financieringsinstrument is, kan in de statuten de

27 Van Groeningen 1989, p. 143

28 Schwarz 1990 
mogelijkheid worden opgenomen het aandeel in te trekken onder terugbetaling van het gestorte kapitaal, aldus Schwarz. ${ }^{29}$

Eisma stelt dat er grote vrijheid bestaat van inhoudelijke vormgeving van participatiebewijzen, zodat participatiebewijzen gecreëerd kunnen worden die materieel gezien aandelen zonder stemrecht zijn. Daarvan is volgens Eisma sprake indien de houders van die bewijzen op gelijke voet staan met houders van gewone aandelen. De participatiebewijzen moeten in dat geval aanspraak maken op de winst en het liquidatiesaldo, aan toonder luiden en vergaderrecht hebben, vergelijkbaar met het vergaderrecht dat aan de houder van bewilligde certificaten toekomt. ${ }^{30}$ In zijn conclusie stelt hij dat een participatiebewijs met de bedoelde rechten niet nietig is, omdat materieel gezien sprake is van een aandeel zonder stemrecht. ${ }^{31}$

Eisma \& De Keijzer ${ }^{32}$ pleiten voor een eenvoudige regeling met betrekking tot het aandeel zonder stemrecht, indien dat aandeel in Nederland ingevoerd zou worden. Het stemrechtloze aandeel zou zich moeten ontwikkelen en de vennootschap de nodige flexibiliteit geven. De Antilliaanse wetgeving zou daarvoor model kunnen staan. Zij achten verplichte preferentie, het herleven van stemrecht bij het niet uitkeren van dividend en stemrecht bij een aantal bijzondere besluiten niet gewenst of noodzakelijk. Eisma \& De Keijzer staan aldus een ander soort stemrechtloos aandeel voor ogen dan Faasen en Schwarz. Eisma \& De Keijzer concluderen echter ook dat er geen noodzaak is tot invoering van het stemrechtloze aandeel, mede omdat met certificaten of participatiebewijzen hetzelfde of meer kan worden bereikt. Zij zien wel een rol weggelegd voor het stemrechtloze aandeel als zeggenschapsneutraal financieringsinstrument, bijvoorbeeld bij familievennootschappen die kapitaal via de beurs willen aantrekken. In algemene zin zou echter ook volstaan kunnen worden met het participatiebewijs. ${ }^{33}$ Het door Van der Grinten $^{34}$ genoemde argument dat de algemene vergadering door de invoering van het stemrechtloze aandeel beter zou functioneren, zien zij niet. Daarvoor zijn andere maatregelen noodzakelijk. In dat kader noemen Eisma \& De Keijzer het stellen van aandelen op naam, het afschaffen van certificering van aandelen of het afschaffen van oligarchische regelingen. ${ }^{35}$ Anders dan Faasen, ${ }^{36}$ Noordraven ${ }^{37}$ en Schwarz $^{38}$ zien Eisma \& De Keijzer in het kader van beschermingsconstructies

29 Schwarz 1990, p. 3, 5, 7, 9-11, 13, 14, 18, 20, 22, 24 en 26

30 Eisma 1991, p. 36.

31 Eisma 1991, p. 37.

32 Eisma \& De Keijzer 1994, p. 13, 16, 19 en 20.

33 Eisma \& De Keijzer 1994, p. 19. Eisma \& De Keijzer refereren aan de participatiebewijzen bij KLM en SHV, die op Duitse en Zwitserse leest zijn geschoeid.

34 Van der Grinten 1971 (1), p. 304

35 Eisma \& De Keijzer 1994, p. 15.

36 Faasen 1989, p. 459 e.v.

37 Noordraven 1988 , p. 180

38 Schwarz 1990, p. 24. 
eerder een rol voor het participatiebewijs dan voor het stemrechtloze aandeel weggelegd. ${ }^{39}$

Ook Buijs houdt een pleidooi voor het stemrechtloze aandeel. ${ }^{40}$ Anders dan de eerder aangehaalde schrijvers ziet hij daarbij niet zozeer een rol voor dat aandeel weggelegd als vervanging van beschermingsconstructies, tenzij de meerderheid van de aandelen met stemrecht in handen is van het bestuur van de vennootschap of vertrouwde derden. Hij ziet vooral als voordeel van het stemrechtloze aandeel dat de bestaande zeggenschapsverhoudingen niet wijzigen bij het aantrekken van risicodragend kapitaal, bijvoorbeeld in familieverhoudingen of bij joint ventures. Andere voorbeelden zijn de positie van een venture capitalist bij een management buy-out en personeelsaandelen. Stemrechtloze aandelen vindt Buijs een 'koninklijkere route' dan - bijvoorbeeld - participatiebewijzen, certificaten of andere constructies waarbij zeggenschap en kapitaaldeelneming worden ontkoppeld. Juist bij de rol van financieringinstrument om de bestaande zeggenschapsverhoudingen niet te wijzigen, vraagt Buijs zich af of het stemrechtloze aandeel in de BV niet uitsluitend op naam moet luiden en niet vrij overdraagbaar moet zijn. Buijs heeft bezwaren tegen het stemrechtloze aandeel, zoals Schwarz dat (0-aandeel) schetst. Hij is het met Schwarz eens dat het stemrechtloze aandeel een financieringsinstrument is. Buijs ziet echter dat instrument zowel voor de belegger als de houders van aandelen met stemrecht ter handhaving van de bestaande zeggenschapsverhoudingen. Dat kan aldus zowel gelden voor de NV als de BV. Om die reden is Buijs het niet met Schwarz eens dat stemrechtloze aandelen slechts aan toonder kunnen luiden. Hij maakt daarbij de vergelijking dat niet-royeerbare certificaten van aandelen in een $\mathrm{BV}$ ook financieringsinstrumenten zijn en niet aan toonder mogen zijn gesteld. Uit het oogpunt van rechtszekerheid en betrouwbaarheid voelt Buijs ook weinig voor de voorwaardelijke stemrechtloosheid van het door Schwarz geschetste 0-aandeel, waarbij stemrecht (op verzoek) herleeft ingeval het cumulatief preferente dividend niet wordt voldaan en na betaling weer teniet gaat. Daarom kan een dergelijk voorwaardelijk stemrechtloos aandeel geen alternatief zijn voor beschermingsconstructies.

Buijs zoekt voor het stemrechtloze aandeel ansluiting bij het Antilliaanse stemrechtloze aandeel. ${ }^{41}$ Buijs is van mening dat de houders van stemrechtloze aandelen in ieder geval over enkele onderwerpen moeten kunnen (mee)stemmen. Het is aldus geen absoluut stemrechtloos aandeel, maar een aandeel met een stemrecht dat tot bepaalde onderwerpen beperkt is krachtens wet of statuten. De stemrechtloze aandeelhouder van Buijs heeft wel alle normale vergader- en informatierechten, gelijk aan die van houders van met medewerking van de vennootschap uitgegeven certificaten. Daarnaast moet altijd ten minste twintig procent van het maatschappelijk kapitaal van de vennootschap zijn geplaatst in de

39 Eisma \& De Keijzer 1994, p. 18

40 Buijs 1995, p. 55-61.

41 Zie noot 9. 
vorm van aandelen met stemrecht, die door derden worden gehouden. Daarboven kunnen vervolgens stemrechtloze aandelen worden geplaatst tot maximaal vier keer het geplaatste kapitaal van stemrechthebbende aandelen. Gelet op de door Buijs voorgestelde grens van twintig procent past de gedachte van Van der Grinten en Slagter van een inwisselbaar stemrechtloos aandeel aan toonder in een aandeel met stemrecht op naam niet in het stemrechtloze aandeel van Buijs. Volgens Buijs zou de wet moeten voorzien in een minimumbescherming van de stemrechtloze aandeelhouder, welke bescherming eventueel statutair uit te breiden is. Wijziging van de statuten van de vennootschap mag geen nadeel aan de rechten van de stemrechtloze aandeelhouder toebrengen, tenzij de vergadering van stemrechtloze aandeelhouders daarmee instemt (bij gewone of een statutair gecreëerde gekwalificeerde meerderheid). Bij een fusiebesluit geldt deze bescherming ook, bij een ontbindingsbesluit echter niet. In die zin gaat Buijs deels met Schwarz mee. Voorts stelt Buijs voor de stemrechtloze aandelen uit te zonderen van de vaststellingsregel over het aanwezig of vertegenwoordigd zijn van aandeelhouders of het geplaatste kapitaal. Ook zou de stemrechtloze aandeelhouder geen voorkeursrecht moeten hebben bij de uitgifte van aandelen met stemrecht, maar wel bij de uitgifte van stemrechtloze aandelen. Buijs stipt ook aan dat de effectenbeurs geen niet-royeerbare certificaten van aandelen ter notering toelaat, ook al is het bestuur van het administratiekantoor daadwerkelijk onafhankelijk. Het zal om die reden ook niet voor de hand liggen dat de effectenbeurs stemrechtloze aandelen toelaat, aldus Buijs.

Marcusse \& Mulder ten Kate ${ }^{42}$ gaan in op de scheiding van de aan een aandeel verbonden zeggenschaps- en financiële rechten, anders dan door middel van certificering. Zij schetsen daarvoor de mogelijkheid van het uitgeven van aandelen direct gevolgd door een verpanding aan de vennootschap van die aandelen zelf of de mogelijkheid van het onder voorbehoud van een pandrecht overdragen van aandelen aan werknemers, waarbij het aan de aandelen verbonden stemrecht bij de vennootschap blijft. Zij stellen dat de onmogelijkheid om het stemrecht uit te oefenen op zich niet in strijd met de wet is. Zij concluderen echter dat indien door middel van de geschetste constructie van verpanding sprake is van een doelbewust en bij voortduring frustreren van de uitoefening van het stemrecht die constructie mogelijk in strijd is met de vennootschappelijke openbare orde en nietigheid tot gevolg heeft. In het nieuwe BV-recht speelt die vraag naar mijn mening niet, omdat de wetgever heeft voorzien in het stemrechtloze aandeel, waarbij bij voortduring de uitoefening van het stemrecht "gefrustreerd" wordt.

Van Duuren plaatst de behoefte aan het stemrechtloze aandeel in het kader van de joint venture-vennootschap. Bij drie of meer aandeelhouders in een dergelijke vennootschap kan het van belang zijn de vastgestelde stemverhoudingen niet te wijzigen in geval van een aanvullende kapitaalstorting door een van die aandeelhouders.

42 Marcusse \& Mulder ten Kate 2001, p. 149-150. 
De loskoppeling tussen stemrecht en eigen vermogen is dan vereist. De wet zou op dit punt moeten worden versoepeld en meer vrijheid moeten bieden. ${ }^{43}$

Uit voorgaand, min of meer chronologisch, overzicht van opvattingen in de literatuur volgt dat er vele voorstanders van het stemrechtloze aandeel zijn, zij het dat de uitwerking van dat aandeel per auteur verschilt.

Tegenstanders van het stemrechtloze aandeel zijn er ook. Zo gaat Den Boogert in op het door Schwarz bepleitte 0 -aandeel. ${ }^{44}$ Hij stelt dat met de bewilligde certificaten te leven valt en dat niet valt in te zien waarom en hoe het 0 -aandeel tot een doelmatiger machtsverdeling binnen de $\mathrm{NV}$ en tot een betere positionering van kapitaalverschaffers zou kunnen bijdragen als vervanging van de oligarchische constructies. Niettemin kan het 0 -aandeel een nuttige functie als nieuw financieringsinstrument op de kapitaalmarkt vervullen, aldus Den Boogert. De kritiek van Den Boogert op het 0 -aandeel van Schwarz ziet met name op het ontbreken van een projectie van het 0 -aandeel op de bestaande, Nederlandse vennootschapspraktijk en een analyse van de daarmee teweeg te brengen veranderingen. Den Boogert komt vervolgens niet zelf met een alternatief, doch houdt vast aan de (uitgifte van) bewilligde certificaten.

Van der Ploeg stelt, onder bijval van Voûte, dat het betoog van Schwarz op praktijkbehoeften voor het 0 -aandeel op 'magere pijlers' berust. In de praktijk zou weinig behoefte aan het 0 -aandeel zijn. ${ }^{45}$

Rietkerk is tegen het stemrechtloze aandeel bij beursgenoteerde vennootschappen. ${ }^{46}$ $\mathrm{Hij}$ is van mening dat voorstellen tot invoering van een dergelijk aandeel te lichtvaardig worden gedaan. Er zouden bovendien geen economische argumenten zijn die vóór pleiten.

Blom is het in zijn reactie op Rietkerk eens wat betreft het stemrechtloze aandeel bij beursgenoteerde vennootschappen. ${ }^{47}$ Echter, Blom ziet wel voordelen van het stemrechtloze aandeel in de BV die bijzonder winstgevend is. Bijvoorbeeld waar het gaat om bestuurders-grootaandeelhouders die hun onderneming en zaken goed op orde hebben en maximalisatie van de waarde van hun aandelen op lange termijn nastreven. Voor de belegger kan het zeer voordelig zijn als stemrechtloze aandeelhouder passief met de stemgerechtigde bestuurder-grootaandeelhouder mee te delen.

In zijn naschrift ${ }^{48}$ stelt Rietkerk dat hij, in tegenstelling tot Blom, geen plaats ziet voor het stemrechtloze aandeel bij de BV. Bij de BV voorziet certificering van aandelen al in de behoefte van een financieel instrument voor het door Blom beoogde doel.

Samenvattend kan gesteld worden dat er meer voorstanders dan tegenstanders voor de invoering van het stemrechtloze aandeel zijn. De argumenten van de

43 Van Duuren 2002, p. 104-105. Zie ook Van Duuren 2007, p. 245.

44 Den Boogert 1992, p. 12-13.

45 Van der Ploeg 1990, p. 268 en Voûte 1991, p. 101

46 Rietkerk 1992, p. 101

47 Blom 1992, p. 205-206.

48 Zie Blom 1992, p. 206. 
voorstanders lopen echter nogal uiteen, evenals de meningen over hoe dat aandeel zou moeten worden vormgegeven. Alles overziende, sluit ik mij aan bij de voorstanders, en beperk ik mij tot het BV-recht, dan vooral bij Buijs en Van Duuren. Het stemrechtloze aandeel als alternatief voor certificering zonder bestaande zeggenschapsverhoudingen aan te tasten is naar mijn mening een doorslaggevend argument voor invoering van het stemrechtloze aandeel. ${ }^{49}$

\subsection{Het stemrechtloze aandeel in andere landen}

Ook rechtstelsels in andere landen kennen stemrechtloze aandelen, bijvoorbeeld in de (voorheen geheten) Nederlandse Antillen, ${ }^{50}$ het Verenigd Koninkrijk, Spanje, België, Duitsland, Italië, Frankrijk, Zwitserland, de Verenigde Staten en Japan. ${ }^{51}$

Voorts voorzag het (ingetrokken) gewijzigd voorstel voor een vijfde EG-richtlijn ter harmonisering van het vennootschapsrecht in een stemrechtloos aandeel. ${ }^{52}$ Art. 33 lid 2 van dat voorstel bepaalde, kort gezegd, dat een lidstaat het stemrecht op aandelen kan beperken of uitsluiten. ${ }^{53}$

49 Uit dit onderzoek zal blijken dat stemrechtloze aandelen en certificaten van aandelen (met of zonder vergaderrecht) naast elkaar kunnen bestaan en dat in voorkomend geval voor de ene dan wel de andere rechtsfiguur kan worden gekozen. Datzelfde geldt voor participatiebewijzen.

50 Sinds 1987. Zie hierover Galavazi \& Van Wilsum 1988, p. 130-131; Burgers 1987 en noot 2.

51 Kamerstukken II, 2008/09, 31058, nr. 6, p. 18 (Nota naar aanleiding van het verslag). De Nota meldt dat de ervaringen in de genoemde rechtsstelsels, voor zover bekend, positief zijn. Zie Noordraven 1988 , p. 181, voor een korte beschrijving van de stemrechtloze aandelen in de Verenigde Staten, Engeland, Duitsland en de Nederlandse Antillen. Faasen 1989 doet een rechtsvergelijkend onderzoek met betrekking tot Engeland en Duitsland en concludeert dat de regelingen in Engeland en Duitsland over het stemrechtloze aandeel een goede basis geven om in het Nederlandse recht te komen tot een stemrechtloos aandeel (zie p. 501). Zie ook Schwarz 1990, noot 17 en 28, voor een korte beschrijving van de aandelen zonder stemrecht in België, Frankrijk, Engeland, Zwitserland, Spanje en de Nederlandse Antillen met verdere verwijzing naar literatuur. Zie tevens het Rapport van de Expertgroep van 6 mei 2004, p. 67-70 voor een beschrijving van de stemrechtloze aandelen in diverse Europese landen. Zie ook Heikens 2008 met betrekking tot het Verenigd Koninkrijk, België en de Nederlandse Antillen. Voor het stemrechtloze aandeel in het recht van Delaware, zie Smeets 2005, p. 87. Voor een bespreking van het Antilliaanse stemrechtloze aandeel zie: P. van Schilfgaarde, 'De Besloten Vennootschap naar het recht van de Nederlands Antillen', Ondernemingsrecht 2000-2, p. 31-36; J.W. Winter, 'Nieuw: de Antilliaanse Besloten Vennootschap (I)', WPNR 2000, 6385, p. 19-22 en S.R. Hagen, 'Extreme makeover op Curaçao', V\&O 2004-7/8, p. 132-135. Voor een vergelijking van de Nederlandse BV met haar Europese equivalenten zie: T.P. van Duuren, 'De positie van de Nederlandse BV ten opzichte van haar buitenlandse equivalenten en de Europese BV', Ondernemingsrecht 2004-1, p. 4-10.

52 Dossier COM/1972/887.

53 Op 9 januari 2004 heeft de Commissie ingetrokken het voorstel van 9 oktober 1972 voor een Vijfde Richtlijn van de Raad van Ministers van de Europese Gemeenschappen strekkende tot het coördineren van de waarborgen welke in de Lidstaten worden verlangd van de vennootschappen in de zin van art. 58 lid 2, van het Verdrag om de belangen te beschermen, zowel van de deelnemers in deze vennootschappen als van derden, met betrekking tot de structuur van de naamloze $\rightarrow$ 
Schwarz kijkt bij zijn pleidooi voor het stemrechtloze aandeel onder meer naar Duitsland. ${ }^{54}$ Faasen zoekt de combinatie van Duitsland en Engeland op. ${ }^{55}$ Eisma \& De Keijzer, hoewel geen absolute voorstanders van het stemrechtloze aandeel, zien meer in een stemrechtloos aandeel naar Antilliaans model. ${ }^{56}$ Ook Buijs kijkt naar het Antilliaanse stemrechtloze aandeel. ${ }^{57}$

Het stemrechtloze aandeel is in het internationale rechtsverkeer een bekende rechtsfiguur. Dat was een van de argumenten voor de wetgever om uiteindelijk tot invoering daarvan over te gaan. ${ }^{58}$ Het gaat het onderwerp van dit onderzoek te buiten een beschrijving te geven van het stemrechtloze aandeel in diverse landen. Evenmin is rechtsvergelijking onderwerp van dit onderzoek.

\subsection{Uitgangspunten bij de herziening van het BV-recht en de totstandkoming van de wet}

De Wet vereenvoudiging en flexibilisering BV-recht maakt de regels voor de BV eenvoudiger en flexibeler, althans dat is de doelstelling van de wetgever. Daardoor krijgt de BV een meer eigen karakter en onderscheidt zij zich van de NV. ${ }^{59}$ Ook moet het (nieuwe) BV-recht beter aan te sluiten bij de behoefte in de praktijk. ${ }^{60}$

De noodzaak tot aanpassing van het BV-recht is volgens de wetgever gelegen in het feit dat veel wettelijke bepalingen voor de BV als star en onnodig belastend worden ervaren: "Dit wetsvoorstel maakt de regels voor besloten vennootschappen met beperkte aansprakelijkheid (bv's) eenvoudiger en flexibeler. De bv verkrijgt hierdoor als rechtsvorm een meer eigen karakter, dat haar duidelijker onderscheidt van de nv. Bij de herziening staat voorop dat de nieuwe bv zoveel mogelijk aansluit bij de wensen die in de praktijk leven. (...) De bestaande bv-regeling is voor een groot deel ontleend aan het nv-recht. Veel wettelijke bepalingen worden voor de bv als star en onnodig belastend ervaren. De mogelijkheden voor aandeelhouders om hun onderlinge verhoudingen te regelen, worden verruimd. Er ontstaat meer ruimte

vennootschap alsmede de bevoegdheden en verplichtingen van haar organen, PbEG 1972 C 131/49, zoals gewijzigd door het voorstel van 19 augustus 1983 (PbEG 1983 C 120), het voorstel van 20 december 1990 (PbEG 1991 C 7) en door het voorstel van 20 november 1991 (PbEG 1991 C 321/9). Dit intrekkingsbesluit van de Commissie is bekend gemaakt in $P b E U 2004$ C 5/02.

54 Zie Schwarz 1990

55 Faasen 1989, p. 501

56 Eisma \& De Keijzer 1994, p. 13.

57 Buijs 1995, p. 57.

58 Kamerstukken II 2006/07, 31 058, nr. 3, p. 11-12 (MvT).

59 Zie voor een vergelijking tussen de coöperatie en de (flex-)BV: R.W.A. van Thiel, 'De algemene vergadering bij de coöperatie en de Flex-BV', $V \& O$ 2010-3, p. 43-47.

60 Kamerstukken II 2006/07, 31 058, nr. 3, p. 1 (MvT). 
om de inrichting van de vennootschap aan te passen aan de aard van de onderneming en de samenwerkingsrelatie van de aandeelhouders." $" 11$

Daarnaast dwongen Europese ontwikkelingen tot een rechtsvorm die internationaal concurrerend is, zodat Nederland aantrekkelijk blijft als vestigingsland voor nationale en internationale ondernemingen. Veel Europese landen hebben op het moment van invoering van de flex-BV al een flexibele besloten rechtsvorm ingevoerd. Op deze Europese ontwikkelingen kom ik hieronder terug. Ook bood de herziening van het BV-recht de mogelijkheid bestaande knelpunten op te lossen. ${ }^{62}$

De hoofdlijnen van het wetsvoorstel zijn: meer vrijheid van inrichting en een evenwichtig systeem van crediteurenbescherming. Bij de vrijheid van inrichting speelt de bescherming van minderheidsaandeelhouders een belangrijke rol. De crediteurenbescherming is gebaseerd op een uitkeringstest in combinatie met aansprakelijkheidssancties voor bestuurders en aandeelhouders. ${ }^{63}$ Het minimumkapitaal van $€ 18.000$ is afgeschaft. Daarnaast is de verplichte blokkering van de overdraagbaarheid van aandelen vervallen, zijn de mogelijkheden verruimd om besluitvorming buiten de algemene vergadering te laten plaatsvinden, is de wettelijke geschillenregeling verbeterd en is de mogelijkheid ingevoerd om in de statuten te voorzien in stemrechtloze of winstrechtloze aandelen of in een flexibele verdeling van stemrecht. ${ }^{64}$

Meer in het algemeen golden bij de invoering van de flex-BV de volgende uitgangspunten:

- minder dwingend en meer regelend recht;

- meer vrijheid voor aandeelhouders om de onderneming naar eigen inzicht en wensen vorm te geven, met voldoende waarborgen voor de belangen van andere partijen (in het bijzonder minderheidsaandeelhouders); ${ }^{65}$

- vervallen van regels die onnodig belemmerend of ineffectief zijn;

- vermindering van (administratieve) lasten;

- een evenwichtige bescherming van crediteuren;

- het wegnemen van rechtsonzekerheid;

61 Kamerstukken II 2006/07, 31 058, nr. 3, p. 1 (MvT). Zie ook Kamerstukken II 2009/10, 32 426, nr. 3 , p. 1 (MvT).

62 Voor dit alles: Kamerstukken II 2006/07, 31 058, nr. 3, p. 1 (MvT).

63 Zie art. 2:216 BW.

64 Kamerstukken II 2006/07, 31 058, nr. 3, p. 1 (MvT).

65 De algemene beschermingsregels van Boek 2 BW kunnen in de volgende categorieën worden ingedeeld:

a. unanimiteit (art. 2:226 lid 2 en 3, 2:228 lid 4 en 5 en 2:231 lid 3, 2:242 lid 2, 2:252 lid 1 en 2:253 $\mathrm{BW})$;

b. goedkeuring (art. 2:231 lid 4 en 2:231a lid 1 BW);

c. instemming (art. 2:195 lid 3, 2:208 lid 3 en 4, 2:216 lid 6 en lid 8, 2:226 lid 2 en 3, 2:227 lid 4 en 2:238 lid $1 \mathrm{BW}) ;$ en

d. vrijstelling (art. 2:192 lid 1, 2:192 lid 3 jo. 2:192a en 2:195 lid 4 BW).

Zie Quist 2010, p. 99. Van Veen 2007, p. 956, merkt op dat niet altijd duidelijk is waarom voor de ene dan wel de andere variant is gekozen. Nowak \& Van den Ingh 2007, p. 125 en Kamerstukken II 2006/07, 31 058, nr. 4, p. 7-8. 
- aansluiten bij de behoeften van de hedendaagse, nationale en internationale praktijk;

- aansluiten bij ontwikkelingen in de ons omringende landen en de Europese Unie; en

- geen nieuwe rechtsvorm, maar oplossing van knelpunten in het huidige (lees: inmiddels oude) BV-recht. ${ }^{66}$

De door de wetgever gememoreerde Europese ontwikkelingen bestaan onder meer uit de jurisprudentie over de vrijheid van vestiging van rechtspersonen. In de afgelopen jaren heeft die jurisprudentie zich snel ontwikkeld. Ik noem als ijkpunten ${ }^{67}$ het Centros-arrest ${ }^{68}$ en het Inspire Art-arrest. ${ }^{69}$

In het Centros-arrest ging het om het recht van vrije nevenvestiging ex art. 52 en 58 van het EG-Verdrag. Een Engelse Limited, die in Engeland geen activiteiten had ontplooid, wenste een filiaal van Centros in Denemarken in te schrijven. Het Hof overwoog (r.o. 30) dat het in strijd met dat recht is indien een lidstaat het filiaal van een vennootschap dat is opgericht in overeenstemming met het recht van een andere lidstaat, waar zij haar zetel heeft, weigert in te schrijven op grond dat het filiaal is opgericht met de bedoeling dat de vennootschap haar volledige economische activiteit in de staat van ontvangst kan ontplooien, waardoor de nevenvestiging ontsnapt aan de nationale regels inzake minimumkapitaal en de storting daarvan. Het recht van vrije nevenvestiging laat onverlet dat de lidstaat maatregelen kan treffen ter bestrijding of bestraffing van fraude.

In het Inspire Art-arrest ging het om de weigering van de Amsterdamse Kamer van Koophandel om de Engelse Limited Inspire Art Ltd. in te schrijven, omdat de vennootschap niet vermeldde dat zij een formeel buitenlandse vennootschap in de zin van de Wet op de formeel buitenlandse vennootschappen is. De Elfde Richtlijn ${ }^{70}$ verzet zich tegen een nationale wettelijke regeling als de Wet op de formeel buitenlandse vennootschappen, die het filiaal van een vennootschap die in overeenstemming met de nationale wettelijke regeling van een andere lidstaat is opgericht,

66 Kamerstukken II 2006/07, 31 058, nr. 3, p. 3 e.v. (MvT).

67 Andere - niet door de wetgever genoemde - ijkpunten in de Europese ontwikkelingen zijn het Daily Mail-arrest (HvJ EG 27 september 1988, nr. 81/87), het Überseering-arrest (HvJ EG 5 november 2002, nr. C-208/00, NJ 2003, 58) en - in het verlengde van deze arresten - het Sevic-arrest (HvJ EG 13 december 2005, nr. C-411/03, NJ 2009, 201) en het Cartesio-arrest (HvJ EG 16 december 2008, nr. C-210/06, NJ 2009, 202). Zie over deze arresten en het BV-recht in de diverse lidstaten Van Duuren 2004 en Van Daelen \& Huybens 2010. Zie meer recent met betrekking tot grensoverschrijdende omzetting van vennootschappen en rechtspersonen: HvJ EG 12 juli 2012, nr. C-378/10, JOR 2012, 285, m.nt. Vossestein (Vale). Zie ook over dit arrest Van Boxel 2012 en E.R. Roelofs, 'Het Vale-arrest: een nieuwe stap op het gebied van grensoverschrijdende omzetting', WPNR 2012, 6950, p. 792-798.

68 HvJ EG 9 maart 1999, nr. C-212/97, NJ 2000, 48, m.nt. P. Vlas, JOR 1999, 117, m.nt. G. van Solinge.

69 HvJ EG 30 september 2003, nr. C-167/01, NJ 2004, 394, m.nt. P. Vlas, JOR 2003, 249, m.nt. G.J. Vossestein. Zie naar aanleiding van dit arrest ook Van den Braak 2006.

70 Art. 2 van de Elfde richtlijn (89/666/EEG) van de Raad van 21 december 1989 betreffende de openbaarmakingsplicht voor in een lidstaat opgerichte bijkantoren van vennootschappen die onder het recht van een andere staat vallen. 
openbaarmakingsverplichtingen oplegt waarin deze richtlijn niet voorziet, aldus het Hof in r.o. 72. Daarnaast verzetten art. 43 en 48 van het EG-Verdrag zich tegen een nationale wettelijke regeling als de Wet op de formeel buitenlandse vennootschappen, die de vrijheid van vestiging van een filiaal in die lidstaat door een vennootschap die in overeenstemming met de wettelijke regeling van een andere lidstaat is opgericht, afhankelijk stelt van bepaalde voorwaarden betreffende het minimumkapitaal en de aansprakelijkheid van bestuurders die in het nationale vennootschapsrecht voor de oprichting van vennootschappen worden gesteld. De redenen waarom de vennootschap in de eerste lidstaat is opgericht, en de omstandigheid dat zij haar werkzaamheden uitsluitend of nagenoeg uitsluitend in de lidstaat van vestiging uitoefent, ontnemen haar niet het recht, zich op de door het EG-Verdrag gewaarborgde vrijheid van vestiging te beroepen, tenzij er sprake is van misbruik, hetgeen van geval tot geval moet worden aangetoond, aldus het Hof in r.o. 105.

De Wet op de formeel buitenlandse vennootschappen is vervolgens aangepast. ${ }^{71}$

De hierna te bespreken Expertgroep en de wetgever hebben daarom ook gekeken naar de rechtsvormen in het vennootschapsrecht van de andere EU-lidstaten. In die lidstaten was reeds het vennootschapsrecht hervormd of zijn of waren daartoe voornemens. ${ }^{72}$ Met andere woorden: de Nederlandse rechtsvormen moeten kunnen concurreren met rechtsvormen in het vennootschapsrecht van andere Europese landen. ${ }^{73}$ Het verplichte minimumkapitaal van $€ 18.000$ voor de BV was daarbij een obstakel in de concurrentie met niet-Nederlandse rechtspersonen. ${ }^{74}$

Naast deze Europese ontwikkelingen en rechtspraak stelt Timmerman ook een andere ontwikkeling aan de orde. ${ }^{75}$ Hij refereert aan de individualisering in de Westerse samenleving. Als gevolg daarvan wordt sturing door de wetgever minder makkelijk aanvaard. De burger wenst keuzevrijheid en aanvaardt minder makkelijk regels van dwingend recht, bijvoorbeeld op het gebied van het BV-recht. Timmerman spreekt dan ook liever over versoepeling van het BV-recht. ${ }^{76}$

Om te komen tot het wetsvoorstel voor de flex-BV heeft de wetgever een aantal stappen ondernomen. In november 2003 is door de minister van Justitie en de staatssecretaris van Economische Zaken een expertgroep ingesteld onder voorzitterschap van De Kluiver (hierna: "de Expertgroep"). Aan de Expertgroep is gevraagd om aanbevelingen te doen met betrekking tot knelpunten in het BV-recht

71 Wet van 28 april 2005 tot wijziging van de Wet op de formeel buitenlandse vennootschappen (Stb. 230), in werking getreden op 1 juni 2005 (Stb. 263). Zie over de wijzigingen in de Wet op de formeel buitenlandse vennootschappen als gevolg van de invoering van de flex-BV Roelofs: 2012 (1).

72 Zie Rapport van de Expertgroep, p. 7.

73 In gelijke zin Van den Heuvel 2011, p. 73. Zie bijvoorbeeld voor een bespreking van de Nederlandse BV en haar buitenlandse equivalenten: T.P. van Duuren, 'De positie van de Nederlandse BV ten opzichte van haar buitenlandse equivalenten en de Europese BV', Ondernemingsrecht 2004-1, p. 4-10.

74 Zie voor een historische achtergrond: Van der Sangen \& Raaijmakers 2004, p. 251-253.

75 Timmerman 2004, p. 27.

76 Zie ook L. Timmerman, 'Is versoepeling van het Nederlandse n.v./b.v.-recht wenselijk?', TVVS 1992-7, p. 163-168 en De Kluiver 1994, p. 174. 
zoals deze in de praktijk en in de literatuur worden gesignaleerd. ${ }^{77}$ Het rapport van de Expertgroep 'Vereenvoudiging en flexibilisering van het Nederlandse BV-recht' is op 6 mei 2004 (hierna: "het Rapport van de Expertgroep") verschenen. ${ }^{78}$ De hiervoor genoemde uitgangspunten bij de invoering van de flex-BV komen grotendeels uit het Rapport van de Expertgroep. ${ }^{79}$ Het Rapport van de Expertgroep bevat een groot aantal aanbevelingen, verdeeld in drie hoofdthema's: (i) orgaanstructuur en bevoegdheden organen, (ii) beslotenheid en geschillenregeling en (iii) vermogen en schuldeisersbescherming. Daarnaast heeft de Expertgroep ook voorstellen geformuleerd ten aanzien van de regeling voor tegenstrijdig belang, doeloverschrijding en de taal van de statuten. De aanbevelingen van de Expertgroep zijn voor een belangrijk deel gebaseerd op rechtsvergelijkend onderzoek naar de BV-regelingen in andere landen. ${ }^{80}$ Op basis van onder meer het Rapport van de Expertgroep is een ambtelijk voorontwerp opgesteld dat in tranches ter consultatie beschikbaar is gesteld. ${ }^{81}$ Hierop is door een groot aantal partijen, waaronder advocatenkantoren, gereageerd. Ik zal daaraan in de volgende paragraaf aandacht besteden. In aanvulling op de schriftelijke consultatie is in december 2005 een expertmeeting gehouden. ${ }^{82}$ Over het wetsvoorstel is advies gevraagd aan de Commissie vennootschapsrecht. ${ }^{83}$

Hiervoor somde ik de uitgangspunten bij invoering van de flex-BV op. Eén uitgangspunt heeft, gelet op mijn onderzoeksvragen, mijn nadere aandacht, te weten: meer vrijheid voor aandeelhouders om de onderneming naar eigen inzicht en wensen vorm te geven met voldoende waarborgen voor de belangen van andere partijen (in het bijzonder minderheidsaandeelhouders). Nowak \& Van den Ingh ${ }^{84}$ wijzen er op dat in de flexibiliteit bij inrichting van de vennootschap die de flex-BV biedt ook gevaar schuilt. Belangen van bijvoorbeeld minderheidsaandeelhouders kunnen daardoor in de knel komen. Ook Leemrijse signaleert dat. ${ }^{85} \mathrm{Zij}$ merkt tevens

77 Rapport van de Expertgroep, p. III.

78 Te raadplegen op http://www.rijksoverheid.nl/onderwerpen/flexibele-bv. Voor een bespreking van het Rapport van de Expertgroep zie bijvoorbeeld Fleming 2004 en Zaman 2004 (1)

79 Rapport van de Expertgroep, p. 1. Zie voor een verdere verdieping van die uitgangspunten p. 2-8 van het Rapport van de Expertgroep.

80 Kamerstukken II 2006/07, 31 058, nr. 3, p. 2 (MvT).

81 Daarnaast heeft het Instituut voor Ondernemingsrecht Groningen in opdracht van het Ministerie van Economische Zaken twee onderzoeken op het terrein van kapitaalbescherming verricht. Het eerste onderzoek richt zich op kapitaalbeschermingsvragen in het BV-recht (Versoepeling van het BVkapitaalbeschermingsrecht, M.L. Lennarts en J.N. Schutte-Veenstra, Eindrapport van 31 maart 2004, Instituut voor Ondernemingsrecht Groningen). Het tweede onderzoek richt zich in bredere zin op alternatieven voor kapitaalbescherming en besteedt nadere aandacht aan systemen met aandelen zonder nominale waarde (Alternatieve systemen voor kapitaalbescherming, H.E. Boschma, M.L. Lennarts en J.N. Schutte-Veenstra, Eindrapport van 18 augustus 2005, Instituut voor Ondernemingsrecht Groningen). Beide onderzoeksrapporten zijn te raadplegen op www.justitie.nl/BVrecht en op www.flexBV.ez.nl.

82 Expertmeeting inzake het BV-recht, gehouden op 16 december 2005. Het verslag van deze expertmeeting is te vinden op http://www.rijksoverheid.nl/onderwerpen/flexibele-bv.

83 Voor dit alles: Kamerstukken II 2006/07, 31 058, nr. 3, p. 1 (MvT).

84 Nowak \& Van den Ingh 2007, p. 123.

85 Leemrijse 2005, p. 40 
op dat de minderheidsaandeelhouder zich in beginsel moet schikken in de besluitvorming door de meerderheid. Aandeelhouders moeten zich in hun onderlinge verhoudingen laten leiden door de vennootschappelijke redelijkheid en billijkheid van art. 2:8 BW. Naar mijn mening speelt de redelijkheid en billijkheid niet alleen tussen meerderheids- en minderheidsaandeelhouders, maar ook tussen aandeelhouders met en zonder stemrecht. Ik stipte dat thema al in mijn inleiding aan. In hoofdstuk 7 kom ik op dit thema inhoudelijk terug.

Het wetsvoorstel tot Wijziging van Boek 2 van het Burgerlijk Wetboek in verband met de aanpassing van de regeling voor besloten vennootschappen met beperkte aansprakelijkheid (Wet vereenvoudiging en flexibilisering bv-recht) is 31 mei 2007 door de minister bij de Tweede Kamer ingediend. Het (gewijzigde) wetsvoorstel is 15 december 2009 door de Tweede Kamer aangenomen. Op 12 juni 2012 is het wetsvoorstel door de Eerste Kamer aangenomen.

Het wetsvoorstel tot Aanpassing van de wetgeving aan en invoering van de Wet vereenvoudiging en flexibilisering bv-recht (Invoeringswet vereenvoudiging en flexibilisering bv-recht) is 22 juni 2010 door de minister bij de Tweede Kamer ingediend. Het (gewijzigde) wetsvoorstel is 4 oktober 2011 door de Tweede Kamer aangenomen. Op 12 juni 2012 is het wetsvoorstel door de Eerste Kamer aangenomen.

De Invoeringswet heeft onder meer betrekking op buitenstatutaire afspraken, het aanpassen van de regels voor fusie en splitsing aan de wijzigingen in het BV-recht, de aanpassing van art. 3:259 BW over pandrecht op gecertificeerde aandelen, het in kaart brengen van de incidentele en administratieve lasten van het wetsvoorstel BV-recht, fiscale aspecten, overgangsrechtelijke vraagstukken en de gevolgen voor andere wetgeving van de introductie van winst- en stemrechtloze aandelen. ${ }^{86}$

Beide wetsvoorstellen zijn op 1 oktober 2012 inwerking getreden.

\subsection{Het ambtelijk voorontwerp van het wetsvoorstel en de uiteindelijke keuze voor het stemrechtloze aandeel}

\subsubsection{Inleiding}

In deze paragraaf bespreek ik het ambtelijk voorontwerp van het wetsvoorstel en de uiteindelijke keuze van de wetgever voor het stemrechtloze aandeel. In paragraaf 2.5.2 beschrijf ik op hoofdlijnen het ambtelijk voorontwerp en de aanbevelingen van de Expertgroep. In paragraaf 2.5.3 ga ik in op de reacties uit de rechtspraktijk op het voorontwerp. Vervolgens stel ik in paragraaf 2.5.4 de reacties in de literatuur op het voorontwerp aan de orde. Daarna bespreek ik in paragraaf 2.5.5 de uiteindelijke keuze van de wetgever voor het stemrechtloze aandeel. Paragraaf 2.5.6 vormt de samenvatting van deze paragraaf.

86 Kamerstukken II 2009/10, 32 426, nr. 3, p. 2 (MvT). 


\subsubsection{Het ambtelijk voorontwerp en de aanbevelingen van de Expertgroep}

In de vorige paragraaf memoreerde ik al dat het ambtelijk voorontwerp ${ }^{87}$ in tranches ter consultatie beschikbaar is gesteld. Er zijn drie tranches, te weten: (i) orgaanstructuur en bevoegdheden en aandelen en certificaten, (ii) beslotenheid en geschillenregeling en (iii) kapitaal en vermogen en overige onderwerpen, gelijk de hoofdthema's van het Rapport van de Expertgroep. Voor het stemrechtloze aandeel is de eerste tranche van belang. Ik zal op die tranche in deze paragraaf ingaan.

Het oude BV-recht kende geen stemrechtloos aandeel. In zekere zin is het stemrechtloze aandeel te vergelijken met rechtsfiguren als (onder het oude recht) het bewilligde certificaat en het statutaire winstrecht. Ook in het ambtelijk voorontwerp van de eerste tranche komt het stemrechtloze aandeel niet voor. De memorie van toelichting bij het ambtelijk voorontwerp neemt de aanbeveling van de Expertgroep om geen stemrechtloos aandeel in het Nederlandse recht te introduceren en de overwegingen van de Expertgroep daarbij over. ${ }^{88}$

Van belang is daarom van de anbeveling en de overwegingen van de Expertgroep kennis te nemen. Dat belang is bovendien een onderzoeksbelang, omdat in dit onderzoek ook de verhouding tussen de verscheidene rechtsfiguren zonder stemrecht aan de orde komen.

Het Rapport van de Expertgroep ${ }^{89}$ stelt dat het voor een BV onder omstandigheden wenselijk kan zijn om stemrechtloze aandelen uit te geven: "Een voorbeeld is de situatie waarin een vennootschap haar werknemers de mogelijkheid wil bieden om te participeren in de vennootschap. Hiermee beoogt een vennootschap deze werknemers financieel te laten deelnemen, hetgeen een prikkel kan vormen voor de betrokkenheid en productiviteit van de werknemers. Thans vindt werknemersparticipatie veelal plaats door middel van het uitgeven van certificaten van aandelen aan de werknemers. In joint-ventureverhoudingen of familievennootschappen kunnen stemrechtloze aandelen van betekenis zijn teneinde het eigen vermogen te vergroten zonder dat de bestaande zeggenschapsverhoudingen tussen de aandeelhouders wijzigt ('wijzigen', toevoeging RAW). Denkbaar is voorts dat een bank of een financieringsmaatschappij, als onderdeel van de tegenprestatie voor het beschikbaar stellen van financiële middelen, behoefte heeft aan aandelen waaraan zij onder bepaalde voorwaarden of ten aanzien van bepaalde besluiten stemrecht ontleent." ${ }^{90}$

87 Zie voor een bespreking van het ambtelijk voorontwerp bijvoorbeeld Leemrijse 2005 .

88 Zie MvT, p. 10-11 en 25 bij het ambtelijk voorontwerp van de eerste tranche.

89 Het Rapport van de Expertgroep is onder meer besproken tijdens het vijftiende congres van het Instituut voor Ondernemingsrecht: De vereenvoudiging van het BV-recht. Zie Fleming 2004 voor een verslag van dat congres.

90 Rapport van de Expertgroep, p. 66. 
Vervolgens bespreekt de Expertgroep de stemrechtloze aandelen, zoals andere landen die kennen. Daarna stelt de Expertgroep de vraag of stemrechtloze aandelen in Nederland zouden moeten worden ingevoerd, gelet op het feit dat Nederland reeds certificaten van aandelen en statutaire winstrechten kent. De Expertgroep noemt een aantal verschillen tussen deze drie rechtsfiguren: "Het verschil tussen stemrechtloze aandelen en certificaten is in de eerste plaats dat aandelen worden uitgegeven door de vennootschap, terwijl certificering in beginsel een contractuele aangelegenheid is tussen aandeelhouder en certificaathouder. In de tweede plaats moeten de belangen van de certificaathouder worden behartigd door een aandeelhouder, te weten het administratiekantoor, terwijl de stemrechtloze aandeelhouder in beginsel geen belangenbehartiging kent. In de derde plaats kent de wet aan de certificaathouder op een aantal plaatsen dezelfde rechten toe als de aandeelhouder. Het is de vraag of stemrechtloze aandeelhouders ook vergaderrecht zouden moeten hebben. (...)" ${ }^{\text {91 }}$

Daarnaast stelt de Expertgroep de afbakening met het statutaire winstrecht aan de orde: "Immers, een aandeelhouder brengt vermogen in en verkrijgt als 'tegenprestatie' in hoofdlijnen vergader- en stemrecht en een recht op uitkering van winst en liquidatiesaldo. Bij het stemrechtloos aandeel wordt het stemrecht van het aandeel 'weggesneden' en resteert een rechtsverhouding die slechts omvat een recht op uitkering van winst en liquidatiesaldo. Op deze wijze ontstaat een instrument dat gelijkenis vertoont met een statutair winstrecht, dat immers ook tegen inbreng kan worden uitgegeven." 92

Vervolgens bespreekt de Expertgroep het verschil tussen een stemrechtloos aandeel en een winstbewijs indien de houder van een stemrechtloos aandeel onder bepaalde omstandigheden of ten aanzien van bepaalde besluiten wél stemrecht kan uitoefenen, bijvoorbeeld in gevallen waarin het financieel belang van de stemrechtloze aandeelhouder in het geding is. Het zou dan kunnen gaan om een bijzonder stemrecht in geval van uitkering en emissie van aandelen zonder voorkeursrecht. Ook stelt de Expertgroep de vraag of, en zo ja, welke overige rechten aan houders van stemrechtloze aandelen moeten worden toegekend. De wet zou kunnen bepalen dat de stemrechtloze aandeelhouder dezelfde rechten heeft als de houder van een met medewerking van de vennootschap uitgegeven certificaat. ${ }^{93}$

Uiteindelijk overweegt de Expertgroep: "De Expertgroep meent dat de vele complicaties die de invoering van stemrechtloze aandelen bij de BV met zich brengt, niet opwegen tegen de voordelen daarvan. Een groot deel van de voordelen van stemrechtloze aandelen kan ook worden behaald met certificering van aandelen en de uitgifte van statutaire winstbewijzen. Hierbij wijst de Expertgroep er op dat in haar voorstel de statuten aan houders van certificaten, ook als de vennootschap aan de certificering heeft meegewerkt, het vergaderrecht kunnen onthouden, terwijl aan

91 Rapport van de Expertgroep, p. 68.

92 Rapport van de Expertgroep, p. 69. Zie ook Baert 1999, p. 132.

93 Rapport van de Expertgroep, p. 69. 
stemrechtloze aandelen doorgaans bijzonder stemrecht wordt gekoppeld. ${ }^{94}$ Het voorstel van de Expertgroep dat de statuten kunnen variëren in de toekenning van stemrecht, zal er bovendien toe leiden dat minder behoefte zal bestaan aan stemrechtloze aandelen." ${ }^{95}$

De aanbeveling van de Expertgroep luidt dan ook in Nederland geen stemrechtloze aandelen in te voeren, omdat (i) certificaten en statutaire winstbewijzen reeds mogelijk zijn, (ii) gedifferentieerd stemrecht conform art. 2:228 (nieuw) BW mogelijk wordt, en (iii) een gecompliceerde regeling, zoals in het buitenland moet worden vermeden. ${ }^{96}$

\subsubsection{Reacties uit de rechtspraktijk op het ambtelijk voorontwerp van het wetsvoorstel}

In de consultatie van de eerste tranche is echter - vanuit de praktijk, en dan met name van advocatenkantoren - de kritiek ${ }^{97}$ gekomen op het feit dat het ambtelijk

94 De Expertgroep refereert hierbij aan de Belgische BVBA. Zie Rapport van de Expertgroep, p. 69. Naar Nederlands recht is aan het stemrechtloze aandeel geen bijzonder stemrecht verbonden, anders dan de in paragraaf 6.2 te bespreken beschermingsregels.

95 Rapport van de Expertgroep, p. 70.

96 Rapport van de Expertgroep, p. 70.

97 Zonder volledigheid te willen pretenderen, noem ik de volgende reacties, te vinden op http://www. rijksoverheid.nl/onderwerpen/flexibele-BV/documenten-en-publicaties:

- Loyens \& Loeff d.d. 6 april 2005: De introductie van het stemrechtloze aandeel leidt op zich niet tot vereenvoudiging van het BV-recht. De meerwaarde zit in de gewenste flexibilisering en het gebruik in bijvoorbeeld internationale (houdster)structuren. Met certificering en statutaire winstrechten kan tot op zekere hoogte hetzelfde worden bereikt, doch certificering werkt juridisch-technisch anders uit en werkt kostenverhogend. In internationale verhoudingen leidt certificering tot kwalificatie problemen;

- verslag van de Expertmeeting inzake het BV-recht d.d. 16 december 2005: afsluitende ronde: "Benadrukt wordt dat de praktijk behoefte heeft aan stemrechtloze aandelen";

- Simmons \& Simmons d.d. april 2005: Introductie van een stemrechtloos aandeel zou naast certificering en statutaire winstrechten meer keuzevrijheid en flexibiliteit voor de praktijk inhouden, waaraan in de praktijk behoefte bestaat. Certificering is onhandig, duur en in het buitenland moeilijk uit te leggen. Boekhoudkundig is er een verschil tussen het stemrechtloze aandeel en het statutaire winstrecht. De gerechtigdheid tot de winst van de houder van het statutaire winstrecht zal op de balans moeten worden vermeld. Die houder heeft voorrang op de aandeelhouder bij de uitkering van de winst, zodat er voor de aandeelhouder minder overblijft;

- Nederlandse Vereniging van Participatiemaatschappijen d.d. 25 maart 2005: Door de introductie van stemrechtloze aandelen vervalt de noodzaak van certificering, het administratiekantoor, de kosten van oprichting en de jaarlijkse administratie- en accountantskosten daarvan;

- Houthoff Buruma d.d. 25 maart 2005: Er bestaat in de praktijk behoefte aan het stemrechtloze aandeel. Vrijwel alle EU-landen kennen een dergelijk aandeel. De argumenten van de Expertgroep tegen het stemrechtloze aandeel zijn niet overtuigend. Met statutaire winstrechten is niet hetzelfde te bereiken. De houder van een dergelijk recht profiteert niet van de waardestijging van de onderneming. Certificering is een relatief gecompliceerde structuur, waarbij niet wordt bereikt dat op de aandelen geen stemrecht kan worden uitgebracht. De noodzaak van stemrechtloze $\rightarrow$ 
voorontwerp niet voorzag in het stemrechtloze aandeel. ${ }^{98}$ Aan dat aandeel bestaat in de praktijk veel behoefte. Om uiteenlopende redenen zijn statutaire winstbewijzen, certificering van aandelen en aandelen met flexibel stemrecht niet altijd een goed alternatief. Zo valt certificering in het buitenland lastig uit te leggen. Ten eerste, omdat het op zich al een typisch Nederlands verschijnsel is. Ten tweede, omdat de structuur van certificering complexer en duurder is dan een stemrechtloos aandeel dat eenvoudig statutair is geregeld.

\subsubsection{Reacties in de literatuur op het ambtelijk voorontwerp van het wetsvoorstel}

In de literatuur is (dezelfde) kritiek geuit. Kodde stelt dat de door de Expertgroep genoemde alternatieven voor stemrechtloze aandelen, te weten certificaten en winstrechten, niet aansluiten bij de behoefte in de private equity praktijk. ${ }^{99}$ Van Duuren benadrukt juist dat aan de alternatieven van de Expertgroep nadelen kleven, zoals de onduidelijke grenzen bij uitgifte van winstbewijzen, juist omdat stemrechtloze aandelen onder het oude recht niet waren toegestaan. Daarnaast is een belangrijk nadeel bij certificering de kosten daarvan, bestaande uit het oprichten en in stand houden van een administratiekantoor. Van Duuren stelt dat stemrechtloze aandelen een goede rol kunnen spelen in het geval waarin het ongewenst is dat de stemverhoudingen binnen de vennootschap gewijzigd worden door nieuwe kapitaalinjecties. Van Duuren ziet het stemrechtloze aandeel derhalve als een nuttig financieringsinstrument. ${ }^{100}$

aandelen wordt ook niet minder groot door een flexibele stemverdeling. Een dergelijke verdeling leidt juist tot de conclusie dat stemrechtloze aandelen ook mogelijk zijn;

- VNO-NCW d.d. 24 maart 2005: De afwijzing van het stemrechtloze aandeel overtuigt niet. De alternatieven zijn technisch onnodig gecompliceerd, werken juridiserend en voldoen daardoor niet aan de uitgangspunten van het wetsvoorstel. Stemrechtloze aandelen kunnen nuttig zijn bij werknemersparticipaties, externe kredietverschaffing en nieuwe vormen van ondernemingsfinanciering, waaronder private equity;

- Allen \& Overy d.d. 23 maart 2005: Stemrechtloze aandelen zijn in het buitenland een geaccepteerd fenomeen. Certificering en statutaire winstrechten zijn geen goed alternatief. Bij certificering verplaatst het stemrecht slechts. Daardoor kunnen niet de gewenste stemverhoudingen worden bereikt. Bovendien is de oprichting van een (stichting) administratiekantoor vereist met vaststelling van administratievoorwaarden, hetgeen (onnodig) kostenverhogend is. De toelaatbaarheid van statutaire winstrechten en participatiebewijzen is onduidelijk. Stemrechtloze aandelen hebben internationaal boekhoudkundige of jaarrekeningtechnische voordelen. Stemrechtloze aandelen, certificaten en statutaire winstrechten kunnen naast elkaar bestaan;

- Nauta Dutilh d.d. maart 2005: Het stemrechtloze aandeel is juist geheel in lijn met de gedachte achter het wetsvoorstel. Invoering is daarom gewenst;

- Kennedy Van der Laan d.d. 2 juni 2006: Aandelen zonder stemrecht passen in de flexibilisering van het BV-recht. Certificering is relatief gecompliceerd en duur.

98 Albicher \& Van Mierlo 2005 bespreken de eerste tranche en vatten de kritiek samen op p. 124

99 Kodde 2005, p. 582

100 Van Duuren 2006 (1), p. 13; Van Duuren 2006 (2), p. 8-9 en Verburgh 2006, p. 618. 
Marges is van mening dat het stemrechtloze aandeel in de praktijk een nuttige rol zou kunnen spelen. Anders dan bij het stemrechtloze aandeel, profiteert de houder van een winstrecht in beginsel niet van een waardestijging van de onderneming. Bij certificering vindt alleen een verschuiving van het stemrecht naar het administratiekantoor plaats. Portier ziet als nadeel van certificering dat niet in alle gevallen het bestaan van stemrecht gewenst is. ${ }^{101}$ Ook onderkent Marges de versterking van de concurrentiepositie van de Nederlandse BV ten opzichte van vergelijkbare rechtspersonen in buitenlandse rechtstelsels. ${ }^{102}$ De argumentatie van Marges is niet geheel sluitend. De houder van een winstrecht heeft ook niet te lijden van een waardedaling van de onderliggende waarde in het geval de onderneming minder of geen winst maakt. In dat geval zal de houder van het winstrecht minder of geen winst uitgekeerd zien, maar de keerzijde is dat zijn risico, anders dan bij de aandeelhouder, beperkter is.

Koster wijst op de extra flexibiliteit die het stemrechtloze aandeel biedt. ${ }^{103} \mathrm{Ik}$ neem aan dat hij bedoelt dat naast de reeds bestaande figuren van winstrechten en certificaten het stemrechtloze aandeel een extra alternatief biedt. Koster, Portier en Vermeulen menen dat het stemrechtloze aandeel 'internationaal beter aansluit' dan certificaten en statutaire winstrechten. Invoering van het stemrechtloze aandeel is ook om die reden noodzakelijk. ${ }^{104}$

Portengen is het eens met de argumentatie van de Expertgroep dat de introductie van het stemrechtloze aandeel niet leidt tot vereenvoudiging van het BV-recht. Daarnaast kan Portengen zich ook vinden in de overweging van de wetgever dat met certificering en statutaire winstrechten financieel-economisch eenzelfde resultaat kan worden bereikt als met stemrechtloze aandelen. Die argumenten wegen volgens Portengen echter niet op tegen (i) de eerder genoemde flexibilisering, (ii) het gebruik van het aandeel in internationale (houdster)structuren en (iii) de kwalificatieproblemen van certificaten en statutaire winstrechten in het kader van belastingverdragen. Ook Portengen noemt de eerder aangehaalde bezwaren tegen certificering, namelijk (i) de kostenverhogende werking en (ii) het slechts verschuiven van het stemrecht naar het administratiekantoor. ${ }^{105}$

Portier, gelijk Van Duuren, ${ }^{106}$ stelt dat bij gebruik van participatiebewijzen (waaronder begrepen statutaire winstrechten) die vrijwel als stemrechtloze aandelen worden vormgegeven het gevaar van nietigheid in de zin van art. 3:40 lid 1 BW dreigt. Onder het oude recht waren stemrechtloze aandelen immers niet mogelijk. ${ }^{107}$ Daarom ziet hij de aanbeveling van de Expertgroep niet als een juiste.

\author{
101 Portier 2008, p. 233 \\ 102 Marges 2006, p. 23. \\ 103 Koster 2006, p. 434 \\ 104 Koster 2006, p. 434; Portier 2008, p. 233-234 en Vermeulen 2006, p. 173. \\ 105 Portengen 2006, p. 99-100. \\ 106 Van Duuren 2006 (1), p. 13 en Van Duuren 2006 (2), p. 8-9. \\ 107 Portier 2008, p. 233.
}


Voor zover mij bekend, was alleen Van der Krans het met de aanbeveling van de Expertgroep en de oorspronkelijke keuze van de wetgever eens om niet te voorzien in een stemrechtloos aandeel. Hij vindt dat een goed verdedigbare keuze gelet op het corporate governance debat, waarbij de participatie en het stemmen door aandeelhouders gestimuleerd wordt. ${ }^{108}$

\subsubsection{Uiteindelijke keuze van de wetgever: wél een stemrechtloos aandeel}

De wetgever heeft zich alle kritiek aangetrokken en uiteindelijk wel gekozen voor het stemrechtloze aandeel. De memorie van toelichting verwoordt deze ommezwaai als volgt: "Anders dan bij het opstellen van het ambtelijk voorontwerp werd verondersteld, is gebleken dat er ook naast de invoering van flexibel stemrecht in de statuten (artikel 228 lid 4) behoefte bestaat aan wettelijke facilitering van aandelen zonder stemrecht. Er is in dit verband opgemerkt dat het stemrechtloze aandeel in internationaal verband een gebruikelijke figuur is en daarom van nut kan zijn voor internationale (houdster) structuren. In het preadvies van de Vereeniging Handelsrecht van mr. Van Duuren (hierna: het eerste preadvies) is aangegeven dat de status van participatiebewijzen, zijnde winstrechten die statutair worden vormgeven als een aandeel zonder stemrecht, naar huidig recht onzeker is. Uit de consultatie komt naar voren dat ook certificering in de praktijk geen bevredigend alternatief biedt, omdat daarmee niet wordt bereikt dat op de aandelen geen stemrecht kan worden uitgeoefend. Certificering blijkt bovendien in het buitenland moeilijk uit te leggen en leidt tot relatief hoge kosten in de vorm van het instellen van een administratiekantoor."109

\subsubsection{Samenvatting en commentaar}

De wetgever neemt de in de consultatie en de literatuur genoemde argumenten voor het stemrechtloze aandeel over. Het is echter jammer dat de wetgever niet een uitvoerige motivering voor zijn ommezwaai heeft gegeven. Dat zou het onderscheid tussen de verscheidene rechtsfiguren zonder stemrecht ten goede zijn gekomen.

\subsection{Het stemrechtloze aandeel op hoofdlijnen}

De kritiek op het ontbreken van het stemrechtloze aandeel in het ambtelijk voorontwerp heeft uiteindelijk tot introductie van het stemrechtloze aandeel geleid. In de vorige paragraaf beschreef ik die ontwikkeling en besprak ik de argumenten om uiteindelijk toch voor het stemrechtloze aandeel te kiezen. In deze paragraaf bespreek ik het stemrechtloze aandeel op hoofdlijnen.

108 Van der Krans 2005, p. 8.

109 Kamerstukken II 2006/07, 31 058, nr. 3, p. 11-12 (MvT). 
Art. 2:228 BW, meer in het bijzonder lid 5, introduceert het stemrechtloze aandeel. De statuten kunnen bepalen dat, in afwijking van de hoofdregels van art. 2:228 lid 1 tot en met $4 \mathrm{BW}$, aan aandelen geen stemrecht in de algemene vergadering is verbonden. Een dergelijke regeling kan slechts worden getroffen ten aanzien van alle aandelen van een bepaalde soort of aanduiding waarvan alle aandeelhouders instemmen of waarvan voor de uitgifte in de statuten is bepaald dat daaraan geen stemrecht in de algemene vergadering is verbonden. De aandelen worden in de statuten als stemrechtloos aangeduid. Ten aanzien van stemrechtloze aandelen kan niet op grond van art. 2:216 lid $7 \mathrm{BW}$ worden bepaald dat zij geen recht geven tot deling in de winst of de reserves van de vennootschap.

Met de introductie van het stemrechtloze aandeel in de flex-BV is ook de definitie van de BV, zoals verwoord in art. 2:175 lid $1 \mathrm{BW}$, gewijzigd. Dat artikellid omschrijft de besloten vennootschap met beperkte aansprakelijkheid als een rechtspersoon met een in een of meer overdraagbare aandelen verdeeld kapitaal. De aandelen zijn op naam gesteld. Een aandeelhouder is niet persoonlijk aansprakelijk voor hetgeen in naam van de vennootschap wordt verricht en is niet gehouden boven het bedrag dat op zijn aandelen behoort te worden gestort in de verliezen van de vennootschap bij te dragen, onverminderd het bepaalde in art. 2:192 BW. Ten minste één aandeel met stemrecht ${ }^{110}$ wordt gehouden door een ander dan en anders dan voor rekening van de vennootschap of een van haar dochtermaatschappijen. Voor invoering van de flex-BV werd de BV in art. 2:175 lid 1 (oud) BW omschreven als een rechtspersoon met een in aandelen verdeeld maatschappelijk kapitaal. Aandeelbewijzen worden niet uitgegeven; de aandelen zijn niet vrij overdraagbaar. Een aandeelhouder is niet persoonlijk aansprakelijk voor hetgeen in naam van de vennootschap wordt verricht en is niet gehouden boven het bedrag dat op zijn aandelen behoort te worden gestort in de verliezen van de vennootschap bij te dragen. Het verbod tot uitgifte van aandeelbewijzen in met inwerkingtreding van de flex-BV komen te vervallen.

De wetgever heeft gekozen voor een eenvoudige regeling van het stemrechtloze aandeel. De wetgever verdedigt die keuze door aansluiting te zoeken bij de regeling voor flexibel stemrecht (art. 2:228 lid 4 BW), waarbij evenmin is gekozen voor een uitgebreide regeling voor aandelen die relatief gezien weinig zeggenschap hebben. ${ }^{111}$ Uit paragraaf 2.3 bleek reeds dat in de ons omringende landen er ook wel voor gekozen is in bepaalde gevallen het stemrecht van een stemrechtloos aandeel te doen herleven. Ook Faasen en Schwarz hebben dat bepleit. ${ }^{12}$ Doel van de

110 Daarmee wordt bedoeld een aandeel met stemrecht in de algemene vergadering. Iedere vennootschap heeft een algemene vergadering nodig waarin besluiten genomen kunnen en moeten worden. Er moet dus altijd een aandeel met stemrecht in de algemene vergadering zijn, zo leert Kamerstukken I 2011/ 12, 31058 en 32 426, nr. C, p. 8 (MvA I). 'Bij gelegenheid' zal de wettekst worden aangepast en na de woorden "één aandeel met stemrecht" zal worden toegevoegd "in de algemene vergadering", zie Kamerstukken I 2011/12, 31 058, nr. E, p. 24 (Nadere MvA I).

111 Kamerstukken II 2006/07, 31 058, nr. 3, p. 12 (MvT).

112 Faasen 1989, p. 501 en Schwarz 1990, p. 13-14. 
eenvoudige regeling is tevens de complicaties, zoals door de expertgroep genoemd, te voorkomen. ${ }^{113}$ Ik verwijs naar paragraaf 2.5 .2 over het ambtelijk voorontwerp van het wetsvoorstel.

Nadat sinds de jaren zeventig van de vorige eeuw al een pleidooi gehouden is voor het stemrechtloze aandeel, welk pleidooi zich in de consultatie van de eerste tranche van het ambtelijk voorontwerp vanuit de praktijk heeft voortgezet, wordt het aandeel dan ook na introductie daarvan positief ontvangen. ${ }^{114}$ De eerder in het kader van het pleidooi voor het stemrechtloze aandeel naar voren gebrachte argumenten worden daarbij vaak herhaald.

Echter, er is ook een aantal kritiekpunten op het stemrechtloze aandeel, zoals de wetgever dat heeft geïntroduceerd. Ik kom daarop in paragraaf 4.2 en paragraaf 6.2 bij de verdere bespreking van het stemrechtloze aandeel en in hoofdstuk 9 , waarin ik onder meer aanbevelingen doe, terug.

Het stemrechtloze aandeel kan blijkens de wettekst statutair worden gecreëerd voor uitgifte of na uitgifte daarvan. Na uitgifte van een aandeel kan het daaraan verbonden stemrecht slechts worden ontnomen indien alle houders van die aandelen daarmee instemmen. ${ }^{115}$

De stemrechtloze aandeelhouder heeft alle aandeelhoudersrechten, behalve het stemrecht en het voorkeursrecht ex art. 2:206a BW, tenzij - wat het voorkeursrecht betreft - de statuten anders bepalen. ${ }^{116}$ Zo heeft de stemrechtloze aandeelhouder wel vergaderrecht en winstrecht. Op grond van het bepaalde in art. 2:346 BW kunnen stemrechtloze aandeelhouders onder de in dat artikel geformuleerde voorwaarden een enquêteverzoek indienen. Ook kunnen zij zich tot de rechter wenden met de vordering tot vernietiging van een besluit op grond van art. 2:15 BW. ${ }^{117}$ Hierbij speelt tevens de vennootschappelijke redelijkheid en billijkheid een rol. ${ }^{118}$ Op de rechten van de stemrechtloze aandeelhouder ga ik in paragraaf 6.2 nader in.

Uit de definitie van de BV volgt dat er altijd één aandeel met stemrecht moet zijn, zodat in de algemene vergadering altijd tot besluitvorming kan worden overgegaan. Daarvoor is - uiteraard - stemrecht vereist. ${ }^{119}$

Een aandeel kan niet zowel stemrechtloos als winstrechtloos zijn, zo volgt uit art. 2:190 BW. Rechten die stemrecht noch aanspraak op uitkering van winst of reserves omvatten, worden niet als aandeel aangemerkt. Aan een stemrechtloos

113 Kamerstukken II 2006/07, 31 058, nr. 3, p. 12 (MvT).

114 Zie Van den Nieuwenhuijzen 2008, p. 19; Van Duuren 2007, p. 245, met betrekking tot joint ventures; Advies van de Commissie vennootschapsrecht over het wetsvoorstel inzake de vereenvoudiging en flexibilisering van het b.v.-recht d.d. 23 november 2006, p. 12, te vinden op http://www.rijksoverheid.nl/onderwerpen/flexibele-BV en het advies d.d. 20 september 2007 van de Gecombineerde Commissie Vennootschapsrecht van de Nederlandse Orde van Advocaten en de Koninklijke Notariële Beroepsorganisatie, par. 2.3, p. 2.

115 Kamerstukken II 2006/07, 31 058, nr. 3, p. 86 (MvT).

116 Zie paragraaf 6.2.3.5.

117 Kamerstukken II 2006/07, 31 058, nr. 3, p. 12 (MvT)

118 Art. 2:8 lid 1 sub b BW.

119 Kamerstukken II 2006/07, 31 058, nr. 6, p. 16 (NV II) 
aandeel zal daarom altijd enig recht op uitkering van winst of reserves verbonden moeten zijn. ${ }^{120}$ Daarom bepaalt de laatste volzin van art. 2:228 lid $5 \mathrm{BW}$ dat ten aanzien van stemrechtloze aandelen niet op grond van art. 2:216 lid 7 BW kan worden bepaald dat zij geen recht geven tot deling in de winst of de reserves van de vennootschap. Art. 2:216 lid $7 \mathrm{BW}$ voorziet in de mogelijkheid dat de statuten bepalen aandelen van een bepaalde soort of aanduiding geen of slechts beperkt recht geven tot deling in de winst of reserves van de vennootschap. Daaruit volgt dat wel sprake kan zijn van een stemrechtloos aandeel met beperkt winstrecht of een beperkt recht op de reserves van de vennootschap.

Geheel stemrechtloos is het stemrechtloze aandeel niet. Naast art. 2:216 lid 8 jo. lid 6 volgt dat bijvoorbeeld ook uit art. 2:231 lid 4 BW. ${ }^{121}$ Ik kom daarop in paragraaf 6.2.3.6 en paragraaf 6.2.3.7 terug.

Het stemrechtloze aandeel moet worden onderscheiden van het aandeel met een variabele verdeling van stemrecht, zoals bedoeld in art. 2:228 lid 4 BW. Het wettelijk uitgangspunt is dat het stemrecht zich evenredig verhoudt tot de nominale waarde van de aandelen (art. 2:228 lid 2 en 3 BW). Daarvan kan echter op grond van art. 2:228 lid $4 \mathrm{BW}$ worden afgeweken. Bij statuten kan daarom worden voorzien in een flexibel stemrecht. ${ }^{122}$ Op het flexibele stemrecht ga ik in dit onderzoek niet in. Onderwerp van het onderzoek is immers de kapitaalverschaffer zonder stemrecht.

Het stemrechtloze aandeel moet eveneens worden onderscheiden van het aandeel waarop geen stem kan worden uitgebracht, zoals bedoeld in art. 2:228 lid 6 BW. Dat lid bepaalt (onder meer) dat voor een aandeel dat toebehoort aan de vennootschap of aan een dochtermaatschappij daarvan in de algemene vergadering geen stem kan worden uitgebracht; evenmin voor een aandeel waarvan een van deze vennootschappen de certificaten houdt.

120 Kamerstukken II 2006/07, 31 058, nr. 3, p. 86-87 (MvT).

$121 \mathrm{Zie}$ ook art. 2:232 BW met betrekking tot statutenwijziging en rechten van derden, anders dan aandeelhouders, bijvoorbeeld houders van winstrechten.

122 Zie Kamerstukken II 2006/07, 31 058, nr. 3, p. 84 (MvT). 
In de flex-BV kunnen op hoofdlijnen de volgende soorten aandelen worden onderscheiden: ${ }^{123}$

\begin{tabular}{|l|l|l|}
\hline soort aandeel & beschrijving & $\begin{array}{l}\text { BW Boek 2 } \\
\text { art. }\end{array}$ \\
\hline $\begin{array}{l}\text { aandelen met volledig } \\
\text { stemrecht }\end{array}$ & $\begin{array}{l}\text { aandelen met stemrecht ten aanzien } \\
\text { van alle voorkomende onderwerpen in } \\
\text { de algemene vergadering (ongeacht het } \\
\text { aantal stemmen dat op deze andelen } \\
\text { kan worden uitgebracht) }\end{array}$ & 228 lid 1 \\
\hline $\begin{array}{l}\text { stemrechtloze } \\
\text { aandelen }{ }^{124}\end{array}$ & $\begin{array}{l}\text { aandelen die geen stemrecht hebben in } \\
\text { de algemene vergadering (ongeacht of } \\
\text { deze aandelen stemrecht toekomt in } \\
\text { een vergadering van houders van } \\
\text { stemrechtloze aandeelhouders) }\end{array}$ & 228 lid 5 \\
\hline $\begin{array}{l}\text { beperkt stemgerech- } \\
\text { tigde aandelen }\end{array}$ & $\begin{array}{l}\text { aandelen met beperkt stemrecht ten } \\
\text { aanzien van alle besluiten in de } \\
\text { algemene vergadering }\end{array}$ & $\begin{array}{l}228 \text { lid 2 jo. } \\
\text { lid 4 }\end{array}$ \\
\hline winstrechtloze aandelen & $\begin{array}{l}\text { aandelen die geen recht geven op uit- } \\
\text { kering van winst en/of reserves }\end{array}$ & 216 lid 7 \\
\hline $\begin{array}{l}\text { beperkt winstgerech- } \\
\text { tigde aandelen }\end{array}$ & $\begin{array}{l}\text { aandelen die beperkt recht geven op } \\
\text { uitkering van winst en/of reserves } 25\end{array}$ & 216 lid 7 \\
\hline $\begin{array}{l}\text { aandelen met } \\
\text { gedifferentieerd } \\
\text { stemrecht }\end{array}$ & $\begin{array}{l}\text { aandelen waarop meer dan één stem } \\
\text { kan worden uitgebracht ten aanzien } \\
\text { van alle besluiten in de algemene } \\
\text { vergadering }\end{array}$ & $\begin{array}{l}228 \text { lid } 3 \text { jo. } \\
\text { lid 4 }\end{array}$ \\
\hline
\end{tabular}

123 Dit overzicht is deels ontleend aan Ten Berg 2007, p. 341-345 en Portier 2008, p. 225. Zij hebben geen rekening kunnen houden met wijziging in het wetsontwerp na hun publicaties. Zie Kamerstukken II 2006/07, 31 058, nr. 3, p. 84 (MvT); Kamerstukken II 2008/09, 31 058, nr. 6, p. 16 (NV II); Kamerstukken II 2008/09, 31 058, nr. 7, p. 11 (Nota van wijziging).

124 Ook zijn stemrechtloze aandelen met een beperkt recht op winst en/of reserves mogelijk. Zie paragraaf 4.2.5

125 Kamerstukken I 2011/12, 31058 en 32 426, nr. C, p. 7 (MvA I): "Het is mogelijk een aandeel uit te geven dat niet deelt in de winst, maar wel in het overschot na vereffening." 
De wetgever heeft tijdens de parlementaire behandeling van het wetsvoorstel nog eens de voor- en nadelen van het stemrechtloze aandeel geschetst: ${ }^{126}$

\begin{tabular}{|c|c|}
\hline Voordelen & Nadelen $^{127}$ \\
\hline $\begin{array}{l}\text { Stemrechtloze aandelen vereenvoudi- } \\
\text { gen de mogelijkheid om aandelen toe } \\
\text { te kennen in situaties waarin het vooral } \\
\text { gaat om het bieden van financiële } \\
\text { deelname in de vennootschap, zonder } \\
\text { de stemverhoudingen aan te tasten. } \\
\text { Dat is zichtbaar in situaties waarin men } \\
\text { wel financieel voordeel maar geen } \\
\text { zeggenschap (meer) wil toekennen aan } \\
\text { investeerders, zoals bij (erf-)opvolging } \\
\text { in familievennootschappen, }{ }^{128} \text { bij } \\
\text { werknemersparticipaties }{ }^{129} \text { en bij } \\
\text { banken en financieringsmaatschappijen. }\end{array}$ & $\begin{array}{l}\text { Aan aandeelhouders wordt een belang- } \\
\text { rijk element van het aandeelhouder- } \\
\text { schap ontnomen. Daarom is in het } \\
\text { wetsvoorstel ter bescherming van de } \\
\text { minderheidsaandeelhouder geregeld dat } \\
\text { het winstrecht of stemrecht niet zonder } \\
\text { de instemming van de aandeelhouder } \\
\text { kan worden ontnomen en is bepaald dat } \\
\text { rechten die stemrecht noch aanspraak op } \\
\text { uitkering van winst of reserves omvatten } \\
\text { niet als aandeel worden angemerkt. }\end{array}$ \\
\hline $\begin{array}{l}\text { Stemrechtloze aandelen zijn behulpzaam } \\
\text { in situaties waarin men wil voorkomen } \\
\text { dat de aanvankelijk overeengekomen } \\
\text { stemverhoudingen in een vennootschap } \\
\text { zouden wijzigen bij toekomstige } \\
\text { kapitaalinjecties. }^{130}\end{array}$ & $\begin{array}{l}\text { Als gevolg van eigen keuzes binnen } \\
\text { één vennootschap kan er een grote } \\
\text { diversiteit van aandelen bestaan. Hier- } \\
\text { door kan de complexiteit van statutaire } \\
\text { regelingen toenemen. }\end{array}$ \\
\hline
\end{tabular}

126 Kamerstukken II 2008/09, 31 058, nr. 6, p. $18-19$ (NV II) en Kamerstukken II 2010/11, 32 426, nr. 7 , p. 7 (NV II). In de literatuur wordt ook het gebruik van stemrechtloze aandelen bij drinkwaterbedrijven genoemd: J.D.M. Schoonbrood \& T.J.C. Klein Bronsvoort, 'Lekken in het verzwakte structuurregime bij drinkwaterbedrijven en vennootschappen met een one tier board?', Ondernemingsrecht 2011-16, p. 565-570.

127 Kamerstukken II 2008/09, 31 058, nr. 6, p. 19 (NV II)

128 Ook Portier 2008, p. 232. Portier ziet een rol voor het stemrechtloze aandeel weggelegd in het kader van bedrijfsopvolging. Hij noemt als voorbeeld een vader die de zeggenschap over zijn onderneming wil overdragen aan de kinderen. Vader wil echter wel financieel betrokken blijven. In dat geval kan vader de stemrechtloze aandelen in de vennootschap houden en de kinderen 'gewone' aandelen. Daarnaast kunnen stemrechtloze aandelen een oplossing bieden indien het ene deel van de familie wel en het andere deel niet (nader) wenst te investeren. Door het uitgeven van stemrechtloze aandelen aan het investerende familiedeel wordt bereikt dat zij aanvullende financiële rechten krijgt, terwijl de zeggenschapsverhoudingen binnen de vennootschap niet wijzigen.

129 Ook Portier 2008, p. 232.

130 Portier 2008, p. 231, noemt bijvoorbeeld private equity transacties, waarbij de financiering door investeringsmaatschappijen door middel van een combinatie van eigen en vreemd vermogen geschiedt. Portier ziet het als geen bezwaar dat investeringsmaatschappijen - als houders van stemrechtloze aandelen - vergaderrecht hebben, omdat daarvan ook reeds sprake was onder het oude recht. 


\begin{tabular}{|c|c|}
\hline Voordelen & Nadelen \\
\hline $\begin{array}{l}\text { Ten opzichte van certificering van aan- } \\
\text { delen heeft de uitgifte van stemrechtloze } \\
\text { aandelen als voordeel dat de invoerings- } \\
\text { kosten lager zijn, omdat geen (stichting) } \\
\text { administratiekantoor behoeft te worden } \\
\text { opgericht. }\end{array}$ & \\
\hline $\begin{array}{l}\text { Stemrechtloze aandelen zijn in inter- } \\
\text { nationaal verband een gebruikelijke } \\
\text { figuur en kunnen daarom van nut zijn } \\
\text { voor internationale (houdster-)structu- } \\
\text { ren en voor de aantrekkelijkheid van } \\
\text { Nederland als vestigingsland. }\end{array}$ & \\
\hline $\begin{array}{l}\text { De fiscale kwalificatie van stemrecht- } \\
\text { loze aandelen is door de buitenlandse } \\
\text { fiscus eenvoudiger. Bovendien blijkt in } \\
\text { het buitenland certificering moeilijk uit } \\
\text { te leggen. }\end{array}$ & \\
\hline $\begin{array}{l}\text { Anders dan bij certificaten, waar het } \\
\text { stemrecht toekomt aan een (stichting) } \\
\text { administratiekantoor, kan men bereiken } \\
\text { dat er helemaal geen stemrecht bestaat. }\end{array}$ & \\
\hline $\begin{array}{l}\text { Ten opzichte van participatiebewijzen, } \\
\text { zijnde winstrechten die statutair wor- } \\
\text { den vormgeven als een aandeel zonder } \\
\text { stemrecht, is het voordeel van stem- } \\
\text { rechtloze aandelen dat naar huidig } \\
\text { recht de status van participatiebewijzen } \\
\text { onzeker is. }\end{array}$ & \\
\hline
\end{tabular}

Dit onderzoek ziet op het stemrechtloze aandeel als bedoeld in art. 2:228 lid 5 BW. De door Portier gegeven definitie ('stemrechtloze aandelen zijn aandelen die geen stemrecht hebben in de algemene vergadering') lijkt mij als uitgangspunt juist, te meer omdat de wetgever heeft bedoeld een eenvoudig stemrechtloos aandeel te introduceren. ${ }^{131}$ In paragraaf 4.2.4 zal ik die definitie verder aanscherpen.

In verband met de invoering van het stemrechtloze aandeel zijn ook art. $2: 24 \mathrm{~d}$, 2:63a, 2:152, 2:175, 2:190, 2:194, 2:206a, 2:220, 2:224a, 2:242, 2:252, 2:262 en 2:346 $\mathrm{BW}$ aangepast. Waar nodig zal ik in dit onderzoek op deze artikelen nader ingaan.

131 Portier 2008, p. 225 en Kamerstukken II 2006/07, 31 058, nr. 3, p. 12 (MvT). 


\subsection{Geen stemrechtloos aandeel in het NV-recht}

De wetgever heeft er vooralsnog niet voor gekozen het stemrechtloze aandeel ook in de NV in te voeren. ${ }^{132}$ In de Nota naar aanleiding van het verslag merkt hij daarover op: "De behoefte aan de invoering van stemrechtloze aandelen en aandelen van een bepaalde aanduiding is tot nu toe alleen naar voren gekomen in het kader van het $B V$-recht. Vooralsnog bestaat er geen aanleiding om dergelijke aandelen ook bij naamloze vennootschappen in te voeren." 133

Dat standpunt staat haaks op het hiervoor in paragraaf 2.2 geschetste pleidooi voor invoering van het stemrechtloze aandeel, juist ook in de NV. Ik refereer aan het geconstateerde probleem van absenteïsme op de algemene vergadering van een NV en de gevolgen voor de besluitvorming en het feit dat vaak een aandeel puur als belegging wordt gehouden, veelal bij beursgenoteerde NV's. De aandeelhouder is in dat geval dikwijls alleen geïnteresseerd in dividend en waardestijging van het aandeel.

Het gaat in het kader van dit onderzoek te ver om deze discussie te verdiepen. Opvallend is echter wel dat waar het in de discussie, zoals beschreven in paragraaf 2.2, vooral ging om het pleidooi voor het stemrechtloze aandeel bij de NV, de wetgever heeft gekozen voor introductie van dat aandeel in de BV. Niet uit te sluiten is dat ook bij de NV (nog steeds) behoefte is aan het stemrechtloze aandeel. ${ }^{134}$

\subsection{Samenvatting en conclusie}

$\mathrm{Na}$ een periode van circa veertig jaren van pleidooi voor het stemrechtloze aandeel heeft de wetgever eindelijk gekozen voor de introductie daarvan. Hoewel de discussie over het stemrechtloze aandeel zich voornamelijk toespitste op de NV en wat minder op de BV, kent alleen het BV-recht thans het stemrechtloze aandeel. De wetgever kon niet om de behoefte heen die in de praktijk aan dat aandeel bestaat. In algemene zin dwongen Europese ontwikkelingen, op grond van jurisprudentie en wegens de concurrentiepositie van de Nederlandse BV, tot flexibilisering van het

132 Zie in algemene zin Kamerstukken II 2006/07 31 058, nr. 3, p. 7 en 36 (MvT) en Kamerstukken II 2006/07 31 058, nr. 4, p. 5 (Advies Raad van State).

133 Kamerstukken II 2008/09, 31 058, nr. 6, p. 19 (NV II). Zie ook Kamerstukken II 2011/2012, 32 426, nr. 7, p. 33 (NV II)

134 Nowak \& Van den Ingh 2005 achten de keuze van de minister bij het voorontwerp van het wetsvoorstel vanuit wetsystematisch oogpunt geen juiste. De minister heeft ervan afgezien de gesignaleerde knelpunten bij de NV en de BV alleen voor de BV aan te passen, omdat het karakter van de NV verschilt van de BV. Volgens Nowak \& Van den Ingh gaan de doelstellingen, waaronder een grotere inrichtingsvrijheid, van het wetsvoorstel evenzeer voor de niet beursgenoteerde NV op. Voor de beursgenoteerde NV zou dat anders liggen. Zie ook Nowak \& Van den Ingh 2007, par. 2, p. 122. Zie voor een pleidooi voor het stemrechtloze aandeel bij de NV vanuit het oogpunt van cash out (de)merger, Koster 2011. 
BV-recht, als onderdeel waarvan thans stemrechtloze aandelen gecreëerd kunnen worden.

De wetgever heeft gekozen voor een eenvoudige regeling van het stemrechtloze aandeel. ${ }^{135}$ Kennelijk heeft hij daarbij met een schuin oog naar het stemrechtloze aandeel, zoals Buijs ${ }^{136}$ dat voor ogen staat, gekeken. Het stemrechtloze aandeel is een aandeel dat geen stemrecht heeft in de algemene vergadering. De BV moet ten minste één aandeel met stemrecht hebben. Geheel stemrechtloos is het stemrechtloze aandeel niet, omdat de wet op diverse plaatsen de houder van dat aandeel beschermt. Stemrechtloze aandelen lenen zich vooral in situaties waarin slechts een financiële deelname in de BV is beoogd of indien voorkomen moet worden dat de overeengekomen stemverhoudingen in de algemene vergadering wijzigen. Te denken is daarbij aan bedrijfsopvolging in de familiesfeer of joint venture verhoudingen. Daarnaast is het stemrechtloze aandeel eenvoudiger te creëren dan het certificaat van aandeel. Bij het stemrechtloze aandeel is geen sprake van stemrecht in de algemene vergadering, terwijl bij het certificaat van aandeel slechts een verschuiving van het stemrecht plaats vindt. Tot slot, in het buitenland is het stemrechtloze aandeel als rechtsfiguur meer bekend dan het certificaat van aandeel.

135 Uit paragraaf 4.2 en paragraaf 6.2 zal blijken dat geenszins sprake is van een eenvoudige regeling. 136 Zie Buijs 1995. 

Hoofdstuk 3

KAPITAAL, AANDELEN EN VERWANTE RECHTSFIGUREN

\subsection{Inleiding}

In dit hoofdstuk bespreek ik de begrippen 'kapitaal' van en 'aandelen' in (het kapitaal van) een BV. Ik sta ook stil bij aan aandelen verwante figuren. Het doel van dit hoofdstuk is te komen tot een inventarisatie van de rechtsfiguren zonder stemrecht in de BV. Deze rechtsfiguren moeten tevens kapitaal, in de zin van het juridische kapitaalbegrip, zijn.

Het spreekt voor zich dat het in paragraaf 2.6 reeds besproken stemrechtloze aandeel ex art. 2:228 lid 5 BW een rechtsfiguur zonder stemrecht is. Datzelfde geldt voor het aandeel waarbij het stemrecht is overgedragen aan de vruchtgebruiker of pandhouder. Deze twee rechtsfiguren bespreek ik in respectievelijk paragraaf 4.5 en 4.6.

De vragen die in dit hoofdstuk centraal staan zijn: 'Welke rechtsfiguren zonder stemrecht zijn er (nog meer) in de BV?', 'Wat is de kwalificatie van deze rechtsfiguren zonder stemrecht?' en 'Wat zijn de verschillen tussen deze rechtsfiguren zonder stemrecht?'.

In paragraaf 3.2 besteed ik allereerst aandacht aan het (juridische) begrip 'kapitaal'. In het verlengde daarvan ligt de dualistische structuur van de BV, die ik in paragraaf 3.3 bespreek. Vervolgens ga ik in paragraaf 3.4 in op het onderscheid tussen eigen en vreemd vermogen. Daarmee is het kapitaalbegrip omlijnd en wordt de plaats van het kapitaal in de BV duidelijk. In paragraaf 3.5 bespreek ik het effectenbegrip als verzamelbegrip voor - al dan niet via de effectenbeurs verhandelbare waardepapieren, zoals bijvoorbeeld aandelen en obligaties. Vervolgens sta ik in paragraaf 3.6 stil bij de vraag wat een aandeel is. Diverse soorten aandelen en aanverwante stukken zullen in paragraaf 3.7 de revue passeren om te komen tot een inventarisatie van kapitaal zonder stemrecht in de BV. Tot slot vat ik in paragraaf 3.8 samen en trek ik conclusies.

\subsection{Het kapitaal van de BV}

In de literatuur wordt een aantal gemeenschappelijke kenmerken van een kapitaalvennootschap onderscheiden. Die kenmerken zijn (i) rechtspersoonlijkheid, 
(ii) beperkte aansprakelijkheid, (iii) overdraagbaarheid van aandelen, (iv) een gecentraliseerd management in de vorm van een bestuur (v) en gedeelde eigendom door kapitaalverschaffers. ${ }^{1}$

Het bijeenbrengen van kapitaal ter financiering van de ondernemingsactiviteiten van de vennootschap en de beperkte aansprakelijkheid van haar financiers of aandeelhouders is al zo oud als de oprichting van de Verenigde Oost-Indisch Compagnie (VOC) in $1602 .^{2}$ In Amerikaanse literatuur wordt in dit kader gerefereerd aan de 'Act of Magic'. ${ }^{3}$ Daarmee wordt bedoeld dat deelnemers in het kapitaal van de VOC dat kapitaal permanent aan de VOC ter beschikking stelden. Voor de VOC was dit geen lening, omdat er geen terugbetalingsverplichting van de hoofdsom gold. De VOC kon in feite doen en laten met het kapitaal wat zij wilde. Voor de deelnemer in het kapitaal van de VOC bestond de mogelijkheid tot verkoop van het aandeel in de VOC zonder dat daartoe medewerking van de VOC was vereist. Deze structuur en wijze van financiering van het (eigen) vermogen van de VOC wijkt niet veel af van het huidige BV-recht.

De besloten vennootschap is een kapitaalvennootschap. Het kapitaal dat bij oprichting wordt gerealiseerd, vormt de eerste aanzet tot het (eigen) vermogen van de vennootschap. Dat vermogen wordt gefinancierd of bijeengebracht door de uitgifte van aandelen en door het creëren van reserves, zoals het reserveren van winst of agioreserve. Zowel onder het oude als het nieuwe BV-recht is de aandeelhouder niet persoonlijk aansprakelijk voor hetgeen in naam van de vennootschap wordt verricht. ${ }^{4}$ Aandeelhouders houden aldus aandelen in het kapitaal van de BV en nemen in dat kapitaal deel. In paragraaf $3.6 \mathrm{ga}$ ik nader op het aandeel in.

Door invoering van de flex-BV is het verplichte maatschappelijk kapitaal als bedoeld in art. 2:175 lid $1 \mathrm{BW}$ komen te vervallen. ${ }^{5}$ De wet spreekt nu alleen over de BV als een rechtspersoon met een in aandelen verdeeld kapitaal. Dat neemt niet weg dat het mogelijk blijft in de statuten een maatschappelijk kapitaal op te nemen. ${ }^{6}$

Het kapitaal wordt gevormd doordat de aandeelhouder het aandeel neemt, waartegenover de aandeelhouder tot inbreng van hetgeen overeengekomen op dat aandeel verplicht is. Deze verplichtingen zijn vastgelegd in art. 2:191 en 2:191a BW. Art. 2:191 BW bepaalt onder meer dat bij het nemen van het aandeel moet daarop het nominale bedrag worden gestort. Bedongen kan worden dat het nominale bedrag of een deel daarvan eerst behoeft te worden gestort na verloop van een bepaalde tijd of nadat de vennootschap het zal hebben opgevraagd. Een aandeelhouder kan niet geheel of gedeeltelijk worden ontheven van de verplichting tot

Kraakman e.a. 2009, p. 5.

Zie Asser/Maeijer, Van Solinge \& Nieuwe Weme 2-II* 2009, nr. 1 en De Jongh 2012, p. 7-8.

Steins Bisschop 2010, p. 214.

Art. 2:175 BW, uitgezonderd de mogelijkheden die art. 2:192 BW biedt.

Ook art. 2:190 BW is wegens het verdwijnen van de verplichting tot het hebben van een maatschappelijk kapitaal (zie art. 2:178 BW). Op art. 2:190 BW kom ik in het kader van het begrip 'aandeel' in paragraaf 3.6 terug.

6 Art. 2:178 BW. Zie hierover Bier 2008 (1), p. 172-174. 
storting, behoudens het bepaalde in art. 2:208 BW. Art. 2:191a BW drukt uit onder meer dat storting op een aandeel in geld, eventueel in een andere valuta dan de euro, moet geschieden voor zover niet een andere inbreng is overeengekomen. Het minimum gestort en geplaatst kapitaal van $€ 18.000$ is bij de invoering van de flex-BV afgeschaft. ${ }^{7}$ Hoewel oorspronkelijk bedoeld ter bescherming van crediteuren, is op die verplichting veel kritiek gekomen. ${ }^{8}$ Daarnaast geldt dat $€ 18.000$ bij oprichting voor de ene BV voldoende is en voor de andere BV volstrekt niet. Vergelijk bijvoorbeeld een onderneming in de dienstverlening en een onderneming met kapitaalintensieve productiemiddelen. In dit kader wordt ook wel van 'adequate financiering' van de door de vennootschap gedreven onderneming gesproken. ${ }^{9} \mathrm{De}$ invoering van de flex-BV maakt de oprichting van een BV met een zeer gering kapitaal mogelijk, bijvoorbeeld één aandeel met een nominale waarde van $€ 0,01{ }^{10}$ Blijkens art. 2:191 lid 1 BW kan bedongen worden dat de nominale waarde eerst later dan bij oprichting zal worden gestort.

\subsection{De dualistische structuur van de BV}

De 'Act of Magic' vindt zijn neerslag in de dualistische structuur van de kapitaalvennootschap. ${ }^{11}$ Een kapitaalvennootschap kent ten minste twee organen, namelijk het bestuur en de algemene vergadering. ${ }^{12}$ Het kapitaal is vertegenwoordigd in de

7 Art. 2:178 lid 2 (oud) BW.

8 Kamerstukken II 2006/07, 31 058, nr. 3, p. 26 (MvT).

9 Buijn 2007, p. 356-357 en Bier 2008, p. 188, noot 32.

10 Kamerstukken II 2006/07, 31 058, nr. 3, p. 26 (MvT).

11 Asser/Maeijer, Van Solinge \& Nieuwe Weme 2-II* 2009, nr. 18 en 316. De pluralistische structuur van de structuurvennootschap laat ik buiten beschouwing. Door invoering van de Wet bestuur en toezicht (Wet van 6 juni 2011 tot wijziging van boek 2 van het Burgerlijk Wetboek in verband met de aanpassing van regels over bestuur en toezicht in naamloze en besloten vennootschappen, Kamerstukken 31 763, Stb. 2011, 275 en Wet van 27 september 2012 tot wijziging van boek 2 van het Burgerlijk Wetboek ter verduidelijking van de artikelen 297a en 297b, Kamerstukken 32 873, Stb. 2012, 440. Beide in werking getreden op 1 januari 2013, Stb. 2012, 455 resp. 456) is ook een monistische structuur mogelijk geworden. Met deze wet is een regeling ingevoerd voor het opnemen van uitvoerende bestuurders en toezichthoudende bestuurders in één vennootschapsorgaan (one tier board, art. 2:129a en 239a BW). Daarmee worden inrichting van bestuur en toezicht zowel volgens het dualistische als het monistische model wettelijk vastgelegd. De wet bevat voorts regels voor het geval een bestuurder of commissaris een belang heeft dat tegenstrijdig is met het belang van de vennootschap. Bij de inrichting van een monistisch stelsel verdient dit onderwerp aandacht, omdat de invoering van een stelsel waarbij uitvoerende en toezichthoudende bestuurders in één orgaan zitting nemen, niet zonder gevolgen kan blijven voor wetsbepalingen waarbij - doorgaans om redenen van corporate governance - een dwingendrechtelijke bevoegdheidsverdeling is gemaakt. De wet levert ten slotte een bijdrage aan het vergroten van de bruikbaarheid van de rechtsvorm van de naamloze en de besloten vennootschap in nationale en internationale ondernemingsverhoudingen. Nederland moet rekening houden met een vergrote concurrentie van rechtsvormen in het buitenland.

12 Zie Kamerstukken II 2006/07, 31 058, nr. 3, p. 11 (MvT): "Het is in boek 2 gebruikelijk om te spreken van de algemene vergadering en niet van de algemene vergadering van aandeelhouders, $\rightarrow$ 
algemene vergadering. Het bestuur vertegenwoordigt de factor arbeid en brengt door het drijven van de onderneming van de vennootschap het kapitaal tot rendement. De bevoegdheden van het bestuur van de vennootschap zien dan ook op het drijven van de onderneming en het ontplooien van economische activiteit. Het bestuur is belast met het besturen van de vennootschap (art. 2:239 lid 1 BW). Het bestuur neemt besluiten over de economische activiteit en vertegenwoordigt de vennootschap in het rechtsverkeer (art. 2:240 lid 1 BW). Daarbij is het bestuur gebonden aan en dient het te handelen binnen de grenzen van de statuten. Denk bijvoorbeeld aan de doelomschrijving van de vennootschap (art. 2:7 BW) en - in voorkomend geval - bestuursbesluiten die ter voorafgaande goedkeuring aan de algemene vergadering moeten worden voorgelegd.

De algemene vergadering gaat over het kapitaal en de inrichting van de vennootschap. Daar liggen dan ook de wettelijke bevoegdheden van de algemene vergadering. Te denken valt bijvoorbeeld aan besluiten over het kapitaal zelf (vermeerdering art. 2:206 BW/vermindering art. 2:208 BW), het besluit tot vaststelling van de jaarrekening (art. 2:210 lid $3 \mathrm{BW}$ ), het besluit tot wijziging van de statuten van de vennootschap (art. 2:231 BW), het besluit tot ontbinding van de vennootschap (art. 2:19 BW), het besluit tot aanvraag tot faillissement van de vennootschap (art. 2:246 BW), en - meer indirect - het besluit tot benoeming en ontslag van bestuurders (art. 2:242/2:244 BW) en (eventueel) commissarissen (art. 2:252/254 BW), en besluiten over fusie (art. 2:317 BW). Daarnaast heeft de algemene vergadering alle bevoegdheden, die niet aan het bestuur of anderen is toegekend (art. 2:217 BW).

Uit het Forumbank-arrest ${ }^{13}$ is af te leiden dat de algemene vergadering echter niet de hoogste macht in de BV is. ${ }^{14}$ De verhouding tussen de algemene vergadering en het bestuur van de vennootschap moet zo worden gezien dat de algemene vergadering de grote lijnen van het beleid uitzet en dat het bestuur die lijnen uitwerkt en het beleid uitvoert. ${ }^{15}$ Weliswaar is in de BV sprake van bestuursautonomie, niettemin zijn aan de algemene vergadering belangrijke bevoegdheden toegekend. Ik verwijs naar Bijlage 1 voor de aan gewone aandelen verbonden rechten. Bij de algemene vergadering ligt het zwaartepunt van de bevoegdheidsverdeling. Dat wordt nog eens versterkt door de ontslagbevoegdheid van bestuurders van art. 2:224 $\mathrm{BW}^{16}$ en de instructiebevoegdheid van art. 2:239 lid $4 \mathrm{BW}$.

omdat ook anderen dan aandeelhouders toegang tot de algemene vergadering kunnen hebben. Dit geldt voor de aanduiding van de algemene vergadering als orgaan en als bijeenkomst. Deze technische verduidelijking wordt in dit wetsvoorstel op verschillende plaatsen doorgevoerd." Zie ook Kamerstukken II 2009/10, 32 426, nr. 3, p. 22 (MvT).

13 HR 21 januari 1955, NJ 1959, 43, m.nt. HB (Forumbank).

14 Asser/Maeijer, Van Solinge \& Nieuwe Weme 2-II* 2009, nr. 316.

15 Zie hierover bijvoorbeeld Noordraven 1988, p. 172-173.

16 Zie in dit kader onder meer HR 21 december 2011, LJN AD4499, NJ 2005, 96, m.nt. S.C.J.J. Kortmann, JOR 2002, 38, m.nt. Faber en Bartman (SOBI/Hurks). 
Onder het oude recht gold dat de aanwijzingen van de algemene vergadering van algemene aard moesten zijn en dat van een concrete instructiebevoegdheid geen sprake is. Daarnaast speelde de vraag of het bestuur de aanwijzingen had mogen opvolgen, hetgeen een inhoudelijke beoordeling vergde. ${ }^{17}$ In het nieuwe BV-recht ligt de instructiebevoegdheid genuanceerder. Ik werk het thema van de instructiebevoegdheid nader uit in paragraaf 5.5. De instructiebevoegdheid raakt ook het belang van de kapitaalverschaffer zonder stemrecht.

In de rechtspraktijk komt het echter veelvuldig voor dat aandeelhouders macht naar zich toetrekken door middel van de statuten van de vennootschap of een directiestatuut of -reglement, waarbij bestuurders verplicht zijn bepaalde, belangrijke besluiten ter voorafgaande goedkeuring aan de algemene vergadering voor te leggen. De wettelijke basis daarvan is art. 2:239 lid 3 BW. Ook komt het voor dat het bestuur gehouden is een beleidsplan ter voorafgaande goedkeuring aan de algemene vergadering voor te leggen. Het bestuur is gehouden binnen de kaders van dat goedgekeurde beleidsplan, al dan niet gekoppeld aan een budget, de vennootschap te besturen. Wijkt het bestuur van het beleidsplan af, dan zal het de algemene vergadering moeten raadplegen. Het eerder genoemde zwaartepunt komt dan eens te meer bij de algemene vergadering te liggen.

In paragraaf 2.4 besprak ik de uitgangspunten bij de invoering van de flex-BV, waaronder meer vrijheid voor aandeelhouders om de vennootschap naar eigen inzicht en wensen vorm te geven met voldoende waarborgen voor de belangen van andere partijen. Ik sluit niet uit dat als gevolg van dat uitgangspunt de algemene vergadering - in voorkomend geval - wel de hoogste macht in de BV is of zal worden. ${ }^{18}$ Op de dualistische structuur van de BV kom ik in paragraaf 5.5 terug.

\subsection{Eigen en vreemd vermogen}

Het door de aandeelhouder aan de vennootschap bij oprichting van de vennootschap ter beschikking gestelde kapitaal wordt gezien als eerste aanzet tot het (eigen) vermogen van de vennootschap. Dat vermogen heeft de vennootschap nodig om haar onderneming te drijven, aan het rechtsverkeer deel te nemen en rechtshandelingen te kunnen verrichten. De vennootschap beschouwt dat kapitaal als van haar, omdat - anders dan bij vreemd vermogen - geen terugbetalings- of renteverplichting ${ }^{19}$ geldt. De aandeelhouder stelt kapitaal ter beschikking, omdat hij

17 Naast het eerder genoemde Forumbank-arrest zie ook HR 13 juli 2007, JOR 2007, 178 (ABN AMRO); HR 9 juli 2010, JOR 2010, 288 (ASMI); OK 9 maart 2000, JOR 2000, 99 (Te Pas); Rb. Utrecht 15 maart 2000, JOR 2000, 233 m.nt. Van der Ingh (Unirobe/Geense Beheer); Rb. Leeuwarden 12 november 1987, $N J$ 1988, 699 (Dirkse/Interpolacel) en Vzr. Rb. 's-Gravenhage 7 augustus 2002, JOR 2002, 173 m.nt. Van den Ingh (Wittke/NEM). Kamerstukken II 2006/2007, 31058 , nr. 3, p. 90 (MvT).

18 Zie ook Asser/Maeijer, Van Solinge \& Nieuwe Weme 2-II* 2009, nr. 316.

19 In beginsel: preferente aandelen kunnen een 'rente'-component in zich hebben. 
rendement in de vorm van dividend en/of waardevermeerdering van zijn aandeel wenst of verwacht.

In de literatuur wordt de aandeelhouder ook wel aangeduid als een risicodragende kapitaalverschaffer. Daarmee wordt bedoeld dat het gevaar bestaat dat het door de aandeelhouder aan de vennootschap verstrekte kapitaal teniet kan gaan. De vennootschap kan immers failliet gaan of de aandelen kunnen in waarde dalen. Dat risico lijkt mij echter inherent aan het verschaffen van kapitaal aan een onderneming. Zowel de verschaffer van eigen vermogen als de verschaffer van vreemd vermogen lopen risico. Bij de verschaffer van vreemd vermogen is dat risico erin gelegen dat de verstrekte lening niet kan worden terugbetaald en - indien zekerheden zijn verstrekt - de zekerheden niet voldoende blijken te zijn om volledig verhaal te bieden voor de verstrekte lening. Om deze reden vind ik de aanduiding risicodragend niets toevoegen en gebruik ik haar in dit onderzoek niet.

Het begrip 'kapitaal', zoals ik dat in dit onderzoek gebruik, ziet op het juridische kapitaalbegrip, zoals bedoeld in art. 2:191 en 191a BW en dat ik uiteen heb gezet in paragraaf 3.2. Aandeelhouders nemen aldus deel in het kapitaal van de vennootschap door het houden van één of meerdere aandelen. Het kapitaal dat bij oprichting van de vennootschap bijeen gebracht wordt, ${ }^{20}$ is te beschouwen als het eerste eigen vermogen van de vennootschap. Aandeelhouders zijn aldus kapitaalverschaffers. ${ }^{21}$

Kapitaal is iets anders dan eigen vermogen. Het eigen vermogen wordt, zoals gezegd, gefinancierd of bijeengebracht door de uitgifte van aandelen en door het creëren van reserves, zoals het reserveren van winst of agioreserve. ${ }^{22}$ Ik verwijs verder naar art. 2:364 lid 4 en art. 2:373 lid 1 en 2 BW. De grens tussen eigen en vreemd vermogen is soms lastig te trekken, ${ }^{23}$ gelijk het eerder genoemde onderscheid tussen 'risicodragend' en 'niet-risicodragend' lastig te maken is. ${ }^{24}$ Galavazi \& Van Wilsum stellen dat de rechtsverhouding tussen de vennootschap en een aandeelhouder in hoofdzaak bepaald wordt door twee kenmerken. ${ }^{25}$ De aandeelhouder staat in een lidmaatschapsverhouding tot de vennootschap ${ }^{26}$ en is gerechtigd tot het vermogen van die vennootschap, bijvoorbeeld door zijn aanspraak op het liquidatiesaldo na ontbinding van de vennootschap. Bij vreemd vermogen is sprake van een contractuele verhouding tussen de geldgever en de vennootschap, welke contractuele verhouding tussen de aandeelhouder en de vennootschap ontbreekt. De schuldeiser heeft jegens de vennootschap recht op betaling van rente en aflossing. Hij kan zich op het vermogen van de vennootschap verhalen, maar is niet tot dat

20 Art. 2:178 lid 1 BW

21 Asser/Maeijer, Van Solinge \& Nieuwe Weme 2-II* 2009, nr. 93.

22 Asser/Maeijer, Van Solinge \& Nieuwe Weme 2-II* 2009, nr. 91-92.

23 Van Geffen 2004, p. 211.

24 Zie bijvoorbeeld Eisma 1991, p. 27.

25 Galavazi \& Van Wilsum 1988, p. 131. Wat betreft het liquidatiesaldo kan op grond van art. 2:216 lid 7 BW statutair worden bepaald dat geen recht bestaat op dat saldo.

26 Schwarz 1986, p. 71-74; Slagter 2004, p. 425; Rensen 2005, p. 32; Olaerts 2007, p. 23; Asser/ Maeijer, Van Solinge \& Nieuwe Weme 2-II* 2009, nr. 44 en 190 en Ten Berg 2007, p. 341. 
vermogen gerechtigd. In die zin is geen sprake van een lidmaatschapsverhouding. Een ander onderscheid tussen eigen en vreemd vermogen zou kunnen zijn dat op het eigen vermogen vaak een variabel rendement wordt voldaan, namelijk het dividend op aandelen, terwijl bij vreemd vermogen vaak sprake is van een vast rendement, namelijk het (vaste) rentepercentage. Een volgend gezichtspunt is dat eigen vermogen niet wordt afgedekt door de zekerheden op de activa van de vennootschap en vreemd vermogen vaak wel.

Bij traditionele vormen van een gewoon aandeel en een (obligatie)lening met een vaste rente en looptijd is het onderscheid tussen eigen en vreemd vermogen en risicodragend en niet-risicodragend kapitaal het grootst en makkelijk te maken. In de rechtspraktijk komen echter zeer veel verschillende financieringsinstrumenten voor. Zonder volledigheid te pretenderen, noem ik (cumulatief) preferente aandelen, ${ }^{27}$ converteerbare obligaties, achtergestelde leningen, winstdelende obligaties, participatie- en winstbewijzen. Niet altijd is duidelijk of dergelijke instrumenten te kwalificeren zijn als eigen dan wel vreemd vermogen.

Eisma maakt een driedeling om effecten - op dat begrip kom ik in paragraaf 3.5 terug - te onderscheiden en stelt daarbij het vermogen van de vennootschap centraal. ${ }^{28}$ Die driedeling is als volgt: (i) effecten die voor de uitgevende instelling eigen vermogen vertegenwoordigen (uitgegeven aandelen in het kapitaal van de vennootschap), (ii) effecten die voor de uitgevende instelling vreemd vermogen vertegenwoordigen (obligaties) en (iii) effecten met een gemengd karakter (converteerbare obligaties, winst- en oprichtersbewijzen en, in bepaalde opzichten, certificaten van aandelen).

Bij de bespreking van de soorten effecten en de verschillende soorten rechtsfiguren, in de zin van kapitaal, zonder stemrecht is het van belang deze driedeling in het achterhoofd te houden. Het onderscheid tussen kapitaal, eigen en vreemd vermogen speelt hierbij ook een rol.

\subsection{Het begrip 'effecten'}

In deze paragraaf staat de vraag centraal wat effecten zijn. Voor de definitie van het begrip 'effecten' kan aansluiting worden gezocht bij art. 1:1 Wft. ${ }^{29}$ Een effect is:

27 Onder IFRS, IAS 32, worden preferente aandelen als vreemd vermogen aangemerkt, omdat een dergelijk aandeel voor de vennootschap een (voorwaardelijke) betalingsverplichting met zich mee brengt. Boekhoudkundig is dan geen sprake van winst, maar van betaling van een schuld.

28 Eisma e.a. 2002, p. 24.

29 Wet van 28 september 2006, houdende regels met betrekking tot de financiële markten en het toezicht daarop (Wet op het financieel toezicht). De Wet toezicht effectenverkeer 1995 (Wte 1995) was tot 2007 één van de belangrijkste wetten van onder meer het Nederlandse effectenrecht. In Nederland is het wettelijke toezicht op het effectenverkeer vanaf 2007 geregeld in de Wet op het financieel toezicht, die per 1 januari 2007 in werking is getreden. Zie ook Grundmann-van de Krol 2004 
a. een verhandelbaar aandeel of een ander daarmee gelijk te stellen verhandelbaar waardebewijs of recht niet zijnde een appartementsrecht;

b. een verhandelbare obligatie of een ander verhandelbaar schuldinstrument; of

c. elk ander door een rechtspersoon, vennootschap of instelling uitgegeven verhandelbaar waardebewijs waarmee een in onderdeel $a$ of $b$ bedoeld effect door uitoefening van de daaraan verbonden rechten of door conversie kan worden verworven of dat in geld wordt afgewikkeld.

De Wft ziet op beursgenoteerde vennootschappen, zodat deze definitie wegens de beperking tot de BV van dit onderzoek minder bruikbaar is, maar niettemin een goed uitgangspunt vormt. In het kader van de definitie van 'effect' wordt ook wel onderscheiden tussen effecten met en zonder aandelenkarakter. Het aandelenkarakter houdt in 'een aandeel of een daarmee vergelijkbaar effect, of een door de betrokken uitgevende instelling uitgegeven effect waarmee een aandeel of een daarmee vergelijkbaar recht kan worden verkregen'. ${ }^{30}$ De omschrijving 'aandelen en andere - al of niet op een effectenbeurs - verhandelbare stukken' ${ }^{31}$ voor de verzamelterm $^{32}$ 'effecten' is breder en spreekt om die reden meer aan. Die verzamelterm brengt ook tot uitdrukking dat een beurs of markt niet per se noodzakelijk is voor de verhandelbaarheid van effecten. Dat sluit aan bij het besloten karakter van de BV en de beperkte overdraagbaarheid van in een BV gehouden aandelen. Anders gezegd: hoewel aandelen in een BV in beginsel beperkt overdraagbaar zijn, ${ }^{33}$ sluit dat de verhandelbaarheid niet uit. Eisma stelt dat het bij effecten gaat om al dan niet 'in een papier belichaamde rechten op toekomstig geld, door het uitgeven waarvan de emittent huidig geld ter beschikking verkrijgt, in welke rechten kan worden belegd en welke rechten meestal gestandaardiseerd en overdraagbaar zullen zijn'. ${ }^{34}$ In dat kader maakt hij een onderscheid in effecten, waarbij het vermogen van de uitgeven instelling centraal staat. Ik verwijs naar paragraaf 3.4 .

\subsection{Het begrip 'aandeel'}

Een aandeel is een vermogensrecht in de zin van art. 3:6 BW. Dat vermogensrecht wordt door de aandeelhouder jegens de vennootschap uitgeoefend. ${ }^{35}$ Art. 2:190 BW geeft een negatieve definitie van een aandeel. Rechten die stemrecht noch aanspraak

30 J.M. van Dijk, Tekst \& Commentaar Ondernemingsrecht en Effectenrecht, Deventer: Kluwer 2007, art. 1:1 Wft, aant. 7, p. 1556.

31 Asser/Maeijer, Van Solinge \& Nieuwe Weme 2-II* 2009, nr. 217.

32 Van Schilfgaarde \& Winter 2006, p. 124

33 Zie art. 2:195 BW. Hoofdregel is de in dat artikel geregelde aanbiedingsplicht.

34 Eisma e.a. 2002, p. 23

35 Asser/Maeijer, Van Solinge \& Nieuwe Weme 2-II* 2009, nr. 202; HR 2 december 1994, NJ 1995 , 288 (Poot/ABP), r.o. 3.4.3, m.nt. Ma en Kamerstukken II 2008/09, 31 058, nr. 6, p. 46 (NV II). 
op uitkering van winst of reserves omvatten, worden niet als aandeel aangemerkt. Over die negatieve definitie en wat een aandeel is, zegt de wetgever het volgende: "De minimumvereisten voor een aandeel zijn dus dat er sprake is van een recht dat als aandeel is uitgegeven met inachtneming van de voor uitgifte voorgeschreven formaliteiten en waaraan ten minste stemrecht of aanspraak op uitkeringen uit winst of reserves is verbonden. Ook als er slechts een beperkt winstrecht bestaat en geen enkel stemrecht (...) is er dus sprake van een aandeel. Uit het voorgestelde artikel 190 vloeit immers voort dat ook de enkele aanspraak op reserves voldoende is voor de kwalificatie als aandeel. De formele vereisten voor uitgifte van een aandeel waarborgen het onderscheid met andere figuren waaraan winstrechten zijn verbonden, zoals (statutaire) participatie- of winstbewijzen. Als aan een aandeel slechts een beperkt winstrecht is verbonden en geen stemrecht, betekent dat niet dat het aandeel dan in vennootschapsrechtelijke zin een inhoudsloos recht is. Aan een aandeel zijn immers meer rechten verbonden dan alleen stemrecht of een recht op uitkeringen. Het betreft onder andere het recht om de algemene vergadering bij te wonen en daar het woord te voeren, het recht om een algemene vergadering bijeen te roepen of onderwerpen voor de agenda aan te dragen en het recht om onder bepaalde voorwaarden om een enquete te verzoeken of gebruik te maken van de geschillenregeling." Even verderop overweegt de wetgever: "Uit de negatieve definitie moet niet worden afgeleid dat alle rechten die wél aanspraak geven op uitkering van winst of reserves, als aandeel worden aangemerkt." Het gaat bij aandelen om 'rechten die zijn ingebed in de vennootschapsrechtelijke verhouding tussen de vennootschap en de aandeelhouder'. ${ }^{36}$

In de literatuur wordt een 'aandeel' verschillend omschreven of gedefinieerd. Het aandeel als vermogensrecht in verhouding tot (het kapitaal van) de vennootschap staat daarbij centraal. De aandeelhouder staat in een rechtsbetrekking - een lidmaatschapsverhouding ${ }^{37}$ - tot de vennootschap. De gemene deler van de opvattingen in de literatuur is dat het aandeel een vermogensrecht van eigen aard is. Het aandeel is geen zakelijk recht, maar ook geen gewoon vorderingsrecht, want de schuld die uit hoofde van het aandeel voor de vennootschap jegens de aandeelhouder ontstaat, is van eigen specifieke aard. ${ }^{38}$ De eigen aard bestaat hierin dat aan aandelen zeggenschapsrechten

36 Voor dit alles: Kamerstukken II 2008/09, 31 058, nr. 6, p. $46-47$ (NV II).

37 Schwarz 1986, p. 71-74; Van der Grinten 1991, p. 122 en 125; Bos 2005, p. 100 en 102; Asser/Maeijer, Van Solinge \& Nieuwe Weme 2-II* 2009, nr. 190; Ten Berg 2007, p. 341 en Slagter 2004, p. 425.

38 Asser/Maeijer, Van Solinge \& Nieuwe Weme 2-II* 2009, nr. 202. Ten Berg 2007, p. 340. Prinsen 2004, p. 56, stelt dat aandelen vermogensrechten van eigen aard zijn op het kapitaal van een vennootschap. Slagter 2005, p. 263, refereert (logischerwijs) aan de oude wettelijke definitie van aandelen: aandelen zijn de gedeelten waarin het maatschappelijk kapitaal is verdeeld (art. 2:190 oud BW). Van Schilfgaarde \& Winter 2009, p. 120, zien het aandeel als een recht en spreken daarom over 'het recht van aandeel'. Bier 2008 (1), p. 174, spreekt over een recht jegens de vennootschap dat de houder daarvan zeggenschapsrechten en economische rechten geeft. Zie ook Eisma 2002, p. 27-28. De Kluiver 1994, p. 176, omschrijft het aandeel vanuit rechtseconomisch perspectief als een ratio, 'an undivided fractional interest shared with changing numbers of other holders in a changing aggregate of economic values'. 
en financiële rechten jegens de vennootschap zijn verbonden. Aan aandelen zijn echter ook verplichtingen verbonden. In de flex-BV is het niet meer per definitie zo dat aan aandelen zeggenschapsrechten en financiële rechten verbonden zijn. Er kunnen immers stemrechtloze en winstrechtloze aandelen zijn. Ik verwijs naar de eerder aangehaalde, negatieve, wettelijke definitie als kennelijke 'ondergrens' van een aandeel. Er ontstaat daarom een kwalificatieprobleem. Bij het stemrechtloze aandeel rijzen vragen van afbakening met het participatiebewijs. ${ }^{39}$ De zoektocht naar de specifieke materiële kenmerken van een aandeel levert weinig resultaat op. In de literatuur is in verband met de invoering van de flex-BV daarom ook wel gesteld dat 'een aandeel is een aandeel indien het als zodanig uitgegeven is', hetgeen door de hiervoor aangehaalde parlementaire geschiedenis wordt bevestigd. ${ }^{40}$

Kortom, een 'aandeel' is een vermogensrecht, waaraan in beginsel zeggenschapsrechten en financiële rechten zijn verbonden en dat niet strak omlijnd of gedefinieerd is. In paragraaf 4.2.4 zal ik mijn definitie van het stemrechtloze aandeel formuleren.

\subsection{Soorten aandelen en verwante stukken}

\subsubsection{Inleiding}

In deze paragraaf bespreek ik op hoofdlijnen de verschillende soorten aandelen en aan aandelen verwante stukken. Het doel van deze paragraaf is te komen tot de identificatie van rechtsfiguren, in de zin van kapitaal zonder stemrecht. De afbakening in deze paragraaf is erin gelegen dat ik slechts in ga op mogelijke soorten aandelen en aan aandelen verwante stukken in de BV, die op naam luiden. Een verdere afbakening vindt plaats, doordat ik niet in ga op van aandelen afgeleide producten (derivaten), zoals claims, warrants, termijncontracten, swaps, opties of stock appreciation rights. Een laatste afbakening is de verschijningsvorm van het aandeel. Omdat aandelen in een $\mathrm{BV}$ op naam luiden en daarvan - in beginsel ${ }^{41}$ - geen aandeelbewijzen worden uitgegeven, ga ik ook niet in op toonderaandelen en verschijningsvormen, zoals $\mathrm{K}$-stukken, CF-stukken en verzamelstukken. Achtereenvolgens komen aan de orde: gewone aandelen en de daaraan verbonden rechten, (cumulatief) preferente aandelen, prioriteitsaandelen, oprichtersaandelen, bonusaandelen, certificaten van aandelen,

39 Daarover meer in paragraaf 4.7. Eisma 1991, p. 27, spreekt over een hachelijke zaak.

40 Eisma 1991, p. 36, welke opvatting bijval heeft gekregen van Ten Berg 2007, p. 341; Portengen 2007, p. 942; Portier 2008, p. 244 en Van den Nieuwenhuijzen 2008, p. 23. De Gecombineerde Commissie Vennootschapsrecht van de Nederlandse Orde van Advocaten en de Koninklijke Notariële Beroepsorganisatie stelde in haar advies d.d. 20 september 2007 dat, gelet op de kwalificatievraag, er minimale eisen aan een aandeel zouden moeten worden gesteld, zie par. 2.3, p. 2 van het advies, te raadplegen via http://www.notaris.nl/subsites/commissie/adviezen.htm.

41 De bepaling onder het oude recht dat aandeelbewijzen niet mogen worden uitgegeven is geschrapt, zie art. 2:175 BW en Kamerstukken II 2006/07, 31 058, nr. 3, p. 38 (MvT). 
oprichters- en winstbewijzen, letteraandelen, tracking stock, loyaliteitsaandelen, participatiebewijzen en (converteerbare) obligaties.

\subsubsection{Gewone aandelen}

Gewone aandelen in een BV zijn op naam gestelde aandelen, waaraan geen bijzondere rechten zijn verbonden, zoals de te bespreken preferente of prioriteitsaandelen. De aan gewone aandelen verbonden rechten bespreek ik in paragraaf 3.7.3. Waar ik in dit onderzoek over aandeel en aandeelhouder spreek, doel ik op de hiervoor omschreven gewone aandelen in een BV gehouden door een aandeelhouder.

De BV kent alleen op naam gestelde aandelen. De bepaling onder het oude recht dat aandeelbewijzen niet mogen worden uitgegeven, is geschrapt. ${ }^{42}$ Toonderaandelen mogen niet worden uitgegeven. De gedachte daar achter is dat dit het besloten karakter van de BV zou doorkruisen. Art. 2:195 BW biedt in afwijking van de hoofdregel van de aanbiedingsregeling de mogelijkheid aandelen vrij overdraagbaar te maken. Het bestuur van de BV houdt een aandeelhoudersregister bij waarin de gegevens van de houder van het betreffende aandeel en de gegevens van het aandeel zelf worden opgenomen. ${ }^{43}$ Op het aandeelhoudersregister kom ik in paragraaf 4.11 terug.

\subsubsection{Aan gewone aandelen verbonden rechten}

Het aandeelhouderschap wordt als de eerder genoemde lidmaatschapsverhouding gezien. De aandeelhouder staat in een rechtsbetrekking tot de vennootschap, welke betrekking wordt ingevuld door de wet en de statuten van de vennootschap. Daaruit vloeien rechten en verplichtingen voort. Aan gewone aandelen zijn zeggenschapsrechten en financiële rechten verbonden. Tot de zeggenschapsrechten worden bijvoorbeeld het stem- en vergaderrecht gerekend. Aan aandelen verbonden financiële rechten zijn bijvoorbeeld het recht op dividend en de aanspraak op het liquidatiesaldo. Voor de aan gewone aandelen verbonden rechten ${ }^{44}$ verwijs ik naar Bijlage 1.

\subsection{4 (Cumulatief) preferente aandelen}

Preferente aandelen zijn aandelen waaraan bijzondere, statutaire financiële rechten zijn verbonden, bijvoorbeeld ten aanzien van de winst en/of het liquidatiesaldo. Gewone preferente aandelen geven recht op een bepaald percentage van de winst voordat aan de overige, gewone aandeelhouders dividend wordt uitgekeerd. ${ }^{45}$ Het

42 Zie art. 2:175 BW en Kamerstukken II 2006/07, 31 058, nr. 3, p. 38 (MvT).

43 Art. 2:175 en 2:194 BW.

44 Zie uitputtend Asser/Maeijer, Van Solinge \& Nieuwe Weme 2-II* 2009, nrs. 319-380.

45 Soms ziet de preferente ook op het overschot na vereffening in de zin van art. 2:23b BW. Asser/ Maeijer, Van Solinge \& Nieuwe Weme 2-II* 2009, nr. 219. Vgl. 2:206 a lid 2 aanhef onder b BW. 
percentage wordt gekoppeld aan de nominale waarde van het aandeel. Indien de vennootschap winst maakt, ontvangen de preferente aandeelhouders eerst hun percentage ten laste van de winst. Indien er na uitkering aan de preferente aandeelhouders winst overblijft, komen de gewone aandeelhouders aan bod. De preferente aandeelhouders delen dan niet meer mee in de 'overwinst', tenzij sprake is van preferent winstdelende aandelen. In dat laatste geval delen die aandelen, gelijk gewone aandelen, ook verder in de winst. Van cumulatief preferente aandelen spreekt men indien die aandelen ook recht geven op uitkering van het percentage dat bij gebrek aan winst in de voorgaande jaren niet kon worden uitgekeerd, naast uitkering van het percentage dat ziet op het huidige boekjaar. Ook cumulatief preferente aandelen kunnen winstdelend zijn. ${ }^{46}$ Preferente aandelen kunnen (uiteraard) stemrechtloos zijn. In dat geval is sprake van een aandeel zonder stemrecht met bijzondere, financiële rechten.

\subsubsection{Prioriteitsaandelen}

Prioriteitsaandelen zijn aandelen van een bepaalde soort of aanduiding waaraan de statuten bijzondere zeggenschapsrechten verbinden, zoals het recht van het doen van een bindende voordracht voor de benoeming van bestuurders of commissarissen. ${ }^{47}$ Andere voorbeelden zijn het recht van veto bij statutenwijziging of ontbinding. De wettelijke basis van prioriteitsaandelen voor de BV is art. 2:201 lid $3 \mathrm{BW}$. Net als bij preferente aandelen wordt aldus bij statuten van art. 2:201 lid $1 \mathrm{BW}$ afgeweken. Daarmee wordt het gelijkheidsbeginsel doorbroken. Uit de definitie van het prioriteitsaandeel volgt dat het gaat om versterkt zeggenschapsrecht, zodat de houder van een prioriteitsaandeel niet kwalificeert als aandeel zonder stemrecht.

\subsubsection{Oprichtersaandelen}

Oprichtersaandelen zijn aandelen die aan een of meerdere oprichters van de vennootschap tegen inbreng zijn uitgegeven, bijvoorbeeld voor bewezen diensten. ${ }^{48}$ Het bepaalde in art. 2:204 BW is op een dergelijke uitgifte van toepassing. De term 'oprichtersaandelen' refereert aldus aan degene(n) aan wie het aandeel is uitgegeven. Een oprichtersaandeel moet worden onderscheiden van het hierna in

46 Asser/Maeijer, Van Solinge \& Nieuwe Weme 2-II* 2009, nr. 219; Van Schilfgaarde \& Winter 2009, p. 139-140; Slagter 2005, p. 266 en Sanders \& Westbroek 2005, p. 97. Galavazi \& Van Wilsum stellen dat een cumulatief preferente aandeelhouder een positie inneemt die sterk lijkt op een gewone schuldeiser in vergelijking met de overige, gewone aandeelhouders, zie Galavazi \& Van Wilsum 1988, p. 13, rechterkolom. Die positie komt nog eens versterkt tot uitdrukking indien sprake is van een stemrechtloos (cumulatief) preferent aandeel.

47 Asser/Maeijer, Van Solinge \& Nieuwe Weme 2-II* 2009, nr. 220; Van Schilfgaarde \& Winter 2009, p. 140; Slagter 2005, p. 267 en Sanders \& Westbroek 2005, p. 98.

48 Asser/Maeijer, Van Solinge \& Nieuwe Weme 2-II* 2009, nr. 233. 
paragraaf 3.7.9 te bespreken oprichtersbewijs. Omdat oprichtersaandelen in de regel gewone aandelen zijn, is aan het oprichtersaandeel stemrecht verbonden. Het oprichtersaandeel kwalificeert in dat geval niet als aandeel zonder stemrecht.

\subsubsection{Bonusaandelen}

Bonusaandelen zijn aandelen die worden uitgegeven ten laste van de reserves van de vennootschap. Een variant van bonusaandelen is het stockdividend, waarbij aandelen worden uitgegeven ten laste van de winst in een boekjaar. In beide gevallen hebben de aandeelhouders geen stortingsplicht. ${ }^{49}$ De inbreng heeft al plaatsgevonden. Daarom is het bonusaandeel naar mijn mening niet te beschouwen als een rechtsfiguur dat kapitaal in de vennootschap vertegenwoordigt, in de zin dat de aandeelhouder kapitaal verschaft door middel van (eigen) inbreng. In veel gevallen betreffen het gewone aandelen, waaraan aldus stemrecht is verbonden. Het bonusaandeel kwalificeert in dat geval niet als aandeel zonder stemrecht. Dat neemt uiteraard niet weg dat bonusaandelen aandelen zonder stemrecht kunnen zijn.

\subsubsection{Certificaten van aandelen}

De aandeelhouder kan zijn aandelen certificeren. ${ }^{50}$ Van den Ingh omschrijft certificering van aandelen als volgt: "Certificering van aandelen omvat alle rechtshandelingen die strekken tot verkrijging, krachtens overdracht of uitgifte, van aandelen door de uitgever van certificaten van die aandelen en/of tot uitgifte van certificaten aan degenen voor wie hij als rechthebbende de aandelen ten titel van beheer zal houden." 51 Door certificering wordt de juridische en economische eigendom van de aandelen feitelijk gesplitst. De aandelen worden overgedragen aan en gehouden door een administratiekantoor, dat aldus in goederenrechtelijke zin rechthebbende is. In de praktijk is de rechtsvorm van dat administratiekantoor veelal een stichting, ook wel STAK (STichting AdministratieKantoor) genoemd. De stichting beheert de aandelen en geeft de certificaten uit aan de certificaathouder(s). De rechtsverhouding tussen het administratiekantoor en de certificaathouder(s) is een beheerovereenkomst, die belichaamd wordt in de administratievoorwaarden. Er is aldus sprake van een contractuele grondslag. Tussen het administratiekantoor als aandeelhouder en de vennootschap gelden de wet en de statuten, zodat sprake is van een wettelijke en statutaire basis. In de praktijk komt het ook voor dat de STAK als aandeelhouder in de vennootschap partij is bij een aandeelhoudersovereenkomst, bijvoorbeeld als slechts een deel van de aandelen is gecertificeerd. Strikt genomen,

49 Asser/Maeijer, Van Solinge \& Nieuwe Weme 2-II* 2009, nr. 222; Van Schilfgaarde \& Winter 2009, p. 140; Slagter 2005, p. 217 en 268-269; en Sanders \& Westbroek 2005, p. 130.

50 Voogd 1993, p. 23 e.v.; Asser/Maeijer, Van Solinge \& Nieuwe Weme 2-II* 2009, nr. 230; Van Schilfgaarde \& Winter 2009, p. 141; Slagter 2005, p. 269; Sanders \& Westbroek 2005, p. 140 en Hamers 1996, p. 69 e.v.

51 Van den Ingh 1991, p. 18 
staat dat feit buiten de certificering van aandelen. Het administratiekantoor heeft als aandeelhouder in beginsel de aan de aandelen verbonden zeggenschapsrechten, terwijl de certificaathouder de financiële rechten van het aandeel heeft, zoals het recht op dividend. In de regel berust het aan het aandeel verbonden stemrecht bij de STAK en kunnen andere zeggenschapsrechten aan de certificaathouder(s) zijn toebedeeld. De rechtsfiguur van certificering van aandelen is te vergelijken met het stemrechtloze aandeel. De houder van een certificaat van aandeel is een kapitaalverschaffer zonder stemrecht. In paragraaf 6.3 ga ik nader op deze kapitaalverschaffer in.

\subsubsection{Oprichters-en winstbewijzen}

In de statuten van een vennootschap kan op grond van het bepaalde in art. 2:216 lid 1 jo. 2:232 BW worden bepaald dat aan bepaalde personen, niet zijnde aandeelhouders, een winstrecht wordt toegekend door middel van de uitgifte van winstbewijzen. ${ }^{52,53}$ Indien deze bewijzen aan de oprichters van de vennootschap worden uitgegeven, spreekt men van oprichtersbewijzen. Winst- of oprichtersbewijzen worden uitgegeven als beloning voor bewezen diensten of om andere redenen. In de praktijk wordt van deze bewijzen niet veel gebruik gemaakt. Strikt genomen is de uitgifte van een bewijs niet noodzakelijk. Een regeling daartoe in de statuten is voldoende om het winstrecht te creëren. De rechtsverhouding tussen de houder van een winstbewijs en de vennootschap enerzijds en tussen de aandeelhouder en de

52 In de memorie van toelichting op het ambtelijk voorontwerp, eerste tranche, overweegt de wetgever onder meer (p. 10-11): "Een recht om te delen in de winst kan worden opgenomen in de statuten. Anders dan bij een stemrechtloos aandeel is er bij een statutair winstrecht geen inbreng vereist, is het geen onderdeel van het aandelenkapitaal en zijn er geen vergaderrechten aan verbonden. Een statutair winstrecht kan voorzien in de behoefte om rechten uit te geven met winstdeling doch zonder invloed op de besluitvorming. Een vergelijkbaar resultaat kan worden bereikt via certificering van aandelen. Bij certificering worden de zeggenschap en het financieel-economisch belang gescheiden. (...) Het toevoegen van de figuur van het stemrechtloze aandeel aan de bestaande instrumenten van het statutair winstrecht en certificering zou voor de praktijk meer keuzevrijheid en dus meer flexibiliteit opleveren. (...) De voordelen lijken beperkt, omdat vergelijkbare resultaten kunnen worden bewerkstelligd via statutaire winstrechten en certificering. De nadelen van stemrechtloze aandelen bestaan ondermeer uit de onduidelijkheid die zou ontstaan bij de afbakening tussen statutaire winstrechten en aandelen zonder stemrecht. (...)" De redenering van de wetgever is om meerdere redenen niet juist. Ten eerste, de wetgever gaat bij het statutair winstrecht ervan uit dat geen inbreng plaatsvindt. Bij het stemrechtloze aandeel en het certificaat van aandeel vindt in ieder geval enige inbreng plaats. Ten tweede, de houders van stemrechtloze aandelen hebben per definitie vergaderrecht. Ten derde, de wetgever lijkt ervan uit te gaan dat de certificaathouder per definitie geen invloed heeft op de besluitvorming. Dat lijkt mij onjuist, omdat de indirecte invloed van de certificaathouder op de besluitvorming in de BV er vaak wel is. In het bestuur van de STAK wordt in de praktijk vaak een bestuurder namens de certificaathouders benoemd. Ook komen stemvolmachten voor. De STAK dient daarnaast mede de belangen van de certificaathouders in haar besluitvorming te betrekken. Juist vanwege de verschillen tussen de drie rechtsfiguren van het stemrechtloze aandeel, het certificaat en het participatiebewijs (althans het statutaire winstrecht) hebben die rechtsfiguren bestaansrecht naast elkaar.

53 Vgl. stock appreciation rights. 
vennootschap anderzijds verschilt essentieel. Bij het aandeelhouderschap is sprake van een lidmaatschapsverhouding. Bij winstbewijzen is de heersende opvatting in de literatuur dat sprake is van schuldvorderingspapieren en dat sprake is van een contractuele verhouding. ${ }^{54} \mathrm{Zij}$ kunnen op naam, aan order of toonder luiden. De wet noemt winstbewijzen als zodanig niet. Aan houders van winstbewijzen komt geen stemrecht toe.

Anders dan bij de houder van een participatiebewijs, neemt de houder van een winstbewijs geen deel in het kapitaal van de vennootschap. ${ }^{55}$ Tegenover de uitgifte van het winstbewijs staat geen verplichting tot storting of inbreng, zoals dat bijbijvoorbeeld - de aandeelhouder en de houder van een participatiebewijs wel het geval is. Hoewel de houder van een winstbewijs, gelijk de stemrechtloze aandeelhouder, geen stemrecht heeft en aan zijn rechten niet zomaar afbreuk kan worden gedaan, ${ }^{56}$ verschaft hij echter geen kapitaal. Naar mijn mening kwalificeert het oprichters- en winstbewijs bij gebrek aan verplichting tot storting of inbreng niet als een rechtsfiguur zonder stemrecht. De houder van dergelijke bewijzen is daarom niet een kapitaalverschaffer zonder stemrecht. Het verschil in lidmaatschapsverhouding enerzijds en contractuele verhouding anderzijds acht ik in het kader van deze kwalificatie minder van belang.

\subsubsection{Letteraandelen}

Aandelen kunnen met letters worden aangeduid. ${ }^{57}$ Daarmee kan onderscheid worden gemaakt aan de met een letter aangeduide aandelen verbonden rechten, bijvoorbeeld dat de houder van het aandeel met een bepaalde letter (slechts) gerechtigd is tot een bepaald gedeelte van het eigen vermogen. Vaak betreffen het gewone aandelen, maar dat hoeft niet. In een flex-BV kunnen bijvoorbeeld gewone aandelen met letter A, winstrechtloze aandelen met letter B en stemrechtloze aandelen met letter $\mathrm{C}$ worden aangeduid. Letteraandelen behoeven een statutaire basis. Letteraandelen kunnen ook worden gebruikt voor zowel speciale zeggenschaps- als financiële rechten. Zo kunnen prioriteitsaandelen met een letter worden aangeduid, maar ook preferente aandelen. Differentiatie binnen de zeggenschaps- en financiële rechten is ook mogelijk. In dat laatste geval is te denken aan dividendpolitiek, zodat houders van die bepaalde

54 Asser/Maeijer, Van Solinge \& Nieuwe Weme 2-II* 2009, nr. 233; Van Schilfgaarde \& Winter 2009, p. 140; Slagter 2005, p. 278; Sanders \& Westbroek 2005, p. 100; Eisma e.a. 2002, p. 36-37; Rensen 2005, p. 36; Uittien \& Alleman 2010, p. 308 en Van der Grinten 1991, p. 122-124. Sanders \& Westbroek 2005, p. 100, noot 4, stellen dat winstbewijzen ook wel worden aangeduid als participatiebewijzen. Ook Eisma ziet winstbewijzen als participatiebewijzen, zie Eisma 1991, p. 29. Dat lijkt mij niet juist gelet op de gegeven definitie van het participatiebewijs.

55 Van der Grinten 1991, p. 124-125; Prinsen 2004, p. 127, noot 140 en Rensen 2005, p. 36

56 Zie art. 2:232 BW, Asser/Maeijer, Van Solinge \& Nieuwe Weme 2-II* 2009, nr. 233 en Sanders \& Westbroek 2005, p. 101

57 Asser/Maeijer, Van Solinge \& Nieuwe Weme 2-II* 2009, nr. 226; Van Schilfgaarde \& Winter 2009, p. 140; Slagter 2005, p. 265; Sanders \& Westbroek 2005, p. 99 en Bier 2003, p. 145-147. 
letteraandelen kunnen bepalen of zij de hen toekomende winst willen reserveren of uitkeren, al dan niet gedeeltelijk. Voor de BV is de wettelijke basis van letteraandelen art. 2:201 lid 3 BW. Gelet op het voorgaande zijn letteraandelen strikt genomen aldus geen aandelen van een bepaalde soort.

\subsubsection{Tracking stock}

Door middel van tracking stock, veelal letteraandelen, kunnen aan aandelen winstrechten worden toegekend van een bepaald bedrijfsonderdeel, bijvoorbeeld een divisie, of een deelneming in plaats van het recht op winst van de gehele onderneming. In tegenstelling tot een gewoon aandeel vertegenwoordigt tracking stock aldus een deel in het ondernemingsvermogen. Tracking stock is niet in de wet geregeld. Feitelijk is sprake van letteraandelen, zodat de statuten erin moeten voorzien. ${ }^{58}$

\subsubsection{Loyaliteitsaandelen}

Loyaliteitsaandelen zijn gewone aandelen waarbij aan bepaalde, loyale aandeelhouders extra stem- of winstrechten zijn toegekend. Het gaat daarbij om aandeelhouders die reeds langere tijd aan de vennootschap verbonden zijn of aandeelhouders die zich voor langere tijd aan de vennootschap binden, al dan niet op grond van een overeenkomst. ${ }^{59}$ Het loyaliteitsdividend moet in de statuten zijn geregeld. ${ }^{60}$ Omdat loyaliteitsaandelen in de regel gewone aandelen zijn, kwalificeren zijn niet als aandeel zonder stemrecht.

\subsubsection{Participatiebewijzen}

Participatiebewijzen ${ }^{61}$ worden tegen storting of inbreng verkregen en vertegenwoordigen kapitaal in de vennootschap. De houder van een participatiebewijs participeert in het eigen vermogen van de vennootschap. De storting of inbreng door de houder van het participatiebewijs wordt als (overige) reserve geboekt. Aan een participatiebewijs zijn soms alle rechten - gelijk een gewoon aandeel verbonden, behalve het stemrecht. ${ }^{62}$ Dat hoeft echter niet. Ook het vergaderrecht

58 Asser/Maeijer, Van Solinge \& Nieuwe Weme 2-II* 2009, nr. 228; Slagter 2005, p. 265; Sanders \& Westbroek 2005, p. 99; Bier 2003, p. 148-156 e.v. en Groenewald 2004, p. 194 e.v.

59 Asser/Maeijer, Van Solinge \& Nieuwe Weme 2-II* 2009, nr. 226

60 HR 14 december 2007, LJN BB3523, NJ 2008, 105 (DSM), m.n. Ma; JOR 2008, 11, m.nt. Doorman (DSM). Zie over loyaliteitsdividend ook De Beurs 2011 en Koelemeijer \& Hendriks 2012.

61 Zie uitgebreid over het participatiebewijs: Blanco Fernández \& Schwarz 1992, p. 287 e.v. en Prinsen 2004, p. 127-137.

62 In dat kader is onder het oude recht betoogd dat het op contractuele wijze creëren van stemrechtloze aandelen door het uitgeven van participatiebewijzen met als doel het aan aandelen dwingendrechtelijke verbonden stemrecht te omzeilen nietig in de zin van art. 3:40 lid $1 \mathrm{BW}$ is, zie $\rightarrow$ 
kan de houder van een participatiebewijs, anders dan een aandeelhouder, worden onthouden. Houders van participatiebewijzen hebben aanspraak op een deel van de winst en/of het liquidatiesaldo. ${ }^{63}$ Participatiebewijzen hebben net als winstbewijzen een statutaire basis en een contractuele grondslag. Hoofdregel is immers dat de winst de aandeelhouders ten goede komt. Houders van participatiebewijzen zijn geen aandeelhouders, zodat de statuten er in moeten voorzien houders van participatiebewijzen een (recht op een) deel van de winst te doen toekomen. Die statutaire basis houdt evenwel niet in dat sprake zou zijn van een lidmaatschapsverhouding, zoals daarvan bij de aandeelhouder sprake is. Er is sprake van een andere verhouding. De invulling van het recht op (een deel van) de winst heeft een contractuele grondslag. ${ }^{64}$ Veelal zal op die rechtsverhouding Nederlands recht van toepassing zijn, gelet op het feit dat een BV een rechtspersoon naar Nederlands recht is, tenzij voor een ander toepasselijk recht wordt gekozen. Het gevolg van de toepassing van het Nederlandse recht en de contractuele verhouding is dat ook de bepalingen van Boek 6 BW, waaronder de redelijkheid en billijkheid van art. 6:2 en 6:248 BW, van toepassing zijn. De vraag of de houder van een participatiebewijs ook als 'betrokkene' in de zin van art. 2:8 BW aan te merken is, behandel ik in paragraaf 7.4

Vanuit economisch perspectief is het de vraag (i) of de waarde van een participatiebewijs gelijk opgaat met de waarde van een aandeel, en (ii) of de waarde van een participatiebewijs afhankelijk is van de waarde(ontwikkeling) van de vennootschap. ${ }^{65}$ In de regel zal op beide vragen het antwoord ontkennend zijn, omdat aan het participatiebewijs doorgaans een lager winstrecht en minder rechten verbonden zijn dan aan een aandeel. Ook de (on)voorwaardelijkheid van het winstrecht speelt daarbij een rol. Boekhoudkundig is er een verschil tussen het stemrechtloze aandeel en het statutaire winstrecht. De gerechtigdheid tot de winst van de houder van het statutaire winstrecht zal op de balans moeten worden vermeld. Die houder heeft voorrang op de aandeelhouder bij de uitkering van de winst, zodat er voor de aandeelhouder minder overblijft. ${ }^{66}$

Op het onderscheid tussen het stemrechtloze aandeel en het participatiebewijs kom ik in paragraaf 4.7 terug. Het participatiebewijs is naar mijn mening te

Blanco Fernández \& Schwarz 1992, p. 288. Eisma 1991, p. 37, is van mening dat geen sprake is van nietigheid. Hij stelt dat het participatiebewijs zo kan worden ingericht dat in materiële zin sprake is van een stemrechtloos aandeel. Gelet op de introductie van het stemrechtloze aandeel in de flex-BV is deze discussie inmiddels achterhaald.

63 Asser/Maeijer, Van Solinge \& Nieuwe Weme 2-II* 2009, nr. 233; Van Schilfgaarde \& Winter 2009 , p. 140; Slagter 2005, p. 279; Sanders \& Westbroek 2005, p. 100, noot 4; Eisma 1991, p. 29 en Blanco Fernández \& Schwarz 1992, p. 287.

64 Asser/Maeijer, Van Solinge \& Nieuwe Weme 2-II* 2009, nr. 233; Sanders \& Westbroek 2005, p. 100; Eisma 1991, p. 30, 31 en 37; Ten Berg 2007, p. 341; Bier 2008 (1), p. 175; Galavazi \& Van Wilsum 1988, p.132, rechterkolom; Blanco Fernández \& Schwarz 1992, p. 290 en Stokkermans 2008 (1), p. 26.

65 Van den Nieuwenhuijzen 2008, p. 23

66 Prinsen 2004, p. 133 en reactie Simmons \& Simmons, zie voetnoot 97 in hoofdstuk 2. 
beschouwen als een rechtsfiguur zonder stemrecht. De houder van een participatiebewijs is daarom te beschouwen als een kapitaalverschaffer zonder stemrecht.

\subsubsection{4 (Converteerbare) obligaties}

Naast de hiervoor genoemde aandelen, certificaten van aandelen en aan aandelen verwante stukken sta ik ook stil bij obligaties, meer in het bijzonder bij converteerbare obligaties. ${ }^{67}$ Houders van obligaties zijn schuldeisers van een vennootschap. Meestal geven obligaties een vaste rente. Vaak luiden zij aan toonder, maar dat hoeft niet. Obligaties kunnen ook op naam luiden. De wet spreekt over schuldbrieven. ${ }^{68}$ Ook komen winstdelende obligaties voor, waarbij de houder van een dergelijke obligatie recht heeft op een deel van de winst (in de vorm van rente). Een andere vorm van een winstdelende obligatie is dat door de vennootschap aan de obligatiehouder eerst rente wordt voldaan indien de vennootschap winst heeft gemaakt. De heersende opvatting in de literatuur is dat een obligatiehouder een schuldeiser van de vennootschap is. ${ }^{69}$ Hij verschaft, als verstrekken van vreemd vermogen, geen kapitaal in de zin van het kapitaalbegrip van paragraaf 3.2. Om die reden beschouw ik de obligatie niet als een rechtsfiguur zonder stemrecht en de obligatiehouder niet als een kapitaalverschaffer (zonder stemrecht) van de vennootschap.

De vraag is of een converteerbare obligatie ${ }^{70}$ ook te beschouwen is als een rechtsfiguur zonder stemrecht. De houder van een converteerbare obligatie heeft het recht onder bepaalde voorwaarden zijn obligatie in te wisselen voor een aandeel. De schuld van de vennootschap, zijnde vreemd vermogen, wordt in dat geval omgezet in eigen vermogen. Naar mijn mening kwalificeert de converteerbare obligatie niet als een rechtsfiguur zonder stemrecht en de houder van een converteerbare obligatie niet als een kapitaalverschaffer (zonder stemrecht) van de vennootschap. Zolang die houder zijn recht nog niet uitgeoefend heeft, is hij immers schuldeiser van de vennootschap en geen kapitaalverschaffer in de zin van het in paragraaf 3.4 genoemde kapitaalbegrip. Na conversie is de houder van de obligatie mogelijk een kapitaalverschaffer zonder stemrecht, namelijk in het geval geconverteerd is in een stemrechtloos aandeel.

Het onderscheid met het hiervoor besproken participatiebewijs is gelegen in het feit dat het participatiebewijs, anders dan de converteerbare obligatie, een statutaire basis heeft, omdat de hoofdregel is dat de winst ter beschikking van de aandeelhouders staat (art. 2:216 BW). ${ }^{71}$ Hoewel het participatiebewijs ook, en de converteerbare obligatie uitsluitend, een contractuele grondslag hebben, is de statutaire

67 Zie over dit onderwerp uitgebreid: Prinsen 2004.

$68 \mathrm{Vgl}$. art. 2:102 BW.

69 Asser/Maeijer, Van Solinge \& Nieuwe Weme 2-II* 2009, nr. 234; Van Schilfgaarde \& Winter 2009, p. 141-142; Slagter 2005, p. 275; Sanders \& Westbroek 2005, p. 91-92 en Eisma e.a. 2002, p. 33-36.

70 Zie uitgebreid over converteerbare obligaties: Prinsen 2004.

71 Blanco Fernández \& Schwarz 1992, p. 289-290. 
basis - naar mijn mening - doorslaggevend voor het feit dat het participatiebewijs wel, en de houder van converteerbare obligatie niet, als een kapitaalverschaffer zonder stemrecht is aan te merken. Daarbij komt dat de obligatiehouder een gewone crediteur van de vennootschap is ${ }^{72}$ en de houder van een participatiebewijs, gelijk een aandeelhouder, een post-concurrente crediteur is. De vennootschap zal de obligatiehouder op grond van de leningsovereenkomst in de regel moeten terugbetalen. Bij een aandeelhouder of houder van een participatiebewijs is van een dergelijke verplichting geen sprake. Toegegeven zij, dat de scheidslijn bij de diverse, hybride financieringsinstrumenten, die zowel kenmerken van een aandeel als kenmerken van een lening vertonen, niet altijd scherp te trekken is. ${ }^{73}$

\subsection{Samenvatting en conclusie}

In dit hoofdstuk kwamen de begrippen 'kapitaal' van en 'aandelen' in een BV aan de orde en werden de rechtsfiguren zonder stemrecht in de BV geïnventariseerd. Het stemrechtloze aandeel en het aandeel waarbij het stemrecht is overgedragen aan de vruchtgebruiker of pandhouder is daarbij buiten beschouwing gelaten.

De BV is een rechtspersoon met een in aandelen verdeeld kapitaal. Het kapitaal wordt gevormd doordat de aandeelhouder het aandeel neemt, waartegenover de aandeelhouder tot inbreng van hetgeen overeengekomen op dat aandeel verplicht is. De invoering van de flex-BV maakt de oprichting van een BV met een zeer gering kapitaal mogelijk. Dat kapitaal hoeft niet bij oprichting te worden gestort. Het kapitaal dat bij oprichting bijeen wordt gebracht, is het eerste eigen vermogen van de BV. Het aandeel vertegenwoordigt de lidmaatschapsverhouding van de aandeelhouder met de vennootschap. Het aandelenkapitaal behoort tot het eigen vermogen van de BV.

De dualistische structuur van de BV brengt mee dat de algemene vergadering over het kapitaal en de inrichting van de vennootschap gaat. In dat kader zijn aan de algemene vergadering wettelijke bevoegdheden toegekend. Het bestuur van de BV gaat over het drijven van de aan de BV verbonden onderneming en het ontplooien van de economische activiteit. De verhouding tussen de algemene vergadering en het bestuur kan zo worden gezien dat de algemene vergadering de grote lijnen van het beleid uitzet en het bestuur die lijnen uitwerkt en het beleid uitvoert. Daarbij is sprake van bestuursautonomie.

Effecten zijn aandelen en andere, al dan niet op een effectenbeurs, verhandelbare stukken. 'Effecten' is een verzamelterm, waaronder het 'aandeel' valt. Een aandeel is een vermogensrecht, welk recht door de aandeelhouder jegens de BV wordt

72 Tenzij sprake is van een achtergestelde obligatie.

73 Zie bijvoorbeeld Galavazi \& Van Wilsum 1988, p. 131; Ten Berg 2007, p. 340-341; Bier 2008 (1), p. 174-175 en Eisma e.a. 2002, p. 22 e.v. Denk bijvoorbeeld ook aan perpetuals (eeuwigdurende obligaties). 
uitgeoefend. Art. 2:190 BW geeft een negatieve definitie van een aandeel. De heersende opvatting in de literatuur ten aanzien van de materiële kenmerken van een aandeel is dat 'een aandeel een aandeel is indien het als zodanig is uitgegeven'.

Gewone aandelen in een BV zijn aandelen op naam, waaraan geen bijzondere rechten zijn verbonden. Voor het overzicht van aan gewone aandelen verbonden rechten verwijs ik naar Bijlage 1.

Uit de inventarisatie van soorten aandelen en verwante stukken blijkt dat - naast het stemrechtloze aandeel en het aandeel waarbij het stemrecht is overgedragen aan de vruchtgebruiker of pandhouder (dat in paragraaf 4.5 respectievelijk $4.6 \mathrm{zal}$ worden besproken) - het participatiebewijs en het certificaat van aandeel te beschouwen zijn als rechtsfiguren zonder stemrecht, die tevens kapitaal in de BV vertegenwoordigen. 


\section{Hoofdstuk 4}

\section{KAPITAALPARTICIPATIE ZONDER STEMRECHT}

\subsection{Inleiding}

Uit het voorgaande volgt dat de rechtsfiguren zonder stemrecht in mijn onderzoek zijn: (i) het stemrechtloze aandeel, (ii) het certificaat van aandeel, (iii) het aandeel waarbij stemrecht is overgedragen aan de vruchtgebruiker, (iv) het aandeel waarbij stemrecht is overgedragen aan de pandhouder en (v) het participatiebewijs.

In dit hoofdstuk staat de aard van deze rechtsfiguren centraal. Achtereenvolgens bespreek ik het stemrechtloze aandeel (paragraaf 4.2), certificaten van aandelen (paragraaf 4.4), het aandeel waarbij stemrecht is overgedragen aan de vruchtgebruiker (paragraaf 4.5), het aandeel waarbij stemrecht is overgedragen aan de pandhouder (paragraaf 4.6) en het participatiebewijs (paragraaf 4.7). In paragraaf 4.3 bezie ik het stemrechtloze aandeel in het licht van enkele wettelijke bepalingen. In paragraaf 4.8 sta ik stil bij het belang van de kwalificatie van de rechtsfiguren zonder stemrecht. Vervolgens baken ik in paragraaf 4.9 het door mij gebruikte begrip 'rechtsfiguur zonder stemrecht' verder af. In paragraaf 4.10 definieer ik het begrip van 'de kapitaalverschaffer zonder stemrecht', zoals ik dat in dit onderzoek verder zal gebruiken. Daarna stel ik in paragraaf 4.11 de vraag of, en zo ja, welke rechtsfiguren zonder stemrecht in het aandeelhoudersregister moeten worden opgenomen. Ik sluit af met een samenvatting en conclusie (paragraaf 4.13).

\subsection{Het stemrechtloze aandeel}

\subsubsection{Inleiding}

In hoofdstuk 2 besprak ik het stemrechtloze aandeel op hoofdlijnen. Zoals opgemerkt, heeft de wetgever gekozen voor een eenvoudig stemrechtloos aandeel. ${ }^{1}$ In deze paragraaf ga ik nader in op het stemrechtloze aandeel van art. 2:228 lid 5 BW.

1 Uit de parlementaire geschiedenis is niet goed op te maken waarom gekozen is voor het stemrechtloze aandeel in deze eenvoudige vorm. In de literatuur - ik verwijs naar hoofdstuk 1 - zijn pogingen gedaan om het stemrechtloze aandeel vorm te geven. Zie bijvoorbeeld Faasen 1989; Schwarz 1990; Eisma \& De Keijzer 1994 en Buijs 1995. 


\begin{tabular}{|c|c|c|}
\hline & Kenmerken (op hoofdlijnen) van het stemrechtloze aandeel & $\begin{array}{l}\text { BW Boek } \\
2 \text { art. }\end{array}$ \\
\hline 1. & $\begin{array}{l}\text { Het stemrechtloze aandeel kan statutair worden gecreëerd voor } \\
\text { uitgifte of na uitgifte daarvan. }\end{array}$ & $228 \operatorname{lid} 5$ \\
\hline 2. & $\begin{array}{l}\text { Na uitgifte van een aandeel kan het daaraan verbonden stemrecht } \\
\text { slechts worden ontnomen indien alle houders van die aandelen } \\
\text { daarmee instemmen. }\end{array}$ & $228 \operatorname{lid} 5$ \\
\hline 3. & $\begin{array}{l}\text { De stemrechtloze aandeelhouder heeft alle aandeelhoudersrechten, } \\
\text { behalve het stemrecht in de algemene vergadering en het voor- } \\
\text { keursrecht ex art. 2:206a BW, tenzij - wat het voorkeursrecht } \\
\text { betreft - de statuten anders bepalen. Zo heeft de stemrechtloze } \\
\text { aandeelhouder wel vergaderrecht en winstrecht. }\end{array}$ & $228 \operatorname{lid} 5$ \\
\hline 4. & $\begin{array}{l}\text { Stemrechtloze aandeelhouders kunnen een enquêteverzoek indie- } \\
\text { nen. }\end{array}$ & 346 \\
\hline 5. & $\begin{array}{l}\text { Stemrechtloze aandeelhouders kunnen zich tot de rechter wenden } \\
\text { met de vordering tot vernietiging van een besluit. Hierbij speelt de } \\
\text { vennootschappelijke redelijkheid en billijkheid een rol. }\end{array}$ & 15 jo. 8 \\
\hline 6. & $\begin{array}{l}\text { Uit de definitie van de BV volgt dat er ten minste één aandeel met } \\
\text { stemrecht moet zijn, zodat in de algemene vergadering altijd tot } \\
\text { besluitvorming kan worden overgegaan. Daarvoor is - uiteraard - } \\
\text { stemrecht vereist. }\end{array}$ & 175 \\
\hline 7. & $\begin{array}{l}\text { Een aandeel kan niet zowel stemrechtloos als winstrechtloos zijn. } \\
\text { Aan een stemrechtloos aandeel zal daarom altijd recht op uitkering } \\
\text { van winst of reserves, al dan niet beperkt, verbonden moeten zijn. }\end{array}$ & $\begin{array}{l}190, \\
228 \operatorname{lid} 5 \\
216 \operatorname{lid} 7\end{array}$ \\
\hline 8. & $\begin{array}{l}\text { Geheel stemrechtloos is het stemrechtloze aandeel niet. In een } \\
\text { aantal gevallen is aan de stemrechtloze aandeelhouder bijzondere } \\
\text { rechten toegekend, althans is een aparte regeling ter bescherming } \\
\text { van de positie van de stemrechtloze aandeelhouder getroffen. }\end{array}$ & $\begin{array}{l}\text { Zie par. } \\
6.2 .3 .6 \\
\text { en } \\
6.2 .3 .7 \\
\end{array}$ \\
\hline 9. & $\begin{array}{l}\text { Het is niet mogelijk om met de stemrechtloosheid van het stem- } \\
\text { rechtloze aandelen te variëren per besluit. Het stemrecht ontbreekt } \\
\text { voor alle besluiten in de algemene vergadering. }\end{array}$ & \\
\hline
\end{tabular}

2 Kamerstukken II 2008/09, 31 058, nr. 6, p. 16 (NV II). Dat neemt niet weg dat differentiatie van stemrecht wel mogelijk is door de bevoegdheid van besluiten die niet dwingendrechtelijk aan de algemene vergadering toekomt statutair toe te kennen aan een vergadering van een houders van aandelen van een bijzonder soort of aanduiding. Zie hierover Ten Berg 2012, p. 616 en Boschma \& Kuijers-Tollenaar 2013, p. 105. 


\subsubsection{Commentaar op de wettekst}

Portier heeft kritiek geuit op de formulering van art. 2:228 lid 5 BW. ${ }^{3}$ De tweede volzin luidt:

"Een dergelijke regeling (dat aan aandelen geen stemrecht is verbonden, toevoeging RAW) kan slechts worden getroffen ten aanzien van alle aandelen van een bepaalde soort of aanduiding waarvan alle aandeelhouders instemmen of waarvan voor de uitgifte in de statuten is bepaald dat daaraan geen stemrecht in de algemene vergadering is verbonden."

De achterliggende gedachte is dat de wetgever kennelijk heeft bedoeld dat de aandeelhouder niet zonder zijn instemming het stemrecht kan worden ontnomen. Die gedachte kan niet gelden voor aandelen die nog niet zijn uitgegeven. Die aandelen zijn immers nog niet bij een aandeelhouder geplaatst en dus is zijn instemmingsrecht tot ontneming van zijn stemrecht niet aan de orde. Met Portier ben ik dan ook van mening dat de tweede volzin beter als volgt geformuleerd kan worden:

"Een dergelijke regeling (dat aan aandelen geen stemrecht is verbonden, toevoeging RAW) kan slechts worden getroffen ten aanzien van alle aandelen van een bepaalde soort of aanduiding waarvan alle aandeelhouders instemmen, dan wel ten aanzien van alle aandelen van een bepaalde soort of aanduiding die niet zijn geplaatst."

\subsubsection{Kwalificatie van het stemrechtloze aandeel}

In paragraaf 2.5.2 besprak ik de overwegingen van de Expertgroep om geen aanbeveling te doen voor het stemrechtloze aandeel in de flex-BV. In het ambtelijk voorontwerp van het wetsvoorstel van de flex-BV kwam het stemrechtloze aandeel dan ook niet terug. Ik schetste eerder dat daarop vanuit de wetenschap en de rechtspraktijk kritiek is gekomen. De Expertgroep overwoog dat de eventuele invoering van het stemrechtloze aandeel in het Nederlandse recht gezien moet worden in de context van de certificaten van aandelen en de statutaire winstrechten (lees: participatiebewijzen). Het verschil tussen het stemrechtloze aandeel en het certificaat van aandeel is dat in het eerste geval sprake is van een relatie, zijnde een lidmaatschapverhouding, met de vennootschap. Bij een certificaat is sprake van een contractuele verhouding tussen de aandeelhouder (het AK) en de certificaathouder. Die contractuele verhouding wordt in de zogeheten administratievoorwaarden tussen de STAK en de certificaathouder vastgelegd. In het verlengde daarvan ligt de belangenbehartiging. De STAK behartigt (mede) de belangen van de

3 Portier 2008, p. 236. 
certificaathouder. ${ }^{4}$ Soms is aan de vergadering van certificaathouders het recht toegekend een bestuurder in het bestuur van de STAK te benoemen. Deze constatering van verschillen door de Expertgroep is juist. Echter, voor het vormgeven van de relatie certificaathouder-STAK zijn de administratievoorwaarden maatgevend. ${ }^{5}$ De Expertgroep stelt dat afbakening met het participatiebewijs lastig is, omdat de gelijkenis tussen het participatiebewijs en het stemrechtloze aandeel groot is. Op zich is dat juist, zij het dat bij het stemrechtloze aandeel van een lidmaatschapsverhouding en bij het participatiebewijs van een contractuele verhouding sprake is. ${ }^{6}$

Ook in de literatuur is dit kwalificatieprobleem aan de orde gekomen. Daarom is in verband met de invoering van de flex-BV ook wel gesteld dat 'een aandeel een aandeel is indien het als zodanig uitgegeven is', ${ }^{7}$ hetgeen door de aangehaalde parlementaire geschiedenis wordt bevestigd. ${ }^{8}$ Ik verwijs naar paragraaf 3.6. De statuten van de BV zullen dus uitsluitsel moeten geven en moeten aangeven wat voor soort rechten de BV kan uitgeven of zijn uitgegeven die geheel of gedeeltelijk recht geven op delen in de winst (of een andere uitkering). ${ }^{9}$ Is sprake van een stemrechtloos aandeel of een participatiebewijs?

De stemrechtloze aandeelhouder ontbeert het stemrecht, maar aan hem komt wel vergaderrecht ex art. 2:227 BW toe. De afbakening met de certificaathouder kan zijn dat in voorkomende gevallen aan de certificaathouder geen vergaderrecht toekomt. Dat laatste geldt ook in de regel voor de houder van het participatiebewijs. Op grond van art. 2:227 lid 2 BW komt het vergaderrecht immers slechts aan de certificaathouder toe indien zulks bij de statuten is bepaald. Dat kan voor de rechtspraktijk een overweging zijn juist voor het certificaat zonder vergaderrecht in plaats van het stemrechtloze aandeel te kiezen, bijvoorbeeld ingeval van werknemersparticipatie waarbij de mogelijkheid tot participatie aan een grote groep van werknemers wordt geboden. ${ }^{10}$

4 Rapport van de Expertgroep, p. 68. De Expertgroep stelde ook de vraag of de stemrechtloze aandeelhouder vergaderrecht zou moeten hebben in relatie tot het vergaderrecht van de - onder het oude recht - van de bewilligde certificaathouder. Onder de flex-BV heeft de stemrechtloze aandeelhouder vergaderrecht, zodat deze vraag door de invoering van de wet achterhaald is.

5 Zie Schwarz 1990 , p. 11, voetnoot 27.

6 Zoals gesteld, wordt in de literatuur aangenomen dat ook sprake is van een statutaire grondslag vanwege het bepaalde in art. 2:216 BW. Kritisch over deze opvatting Blanco Fernández \& Schwarz 1992, p. 288-289: voor de uitgifte van een participatiebewijs is geen statutaire basis vereist. In paragraaf 3.7.13 kom ik hierop terug.

7 Eisma 1991, p. 36, welke opvatting navolging heeft gekregen door Ten Berg 2007, p. 341; Portengen 2007, p. 942; Portier 2008, p. 244 en Van den Nieuwenhuijzen 2008, p. 23. Zie ook voetnoot 40.

8 Kamerstukken II 2008/09, 31 058, nr. 6, p. 46 (NV II).

9 Bier 2008 (1), p. 175.

10 Kodde 2005, p. 583; Ten Berg 2007, p. 343, voetnoot 32; Portier 2008, p. 234 en Van Engelen 2011, p. 122. 


\subsubsection{Mijn definitie van het stemrechtloze aandeel}

In de literatuur is geen eenduidige definitie van 'aandeel' te vinden. De wetgever gaat uit van een negatieve definitie. Vast staat wel dat een aandeel een vermogensrecht is. Rechten die stemrecht noch aanspraak op uitkering van winst of reserves omvatten, worden niet als een aandeel aangemerkt. Hoe is het stemrechtloze aandeel in de BV te kwalificeren en te definiëren? ${ }^{11}$

De BV is krachtens art. 2:175 BW als een rechtspersoon met een in een of meer overdraagbare aandelen verdeeld kapitaal. De aandelen zijn op naam gesteld. Een aandeelhouder is niet persoonlijk aansprakelijk voor hetgeen in naam van de vennootschap wordt verricht en is niet gehouden boven het bedrag dat op zijn aandelen behoort te worden gestort in de verliezen van de vennootschap bij te dragen, onverminderd het bepaalde in art. 2:192 BW. Ten minste één aandeel met stemrecht wordt gehouden door een ander dan en anders dan voor rekening van de vennootschap of een van haar dochtermaatschappijen. ${ }^{12}$

Mijn definitie van het stemrechtloze aandeel luidt als volgt:

Het stemrechtloze aandeel is een vermogensrecht op naam, in de vorm van een aandeel uitgegeven door de $B V$, dat kapitaal in een $B V$ vertegenwoordigt, waaraan de rechten volgens de wet en de statuten van de BV zijn verbonden, waaronder het recht - al dan niet beperkt - op winst en/of reserves van die $B V$, doch aan welk aandeel geen stemrecht in de algemene vergadering is verbonden.

Het element vermogensrecht in de definitie geeft de koppeling met art. 3:6 BW. Het element 'in de vorm van een aandeel uitgegeven door de BV' sluit aan bij de eerder weergegeven discussie en kwalificatievraag 'wat is een aandeel'? Dat maakt duidelijk dat het stemrechtloze aandeel een statutaire basis heeft en de lidmaatschapsverhouding weergeeft. Bij oprichting van de BV wordt het aandeel geplaatst dan wel na oprichting na een emissiebesluit van de algemene vergadering uitgegeven. Het element 'het recht op winst en/of reserves' geeft aan dat de aandeelhouder van het stemrechtloze aandeel recht heeft op de winst van de BV conform het bepaalde in art. 2:216 BW en dat die aandeelhouder recht heeft op de reserves, zoals het liquidatiesaldo bij ontbinding van de vennootschap (art. 2:23b BW).

11 Zie ook het advies d.d. 20 september 2007 van de Gecombineerde Commissie Vennootschapsrecht van de Nederlandse Orde van Advocaten en de Koninklijke Notariële Beroepsorganisatie, par. 2.3, p. 2.

12 Met 'één aandeel met stemrecht' wordt bedoeld een aandeel met stemrecht in de algemene vergadering. Iedere vennootschap heeft een algemene vergadering nodig waarin besluiten genomen kunnen en moeten worden. Er moet dus altijd een aandeel met stemrecht in de algemene vergadering zijn, zo leert Kamerstukken I 2011/12, 31058 en 32 426, nr. C, p. 8 (MvA I). 'Bij gelegenheid' zal de wettekst van art. 2:175 BW worden aangepast en na de woorden 'één aandeel met stemrecht' zal worden toegevoegd "in de algemene vergadering", zie Kamerstukken I 2011/12, 31 058, nr. E, p. 24 (Nadere MvA I). 
Conform het bepaalde in art. 2:216 lid 7 BW kan sprake zijn van een beperkt recht op winst en/of reserves. Tot slot brengt de definitie tot uitdrukking dat de stemrechtloze aandeelhouder stemrecht in de algemene vergadering ontbeert. ${ }^{13}$

De statuten vermelden het nominale bedrag van de aandelen. Zijn er aandelen van verschillende soort, dan vermelden de statuten het nominale bedrag van elke soort. Indien de statuten bepalen dat er een maatschappelijk kapitaal is, dan wordt het bedrag daarvan vermeld. De akte van oprichting vermeldt het bedrag van het geplaatste kapitaal en het gestorte deel daarvan. ${ }^{14}$ Zoals in paragraaf 3.2 als hoofdregel aan de orde kwam, moet bij het nemen van het aandeel daarop het nominale bedrag worden gestort. Bedongen kan worden dat het nominale bedrag of een deel daarvan eerst behoeft te worden gestort na verloop van een bepaalde tijd of nadat de vennootschap het zal hebben opgevraagd. ${ }^{15}$

\subsubsection{Het stemrechtloze aandeel met beperkt recht op winst en/of reserves}

Bij gebrek aan stemrecht in de algemene vergadering zijn voornamelijk de aan het stemrechtloze aandeel verbonden financiële rechten van belang. De financiële rechten vormen een 'wezenlijk onderdeel van het aandeelhouderschap'. ${ }^{16}$ Art. 2:216 BW geeft de stemrechtloze aandeelhouder recht op uitkeringen, waaronder dividend.

De Gecombineerde Commissie Vennootschapsrecht heeft gewezen op het volgende. ${ }^{17}$ Art. 2:216 lid 7 BW stelt dat bij de statuten kan worden bepaald dat aandelen van een bijzondere ${ }^{18}$ soort of aanduiding geen of slechts beperkt recht geven tot deling in de winst of reserves van de vennootschap. Dat aandeelhouders zonder (enig) stemrecht niet ook verstoken mogen worden van aanspraak op winst of reserves, vindt de Gecombineerde Commissie Vennootschapsrecht begrijpelijk. Er is echter naar de mening van de Gecombineerde Commissie Vennootschapsrecht geen reden om aandelen zonder stemrecht (of aandelen met een beperkt stemrecht) die slechts in beperkte mate aanspraak geven op winst of reserves te verbieden.

De wetgever heeft dit onderkend: "Gelet op de (negatieve) omschrijving van het begrip aandeel in het voorgestelde artikel 190 is het van belang dat artikel 228 uitsluit dat aan stemrechtloze aandelen het winstrecht geheel wordt ontnomen. Dit ligt anders bij het toekennen van een beperkt winstrecht. Zoals hierboven is opgemerkt in antwoord op vragen van de SP-fractie bij artikel 190 wordt ook een aandeel zonder

13 Kamerstukken I 2011/12, 31058 en 32 426, nr. C, p. 7 (MvA I). De stemrechtloze aandeelhouder heeft wel stemrecht in de vergadering van houders van stemrechtloze aandelen als apart orgaan in de zin van art. 2:189a BW.

14 Art. 2:178 lid 1 BW.

15 Art. 2:190 lid $1 \mathrm{BW}$.

16 Kamerstukken II 2006/07, 31 058, nr. 3, p. 75 (MvT).

17 Advies d.d. 20 september 2007 van de Gecombineerde Commissie Vennootschapsrecht van de Nederlandse Orde van Advocaten en de Koninklijke Notariële Beroepsorganisatie, par. 3.29, p. 13. Zie ook Portier 2008, p. 235.

18 Lees: bepaalde soort of aanduiding. 
stemrecht en met slechts een beperkt winstrecht als aandeel aangemerkt. De in artikel 228 lid 5, laatste zin, opgenomen verwijzing naar artikel 216 lid 7 is in dat opzicht te ruim gesteld en wordt bij nota van wijziging beperkt tot het geheel ontnemen van het recht op winst en reserves. "19

Een stemrechtloos aandeel met een beperkt winstrecht is aldus mogelijk. Datzelfde geldt ten aanzien van de reserves.

Zonder enige aanspraak op winst of reserves kunnen stemrechtloze aandelen gelet op de negatieve definitie van art. 2:190 BW en de laatste volzin van art. 2:228 lid 5 BW niet zijn: "Ten aanzien van stemrechtloze aandelen kan niet op grond van artikel 216 lid 7 worden bepaald dat zij geen recht geven tot deling in de winst of de reserves van de vennootschap." $\mathrm{Er}$ is in dat geval immers geen sprake van een aandeel, terwijl winstrechtloze aandelen alleen stemrecht kunnen hebben en geen enkele aanspraak op uitkering van winst en reserves. Aan een stemrechtloos aandeel zal daarom altijd enig recht op uitkering van winst of reserves verbonden moeten zijn. ${ }^{20}$ Art. 2:228 lid 5 laatste volzin BW kan beter als volgt worden geformuleerd: "Ten aanzien van stemrechtloze aandelen kan niet op grond van artikel 216 lid 7 worden bepaald dat zij geen enkel recht geven tot deling in de winst of de reserves van de vennootschap." De toevoeging van het woord 'enkel' brengt naar mijn mening expliciet tot uitdrukking dat aan het stemrechtloze aandeel altijd enig recht op uitkering van winst of reserves verbonden moet zijn.

De vraag is of onder 'reserves' als bedoeld in art. 2:216 lid 7 en art. 2:228 lid 5 BW ook het liquidatieoverschot in de zin van art. 2:23b BW moet worden verstaan. Ik zou die vraag bevestigend willen beantwoorden. In de eerste plaats ziet art. 2:216 BW niet alleen op uitkering van winst, maar ook op andere uitkeringen. ${ }^{21}$ In de tweede plaats meen ik dat art. 2:216 lid 7 BW de basis is om het recht op het liquidatieoverschot te beperken. Voor deze opvatting meen ik steun te vinden in de parlementaire geschiedenis. In de memorie van toelichting is over art. 2:216 lid 7 BW onder meer opgemerkt: “(...) Het wetsvoorstel maakt het dus mogelijk dat in de statuten wordt voorzien in winstrechtloze aandelen. De expertgroep heeft in dit verband opgemerkt dat het in sommige gevallen gewenst kan zijn dat een aandeelhouder niet deelt in de winst van de bv en evenmin recht heeft op een gedeelte van het liquiditeitsoverschot, bijvoorbeeld indien de oprichter van een familievennootschap als aandeelhouder wil meebeslissen over de gang van zaken in de vennootschap, maar de winst geheel aan zijn kinderen wil doen toekomen. De mogelijkheid om aandelen uit te sluiten van het recht op uitkeringen kan niet worden toegepast ten aanzien van stemrechtloze aandelen. Dit volgt uit artikel 228 lid 5 van dit wetsvoorstel. (...)" ${ }^{\$ 2}$ Hoewel het eerste deel van deze passage ziet op winstrechtloze

19 Kamerstukken II 2008/09, 31 058, nr. 6, p. 51 (NV II). Zie ook Kamerstukken II 2008/09, 31 058, nr. 7, p. 9.

20 Kamerstukken II 2006/07, 31 058, nr. 3, p. 86-87 (MvT).

21 Kamerstukken II 2006/07, 31 058, nr. 3, p. 75 (MvT).

22 Kamerstukken II 2006/07, 31 058, nr. 3, p. 75 (MvT). 
aandelen, gaat de wetgever daarna in op het stemrechtloze aandeel. Daarbij worden de woorden 'recht op uitkeringen' kennelijk gebruikt als algemene noemer voor het recht op winst en de reserves van de vennootschap als bedoeld in art. 2:216 lid 7 BW. Er wordt niet opgemerkt dat het liquidatieoverschot niet onder dergelijke uitkeringen zou vallen.

Het laatste deel van het citaat is blijkens de parlementaire geschiedenis achterhaald: een stemrechtloos aandeel kan ook een beperkt recht op winst en/of de reserves van de vennootschap geven. Ten tijde van de behandeling van het wetsvoorstel in de Eerste Kamer heeft de minister opgemerkt dat de statuten zo kunnen worden ingericht dat het mogelijk is een aandeel uit te geven dat niet deelt in de winst, maar wel deelt in het overschot na vereffening, ${ }^{23}$ en dat de reserves deel kunnen uitmaken van het overschot na vereffening. ${ }^{24}$

Het voorgaande leidt naar mijn mening tot het volgende keuzemenu van stemrechtloze aandelen:

\begin{tabular}{|l|l|l|l|}
\hline winst / reserves & volledig & beperkt & geen \\
\hline volledig & $\sqrt{ }$ & $\sqrt{ }$ & $\sqrt{ }$ \\
\hline beperkt & $\sqrt{ }$ & $\sqrt{ }$ & $\sqrt{ }$ \\
\hline geen & $\sqrt{ }$ & $\sqrt{ }$ & x \\
\hline
\end{tabular}

Deze aandelen zijn telkens te beschouwen als een stemrechtloos aandeel van een aparte soort of aanduiding. Ik verwijs naar paragraaf 4.2.6. Er kunnen in het kapitaal van een BV dus verschillende soorten stemrechtloze aandelen gecreëerd worden. Dat heeft ook tot gevolg dat er meerdere organen - in de zin van art. 2:189a BW van stemrechtloze aandeelhouders zijn. Ik verwijs naar paragraaf 4.2.7.

Mij zou kunnen worden tegengeworpen dat uit de parlementaire geschiedenis een enge opvatting af te leiden is, namelijk dat er slechts vier mogelijkheden van stemrechtloze aandelen zijn. Een stemrechtloos aandeel met volledig winstrecht en volledig recht op reserves, een stemrechtloos aandeel met volledig winstrecht en beperkt recht op reserves, een stemrechtloos aandeel met beperkt winstrecht en volledig recht op reserves en een stemrechtloos aandeel met beperkt winstrecht en beperkt recht op reserves. Ik meen dat de door mij hiervoor geuite, ruime opvatting de voorkeur heeft. ${ }^{25}$ Ten eerste, omdat art. 2:190 BW stelt 'aanspraak op uitkering van winst of reserves' en niet 'aanspraak op uitkering van winst en reserves'. Ten tweede, omdat de minster tijdens de behandeling in de Eerste Kamer heeft opgemerkt dat de statuten zo kunnen worden ingericht dat het mogelijk is een aandeel uit

23 Kamerstukken I 2011/12, 31058 en 32 426, nr. C, p. 8 (MvA I).

24 Kamerstukken I 2011/12, 31058 en 32 426, nr. C, p. 23 (MvA I). Zie ook Kamerstukken II 2006/07, 31 058, nr. 4, p. 14 (Advies Raad van State en nader rapport).

25 In gelijke zin: Asser/Maeijer, Van Solinge \& Nieuwe Weme 2-IIA 2013, nr. 307. 
te geven dat niet deelt in de winst, maar wel deelt in het overschot na vereffening. ${ }^{26}$ In het kader van deze twee argumenten citeer ik de parlementaire geschiedenis: "De negatief geformuleerde omschrijving in het voorgestelde artikel 190 biedt in dit verband de vereiste minimale duidelijkheid door te bepalen wat niet als aandeel wordt aangemerkt, namelijk een recht dat stemrecht noch aanspraak op uitkering van winst of reserves omvat. (...) De minimumvereisten voor een aandeel zijn dus dat er sprake is van een recht dat als aandeel is uitgegeven met inachtneming van de voor uitgifte voorgeschreven formaliteiten en waaraan ten minste stemrecht of aanspraak op uitkeringen uit winst of reserves is verbonden. Ook als er slechts een beperkt winstrecht bestaat en geen enkel stemrecht, een voorbeeld dat de leden van de CDA-fractie noemden, is er dus sprake van een aandeel. Uit het voorgestelde artikel 190 vloeit immers voort dat ook de enkele aanspraak op reserves voldoende is voor de kwalificatie als aandeel. (...) Als aan een aandeel slechts een beperkt winstrecht is verbonden en geen stemrecht, betekent dat niet dat het aandeel dan in vennootschapsrechtelijke zin een inhoudsloos recht is." (onderstreping, RAW). ${ }^{27}$

Daarnaast wijs ik er op dat de laatste volzin van het oorspronkelijke art. 2:228 lid 5 BW luidde: "Artikel 216 lid 7 is niet van toepassing op stemrechtloze aandelen." Ik citeer de minister nogmaals: "De in artikel 228 lid 5, laatste zin, opgenomen verwijzing naar artikel 216 lid 7 is in dat opzicht te ruim gesteld en wordt bij nota van wijziging beperkt tot het geheel ontnemen van het recht op winst en reserves." (onderstreping, RAW) ${ }^{28}$ Vervolgens is de laatste volzin van art. 2:228 lid 5 BW gewijzigd en luidt deze zoals hiervoor aangehaald.

Samenvattend, een stemrechtloos aandeel moet enige aanspraak op uitkering van winst of reserves hebben.

\subsection{6 'Bepaalde soort of aanduiding'}

Uit de tweede volzin van art. 2:228 lid 5 BW volgt dat stemrechtloze aandelen als een bepaalde soort of met een bepaalde aanduiding gecreëerd worden. In de praktijk kunnen daarvoor bijvoorbeeld de eerder besproken letteraandelen gebruikt worden. Als voorbeeld: de gewone aandelen (met winst- en stemrecht) in een vennootschap kunnen met de letter A worden aangeduid, de stemrechtloze aandelen met letter B en de winstrechtloze aandelen met letter C. Als aanduiding kan echter ook een uniek nummer worden gebruikt. De wetgever licht toe:

26 Kamerstukken I 2011/12, 31058 en 32 426, nr. C, p. 8 (MvA I). Zulks naar aanleiding van een vraag van BDO of 'het overigens überhaupt (cursivering, RAW) mogelijk is een aandeel uit te geven dat niet deelt in de winst, maar wel in een liquidatiesaldo?' Zie de brief van BDO d.d. 8 november 2011 aan de Eerste Kamer.

27 Kamerstukken II 2006/07, 31 058, nr. 6, p. 46 (NV II)

28 Kamerstukken II 2008/09, 31 058, nr. 6, p. 51 (NV II). Zie ook Kamerstukken II 2008/09, 31 058, nr. 7, p. 9. 
"Op verschillende plaatsen in het wetsvoorstel wordt de mogelijkheid geopend om bepaalde rechten of bevoegdheden toe te kennen aan houders van aandelen met een bepaalde aanduiding. Tevens wordt in artikel 189a het orgaanbegrip uitgebreid met de vergadering van aandeelhouders van een bepaalde aanduiding. Vennootschappen krijgen hierdoor meer mogelijkheden tot het toekennen van rechten en bevoegdheden aan bepaalde aandeelhouders, zonder dat een nieuw soort aandelen behoeft te worden gecreëerd. Men kan bijvoorbeeld de bevoegdheid tot benoeming van bestuurder A toekennen aan de houders van aandelen met de volgnummers 1-20. Bij de vraag of de toepassing van een wettelijke bepaling uitgebreid zou moeten worden tot aandelen met een bepaalde aanduiding heeft de bescherming van aandeelhouders een belangrijke rol gespeeld. Anders dan bij aandelen van een bepaalde soort is bij aandelen van een bepaalde aanduiding niet voorafgaand aan de uitgifte van het aandeel duidelijk dat er sprake is van een bijzondere positie. Om deze reden is bijvoorbeeld artikel 201 lid 3 uit het ambtelijk voorontwerp, waarin was bepaald dat aan aandelen van een bepaalde aanduiding bijzondere rechten inzake de zeggenschap in de vennootschap konden worden verbonden, niet gehandhaafd in het wetsvoorstel. In artikel 228 lid 5 wordt daarentegen wel de mogelijkheid geboden om van aandelen met een bepaalde aanduiding stemrechtloze aandelen te maken, omdat deze bepaling voorziet in een specifieke bescherming van de betrokken aandeelhouder. Hetzelfde geldt voor de mogelijkheid om het winstrecht aan een aandeel te ontnemen in artikel 216 lid 7."29

en

"Door ook houders van aandelen van een bepaalde aanduiding onder het orgaanbegrip te brengen, wordt het mogelijk om houders van specifieke aandelen, welke bijvoorbeeld zijn aangeduid met letters of cijfers, aan te wijzen als bevoegd orgaan zonder dat hiervoor een nieuw soort aandelen behoeft te worden gecreëerd. ${ }^{30}$ Ook bij één soort aandelen wordt het dus mogelijk om aandelen door middel van een nummering een bepaald recht te geven." ${ }^{31}$

De aanduiding moet op grond van het bepaalde in art. 2:194 lid $1 \mathrm{BW}$ in het aandeelhoudersregister worden geregistreerd. De wetgever stelt hierover: "In het wetsvoorstel bv-recht is niet geregeld hoe een dergelijke aanduiding wordt vastgelegd. Anders dan bij een aandeel van een bepaalde soort blijkt bij aandelen met een bepaalde aanduiding niet uit de statuten dat aan een specifiek aandeel een bijzondere positie is verbonden. Met het oog op een ordentelijke vaststelling van de rechten en verplichtingen van aandeelhouders is het van belang dat de aanduiding

29 Kamerstukken II 2006/07, 31 058, nr. 3, p. 37 (MvT).

30 Kamerstukken II 2006/07, 31 058, nr. 3, p. 42 (MvT) en Kamerstukken I 2011/12, 31058 en 32 426, nr. C, p. 16 (MvA I).

31 Kamerstukken II 2006/07, 31 058, nr. 3, p. 42 (MvT) en Kamerstukken II 2009/10, 32 246, nr. 3, p. 24 (MvT Invoeringswet). 
wordt geregistreerd. Daarom is in artikel 194 lid 1 bepaald dat de aanduiding in het aandeelhoudersregister moet worden vermeld." ${ }^{32}$

Aandelen van een bepaalde soort en aandelen met een bepaalde aanduiding zijn twee aparte categorieën, zo volgt uit de parlementaire geschiedenis: “(...) indien aan een of meer aandelen met een bepaalde aanduiding (bijvoorbeeld de gewone aandelen $1 \mathrm{t} / \mathrm{m}$ 5) een bepaalde bevoegdheid op grond van artikel 189a wordt toegekend, deze aandelen daardoor nog niet kwalificeren als behorende tot een soort. In artikel 189 a en elders in het wetsvoorstel wordt telkens gesproken van aandelen van een bepaalde soort of aanduiding. Deze formulering impliceert dat er sprake is van twee categorieën. (...) De zeggenschap [kan] niet alleen worden toegekend aan een nieuw uitgegeven soort aandelen, maar ook aan bestaande aandelen met een bepaalde aanduiding." 33

De eerste twee volzinnen van art. 2:178 lid $1 \mathrm{BW}$ bepalen: "De statuten vermelden het nominale bedrag van de aandelen. Zijn er aandelen van verschillende soort, dan vermelden de statuten het nominale bedrag van elke soort." In de literatuur is opgemerkt dat art. 2:178 lid $1 \mathrm{BW}$ alleen spreekt over aandelen van verschillende soort en niet van aandelen van verschillende soort of aanduiding. ${ }^{34} \mathrm{De}$ minister heeft ervan afgezien in art. 2:178 lid $1 \mathrm{BW}$ ook aandelen van een bepaalde aanduiding toe te voegen. "Zou een dergelijke aanduiding in de statuten moeten worden vermeld, dan zou de beoogde flexibiliteit niet worden gerealiseerd", aldus de minister. ${ }^{35}$

Naar mijn mening bedoelt de minister daarmee kennelijk te zeggen dat aandelen van een bepaalde aanduiding niet per definitie statutair gecreëerd behoeven te worden. Een besluit van de algemene vergadering en vermelding van de aanduiding in het aandeelhoudersregister ex art. 2:194 lid 1 BW is kennelijk voldoende, bijvoorbeeld indien men na oprichting aan gewone aandelen - reeds bestaande aandelen, in de woorden van de minister - benoemingsrechten wil verbinden. Daarnaast is het ook mogelijk aandelen met een bepaalde aanduiding statutair te creëren, zo begrijp ik de minister. Dat zou inhouden dat een besluit van de algemene vergadering tot statutenwijziging en een statutenwijziging vereist is. Tot slot geldt dat, zoals gezegd, de aanduiding in het aandeelhoudersregister moet worden vermeld.

Op zich getuigt deze regeling inderdaad van flexibiliteit, in de zin dat met flexibiliteit kennelijk bedoeld is (i) de mogelijkheid zowel in als buiten de statuten aandelen met een bepaalde aanduiding te creëren en bepaalde bevoegdheden aan die aandelen toe te kennen en (ii) weinig formaliteiten op te werpen - indien de

32 Kamerstukken II 2009/10, 32 246, nr. 3, p. 24 (MvT Invoeringswet).

33 Kamerstukken I 2011/12, 31058 en 32 426, nr. E, p. 24 (Nadere MvA I).

34 Nowak \& Van den Ingh 2007, p. 129. Oranje 2008 (1), p. 36-37. Ook vanuit de rechtspraktijk is dat betoogd, althans opgemerkt. Zie de brief van BDO d.d. 8 november 2011 aan de leden van de Commissie voor Veiligheid en Justitie van de Eerste Kamer en het antwoord daarop van de minister: Kamerstukken I 2011/12, 31058 en 32 426, nr. C, p. 16 (MvA I).

35 Kamerstukken I 2011/12, 31058 en 32 426, nr. C, p. 16 (MvA I). 
aandelen met een bepaalde aanduiding buiten statutair gecreëerd worden - in de zin dat geen statutenwijziging vereist is (voor welke statutenwijziging naast een daartoe strekkend besluit van de algemene vergadering ook een notariële akte is vereist). Dat laatste is slechts ten dele een voordeel, omdat voor de uitgifte van een nieuw aandeel met een bepaalde aanduiding in ieder geval een notariële akte is vereist. ${ }^{36}$

Toch volg ik de gedachtegang van de minister niet. Uit de hiervoor geciteerde parlementaire geschiedenis volgt dat de wetgever bij aandelen met een bepaalde aanduiding oog heeft gehad op de mogelijkheid aan die aandelen zeggenschap te verbinden, bijvoorbeeld door middel van de benoeming van een bestuurder in de zin van art. 2:242 lid 1 BW. ${ }^{37}$ Op een andere plaats in de parlementaire geschiedenis wordt dat nog eens bevestigd: "Om de mogelijkheden van besluitvorming te verruimen, voorziet artikel 242 in de mogelijkheid dat de statuten bepalen dat bestuurders worden benoemd door een vergadering van houders van aandelen van een bepaalde soort of aanduiding. Het wordt hiermee mogelijk dat aandeelhouders of groepen van aandeelhouders ieder een eigen bestuurder benoemen." en "De expertgroep heeft opgemerkt dat de expliciete grondslag in artikel 242 voor een statutaire regeling desondanks gewenst is vanwege haar eenvoud en ondubbelzinnigheid. Deze aanbeveling is overgenomen." ${ }^{38}$ Met andere woorden: enkel de statuten kunnen de vergadering van aandelen met een bepaalde aanduiding de bevoegdheid toekennen een bestuurder te benoemen, hetgeen naast dit citaat ook uit art. 2:242 lid $1 \mathrm{BW}$ zelf voortvloeit. Ik wijs ook op het meer algemene art. 2:201 lid 3 BW dat bepaalt dat de statuten kunnen bepalen dat aan aandelen van een bepaalde soort of aanduiding bijzondere rechten als in de statuten omschreven inzake de zeggenschap in de vennootschap zijn verbonden. Voorts noem ik als voorbeeld art. 2:228 lid 4 BW. Voor het creëren van een aandeel met gedifferentieerd stemrecht is een statutenwijziging vereist. Enkel een besluit van de algemene vergadering, inhoudende dat aandelen met een bepaalde aanduiding worden gecreëerd, is dus niet voldoende.

Kortom: indien de wetgever heeft bedoeld dat het mogelijk is buiten statutair aandelen met een bepaalde aanduiding te creëren, heeft die mogelijkheid in het geval dat aan die aandelen benoemingrechten van een bestuurder (art. 2:242 BW) of commissaris (art. 2:252 BW) worden toegekend geen toegevoegde waarde. Alleen de statuten kunnen, zoals gezegd, een dergelijk recht aan een vergadering van houders van aandelen met een bepaalde aanduiding toekennen. Datzelfde geldt (bijvoorbeeld) voor de bevoegdheden op grond van het bepaalde in art. 2:192, 2:206, 2:210 lid 7, 2:239, 2:244 jo. 2:242, 2:245, 2:254 jo. 2:252 BW. Het komt mij daarom voor dat de minister ten onrechte aandelen met een bepaalde aanduiding koppelt aan het verlenen van bijzondere bevoegdheden aan de vergadering van

36 Art. 2:196 lid $1 \mathrm{BW}$, naast een besluit tot uitgifte ex art. 2:206 lid $1 \mathrm{BW}$

37 Voor de benoeming van commissarissen geldt een soortgelijke regeling, zie art. 2:252 lid $1 \mathrm{BW}$.

38 Kamerstukken II 2006/07, 31 058, nr. 3, p. 91 (MvT). 
houders van aandelen met die aanduiding als orgaan van de vennootschap in de zin van art. 2:189a BW.

De kennelijke gedachtegang van de minister dat een bepaalde aanduiding niet in de statuten hoeft te worden vermeld, gaat ook niet op bij (het creëren van) stemrechtloze aandelen. Art. 2:228 lid 5 eerste volzin BW bepaalt immers dat in afwijking van de leden 1 tot en met 4 van dat artikel de statuten kunnen bepalen dat aan aandelen geen stemrecht in de algemene vergadering is verbonden. Het stemrechtloze aandeel is een aandeel waaraan - in beginsel - geen bijzondere bevoegdheden zijn verbonden. ${ }^{39}$

Een voorbeeld verduidelijkt het voorgaande. Een BV heeft twee aandeelhouders, A en B, die ieder voor vijftig procent aandeelhouder zijn in het kapitaal van de vennootschap. Het kapitaal bestaat uit honderd gewone aandelen. A en B zijn tevens gezamenlijk bevoegd bestuurder van de vennootschap. De BV heeft substantiële, additionele financiering nodig. Aandeelhouder A kan geen aanvullende middelen aanwenden. Dat lukt aandeelhouder B echter wel. Aandeelhouder B wil in ruil daarvoor echter wel meer zeggenschap in de vennootschap, in de vorm van een door hem te benoemen derde bestuurder met - eveneens - een gezamenlijke vertegenwoordigingsbevoegdheid. Bovendien is hij slechts bereid de financiering als vreemd vermogen te verstrekken, waarbij de vennootschap zekerheden verstrekt. Aldus geschiedde. Indien aan een van de door B gehouden aandelen een aanduiding - 'B' van benoeming - wordt toegevoegd, verkrijgt hij als houder van een aandeel met een bepaalde aanduiding als orgaan van de vennootschap nog geen bevoegdheid 'zijn' bestuurder te benoemen. Daarvoor is een statutenwijziging vereist, waarbij in de statuten op de voet van art. 2:242 lid $1 \mathrm{BW}$ wordt bepaald dat de benoeming van een van de bestuurders van het driehoofdige bestuur van de vennootschap geschiedt door de vergadering van houders van aandelen met aanduiding B. Uit de hiervoor aangehaalde parlementaire geschiedenis blijkt dat in dit voorbeeld sprake is van een soort aandeel in de BV, namelijk de soort 'gewone aandelen'. Van deze gewone aandelen is aan een aandeel een aanduiding B toegevoegd. Die enkele aanduiding makkt dat aandeel nog niet van een aparte soort. Tot zover ben ik het met de redenering van de minister eens. Echter, waar de minister stelt dat "Zou een dergelijke aanduiding in de statuten moeten worden vermeld, dan zou de beoogde flexibiliteit niet worden gerealiseerd" ben ik het niet met hem eens. Uit het voorbeeld volgt dat de aanduiding B, wegens de benoemingsbevoegdheid, eveneens als die bevoegdheid zelf, in de statuten moeten worden omschreven.

Ik pas het hiervoor genoemde voorbeeld iets aan. Indien aandeelhouder B bereid is de financiering als eigen vermogen te verstrekken en geen additionele zeggenschap of zekerheid wenst, kan in de financieringsbehoefte van de BV ook worden voorzien door middel van uit te geven stemrechtloze aandelen. De stemverhoudingen in de algemene vergadering worden daardoor niet beïnvloed en indien de nominale waarde van de stemrechtloze aandelen gelijk is aan de nominale waarde

39 In die zin gaat ook de 'koppeling' van de minister niet op. 
van de gewone aandelen in het kapitaal van de vennootschap, bestaan voor aandeelhouder A en B ook gelijke winstrechten, ${ }^{40}$ zij het dat aandeelhouder B als gevolg van zijn pakket stemrechtloze aandelen een groter winstdeel heeft teneinde in rendement op het door hem ten opzichte van aandeelhouder A extra geïnvesteerde vermogen te voorzien. In dit voorbeeld is, althans lijkt, sprake van twee verschillende soorten aandelen, namelijk gewone en stemrechtloze aandelen, die blijkens art. 2:178 lid $1 \mathrm{BW}$ als zodanig in de statuten moeten worden omschreven. Dat is echter op grond van de wet niet het enige juiste antwoord. Uit art. 2:228 lid 5 BW volgt immers dat stemrechtloze aandelen als aandelen van een bepaalde soort of aanduiding gecreëerd kunnen worden. Niettemin geldt, ongeacht of stemrechtloze aandelen nu als aandelen van een bepaalde soort of met een bepaalde aanduiding gecreëerd worden, dat stemrechtloze aandelen slechts bij statutaire regeling gecreëerd kunnen worden.

De uitwerking van deze twee voorbeelden verschilt in notarieel opzicht niet veel van elkaar. ${ }^{41}$ De ene uitwerking is niet veel meer werk dan de andere. Uit deze voorbeelden volgt mijns inziens tevens dat aan art. 2:178 lid $1 \mathrm{BW}$ de woorden "van een bepaalde aanduiding" kunnen worden toegevoegd. Daartegen bestaat geen principieel bezwaar. Ik zou zelfs verder willen gaan. Uit de hiervoor gegeven voorbeelden volgt dat er feitelijk geen verschil bestaat tussen aandelen van een bepaalde soort of aandelen met een bepaalde aanduiding. Of beter gezegd, dat aandelen met een bepaalde aanduiding niets toevoegen. Beter zou zijn de verschillende soorten aandelen van een aparte aanduiding te voorzien, zoals bij letteraandelen in de praktijk al sinds jaar en dag geschiedt.

Ik sluit niet uit dat de minister zich heeft laten inspireren door de DSMbeschikking inzake een loyaliteitsdividend. ${ }^{42}$ Daarin overwoog de Hoge Raad: "De daarin opgenomen hoofdregel (art. 2:92 lid 1 BW, toevoeging RAW) dat aan alle aandelen in verhouding tot hun bedrag gelijke rechten en verplichtingen zijn verbonden, is van regelend recht, nu daarvan in de statuten kan worden afgeweken. Uit de tekst en de strekking van deze bepaling volgt niet dat een statutaire afwijking van deze hoofdregel slechts mogelijk is met betrekking tot aandelen van een bepaalde soort. In het bijzonder schrijft art. 2:92 lid 1, gelezen in verband met het bepaalde in art. 2:105 BW, niet dwingend voor dat aan aandelen van dezelfde soort altijd in omvang gelijke aanspraken op dividend moeten zijn verbonden. Art. 2:92 lid 1 verzet zich daarom niet tegen een regeling in de statuten waarbij aan geregistreerde aandeelhouders onder bepaalde voorwaarden een financiële uitkering, bijvoorbeeld in de vorm van een aanvullend dividend, wordt toegekend, mits deze regeling geen schending oplevert van het in art. 2:92 lid 2 BW neergelegde

40 Zie art. 2:216 lid $6 \mathrm{BW}$.

41 Bier 2008 (2), p. 66, spreekt in dit kader over 'vennootschappelijke techniek'.

42 HR 14 december 2007, LJN BB3523, NJ 2008, 105, m.nt. Ma, JOR 2008, 11, m.nt. A. Doorman (DSM), r.o. 3.3. Zie verder over het loyaliteitsdividend (van DSM) bijvoorbeeld: Van Olffen 2006; Bier 2008 (2); Schild 2008; Van Veen 2008 (1); Hendriks \& Koelemeijer 2009; De Beurs 2011; Bier 2012 (2), p. 176-180, G.T.M.J. Raaijmakers 2012, p. 59-60 en Koelemeijer \& Hendriks 2012. 
gelijkheidsbeginsel." Met andere woorden: voor het creëren van een loyaliteitsdividend is het niet nodig een apart soort aandelen te creëren. Binnen een soort van aandelen kunnen aan houders van die soort verschillende rechten worden toegekend. Uit de overweging van de Hoge Raad volgt dat de regeling omtrent het loyaliteitsdividend in de statuten moet worden omschreven. Uit de statuten kan dus volgen dat aan bepaalde houders van gewone aandelen rechten van een ander inhoud of omvang worden toegekend dan aan de andere houders van die gewone aandelen. De positie van de houders van de gewone aandelen verschilt dus. ${ }^{43}$ Op grond van art. 2:201 lid $2 \mathrm{BW}$ moet de vennootschap echter wel de aandeelhouders die zich in gelijke omstandigheden bevinden op dezelfde wijze behandelen.

Uit het voorgaande komt naar voren dat het onderscheid tussen een 'bepaalde soort of aanduiding' wellicht niet van groot praktisch belang is, zij het dat de vennootschappelijke techniek - dat wil zeggen de omschrijving en de inrichting van de statuten - verschilt. Toch is deze kwestie niet geheel academisch. De wet koppelt aan het zijn van 'soort' aandelen diverse gevolgen. Los van mijn aanbeveling noem ik art. 2:178 BW. De statuten moeten het nominale bedrag van de verschillende soorten aandelen noemen. Ik noem ook het voorkeursrecht ex art. 2:206c BW. Dat artikel koppelt het voorkeursrecht aan aandelen van een bepaalde soort. Voor het orgaanbegrip heeft het verschil tussen soort of aanduiding blijkens art. 2:189a BW geen gevolgen. Datzelfde geldt voor het bepaalde in art. 2:231 lid 4 BW.

Tot slot, hoe moet het onderscheid tussen een 'bepaalde soort of aanduiding', naast de vennootschappelijke techniek, praktisch worden gezien? Ik sluit me twijfelend aan bij Nowak \& Van den Ingh. Zij stellen dat de verzameling van aandelen van een bepaalde aanduiding als een deelverzameling van de verzameling van aandelen van een bepaalde soort kan worden beschouwd. Binnen een bepaalde aandelensoort kunnen dus andere of extra bevoegdheden aan een aandeel van dat soort worden gegeven door het geven van een bepaalde aanduiding, bijvoorbeeld een cijfer of letter, aan dat aandeel. ${ }^{44}$ De vraag blijft of dan toch niet sprake is van een aparte soort, juist omdat deze bevoegdheden statutair moeten worden toegekend. Wellicht kan de aanduiding het beste gebruikt worden om binnen aandelen van een bepaalde soort de houders van die aandelen makkelijk te identificeren, bijvoorbeeld behorende tot een bepaalde familiestaak. Kortom, het verschil tussen een bepaalde soort of een bepaalde aanduiding is vaag en, lijkt mij, voor de rechtspraktijk minder relevant.

\subsubsection{De vergadering van stemrechtloze aandeelhouders}

Uit art. 2:189a BW volgt dat onder orgaan van de vennootschap onder meer wordt verstaan de vergadering van houders van aandelen van een bepaalde soort of aanduiding. Door ook houders van aandelen van een bepaalde aanduiding onder het

43 Bier 2012 (2), p. 174-175

44 Nowak \& Van den Ingh 2007, p. 130. 
orgaanbegrip te brengen, wordt het mogelijk om houders van specifieke aandelen, welke bijvoorbeeld zijn aangeduid met letters of cijfers, aan te wijzen als bevoegd orgaan zonder dat hiervoor een nieuw soort aandelen behoeft te worden gecreëerd. ${ }^{45}$ Hoofdregel is dat de stemrechtloze aandeelhouder geen stemrecht heeft in de algemene vergadering. Het is niet mogelijk om met de stemrechtloosheid van het stemrechtloze aandelen te variëren per besluit. Het stemrecht ontbreekt voor alle besluiten in de algemene vergadering. Heeft de stemrechtloze aandeelhouder dan wel stemrecht in de vergadering van houders stemrechtloze aandelen? De vennootschap kan immers een vergadering van aandeelhouders van aandelen van een bepaalde soort of aanduiding hebben.

Art. 2:189a BW bepaalt dat voor de toepassing van de art. 2:192, 197 lid 3, 198 lid 3, 206, 210 lid 6 66, 216 lid 1, 227 lid 2, 239 en 244 BW onder orgaan van de vennootschap wordt verstaan de algemene vergadering, de vergadering van houders van aandelen van een bepaalde soort of aanduiding, het bestuur, de raad van commissarissen en de gemeenschappelijke vergadering van het bestuur en de raad van commissarissen.

De vergadering van stemrechtloze aandeelhouders is aldus een orgaan van de vennootschap. Met Portier ben ik van mening dat de stemrechtloze aandeelhouders in zijn 'eigen' vergadering van stemrechtloze aandeelhouders stemrecht heeft. ${ }^{47}$ De wet noch de toelichting ${ }^{48}$ daarop beperken dat. Bij de behandeling van het wetsvoorstel in de Eerste Kamer heeft de minister bevestigd dat aan stemrechtloze aandelen stemrecht toekomt in de vergadering van stemrechtloze aandeelhouders en daarbij benadrukt dat aan dat aandeel geen stemrecht toekomt in de algemene vergadering. ${ }^{49}$ Bestuurders en commissarissen hebben in de vergadering van stemrechtloze aandeelhouders geen raadgevende stem. ${ }^{50}$ Het komt mij echter voor dat uit de eisen van de vennootschappelijke redelijkheid en billijkheid kan voortvloeien dat de vergadering van houders van stemrechtloze aandelen, indien haar als orgaan statutaire bevoegdheden zijn toegekend, bij (belangrijke) besluiten ${ }^{51}$ de bestuurders (en commissarissen) in de gelegenheid stelt hun raadgevende stem te doen horen, te meer indien de bestuurders niet tevens aandeelhouders zijn. ${ }^{52}$ In de regel staan aandeelhouders op wat meer afstand van de vennootschap. De bestuurders kunnen hen bij de besluitvorming van raad voorzien. Het niet-naleven daarvan kan in dit geval een grond voor vernietiging van het besluit ex art. 2:15 lid 1 sub b BW zijn.

45 Kamerstukken II 2006/07, 31 058, nr. 3, p. 42 (MvT).

46 Bedoeld zal zijn art. 2:216 lid 7 BW.

47 Portier 2008, p. 245. In gelijke zin Oranje 2008, p. 56.

48 Af te leiden uit: Kamerstukken II 2008/09, 31 058, nr. 6, p. 39 (NV II)

49 Kamerstukken I 2011/12, 31058 en 32 426, nr. C, p. 7 (MvA I).

50 Kamerstukken I 2011/12, 31 058, nr. E, p. 22 (Nadere MvA I). De minster dacht hierover in eerste instantie anders, zie: Kamerstukken I 2011/12, 31058 en 32 426, nr. C, p. 24 (MvA I) en Kamerstukken I 2011/12, 31 058, nr. D, p. 16 (NVV I).

51 Zie ten aanzien van de benoeming en ontslag van bestuurders paragraaf 6.2.3.3.

52 In gelijke zin: Boschma \& Kuijers-Tollenaar 2013, p. 104. 
Indien sprake is van een orgaan, kunnen aan dat orgaan bevoegdheden worden toegekend, bijvoorbeeld de bevoegdheden genoemd in art. 2:192, 2:197 lid 3, 2:198 lid 3, 2:206, 2:210 lid 7, 2:216 lid 1, 2:227 lid 2, 2:239 en 2:244 BW. Het gaat daarbij om kwalitatieve verbintenissen (art. 2:192 BW), overdracht en overgang van het stemrecht in het kader van vruchtgebruik (art. 2:197 lid 3 BW), overdracht en overgang van het stemrecht in het kader van pandrecht (art. 2:198 lid $3 \mathrm{BW}$ ), uitgifte van aandelen na oprichting van de vennootschap en het verlenen van rechten tot het nemen van aandelen (art. 2:206 BW), de bevoegdheid te bepalen welk deel van het resultaat van het boekjaar wordt gereserveerd of hoe het verlies wordt verwerkt (art. 2:210 lid $7 \mathrm{BW}$ ), de bevoegdheid tot bestemming van de winst die door de vaststelling van de jaarrekening is bepaald en tot vaststelling van uitkeringen (art. 2:216 lid $1 \mathrm{BW}$ ), het verbinden en ontnemen van vergaderrecht aan certificaten van aandelen (art. 2:227 lid $2 \mathrm{BW}$ ), het goedkeuren van besluiten van het bestuur (art. 2:239 lid $3 \mathrm{BW}$ ), ${ }^{53}$ het geven van aanwijzingen aan het bestuur (art. 2:239 lid 4 BW) en het schorsen en ontslaan van een bestuurder (art. 2:244 jo. $242 \mathrm{BW}$ ).

In de opsomming van artikelen in art. 2:189a BW ontbreken art. 2:242 en 2:252 BW. Art. 2:242 en $252 \mathrm{BW}$ regelen de benoeming van bestuurders respectievelijk van commissarissen. Die regeling komt er op neer dat in de statuten aan een vergadering van houders van aandelen van een bepaalde soort of aanduiding het recht kan worden toegekend bestuurders en/of commissarissen te benoemen. Indien aan de houders van stemrechtloze aandelen dat recht is toegekend, is in het kader van de benoeming aldus ook sprake van een vergadering van stemrechtloze aandeelhouders en is eveneens sprake van een orgaan in de zin van art. 2:189a BW. In de opsomming van artikelen in art. 2:189a BW ontbreken ook art. 2:195 lid 4 (het verlenen van goedkeuring an de overdraagbaarheid van aandelen), ${ }^{54}$ 2:206a (het uitsluiten of beperken van het voorkeursrecht) en 2:245 (het vaststellen van de bezoldiging van bestuurders) BW. Ook deze bevoegdheden kunnen aan de vergadering van stemrechtloze aandeelhouders worden toegekend.

In paragraaf 4.2.5 besprak ik de mogelijkheid tot het creëren van diverse stemrechtloze aandelen met ieder een ander recht op uitkeringen (winst en/of reserves, al dan niet beperkt), zijnde verschillende aandelen van een bepaalde soort of aanduiding in de zin van art. 2:228 lid 5 BW. Er is dan telkenmale ook sprake van een andere vergadering van stemrechtloze aandeelhouders. Een voorbeeld verduidelijkt dit. Een

53 Een volledige statutaire ontneming van de bevoegdheden van het bestuur is niet mogelijk. Dat zou de bestuursautonomie te sterk aantasten. Besluiten van het bestuur kunnen slechts onderworpen worden aan de goedkeuring van een orgaan van de vennootschap. Zie Kamerstukken II 1998/99, 26277 , nr. 3, p. 11 (MvT). Vaak zal het gaan om besluiten die van ingrijpende aard zijn op de vennootschap of de door haar gedreven onderneming. Zie voor een lijst van besluiten in het structuurregime art. 2:274 lid 1 BW. De goedkeuring van bestuursbesluiten door een orgaan van de vennootschap doen niet af aan de vertegenwoordigingsbevoegdheid van het bestuur. Handelt het bestuur in strijd met de vereiste goedkeuring, dan is de vennootschap jegens derden niettemin gebonden, doch is sprake van onbehoorlijke taakvervulling in de zin van art. 2:9 BW

54 Kamerstukken II 2006/07, 31 058, nr. 3, p. 50 (MvT) 
BV heeft een kapitaal, bestaande uit gewone aandelen met aanduiding A, stemrechtloze aandelen met volledig recht op winst en reserves met aanduiding B en stemrechtloze aandelen met beperkt recht op winst, doch volledig recht op reserves met aanduiding C. Op aandeelhoudersniveau zijn er in dit geval drie organen, te weten de algemene vergadering (de houders van aandelen met de aanduidingen A, B en C), de vergadering van houders van aandelen $B$ en de vergadering van houders van aandelen C. In dit voorbeeld ging het - wat betreft de stemrechtloze aandelen - om een verschil in het recht op de winst.

Ook in het kader van het toekennen van benoemingsrechten van bestuurders en/ of commissarissen aan stemrechtloze aandeelhouders kan gebruik worden gemaakt van de mogelijkheid tot het creëren van verschillende aandelen van een bepaalde soort of aanduiding. Een voorbeeld verduidelijkt dit. Een BV heeft een kapitaal, verdeeld in gewone aandelen met aanduiding A. De vennootschap wil kapitaal aantrekken, doch de houders van aandelen A willen niet hun invloed in de algemene vergadering zien verminderen. Een aantal investeerders is bereid kapitaal te verstrekken. Er is sprake van drie investeerders die een aanzienlijke kapitaalinjectie willen doen. Zij willen wel enige invloed op bestuursniveau in de vennootschap. Daarnaast is er een groot aantal kleinere investeerders. De vennootschap kan in dat geval stemrechtloze aandelen B met het benoemingsrecht van een bestuurder aan de drie grote investeerders uitgeven. ${ }^{55}$ Aan de groep van kleine investeerders kunnen 'gewone' - dat wil zeggen zonder benoemingsrechten - stemrechtloze aandelen C worden uitgegeven. De houders van de stemrechtloze aandelen B vormen samen de vergadering van houders van stemrechtloze aandelen B. Op gelijke wijze geldt dat voor de houders van stemrechtloze aandelen $\mathrm{C}$. Weliswaar hebben zowel de houders van de stemrechtloze aandelen B als C stemrecht in hun respectieve vergadering, doch aan de houders van de stemrechtloze aandelen $\mathrm{C}$ zijn geen rechten toegekend op grond waarvan zij als vergadering besluiten kunnen nemen, in welk kader iedere houder van stemrechtloze aandelen $\mathrm{C}$ zijn stemrecht kan uitoefenen. Dit is anders ten aanzien van de houder van stemrechtloze aandelen B. Deze aandeelhouder kan in zijn vergadering van zijn stemrecht gebruik maken ten aanzien van de benoeming van de bestuurder.

In de literatuur is kritiek op art. 2:189a BW geuit. Van den Ingh stelt dat door de verwijzing naar art. 2:239 BW de indruk wordt gewekt dat de instructiebevoegdheid aan alle daarin genoemde organen kan worden toegekend. Hij stelt een beperking tot organen van aandeelhouders voor. ${ }^{56}$ Oranje vindt zelfs dat laatste te ver gaan, omdat daaronder ook wordt begrepen de vergadering van houders van aandelen van een bepaalde soort of aanduiding. De vergadering van houders van aandelen A die een eigen bestuurder $\mathrm{A}$ in het bestuur van de vennootschap heeft benoemd, zou niet bevoegd moeten zijn instructies aan het bestuur te geven. ${ }^{57}$ Dat zou - in de

55 Zie art. 2:206 BW.

56 Van den Ingh 2002 , p. 25.

57 Oranje 2008 (1), p. 37. 
gedachtegang van Oranje - inhouden dat ook de vergadering van stemrechtloze aandeelhouders geen instructies aan het bestuur zouden mogen geven. Naar mijn mening hoeft niet gevreesd te worden voor een te grote invloed van een groep van aandeelhouders, omdat de instructiebevoegdheid wordt begrensd door het vennootschappelijk belang (de tenzij-clausule van art. 2:239 lid 4 BW, laatste volzin). Het bestuur moet deze aanwijzingen opvolgen, tenzij dat tegen het belang van de vennootschap en de met haar verbonden onderneming indruist. Daarnaast, specifiek gericht op de stemrechtloze aandeelhouder, zijn stemrechtloze aandeelhouders in zekere zin te vergelijken met minderheidsaandeelhouders. Het komt de bescherming van die aandeelhouders ten goede indien de vergadering van stemrechtloze aandeelhouders instructies aan het bestuur van de vennootschap kan geven. Op grond van art. 2:239 lid 4 BW kunnen de statuten in die mogelijkheid voorzien. In paragraaf 5.5.3 en 5.5.4 ga ik nader op de instructiebevoegdheid in.

Tijdens de parlementaire behandeling van het wetsvoorstel is de vraag aan de orde gekomen of de regels inzake de oproeping, agendering, besluitvorming en vastlegging die voor de algemene vergadering gelden, van overeenkomstige toepassing zouden moeten worden verklaard op vergaderingen van houders van aandelen van een bepaalde soort of aanduiding. De minister achtte een wettelijke regeling niet nodig. Indien vennootschappen ervoor kiezen om de houders van aandelen van een bepaalde soort of aanduiding bijzondere bevoegdheden toe te kennen, staat het hen vrij om de wettelijke regels van overeenkomstige toepassing te verklaren of dit anderszins te regelen. ${ }^{58}$ Met Boschma \& Kuijers-Tollenaar ben ik van mening dat het aanbeveling verdient een dergelijke regeling omtrent oproeping, agendering en besluitvorming in voorkomend geval statutair of reglementair - bij voorkeur vanwege de rechtszekerheid in de statuten - vast te leggen. ${ }^{59}$

\subsubsection{Vastlegging van besluiten van de vergadering van houders van stemrechtloze aandeelhouders}

Art. 2:230 lid $4 \mathrm{BW}$ verplicht het bestuur van de vennootschap tot het vastleggen van besluiten van de algemene vergadering. Een wettelijke regeling met betrekking tot het notuleren van de algemene vergadering ontbreekt. Voor het bestuur geldt een bewaarplicht op grond van het bepaalde in art. 2:10 lid 3 BW ten aanzien van de aantekeningen van de besluiten. De aantekeningen of besluitenlijst ${ }^{60}$ liggen ten kantore van de vennootschap ter inzage van de aandeelhouders en anderen aan wie vergaderrecht toekomt. Besluiten van de algemene vergadering kunnen de rechten en verplichtingen van de vennootschap raken.

58 Kamerstukken I 2011/12, 31058 en 32 426, nr. C, p. 25 (MvA I).

59 Boschma \& Kuijers-Tollenaar 2013, p.106-108, waar zij deze regels, waarvan de inhoud sterk afhankelijk is van de omstandigheden van het geval, uitwerken.

60 Asser/Maeijer, Van Solinge \& Nieuwe Weme 2-II* 2009, nr. 360. 
De vraag is of het bestuur ook verplicht is tot het vastleggen van besluiten van de vergadering van stemrechtloze aandeelhouders. Het antwoord van de wetgever daarop is 'nee': "Het vereiste van het schriftelijk vastleggen van besluiten van de algemene vergadering dient ter informatie van de vergadergerechtigden. De vereenvoudiging en flexibilisering van het bv-recht beoogt onder meer om de regeldruk voor bedrijven te verminderen. Daarom wordt bijvoorbeeld in artikel 210 lid 5 voorgesteld dat, ingeval alle aandeelhouders tevens bestuurder zijn, de ondertekening van de jaarrekening door alle bestuurders en commissarissen geldt als vaststelling daarvan. Indien vennootschappen ervoor kiezen om de houders van aandelen van een bepaalde soort of aanduiding bijzondere bevoegdheden toe te kennen, staat het hen vrij om de wettelijke regels van overeenkomstige toepassing te verklaren of dit anderszins te regelen." ${ }^{61}$

Het antwoord van de wetgever lijkt mij geen gelukkig antwoord. ${ }^{62}$ De vergadering van houders van stemrechtloze aandelen is een orgaan in de zin van art. 2:189a BW. De wet biedt de mogelijkheid bijvoorbeeld het recht tot benoeming ex art. 2:242 BW en ontslag ex art. 2:244 BW van een bestuurder aan de vergadering van houders van stemrechtloze aandelen als orgaan toe te kennen. Datzelfde geldt bijvoorbeeld voor de bezoldiging van bestuurders op grond van het bepaalde in art. 2:245 BW. Dat zijn belangrijke besluiten, welke besluiten bovendien de rechten en verplichtingen van de vennootschap raken. Niet valt in te zien waarom de wetgever ten aanzien van de verplichting van het bestuur tot het vastleggen van besluiten onderscheid maakt tussen de algemene vergadering en een vergadering van houders van aandelen van een bepaalde soort of aanduiding als orgaan van de vennootschap. Juist omdat het kan gaan om besluiten van de vergadering van houders van aandelen van een bepaalde soort of aanduiding, zoals de vergadering van houders van stemrechtloze aandelen, die de rechten en verplichtingen van de vennootschap kunnen raken, ben ik van mening dat op het bestuur de wettelijke verplichting zou moeten rusten om ook ten aanzien van besluiten van die organen schriftelijk aantekening te houden. Daaraan doet niet af dat het bestuur in de vergadering van houders van stemrechtloze aandelen geen raadgevende stem heeft. Het schriftelijk aantekening houden door het bestuur van besluiten van de vergadering van houders van stemrechtloze aandelen staat wat mij betreft los van de raadgevende stem. Voor het aantekening houden hoeft het bestuur niet ter vergadering aanwezig te zijn, maar zou het bestuur ook een besluitenlijst kunnen opstellen aan de hand van mededelingen van de voorzitter of secretaris van de vergadering van houders van stemrechtloze aandelen dan wel de notulen van die vergadering overeenkomstig art. 2:230 lid 4 BW ter inzage houden. Het voorstel van de wetgever in voorkomend geval art. 2:230 lid $4 \mathrm{BW}$ van overeenkomstige toepassing te verklaren, acht ik met het oog op de rechtszekerheid te vrijblijvend.

61 Kamerstukken I 2011/12, 31058 en 32 426, nr. C, p. 25 (MvA I).

62 In gelijke zin: Boschma \& Kuijers-Tollenaar 2013, p. 105. 
Ik merkte al op dat een wettelijke regeling met betrekking tot het notuleren van de algemene vergadering ontbreekt. ${ }^{63}$ In de praktijk bepalen de statuten van een BV veelal dat notulen van de algemene vergadering moeten worden opgemaakt. Niet alleen lijkt me dat een nuttige statutaire regeling ten aanzien van de notulen van de algemene vergadering, maar ook ten aanzien van de vergadering van houders van stemrechtloze aandelen. Asser/Maeijer, Van Solinge \& Nieuwe Weme stellen dat bij vennootschappen met een gespreid aandelenbezit op grond van de vennootschappelijke redelijkheid en billijkheid door iedere vergadergerechtigde kan worden verlangd dat er notulen worden opgemaakt. ${ }^{64}$ Voor de flex-BV geldt dat mijns inziens eens te meer. Niet alleen kan het gaan om gespreid aandelenbezit, maar ook om diverse soorten aandelen of aandelen met een bepaalde aanduiding in het kapitaal van de BV. Anders dan Asser/Maeijer, Van Solinge \& Nieuwe Weme zou ik niet een beperking tot 'iedere vergadergerechtigde' willen aanbrengen. Naar mijn mening kan een ieder die tot de kring van betrokkenen in de zin van art. 2:8 BW behoort deugdelijke verslaglegging van de besluiten en de besluitvorming in de vorm van notulen verlangen. Zo is een houder van een participatiebewijs in de regel niet vergadergerechtigd. Besluiten van de algemene vergadering kunnen afbreuk doen aan zijn rechten. De houder van een participatiebewijs heeft in het kader van een procedure tot vernietiging van een besluit ex art. 2:15 BW belang bij opgemaakte en deugdelijke notulen. Dat geldt te meer in het kader van vernietiging wegens strijd met de vennootschappelijke redelijkheid en billijkheid. Het gaat daarbij om een belangenafweging. Het is van belang dat de rechter kennis neemt van de redenen en overwegingen die tot het bestreden besluit hebben geleid. De notulen kunnen daarbij een belangrijk hulpmiddel zijn.

\subsubsection{Het stemrechtloze aandeel en het aandeel met een gedifferentieerd stemrecht}

In paragraaf 2.6 stelde $\mathrm{ik}$ al dat het stemrechtloze aandeel moet worden onderscheiden van het aandeel met een variabele verdeling van stemrecht, zoals bedoeld in art. 2:228 lid 4 BW. Het wettelijk uitgangspunt is dat het stemrecht zich evenredig verhoudt tot de nominale waarde van de aandelen (art. 2:228 lid 2 en 3 BW). Daarvan kan echter op grond van art. 2:228 lid 4 BW worden afgeweken, zodat ondanks de gelijke nominale waarde aan een aandeel meer stemrechten zijn verbonden. Bij statuten kan daarom worden voorzien in een flexibel stemrecht ten aanzien van alle besluiten van de algemene vergadering. ${ }^{65}$ Op het flexibele stemrecht ga ik in dit onderzoek niet in. Onderwerp van mijn onderzoek is immers de kapitaalverschaffer zonder stemrecht.

63 Zie uitgebreid over notulen, notulering en inzage in de notulen: Vletter-van Dort 2001, p. 113-123.

64 Asser/Maeijer, Van Solinge \& Nieuwe Weme 2-II* 2009, nr. 361.

65 Kamerstukken II 2006/07, 31 058, nr. 3, p. 84 (MvT); Kamerstukken II 2008/09, 31 058, nr. 6, p. 16 (NV II); Kamerstukken II 2008/09, 31 058, nr. 7, p. 11 (Nota van wijziging); Dortmond 2009 (1), p. 35 en Ten Berg 2007, p. 341-345. Daarnaast bestaat de mogelijkheid van differentiatie van $\rightarrow$ 


\subsection{Het stemrechtloze aandeel bezien in het licht van enkele wettelijke bepalingen}

\subsubsection{Inleiding}

Het stemrechtloze aandeel is in het BV-recht een nieuwe rechtsfiguur. Naast de invoering daarvan in art. 2:228 lid $5 \mathrm{BW}$ verandert er een aantal andere bepalingen in Boek 2 BW. Daarnaast is het de vraag is of het stemrechtloze aandeel een andere uitleg van reeds bestaande bepalingen met zich mee brengt. Deze onderwerpen staan in deze paragraaf centraal. Achtereenvolgens worden besproken de berekening van meerderheden en quora (art. 2:24d BW), het begrip 'dochtermaatschappij' (art. 2:24a BW), het begrip 'groepsmaatschappij' (art. 2:24b BW), het begrip 'deelneming' (art. 2:24c BW), het begrip 'afhankelijke maatschappij' (art. 2:63a, 2:152 en 2:262 BW), de uitzondering op het toestemmingsvereiste van art. 1:88 lid $5 \mathrm{BW}$, de Wet ter voorkoming van witwassen en financieren van terrorisme (Wwft) en de Wet toezicht trustkantoren (Wft), de faillissementspauliana (art. 42 Fw), het begrip 'in overwegende mate bij machte' in Boek $1 \mathrm{BW}$, publiekrechtelijke wetgeving, overige wijzigingen in de wet en - tot slot - het overgangsrecht.

\subsubsection{De berekening van meerderheden en quora (art. 2:24d BW)}

Art. 2:24d lid $1 \mathrm{BW}$ bepaalt als hoofdregel dat bij de vaststelling in hoeverre de leden of aandeelhouders stemmen, aanwezig of vertegenwoordigd zijn, of in hoeverre het aandelenkapitaal verschaft wordt of vertegenwoordigd is, geen rekening wordt gehouden met lidmaatschappen of aandelen waarvan de wet of een statutaire regeling als bedoeld in art. 2:228 lid $5 \mathrm{BW}$ bepaalt dat daarvoor geen stem kan worden uitgebracht. De uitzondering op deze hoofdregel wordt gevormd door art. 2:24d lid $2 \mathrm{BW}$. Dat artikellid bepaalt dat voor de toepassing van de art. 2:24c, 63a, 152, 201a, 220, 224a, 262, 265a, 333a lid 2, 334ii lid 2, 336 lid 1, 346, 379 lid 1 en lid 2, 407 lid 2, 408 lid 1 en 414 BW ten aanzien van BV tevens rekening gehouden met stemrechtloze aandelen, zoals bedoeld in art. 2:228 lid 5 BW.

De hoofdregel van het eerste lid is aldus dat stemrechtloze aandelen bij de berekening van meerderheden en quora in het kader van de besluitvorming dan wel het verschaffen van aandelenkapitaal of vertegenwoordigd zijn, niet meetellen. Het gaat in art. 2:24d lid $1 \mathrm{BW}$ om de situatie van zeggenschap of stemming. Daarmee wordt voorkomen dat de stemrechtloze aandeelhouder besluitvorming kan frustreren door niet aanwezig te zijn, bijvoorbeeld in het geval dat in de statuten bepaald is dat

stemrecht door de bevoegdheid van besluiten die niet dwingendrechtelijk aan de algemene vergadering toekomt statutair toe te kennen aan een vergadering van een houders van aandelen van een bijzonder soort of aanduiding. Zie hierover Ten Berg 2012, p. 616 en Boschma \& Kuijers-Tollenaar 2013, p. 105. 
de bevoegdheid tot wijziging is uitgesloten, in welk geval wijziging niettemin mogelijk is met algemene stemmen in een vergadering waarin het gehele geplaatste kapitaal vertegenwoordigd is (art. 2:231 lid $1 \mathrm{BW}$ ). Anders gezegd, bij het bepalen van de mate waarin het gehele geplaatste kapitaal vertegenwoordigd is, tellen stemrechtloze aandelen niet mee. Niettemin wordt de stemrechtloze aandeelhouder bij statutenwijziging beschermd door het bepaalde in art. 2:231 lid 4 BW.

Het tweede lid formuleert voor de daarin genoemde artikelen de uitzondering. ${ }^{66}$ Het gaat daarbij om de situatie dat een bepaalde omvang in de deelname van het kapitaal relevant is. De in art. 2:24d lid 2 BW genoemde artikelen behelzen de volgende onderwerpen: het begrip 'deelneming' (art. 2:24c BW), het begrip 'afhankelijke maatschappij' in de structuurregeling (art. 2:63a, 2:152 en 2:262 BW), het recht om bijeenroeping van een algemene vergadering te verzoeken (art. 2:220 BW), het agenderingsrecht (art. 2:224a BW), het verzwakte regime bij de structuurregeling (art. 2:265a BW), het uitstotingsrecht in de geschillenregeling (art. 2:336 lid $1 \mathrm{BW}$ ), het enquêterecht (art. 2:346 BW), de verplichting tot vermelding van gegevens van vennootschappen of rechtspersonen waarin ten minste een vijfde van het kapitaal wordt verschaft (art. 2:379 lid 1 en lid 2 BW) of die in relatie staan tot een in de geconsolideerde jaarrekening betrokken vennootschap of rechtspersoon (art. 2:414 lid 1, onderdeel e, en lid 2, onderdeel d BW), de regeling van de driehoeksfusie (art. 2:333a lid $2 \mathrm{BW}$ ) en de driehoekssplitsing (art. 2:334ii BW) en het recht bezwaar te maken tegen het achterwege blijven van consolidatie van de jaarrekening (art. 2:407 lid 2, onderdeel c, en art. 2:408 lid 1, onderdeel a BW).

Ook voor de uitkoopregeling (art. 2:201a BW) wordt een uitzondering gemaakt. Om te voorkomen dat een aandeelhouder die minder dan 95 procent van het geplaatste kapitaal vertegenwoordigt, de minderheid zou kunnen uitkopen (omdat een deel van zijn aandelen stemrechtloos is), is in art. 2:201a BW bepaald dat een aandeelhouder voor het uitkooprecht niet alleen 95 procent van het geplaatste kapitaal moet verschaffen, maar tevens 95 procent van de stemrechten in de algemene vergadering moet kunnen uitoefenen. ${ }^{67}$

De wetgever stelt dat de uitzonderingsregel van art. 2:24d lid $2 \mathrm{BW}$ is opgenomen om te benadrukken dat het gaat om stemrechtloze aandelen in de zin van art. 2:228 lid 5 BW, welke aandelen alleen het BV-recht kent. Daarnaast moet in de systematiek van art. 2:24d lid 2 BW rekening gehouden worden met rechten waarvan het wenselijk is dat deze voor alle aandeelhouders gelden, met inbegrip van houders van stemrechtloze aandelen. Tot slot merkt de wetgever op dat uitzonderingen op de hoofdregel van art. 2:24d BW noodzakelijk zijn om te voorkomen dat

66 Ten Berg heeft kritiek geuit op een eerdere formulering van dit artikel. Zie Ten Berg 2007, p. 342 344. Tijdens de behandeling in de Tweede Kamer van het wetsvoorstel is deze kritiek aan de orde geweest, zie Kamerstukken II 2008/09, 31 058, nr. 6, p. 14-15 (NV II) en Kamerstukken II 2008/09, 31058 , nr. 7, p. 12 (Nota van Wijziging). Het gaat mijn onderzoeksvraag te buiten die eerdere formulering en de reacties daarop uitgebreid te bespreken. Zie ook Portier 2008, p. 238 en Dortmond 2009 (1).

67 Kamerstukken II 2008/09, 31 058, nr. 6, p. 15 (NV II) 
bepaalde regelingen kunnen worden ontweken door gebruik te maken van stemrechtloze aandelen of om te voorkomen dat bepaalde regelingen ingeval van stemrechtloze aandelen een ongewenst effect hebben. ${ }^{68}$

\subsubsection{Het begrip 'dochtermaatschappij' (art. 2:24a BW)}

Art. 2:24a lid 1 BW definieert het begrip 'dochtermaatschappij'. Een dochtermaatschappij van een rechtspersoon is (i) een rechtspersoon waarin de rechtspersoon of een of meer van zijn dochtermaatschappijen, al dan niet krachtens overeenkomst met andere stemgerechtigden, alleen of samen meer dan de helft van de stemrechten in de algemene vergadering kunnen uitoefenen of (ii) een rechtspersoon waarvan de rechtspersoon of een of meer van zijn dochtermaatschappijen lid of aandeelhouder zijn en, al dan niet krachtens overeenkomst met andere stemgerechtigden, alleen of samen meer dan de helft van de bestuurders of van de commissarissen kunnen benoemen of ontslaan, ook indien alle stemgerechtigden stemmen. Indien aan een van de twee criteria is voldaan, is sprake van een dochtermaatschappij. Bij het begrip 'dochtermaatschappij' gaat het om zeggenschap in een rechtspersoon ${ }^{69}$ Het begrip dochtermaatschappij speelt een rol bij de inkoop of verkrijging van aandelen (art. 2:207a en 2:207d BW) en bij de uitoefening van stemrecht op een aandeel dat toebehoort aan de vennootschap of een dochtermaatschappij (art. 2:228 lid 6 BW). Daarnaast speelt het begrip een rol in het jaarrekeningenrecht, meer in het bijzonder in het kader van de consolidatieplicht als bedoeld in art. 2:406 BW. In dat laatste geval gaat het om het opnemen van de financiële gegevens als gevolg van die zeggenschap.

Op grond van de hoofdregel van art. 2:24d lid 1 BW tellen (daarom) stemrechtloze aandelen bij de bepaling of sprake is van een dochtermaatschappij niet mee. Bij het eerste criterium ligt dat voor de hand, omdat stemrechtloze aandeelhouders immers niet stemgerechtigd zijn in de algemene vergadering. Bij het tweede criterium gaat het om het kunnen benoemen of ontslaan van bestuurders of commissarissen. Dat criterium geldt pas indien op grond van het eerste criterium niet reeds tot een dochtermaatschappij gekomen is. Geheel consistent is de hoofdregel van art. 2:24d lid $1 \mathrm{BW}$ niet, omdat op grond van art. 2:242 jo. 2:244 en 2:252 jo. 2:254 BW de bevoegdheid tot benoeming en ontslaan van bestuurders en commissarissen aan de vergadering van stemrechtloze aandeelhouders kan worden toegekend. Bij de benoeming van een bestuurder of commissaris door de vergadering van stemrechtloze aandeelhouders geldt de beperking dat iedere aandeelhouder met stemrecht moet deelnemen aan de benoeming van ten minste een bestuurder of

68 Voor dit alles Kamerstukken II 2008/09, 31 058, nr. 6, p. 14-15 (NV II).

69 Kamerstukken II 2008/09, 31 058, nr. 6, p. 15 (NV II). De definitie van 'dochtermaatschappij’ vloeit voort uit artikel 1, eerste lid, onderdeel a, van de Zevende richtlijn vennootschapsrecht (Richtlijn 83/ 349/EEG van de Raad van 13 juni 1983 op de grondslag van artikel 54, lid 3, sub g) van het Verdrag betreffende de geconsolideerde jaarrekening, $P b E G$ L 193). 
commissaris. Ik verwijs naar paragraaf 6.2.3.3 en 6.2.3.4 De bevoegdheid tot benoeming en ontslaan van bestuurders en commissarissen van de vergadering van stemrechtloze aandeelhouders staat aldus los van het uitoefenen van meer dan de helft van de stemrechten volgens het eerste criterium. Stel dat een BV twee aandeelhouders heeft: een BV houdt alle gewone aandelen in die BV en een andere BV houdt alle stemrechtloze aandelen in die BV. Indien de stemrechtloze aandeelhouder voornoemde bevoegdheden zijn toegekend en op grond van die bevoegdheden meer dan de helft van de bestuurders of commissarissen kan benoemen, dan is de betreffende BV zowel dochtermaatschappij van de BV die alle gewone aandelen houdt als van de BV die alle stemrechtloze aandelen houdt. Een rechtspersoon kan dus dochtermaatschappij zijn van twee of meer andere rechtspersonen. ${ }^{70}$ Vele variaties van 'dochtermaatschappij' zijn mogelijk, indien de benoeming van bestuurders toekomt aan diverse soorten aandelen. Daarbij komt dat de benoeming van bestuurders respectievelijk commissarissen in andere handen kan zijn.

\subsubsection{Het begrip 'groepsmaatschappij' (art. 2:24b BW)}

Art. 2:24b BW definieert de begrippen 'groep' en 'groepsmaatschappij'. Een groep is een economische eenheid waarin rechtspersonen en vennootschappen organisatorisch zijn verbonden. Groepsmaatschappijen zijn rechtspersonen en vennootschappen die met elkaar in een groep zijn verbonden. Uit het artikel volgen twee kernelementen, namelijk een economische eenheid en een organisatorisch verband. Uit de wetsgeschiedenis volgt nog een derde element, namelijk 'gemeenschappelijke leiding' of 'centrale leiding': "Van een groep zal men in het algemeen kunnen spreken, indien een aantal ondernemingen als een economische eenheid onder een gemeenschappelijke leiding optreedt. De band tussen hen zal gewoonlijk in kapitaaldeelneming zijn uitdrukking vinden; met het oog op de zeggenschap die voor het kunnen optreden als eenheid is vereist, zal deze deelneming in de regel een-directe of indirecte - meerderheidsdeelneming zijn; $50 \%$ - en minderheidsdeelnemingen zullen slechts tot het lidmaatschap van de groep leiden, indien de deelneming met bijzondere rechten is versterkt, omdat anders de deelnemende onderneming haar leiding niet met beslissende stem kan doorzetten." ${ }^{, 71}$ Een dochtermaatschappij kan een groepsmaatschappij zijn, maar dat is niet per definitie zo.

Ook de begrippen 'groep' en 'groepsmaatschappij' spelen een belangrijke rol in het jaarrekeningenrecht. ${ }^{72}$ Daarnaast zijn de begrippen van belang in het kader van

70 In gelijke zin: Willemars 2011, p. 135

71 Kamerstukken II 1979/80, 16 326, nr. 3, p. 42 (MvT). Kamerstukken II 1987/88, 19 813, nr. 5, p. 4 (MvA).

72 Art. 2:403 BW en de geconsolideerde jaarrekening, art. 2:405 en 406 BW. Zie ook meer Bartman \& Dorresteijn 2009, p. 32-37. 
de structuurvennootschap, ${ }^{73}$ de driehoeksfusie ${ }^{74}$ en driehoekssplitsing ${ }^{75}$ en de uitkoop van aandeelhouders. ${ }^{76}$

Bij de begrippen gaat het niet om het kunnen uitoefenen van zeggenschap, maar om de daadwerkelijke uitoefening daarvan. Alleen in dat laatste geval is sprake van centrale leiding, welke van belang is voor de economische eenheid en het organisatorisch verband. De daadwerkelijke uitoefening van zeggenschap is een feitelijk(e) vraag of criterium. De Hoge Raad heeft overwogen dat 'uit de wetsgeschiedenis naar voren komt dat optreden onder gezamenlijke leiding kenmerkend is voor de aanwezigheid van een groep en dat daarvoor zeggenschap is vereist. Uit de wetsgeschiedenis blijkt weliswaar dat het bezit van een meerderheidsbelang niet noodzakelijkerwijs leidt tot een groepsrelatie tussen een moedermaatschappij en een dochtermaatschappij, maar een redelijke verdeling van de bewijslast brengt mee dat de partij die zich erop beroept dat ondanks de aanwezigheid van een meerderheidsbelang een groepsrelatie ontbreekt de daarvoor relevante feiten en omstandigheden stelt en zo nodig aannemelijk maakt. ${ }^{, 77}$ Uit de literatuur volgt daarentegen dat het niet per definitie om zeggenschap als gevolg van een kapitaaldeelneming hoeft te gaan. $^{78}$

Op grond van de hoofdregel van art. 2:24d lid 1 BW tellen stemrechtloze aandelen bij de bepaling of sprake is van een groepsmaatschappij niet mee. Ook hier geldt dat deze hoofdregel niet geheel consistent is. Op grond van art. 2:242 jo. 2:244 en 2:252 jo. 2:254 BW kan immers de bevoegdheid tot benoeming en ontslaan van bestuurders en commissarissen aan de vergadering van stemrechtloze aandeelhouders worden toegekend. Een dergelijke toekenning is een omstandigheid die mijns inziens bij de feitelijke invulling van het criterium van 'centrale leiding' moet worden betrokken.

\subsubsection{Het begrip 'deelneming' (art. 2:24c BW)}

Art. 2:24c BW definieert het begrip 'deelneming'. Een rechtspersoon of vennootschap heeft een deelneming in een rechtspersoon, indien hij of een of meer van zijn dochtermaatschappijen alleen of samen voor eigen rekening aan die rechtspersoon kapitaal verschaffen of doen verschaffen teneinde met die rechtspersoon duurzaam verbonden te zijn ten dienste van de eigen werkzaamheid. Indien een vijfde of meer van het geplaatste kapitaal wordt verschaft, wordt het bestaan van een deelneming vermoed, aldus art. 2:24c lid 1 BW. Art. 2:24c lid 2 BW geeft een tweetal

73 Art. 2:263 lid 3 sub b en c en 2:265 lid 3 BW.

74 Art. 2:333a BW.

75 Art. 2:334ii BW.

76 Art. 2:201a BW en - ingeval van een openbaar bod - art. 2:359c BW.

77 HR 18 november 2011, LJN BQ2860, r.o. 3.4.1.

78 Slagter 2005, p. 584-585. Van Schilfgaarde \& Winter 2009, p. 49. A.N. Knol, Sdu Commentaar Ondernemingsrecht, aant. C.4 bij art. 2:24b BW, Den Haag: Sdu Uitgevers 2008, p. 133. Bartman \& Dorresteijn 2009, p. 31. Willemars 2011, p. 135. 
alternatieven van deelneming indien de rechtspersoon als vennoot - en derhalve op grond van een contractuele verhouding - in een vennootschap deelneemt.

Voor het begrip 'deelneming' is de omvang van de kapitaalinbreng in de andere rechtspersoon bepalend. Het begrip is van belang voor het jaarrekeningenrecht. ${ }^{79}$ Zo moeten op grond van art. 2:367 BW deelnemingen onder de financiële activa afzonderlijk op de balans worden opgenomen. Op grond van art. 2:377 BW moet het resultaat van de deelneming afzonderlijk op de winst- en verliesrekening worden opgenomen. Art. 2:389 BW geeft voorschriften omtrent de waardering van deelnemingen. ${ }^{80}$ Ook is het begrip van belang in het kader van het structuurregime. ${ }^{81}$

De uitzonderingsregel van art. 2:24d lid 2 BW bepaalt dat stemrechtloze aandelen bij de toepassing van art. 2:24c BW meetellen bij de vaststelling van de aanwezigheid van een deelneming. Daarmee wordt volgens de wetgever voorkomen dat vennootschappen stemrechtloze aandelen zouden gebruiken om te ontkomen aan de verplichting informatie over die deelnemingen in de financiële verslaggeving op te nemen. ${ }^{82}$ Aan stemrechtloze aandelen zijn immers altijd, al dan niet beperkte, financiële rechten verbonden.

\subsubsection{Het begrip 'afhankelijke maatschappij' (art. 2:63a, 2:152 en 2:262 BW)}

Art. 2:63a, 2:152 en art. 2:262 BW betreffen het begrip 'afhankelijke maatschappij'. De drie bepalingen komen er op neer dat onder een 'afhankelijke maatschappij' wordt verstaan (i) een rechtspersoon waaraan de vennootschap of een of meer afhankelijke maatschappijen alleen of samen voor eigen rekening ten minste de helft van het geplaatste kapitaal verschaffen, of (ii) een vennootschap waarvan een onderneming in het handelsregister is ingeschreven en waarvoor de vennootschap of een afhankelijke maatschappij als vennoot jegens derden volledig aansprakelijk is voor alle schulden. Uit deze bepalingen vloeit voort dat de mate van kapitaalverschaffing van belang is. De daaraan verbonden zeggenschap is niet relevant. ${ }^{83}$ Art. 2:24d lid 2 BW komt er op neer dat bij de vraag of sprake is van een afhankelijke maatschappij tevens rekening gehouden moet worden met de stemrechtloze aandelen in die $\mathrm{BV}^{84}$ De uitzondering is opgenomen om te voorkomen dat de structuurregeling kan worden ontweken door gebruik te maken van stemrechtloze aandelen of om te voorkomen dat bepaalde regelingen ingeval van stemrechtloze aandelen een ongewenst effect hebben. ${ }^{85}$ Het begrip 'afhankelijke

79 Kamerstukken II 2008/09, 31 058, nr. 6, p. 15 (NV II).

80 Zie verder ook art. 2:370, 2:375, 2:407, 2:413 en 2:414 BW.

81 Zie art. 2:263, 2:265 en 2:274 BW.

82 Kamerstukken II 2008/09, 31 058, nr. 6, p. 15 (NV II)

83 Asser/Maeijer, Van Solinge \& Nieuwe Weme 2-II* 2009, nr. 525.

84 Kamerstukken II 2006/07, 31 058, nr. 3, p. 97 (MvT) en Kamerstukken II 2008/09, 31 058, nr. 7, p. 12 en 18

85 Voor dit alles Kamerstukken II 2008/09, 31 058, nr. 6, p. 15 (NV II). 
maatschappij' is onder meer van belang bij de vaststelling of op een vennootschap het structuurregime in de zin van art. 2:263 BW van toepassing is.

Met Willemars ben ik van mening dat de uitzondering van art. 2:24d BW ingeval van een afhankelijke maatschappij er toe kan leiden dat indien een vennootschap stemrechtloze aandelen in een andere vennootschap houdt de structuurregeling van toepassing is, terwijl die stemrechtloze aandeelhouder geen zeggenschap kan uitoefenen over de afhankelijke maatschappij. ${ }^{86}$ Dit klemt te meer, omdat in de literatuur tevens is gesteld dat sprake moet zijn van daadwerkelijke afhankelijkheid, in die zin dat de afhankelijke maatschappij aan de centrale leiding van de kapitaalverschaffende vennootschap moet zijn onderworpen. Gevolg daarvan is dat de afhankelijke maatschappij daadwerkelijk tot het concern behoort. ${ }^{87}$

\subsubsection{Het verzwakte structuurregime van art. 2:265a BW}

Art. 2:265a BW geeft een uitzondering ${ }^{88}$ op het structuurregime van art. 2:264 e.v. BW. Het eerstgenoemde artikel bepaalt onder meer dat de regel van art. 2:272 BW, inhoudende dat de raad van commissarissen het bestuur van de structuurvennootschap benoemt, niet geldt voor een vennootschap waarin een natuurlijk persoon het gehele geplaatste kapitaal verschaft of doet verschaffen, of twee of meer natuurlijke personen volgens een onderlinge regeling tot samenwerking het gehele geplaatste kapitaal verschaffen of doen verschaffen. Er is dan sprake van een verzwakt structuurregime. De vraag is hoe de 'onderlinge regeling tot samenwerking' moet worden gezien, indien de aandelen in een BV in meerdere handen zijn en indien sprake is van stemrechtloze aandelen. In een familievennootschap kan deze situatie zich voordoen. Het verzwakte structuurregime van art. 2:265a BW is juist met het oog op de familievennootschap in de wet opgenomen. ${ }^{89}$ Op grond van art. 2:24d lid 2 BW tellen stemrechtloze aandelen in het kader van het verzwakte structuurregime mee voor de vraag of kapitaal is verschaft.

De wetgever licht het begrip 'onderlinge regeling tot samenwerking' als volgt toe:

"Indien er slechts één aandeelhouder is die de aandelen direct of indirect houdt, kan de vennootschap met de aandeelhouder worden geïdentificeerd. Indien er meerdere aandeelhouders zijn, moeten deze hun persoonlijke betrokkenheid en gebondenheid jegens elkaar hebben vormgegeven in een onderlinge regeling tot samenwerking. Deze formulering is ontleend aan artikel 2:155/265 lid 1 onder c BW. De onderlinge

86 Willemars 2011, p. 135 en 136-138.

87 Asser/Maeijer, Van Solinge \& Nieuwe Weme 2-II* 2009, nr. 525 en Willemars 2011, p. 136-138, beiden met verwijzingen naar literatuur.

88 Naast art. 2:265 BW.

89 Kamerstukken II 2001/02, 28 179, nr. 5, p. 36 (NV II). Zie ook Roest 2005, p. 994-995 en Van Veen 2005, p. 352. 
regeling kan de vorm hebben van een overeenkomst, maar ook van een stichting of vennootschap die de aandelen voor economische belanghebbenden houdt." 90

en

"De woorden «onderlinge regeling tot samenwerking» zijn tot nu toe gebruikt om het economische begrip joint venture te omschrijven. Een onderlinge regeling tot samenwerking heeft dan de vorm van een overeenkomst tussen twee investerende vennootschappen die onder meer bepalingen omvat over de verhouding van de aandelenpakketten. Het hebben van een blokkeringregeling is, hoewel in joint venture verhoudingen zeker niet ongebruikelijk, op zichzelf niet voldoende om te spreken van een onderlinge regeling tot samenwerking. Dat vereist een actieve vormgeving van de gedachten en voornemens rondom het beleid. Van de aandeelhouders wordt verwacht dat zij gezamenlijk, en niet bij meerderheid maar unaniem (de regeling spreekt over alle aandelen) een beleid vormgeven. De wet leent zich slecht voor een nadere opsomming van eisen. Bij de vraag of sprake is van een onderlinge regeling is de rechtspraak normgevend. Men denke aan de uit het verbintenissenrecht bekende norm over de uitleg van overeenkomsten: bepalend is de bedoeling die partijen in de gegeven omstandigheden over en weer redelijkerwijs aan deze bepalingen mochten toekennen en hetgeen zij te dien aanzien redelijkerwijs van elkaar mochten verwachten. Daarbij kan mede van belang zijn tot welke maatschappelijke kringen partijen behoren en welke rechtskennis van zodanige partijen kan worden verwacht (HR 13 maart 1981, NJ 1981, 635)." "91

Uit de geciteerde parlementaire geschiedenis leid ik af dat het bij een onderlinge regeling tot samenwerking moet gaan om (i) een overeenkomst tussen alle aandeelhouders in de BV, (ii) deze aandeelhouders hun persoonlijke betrokkenheid en gebondenheid jegens elkaar door middel van deze overeenkomst hebben vormgegeven, (iii) in deze overeenkomst, althans als uitvloeisel van deze overeenkomst en de persoonlijke betrokkenheid, een actieve vormgeving van de gedachten en voornemens rondom het beleid zijn opgenomen, althans hebben plaatsgevonden dan wel plaats vindt en (iv) beleid wordt bij unanimiteit vormgegeven. ${ }^{92}$

90 Kamerstukken II 2001/02, 28 179, nr. 3, p. 31-32 (MvT)

91 Kamerstukken II 2001/02, 28 179, nr. 5, p. 35-36 (NV II). Zie wat betreft uitleg van overeenkomsten echter ook HR 23 maart 2001, NJ 2003, 715, m.nt. Verstijlen (Ofasec/NTM): in beginsel zijn van doorslaggevende betekenis de bewoordingen waarin het beding is vervat, gelezen in het licht van de gehele tekst van de akte alsmede gelet op de aard en de strekking van de overeenkomsten, zodat geen plaats is voor een maatstaf die berust op hetgeen partijen over en weer van elkaar mochten begrijpen. Zie ook HR 20 februari 2004, NJ 2005, 493, m.nt. Du Perron, JOR 2004, 157, m.nt. Kortmann (DSM/Fox).

92 Zie voor de essentialia van een overeenkomst, zijnde een onderlinge regeling tot samenwerking: Van Veen 2005, p. 354-356 
Dat het beleid bij unanimiteit wordt vormgegeven, houdt volgens de heersende leer in de literatuur niet in dat ook besluiten met unanimiteit moeten worden genomen. Anders zou sprake zijn van een vetorecht, dat juist de beoogde samenwerking zou frustreren. Besluitvorming kan aldus bij gewone of gekwalificeerde meerderheid plaatsvinden. ${ }^{93}$ Wel moeten alle natuurlijke personen kunnen deelnemen aan het overleg in het kader van de besluitvorming, in dat overleg zich constructief opstellen en moeten zij zich inspannen om naar beste vermogen het gezamenlijk beleid tot stand te brengen. ${ }^{94}$

De overeenkomst is vormvrij en zal vaak een aandeelhoudersovereenkomst zijn. Het verdient de voorkeur de overeenkomst schriftelijk aan te gaan. ${ }^{95}$

Terug naar het stemrechtloze aandeel. Dat aandeel is te vergelijken met een certificaat van aandeel. In de literatuur wordt op basis van de hiervoor geciteerde parlementaire geschiedenis ("De onderlinge regeling kan de vorm hebben van een overeenkomst, maar ook van een stichting of vennootschap die de aandelen voor economische belanghebbenden houdt.") aangenomen dat ook indien aandelen in de vennootschap zijn gecertificeerd sprake kan zijn van een onderlinge regeling tot samenwerking. ${ }^{96}$ Onder het oude BV-recht werd daarbij geen verschil gemaakt tussen certificaten met of zonder medewerking van de vennootschap uitgegeven. ${ }^{97}$ Ik zou deze lijn ook willen volgen onder het huidige BV-recht, waarbij aan certificaten al dan niet vergaderrecht wordt verleend.

Om te voldoen aan het vereiste van een onderlinge regeling tot samenwerking zal er een samenwerkingsovereenkomst tussen de certificaathouders gesloten moeten worden. Die overeenkomst moet aan dezelfde voorwaarden voldoen, zoals hiervoor omschreven. Daarnaast zal, meer in het bijzonder, die overeenkomst zo moeten worden ingericht dat de certificaathouders controle hebben over het administratiekantoor zodat zij feitelijk het beleid in de vennootschap kunnen vormgeven. Essentieel wordt daarbij geacht dat (i) de vergadering van certificaathouders het recht heeft bestuurders van het administratiekantoor te benoemen en te ontslaan en (ii) het bestuur van het administratiekantoor haar stem in de algemene vergadering van de vennootschap zal uitbrengen conform de instructies van de vergadering van certificaathouders. $^{98}$ In het geval dat aan de certificaten van aandelen geen

93 De Nijs Bik 2002, p. 99; De Nijs Bik 2004, p. 36-37; Van Veen 2005, p. 355; Roest 2005, p. 996 en Asser/Maeijer, Van Solinge \& Nieuwe Weme 2-II* 2009, nr. 555 onder verwijzing naar literatuur.

94 De Nijs Bik 2004, p. 36-37 en Van Veen 2005, p. 355

95 Asser/Maeijer, Van Solinge \& Nieuwe Weme 2-II* 2009, nr. 555.

96 Schwarz 2002, p. 48; Van Veen 2005, p. 357; Roest 2005, p. 996 en Sanders \& Westbroek 2005, p. 247-248.

97 Van Veen 2005, p. 358. Anders: Schwarz 2002, p. 48-49.

98 Van Veen 2005, p. 357-358; Roest 2005, p. 996. Enigszins anders: Schwarz 2002, p. 48, die - zo begrijp ik - ook een wat lossere vorm van controle mogelijk acht (althans meer varianten ziet), mede afhankelijk van de vraag of de certificaten met of zonder medewerking van de vennootschap zijn uitgegeven. Met Schwarz ben ik eens dat het voor de hand ligt om de houders van bewilligde certificaten meer controle te geven dan houders van niet-bewilligde certificaten (en in de terminologie van het huidige recht de houders van certificaten met en zonder vergaderrecht). 
vergaderrecht is toegekend, ligt het mijns inziens minder voor de hand dat sprake is van een onderlinge regeling tot samenwerking. Indien de statuten van de vennootschap zulks immers niet bepalen, is het niet logisch de certificaathouders op andere wijze wel invloed op het beleid van de vennootschap te geven. De vennootschap waarvan de aandelen zijn gecertificeerd kan niet kwalificeren voor het verzwakte regime, indien (i) geen sprake is van een samenwerkingsovereenkomst tussen de certificaathouders of (ii) de certificaathouders geen controle over het administratiekantoor hebben. ${ }^{99}$

Hoe moet het stemrechtloze aandeel in het kader van het verzwakte structuurregime van art. 2:265a BW worden gezien? De wetgever heeft zich hierover niet uitgelaten. Echter, op grond van art. 2:24d lid 2 BW tellen stemrechtloze aandelen mee voor de vraag of kapitaal is verschaft, zodat de wetgever kennelijk heeft beoogd art. 2:265a BW ook toepassing te laten vinden indien in een BV stemrechtloze aandelen zijn uitgegeven. Mijns inziens moet wat betreft het stemrechtloze aandeel en het verzwakte structuurregime van art. 2:265a BW aansluiting worden gezocht bij de mogelijkheid dat indien aandelen in de vennootschap zijn gecertificeerd sprake kan zijn van een onderlinge regeling tot samenwerking. Er zal sprake moeten zijn van een overeenkomst tussen alle aandeelhouders in de BV, dus tussen de houders van aandelen met en zonder stemrecht. Wat zou de inhoud van een dergelijke overeenkomst moeten zijn? Hiervoor stelde ik dat vereiste van een onderlinge regeling tot samenwerking onder meer is dat in die regeling of overeenkomst een actieve vormgeving van de gedachten en voornemens rondom het beleid zijn opgenomen, althans hebben plaatsgevonden dan wel plaats vindt, en dat het beleid bij unanimiteit wordt vormgegeven. Certificaathouders dienen controle over het administratiekantoor te hebben. Houders van stemrechtloze aandelen ontberen stemrecht in de algemene vergadering en kunnen evenmin bestuurders benoemen of ontslaan, tenzij in de statuten anders is bepaald. In de regel zullen stemrechtloze aandelen worden uitgegeven om de houder van die aandelen geen zeggenschap in de vennootschap te verlenen. Het is dan de vraag of in de praktijk via de onderlinge regeling tot samenwerking via de achterdeur die zeggenschap wel zal worden verleend. Op het eerste gezicht lijken stemrechtloze aandelen daarom niet bruikbaar bij het vormgeven van een onderlinge regeling tot samenwerking in het kader van een verzwakt structuurregime.

Op welke manier zou een onderlinge regeling tot samenwerking met stemrechtloze aandelen kunnen worden vormgegeven, zodat voor een verzwakte structuurregime geopteerd kan worden? $\mathrm{Bij}$ het vormen van de onderlinge regeling tot samenwerking en in de statuten van de vennootschap zal 'controle' aan de houders van stemrechtloze aandelen moeten worden toegekend. Dat kan bijvoorbeeld door middel van het toekennen van het recht tot het benoemen en ontslaan van een bestuurder ex art. 2:242 en 2:244 BW. Andere mogelijkheden zijn: het goedkeuren

99 Kamerstukken II 2001/02, 28 179, nr. 3, p. 32 (MvT). Kamerstukken II 2001/02, 28 179, nr. 5, p. 36 (NV II). Roest 2005, p. 996, 997 en 999. 
van bestuursbesluiten ex art. 2:239 lid $3 \mathrm{BW}$, het toekennen van instructiebevoegdheid ex art. 2:239 lid 4 BW, het recht tot het doen van een bindende voordracht tot benoeming van een bestuurder ex art. 2:243 $\mathrm{BW}$, het recht de bezoldiging van het bestuur vast te stellen ex art. 2:245 BW en het recht tot het bestemmen van de winst ex art. 2:216 BW. Met name het recht tot goedkeuring van bestuursbesluiten, het recht van benoemen en ontslag van bestuurders en de instructiebevoegdheid acht ik essentialia in de onderlinge regeling tot samenwerking.

Herhaald zij, dat het toekennen van deze bevoegdheden aan houders van stemrechtloze aandeelhouders op het eerste gezicht niet strookt met het doel van de uitgifte van deze aandelen. Ook zou men mij kunnen tegenwerpen dat bij toekennen van deze bevoegdheden weliswaar de positie van de houders van stemrechtloze aandelen is versterkt, maar dat die aandeelhouders stemrecht in de algemene vergadering blijven ontberen. Anders dan bij certificering van aandelen, kan niet de bevoegdheid worden toegekend dat volgens 'instructie' wordt gestemd. Indien aan de vergadering van stemrechtloze aandeelhouders een instructiebevoegdheid ex art. 2:239 lid 4 BW is toegekend, zal het bestuur die instructie niet (moeten) opvolgen indien de instructie in strijd is met het belang van de vennootschap en de met haar verbonden onderneming.

Deze tegenwerpingen nemen niet weg dat er mijns inziens geen goed argument te bedenken is waarom bij gebruikmaking van de rechtsfiguur van certificering wel sprake kan zijn van een onderlinge regeling tot samenwerking, welke samenwerking op de hiervoor omschreven wijze is vormgegeven, en bij gebruikmaking het stemrechtloze aandeel als rechtsfiguur niet. Te meer, omdat het certificaat met vergaderrecht en het stemrechtloze aandeel grote gelijkenis vertonen. Mijn conclusie is dan ook dat familievennootschappen, waarbij stemrechtloze aandelen uitgegeven zijn, kunnen opteren voor het verzwakt structuurregime van art. 2:265a BW, mits de onderlinge regeling tot samenwerking op de wijze als hiervoor omschreven is vormgegeven en aan de overige vereisten van art. 2:265a BW is voldaan. ${ }^{100}$

\subsubsection{De uitzondering op het toestemmingsvereiste van art. 1:88 lid $5 \mathrm{BW}^{101}$}

Art. 1:88 lid 1 sub c BW stelt dat de ene echtgenoot van de andere echtgenoot toestemming behoeft voor het aangaan van overeenkomsten die ertoe strekken dat hij, anders dan in de normale uitoefening van zijn beroep of bedrijf, zich als borg of hoofdelijk medeschuldenaar verbindt, zich voor een derde sterk maakt, of zich tot zekerheidstelling voor een schuld van de derde verbindt. Art. 1:88 lid $5 \mathrm{BW}$ stelt dat toestemming voor een rechtshandeling als bedoeld in lid 1 onder $\mathrm{c}$, niet vereist is,

100 In gelijke zin Roest 2012, p. 105.

101 Deze paragraaf en het daarin vervatte standpunt heb ik eerder verdedigd, zie Wolf 2011 (1). Zie over het stemrechtloze aandeel en art. 1:88 lid 5 BW ook Van den Munckhof 2011, mijn reactie daarop, Wolf 2012, en het naschrift van Van den Munckhof 2012. 
indien zij wordt verricht door een bestuurder van een naamloze vennootschap of van een besloten vennootschap met beperkte aansprakelijkheid, die daarvan alleen of met zijn medebestuurders de meerderheid van de aandelen houdt en mits zij geschiedt ten behoeve van de normale uitoefening van het bedrijf van die vennootschap. Art. 1:88 BW speelt een grote rol in de financieringspraktijk.

$\mathrm{Nu}$ de flex-BV (onder meer) stemrechtloze aandelen kent, is de vraag wat onder 'de meerderheid der aandelen' in de zin van art. 1:88 lid 5 BW moet worden verstaan. ${ }^{102}$ De wetgever is op deze vraag niet ingegaan. Bij beantwoording van deze vraag beperk ik mij (voornamelijk) tot het stemrechtloze aandeel.

Uit de parlementaire geschiedenis blijkt dat art. 1:88 BW in het belang van de andere echtgenoot beperkt moet worden uitgelegd. Garanties ten behoeve van derden plegen uitzonderlijke en gevaarlijke handelingen te zijn. De uitoefenaar van een zelfstandig beroep die door middel van een eenmanszaak of vennootschap onder firma aan het handelsverkeer deelneemt, draagt daarvoor de volle aansprakelijkheid, waarvan zijn echtgenote de financiële gevolgen kan ondervinden, zonder dat diens persoonlijke toestemming voor de aansprakelijkheid scheppende handeling is vereist. Deze persoonlijke aansprakelijkheid kan in beginsel worden uitgesloten door het beroep of bedrijf door middel van een naamloze of besloten vennootschap uit te oefenen. De enkele aansprakelijkheid van deze vennootschap wordt in de praktijk, niet ten onrechte, veelal onvoldoende geacht bij belangrijke transacties, zoals geldleningen. Gebruikelijk is dan ook dat daarvoor door de wederpartij extra zekerheid wordt verlangd door middel van handelingen als die waarop art. 1:88 lid 1 sub c BW het oog heeft. Lid 5 komt aan deze behoefte van de praktijk tegemoet. Dit is ook tegenover de andere echtgenoot gerechtvaardigd, omdat deze geen extra risico loopt vergeleken bij een rechtstreekse beroeps- of bedrijfsuitoefening buiten de rechtsvorm van de besloten vennootschap. ${ }^{103}$ Juist de weigering van de toestemming voor de extra zekerheid kan het gezin in financiële moeilijkheden brengen, omdat het (onmisbare) bankkrediet dan niet kan worden verkregen. ${ }^{104}$ Tot zover de algemene gedachten van de wetgever achter art. 1:88 lid 1 en 5 BW. De Hoge Raad heeft de restrictieve uitleg van de uitzondering op het toestemmingsvereiste van art. 1:88 lid $5 \mathrm{BW}$ herhaald. ${ }^{105}$

102 Lennarts \& Boschma 2010, p. 710, werpen (terecht) deze vraag op.

103 Parl. Gesch. Invoering Boek 3, 5 en 6 BW, Aanpassing BW, p. 20

104 Parl. Gesch. Invoering Boek 3, 5 en 6 BW, Aanpassing BW, p. 36. Het belang van het gezin staat voorop, zie onder meer HR 23 mei 1969, NJ 1969, 340, m.nt. H. Drion; HR 4 januari 1974, NJ 1974, 515 en HR 15 december 1978, NJ 1979, 427, m.nt. E.A.A. Luijten. Art. 1:88 BW beoogt de niethandelende echtgenoot te beschermen, zie HR 13 maart 1993, NJ 1994, 92, m.nt. E.A.A. Luijten; HR 19 november 1993, NJ 1994, 259, m.nt. WMK en HR 22 september 1995, NJ 1996, 521 m.nt. WMK. Het resultaat van het vernietigen van de rechtshandeling door de niet-handelende echtgenoot kan de handelend echtgenoot ook ten voordeel strekken. Zie HR 31 mei 1991, NJ 1991, 777, m.nt. E.A.A. Luijten.

105 HR 14 april 2000, r.o. 3.4, LJN AA5526, NJ 2000, 689, m.nt. WMK en JOR 2000, 113 (Soetelieve/ Stienstra) en HR 19 december 2008, LJN BF3942 (Fortis). 
Tijdens de parlementaire behandeling van art. 1:88 BW is zijdelings het begrip 'meerderheid van de aandelen' aan de orde gekomen. Zo is opgemerkt dat 'meerderheid van de aandelen' niet hetzelfde is als meerderheid van stemmen of meerderheid van geplaatst kapitaal. Bovendien zijn veel aandelen gecertificeerd. ${ }^{106}$ Door de wetgever is daarop gereageerd dat geen rekening gehouden is met afwijkingen van de normale regeling van het stemrecht en evenmin met de mogelijkheid van certificering van aandelen. De wetgever heeft het oog op vennootschappen met een eenvoudige en doorzichtige regeling, waarvan de structuur zelden gecompliceerd is. Afwijking van de wettelijke stemregeling en certificering van aandelen zijn denkbaar, maar zullen weinig voorkomen. Van belang is een combinatie van zeggenschap en financieel belang, zoals die zich ook voordoet bij de eenmanszaak en de vennootschap onder firma. Wie een voorkeur heeft voor een ingewikkelde structuur, moet voor het verschaffen van borgtocht de toestemming van zijn echtgenoot zien te verkrijgen, aldus de wetgever. ${ }^{107}$ In ander verband merkte de wetgever op dat het erom gaat of een bestuurder wegens de zeggenschap en het financiële belang dat hij in die rechtspersoon heeft, zo nauw daarmee verbonden is, dat hij in de praktijk als de ondernemer kan gelden. ${ }^{108}$

Hoewel ten tijde van de parlementaire behandeling van art. 1:88 BW in de literatuur al aandacht is besteed aan de vraag of certificering van aandelen en middellijk aandeelhouderschap onder de uitzondering van het toestemmingsvereiste vallen, ${ }^{109}$ heeft de wetgever aldus nagelaten daarop een duidelijk antwoord te geven.

Ook is tijdens de parlementaire behandeling van art. 1:88 lid 5 BW aarzeling geuit tegen de uitzondering op het toestemmingvereiste. Zo is opgemerkt dat geen toestemming van de andere echtgenoot is vereist indien de echtgenoot bestuurder van een NV of BV is en weliswaar tezamen met zijn medebestuurders de meerderheid der aandelen houdt, doch zelf slechts een (zeer) gering gedeelte van de aandelen houdt. Het gevolg zou zijn dat de echtgenoot van een bestuurder van een $\mathrm{NV}$ of BV een veel groter risico loopt dan die van de ondernemer in een eenmanszaak. ${ }^{110}$ Door de wetgever is hierover opgemerkt dat deze situatie zich slechts zelden zal voordoen, dat de echtgenoten van vennoten van een vennootschap onder firma grotere risico's lopen en dat sprake is van een indirect risico. Eerst zal de rechtspersoon worden aangesproken. Een andere, meer bevredigende regel is volgens de wetgever niet goed te vinden. Zou vereist zijn dat de bestuurder de meerderheid, of ten minste de helft van de aandelen moet bezitten, dan komt men in elk geval in moeilijkheden bij NV's en BV's met meer dan twee bestuurders, en veelal reeds bij deze rechtspersonen met meer dan één bestuurder. ${ }^{111}$

106 Parl. Gesch. Invoering Boek 3, 5 en 6 BW, Aanpassing BW, p. 34 107 Parl. Gesch. Invoering Boek 3, 5 en 6 BW, Aanpassing BW, p. 35

108 Parl. Gesch. Invoering Boek 3, 5 en 6 BW, Aanpassing BW, p. 36.

109 Van Mourik 1983, p. 104 en Honée 1984, p. 94.

110 Parl. Gesch. Invoering Boek 3, 5 en 6 BW, Aanpassing BW, p. 23.

111 Parl. Gesch. Invoering Boek 3, 5 en 6 BW, Aanpassing BW, p. 25 
In de literatuur en rechtspraak bestond verdeeldheid over de vraag of de uitzondering op het toestemmingsvereiste van art. 1:88 lid 5 BW ook ziet op gevallen waarin rechtshandelingen worden verricht door een 'indirecte' bestuurderaandeelhouder. ${ }^{112}$

Uit het Kelders/Fortis-arrest ${ }^{113}$ volgt dat de uitzondering van art. 1:88 lid 5 BW geldt onverschillig of de bestuurder van een NV of BV die daarvan alleen of met zijn medebestuurders de meerderheid van de aandelen houdt en die zich voor de nakoming van de verplichtingen van die vennootschap als borg verbindt, rechtstreeks aandeelhouder van de desbetreffende vennootschap is of dat die aandelen worden gehouden door één of meer tussengeschakelde vennootschappen. Wél dient ook ten aanzien van de eventueel tussengeschakelde vennootschappen te zijn voldaan aan de eisen van bestuur en aandeelhouderschap die art. 1:88 lid 5 BW stelt, aldus de Hoge Raad. De Hoge Raad overweegt verder dat het moet gaan om een 'gecontroleerde vennootschap' die als tussenschakel fungeert. ${ }^{114}$ Ook refereert de Hoge Raad aan de in de parlementaire geschiedenis genoemde combinatie van zeggenschap en financieel belang. ${ }^{115}$ In zijn $N J$-noot stelt Kleijn ${ }^{116}$ dat het criterium van de ingewikkeldheid van de structuur - door hem een formeel criterium genoemd tot rechtsonzekerheid leidt en dat certificering van aandelen niet per definitie tot een ingewikkelde structuur leidt. ${ }^{117}$ Ook daarbij kunnen zeggenschap en financieel belangdoor Kleijn een materieel criterium genoemd - immers gehandhaafd blijven. Het

112 In bevestigende zin: Rb. Utrecht 18 september 1996, JOR 1996, 116; Hof Amsterdam 6 november 1997, JOR 1998, 95, m.nt. C.J. Groffen (waarvan cassatie: het Kelders/Fortis-arrest). Groffen onderschrijft de uitspraak van het hof. Hof Amsterdam 13 december 2001, NJ 2004, 145, r.o. 4.3; Rb. 's-Gravenhage 26 februari 2003, JOR 2003, 188, r.o. 3.2 en Rb. Amsterdam 16 april 2003, JOR 2003, 191, r.o. 8.1. Honée 1984, p. 94, lijkt ook die mening toegedaan. In ontkennende zin: Rb. Utrecht 18 september 1996, JOR 1996, 116, r.o. 4.5; Hof Arnhem 8 oktober 2002, NJ 2003, 444, JOR 2003, 187, m.nt. A.J. Verdaas (Ledegang/Roordink Bedrijfswagens) en Rb. Utrecht 2 april 2003, LJN AF6970, NJ 2003, 353, JOR 2003, 190, m.nt. A.J. Verdaas, r.o. 4.6. Zie voor een overzicht van literatuur sub 8 van de concl. P-G bij HR 11 juli 2003, LJN AF7513. Zie ook Verdaas in sub 2 van zijn noot onder hetzelfde arrest, JOR 2003, 223. In zijn noot onder JOR 2003, 191 stelt Verdaas dat indirect aandeelhouderschap onder de uitzondering op het toestemmingsvereiste valt, mits de directe of indirecte bestuurder van de betrokken vennootschap een doorslaggevende stem in de algemene vergadering en enig financieel belang als aandeelhouder heeft dan wel een daarmee gelijk te stellen financieel belang, bijvoorbeeld als certificaathouder.

113 HR 11 juli 2003, LJN AF7513, NJ 2004, 173, m.nt. WMK, JOR 2003, 223, m.nt. Verdaas (Kelders Fortis). Onder het vóór 1 januari 1992 geldende recht besliste de Hoge Raad nog in tegengestelde zin, zie HR 22 september 1995, NJ 1996, 521, m.nt. WMK.

114 r.o. 3.6

115 r.o. 3.4 .

116 sub 3 van de noot.

117 Kleijn spreekt over een eenvoudige certificering, waarbij de directeur-grootaandeelhouder (vooralsnog) zelf alle certificaten houdt en daardoor volledige zeggenschap behoudt en zijn financieel belang continueert. 
Hof 's-Hertogenbosch oordeelde in navolging van het Kelders/Fortis-arrest dat ook voor een extra tussengeschakelde vennootschap de uitzondering van lid 5 opgaat. ${ }^{118}$

In het Fortis/Van der Zee-arrest ${ }^{119}$ beantwoordde de Hoge Raad de vraag of art. 1:88 lid $5 \mathrm{BW}$ toepassing vindt in een situatie die mede ziet op handelingen van een echtgenoot die bestuurder is van een BV en de aandelen daarvan niet houdt maar slechts heeft gekocht zonder dat die aan hem zijn geleverd. De Hoge Raad achtte lid 5 in die situatie niet van toepassing. De kwalificatie 'economische eigendom van de aandelen' van het onderdeel voor deze rechtstoestand maakt dit niet anders, aldus de Hoge Raad. ${ }^{120}$ De Hoge Raad lijkt in dit arrest gewicht toe te kennen aan het feit dat de bestuurder vanwege de economische eigendom van de aandelen geen zeggenschap in de algemene vergadering had. Daarmee sluit hij aan bij de in de parlementaire geschiedenis genoemde combinatie van zeggenschap en financieel belang. Het ontbreken van zeggenschap in de algemene vergadering kan zich ook voordoen bij een bestuurder die tevens en alleen stemrechtloze aandelen in een BV houdt. In dat geval lijkt mij toestemming van de andere echtgenote vereist en gaat de uitzondering van art. 1:88 lid $5 \mathrm{BW}$ aldus niet op.

In het Abbink/SNS Bank-arrest ${ }^{121}$ kwam de vraag aan de orde of de uitzondering van het toestemmingsvereiste ook geldt in geval van certificering van aandelen. In de literatuur en rechtspraak was daarover discussie. ${ }^{122}$ De casus was als volgt. In een BV waren alle aandelen gecertificeerd en werden gehouden door een STAK. De enig bestuurder van de BV was tevens enig bestuurder van de STAK. De BV had met de bank een kredietovereenkomst gesloten. De bestuurder van de BV, tevens certificaathouder, had zich persoonlijk als hoofdelijk medeschuldenaar jegens de bank ter zake van deze kredietovereenkomst verbonden. De echtgenote van de bestuurder vernietigde deze laatste rechtshandeling ex art. 1:89 BW, stellende dat haar toestemming in de zin van art. 1:88 BW voor het aangaan van die rechtshandeling was vereist. De uitzondering van art. 1:88 lid $5 \mathrm{BW}$ gaat niet op, omdat de aandelen zijn gecertificeerd, aldus de echtgenote.

118 Hof 's-Hertogenbosch 11 januari 2011, LJN BP1015, JOR 2012, 191, r.o. 4.6. De ondernemer had als aandeelhouder het financiële belang via de ene holding en als bestuurder de zeggenschap via de andere holding.

119 HR 20 januari 2006, LJN AU5681, NJ 2006, 79, JOR 2006, 195, m.nt. Verdaas (Fortis/Van der Zee). Zie ook Rb. 's-Hertogenbosch 18 januari 2012, LJN BV2015, JOR 2012, 367.

120 r.o. 3.5 .

121 HR 8 oktober 2010, LJN BN1402, NJ 2011, 30, m.nt. Verstappen; JOR 2010, 367; JIN 2010, 863, m.nt. Vergouwen en Boekhorst; en Breedveld-de Voogd 2010.

122 Zie in positieve zin: Van Mourik 1983, p. 104, en Honée 1984, p. 94. Zie ook Kleijn in zijn noot onder het Kelders/Fortis-arrest (NJ 2004, 173). Kleijn pleit er voor eenvoudige certificering gelijk te behandelen als de situatie waarin sprake is van indirect aandeelhouderschap, zoals in het Kelders/ Fortis-arrest. In dezelfde zin Hof Amsterdam 13 december 2001, NJ 2004, 145, Rb. Rotterdam 26 maart 2003, JOR 2003, 189 en Rb. Almelo 21 februari 2007, JOR 2007, 130, m.nt. Steneker. Verdaas stelde in sub 8 van zijn noot onder het Fortis/Van der Zee-arrest (JOR 2006, 195) dat op grond van de overwegingen in dat arrest ingeval van certificering de uitzondering van art. 1:88 lid 5 BW niet op gaat. In sub 15 van zijn noot in JOR 2003, 191 dacht hij daarover nog anders. 
De Hoge Raad beantwoordde de vraag of de uitzondering van het toestemmingsvereiste ook geldt in geval van certificering van aandelen bevestigend. De Hoge Raad formuleert het in r.o. 3.6 als volgt: "Anders dan het middel ingang wil doen vinden, biedt de totstandkomingsgeschiedenis van art. 1:88 BW (...) geen steun voor de lezing dat de wetgever het geval van certificering van aandelen als noodzakelijk leidende tot een ingewikkelde vennootschapsstructuur, zonder meer buiten het toepassingsbereik van de uitzonderingsbepaling van art. 1:88 lid 5 heeft willen houden. Veeleer blijkt dat de wetgever een uitgebreidere regeling - waarin, wat betreft de inrichting van de vennootschap, met verschillende mogelijkheden rekening wordt gehouden - niet nodig heeft geoordeeld op de grond dat vennootschappen als waarop de onderhavige bepaling ziet, zelden gecompliceerd van structuur zullen zijn. Uit deze, met het oog op de praktijk gemotiveerde keuze voor een eenvoudige regeling, kan niet worden afgeleid dat inrichtingsvormen waarmee, blijkens de ontstaansgeschiedenis, in lid 5 geen rekening is gehouden, bij voorbaat aan toepassing van deze uitzonderingsbepaling in de weg staan. Beoordeeld zal moeten worden (...) of in voorkomend geval de handelend echtgenoot zo nauw verbonden is met de onderneming dat hij in de praktijk als ondernemer kan gelden, doordat hij de zeggenschap uitoefent en financieel belang heeft bij de bedrijfsresultaten van de vennootschap ten behoeve waarvan hij zich als hoofdelijk medeschuldenaar verbindt. (...) $\mathrm{Nu}$ voorts niet kan worden gesproken van een complexe vennootschapsstructuur anders dan dat de aandelen zijn gecertificeerd via een stichting, moet het in overeenstemming met de strekking van art. 1:88 lid 5 worden geoordeeld de rechtsgeldigheid van een in privé aangegane verbintenis als de onderhavige, niet te onderwerpen aan toestemming van de echtgenote. (...)”

Uit r.o. 3.6 van het arrest blijkt bovendien dat de Hoge Raad belang heeft gehecht aan het feit dat sprake was van een eenvoudige certificeringsconstructie. Daarbij overweegt de Hoge Raad dat, door zijn positie als enig bestuurder van de stichting (zijnde de enig aandeelhouder van de BV) tevens certificaathouder, de bestuurder zijn zeggenschap binnen de BV alsmede zijn financieel belang bij de bedrijfsresultaten van de BV heeft behouden. De Hoge Raad overweegt dat deze eenvoudige certificeringsconstructie zich niet van het geval van indirecte zeggenschap, die aan de orde was in het Kelders/Fortis-arrest, onderscheidt.

Uit de hiervoor aangehaalde parlementaire geschiedenis volgt dat de wetgever bij de totstandkoming van art. 1:88 lid 5 BW geen rekening heeft gehouden met de mogelijkheid van certificering van aandelen. Naar de letter van de wet valt certificering aldus niet onder de uitzondering van art. 1:88 lid $5 \mathrm{BW}$. Uit het Abbink/SNS Bank-arrest volgt echter dat de Hoge Raad de strekking van de wet voorop stelt. Het arrest is in lijn met het Kelders/Fortis-arrest. Anders dan in het Fortis/Van der Zee-arrest, kon de bestuurder in het Abbink/SNS Bank-arrest via de STAK zeggenschap uitoefenen. 
De lijn in de jurisprudentie is aldus dat voor de uitzondering van art. 1:88 lid 5 BW het formele criterium - de ingewikkeldheid van de vennootschapsstructuur en het materiële criterium - de combinatie van zeggenschap en financieel belang - leidend zijn. De mate van ingewikkeldheid van de vennootschapsstructuur hangt af van de gekozen constructie. De gekozen constructie bepaalt ook de mate van zeggenschap en financieel belang, alsmede de combinatie daarvan.

De lijn is te begrijpen vanuit het oogpunt en de eisen van een vlot lopend handelsverkeer, maar erg concreet zijn deze criteria niet, althans de toepassing van deze criteria brengt rechtsonzekerheid met zich mee. In het Kelders/Fortis-arrest was sprake van een kerstboomstructuur, ${ }^{123}$ terwijl in het Abbink/SNS Bank-arrest sprake was van een eenvoudige certificering, waarbij de handelende bestuurder zowel bestuurder van de BV als van de STAK was. ${ }^{124}$ In een vennootschappelijke structuur zijn er vele combinaties van zeggenschap en financieel belang mogelijk. De uitwerking daarvan is sterk casuïstisch. De toetsing van het formele en materiële criterium is (uiteindelijk) aan de feitenrechter overgelaten.

De vraag is dan ook waar de grens van de complexe vennootschapsstructuur ligt. De genoemde arresten geven echter geen antwoord op de vraag wanneer het te complex wordt en dat werkt rechtsonzekerheid in de hand. ${ }^{125}$ Zo zijn ook bij certificering vele constructies mogelijk, mede ingegeven door het doel van de certificering. In de literatuur wordt gesteld dat ingeval van certificering, waarbij de enig certificaathouder een van de bestuurders van de STAK is, zonder in het bestuur van de STAK de (overwegende) zeggenschap te hebben, het wel mogelijk is het ontbreken van toestemming van de andere echtgenoot met succes in te roepen. ${ }^{126}$ Het Abbink/SNS Bank-arrest leert dat eenvoudige certificering wel onder de uitzondering van het toestemmingsvereiste valt.

Het formele en materiële criterium spelen uiteraard niet alleen ingeval van certificering. Bij de beoordeling van de uitzondering op het toestemmingsvereiste zal telkenmale naar de gehele vennootschapstructuur gekeken moeten worden. Vele

123 Zie voor een mooi schema: Waal 2003, p. 162.

124 Breedveld-de Voogd 2010, p. 14, stelt dat uit het Abbink/SNS Bank-arrest niet blijkt dat eisen worden gesteld aan de rechten die de certificaathouder jegens de STAK kan uitoefenen, anders dan dat vastgesteld moet worden dat hij certificaathouder is. Naar mijn mening doet de Hoge Raad dat wel. De Hoge Raad neemt tot maatstaf of in voorkomend geval de handelend echtgenoot zo nauw verbonden is met de onderneming dat hij in de praktijk als ondernemer kan gelden, doordat hij zeggenschap uitoefent en financieel belang heeft bij de bedrijfsresultaten van de vennootschap ten behoeve waarvan hij zich als hoofdelijk medeschuldenaar verbindt. Bij toetsing zal de rechter in voorkomend geval de inhoud van de administratievoorwaarden moeten betrekken. In dit concrete geval was er geen noodzaak de administratievoorwaarden te betrekken, omdat de handelende bestuurder zowel bestuurder van de BV als van de STAK was. Als bestuurder van de STAK en certificaathouder kon hij aldus zelfstandig de inhoud van de administratievoorwaarden bepalen.

125 Zie in dezelfde zin Breedveld-de Voogd 2010, p. 14 en L.C.A. Verstappen in zijn NJ-noot (NJ 2011, 30) onder het Abbink/SNS Bank-arrest, sub 10. Verstappen spreekt van een 'weinig gelukkige' uitspraak.

126 G.C. Vergouwen en I. Boekhorst in hun noot onder het Abbink/SNS Bank-arrest, JIN 2010, 863. 
vragen rijzen dan. ${ }^{127}$ Hoeveel aandeelhouders zijn er? Op welke wijze participeren de aandeelhouders in de betrokken vennootschap? Hoeveel bestuurders heeft de betrokken vennootschap? Zijn de bestuurders zelfstandig of gezamenlijk bevoegd de betrokken vennootschap te vertegenwoordigen? In welke mate zijn de bestuurders aandeelhouder? Hoeveel aandelen houden zij? Zijn er aandelen met bijzondere rechten? Zo ja, wat is de inhoud van die rechten? Door wie worden die aandelen gehouden? Is er een aandeelhoudersovereenkomst gesloten? Zo ja, wat is de inhoud van die overeenkomst? Zijn er stemovereenkomsten gesloten? Zo ja, wat is de inhoud van die overeenkomsten? Er kunnen in dit kader nog meer vragen bedacht worden. Het spreekt voor zich dat indien er geen snel en eenvoudig antwoord op deze vragen kan worden gegeven al gauw geen sprake meer is van een eenvoudige structuur. In dat geval gaat de uitzondering op het toestemmingvereiste van art. 1:88 lid $5 \mathrm{BW}$ niet op, te meer omdat art. 1:88 BW beoogt de andere echtgenoot en het gezin te beschermen.

De flex-BV neemt deze rechtsonzekerheid niet weg. Naast gewone aandelen kunnen in de flex-BV ook winstrecht- en stemrechtloze aandelen voorkomen. Indien door middel van stemrechtloze aandelen een vennootschapsstructuur gecreëerd wordt welke gelijk is aan de eenvoudige certificering, zoals in het Abbink/SNS Bank-arrest aan de orde was, lijkt mij de uitzondering op het toestemmingvereiste nog steeds opgaan.

Een andere situatie is de volgende. Stel dat er in een BV één winstrechtloos aandeel is, gehouden door de bestuurder van de BV, en voorts stemrechtloze aandelen, waarvan er één gehouden wordt door de bestuurder en de rest van de stemrechtloze aandelen door een of meerdere derden. Van een ingewikkelde structuur lijkt geen sprake te zijn. De aandeelhouders en de aan de aandelen verbonden rechten zijn op grond van art. 2:194 BW kenbaar uit het aandeelhoudersregister. De bestuurder heeft de combinatie van zeggenschap en financieel belang. Dat belang is weliswaar zeer beperkt; hij heeft (bovendien) geen meerderheid van de stemrechtloze aandelen. Daartegenover staat wel dat hij de (volledige) zeggenschap in de vennootschap heeft en hij alle winstrechtloze aandelen houdt. De vraag is of er een bepaalde verhouding of percentage geldt voor het houden van de meerderheid van de aandelen en voor welke soort aandelen, meer in het bijzonder voor het stemrechtloze aandeel, die verhouding in een BV geldt. ${ }^{128}$ Het financiële belang van de bestuurder in dit voorbeeld is immers niet erg groot.

127 In gelijke zin: L.C.A. Verstappen in zijn $N J$-noot $(N J$ 2011, 30) onder het Abbink/SNS Bank-arrest, sub 10 .

128 Een fiscaal uitstapje: ten aanzien van de deelnemingsvrijstelling heeft de wetgever overwogen dat zowel winstrechtloze als stemrechtloze aandelen meetellen bij de beoordeling of aan het vijf procentcriterium is voldaan en dat resultaten behaald met beide soorten aandelen onder de deelnemingsvrijstelling kunnen vallen, Kamerstukken II 2010/11, 32 426, nr. 7, p. 37. De minister merkt tevens op dat "de toekenning van stemrechtloze aandelen in het kader van werknemersparticipatie alleen tot belastingheffing in box 2 (in plaats van box 3), indien een werknemer daardoor een belang van ten $\rightarrow$ 
In de literatuur is de vraag aan de orde geweest of het percentage stemrechtloze aandelen niet moet worden gemaximeerd. De argumenten daarvoor zijn dat daarmee wordt voorkomen dat de zeggenschap in de algemene vergadering overwegend toekomt aan degenen die het minst in het kapitaal van de vennootschap hebben bijgedragen. ${ }^{129}$ Ongelimiteerde toepassing van het stemrechtloze aandeel zou de vennootschap tot een kapitaal aantrekkende stichting reduceren. ${ }^{130}$ Ongebreidelde uitgifte van aandelen zonder stemrecht zou leiden tot aantasting van de vennootschappelijke basiselementen, zoals het beginsel dat kapitaalverschaffers een zekere mate van zeggenschap hebben, de dualistische structuur van de vennootschap en het feit dat economische bindingen veelal verlopen via de aan aandelen gekoppelde zeggenschap. ${ }^{131}$ Over wat het maximale percentage dan zou moeten zijn, bestaat in de literatuur geen eenduidigheid en evenmin over de sanctie indien die bovengrens wordt overschreden. ${ }^{132}$

De wetgever heeft niet gekozen voor een maximum percentage uit te geven stemrechtloze aandelen. ${ }^{133}$ Art. 2:175 lid $1 \mathrm{BW}$, laatste volzin, bepaalt immers dat ten minste één aandeel met stemrecht wordt gehouden door een andere dan en anders dan voor rekening van de vennootschap of een van haar dochtermaatschappijen.

De vraag blijft hoe het criterium van 'de meerderheid der aandelen' moet worden ingevuld. Het antwoord op die vraag is in de flex-BV er niet makkelijker op geworden. Naast winstrechtloze en stemrechtloze aandelen kunnen in de flex-BV ook aandelen met volledig stemrecht, beperkt stemgerechtigde aandelen, beperkt winstgerechtigde aandelen en aandelen met gedifferentieerd stemrecht worden uitgegeven. ${ }^{134}$ Met het oog op de strekking van art. 1:88 $\mathrm{BW}$ en de in het handelsverkeer vereiste rechtszekerheid zal de feitenrechter het formele en materiële criterium terughoudend moeten toetsen en zullen slechts eenvoudige situaties het formele en materiële criterium kunnen doorstaan. In het door mij gegeven, extreme voorbeeld houdt de bestuurder het enige winstrechtloze aandeel en slechts één stemrechtloos aandeel. Er is dan weliswaar sprake van de combinatie zeggenschap (in het voorbeeld volledige zeggenschap) en financieel belang, maar het wringt toch.

minste $5 \%$ van het geplaatste kapitaal van die soort aandelen van de vennootschap verkrijgt. Indien in de praktijk blijkt dat dit tot problemen leidt, dan biedt de wet de mogelijkheid om bij ministeriële regeling te bepalen dat dergelijke aandelen niet een afzonderlijke soort vormen.", zie Kamerstukken I 2011/12, 31058 en 32 426, nr. C. p. 3 (MvA I).

129 Van der Grinten 1971 (1), p. 304-305, voetnoot 8. Zie ook Faasen 1989, p. 501.

130 Van Schilfgaarde 1988, p. 35; Ten Berg 2007, p. 338 en Kamerstukken II 2006/07, 31 058, nr. 3, p. 38 (MvT).

131 Schwarz 1990, p. 20-22 en Eisma \& De Keijzer 1994, p. 12.

132 Schwarz 1990, p. 22 en 25 en Eisma \& De Keijzer 1994, p. 12. Van den Nieuwenhuijzen stelt dat geen eenduidig antwoord is te formuleren op de vraag wat die bovengrens zou moeten zijn. Zie Van den Nieuwenhuijzen 2008, p. 24.

133 Portier heeft de argumenten voor een maximum percentage stemrechtloze aandelen ontkracht. Zie Portier 2008, p. 242-244

134 Zie par. 2.6. 
Om niettemin een grens te stellen wat betreft het financiële belang pleit ik ervoor aan te sluiten bij art. 2:346 lid 1 onder b BW. ${ }^{135}$ Tot het indienen van een enquêteverzoek als bedoeld in art. 2:345 BW is - kort gezegd - bevoegd de aandeelhouder die tien procent van de aandelen in het kapitaal van de vennootschap houdt. Ten aanzien van deze kapitaaleis geldt wat mij betreft alleen dit proportionele minimumvereiste en geen absoluut minimumvereiste van een bedrag aan gehouden aandelen. Bij het houden van tien procent van de aandelen in het kapitaal van de vennootschap kan naar mijn mening - hoewel arbitrair - van enig substantieel belang worden gesproken. ${ }^{136}$ De grens van tien procent sluit ook aan bij het bepaalde in art. 2:220 (oud) BW. ${ }^{137}$ Dat artikel stelde dezelfde grens - thans één procent - voor het bijeenroepen van een algemene vergadering na rechterlijke machtiging. Bij de berekening van die grens dient rekening gehouden te worden met het bepaalde in art. 2:24d jo. 2:228 lid 6 BW. ${ }^{138}$ De grens van tien procent komt ook terug in art. 1 Pensioenwet. ${ }^{139}$

Een dergelijk proportioneel minimumvereiste komt ook het handelsverkeer en de rechtszekerheid ten goede. Het financiële belang van de handelende bestuurder is in dat geval eenvoudig toetsbaar. Voor de rechtspraktijk, meer in het bijzonder de financieringspraktijk, kunnen daarmee discussies achteraf worden voorkomen. ${ }^{140}$ In het kader daarvan merk ik nog op dat op de crediteur een onderzoeksplicht rust ten aanzien van de bevoegdheid van de handelend bestuurder als (aspirant-)borg, bijvoorbeeld of die bestuurder gehuwd is, en zo ja, of diens echtgenote toestemming voor het aangaan van de borgtocht heeft verleend. ${ }^{141}$ Raadpleging van het handelsregister is vereist en kan uitkomst bieden. ${ }^{142}$

135 Uitgaande van de Wet van 18 juni 2012 tot wijziging van boek 2 van het Burgerlijk Wetboek in verband met de aanpassing van het recht van enquête (Kamerstukken 32 887, Stb. 2012, 274). Deze wet zal inwerking treden op 1 januari 2013 (Stb. 2012, 305).

136 Van Uchelen-Schipper 2012, p. 190, vraagt zich af of de door mij gestelde ondergrens van tien procent zinvol is. Zij stelt dat of van een financieel belang substantieel sprake is per geval moet worden uitgemaakt. Naar mijn mening zal sprake moeten zijn van tien procent van het aandelenkapitaal ongeacht het soort aandelen.

137 In het wetvoorstel van de flex-BV wijzigt dit percentage in art. 2:220 BW van tien naar één procent. Eén procent komt mij echter als een zeer gering belang voor.

138 Art. 2:24d (oud) BW is in min of meer in dezelfde vorm teruggekomen in art. 2:24d lid 2 BW. Art. 2:228 lid $6 \mathrm{BW}$ is 'in de flex-BV' niet gewijzigd.

139 Zie hierover Kamerstukken II 2009/10, 32 426, nr. 3, p. 37 (MvT)

140 Concl. P-G Hartkamp bij het Fortis/Van der Zee-arrest, sub 13.

141 Vgl. 3:24 lid 2 BW. Rb. Utrecht 18 september 1996, JOR 1996, 116, r.o. 4.8 en Hof Arnhem 8 oktober 2002, NJ 2003, 444, JOR 2003, 187, m.nt. A.J. Verdaas (Ledegang/Roordink Bedrijfswagens), r.o. 5.6.

142 In het handelsregister zijn onder meer opgenomen: de statutaire bestuurder(s) van de vennootschap en hun bevoegdheid de vennootschap te vertegenwoordigen (art. 22 lid 1 sub a Handelsregisterbesluit 2008), het kapitaal van de vennootschap, onderverdeeld naar soort indien er verschillende soorten aandelen zijn (art. 22 lid 1 sub c Handelsregisterbesluit 2008), ingeval van enig aandeelhouderschap $\rightarrow$ 


\subsubsection{De Wet ter voorkoming van witwassen en financieren van terrorisme (Wwft) en de Wet toezicht trustkantoren $(W t t)^{143}$}

De Wet ter voorkoming van witwassen en financieren van terrorisme (Wwft)

De Wet ter voorkoming van witwassen en financieren van terrorisme (Wwft) ${ }^{144}$ geeft onder meer regels over de identificatie van cliënten voor advocaten, (kandidaat-)notarissen, belastingadviseurs, registeraccountants, accountants-administratieconsulenten, dan wel degenen die anderszins zelfstandig onafhankelijk beroeps- of bedrijfsmatig daarmee vergelijkbare activiteiten verrichten, zoals administratiekantoren en trustkantoren. Met de invoering van de Wwft op 1 augustus 2008 heeft de wetgever voldaan aan de verplichting tot implementatie van de derde anti-witwasrichtlijn en de Richtlijn voor Politiek Prominente Personen (PPP-Richtlijn). ${ }^{145}$ De Wwft hanteert voor de regels over de identificatieplicht de term 'cliëntenonderzoek'. Dat begrip is ruimer dan het louter identificeren van de cliënt door vrije beroepsuitoefenaren. Over dat cliëntenonderzoek bepaalt art. 3 van de Wwft onder meer dat bijvoorbeeld de vrije beroepsuitoefenaar ${ }^{146}$ cliëntenonderzoek verricht ter voorkoming van witwassen en financieren van terrorisme. Dat cliëntenonderzoek stelt hem in staat om de cliënt te identificeren en zijn identiteit te verifiëren en indien van toepassing, de uiteindelijk belanghebbende te identificeren. Onder de uiteindelijk belanghebbende (of 'UBO') wordt onder meer verstaan een natuurlijke persoon die een belang houdt van meer dan 25 procent van het kapitaal of meer dan

de gegevens van die aandeelhouder (art. 22 lid 1 sub e Handelsregisterbesluit 2008). Daarnaast kan bij het handelsregister de akte van oprichting en/of de statuten van de vennootschap worden opgevraagd. Ook het aandeelhoudersregister als bedoeld in art. 2:194 BW en eventuele akte van levering van aandelen als bedoeld in art. 2:196 BW kunnen uitkomst bieden. Het aandeelhoudersregister en de akte van levering van aandelen betreffen echter niet voor derden toegankelijke informatie, zodat indien die stukken geraadpleegd moeten worden in het kader van de toetsing van het formele en materiële criterium er veelal geen sprake van een eenvoudige situatie meer zal zijn. In dat geval gaat de uitzondering op het toestemmingsvereiste van lid 5 van art. 1:88 BW niet op.

143 Deze paragraaf en het daarin vervatte standpunt heb ik eerder verdedigd, zie Wolf 2011 (2).

144 Wet van 15 juli 2008, houdende samenvoeging van de Wet identificatie bij dienstverlening en de Wet melding ongebruikelijke transacties (Wet ter voorkoming van witwassen en financieren van terrorisme), Kamerstukken 31237 en 31 238. In werking getreden op 1 augustus 2008, Stb. 2008, 303 en 304

145 Richtlijn 2005/60/EG van het Europees Parlement en de Raad van de Europese Unie van 26 oktober 2005 tot voorkoming van het gebruik van het financiële stelsel voor het witwassen van geld en de financiering van terrorisme ( $P b E U 2005$ L 309) en ter uitvoering van Richtlijn 2006/70 van de Commissie van de Europese Gemeenschappen van 1 augustus 2006 tot vaststelling van uitvoeringsmaatregelen van Richtlijn 2005/60/EG van het Europees Parlement en de Raad wat betreft de definitie van politiek prominente personen en wat betreft de technische criteria voor vereenvoudigde klantenonderzoeksprocedures en voor vrijstellingen op grond van occasionele of zeer beperkte financiële activiteiten (PbEU 2006 L 214).

146 De Wwft spreekt over 'instelling', waaronder de vrije beroepsuitoefenaar wordt begrepen, zie art. 1 lid 1 onder a Wwft. 
25 procent van de stemrechten van de aandeelhoudersvergadering kan uitoefenen van een rechtspersoon, anders dan een stichting, dan wel op andere wijze feitelijk zeggenschap kan uitoefenen in deze rechtspersoon. ${ }^{147}$ Hoe werkt deze bepaling in het geval van het stemrechtloze aandeel uit?

Zoals gezegd, is de Wwft onder meer gebaseerd op de derde anti-witwasrichtlijn. Die richtlijn definieert in art. 3 aanhef lid 6 de uiteindelijk begunstigde (of belanghebbende) als volgt:

“(...) "uiteindelijke begunstigde”: de natuurlijke perso(o)n(en) die de uiteindelijke eigenaar is (zijn) van of het zeggenschap heeft (hebben) over de cliënt en/of de natuurlijke persoon voor wiens rekening een transactie of activiteit wordt verricht. De uiteindelijke begunstigde omvat ten minste:

a) bij vennootschappen:

i) de natuurlijke perso(o)n(en) die de uiteindelijke eigenaar is (zijn) van of zeggenschap heeft (hebben) over een juridische entiteit, via het rechtstreeks of onrechtstreeks houden van een toereikend percentage van de aandelen of stemrechten van deze juridische entiteit, met inbegrip van participatie in de vorm van toonderaandelen, waarbij het niet gaat om een op een gereglementeerde markt genoteerde vennootschap die is onderworpen aan openbaarmakingsvereisten die in overeenstemming zijn met de Gemeenschapswetgeving, of aan gelijkwaardige internationale normen; een percentage van $25 \%$ plus een aandeel geldt als toereikend om aan dit criterium te voldoen;

ii) de natuurlijke perso(o)n(en) die op een andere wijze zeggenschap over het beheer van een juridische entiteit uitoefen(t)(en),

b) in het geval van juridische entiteiten, zoals stichtingen, en van juridische constructies, zoals trusts, die gelden beheren of uitkeren:

i) voorzover de toekomstige begunstigden reeds werden vastgelegd, de natuurlijke perso(o)n (en) die de begunstigde van $25 \%$ of meer van het vermogen van een juridische constructie of rechtspersoon is (zijn),

ii) voorzover de afzonderlijke personen die de begunstigden van de juridische entiteit of de juridische constructie zijn, nog niet werden vastgelegd, de groep van personen in wier belang de juridische entiteit of de juridische constructie hoofdzakelijk werd opgericht of werkzaam is;

iii) de natuurlijke perso(o)n(en) die zeggenschap over $25 \%$ of meer van het vermogen van een juridische constructie of juridische entiteit uitoefen(t)(en)."

De twaalfde overweging van deze richtlijn stelt: "Voorzover de verschaffers van het vermogen van de juridische entiteit of constructie aanzienlijke zeggenschap hebben over het gebruik van het vermogen, moeten zij als uiteindelijke begunstigde worden geïdentificeerd."

147 Art. 1 lid 1 onder f Wwft. 
De definitie van 'uiteindelijke begunstigde' komt uit het voorstel voor de derde antiwitwasrichtlijn. ${ }^{148}$ In dat voorstel luidde de definitie als volgt:

“a) de natuurlijke persoon die uiteindelijk rechtstreeks of middellijk eigenaar is van of zeggenschap heeft over ten minste $10 \%$ van de aandelen of van de stemrechten van een rechtspersoon, of die anderszins een vergelijkbare invloed uitoefent op het bestuur van een rechtspersoon die geen aan een officiële effectenbeurs genoteerde vennootschap is die onderworpen is aan openbaarmakingsvereisten die in overeenstemming zijn met de Gemeenschapswetgeving, of aan gelijkwaardige internationale normen;

b) de natuurlijke persoon die rechtstreeks of middellijk de uiteindelijke begunstigde is van ten minste $10 \%$ van het vermogen van een stichting, een trust of een soortgelijke juridische constructie, of die invloed uitoefent over een vergelijkbaar deel van het vermogen van een stichting, een trust of een soortgelijke juridische constructie die geen aan een officiële effectenbeurs genoteerde vennootschap is die onderworpen is aan openbaarmakingsvereisten die in overeenstemming zijn met de Gemeenschapswetgeving, of aan gelijkwaardige internationale normen;

c) de natuurlijke persoon voor wiens rekening een transactie of activiteit wordt verricht."

In het advies van het Europees Economisch en Sociaal Comité over het voorstel voor de derde anti-witwasrichtlijn ${ }^{149}$ wordt gesteld dat het voorgestelde percentage van tien procent te laag is en 25 procent zou moeten bedragen. Een duidelijk en sluitende motivering voor dit advies tot verhoging van dat percentage kan ik niet herleiden. ${ }^{150}$ Er wordt door het Europees Economisch en Sociaal Comité weliswaar verwezen naar art. 7 van het voorstel, maar daaruit kan ik niet een reden voor het advies tot verhoging afleiden. Het minimumpercentage van 25 lijkt derhalve arbitrair gekozen te zijn. Niettemin komt dat de rechtszekerheid ten goede.

Terug naar de vraag: 'hoe moet de definitie van 'uiteindelijk belanghebbende' geïnterpreteerd worden ingeval sprake is van een natuurlijk persoon die meer dan 25 procent van de stemrechtloze aandelen in een vennootschap houdt (en voor het overige geen aandelen, althans geen aandeel waaraan stemrecht is verbonden)'? Het deel van de definitie 'die een belang houdt van meer dan 25 procent van het kapitaalbelang of meer dan 25 procent van de stemrechten van de aandeelhoudersvergadering kan uitoefenen van een rechtspersoon (...), dan wel op andere wijze feitelijk zeggenschap kan uitoefenen in deze rechtspersoon', roept in dat kader vragen op. Onder een kapitaalbelang kan ook een kapitaalbelang van stemrechtloze aandelen worden verstaan. Ook de stemrechtloze aandeelhouder houdt immers aandelen in het kapitaal van de vennootschap. Het woord 'of' in de definitie lijkt te

148 Voorstel voor een richtlijn van het Europees Parlement en de Raad tot voorkoming van het gebruik van het financiële stelsel voor het witwassen van geld, met inbegrip van terrorismefinanciering van 30 juni 2004, $\operatorname{COM}(2004) 448$ def.

149 Advies van het Europees Economisch en Sociaal Comité over het "Voorstel voor een richtlijn van het Europees Parlement en de Raad tot voorkoming van het gebruik van het financiële stelsel voor het witwassen van geld, met inbegrip van terrorismefinanciering", COM(2004)448 def., ECO/147 "Witwassen" van 11 mei 2005

150 Zie par. 3.3 .2 van het advies. 
impliceren dat het - als alternatieven - zowel om een financieel belang (in de vorm van stemrechtloze aandelen) als om een zeggenschapsbelang (in de vorm van aandelen, waaraan in ieder geval stemrecht is verbonden, doch winstrechtloze aandelen kunnen ook daaronder vallen) kan gaan. Een argument voor deze benadering is dat als 'uiteindelijk belanghebbende' in het kader van het vermogen van een trust of stichting wordt aangemerkt "de begunstigde van of degene die bijzondere zeggenschap heeft over $25 \%$ of meer van het vermogen". Ook in deze definitie is aldus het alternatief opgenomen.

De parlementaire geschiedenis van de Wwft biedt geen uitkomst, anders dan dat over de 'uiteindelijk belanghebbende' wordt opgemerkt: "De aandacht voor de uiteindelijk belanghebbende in het anti-witwasbeleid is ingegeven door het feit dat bij witwassen gebruik wordt gemaakt van allerlei constructies om de ware herkomst van gelden te verhullen. Vooral relevant in dit verband is het gebruik van rechtspersonen. De juridische eigenschappen die het een rechtspersoon mogelijk maken op relatief eenvoudige wijze deel te nemen aan het rechtsverkeer - het optreden onder een handelsnaam, het snel kunnen wisselen van bestuur, de verhandelbaarheid van aandelenkapitaal - kunnen personen met kwaad in de zin in staat stellen om op anonieme wijze opbrengsten verkregen uit misdrijven onder te brengen in een rechtspersoon. (...) Om te voorkomen dat een achter een rechtspersoon of keten van rechtspersonen schuil gaande natuurlijke persoon anoniem kan blijven als deze deelneemt aan het financiële verkeer, wordt in dit wetsvoorstel voorgesteld een verplichting te regelen voor instellingen om in risicovolle gevallen naast de cliënt, ook de uiteindelijk belanghebbende van een transactie te identificeren. Verder zal een instelling zich dienen te vergewissen van de structuur van de groep waartoe de cliënt behoort." Deze onduidelijkheid is begrijpelijk, omdat ten tijde van de invoering van de Wwft het Nederlandse recht geen stemrecht- en winstrechtloze aandelen kende. Dat is met invoering van de flex-BV echter anders geworden. Het had voor de hand gelegen, mede gelet op het hiervoor geciteerde belang en de toets van de uiteindelijk belanghebbende, dat de wetgever bij invoering van de flex-BV aan dit onderdeel aandacht zou hebben besteed.

In het kader van de uitleg van het begrip 'meerderheid der aandelen' in de zin van art. 1:88 BW (paragraaf 4.3.8) gaf ik het - wellicht academische - voorbeeld dat er in een BV één winstrechtloos aandeel is, gehouden door de bestuurder van de BV, en voorts stemrechtloze aandelen, waarvan er één gehouden wordt door de bestuurder en de rest van de stemrechtloze aandelen door een of meerdere derden. Wie is of zijn in dat geval de 'uiteindelijk belanghebbende(n)'? Is dat de bestuurder, omdat hij meer dan 25 procent (lees: de volledige zeggenschap) van de zeggenschapsrechten van de BV heeft? Dat lijkt op grond van de wettekst voor de hand te liggen, maar het wringt. De bestuurder heeft, ondanks zijn zeggenschap zowel op bestuurders- als op aandeelhoudersniveau, een beperkt financieel belang in de vennootschap. Is hij dan wel de uiteindelijk belanghebbende? Of zijn dat de stemrechtloze aandeelhouders, omdat zij een belang hebben in het kapitaal van de vennootschap en recht hebben op het aan hun aandeel of aandelen verbonden dividend en op het (batig) liquidatiesaldo na 
ontbinding en vereffening van de vennootschap? Is die stemrechtloze aandeelhouder, ondanks dat hij het stemrecht ontbeert, de uiteindelijk belanghebbende? Of is dat ook de genoemde bestuurder, omdat hij - naast de stemrechtloze aandeelhouders - een kapitaalverschaffer van de BV is? Dat laatste ligt wellicht minder voor de hand, zeker als in de statuten opgenomen is dat de winstrechtloze aandeelhouder ook geen recht heeft op de reserves van de vennootschap (art. 2:216 lid $7 \mathrm{BW}){ }^{151}$ bijvoorbeeld in geval van ontbinding en vereffening (art. 2:23b BW). Niettemin verschaft de bestuurder in dit voorbeeld wel enig kapitaal.

De Invoeringswet van de flex-BV schept evenmin duidelijkheid. De Invoeringswet wijzigt de definitie van 'uiteindelijk belanghebbende'. In art. 1 onderdeel f onder 1 Wwft wordt de zinsnede "of meer dan 25 procent van de stemrechten van de aandeelhoudersvergadering kan uitoefenen" vervangen door "of meer dan 25 procent van de stemmen in de algemene vergadering". ${ }^{152}$ Dat is louter een wijziging van terminologische aard. ${ }^{153}$

Voor de rechtspraktijk, meer in het bijzonder voor de genoemde zakelijke dienstverleners, schept deze problematiek rechtsonzekerheid.

Wet toezicht trustkantoren (Wtt)

Ook in de Wet toezicht trustkantoren (Wtt) ${ }^{154}$ wordt gesproken over de 'uiteindelijk belanghebbende'. Art. 1 aanhef onder c definieert de uiteindelijk belanghebbende in die zin van de Wtt als volgt:

“(...) de natuurlijke persoon die een gekwalificeerde deelneming houdt in een doelvennootschap, dan wel begunstigde is van ten minste tien procent van het vermogen van een stichting of van een trust als bedoeld in het Verdrag inzake het recht dat toepasselijk is op trusts en inzake de erkenning van trusts (Trb. 1985, 141)."

De doelvennootschap is de rechtspersoon of vennootschap waaraan het trustkantoor diensten verleent. Het doel van de Wtt is het bevorderen van de integriteit van het financiële stelsel door middel van de regulering van de trustsector. ${ }^{155} \mathrm{De}$ Wijzigingswet financiële markten $2012^{156}$ heeft de definitie van 'uiteindelijk belang-

151 Kamerstukken II 2006/07, 31 058, nr. 3, p. 75 (MvT).

152 Kamerstukken II 2009/10, 32 426, nr. 2, p. 14 en Kamerstukken I 2011/12, 32 426, nr. A, p. 20 (Gewijzigd voorstel van wet).

153 Kamerstukken II 2009/10, 32 426, nr. 3, p. 36 (MvT).

154 Wet van 17 december 2003, houdende het toezicht op trustkantoren (Wet toezicht trustkantoren). Kamerstukken 29 041. In werking getreden 1 maart 2004, Stb. 2004, 9 en 58.

155 Kamerstukken II 2010/11, 32 781, nr. 3, p. 4 (MvT).

156 Wet van 1 december 2011 tot wijziging van de Wet op het financieel toezicht en enige andere wetten (Wijzigingswet financiële markten 2012), Kamerstukken 32 781, Stb. 2011, 610. In werking getreden op 1 juli 2012 volgens het Besluit van 22 december 2011, houdende de vaststelling van het tijdstip van inwerkingtreding van de Wijzigingswet financiële markten 2012, alsmede twee andere wetten tot wijziging van de Wet op het financieel toezicht en enige andere wetten, Stb. 2011, 671. 
hebbende' aangepast. De definitie van 'uiteindelijk belanghebbende' in art. 1 lid 1 onderdeel c Wtt luidt als volgt:

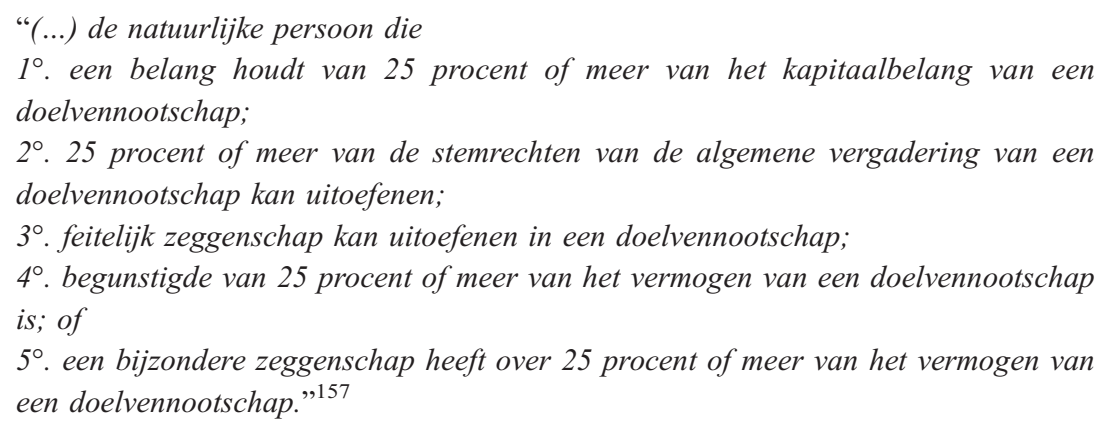

De wetgever licht de wijziging als volgt toe: "De aanpassing is gebaseerd op de definitie van dit begrip in de Wwft en Richtlijn 2005/60/EG van het Europees Parlement en de Raad van 26 oktober 2005 tot voorkoming van het gebruik van het financiële stelsel voor het witwassen van geld en de financiering van terrorisme. De definities van het begrip in beide wetten worden gelijk getrokken, met dien verstande dat het bij trustkantoren gaat om de doelvennootschap en niet om de cliënt, zoals in de Wwft. Door het element 'feitelijke zeggenschap' op te nemen in subonderdeel 3 van artikel 1, onderdeel c, wordt de definitie in lijn gebracht met de in artikel 3, zesde lid, van Richtlijn 2005/60/EG, opgenomen definitie van het begrip 'uiteindelijk belanghebbende'. Met het begrip feitelijke zeggenschap is aangesloten bij artikel 3, zesde lid, onder a, van Richtlijn 2005/60/EG. In de evaluatie van de Wtt is aan de orde gekomen dat het wenselijk is een natuurlijke persoon pas als uiteindelijk belanghebbende aan te merken als hij ten minste $25 \%$ kapitaalbelang heeft, $25 \%$ van de stemrechten houdt, begunstigde is van ten minste $25 \%$ van het vermogen of een bijzondere zeggenschap heeft over 25\% of meer van het vermogen. In de Wtt ligt die grens thans op ten minste 10\% (artikel 1, onderdeel c, Wtt). Aangezien in eerder genoemde richtlijn 25\% als grenswaarde wordt aangehouden en er geen redenen zijn een strenger national regime voor trustkantoren in stand te houden, wordt voorgesteld ook in de Wtt de grenswaarde van 25\% te introduceren." 158

Conclusie

Op grond van deze wijziging in de Wtt, de toelichting daarop in de memorie van toelichting en de koppeling tussen de Wwft en de Wtt ben ik van mening dat onder

157 De aan het onderdeel toegevoegde tenzij-clausule ziet niet op de BV, welke vennootschap onderwerp van mijn onderzoek is.

158 Kamerstukken II 2010/11, 32 781, nr. 3, p. $42-43$ (MvT). Zie ook Kamerstukken II 2010/11, 32 781, nr. 7, p. 9 (NV II). 
het begrip 'uiteindelijk belanghebbende' (ook) moet worden verstaan de stemrechtloze aandeelhouder met een zodanig kapitaalbelang dat hij ten minste 25 procent van het totale, geplaatste kapitaal in de BV houdt. Via zijn aandeelhouderschap heeft hij immers een meer dan substantieel, financieel belang in de (doel)vennootschap. Dat die stemrechtloze aandeelhouder het stemrecht ontbeert, doet daaraan niet af, mede gelet op zowel het doel van de Wwft als de Wtt.

\subsubsection{De faillissementspauliana (art. $\left.42 F_{w}\right)^{159}$}

Art. 42 Fw regelt de faillissementspauliana. Het artikel bepaalt dat de curator ten behoeve van de boedel elke rechtshandeling kan vernietigen die de schuldenaar vóór de faillietverklaring onverplicht heeft verricht en waarvan hij bij het verrichten van die rechtshandeling wist of behoorde te weten dat daarvan benadeling van de schuldeisers het gevolg zou zijn. Art. $43 \mathrm{Fw}$ geeft, als nadere uitwerking van art. 42 Fw, voor een aantal specifieke gevallen een vermoeden van wetenschap van deze benadeling, behoudens tegenbewijs. Ik schets een aantal van die gevallen. Indien de rechtshandeling waardoor de schuldeisers zijn benadeeld, is verricht binnen een jaar voor de faillietverklaring en de schuldenaar zich niet reeds voor de aanvang van die termijn daartoe had verplicht, wordt de wetenschap van benadeling vermoed aan beide zijden te bestaan:

(i) bij rechtshandelingen, door de schuldenaar die rechtspersoon is, verricht met of jegens een natuurlijk persoon, wiens echtgenoot, pleegkinderen of bloed- of aanverwanten tot in de derde graad, afzonderlijk of tezamen, als aandeelhouder rechtstreeks of middellijk voor ten minste de helft van het geplaatste kapitaal in die rechtspersoon deelnemen (art. 43 lid 1 sub 4 onder c Fw);

(ii) bij rechtshandelingen, door de schuldenaar die rechtspersoon is, verricht met of jegens een andere rechtspersoon, indien een bestuurder, natuurlijk persoon of een commissaris van een van deze rechtspersonen, of diens echtgenoot, pleegkind of bloed- of aanverwant tot in de derde graad, afzonderlijk of tezamen, als aandeelhouder rechtstreeks of middellijk voor ten minste de helft van het geplaatste kapitaal deelneemt in de andere (art. 43 lid 1 sub 5 onder c Fw);

(iii) bij rechtshandelingen, door de schuldenaar die rechtspersoon is, verricht met of jegens een andere rechtspersoon, indien in beide rechtspersonen voor ten minste de helft van het geplaatste kapitaal rechtstreeks of middellijk wordt deelgenomen door dezelfde rechtspersonen, dan wel dezelfde natuurlijke personen, al dan niet tezamen met zijn echtgenoot, zijn pleegkinderen en zijn bloed- of aanverwanten tot in de derde graad (art. 43 lid 1 sub 5 onder d Fw).

Ook hier rijst de vraag hoe deze bepalingen ten aanzien van stemrechtloze aandelen moeten worden uitgelegd. Wat wordt verstaan onder deelname in ten minste de helft van het geplaatste kapitaal? 
Art. 43 Fw somt een aantal rechtshandelingen met een verdacht karakter op, hetgeen blijkens de parlementaire geschiedenis de achtergrond van het bewijsvermoeden is. Daarbij spelen de aard van de rechtshandeling, de persoon van de wederpartij en het tijdstip waarop de rechtshandeling werd verricht een rol. ${ }^{160}$

Concluderend: gelet op de achtergrond van art. 43 Fw, meer in het bijzonder het in dat artikel opgenomen bewijsvermoeden, pleit ik ervoor in situaties als bedoeld in art. 43 lid 1 sub 4 onder $\mathrm{c}$ en sub 5 onder $\mathrm{c}$ en $\mathrm{d}$ Fw onder de woorden 'ten minste de helft van het geplaatste kapitaal' ook te verstaan de stemrechtloze aandeelhouder met een zodanig kapitaalsbelang dat hij ten minste de helft van het totale, geplaatste kapitaal in de BV houdt. Via zijn aandeelhouderschap kan hij immers een meer dan substantieel, financieel belang hebben bij de verdachte rechtshandeling die 'zijn' vennootschap is aangegaan. Dat die stemrechtloze aandeelhouder het stemrecht ontbeert, doet daaraan niet af. Te meer omdat het bij het verrichten van rechtshandelingen niet gaat om het stemrecht in de algemene vergadering, maar om de vertegenwoordigingsbevoegdheid door het bestuur van de vennootschap.

\subsubsection{Het begrip 'in overwegende mate bij machte' in Boek 1 BW $W^{161}$}

In art. 1:141 BW lid 4 speelt het begrip 'in overwegende mate bij machte' een rol. Ook in het voorheen geldende art. 1:126 lid 3 BW kwam dit begrip terug. ${ }^{162}$ Art. 1:126 lid 1 BW bepaalde dat buiten de gemeenschap van vruchten en inkomsten de goederen en schulden vallen die behoren tot een door een van de echtgenoten uitgeoefend bedrijf of vrij beroep. Krachtens art. 1:126 lid 2 BW kwamen echter wel ten bate of laste van de gemeenschap van vruchten en inkomsten de vergoedingen ten bedrage van de winsten en verliezen van het bedrijf of beroep, vast te stellen naar normen die in het maatschappelijk verkeer als redelijk worden beschouwd. Art. 1:126 lid 3 BW bepaalde dat voor zover een echtgenoot in overwegende mate bij machte is te bepalen dat de winsten van een niet op zijn eigen naam uitgeoefend bedrijf hem rechtstreeks of middellijk ten goede komen, dat bedrijf voor de toepassing van art. 1:126 lid 2 BW wordt aangemerkt als een door die echtgenoot uitgeoefend bedrijf. Met andere woorden: art. 1:126 lid 3 BW gaf een maatstaf om te bepalen wanneer sprake is van een door een echtgenoot

160 G.W. van der Feltz, Geschiedenis van de Wet op het Faillissement en de Surséance van Betaling, Haarlem: De Erven F. Bohn 1986, p. 442-443 en R.J. de Weijs, Groene Serie Faillissementswet, art. $43 \mathrm{Fw}$, aant. 5, Deventer: Kluwer.

161 Deze paragraaf en het daarin vervatte standpunt heb ik eerder verdedigd, zie Wolf 2011 (2).

162 Art. 1:126 BW is bij Wet aanpassing wettelijke gemeenschap van goederen per 1 januari 2012 vervallen. Zie Wet van 18 april 2011 tot wijziging van de titels 6, 7 en 8 van Boek 1 van het Burgerlijk Wetboek (aanpassing wettelijke gemeenschap van goederen), Stb. 2011, 205 en Besluit van 20 juni 2011 tot wijziging van het Besluit Huwelijksgoederenregister 1969 in verband met de wet van 18 april 2011 tot wijziging van de titels 6,7 en 8 van boek 1 van het Burgerlijk Wetboek (aanpassing wettelijke gemeenschap van goederen) (Stb. 2011, 205), Stb. 2011, 335. 
uitgeoefend bedrijf, omdat in voorkomend geval winsten en verliezen van het bedrijf voor rekening van de gemeenschap van vruchten en inkomsten komen.

In art. 1:141 BW komt het begrip 'in overwegende mate bij machte' in ander verband terug. Het gaat daarbij om in huwelijkse voorwaarden opgenomen periodieke verrekenbedingen. Over dergelijke bedingen bepaalt art. 1:141 lid 1 BW dat indien een verrekenplicht betrekking heeft op een in de huwelijkse voorwaarden omschreven tijdvak van het huwelijk en over dat tijdvak niet is afgerekend, de verplichting tot verrekening over dat tijdvak in stand blijft en deze zich uitstrekt over het saldo, ontstaan door belegging en herbelegging van hetgeen niet verrekend is, en over de vruchten daarvan. Met andere woorden: de verplichting tot nakoming van een periodiek verrekenbeding blijft bestaan. Art. 1:141 lid 4 BW geeft een nadere invulling van de verrekenplicht. Indien een echtgenoot in overwegende mate bij machte is te bepalen dat de winsten van een niet op zijn eigen naam uitgeoefende onderneming hem rechtstreeks of middellijk ten goede komen, en een verrekenbeding is overeengekomen dat ook ondernemingswinsten omvat, worden de niet uitgekeerde winsten uit zodanige onderneming, voor zover in het maatschappelijk verkeer als redelijk beschouwd, eveneens in aanmerking genomen bij de vaststelling van de verrekenplicht van die echtgenoot, onverminderd art. 1:141 lid $1 \mathrm{BW}$. Met andere woorden: indien het verrekenbeding bepaalt dat ook ondernemingswinsten daarin betrokken moeten worden, moet bij het vaststellen van die ondernemingswinsten (onder meer) gekeken worden naar de onderneming waarin de echtgenoot in overwegende mate bij machte is te bepalen dat de winsten van een niet op zijn eigen naam uitgeoefende onderneming hem rechtstreeks of middellijk ten goede komen.

Wat wordt onder 'in overwegende mate bij machte verstaan'? Meer in het bijzonder: hoe werkt dit uit in het geval waarin sprake is van door een echtgenoot in een BV gehouden stemrechtloze aandelen? ${ }^{163}$

De parlementaire geschiedenis bij art. 1:141 BW leert het volgende: "Het vierde lid verschaft een voorziening in geval een echtgenoot in overwegende mate bij machte is te bepalen dat de winst van een niet op zijn naam gevoerde onderneming hem rechtstreeks of onmiddellijk ten goede komt. Het gaat dan om een onderneming die in vorm van een rechtspersoon of vennootschap onder firma wordt gedreven. In dat geval dient voor de uitvoering van een beding dat winsten uit een dergelijke onderneming in de verrekening betrekt, een in het maatschappelijk verkeer als redelijk beschouwde winst te worden bepaald. Voor zover deze winst niet is uitgekeerd, dient deze alsnog in de verrekening te worden betrokken. Deze bepaling is gebaseerd op artikel 126. Aan artikel 126, derde lid, is ook ontleend het begrip "het in overwegende mate bij machte zijn te bepalen». Voorwaarde is wel dat de verrekenplicht ook impliciet of expliciet dergelijke ondernemingswinsten omvat."164

163 Van Mourik 2011, p. 841, voetnoot 3, spreekt gelet op de introductie van stemrechtloze aandelen van een nog interessantere problematiek.

164 Kamerstukken II 2000/01, 27 544, nr. 3, p. 17 (MvT). 
Uit de parlementaire geschiedenis blijkt voorts dat met de woorden 'in overwegende mate bij machte' tot uitdrukking wordt gebracht dat niet de formele bevoegdheid tot winstbepaling beslissend is, maar de machtsverhouding binnen het orgaan dat bevoegd is de winst te bepalen. ${ }^{165}$ De parlementaire geschiedenis stelt over art. 1:126 lid 3 BW: "Het derde lid is opgenomen, omdat de redelijkheid gebiedt dat het in het vorige lid bepaalde niet wordt ontgaan, wanneer een bedrijf niet ten name van een echtgenoot wordt uitgeoefend, maar hij wel bij machte is aan de winsten van het bedrijf een zodanige bestemming te geven, dat zij hem rechtstreeks of middellijk ten goede komen. Hierbij valt vooral te denken aan een bedrijf dat een echtgenoot doet uitoefenen door een naamloze vennootschap, waarin hij in overwegende mate zeggenschap uitoefent en welker ingehouden wordende winsten de waarde verhogen van de aandelen die rechtstreeks of middellijk tot het eigen vermogen van deze echtgenoot behoren." "166 Naar aanleiding van deze passage in de parlementaire geschiedenis is in de literatuur verdedigd dat het gaat om 'bij machte zijn' en dat de woorden 'in overwegende mate' geschrapt kunnen worden. ${ }^{167}$

In lagere rechtspraak wordt 'in overwegende mate' als 'in beslissende mate, in dier voege dat de aandeelhouder minimaal vijftig procent van de aandelen bezit' gelezen. ${ }^{168}$ In het arrest van de Hoge Raad van 4 mei $2007^{169}$ was sprake van een situatie waarin aandelen in een BV waren gecertificeerd. De man hield samen met zijn twee broers alle certificaten, ieder voor een derde. Tevens waren zij allen bestuurder van de BV. Bestuursbesluiten moesten met volstrekte meerderheid worden genomen. Er was dus sprake van een formele minderheidspositie van de man. Niettemin, zo leert het arrest, kan ook feitelijke zeggenschap van een echtgenoot over de winstbestemming ertoe leiden dat niet uitgekeerde winsten ex art. 1:141 lid 4 BW bij de verrekening in aanmerking moeten worden genomen.

Uit de wettekst en de aangehaalde parlementaire geschiedenis leid ik af dat sprake moet zijn van feitelijke zeggenschap. Ook in de literatuur wordt dat verdedigd. ${ }^{170}$ De feitelijke machtsverhoudingen zijn relevanter dan de formele, juridische verhoudingen. Daarbij gaat het om zeggenschap op aandeelhoudersniveau. Op dat niveau wordt immers de winst bestemd, welke winst krachtens de hoofdregel van art. 2:216 BW ter beschikking van de algemene vergadering staat, voor zover bij de statuten niet anders is bepaald. Daarom ben ik met Van Mourik eens dat de echtgenoot niet tevens bestuurder van de vennootschap moet zijn, wil

165 Kamerstukken II 2000/01, 27 544, nr. B, p. 3.

166 Van Zeben 1969 (Parl. Gesch. Inv.w. Boek 1 BW, MvA II), p. 1240

167 A.L.G.A. Stille, Groene Serie Personen- en Familierecht, BW Boek 1, art. 126, aant. 7, Deventer: Kluwer.

168 Rb. Zwolle 23 juni 2004, LJN AP4551. In het arrest van het Hof Amsterdam van 31 december 1998, nr. 44/98 (niet gepubliceerd, doch aangehaald in Vakstudie Nieuws 2000, 45.28) ging het om een door de man gehouden meerderheidsbelang. Ook daarbij gold de toets of de man in overwegende mate bij machte was te bepalen dat de winst hem rechtstreeks of middellijk ten goede komt.

$169 L J N$ AZ7621, met name r.o. 3.4 (Pelshouderij).

170 Zonnenberg 2009, p. 284. 
voldaan zijn aan het zeggenschapscriterium. ${ }^{171}$ Van Mourik stelt voorts dat het feit dat de echtgenoot tevens bestuurder van de vennootschap is, een aspect is dat zwaar weegt bij beoordeling van die feitelijke verhoudingen. ${ }^{172}$ Als voorbeeld haalt hij aan twee broers die ieder vijftig procent van de aandelen in het kapitaal van een vennootschap houden. De ene broer is tevens bestuurder van de vennootschap. De ander is niet in de vennootschap werkzaam. Het is volgens Van Mourik aannemelijk dat de broer-aandeelhouder-bestuurder de overwegende zeggenschap heeft. Mijns inziens lijkt dat inderdaad voor de hand te liggen, maar vanzelfsprekend is het niet. Het gaat immers om zeggenschap op aandeelhoudersniveau. In het door Van Mourik gegeven voorbeeld zal het waarschijnlijk zo zijn dat de bestuurder-aandeelhouder zijn broer in de algemene vergadering zal kunnen overtuigen. De klassieke situatie $^{173}$ waarin de bestuurder-aandeelhouder in het belang van de vennootschap de winst geheel of gedeeltelijk wil reserveren, maar de 'outside-aandeelhouder' alle winst als dividend wil uitkeren, is ook denkbaar. Dergelijke (belangen)tegenstellingen zijn de familievennootschap niet vreemd. Vandaar dat certificering in dat kader een aangewezen middel is.

Dat brengt mij terug bij het reeds aangehaalde arrest van de Hoge Raad van 4 mei 2007. Ook daar was sprake van certificering en was de slotsom dat de niet uitgekeerde winsten niet in aanmerking genomen moesten worden bij de vaststelling van de verrekenplicht van de echtgenoot. Over een periode van zes jaar was er geen dividend op de certificaten uitgekeerd, terwijl het gemiddelde jaarlijkse resultaat $€ 92.059$ was. De stelling van de vrouw was dat er jaarlijks een aanzienlijk dividend uitgekeerd had kunnen worden zonder dat de continuitteit van de onderneming in gevaar zou zijn of komen. Tot de slotsom dat sprake van niet uitkeerbare winsten was, is gekomen langs de weg van art. 1:141 lid 4 BW. Er was een formeel obstakel, de man was namelijk gelet op de structuur van de vennootschap niet in overwegende mate bij machte te bepalen dat de winsten hem ten goede zouden komen. Uit de conclusie van de A-G volgt dat de rechtbank de materiële weg volgde. De rechtbank was voornemens een deskundige te benoemen, die de rechtbank vanuit bedrijfseconomisch oogpunt zou kunnen adviseren of sprake was van uitkeerbare winsten. ${ }^{174}$ Uit het arrest volgt dat het formele criterium het materiële criterium de pas heeft afgesneden.

Terug naar het voorbeeld van Van Mourik, dat niet geheel overtuigt. Relevanter zijn mijns inziens de statutaire bepalingen omtrent de winstbestemming. De algemene vergadering is bevoegd tot bestemming van de winst die door de vaststelling van de jaarrekening is bepaald en tot vaststelling van uitkeringen, voor zover het eigen vermogen groter is dan de reserves die krachtens de wet of de statuten moeten worden aangehouden. De statuten kunnen de bevoegdheid tot het

171 Van Mourik 2011, p. 841.

172 Van Mourik 2011, p. 841

173 Zie HR 9 juli 1990, NJ 1991, 51, m.nt. Ma (Sluis).

174 Zie sub 1.6 van de concl. A-G onder het arrest. 
bestemmen van de winst beperken of toekennen aan een ander orgaan, zo leert art. 2:216 lid $1 \mathrm{BW}$. Het is daarom - bijvoorbeeld - mogelijk dat de statuten bepalen dat het bestuur eerst de mogelijkheid heeft te besluiten (een gedeelte van) de winst te reserveren. De algemene vergadering kan vervolgens besluiten wat zij met het eventuele restant van de winst doet: uitkeren of reserveren. Indien de statuten een dergelijke regeling kennen, is het feit dat de echtgenoot enig bestuurder van de vennootschap is zeer relevant. Hij is dan immers bij machte (een deel van) de winst te reserveren, ook al heeft hij geen meerderheidsbelang in het kapitaal van de vennootschap. Overigens wordt deze conclusie niet alleen verbonden aan een statutaire bepaling van deze aard, maar kan zij ook het gevolg zijn van een aandeelhoudersovereenkomst die tot hetzelfde effect leidt. ${ }^{175}$

In de flex-BV kan sprake zijn van een kapitaal, bestaande uit een winstrechtloos aandeel en een of meerdere stemrechtloze aandelen. Een echtgenoot houdt alle stemrechtloze aandelen en plaatst het winstrechtloze aandeel bij een bevriende derde, die tevens bestuurder van de BV is. Het huwelijk loopt op de klippen, het periodieke verrekenbeding is niet nagekomen en de substantiële winsten van de BV zijn over een aantal jaren gereserveerd. In deze situatie is geen sprake van feitelijke zeggenschap van de echtgenoot/ondernemer. Hij is immers houder van de stemrechtloze aandelen en heeft derhalve geen zeggenschap in de algemene vergadering. In financiële zin draagt hij als aandeelhouder echter wel alle lasten en baten. In een dergelijke situatie kunnen aldus vraagtekens worden geplaatst bij het zeggenschapscriterium van art. 1:141 lid 4 BW. Het feitelijk zeggenschapscriterium lijkt in de flex-BV, samenhangend met de introductie van het stemrechtloze aandeel, niet goed hanteerbaar. Met Van Mourik ben ik eens dat hierdoor willekeur kan ontstaan. Terecht werpt hij de vraag op waarom de ingehouden winsten niet altijd, naar evenredigheid van het aandelenbezit, in de verrekening betrokken worden indien het verrekenbeding winst uit onderneming omvat. ${ }^{176}$ De oplossing ten aanzien van het stemrechtloze aandeel in de flex-BV ligt in de positieve beantwoording van die vraag. Datzelfde geldt voor certificaten van aandelen. De nuancering van het antwoord ligt in het woord 'altijd', zoals opgenomen in de vraag van Van Mourik. De vraag is of altijd moet worden uitgekeerd. Het antwoord daarop ligt in de toets 'voor zover in het maatschappelijk verkeer als redelijk beschouwd', zoals opgenomen in art. 1:141 lid $4 \mathrm{BW}$.

\subsubsection{Publiekrechtelijke wetgeving}

Anders dan bij de hiervoor besproken bepalingen, heeft de wetgever wel stilgestaan bij een aantal publiekrechtelijke regelingen in verband met de introductie van het stemrechtloze aandeel. Het gaat om art. 91 lid 1 onder a en b Comptabiliteitswet, art. 185 Provinciewet en art. 184 Gemeentewet. Deze artikelen zijn ongewijzigd

175 In gelijke zin: Zonnenberg 2009, p. 283

176 Van Mourik 2011, p. 841. 
gelaten. De wetgever merkt daarover op: "De Comptabiliteitswet geeft de Algemene Rekenkamer bevoegdheden bij bv's waarvan de Staat het gehele of nagenoeg het gehele geplaatste aandelenkapitaal houdt (artikel 91, eerste lid, onder a) dan wel ten minste 5\% van het geplaatste aandelenkapitaal houdt, indien daarmee een groter financieel belang is gemoeid dan een door de minister van Financiën vast te stellen bedrag (artikel 91, eerste lid, onder b). Zie verder artikel 34, vijfde lid, van de Comptabiliteitswet 2001, waarin een deelneming door de Staat in een bv waarvan de Staat ten minste 5\% van het geplaatste aandelenkapitaal houdt of door die deelneming zal verkrijgen, voor een termijn van dertig dagen moet worden voorgehangen bij de Staten-Generaal. Hetzelfde geldt voor een in aandelen converteerbare lening (artikel 34, zesde lid, Comptabiliteitswet 2001). Krachtens artikel 185 van de Provinciewet en artikel 184 van de Gemeentewet heeft de Algemene Rekenkamer de bevoegdheid om bij bv's waarin de provincie of gemeente meer dan $50 \%$ van het geplaatste aandelenkapitaal houdt, nadere inlichtingen in te winnen over de jaarrekeningen en het rapport van de accountant en bij die bv's een onderzoek in te stellen. (...) Het wetsvoorstel bv-recht gaat ervan uit dat ook aandelen zonder stemrecht of zonder winstrecht, aandelen zijn. Het gaat om maatschappijen waarin een kapitaalinbreng van een bepaalde omvang is gedaan. De vraag welke rechten aan die aandelen zijn verbonden, is niet bepalend. De rol van de Algemene Rekenkamer en de Staten-Generaal is ingegeven door hun controlerende taak ten aanzien van de financiële betrokkenheid die de Staat, provincie of gemeente in een $b v$ heeft. Er is geen reden om die controle uit te sluiten indien het belang van de overheid in de bv - deels - in stemrecht- of winstrechtloze aandelen zit."

Deze toelichting is niet geheel duidelijk. Enerzijds wordt gesteld dat de financiële betrokkenheid van een bepaalde omvang reden is de in de genoemde regelingen bevoegdheden te kunnen uitoefenen. In lijn met die gedachte zou ook de financiële betrokkenheid van een bepaalde omvang in alleen stemrechtloze aandelen voldoende zijn. Anderzijds lijkt die conclusie wat voorbarig, gelet op het feit dat de wetgever in de laatste zin - nota bene tussen gedachtestreepjes - het woord 'deels' heeft toegevoegd. Ik zou menen dat ook alleen een betrokkenheid in stemrechtloze aandelen voldoende is om de in de genoemde regelingen bevoegdheden te kunnen uitoefenen. Het gaat immers om gemeenschapsgelden. De kapitaalsinbreng staat voorop.

\subsubsection{Overige wijzigingen in de wet}

In verband met de invoering van het stemrechtloze aandeel en de regeling van het vergaderrecht ex art. 2:227 BW zijn art. 2:24d, 175, 190, 194, 206a, 220, 224a, 242, 252 en $346 \mathrm{BW}$ aangepast.

Art. 2:24d BW, art. 2:175 BW (definitie van de BV), art. 2:190 BW (negatieve definitie van 'een aandeel') en art. 2:194 BW (het aandeelhoudersregister) zijn in dit hoofdstuk al aan de orde gekomen. 
Art. 2:206a BW (het voorkeursrecht), art. 2:220 BW (het bijeenroepen van een buitengewone algemene vergadering na machtiging daartoe door de voorzieningenrechter door een of meer aandeelhouders die gezamenlijk ten minste 1/100 van het geplaatste kapitaal vertegenwoordigen), art. 2:224a BW (opnemen van een onderwerp op de agenda van de algemene vergadering, verzocht door een of meer aandeelhouders die gezamenlijk ten minste een honderdste gedeelte van het geplaatste kapitaal vertegenwoordigen), art. 2:242 BW (benoeming van bestuurders), art. 2:252 BW (benoeming van commissarissen) en art. 2:346 BW (het indienen van een enquêteverzoek ex art. 2:345 BW door een of meer aandeelhouders die gezamenlijk ten minste een tiende gedeelte van het geplaatste kapitaal vertegenwoordigen) zullen in hoofdstuk 6 en 8 worden besproken.

\subsubsection{Overgangsrecht}

Ten aanzien van het overgangsrecht heeft de wetgever in algemene zin overwogen dat het wetsvoorstel BV-recht vooral optionele bepalingen kent, die niet tot verplichtingen en dus ook niet tot een overgangstermijn leiden. Als algemeen uitgangspunt geldt bij een wetswijziging dat de nieuwe bepalingen vanaf het moment van inwerkingtreding onmiddellijk van toepassing zijn, maar enkel ten aanzien van feiten die na dat moment voorvallen. ${ }^{177}$ De invoering van stemrechtloze aandelen leidt niet tot overgangsrechtelijke problemen. Deze aandelen zijn optioneel en ze ontstaan pas als de statuten daartoe zijn aangepast en als ze zijn uitgegeven. ${ }^{178} \mathrm{Bij}$ een bestaande $\mathrm{BV}$ kunnen de statuten worden gewijzigd om gebruik te maken van de mogelijkheden die de flex-BV biedt. ${ }^{179}$ Een en ander volgt uit art. 68a Overgangswet NBW.

\subsection{Certificaten van aandelen}

\subsubsection{Inleiding}

In deze paragraaf ga ik in op certificaten van aandelen. In de eerste deelparagraaf geef ik antwoord op de vraag wat certificaten zijn (paragraaf 4.4.2). Vervolgens ga $i k$ in op certificaten met en zonder vergaderrecht (paragraaf 4.4.3). In de derde deelparagraaf stel ik de niet-royeerbare, beperkt royeerbare en royeerbare certificaten aan de orde (paragraaf 4.4.4). In paragraaf 4.4.5 komt de levering van een certificaat van aandeel aan de orde. Tot slot besteed ik aandacht aan het overgangsrecht in paragraaf 4.4.6. De bespreking in deze paragraaf blijft beperkt tot het certificaat van aandeel in de BV.

177 Kamerstukken II 2009/10, 32 426, nr. 3, p. 16-17 (MvT Invoeringswet).

178 Kamerstukken II 2009/10, 32 426, nr. 3, p. 21 (MvT Invoeringswet).

179 Kamerstukken I, 31058 en 32 426, nr. C, p. 9 (MvA I). 


\subsubsection{Wat zijn certificaten?}

In paragraaf 3.7.8 besprak ik kort de rechtsfiguur van certificaten van aandelen. Die rechtsfiguur is niet in de wet geregeld. Het gaat om een driehoeksverhouding. ${ }^{180}$ In de eerste plaats, de verhouding tussen de vennootschap en het administratiekantoor. Het administratiekantoor is in de praktijk veelal een stichting, afgekort tot STAK. ${ }^{181}$ De STAK is juridisch eigenaar en houder van de aandelen in de vennootschap. De STAK oefent alle aan de aandelen verbonden rechten uit. Niet alle aandelen in de vennootschap hoeven gecertificeerd te zijn. In de praktijk komt ook certificering van een deel van de aandelen voor. De rechtsverhouding tussen de vennootschap en de STAK wordt bepaald door de wet en de statuten.

In de tweede plaats, de verhouding tussen de STAK en de certificaathouders. De STAK geeft certificaten van aandelen aan de certificaathouders uit. Die rechtsverhouding is een contractuele - namelijk een beheersovereenkomst, zijnde een overeenkomst van eigen aard - en wordt vaak aangeduid als de administratievoorwaarden. Dat zijn de voorwaarden waaronder de STAK aan de certificaathouders de certificaten heeft uitgegeven. Die voorwaarden regelen het beheer en de administratie. Ook spelen in die verhouding de statuten van de STAK een rol. Het certificaat is als een vorderingsrecht van de certificaathouder jegens de STAK te beschouwen. ${ }^{182} \mathrm{Er}$ is dus geen rechtstreekse financiële aanspraak jegens de vennootschap.

In de derde plaats, de rechtsverhouding tussen de BV en de certificaathouder. De inhoud van die verhouding werd onder het oude recht voornamelijk bepaald door het antwoord op de vraag of de certificaten met of zonder medewerking van de vennootschap waren uitgegeven. In het huidige BV-recht speelt de vraag of aan certificaten vergaderrecht is toegekend. Ik kom hierop in paragraaf 4.4.3 terug.

Naast deze driehoeksverhouding bestaat ook een rechtsverhouding tussen de certificaathouders onderling. Indien niet alle aandelen gecertificeerd zijn, speelt ook nog de verhouding tussen de certificaathouders en aandeelhouders in de BV een rol.

In de praktijk wordt een en ander als volgt vormgegeven. Eerst wordt een administratiekantoor opgericht (vaak een stichting). Vervolgens worden de administratievoorwaarden vastgesteld. Als laatste worden de aandelen ten titel van beheer ${ }^{183}$ aan de STAK overgedragen, waarna certificaten van aandelen aan de certificaathouders worden uitgereikt. ${ }^{184}$

180 In zijn dissertatie bespreekt Van den Ingh deze driehoeksverhouding uitgebreid: zie Van den Ingh 1991, p. 11-14 en p. 151 e.v.

181 Asser/Maeijer, Van Solinge \& Nieuwe Weme 2-II* 2009, nr. 658 en 661.

182 Een vermogensrecht in de zin van art. 3:6 BW. Asser/Maeijer, Van Solinge \& Nieuwe Weme 2-II* 2009, nr. 661; Van den Ingh 1991, p. 128 en Rensen 2005, p. 35

183 Art. 3:84 lid 3 BW staat daaraan niet in de weg. Zie Asser/Maeijer, Van Solinge \& Nieuwe Weme 2-II* 2009, nr. 658; Van den Ingh 1991, p. 25-28 en HR 19 mei 1995, NJ 1996, 119, m.nt. WMK (Keereweer/Sogelease).

184 In de literatuur wordt een onderscheid gemaakt tussen certificering tegen aandelen en tegen contanten. Zie Van den Ingh 1991, p. 16-19. 
Omdat het certificaat een vorderingsrecht is, is het overdraagbaar, tenzij zulks op grond van art. 3:83 lid $2 \mathrm{BW}$ in de administratievoorwaarden uitgesloten is. ${ }^{185}$ Beperking van de overdracht van certificaten (op naam) door middel van blokkeringsclausules in de administratievoorwaarden is ook mogelijk ${ }^{186}$ en komt in de praktijk bij gecertificeerde aandelen in een BV vaak voor.

Door certificering van aandelen worden de aan het aandeel verbonden zeggenschaps- en financiële rechten gescheiden. Het aan het aandeel verbonden stemrecht wordt door de STAK, als aandeelhouder, uitgeoefend. De zeggenschap berust aldus bij de STAK, terwijl zij niet het kapitaal van de vennootschap heeft verschaft. De certificaathouders die het kapitaal hebben verschaft, hebben geen zeggenschap. De macht is aldus verschoven van een grotere groep aandeelhouders naar een kleine groep buitenstaanders, bestaande uit het bestuur van de STAK. In de administratievoorwaarden kunnen ook zeggenschapsrechten aan het certificaat verbonden worden, bijvoorbeeld ten aanzien van de samenstelling van het bestuur van de STAK. ${ }^{187}$

De samenstelling van het bestuur van de STAK kan divers zijn. ${ }^{188}$ Ingeval het motief van de certificering bedrijfsopvolging is, waarbij vader meerdere kinderen heeft en alleen de oudste zoon geschikt is hem in de onderneming op te volgen, zal het bestuur van de STAK doorgaans bestaan uit een bestuurslid namens de onderneming (bijvoorbeeld de zoon), een bestuurslid namens de andere kinderencertificaathouders, welke bestuursleden samen een onafhankelijk derde als bestuurslid benoemen teneinde besluitvorming in het bestuur van de STAK mogelijk te maken. Een soortgelijke situatie doet zich voor indien sprake is van een 50-50 aandelenverhouding in de vennootschap. De aandelen kunnen in dat geval worden gecertificeerd, waarbij iedere aandeelhouder tevens bestuurslid van de STAK benoemt. Beide bestuursleden benoemen vervolgens een onafhankelijk derde als bestuurslid, zodat de besluitvorming in de algemene vergadering (bij monde van de

185 Het gaat daarbij om het beding tussen de certificaathouder als schuldeiser en het administratiekantoor als schuldenaar. Een dergelijk beding in de zin van art. 3:83 lid 2 BW sorteert goederenrechtelijk effect. Het gevolg is dat het certificaat onoverdraagbaar is, zodat iedere overdracht in strijd met het beding ongeldig is. Het beding heeft absolute derdenwerking. Of de derde aan wie het certificaat is overgedragen op de hoogte was het beding, doet niet ter zake. Zie HR 17 januari 2003, LJN AF0168, NJ 2004, 281, m.nt. HJS, JOR 2003, 52, m.nt. M.H.E. Rongen (Oryx/Van Eesteren) en Asser/ Mijnssen, De Haan \& Van Dam 3-I, 2010, nr. 202. Van beschikkingsonbevoegdheid van de vervreemder is geen sprake, omdat aan het voorvereiste van overdraagbaarheid niet is voldaan, zie F.E.J. Beekhoven van de Boezem \& G.J.L. Bergervoet, Groene Serie Vermogensrecht, art. 3:83 BW, aant. 33, Deventer: Kluwer. Beekhoven van de Boezem \& Bergervoet onderscheiden twee mogelijkheden van werking dat aan het beding toekomt, namelijk (i) obligatoire werking en (ii) absolute derdenwerking, hetgeen een kwestie van uitleg van het beding is. Overigens leidt een en ander ook tot wanprestatie van de vervreemder jegens zijn wederpartij met wie het beding van onoverdraagbaarheid is overeengekomen.

186 Asser/Maeijer, Van Solinge \& Nieuwe Weme 2-II* 2009, nr. 661 en uitgebreid Van den Ingh 1991, p. $129-132$

187 Asser/Maeijer, Van Solinge \& Nieuwe Weme 2-II* 2009, nr. 661.

188 Zie Van den Ingh 1991, p. 198-202. 
STAK als enig aandeelhouder) bij het staken der stemmen niet gefrustreerd zou worden.

De STAK ontvangt het dividend en andere uitkeringen. De administratievoorwaarden bepalen in de regel dat de STAK jegens de certificaathouders gehouden is een overeenkomstig dividend of andere uitkering ter beschikking te stellen aan de certificaathouders. Soortgelijke bepalingen treft men in de administratievoorwaarden aan met betrekking tot bonus-aandelen, stockdividenden en liquidatie-uitkeringen. In feite houdt de STAK de gecertificeerde aandelen voor rekening en risico van de certificaathouders. De waarde van de certificaten is gekoppeld aan de waarde van de aandelen. Zo zal bij een waardestijging van de aandelen in de regel ook de waarde van certificaten stijgen (en vice versa bij een waardedaling).

In de BV luiden certificaten op naam. ${ }^{189}$ Certificaatbewijzen worden niet uitgegeven. Het bestuur van de STAK houdt een register van certificaathouders bij. Levering van het certificaat op naam geschiedt door middel van cessie. ${ }^{190}$

Er zijn diverse motieven voor certificering, ${ }^{191}$ bijvoorbeeld bij bedrijfsopvolging of werknemersparticipatie. Ook kan certificering worden gebruikt om impasses te voorkomen, bijvoorbeeld ingeval twee andeelhouders ieder de helft van de aandelen bezitten. Daarnaast kan de rechtsfiguur door kleinere aandeelhouders gebruikt worden om hun belangen te bundelen ten opzichte van grootaandeelhouders. Te denken is ook aan het verzekeren dat stemrechten in één hand blijven ingeval van echtscheiding of erfopvolging. Indien de certificering ongedaan wordt gemaakt, spreekt men van decertificering. ${ }^{192}$

Uit het voorgaande is af te leiden dat bij certificering het stemrecht verhuist van de certificaathouder naar de STAK, terwijl bij het stemrechtloze aandeel het stemrecht sowieso niet bestaat. Het is de vraag of het bestaan van stemrecht gewenst is, omdat het bestuur van de STAK bij uitoefening van het stemrecht ook rekening zal moeten houden met de (financiële) belangen van de certificaathouder (en uiteraard het statutaire doel van de STAK). Een ander verschil met het stemrechtloze aandeel is dat certificering tot hogere kosten leidt. Zo moet een STAK bij notariële akte worden opgericht. De STAK moet worden ingeschreven in het handelsregister van de Kamer van Koophandel en de te certificeren aandelen moeten bij notariële akte worden overgedragen. Daarnaast zullen administratievoorwaarden opgesteld moeten worden.

189 Art. 2:202 BW.

190 Art. 3:94 BW. Nevenrechten gaan daarbij ex art. 6:142 BW mee over.

191 Zie Asser/Maeijer, Van Solinge \& Nieuwe Weme 2-II* 2009, nr. 659; Van den Ingh 2003 (1), p. 181; Zaman 2004 (2), p. 215; Van den Ingh 2008, p. 6 en uitgebreid: Van den Ingh 1991, p. 28-41. Kamerstukken II 2006/07, 31 058, nr. 3, p. 81 (MvT). Voor motieven bij beursvennootschappen: zie Van den Ingh 2008, p. 4-5 en Moerland 2002, p. 280 e.v.

192 Zie daarover onder meer Van den Ingh 1991, p. 19, voetnoot 18; Van den Ingh 2008, p. 9-10 en Heijstek 2006, p. 5. 


\subsubsection{Certificaten met of zonder vergaderrecht}

Onder het oude BV-recht konden certificaten met of zonder medewerking van de vennootschap worden uitgegeven. Ook daarvoor bood de wet geen regels, zodat in de literatuur discussie is ontstaan over de vraag wanneer sprake is van met en zonder medewerking van de vennootschap uitgegeven certificaten. ${ }^{193}$ In die discussie konden twee opvattingen worden onderscheiden, namelijk de ruime en de enge opvatting. De ruime opvatting gaat er vanuit dat iedere vorm van betrokkenheid van de vennootschap bij de certificering leidt tot certificaten die met medewerking van de vennootschap zijn uitgegeven. Dat is een vraag van feitelijke aard, waarvan het antwoord afhangt van de omstandigheden van het geval. Daarbij speelt bijvoorbeeld een rol of de vennootschap het initiatief tot certificering heeft genomen, het bestuur van de vennootschap ook (al dan niet ten dele) het bestuur van de STAK vormt en de vennootschap de kosten van de certificering heeft voldaan. ${ }^{194}$ De enge opvatting houdt in dat in de statuten van de vennootschap is bepaald dat de vennootschap met medewerking certificaten van aandelen uitgeeft en dat aan die uitgifte een besluit van de algemene vergadering (van aandeelhouders) ten grondslag ligt. Dat is een op de rechtshandeling gerichte benadering. ${ }^{195}$ Tegenstanders van de ruime opvatting stellen ook de vraag aan de orde hoe de feitelijke betrokkenheid van de vennootschap zich verhoudt tot de bepaling in de statuten van de vennootschap dat de vennootschap dat geen medewerking aan de uitgifte van certificaten verleent. Overigens kan een soortgelijke bepaling ook voorkomen in de statuten van de STAK en in de administratievoorwaarden, die de rechtsverhouding tussen de STAK en de certificaathouder beheersen.

De rechtspraak onder het oude recht leek uit te gaan van de enge opvatting. ${ }^{196}$

De vraag of certificaten met of zonder medewerking van de vennootschap zijn

193 Zie voor een mooi overzicht van deze discussie Hamers 1996, p. 73-77; Asser/Maeijer, Van Solinge \& Nieuwe Weme 2-II* 2009, nr. 670; Van den Ingh 2003 (1), p. 182, met naam en 'toenaam' (vindplaats) van voor- en tegenstanders van de ruime dan wel enge opvatting; Portengen \& Groenland 2003, p. 947 e.v. en Van Gendt 2011, p. 32-33. Ook Quist 2010 (1), p. 727-729, geeft daarvan een overzicht. Quist 2010 (2), p. 748 e.v. bespreekt hoe te komen van 'met medewerking' naar 'zonder medewerking' en vice versa, zoals hij noemt het 'omkatten' van certificaten. Zie ook Huizink 2001, p. 693-694 en Stelling 2001, p. 972-973. Meijers 2004, p. 141 e.v. pleit voor een 'resultaat gerichte benadering'.

194 Van den Ingh 2008, p. 7, voetnoot 21; Quist 2010 (1), p. 727. Voorstander van de ruime opvatting zijn bijvoorbeeld Schwarz (zie Schwarz 1992, p. 7 en - genuanceerder - Schwarz 2002, p. 49), Voogd (Voogd 1993, p. 26) en Hamers (Hamers 1996, p.77).

195 Voorstander van de enge opvatting zijn bijvoorbeeld Van den Ingh, zie Van den Ingh 1991, p. 85-90; Van den Ingh 1992, p. 77; Van den Ingh 2003 (1), p. 182; Van den Ingh 2008, p. 7; Portengen \& Groenland 2003 en Zaman 2004 (2), p. 217.

196 Hof Amsterdam (OK) 21 juni 2007, JOR 2007/182, (Kalter/The Greenery), r.o. 3.2: “In de statuten van The Greenery is met zoveel woorden bepaald dat The Greenery geen medewerking verleent aan de uitgifte van certificaten van aandelen en artikel 1.5 van de administratievoorwaarden bepaalt dat aan de certificaathouders niet de rechten toekomen die de wet toekent aan houders van certificaten die met medewerking van de vennootschap zijn uitgegeven. Er is geen rechtsregel of regel van $\rightarrow$ 
uitgegeven, is van belang, omdat in het eerste geval de certificaathouder in een rechtstreekse verhouding tot de vennootschap komt te staan en aan hem dezelfde rechten, behalve het stemrecht, toekomen als een (gewone) aandeelhouder. In het geval certificaten zonder medewerking van de vennootschap uitgegeven zijn, ontstaat slechts een rechtsbetrekking tussen de STAK en de certificaathouder. ${ }^{197}$ Wel kan de certificaathouder in voorkomend geval een enquêteverzoek indienen onder de voorwaarden als genoemd in art. 2:346 BW. Dat artikel maakt namelijk geen onderscheid tussen met of zonder medewerking van de vennootschap uitgegeven certificaten. Daarnaast was de vraag of certificaten met of zonder medewerking van de vennootschap zijn uitgegeven van belang vanwege het wettelijk, gezamenlijk pandrecht van de certificaathouders als bedoeld in art. 3:259 BW. Meer in het bijzonder bepaalde lid 2 van dat artikel (oud BW) onder meer dat indien de oorspronkelijke aandelen of schuldvorderingen op naam gesteld zijn en de certificaten uitgegeven zijn met medewerking van de uitgever van de oorspronkelijke aandelen of schuldvorderingen, de certificaathouders tevens gezamenlijk een pandrecht op die aandelen of schuldvorderingen verkrijgen. Zijn de certificaten uitgegeven voor schuldvorderingen op naam zonder medewerking van de schuldenaar,

openbare orde die het een of het ander verbiedt dan wel zich ertegen verzet dat certificaten van aandelen onder dergelijke voorwaarden worden uitgegeven of aanvaard. Degenen die certificaten van aandelen B in The Greenery hebben verworven hebben, zo is onbetwist gesteld, de toepasselijkheid van de administratievoorwaarden ook aanvaard (door ondertekening van de overeenkomst tot voorwaardelijke toekenning van die certificaten, respectievelijk van optierechten op die certificaten). Tezamen genomen rechtvaardigen deze omstandigheden naar het oordeel van de Ondernemingskamer de conclusie dat geen sprake is van bewilligde certificaten.". Zie ook Rb. Amsterdam 25 augustus 2010, JOR 2010, 301, m.nt. Nowak, r.o. 4.2: "Tot de in artikel 2:8 BW bedoelde kring van de krachtens de wet en de statuten betrokkenen behoren ondermeer houders van met medewerking van de vennootschap uitgegeven certificaten. Deze houders zijn immers krachtens de wet bij de organisatie van de vennootschap betrokken, ondermeer ingevolge de artikelen 2:220 lid $2 \mathrm{BW}$ (recht op het bijeenroepen van een algemene vergadering) en 3:259 lid $2 \mathrm{BW}$ (gezamenlijk pandrecht op de onderliggende aandelen). Of Hofmans c.s. nu, zoals hij stelt, behoort tot deze krachtens de wet bij de vennootschap betrokkenen, is afhankelijk van de medewerking die de vennootschap aan de uitgifte van de door hem gehouden certificaten heeft verleend. Gezien de wettelijk vastgelegde beslotenheid van de aandeelhouderskring en het vereiste van duidelijkheid voor de vennootschap jegens wie zij de verplichtingen ingevolge artikel 2:8 BW in acht dient te nemen, heeft alleen die medewerking van de vennootschap tot gevolg dat de door artikel 2:8 BW bestreken kring van personen wordt uitgebreid, die als een op dat rechtsgevolg gerichte rechtshandeling van de vennootschap kan worden aangemerkt. Ingevolge de artikelen 3:33 jo 3:59 BW vereist aldus de door de vennootschap verleende medewerking, teneinde dat rechtsgevolg te bewerkstelligen, een daarop gerichte wil die zich door verklaring of gedraging van de vennootschap heeft geopenbaard. Dat is hier niet het geval. Immers, de statuten van de vennootschap schrijven voor dat aan de uitgifte van certificaten geen medewerking wordt verleend en uit de aanbiedingsbrieven aan Hofmans c.s. volgt dat hem uitdrukkelijk geen andere rechten worden verleend dan rechten die voortvloeien uit de certificaten zelf (r.o. 2.3 hiervoor). Hofmans c.s. heeft dit ook aanvaard."

197 Onder het oude BV-recht werd daarmee ontkomen aan de werking van art. 2:212, 2:220 lid 2, 2:223, 2:224, 2:227 en 2:238 (oud) BW. 
dan verkrijgen de certificaathouders een zodanig pandrecht door mededeling van de uitgifte aan de schuldenaar, aldus dat oude artikellid.

In de flex-BV is het onderscheid tussen met of zonder medewerking van de vennootschap uitgegeven certificaten verdwenen. Het gaat nu om de vraag of aan certificaten vergaderrecht is toegekend. Onder vergaderrecht wordt krachtens art. 2:227 BW verstaan het recht om, in persoon of bij schriftelijk gevolmachtigde, de algemene vergadering bij te wonen en daar het woord te voeren. Het vergaderrecht komt toe aan aandeelhouders, aan houders van certificaten waaraan bij de statuten vergaderrecht is verbonden, aan aandeelhouders die vanwege een vruchtgebruik of pandrecht geen stemrecht hebben en aan vruchtgebruikers en pandhouders die stemrecht hebben. Vruchtgebruikers en pandhouders die geen stemrecht hebben, hebben vergaderrecht, indien de statuten dit bepalen en bij de vestiging of overdracht van het vruchtgebruik of pandrecht niet anders is bepaald. De statuten kunnen bepalen dat het verbinden en ontnemen van vergaderrecht aan certificaten van aandelen geschiedt door een daartoe in de statuten aangewezen orgaan (art. 2:227 lid $2 \mathrm{BW}$ ). Een statutaire regeling waarbij aan certificaathouders vergaderrecht is toegekend, kan slechts met instemming van de betrokken certificaathouders worden gewijzigd, tenzij bij het toekennen van het vergaderrecht de bevoegdheid tot wijziging uitdrukkelijk in de statuten was voorbehouden. Deze regel is van overeenkomstige toepassing op vruchtgebruikers en pandhouders (art. 2:227 lid $4 \mathrm{BW}$ ). De statuten kunnen bepalen dat het vergaderrecht is opgeschort zolang een vergadergerechtigde in gebreke is te voldoen aan een wettelijke of statutaire verplichting. De statuten kunnen bepalen, dat voor bijwoning van de algemene vergadering vereist is, dat de vergadergerechtigde van zijn voornemen hiertoe kennis geeft aan het bestuur van de vennootschap. Bij de oproeping van de vergadering wordt alsdan vermeld de dag waarop de kennisgeving uiterlijk moet geschieden. Deze dag kan niet vroeger worden gesteld dan op de derde dag voor die van de vergadering (art. 2:227 lid $6 \mathrm{BW}$ ).

De parlementaire geschiedenis noemt dat in de praktijk behoefte bestaat aan een algemene regeling die duidelijkheid biedt ten aanzien van het vergaderrecht en de vergadergerechtigden. De wetgever memoreert in dit kader de hiervoor aangehaalde discussie over met of zonder medewerking uitgegeven certificaten. Het wegnemen van die discussie is van belang voor de positie van de certificaathouder en het vergemakkelijken van de besluitvorming buiten vergadering. Onder het oude BVrecht (zie art. 2:238 (oud) BW) was het niet mogelijk besluiten buiten vergadering te nemen indien met medewerking van de vennootschap certificaten van aandelen waren uitgegeven. De onduidelijkheid van het onderscheid tussen met of zonder medewerking uitgegeven certificaten kon tot gevolg hebben dat handelingen die ter uitvoering van buiten vergadering genomen besloten zijn verricht niet rechtsgeldig waren. In het huidige art. 2:238 $\mathrm{BW}$ is het wel mogelijk besluiten buiten vergadering 
te nemen, mits alle vergadergerechtigden instemmen met die wijze van besluitvorming. Daarmee wordt de genoemde rechtsonzekerheid weggenomen. ${ }^{198}$

De statuten van de BV kunnen aldus bepalen of aan de certificaten vergaderrecht is verbonden. Indien dat het geval is, rust op het bestuur van de vennootschap de verplichting tot het inschrijven van de houders van certificaten met vergaderrecht. ${ }^{199}$ De statuten kunnen bepalen dat het vergaderrecht slechts kan worden uitgeoefend, indien de certificaathouder in dat register is ingeschreven. Uit het aandeelhoudersregister is dus kenbaar of een certificaathouder vergadergerechtigd is, terwijl de grondslag van die gerechtigdheid de statuten zijn.

Daarnaast bepaalt de hoofdregel van art. 2:227 lid 4 BW dat het aan certificaathouders toegekende vergaderrecht slechts met instemming van die certificaathouder kan worden gewijzigd. ${ }^{200}$ Overeenkomstig het bepaalde in art. 2:227 lid 2 BW kunnen de statuten daarvoor een bepaald orgaan aanwijzen. Dat orgaan is in dat geval bevoegd om te besluiten of aan een of meerdere certificaten vergaderrecht wordt verbonden of ontnomen. Het orgaan dient een orgaan te zijn in de zin van art. 2:189a BW. Andere mogelijkheden op grond van art. 2:227 lid 2 BW zijn statutaire regelingen die bepalen dat certificaten in het algemeen geen vergaderrecht hebben, dat alle certificaten vergaderrecht hebben of dat het vergaderrecht slechts toekomt aan bepaalde, in de statuten aangeduide certificaten. "Uitgangspunt (...) is dat de vennootschap zelf bepaalt of er certificaten met vergaderrecht worden toegelaten, en zo ja, aan welke certificaten dat vergaderrecht toekomt. Het zijn (...) in beginsel de aandeelhouders die bepalen in hoeverre de besluitvorming in de algemene vergadering open staat voor anderen", aldus de wetgever. ${ }^{201}$

De wet koppelt naast het vergaderrecht ook andere rechten aan een certificaat met vergaderrecht, bijvoorbeeld het recht om kennis te nemen van oproepingsbrieven voor een algemene vergadering (art. 2:224 lid 1 BW) en het recht om de voorzieningenrechter te verzoeken om een machtiging tot het bijeenroepen van een algemene vergadering (art. 2:220 BW). De wetgever heeft ervoor gekozen niet te spreken over certificaathoudersrechten, maar van het begrip 'vergaderrecht'. ${ }^{202}$ "Dat brengt beter tot uitdrukking dat het gaat om rechten jegens de vennootschap en niet om rechten die de certificaathouder bijvoorbeeld jegens de aandeelhouder ten titel van beheer kan uitoefenen. Bovendien komen de rechten van de certificaat-

198 Kamerstukken II 2006/07, 31 058, nr. 3, p. 81 (MvT).

199 Zie art. 2:194 lid 1 laatste volzin BW.

200 De mogelijkheid om de toekenning en ontneming van vergaderrecht ook mogelijk te maken door een besluit van een orgaan sluit aan bij de regeling voor stemrecht van pandhouders en vruchtgebruikers, waarbij de toekenning van stemrecht eveneens buiten de statuten om plaatsvindt (art. 2:197 lid 3 en 2:198 lid 3 BW), zie Kamerstukken II 2006/07, 31 058, nr. 3, p. 82 (MvT). Van Veen 2008 (2), p. 5, pleit voor meer flexibiliteit. Hij stelt dat bij de uitgifte van certificaten de wijzigingsbevoegdheid van art. 2:227 lid $4 \mathrm{BW}$ reeds kan worden voorbehouden, zodat de instemmingseis toepassing mist.

201 Kamerstukken II 2006/07, 31 058, nr. 3, p. 82 (MvT).

202 Voor kritiek op deze terminologie zie Nowak \& Van den Ingh 2007, p. 125. Zij hebben gepleit voor de term 'certificaathoudersrechten'. Portier 2008, p. 260, vindt 'afgeleide aandeelhoudersrechten' een betere term. 
houder op grond van art. 2:228 lid 2 BW in bepaalde gevallen ook toe aan pandhouders en vruchtgebruikers en aan de aandeelhouder die geen stemrecht heeft (art. 2:197 lid 4 en 2:198 lid 4 BW)", aldus de wetgever. ${ }^{203}$ Op grond van art. 3:259 BW hebben de houders van certificaten met vergaderrecht een gezamenlijk, wettelijk pandrecht op de aandelen. Het pandrecht geeft aan de certificaathouders de bevoegdheid om bij niet-uitbetaling van de winstrechten de aandelen overeenkomstig art. 3:259 lid 3 BW te doen verkopen en zich uit de opbrengst te voldoen.

De houder van certificaten met vergaderrecht is te vergelijken met de houder van een stemrechtloos aandeel. ${ }^{204}$ In grote lijnen en de verschillen weg denkend, ${ }^{205}$ komt het er op neer dat de houders van deze rechtsfiguren min of meer dezelfde of gelijke rechten hebben, zij het dat zij het stemrecht ontberen. ${ }^{206}$ Beter gezegd, bij het stemrechtloze aandeel ontbreekt het stemrecht. Bij het certificaat is het stemrecht 'verschoven' van de certificaathouder naar de STAK.

De rechtsfiguur van het certificaat zonder vergaderrecht staat, wegens het ontbreken van dat recht, wat verder van het stemrechtloze aandeel af. Niettemin is de houder van een dergelijk certificaat, gelijk het certificaat met vergaderrecht, te beschouwen als een kapitaalverschaffer zonder stemrecht. Op de rechten van de certificaathouder met en zonder vergaderrecht ga ik in paragraaf 6.3 nader in.

\subsubsection{Niet-royeerbare, beperkt royeerbare en royeerbare certificaten}

Naast het onderscheid tussen certificaten met en zonder vergaderrecht bestaat nog het onderscheid tussen royeerbare, beperkt royeerbare en niet-royeerbare certificaten. ${ }^{207}$ De royeerbaarheid van certificaten ziet op het recht van de certificaathouder zijn certificaten voor aandelen om te wisselen. Heeft hij dat recht niet, dan is sprake van niet-royeerbare certificaten. ${ }^{208}$ Heeft hij dat recht wel, dan is sprake van royeerbare certificaten. De tussenvorm is het beperkt royeerbare certificaat. De certificaathouder heeft in dat geval onder bepaalde voorwaarden recht om 'om te wisselen'. Veelal is in de administratievoorwaarden bepaald of, en zo ja, onder welke voorwaarden, de certificaten tegen aandelen om te wisselen zijn. Beperkte royeerbaarheid kan echter ook voortvloeien uit de statuten van het administratiekantoor. In de literatuur worden

203 Kamerstukken II 2006/07, 31 058, nr. 3, p. 82 (MvT)

204 Zie ook Faasen 1989, p. 466, die over een vergelijkbare functie spreekt.

205 Zie voor deze verschillen respectievelijk paragraaf 6.2.3 en 6.3.3.

206 Zie over de (on)wenselijkheid van certificaten met stemrecht Zaman \& Oostwouder 2001 naar aanleiding van het SER-advies van 19 januari 2001 om in bepaalde gevallen certificaathouders stemrecht toe te kennen. Zie over certificaten met stemvolmacht aan de certificaathouder bij beursvennootschappen: Timmermans 2009. Zie over de toekomst van aandelencertificering bij beursvennootschappen: Moerland 2002.

207 Zie Asser/Maeijer, Van Solinge \& Nieuwe Weme 2-II* 2009, nr. 662 en uitgebreid Van den Ingh 1991, p. 78-80.

$208 \mathrm{Zie}$ echter voor een voorbeeld waarin een vordering tot decertificering van niet-royeerbare certificaten is toegewezen: Hof Amsterdam 26 januari 1995, KG 1995, 192 (Kluft Distrifood) en De Bontridder 1995, p. 44 e.v. over dit arrest. 
als voorbeelden genoemd: na toestemming van het bestuur van de vennootschap wiens aandelen zijn gecertificeerd, na toestemming van een besluit van een daartoe aangewezen orgaan, bijvoorbeeld de vergadering van certificaathouders, alleen in of na een bepaalde periode, indien in enig jaar een bepaald minimumdividend niet is uitgekeerd. $^{209}$

Eerder besprak ik al de motieven om tot certificering te komen. Veelal zal het initiatief daartoe genomen worden door (het bestuur van) de vennootschap. De administratievoorwaarden, waaronder ook bepalingen over royeerbaarheid, worden vastgesteld door de STAK. Juist vanwege het feit dat vaak het initiatief tot certificering van de vennootschap uitgaat en de motieven die tot certificering leiden, zal in de BV veelal worden besloten tot niet-royeerbare of beperkte royeerbare certificaten.

Het onderscheid tussen royeerbare, beperkt royeerbare en niet-royeerbare certificaten is van belang voor de kwalificatie van kapitaalverschaffer zonder stemrecht en de verschillen tussen de rechtsfiguren die daarbij horen. Immers, de stemrechtloze aandeelhouder heeft per definitie geen stemrecht en kan dat ook niet verkrijgen. Dat is anders bij de houder van royeerbare of beperkt royeerbare certificaten. Ik kom daarop in paragraaf 6.3.3.7 terug. Overigens heeft de Hoge Raad bepaalt dat in een besloten familievennootschap niet-royeerbare certificaten in zijn algemeenheid naar maatschappelijke maatstaven niet onaanvaardbaar zijn. ${ }^{210}$

\subsubsection{Levering van een certificaat van aandeel (met vergaderrecht)}

Een certificaat van aandeel is een vorderingsrecht op naam. Dat vorderingsrecht wordt overeenkomstig het bepaalde in art. 3:94 BW geleverd. Anders dan bij de levering van een aandeel, ${ }^{211}$ is dus voor de levering van een certificaat geen notariële, maar een onderhandse akte vereist. ${ }^{212}$

Op grond van art. 2:194 BW moet de naam en het adres van de houder van certificaten met vergaderrecht als vergadergerechtigde in het aandeelhoudersregister worden opgenomen. Daarnaast moet worden vermeld de datum van verkrijging en de datum van betekening of erkenning. Art. 2:196c BW is in de wet opgenomen, omdat het van belang is dat de gegevens in het aandeelhoudersregister juist zijn. ${ }^{213}$ Art. 2:196c BW bepaalt daarom dat art. 2:196a en 196b BW van overeenkomstige toepassing zijn met betrekking tot de levering van een certificaat van aandeel waaraan vergaderrecht is verbonden, met dien verstande dat de in art. 2:196b BW bedoelde overlegging of betekening geschiedt van een afschrift van de akte van

209 Van den Ingh 1991, p. 79-80.

210 HR 1 juli 1988, NJ 1989, 226, m.nt. Ma (Drukker).

211 Zie art. 2:196 BW.

212 Kamerstukken II 2008/09, 31 058, nr. 6, p. 41 (NV II).

213 Kamerstukken II 2006/07, 31 058, nr. 3, p. 58 (MvT). 
levering. Het aan de certificaten verbonden vergaderrecht kan aldus eerst worden uitgeoefend nadat de vennootschap de levering heeft erkend of de levering aan haar is betekend. Vindt geen erkenning volgens het bepaalde in art. 2:196a BW door de vennootschap plaats, dan staat de certificaathouder met vergaderrecht aldus de mogelijkheid van art. 2:196b BW open. In feite is art. 2:196c BW een vormvoorschrift, in die zin dat het artikel duidelijk maakt dat de in art. 2:196b BW bedoelde overlegging of betekening geschiedt van een afschrift van de akte van levering. ${ }^{214}$

\subsubsection{Overgangsrecht}

\subsubsection{Inleiding}

In de flex-BV kan bij de statuten worden bepaald dat aan houders van certificaten vergaderrecht toekomt (art. 2:227 lid 2 BW). Krachtens art. 2:194 lid 1 laatste volzin BW dienen in het aandeelhoudersregister de namen en adressen van de houders van certificaten met vergaderrecht opgenomen te worden. Eerder memoreerde ik de discussie onder het oude recht wanneer sprake is van met en zonder medewerking van de vennootschap uitgegeven certificaten. Wat houdt de wetswijziging voor deze certificaten in? De wetgever heeft ten tijde van de parlementaire behandeling in de Tweede Kamer reeds ten aanzien van de certificaten van aandelen die met medewerking van de vennootschap zijn uitgegeven opgemerkt dat het in de rede ligt dat het vergaderrecht van certificaten die thans reeds (lees: onder het oude recht, RAW) als bewilligd in het aandeelhoudersregister zijn vermeld, wordt geëerbiedigd. ${ }^{215}$

Dat is geen sluitende redenering, omdat art. 2:194 (oud) BW niet voorziet in de mogelijkheid, althans de verplichting, tot het inschrijven van certificaathouders in het aandeelhoudersregister. Het is de vraag of inschrijving in het aandeelhoudersregister van bewilligde certificaathouders onder het oude recht veel is voorgekomen. $^{216}$ Later heeft de wetgever dat beter verwoord: "Alle houders van

214 Kamerstukken II 2006/07, 31 058, nr. 3, p. 58 (MvT).

215 Kamerstukken II 2006/07, 31 058, nr. 3, p. 83 (MvT) en Kamerstukken II 2010/11, 32 426, nr. 7, p. 32 (NV II): "Tevens is in het overgangsrecht opgenomen dat tot het moment van die statutenwijziging onder certificaten waaraan bij de statuten vergaderrecht is verbonden tevens worden verstaan certificaten die voor inwerkingtreding van de wet over vergaderrecht beschikten en die in het aandeelhoudersregister zijn opgenomen. Er is dan ook geen probleem meer met de pandrechten, zoals door de vragenstellers naar voren is gebracht. De tekst van artikel 3:259 spreekt van "certificaten uitgegeven met medewerking van de uitgever van de oorspronkelijke aandelen". Daaronder vallen dan de certificaten waarvan de houders alleen in het aandeelhoudersregister geregistreerd staan en de houders van certificaten die tevens in de statuten zijn aangewezen. Er kan dan geen sprake meer zijn van een categorie van houders van certificaten die met medewerking van de vennootschap zijn uitgegeven, maar waaraan niet in de statuten vergaderrechten zouden zijn toegekend." De terechte zorg van Portier 2008, p. 262, dat mogelijk geen wettelijk pandrecht ex art. 3:259 BW op de aandelen waartegenover certificaten met vergaderrecht worden uitgegeven, zou rusten, is blijkens het overgangsrecht gelukkig onterecht gebleken.

216 In gelijke zin: Portengen 2007, p. 948 en Nowak \& Van den Ingh 2007, p. 126. 
certificaten die nu aanspraak kunnen maken op aanwezigheid bij de algemene vergadering, dienen onder de nieuwe regeling als vergadergerechtigd te worden aangemerkt." ${ }^{217}$ Houders van - onder het oude recht - bewilligde certificaten hebben vergaderrecht en moeten bijvoorbeeld ook voor een algemene vergadering worden opgeroepen. ${ }^{218}$ Het oude recht kende echter het begrip 'vergaderrecht' niet. De wijziging van art. 2:227 lid 2 en 2:194 BW brengt mee dat in de statuten dat vergaderrecht aan die certificaathouders moet worden toegekend en dat die vergadergerechtigden in het aandeelhoudersregister moeten worden ingeschreven. Gebeurt dat niet, dan vallen de 'oude' bewilligde certificaathouders tussen wal en schip en blijft de discussie onder het oude recht wanneer sprake is van al dan niet bewilligde certificaten bestaan. Dat komt de rechtszekerheid niet ten goede. Vanwege deze achtergrond en wijzigingen is aldus overgangsrecht noodzakelijk.

Ik neem overigens aan dat de wetgever met het hiervoor aangehaalde citaat tevens bedoeld heeft te zeggen dat de bewilligde certificaathouders onder het oude recht onder het nieuwe recht het vergaderrecht mag uitoefenen, ook al zijn de statuten daartoe nog niet aangepast.

Ik maak ten aanzien van de certificaten van aandelen eerst algemene overgangsrechtelijke opmerkingen en vervolgens specifieke overgangsrechtelijke opmerkingen.

\subsubsection{Overgangsrecht algemeen}

In paragraaf 4.3.14 merkte ik reeds op dat de hoofdregel is dat de wet onmiddellijke werking heeft ten aanzien van feiten die na de inwerkingtreding zich hebben voorgedaan. Deze regel volgt uit art. 68a Overgangswet NBW.

In de literatuur ${ }^{219}$ wordt het voorbeeld genoemd dat voor de inwerkingtreding van de wet een verkoop van bewilligde certificaten plaats vindt. De levering van deze certificaten moet echter nog plaatsvinden. Indien de levering na inwerkingtreding geschiedt, is art. 2:196c BW van toepassing. Daarnaast geldt dat op grond van art. 2:194 BW na levering de houder van die certificaten als vergadergerechtigde in het aandeelhoudersregister moet worden opgenomen. Art. 2:196c BW bepaalt dat art. 2:196a en 2:196b BW van overeenkomstige toepassing zijn met betrekking tot de levering van een certificaat van aandeel waaraan vergaderrecht is verbonden, met dien verstande dat de in art. 2:196b BW bedoelde overlegging of betekening geschiedt van een afschrift van de akte van levering. Het aan de certificaten verbonden vergaderrecht kan aldus eerst worden uitgeoefend nadat de vennootschap de levering heeft erkend of de levering aan haar is betekend. Op grond van de laatste volzin van art. 2:194 lid $1 \mathrm{BW}$ moet ook de datum van

217 Kamerstukken II 2009/11, 32 426, nr. 3, p. 14-15 (MvT).

218 Kamerstukken II 2010/11, 32 426, nr. 7, p. 32 (NV II).

219 Schoonbrood 2012, p. 424. 
erkenning of betekening door de vennootschap in het aandeelhoudersregister worden opgenomen.

Een andere overgangrechtelijke hoofdregel volgt uit art. 69 Overgangswet NBW. Kort gezegd, bepaalt dat artikel dat de wet geen wijziging in bestaande rechten aanbrengt. Bestaande rechten worden geëerbiedigd. Er ontstaan geen nieuwe rechten door de inwerkingtreding van de wet.

In de literatuur ${ }^{220}$ wordt het voorbeeld genoemd dat sprake is van gecertificeerde aandelen. Er is niet vastgelegd of sprake is van bewilligde of niet-bewilligde certificaten. De vennootschap heeft de certificaten en haar houders telkens behandeld als ware sprake van niet-bewilligde certificaten. Desondanks schrijft de vennootschap de houders van deze certificaten op grond van art. 2:194 BW als vergadergerechtigden in het aandeelhoudersregister in. Op een later moment worden de statuten gewijzigd en wordt aan de certificaten vergaderrecht toegekend. Als gevolg hiervan ontstaat het pandrecht als bedoeld in art. 3:259 BW. In feite is art. 69 Overgangswet NBW op dit voorbeeld niet van toepassing. Het wettelijk pandrecht ontstaat niet door de inwerkingtreding van de wet, maar door het feit dat de vennootschap vergaderrecht aan de certificaten toekent.

\subsubsection{Overgangsrecht specifiek}

Naast de hiervoor beschreven algemene regels van het Overgangsrecht kent de wet ook specifiek overgangsrecht voor certificaten van aandelen. Voor deze rechtsfiguur geldt art. V.2 lid 1 en 6 van het Overgangsrecht. ${ }^{221}$ Uit art. V.2 lid 1 volgt de verplichting van de vennootschap ten spoedigste, doch uiterlijk een jaar na de datum van inwerkingtreding van deze wet, dat wil zeggen uiterlijk 1 oktober 2013, de namen en adressen van de houders van certificaten van aandelen waaraan vergaderrecht is verbonden met vermelding van de datum waarop het vergaderrecht aan hun certificaat is verbonden en de datum van erkenning of betekening in het aandeelhoudersregister in te schrijven. Is het aandeelhoudersregister een maand vóór de datum van de eerste algemene vergadering na 1 oktober 2012 nog niet overeenkomstig art. 2:194 lid 1 laatste volzin BW voltooid, dan is art. 2:223 lid 2 en 3 oud BW van toepassing. Houders van certificaten die met medewerking van de vennootschap zijn uitgegeven, kunnen de vennootschap schriftelijk verzoeken hen als vergadergerechtigden in te schrijven in het register. Indien het bestuur dit verzoek afwijst, kunnen de houders van de certificaten de rechtbank verzoeken het bestuur op te dragen hen als vergadergerechtigden in te schrijven in het register. Art. V.2 lid 6 bepaalt dat indien er voor de van inwerkingtreding van de wet met medewerking van de vennootschap certificaten van haar aandelen uitgegeven zijn,

220 Schoonbrood 2012, p. 425.

221 Kamerstukken II 2009/10, 32 426, nr. 2, p. 16 (Voorstel van wet), gewijzigd bij Nota van wijziging Kamerstukken II 2010/11, 32 426, nr. 8, p. 9-10 en 18. Ten aanzien van lid 6: Kamerstukken II 2010/11, 32 426, nr. 6, p. 12-13 en Kamerstukken II 2010/11, 32 426, nr. 7, p. 32-33. 
de vennootschap bij de eerstvolgende statutenwijziging vergaderrecht moet verbinden aan de houders van deze certificaten overeenkomstig art. 2:227 lid $2 \mathrm{BW}$. Tot het moment van die statutenwijziging worden onder certificaten waaraan bij de statuten vergaderrecht is verbonden tevens verstaan certificaten die voor inwerkingtreding van de wet over vergaderrecht beschikten en die in het aandeelhoudersregister zijn opgenomen.

Dit overgangsrecht komt er voor de vennootschap kort gezegd en praktisch op neer dat zij, althans haar bestuur, zich zal moeten afvragen of er voor invoering van de flex-BV certificaten zijn uitgegeven. Zo ja, dan is de vraag of sprake is van bewilligde certificaten en/of aan niet-bewilligde certificaten vergaderrecht moet worden toegekend. Indien het antwoord op deze vragen eveneens bevestigend luidt, zal de vennootschap moeten nagaan of de gegevens van die certificaathouders in het aandeelhoudersregister zijn opgenomen. Als dat niet het geval is, vergt het overgangsrecht aanpassing van de statuten. Ook de notaris zal zich deze vragen, althans aan zijn cliënte, in het kader van zijn advisering moeten stellen. Tot het moment dat de statuten aangepast zijn, worden onder certificaten waaraan bij de statuten vergaderrecht is verbonden tevens verstaan certificaten die voor inwerkingtreding van de wet over vergaderrecht beschikten en die in het aandeelhoudersregister zijn opgenomen. Met andere woorden: in deze overgangsperiode is de aantekening in het aandeelhoudersregister voldoende om aan deze certificaten vergaderrecht toe te kennen, zulks in afwijking van het bepaalde in art. 2:227 lid 2 BW.

Uit het artikel blijkt voorts dat de vennootschap niet direct (doch wel ten spoedigste), maar binnen een jaar na invoering van de flex-BV (dus vóór 1 oktober 2013), de vergadergerechtigde certificaathouders in het aandeelhoudersregister moeten zijn vermeld. Met Portier ${ }^{222}$ ben ik van mening dat de eerste volzin van art. V.2 lid 1 van het Overgangsrecht had moeten luiden dat het bestuur van de vennootschap voldoet aan het bepaalde in art. 2:194 lid 1, laatste volzin, BW conform de verplichting van dat laatste artikel dat het bestuur van de vennootschap het aandeelhoudersregister bijhoudt. Eenzelfde fout treft men aan in art. V.2 lid 6 van het Overgangsrecht. Dat artikellid had moeten luiden dat "de vennootschap bij de eerstvolgende statutenwijziging vergaderrecht [dient] te verbinden aan deze certificaten overeenkomstig artikel 227 lid 2'”. Blijkens art. 2:227 lid 2 BW wordt immers vergaderrecht aan certificaten verbonden en niet aan de houders van certificaten.

Terecht vraagt Schwarz ${ }^{223}$ zich af of het bestuur van de vennootschap wel het aangewezen orgaan is om te bepalen of sprake is van bewilligde certificaten, waarvan de houders als vergadergerechtigde in het aandeelhoudersregister moeten worden ingeschreven. Met hem ben ik van mening dat die vraag niet aan het bestuur zou moeten zijn en dat de bevoegdheid tot erkenning van vergadergerechtigdheid slechts aan de algemene vergadering toekomt. Dat strookt ook met het uitgangspunt 
van de wetgever dat het de aandeelhouders zijn die bepalen in hoeverre besluitvorming in de algemene vergadering voor anderen open staat. ${ }^{224}$ De wetgever heeft kennelijk vooral voor een praktische insteek van het overgangsrecht gekozen.

Zijn alle houders van met medewerking van de vennootschap uitgegeven certificaten een maand vóór de datum van de eerste algemene vergadering na invoering van de flex-BV nog niet in het aandeelhoudersregister geregistreerd, dan geldt art. 2:223 lid 2 en 3 (oud) BW. Dat houdt in dat de houders van bewilligde certificaten worden opgeroepen door aankondiging in een landelijk verspreid dagblad of, indien alle aandeelhouders en alle houders van bewilligde certificaten daarmee instemmen, door elektronische oproeping. In de statuten kan van beide wijzen van oproeping afgeweken zijn. Indien de afwijkende statutaire regeling in een efficiëntere regeling tot oproeping voorziet, kan het aangewezen zijn die regeling gedurende de overgangsperiode te handhaven. ${ }^{225}$ Dat geldt te meer indien de registratie van alle certificaathouders met vergaderrecht in het aandeelhoudersregister nog niet is voltooid. De tweede volzin van art. V.2 lid 1 gaat er immers vanuit dat zolang niet alle certificaathouders met vergaderrecht in het aandeelhoudersregister zijn ingeschreven de oude oproepingsvereisten van art. 2:223 lid 2 en 3 (oud) BW blijven gelden. ${ }^{226}$ Ik kom op de vraag wanneer sprake is van een situatie van 'voltooiing' terug.

Art. V.2 lid 1 van de overgangsbepaling is mede tot stand gekomen naar aanleiding van opmerkingen uit de rechtspraktijk over (een mogelijk) overgangsrecht. ${ }^{227}$ Het probleem is gesignaleerd dat niet altijd duidelijk is of sprake is van met of zonder medewerking van de vennootschap uitgegeven certificaten. Om die reden zal een BV niet altijd vrijwillig overgaan tot het opnemen van die vergadergerechtigden in het aandeelhoudersregister. Daarom bepalen de laatste twee volzinnen van art. V.2 lid 1 dat houders van certificaten die met medewerking van de vennootschap zijn uitgegeven (althans dat is hun standpunt) de vennootschap schriftelijk kunnen verzoeken hen als vergadergerechtigden in het register in te schrijven. Indien het bestuur dat verzoek afwijst, kunnen zij de rechtbank verzoeken het bestuur op te dragen hen als vergadergerechtigden in te schrijven in het register. De rechter beslist dan of sprake is van al dan niet bewilligde certificaten. De eerder genoemde ruime en enge leer ten aanzien van de vraag wanneer sprake is van met of zonder medewerking van de vennootschap uitgegeven certificaten blijven dus ook na invoering van de flex-BV nog enige tijd relevant. De wetgever merkt nog op dat

224 Kamerstukken II 2006/07, 31 058, nr. 3, p. 82 (MvT).

225 In gelijke zin: Schoonbrood 2012, p. 432.

226 Kamerstukken II 2009/10, 32 426, nr. 3, p. 15 (MvT).

227 Kamerstukken II 2009/10, 32 426, nr. 3, p. 38 (MvT). Portier 2008, p. 264-268 en het advies d.d. 23 september 2010 van de Gecombineerde Commissie Vennootschapsrecht van de Nederlandse Orde van Advocaten en de Koninklijke Notariële Beroepsorganisatie, par. III, p. 5-8. Voor kritiek op een eerder ontwerp van dit artikel (zie voor dat ontwerp Kamerstukken II 2009/10, 32 246, nr. 2, p. 16), zie Portier 2011, p. 47 e.v. Zie voor een bespreking van dat eerdere ontwerp: Lennarts \& Boschma 2010, p. 712 en Seubring 2010, p. 187-188. 
het gaat om een verzoekschriftprocedure en dat in spoedeisende gevallen - bijvoorbeeld bij een naderende algemene vergadering - het ook mogelijk is dat de certificaathouders zich tot de voorzieningenrechter wenden. Ook kan de certificaathouder een verzoek bij de rechtbank indienen, indien het bestuur om een andere reden dan de betwisting van de bewilliging de inschrijving weigert. ${ }^{228}$

De vraag is of deze regeling een gelukkige, althans een doordachte, is. ${ }^{229}$ De rechter zal aan de hand van de in de literatuur en jurisprudentie heersende, enge leer over de vraag of sprake is van bewilligde certificaten beslissen. De uitkomst van een dergelijke procedure is afhankelijk van de feiten en omstandigheden van het geval. Daarnaast kan het enige tijd duren voordat sprake is van een onherroepelijke uitspraak op het verzoek tot inschrijving als vergadergerechtigde door de certificaathouder. Niet alleen is dat gelegen in de mogelijkheden van hoger beroep en cassatie zowel voor de certificaathouder als de vennootschap, maar ook in de feitelijke duur van een procedure.

Zoals betoogd, is de certificaathouder niet alleen gebaat bij zijn inschrijving als vergadergerechtigde in het aandeelhoudersregister, maar is het eindstation de wijziging van de statuten, waarbij aan zijn certificaat vergaderrecht is toegekend. De laatste volzin van art. V.2 lid 1 van het Overgangsrecht bepaalt dat echter niet. Kan de certificaathouder niettemin, naast het verzoek tot inschrijving, verzoeken dat de vennootschap de statuten wijzigt, in die zin dat aan het certificaat vergaderrecht is verbonden ex art. 2:227 lid 2 BW? Omdat de wet dat niet bepaalt, is dat mijn inziens niet mogelijk. Met Portier ${ }^{230}$ ben ik van mening dat de wet zou moeten bepalen dat inschrijving van de certificaathouder als vergadergerechtigde in het aandeelhoudersregister op last van de rechter of voorzieningenrechter, zoals hierna te bespreken, tot gevolg heeft dat certificaathoudersrechten ontstaan. Wel acht ik het mogelijk dat de certificaathouder een vordering instelt, indien de vennootschap het bepaalde in art. V.2 lid 6 van het Overgangsrecht niet nakomt.

Indien de certificaathouder een spoedeisend belang heeft, kan hij ook een verzoek bij de voorzieningenrechter indienen. De aard van een dergelijke procedure houdt echter in dat de voorzieningenrechter slechts een voorlopig oordeel en een voorlopige maatregel kan geven. Het voorlopig oordeel ziet op de vraag of sprake is van een bewilligd certificaat. Dat zal de verzoeker aanstonds duidelijk moeten maken, wil hij niet het risico lopen dat zijn verzoek door de voorzieningenrechter zal worden afgewezen. In de regel zal de voorzieningenrechter vanwege de aard van de procedure niet geneigd zijn het verzoek toe te wijzen, indien niet uit de feiten en omstandigheden direct en eenvoudig vast te stellen is dat sprake is van een bewilligd certificaat. Indien het antwoord daarop positief is, is vervolgens de vraag welke voorlopige maatregel de voorzieningenrechter kan opleggen (en voor de certificaathouder hoe hij zijn verzoek moet formuleren). Een verklaring voor recht is in kort

228 Kamerstukken II 2009/10, 32 426, nr. 3, p. 38 (MvT).

229 In gelijke zin: Van Gendt 2011, p. 35-36.

230 Portier 2011, p. 49. 
geding niet mogelijk. De beslissing dat de vennootschap de certificaathouder als vergadergerechtigde in het aandeelhoudersregister moet inschrijven, is naar mijn mening in strijd met de aard van de kort geding procedure. Wel zou de beslissing mogelijk moeten zijn dat de vennootschap de certificaathouder als vergadergerechtigde in het aandeelhoudersregister moet inschrijven gedurende de periode dat in een bodemprocedure nog niet onherroepelijk is beslist, eventueel op straffe van verbeurte van een dwangsom. Er is in dat geval sprake van een voorwaardelijke inschrijving.

Overigens is ook tegen een uitspraak van de voorzieningenrechter hoger beroep mogelijk, zodat ook in dat geval de problematiek van de onherroepelijke uitspraak en de daarmee gepaard gaande rechtsonzekerheid speelt.

De vraag is bovendien wat de status van de certificaathouder is gedurende de genoemde procedures. In het verlengde daarvan ligt de vraag of de vennootschap met de - naar haar mening - niet vergadergerechtigde certificaathouder rekening moet houden. De wet refereert in een aantal bepalingen aan de vergadergerechtigden. Te denken valt bijvoorbeeld aan de oproeping tot de algemene vergadering (art. 2:223 BW), de agenda van de algemene vergadering (art. 2:224 BW), de in acht te nemen termijn voor oproeping (art. 2:225 BW), het afwijken van de plaats van de algemene vergadering (art. 2:226 BW), de inhoud van het vergaderrecht (art. 2:227/ $227 \mathrm{a} \mathrm{BW}$ ), de aankondiging van het voorstel tot statutenwijziging (art. 2:233 BW) en de besluitvorming buiten vergadering (art. 2:238 BW). De parlementaire geschiedenis zwijgt over de hiervoor geschetste problematiek.

De vennootschap staat gedurende die onzekere periode waarin de procedures nog lopen en geen onherroepelijke uitspraak is verkregen voor de keuze wel of niet rekening te houden met de "bewilligde" certificaathouder. Doet zij dat wel, dan wordt mogelijk besluitvorming gefrustreerd. Doet zij dat niet, dan loopt zij het risico dat besluiten ex art. 2:14 of 2:15 BW respectievelijk nietig of vernietigbaar zijn. Waarin is de oplossing gelegen? Naar mijn mening moet de vennootschap aan de hand van een aantal factoren een risicoanalyse maken. Afhankelijk van het belang dat de certificaathouder (via de STAK) in het kapitaal van de vennootschap vertegenwoordigd, de aard van het te nemen besluit in de algemene vergadering of door het bestuur van de vennootschap, het kenbare belang van de vennootschap en het kenbare belang van de betreffende certificaathouder, doen de vennootschap en haar organen er verstandig aan de certificaathouder gedurende de discussie over de vraag of de certificaathouder wel of niet vergaderrecht toekomt bij de besluitvorming, voor zover rechtens vereist, te betrekken. Die uitkomst van een dergelijke analyse is sterk afhankelijk van de omstandigheden van het geval.

Een andere vraag is wanneer sprake is van een voltooide inschrijving in het aandeelhoudersregister in de zin van de tweede volzin van art. 2:194 lid 1 BW. ${ }^{231}$ Indien het bestuur van de vennootschap daadwerkelijk en vrijwillig aantekening in het register heeft gemaakt, zal de beantwoording van deze vraag geen problemen

231 Ook Van Gendt 2011, p. 36, werpt deze vraag op. 
opleveren. Van voltooiing is dan (al snel) sprake. Anders is dat in geval de vennootschap de vergadergerechtigdheid betwist en de certificaathouder zich tot de rechter wendt. Naar mijn mening is in die situatie van voltooiing sprake indien het bestuur van de vennootschap op grond van een onherroepelijke uitspraak in een bodemprocedure tot aantekening in het aandeelhoudersregister van de vergadergerechtigde certificaathouder is overgegaan.

Is het register een maand vóór de datum van de eerste algemene vergadering na het tijdstip van inwerkingtreding van de invoeringswet flex-BV (dus vóór 1 oktober 2013) nog niet overeenkomstig art. 2:194 lid 1, laatste volzin, BW voltooid, dan geldt art. 2:223 lid 2 en 3 (oud) BW. Met andere woorden: de oproepingseisen onder het oude recht blijven gelden, zolang van voltooiing nog geen sprake is. Dat houdt naar mijn mening ook in dat voor algemene vergaderingen volgend op de eerste algemene vergadering na 1 oktober 2012 de oude oproepingsvereisten (blijven) gelden. Portier is van mening dat de overgangsregeling slechts van toepassing is gedurende dertien maanden na inwerkingtreding van de wet en dat voor de algemene vergaderingen in het tweede en volgende jaar na inwerkingtreding van de wet de oproepingsvereisten van art. 2:223 (nieuw) BW gelden. ${ }^{232}$ Portier gaat er mijn inziens aan voorbij dat, zoals hiervoor om diverse redenen uiteengezet, van voltooiing eerst op een later moment sprake kan zijn.

Tijdens de parlementaire behandeling heeft de wetgever opgemerkt dat zij niet grote problemen verwacht met de opname van vergadergerechtigden in het aandeelhoudersregister. Op grond van art. 2:194 lid 3 BW zijn de vergadergerechtigden gehouden het bestuur van de vennootschap tijdig de benodigde gegevens voor opname in het register te verstrekken. Het administratiekantoor, of een andere aandeelhouder ten titel van beheer, kan daarbij volgens de wetgever behulpzaam zijn. Het administratiekantoor beschikt immers over de noodzakelijke gegevens, zodat op verzoek van de certificaathouder de inschrijving eenvoudig kan worden gerealiseerd. ${ }^{233}$ Het spreekt voor zich dat dit optimisme alleen geldt in het geval van bewilligde certificaten en dat juist bij dergelijke certificaten de bedoelde gegevens vaak al bij de vennootschap bekend zullen zijn. Een houder van een bewilligd certificaat staat in de regel dichter bij de vennootschap. Daarnaast blijft gelden dat het bestuur (uiteindelijk) verantwoordelijk is voor inschrijving en zo nodig nader onderzoek zal moeten doen. ${ }^{234}$ Dat onderzoek kan er bijvoorbeeld in bestaan dat het bestuur van de vennootschap een schriftelijke verklaring van het administratiekantoor verlangt, inhoudende dat het administratiekantoor opgave aan het bestuur van de vennootschap heeft gedaan van alle haar bekende certificaathouders. ${ }^{235}$ Ten onrechte stelt de wetgever echter dat 'het administratiekantoor (of een andere

232 Portier 2011, p. 50.

233 Kamerstukken II 2009/10, 32 426, nr. 3, p. 14-15 (MvT) en Kamerstukken II 2006/07, 31 058, nr. 3 , p. $48(\mathrm{MvT})$

234 In gelijke zin: Wouters 2011, p. 241.

235 In gelijke zin: Schoonbrood 2012, p. 432. 
aandeelhouder ten titel van beheer) op verzoek van de certificaathouder zal zorgdragen voor de inschrijving in het register'. ${ }^{236}$ Uit art. 2:194 BW en art. V.2 lid 1 van het Overgangsrecht volgt naar mijn mening dat het administratiekantoor de bevoegdheid tot inschrijving niet toekomt. Evenmin komt het administratiekantoor de bevoegdheid toe een verzoek tot inschrijving aan het bestuur van de vennootschap te doen. ${ }^{237}$

Ook op een andere reden is de vraag of het optimisme van de wetgever gerechtvaardigd is. Ik ga terug naar de toelichting van de wetgever: "Uitgangspunt is de kenbaarheid van de aanwezigheid van bewilligde certificaathouders door middel van opname in het register. Zij dienen persoonlijk uitgenodigd te worden voor de algemene vergadering, aldus het nieuwe artikel 223. Opname in het register dient na inwerkingtreding van de wet dan ook zo snel mogelijk plaats te vinden. Is die opname nog niet afgerond op het moment waarop de eerste algemene vergadering na de datum van inwerkingtreding van het nieuwe bv-recht wordt gehouden, dan zal van die vergadering alsnog aankondiging moeten worden gedaan in een dagblad overeenkomstig het huidige artikel 223 lid 2. Zijn alle namen bekend en in het register opgenomen, dan kan worden overgestapt op de bijeenroeping overeenkomstig het nieuwe artikel 223. (onderstreping, RAW) Uiteindelijk dient de volledige opname in het register binnen een jaar na de datum van inwerkingtreding afgerond te zijn (zie artikel V.2 lid 1 van het wetsvoorstel). De aanwezigheid van certificaathouders met vergaderrechten hoeft dus geen aanleiding te zijn voor een onmiddellijke statutenwijziging. De vergaderrechten blijken immers uit het aandeelhoudersregister zodra dat is bijgewerkt. Maar uiteindelijk zullen de statuten wel bij de eerstvolgende gelegenheid (...) na inwerkingtreding van deze wetgeving aangepast moeten worden (zie artikel V.2 lid 6 van het wetsvoorstel)."238

Uit deze toelichting volgt niet dat de wetgever (voldoende) rekening heeft gehouden met het reeds gesignaleerde probleem dat niet altijd duidelijk is of sprake is van met medewerking van de vennootschap uitgegeven certificaten. Met andere woorden: niet alle namen van houders van bewilligde certificaten zullen de vennootschap bekend te zijn, althans dat zal de vennootschap niet altijd kunnen of willen vaststellen. Zo zal de vennootschap bij betwisting van de bewilligdheid van de certificaten de namen van de desbetreffende certificaathouders wel bekend zijn, maar zal de vennootschap niet de certificaathouders als vergadergerechtigden in het aandeelhoudersregister willen opnemen. Gevolg daarvan is dat niet, zoals de wetgever stelt, de (nieuwe) oproepingsvereisten van art. 2:223 BW in acht genomen moeten worden, maar dat oproeping volgens art. 2:223 lid 2 (oud) BW vereist blijft. ${ }^{239}$ In dit kader verwijs ik naar hetgeen ik hiervoor heb gesteld ten aanzien van de voltooiing van de inschrijving in het aandeelhoudersregister.

236 Kamerstukken II 2009/10, 32 426, nr. 3, p. 15 (MvT).

237 In gelijke zin: Portier 2011, p. 49.

238 Kamerstukken II 2009/10, 32 426, nr. 3, p. 15 (MvT).

239 In gelijke zin: Portier 2011, p. 49. 
Portier stelde een andere regeling voor in het geval de vennootschap het verzoek van de certificaathouder tot inschrijving van zijn vergadergerechtigdheid afwijst. Kort gezegd, komt die regeling erop neer dat de algemene vergadering zal besluiten of de certificaathouder vergadergerechtigd is. Dat besluit zou moeten worden genomen volgens dezelfde procedure en met eenzelfde meerderheid als een besluit tot statutenwijziging. Voor een afwijzend besluit zou de rechter als vangnet dienen. ${ }^{240}$ Dit voorstel is niet door de wetgever overgenomen: "Indien het bestuur betwist dat de certificaten met medewerking van de vennootschap zijn uitgegeven, is het aan de rechter om te bepalen of er sprake is van bewilligde certificaten. (...) Het gaat hier om een oordeel over de aanwezigheid van bepaalde bevoegdheden, dat beter genomen kan worden door een onafhankelijke rechter dan door een vergadering van aandeelhouders die belanghebbenden zijn bij het toelaten van certificaathouders tot hun vergadering." 241 De motivering van de wetgever komt mij als zuiver voor.

De gedachte achter art. V.2 lid 6 van het Overgangsrecht is de invoering van de flex-BV zo geruisloos mogelijk te laten verlopen met zo weinig mogelijk incidentele lasten. ${ }^{242}$ Ook heeft de wetgever overwogen dat het in de praktijk lastig kan zijn om vennootschappen die certificaathouders met vergaderrecht in het aandeelhoudersregister hebben opgenomen te dwingen tevens de statuten te wijzigen. Voor houders van certificaten die met medewerking van de vennootschap uitgegeven zijn, geldt dat het opnemen in de statuten van hun vergaderrecht pas hoeft plaats te vinden bij de eerstvolgende statutenwijziging en niet meer binnen vijf jaar, zoals in het oorspronkelijke voorstel van het overgangsrecht was opgenomen. De vergadergerechtigden blijken immers reeds binnen een jaar na invoering van de flex-BV uit het aandeelhoudersregister, tenzij sprake is van de hiervoor besproken verzoekschriftprocedure. Daarnaast is in het overgangsrecht opgenomen dat tot het moment van die statutenwijziging onder certificaten waaraan bij de statuten vergaderrecht is verbonden tevens worden verstaan certificaten die voor inwerkingtreding van de wet over vergaderrecht beschikten en die in het aandeelhoudersregister zijn opgenomen. ${ }^{243}$ Ik merkte daarover al op dat dit geen sluitende redenering is, omdat art. 2:194 (oud) BW niet voorziet in de mogelijkheid, althans de verplichting, tot het inschrijven van certificaathouders in het aandeelhoudersregister. Het is de vraag of inschrijving in het aandeelhoudersregister van bewilligde certificaathouders onder het oude recht (veel) is voorgekomen.

Op zich is het voormelde streven naar een geruisloze invoering van de flex-BV met zo weinig mogelijk incidentele lasten een goed streven. Dat houdt echter wel in dat art. V.2 nog geruime tijd na invoering van de flex-BV relevant is. Indien er immers geen directe aanleiding is de statuten te wijzingen, zal de certificaathouder

240 Portier 2008, p. 264-268 en Portier 2011, p. 49.

241 Kamerstukken II 2009/10, 32 426, nr. 3, p. 38 (MvT). Zie de reactie daarop van Portier 2011, p. 49.

242 Kamerstukken II 2009/10, 32 426, nr. 3, p. 15 (MvT).

243 Kamerstukken II 2010/11, 32 426, nr. 7, p. 32 (NV II). 
met vergaderrecht enig geduld moeten hebben, alvorens aan zijn certificaten op grond van de statuten vergaderrecht is verbonden. In de tussentijd zal hij bij wege van overgang genoegen moeten nemen met de inschrijving als vergadergerechtigde certificaathouder in het aandeelhoudersregister. Indien de statutenwijziging eenmaal daar is, moet vervolgens niet vergeten worden - niet alleen door de vennootschap zelf, maar ook door de adviserende notaris - de statuten in voormelde zin te wijzigen. $^{244}$

In het overgangsrecht zit voorts een lacune. De eerste volzin van art. V.2 lid 1 bepaalt dat de vennootschap ten spoedigste, doch uiterlijk een jaar na de datum van inwerkingtreding van de wet (dus vóór 1 oktober 2013) aan art. 2:194 lid 1 laatste volzin BW voldoet. Dat heeft ook gevolgen voor certificaten met vergaderrecht die na invoering van de flex-BV worden uitgegeven. Voor dergelijke, nieuwe certificaten zou geen overgangsrecht moeten gelden, te meer omdat voor die certificaten de gememoreerde problematiek onder het oude recht niet speelt. De houders van certificaten met vergaderrecht die na invoering van de flex-BV worden of zijn uitgegeven, moeten daarom mijns inziens direct in het aandeelhoudersregister worden ingeschreven. Er is geen reden de vennootschap voor de inschrijving van die certificaathouders een termijn van één jaar te gunnen. Bovendien zou, indien het aandeelhoudersregister nog niet is bijgewerkt een maand voor de eerste algemene vergadering na inwerkingtreding van de wet, een en ander ertoe leiden dat volgens art. 2:223 lid 2 en 3 (oud) BW moet worden opgeroepen. ${ }^{245}$ Aan de eerste volzin van art. V.2 lid 1 van het overgangsrecht moet daarom na de punt worden toegevoegd: "Indien sprake is van houders van certificaten van aandelen waaraan vergaderrecht is verbonden, welke certificaten na inwerkingtreding van de wet zijn uitgegeven, voldoet het bestuur van de vennootschap omgaand na uitgifte van die certificaten aan artikel 194 lid 1, laatste volzin."

Dezelfde problematiek speelt bij bewilligde certificaten, waarvan buiten twijfel is dat deze certificaten met medewerking van de vennootschap zijn uitgegeven en de vennootschap deze certificaathouders altijd als zodanig heeft behandeld. De wetgever licht dat toe: "Alle houders van certificaten die nu aanspraak kunnen maken op aanwezigheid bij de algemene vergadering, dienen onder de nieuwe regeling als vergadergerechtigd te worden aangemerkt." 246 Ik neem dat de wetgever met dit citaat tevens bedoeld heeft te zeggen dat de bewilligde certificaathouders onder het oude recht onder het nieuwe recht het vergaderrecht mag uitoefenen, ook al is door de statuten nog geen vergaderrecht aan de certificaten toegekend. Met Schoonbrood $^{247}$ ben ik van mening dat de vennootschappelijke redelijkheid en billijkheid mee brengt dat de vennootschap deze certificaathouders als vergadergerechtigde

244 Zie ten aanzien van het gestelde in deze alinea ook in gelijke zin: Schoonbrood 2012, p. 433. 245 In gelijke zin: Portier 2011, p. 48 en Wouters 2011, p. 241.

246 Kamerstukken II 2009/11, 32 426, nr. 3, p. 14-15 (MvT).

247 Schoonbrood 2012, p. 433. 
moet blijven behandelen. ${ }^{248}$ De vennootschap zal niet kunnen stellen dat deze certificaathouders niet meer de algemene vergadering mogen bijwonen en daarin het woord mogen voeren. Het bestuur van de vennootschap zal niet mogen weigeren deze certificaathouder als vergadergerechtigde in het aandeelhoudersregister in te schrijven. Weigert het bestuur dat toch, dan rest de bewilligde certificaathouder niets anders dan de weg van art. V.2 lid $6 .^{249}$

Indien buiten twijfel is dat de certificaten met medewerking van de vennootschap zijn uitgegeven en de vennootschap deze certificaathouders altijd als zodanig behandeld heeft, is er geen reden het bestuur van de vennootschap een jaar de tijd te geven voor de aantekening als vergadergerechtigde van deze certificaathouders. Art. V.2 lid 1 geeft als termijn "ten spoedigste, doch uiterlijk een haar na de datum van inwerkingtreding van deze wet". Niet valt in te zien waarom het bestuur van de vennootschap niet omgaand aan de verplichting van art. 2:194 lid 1 BW zou kunnen voldoen. Aan de eerste volzin van art. V.2 lid 1 van het overgangsrecht moet daarom na de punt worden toegevoegd: "Indien sprake is van houders van certificaten van aandelen, welke certificaten voor inwerkingtreding van de wet met medewerking van de vennootschap zijn uitgegeven en de vennootschap en haar organen zulks hebben erkend of dienovereenkomstig hebben gehandeld, voldoet het bestuur van de vennootschap omgaand na inwerkingtreding van de wet aan artikel 194 lid 1, laatste volzin."

Tot slot sta ik stil bij de statuten van de vennootschap in verband met het overgangsrecht. Indien de statuten van de vennootschap naar oud recht bepalen dat de vennootschap geen medewerking aan certificering verleent, zullen de statuten moeten worden gewijzigd indien de vennootschap certificaten met vergaderrecht wil uitgeven. Datzelfde geldt als de statuten niets zeggen over het verlenen van medewerking aan certificering of daaraan voorwaarden stellen.

Een gebruikelijke bepaling in statuten van een BV onder het oude recht is: "Met medewerking van de vennootschap kunnen certificaten van aandelen worden uitgegeven.", welke bepaling of woorden van gelijke strekking ook in veel modelstatuten wordt (worden) aangetroffen. Die bepaling houdt niet per definitie in dat de vennootschap medewerking aan certificering verleent. Mogelijk zijn er aldus niet bewilligde certificaten uitgegeven. Naar mijn mening zal in dat geval - indien de vennootschap alsnog vergaderrecht aan de niet bewilligde certificaten wil verbinden tot aantekening in het aandeelhoudersregister en tot statutenwijziging moeten overgaan. De aangehaalde bepaling is geen aanleiding aan te nemen dat op grond daarvan

248 Zie ook art. 75 Overgangswet NBW.

249 Portier 2011, p. 48 en 42, stelde in dat kader aanpassing van het overgangsrecht voor in die zin dat de houders van met medewerking van de vennootschap uitgegeven certificaten tot het op moment dat de statutenwijziging (waarbij aan de certificaten vergaderrecht wordt toegekend) is voltooid als vergadergerechtigd worden angemerkt vanaf het moment dat zij in het aandeelhoudersregister als vergadergerechtigd zijn ingeschreven. 
de statuten niet moeten worden gewijzigd en dat (slechts) aantekening van het vergaderrecht van de certificaathouder in het aandeelhoudersregister voldoende is. ${ }^{250}$

In de rechtspraktijk kan het voorkomen dat vooruitlopend op de invoering van de flex-BV de statuten bepalen dat de vennootschap met medewerking certificaten uitgeeft en dat aan deze certificaten vergaderrecht is verbonden, althans dat onder certificaten met medewerking van de vennootschap bij inwerkingtreding van de flex-BV moet worden verstaan certificaten met vergaderrecht en dat de statuten onder de opschortende voorwaarde dat de flex-BV in werking treedt vergaderrecht aan de certificaten verbinden. Indien dat het geval is, hoeft naar mijn mening geen statutenwijziging in de zin van art. V.2 lid 6 plaats te vinden ${ }^{251}$ en kan het bestuur van de vennootschap, conform het bepaalde in art. 2:194 lid $1 \mathrm{BW}$, volstaan met het vermelden in het aandeelhoudersregister van de vergadergerechtigde certificaathouder. $^{252}$

\subsubsection{Conclusie}

Ten aanzien van het overgangsrecht voor certificaathouders zijn in algemene zin art. $68 \mathrm{a}$ en 69 Overgangswet NBW relevant. Daarnaast geeft de wet specifiek overgangsrecht voor certificaten van aandelen in art. V.2 lid 1 en 6 van het Overgangsrecht. De vennootschap, althans haar bestuur, moet zo snel mogelijk, doch uiterlijk 1 oktober 2013 de vergadergerechtigde certificaathouder in het aandeelhoudersregister vermelden. Is het aandeelhoudersregister een maand vóór de datum van de eerste algemene vergadering na het tijdstip van inwerkingtreding van de wet nog niet overeenkomstig art. 2:194 lid 1 laatste volzin BW voltooid, dan is art. 2:223 lid 2 en 3 (oud) BW van toepassing. Houders van certificaten die met medewerking van de vennootschap zijn uitgegeven, kunnen de vennootschap schriftelijk verzoeken hen als vergadergerechtigden in het aandeelhoudersregister in te schrijven. Indien het bestuur dit verzoek afwijst, kunnen de houders van de certificaten de rechtbank verzoeken het bestuur op te dragen hen als vergadergerechtigden in te schrijven. Zijn er voor het tijdstip van inwerkingtreding van de wet met medewerking van de vennootschap certificaten van haar aandelen uitgegeven, dan dient de vennootschap bij de eerstvolgende statutenwijziging vergaderrecht te verbinden aan deze certificaten overeenkomstig art. 2:227 lid $2 \mathrm{BW}$. Tot het moment van die statutenwijziging worden onder certificaten waaraan bij de statuten vergaderrecht is verbonden tevens verstaan certificaten die voor inwerkingtreding van de wet over vergaderrecht beschikten en die in het aandeelhoudersregister zijn opgenomen en mogen de vergadergerechtigde certificaathouders de aan hen toekomende rechten uitoefenen. Ten aanzien van deze overgangsregeling heb ik een aantal aanbevelingen

250 In gelijke zin: Schoonbrood 2012, p. 432

251 In gelijke zin: Schoonbrood 2012, p. 432.

252 In gelijke zin: Portier 2011, p. 50. 
tot verbetering van de regeling gedaan. Niet altijd is de regeling helder geformuleerd. Bovendien bevat het overgangsrecht een aantal lacunes.

\subsection{Het aandeel waarbij het stemrecht is overgedragen aan de vruchtgebruiker}

Vruchtgebruik geeft het recht om goederen, die aan een ander toebehoren, te gebruiken en daarvan de vruchten te genieten. Het recht op vruchtgebruik ontstaat door vestiging of verjaring. ${ }^{253}$ Het vruchtgebruik op aandelen is geregeld in art. 2:197 $\mathrm{BW}^{254}$ Dat artikel is een bijzondere regeling en een nadere uitwerking van de algemene regels over vruchtgebruik van Titel 8 Boek 3 BW. Voor het vestigen van een vruchtgebruik op aandelen op naam is, naast een geldige titel en beschikkingsbevoegdheid, overeenkomstig art. 2:196 BW een notariële akte vereist. ${ }^{255}$

Art. 2:197 BW houdt in dat de bevoegdheid tot het vestigen van vruchtgebruik op een aandeel niet bij de statuten kan worden beperkt of uitgesloten. De aandeelhouder heeft het stemrecht op de aandelen waarop een vruchtgebruik is gevestigd. In afwijking van deze hoofdregel, zo bepaalt art. 2:197 lid 3 BW, komt het stemrecht toe aan de vruchtgebruiker, indien dit bij de vestiging van het vruchtgebruik is bepaald of nadien schriftelijk tussen de aandeelhouder en de vruchtgebruiker is overeengekomen en de vruchtgebruiker een persoon is aan wie de aandelen vrijelijk kunnen worden overgedragen. Indien de vruchtgebruiker een persoon is aan wie de aandelen niet vrijelijk kunnen worden overgedragen, komt hem het stemrecht uitsluitend toe, indien dit bij de vestiging van het vruchtgebruik is bepaald of nadien schriftelijk tussen de aandeelhouder en de vruchtgebruiker is overeengekomen, mits zowel deze bepaling als - bij overdracht van het vruchtgebruik - de overgang van het stemrecht is goedgekeurd door een daartoe in de statuten aangewezen orgaan, dan wel - bij ontbreken van zodanige aanwijzing - door de algemene vergadering. Hiervan kan in de statuten worden afgeweken. Bij een vruchtgebruik als bedoeld in de art. 4:19 en 4:21 BW komt het stemrecht eveneens aan de vruchtgebruiker toe, tenzij bij de vestiging van het vruchtgebruik door partijen of door de kantonrechter op de voet van art. 4:23 lid 4 BW anders wordt bepaald. Op de in art. 2:197 lid 3 BW bedoelde schriftelijke overeenkomst zijn art. 2:196a en 2:196b BW van overeenkomstige toepassing. De aandeelhouder die vanwege een vruchtgebruik geen stemrecht heeft en de vruchtgebruiker die stemrecht heeft, hebben de rechten die door de wet zijn toegekend aan de houders van certificaten van aandelen waaraan vergaderrecht is verbonden, zo bepaalt art. 2:197 lid $4 \mathrm{BW}$ onder meer.

253 Art. 3:201 en 3:202 BW.

$254 \mathrm{Zie}$ voor een uitvoerige bespreking van dit onderwerp: Bos 2005 en Koster 2012.

255 Bos 2005, p. 77-82 en Asser/Maeijer, Van Solinge \& Nieuwe Weme 2-II* 2009, nr. 305. 
Uit het artikel vloeit als hoofdregel voort dat, ondanks het gevestigde vruchtgebruik op het aandeel, het stemrecht bij de aandeelhouder blijft (lid 2), tenzij sprake is van een regeling als bedoeld in lid 3. Het derde lid is in verband met de invoering van de flex-BV aangepast. Reden daarvoor is de afschaffing van de verplichte blokkeringsregeling in de flex-BV. Anders dan onder het oude recht, bestaat onder de flex-BV ook de mogelijkheid de toekenning van het stemrecht aan de vruchtgebruiker op een later moment te doen plaatsvinden in een schriftelijke overeenkomst tussen de aandeelhouder en de vruchtgebruiker. Art. 2:196a BW is van overeenkomstige toepassing verklaard. Dat artikel gaat over de vestiging en levering van het vruchtgebruik. De overeenkomstige toepassing leidt ertoe, dat (indien de vennootschap niet zelf partij is bij de rechtshandeling) de vruchtgebruiker een na de vestiging van het vruchtgebruik toegekend stemrecht eerst kan uitoefenen nadat de vennootschap de rechtshandeling heeft erkend of de overeenkomst aan haar is betekend overeenkomstig de bepalingen in art. 2:196a en 2:196b BW. ${ }^{256}$ Voorts is in het kader van de invoering van de flex-BV art. 2:197 lid 4 BW aangepast. Die wijziging houdt verband met de nieuwe regeling over de certificaten met vergaderrecht, als bedoeld in art. 2:227 $\mathrm{BW}$, en het stemrechtloze aandeel, als bedoeld in art. 2:228 lid $5 \mathrm{BW}$.

Voor dit onderzoek is relevant de uitzondering op de hoofdregel, zoals geformuleerd in art. 2:197 lid 3 BW. In die situatie wordt het stemrecht door de aandeelhouder aan de vruchtgebruiker overgedragen. Daarmee is die aandeelhouder geworden tot een kapitaalverschaffer zonder stemrecht. Op grond van art. 2:197 lid 3 BW komt het stemrecht toe aan de vruchtgebruiker in de volgende situaties. Allereerst moet onderscheid worden gemaakt of de vruchtgebruiker een persoon is aan wie de aandelen vrijelijk kunnen worden overgedragen. Zo ja, dan komt de vruchtgebruiker stemrecht toe (i) indien dit bij de vestiging van het vruchtgebruik is bepaald of (ii) indien het vruchtgebruik reeds is gevestigd en nadien schriftelijk tussen de aandeelhouder en de vruchtgebruiker de overdracht van het stemrecht is overeengekomen. Indien de vruchtgebruiker niet een persoon is aan wie de aandelen vrijelijk kunnen worden overgedragen, komt hem het stemrecht toe in de hiervoor onder (i) en (ii) genoemde gevallen, mits zowel de regeling over de overgang van het stemrecht als die overgang zelf door een daartoe in de statuten aangewezen orgaan, dan wel - bij ontbreken van zodanige aanwijzing - door de algemene vergadering wordt goedgekeurd. Het spreekt voor zich dat indien de goedkeuring ontbreekt, het stemrecht niet aan de vruchtgebruiker toekomt. Er is immers niet aan alle daartoe gestelde vereisten voldaan. Van de goedkeuringsregel kan in de statuten worden afgeweken.

Uiteraard heeft de vruchtgebruiker recht op 'dividend', althans 'uitkering uit het uit behaalde winsten stammende, [dat] (nog) niet ten behoeve van de bedrijfsuitoefening gebonden vermogen behoort, en uit dien hoofde uit zijn aard voor 'winst'uitkering vatbaar is'. Bonusaandelen of andere uitkeringen ten laste van de

256 Kamerstukken II 2006/07, 31 058, nr. 3, p. 58 (MvT) 
agioreserves en claimrechten vallen er niet onder. ${ }^{257}$ Naast het recht op dividend komt de vruchtgebruiker in bepaalde gevallen, overeenkomstig het bepaalde in art. 2:227 BW, vergaderrecht toe.

Uit het voorgaande volgt dat indien het stemrecht rechtsgeldig door de aandeelhouder aan de vruchtgebruiker is overgedragen, die aandeelhouder is geworden tot een kapitaalverschaffer zonder stemrecht. De vruchtgebruiker met stemrecht valt uiteraard niet onder het begrip kapitaalverschaffer zonder stemrecht. Hij is immers geen kapitaalverschaffer en hij heeft wél stemrecht. De vruchtgebruiker met stemrecht laat ik daarom verder onbesproken.

Samengevat is het in het kader van dit onderzoek van belang de volgende punten in het achterhoofd te houden:

1. de bevoegdheid tot het vestigen van vruchtgebruik op een aandeel kan niet bij de statuten worden beperkt of uitgesloten;

2. de hoofdregel ter zake van het stemrecht is dat de aandeelhouder het stemrecht heeft op de aandelen waarop vruchtgebruik is gevestigd;

3. de aandeelhouder wordt stemrechtloos indien het stemrecht bij de vestiging van het vruchtgebruik aan de vruchtgebruiker is overgedragen of indien die overdracht nadien schriftelijk tussen de aandeelhouder en de vruchtgebruiker is overeengekomen. De vruchtgebruiker moet iemand zijn aan wie de aandelen vrij kunnen worden overgedragen. Als dat laatste niet het geval is, moet - kort gezegd - zowel de regeling over de overdracht van het stemrecht als de overdracht van het stemrecht zelf door de algemene vergadering worden goedgekeurd.

Art. 2:197 lid 4 BW bepaalt dat de aandeelhouder die vanwege een vruchtgebruik geen stemrecht heeft, de rechten heeft die door de wet zijn toegekend aan de houders van certificaten van aandelen waaraan vergaderrecht is verbonden. Uit art. 2:227 lid 2 BW volgt dat de aandeelhouder, die vanwege een vruchtgebruik geen stemrecht heeft, wel vergaderrecht heeft. Indien certificaten met vergaderrecht in vruchtgebruik worden gegeven, komen het vergaderrecht en de daaraan gekoppelde, wettelijke rechten aan de certificaathouder toe. Uit art. 2:227 lid 2 BW volgt dwingendrechtelijk dat het vergaderrecht kan toekomen aan vruchtgebruikers van aandelen, maar niet aan vruchtgebruikers van certificaten, aldus de wetgever. ${ }^{258}$

Art. 2:197 BW laat toe dat vruchtgebruik wordt gevestigd op stemrechtloze aandelen. De wettekst geeft immers geen beperking tot bepaalde soorten van aandelen. De stemrechtloze aandeelhouder heeft geen stemrecht in de algemene vergadering, maar wel in de vergadering van houders van stemrechtloze aandelen. Ik verwijs naar paragraaf 4.2.7. Indien op grond van art. 2:197 BW vruchtgebruik op stemrechtloze aandelen wordt gevestigd, komt conform de hoofdregel van art. 2:197 lid $2 \mathrm{BW}$ het stemrecht van de stemrechtloze aandeelhouder in de

257 Asser/Maeijer, Van Solinge \& Nieuwe Weme 2-II* 2009, nr. 310 en HR 23 mei 1958, NJ 1958, 458 (Pierlot/Kreemer).

258 Kamerstukken II 2008/09, 31 058, nr. 6, p. 48 (NV II). 
vergadering van houders van stemrechtloze aandelen aan hem toe, tenzij op grond van art. 2:197 lid $3 \mathrm{BW}$ dit stemrecht is overgedragen aan de vruchtgebruiker. ${ }^{259}$

Met betrekking tot de aandeelhouder waarbij stemrecht is overgedragen aan de vruchtgebruiker is art. V.1 van het Overgangsrecht van belang. ${ }^{260}$ Dat artikel bepaalt dat de art. 68a, 69, 71, 74, 75, 79 tot en met 82 en 173 van de Overgangswet nieuw Burgerlijk Wetboek van overeenkomstige toepassing zijn op de wijzigingen ingevolge de Wet vereenvoudiging en flexibilisering bv-recht. Waar in die artikelen wordt verwezen naar 'de wet' wordt daaronder verstaan de Wet vereenvoudiging en flexibilisering bv-recht. De Overgangswet nieuw Burgerlijk Wetboek regelt het overgangsrecht dat van toepassing is op de invoering, sinds 1992, van Boek 1 tot en met 8 van het Burgerlijk Wetboek. De overgangsbepalingen in verband met Boek 2 uit de Overgangswet NBW zijn voor het wetsvoorstel niet relevant en daarom niet van toepassing verklaard. De wetgever licht toe: "Als algemeen uitgangspunt geldt bij een wetswijziging dat de nieuwe bepalingen vanaf het moment van inwerkingtreding onmiddellijk van toepassing zijn, maar enkel ten aanzien van feiten die na dat moment voorvallen (zie ook art. 29 Overgangswet nieuw Burgerlijk Wetboek, hierna: Overgangswet NBW). Wanneer onder het huidige recht (lees: oude recht, RAW) recht besluiten en rechtshandelingen rechtsgeldig tot stand zijn gekomen en zijn verricht, kunnen gewijzigde voorwaarden voor rechtsgeldigheid onder het nieuwe recht daarin geen verandering brengen." ${ }^{261}$ Met andere woorden: de inwerkingtreding van de flex-BV doet aan een rechtsgeldig gevestigd vruchtgebruik op aandelen, waarbij de aandeelhouder zijn stemrecht aan de vruchtgebruiker heeft overgedragen, niets af.

\subsection{Het aandeel waarbij het stemrecht is overgedragen aan de pandhouder}

Pandrecht is een beperkt recht. Het is tevens een zekerheidsrecht op niet-registergoederen. ${ }^{262}$ Het pandrecht op aandelen is geregeld in art. 2:198 BW. ${ }^{263}$ Dit artikel brengt een belangenafweging tot uitdrukking tussen het belang van de vennootschap, het belang van de aandeelhouders bij zeggenschap, het belang in het kader van de beslotenheid van de vennootschap (de kring van aandeelhouders) en de (economische) belangen van de pandhouder. ${ }^{264}$ Het pandrecht op aandelen ex art. 2:198 BW is een bijzondere regeling en een nadere uitwerking van de algemene regels over pandrecht van Titel 9, Afdeling 1, 2 en 3 Boek 3 BW. Voor het vestigen van het pandrecht op aandelen op naam is, naast een geldige titel en beschikkingsbevoegdheid, overeenkomstig art. 2:196 BW een notariële akte vereist. In de

259 In gelijke zin: Koster 2012, p. 212.

260 Kamerstukken II 2009/10, 32 426, nr. 2, p. 15

261 Kamerstukken II 2009/10, 32 426, nr. 3, p. 17

262 Art. 3:227 BW.

263 Zie voor een uitvoerige bespreking van dit onderwerp: Hamers 1996 en Koster 2012

264 Hamers 1996, p. 11. 
praktijk is pandrecht op aandelen in het kader van financiering van een onderneming van belang. Op grond van art. 3:239 BW is een stil pandrecht op aandelen is mogelijk. ${ }^{265}$ De regeling over pandrecht op aandelen lijkt sterk op die van vruchtgebruik op aandelen. Pandrecht is een afhankelijk recht in de zin van art. 3:82 BW en volgt aldus het recht waaraan zij verbonden is. In geval van cessie van de vordering waarvoor het pandrecht is verleend, gaat het pandrecht daarom over op de cessionaris.

Art. 2:198 BW bepaalt dat op aandelen pandrecht kan worden gevestigd, indien de statuten niet anders bepalen. De aandeelhouder heeft het stemrecht op de verpande aandelen. In afwijking van deze hoofdregel komt, zo bepaalt art. 2:198 lid 3 BW, het stemrecht toe aan de pandhouder, indien dit - al dan niet onder opschortende voorwaarde - bij de vestiging van het pandrecht is bepaald of nadien schriftelijk tussen de aandeelhouder en de pandhouder is overeengekomen en de pandhouder een persoon is, aan wie de aandelen vrijelijk kunnen worden overgedragen. Indien de pandhouder een persoon is aan wie de aandelen niet vrijelijk kunnen worden overgedragen, komt hem het stemrecht uitsluitend toe, indien dit, al dan niet onder opschortende voorwaarde, bij de vestiging van het pandrecht is bepaald of nadien schriftelijk tussen de aandeelhouder en de pandhouder is overeengekomen, mits zowel deze bepaling als - indien een ander in de rechten van de pandhouder treedt - de overgang van het stemrecht is goedgekeurd door een daartoe in de statuten aangewezen orgaan, dan wel - bij ontbreken van zodanige aanwijzing - door de algemene vergadering. Hiervan kan in de statuten worden afgeweken. Op de in art. 2:198 lid 3 bedoelde schriftelijke overeenkomst zijn art. 2:196a en 2:196b BW van overeenkomstige toepassing. Art. 2:198 lid $4 \mathrm{BW}$ bepaalt onder meer dat de aandeelhouder die vanwege een pandrecht geen stemrecht heeft en de pandhouder die stemrecht heeft, de rechten hebben die door de wet zijn toegekend aan de houders van certificaten van aandelen waaraan vergaderrecht is verbonden.

Anders dan bij vruchtgebruik op aandelen, kan bij pandrecht op aandelen de mogelijkheid van het vestigen van dat recht in de statuten worden uitgesloten (vgl. art. 2:197 lid 1 en 2:198 lid $1 \mathrm{BW}$ ).

Uit het artikel vloeit als hoofdregel voort dat, ondanks het gevestigde pandrecht op het aandeel, het stemrecht bij de aandeelhouder blijft (lid 2), tenzij sprake is van een regeling als bedoeld in lid 3. Lid 3, 4 en 5 van art. 2:198 BW zijn in verband met de invoering van de flex-BV aangepast. Reden voor het aanpassen van het derde lid is de afschaffing van de verplichte blokkeringsregeling in de flex-BV. Anders dan onder het oude recht, bestaat onder de flex-BV ook de mogelijkheid de toekenning van het stemrecht aan de pandhouder na de vestigen van het pandrecht te laten plaatsvinden via een schriftelijke overeenkomst tussen de aandeelhouder en de pandhouder. Art. 2:196a en 2:196b BW zijn van overeenkomstige toepassing verklaard. De overeenkomstige toepassing leidt ertoe, dat (indien de vennootschap

265 Hamers 1996, p. 36; Rensen 2005, p. 37 en Asser/Maeijer, Van Solinge \& Nieuwe Weme 2-II* 2009, nr. 305. 
niet zelf partij is bij de rechtshandeling) de pandhouder een na de vestiging van het pandrecht toegekend stemrecht eerst kan uitoefenen nadat de vennootschap de rechtshandeling heeft erkend of de overeenkomst aan haar is betekend overeenkomstig de bepalingen in art. 2:196a en 2:196b BW. In de memorie van toelichting is aandacht besteed aan het feit dat in de praktijk veelvuldig in pandakten wordt overeengekomen dat het stemrecht slechts op de pandhouder overgaat ingeval de pandgever de verplichtingen, waarvoor hij zekerheid heeft gesteld, niet nakomt, vaak in combinatie met de aanvullende, opschortende voorwaarde dat de pandhouder kenbaar maakt dat hij zijn stemrecht gaat uitoefenen. Ter verduidelijking is daarom in art. 2:198 lid 3 BW bepaald dat de toekenning van het stemrecht aan de pandhouder onder opschortende voorwaarde kan worden verleend. ${ }^{266}$ Hieruit volgt dat ook de goedkeuring van de overgang van het stemrecht kan plaatsvinden onder die opschortende voorwaarde, aldus de memorie van toelichting. Daarnaast stelt de wetgever dat in art. 2:198 lid $3 \mathrm{BW}$ is verduidelijkt dat goedkeuring van overdracht van het stemrecht slechts is vereist, indien degene die in de rechten van de pandhouder treedt, een persoon is aan wie de aandelen niet vrijelijk kunnen worden overgedragen. Indien een pandhouder zijn vordering waarop het pandrecht betrekking heeft, overdraagt aan een derde, is voor de overgang van het stemrecht geen goedkeuring van de algemene vergadering vereist indien die derde behoort tot de kring van personen aan wie de aandelen vrijelijk kunnen worden overgedragen. ${ }^{267}$ Met deze verduidelijking van art. 2:198 lid 3 BW en de toelichting daarop van de wetgever is aan de onduidelijkheid in de praktijk een einde gekomen.

Voor dit onderzoek is relevant de uitzondering op de hoofdregel, zoals geformuleerd in art. 2:198 lid 3 BW. In die situatie wordt het stemrecht door de aandeelhouder aan de pandhouder overgedragen. Daarmee is die aandeelhouder geworden tot een kapitaalverschaffer zonder stemrecht. Op grond van art. 2:198 lid 3 BW komt het stemrecht toe aan de pandhouder in de volgende situaties. Allereerst moet onderscheid worden gemaakt of de pandhouder een persoon is aan wie de aandelen vrijelijk kunnen worden overgedragen. Zo ja, dan komt de pandhouder stemrecht toe (i) indien dit bij de vestiging van het pandrecht is bepaald of (ii) indien het pandrecht reeds is gevestigd en nadien schriftelijk tussen de aandeelhouder en de pandhouder de overdracht van het stemrecht is overeengekomen. Indien de pandhouder niet een persoon is aan wie de aandelen vrijelijk kunnen worden overgedragen, komt hem het stemrecht toe in de hiervoor onder (i) en (ii) genoemde gevallen, mits zowel de regeling over de overgang van het stemrecht als die overgang zelf door een daartoe in de statuten aangewezen orgaan, dan wel - bij

266 Het beding dat de pandhouder eerst stemrecht toekomt wanneer de pandgever zijn verplichtingen voortvloeiende uit een overeenkomst van geldlening niet nakomt. Zie bijvoorbeeld HR 6 april 1990, NJ 1991, 559 (Natco/Canadian Land), r.o. 3.4. Zie over dit arrest ook L. Timmerman, 'Stemrecht op verpande aandelen', TVVS 1990-8, p. 202. Zie ook C.H. Schot \& G.J.W. Kinnegim, 'Overgang van het stemrecht bij vestigen pandrecht op aandelen - een civielrechtelijke en fiscaalrechtelijke analyse', Ondernemingsrecht 2003-6, p. 210-217.

267 Voor dit alles: Kamerstukken II 2006/07, 31 058, nr. 3, p. 59 (MvT). 
ontbreken van zodanige aanwijzing - door de algemene vergadering wordt goedgekeurd. In het kader van cessie is deze goedkeuring ook van belang. Het stemrecht komt de cessionaris slechts toe indien de overgang daarvan is goedgekeurd. Het spreekt voor zich dat indien de goedkeuring ontbreekt, het stemrecht niet aan de pandhouder toekomt. Er is immers niet aan alle daartoe gestelde vereisten voldaan.

Art. 2:198 lid 3 BW bepaalt tevens dat de statuten de toekenning van het stemrecht aan de pandhouder mogen uitsluiten. Bij vruchtgebruik kan dat niet. Ook kan van de goedkeuringsregel in de statuten worden afgeweken. Art. 2:198 lid 3 BW bepaalt immers: "Van het bepaalde in de voorgaande twee zinnen kan in de statuten worden afgeweken. (onderstreping, RAW)" Indien de statuten toekenning van het stemrecht aan de pandhouder uitsluiten, is een onherroepelijke volmacht van de aandeelhouder aan de pandhouder, waarbij de aandeelhouder zich verbindt geen stemrecht uit te oefenen, nietig. ${ }^{268}$

De wijziging in lid 4 heeft te maken met de al bij het vruchtgebruik op aandelen genoemde wijziging. ${ }^{269}$ De wijziging houdt verband met de nieuwe regeling over de certificaten met vergaderrecht, als bedoeld in art. 2:227 BW. ${ }^{270}$ De pandhouder komt in de bepaalde gevallen vergaderrecht als bedoeld in art. 2:227 BW toe.

Daarnaast is art. 2:198 lid 4 BW gewijzigd vanwege de mogelijkheid tot het vestigen van stil pandrecht op aandelen. Op grond van het bepaalde in art. 2:196a lid $2 \mathrm{BW}$ kan de vennootschap tot spontane erkenning van dat pandrecht overgaan. Daardoor wordt het stil pandrecht openbaar. Voor de aandeelhouder/pandgever brengt dit onzekerheid met zich mee. Hij kan als gevolg van de mogelijkheid tot spontane erkenning door de vennootschap geen invloed uitoefenen op het moment waarop het pandrecht van kleur verschiet, als gevolg waarvan de pandhouder zijn (zeggenschaps-)rechten kan uitoefenen. Niet alleen op grond van het goedkeuringsvereiste van art. 2:198 lid $3 \mathrm{BW}$, maar ook op grond van art. 2:196a lid $2 \mathrm{BW}$ kan de vennootschap aldus invloed uitoefenen of en wanneer het stemrecht op de pandhouder overgaat. Art. 2:198 lid 4 BW komt aan deze onzekerheid tegemoet door te bepalen dat bij de vestiging van het pandrecht kan worden bepaald dat art. 2:196a lid 2 BW buiten toepassing blijft. Doordat art. 3:239 lid $3 \mathrm{BW}^{271}$ van overeenkomstige toepassing wordt verklaard, wordt verduidelijkt dat de omzetting van een stil pandrecht in een openbaar pandrecht slechts mogelijk is wanneer de pandgever of de schuldenaar in zijn verplichtingen jegens de pandhouder tekortschiet of hem goede grond geeft te vrezen dat in die verplichtingen zal worden tekortgeschoten. ${ }^{272}$

268 Perrick 1993, p. 91.

269 Kamerstukken II 2006/07, 31 058, nr. 3, p. 60 (MvT).

270 Zie paragraaf 4.4.3.

271 Art. 3:239 lid 3 BW luidt: "Wanneer de pandgever of de schuldenaar in zijn verplichtingen jegens de pandhouder tekortschiet of hem goede grond geeft te vrezen dat in die verplichtingen zal worden tekortgeschoten, is deze bevoegd van de verpanding mededeling te doen aan de in het eerste lid genoemde personen. Pandhouder en pandgever kunnen overeenkomen dat deze bevoegdheid op een ander tijdstip ingaat."

272 Kamerstukken II 2006/07, 31 058, nr. 3, p. 60 (MvT). 
Art. 2:198 lid 5 (oud) BW is licht gewijzigd teruggekomen in art. 2:198 lid 6 BW en is gewijzigd in het kader van de wijziging van art. 2:195 BW in een anbiedingsregeling.

De pandhouder is op grond van art. 3:246 lid 1 BW bevoegd het dividend waaronder ook claimrechten, stockdividend en bonusaandelen - op de aandelen te innen, tenzij het een stil pandrecht betreft. Het pandrecht komt dan op het geïnde bedrag te rusten (art. 3:246 lid $5 \mathrm{BW}$ ). Indien de vordering van de pandhouder opeisbaar wordt, kan de pandhouder zich hieruit voldoen (art. 3:255 BW).

Uit het voorgaande volgt dat indien het stemrecht rechtsgeldig aan de pandhouder door de aandeelhouder is overgedragen, die aandeelhouder is geworden tot een kapitaalverschaffer zonder stemrecht. Feitelijk kan aldus een stemrechtloos aandeel worden gecreëerd. De pandhouder met stemrecht valt uiteraard niet onder het begrip kapitaalverschaffer zonder stemrecht. Hij is immers geen kapitaalverschaffer en hij heeft wél stemrecht. De pandhouder met stemrecht laat ik daarom verder onbesproken.

Samengevat is het in het kader van dit onderzoek van belang de volgende punten in het achterhoofd te houden:

1. de bevoegdheid tot het vestigen van pandrecht op een aandeel kan bij de statuten worden beperkt of uitgesloten;

2. de hoofdregel ter zake van het stemrecht is dat de aandeelhouder het stemrecht heeft op de aandelen waarop het pandrecht is gevestigd;

3. de aandeelhouder wordt stemrechtloos indien het stemrecht bij de vestiging van het pandrecht aan de pandrechter is overgedragen of indien die overdracht nadien schriftelijk tussen de aandeelhouder en de pandrechter is overeengekomen. De pandrechter moet iemand zijn aan wie de aandelen vrij kunnen worden overgedragen. Als dat laatste niet het geval is, moet - kort gezegd - zowel de regeling over de overdracht van het stemrecht als de overdracht van het stemrecht zelf door de algemene vergadering worden goedgekeurd.

Art. 2:198 lid 4 BW bepaalt dat de aandeelhouder die vanwege een pandrecht geen stemrecht heeft, de rechten heeft die door de wet zijn toegekend aan de houders van certificaten van aandelen waaraan vergaderrecht is verbonden. Uit art. 2:227 lid 2 BW volgt dat de aandeelhouder die vanwege een pandrecht geen stemrecht heeft, wel vergaderrecht heeft. Indien certificaten met vergaderrecht in pand worden gegeven, komen het vergaderrecht en de daaraan gekoppelde, wettelijke rechten aan de certificaathouder toe. Uit art. 2:227 lid 2 BW volgt dwingendrechtelijk dat het vergaderrecht kan toekomen aan pandhouders van aandelen, maar niet aan pandhouders van certificaten, aldus de wetgever. ${ }^{273}$

Art. 2:198 BW laat toe dat pandrecht wordt gevestigd op stemrechtloze aandelen. De wettekst geeft immers geen beperking tot bepaalde soorten van aandelen. De

273 Kamerstukken II 2008/09, 31 058, nr. 6, p. 48 (NV II). 
stemrechtloze aandeelhouder heeft geen stemrecht in de algemene vergadering, maar wel in de vergadering van houders van stemrechtloze aandelen. Ik verwijs naar paragraaf 4.2.7. Indien op grond van art. 2:198 BW pandrecht op stemrechtloze aandelen wordt gevestigd, komt conform de hoofdregel van art. 2:198 lid 2 BW het stemrecht van de stemrechtloze andeelhouder in de vergadering van houders van stemrechtloze aandelen aan hem toe, tenzij op grond van art. 2:198 lid 3 BW dit stemrecht is overgedragen aan de pandhouder. ${ }^{274}$

Voor het overgangsrecht met betrekking tot de aandeelhouder waarbij stemrecht is overgedragen aan de pandhouder geldt op gelijke wijze hetgeen ik heb opgemerkt in paragraaf 4.5 ten aanzien van het overgangsrecht met betrekking tot de aandeelhouder waarbij stemrecht is overgedragen aan de vruchtgebruiker.

\subsection{Het participatiebewijs}

In paragraaf 3.7.13 heb ik op hoofdlijnen het participatiebewijs besproken. Participatiebewijzen worden tegen storting of inbreng verkregen en vertegenwoordigen kapitaal in de vennootschap. Aan een participatiebewijs zijn soms alle rechten die een aandeelhouder toekomen verbonden, behalve het stemrecht. Houders van participatiebewijzen hebben anspraak op een deel van de winst en/of het liquidatiesaldo. Participatiebewijzen hebben een statutaire basis en een contractuele grondslag. In de literatuur worden participatiebewijzen ook wel als statutaire winstrechten omschreven. ${ }^{275}$ Zoals betoogd, moet het participatiebewijs worden onderscheiden van het winstbewijs. ${ }^{276}$

In de literatuur is de kwalificatievraag ten aanzien van het participatiebewijs, meer in het bijzonder in verhouding tot het stemrechtloze aandeel, gerezen. ${ }^{277} \mathrm{Bij}$ het stemrechtloze aandeel gaat het om een lidmaatschapsverhouding van de houder van dat aandeel tot de vennootschap. Die verhouding wordt in de eerste plaats vorm gegeven door de wet en de statuten van de vennootschap. In de tweede plaats wordt die verhouding vormgegeven door - indien van toepassing - de aandeelhoudersovereenkomst. In dat laatste geval is sprake van een contractuele verhouding. Eerder besprak ik dat het participatiebewijs een statutaire basis op grond van het bepaalde in art. 2:216 lid 1 BW heeft, althans moet hebben. Dat artikellid bepaalt sinds invoering van de flex-BV dat de algemene vergadering bevoegd is tot bestemming van de winst die door de vaststelling van de jaarrekening is bepaald en tot vaststelling van uitkeringen, voor zover het eigen vermogen groter is dan de reserves die krachtens de wet of de statuten moeten worden aangehouden. De

274 In gelijke zin: Koster 2012, p. 212.

275 Eisma 1991, p. 29; Ten Berg, p. 341; Asser/Maeijer, Van Solinge \& Nieuwe Weme 2-II* 2009, nr. 233; Slagter 2005, p. 278- 279 en Sanders \& Westbroek 2005, p. 100, waar de termen door elkaar worden gebruikt.

276 Zie paragraaf 3.7.9.

277 Faasen 1989, p. 466; Ten Berg 2007, p. 340 en Demirtas \& Daverschot 2010, p.104. 
statuten kunnen deze bevoegdheden beperken of toekennen aan een ander orgaan. Voor de vaststelling van het eigen vermogen en de reserves is de laatst vastgestelde jaarrekening bepalend.

Voor het overige wordt de rechtsverhouding tussen de houder van het participatiebewijs en de vennootschap ingevuld door de bepalingen van de participatieovereenkomst of participatievoorwaarden. Beiden, de stemrechtloze aandeelhouder en de houder van het participatiebewijs, hebben echter geen stemrecht. De rechtsfiguren lijken op elkaar, terwijl in het ene geval een wettelijke en statutaire verhouding en in het andere geval een contractuele verhouding leidend is. In de literatuur is betoogd dat het participatiebewijs zo kan worden vormgegeven dat materieel sprake is van een stemrechtloos aandeel. ${ }^{278}$ Juist vanwege deze afbakeningsproblematiek was de uiteindelijke aanbeveling van de Expertgroep geen stemrechtloos andeel in Nederland in te voeren. ${ }^{279}$ Het ambtelijk voorontwerp kende daarom het stemrechtloze aandeel niet. ${ }^{280} \mathrm{Ik}$ verwijs naar paragraaf 2.5.2, waarin ik het standpunt en de overwegingen van de Expertgroep en het ambtelijk voorontwerp heb besproken. Wat hiervan ook zij, in feite kan de kwalificatievraag alleen worden beantwoord aan de hand van de wijze waarop en de vorm waarin het bewijs (aandeel of participatie) is uitgegeven. ${ }^{281}$ Wat is er gebeurd om het stemrechtloze aandeel of het participatiebewijs uit te geven? Welke stukken zijn er opgemaakt? ${ }^{282}$ Hoe is het recht in die stukken aangeduid, als stemrechtloos aandeel of als participatiebewijs? De kwalificatie heeft ook gevolgen voor de latere overdracht van het betreffende recht. Voor de overdracht van een stemrechtloos andeel is een notariële akte ex art. 2:196 BW vereist. Voor de overdracht van een participatiebewijs gelden de vereisten voor de overdracht van een vordering (cessie) ex art. 3:94 BW. Bij de overdracht van beide soorten rechten moeten ook de wet, statuten en overeenkomsten in acht genomen worden. Bij het stemrechtloze

278 Galavazi \& Van Wilsum 1988, p. 133; Eisma 1991, p. 35-37 en Demirtas \& Daverschot 2010, p.104. Zie voor een tegengestelde opvatting Faasen 1989, p. 467; Blanco Fernández \& Schwarz 1992, p. 288; Baert 1999, p. 132; Van Duuren 2006 (2), p. 9 en Portier 2008, p. 233. Door de invoering van het stemrechtloze aandeel behoort deze discussie tot de verleden tijd.

279 Rapport Expertgroep, p. 69-70.

280 Zie ook de memorie van toelichting bij het ambtelijk voorontwerp, eerste tranche, p. 10-11, en voetnoot 52 .

281 De Gecombineerde Commissie Vennootschapsrecht van de Nederlandse Orde van Advocaten en de Koninklijke Notariële Beroepsorganisatie stelde in haar advies d.d. 20 september 2007 dat gelet op de kwalificatievraag er minimale eisen aan een aandeel zouden moeten worden gesteld, zie par. 2.3, p. 2 van het advies, te raadplegen via http://www.notaris.nl/subsites/commissie/adviezen.htm.

282 Galavazi \& Van Wilsum 1988, p. 133, noemen de grote mate van vrijheid om de voorwaarden vast te stellen waaronder de participatiebewijzen zullen worden uitgegeven. Eisma 1991, p. 36, stelt: "Een aandeel is een aandeel indien het als zodanig is uitgegeven.”. Ten Berg 2007, p. 341, spreekt over een aandeel is een aandeel als er aandeel op staat en vindt dat een prachtig handvat voor de praktijk. In gelijke zin Portengen 2007, p. 942. Zie ook Bier 2008 (1), p. 175. Wat betreft de 'vorm' ga ik er aan voorbij dat in de praktijk vaak geen participatiebewijzen in de vorm van papier worden uitgegeven en de BV in de regel geen aandeelhoudersbewijzen verstrekt (hoewel dat sinds de invoering van de flex-BV wel mogelijk is). 
aandeel zullen dat in de eerste plaats de wet en de statuten van de vennootschap zijn en - indien van toepassing - de aandeelhoudersovereenkomst. Bij overdracht van het participatiebewijs zijn vooral de bepalingen uit de participatieovereenkomst of participatievoorwaarden van belang. ${ }^{283}$

Voor het overgangsrecht met betrekking tot de houder van een participatiebewijs geldt op gelijke wijze hetgeen ik heb opgemerkt in paragraaf 4.5 ten aanzien van het overgangsrecht met betrekking tot de aandeelhouder, waarbij stemrecht is overgedragen aan de vruchtgebruiker.

\subsection{Belang van de kwalificatie van de rechtsfiguren zonder stemrecht}

In paragraaf 4.2 .3 besprak ik de kwalificatie van het stemrechtloze aandeel. Daarbij kwamen ook de verschillen met de andere rechtsfiguren zonder stemrecht aan de orde. De conclusie is dat 'een aandeel is een aandeel indien het als zodanig uitgegeven is'. De statuten van de BV zullen dus uitsluitsel moeten geven en moeten aangeven wat voor soort rechten de BV kan uitgeven of heeft uitgegeven die recht geven op delen in de winst. Dit geldt voor het stemrechtloze aandeel, het certificaat met vergaderrecht en het participatiebewijs. Bij de aandeelhouder waarbij stemrecht is overgedragen aan de vruchtgebruiker of pandhouder, gelden de contractuele verhoudingen, zoals neergelegd in de akte waarbij dat vruchtgebruik of pandrecht is gevestigd.

Het belang van de kwalificatie van de rechtsfiguren zonder stemrecht is niet alleen gelegen in de vraag welke rechten aan die rechtsfiguur verbonden zijn, maar ook bijvoorbeeld voor de vraag of, en zo ja op welke wijze, de rechtsfiguur aan een derde kan worden overgedragen. Voor een (stemrechtloos) aandeel is een notariële akte ex art. 2:196 BW vereist en welke overdracht overigens onderworpen is aan de wet, de statuten van de vennootschap en (indien van toepassing) de aandeelhoudersovereenkomst. Voor de overdracht van zowel het certificaat als het participatiebewijs is een akte van cessie in de zin van art. 3:94 BW vereist, waarbij respectievelijk de administratievoorwaarden of de voorwaarden waaronder het participatiebewijs uitgegeven is, in acht genomen moeten worden.

\subsection{Verdere afbakening}

\subsubsection{Inleiding en algemene opmerkingen}

In deze paragraaf wordt de kapitaalverschaffer zonder stemrecht verder afgebakend. ${ }^{284}$ In de voorgaande paragrafen heb ik de instrumenten van de kapitaalverschaffer zonder

283 Overdraagbaarheid van het participatiebewijs kan bijvoorbeeld uitgesloten zijn, zie art. 3:83 lid 2 BW.

284 Zie bijvoorbeeld Faasen 1989, p. 458 e.v., voor de wijzen van directe en indirecte beperking van stemrecht. 
stemrecht geschetst. Daarbij ging het om instrumenten waarbij aan dat instrument zelf $a b$ initio - geen stemrecht is toegekend. Een voorbeeld daarvan is het stemrechtloze aandeel of het participatiebewijs. Ook bij de houder van een certificaat is de uitgangspositie dat die kapitaalverschaffer geen stemrecht heeft. Ik laat de eventuele royeerbaarheid van het certificaat buiten beschouwing. Bij de aandeelhouder waarbij stemrecht is overgedragen aan de vruchtgebruiker of pandhouder geldt dat het die aandeelhouder zelf is die zijn rechten aan de pandhouder of vruchtgebruiker overdraagt. Zijn wil is daarop gericht. Hij verricht daartoe de rechtshandeling. Met andere woorden: van die kapitaalverschaffer gaat het initiatief uit. Dat is anders in geval van beslag op aandelen en het geval waarin het stemrecht van de aandeelhouder is opgeschort. Ik licht deze situaties in respectievelijk paragraaf 4.9.2 en paragraaf 4.9.3 toe.

Naast deze gevallen kan het stemrecht op aandelen worden geschorst. Blijkens de jurisprudentie van de OK komt dat vaak voor. ${ }^{285}$ Ook dat laat ik in dit onderzoek verder buiten beschouwing.

Daarnaast is het mogelijk om de zeggenschapsrechten van de financiële rechten los te koppelen door middel van de economische overdracht van aandelen. De meest vergaande vorm daarin is dat de juridisch eigenaar van het aandeel alle aan het aandeel verbonden rechten overdraagt, behalve het eigendomsrecht. In feite is die juridische eigenaar in dat geval een kapitaalverschaffer zonder stemrecht. De juridisch eigenaar blijft ten opzichte van de vennootschap aandeelhouder. De waardevermeerdering of -vermindering komt, evenals het dividend, voor rekening en risico van de economische eigenaar. Het aan het aandeel verbonden stemrecht wordt door middel van een volmacht door de economisch eigenaar in naam van de juridische eigenaar uitgebracht. De verhouding tussen de juridisch eigenaar en de economisch eigenaar is een contractuele. Gelet op de contractsvrijheid zijn zeer veel vormen van economische eigendom mogelijk en daarom sterk casuïstisch. Het gaat mede om die reden te ver deze rechtsfiguur in dit onderzoek te betrekken. Bovendien lijkt de rechtsfiguur op de rechtsfiguur van certificering van aandelen, welke laatste rechtsfiguur in de rechtspraktijk veel voorkomt.

Ook door middel van holdingstructuren en middellijk aandeelhouderschap kan feitelijk een stemrechtloze aandeelhouder gecreëerd worden. Daarbij geldt echter dat die middellijk aandeelhouder als houder van gewone aandelen wel de aan de aandelen verbonden zeggenschapsrechten kan uitoefenen, zij het dat hij vanwege dat middellijk aandeelhouderschap geen of beperkte zeggenschap in de BV, waaruit de winst wordt genoten, kan uitoefenen. Ook dergelijke structuren kennen zeer vele varianten. Bovendien is van een echte kapitaalverschaffer zonder stemrecht, in de

285 Zie bijvoorbeeld Hof Amsterdam (OK) 3 maart 1999, JOR 1999, 87 (Gucci); Hof Amsterdam (OK) 30 november 2000, JOR 2001, 11; Hof Amsterdam (OK) 31 augustus 2001, JOR 2001, 207 (Bug Byte); Hof Amsterdam (OK) 22 februari 2002, JOR 2002, 63 (VEB/RNA); Hof Amsterdam (OK) 7 augustus 2002, JOR 2002, 193, m.nt. Josephus Jitta (Scheipar); Hof Amsterdam (OK) 31 oktober 2002, JOR 2003, 59; Hof Amsterdam (OK) 25 september 2003, JOR 2003, 281, m.nt. Josephus Jitta; HR 25 maart 2011, LJN BO7067, JOR 2011, 115, m.nt. A. Doorman (Inter Access); Hof Amsterdam (OK) 15 juni 2011, LJN BQ9724. Zie verder art. 2:349a lid 2 BW. 
zin van dit onderzoek, in deze structuren geen sprake. Om deze redenen blijven de holdingstructuren in voornoemde zin in dit onderzoek buiten beschouwing.

Een laatste woord over de stemovereenkomst. Een stemovereenkomst is een overeenkomst, waarbij de aandeelhouder zich jegens zijn mede-aandeelhouders of jegens een derde verbindt zijn stem in de algemene vergadering op een bepaalde wijze uit te brengen. ${ }^{286}$ Ook hiervoor geldt dat de aandeelhouder die een dergelijke overeenkomst sluit het stemrecht verbonden aan zijn aandeel kan uitoefenen en uitoefent, zij het dat hij een contractuele afspraak heeft gemaakt dat op een bepaalde wijze te doen. Daarom kwalificeert hij niet als een kapitaalverschaffer zonder stemrecht.

\subsubsection{Beslag op aandelen}

Het executoriaal beslag van onder meer andelen op naam wordt geregeld in art. 474a e.v. Rv. ${ }^{287}$ Art. 474ba Rv geeft een regeling over het stemrecht en bepaalt onder meer dat het stemrecht verbonden aan een in beslag genomen aandeel op naam, en andere aan dat aandeel verbonden bevoegdheden die niet onder art. 474b $\mathrm{Rv}$ vallen, blijven gedurende het beslag bij de geëxecuteerde. De regel is aldus dat de aandeelhouder tijdens het executoriale beslag van zijn aandelen het stemrecht op die aandelen behoudt.

De beslaglegger is niet aan te merken als een kapitaalverschaffer van de BV. Hij heeft in geval van executoriaal beslag een aanspraak op de aandeelhouder. In geval van conservatoir beslag pretendeert de beslaglegger een aanspraak op de aandeelhouder te hebben. Die aanspraak kan er in bestaan dat de beslaglegger verhaal wenst te halen voor zijn vordering (verhaalsbeslag). De schuldenaar moet immers volgens art. 3:276 BW met zijn gehele vermogen instaan voor zijn schulden. De aanspraak kan er ook in bestaan dat de beslaglegger rechthebbende is, althans pretendeert te zijn, op de aandelen (leveringsbeslag).

\subsubsection{Opschorting van stemrecht}

Art. 2:228 lid $1 \mathrm{BW}$ geeft de hoofdregel dat (slechts) aandeelhouders stemrecht hebben. De laatste volzin van het eerste lid van dat artikel bepaalt dat de statuten kunnen bepalen dat een aandeelhouder niet gerechtigd is tot uitoefening van het stemrecht zolang hij in gebreke is te voldoen aan een wettelijke of statutaire verplichting. Uitgangspunt is aldus dat de aandeelhouder stemrecht heeft. Indien hijzelf in gebreke is met enige wettelijke of statutaire verplichting is hij niet gerechtigd zijn stemrecht uit te oefenen. Met andere woorden: het stemrecht is in

286 Slagter 2005, p. 301

287 Art. 474a- 474i Rv voor het executoriale beslag op aandelen op naam in de BV. Voor het conservatoire beslag gelden de art. 714-717 Rv. 
die situaties opgeschort. ${ }^{288} \mathrm{Er}$ is sprake van een situatie die in de risicosfeer van de aandeelhouder ligt en voor zijn rekening komt. Anders dan bij bijvoorbeeld het stemrechtloze aandeel of het participatiebewijs, ligt het op de weg van de aandeelhouder wiens stemrecht is opgeschort die situatie op te heffen door alsnog aan zijn verplichtingen te voldoen. De aandeelhouder wiens stemrecht opgeschort is, beschouw ik niet als een kapitaalverschaffer zonder stemrecht. Die aandeelhouder beschikt in beginsel namelijk wel over stemrecht, doch het is aan hem te wijten dat hij zijn stemrecht (tijdelijk) niet kan uitoefenen. Hij houdt zich niet aan zijn verplichtingen. Bij het stemrechtloze aandeel of het participatiebewijs is sprake van een rechtsfiguur waarbij aan de houder van dat effect überhaupt geen stemrecht toekomt.

Art. 2:228 lid $1 \mathrm{BW}$ is in feite de algemene opschortingsregel met betrekking tot het stemrecht. Onder het oude recht bestonden ten aanzien van aandelen in een BV twee bijzondere situaties van opschorting van stemrecht, namelijk in geval van (i) niet nakoming van een verplichting tot aanbieding of overdracht van aandelen (art. 2:195a lid 1 (oud) BW) of (ii) het niet voldoen aan een statutaire kwaliteitseis (art. 2:195b lid 1 (oud) BW). Bij invoering van de flex-BV zijn de art. 2:195 $\mathrm{a}^{289}$ en 2:195 $\mathrm{b}^{290}$ (oud) BW komen te vervallen en vervangen door art. 2:192 (lid 4) BW. Dat artikellid bepaalt onder meer dat de statuten kunnen bepalen dat zolang een aandeelhouder een statutaire verplichting niet nakomt of niet aan een statutaire eis voldoet, het stemrecht, het recht op uitkeringen of het vergaderrecht is opgeschort. Ook hiervoor geldt dat sprake is van een situatie die in de risicosfeer van de aandeelhouder ligt en voor zijn rekening komt, zodat die aandeelhouder niet als een kapitaalverschaffer zonder stemrecht te beschouwen is.

Over de duur van de opschorting bepaalt art. 2:228 lid $1 \mathrm{BW}$ niet anders dan 'zolang hij in gebreke is'. Niet alleen blijkt uit de wettekst dat sprake is van een tijdelijke maatregel; dat volgt ook uit de aard van het middel zelf. In de literatuur is een maximum van een jaar bepleit. ${ }^{291}$ Een ingebrekestelling voor het in leven roepen van de opschorting is niet vereist. De statuten kunnen zo geformuleerd zijn dat de opschorting van rechtswege geldt. Een mededeling door het bestuur van de vennootschap dat het stemrecht opgeschort is, is vanuit praktisch oogpunt gewenst. $^{292}$

Volledigheidshalve noem ik voor de BV als gevallen waarin het stemrecht op aandelen niet kan worden uitgeoefend art. 2:183 lid 4 en 2:196a lid 1 BW. Art. 2:183 lid 4 BW bepaalt onder meer dat een aandeelhouder na de omzetting de aan een aandeel verbonden rechten niet kan uitoefenen, zolang hij niet in het aandeelhoudersregister is ingeschreven. Art. 2:196a lid 1 BW bepaalt onder meer dat de levering van

288 Zie over opschorting van aandeelhoudersrechten: Rensen 2005, p. 293-306, meer in het bijzonder met betrekking tot het stemrecht, p. 299-304.

289 Zie Bijlage 2.

290 Zie Bijlage 2.

291 Rensen 2005, p. 298.

292 Rensen 2005, p. 297. 
een aandeel overeenkomstig art. 2:196 lid 1 BW mede van rechtswege tegenover de vennootschap werkt. Behoudens in het geval dat de vennootschap zelf bij de rechtshandeling partij is, kunnen de aan het aandeel verbonden rechten eerst worden uitgeoefend nadat zij de rechtshandeling heeft erkend of de akte aan haar is betekend overeenkomstig de bepalingen van art. 2:196b BW, dan wel deze heeft erkend door inschrijving in het aandeelhoudersregister als bedoeld in art. 2:196a lid $2 \mathrm{BW}$. Ook in art. 2:228 lid $6 \mathrm{BW}$ geeft de wet een situatie waarin het stemrecht niet kan worden uitgeoefend. Dat artikellid bepaalt onder meer dat voor een aandeel dat toebehoort aan de vennootschap of aan een dochtermaatschappij daarvan in de algemene vergadering geen stem kan worden uitgebracht. Dat geldt ook voor een aandeel waarvan de vennootschap of aan een dochtermaatschappij de certificaten houdt.

Ook voor (al) deze gevallen geldt dat de aandeelhouder niet als kapitaalverschaffer zonder stemrecht te beschouwen is.

\subsection{Terminologie: de kapitaalverschaffer zonder stemrecht}

In de vorige paragrafen zijn de rechtsfiguren zonder stemrecht, die kapitaal in de BV vertegenwoordigen, geïdentificeerd en is de aard van die rechtsfiguur besproken. Houders van deze rechtsfiguren duid ik in het vervolg aan als kapitaalverschaffers zonder stemrecht zijn. Dat zijn aldus:

a. de stemrechtloze aandeelhouder;

b. de houder van certificaten van aandelen (met of zonder vergaderrecht);

c. de aandeelhouder waarbij stemrecht is overgedragen aan de vruchtgebruiker;

d. de aandeelhouder waarbij stemrecht is overgedragen aan de pandhouder; en

e. de houder van een participatiebewijs.

\subsection{Het aandeelhoudersregister (art. 2:194 BW)}

Art. 2:194 BW geeft een regeling over het aandeelhoudersregister. ${ }^{293}$ Het artikel bepaalt onder meer dat het bestuur van de vennootschap een register houdt waarin de namen en adressen van alle aandeelhouders zijn opgenomen, met vermelding van de datum waarop zij de aandelen hebben verkregen, de datum van de erkenning of

293 Op 17 december 2012 heeft de Minister van Veiligheid en Justitie een brief aan de Tweede Kamer gezonden (Kamerstukken II 2012/13, 32 608, nr. 4) over zijn voornemen tot het instelling van een centraal aandeelhoudersregister voor besloten en niet-beursgenoteerde vennootschappen. De redenen daarvoor zijn het tegen gaan van misbruik van rechtspersonen, belastingontduiking (denk aan de vastgoedfraude en de BTW-carrousel fraude) en witwassen. Een centraal aandeelhoudersregister biedt de mogelijkheid eenvoudig vast te stellen wie de aandeelhouders van een besloten en nietbeursgenoteerde vennootschap is en welke aandelen in welke rechtspersonen bepaalde personen hebben, aldus de minister. 
betekening, de soort of aanduiding van de aandelen, en van het op ieder aandeel gestorte bedrag. Indien een aandeelhouder niet gebonden is aan een statutaire verplichting of eis als bedoeld in art. 2:192 lid $1 \mathrm{BW}$, wordt dat vermeld. In het register worden opgenomen de namen en adressen van de houders van certificaten van aandelen waaraan vergaderrecht is verbonden, met vermelding van de datum waarop het vergaderrecht aan hun certificaat is verbonden en de datum van erkenning of betekening. Het register wordt regelmatig bijgehouden; daarin wordt mede aangetekend elk verleend ontslag van aansprakelijkheid voor nog niet gedane stortingen. Aandeelhouders en anderen van wie gegevens in het register moeten worden opgenomen, verschaffen aan het bestuur tijdig de nodige gegevens. Het bestuur verstrekt desgevraagd aan een aandeelhouder en een houder van een certificaat van een aandeel waaraan bij of krachtens de statuten vergaderrecht is verbonden om niet een uittreksel uit het register met betrekking tot zijn recht op een aandeel of certificaat van een aandeel. Rust op het aandeel een recht van vruchtgebruik of een pandrecht, dan vermeldt het uittreksel aan wie de in de art. 2:197, 2:198 en 2:227 BW bedoelde rechten toekomen. Het bestuur legt het register ten kantore van de vennootschap onder meer ter inzage van de aandeelhouders en de houders van certificaten van aandelen waaraan bij of krachtens de statuten vergaderrecht is verbonden.

Op grond van art. 2:227 lid 2 BW kan aan een certificaat vergaderrecht worden toegekend. Indien hiervan gebruik wordt gemaakt, is het van belang dat de vennootschap daarvan op de hoogte is. $\mathrm{Bij}$ de organisatie van de algemene vergadering zal immers bekend moeten zijn wie moet worden opgeroepen. In verband met de invoering van de mogelijkheid van stemrechtloze aandelen was in een eerder ontwerp van art. 2:194 lid $1 \mathrm{BW}$ bepaald dat, indien aan aandelen op grond van een statutaire regeling geen stemrecht toekomt, dit moet worden vermeld in het aandeelhoudersregister. De vermelding is onder meer van belang vanwege art. 2:24d BW, waarin is bepaald dat stemrechtloze aandelen niet meetellen bij de berekening van meerderheden en quora in de algemene vergadering, aldus de memorie van toelichting en de oorspronkelijke gedachte van de wetgever. ${ }^{294}$ Voor het overige verwijs ik ten aanzien van de certificaathouder naar paragraaf 4.4.6 waar ik 'zijn' overgangsrecht besprak.

Art. 2:189a BW biedt de mogelijkheid aandelen een bepaalde aanduiding te geven. Dat kunnen aandelen zijn met speciale rechten, bevoegdheden en verplichtingen op grond van art. 2:192 BW, maar ook winstrechtloze of stemrechtloze aandelen (art. 2:216 lid 7 en art. 2:228 lid 5 BW). Anders dan bij aandelen van een bepaalde soort, blijkt bij aandelen met een bepaalde aanduiding niet uit de statuten dat aan een specifiek aandeel een bijzondere positie is verbonden. Daarom is registratie van de bepaalde aanduiding van belang. ${ }^{295}$ De Invoeringswet van het

294 Kamerstukken II 2006/07, 31 058, nr. 3, p. 48 (MvT). Zie ook Kamerstukken II 2008/09, 31 058, nr. 7, p. 14 (Nota van wijziging).

295 Kamerstukken II 2010/11, 32 426, nr. 3, p. 24 (MvT). 
wetsvoorstel van de flex-BV heeft de bepaling verder aangescherpt. Niet het stemrechtloze karakter van aandelen moet worden vermeld, maar de soort of aanduiding van de aandelen die worden gehouden. Indien er aandelen met bijzondere rechten zijn, kan uit de vermelding in het register van de soort of de aanduiding van de aandelen met behulp van de statuten worden vastgesteld welke rechten er wel of niet aan het aandeel zijn verbonden. Die omvatten dus zowel de winst- als de stemrechten. ${ }^{296}$ Ook de 'persoonsgebonden niet-gebondenheid' aan een statutaire verplichting van een aandeelhouder op grond van art. 2:192 BW moet worden geregistreerd. ${ }^{297}$

Tevergeefs zoekt men in art. 2:194 BW naar het participatiebewijs. Bezien vanuit de optiek van het vergaderrecht, lijkt dat op het eerste gezicht een logische gedachte. Niet uit te sluiten is echter dat in de contractuele voorwaarden van (de uitgifte van) het participatiebewijs vergaderrecht aan de houder van het participatiebewijs worden toegekend. Indien dat het geval is, is op dit punt het onderscheid tussen het participatiebewijs en het certificaat met vergaderrecht vervallen. Hetzelfde geldt voor de aandeelhouder die geen stemrecht heeft en de vruchtgebruiker of pandhouder die wel stemrecht hebben. De aandeelhouder zonder stemrecht heeft immers wel vergaderrecht. Het hebben van vergaderrecht is daarom geen onderscheidend criterium. Andere argumenten om het participatiebewijs met vergaderrecht niet in het aandeelhoudersregister te registreren, zijn er ook niet. De participatie vertegenwoordigt kapitaal in de vennootschap, gelijk een aandeel. De houder van het participatiebewijs heeft wel ingebracht of gestort, terwijl de pandhouder of vruchtgebruiker een dergelijke inbreng niet heeft gedaan. ${ }^{298}$ De inbreng van de houder van het participatiebewijs is, naar mijn mening, te meer reden om hem wel in het aandeelhoudersregister op te nemen. Ook jegens de houder van een participatiebewijs moet de vennootschappelijke redelijkheid en billijkheid in acht genomen worden. Ik verwijs naar paragraaf 7.4.2. Het onderscheid wel of geen stemrecht is ook geen criterium, omdat de stemrechtloze aandeelhouder wel in het aandeelhoudersregister wordt geregistreerd. Datzelfde geldt door de pandhouder of vruchtgebruiker zonder stemrecht (voor een stil pandrecht uiteraard niet). Ook in deze zin is er geen reden de houder van het participatiebewijs niet in het aandeelhoudersregister te registreren. Het staat het bestuur van een vennootschap uiteraard vrij een apart register van houders van participatiebewijzen bij te houden. Ten aanzien van vergadergerechtigde certificaathouder merkt de wetgever op: "Overwogen is om te voorzien in een afzonderlijk register van certificaathouders, maar inpassing in art. 2:194 BW heeft als voordeel dat gebruik kan worden gemaakt van het systeem van het aandeelhoudersregister, waarmee men in de praktijk al bekend is. In de

296 Kamerstukken II 2010/11, 32 426, nr. 8, p. 11 (Nota van wijziging). Kamerstukken I 2011/12, 31058 en 32 426, nr. C, p. 8 (MvA I).

297 Kamerstukken II 2010/11, 32 426, nr. 7, p. 25 (NV II) en Kamerstukken II 2010/11, 32 426, nr. 8, p. 11 (Nota van wijziging).

298 Een beslag op aandelen op naam moet ook in het aandeelhoudersregister worden aangetekend mede vanwege de blokkerende werking van het beslag, zie art. 474c lid 4 jo. 474e Rv. 
praktijk is al een model ontwikkeld voor het bijhouden in het aandeelhoudersregister van certificaten die met medewerking van de vennootschap zijn uitgegeven." ${ }^{299}$ De wetgever heeft dus niet voor een apart certificaathoudersregister gekozen.

Het aandeelhoudersregister kan elektronisch worden bijgehouden, bijvoorbeeld een website met een inlogcode voor aandeelhouders en certificaathouders met vergaderrecht. Het bestuur van de vennootschap kan ook gegevens invoeren in een computersysteem dat door aandeelhouders en certificaathouders met vergaderrecht ten kantore van de vennootschap geraadpleegd kan worden. ${ }^{300}$

\subsection{Vermelding in de jaarrekening en het jaarverslag (art. 2:392 lid 1 sub f BW)}

Op grond van art. 2:392 lid $1 \mathrm{sub} \mathrm{fBW}$ is het bestuur verplicht aan de jaarrekening en het jaarverslag een opgave te doen van het aantal winstbewijzen en soortgelijke rechten, het aantal stemrechtloze aandelen en het aantal aandelen dat geen of slechts een beperkt recht geeft tot deling in de winst of reserves van de vennootschap, met vermelding van de bevoegdheden die zij geven. De wetgever heeft deze wijziging als volgt gemotiveerd: "Naar de letter eist artikel 378 lid 2 zowel vermelding van de stemrechtloze als van de niet in de winst delende aandelen, aangezien deze aandelen aparte soorten aandelen zijn in de zin van artikel 378. Invoering van die aandelen hoeft dan ook niet tot aanpassing van artikel 378 te leiden. De huidige tekst van artikel 392, en dan vooral lid 1 onder $f$, is op dit punt minder duidelijk als er niet uitdrukkelijk naar de niet winstdelende aandelen wordt verwezen. Daarom worden winstrechtloze en stemrechtloze aandelen toegevoegd aan onderdeel $f$ van lid 1. Omdat in het kader van het wetsvoorstel bv-recht enkel spreekt van winst- of stemrechtloze aandelen, is deze terminologie aangehouden." ${ }^{301}$ Onder het oude recht luidde art. 2:392 lid 1 sub f BW als volgt: "een opgave van het aantal winstbewijzen en soortgelijke rechten met vermelding van de bevoegdheden die zij geven". Onder het oude recht werd onder bevoegdheden verstaan "rechten of aanspraken op winst en niet bevoegdheden in de zin van zeggenschap, ${ }^{302} \mathrm{Ik}$ neem aan dat de wetgever, gelet op de hiervoor aangehaalde toelichting, daarin geen wijziging heeft beoogd.

299 Kamerstukken II 2006/07, 31 058, nr. 3, p. 48 (MvT)

300 Kamerstukken II 2006/07, 31 058, nr. 3, p. 49 (MvT)

301 Kamerstukken II 2009/10, 32 426, nr. 3, p. 33 (MvT).

302 Th.S. IJsselmuiden, Groene Serie Rechtspersonen, art. 3:296 BW, aant. 12, Deventer: Kluwer. 


\subsection{Samenvatting en conclusie}

\section{Algemeen}

In dit hoofdstuk zijn aandelen en andere rechtsfiguren zonder stemrecht besproken. Deze rechtsfiguren zijn: (i) het stemrechtloze aandeel, (ii) certificaten van aandelen (met of zonder vergaderrecht), (iii) het aandeel waarbij het stemrecht is overgedragen aan de vruchtgebruiker, (iv) het aandeel waarbij het stemrecht is overgedragen aan de pandhouder en (v) het participatiebewijs. De houder van een van deze rechtsfiguren is te beschouwen als een 'kapitaalverschaffer zonder stemrecht' in de zin van dit onderzoek.

Het stemrechtloze aandeel

Art. 2:175 BW en de literatuur geven geen (eenduidige) definitie van een aandeel. Een aandeel is een aandeel als het als zodanig is uitgegeven. In art. 2:228 lid 5 BW ontbreekt een definitie van het stemrechtloze aandeel. Mijn definitie van het stemrechtloze aandeel is: 'het stemrechtloze aandeel is een vermogensrecht op naam, in de vorm van een aandeel uitgegeven door de BV, dat kapitaal in een BV vertegenwoordigt, waaraan de rechten volgens de wet en de statuten van de BV zijn verbonden, waaronder het recht - al dan niet beperkt - op winst en/of reserves van die $\mathrm{BV}$, doch aan welk aandeel geen stemrecht in de algemene vergadering is verbonden'. Stemrechtloze aandelen zijn aandelen van een bepaalde soort of aanduiding. De tweede volzin van art. 2:228 lid 5 BW zou naar mijn mening beter geformuleerd kunnen worden. Die zin zou moeten luiden: 'Een dergelijke regeling (dat aan aandelen geen stemrecht is verbonden, toevoeging RAW) kan slechts worden getroffen ten aanzien van alle aandelen van een bepaalde soort of aanduiding waarvan alle aandeelhouders instemmen, dan wel ten aanzien van alle aandelen van een bepaalde soort of aanduiding die niet zijn geplaatst.'

Op grond van art. 2:216 lid 7 BW kunnen verschillende soorten stemrechtloze aandelen worden gecreëerd die geheel of gedeeltelijk recht geven op winst en/of reserves, of een combinatie daarvan.

De vergadering van houders van stemrechtloze aandelen is een orgaan van de vennootschap in de zin van art. 2:189a BW. Dat maakt het mogelijk aan dat orgaan bepaalde bevoegdheden toe te kennen, zoals de benoeming van een bestuurder en/of commissaris. Houders van stemrechtloze aandelen hebben in 'hun' vergadering stemrecht. Bestuurders en commissarissen hebben in de vergadering van stemrechtloze aandeelhouders geen raadgevende stem. Het komt mij echter voor dat uit de eisen van de vennootschappelijke redelijkheid en billijkheid kan voortvloeien dat de vergadering van houders van stemrechtloze aandelen, indien haar als orgaan statutaire bevoegdheden zijn toegekend, bij (belangrijke) besluiten de bestuurders (en commissarissen) in de gelegenheid stelt hun raadgevende stem te doen horen, te meer indien de bestuurders niet tevens aandeelhouders zijn. Wettelijk is het bestuur van de vennootschap niet verplicht aantekening te houden van besluiten van de 
vergadering van stemrechtloze aandeelhouders of deze vast te leggen. Ik ben van mening een dergelijke verplichting op het bestuur zou moeten rusten. Daarnaast zou wettelijk verankerd moeten worden dat notulen moeten worden opgemaakt van de vergadering van houders van stemrechtloze aandelen en de algemene vergadering. Dat komt de toetsing van de besluiten en de besluitvorming ten goede.

De hoofdregel van art. 2:24d lid $1 \mathrm{BW}$ is dat stemrechtloze aandelen bij de vraag in hoeverre de leden of aandeelhouders stemmen, aanwezig of vertegenwoordigd zijn, of in hoeverre het aandelenkapitaal verschaft wordt of vertegenwoordigd is, niet meetellen. Art. 2:24d lid 2 BW formuleert voor de daarin genoemde artikelen de uitzondering.

Op grond van deze hoofdregel tellen stemrechtloze aandelen bij de bepaling of sprake is van een dochtermaatschappij in de zin van art. 2:24a BW niet mee. Datzelfde geldt voor de bepaling of sprake is van een groepsmaatschappij als bedoeld in art. 2:24b BW. Ik meen dat de hoofdregel van art. 2:24d lid $1 \mathrm{BW}$ niet consistent is, omdat op grond van art. 2:242 jo. 2:244 en 2:252 jo. 2:254 BW de bevoegdheid tot benoeming en ontslaan van bestuurders en commissarissen aan de vergadering van stemrechtloze aandeelhouders kan worden toegekend. Vele variaties van 'dochtermaatschappij' zijn mogelijk, indien de benoeming van bestuurders toekomt aan diverse soorten aandelen. Een dergelijke toekenning van bevoegdheid is een omstandigheid die mijns inziens ook bij de feitelijke invulling van het criterium van 'centrale leiding' bij het bepalen of sprake is van een groep of groepsmaatschappij moet worden betrokken.

De uitzonderingsregel van art. 2:24d lid 2 BW bepaalt dat stemrechtloze aandelen bij de toepassing van art. 2:24c BW meetellen bij de vaststelling van de aanwezigheid van een deelneming. Daarmee wordt volgens de wetgever voorkomen dat vennootschappen stemrechtloze aandelen zouden gebruiken om te ontkomen aan de verplichting informatie over die deelnemingen in de financiële verslaggeving op te nemen. Art. 2:24d lid $2 \mathrm{BW}$ komt er op neer dat bij de bepaling of sprake is van een afhankelijke maatschappij in de zin van art. 2:63a, 2:152 en art. 2:262 BW tevens rekening gehouden moet worden met de stemrechtloze aandelen in die BV. Mij dunkt dat dit ertoe kan leiden dat indien een vennootschap stemrechtloze aandelen in een andere vennootschap houdt de structuurregeling van toepassing is, terwijl die stemrechtloze aandeelhouder geen zeggenschap kan uitoefenen over de afhankelijke maatschappij.

Familievennootschappen waarbij stemrechtloze aandelen zijn uitgegeven, kunnen opteren voor het verzwakte structuurregime van art. 2:265a BW, mits aan het vereiste van 'onderlinge regeling tot samenwerking' en aan de overige vereisten van art. 2:265a BW is voldaan.

Het begrip 'meerderheid der aandelen' in de zin van art. 1:88 lid 5 BW wordt ingevuld door het formele criterium van de vennootschapsstructuur en het materiële criterium van de combinatie van zeggenschap en financieel belang. Voor de invulling van het financiële belang van het materiële criterium zou ik een 
proportionele minimumgrens van tien procent van door de handelend bestuurder te houden stemrechtloze aandelen willen stellen.

Onder het begrip 'uiteindelijk belanghebbende' in de Wwft en Wtt moet naar mijn mening (ook) worden verstaan de stemrechtloze aandeelhouder met een zodanig kapitaalsbelang dat hij ten minste 25 procent van het geplaatste kapitaal in de BV houdt. Via zijn aandeelhouderschap heeft hij immers een meer dan substantieel, financieel belang in de (doel)vennootschap. Dat die stemrechtloze aandeelhouder het stemrecht ontbeert, doet daaraan niet af.

Gelet op de achtergrond en de strekking van art. $43 \mathrm{Fw}$, meer in het bijzonder het in dat artikel opgenomen bewijsvermoedens, pleit ik ervoor in situaties als bedoeld in art. 43 lid 1 sub 4 onder $\mathrm{c}$ en sub 5 onder $\mathrm{c}$ en $\mathrm{d}$ Fw onder de woorden 'ten minste de helft van het geplaatste kapitaal' ook te verstaan de stemrechtloze aandeelhouder met een zodanig kapitaalsbelang dat hij ten minste de helft van het geplaatste kapitaal in de BV houdt.

Het begrip 'in overwegende mate bij machte' als bedoeld in art. 1:141 lid 4 BW moet worden uitgelegd als een feitelijk zeggenschapscriterium. Dat criterium lijkt in de flex-BV wegens de introductie van het stemrechtloze aandeel niet goed hanteerbaar. Indien tussen echtelieden een periodiek verrekenbeding is overeengekomen, dat mede winst uit onderneming omvat, terwijl een van de echtgenoten stemrechtloze aandelen in een BV houdt, zouden de ingehouden winsten, naar evenredigheid van het aandelenbezit, in de verrekening betrokken moeten worden.

De invoering van stemrechtloze aandelen leidt niet tot overgangsrechtelijke problemen. Deze aandelen zijn optioneel en ze ontstaan pas als de statuten daartoe zijn aangepast en als ze zijn uitgegeven.

\section{Certificaten van aandelen}

De rechtsfiguur van certificering van aandelen is te vergelijken met het stemrechtloze aandeel. Door certificering wordt de juridische en economische eigendom van de aandelen gesplitst. De aandelen worden overgedragen aan en gehouden door een administratiekantoor. Het AK beheert de aandelen en geeft de certificaten uit aan de certificaathouder(s). De rechtsverhouding tussen het administratiekantoor en de certificaathouder(s) is een beheerovereenkomst, die belichaamd wordt in de administratievoorwaarden. Tussen het administratiekantoor als aandeelhouder en de vennootschap gelden de wet en de statuten, zodat sprake is van een wettelijke en statutaire basis. Het administratiekantoor heeft als aandeelhouder in beginsel de aan de aandelen verbonden zeggenschapsrechten, terwijl de certificaathouder de financiële rechten van het aandeel heeft, zoals het recht op dividend. Er kan onderscheid worden gemaakt tussen royeerbare, beperkt royeerbare en niet-royeerbare certificaten. In de flex-BV is het onder het oude recht bestaande onderscheid tussen met of zonder medewerking van de vennootschap uitgegeven certificaten verdwenen. Het gaat in de flex-BV om de vraag of bij de statuten aan certificaten vergaderrecht in de zin van art. 2:227 BW is verbonden. Uitgangspunt is dat de vennootschap zelf bepaalt of er certificaten met vergaderrecht worden toegelaten, en zo ja, aan welke 
certificaten dat vergaderrecht toekomt. De hoofdregel van art. 2:227 lid 4 BW bepaalt dat het aan certificaathouders toegekende vergaderrecht slechts met instemming van die certificaathouder kan worden gewijzigd. Op grond van art. 2:227 lid 2 BW zijn statutaire regelingen mogelijk, die bepalen dat (i) certificaten in het algemeen geen vergaderrecht hebben, (ii) alle certificaten vergaderrecht hebben of (iii) het vergaderrecht slechts toekomt aan bepaalde, in de statuten aangeduide certificaten. De wet koppelt aan het vergaderrecht talloze andere rechten, zoals bijvoorbeeld het recht om kennis te nemen van oproepingsbrieven voor een algemene vergadering (art. 2:224 lid $1 \mathrm{BW}$ ) en het recht om de voorzieningenrechter te verzoeken om een machtiging tot het bijeenroepen van een algemene vergadering (art. 2:220 BW). Art. 2:227 BW heeft tot gevolg dat bij de toepassing van art. 3:259 BW ten aanzien van certificaten van aandelen in een BV slechts medewerking van de uitgever van de oorspronkelijke aandelen aangenomen kan worden, indien er sprake is van certificaten waaraan statutair vergaderrecht is verbonden.

Voor certificaathouders zijn in algemene zin art. 68a en 69 Overgangswet NBW relevant. Specifieke overgangsregels voor certificaten van aandelen zijn te vinden in art. V.2 lid 1 en 6 van het Overgangsrecht. De vennootschap, althans haar bestuur, moet zo snel mogelijk, doch uiterlijk 1 oktober 2013 de vergadergerechtigde certificaathouder in het aandeelhoudersregister vermelden. Is het aandeelhoudersregister een maand vóór de datum van de eerste algemene vergadering na het tijdstip van inwerkingtreding van de wet nog niet overeenkomstig art. 2:194 lid 1 laatste volzin BW voltooid, dan zijn art. 2:223 lid 2 en 3 (oud) BW van toepassing. Houders van certificaten die met medewerking van de vennootschap uitgegeven zijn, kunnen de vennootschap schriftelijk verzoeken hen als vergadergerechtigden in het aandeelhoudersregister in te schrijven. Indien het bestuur dit verzoek afwijst, kunnen de houders van deze certificaten de rechtbank verzoeken het bestuur op te dragen hen als vergadergerechtigden in te schrijven. Zijn er voor het tijdstip van inwerkingtreding van de wet met medewerking van de vennootschap certificaten van haar aandelen uitgegeven, dan dient de vennootschap overeenkomstig art. 2:227 lid 2 BW bij de eerstvolgende statutenwijziging vergaderrecht te verbinden aan deze certificaten. Tot het moment van die statutenwijziging worden onder certificaten waaraan bij de statuten vergaderrecht is verbonden tevens verstaan certificaten die voor inwerkingtreding van de wet over vergaderrecht beschikten en die in het aandeelhoudersregister zijn opgenomen. Deze vergadergerechtigde certificaathouders mogen de aan hen toekomende rechten uitoefenen. Ten aanzien van deze overgangsregeling heb ik een aantal aanbevelingen tot verbetering van de regeling gedaan. Niet altijd is de regeling helder geformuleerd. Bovendien bevat het overgangsrecht een aantal lacunes. Ik verwijs naar paragraaf 4.4.6.3.

Het aandeel waarbij het stemrecht is overgedragen aan de vruchtgebruiker of de pandhouder

Het vruchtgebruik op aandelen is geregeld in art. 2:197 BW. Het pandrecht op aandelen is geregeld in art. 2:198 BW. De hoofdregel van beide regelingen is dat de 
aandeelhouder het stemrecht heeft op de aandelen waarop het vruchtgebruik of het pandrecht is gevestigd. Op grond van art. 2:197 lid $3 \mathrm{BW}$, respectievelijk art. 2:198 lid $3 \mathrm{BW}$, wordt de aandeelhouder stemrechtloos indien het stemrecht bij de vestiging van het vruchtgebruik, respectievelijk het pandrecht, aan de vruchtgebruiker, respectievelijk de pandhouder, is overgedragen of indien die overdracht nadien schriftelijk tussen de aandeelhouder en de vruchtgebruiker, respectievelijk de pandhouder, is overeengekomen. Art. 2:196a BW is daarbij van overeenkomstige toepassing verklaard. De vruchtgebruiker, respectievelijk de pandhouder, moet iemand zijn aan wie de aandelen vrij kunnen worden overgedragen. Als dat laatste niet het geval is, moet - kort gezegd - zowel de regeling over de overdracht van het stemrecht als de overdracht van het stemrecht zelf door de algemene vergadering worden goedgekeurd. Art. 2:197 lid 4 BW, respectievelijk art. 2:198 lid 4 BW, bepaalt dat de aandeelhouder die vanwege een vruchtgebruik, respectievelijk pandrecht, geen stemrecht heeft, de rechten heeft die door de wet zijn toegekend aan de houders van certificaten van aandelen waaraan vergaderrecht is verbonden. Uit art. 2:227 lid $2 \mathrm{BW}$ volgt dat de aandeelhouder die vanwege een vruchtgebruik of pandrecht geen stemrecht heeft, wel vergaderrecht heeft. De inwerkingtreding van de flex-BV doet aan een reeds rechtsgeldig gevestigd vruchtgebruik of pandrecht op aandelen, waarbij de aandeelhouder zijn stemrecht aan de vruchtgebruiker of pandhouder heeft overgedragen, niet af.

\section{Het participatiebewijs}

Participatiebewijzen worden tegen storting of inbreng verkregen en vertegenwoordigen kapitaal in de vennootschap. Aan een participatiebewijs zijn soms alle rechten die een aandeelhouder toekomen verbonden, behalve het stemrecht. Houders van participatiebewijzen hebben aanspraak op een deel van de winst en/of het liquidatiesaldo. Participatiebewijzen hebben een statutaire basis en een contractuele grondslag. De rechtsverhouding tussen de houder van het participatiebewijs en de vennootschap wordt ingevuld door de participatievoorwaarden. De inwerkingtreding van de flex-BV doet aan de rechtsgeldigheid van reeds uitgegeven participatiebewijzen niet af. 


\section{Hoofdstuk 5}

\section{INTERNE VERHOUDINGEN IN DE BV}

\section{$5.1 \quad$ Inleiding}

In dit hoofdstuk staan de interne verhoudingen in de BV centraal. Met de interne verhoudingen in de BV bedoel ik de onderlinge betrekkingen tussen de kapitaalverschaffer, de algemene vergadering, het bestuur van de vennootschap en de vennootschap zelf. De interne verhoudingen benader ik vanuit een vijftal thema's. Ten eerste, het principaal-agent probleem. In de rechtseconomie is dit probleem uitgewerkt in de principal-agent theory (paragraaf 5.2). Ten tweede, de aard van de BV, namelijk het besloten karakter van die rechtspersoon, en de aard van de samenwerking in de BV (paragraaf 5.3). Ten derde, het vennootschappelijk belang (paragraaf 5.4). Ten vierde, de dualistische structuur van de BV en de instructiebevoegdheid van de algemene vergadering (paragraaf 5.5). Ten vijfde, de grens van het dienen van het eigen belang door aandeelhouders (paragraaf 5.6). Deze thema's vat ik samen in paragraaf 5.7, waarin ik tevens een conclusie ten aanzien van de interne verhoudingen in de BV trek.

Deze interne verhoudingen en de daarin door mij te onderscheiden thema's geven het kader of het spanningsveld weer, waarin de kapitaalverschaffer zonder stemrecht zich bevindt.

\subsection{Principal-agent theory}

In paragraaf 3.2 stipte ik de vijf belangrijkste kenmerken van een kapitaalvennootschap aan. ${ }^{1}$ Die kenmerken kunnen aanleiding geven tot belangenconflicten. ${ }^{2}$ Bij de vaststelling van de in de inleiding van dit hoofdstuk geschetste, interne verhoudingen speelt op een hoger, abstracter niveau de principal-agent theory. ${ }^{3}$ De

1 Die kenmerken zijn (i) rechtspersoonlijkheid, (ii) beperkte aansprakelijkheid, (iii) overdraagbaarheid van aandelen, (iv) een gecentraliseerd management in de vorm van een bestuur (v) en gedeelde eigendom door kapitaalverschaffers.

2 Olaerts 2007, p. 17 en de aldaar in noot 50 aangehaalde literatuur

3 Kraakman e.a. 2009, p. 35. Zie ook M.J. Hatch en A.L. Cunliffe, Organization Theory, Modern, Symbolic, and Postmodern perspectives, Oxford: Oxford University Press, 2006, p. 261 en Eijsbouts 2011, p. 48 
principal-agent theory behelst het probleem dat de principaal voor zijn welbevinden afhankelijk is van de agent. Meer in het bijzonder rijst de vraag hoe de principaal de agent kan motiveren te handelen in zijn belang in plaats van dat de agent in diens eigen belang handelt. In veel contractuele relaties ligt dat potentiële probleem verborgen. De kern van het probleem is, dat de agent in de regel over meer en betere informatie beschikt dan de principaal, ook wel informatieasymmetrie genoemd. De agent is meestal de specialist en heeft door zijn positie ook een kennisvoorsprong. De agent is weliswaar gehoorzaamheid verschuldigd aan zijn principaal, maar de principaal kan hem niet afdoende controleren. Los van deze afstand tussen de principaal en de agent, krijgt de agent juist en mede door zijn informatie- en kennisvoorsprong ruimte om buiten of zelfs tegen het belang van zijn principaal zijn eigen belang te dienen. Dat werkt opportunistisch handelen van de agent in de hand. De waarde van de prestatie van de agent voor de principaal vermindert door dit agency problem. Direct, omdat de belangen van de principaal (mogelijk) niet (optimaal) worden gediend. Maar ook indirect. Om zich van de kwaliteit van de prestatie van de agent te verzekeren zal de principaal de agent moeten controleren. Die kosten worden ook wel agency costs genoemd. Hoe complexer de taken van de agent zijn en de vrijheid die in dat kader en daarom aan de agent door de principaal moet worden gegeven, des te groter deze kosten zullen zijn.

In een onderneming kan sprake zijn van drie agency problems. ${ }^{4}$ Het eerste is het probleem tussen aandeelhouders (principalen) en bestuurders (agenten) van een vennootschap. ${ }^{5}$ Het probleem ligt hierin dat de aandeelhouders zich ervan willen verzekeren dat de bestuurders in het belang van de aandeelhouders handelen en niet in het belang van de bestuurder zelf. Het tweede probleem speelt tussen meerderheids- en minderheidsaandeelhouders. In dat geval zijn de minderheidsaandeelhouders de principalen en de meerderheidsaandeelhouders de agenten. Hoe kunnen de minderheidsaandeelhouders zich ervan verzekeren dat ook hun belang wordt gediend? Hoe kunnen zij zich ervan verzekeren dat zij niet worden 'overstemd' door de meerderheidaandeelhouders? ${ }^{6}$ In breder verband komt dit probleem binnen een vennootschap aan de orde wanneer een van de bij de vennootschap betrokkenen het in zijn macht heeft besluiten te nemen die de belangen van andere betrokkenen als geheel raken. Te denken valt aan aandeelhouders met vetorechten en aan houders van prioriteits- en preferente aandelen. Het derde agency problem heeft betrekking op de onderneming zelf, meer in het bijzonder haar eigenaren en haar contractspartijen (dat wil zeggen derden met wie de vennootschap overeenkomsten heeft gesloten). Te

4 Kraakman e.a. 2009, p. 36-37. De visie van Kraakman e.a. is overigens ingegeven door de law \& economics school, waarbij een instrumentele kijk op de vennootschap naar voren komt. De onderneming moet rendement opleveren en daarom zo efficiënt mogelijk ingericht zijn. Het bestuur moet aandeelhouderswaarde creëren. Er wordt uitgegaan van het shareholdersmodel in plaats van het in Nederland gebruikelijke stakeholdersmodel. Zie Barneveld 2009, p. 231 en Schuit 2008, p. 225 e.v.

5 Schwarz 2002, p. 44.

6 Bijvoorbeeld door middel van een stemovereenkomst. Dit probleem ligt echter besloten in de 'democratie' van de BV. Besluiten worden in beginsel bij meerderheid van stemmen genomen. 
denken valt aan werknemers, leveranciers, klanten en dergelijke. De onderneming is in dit probleem de agent en de contractspartijen zijn de principalen. Hoe kunnen bijvoorbeeld klanten zich ervan verzekeren dat zij niet worden afgezet?

In het kader van dit onderzoek zijn deze agency problems van belang. Bij het eerste probleem staat de kapitaalverschaffer zonder stemrecht als principaal in verhouding tot het bestuur van de vennootschap als agent. Een bijkomend en klemmend probleem is dat die kapitaalverschaffer geen stemrecht heeft. Hij heeft aldus geen of minder mogelijkheden om zich ervan te verzekeren dat het bestuur in zijn belang handelt. Hoewel, bijvoorbeeld, de stemrechtloze aandeelhouder dezelfde rechten, behalve het stemrecht, als een gewone aandeelhouder heeft, is hij - waar het gaat om het nemen van besluiten in de algemene vergadering - afhankelijk van de aandeelhouder met stemrecht. Met andere woorden: waar een gewone aandeelhouder met stemrecht via dat stemrecht als principaal zijn eigen belang kan en mag dienen, staat de stemrechtloze aandeelhouder aan de kant en mag hij hopen dat de aandeelhouder met stemrecht in diens stemgedrag ook rekening houdt met het belang van de stemrechtloze aandeelhouder. Dat slaat de brug naar het tweede agency problem tussen meerderheids- en minderheidsaandeelhouders. In zekere zin is de kapitaalverschaffer zonder stemrecht slechter af dan de minderheidsaandeelhouder. Indien sprake is van een gewone minderheidsaandeelhouder heeft die aandeelhouder wel stemrecht, hetgeen een voordeel kan zijn in situaties waarin besluiten met een gekwalificeerde meerderheid moeten worden genomen. De kapitaalverschaffer zonder stemrecht heeft dat voordeel niet. Hij kan dus niet of in mindere mate dan de minderheidsaandeelhouder zich ervan verzekeren dat zijn belang wordt gediend. Dat is een argument om de stemrechtloze aandeelhouder het recht tot benoeming van een bestuurder of het instructierecht toe te kennen.

Het derde agency problem gaat niet alleen uit van de interne verhoudingen, maar ook van externe verhoudingen. Vertaald naar het Nederlandse vennootschapsrecht kan worden uitgegaan van het stakeholders-model. ${ }^{7}$ Het bestuur - en, indien ingesteld, de raad van commissarissen van een BV - moeten bij de uitoefening van hun taak het belang van de door de vennootschap gedreven onderneming nastreven. Dat vennootschappelijke belang is, uitgaande van de resultante-benadering, de resultante van de afweging van belangen van hen die bij de vennootschap en de door haar gedreven onderneming zijn betrokken. Daartoe behoren in de eerste plaats de aandeelhouders, maar bijvoorbeeld ook werknemers, afnemers, leveranciers, financiers en schuldeisers van de onderneming. ${ }^{8}$ Op dit vennootschappelijk belang kom ik in paragraaf 5.4 terug.

Agency problems kunnen agency costs opleveren. In het algemeen kan worden gesteld dat het terugdringen van de agency costs in het belang van alle partijen is. ${ }^{9}$ Voor beursgenoteerde ondernemingen geldt de Corporate Governance Code. Deze code beoogt onder meer de agency costs te reduceren door opportunistisch gedrag

7 Asser/Maeijer, Van Solinge \& Nieuwe Weme 2-II* 2009, nr. 394 en Steins Bisschop 2010, p. $223-224$.

8 Asser/Maeijer, Van Solinge \& Nieuwe Weme 2-II* 2009, nr. 394 en 395.

9 Kraakman e.a. 2009, p. 37. 
van zowel de principaal als de agent te reguleren. Beursgenoteerde ondernemingen zijn NV's. Dit onderzoek stelt echter de kapitaalverschaffer zonder stemrecht in de $B V$ centraal, zodat de Corporate Governance Code voor deze rechtspersoon geen richtlijn is voor het terugdringen van de agency costs en voor het vaststellen van de interne verhoudingen en welke (rechts)normen in die verhoudingen gelden. Daarbij speelt in het bijzonder een rol dat - hoewel historisch gezien de NV en de BV nauw aan elkaar verwant zijn - de aard van de BV veelal een andere is dan die van de NV. In de BV gaat het in de regel om besloten verhoudingen, anders dan in de NV. In die laatste vennootschap staan veelal open verhoudingen centraal. Ik licht de beslotenheid van de BV in de volgende paragraaf, paragraaf 5.3, toe.

In het algemeen kan gesteld worden dat de in dit hoofdstuk te bespreken interne verhoudingen van invloed zijn op de vennootschappelijke redelijkheid en billijkheid van art. 2:8 BW. Daarop kom ik in hoofdstuk 7 terug.

\subsection{De beslotenheid van de BV}

\subsubsection{Inleiding}

Bij het antwoord op de vraag wat de verhouding is van de in paragraaf 4.10 aangeduide kapitaalverschaffers zonder stemrecht tot de vennootschap, haar bestuur en de andere kapitaalverschaffers van de vennootschap, meer in het bijzonder de aandeelhouders met stemrecht, speelt de besloten aard ${ }^{10}$ van de BV een rol.

\subsubsection{Aard van de samenwerking in de BV}

De BV is een veel gebruikte rechtsvorm in het MKB en is sinds 1 oktober 2012 in het bijzonder geschikt voor kleinere ondernemingen, familiebedrijven, als dochteronderneming in concernverhoudingen, als investeringsmaatschappij in het kader van private equity of als joint venture vennootschap. De aandelen in een BV zijn vaak in een hand of een beperkt aantal handen. Veel ondernemers in het MKB drijven hun onderneming door middel van een of meerdere werkmaatschappijen-besloten vennootschappen met een holding, waarin de directeur-grootaandeelhouder - soms samen met een andere directeur-grootaandeelhouder - alle aandelen houdt en tevens bestuurder is. Ook kan sprake zijn van een BV waarin hij, de directeur-grootaandeelhouder, te maken heeft met een of meerdere minderheidsaandeelhouders. Indien de directeur-grootaandeelhouder enig aandeelhouder-bestuurder is, wordt ook wel gesproken van een eenmans-BV.

De aandeelhouders zijn bij de BV bekend. Aandelen in een BV luiden immers op naam. Er wordt een aandeelhoudersregister bijgehouden. De aandelen zijn door de hoofdregel van de aanbiedingsregeling van art. 2:195 BW in beginsel niet vrij overdraagbaar aan derden. De aandeelhouders zijn vaak erg betrokken bij de BV. De

10 Asser/Maeijer, Van Solinge \& Nieuwe Weme 2-II* 2009, nr. 14. 
financiering van de BV vindt plaats door familie- of privékapitaal, bankkrediet of door private equity. Veel bedrijven in het MKB zijn bovendien familiebedrijven. De Kluiver onderscheidt in meer of mindere mate vier kenmerken van een familievennootschap: (i) het bestuur wordt in beginsel gevormd door familieleden die tevens aandeelhouders zijn en vaak reeds langere tijd in het bedrijf hebben gewerkt, (ii) de aandelen zijn in handen van familieleden, in beginsel verworven door vererving of schenking, (iii) de mogelijkheid van toe- en uittreding van aandeelhouders zijn beperkt en (iv) een betrekkelijk conservatieve financiering; winst wordt in beperkte mate uitgekeerd en in aanzienlijke mate gereserveerd. ${ }^{11}$

Ter illustratie: dit alles ligt voor de NV in de regel anders. Het zijn veelal open vennootschappen, al dan niet beursgenoteerd. De aandelen in de NV zijn vaak in meer handen dan bij de BV. Niet altijd is het vanzelfsprekend dat de NV haar aandeelhouders kent, zeker niet als het om een beursgenoteerde vennootschap gaat. De aandeelhouders in een NV zijn vaak minder betrokken bij de vennootschap en de door haar gedreven onderneming. Ik refereer aan het aandeelhoudersabsenteïsme, zoals ik dat in paragraaf 2.2 in het kader van het pleidooi voor het stemrechtloze aandeel aan de orde heb gesteld. Samengevat: de aard van de vennootschap en de aard van het aandeelhouderschap verschilt. Het karakter van een beursvennootschap is een totaal andere dan het karakter van een joint venture-BV of een BV met een directeur-grootaandeelhouder. ${ }^{12}$

Uit het voorgaande volgt dat ondernemers in een BV samenwerken. De samenwerkende partners kiezen elkaar uit wegens bijzondere kwaliteiten of hoedanigheden en wensen veelal op basis van gelijkwaardigheid samen te werken. ${ }^{13} \mathrm{Zij}$ drijven gezamenlijk door middel van de BV hun onderneming. ${ }^{14}$ De BV is daarbij het middel of instrument. ${ }^{15}$ In de literatuur wordt in dit geval ook wel gesproken over een intern-besloten vennootschap, namelijk het samenwerkingsverband dat vanwege de persoon is aangegaan en dat haar besloten karakter tegen de invloed van derden met wettelijke middelen wenst te beschermen. ${ }^{16}$ De samenwerking is gericht op het behalen van het gemeenschappelijke doel. ${ }^{17}$ Bij personenvennootschappen is

11 De Kluiver 2005, p. 986.

12 In dezelfde zin Olaerts 2007, p. 276-277. Zie over de positie van de directeur-grootaandeelhouder in het nieuwe BV-recht: Raaijmakers \& Van der Sangen 2011, p. 90 e.v. en Raaijmakers \& Van der Sangen 2012, p. 513 e.v. Zie over typen vennootschappen en typen aandeelhouders: Bartman \& De Groot 2012, p. 250-255.

13 Deze gelijkwaardigheid hoeft in een BV met meerdere aandeelhouders, waaronder stemrechtloze aandeelhouders, niet per se het geval te zijn.

14 De BV wordt ook wel gekenschetst als een organisatorisch samenwerkingsverband, zie Asser/ Maeijer, Van Solinge \& Nieuwe Weme 2-II* 2009, nr. 19.

15 Van der Sangen 2003, p. 33 en Sanders \& Westbroek 2005, p. 8. Zie voor de BV en haar verschillende doeleinden: Slagter 2005, p. 159-165.

16 Hamers 1996, p. 139. Daartegenover staat de niet intern-besloten vennootschap. De samenwerking vanwege de persoon staat niet of minder voorop. Zie Hamers 1996, p. 140.

17 Dit neemt niet weg dat niet per definitie sprake hoeft te zijn van samenwerking in een BV. Te denken valt aan de eenmans-BV. Op deze BV richt dit onderzoek zich echter niet. 
het middel of instrument om het gemeenschappelijke doel te behalen in de regel de vennootschap onder firma. Ingeval een vennootschap onder firma in een BV wordt omgezet, wordt de samenwerking tussen de vennoten (aangegaan met het oog op de persoon) voortgezet als aandeelhouders/bestuurders in een BV. In de BV bestaat dus (ook) de wil en verplichting tot samenwerking. Ook de wetgever heeft bij de herziening van het BV-recht oog gehad voor de samenwerking in de BV: "De mogelijkheden voor aandeelhouders om hun onderlinge verhoudingen te regelen, worden verruimd. Er ontstaat meer ruimte om de inrichting van de vennootschap aan te passen aan de aard van de onderneming en de samenwerkingsrelatie van de aandeelhouders." 18 De wetgever volgde daarmee de constatering van de Expertgroep dat de BV minder als institutioneel fenomeen en meer als contractueel verband tussen aandeelhouders wordt gezien. ${ }^{19}$

Als aandeelhouder verschaffen de ondernemers vermogen aan de BV en geven zij daarvoor vaak persoonlijke zekerheden aan de financier af. Daarnaast zijn zij, als bestuurders, voor hun inkomen afhankelijk van de BV. Ownership en control in deze persoonsgebonden BV's vallen samen. Beter gezegd: ownership en control zijn geïntegreerd. ${ }^{20}$ Het is de vraag in hoeverre de persoonsgebonden samenwerking tussen de ondernemers los te zien is van de BV zelf. ${ }^{21}$ Onder het oude recht werd de blokkeringsregeling van art. 2:195 (oud) BW gezien als de vorm waarin die persoonsgebonden samenwerking was geformaliseerd. ${ }^{22}$ Daarnaast werd de blokkeringsregeling gezien als 'centraal onderdeel' van het besloten karakter van de BV. ${ }^{23}$

Samenwerken impliceert ook loyaliteit, juist om het gemeenschappelijk doel te behalen of dat doel tot een succes te brengen. Wat betreft het eigen belang van de aandeelhouder merk ik op dat de arresten van de Hoge Raad, ${ }^{24}$ die dat belang (in beginsel) voorop stellen, alle zien op situaties waarin sprake was van aandeelhouders in een NV. In paragraaf $5.6 \mathrm{kom}$ ik op deze arresten, waarin de grens van het dienen van het eigen belang door de aandeelhouder centraal staat, terug. De samenwerking in de beslotenheid van de BV, waarbij loyaliteit aldus een grote rol speelt, houdt naar mijn mening ook in dat de aandeelhouders in een BV niet zonder meer vrij zijn alleen hun eigen belang in de algemene vergadering te laten

18 Kamerstukken II 2006/07, 31 058, nr. 3, p. 1 (MvT). Zie ook Kamerstukken II 2009/10, 32 426, nr. 3 , p. 1 (MvT).

19 Rapport van de Expertgroep, p. 2.

20 Uitgangspunt is de 'separation of ownership from control', welke scheiding de dualistische structuur van de BV vormt. M.J.G.C. Raaijmakers 1994, p. 343. Van der Sangen 2003, p. 33, spreekt over 'joint control'.

21 Zie Van der Sangen 2003 en de aldaar in par. 2 aangehaalde literatuur.

22 M.J.G.C. Raaijmakers 1991 (2), p. 1011 en Slagter 2005, p. 231.

23 Kamerstukken II 2006/07, 31 058, nr. 3, p. 49 (MvT). Zie uitgebreid over de blokkeringsregeling: Schwarz 1986. Schwarz spreekt, p. 75, over de blokkeringsregeling als waarborg voor de interne beslotenheid van de BV, welke regeling ziet op de overdracht van zeggenschap. De zeggenschap is aan het aandeelhouderschap verbonden.

24 HR 30 juni 1944, NJ 1944, 465 (Wennex); HR 13 november 1959, NJ 1960, 472 (Distilleerderij Melchers) en HR 19 februari 1960, NJ 1960, 473, m.nt. HB (Aurora). 
prevaleren en hun stemgedrag te laten bepalen door dat eigen belang. ${ }^{25}$ De vennootschappelijke redelijkheid en billijkheid moet immers in acht worden genomen. ${ }^{26}$

Samengevat gaat het in een dergelijke 'quasi-vof', ${ }^{27}$ zoals de hiervoor besproken $\mathrm{BV}$ ook wel wordt genoemd, om een besloten verhouding van een onderlinge betrekking - een affectio societatis - waarvan de kenmerken zijn gelijkwaardigheid, samenwerken, vertrouwen, loyaliteit en persoonsgebondenheid (intuiti personae). ${ }^{28}$

In de rechtspraktijk komt het voor dat aandeelhouders stemovereenkomsten, aandeelhoudersovereenkomsten ${ }^{29}$ of joint venture overeenkomsten sluiten, ${ }^{30}$ waarin partijen meer concrete afspraken met betrekking tot hun samenwerking maken. Daarnaast komt het voor dat partijen afspraken over stemgedrag bij het nemen van bepaalde besluiten in de algemene vergadering maken. De aandeelhouders, als partijen bij de overeenkomst, zijn aldus contractueel gebonden. Dat is een andere grondslag van verbondenheid en verhouding dan de verhouding waarin de rechtspersoon en degenen die krachtens de wet en de statuten bij zijn organisatie zijn betrokken in de zin van art. 2:8 BW. Het enkele feit dat iemand aandeelhouder in een vennootschap is en met die vennootschap in een lidmaatschapverhouding staat, maakt dat art. 2:8 BW van toepassing is.

Op het eerste gezicht lijkt het dat de vennootschappelijke verhouding en in dat kader de vennootschappelijke redelijkheid en billijkheid een wat lossere verhouding zou zijn dan de contractuele gebondenheid en verhouding ingeval van een aandeelhoudersovereenkomst. Het is de vraag of dat juist is, bezien in het licht van de eerder geschetste 'quasi-vof'. In de eerste plaats schetste ik het karakter van de BV:

25 Zie ook Van der Sangen 2003, p. 33.

26 Verdam 1995, p. 247; Maeijer 2000, p. 287 en Hof Amsterdam (OK) 16 maart 1995, JOR 1996, 54 m.nt. Van den Ingh (Holstar), r.o. 5.3: "De omzet en de winst van Holstar B.V. moesten behaald worden door de loyale inzet van beide directeuren/aandeelhouders en het gaat niet aan dat een van beiden, te weten Ramp, zelfs nog voordat de samenwerking van hen beiden in het verband van de vennootschap op een behoorlijke wijze beëindigd was, concurrerende activiteiten is gaan ontwikkelen, de samenwerking abrupt feitelijk heeft beëindigd en de activiteiten die hij tot dan in het kader van de vennootschap bedreef toen voor zich en samen met anderen is gaan bedrijven in volle concurrentie met de vennootschap. Deze gedragingen, die schade opleverden voor zowel de vennootschap als ook voor Lensen, zijn in strijd met de redelijkheid en billijkheid die Ramp jegens de vennootschap en jegens Lensen in acht behoorde te nemen.”. Vgl. HR 19 oktober 1990, NJ 1991, 21, m.nt. Ma (Akkoca).

27 Ontleend aan M.J.G.C. Raaijmakers 1991 (1), p. 207-210.

28 Verdam 1995, p. 83-87. Zie ook bijvoorbeeld M.J.G.C. Raaijmakers 1991 (1), p. 207-210 en M.J.G.C. Raaijmakers 1994, p. 79.

29 De wetgever heeft bij invoering van de flex-BV vastgehouden aan het onderscheid tussen statuten en aandeelhoudersovereenkomsten. Incorporation by reference wordt niet toegestaan. Zie Kamerstukken II 2006/07, 31 058, nr. 3, p. 15 (MvT). Zie voor de nuance in de rechtspraak Hof Amsterdam (OK) 20 mei 1999, NJ 2000, 199, JOR 2000, 72 (Cromwilld/Versatel) en Hof Amsterdam (OK) 8 mei 2002, JOR 2002, 112, m.nt. Blanco Fernández (Broadnet).

30 Of die samenwerking in dat geval als een maatschap gekwalificeerd kan worden, laat ik buiten beschouwing. Zie daarover Verdam 1995, p. 239-243, met verwijzingen naar literatuur. 
beslotenheid, gericht op samenwerken en loyaliteit. In de tweede plaats gelden gelet op dat karakter versterkte normen van redelijkheid en billijkheid. ${ }^{31}$ Dat geldt ook in joint venture verhoudingen. ${ }^{32}$ In de derde plaats kleuren aandeelhoudersovereenkomsten de samenwerking en de vennootschappelijke redelijkheid en billijkheid in. ${ }^{33}$ Met andere woorden: van een 'lossere' verhouding is naar mijn mening geen sprake.

\subsubsection{Beslotenheid van de (flex-)BV}

Tijdens de parlementaire behandeling van het wetsvoorstel van de flex-BV heeft de wetgever aandacht besteed aan het besloten karakter van de BV. ${ }^{34}$ De wetgever stelt dat de BV zich in de praktijk heeft ontwikkeld tot een rechtsvorm die met name wordt gebruikt in besloten verhoudingen. Door de afschaffing van de verplichte blokkeringsregeling van art. 2:195 (oud) $\mathrm{BW}^{35}$ kan echter een belangrijk middel, dat de beslotenheid van de BV vormgeeft, verdwijnen. Niettemin heeft de wetgever als hoofdregel gekozen voor een aanbiedingsregeling in art. 2:195 BW. Art. 2:195 lid $1 \mathrm{BW}$ bepaalt dat voor een geldige overdracht van aandelen vereist is dat de aandeelhouder die een of meer aandelen wil vervreemden, deze eerst aanbiedt aan zijn mede-aandeelhouders naar evenredigheid van het aantal aandelen dat ten tijde van de aanbieding door ieder van hen wordt gehouden, tenzij de statuten anders bepalen. Aan houders van aandelen van een bepaalde soort of aanduiding waaraan ingevolge een statutaire regeling geen stemrecht of recht op deling in de winst of reserves toekomt, kunnen slechts aandelen van dezelfde soort of aanduiding worden aangeboden. Ook hiervan kan statutair worden afgeweken. De aandeelhouder ontvangt, indien hij dit verlangt, van de mede-aandeelhouders een prijs, gelijk aan de waarde van zijn aandeel of andelen, vastgesteld door een of meer onafhankelijke deskundigen. Indien vaststaat dat niet al de aandelen waarop het aanbod betrekking heeft tegen contante betaling worden gekocht, zal de aanbieder de aandelen binnen drie maanden na die vaststelling vrijelijk mogen overdragen. De overdraagbaarheid van aandelen kan bij de statuten ook voor een bepaalde termijn worden uitgesloten. Voor een dergelijke regeling is de instemming vereist van alle houders van aandelen waarop de uitsluiting van de overdraagbaarheid betrekking heeft, zo bepaalt art. 2:195 lid 3 BW. De overdraagbaarheid van aandelen kan bij de statuten ook op andere wijze dan overeenkomstig art. 2:195 lid 1 of lid 3 BW worden beperkt. Een overdracht in strijd met een statutaire beperking is ongeldig. Een dergelijke statutaire regeling moet zodanig zijn dat een aandeelhouder die zijn aandelen wil overdragen, indien hij dit verlangt, een prijs ontvangt, gelijk aan de

31 Van der Sangen 2003, p. 34.

32 Hof Amsterdam (OK) 20 mei 1999, NJ 2000, 199, JOR 2000, 72, m.nt. Blanco Fernández (Cromwilld/Verstatel).

33 Van der Sangen 2003, p. 39.

34 Kamerstukken II 2006/07, 31 058, nr. 3, p. 12-17 (MvT).

35 Zie Bijlage 2. 
waarde van zijn aandeel of aandelen, vastgesteld door een of meer onafhankelijke deskundigen. De statuten kunnen voorzien in een daarvan afwijkende prijsbepalingsregeling, welke regeling niet aan een aandeelhouder tegen zijn wil kan worden opgelegd. Bepalingen in de statuten omtrent de overdraagbaarheid van aandelen vinden geen toepassing, indien de overdracht door die bepalingen onmogelijk of uiterst bezwaarlijk is, tenzij dit het gevolg is van een statutaire uitsluiting als bedoeld in lid 3 of een statutaire prijsbepalingsregeling waaraan de aandeelhouder is gebonden, zo bepaalt art. 2:195 lid 5 BW. Indien de aandeelhouder krachtens de wet tot overdracht van zijn aandeel aan een eerdere houder verplicht is, vinden art. 2:195 lid $1 \mathrm{BW}$ en bepalingen in de statuten omtrent overdraagbaarheid geen toepassing.

De hoofdregel van lid 1 is dus de aanbiedingsregeling. Van deze hoofdregel kan bij statuten worden afgeweken, in die zin dat sprake is van een beperking of tijdelijke uitsluiting van de overdraagbaarheid (lid 3 en 4). Art. 2:195 lid 3 BW staat er niet aan in de weg dat de uitsluiting van de overdraagbaarheid wordt beperkt tot aandelen van een bepaalde soort of aanduiding. ${ }^{36}$ Dat geldt dus ook voor stemrechtloze aandelen. Overdraagbaarheid kan niet geheel worden uitgesloten of uiterst bezwaarlijk worden gemaakt (lid 5). Ook kan worden bepaald dat in het geheel geen aanbiedingsregeling geldt. ${ }^{37}$ Indien van een dergelijke, statutaire afwijking geen sprake is, geldt de wettelijke aanbiedingsregeling en is voor een geldige overdracht vereist dat de aandeelhouder zijn aandelen eerst aanbiedt aan zijn medeaandeelhouders.

De wetgever heeft geen verandering gebracht in het feit dat aandelen in een BV op naam luiden, zodat bekend is wie de aandeelhouders zijn. ${ }^{38}$ Aandelen aan toonder zijn niet toegestaan. Dat past bij een rechtsvorm waarin de betrokkenen relatief veel ruimte hebben om hun onderlinge verhoudingen naar eigen inzicht vorm te geven. Bovendien komt daarmee het besloten karakter van de BV tot uitdrukking. Daarnaast leidt de aanbiedingregeling en de verplichte op naam stelling van aandelen tot voldoende onderscheid ten opzichte van de NV, aldus de wetgever. ${ }^{39}$ Aandeelhouders kunnen verder vorm geven aan het besloten karakter van de BV door de wettelijke bepalingen inzake statutaire verplichtingen (art. 2:192 BW), statutaire verplichtingen tot aanbieding en overdracht (art. 2:195a BW) en statutaire eisen aan het aandeelhouderschap (art. 2:195b BW). Wat betreft de

36 Kamerstukken II 2008/09, 31 058, nr. 6, p. 13 (NV II). Zie ook Kamerstukken II 2008/09, 31 058, nr. 7, p. 14 (Nota van wijziging).

37 Kamerstukken II 2006/07, 31 058, nr. 3, p. 13 en 49 (MvT).

$38 \mathrm{Vgl}$. art. 2:194 BW: de verplichting tot het bijhouden van een aandeelhoudersregister. Kamerstukken II 2008/09, 31 058, nr. 6, p. 20 (NV II).

39 Kamerstukken II 2006/07, 31 058, nr. 3, p. 12-13 en 49-53 (MvT). In Kamerstukken II 2008/09, 31 058, nr. 6 (NV II), p. 20, verwoordt de wetgever het besloten karakter als volgt: "Dat de flexibele $b v$ is toegesneden op besloten verhoudingen blijkt ook uit het voorgestelde artikel 195, waarin als wettelijk uitgangspunt is opgenomen dat een aandeelhouder die een of meer van zijn aandelen wil overdragen, deze eerst moet aanbieden aan zijn medeaandeelhouders." en op p. 22: "Een blokkeringsregeling is bedoeld om in de interne verhoudingen de beslotenheid te waarborgen (...)." 
statutaire verplichtingen wordt meer vrijheid geboden ten aanzien van de inwerkingtreding, sanctionering en ontheffing van statutaire verplichtingen en wordt het mogelijk gemaakt verplichtingen tussen aandeelhouders onderling of jegens derden in de statuten op te nemen (art. 2:192 BW), aldus de wetgever. ${ }^{40}$

\subsubsection{Conclusie}

De conclusie is dat ook in de flex-BV de beslotenheid een van de factoren is die de interne verhoudingen bepaalt. Datzelfde geldt voor de aard van de samenwerking in of door middel van de BV. Beide factoren, doch niet uitsluitend deze factoren, vullen de (rechts)normen in de interne verhoudingen in. Ik ga op deze normen in hoofdstuk $7 \mathrm{in}$.

\subsection{Het vennootschappelijk belang}

\subsubsection{Inleiding}

In paragraaf 5.2 stipte ik in het kader van het derde agency problem het vennootschappelijk belang aan. Het bestuur en de raad van commissarissen van een BV moeten bij de uitoefening van hun taken het belang van de door de vennootschap gedreven onderneming nastreven. ${ }^{41}$ Het bestuur moet de belangen afwegen van hen die bij de vennootschap zijn betrokken. ${ }^{42}$ Over wat het begrip "vennootschappelijk belang' inhoudt, zwijgt de wet. ${ }^{43}$ Er bestaan in de literatuur verschillende opvattingen over dat begrip: $:^{44}$ de holistische opvatting, de resultante-benadering, een combinatie van deze opvattingen en de - door Eijsbouts genoemde ${ }^{45}$ - leer van de leegte. Ik bespreek deze opvattingen achtereenvolgens in de volgende paragrafen.

40 Kamerstukken II 2006/07, 31 058, nr. 3, p. 13 (MvT). Op p. 14 en 15 van de MvT wordt dit verder toegelicht.

41 HR 1 april 1949, NJ 1949, 465, m.nt. Ph.A.N.H. (Doetinchemse IJzergieterij).

42 Bevestigd in HR 13 juli 2007, LJN BA7972, NJ 2007, 434, m.nt. Ma, JOR 2007, 178, m.nt. Nieuwe Weme (ABN AMRO), r.o. 4.5. Ook indien sprake is van mogelijke verkoop van een onderneming (of een deel daarvan) of fusie 'geldt dat het bestuur bij de vervulling van zijn bij wet of statuten opgedragen taken het belang van de vennootschap en de daaraan verbonden onderneming behoort voorop te stellen en de belangen van alle betrokkenen, waaronder die van de aandeelhouders, bij zijn besluitvorming in aanmerking behoort te nemen.' Zie ook HR 9 juli 2010, LJN BM0976, NJ 2010, 544, m.nt. Van Schilfgaarde, JOR 2010, 228, m.nt. Van Ginneken (ASMI), r.o. 4.4.1.

43 Wel noemt de wet op diverse plaatsen 'het vennootschappelijk belang'. Zie voor de BV bijvoorbeeld art. 2:217 lid 2, 2:224a lid 1, 2:250 lid 2, 2:336 lid 1 en 2:342 BW.

44 Zie voor een overzicht van de verschillende opvattingen Asser/Maeijer, Van Solinge \& Nieuwe Weme 2-II* 2009, nr. 394; Schwarz 1995, p. 529; Delfos-Roy 1997, p. 9-23; Slagter 2005, p. 10-21; Assink 2010, p. 36-47; Eijsbouts 2010, p. 69-72; Bulten 2011, p. 66 en Eijsbouts \& Kemp 2012, p. 127-131. Zie ook Eijsbouts 2011, p. 49-50, die in het kader van maatschappelijk verantwoord ondernemen een enlightened shareholder value naar Brits voorbeeld voorstelt. Zie over het vennootschappelijk belang in concernverband Bartman \& Dorresteijn 2009, p. 24-27. 


\subsubsection{De holistische opvatting}

Een aantal schrijvers hangt de holistische opvatting van het vennootschappelijk belang aan. Maeijer is aanhanger van het vennootschappelijk belang als een zelfstandig belang. De vennootschap heeft belang bij haar eigen gezonde bestaan, uitgroei en voortbestaan met het oog op het door haar te bereiken doel. Onder dat belang valt ook de continuïteit van de door de vennootschap gedreven onderneming en de daarin werkzame werknemers. ${ }^{46}$ Mendel heeft een met Maeijer vergelijkbare opvatting en noemt deze opvatting holistisch. ${ }^{47}$ Ook Delfos-Roy en Slagter zijn onder de holistische opvatting te scharen. Zij stellen dat het belang van de vennootschap wordt bepaald door het vennootschappelijke doel en de continuïteit op de lange termijn. Het maken van winst is een korte termijn gedachte dat een noodzakelijke voorwaarde is van de continuïteit van de vennootschap op lange(re) termijn. ${ }^{48}$ Het vennootschappelijk belang varieert naar de aard en de omvang van de vennootschap en is geen optelsom van de deelbelangen van de bij de vennootschap betrokkenen, zoals aandeelhouders, werknemers, leveranciers, afnemers, schuldeisers, banken, overheid etc. Daarbij kan niet worden volstaan met een afweging tussen de belangen van de bij de vennootschap betrokkenen, omdat een vennootschap rechtspersoonlijkheid heeft en aldus zelfstandig rechten en verplichtingen draagt. Een vennootschap heeft aldus een eigen belang, dat slechts deels afhankelijk is van de belangen van de bij de vennootschap betrokkenen, meer in het bijzonder van haar aandeelhouders. ${ }^{49}$ Slagter betrekt bovendien de aard van de door de vennootschap gedreven onderneming bij het vennootschappelijk belang. Slagter noemt als voorbeelden dat bij een beleggingsmaatschappij of een praktijkvennootschap het vennootschappelijk belang bijna identiek aan het belang van de collectiviteit van de aandeelhouders is en dat bij een kleine vennootschap of bij een kapitaalintensieve (grote) vennootschap de belangen van de aandeelhouders zwaarder wegen dan bij een grote industriële, arbeidsintensieve vennootschap. ${ }^{50}$ Begrijp ik Assink goed, dan sluit ook hij zich aan bij de holistische opvatting, daar waar hij spreekt van het belang van een autonoom begrip 'belang van de vennootschap. ${ }^{51}$ Ook Eijsbouts \& Kemp zijn voorstanders van deze leer. ${ }^{52}$

45 Eijsbouts 2010, p. 69.

46 Maeijer 1990, p. 465 en Maeijer 2000, p. 282-284.

47 Mendel 1989, p. 10 en 14 en de reactie van Maeijer 1990, p. 466, daarop.

48 Ook hierin komt de tegenstelling tussen het (meer Angelsaksische) shareholders- en het (meer Europese) stakeholdersmodel terug.

49 Delfos-Roy, p. 9-20 en Slagter 2005, par. 2, p. 12-14 en het schema op p. 20. In gelijke zin Hammerstein 2011, p. 600.

50 Slagter 2005 , p. 12.

51 Assink 2010, p. 47. Dat leid ik ook af uit Assink 2009, p. 60-61. Assink 2010, p. 47, lijkt daarmee afstand te doen van de resultante benadering, die hij eerder verdedigde; zie Assink 2007, p. 79-80.

52 Eijsbouts \& Kemp 2012, p. 129. 


\subsubsection{De resultante-benadering}

Een andere opvatting ten aanzien van het vennootschappelijk belang kan de resultante-benadering zijn. Het vennootschappelijk belang is de resultante van de afweging van alle betrokken deelbelangen. Deze opvatting wordt onder meer aangehangen door Van Solinge \& Nieuwe Weme, Van Schilfgaarde \& Winter en Vletter-van Dort. ${ }^{53}$ Uitgegaan wordt van de concrete omstandigheden van het geval, waarbij de belangen van de aandeelhouders, de werknemers, de leveranciers, de afnemers, de schuldeisers, de banken, de overheid en de continuïteit van de onderneming worden meegewogen. Afhankelijk van de omstandigheden van het geval wordt bepaald welk deelbelang in dat geval prevaleert. Daarbij zijn ook de aard van de onderneming en de aard van het aandeelhouderschap van belang. Het belang van de vennootschap is niet gelijk aan het belang van de aandeelhouders. ${ }^{54}$

\subsubsection{De gecombineerde opvatting}

In de literatuur zijn ook voorstanders van een combinatie van beide opvattingen te vinden. ${ }^{55}$ Van Ginneken en Timmerman stellen dat het vennootschappelijk belang neerkomt op het creëren van lange termijn aandeelhouderswaarde, zoals vastgelegd in het beleid en de strategie, waarbij sprake is belangenpluralisme en alle betrokken belangen worden afgewogen. ${ }^{56}$ In deze opvatting ligt aldus het accent op de lange termijn aandeelhouderswaarde. Ook Verdam is een voorstander van deze 'enlightened shareholder value', zij het dat Verdam eerst 'de ondernemende vennootschap als goedlopende en renderende onderneming' voorop stelt. Aan de belangen van de aandeelhouders komt afhankelijk van de omstandigheden van het geval bij conflicterende belangen een groot gewicht toe. ${ }^{57}$

53 Van Solinge \& Nieuwe Weme als huidige bewerkers van Asser/Maeijer, Van Solinge \& Nieuwe Weme 2-II* 2009, nr. 394 (slot) en nr. 395; Van Schilfgaarde \& Winter 2009, p. 27-29 en Vletter-van Dort 2001, p. 58. Vletter-van Dort kiest voor de resultante-benadering, 'waartoe ook het belang bij het bevorderen van de door de vennootschap gedreven onderneming behoort'.

54 HR 1 april 1949, NJ 1949, 465, m.nt. Ph.A.N.H. (Doetinchemse IJzergieterij).

55 Bier 2012 (2), p. 194, die van mening is dat voor beide opvattingen - de holistische opvatting en de resultante benadering - wat te zeggen valt.

56 Timmerman 2009 (1), p. 7, spreekt over de 'enlightened shareholder value' (met reactie van De Kluiver 2009, p. 19-20 en naschrift van Timmerman 2009 (2), p. 25) en Van Ginneken \& Timmerman 2011, p. 604. De Jongh 2011, p. 611, spreekt liever van duurzame waardereactie om de maatschappelijke inbedding van de onderneming te benadrukken en om te voorkomen dat het lange termijn belang mogelijk zou moeten wijken voor een (financieel) voordeel op korte termijn.

57 Verdam 2013, p. 100-101. 


\subsubsection{De leer van de leegte}

Onder meer Winter spreekt over het vennootschappelijk belang als een lege norm, die geen richting geeft. ${ }^{58}$ Het is een inhoudsloos begrip. Het is de aandeelhouder die de overwegende zeggenschap in de vennootschap heeft, die het begrip inhoud geeft.

\subsubsection{Functie van het vennootschappelijk belang}

In de literatuur wordt opgemerkt dat het vennootschappelijk belang als richtsnoer voor het handelen van (onder meer) bestuurders geldt. Assink noemt het vennootschappelijk belang een dwingendrechtelijke hoeksteen van het ondernemingsrech $t^{59}$ of richtsnoer. ${ }^{60}$ Er is sprake van een open norm, die in een concrete situatie zal resulteren in een juiste belangenafweging met een redelijke en billijke uitkomst. ${ }^{61}$ Daarmee wordt naar mijn mening tot uitdrukking gebracht dat besluitvorming door het bestuur op basis van de open norm van het vennootschappelijk belang (onder meer) getoetst wordt an de vennootschappelijke redelijkheid en billijkheid van art. 2:8 BW.

Uit de rechtspraak volgt dat bij het bepalen wat het vennootschappelijk belang is ook het doel van de vennootschap betrokken moet worden ${ }^{62}$. Daarnaast volgt uit rechtspraak dat een besluit gelet op het vennootschappelijk belang genomen mag worden ook al botst dat met het belang van een of meerdere aandeelhouders. ${ }^{63}$ Ook uit deze rechtspraak volgt dat het vennootschappelijk belang de functie van een richtsnoer heeft.

\subsubsection{Het vennootschappelijk belang in de flex- $B \mathrm{~V}$}

De wetgever heeft bij invoering van de flex-BV de institutionele opvatting - de opvatting die uitgaat van de vennootschap als zelfstandige organisatie - en het daarbij behorende vennootschappelijke belang gehandhaafd, zij het dat de wetgever met de Expertgroep constateert dat de BV (intussen) minder als institutioneel fenomeen en meer als contractueel verband tussen aandeelhouders wordt gezien. ${ }^{64}$ In paragraaf 2.4 besprak ik de uitgangspunten bij de herziening van het BV-recht. Een van die uitgangspunten was meer vrijheid voor aandeelhouders om de onderneming naar eigen inzicht en wensen vorm te geven met voldoende waarborgen voor de belangen van andere partijen, in het bijzonder het belang van

58 Winter 2007, p. 132-133. Zie verder Eijsbouts \& Kemp 2012, p. 128.

59 Assink 2010, p. 37.

60 Assink 2009, p. 61.

61 Asser/Maeijer, Van Solinge \& Nieuwe Weme 2-II* 2009, nr. 394 (slot) en Bulten 2011, p. 67.

62 HR 20 september 1996, NJ 1997, 149, JOR 1996, 119 (Playland). Zie ook Stienstra 2005, p. 23.

63 HR 1 april 1949, NJ 1949, 465, m.nt. Ph.A.N.H. (Doetinchemse IJzergieterij).

64 Kamerstukken II 2006/07, 31 058, nr. 3, p. 1 (MvT). Zie ook Kamerstukken II 2009/10, 32 426, nr. 3 , p. 1 (MvT). 
minderheidsaandeelhouders. In de memorie van toelichting wordt gesteld dat een evenwicht moet worden gevonden tussen enerzijds meer vrijheid van inrichting voor de aandeelhouders en anderzijds de belangen van andere partijen. De wetgever memoreert het algemene uitgangspunt dat 'het bestuur en de raad van commissarissen zich bij hun handelen moeten richten naar het belang van de vennootschap en de met haar verbonden onderneming. Dat belang vereist dat in de besluitvorming tevens de belangen van andere partijen die bij de vennootschap zijn betrokken worden meegewogen, zoals werknemers, afnemers en leveranciers. De grotere flexibiliteit van de flex-BV zal de invulling van het vennootschappelijk belang kunnen kleuren', aldus de wetgever. Meer in het bijzonder stelt de wetgever daarover: "Bij kleine vennootschappen met een beperkt aantal aandeelhouders zal het vennootschappelijk belang dichter liggen bij het belang van de aandeelhouders dan bij een grote vennootschap met veel werknemers en maatschappelijke belangen." ${ }^{\circ 5}$ en "Het belang van de vennootschap waarborgt dat bij de besluitvorming rekening wordt gehouden met de belangen van alle partijen die bij de vennootschap zijn betrokken en draagt aldus bij aan het vinden van een evenwicht tussen vrijheid van inrichting en bescherming van andere belangen in het wetsvoorstel. Hierbij past de belangrijke kanttekening dat het vennootschappelijk belang bij kleinere vennootschappen met slechts één of enkele aandeelhouders dichter zal liggen bij het belang van de aandeelhouders dan bij een grote vennootschap met een verspreid aandeelhouderschap en meer uiteenlopende belangen." 66 Daarbij merkt de wetgever op dat het belang van de vennootschap in de statuten nader kan worden beschreven. Dat mag er echter niet toe leiden dat belangen van bepaalde partijen worden weggeschreven. ${ }^{67}$

Door de Wet bestuur en toezicht ${ }^{68}$ is een lid 5 aan art. 2:239 BW toegevoegd, dat luidt: "Bij de vervulling van hun taak richten de bestuurders zich naar het belang van de vennootschap en de met haar verbonden onderneming." De parlementaire geschiedenis licht toe: "Het voorgestelde lid 5 legt de norm voor het handelen van iedere bestuurder vast. Bij de vervulling van hun taak richten de bestuurders zich naar het belang van de vennootschap en de met haar verbonden onderneming. Daarbij maakt het niet uit of zijn taak uitvoerend of algemeen/toezichthoudend is." 69 Later overweegt de wetgever: "Het bestuur en de raad van commissarissen van een NV/BV hebben op grond van de wet de opdracht om zich te richten naar het

65 Voor dit alles: Kamerstukken II 2006/07, 31 058, nr. 3, p. 3 (MvT).

66 Kamerstukken II 2008/09, 31 058, nr. 6, p. 12-13 en 52 (NV II).

67 Kamerstukken II 2008/09, 31 058, nr. 6, p. 13 (NV II).

68 Wet van 6 juni 2011 tot wijziging van boek 2 van het Burgerlijk Wetboek in verband met de aanpassing van regels over bestuur en toezicht in naamloze en besloten vennootschappen, Kamerstukken 31 763, Stb. 2011, 275 en Wet van 27 september 2012 tot wijziging van boek 2 van het Burgerlijk Wetboek ter verduidelijking van de artikelen 297a en 297b, Kamerstukken 32 873, Stb. 2012, 440. Beide in werking getreden op 1 januari 2013, Stb. 2012, 455 resp. 456.

69 Kamerstukken II 2008/09, 31 763, nr. 3, p. 10 (MvT). Zie verder Kamerstukken II 2008/09, 31 763, nr. 6, p. 19 e.v. (NV II). 
belang van de vennootschap en de daarmee verbonden onderneming. Zij moeten de hiervoor bedoelde verschillende belangen behoorlijk afwegen bij de vervulling van hun taak. In de regel moeten zij zich richten op de continuïteit van de onderneming voor de langere termijn. Het voortbestaan van ondernemingen is van groot belang voor de werkgelegenheid en het behoud van inkomen van de Nederlandse beroepsbevolking. In meer brede zin is een goed en verantwoord bestuur van ondernemingen ook van groot belang voor het welzijn van burgers en instellingen, bijvoorbeeld omdat zij in ondernemingen beleggen of doordat ondernemingsactiviteiten invloed hebben op het leefmilieu. Het voorgaande geldt voor beursvennootschappen maar evenzeer voor vennootschappen zonder beursnotering." 70 en "Dat betekent dat de bestuurders en commissarissen onder meer de belangen van kapitaalverschaffers, werknemers, crediteuren en andere contractspartijen moeten afwegen. Het belang van de aandeelhouders mag derhalve niet automatisch voorop worden gesteld."71

\subsubsection{Conclusie}

Het vennootschappelijk belang dient als richtsnoer voor het handelen van het bestuur en de raad van commissarissen van de BV. De wetgever lijkt uit te gaan van de gecombineerde opvatting van het vennootschappelijk belang.

\subsection{De dualistische structuur van de BV en de instructiebevoegdheid van de algemene vergadering}

\subsubsection{Inleiding}

Eerder stelde ik aan de orde dat de aandeelhouder bij het uitoefenen van zijn stemrecht in beginsel zijn eigen belang voorop mag stellen. Dat eigen belang hoeft niet parallel te lopen met het vennootschappelijk belang en raakt de dualistische structuur van de BV die ik in paragraaf 3.3 besprak. Op die plaats ging ik kort in op de instructiebevoegdheid van de algemene vergadering. De instructiebevoegdheid van de algemene vergadering raakt ook de in dit hoofdstuk te bespreken interne verhoudingen. De kapitaalverschaffer zonder stemrecht ziet zich geconfronteerd met kapitaalverschaffers met stemrecht die door middel van de instructiebevoegdheid invloed op het bestuur en de vennootschap kunnen uitoefenen. ${ }^{72}$ In dat kader is de vraag in hoeverre het bestuur instructies dient op te volgen en met welke belangen, waaronder bijvoorbeeld die van de kapitaalverschaffer zonder stemrecht, het bestuur rekening moet houden.

70 Kamerstukken II 2008/09, 31 763, nr. 6, p. 1-2 (NV II).

71 Kamerstukken II 2008/09, 31 763, nr. 6, p. 9 (NV II).

72 Daarbij ga ik ervan uit dat op grond van art. 2:239 lid $4 \mathrm{BW}$ niet in de statuten is bepaald dat de vergadering van houders van stemrechtloze aandelen het bestuur instructies kan geven. 


\subsubsection{Bestuursautonomie}

Behoudens beperkingen volgens de statuten is het bestuur belast met het besturen van de vennootschap. ${ }^{73}$ Het bestuur is autonoom in de uitoefening van zijn taak en bevoegdheden. ${ }^{74}$ Recente(re) rechtspraak heeft dit nogmaals bevestigd. ${ }^{75}$ Uit het ABN AMRO-arrest ${ }^{76}$ volgt dat (i) het bepalen van de strategie van een vennootschap en de daaraan verbonden onderneming in beginsel een aangelegenheid is van het bestuur van de vennootschap, (ii) de raad van commissarissen daarop toezicht houdt, (iii) de algemene vergadering van aandeelhouders haar opvattingen terzake tot uitdrukking kan brengen door uitoefening van de haar in wet en statuten toegekende rechten (in het algemeen betekent dit laatste dat het bestuur van een vennootschap aan de algemene vergadering van aandeelhouders verantwoording heeft af te leggen van zijn beleid maar dat het, behoudens afwijkende wettelijke of statutaire regelingen, niet verplicht is de algemene vergadering vooraf in zijn besluitvorming te betrekken als het gaat om handelingen waartoe het bestuur bevoegd is), en (iv) het bestuur bij de vervulling van zijn bij wet of statuten opgedragen taken het belang van de vennootschap en de daaraan verbonden onderneming behoort voorop te stellen en de belangen van alle betrokkenen, waaronder die van de andeelhouders, bij zijn besluitvorming in aanmerking behoort te nemen.

Deze autonomie schept ook verantwoordelijkheid en in voorkomend geval aansprakelijkheid, bijvoorbeeld jegens de vennootschap. Art. 2:9 BW brengt deze aspecten tot uitdrukking. Elke bestuurder is tegenover de rechtspersoon gehouden tot een behoorlijke vervulling van zijn taak. Tot de taak van de bestuurder behoren alle bestuurstaken die niet bij of krachtens de wet of de statuten aan een of meer andere bestuurders zijn toebedeeld. Elke bestuurder draagt verantwoordelijkheid voor de algemene gang van zaken. Hij is voor het geheel aansprakelijk terzake van onbehoorlijk bestuur, tenzij hem mede gelet op de aan anderen toebedeelde taken

73 Art. 2:239 lid $1 \mathrm{BW}$.

74 HR 21 januari 1955, NJ 1959, 43, m.nt. HB (Forumbank) en Asser/Maeijer, Van Solinge \& Nieuwe Weme 2-II* 2009, nr. 316.

75 HR 13 juli 2007, LJN BA7972, NJ 2007, 434, m.nt. Ma, JOR 2007, 178, m.nt. Nieuwe Weme (ABN AMRO), r.o. 4.3 en 4.5; HR 9 juli 2010, LJN BM0976, NJ 2010, 544, m.nt. Van Schilfgaarde, JOR 2010, 228, m.nt. Van Ginneken (ASMI), r.o. 4.4.1; Hof Amsterdam (OK) 17 januari 2007, LJN AZ6440, JOR 2007, 42, m.nt. Blanco Fernández (Stork), r.o. 3.14; Hof Amsterdam (OK) 9 maart 2000, JOR 2000, 99 (Te Pas/Willem III); Rb. Utrecht 15 maart 2000, JOR 2000, 233 m.nt. Van den Ingh (Unirobe/Geense Beheer); Rb. Leeuwarden 12 november 1987, NJ 1988, 699 (Dirkse/ Interpolacel) en Vzr. Rb. 's-Gravenhage 7 augustus 2002, JOR 2002, 173, m.nt. Van den Ingh (Wittke/NEM). Zie ook Kamerstukken II 2006/2007, 31 058, nr. 3, p. 90 (MvT).

76 HR 13 juli 2007, LJN BA7972, NJ 2007, 434, m.nt. Ma, JOR 2007, 178, m.nt. Nieuwe Weme (ABN AMRO), r.o. 4.3 en 4.5 . 
geen ernstig verwijt kan worden gemaakt en hij niet nalatig is geweest in het treffen van maatregelen om de gevolgen van onbehoorlijk bestuur af te wenden. ${ }^{77}$

\subsubsection{Instructiebevoegdheid van de algemene vergadering}

De instructiebevoegdheid van de algemene vergadering vindt haar grondslag in art. 2:239 lid 4 BW. $^{78}$ Dat artikellid stelt dat de statuten kunnen bepalen dat het bestuur zich dient te gedragen naar de aanwijzingen van een ander orgaan van de vennootschap. Het bestuur is gehouden de aanwijzingen op te volgen, tenzij deze in strijd zijn met het belang van de vennootschap en de met haar verbonden onderneming. Hieruit volgt dat de dualistische structuur in de flex-BV is gehandhaafd en dat de algemene vergadering een instructiebevoegdheid kan hebben. Tegelijkertijd is de instructiebevoegdheid (niettemin) een inbreuk op de dualistische structuur en de autonomie van het bestuur. ${ }^{79}$ De wetgever heeft overigens de aandeelhouderbestuurde BV afgewezen, omdat dat zich niet goed verhoudt met het uitgangspunt dat het bestuur van de vennootschap het vennootschappelijk belang moet dienen. ${ }^{80}$ Dat laatste brengt de wettekst ook tot uitdrukking. De parlementaire geschiedenis stelt: "Het onderscheid tussen algemene en concrete aanwijzingen komt te vervallen. Het bestuur is gehouden om de aanwijzingen op te volgen, tenzij dat in strijd is met het belang van de vennootschap en de met haar verbonden onderneming. Het bestuur mag derhalve de instructies van een ander orgaan niet slaafs navolgen, maar dient een zelfstandige belangenafweging uit te voeren. In concernverhoudingen betekent dit dat het bestuur van de dochter de instructies van de moeder als aandeelhouder dient te toetsen aan het belang van de dochtervennootschap. Op advies van de expertgroep is in de wettelijke bepaling expliciet tot uitdrukking gebracht dat het bestuur niet gehouden is de aanwijzingen op te volgen indien dat in strijd is met het belang van de vennootschap. Volgens de expertgroep sluit dit aan bij de praktijk, met name in situaties waarin aan buitenlandse

77 De tekst van art. 2:9 BW, zoals die luidt na inwerkingtreding van de Wet vereenvoudiging en flexibilisering bv-recht, de Invoeringswet vereenvoudiging en flexibilisering bv-recht en de Wet Bestuur en Toezicht (Wet van 6 juni 2011 tot wijziging van boek 2 van het Burgerlijk Wetboek in verband met de aanpassing van regels over bestuur en toezicht in naamloze en besloten vennootschappen, Kamerstukken 31 763, Stb. 2011, 275 en Wet van 27 september 2012 tot wijziging van boek 2 van het Burgerlijk Wetboek ter verduidelijking van de artikelen 297a en 297b, Kamerstukken 32 873, Stb. 2012, 440. Beide in werking getreden op 1 januari 2013, Stb. 2012, 455 resp. 456.).

78 Zie over de instructiebevoegdheid ook Bartman \& De Groot 2012.

79 Oranje 2008 (1), p. 26, merkt op dat de autonomie van het bestuur moet worden gerelativeerd. Zo kan de algemene vergadering ruimschoots van haar instructiebevoegdheid gebruik maken. In dat geval is het bestuur slechts uitvoerend. Daarnaast kan de algemene vergadering het bestuur ontslaan. Zie onder meer HR 21 december 2001, LJN AD4499, NJ 2005, 96, m.nt. S.C.J.J. Kortmann, JOR 2002, 38, m.nt. Faber en Bartman (SOBI/Hurks).

80 Kamerstukken II 2006/07, 31 058, nr. 3, p. 10 (MvT). Zie ook Rapport van de Expertgroep, p. 3. Oranje is bijvoorbeeld voorstander van een aandeelhouderbestuurder BV, zie Oranje 2008 (1), p. 24-33 en Oranje 2008 (2), p. 7. 
aandeelhouders duidelijkheid moet worden verschaft omtrent de reikwijdte van het instructierecht. De commissie vennootschapsrecht heeft terecht opgemerkt dat het vanzelf spreekt dat een instructierecht wordt begrensd door het vennootschappelijk belang. Ik hecht er evenwel aan om ter wille van de duidelijkheid in de praktijk de norm van het vennootschappelijk belang bij het instructierecht in de wet vast te leggen." ${ }^{81}$ De wetgever heeft daarmee de door de Expertgroep gesignaleerde knelpunten en kanttekeningen ten aanzien van de regeling onder het oude recht erkend en de aanbevelingen van de Expertgroep overgenomen. ${ }^{82}$

De stemrechtloze aandeelhouder kan in de algemene vergadering wegens het ontbreken van zijn stemrecht geen directe invloed uitoefenen, waaronder besluiten in de algemene vergadering met betrekking tot de instructiebevoegdheid. Wel kan de stemrechtloze aandeelhouder op grond van zijn vergader- en spreekrecht de besluitvorming tijdens de algemene vergadering (proberen te) beïnvloeden. In voorkomend geval zal het bestuur van de vennootschap ook het belang van de stemrechtloze aandeelhouder in haar afweging tot besluitvorming moeten betrekken. Bovendien zullen de aandeelhouders met stemrecht bij de besluitvorming in de algemene vergadering in het kader van de instructiebevoegdheid ook rekening moeten houden met de gerechtvaardigde belangen van de stemrechtloze aandeelhouder en andere kapitaalverschaffers zonder stemrecht. Het eigen belang van de aandeelhouder is immers niet absoluut. In paragraaf 5.6 ga ik op dit laatste thema nader in.

Met andere woorden: de grens van de instructiebevoegdheid is het vennootschappelijke belang. Het bestuur van de vennootschap is niet per definitie gehouden de instructies van de algemene vergadering op te volgen. In paragraaf 5.4 schetste ik dat het vennootschappelijk belang ruimer en anders is dan alleen het (eigen) belang van de aandeelhouders van de vennootschap. Niettemin spelen bij het vennootschappelijke belang ook de belangen van de aandeelhouders een rol, waaronder de belangen van de stemrechtloze aandeelhouders.

\subsubsection{Instructiebevoegdheid en het orgaanbegrip van art. 2:189a BW}

In het kader van de instructiebevoegdheid wijs ik op deze plaats op het orgaanbegrip als bedoeld in art. 2:189a BW. Onder het begrip 'orgaan' valt ook de vergadering van stemrechtloze aandeelhouders. De statuten kunnen daarom op grond van art. 2:239 lid 4 BW bepalen dat die vergadering het bestuur aanwijzingen mag

81 Kamerstukken II 2006/07, 31 058, nr. 3, p. 90 (MvT). Zie over concernverhoudingen bijvoorbeeld Van der Korst 2010 en M. Olaerts, 'Perikelen in concernverhoudingen', TvOB 2011-1, p. 6-13, met name par. 2 en de aldaar aangehaalde jurisprudentie en literatuur.

82 Zie Rapport van de Expertgroep, p. 34-36, met een overzicht van de jurisprudentie en de opvattingen in de literatuur. Van der Korst 2010, p. 273, is kritisch over de aanbevelingen van de Expertgroep. Hij stelt dat sprake is van een ontoelaatbare inbreuk op de bestuursautonomie, omdat aan het bestuur zijn basale bevoegdheid om beleid en strategie van de vennootschap te bepalen wordt ontrokken. 
geven. In de literatuur is kritiek op art. 2:189a BW geuit. Van den Ingh stelt dat door de verwijzing naar art. 2:239 BW de indruk wordt gewekt dat de instructiebevoegdheid aan alle daarin genoemde organen kan worden toegekend. Hij stelt een beperking tot organen van aandeelhouders voor. ${ }^{83}$ Oranje vindt zelfs dat laatste te ver gaan, omdat daaronder ook wordt begrepen de vergadering van houders van aandelen van een bepaalde soort of aanduiding. De vergadering van houders van aandelen A die een eigen bestuurder A in het bestuur van de vennootschap heeft benoemd, zou niet bevoegd moeten zijn instructies aan het bestuur te geven. ${ }^{84}$ Dat zou - in de gedachtegang van Oranje - inhouden dat ook de vergadering van stemrechtloze aandeelhouders geen instructies aan het bestuur zouden mogen geven.

Naar mijn mening hoeft niet gevreesd te worden voor een te grote invloed van een groep van andeelhouders, omdat de instructiebevoegdheid wordt begrensd door het vennootschappelijk belang (de tenzij-clausule van art. 2:239 lid 4 BW, laatste volzin). Het bestuur moet in beginsel ${ }^{85}$ deze aanwijzingen opvolgen, tenzij dat tegen het belang van de vennootschap en de met haar verbonden onderneming indruist. In de literatuur wordt er mijns inziens terecht op gewezen dat de instructie volgens de wettekst aan het bestuur als orgaan wordt gegeven en niet aan individuele bestuurders kan worden gegeven. Met Boschma \& Kuijers-Tollenaar ben ik van mening dat daarom geen instructiebevoegdheid toekomt ten aanzien van individuele bestuurders in een joint venture-vennootschap, waarbij ieder vergadering van houders van aandelen van een bepaalde soort of aanduiding een bestuurder benoemt, zij het dat diezelfde vergadering in voorkomend geval tot schorsing of ontslag van de betreffende bestuurder kan overgaan. ${ }^{86}$

Bovendien, specifiek gericht op de stemrechtloze aandeelhouder, zijn stemrechtloze aandeelhouders in zekere zin te vergelijken met minderheidsaandeelhouders. Het komt de bescherming van die aandeelhouders ten goede indien de vergadering van stemrechtloze aandeelhouders instructies aan het bestuur van de vennootschap kan geven. Daartoe biedt de wet de mogelijkheid. Bij het voorgaande past echter een kanttekening. De vraag is of in de praktijk snel of vaak gebruik gemaakt zal worden van de mogelijkheid de vergadering van stemrechtloze aandeelhouders instructiebevoegdheid toe te kennen. Indien dat gebeurt, is vervolgens de vraag of, naast de genoemde begrenzing door het vennootschappelijke belang, andere aandeelhouders te vrezen hebben van deze instructiebevoegdheid. Bij de stemrechtloze aandeelhouder staan vooral de aan het aandeel verbonden financiële rechten centraal. Dat belang deelt hij met andere aandeelhouders aan wiens aandelen financiële rechten

83 Van den Ingh 2002, p. 25. In gelijke zin: Asser/Maeijer, Van Solinge \& Nieuwe Weme 2-II* 2009, nr. 413. Anders: Van Schilfgaarde is van mening dat ook aan de raad van commissarissen instructiebevoegdheid zou moeten toekomen, zie Van den Ingh 2002, p. 130 (verslag van de discussie).

84 Oranje 2008 (1), p. 37.

85 In beginsel, omdat uit de parlementaire geschiedenis volgt dat het bestuur niet slaafs moet navolgen, maar een zelfstandige belangenafweging moet maken. Zie Kamerstukken II 2006/07, 31 058, nr. 3 , p. $90(\mathrm{MvT})$.

86 Boschma \& Kuijers-Tollenaar 2013, p. 103. 
zijn verbonden. Op het eerste gezicht laat het zich moeilijk denken dat de vergadering van stemrechtloze aandeelhouders een instructie zou geven die niet indruist tegen de financiële belangen van de stemrechtloze aandeelhouders, maar die wel indruist tegen de financiële belangen van andere aandeelhouders aan wiens aandelen financiële rechten zijn verbonden. Niettemin is het denkbaar dat een door de vergadering van houders van stemrechtloze aandelen gegeven instructie weliswaar niet strijdig is met het vennootschappelijk belang, maar niettemin niet in lijn in met de visie van (een groep) andere aandeelhouders, die op hun beurt ook van mening zijn dat hun visie strookt met datzelfde vennootschappelijke belang. Het bestuur van de vennootschap zal naar mijn mening in dat geval op grond van de tenzij-clausule van art. 2:239 lid $4 \mathrm{BW}$ de knoop moeten doorhakken.

Een andere, interessante vraag is of het toekennen van instructiebevoegdheid aan de vergadering van stemrechtloze aandeelhouders strookt met het feit dat aan stemrechtloze aandelen geen stemrecht in de algemene vergadering verbonden is. Het bestuur van de vennootschap is immers in beginsel gehouden de instructie op te volgen. Met andere woorden: is sprake van zeggenschap, terwijl het de bedoeling is dat zeggenschap aan de stemrechtloze aandeelhouder wordt onthouden, anders dan zijn vergaderrecht? Naar mijn mening moet een onderscheid worden gemaakt tussen zeggenschap op bestuursniveau en zeggenschap op aandeelhoudersniveau. Met de statutaire toekenning van het instructierecht aan de vergadering van stemrechtloze aandeelhouders komt geen zeggenschap op aandeelhoudersniveau, doch zeggenschap op bestuursniveau aan die aandeelhouders toe. Zeggenschap die dwingendrechtelijk aan de algemene vergadering toekomt, wordt aldus niet doorkruist. Bovendien past een nuancering. De stemrechtloze aandeelhouder mist weliswaar wegens het ontbreken van het aan zijn aandeel verbonden stemrecht concrete zeggenschap in de algemene vergadering. Niettemin kan hij door middel van zijn vergaderrecht trachten de besluitvorming op aandeelhoudersniveau te beïnvloeden. Indien het bestuur de gegeven instructie niet opvolgt, is een mogelijke route de vernietiging ex art. 2:15 BW van het door het bestuur genomen besluit wegens strijd met de vennootschappelijke redelijkheid en billijkheid te vorderen. Het is echter de vraag of die vordering kans van slagen heeft, omdat het te verwachten is dat het bestuur zal stellen dat zij de instructie niet heeft opgevolgd, omdat die instructie in strijd is met het belang van de vennootschap en de met haar verbonden onderneming. ${ }^{87}$

Voor de toekenning van de bevoegdheid tot het geven van aanwijzingen aan het bestuur aan de vergadering van stemrechtloze aandeelhouders is een besluit tot

87 Zie hierover paragraaf 8.6. Een andere mogelijkheid zou zijn dat de vergadering van stemrechtloze aandeelhouders de bestuurder schorst of ontslaat. Die bevoegdheid moet dan wel aan de vergadering van stemrechtloze aandeelhouders statutair zijn toegekend. Daarbij geldt een aantal beperkingen. Zo heeft de vergadering van stemrechtloze aandeelhouders indien de benoemingsbevoegdheid is toegekend niet het alleenrecht op de benoeming van alle bestuurders en kan de schorsings- en ontslagbevoegdheid ook aan een ander orgaan dan de vergadering van houders van stemrechtloze aandelen zijn toegekend. Zie hierover paragraaf 6.2.3.3. 
statutenwijziging met volstrekte meerderheid voldoende. ${ }^{88}$ Hoewel een dergelijk besluit gevolgen kan hebben voor de zeggenschapsverhoudingen binnen de vennootschap, kunnen minderheidsaandeelhouders gebruik maken van hun recht vernietiging van dat besluit te vorderen, een enquêteprocedure te entameren of een vordering tot uittreding instellen. ${ }^{89}$ Het besluit tot statutenwijziging waarbij de instructiebevoegdheid aan de vergadering van stemrechtloze aandeelhouders wordt ontnomen of gewijzigd, vereist - naar ik meen - een gelijke meerderheid. ${ }^{90}$ In voorkomend geval heeft de stemrechtloze aandeelhouder de voornoemde rechten om tegen een dergelijk besluit op te komen.

Indien op grond van art. 2:239 lid $4 \mathrm{BW}$ instructiebevoegdheid aan de algemene vergadering toegekend is, geldt een gelijke redenering. De minister verwoordt het aldus: "Bij een besluit tot statutenwijziging waarbij de bevoegdheid tot het verlenen van een concrete instructie wordt ingevoerd, is geen sprake van afbreuk van rechten van minderheidsaandeelhouders. Bij vennootschappen met een meerderheidsaandeelhouder zal die meerderheidsaandeelhouder doorgaans in staat zijn om het bestuur te benoemen. Het bestuur is op grond van artikel 239 lid 1 belast met het besturen van de vennootschap. Artikel 239 lid 4 biedt de mogelijkheid om in de statuten een orgaan de bevoegdheid te geven tot algemene instructies aangaande die bestuurstaak. In het wetsvoorstel wordt deze mogelijkheid uitgebreid tot concrete instructies. Noch bij algemene, noch bij concrete instructies is sprake van inperking van de bevoegdheid van de algemene vergadering of van aantasting van rechten van (minderheids)aandeelhouders. Zowel bij bestuursbesluiten in het algemeen als bij bestuursbesluiten na instructie worden (minderheids)aandeelhouders beschermd door de regel dat het bestuur zich moet richten naar het belang van de vennootschap (vgl. het voorgestelde artikel 239 lid 4). Hiermee wordt voorkomen dat het bestuur zich uitsluitend laat leiden door een deelbelangen [bedoeld zal zijn: deelbelang, RAW], in het bijzonder dat van de meerderheidsaandeelhouder. Voor extra eisen aan de besluitvorming, bijvoorbeeld door het van toepassing verklaren van artikel 242 lid 1, tweede volzin, wordt daarom geen aanleiding gezien." 91

Art. 2:239 lid 4 BW stelt dat de statuten kunnen bepalen dat het bestuur zich dient te gedragen naar de anwijzingen van een ander orgaan van de vennootschap. Houdt 'een ander orgaan' in dat aan slechts één ander orgaan die aanwijzingsbevoegdheid kan worden toegekend of kan - tegelijkertijd - aan meer dan één orgaan die bevoegdheid worden toegekend? Voor zover mij bekend, zwijgen de parlementaire geschiedenis, de literatuur en de jurisprudentie hierover. Ook de parlementaire geschiedenis bij de flex-BV geeft geen antwoord op deze vraag. Op grond van de tekstuele uitleg van de wettekst lijkt het voor de hand te liggen dat de wetgever

88 Kamerstukken I 2011/12, 31 058, nr. E, p. 18 (Nadere MvA I).

89 Kamerstukken I 2011/12, 31058 en 32 426, nr. C, p. 26 (MvA I)

90 Kamerstukken I 2011/12, 31 058, nr. E, p. 18 (Nadere MvA I)

91 Kamerstukken I 2011/12, 31 058, nr. E, p. 18 (Nadere MvA I). 
slechts één ander orgaan heeft bedoeld. Op het eerste gezicht lijkt dat ook om een andere reden voor de hand te liggen. Indien in een BV aan twee organen bijvoorbeeld de algemene vergadering en de vergadering van stemrechtloze aandeelhouders - een statutaire aanwijzingsbevoegdheid is toegekend, kunnen de aanwijzingen van deze organen strijdig met elkaar zijn. Welke anwijzing weegt in dat geval zwaarder? Die van de algemene vergadering of die van de vergadering van stemrechtloze aandeelhouders? Om dergelijke problemen te voorkomen ligt het daarom voor de hand art. 2:239 lid 4 BW te interpreteren dat slechts aan één orgaan een statutaire aanwijzingsbevoegdheid kan worden toegekend.

Ik neig echter naar een andere opvatting, namelijk dat op grond van art. 2:239 lid 4 BW aan meerdere organen een statutaire aanwijzingsbevoegdheid kan worden toegekend. ${ }^{92}$ Weliswaar kan zich dan de mogelijkheid voor doen dat aanwijzingen tegenstrijdig zijn, maar dat neemt niet weg dat het bestuur bij iedere aanwijzing alvorens die aanwijzing op te volgen zich zal moeten afvragen of die aanwijzing in strijd is met het belang van de vennootschap en de met haar verbonden onderneming. Dat geldt ook indien slechts aan één orgaan een statutaire aanwijzingsbevoegdheid is toegekend. Indien in het gegeven voorbeeld het bestuur wel de aanwijzing van de vergadering van stemrechtloze aandeelhouders opvolgt, maar niet de aanwijzing van de algemene vergadering, heeft de algemene vergadering de mogelijkheid ex art. 2:224 BW het bestuur te schorsen of te ontslaan. Het machtsevenwicht in de BV komt weer anders te liggen indien aan de vergadering van stemrechtloze aandeelhouders de bevoegdheid tot benoeming ex art. 2:242 BW en de bevoegdheid tot ontslag ex art. 2:244 BW van een bestuurder is toegekend. ${ }^{93} \mathrm{De}$ opvatting dat op grond van art. 2:239 lid $4 \mathrm{BW}$ aan meerdere organen een statutaire aanwijzingsbevoegdheid kan worden toegekend, moet worden gerelativeerd. Het komt mij namelijk voor dat in de praktijk van deze mogelijkheid weinig gebruik gemaakt zal worden.

Voor het wijzigen van de instructiebevoegdheid (toekenning, ontneming of wijziging) is een statutenwijziging vereist. Daarvoor geldt een gewone meerderheid. ${ }^{94}$

\subsubsection{Conclusie}

Mijn conclusie ten aanzien van de dualistische structuur van de BV en de instructiebevoegdheid van de algemene vergadering is als volgt. Het bestuur is autonoom in de uitoefening van zijn taak en bevoegdheden. De dualistische structuur is in de flex-BV gehandhaafd. De algemene vergadering kan een statutaire instructiebevoegdheid jegens het bestuur hebben. De instructiebevoegdheid is een

92 Inmiddels in gelijke zin: Boschma \& Kuijers-Tollenaar 2013, p. 103-104. Zij wijzen er onder meer ter vergelijking tevens op dat (i) de bevoegdheid tot ontslag van een bestuurder aan meerdere organen kan toekomen en dat (ii) bestuursbesluiten ter voorafgaande goedkeuring van meerdere organen kunnen worden voorgelegd.

93 Zie hierover paragraaf 6.2.3.3. In gelijke zin: Boschma \& Kuijers-Tollenaar 2013, p. 104.

94 Kamerstukken I 2011/2012, 31058 en 32 426, nr. C, p. 26 (MvA I). 
inbreuk op de dualistische structuur en de autonomie van het bestuur. De statuten kunnen bepalen dat het bestuur zich dient te gedragen naar de aanwijzingen van een ander orgaan van de vennootschap. Het bestuur is gehouden de aanwijzingen op te volgen, tenzij deze in strijd zijn met het belang van de vennootschap en de met haar verbonden onderneming. Daaronder valt ook het belang van de stemrechtloze aandeelhouder. Op grond van het orgaanbegrip van art. 2:189a BW kan ook aan de vergadering van stemrechtloze aandeelhouders instructiebevoegdheid toekomen. Op grond van art. 2:239 lid 4 BW kan aan meerdere organen een statutaire instructiebevoegdheid worden toegekend.

\subsection{De grens van het dienen van het eigen belang door de aandeelhouder}

Onder het oude recht bepaalde art. 2:192 $\mathrm{BW}^{95}$ dat een aandeelhouder niet, zelfs niet door een wijziging van de statuten, tegen zijn wil enige verplichting kan worden opgelegd boven de storting van de nominale waarde van zijn aandeel. ${ }^{96}$ In feite was dat de enige, wettelijke regel voor aandeelhouders, naast de regel dat de aandeelhouder zijn stemrecht niet in strijd met de wet, de goede zeden, de openbare orde en de statuten van de vennootschap mag uitoefenen. In het Wennex-, het Distilleerderij Melchers- en het Aurora-arrest heeft de Hoge Raad bepaald dat de aandeelhouder zich bij de uitoefening van zijn stemrecht in beginsel mag laten leiden door zijn eigen belang. Het stemrecht dat de aandeelhouder gegeven is, dient om zijn belang te dienen. ${ }^{97}$

Ook hier rijst de vraag in hoeverre de kapitaalverschaffer met stemrecht zich moet laten leiden door andere belangen, zoals het vennootschappelijk belang, en in het kader van dit onderzoek - de belangen van de kapitaalverschaffers zonder stemrecht, die immers niet via het stemrecht voor hun belang kunnen opkomen. Van de door mij geïdentificeerde kapitaalverschaffers zonder stemrecht kunnen alleen de stemrechtloze aandeelhouder, de certificaathouder met vergaderrecht en de aandeelhouder wiens stemrecht aan de vruchtgebruiker of pandhouder is overgedragen, vanwege hun vergaderrecht invloed op de besluitvorming in de algemene vergadering uitoefenen. In de regel zal aan (de houder van) een participatiebewijs geen vergaderrecht zijn toegekend.

95 Onder de flex-BV is art. 2:192 BW ingrijpend gewijzigd. Ik kom daarop terug in paragraaf 6.2.3.9.

96 Zie Asser/Maeijer, Van Solinge \& Nieuwe Weme 2-II* 2009, nr. 106.

97 HR 30 juni 1944, NJ 1944, 465 (Wennex); HR 13 november 1959, NJ 1960, 472 (Distilleerderij Melchers) en HR 19 februari 1960, NJ 1960, 473, m.nt. HB (Aurora). Pres. Rb. Assen 17 december 1993, $K G$ 1994, 90. Zie ook Schwarz 1986, p. 63; Slagter 2005, p. 14 en Olaerts 2007, p. 266-267. De Expertgroep refereert tevens aan dit eigen belang, zie Rapport van de Expertgroep p. 23. 
Deze vrijheid tot het dienen van het eigen belang is echter niet onbegrensd. ${ }^{98} \mathrm{Ik}$ merkte al op dat uit het Wennex-, het Distilleerderij Melchers- en het Aurora-arrest volgt dat de aandeelhouder zich bij de uitoefening van zijn stemrecht in beginsel mag laten leiden door zijn eigen belang. In het Wennex-arrest was de grens misbruik van recht. De aandeelhouder is voorts gehouden de vennootschappelijke redelijkheid en billijkheid van art. 2:8 BW in acht te nemen. Hij zal bij het uitoefenen van zijn stemrecht de belangen moeten betrekken van degenen die krachtens de wet en de statuten bij de (organisatie van de) vennootschap zijn betrokken, bijvoorbeeld minderheidsaandeelhouders. Uit oudere rechtspraak volgt deze regel reeds. ${ }^{99}$ Daarnaast zal de aandeelhouder bij het uitoefenen van zijn stemrecht ook het vennootschappelijke belang moeten betrekken. ${ }^{100}$ Bij zijn belangenafweging mag echter zijn eigen belang als aandeelhouder een gewichtige rol spelen. ${ }^{101}$ Als voorbeeld van deze belangenafweging verwijs ik naar de overweging van de OK in de Jeezet/Synpact-beschikking ten aanzien van het uitkeren of het reserveren van winst: “(...) In beginsel hebben de aandeelhouders zonder meer recht op uitkering van de in een boekjaar gerealiseerde winst. Dit is anders indien de statuten bepalen dat de winst ter beschikking staat van een vennootschapsorgaan, bijvoorbeeld van de algemene vergadering van aandeelhouders. In dat geval dient de algemene vergadering van aandeelhouders een besluit tot winstbestemming te nemen; zij kan besluiten tot (gehele of gedeeltelijke) reservering of tot (gehele of gedeeltelijke) uitkering. De algemene vergadering van aandeelhouders dient bij het nemen van het besluit tot winstbestemming de redelijkheid en billijkheid in het oog te houden. Het belang van een (minderheids)aandeelhouder bij uitkering van dividend dient zorgvuldig te worden afgewogen tegen het belang van de vennootschap en de wens van de andere aandeelhouder(s) om de winst (geheel of gedeeltelijk) aan de reserves toe te voegen. In beginsel dient de winst aan de aandeelhouders te worden uitgekeerd, tenzij het vennootschappelijk belang vereist dat tot (gehele of gedeeltelijke) reservering van de winst wordt overgegaan. (...)"102

De Jongh spreekt in dit kader van twee botsende beginselen: het autonomiebeginsel (aandeelhouders mogen hun eigen belang tot uitgangspunt nemen bij de uitoefening van hun rechten) en het billijkheidsbeginsel (aandeelhouders houden rekening met de in het geding zijnde belangen van de vennootschap en van andere institutioneel betrokkenen). ${ }^{103}$ Van der Sangen meent dat in een persoonsgebonden

98 Zie Timmerman 1975, p. 246 en de in noot 17 op die pagina aangehaalde literatuur; Schwarz 1986, p. 64; J.B. Huizink, Groene Serie Rechtspersonen, art. 2:8 BW, aant. 2, Deventer: Kluwer. Olaerts 2007, p. 271, spreekt over 'predominant' gedrag van de aandeelhouder.

99 HR 13 februari 1942, NJ 1942, 360; Hof 's-Gravenhage 1 oktober 1982, NJ 1983, 393 (Van Rees/ Smits) en Hof Arnhem 26 mei 1992, NJ 1993, 182, m.nt. Ma (Uniwest).

100 Koelemeijer 1999, p. 104; Assink 2009, p. 109 en Schrama 2012, p. 103

101 Van Schilfgaarde \& Winter 2009, p. 228-229.

102 Hof Amsterdam (OK) 6 juni 2011, LJN BQ9757, JOR 2011, 282, m.nt. Blanco Fernández (Jeezet/ Synpact), r.o. 3.10

103 De Jong 2011, p. 612. 
samenwerking de aandeelhouders een loyaliteitsverplichting jegens elkaar hebben zich in te zetten voor het bereiken van het samenwerkingsdoel. Volgens hem impliceert dit dat de aandeelhouder bij een dergelijke samenwerking in zijn stemgedrag niet vrij is, in die zin dat hij dat gedrag niet uitsluitend en alleen kan laten bepalen door zijn eigen belang. ${ }^{104} \mathrm{Ik}$ sluit mij bij die visie aan. In voorkomend geval voorziet de wet in een corrigerend middel. Indien de aandeelhouder door zijn gedrag het belang van de vennootschap schaadt, kan de andere aandeelhouder ex art. 2:336 BW uitstoting van die aandeelhouder vorderen.

In recentere rechtspraak heeft de OK zijn licht over het eigen belang van de aandeelhouder laten schijnen. Uit de PCM-beschikkingen volgt dat (toekomstige) ${ }^{105}$ aandeelhouders het eigen belang niet onbeperkt kunnen nastreven. ${ }^{106}$ De PCM-beschikkingen zijn een bevestiging van de eerdere Gucci- ${ }^{107}$ en Breevastbeschikking. ${ }^{108}$ In de Gucci-beschikking formuleert de OK het zo: ${ }^{109}$ "Anderzijds heeft, mede gezien het bepaalde in artikel 2:8 van het Burgerlijk Wetboek, te gelden dat de verwerver van een pakket aandelen als hier in het geding als behoorlijk aandeelhouder in verband met en bij gelegenheid van de verkrijging van die aandelen opening van zaken geeft, met de vennootschap wier aandelen hij verkrijgt redelijk overleg pleegt en in zijn handelen niet alleen zijn eigen belangen maar ook de belangen van de vennootschap in al haar facetten en de belangen van de bij de vennootschap betrokken personen betrekt." Ook hieruit volgt de eerder genoemde belangenafweging. In de Breevast-beschikking vindt men soortgelijke bewoordingen. ${ }^{10}$ Hoewel de bewoordingen wat anders zijn, is ook uit de AHAM-beschikking $^{111}$ af te leiden dat de aandeelhouder de vennootschappelijke redelijkheid en billijkheid in acht moet nemen.

104 Van der Sangen 2003, p. 34. Vgl. Van Schilfgaarde \& Winter 2009, p. 228-229.

105 In de literatuur is kritiek geuit op de overweging van de OK dat van een toekomstig aandeelhouder mag worden verwacht dat hij het vennootschappelijk belang in acht neemt. Daarnaast zou de grondslag van aansprakelijkheid van een toekomstig aandeelhouder niet art. 2:8 BW zijn (er is immers nog geen sprake van aandeelhouderschap), maar art. 6:162 BW. Zie bijvoorbeeld Kaemingk 2012, p. 505 en 507; Mol 2012, p. 114-115 en Schrama 2012, p. 104. Prinsen 2011, p. 47, betwijfelt of de Hoge Raad tot hetzelfde oordeel zou zijn gekomen. Ik volg de kritiek in de literatuur ten aanzien van deze overweging van de $O K$.

106 Hof Amsterdam (OK) 10 januari 2008, JOR 2008, 39, m.nt. Brink (PCM I) en Hof Amsterdam (OK) 27 mei 2010, LJN BM5928, JOR 2010, 189, m.nt. T.M. Stevens (PCM II), r.o. 3.13. Zie over de laatste PCM-beschikking onder meer H.L. Kaemingk, 'Wanbeleid bij PCM: observaties bij de beschikking van de Ondernemingskamer', TOP 2010-7, p. 263-269.

107 Hof Amsterdam (OK) 3 maart 1999, NJ 1999, 305, JOR 1999, 87 (Gucci).

108 Hof Amsterdam (OK) 11 maart 1999, NJ 1999, 351, JOR 1999, 89, m.nt. Brink (Breevast).

109 r.o. 3.3

110 r.o. 4.16.

111 Hof Amsterdam (OK) 10 december 2008, JOR 2009, 38 (AHAM), r.o. 3.17. 
Schrama stelt dat van de instructiebevoegdheid van art. 2:239 lid 4 BW 'een zekere normerende werking ten aanzien van aandeelhouders' uit gaat, omdat het bestuur een instructie niet hoeft op te volgen indien deze in strijd is met het belang van de vennootschap en de met haar verbonden onderneming. Art. 2:239 lid 4 BW richt zich echter naar mijn mening tot het bestuur en niet tot de aandeelhouder. Het bestuur dient zich immers te gedragen naar de aanwijzingen van een ander orgaan van de vennootschap. Ik begrijp de woorden van Schrama zo - en ben het in die zin daarmee eens, dat het orgaan dat de instructiebevoegdheid toekomt bij de besluitvorming over de te geven instructie het belang van de vennootschap en de met haar verbonden onderneming in haar overwegingen zal moeten betrekken. Daarmee kan worden voorkomen, althans de kans worden verkleind, dat het bestuur juist vanwege het belang van de vennootschap en de met haar verbonden onderneming de gegeven instructie niet zal opvolgen.

Concluderend: de vrijheid van de aandeelhouder zijn stemrecht uit te oefenen wordt begrensd door de norm van art. 2:8 BW en het vennootschappelijk belang. Het stemgedrag zal aan die norm getoetst (kunnen) worden. ${ }^{112}$

\subsection{Samenvatting en conclusie}

In dit hoofdstuk besprak ik de interne verhoudingen in de BV. Het gaat daarbij om de onderlinge betrekkingen tussen de kapitaalverschaffer, de algemene vergadering, het bestuur van de vennootschap en de vennootschap. Deze verhoudingen kunnen vanuit de rechtseconomie benaderd worden door de principal-agent theory. De kapitaalverschaffers zonder stemrecht moeten zich ervan kunnen verzekeren dat ook hun belang door de diverse actoren in het vennootschappelijk verband wordt gediend. In de flex-BV blijft de beslotenheid een van de factoren die de interne verhoudingen bepaalt. Datzelfde geldt voor de aard van de samenwerking in of door middel van de BV. Beide factoren, doch niet uitsluitend deze factoren, vullen de (rechts)normen in de interne verhoudingen in. Het vennootschappelijk belang dient als richtsnoer voor het handelen van het bestuur en de raad van commissarissen van de BV. De wetgever lijkt uit te gaan van de gecombineerde opvatting van het vennootschappelijk belang. Het bestuur is autonoom in de uitoefening van zijn taak en bevoegdheden. De dualistische structuur is in de flex-BV gehandhaafd. De algemene vergadering kan een statutaire instructiebevoegdheid jegens het bestuur hebben. De instructiebevoegdheid is een inbreuk op de dualistische structuur en de autonomie van het bestuur. De statuten kunnen bepalen dat het bestuur zich dient te gedragen naar de aanwijzingen van een ander orgaan van de vennootschap. Het bestuur is gehouden de aanwijzingen op te volgen, tenzij deze in strijd zijn met het

112 In gelijke zin Verdam 1995, p. 219; Assink 2009, p. 109; Bulten 2011, p. 88 en Schrama 2012, p. 106. Dit klemt te meer indien sprake is van een meerderheidspositie van de aandeelhouder, zodat hij in feite de vennootschap controleert. 
belang van de vennootschap en de met haar verbonden onderneming. Daaronder valt ook het belang van de kapitaalverschaffer zonder stemrecht. Op grond van het orgaanbegrip van art. 2:189a BW kan ook aan de vergadering van stemrechtloze aandeelhouders instructiebevoegdheid toekomen. Naar mijn mening kan aan meerdere organen een statutaire instructiebevoegdheid ex art. 2:239 lid 4 BW worden toegekend. De vrijheid van de aandeelhouder zijn stemrecht uit te oefenen wordt begrensd door de norm van art. 2:8 BW en het vennootschappelijk belang. Zijn stemgedrag zal aan die norm getoetst (kunnen) worden. 

Hoofdstuk 6

\section{DE RECHTEN VAN DE KAPITAALVERSCHAFFER ZONDER STEMRECHT}

\subsection{Inleiding}

In dit hoofdstuk staan de rechten van de kapitaalverschaffers zonder stemrecht centraal. Hun (rechts)positie wordt niet alleen vormgegeven door het in hoofdstuk 5 besproken spanningsveld van de interne verhoudingen, maar ook - en vooral - door de hen toekomende rechten. Daarbij gaat het om rechten die hen zijn toegekend door de wet, de statuten van de BV en interne regelgeving, zoals reglementen en aandeelhoudersovereenkomsten. Aan de orde komen daarom telkens de aard van de rechtsfiguur en de rechten en verplichtingen die op grond van de wet en de statuten aan die rechtsfiguur zonder stemrecht verbonden (kunnen) zijn. Waar nodig ga ik vervolgens in op bijzondere, specifieke thema's die bij de desbetreffende kapitaalverschaffer zonder stemrecht een rol spelen. Ik begin met de stemrechtloze aandeelhouder (paragraaf 6.2). Vervolgens komt de houder van een certificaat met en zonder vergaderrecht aan de orde (paragraaf 6.3). Daarna bespreek ik de aandeelhouder wiens stemrecht is overgedragen aan de vruchtgebruiker of de pandhouder (paragraaf 6.4). Als laatste sta ik stil bij de houder van een participatiebewijs (paragraaf 6.5). In paragraaf 6.6 komt de aansprakelijkheid van de kapitaalverschaffer zonder stemrecht ex art. 2:216 lid 3 BW aan de orde. In paragraaf 6.7 ga ik in op het afzien van de uitoefening van het vergaderrecht. Ik sluit af met een samenvatting en conclusie (paragraaf 6.8).

\subsection{De stemrechtloze aandeelhouder}

\subsubsection{Inleiding}

In deze paragraaf bespreek ik eerst de aard van de rechtsfiguur van het stemrechtloze aandeel (paragraaf 6.2.2). Vervolgens bespreek ik de aan dat aandeel verbonden rechten (paragraaf 6.2.3). 


\subsubsection{Aard van de rechtsfiguur}

In paragraaf 4.2.4 definieerde ik het stemrechtloze aandeel als 'een vermogensrecht op naam, in de vorm van een aandeel uitgegeven door de BV, dat kapitaal in een BV vertegenwoordigt, waaraan de rechten volgens de wet en de statuten van de BV zijn verbonden, waaronder het recht op winst en/of reserves van die BV, doch aan welk aandeel geen stemrecht in de algemene vergadering is verbonden'. Het is aldus een vermogensrecht van eigen aard, waaraan rechten - behalve het stemrecht - en verplichtingen verbonden zijn. Daarnaast bepaalt de aard van deze rechtsfiguur de in hoofdstuk 3 besproken lidmaatschapsverhouding. Een (stemrechtloze) aandeelhouder staat in een lidmaatschapsverhouding tot de vennootschap. De kenmerken 'een vermogensrecht van eigen aard' en 'de lidmaatschapsverhouding' vormen de rechtsfiguur van het stemrechtloze aandeel en geven vorm aan de interne verhoudingen.

Het stemrechtloze aandeel is, zoals gezegd, een nieuwe rechtsfiguur in de BV. De flex-BV, althans de wet, maakt het bovendien mogelijk om beperkt stemgerechtigde aandelen, winstrechtloze aandelen, beperkte winstgerechtigde en aandelen met gedifferentieerd stemrecht te creëren. Daarnaast kent het BV-recht sinds jaar en dag naast gewone aandelen ook en onder meer preferente aandelen en prioriteitsaandelen. Ik verwijs naar het in hoofdstuk 3 gegeven overzicht. Er kan in een BV (dus) sprake zijn van diverse soorten van aandelen en verschaffers van kapitaal. Bij het bepalen van de positie van de stemrechtloze aandeelhouder in de interne verhoudingen moet daarmee rekening gehouden worden. Zo stelde ik in paragraaf 4.3.8 in het kader van het toestemmingsvereiste van art. 1:88 $\mathrm{BW}$ en het stemrechtloze aandeel het begrip 'meerderheid der aandelen' aan de orde. Bij de beoordeling van de uitzondering op dat toestemmingsvereiste zal de gehele vennootschapsstructuur, inclusief het kapitaal, moeten worden betrokken. Bij het bepalen van de positie van de stemrechtloze aandeelhouder in de interne verhoudingen zal een analyse van de vennootschapsstructuur en het aandelenkapitaal in het concrete geval moeten worden gemaakt. Speciale aandacht vereisen de aandelen, waaraan bijzondere rechten zijn verbonden, zoals preferente en prioriteitsaandelen, maar ook de aandelen die op basis van art. 2:216 lid 6 en 7 en 2:228 lid 5 BW kunnen worden gecreëerd en de overige rechtsfiguren van kapitaal zonder stemrecht. Ook de aan de aandelen verbonden zeggenschap en in welke hand(en) die zeggenschap is, zal een punt van aandacht moeten zijn, zodat telkens de mate van zeggenschap en de mate van gerechtigdheid tot het kapitaal kan worden bepaald.

Daarbij zal rekening gehouden moeten worden met de hoofdregel van art. 2:24d lid $1 \mathrm{BW}$, inhoudende onder meer dat het stemrechtloze aandeel niet meetelt bij de vaststelling in hoeverre aandeelhouders stemmen of in hoeverre het aandelenkapitaal verschaft wordt, en de uitzondering van lid 2 van dat artikel voor de daarin opgesomde gevallen. Ik verwijs naar paragraaf 4.3.2. 


\subsubsection{Rechten van de stemrechtloze aandeelhouder}

\subsubsection{Algemeen}

In paragraaf 3.7.3 besprak ik, onder verwijzing naar Bijlage 1 , de aan gewone aandelen verbonden rechten. Er kan een onderverdeling worden gemaakt in aan een individuele aandeelhouder toekomende rechten, aan groepen van aandeelhouders toekomende rechten en aan de algemene vergadering toekomende rechten. Toegespitst op de stemrechtloze aandeelhouder ziet deze onderverdeling er als volgt uit:

\begin{tabular}{|l|l|l|}
\hline & Rechten van de individuele, stemrechtloze aandeelhouder & $\begin{array}{l}\text { BW Boek } 2 \\
\text { art. }\end{array}$ \\
\hline 1. & $\begin{array}{l}\text { het instellen van een vordering tot vernietiging van } \\
\text { besluiten van een orgaan van de vennootschap }\end{array}$ & 15 \\
\hline 2. & $\begin{array}{l}\text { het recht op het liquidatiesaldo na ontbinding en } \\
\text { vereffening van de vennootschap }\end{array}$ & $23 \mathrm{~b}$ \\
\hline 3. & $\begin{array}{l}\text { het recht op inzage in de boeken en bescheiden en andere } \\
\text { gegevensdragers van de BV na haar ontbinding }\end{array}$ & 24 lid 4 \\
\hline 4. & $\begin{array}{l}\text { het recht ingeschreven te worden in het aandeelhouders- } \\
\text { register }\end{array}$ & 194 lid 1 \\
\hline 5. & $\begin{array}{l}\text { het recht om niet een uittreksel uit het aandeelhouders- } \\
\text { register te verkrijgen met betrekking tot zijn recht op } \\
\text { aandeel }\end{array}$ & 194 lid 4 \\
\hline 6. & het recht van inzage in het aandeelhoudersregister & 194 lid 5 \\
\hline 7. & het recht op gelijke behandeling & 201 lid 2 \\
\hline 8. & $\begin{array}{l}\text { het recht op inzage in de beschrijving van de inbreng op } \\
\text { aandelen anders dan in geld bij gelegenheid van de oprichting }\end{array}$ & 204 a lid 1 \\
\hline 9. & $\begin{array}{l}\text { het recht op inzage in de beschrijving van de inbreng op } \\
\text { aandelen anders dan in geld na oprichting }\end{array}$ & $204 \mathrm{~b}$ lid 1 \\
\hline 10. & $\begin{array}{l}\text { het recht de opgemaakte rekening, het jaarverslag en de in } \\
\text { art. 2:392 lid 1 BW genoemde gegevens te kunnen inzien } \\
\text { en het recht op een kosteloos afschrift van deze stukken }\end{array}$ & 212 \\
\hline 11. & het recht op uitkeringen, waaronder dividend & 216 \\
\hline 12. & $\begin{array}{l}\text { het verkrijgen van inlichtingen tijdens de algemene ver- } \\
\text { gadering }\end{array}$ & 217 lid 2 \\
\hline 13. & $\begin{array}{l}\text { het recht de voorzieningenrechter te verzoeken te worden } \\
\text { gemachtigd er toe over te gaan om de bij art. 2:218 BW of } \\
\text { de statuten voorgeschreven algemene vergadering te doen } \\
\text { houden, indien zij die krachtens art. 2:219 BW tot de } \\
\text { bijeenroeping bevoegd zijn in gebreke zijn gebleven }\end{array}$ & $\begin{array}{l}222 \text { jo. } 220 \\
\text { lid } 1\end{array}$ \\
\hline
\end{tabular}




\begin{tabular}{|c|c|c|}
\hline & Rechten van de individuele, stemrechtloze aandeelhouder & $\begin{array}{l}\text { BW Boek } 2 \\
\text { art. }\end{array}$ \\
\hline 14. & $\begin{array}{l}\text { het recht door middel van een oproepingsbrief te worden } \\
\text { opgeroepen voor de algemene vergadering }\end{array}$ & $223 \operatorname{lid} 1$ \\
\hline 15. & $\begin{array}{l}\text { het recht - indien de aandeelhouder hiermee instemt - } \\
\text { langs elektronische weg te worden opgeroepen voor de } \\
\text { algemene vergadering, tenzij de statuten anders bepalen }\end{array}$ & $223 \operatorname{lid} 2$ \\
\hline 16. & $\begin{array}{l}\text { het instemmingsrecht dat besluitvorming plaatsvindt ten } \\
\text { aanzien van onderwerpen waarvan de behandeling niet bij } \\
\text { de oproeping is aangekondigd met inachtneming van de } \\
\text { oproepingstermijn }\end{array}$ & $224 \operatorname{lid} 2$ \\
\hline 17. & $\begin{array}{l}\text { het recht van instemming dat besluitvorming plaatsvindt, } \\
\text { omdat de oproeping of de wettelijke termijn van oproeping } \\
\text { van acht dagen niet in acht is genomen }\end{array}$ & 225 \\
\hline 18. & $\begin{array}{l}\text { het recht van instemming ten aanzien van een besluit tot } \\
\text { statutenwijziging, waarbij (na oprichting van de BV) een } \\
\text { statutaire plaats buiten Nederland voor het houden van een } \\
\text { algemene vergadering wordt aangewezen }\end{array}$ & 226 lid 2 \\
\hline 19. & $\begin{array}{l}\text { het recht van instemming de algemene vergadering op een } \\
\text { andere plaats te houden dan statutair voorgeschreven is }\end{array}$ & $226 \operatorname{lid} 3$ \\
\hline 20. & $\begin{array}{l}\text { het bijwonen van de algemene vergadering en daarin het } \\
\text { woord voeren (vergaderrecht) }\end{array}$ & 227 \\
\hline 21. & $\begin{array}{l}\text { het recht zich te doen vertegenwoordigen door een } \\
\text { advocaat, notaris, registeraccountant of accountant- } \\
\text { administratieconsulent }\end{array}$ & $227 \operatorname{lid} 5$ \\
\hline 22. & $\begin{array}{l}\text { het recht op (i) inzage in de aantekeningen die het bestuur } \\
\text { houdt van de besluiten in de algemene vergadering en } \\
\text { (ii) een afschrift hiervan tegen ten hoogste de kostprijs }\end{array}$ & $230 \operatorname{lid} 4$ \\
\hline 23. & $\begin{array}{l}\text { het recht om kosteloos een afschrift te krijgen van het } \\
\text { voorstel tot wijziging van de statuten }\end{array}$ & $233 \operatorname{lid} 3$ \\
\hline 24. & $\begin{array}{l}\text { het recht om kosteloos een afschrift te krijgen van het } \\
\text { voorstel tot vermindering van het geplaatste kapitaal }\end{array}$ & $\begin{array}{l}208 \operatorname{lid} 5 \text { jo. } \\
233 \operatorname{lid} 3\end{array}$ \\
\hline 25. & $\begin{array}{l}\text { het recht van instemming indien de besluitvorming van } \\
\text { aandeelhouders op een andere wijze dan in een vergadering } \\
\text { geschiedt }\end{array}$ & $238 \operatorname{lid} 1$ \\
\hline 26. & het instellen van de vordering tot uitstoting & $\begin{array}{l}336 \text { jo. } 24 d \\
\text { lid } 2^{1}\end{array}$ \\
\hline
\end{tabular}

1 Kamerstukken II 2008/09, 31 058, nr. 6, p. $14-15$ (NV II). 


\begin{tabular}{|c|c|c|}
\hline & Rechten van de individuele, stemrechtloze aandeelhouder & $\begin{array}{l}\text { BW Boek } 2 \\
\text { art. }\end{array}$ \\
\hline 27. & het instellen van de vordering tot uittreding & 343 \\
\hline 28. & $\begin{array}{l}\text { het indienen van een verzoek tot een voorlopig getuigen- } \\
\text { verhoor }{ }^{2}\end{array}$ & \\
\hline 29. & $\begin{array}{l}\text { het recht op inzage in en een kosteloos afschrift van } \\
\text { stukken die in verband met een juridische fusie of een } \\
\text { juridische splitsing ten kantore van de vennootschap zijn } \\
\text { neergelegd }\end{array}$ & $\begin{array}{l}314 \text { lid } 2 \text { en } \\
334 h \text { lid } 2\end{array}$ \\
\hline 30. & $\begin{array}{l}\text { het instellen van een vordering tot nakoming jegens de } \\
\text { vennootschap van de plicht een accountant opdracht te } \\
\text { verlenen tot onderzoek van de jaarrekening }\end{array}$ & $\begin{array}{l}393 \text { lid } 8 \text { jo. } \\
\text { lid } 1\end{array}$ \\
\hline 31. & $\begin{array}{l}\text { het recht op inzage in of een afschrift van een beperkte } \\
\text { balans en toelichting, indien de vennootschap geen winst } \\
\text { beoogt }\end{array}$ & $\begin{array}{l}396 \text { lid } 8 \text { jo. } \\
\text { lid } 9\end{array}$ \\
\hline
\end{tabular}

\begin{tabular}{|l|l|l|}
\hline & $\begin{array}{l}\text { Rechten die aan een of meer stemrechtloze aandeelhouders } \\
\text { toekomen }\end{array}$ & $\begin{array}{l}\text { BW Boek 2 } \\
\text { art. }\end{array}$ \\
\hline 1. & $\begin{array}{l}\text { het bijeenroepen van een buitengewone algemene verga- } \\
\text { dering na machtiging daartoe door de voorzieningenrechter } \\
\text { door een of meer aandeelhouders die gezamenlijk ten } \\
\text { minste een honderdste van het geplaatste kapitaal verte- } \\
\text { genwoordigen }\end{array}$ & $\begin{array}{l}220 \text { jo. 24d } \\
\text { lid } 2^{3}\end{array}$ \\
\hline 2. & $\begin{array}{l}\text { het recht schriftelijk de behandeling van een bepaald } \\
\text { onderwerp in de algemene vergadering te verzoeken door } \\
\text { een of meer aandeelhouders die gezamenlijk ten minste een } \\
\text { honderdste van het geplaatste kapitaal vertegenwoordigen }\end{array}$ & $\begin{array}{l}224 \mathrm{a} \text { jo. 24d } \\
\text { lid } 2\end{array}$ \\
\hline 3. & $\begin{array}{l}\text { het instellen van de vordering tot overdracht van de } \\
\text { aandelen jegens een mede-aandeelhouder indien die mede- } \\
\text { aandeelhouder het belang van de vennootschap schaadt }\end{array}$ & $\begin{array}{l}336 \text { jo. 2:24d } \\
\text { lid } 2\end{array}$ \\
\hline
\end{tabular}

2 HR 20 oktober 1995, NJ 1996, 120, m.nt. Ma (Perrier/Marceau) en Hof 's-Gravenhage 22 mei 2008, LJN BD2349, JOR 2008, 223 (Verhoeff c.s./KPNQwest)

3 Kamerstukken II 2008/09, 31 058, nr. 3, p. $77-78$ (MvT) en Kamerstukken II 2008/09, 31 058, nr. 6, p. 14 (NV II). 


\begin{tabular}{|l|l|l|}
\hline & $\begin{array}{l}\text { Rechten die aan een of meer stemrechtloze aandeelhouders } \\
\text { toekomen }\end{array}$ & $\begin{array}{l}\text { BW Boek 2 } \\
\text { art. }\end{array}$ \\
\hline 4. & $\begin{array}{l}\text { het indienen van een enquêteverzoek ex art. 2:345 BW bij } \\
\text { een BV met een geplaatst kapitaal van maximaal } € 22,5 \\
\text { miljoen door een of meer aandeelhouders die alleen of } \\
\text { gezamenlijk ten minste een tiende gedeelte van het geplaatste } \\
\text { kapitaal vertegenwoordigen of rechthebbenden zijn op een } \\
\text { bedrag van aandelen daarvan tot een nominale waarde van } \\
€ 225.000 \text { of zoveel minder als de statuten bepalen }\end{array}$ & $\begin{array}{l}\text { jo. } 2: 24 \mathrm{~d} \\
\text { lid } 2^{4}\end{array}$ \\
\hline
\end{tabular}

\begin{tabular}{|l|l|l|}
\hline & $\begin{array}{l}\text { Rechten van de algemene vergadering die de stemrechtloze } \\
\text { aandeelhouder vanwege het ontbreken van het aan zijn } \\
\text { aandeel verbonden stemrecht of anderszins niet toekomen }\end{array}$ & $\begin{array}{l}\text { BW Boek } 2 \\
\text { art. }\end{array}$ \\
\hline 1. & het besluiten tot omzetting in een andere rechtsvorm & 18 jo. $181 \mathrm{lid} 5^{5}$ \\
\hline 2. & het besluiten tot ontbinden van de vennootschap & $19 \mathrm{lid} 1 \mathrm{sub} \mathrm{a}$ \\
\hline 3. & het recht van uitkoop & $201 \mathrm{a} \mathrm{lid} 1^{6}$ \\
\hline 4. & het besluiten tot een emissie van aandelen & $206^{7}$ \\
\hline 5. & het besluiten tot kapitaalvermindering & $208 \mathrm{lid} 1^{8}$ \\
\hline 6. & het jaarlijks vaststellen van de jaarrekening & $210 \mathrm{lid} 3$ \\
\hline 7. & het bestemmen van de winst & $216^{9}$ \\
\hline 8. & het besluiten tot het wijzigen van de statuten & $231^{10}$ \\
\hline 9 & het geven van aanwijzingen (instructiebevoegdheid) & $239^{11}$ \\
\hline
\end{tabular}

4 Kamerstukken II 2008/09, 31 058, nr. 3, p. 114 (MvT) en Kamerstukken II 2008/09, 31 058, nr. 6, p. 14 (NV II). Uitgaande van de Wet van 18 juni 2012 tot wijziging van boek 2 van het Burgerlijk Wetboek in verband met de aanpassing van het recht van enquête (Kamerstukken 32 887, Stb. 2012, 274). Deze wet zal inwerking treden op 1 januari 2013 (Stb. 2012, 305). Bij een BV met een geplaatst kapitaal van meer dan $€ 22,5$ miljoen geldt op grond van art. 2:346 lid 1 sub c (nieuw) BW een percentage van één procent.

5 Zie echter paragraaf 6.2.3.13.

6 Kamerstukken II 2008/09, 31 058, nr. 6, p. 15 (NV II). De uitkoopregeling staat ook niet open voor houders van certificaten van aandelen, zie Kamerstukken II 2008/09, 31 058, nr. 6, p. 41 (NV II).

7 Tenzij de bevoegdheid daartoe aan de vergadering van houders van stemrechtloze aandelen is toegekend. De stemrechtloze aandeelhouder heeft in beginsel geen voorkeursrecht ex art. 2:206a BW. Ik verwijs naar paragraaf 6.2.3.5.

8 Tenzij de instemming van de stemrechtloze aandeelhouder op grond van art. 2:208 lid 2, 3 of 4 BW is vereist.

9 Tenzij de bevoegdheid tot bestemming van de winst aan de vergadering van houders van stemrechtloze aandelen is toegekend.

10 Tenzij sprake is van een situatie als bedoeld in art. 2:231 lid 4 BW.

11 Tenzij de bevoegdheid daartoe aan de vergadering van houders van stemrechtloze aandelen is toegekend. 


\begin{tabular}{|l|l|l|}
\hline & $\begin{array}{l}\text { Rechten van de algemene vergadering die de stemrechtloze } \\
\text { aandeelhouder vanwege het ontbreken van het aan zijn } \\
\text { aandeel verbonden stemrecht of anderszins niet toekomen }\end{array}$ & $\begin{array}{l}\text { BW Boek } 2 \\
\text { art. }\end{array}$ \\
\hline 10. & het benoemen van bestuurders & $242^{12}$ \\
\hline 11. & het schorsen en ontslaan van bestuurders & $244^{13}$ \\
\hline 12. & het vaststellen van de bezoldiging van bestuurders & $245^{14}$ \\
\hline 13. & het benoemen van commissarissen & $252^{15}$ \\
\hline 14. & het schorsen en ontslaan van commissarissen & $254^{16}$ \\
\hline 15. & het vaststellen van de bezoldiging van commissarissen & 255 \\
\hline 16. & $\begin{array}{l}\text { het besluiten tot fusie of splitsing. Er is een goedkeurend } \\
\text { groepsbesluit vereist van de houders van stemrechtloze } \\
\text { aandelen aan wier rechten de fusie of splitsing afbreuk } \\
\text { doet (zie art. 2:330 lid 2 en 2:334ee lid 2 BW). }{ }^{17}\end{array}$ & 317 en $334 \mathrm{~m}$ \\
\hline
\end{tabular}

Niettemin hebben deze besluiten invloed op de positie van de stemrechtloze aandeelhouder. Daarom heeft de wetgever in de flex-BV de stemrechtloze aandeelhouder in een aantal gevallen bijzondere rechten toegekend, althans een aparte regeling ter bescherming van de positie van de stemrechtloze aandeelhouder getroffen. Ik kom daarop in paragraaf 6.2.3.6 terug.

Daarnaast is de geschillenregeling aangepast. De aandeelhouder heeft ex art. 2:343 BW een recht op uittreding. De vordering daartoe kan ook worden ingesteld tegen de vennootschap op grond van gedragingen van één of meer medeaandeelhouders of van de vennootschap zelf. Ik kom op de geschillenregeling in paragraaf 8.9 terug.

Ik noem volledigheidshalve art. 2:192 BW met betrekking tot statutaire verplichtingen of eisen, ${ }^{18}$ waarvan het eerste lid bepaalt dat de statuten met betrekking tot alle aandelen of aandelen van een bepaalde soort of aanduiding kunnen

12 Tenzij de bevoegdheid daartoe aan de vergadering van houders van stemrechtloze aandelen is toegekend

13 Tenzij de bevoegdheid daartoe aan de vergadering van houders van stemrechtloze aandelen is toegekend

14 Tenzij de bevoegdheid daartoe aan de vergadering van houders van stemrechtloze aandelen is toegekend

15 Tenzij de bevoegdheid daartoe aan de vergadering van houders van stemrechtloze aandelen is toegekend

16 Tenzij de bevoegdheid daartoe aan de vergadering van houders van stemrechtloze aandelen is toegekend.

17 Kamerstukken II 2011/12, 32 426, nr. 26, p. 2-3. Aan de vergadering van stemrechtloze aandeelhouders kunnen immers bijzondere bevoegdheden zijn toegekend, zoals de benoeming van een bestuurder of commissaris of een recht van instructie, zie Kamerstukken II 2009/2010, 32 426, nr. 3 , p. 30 (MvT).

18 Zie over art. 2:192 BW en de wijzigingen in een eerder ontwerp van dat artikel: Van Veen 2007, p. 950 e.v. en Van Veen 2009, p. 467 e.v., en de in die bijdragen aangehaalde literatuur. 
(i) bepalen dat verplichtingen van verbintenisrechtelijke aard, jegens de vennootschap of derden of tussen aandeelhouders, aan het aandeelhouderschap zijn verbonden, (ii) eisen verbinden aan het aandeelhouderschap en (iii) bepalen dat de aandeelhouder in gevallen, in de statuten omschreven, gehouden is zijn aandelen of een deel daarvan aan te bieden en over te dragen. Deze verplichtingen of eisen kunnen niet, ook niet onder voorwaarde of tijdsbepaling, tegen de wil van de aandeelhouder worden opgelegd. Art. 2:192 BW schept aldus de mogelijkheid verplichtingen van aandeelhouders in de flex-BV ook statutair te regelen in plaats van enkel in een aandeelhoudersovereenkomst. Uit de laatste volzin volgt dat de aandeelhouder zich aan art. 2:192 lid 1 BW kan onttrekken. Dat wil zeggen dat hij een recht van instemming heeft. ${ }^{19}$ Ten aanzien van hem geldt de nieuwe, statutaire regeling op grond van het artikel, indien hij niet instemt, niet; hij is persoonsgebonden niet-gebonden. Bovendien geldt geen unanimiteitsvereiste. ${ }^{20}$ Op art. 2:192 BW kom ik in paragraaf 6.2.3.9 terug.

\subsubsection{Recht op winst en/of reserves}

Bij gebrek aan stemrecht in de algemene vergadering zijn voornamelijk de aan het stemrechtloze aandeel verbonden financiële rechten van belang. De financiële rechten vormen een 'wezenlijk onderdeel van het aandeelhouderschap'. ${ }^{21}$ Art. 2:216 BW geeft de stemrechtloze aandeelhouder recht op dividend, althans in beginsel recht op uitkering daarvan. Ik licht die voorwaardelijkheid toe. Art. 2:216 lid $1 \mathrm{BW}$ bepaalt dat de algemene vergadering bevoegd is tot bestemming van de winst die door de vaststelling van de jaarrekening is bepaald en tot vaststelling van uitkeringen, voor zover het eigen vermogen groter is dan de reserves die krachtens de wet of de statuten moeten worden aangehouden. De statuten kunnen de bevoegdheden tot bestemming van de winst die door de vaststelling van de jaarrekening is bepaald en tot vaststelling van uitkeringen beperken of toekennen aan een ander orgaan. Onder een beperking valt bijvoorbeeld dat de statuten bepalen dat de winst rechtstreeks ten goede komt aan de aandeelhouders of dat een deel van de winst toekomt aan bepaalde personen (statutair winstrecht). Een andere mogelijkheid is dat de statuten voorschrijven dat de winst onder bepaalde omstandigheden wordt gereserveerd. Bij de statuten kan de bevoegdheid tot bestemming van winst of de vaststelling van uitkeringen worden toegekend aan een ander orgaan. ${ }^{22}$ Het aangewezen orgaan moet een orgaan zijn in

19 Daarbij is geen sprake van besluitvorming of het uitoefenen van stemrecht. Bij de invoering van een statutaire verplichting zal aan de stemrechtloze aandeelhouder moeten worden gevraagd of hij met de invoering instemt. Zie Kamerstukken I 2011/12, 31058 en 32 426, nr. C, p. 19 (MvA I).

20 Kamerstukken II 2008/09, 31 058, nr. 3, p. 45 (MvT).

21 Kamerstukken II 2006/07, 31 058, nr. 3, p. 75 (MvT).

22 Koelemeijer 2012, p. 44, bepleit dat alleen de algemene vergadering bevoegd is de winst te bestemmen. 
de zin van art. 2:189a BW, bijvoorbeeld het bestuur van de vennootschap. ${ }^{23}$ In het geval waarin de statuten bepalen dat de winst die blijkt uit de jaarrekening toekomt aan de aandeelhouders, dient het besluit tot vaststelling van de jaarrekening te worden beschouwd als het besluit dat strekt tot uitkering. ${ }^{24}$ Dat besluit vereist goedkeuring van het bestuur, alvorens rechtsgeldig kan worden overgegaan tot betaalbaarstelling van de uitkering. ${ }^{25}$ Art. 2:216 lid 1 BW geldt ook voor tussentijdse uitkeringen. ${ }^{26}$

Uit het voorgaande volgt dat de (stemrechtloze) aandeelhouder niet zonder meer recht op uitkering van de winst heeft. De algemene vergadering of een ander daartoe aangewezen orgaan moet daartoe besluiten. De algemene vergadering heeft daarin een keuze. Zij kan de winst reserveren of uitkeren of een combinatie daarvan. Daarbij geldt als eis dat het eigen vermogen groter moet zijn dan de wettelijke en statutaire reserves. Vervolgens, nadat de algemene vergadering tot uitkering van de winst of een gedeelte daarvan heeft besloten, moet krachtens art. 2:216 lid $2 \mathrm{BW}$ het bestuur dat uitkeringsbesluit goedkeuren. Het bestuur kan de goedkeuring slechts weigeren indien het weet of redelijkerwijs behoort te voorzien dat de vennootschap na de uitkering niet zal kunnen blijven voortgaan met het betalen van haar opeisbare schulden. Art. 2:216 lid 3 BW voorziet bovendien in aansprakelijkheidsancties voor zowel bestuurder als aandeelhouder. Indien de vennootschap na een uitkering niet kan voortgaan met het betalen van haar opeisbare schulden, zijn de bestuurders die dat ten tijde van de uitkering wisten of redelijkerwijs behoorden te voorzien jegens de vennootschap hoofdelijk verbonden voor het tekort dat door de uitkering is ontstaan, met de wettelijke rente vanaf de dag van de uitkering. Art. 2:248 lid 5 BW is in dat geval van overeenkomstige toepassing. Degene die de uitkering ontving, bijvoorbeeld een aandeelhouder, terwijl hij wist of redelijkerwijs behoorde te voorzien dat de vennootschap na de uitkering niet zou kunnen voortgaan met het betalen van haar opeisbare schulden is gehouden tot vergoeding van het tekort dat door de uitkering is ontstaan, ieder voor ten hoogste het bedrag of de waarde van de door hem ontvangen uitkering, met de wettelijke rente vanaf de dag van de uitkering. Ter zake van deze aansprakelijkheid van de kapitaalverschaffer zonder stemrecht verwijs ik naar paragraaf 6.6.

Art. 2:216 lid 6 BW bepaalt dat bij de berekening van het bedrag, dat op ieder aandeel zal worden uitgekeerd, slechts het bedrag van de verplichte stortingen op het nominale bedrag van de aandelen in aanmerking komt. Met andere woorden: voor de berekening van het dividend per aandeel moet gekeken worden naar het nominale bedrag van dat aandeel. Daarvan kan in de statuten of telkens met

23 Kamerstukken II 2006/07, 31 058, nr. 3, p. 69 (MvT)

24 Kamerstukken II 2006/07, 31 058, nr. 3, p. 68 (MvT).

25 Kamerstukken I 2011/12, 31 058, nr. E, p. 14 (Nadere MvA I). Zie ook: Bier 2012 (2), p. 169.

26 Kamerstukken II 2006/07, 31 058, nr. 3, p. 70 (MvT). Zie ook Kamerstukken I 2011/12, 31 058, nr. E, p. 8 (Nadere MvA I) 
instemming van alle aandeelhouders worden afgeweken. Art. 2:216 lid 6 BW ziet niet alleen op uitkering van winst, maar ook op andere uitkeringen. ${ }^{27}$

Art. 2:216 lid 7 BW stelt dat bij de statuten kan worden bepaald dat aandelen van een bepaalde soort of aanduiding geen of slechts beperkt recht geven tot deling in de winst of reserves van de vennootschap. Daaruit volgt dat wel sprake kan zijn van een stemrechtloos aandeel met beperkt winstrecht. De grens is de laatste volzin van art. 2:228 lid $5 \mathrm{BW}$, namelijk dat ten aanzien van stemrechtloze aandelen niet op grond van art. 2:216 lid $7 \mathrm{BW}$ kan worden bepaald dat zij geen recht geven tot deling in de winst of de reserves van de vennootschap. Aan een stemrechtloos aandeel zal daarom altijd enig recht op uitkering van winst of reserves verbonden moeten zijn. ${ }^{28}$ Onder uitkeringen schaar ik ook het recht op het liquidatieoverschot als bedoeld in art. 2:23b BW. Voor dat standpunt en ook overigens verwijs ik naar paragraaf 4.2.5. Kortom, het recht op winst en/of reserves van de stemrechtloze aandeelhouder is niet ongeclausuleerd.

6.2.3.3 Benoeming, schorsing, ontslag en de vaststelling van de bezoldiging van (een) bestuurder(s) door de vergadering van stemrechtloze aandeelhouders

\section{Inleiding}

Uit het voorgaande bleek dat de wetgever bedoeld heeft een eenvoudig stemrechtloos aandeel in de flex-BV te introduceren. Omdat aan dat aandeel in de algemene vergadering geen stemrecht is verbonden, kan de houder van dat aandeel ook geen bestuurder benoemen. Onder het oude recht was het niet mogelijk dat een aandeelhouder of een groep aandeelhouders een 'eigen' bestuurder benoemde. Vooral in joint venture verhoudingen klemde dat. De oplossing was gelegen in de tussen de joint venture partijen gesloten aandeelhoudersovereenkomst, waarbij de aandeelhouders zich verplichten op een bepaalde manier te stemmen bij benoeming van bestuurders. ${ }^{29}$ De vraag is echter of in de flex-BV de vergadering van stemrechtloze aandeelhouders het recht van benoeming van een bestuurder toekomt. Ik beantwoord die vraag positief en licht dat als volgt toe.

\section{Benoeming}

In paragraaf 4.2.7 besprak ik reeds het orgaanbegrip van art. 2:189a BW. Ik concludeerde dat de vergadering van stemrechtloze aandeelhouders een orgaan van de vennootschap is. Op grond van art. 2:228 lid 5 BW zijn stemrechtloze aandelen, aandelen van een bepaalde soort of aanduiding. Op grond van art. 2:189a BW wordt onder orgaan van de vennootschap verstaan de vergadering van houders van aandelen van een bepaalde soort of aanduiding.

27 Kamerstukken II 2006/07, 31 058, nr. 3, p. 75 (MvT).

28 Kamerstukken II 2006/07, 31 058, nr. 3, p. 86-87 (MvT).

29 Kamerstukken II 2006/07, 31 058, nr. 3, p. 90 (MvT). 
Art. 2:242 lid $1 \mathrm{BW}$ bepaalt dat de benoeming van bestuurders voor de eerste maal bij de akte van oprichting en later door de algemene vergadering geschiedt of, indien de statuten dat bepalen, door een vergadering van houders van aandelen van een bepaalde soort of aanduiding, mits iedere aandeelhouder met stemrecht kan deelnemen aan de besluitvorming inzake de benoeming van ten minste één bestuurder. Op een dergelijke statutaire regeling is art. 2:228 lid 4, derde volzin, BW van overeenkomstige toepassing. Indien een vennootschap toepassing geeft aan art. 2:239a BW (one tier board) wordt bij de benoeming van een bestuurder bepaald of hij wordt benoemd tot uitvoerende bestuurder of niet uitvoerende bestuurder. Het voorgaande geldt niet indien de benoeming overeenkomstig artikel 272 geschiedt door de raad van commissarissen. ${ }^{30}$ Met andere woorden: statutair kan de mogelijkheid gecreëerd worden dat de vergadering van stemrechtloze aandeelhouders haar 'eigen' bestuurder benoemt. ${ }^{31}$ De wetgever verwoordt het aldus: "Een vergadering van houders van aandelen van een bepaalde soort of aanduiding is een orgaan in de zin van het voorgestelde artikel 189a. Dit biedt vennootschappen bijvoorbeeld de mogelijkheid om statutair te bepalen dat de benoeming van een bepaalde bestuurder door de vergadering van houders van stemrechtloze aandelen geschiedt." $" 32$ en even verderop: "Het in het voorgestelde artikel 242 opgenomen vereiste dat iedere aandeelhouder met stemrecht moet kunnen deelnemen aan de besluitvorming inzake de benoeming van ten minste één bestuurder wordt gehandhaafd, omdat het recht om bestuurders en commissarissen te benoemen wordt beschouwd als een essentieel recht van aandeelhouders. Nu een aandeelhouder via het stemrecht in de algemene vergadering op directe wijze invloed kan uitoefenen op het beleid van de vennootschap, moet hij dat ook op indirecte wijze kunnen via de benoeming van een of meer bestuurders (en commissarissen). Dit is slechts anders bij stemrechtloze aandelen, waar men uitdrukkelijk de bedoeling heeft gehad om geen enkele zeggenschap in de algemene vergadering (onderstreping, RAW) toe te kennen." "33 Van de mogelijkheid dat de vergadering van stemrechtloze aandeelhouders een bestuurder benoemt, kan geen gebruik worden gemaakt indien de benoeming van bestuurders op grond van het (volledig) structuurregime door de raad van commissarissen geschiedt.

30 Dit is tekst van art. 2:242 lid $1 \mathrm{BW}$, zoals die luidt na inwerkingtreding van de Wet vereenvoudiging en flexibilisering bv-recht, de Invoeringswet vereenvoudiging en flexibilisering bv-recht en de Wet Bestuur en Toezicht (Wet van 6 juni 2011 tot wijziging van boek 2 van het Burgerlijk Wetboek in verband met de aanpassing van regels over bestuur en toezicht in naamloze en besloten vennootschappen, Kamerstukken 31 763, Stb. 2011, 275 en Wet van 27 september 2012 tot wijziging van boek 2 van het Burgerlijk Wetboek ter verduidelijking van de artikelen 297a en 297b, Kamerstukken 32 873, Stb. 2012, 440. Beide in werking getreden op 1 januari 2013, Stb. 2012, 455 resp. 456.).

31 Kamerstukken II 2006/07, 31 058, nr. 3, p. 91 (MvT) en Kamerstukken I 2011/12, 31058 en 32 426, nr. C, p. 25 (MvA I). Volgens Nowak \& Van den Ingh 2007, p. 130, r.k., is het mogelijk om per bestuurder een ander benoemingsmechanisme te creëren

32 Kamerstukken II 2008/09, 31 058, nr. 6, p. 39 (NV II).

33 Kamerstukken II 2008/09, 31 058, nr. 6, p. 43 (NV II) 
Schorsing en ontslag

De vraag is vervolgens of, indien de statuten tot benoeming van een bestuurder door de vergadering van stemrechtloze aandeelhouders zijn ingericht, de vergadering van stemrechtloze aandeelhouders ook bevoegd is haar bestuurder te schorsen of te ontslaan. Ook het antwoord op die vraag luidt bevestigend. Art. 2:244 lid 1 BW bepaalt immers onder meer dat iedere bestuurder te allen tijde geschorst en ontslagen kan worden door het orgaan dat bevoegd is tot benoeming.

De tweede volzin van art. 2:244 lid $1 \mathrm{BW}$ bepaalt dat de statuten kunnen bepalen dat een bestuurder eveneens kan worden ontslagen door een ander orgaan, tenzij de benoeming overeenkomstig art. 2:272 BW door de raad van commissarissen geschiedt. De statuten van de BV kunnen aldus zodanig worden ingericht dat niet alleen de vergadering van stemrechtloze aandeelhouders een bestuurder kan ontslaan, maar dat dit recht ook aan de vergadering van houders van aandelen van een andere soort of aanduiding toekomt. Uit de wettekst - het woord 'eveneens', dat wil zeggen 'ook' - leid ik af dat het ontslaan van een bestuurder in dat geval een gedeelde en zelfstandige bevoegdheid is. Indien er meerdere organen bevoegd zijn tot ontslag, kan ieder orgaan naast het andere orgaan ontslaan. De wetgever merkt op dat daardoor een patstelling kan ontstaan, bijvoorbeeld als het ene orgaan benoemt en het andere orgaan ontslaat. De wetgever ziet echter ook praktische voordelen, zoals de mogelijkheid dat de vergadering van stemrechtloze aandeelhouders benoemt en de algemene vergadering, naast de vergadering van stemrechtloze aandeelhouders, de bevoegdheid heeft te ontslaan. Daardoor kan een onafhankelijk oordeel over het functioneren van het bestuur worden bevorderd, aldus de wetgever. ${ }^{34}$

De tweede volzin van art. 2:244 lid 1 BW spreekt echter niet over 'schorsen'. De vraag is waarom het andere orgaan, naast de bevoegdheid tot ontslaan, niet ook de bevoegdheid heeft te schorsen. Dat laatste is immers een minder vergaand besluit. ${ }^{35}$ De wetgever motiveert zijn keuze als volgt: "De suggestie in de consultatie om naast ontslag ook schorsing door een ander orgaan mogelijk te maken is niet gevolgd. De raad van commissarissen is op grond van artikel 257 in beginsel te allen tijde bevoegd tot schorsing van een bestuurder. De aanbeveling van de expertgroep waaraan de bepaling uitvoering geeft, was ingegeven door de gedachte dat het toezicht door de raad van commissarissen op het bestuur kan worden versterkt indien dat orgaan ook bevoegd kan worden gemaakt tot ontslag. Het zou niet wenselijk zijn (toevoeging 'zijn' en onderstreping, RAW) indien naast de raad van commissarissen en het orgaan dat bevoegd is tot benoeming nog een ander orgaan bevoegd kan zijn tot schorsing. Door artikel 244 lid 1, tweede zin, te

34 Kamerstukken II 2006/07, 31 058, nr. 3, p. 93-94 (MvT). Desgewenst kan een stemovereenkomst worden gesloten om de bevoegdheid van de algemene vergadering te beperken. Een andere mogelijkheid is een bindende voordracht op grond van art. 2:243 lid 6 jo. lid 1 en 2 BW.

35 In gelijke zin Nowak \& Van den Ingh 2007, p. 131; Portengen 2007, p. 945; Oranje 2008 (1), p. 46 en Oranje 2008 (2), p. 8. 
beperken tot de ontslagbevoegdheid, blijft de voorgestelde aanvullende vorm van toezicht door een ander orgaan beperkt tot uitzonderlijke situaties, namelijk die situaties waarin het functioneren van een bestuurder aanleiding geeft tot ontslag." ${ }^{, 36}$ Erg overtuigend vind ik deze motivering niet. Veel BV's (in het MKB) kennen geen raad van commissarissen. Daarnaast zal in de regel slechts in uitzonderlijke situaties sprake kunnen zijn van schorsing van een bestuurder, omdat een dergelijke maatregel diffamerende werking heeft, althans kan hebben. Hoewel schorsing in beginsel een minder vergaande maatregel dan ontslag is, liggen die twee maatregelen dicht bij elkaar. Een goede reden voor dit verschil ten aanzien van het 'andere orgaan' is er naar mijn mening niet.

De schorsing van een bestuurder door de raad van commissarissen kan te allen tijde worden opgeheven door de vergadering van aandeelhouders die bevoegd is tot benoeming (art. 2:257 lid $2 \mathrm{BW}$ ). ${ }^{37}$

Hoorrecht en raadgevende stem

In paragraaf 4.2.7 stelde ik dat bestuurders en commissarissen in de vergadering van stemrechtloze aandeelhouders geen raadgevende stem hebben. Hoe moet dat echter worden bezien indien aan de vergadering van stemrechtloze aandeelhouders de bevoegdheid tot benoeming en ontslag van een bestuurder is toegekend? Geldt voor een besluit tot ontslag van deze vergadering een minder zware eis, in de zin dat geen sprake is van een hoorrecht van de betreffende bestuurder en raadgevende stem van betreffende bestuurder en zijn eventuele medebestuurders? Over de verhouding tussen het hoorrecht en de raadgevende stem stelt Maeijer het volgende: "Art. 227 lid 4 (en 117 lid 4) bepalen dat de bestuurders en commissarissen als zodanig in de algemene vergadering van aandeelhouders een raadgevende stem hebben. De ratio is dat zij in de gelegenheid moeten worden gesteld van hun visie te doen blijken opdat de aandeelhouders daarmee bij hun stemgedrag rekening kunnen houden. (...) Dit raadplegen is iets anders en gaat verder dan het louter horen van een bestuurder bij een voorgenomen besluit tot ontslag. Het raadplegen geschiedt in het belang van het functioneren van de vennootschap; het horen met het oog op de belangen van de bestuurder in privé. Er is geen expliciete wettelijke bepaling die tot dit horen bij voorgenomen ontslag noopt (zie bij de structuurvennootschap echter art. 2:162 en 272), maar dat in de regel een plicht hiertoe bestaat, wordt afgeleid uit de normen van de redelijkheid en billijkheid bedoeld in art. 2:8."38

Allereerst het hoorrecht. Moet de vergadering van houders van stemrechtloze aandelen de bestuurder ten aanzien van het voorgenomen ontslagbesluit horen? Uit

36 Kamerstukken II 2006/07, 31 058, nr. 3, p. 94 (MvT)

37 Kamerstukken II 2006/07, 31 058, nr. 3, p. 97 (MvT) en Kamerstukken II 2010/11, 32 426, nr. 7, p. 11 (NV II)

38 Sub 3 van zijn noot onder HR 10 maart 1995, NJ 1995, 595, m.nt. Ma (Janssen Pers). Zie ook Schwarz 1995 (1), p. 528, sub 4, die eenzelfde onderscheid maakt. 
het Janssen Pers-arrest ${ }^{39}$ volgt dat de bestuurder over zijn voorgenomen ontslag moet worden gehoord, welk hoorrecht is gebaseerd op art. 2:8 BW. Wordt in strijd daarmee gehandeld, dan staat het ontslagbesluit ex art. 2:15 lid 1 sub b BW bloot aan vernietiging. Ik zou deze lijn ook willen volgen voor besluitvorming ten aanzien van het ontslag in de vergadering van houders van stemrechtloze aandelen.

Dan de raadgevende stem. De regel dat bestuurders en commissarissen op grond van het bepaalde in art. 2:227 lid 7 BW in de algemene vergadering een raadgevende stem hebben, is geschreven in het belang van de vennootschap. Zij moeten vanuit dat belang de gelegenheid krijgen advies uit te brengen over de voorgenomen besluitvorming. ${ }^{40} \mathrm{Bij}$ hun stemgedrag kunnen aandeelhouders met dat advies rekening houden. Dat geldt op grond van het bepaalde in art. 2:238 lid 2 laatste volzin BW en het Hay Group/Schneider-arrest ${ }^{41}$ ook voor besluitvorming buiten vergadering. Het niet-naleven van deze regel is een grond voor vernietiging van het ontslagbesluit ex art. 2:15 lid 1 sub a BW. Oorspronkelijk was de minister van mening dat bestuurders en commissarissen ook een raadgevende stem hebben in de vergadering van houders van aandelen van een bepaalde soort of aanduiding. ${ }^{42}$ Later is hij daarop met de volgende overweging op terug gekomen: "Bij een vergadering van houders van aandelen van een bepaalde soort of aanduiding is geen sprake van een algemene vergadering, noch van besluitvorming in de zin van artikel 238. Het gaat immers om een besluit van een ander orgaan dan de algemene vergadering. Aan een dergelijk orgaan kunnen bij de statuten bevoegdheden worden toegekend. Het geven van advies door het bestuur in het belang van de vennootschap ligt bij nader inzien bij dergelijke statutaire bevoegdheden minder voor de hand dan bij de wettelijke (en statutaire) bevoegdheden van de algemene vergadering." ${ }^{43}$ Erg overtuigend vind ik deze overweging niet. Een besluit tot ontslag van een bestuurder is een belangrijk besluit, ongeacht aan welk orgaan de bevoegdheid daartoe is toegekend. Mijns inziens is er dan ook geen rechtvaardiging voor dit verschil. Het komt mij voor dat uit de eisen van de vennootschappelijke redelijkheid en billijkheid kan voortvloeien dat de vergadering van houders van stemrechtloze aandelen bij een voorgenomen ontslag besluit de bestuurders (en commissarissen) in de gelegenheid stellen hun raadgevende stem te doen horen, te meer indien de bestuurders niet tevens aandeelhouders zijn. In de regel staan aandeelhouders op wat meer afstand van de vennootschap. De bestuurders kunnen hen bij de besluitvorming van raad voorzien. Ik kan mij voorstellen dat deze regel ook geldt voor andere ingrijpende besluiten (zoals schorsing van een bestuurder), waartoe de vergadering

39 HR 10 maart 1995, NJ 1995, 595, m.nt. Ma (Janssen Pers). Zie ook Asser/Maeijer, Van Solinge \& Nieuwe Weme 2-II* 2009, nr. 435.

40 Kamerstukken II 2006/07, 31 058, nr. 3, p. 84 (MvT).

41 HR 22 december 2009, JOR 2010, 40, m.nt. Nowak (Hay Group/Schneider) r.o. 3.4. Zie ook Hof Amsterdam 18 mei 1989, NJ 1990, 591, r.o. 4.8 en r.o. 4.23 ter zake van schending van de raadgevende stem en het hoorrecht.

42 Kamerstukken I 2011/12, 31058 en 32 426, nr. C, p. 24 (MvA I).

43 Kamerstukken I 2011/12, 31 058, nr. E, p. 22 (Nadere MvA I). 
van houders van stemrechtloze aandelen bevoegd is. Het niet-naleven daarvan kan een grond voor vernietiging van het ontslagbesluit ex art. 2:15 lid 1 sub b BW zijn. Toegegeven kan worden dat dit besluitvorming kan bemoeilijken, maar dan zou de hoofdregel moeten zijn dat bestuurders en commissarissen in welke vergadering dan ook en in en buiten vergadering geen raadgevende stem hebben. Die hoofdregel is echter niet het wettelijk uitgangspunt.

In r.o. 3.3 en 3.4 van het hiervoor genoemde Hay Group/Schneider-arrest ${ }^{44}$ baseert de Hoge Raad het hoorrecht kennelijk (ook) op art. 2:227 lid 4 (thans lid 7) BW en niet op de vennootschappelijke redelijkheid en billijkheid. ${ }^{45}$ Of moet het arrest zo worden gelezen dat de raadgevende stem in deze rechtsoverweging de meeste aandacht had? Daarnaast wordt geen onderscheid gemaakt tussen vernietiging op grond van art. 2:15 lid 1 onder a of $b$ BW. Voor het rechtsgevolg heeft dat overigens geen gevolgen, zij het dat blijkens art. 2:15 lid $6 \mathrm{BW}$ alleen een op grond van art. 2:15 lid 1 onder a BW vernietigd besluit kan worden bevestigd.

\section{Bezoldiging}

Van benoeming, schorsing en ontslag is het een kleine stap naar bezoldiging. Daarover bepaalt art. 2:245 BW als hoofdregel dat de bezoldiging van bestuurders door de algemene vergadering wordt vastgesteld. Uit dat artikel volgt dat bij statuten daarvan kan worden afgeweken. Het is daarom mogelijk dat de vergadering van stemrechtloze aandeelhouders ook de bezoldiging van (haar) bestuurder(s) vaststelt. Naar mijn mening houdt dat echter niet in dat die vergadering bij de vaststelling van de hoogte van die bezoldiging volledig een eigen koers zou kunnen varen. Onder omstandigheden kan een besluit tot vaststelling van de bezoldiging op grond van art. 2:8 jo. 2:15 lid 1 onder b BW vernietigbaar zijn.

\section{Tussenconclusie}

De statuten van de flex-BV kunnen aldus zo worden ingericht dat de vergadering van stemrechtloze aandeelhouders een bestuurder kan benoemen, schorsen en ontslaan en zijn bezoldiging kan vaststellen. Daarmee kan de stemrechtloze aandeelhouder, ondanks het ontbreken van zijn stemrecht, zijn invloed in de vennootschap zien toenemen. Die invloed is in zekere mate relatief. Hoewel de door de vergadering van stemrechtloze aandeelhouders benoemde bestuur haar vertrouwen zal genieten, heeft de bestuurder het vennootschappelijk belang in acht te nemen. Hij kan zich aldus niet uitsluitend laten leiden door de belangen van de stemrechtloze aandeelhouders. ${ }^{46}$

De grens van die verhoogde invloed is bovendien gelegen in de voorwaarde als genoemd in art. 2:242 lid 1 BW, namelijk dat iedere aandeelhouder met stemrecht

44 HR 22 december 2009, JOR 2010, 40, m.nt. Nowak (Hay Group/Schneider).

45 In gelijke zin: J.B. Huizink, Groene Serie Rechtspersonen, art. 2:134 BW, aant. 10.4.1, Deventer: Kluwer.

46 Kamerstukken II 2006/07, 31 058, nr. 3, p. 92 (MvT). 
kan deelnemen (lees: moet kunnen deelnemen) aan de besluitvorming inzake de benoeming van ten minste één bestuurder. Wordt er maar één bestuurder benoemd, dan kunnen de statuten bepalen dat die bestuurder door de vergadering van stemrechtloze aandeelhouders wordt benoemd. De aandeelhouders met stemrecht moeten dan wel hun stem in de besluitvorming kunnen laten gelden. De wetgever beschouwt het uitoefenen van invloed op de benoeming van het bestuur als een essentieel recht van aandeelhouders. ${ }^{47}$ Met 'deelnemen aan de besluitvorming' bedoelt de wetgever dat een aandeelhouder de vergaderingen van de tot benoeming bevoegde vergadering van aandeelhouders kan bijwonen, daar het woord kan voeren en mee kan stemmen over de benoeming. ${ }^{48}$ Op een andere plaats verwoordt de wetgever onder verwijzing naar art. 2:24a BW het aldus: "Nu een aandeelhouder via het stemrecht in de algemene vergadering op directe wijze invloed kan uitoefenen op het beleid van de vennootschap, moet hij dat ook op indirecte wijze kunnen via de benoeming van een of meer bestuurders (en commissarissen). Dit is slechts anders bij stemrechtloze aandelen, waar men uitdrukkelijk de bedoeling heeft gehad om geen enkele zeggenschap in de algemene vergadering toe te kennen."49

In de literatuur is opgemerkt dat dit deelnemingsvereiste, of deze 'ondergrens', de flexibiliteit niet ten goede komt. ${ }^{50}$ Argumenten voor het schrappen van de ondergrens zijn dat het volledige structuurregime blijkbaar essentiële rechten van aandeelhouders aantast en dat de redenering dat het uitoefenen van invloed op de benoeming van het bestuur als een essentieel recht van aandeelhouders vaarwel is gezegd vanwege de introductie van stemrechtloze aandelen. ${ }^{51}$ De wetgever heeft echter niet voor schrapping van de ondergrens gekozen. Ten aanzien van de stemrechtloze aandeelhouder geldt aldus dat 'zijn' vergadering een bestuurder kan benoemen indien dat statutair is bepaald. Indien het bestuur van de vennootschap slechts één bestuurder kent, zal de vergadering van stemrechtloze aandeelhouders rekening moeten houden met andere stemgerechtigde aandeelhouders, zodat de invloed van de stemrechtloze aandeelhouder beperkt zal zijn. Dat geldt te meer, indien sprake is van een regeling van flexibel stemrecht in de zin van art. 2:228 lid 4 BW.

\section{Benoeming uit voordracht}

De benoeming van een bestuurder uit een voordracht kan niet alleen door de algemene vergadering geschieden (art. 2:243 lid 1 BW), maar ook door de

47 Kamerstukken II 2006/07, 31 058, nr. 3, p. 91 (MvT).

48 Kamerstukken II 2006/07, 31 058, nr. 3, p. 91 en 95 (MvT).

49 Kamerstukken II 2008/09, 31 058, nr. 6, p. 43 (NV II).

50 Advies d.d. 30 maart 2005 van de Gecombineerde Commissie Vennootschapsrecht van de Nederlandse Orde van Advocaten en de Koninklijke Notariële Beroepsorganisatie 'Eerste tranche ambtelijk voorontwerp Vereenvoudiging en Flexibilisering van het BV-recht, Orgaanstructuur en bevoegdheden, aandelen en certificaten', p. 10, sub 4.20; Nowak \& Van den Ingh 2007, p. 130; Oranje 2008 (1), p. 40 en Oranje 2008 (2), p. 8.

51 Portengen 2007, p. 944. Oranje 2008 (1), p. 40 sluit zich daarbij aan. 
vergadering van houders van aandelen van een bepaalde soort of aanduiding (art. 2:243 lid 5 BW). ${ }^{52}$ Op grond van art. 2:243 lid 2 BW kan de algemene vergadering echter het bindend karakter aan die voordracht ontnemen door middel van een besluit dat met twee derden van de uitgebrachte stemmen, welke stemmen meer dan de helft van het geplaatst kapitaal vertegenwoordigen, wordt genomen.

Indien de statuten op grond van art. 2:242 lid $1 \mathrm{BW}$ bepalen dat de benoeming van bestuurders geschiedt door een vergadering van houders van aandelen van een bepaalde soort of aanduiding, is aldus sprake van een benoeming uit een voordracht.

Toekenning en ontneming van de benoemingsbevoegdheid

In art. 2:242 lid $1 \mathrm{BW}$ wordt verwezen naar art. 2:228 lid 4 derde volzin BW. Indien een besluit tot wijziging van de statuten wordt genomen, inhoudende dat aan een bepaald orgaan anders dan de algemene vergadering de bevoegdheid wordt toegekend een bestuurder te benoemen, kan dat besluit slechts met algemene stemmen (unanimiteit) in een vergadering waarin het gehele geplaatste kapitaal vertegenwoordigd is worden genomen. De achtergrond daarvan is dat een dergelijk besluit ingrijpende gevolgen heeft voor de zeggenschap van aandeelhouders, waartegen de unanimiteitsregel bescherming biedt. ${ }^{53}$

Indien aan de vergadering van stemrechtloze aandeelhouders op grond van art. 2:242 lid $1 \mathrm{BW}$ de bevoegdheid is toegekend een bestuurder te benoemen, kan die bevoegdheid worden ontnomen. Voor een dergelijke statutenwijziging geldt dat ook dit besluit slechts met algemene stemmen (unanimiteit) in een vergadering, waarin het gehele geplaatste kapitaal vertegenwoordigd is, kan worden genomen. Art. 2:228 lid 4 derde volzin BW is eveneens van toepassing. ${ }^{54} \mathrm{Bij}$ een dergelijk besluit tot statutenwijziging wordt de stemrechtloze aandeelhouder beschermd door het bepaalde in art. 2:231 lid 4 BW. Er is een goedkeurend groepsbesluit nodig van de houders van stemrechtloze aandelen. Op gelijke wijze geldt dit naar mijn mening voor het ontnemen van de schorsings- of ontslagbevoegdheid ex art. 2:244 BW.

6.2.3.4 Benoeming, schorsing, ontslag en de vaststelling van de bezoldiging van (een) commissaris(sen) door de vergadering van stemrechtloze aandeelhouders

De regelingen over benoeming (art. 2:252 BW), schorsing, ontslag (art. 2:254 BW) en de vaststelling van de bezoldiging van (een) commissaris(sen) (art. 2:255 BW) door de vergadering van stemrechtloze aandeelhouders volgt in grote lijnen de regelingen daarover ten aanzien van (een) bestuurder(s). ${ }^{55}$ Ik verwijs naar paragraaf 6.2.3.3. In deze paragraaf sta ik stil bij de verschillen tussen deze regelingen.

52 Kamerstukken II 2009/10, 31 058, nr. 20 en 28, p. 2. Een gelijke bepaling geldt voor de benoeming uit voordracht van een commissaris, zie art. 2:252 lid $2 \mathrm{BW}$.

53 Kamerstukken II 2006/07, 31 058, nr. 3, p. 91 (MvT)

54 Kamerstukken I 2011/12, 31058 en 32 426, nr. C, p. 25 (MvA I).

55 Kamerstukken II 2006/07, 31 058, nr. 3, p. 95 en 97 (MvT). 
Indien de vergadering van stemrechtloze aandeelhouders bij statuten het recht is toegekend een commissaris te benoemen, houdt dat niet in dat afstand wordt genomen van de positie van de commissarissen als onafhankelijke toezichthouders. Commissarissen moeten zich bij de vervulling van hun taak richten naar het belang van de vennootschap en de met haar verbonden onderneming. Commissarissen moeten zich daarnaast gedragen naar hetgeen door de redelijkheid en billijkheid wordt gevorderd. De omstandigheid dat een commissaris door een of meer houders van aandelen van een bepaalde soort of aanduiding is benoemd, betekent derhalve niet dat hij zich (uitsluitend) mag laten leiden door de belangen van die aandeelhouders. ${ }^{56}$

Anders dan bij de benoeming van bestuurders, is het bij de benoeming van commissarissen op grond van art. 2:253 BW mogelijk dat de statuten erin voorzien dat de benoeming van een derde van het aantal commissarissen door anderen dan de algemene vergadering of de vergadering van houders van aandelen van een bepaalde soort of aanduiding geschiedt, mits iedere aandeelhouder met stemrecht kan deelnemen aan de besluitvorming over de benoeming van ten minste één commissaris.

Een ander verschil is dat, anders dan in art. 2:245 BW over de bezoldiging van bestuurders is bepaald, over de bezoldiging van de commissarissen niet kan worden bepaald dat een ander orgaan dan de algemene vergadering die bezoldiging vaststelt (art. 2:255 BW).

\subsubsection{Het voorkeursrecht van de stemrechtloze aandeelhouder}

Art. 2:206a BW regelt het voorkeursrecht van de aandeelhouder op door de vennootschap uit te geven aandelen. De hoofdregel wordt geformuleerd door het eerste lid van dat artikel. Iedere aandeelhouder heeft bij uitgifte van aandelen een voorkeursrecht naar evenredigheid van het gezamenlijke bedrag van zijn aandelen, tenzij - kort gezegd - de statuten anders bepalen of een van de uitzonderingen van het tweede lid gelden. Art. 2:206a lid 2 onder c BW bepaalt dat de houder van stemrechtloze aandelen geen voorkeursrecht heeft op uit te geven aandelen (het actieve voorkeursrecht). Daarnaast bepaalt art. 2:206a lid 3 BW (onder meer) dat de houders van gewone aandelen geen voorkeursrecht hebben op de uitgifte van stemrechtloze aandelen (het passieve voorkeursrecht). 'Toepassing van het voorkeursrecht voor houders van stemrechtloze aandelen zou ertoe leiden dat het onderscheid dat de vennootschap heeft willen aanbrengen tussen aandelen met en zonder stemrecht bij de uitgifte van nieuwe aandelen weer zou worden doorbroken. Vennootschappen die het voorkeursrecht toch willen toepassen op stemrechtloze aandelen, hebben de mogelijkheid om in de statuten af te wijken van de wettelijke hoofdregel. Kapitaalverwatering kan hiermee worden tegengegaan', aldus de

56 Kamerstukken II 2006/07, 31 058, nr. 3, p. 96 (MvT). 
wetgever. ${ }^{57}$ De hoofdregel tot uitsluiten van het voorkeursrecht faciliteert het aantrekken van nieuwe financiering in de vennootschap zonder de stemverhoudingen in de algemene vergadering aan te tasten.

Heeft de stemrechtloze aandeelhouder een voorkeursrecht op uit te geven stemrechtloze aandelen? Art. 2:206a lid 2 onder c BW bepaalt dat de houder van stemrechtloze aandelen geen voorkeursrecht heeft 'op uit te geven aandelen'. Zijn met 'uit te geven aandelen' alleen gewone aandelen bedoeld, ${ }^{58}$ of ook aandelen van een bepaalde soort, zoals stemrechtloze aandelen? Het antwoord op deze vragen is dat de stemrechtloze aandeelhouder geen voorkeursrecht heeft op uit te geven stemrechtloze aandelen. De wetgever licht toe: "VNO-NCW wierp ten aanzien van artikel 206a lid 2 de vraag op of de houders van de in de onderdelen $a, b$ en $c$ genoemde soorten aandelen een voorkeursrecht hebben indien aandelen van hun soort worden uitgegeven. De bestaande regeling in artikel 206a, leden 2 en 3 wordt op dit punt niet gewijzigd. De vraag betreft dus in wezen de uitleg van het bestaande recht. De wet bepaalt op dit punt dat houders van de in lid 2 genoemde categorieën van aandelen geen voorkeursrecht hebben op uit te geven aandelen, dus ook niet op uit te geven aandelen van de in lid 2 genoemde categorieën aandelen. De wettelijke regeling biedt ruimte om hiervan desgewenst in de statuten af te wijken."

Ik vraag me af of de hoofdregel dat de stemrechtloze aandeelhouder geen voorkeursrecht heeft op uit te geven stemrechtloze aandelen een gelukkige is. Bij het stemrechtloze aandeel staan de aan dat aandeel verbonden financiële rechten centraal. Indien de vennootschap stemrechtloze aandelen uitgeeft en de zittende stemrechtloze aandeelhouders geen voorkeursrecht toekomt, vindt kapitaalverwatering plaats. Het komt mij voor dat de wetgever dit onderkent: "Als de vennootschap kiest voor de uitgifte van aandelen waaraan bijzondere rechten zijn toegekend of bepaalde rechten zijn ontzegd, verdient het in het algemeen aanbeveling om daarbij aandacht te besteden aan de regeling van het voorkeursrecht." "60 Zoals gesteld, statutaire afwijking van de hoofdregel is mogelijk.

Indien op grond van art. 2:206 BW een besluit tot emissie van gewone aandelen wordt genomen in een BV met stemrechtloze aandelen is sprake van kapitaalverwatering. Indien de statuten van de BV reeds in gewone aandelen voorzien - en dat zal in de regel het geval zijn - dan is geen sprake van een statutenwijziging. De stemrechtloze aandeelhouder wordt daarom niet door art. 2:231 lid 4 BW beschermd. Evenmin wordt de stemrechtloze aandeelhouder door het bepaalde in art. 2:216 lid $8 \mathrm{BW}$ beschermd. De parlementaire geschiedenis zwijgt over

57 Kamerstukken II 2006/07, 31 058, nr. 3, p. 63 (MvT), Kamerstukken II 2008/09, 31 058, nr. 6, p. 17-18 (NV II) en Kamerstukken II 2010/2011, 32 426, nr. 7, p. 25 (NV II).

58 Asser/Maeijer, Van Solinge \& Nieuwe Weme 2-II* 2009, nr. 257.

59 Kamerstukken II 2008/09, 31 058, nr. 6, p. 38 (NV II). Zie ook Ten Berg 2012, p. 617; H.E. Boschma \& J.N. Schutte-Veenstra, Tekst \& Commentaar Ondernemingsrecht en Effectenrecht, art. 2:206a BW, aant. 3, Deventer: Kluwer en J.N. Schutte-Veenstra, Groene Serie Rechtspersonen, art. 2:206a BW, aant. 3, Deventer: Kluwer.

60 Kamerstukken II 2008/09, 31 058, nr. 6, p. 18 (NV II) 
eventuele bescherming. Naar mijn mening kan de stemrechtloze aandeelhouder in deze situatie slechts bescherming ontlenen aan een vordering ex art. 2:15 jo. 2:8 BW. Daarbij zal het vennootschappelijk belang tegen de gerechtvaardigde belangen van de stemrechtloze aandeelhouder moeten worden afgewogen. ${ }^{61}$ Dezelfde bescherming vindt de stemrechtloze aandeelhouder indien een besluit tot emissie van stemrechtloze aandelen wordt genomen, zo komt mij voor.

Een andere situatie: stel dat - in afwijking van de hoofdregel van art. 2:206a lid 2 BW - bij statuten een voorkeursrecht aan de stemrechtloze aandeelhouder op uit te geven stemrechtloze aandelen is toegekend. De algemene vergadering, althans de vennootschap, wil nieuw kapitaal aantrekken in de vorm van stemrechtloze aandelen, maar gunt om haar moverende redenen de huidige stemrechtloze aandeelhouder(s) niet het recht die nieuw uit te geven stemrechtloze aandelen te verwerven. Naar mijn mening kan het voorkeursrecht worden omzeild. De vennootschap kan nieuwe, gewone aandelen uitgeven en die certificeren en vervolgens de certificaten (doen) plaatsen bij nieuwe kapitaalverschaffers. Daarmee worden weliswaar geen aandelen zonder stemrecht gecreëerd, maar wel de zittende stemrechtloze aandeelhouders met voorkeursrecht gepasseerd. Het enige middel voor de zittende stemrechtloze aandeelhouders om hiertegen op te komen, is een vordering ex art. 2:8 jo. 2:15 BW. Art. 2:216 lid 8 en art. 2:231 lid 4 BW lijken mij ook in deze situatie, gelet op de enge uitleg van deze artikelen die ik voor sta, ${ }^{62}$ niet van toepassing. De samenstelling van het bestuur van het administratiekantoor is, zo komt mij voor, een van de omstandigheden die in deze situatie betrokken moet worden bij de beoordeling of sprake is van strijd met de vennootschappelijke redelijkheid en billijkheid. Naarmate de invloed van de BV op de samenstelling van het bestuur van het administratiekantoor groter is, kan dat naar mijn mening de kans van slagen van de vordering tot vernietiging vergroten. Uiteraard is dat echter niet de enige omstandigheid die in de oordeelsvorming betrokken moet worden.

De positie van de stemrechtloze aandeelhouder kan naar mijn mening - naast het toekennen van een voorkeursrecht - worden versterkt indien op de voet van art. 2:206 BW de bevoegdheid tot het uitgeven van nieuwe aandelen wordt toegekend aan de vergadering van stemrechtloze aandeelhouders. De tweede volzin van art. 2:206 lid 1 BW biedt daartoe de mogelijkheid. Ook zou deze bevoegdheid kunnen worden toegekend aan het bestuur van de vennootschap dat bij haar besluitvorming meer dan de algemene vergadering het vennootschappelijk belang moet betrekken, waaronder begrepen maar daartoe niet beperkt de gerechtvaardigde belangen van de stemrechtloze aandeelhouders.

61 Vgl. HR 1 april 1949, NJ 1949, 465, m.nt. Ph.A.N.H. (Doetinchemse IJzergieterij) en HR 19 maart 1975, NJ 1976, 267, m.nt. Wachter (Westertoren/HVA).

62 Zie paragraaf 6.2.3.7. 
6.2.3.6 Bescherming van de stemrechtloze aandeelhouder bij bepaalde besluiten

In paragraaf 2.6 bij de bespreking van het stemrechtloze aandeel op hoofdlijnen merkte ik al op dat het stemrechtloze aandeel niet geheel stemrechtloos is. In paragraaf 6.2.3.1 noemde ik de rechten van de stemrechtloze aandeelhouder. Voor de stemrechtloze aandeelhouder zijn de volgende beschermingsregels van belang. In de beschermingsregels zijn te onderscheiden: (i) goedkeuring, (ii) instemming en (iii) vrijstelling.

\begin{tabular}{|l|l|l|}
\hline & $\begin{array}{l}\text { Besluiten die slechts met een goedkeurend groepsbesluit van } \\
\text { stemrechtloze aandeelhouders kunnen worden genomen }\end{array}$ & $\begin{array}{l}\text { BW Boek 2 } \\
\text { art. }\end{array}$ \\
\hline 1. & $\begin{array}{l}\text { een besluit tot statutenwijziging dat specifiek afbreuk doet } \\
\text { aan enig recht van houders van stemrechtloze aandelen } \\
\text { behoeft, tenzij ten tijde van de toekenning van het recht de } \\
\text { bevoegdheid tot wijziging bij die bepaling uitdrukkelijk was } \\
\text { voorbehouden, een goedkeurend besluit van deze groep van } \\
\text { aandeelhouders, onverminderd het vereiste van instemming } \\
\text { waar dit uit de wet voortvloeit }\end{array}$ & 231 lid 4 \\
\hline 2. & $\begin{array}{l}\text { een besluit tot verhoging of verlaging van het bedrag van de } \\
\text { aandelen en van het maatschappelijk kapitaal }\end{array}$ & $231 \mathrm{a} \mathrm{lid} \mathrm{1}$ \\
\hline
\end{tabular}

\begin{tabular}{|l|l|l|}
\hline & $\begin{array}{l}\text { Besluiten die slechts met instemming van de stemrechtloze } \\
\text { aandeelhouder kunnen worden genomen }\end{array}$ & $\begin{array}{l}\text { BW Boek } 2 \\
\text { art. }\end{array}$ \\
\hline 1. & $\begin{array}{l}\text { het besluit tot het uitsluiten van de overdraagbaarheid van de } \\
\text { stemrechtloze aandelen voor een bepaalde termijn }\end{array}$ & 195 lid $3^{63}$ \\
\hline 2. & $\begin{array}{l}\text { het besluit tot intrekking van stemrechtloze aandelen, tenzij } \\
\text { voor de uitgifte van de aandelen in de statuten is bepaald dat } \\
\text { zij kunnen worden ingetrokken met terugbetaling }\end{array}$ & 208 lid 2 \\
\hline 3. & $\begin{array}{l}\text { het afwijken van het vereiste van evenredigheid bij het } \\
\text { besluit tot vermindering van het nominale bedrag van de } \\
\text { stemrechtloze aandelen zonder terugbetaling en zonder ont- } \\
\text { heffing van de verplichting tot storting }\end{array}$ & 208 lid 3 \\
\hline
\end{tabular}

63 Kamerstukken II 2008/09, 31 058, nr. 6, p. 13 (NV II), Kamerstukken II 2008/09, 31 058, nr. 7, p. 14 (Nota van Wijziging) en Kamerstukken II 2006/07, 31 058, nr. 3, p. 50-51 (MvT). 


\begin{tabular}{|l|l|l|}
\hline & $\begin{array}{l}\text { Besluiten die slechts met instemming van de stemrechtloze } \\
\text { aandeelhouder kunnen worden genomen }\end{array}$ & $\begin{array}{l}\text { BW Boek 2 } \\
\text { art. }\end{array}$ \\
\hline 4. & $\begin{array}{l}\text { een ontheffing van de verplichting tot storting is slechts } \\
\text { mogelijk ter uitvoering van een besluit tot vermindering van } \\
\text { het bedrag van de aandelen. Deze ontheffing, alsmede een } \\
\text { terugbetaling die geschiedt ter uitvoering van een besluit tot } \\
\text { vermindering van het bedrag van de aandelen, moet naar } \\
\text { evenredigheid op alle aandelen geschieden, tenzij voor de } \\
\text { uitgifte van de stemrechtloze aandelen of nadien met in- } \\
\text { stemming van alle houders van stemrechtloze aandelen in de } \\
\text { statuten is bepaald dat ontheffing of terugbetaling kan } \\
\text { geschieden uitsluitend op die aandelen; voor die aandelen } \\
\text { geldt de eis van evenredigheid. Van het vereiste van even- } \\
\text { redigheid mag worden afgeweken met instemming van alle } \\
\text { stemrechtloze aandeelhouders }\end{array}$ & 208 lid 4 \\
\hline 5. & $\begin{array}{l}\text { het besluit tot statutenwijziging waarbij bij de berekening } \\
\text { van het bedrag, dat op ieder aandeel zal worden uitgekeerd, } \\
\text { wordt afgeweken van het bedrag van de verplichte stortingen } \\
\text { op het nominale bedrag van de aandelen }\end{array}$ & 216 lid 8 jo. \\
\hline 6. & $\begin{array}{l}\text { het besluit tot statutenwijziging waarbij wordt bepaald dat } 6 \\
\text { aan stemrechtloze aandelen geen of slechts een beperkt recht } \\
\text { tot deling in de winst en/of reserves van de vennootschap } \\
\text { wordt gegeven }\end{array}$ & $\begin{array}{l}216 \text { lid } 8 \text { jo. } \\
\text { lid } 7\end{array}$ \\
\hline 7. & $\begin{array}{l}\text { het besluit tot wijziging van de statuten (na oprichting van de } \\
\text { vennootschap), inhoudende de aanwijzing van een plaats } \\
\text { buiten Nederland, waar de algemene vergadering wordt } \\
\text { gehouden }\end{array}$ & 226 lid 2 \\
\hline 8. & $\begin{array}{l}\text { het houden van de algemene vergadering op een andere } \\
\text { plaats dan in de statuten is vermeld }\end{array}$ & 226 lid 3 \\
\hline 9. & $\begin{array}{l}\text { het besluit van de algemene vergadering, nadat de aandelen } \\
\text { zijn uitgegeven, dat aan die aandelen geen stemrecht meer in } \\
\text { de algemene vergadering verbonden zal zijn }\end{array}$ & 228 lid $5{ }^{64}$ \\
\hline 10. & $\begin{array}{l}\text { besluitvorming buiten de algemene vergadering } \\
\text { ald }\end{array}$ & 238 \\
\hline
\end{tabular}

64 De wet spreekt van instemming van alle aandeelhouders. 


\begin{tabular}{|l|l|l|}
\hline & $\begin{array}{l}\text { Besluiten waarvan de stemrechtloze aandeelhouder, indien } \\
\text { hij daarmee niet heeft ingestemd, is vrijgesteld }\end{array}$ & $\begin{array}{l}\text { BW Boek 2 } \\
\text { art. }\end{array}$ \\
\hline 1. & een statutaire verplichting & $192 \mathrm{lid} 1^{65}$ \\
\hline 2. & $\begin{array}{l}\text { een statutaire bepaling waarbij is afgeweken van de prijs- } \\
\text { bepalingsregeling (een prijs gelijk aan de waarde van het } \\
\text { aandeel of de aandelen vast te stellen door een of meer } \\
\text { onafhankelijke deskundigen) }\end{array}$ & $\begin{array}{l}192 \mathrm{lid} 3, \\
192 \mathrm{a} \text { lid 1 en } \\
195 \mathrm{lid} 4\end{array}$ \\
\hline
\end{tabular}

Indien een besluit wordt genomen in strijd met de hiervoor genoemde goedkeuringsen instemmingsregels is naar mijn mening in beginsel sprake van een nietig besluit in de zin van art. 2:14 BW. ${ }^{66}$

Voor de rechtspraktijk verdient het aanbeveling het goedkeurende groepsbesluit en niet-instemming ter zake van een statutaire verplichting schriftelijk vast te leggen. In de regel volgt dit uit de besluitenlijst of notulen van de betreffende vergadering van aandeelhouders. Ik verwijs naar paragraaf 4.2.8. Het verdient de voorkeur de instemming door middel van een schriftelijke verklaring van de (of iedere) stemrechtloze aandeelhouder vast te leggen.

\subsubsection{Enkele beschermingsregels nader bezien}

\section{Inleiding}

In deze paragraaf licht ik een aantal van de in paragraaf 6.2.3.6 genoemde beschermingsregels toe. Zoals gezegd, zijn bij gebrek aan stemrecht in de algemene vergadering voornamelijk de aan het stemrechtloze aandeel verbonden financiële rechten van belang. De financiële rechten vormen een wezenlijk onderdeel van het aandeelhouderschap. ${ }^{67}$ De instemmingsrechten van art. 2:216 lid 6 tot en met $8 \mathrm{BW}$ zijn daarom in het bijzonder relevant. Ook art. 2:231 lid 4 BW biedt de stemrechtloze aandeelhouder bescherming. In dat artikel gaat het om een besluit tot statutenwijziging dat specifiek afbreuk doet aan enig recht van de stemrechtloze aandeelhouder. Dat besluit is aan een goedkeurend groepsbesluit van deze groep van aandeelhouders onderworpen. Deze artikelen bespreek ik in deze paragraaf.

\section{Art. 2:216 lid 8 BW}

Stemrechtloze aandeelhouders dienen met name beschermd te worden tegen afbreuk van hun winstrechten. Daartegen biedt het voorgestelde art. 2:216 lid 8 BW

65 In paragraaf 6.2.3.9 ga ik hierop nader in.

66 Uitgezonderd het ontbreken van de vereiste instemming van vergadergerechtigde voor besluitvorming buiten vergadering (art. 2:238 BW). Ik verwijs naar paragraaf 6.2.3.8.

67 Kamerstukken II 2006/07, 31 058, nr. 3, p. 75 (MvT) 
bescherming, aldus de wetgever. ${ }^{68}$ Dat artikellid bepaalt dat voor een statutaire regeling als bedoeld in art. 2:216 lid 6 of lid $7 \mathrm{BW}$ de instemming vereist is van alle houders van aandelen waaraan de statutenwijziging afbreuk doet.

Art. 2:216 lid 6 BW bepaalt dat bij de berekening van het bedrag, dat op ieder aandeel zal worden uitgekeerd, slechts het bedrag van de verplichte stortingen op het nominale bedrag van de aandelen in aanmerking komt. In de statuten of telkens met instemming van alle aandeelhouders kan daarvan worden afgeweken. Art. 2:216 lid $6 \mathrm{BW}$ ziet niet alleen op uitkering van winst, maar ook op andere uitkeringen. Een statutaire afwijking van de hoofdregel voor berekening van de uitkeringen zou afbreuk kunnen doen aan de rechten van bepaalde aandeelhouders. De winstverdeling tussen de aandeelhouders zal immers kunnen wijzigen wanneer voor de berekening een andere maatstaf wordt gehanteerd, aldus de wetgever. ${ }^{69}$ Het woord 'telkens' brengt tot uitdrukking dat bij ieder besluit tot (afwijkende) uitkering instemming van alle aandeelhouders is vereist. Indien de wens bestaat ook toekomstige uitkeringsbesluiten te laten afwijken van de hoofdregel van lid 6, dan kan daarvoor een statutaire regeling worden getroffen. ${ }^{70}$

De vraag is wat de reikwijdte van het instemmingsrecht van art. 2:216 lid 8 BW is. Tijdens de behandeling van het wetsvoorstel in de Eerste Kamer zijn daarover de volgende vragen gesteld: 'Is art. 2:216 lid $8 \mathrm{BW}$ ook van toepassing indien de statutenwijziging uitsluitend voorziet in een hoger winstrecht voor houders van bepaalde aandelen, bijvoorbeeld een statutenwijziging waarbij het recht van preferente aandelen op de winst wordt verhoogd? Leidt een winstregeling die zodanig wordt gewijzigd dat preferente aandelen gelijke rechten op de winst geven als gewone aandelen tot toepassing van art. 2:216 lid $8 \mathrm{BW}$, en zo ja, welke aandeelhouders kunnen zich daarop beroepen, in het bijzonder in het geval dat de vennootschap een winstpotentieel heeft dat voor de houders van gewone aandelen tot een hoger rendement kan leiden dan voor houders van preferente aandelen? Is er dan sprake van afbreuk van winstrecht van houders van preferente aandelen of juist van de houders van gewone aandelen? Hoe luidt het antwoord op deze vraag indien ten aanzien van een aantal gewone aandelen de winstregeling zodanig wordt gewijzigd dat zij een preferent, doch tot een bepaald percentage van de nominale waarde gemaximeerd winstrecht kennen? Kunnen dan de aandeelhouders die gewone aandelen behouden een beroep doen op art. 2:216 lid 8 BW?' Tot slot was een vraag of een wijziging van een regeling omtrent het winstrecht de instemming behoeft van de houders van aandelen die van de wijziging gevolgen zullen ondervinden. ${ }^{71}$

68 Kamerstukken II 2008/09, 31 058, nr. 6, p. 39 (NV II). De wetgever noemt de stemrechtloze aandeelhouder expliciet, zie Kamerstukken II 2006/07, 31 058, nr. 3, p. 75 (MvT).

69 Kamerstukken II 2006/07, 31 058, nr. 3, p. 75 (MvT).

70 Kamerstukken II 2008/09, 31 058, nr. 7, p. 17 (Nota van wijziging).

71 Kamerstukken I 2011/12, 31058 en 32 426, nr. B, p. 14-15 (VV I). 
De minister antwoordde dat het instemmingsrecht van art. 2:216 lid 8 BW geldt voor een statutenwijziging die daadwerkelijk afbreuk doet aan de rechten van aandeelhouders die door een dergelijke statutenwijziging worden getroffen. 'Mogelijk afbreuk doen', 'afbreuk kan doen' of 'gevolgen hebben voor' is niet voldoende. De wetgever licht toe: "Een hoger winstrecht voor houders van bepaalde aandelen leidt de facto tot een lagere winstuitkering aan houders van andere aandelen. Dit moet worden gekwalificeerd als 'afbreuk'. Derhalve vereist een statutenwijziging die voorziet in een hoger winstrecht voor sommige aandeelhouders de instemming van de 'gewone' aandeelhouder. Ingeval een wijziging weliswaar afbreuk kan doen, maar niet noodzakelijkerwijs doet, acht ik de instemming van de aandeelhouder niet vereist. Het is aan de aandeelhouder om ervoor te zorgen dat hij zonodig extra wordt beschermd, via de statuten of een aandeelhoudersovereenkomst." (onderstreping RAW). ${ }^{72}$ Kennelijk staat de wetgever aldus een ruime opvatting van het instemmingsrecht voor.

Dortmond stelt dat de opvatting van de minister te ruim is. ${ }^{73}$ Hij is van mening dat een statutenwijziging die voorziet in een hoger winstrecht voor sommige andeelhouders, niet valt onder de regeling van lid 7 en 8 van art. 2:216 BW. Met Stokkermans ${ }^{74}$ is Dortmond van mening dat instemming van alle aandeelhouder met een statutenwijziging waarbij preferente aandelen geïntroduceerd worden, als gevolg waarvan de gewone aandeelhouders na uitgifte van de preferente aandelen mogelijk geen of minder dividend ontvangen, te ver gaat. Dortmond stelt daarbij dat het in het belang van de financieringsbehoefte van de vennootschap kan zijn dat die preferente aandelen worden ingevoerd en uitgegeven. Is dat belang er niet, dan kan de benadeelde aandeelhouder zo nodig vernietiging van het besluit tot invoering en/of uitgifte van de preferente aandelen wegens strijd met de vennootschappelijke redelijkheid en billijkheid vorderen. Ik noem de opvatting van Dortmond en Stokkermans de enge opvatting.

$\mathrm{Na}$ het hiervoor aangehaalde antwoord van de minister is in de Eerste Kamer verder gedebatteerd. Ik citeer de minister: "Voor de bescherming die artikel 216 lid 8 aan de aandeelhouder biedt, is bepalend of de statutenwijziging afbreuk doet aan het winstrecht dat aan zijn aandelen is verbonden. In het voorbeeld van (...) een statutenwijziging waarmee gewone aandelen worden geconverteerd in preferente aandelen met een lager winstrecht. In dat geval is er sprake van een statutenwijziging die afbreuk doet aan het winstrecht van de houders van aandelen waarop de conversie betrekking heeft. Die aandeelhouders worden derhalve beschermd door artikel 216 lid 8 . Een regeling waarin een wijziging van het winstrecht de instemming vereist van alle aandeelhouders in wier rechten wijziging wordt gebracht (...) zou de flexibiliteit onnodig beperken. (onderstreping RAW)". ${ }^{75}$

72 Kamerstukken I 2011/12, 31058 en 32 426, nr. C, p. 23 (MvA I).

73 Dortmond 2012 (1), p. 200 en Dortmond 2012 (2), p. 461.

74 Stokkermans 2008 (1), p. 30, r.k.

75 Kamerstukken I 2011/12, 31 058, nr. E, p. 20 (MvA I). 
Deze laatste zin brengt mij in verwarring. Moet art. 2:216 lid 8 BW nu ruim of eng worden geïnterpreteerd? Art. 2:216 lid $8 \mathrm{BW}$ verwijst een statutenwijziging in de zin van art. 2:216 lid 6 en 7 BW. Lid 6 stelt dat bij de berekening van het bedrag, dat op ieder aandeel zal worden uitgekeerd slechts het bedrag van de verplichte stortingen op het nominale bedrag van de aandelen in aanmerking komt. In de statuten kan daarvan of telkens - zie hiervoor - met instemming van alle aandeelhouders worden afgeweken. Lid 7 stelt dat bij de statuten kan worden bepaald dat aandelen van een bepaalde soort of aanduiding geen of slechts beperkt recht tot deling in de winst of reserves van de vennootschap geven. Wordt dat recht op deling in de winst en/of reserves, waaronder begrepen het liquidatieoverschot, ${ }^{76}$ van de vennootschap verder beperkt of ontnomen, dan zegt lid 8 dat voor een statutaire wijziging daartoe de instemming is vereist van alle houders van aandelen aan wier rechten de statutenwijziging afbreuk doet. Dortmond ${ }^{77}$ wijst er mijns inziens eveneens terecht op dat het niet zozeer de statutenwijziging hoeft te zijn die afbreuk doet aan winstrechten. In het eerder besproken voorbeeld van de uitgifte van preferente aandelen wegens financieringsbehoefte van de vennootschap zal eerst een statutenwijziging moeten plaatsvinden om die soort aandelen te creëren. Eerst nadat die preferente aandelen - volgend op de statutenwijziging - zijn uitgegeven, kan aan de rechten van de aandeelhouders die door die uitgifte worden getroffen afbreuk worden gedaan. Met andere woorden: de statutenwijziging om de uitgifte van de preferente aandelen mogelijk te maken, doet geen afbreuk aan de rechten van andere aandeelhouders. Dortmond ${ }^{78}$ wijst ook op een andere situatie, namelijk de situatie dat er gewone aandelen worden uitgegeven. Daarvoor is geen statutenwijziging vereist, doch enkel een besluit tot uitgifte ex art. 2:206 BW. Het voorgaande pleit eens te meer voor de enge opvatting. Met andere woorden: art. 2:216 lid 8 BW ziet niet per definitie op een statutenwijziging. Ook dat ben ik met Dortmond eens.

Wellicht moet de volgende toelichting van de minister tijdens de behandeling van het wetsvoorstel in de Tweede Kamer leidend zijn: " $V N O-N C W$ heeft gevraagd of met het woord "afbreuk» in het voorgestelde artikel 216 lid 8 mede gedoeld wordt op de invoering van preferente aandelen. Dat is niet het geval. Het voorgestelde lid 8 biedt aandeelhouders bescherming tegen nadelige gevolgen van een statutenwijziging waarmee hun winstrecht wordt ontnomen of door de invoering van een onevenredige winstverdeling wordt aangetast. De bescherming van aandeelhouders tegen uitgifte van nieuwe gewone of bijzondere aandelen wordt geregeld door het voorkeursrecht (artikel 206a)." 79

Uit het voorgaande leid ik af, en daarmee sluit ik mij an bij de enge opvatting, dat art. 2:216 lid $8 \mathrm{BW}$ ziet op statutaire wijzigingen van het direct aan het aandeel verbonden financiële recht. Art. 2:216 lid $8 \mathrm{BW}$ ziet naar mijn mening niet op een

76 Kamerstukken I 2011/12, 31 058, nr. C, p. 23 (MvA I).

77 Dortmond 2012 (2), p. 461.

78 Dortmond 2012 (2), p. 461.

79 Kamerstukken II 2008/09, 31 058, nr. 6, p. 39 (NV II). 
statutaire wijziging die weliswaar afbreuk doet aan het recht op winst en/of reserves in de vennootschap, doch indirect dat recht raken. Een voorbeeld van een statutaire wijziging in de zin van art. 2:216 lid $7 \mathrm{BW}$, waarvoor blijkens lid 8 van datzelfde artikel instemming is vereist, is een wijziging inhoudende dat de aandeelhouder geen recht meer heeft op de reserves in de vennootschap. Een dergelijke wijziging verandert het direct aan het aandeel verbonden en in de statuten omschreven financiële recht. Een voorbeeld van een statutaire wijziging dat indirect het aan het aandeel verbonden financiële recht raakt, is het volgende. In een BV zijn preferente en gewone aandelen uitgegeven. Bij statutenwijziging wordt het winstrecht op preferente aandelen verhoogd, bijvoorbeeld door middel van het verhogen van het percentage op de winst of dat ook een recht ontstaat op de overwinst. In dat geval wordt inbreuk gemaakt op de bestaande winstrechten van de gewone aandeelhouders. Omdat het winstrecht op de preferente aandelen wordt verhoogd, blijft er minder winst voor de houders van gewone aandelen over. Datzelfde geldt bijvoorbeeld in het geval dat de preferente aandelen cumulatief worden gemaakt. Een ander voorbeeld is de uitgifte van participatiebewijzen. Ook daardoor worden de winstrechten van aandeelhouders indirect geraakt. Bij het voorgaande past, zoals gesteld, naar mijn mening een kanttekening: niet iedere statutenwijziging hoeft afbreuk te doen aan rechten van andere aandeelhouders, zodat art. 2:216 lid 8 BW in dat geval geen toepassing zal vinden.

De gewone aandeelhouders wiens financiële rechten door een voorgenomen besluit indirect worden geraakt, hebben vanwege het aan hun aandelen verbonden stemrecht de mogelijkheid door middel van het uitoefenen van dat stemrecht tijdens de algemene vergadering invloed op de besluitvorming uit te oefenen. De stemrechtloze aandeelhouder heeft die mogelijkheid niet. Dat makkt naar mijn mening niet dat de ruime opvatting van art. 2:216 lid 8 BW verdedigbaar is. Die opvatting komt erop neer dat in voorkomend geval alle aandeelhouders aan wier rechten de statutenwijziging afbreuk doet, zullen moeten instemmen. Feitelijk is dan sprake van een vetorecht. Dat komt de (beoogde) flexibiliteit niet ten goede, bijvoorbeeld bij het door Dortmond ${ }^{80}$ reeds genoemde belang van het aantrekken van nieuwe financiering in de vennootschap. Daarbij kan de parallel getrokken worden met het voorkeursrecht als bedoeld in art. 2:206a BW. Dat artikel bepaalt dat de stemrechtloze aandeelhouder geen wettelijk voorkeursrecht heeft op (gewone) aandelen en evenmin op stemrechtloze aandelen. Ik verwijs naar paragraaf 6.2.3.5. Naar mijn mening heeft de wetgever kennelijk de enge opvatting beoogd. Ware dit anders, dan had het niet voor de hand gelegen het voorkeursrecht ten aanzien van de stemrechtloze aandeelhouder uit te sluiten.

De bescherming van de (stemrechtloze) aandeelhouder wordt gevonden in de mogelijkheid een vordering tot vernietiging van het besluit tot statutenwijziging waarbij indirect afbreuk wordt gedaan aan de financiële rechten wegens strijd met de vennootschappelijke redelijkheid en billijkheid in te stellen.

80 Dortmond 2012 (1), p. 200. 
Uit art. 2:216 lid 7 jo. 2:228 lid 5 BW volgt dat de stemrechtloze aandeelhouder niet geheel uitgesloten kan worden van zijn recht op uitkering. Een beperkt recht op winst of reserves van de vennootschap is wel mogelijk. Het doorbreken van de gelijkheid van winstrechten doet afbreuk aan de rechten van een deel van de aandeelhouders. Een dergelijke ingrijpende wijziging rechtvaardigt dat de wet hiervoor een statutenwijziging voorschrijft, welk besluit daartoe bovendien wordt genomen met instemming van alle houders van aandelen waaraan de statutenwijziging afbreuk doet. "Door te bepalen dat instemming is vereist - en bijvoorbeeld niet een besluit met algemene stemmen van de algemene vergadering - is de bescherming eveneens van toepassing op houders van stemrechtloze aandelen", aldus de wetgever. $^{81}$

Art. 2:216 lid 10 BW bepaalt dat de statuten kunnen bepalen dat de winst waartoe houders van aandelen van een bepaalde soort gerechtigd zijn, geheel of gedeeltelijk te hunnen behoeve wordt gereserveerd. "Vennootschappen die voor de buitenwereld willen aangeven dat een deel van hun vermogen niet beschikbaar is voor uitkering, kunnen kiezen voor het instellen van een statutaire reserve. Statutaire reserves zijn niet vatbaar voor uitkering aan aandeelhouders. Verlaging of opheffing van een dergelijk vrijwillig kapitaal is slechts mogelijk via wijziging van de statuten.", aldus de wetgever. ${ }^{82}$

\section{Art. 2:231 lid 4 BW}

a. de wet

Naast art. 2:216 lid 6 tot en met 8 BW is art. 2:231 lid 4 BW voor de stemrechtloze aandeelhouder van belang. Dat artikellid bepaalt dat een besluit tot statutenwijziging dat specifiek afbreuk aan enig recht van houders van aandelen van een bepaalde soort of aanduiding doet, een goedkeurend besluit van deze groep van aandeelhouders behoeft, tenzij ten tijde van de toekenning van het recht de bevoegdheid tot wijziging bij die bepaling uitdrukkelijk was voorbehouden en onverminderd het vereiste van instemming waar dit uit de wet voortvloeit. Aan aandelen zonder stemrecht zijn financiële rechten verbonden, zoals het recht op uitkering ex art. 2:216 BW. Aan stemrechtloze aandelen kunnen ook zeggenschapsrechten verbonden zijn, zoals voordrachtsrechten, benoemingsrechten of goedkeuringsrechten, of het instructierecht ex art. 2:239 lid 4 BW. Datzelfde geldt voor aandelen van een bepaalde soort of aanduiding. ${ }^{83}$

Uit de parlementaire geschiedenis volgt dat de wetgever bij art. 2:231 lid 4 BW specifiek aan de stemrechtloze aandeelhouder heeft gedacht. De 'groep' van stemrechtloze aandeelhouders heeft een recht van goedkeuring ten aanzien van een besluit tot statutenwijziging dat specifiek afbreuk doet aan de hen toekomende rechten. Te denken daarbij is aan specifieke rechten die bij statuten zijn gekoppeld

81 Kamerstukken II 2006/07, 31 058, nr. 3, p. 75 (MvT).

82 Kamerstukken II 2006/07, 31 058, nr. 3, p. 26 (MvT).

83 Kamerstukken II 2010/11, 32 426, nr. 7, p. 17 (NV II). 
aan de aandelen zonder stemrecht en indien aan die statutaire rechten wijziging wordt gebracht. ${ }^{84}$ Het afbreuk doen aan rechten is ook het geval indien aan stemrechtloze aandelen of aandelen van een andere soort of aanduiding rechten zijn gekoppeld die ook zijn gekoppeld aan andere aandelen, maar de wijziging specifiek betrekking heeft op de aandelen zonder stemrecht. Ook een besluit tot statutenwijziging waarbij de mogelijkheid tot wijziging wordt ingevoerd, is een besluit als bedoeld in art. 2:231 lid 4 BW en behoeft derhalve een goedkeurend besluit van de desbetreffende groep van aandeelhouders, ${ }^{85}$ aldus de wetgever. ${ }^{86}$ Uit de laatste zinsnede volgt dat geen afbreuk aan wettelijke regelingen wordt gedaan waarin de wet een individueel instemmingsrecht voorschrijft, zoals in art. 2:192 lid 1, 2:195 lid 3, 2:208 lid 2, 3 en 4, 2:216 lid 6, 7 en 8, 2:226 lid 2 en 3, 2:228 lid 5, 2:238 lid 1, 2:317 lid 3 en 2:334m lid 3 BW.

Uit art. 2:231 lid $4 \mathrm{BW}$ volgt tevens dat het goedkeurende besluit met betrekking tot het besluit tot statutenwijziging niet is vereist, indien ten tijde van de toekenning van het recht - waaraan het besluit tot statutenwijziging specifiek afbreuk zou doen - de bevoegdheid tot wijziging van die bepaling was voorbehouden. Ten aanzien van dat voorbehoud tot wijziging geldt dat de statutaire regeling bepaalde

84 Concreet kan bijvoorbeeld - niet limitatief - worden gedacht aan intrekking of wijziging van de volgende bevoegdheden of rechten:

1. de vergadering van houders van stemrechtloze aandelen is bevoegd tot bestemming van de winst die door vaststelling van de jaarrekening is bepaald en tot vaststelling van uitkeringen, althans dat de vergadering van houders van stemrechtloze aandelen voorafgaande goedkeuring dient te verlenen;

2. de vergadering van houders van stemrechtloze aandelen is bevoegd te bepalen welk deel van het resultaat van het boekjaar wordt gereserveerd of hoe het verlies wordt verwerkt;

3. de vergadering van houders van stemrechtloze aandelen is bevoegd tot uitgifte van aandelen;

4. houders van stemrechtloze aandelen komt het voorkeursrecht op uit te geven aandelen toe;

5. de vergadering van houders van stemrechtloze aandelen is bevoegd tot het verbinden of ontnemen van vergaderrechten aan certificaten;

6. de vergadering van houders van stemrechtloze aandelen is bevoegd tot benoeming, schorsing en ontslag van bestuurders en/of commissarissen;

7. de vergadering van houders van stemrechtloze aandelen is bevoegd tot benoeming uit een voordracht ex art. 2:243 BW;

8. de vergadering van houders van stemrechtloze aandelen is bevoegd tot het geven van instructies aan het bestuur;

9. wijziging ten nadele van de stemrechtloze aandeelhouder van de aanbiedingsregeling van art. 2:195 BW (bijvoorbeeld in een goedkeuringsregeling of lock up-bepaling).

De parlementaire geschiedenis noemt nog als voorbeeld een statutenwijziging waarbij een voor stemrechtloze aandeelhouders nadelige regeling wordt ingevoerd, die bepaalt dat deze aandeelhouders een slechte prijs voor hun aandelen krijgen ingeval van fusie, splitsing of omzetting. Stemmen zij niet door middel van een goedkeurend groepsbesluit in de zin van art. 2:231 lid 4 BW met deze statutenwijziging in, dan zijn zij aan de nadelige regeling niet gebonden (Kamerstukken II 2011/12, 32 426, nr. 24, p. 14).

85 Niet uit te sluiten is dat de - individuele - stemrechtloze aandeelhouder die niet aan het besluitvormingsproces van het groepsbesluit heeft deelgenomen mogelijk een actie heeft op basis van art. 2:8 jo. 2:15 BW. In vergelijkbare zin: Sanders \& Westbroek 2005, p. 87.

86 Kamerstukken II 2009/10, 31 058, nr. 16, p. 2 en Kamerstukken II 2010/11, 32 426, nr. 7, p. 17 (NV II). 
wijzigingen kan toelaten al dan niet onder nader genoemde omstandigheden, maar ook in algemene bewoordingen wijziging kan toelaten zonder specifieke beperkingen te stellen. ${ }^{87}$ Kortom, art. 2:231 lid 4 BW biedt bescherming tegen afbreuk van statutaire rechten.

b. verhouding tot art. 2:216 lid $8 \mathrm{BW}$

Over de verhouding tussen art. 2:231 lid 4 BW, art. 2:216 lid 8 BW en het voorbehouden van wijzigingen in statutaire regelingen merkt de wetgever op: " $D e$ voorgestelde regeling (art. 2:231 lid 4 BW, RAW) doet, zo blijkt uit de laatste zinsnede, geen afbreuk aan wettelijke regelingen waarin de wet een individueel instemmingsrecht voorschrijft, zoals in artikel 216 lid 8, en laat toe dat bij statuten de bevoegdheid tot de beoogde wijziging is voorbehouden in welk geval het instemmend besluit niet is vereist. De statutaire regeling kan bepaalde wijzigingen toelaten al dan niet onder nader genoemde omstandigheden, maar ook in algemene bewoordingen wijziging toelaten zonder specifieke beperkingen te stellen." 88

c. oorspronkelijk ontwerp

Art. 2:231 lid $4 \mathrm{BW}$ is in de plaats gekomen van het oorspronkelijk ontwerp van art. 2:228 lid $5 \mathrm{BW}$. In dat (laatste) artikel was opgenomen dat een besluit tot wijziging van de statuten waarmee nadeel wordt toegebracht aan de rechten van houders van stemrechtloze aandelen niet zonder hun instemming kan worden genomen. ${ }^{89}$ In de literatuur is op deze bepaling veel kritiek gekomen. ${ }^{90}$ Samengevat komt die kritiek erop neer dat de geboden bescherming te ver ging, omdat het aan houders van stemrechtloze aandelen een vetorecht toekende over een besluit tot statutenwijziging dat in dezelfde mate afbreuk deed aan de rechten van de stemhebbende aandeelhouders, terwijl laatstgenoemden geen vetorecht toekwam. ${ }^{91}$ De bepaling leidde er bovendien toe dat houders van stemrechtloze aandelen ten opzichte van houders van aandelen met een beperkt stemrecht (art. 2:228 lid 4 BW) relatief veel bescherming genoten tegen voor hen nadelige besluiten. ${ }^{92}$ Daarnaast was niet duidelijk wat onder het begrip 'nadeel' moest worden verstaan. Het oorspronkelijk ontwerp van art. 2:228 lid 5 BW is vervolgens geschrapt. ${ }^{93}$ Daarvoor

87 Kamerstukken II 2009/10, 31 058, nr. 16, p. 2 en Kamerstukken II 2010/11, 32 426, nr. 7, p. 17 (NV II). Een regeling van deze strekking is ook opgenomen in artikel 60 Verordening (EG) nr. 2157/2001 betreffende het statuut van de Europese Naamloze Vennootschap (SE) en artikel 45 van de Arubaanse Landsverordening Vennootschap met Beperkte Aansprakelijkheid. Zie ook Van Veen 2009, p. 472, en Dortmond 2011 (1), p. 22.

88 Kamerstukken II 2009/10, 31 058, nr. 16, p. 2

89 Kamerstukken II 2006/07, 31 058, nr. 2, p. 18 (Voorstel van wet).

90 Ten Berg 2007, p. 341-342; Dortmond 2007, p. 352; Van Veen 2007, p. 957; Van der Kroon 2007, p. 12; Van den Nieuwenhuijzen 2008, p. 20-22 en Portier 2008 (1), p. 236-242. Zie ook Kamerstukken II 2008/09, 31 058, nr. 5, p. 5-6.

91 Kamerstukken II 2010/11, 32 426, nr. 7, p. 16-17 (NV II).

92 Kamerstukken II 2008/09, 31 058, nr. 6, p. 39 (NV II).

93 Kamerstukken II 2008/09, 31 058, nr. 7, p. 9 en 11. 
kwam niets in de plaats. Ook dat was weer onwenselijk, omdat de stemrechtloze aandeelhouder onvoldoende bescherming werd geboden tegen besluiten tot statutenwijziging, waarbij bijvoorbeeld afbreuk wordt gedaan aan de hen toegekende zeggenschapsrechten. ${ }^{94}$ Dit is voor de rechtszekerheid en betrouwbaarheid van de BV onwenselijk, aldus de wetgever. Dat is dan ook reden geweest het huidige art. 2:231 lid $4 \mathrm{BW}$ te introduceren. ${ }^{95}$

Uit de parlementaire geschiedenis volgt dat, zoals gesteld, deze regeling in de plaats is gekomen voor het ontwerpartikel 2:228 lid 5 BW. Dat ontwerpartikel zag alleen op stemrechtloze aandelen. Art. 2:231 lid 4 BW ziet echter op houders van aandelen van een bepaalde soort of aanduiding. Daaronder kunnen dus ook andere aandelen dan stemrechtloze aandelen vallen. ${ }^{96}$ De reikwijdte van het artikel is aldus ruimer.

De regeling van art. 2:231 lid $4 \mathrm{BW}$ ondervangt de bezwaren tegen de eerder voorgestelde regeling in art. 2:228 lid $5 \mathrm{BW}$ en is in dat opzicht aldus een verbetering. Niettemin geeft art. 2:231 lid $4 \mathrm{BW}$ aanleiding tot het maken van opmerkingen.

\section{d. kritiek in de literatuur}

In de literatuur is een aantal vragen opgeworpen: ${ }^{97}$ Wat gebeurt er in het geval van een statutenwijziging die afbreuk doet aan een specifiek recht dat is toegekend aan houders van stemrechtloze aandelen en aan stemrechthebbende aandeelhouders van een bepaalde soort of aanduiding? Dienen deze aandeelhouders een gezamenlijk goedkeurend besluit te nemen? Of is de goedkeuring vereist van ieder afzonderlijke vergadering, namelijk zowel die van houders van stemrechtloze aandelen als die van de stemrechthebbende aandeelhouders van een bepaalde soort of aanduiding? Ik zou menen dat het laatste het geval is. ${ }^{98}$ Art. 2:231 lid 4 BW beoogt immers de stemrechtloze aandeelhouder te beschermen. Indien sprake zou zijn van een gezamenlijk goedkeurend besluit kan, afhankelijk van de stemverhoudingen, die bescherming teniet worden gedaan. Mijns inziens is dat ook af te leiden uit de tekst van art. 2:231 lid 4 BW. Het gaat immers om een goedkeurend besluit van 'deze groep van aandeelhouders'. De toelichting op het artikel geeft ook geen aanleiding te veronderstellen dat sprake moet zijn van een gezamenlijk goedkeurend besluit

94 Van Veen 2009, p. 472 en Dortmond 2011 (1), p. 21. Van Veen doet daarbij een voorstel voor een regeling, welk voorstel in feite is teruggekomen in art. 2:231 lid $4 \mathrm{BW}$. De wetgever merkte ten tijde van de schrapping van het oorspronkelijke ontwerp van art. 2:228 lid $5 \mathrm{BW}$ op dat stemrechtloze aandeelhouders met name beschermd moeten worden tegen afbreuk van hun winstrechten. Daartegen zou het voorgestelde art. 2:216 lid 8 BW voldoende bescherming bieden, zie Kamerstukken II 2008/ 09, 31058 , nr. 6, p. 39 (NV II)

95 Kamerstukken II 2009/10, 31 058, nr. 16, p. 2

96 In gelijke zin Van den Heuvel 2011, p. 78. Kritisch hierover Dortmond 2011 (1), p. 21 en 22.

97 Van der Steenstraten 2010, p. 31.

98 In gelijke zin Boschma-Kuijers-Tollenaar 2013, p. 106, onder verwijzing naar art. 2:231a lid 1, 2:330 lid 2 en 2:334ee lid 2 BW, in welke artikelen wordt gesproken over een goedkeurend besluit van elke groep van houders van aandelen van een zelfde soort of aanduiding. 
indien er meerdere aandelen van een bepaalde soort of aanduiding zijn. Daarbij komt dat diezelfde toelichting specifiek de houders van stemrechtloze aandelen als de te beschermen groep noemt. ${ }^{99}$ Overigens heeft het bestuur in deze vergadering op grond van art. 2:231 lid $4 \mathrm{BW}$ geen raadgevende stem. ${ }^{100}$

Een ander kritiekpunt op art. 2:231 lid $4 \mathrm{BW}$ is dat niet duidelijk is wat onder 'specifiek afbreuk doet aan enig recht' wordt verstaan. Dortmond beredeneert dat 'de bedoeling kennelijk is dat het gaat om afbreuk van specifieke rechten verbonden aan de aandelen van een bepaalde soort of aanduiding, al dan niet met stemrecht, en om een beperking van rechten, die ook verbonden zijn aan andere aandelen, doch welke beperking dan alleen geldt voor de bedoelde bepaalde aandelen en niet voor andere aandeelhouders'. ${ }^{101}$ Deze uitleg lijkt mij juist.

Een ander punt van uitleg is de tenzij-clausule ('tenzij ten tijde van de toekenning van het recht de bevoegdheid tot wijziging bij die bepaling uitdrukkelijk was voorbehouden') van art. 2:231 lid 4 BW. Allereerst moet aangenomen worden dat de wijzigingsbevoegdheid in de statuten moet zijn voorbehouden. ${ }^{102}$ De rechten worden immers bij statuten aan de houders van een bepaalde soort of aanduiding toegekend, bijvoorbeeld het recht om bestuurders te benoemen of een voorkeursrecht op uit te geven aandelen. De formulering van een dergelijk beding zal, gelet op de uitleg van art. 2:231 lid $4 \mathrm{BW}$, in de rechtspraktijk voor de nodige hoofdbrekens zorgen. Dortmond noemt als voorbeeld een aan alle aandeelhouders statutair verleend voorkeursrecht. Moet, wil men uitvoering geven aan de tenzij-clausule, in de statuten worden opgenomen dat wat betreft aandelen van een bepaalde soort of aanduiding het voorkeursrecht door een enkel besluit van de algemene vergadering kan worden geschrapt of gewijzigd? ${ }^{103}$ Het antwoord daarop luidt mijns inziens bevestigend. Hoofdregel ten aanzien van de stemrechtloze aandeelhouder is dat hij geen voorkeursrecht heeft op uit te geven aandelen, tenzij de statuten anders bepalen (art. 2:206a lid $2 \mathrm{BW}$ ). Indien het ontnemen van dat recht in de statuten is voorbehouden, volstaat aldus een besluit daartoe van de algemene vergadering. Onder omstandigheden is een dergelijk besluit in strijd met de vennootschappelijke redelijkheid en billijkheid genomen, maar daaraan zal men mijns inziens niet snel toekomen, juist omdat de bevoegdheid tot wijziging ten tijde van de toekenning van het recht is voorbehouden.

Dortmond stelt daarnaast vraagtekens bij de toepassing van de regeling van art. 2:231 lid $4 \mathrm{BW}$. Als voorbeeld noemt hij dat aandelen van een bepaalde soort, net als alle andere aandelen, een statutair algemeen voorkeursrecht hebben bij uitgifte van aandelen. De BV wil af van het voorkeursrecht dat is toegekend aan de

99 Kamerstukken II 2009/10, 31 058, nr. 16, p. 1-2.

100 Af te leiden uit: Kamerstukken I 2011/12, 31 058, nr. E, p. 22 (Nadere MvA I). De minster dacht hierover in eerste instantie anders, zie: Kamerstukken I 2011/12, 31058 en 32 426, nr. C, p. 24 (MvA I) en Kamerstukken I 2011/12, 31 058, nr. D, p. 16 (NVV I).

101 Dortmond 2011 (1), p. 22.

102 In gelijke zin Dortmond 2011 (1), p. 23.

103 Dortmond 2011 (1), p. 23. 
aandeelhouder van een bepaalde soort. Het ontnemen daarvan behoeft een goedkeurend groepsbesluit van die aandeelhouders. Volgens Dortmond zou men dat kunnen omzeilen door de statuten zodanig te wijzigen dat aan geen enkele aandeelhouder een voorkeursrecht meer toekomt. Volgens de algemene regel van art. 2:231 lid 1 BW vereist een dergelijke statutenwijziging geen goedkeurend groepsbesluit in de zin van art. 2:231 lid 4 BW. Vervolgens wijzigt men de statuten weer en kent men alleen een voorkeursrecht toe aan alle aandeelhouders, behalve die van een bepaalde soort. ${ }^{104}$

Ik zou menen dat dit voorbeeld niet in alle gevallen opgaat. Indien sprake is van een BV met een in gewone en stemrechtloze aandelen verdeeld kapitaal, geldt volgens de hoofdregel van art. 2:206a lid $1 \mathrm{BW}$ dat alleen de houders van gewone aandelen een voorkeursrecht op uit te geven gewone aandelen hebben. De toekenning van dat voorkeursrecht aan de houders van stemrechtloze aandelen is een afwijking van de hoofdregel van art. 2:206a lid 2 BW. Aan de stemrechtloze aandeelhouder wordt dus een recht toegekend. De wijziging van de statuten waarbij aan alle aandeelhouders het voorkeursrecht ontnomen wordt, doet aldus specifiek afbreuk aan de rechten van de houders van stemrechtloze aandelen. Mijns inziens is daarom wel degelijk een goedkeurend groepsbesluit in de zin van art. 2:231 lid 4 BW vereist. Ontbreekt een dergelijk besluit, dan is het besluit tot statutenwijziging nietig.

Dortmond noemt ook het voorbeeld van een BV met prioriteitsaandelen en gewone aandelen. In de statuten van die BV wordt een blokkeringsregeling volgens het aanbiedingsysteem ingevoerd. Voor de invoering van de blokkeringsregeling geldt een normaal besluit tot statutenwijziging. Omdat de in te voeren blokkeringsregeling voor alle aandelen geldt, is er ook geen sprake van dat specifiek afbreuk wordt gedaan aan de rechten van prioriteitsaandeelhouders. Vervolgens besluit de algemene vergadering wederom tot statutenwijziging, waarbij de blokkeringsregeling wordt geschrapt, behalve voor de prioriteitsaandelen. Dortmond stelt de vraag of in dat geval sprake is van een besluit dat specifiek afbreuk doet aan het recht op aanbieding dat de houders van prioriteitsaandelen hadden toen het aanbiedingsysteem voor alle aandelen nog in de statuten stond. ${ }^{105}$ Mijns inziens moet ook het antwoord op deze vraag bevestigend luiden. Ik zoek daarbij aansluiting bij art. 2:195 lid 1 BW. Art. 2:195 lid 1 BW bepaalt onder meer dat aan houders van aandelen van een bepaalde soort of aanduiding waaraan ingevolge een statutaire regeling geen stemrecht of recht op deling in de winst of reserves toekomt, slechts aandelen van dezelfde soort of aanduiding kunnen worden aangeboden, tenzij in de statuten anders is bepaald. ${ }^{106}$ Met andere woorden: de hoofdregel, en vertaald naar het

104 Dortmond 2011 (1), p. 22

105 Dortmond 2011 (1), p. 23

106 Ten tijde van het schrijven van zijn bijdrage heeft Dortmond (2011) nog geen rekening kunnen houden met de gewijzigde bepaling van art. 2:195 lid 1 BW. Zie Kamerstukken II 2010/11, 32 426, nr. 6, p. 8; Kamerstukken II 2010/11, 32 426, nr. 7, p. 25 (NV II) en Kamerstukken II 2010/11, 32 426, nr. 8, p. 11 (Nota van wijziging). 
stemrechtloze aandeel, is dat de stemrechtloze aandeelhouder in het kader van de aanbiedingsregeling van art. 2:195 BW alleen kan reflecteren op aangeboden, stemrechtloze aandelen. Van deze hoofdregel kan in de statuten worden afgeweken. Indien dat - volgens het voorbeeld van Dortmond - is gedaan, hebben de aandeelhouders van een bepaalde soort of aanduiding (bijvoorbeeld houders van prioriteitsaandelen en stemrechtloze aandelen) aldus een extra recht. Begrijp ik Dortmond goed, dan konden de prioriteitsaandeelhouders eerst ook reflecteren op gewone aandelen en na de statutenwijziging alleen op prioriteitsaandelen. De (tweede) statutenwijziging doet daarmee specifiek afbreuk aan het recht van de prioriteitsaandeelhouders en vergt aldus een goedkeurend groepsbesluit in de zin van art. 2:231 lid 4 BW.

Concluderend komt het mij voor dat art. 2:231 lid 4 BW, gelet op het doel en strekking van deze bepaling, in de praktijk snel toepassing zal vinden.

\section{e. slotopmerking}

Tot slot wijs ik op art. 2:232 BW. Dat artikel bepaalt dat wijziging van een bepaling van de statuten, waarbij aan een ander dan aan aandeelhouders van de vennootschap als zodanig enig recht is toegekend, kan aan het recht van geen nadeel toebrengen, indien hij niet met de wijziging instemt. Dat is anders indien ten tijde van de toekenning van het recht de bevoegdheid tot wijziging bij die bepaling uitdrukkelijk was voorbehouden. Dat artikel beoogt niet-aandeelhouders te beschermen en strekt aldus niet tot bescherming van de stemrechtloze aandeelhouder. Dit geldt te meer, omdat de stemrechtloze aandeelhouder in veel gevallen, zoals uit voorgaand overzicht volgt, wel invloed kan uitoefenen op besluiten (tot statutenwijziging).

\subsubsection{Besluitvorming buiten vergadering}

De besluitvorming buiten vergadering wordt geregeld in art. 2:238 BW. Lid 1 van dat artikel bepaalt dat besluitvorming van aandeelhouders op andere wijze dan in een vergadering kan geschieden, mits alle vergadergerechtigden met deze wijze van besluitvorming hebben ingestemd. Tenzij de statuten anders bepalen, kan de instemming met de wijze van besluitvorming langs elektronische weg plaatsvinden. De stemrechtloze aandeelhouder zal aldus met besluitvorming buiten vergadering moeten instemmen. De wetgever laat zich niet uit over de gevolgen (nietigheid of vernietigbaarheid) voor de besluitvorming indien de instemming ontbreekt, anders dan "De derde versoepeling houdt in dat besluitvorming buiten vergadering ook mogelijk wordt indien er andere vergadergerechtigden zijn. Hier staat tegenover dat voor een geldige besluitvorming is vereist dat alle vergadergerechtigden hebben ingestemd met de wijze van besluitvorming. Het vereiste van instemming bewerkstelligt dat minderheidsaandeelhouders en andere vergadergerechtigden niet tegen hun wil worden geconfronteerd met besluitvorming door de meerderheidsaandeelhouder(s) zonder dat 
overleg heeft plaatsgevonden in een algemene vergadering."107 en dat "het ontbreken van de instemming gevolgen heeft voor de geldigheid van de buiten vergadering genomen besluiten". ${ }^{108}$ Naar mijn mening kan een buiten vergadering genomen besluit bij gebreke van instemming over de besluitvorming buiten vergadering op grond van art. 2:15 lid $1 \mathrm{sub}$ a BW worden vernietigd. ${ }^{109} \mathrm{Er}$ is namelijk sprake van strijdigheid met een wettelijke bepaling die het tot stand komen van besluiten regelt. Langs deze weg wordt de stemrechtloze aandeelhouder aldus beschermd. Op grond van het hiervoor aangehaalde, eerste citaat is in de literatuur ${ }^{110}$ verdedigd dat sprake is van een nietig besluit indien de vergadergerechtigden niet instemmen met besluitvorming buiten vergadering. Mijn inziens zou de nietigheid van de buiten vergadering genomen besluiten, bij gebreke van instemming van de vergadergerechtigden met die wijze van besluitvorming, de door de wetgever beoogde versoepeling ${ }^{111}$ van de besluitvorming buiten vergadering niet ten goede komen.

De instemming met besluitvorming buiten vergadering hoeft niet schriftelijk te gebeuren. Uit de parlementaire geschiedenis volgt dat 'het op de weg van degene die de wijze van besluitvorming entameert ligt de instemming van de vergadergerechtigden te verkrijgen en - indien daarover achteraf onduidelijkheid mocht bestaan - zo nodig te bewijzen'. ${ }^{112}$ In de literatuur is daarover opgemerkt dat het bezwaarlijk is dat de vergadergerechtigden, waaronder de stemrechtloze aandeelhouder, niet met deze wijze van besluitvorming schriftelijk hoeven in te stemmen. Dat zou tot bewijsproblemen kunnen leiden. Daarnaast is het de vraag of de instemming voor een vergadering of bij voorbaat en voor langere termijn mag worden verleend. Bovendien heeft het instemmingsvereiste als nadeel dat alle vergadergerechtigden moeten instemmen met de besluitvorming buiten vergadering. Een vergadergerechtigde zou wegens het onthouden van instemming de besluitvorming aldus kunnen frustreren. ${ }^{113}$ In dat geval zal de oproepingstermijn van acht dagen ex art. 2:225 BW in acht genomen moeten worden. In de literatuur zijn daarom alternatieven voorgesteld, zoals een bepaling dat bepaalde essentiële besluiten alleen met instemming van alle vergadergerechtigden buiten vergadering kunnen worden genomen. Het gaat daarbij om besluiten tot ontbinding, statutenwijziging, fusie en splitsing. Daarnaast kan gedacht worden aan besluiten die

107 Kamerstukken II 2006/07, 31 058, nr. 3, p. 88-89 (MvT)

108 Kamerstukken II 2008/09, 31 058, nr. 6, p. 18 (NV II)

109 In gelijke zin: De Kluiver 2008, p. 688. Anders: Oranje 2008 (1), p. 70.

110 M.L. Lennarts, Tekst \& Commentaar Ondernemingsrecht en Effectenrecht, art. 2:238 BW, aant. 2, Deventer: Kluwer.

111 Kamerstukken II 2006/07, 31 058, nr. 3, p. 88-89 (MvT)

112 Kamerstukken II 2006/07, 31 058, nr. 3, p. 88 (MvT)

113 Nowak \& Van den Ingh 2007, p. 128 en Oranje 2008 (2), p. 10. Zie ook Kamerstukken II 2006/07, 31058 , nr. 3, p. 88 (MvT). 
in vergadering genomen moeten worden zodra een bepaald percentage van vergadergerechtigden (en/of kapitaal) daarom verzoekt. Een combinatie van deze alternatieven laat zich ook denken. ${ }^{114}$ In de literatuur is er tevens op gewezen dat in de praktijk vaak volstaan zal worden met een e-mail van het bestuur van de vennootschap aan de vergadergerechtigden met het verzoek (i) in te stemmen met de besluitvorming buiten vergadering onder opgave van het te nemen besluit of de te nemen besluiten en (ii) te antwoorden of men voor of tegen stemt. ${ }^{115}$ Dat komt mij als een elegante oplossing voor. Aan de vergadergerechtigden zonder stemrecht hoeft de vraag of men voor of tegen stemt niet te worden gesteld.

Besluitvorming buiten vergadering vindt plaats volgens de algemene regels voor besluitvorming in de algemene vergadering, dat wil zeggen dat besluiten in beginsel worden genomen bij volstrekte meerderheid van de uitgebrachte stemmen (art. 2:230 BW). In beginsel, omdat ten aanzien van de stemrechtloze aandeelhouder rekening gehouden zal moeten worden met de hiervoor genoemde beschermingsregels. Een aandeelhouder die zijn tegenstem wil toelichten, heeft de mogelijkheid om vooraf zijn instemming aan de besluitvorming buiten de algemene vergadering te onthouden. In dat geval zal een algemene vergadering bijeengeroepen moeten worden om besluitvorming mogelijk te maken. ${ }^{116}$ Het vereiste van instemming bewerkstelligt, zoals geciteerd, dat minderheidsaandeelhouders en andere vergadergerechtigden niet tegen hun wil worden geconfronteerd met besluitvorming door de meerderheidsaandeelhouder(s) zonder dat overleg heeft plaatsgevonden in een algemene vergadering. ${ }^{117}$

De parlementaire geschiedenis lijkt te impliceren dat instemming van de (andere) vergadergerechtigden met besluitvorming buiten vergadering vooraf moet geschieden. De wettekst stelt dat echter niet. In art. 2:238 lid 1 BW ontbreekt het woord 'voorafgaand'. Ik ben van mening dat de vergadergerechtigden ook achteraf ${ }^{118}$ hun instemming kunnen geven (expliciet) of kunnen doen blijken (impliciet) doordat de vergadergerechtigden geen bezwaar maken tegen de genomen besluiten. Daarmee wordt ook op dit punt tegemoet gekomen aan de door de wetgever beoogde versoepeling van besluitvorming buiten vergadering. ${ }^{119}$ Mocht voorafgaande instemming ontbreken, dan verdient het aanbeveling die instemming achteraf alsnog expliciet te verkrijgen teneinde onzekerheid over de rechtsgeldigheid van buiten vergadering genomen besluiten te voorkomen.

Eerder stelde ik dat een buiten vergadering genomen besluit bij gebreke van instemming ten aanzien van de besluitvorming buiten vergadering kan worden

114 Nowak \& Van den Ingh 2005, p. 164. Zie ook Timmerman 2004, p. 29.

115 Nowak \& Van den Ingh 2005, p. 164 en Nowak \& Van den Ingh 2007, p. 129.

116 Kamerstukken II 2006/07, 31 058, nr. 3, p. 88 (MvT).

117 Kamerstukken II 2006/07, 31 058, nr. 3, p. 89 (MvT).

118 In de hiervoor beschreven visie van nietigheid van het buiten vergadering genomen besluit wegens het ontbreken van de vereiste instemming van de vergadergerechtigden met deze wijze van besluitvorming zou sprake zijn van bekrachtiging in de zin van art. 2:14 lid 2 BW.

119 Kamerstukken II 2006/07, 31 058, nr. 3, p. 88 (MvT). 
vernietigd op grond van art. 2:15 lid 1 sub a BW. Daarbij past mijns inziens een kanttekening. De vraag is of de vergadergerechtigde kapitaalverschaffer zonder stemrecht wel een redelijk belang in de zin van art. 2:15 lid 3 aanhef onder a BW heeft indien het besluit zonder zijn instemming - vooraf of achteraf - buiten vergadering is genomen. Bij gebrek aan stemrecht kan hij immers niet bewerkstelligen dat geen of een ander besluit zou zijn genomen (of na vernietiging zal worden genomen). De rol van de vergadergerechtigde kapitaalverschaffer zonder stemrecht bij besluitvorming buiten vergadering lijkt mij daarom gemarginaliseerd. Ter bescherming van de vergadergerechtigde kapitaalverschaffer zonder stemrecht zou de wetgever aan art. 2:238 lid 1 BW het woord 'voorafgaand' moeten toevoegen.

Art. 2:238 lid $2 \mathrm{BW}$ bepaalt dat in geval van besluitvorming buiten vergadering de stemmen schriftelijk worden uitgebracht. Aan het vereiste van schriftelijkheid van de stemmen wordt tevens voldaan indien het besluit onder vermelding van de wijze waarop ieder der aandeelhouders heeft gestemd schriftelijk of elektronisch is vastgelegd. Dat houdt bijvoorbeeld in dat genomen besluiten door stemming in (aparte) telefoongesprekken met stemgerechtigden door het bestuur schriftelijk zullen moeten worden vastgelegd en door de stemgerechtigde aandeelhouders zullen moeten worden ondertekend. Ook eventuele andere vergadergerechtigden moeten het besluit ondertekenen. ${ }^{120}$ Tenzij de statuten anders bepalen, kunnen de stemmen ook langs elektronische weg worden uitgebracht. De bestuurders en de commissarissen worden voorafgaand aan de besluitvorming in de gelegenheid gesteld om advies uit te brengen. Het oorspronkelijke ontwerp van het tweede lid stelde ook de eis van het besluit buiten vergadering door alle vergadergerechtigden moest worden ondertekend. Dat betekende geen versoepeling van de bestaande praktijk, zodat die eis is losgelaten. Uit het vastgestelde besluit moet blijken op welke wijze elke aandeelhouder heeft gestemd. ${ }^{121}$ Zoals gezegd, wordt de instemming met de wijze van besluitvorming geregeld in art. 2:238 lid 1 BW.

\subsubsection{De statutaire verplichtingen van art. 2:192 BW}

Art. 2:192 BW geeft een regeling over statutaire verplichtingen en eisen. Dat artikel bepaalt onder meer dat de statuten met betrekking tot alle aandelen of aandelen van een bepaalde soort of aanduiding kunnen (i) bepalen dat verplichtingen van verbintenisrechtelijke aard, jegens de vennootschap of derden of tussen aandeelhouders, aan het aandeelhouderschap zijn verbonden, (ii) eisen verbinden aan het aandeelhouderschap en (iii) bepalen dat de aandeelhouder in gevallen, in de statuten omschreven, gehouden is zijn aandelen of een deel daarvan aan te bieden en over te dragen. Deze verplichtingen of eisen kunnen niet, ook niet onder voorwaarde of

120 Kamerstukken II 2008/09, 31 058, nr. 7, p. 18 (Nota van Wijziging).

121 Kamerstukken II 2009/10, 32 426, nr. 2, p. 4 (Voorstel van wet) en Kamerstukken II 2009/10, 32 426, nr. 3, p. 26 (MvT). Kamerstukken II 2011/12, 32 426, nr. 28. 
tijdsbepaling, tegen de wil van de aandeelhouder worden opgelegd. De statuten kunnen bepalen dat de inwerkingtreding van een statutaire verplichting of eis afhankelijk is van een besluit van een daartoe in de statuten aangewezen orgaan van de vennootschap. De statuten kunnen bovendien bepalen dat een daartoe in de statuten aangewezen orgaan van de vennootschap ontheffing kan verlenen van een statutaire verplichting of eis. Indien de statuten bepalen dat de aandeelhouder in gevallen, in de statuten omschreven, gehouden is zijn aandelen of een deel daarvan aan te bieden en over te dragen, moet deze regeling zodanig zijn dat de aandeelhouder die dit verlangt een prijs ontvangt, gelijk aan de waarde van zijn aandeel of aandelen, vastgesteld door een of meer onafhankelijke deskundigen. De statuten kunnen voorzien in een afwijkende prijsbepalingsregeling. Een dergelijke afwijkende regeling kan aan een aandeelhouder niet tegen zijn wil worden opgelegd.

Het eerste lid van art. 2:192 BW bepaalt, kort gezegd, aldus dat in de statuten verbintenissen tussen aandeelhouders onderling, tussen de aandeelhouder en de vennootschap en tussen de aandeelhouder en derden kunnen worden opgenomen. In de rechtspraktijk werden dergelijke afspraken tussen aandeelhouders - voor zover die afspraken niet in de statuten konden worden opgenomen - vastgelegd in een aandeelhoudersovereenkomst. Art. 2:192 BW maakt het dus mogelijk dergelijke verplichtingen in de statuten op te nemen. Niet altijd is het wenselijk dat te doen. Statuten zijn immers openbaar. In bijvoorbeeld een joint venture kan het daarom raadzaam zijn dergelijke verplichtingen in een niet openbare aandeelhoudersovereenkomst op te nemen.

In het kader van het onderwerp van dit onderzoek - de kapitaalverschaffer zonder stemrecht - rijst de vraag of in de statuten kan worden opgenomen de verplichting van een houder van een gewoon aandeel (aldus met stemrecht) jegens zijn medeaandeelhouders het aan het gewone aandeel verbonden stemrecht niet, gedurende een zekere periode of slechts ten aanzien van bepaalde besluiten niet uit te oefenen. Art. 2:192 BW roept daarnaast vele andere vragen op. Ik beperk mij in deze paragraaf echter tot de hiervoor geschetste vraag. ${ }^{122}$ Ik maak eerst een aantal algemene opmerkingen ten aanzien van art. 2:192 BW.

Een statutaire verplichting ex art. 2:192 BW heeft een vennootschapsrechtelijk karakter en moet daarom worden onderscheiden van verplichtingen voortvloeiende uit een aandeelhoudersovereenkomst. Anders dan bij verplichtingen voortvloeiende uit een aandeelhoudersovereenkomst, gelden statutaire verplichtingen ook voor later

$122 \mathrm{Ik}$ verwijs naar de literatuur over art. 2:192 BW en eerdere ontwerpen daarvan: Dortmond 2007; Van Hövell tot Westervlier 2011; Stokkermans 2008 (2); Stokkermans 2008 (3); Van Veen 2007; Van Veen 2009 en Van Veen 2010. Zie voor de parlementaire geschiedenis: Kamerstukken II 2006/07, 31 058, nr. 2, p. 5-9 (Voorstel van wet); Kamerstukken II 2006/07, 31 058, nr. 3, p. 43-47 (MvT); Kamerstukken II 2008/09, 31 058, nr. 6, p. 48 (NV II); Kamerstukken II 2008/09, 31 058, nr. 7, p. 2-4, 11 en 13; Kamerstukken II 2009/10, 31 058, nr. 25; Kamerstukken II 2009/10, 31 058, nr. 28, p. 1-2; Kamerstukken I 2009/10, 31 058, nr. A, p. 5-6 (Gewijzigd voorstel van wet); Kamerstukken II 2010/11, 32 426, nr. 7, p. 24-25 (NV II); Kamerstukken II 2010/11, 32 426, nr. 8, p. 1-2 en 11 en Kamerstukken I 2011/12, 32 426, nr. A, p. 2 (Gewijzigd voorstel van wet). 
toetredende aandeelhouders. Derden kunnen kennis nemen van de verplichtingen. De statuten van de BV zijn immers via het handelsregister te raadplegen. ${ }^{123}$ Het niet-naleven van een statutaire verplichting, anders dan bij verplichtingen die voortvloeien uit een aandeelhoudersovereenkomst, kan worden onderworpen aan vennootschapsrechtelijke sancties, zoals het ontzeggen van het recht op deelname aan de algemene vergadering (art. 2:227 lid $3 \mathrm{BW}$ ) of opschorting van het stemrecht (art. 2:228 lid $1 \mathrm{BW}$ ). In de flex-BV heeft de wetgever vastgehouden aan het onderscheid tussen statuten en aandeelhoudersovereenkomsten. Een verwijzing naar een aandeelhoudersovereenkomst in de statuten (incorporation by reference) is niet toegestaan. Dit betekent dat men niet een vennootschapsrechtelijk karakter aan een aandeelhoudersovereenkomst kan toekennen door een verwijzing naar die overeenkomst op te nemen in de statuten. De inhoud van de regeling mag niet worden overgelaten aan een orgaan, aldus de memorie van toelichting. ${ }^{124}$

De statutaire verplichtingen mogen worden opgelegd in aanvulling op de wettelijke verplichtingen. Een statutaire verplichting mag niet in strijd zijn met de wet. De verplichting hoeft niet nauwkeurig omschreven te zijn, maar moet (achteraf) voldoende bepaalbaar zijn. De statutaire verplichtingen moeten verband houden met de vennootschap en de door haar gedreven onderneming. De wetgever noemt als voorbeelden van statutaire verplichtingen de verplichting tot het verstrekken van een lening aan de vennootschap of de verplichting tot levering van producten aan de vennootschap. ${ }^{125}$ Het kan echter ook gaan om verplichtingen van verbintenisrechtelijke aard tussen aandeelhouders onderling en jegens derden. ${ }^{126}$ Het is ook geoorloofd om statutair te bepalen dat aandeelhouders naast de vennootschap persoonlijk aansprakelijk kunnen worden gehouden voor bepaalde of alle schulden van de vennootschap. ${ }^{127}$

Kan door middel van art. 2:192 BW een stemrechtloos aandeel gecreëerd worden? De wetgever heeft bij art. 2:192 BW niet gedacht aan stemafspraken. Dat zulks wel mogelijk is, volgt uit art. 2:228 lid 4 BW, waarin een regeling over het flexibele stemrecht is opgenomen. Dat biedt flexibiliteit bij de vormgeving van de stemverhoudingen. In de statuten kan worden bepaald dat bepaalde aandelen recht geven op het uitbrengen van meer dan één stem (meervoudig stemrecht), al dan niet ten aanzien van bepaalde besluiten. Daarnaast kan worden bepaald dat aan bepaalde aandelen ten aanzien van bepaalde besluiten geen stemrecht toekomt. De flex-BV biedt de oprichters meer vrijheid om de stemverhoudingen naar eigen inzicht en behoefte vorm te geven, bijvoorbeeld bij de joint venture vennootschap waarin behoefte bestaat aan bijzonder stemrecht voor een of meer aandeelhouders ten

123 Deze openbaarheid kan aanleiding zijn verplichtingen in een aandeelhoudersovereenkomst op te nemen.

124 Kamerstukken II 2006/07, 31 058, nr. 3, p. 16-17 (MvT).

125 Kamerstukken II 2006/07, 31 058, nr. 3, p. 44 (MvT)

126 Kamerstukken II 2006/07, 31 058, nr. 3, p. 9, 13, 44 en 54 (MvT).

127 Kamerstukken II 2006/07, 31 058, nr. 3, p. 43-44 (MvT). 
aanzien van specifieke bedrijfsonderdelen. Ook valt te denken aan de familievennootschap waarin de wens bestaat om het stemrecht van de verschillende takken van de familie per onderwerp of bedrijfsonderdeel te laten variëren, aldus de wetgever. ${ }^{128}$

Juist omdat de wet in een aparte regeling van flexibel stemrecht voorziet, ben ik van mening dat de verplichting van een houder van een gewoon aandeel jegens zijn mede-aandeelhouders het aan het gewone aandeel verbonden stemrecht niet, gedurende een zekere periode of slechts ten aanzien van bepaalde besluiten niet uit te oefenen, gebaseerd kan worden op art. 2:192 BW. ${ }^{129}$ Dat geldt te meer, omdat de wetgever blijkens de in de memorie van toelichting gegeven voorbeelden verplichtingen van vermogensrechtelijke aard op het oog heeft gehad. Langs de weg van art. 2:192 BW kan echter niet een stemrechtloos aandeel gecreëerd worden.

Uit de laatste volzin ("Een in de vorige zin onder $a, b$ of $c$ bedoelde verplichting of eis kan niet, ook niet onder voorwaarde of tijdsbepaling, tegen de wil van de aandeelhouder worden opgelegd.") van art. 2:192 lid 1 BW volgt dat de aandeelhouders, die niet met de desbetreffende wijziging in de statuten hebben ingestemd, daaraan niet gebonden zijn. Een tegenstemmende of niet-stemmende aandeelhouder kan niet aan de in te voeren verplichting worden onderworpen. Dat geldt aldus naar mijn mening ook voor de stemrechtloze aandeelhouder. Steun voor deze opvatting vind ik in de parlementaire geschiedenis: "De stemrechtloze aandeelhouder heeft dezelfde bescherming als andere aandeelhouders; een statutaire eis of verplichting kan niet tegen zijn wil worden opgelegd. Deze wil is vergelijkbaar met het instemmingsvereiste van een vergadergerechtigde, bedoeld in artikel 227 lid 4; er is geen sprake van besluitvorming, noch van het uitoefenen van stemrecht. Bij de invoering van een statutaire verplichting zal derhalve aan de stemrechtloze aandeelhouder moeten worden gevraagd of hij met de invoering instemt. Het instemmingsvereiste in het voorgestelde artikel 192 beoogt de minderheidsaandeelhouder te beschermen tegen benadeling van zijn persoonlijke vermogen. De aandeelhouder mag er immers van uitgaan dat hij niet is gebonden tot een hoger bedrag dan waartoe hij in het kader van de volstorting van zijn aandelen is gehouden. De bescherming tegen 'extra' verplichtingen op grond van artikel 192 geldt derhalve ongeacht of de aandeelhouder stemrecht heeft.",130

Uit de memorie van toelichting blijkt dat de niet-gebondenheid aan de statutaire verplichting ex art. 2:192 BW persoonsgebonden is en dat die niet-gebondenheid vervalt bij overdracht van het aandeel. Er wordt daarom wel gesproken over 'persoonsgebonden niet-gebondenheid'. Bij overdracht van het aandeel gaan de statutaire verplichtingen over op de nieuwe aandeelhouder en is die nieuwe

128 Kamerstukken II 2006/07, 31 058, nr. 3, p. 85 (MvT).

129 In gelijke zin Van Veen 2007, p. 952.

130 Kamerstukken I 2011/12, 31058 en 32 426, nr. C, p. 19 (MvA I). 
aandeelhouder, anders dan zijn voorganger, aan die regeling gebonden. ${ }^{131}$ Bedoeld zal zijn de overdracht onder bijzondere titel, zo komt mij voor. Met Van Veen ${ }^{132}$ ben ik van mening dat bij opvolging onder algemene titel de opvolger niet gebonden is aan de statutaire verplichting. De opvolger volgt de ander op in diens bezit en houderschap met alle hoedanigheden en gebreken daarvan, zo bepaalt art. 3:116 BW. De wetgever denkt daarover echter anders: "Dat een opvolgende aandeelhouder in beginsel aan een statutaire verplichting van verbintenisrechtelijke aard is gebonden, behoeft geen nadere regeling. Dat volgt reeds uit het persoonsgebonden karakter van de niet-gebondenheid (vgl. blz. 4 van de memorie van toelichting). Het voorgestelde artikel 192 lid 5 (artikel 192a van de nota van wijziging) heeft geen betrekking op overgang van aandelen onder algemene titel. Dit volgt uit het gebruik van het woord «vervreemdt» in de eerste zin. De verkrijger die de aandelen onder algemene titel heeft verkregen, is op grond van artikel 3:116 BW gebonden aan de statutaire verplichting." ${ }^{\prime 33}$ Dit lijkt me niet juist.

Uit de parlementaire geschiedenis komt in het kader van de betekenis van de woorden 'tegen de wil van de aandeelhouder' de vraag naar voren of een aandeelhouder die tegen de statutenwijziging heeft gestemd, desondanks aan de regeling wordt onderworpen als hij nadien aandelen koopt, of als hij nieuwe aandelen neemt bij een emissie, bijvoorbeeld ingeval het vermogen van een aandeelhouder onder bewind is gesteld, er een statutaire kwaliteitseis wordt ingevoerd dat de aandeelhouders het vrije beheer over hun vermogen dienen te hebben en wordt besloten tot een emissie. ${ }^{134}$ De minister zegt daarover dat de statutaire verplichtingen en eisen, bedoeld in art. 2:192 lid 1 onder a en b BW aan het aandeelhouderschap, en niet aan de aandelen, verbonden zijn. Daaruit volgt dat een aandeelhouder die tegen de statutenwijziging heeft gestemd, bescherming geniet, ongeacht of hij na de statutenwijziging meer aandelen heeft verworven. ${ }^{135}$ In de literatuur werd dit standpunt reeds verdedigd. ${ }^{136}$

Overigens kan de (stemrechtloze) aandeelhouder na de invoering van een statutaire verplichting alsnog daarmee instemmen. ${ }^{137}$ Indien een aandeelhouder niet gebonden is aan een statutaire verplichting of eis, wordt dat in het aandeelhoudersregister vermeld. ${ }^{138}$

131 Kamerstukken II 2006/07, 31 058, nr. 3, p. 4 en 47 (MvT).

132 Van Veen 2007, p. 953, noot 28.

133 Kamerstukken II 2008/09, 31 058, nr. 6, p. 38 (NV II).

134 Dit - wat de stemrechtloze aandeelhouder betreft - in afwijking van de hoofdregel van art. 2:206a BW. Zie paragraaf 6.2.3.5

135 Kamerstukken I 2011/12, 31 058, nr. C, p. 19 (MvA I).

136 Van Veen 2010, p. 616-617 en Van der Korst 2011, p. 3

137 Kamerstukken II 2006/07, 31 058, nr. 3, p. 45 (MvT).

138 Art. 2:194 lid 1 BW. Kamerstukken II 2010/11, 32 426, nr. 8, p. 11 (Nota van Wijziging). 
Volledigheidshalve wijs ik in het kader van art. 2:192 BW op art. 2:192a BW. ${ }^{139}$ Dat artikel bepaalt dat indien een aandeelhouder, die niet gebonden is aan een statutaire verplichting of eis als bedoeld in art. 2:192 lid $1 \mathrm{BW}$, zijn aandelen wil vervreemden, maar overdracht van de aandelen in verband met de gebondenheid van de verkrijger aan die verplichting of eis onmogelijk of uiterst bezwaarlijk is, hij de vennootschap kan verzoeken om gegadigden aan te wijzen aan wie hij al zijn aandelen zal kunnen overdragen volgens een regeling in de statuten. Op deze regeling is art. 2:192 lid $3 \mathrm{BW}$ van overeenkomstige toepassing. Indien de vennootschap niet binnen drie maanden na het verzoek gegadigden heeft aangewezen, kan de aandeelhouder binnen zes maanden na het verstrijken van deze termijn zijn aandelen aan een ander overdragen en is de verkrijger van de aandelen niet gebonden aan de statutaire verplichting of eis. Deze regeling geldt ook indien overdracht van aandelen onmogelijk of uiterst bezwaarlijk is in verband met de gebondenheid van de verkrijger aan een statutaire prijsbepalingsregeling waaraan de aandeelhouder niet is gebonden.

\subsubsection{Aanbiedingsregeling}

Art. 2:195 lid 1 BW bepaalt onder meer dat aan houders van aandelen van een bepaalde soort of aanduiding waaraan ingevolge een statutaire regeling geen stemrecht of recht op deling in de winst of reserves toekomt, slechts aandelen van dezelfde soort of aanduiding kunnen worden aangeboden, tenzij in de statuten anders is bepaald. Met andere woorden: de stemrechtloze aandeelhouder kan in het kader van de aanbiedingsregeling van art. 2:195 BW alleen reflecteren op aangeboden, stemrechtloze aandelen. Van deze hoofdregel kan bij de statuten worden afgeweken. Uit de parlementaire geschiedenis leid ik af dat de wetgever heeft willen aansluiten bij het voorkeursrecht ex art. 2:206a BW. ${ }^{140}$

\subsubsection{Uitkoopregeling}

Art. 2:201a BW regelt de uitkoopregeling. Hij die als aandeelhouder voor eigen rekening ten minste 95 procent van het geplaatste kapitaal van de vennootschap verschaft en ten minste 95 procent van de stemrechten in de algemene vergadering kan uitoefenen, kan tegen de gezamenlijke andere aandeelhouders een vordering instellen tot overdracht van hun aandelen aan de eiser, zo bepaalt het eerste lid van

139 Zie voor een - mijns inziens terechte - zeer kritische visie op art. 2:192a BW: Schwarz 2012 (1). Zie ook Kamerstukken I 2011/12, 31 058, nr. D, p. 12 (Nader VV) en Kamerstukken I 2011/12, 31 058, nr. E, p. 18-19 (Nadere MvA I). Zie verder over art. 2:192a BW: Kamerstukken II 2006/07, 31 058, nr. 3, p. 47 (MvT); Kamerstukken II 2008/09, 31 058, nr. 6, p. 21, 37-38, 40-41, 48 (NV II); Kamerstukken II 2008/09, 31 058, nr. 7, p. 11 en 13; Kamerstukken I 2011/12, 31058 en 32 426, nr. C, p. 19-20 (MvA I) en Kamerstukken I 2011/12, 31 058, nr. E, p. 18-19 (Nadere MvA I).

140 Kamerstukken II 2010/11, 32 426, nr. 6, p. 8; Kamerstukken II 2010/11, 32 426, nr. 7, p. 25 (NV II) en Kamerstukken II 2010/11, 32 426, nr. 8, p. 11 (Nota van wijziging). 
dat artikel onder meer. Om te voorkomen dat een aandeelhouder, die minder dan 95 procent van het geplaatste kapitaal vertegenwoordigt, de minderheid zou kunnen uitkopen (omdat een deel van zijn aandelen stemrechtloos is), is in art. 2:201a lid 1 BW bepaald dat een aandeelhouder voor het uitkooprecht niet alleen 95 procent van het geplaatste kapitaal moet verschaffen, maar tevens 95 procent van de stemrechten in de algemene vergadering moet kunnen uitoefenen. ${ }^{141}$ Het recht van uitkoop komt de stemrechtloze aandeelhouder aldus niet toe. ${ }^{142}$ Voor de toepassing van de uitkoopregeling wordt ook rekening gehouden met de stemrechtloze aandelen in een BV, zo bepaalt art. 2:24d lid 2 BW.

\subsubsection{Conversie van het stemrechtloze aandeel}

Het kapitaal van een BV kan per definitie niet alleen maar uit stemrechtloze aandelen bestaan. Met andere woorden: indien in een BV stemrechtloze aandelen bestaan, is er ten minste ook één aandeel met stemrecht, zoals een gewoon aandeel of een winstrechtloos aandeel (vgl. art. 2:175 en 2:190 BW). Uit art. 2:228 lid 5 BW volgt dat stemrechtloze aandelen als aandelen van een bepaalde soort of aanduiding worden aangemerkt en blijkens art. 2:194 BW als zodanig in het aandeelhoudersregister worden geregistreerd. In deze situatie is in een BV aldus sprake van verschillende soorten aandelen.

Indien sprake is van verschillende soorten aandelen, kunnen aandelen van de ene soort worden omgezet in een andere soort. Omzetting of conversie kent geen wettelijke basis. De rechten die aan het aandeel zijn verbonden, wijzigen als gevolg van de conversie. Het gaat daarbij niet om intrekking van het ene aandeel, gevolgd door uitgifte van een ander aandeel. Er is dus sprake van een wijziging van een reeds gehouden aandeel. Voor conversie is een statutaire basis of een statutenwijziging noodzakelijk. ${ }^{143}$

Hoe moet conversie in het licht van het stemrechtloze aandeel worden gezien? In de statuten van een BV kan worden opgenomen dat stemrechtloze aandelen in gewone aandelen geconverteerd kunnen worden. De stemrechtloze aandeelhouder verkrijgt als gevolg van die conversie aldus stemrecht. Indien een dergelijke bepaling niet in de statuten is opgenomen, zullen de statuten in voorkomend geval moeten worden gewijzigd. Indien de statuten wel een dergelijke bepaling tot conversie kennen, is een aantal opties mogelijk. Zo kan onder meer bepaald zijn dat een bepaald orgaan bevoegd is te besluiten tot conversie. Indien de BV gewone aandelen en/of winstrechtloze aandelen kent, ligt het voor de hand dat de algemene vergadering van houders van gewone aandelen en/of de algemene vergadering van

141 Kamerstukken II 2008/09, 31 058, nr. 6, p. 15 (NV II).

142 Tenzij hij ook andere aandelen met stemrecht houdt, waardoor hij wel aan de vereisten van art. 2:201a BW voldoet. In dat geval is art. 2:24d lid 2 BW relevant.

143 Zie over conversie bijvoorbeeld Portengen \& De Groot 2004; Prinsen 2004, p. 136-141; Asser/ Maeijer, Van Solinge \& Nieuwe Weme 2-II* 2009, nr. 194; J.B. Huizink, Groene Serie Rechtspersonen, art. 2:92 BW, aant. 5, Deventer: Kluwer en Van Olffen 1997, p. 49 e.v. 
houders van winstrechtloze aandelen deze bevoegdheid toekomt. Een andere mogelijkheid is dat de conversie blijkens een statutaire bepaling daartoe van rechtswege zal plaatsvinden op een bepaald tijdstip of bij een bepaalde gebeurtenis. In dat geval is sprake van een stemrechtloos aandeel met recht onder tijdsbepaling op of een voorwaardelijk recht op stemrecht. Een duidelijke en correcte formulering is van belang ter vermijding van eventuele toekomstige problemen van uitleg en mogelijke geschillen als gevolg daarvan.

Een stemrechtloos aandeel met een voorwaardelijk recht tot conversie in een gewoon aandeel kan de aantrekkelijkheid van het stemrechtloze aandeel als financieringsinstrument vergroten. De financier en houder van het stemrechtloze aandeel kan onder de conversievoorwaarden zijn invloed door het verkrijgen van stemrecht in de vennootschap zien vergroten.

\subsubsection{Omzetting van de BV in een andere rechtspersoon}

Alleen het BV-recht kent het stemrechtloze aandeel. In hoofdstuk 1 constateerde ik dat de wetgever ervan heeft afgezien het stemrechtloze aandeel ook bij de NV te introduceren. Indien een BV met stemrechtloze aandelen in - bijvoorbeeld - een NV omgezet wordt, is de vraag wat er met die aandelen gebeurt en wat de rechtspositie is van de houder van de stemrechtloze aandelen. Op de omzetting is art. 2:18 BW van toepassing. Voor de omzetting is - kort gezegd - vereist (i) een besluit tot omzetting, (ii) een besluit tot wijziging van de statuten en (iii) een notariële akte tot omzetting die de nieuwe statuten van de omgezette rechtspersoon bevat. Voor de omzetting van een $\mathrm{BV}$ in een $\mathrm{NV}$, coöperatie of onderlinge waarborgmaatschappij is geen rechtelijke machtiging vereist; voor de omzetting van een BV in een stichting of vereniging wel. Voor de omzetting van een BV in een NV geldt bovendien de regel van art. 2:72 lid $1 \mathrm{BW}$, inhoudende dat - kort gezegd - het eigen vermogen van de vennootschap voor de omzetting ten minste overeenkwam met het gestorte en opgevraagde deel van het kapitaal.

Niet alleen speelt de hiervoor gestelde vraag bij omzetting van de BV in een NV, maar ook bij de omzetting van de BV in een andere rechtspersoon, bijvoorbeeld een stichting, coöperatie of vereniging. De houder van het stemrechtloze aandeel kan wegens het ontbreken van stemrecht immers geen invloed op het besluit tot omzetting uitoefenen. ${ }^{144}$ Hij kan de omzetting niet blokkeren.

In de BV zijn voor de omzetting, naast art. 2:18 BW, art. 2:181 en 2:182 BW van belang. Art. 2:182 BW ziet op het besluit tot omzetting in een vereniging, coöperatie of onderlinge waarborgmaatschappij en regelt een aantal procedurele aspecten. Art. 2:181 BW is in dit kader relevanter en bepaalt het volgende. Wanneer de vennootschap zich volgens art. 2:18 BW omzet in een vereniging, coöperatie, of onderlinge waarborgmaatschappij, wordt iedere aandeelhouder lid, tenzij hij de

144 Kamerstukken II 2006/07, 31 058, nr. 3, p. 12 (MvT) en Kamerstukken II 2010/11, 32 426, nr. 7, p. 16-17 (NV II). 
schadeloosstelling heeft gevraagd. Na een besluit tot omzetting in een vereniging, stichting, coöperatie of onderlinge waarborgmaatschappij kan iedere aandeelhouder, daaronder begrepen iedere houder van stemrechtloze of winstrechtloze aandelen, die niet met het besluit tot omzetting heeft ingestemd, de vennootschap schadeloosstelling vragen voor het verlies van zijn aandelen. Wanneer de vennootschap zich omzet in een naamloze vennootschap kan iedere houder van stemrechtloze of winstrechtloze aandelen, die niet met het besluit tot omzetting heeft ingestemd, bij de vennootschap een verzoek tot schadeloosstelling indienen. Het verzoek tot schadeloosstelling moet schriftelijk aan de vennootschap worden gedaan binnen één maand nadat zij aan de aandeelhouder heeft meegedeeld dat hij deze schadeloosstelling kan vragen. De mededeling geschiedt op dezelfde wijze als de oproeping tot een algemene vergadering. De aandelen waarop het verzoek betrekking heeft, vervallen op het moment waarop de omzetting van kracht wordt. Het voorstel tot omzetting vermeldt het bedrag van de schadeloosstelling, vastgesteld door een of meer onafhankelijke deskundigen. De deskundigen brengen over de waardebepaling schriftelijk bericht uit, dat met de oproeping tot de vergadering waarop over de omzetting wordt beslist, wordt meegezonden. Indien tussen partijen op grond van de statuten of een overeenkomst waarbij de vennootschap en de desbetreffende aandeelhouders partij zijn, bepalingen over de vaststelling van de waarde van de aandelen of de vaststelling van de schadeloosstelling gelden, stellen de deskundigen hun bericht op met inachtneming daarvan. De benoeming van deskundigen kan achterwege blijven, indien de statuten of een overeenkomst waarbij de vennootschap en de desbetreffende aandeelhouders partij zijn, een duidelijke maatstaf bevatten aan de hand waarvan de schadeloosstelling zonder meer kan worden vastgesteld. Art. 2:231 lid $4 \mathrm{BW}$ is niet van toepassing ten aanzien van een besluit tot statutenwijziging in het kader van een omzetting van de vennootschap in een andere rechtsvorm. Wanneer een rechterlijke machtiging is vereist voor de omzetting ex art. 2:18 lid 4 en $5 \mathrm{BW}$, wordt die tevens geweigerd indien de belangen van houders van stemrechtloze en winstrechtloze aandelen in de vennootschap onvoldoende zijn ontzien.

Over art. 2:181 BW is in het parlement en de literatuur veel discussie gevoerd. Het gaat te ver om deze discussie ten volle uit de doeken te doen. ${ }^{145}$ Ik volsta daarom met het weergeven op hoofdlijnen van de regeling van omzetting en het

145 Voor de parlementaire discussie verwijs ik naar: Kamerstukken II 2006/07, 31 058, nr. 2, p. 3 (Voorstel van wet); Kamerstukken II 2006/07, 31 058, nr. 3, p. 40-41 (MvT); Kamerstukken II 2009/ 10, 32 426, nr. 2, p. 2, 6-7 (Voorstel van wet); Kamerstukken II 2009/10, 32 426, nr. 3, p. 4-6, 23-24, 27-28 (MvT); Kamerstukken II 2010/11, 32 426, nr. 7, p. 3-7 en 16-24 (NV II); Kamerstukken II 2010/11, 32 426, nr. 8, p. 1, 4-5, 10, 13-14; Kamerstukken II 2011/12, 32 426, nr. 25 en Kamerstukken I 2011-2012, nr. A, p. 2 en 8-9. De wijziging op pagina 2 strookt niet met het tekstvoorstel van art. 2:181 BW op pagina 8-9. Het verschil zit in de toevoeging 'daaronder begrepen iedere houder van stemrechtloze of winstrechtloze aandelen' in de eerste volzin van het tweede lid. Voor de discussie in de literatuur wijs ik bijvoorbeeld op: Dortmond 2010, p. 522-524; $\rightarrow$ 
maken van specifieke opmerkingen ten aanzien van de positie van de stemrechtloze aandeelhouder ingeval van omzetting.

Het uitgangspunt is dat het aandeelhouderschap van de stemrechtloze aandeelhouder wordt gecontinueerd. De aandeelhouder kan echter kiezen voor schadeloosstelling met verval van zijn stemrechtloze aandelen. ${ }^{146}$

Art. 2:181 lid $1 \mathrm{BW}$ brengt dat uitgangspunt en die keuzemogelijkheid tot uitdrukking. De parlementaire geschiedenis stelt expliciet dat dit ook geldt voor de stemrechtloze aandeelhouder. De hoofdregel van het eerste lid is dat de stemrechtloze aandeelhouder bij omzetting ex art. 2:18 BW lid wordt van de vereniging, coöperatie of onderlinge waarborgmaatschappij. Partijen zullen moeten onderhandelen en overeenstemming moeten bereiken over de omvang van de rechten van de stemrechtloze aandeelhouder in de omgezette rechtspersoon. ${ }^{147}$ De parlementaire geschiedenis stelt dat het voorstel van omzetting kan inhouden dat de stemrechtloze aandeelhouder een lidmaatschap zonder stemrecht verkrijgt. ${ }^{148} \mathrm{Bij}$ de omzetting van een $\mathrm{BV}$ in een coöperatie of een onderlinge waarborgmaatschappij is te denken aan het participatiebewijs als alternatief voor het stemrechtloze aandeel.

Art. 2:181 lid 2 BW bepaalt dat de stemrechtloze aandeelhouder die niet instemt met de omzetting in een andere rechtsvorm dan een NV jegens de vennootschap recht heeft op een schadeloosstelling. De gedachte achter de schadeloosstelling voor stemrechtloze aandeelhouders is dat bij omzetting het toekennen van een aan gewone aandeelhouders gelijkwaardige positie aan houders van stemrechtloze aandelen van een verdwijnende BV niet goed mogelijk is. Deze problematiek is in eerste instantie een kwestie van onderhandelen, waarbij de waardering van aandelen en rechten onderwerp van de onderhandelingen zal zijn. Ik acht conversie van aandelen in dit kader zeer wel mogelijk. Niettemin is het noodzakelijk die onderhandelingen te faciliteren door de uitweg van schadeloosstelling te bieden, aldus de wetgever. ${ }^{149}$ Opteert de stemrechtloze aandeelhouder voor een schadeloosstelling, dan wordt hij geen lid van de vereniging, de coöperatie of de onderlinge waarborgmaatschappij. Bij een coöperatieve vereniging of onderlinge waarborgmaatschappij met een in aandelen verdeeld kapitaal is het mogelijk dat de stemrechtloze aandeelhouder zijn aandelen na omzetting kan behouden. Er is dan

Lennarts \& Boschma 2010, p. 706; Dortmond 2011 (2), p. 238-239; Dortmond 2011 (3), p. 508-509 en Van den Heuvel 2011, p. 79-80. Ik wijs volledigheidshalve ook op P.J. Dortmond, 'Omzetting van een openbare vennootschap met rechtspersoonlijkheid in een BV, en andersom', Ondernemingsrecht 2010-8, p. 354-356. Daarnaast wijs ik op het advies d.d. 23 september 2010 van de Gecombineerde Commissie Vennootschapsrecht van de Nederlandse Orde van Advocaten en de Koninklijke Notariële Beroepsorganisatie inzake wetsvoorstel 32426 , aanpassing van de wetgeving aan en invoering van de Wet vereenvoudiging en flexibilisering bv-recht (Invoeringswet vereenvoudiging en flexibilisering bv-recht), p. 1-5.

146 Kamerstukken II 2011/12, 32 426, nr. 25, p. 5.

147 Kamerstukken II 2010/11, 32 426, nr. 7, p. 21 (NV II).

148 Kamerstukken II 2011/12, 32 426, nr. 25, p. 7.

149 Kamerstukken II 2009/10, 32 426, nr. 3, p. 5 en 28 (MvT). Een en ander geldt ook voor winstrechtloze aandelen. 
geen sprake van verlies van aandelen en dus ook niet van aanspraak op schadeloosstelling. ${ }^{150}$

Onder aandeelhouders die niet met het besluit tot omzetting in een vereniging, stichting, coöperatie of onderlinge waarborgmaatschappij instemmen, vallen ook aandeelhouders zonder stemrecht. ${ }^{151}$ De schadeloosstelling moet schriftelijk binnen een maand, nadat de vennootschap de stemrechtloze aandeelhouder heeft medegedeeld dat hij om schadeloosstelling kan verzoeken, worden gevraagd. De mededeling van de vennootschap moet voldoen aan het bepaalde in art. 2:223 BW. De hoogte van de schadeloosstelling wordt op grond van art. 2:181 lid 4 BW bepaald door deskundigen. In de praktijk zullen dat accountants of andere daartoe opgeleide deskundigen zijn.

Art. 2:181 lid $3 \mathrm{BW}$ regelt het uittreedrecht van de stemrechtloze aandeelhouder indien de BV wordt omgezet in een NV. De NV kent geen stemrechtloze aandelen. De stemrechtloze aandeelhouder moet aldus bij omzetting aandeelhouder met winsten stemrecht worden. De parlementaire geschiedenis noemt in dit kader de mogelijkheid van een gering stemrecht. De vraag is echter of de overige aandeelhouders met stemrecht daarmee instemmen, omdat dat een wijziging in de zeggenschapsverhoudingen zou inhouden. ${ }^{152}$ Indien de stemrechtloze aandeelhouder niet met de omzetting instemt, bijvoorbeeld om fiscale of andere redenen, dan kan hij om schadeloosstelling verzoeken. ${ }^{153}$ Ook hier geldt dat het verzoek tot schadeloosstelling schriftelijk aan de vennootschap moet worden gedaan binnen een maand nadat de vennootschap de stemrechtloze aandeelhouder heeft medegedeeld dat hij om schadeloosstelling kan verzoeken. De mededeling van de vennootschap moet voldoen aan het bepaalde in art. 2:223 BW. Praktisch is deze mededeling en de schriftelijke waardebepaling door de deskundige tegelijk met het voorstel tot omzetting aan de stemrechtloze aandeelhouder te zenden. ${ }^{154}$ De stemrechtloze aandelen waarop het verzoek tot schadeloosstelling betrekking heeft, vervallen op het moment waarop de omzetting van kracht wordt. Doet de stemrechtloze aandeelhouder (bewust) geen of te laat een verzoek tot schadeloosstelling, dan blijft hij aandeelhouder en is, gelet op de hiervoor omschreven problematiek, onduidelijk hoe

150 Kamerstukken II 2010/11, 32 426, nr. 7, p. 34 (NV II)

151 Kamerstukken II 2009/10, 32 426, nr. 3, p. 5 en 23-24 (MvT) en Kamerstukken II 2011/12, 32 426, nr. 25 , p. 7.

152 In beginsel bepaalt de nominale waarde het aantal stemmen dat kan worden uitgebracht, tenzij volgens suggestie van Dortmond 2011 (3), p. 508 - gebruik wordt gemaakt van art. 2:118 lid 4 of lid 5 BW. Ook Van Eck 2013, p. 18, wijst er in het kader van een fusie tussen een verdwijnende BV en een verkrijgende NV op dat, indien de stemrechtloze aandeelhouder niet voor schadeloosstelling opteert en dus aandelen in de NV moet verkrijgen, het onduidelijk is hoe deze aandelen eruit moeten zien.

153 Kamerstukken II 2011/12, 32 426, nr. 25, p. 7.

154 Roelofs 2012 (2), p. 15. In gelijke zin in geval van fusie. Zie Roelofs 2012 (3), p. 14 en Van Eck 2013, p. $17-18$ 
dat aandeel er uit moet zien. ${ }^{155}$ Zoals gezegd, kan dat een aandeel met een gering winstrecht zijn, zij het dat art. 2:118 BW slechts beperkte afwijkingen toelaat. ${ }^{156}$ Kort gezegd, komt art. 2:181 lid 3 BW er op neer dat de stemrechtloze aandeelhouder in de BV bij omzetting van die vennootschap in een NV of (i) in de NV aandeelhouder wordt of (ii) een schadeloosstelling ontvangt.

Over de omgekeerde situatie van omzetting van een NV in een BV merkt de wetgever op dat het uitgangspunt is dat aandeelhouders na omzetting over een gelijkwaardig aandeel in de BV zullen beschikken, omdat het niet voor de hand ligt dat er in het kader van de omzetting stemrechtloze aandelen ontstaan. Aandeelhouders kunnen daarnaast stemmen tegen een omzetting waarbij hun stemrecht wordt ontnomen. Het tegen hun wil ontnemen van stemrecht zal in de regel in strijd zijn met de vennootschappelijke redelijkheid en de billijkheid. ${ }^{157}$

De vraag is wat onder 'instemming' in de zin van art. 2:181 lid 2 en 3 BW moet worden verstaan. De wettekst spreekt over "kan iedere aandeelhouder, daaronder begrepen iedere houder van stemrechtloze (...), die niet met het besluit tot omzetting heeft ingestemd." Mijns inziens moet daaruit niet worden afgeleid dat die instemming via of van de vergadering van houders van stemrechtloze aandelen moet worden verkregen. ${ }^{158}$ Het besluit tot omzetting is immers niet aan goedkeuring of instemming van dat orgaan onderworpen. Bovendien brengt de wettekst tot uitdrukking dat het gaat om iedere aandeelhouder. Een besluit van de vergadering van houders van stemrechtloze aandelen brengt mee dat de stemrechtloze aandeelhouders in dat orgaan hebben gestemd en dat bij meerderheid wordt besloten. Indien een besluit tot instemming van de vergadering van houders van stemrechtloze aandelen vereist zou zijn, strookt dat niet met de wettekst. Kortom, het gaat om een individuele instemming van iedere stemrechtloze aandeelhouder, ${ }^{159}$ waaraan naar mijn mening geen vormvereisten zijn gesteld. ${ }^{160}$ Het verdient de voorkeur deze instemming ondubbelzinnig, onvoorwaardelijk en schriftelijk vast te leggen.

Alleen indien de stemrechtloze aandeelhouder niet met de omzetting instemt, kan hij aanspraak maken op schadeloosstelling. De omgezette rechtspersoon kan niet worden verplicht de stemrechtloze aandeelhouder een andere positie te geven dan deze aandeelhouder in de situatie voor omzetting had. ${ }^{161}$

Art. 2:181 lid 4 BW brengt tot uitdrukking dat het rapport van de deskundigen moet zijn uitgebracht voordat over de omzetting wordt besloten. Daardoor kan de

155 In gelijke zin in het geval van fusie Van Eck 2013, p. 18. Zie ook de suggestie van Dortmond 2011 (3), p. 508.

156 Ten Berg 2012, p. 614 en 619, noemt in dit kader en werkt een voorbeeld uit van high en low voting shares.

157 Kamerstukken II 2009/10, 32 426, nr. 3, p. 28 (MvT). Een en ander geldt ook voor winstrechtloze aandelen.

158 Anders Roelofs 2012 (2), p. 13. Vgl. Kamerstukken II 2010/11, 32 426, nr. 7, p. 17 (NV II).

159 In gelijke zin: Ten Berg 2012, p. 619.

160 Vgl. Kamerstukken II 2006/07, 31 058, nr. 3, p. 89 (MvT).

161 Kamerstukken II 2010/11, 32 426, nr. 7, p. 18 (NV II). 
aandeelhouder voordat hij van zijn uittreedrecht gebruik maakt de gevolgen daarvan overzien en een weloverwogen keuze maken. De deskundigen moeten een tussen partijen op grond van de statuten of een overeenkomst geldende regeling over de vaststelling van de waarde respecteren. ${ }^{162}$ De benoeming kan ook achterwege blijven indien de aandeelhouders hebben verklaard geen gebruik te maken van hun uittreedrecht. ${ }^{163}$ Onduidelijk is echter hoeveel deskundigen moeten worden benoemd en door wie die deskundigen worden benoemd. ${ }^{164}$ Voor de hand ligt dat de het bestuur van de vennootschap de deskundigen benoemt, omdat het deskundigenbericht moet worden verkregen voordat over de omzetting wordt besloten (art. 2:181 lid 4 BW). Het bestuur zal aan de hand van de omstandigheden van het geval ook moeten bepalen hoeveel deskundigen zij benoemt. Om onduidelijkheid hierover te voorkomen kan ook in de statuten ten aanzien van de wijze van benoeming en het aantal deskundigen worden voorzien. ${ }^{165}$ Indien de stemrechtloze aandeelhouder het niet met de hoogte van de door de deskundigen vastgestelde schadeloosstelling eens is, acht ik het mogelijk dat de rechter (nieuwe) deskundigen benoemt die een bindende schadeloosstelling vaststellen. ${ }^{166}$

De parlementaire geschiedenis geeft een aanwijzing over de hoogte van de schadeloosstelling. De schadeloosstelling zal worden bepaald aan de hand van de nominale waarde van de aandelen en zal daarnaast doorgaans nog een element van schadeloosstelling bevatten voor het verlies van dividendinkomsten of andere financiële aanspraken. De schadeloosstelling zal op het moment van het verlijden van de akte van omzetting op de derdenrekening van de notaris moeten staan ten behoeve van de houders van de stemrechtloze aandelen. ${ }^{167}$ Nagtegaal \& SnijderKuipers ${ }^{168}$ stellen dat de wet een andere vorm van schadeloosstelling niet uitsluit. Partijen zouden bijvoorbeeld overeen kunnen komen dat de stemrechtloze aandeelhouder schadeloos wordt gesteld door toekenning van een winstbewijs. Ik acht deze mogelijkheid niet zonder meer mogelijk, omdat de parlementaire geschiedenis stelt

162 De parlementaire geschiedenis gaat in op een statutenwijziging waarbij een voor stemrechtloze aandeelhouders nadelige regeling wordt ingevoerd, die bepaalt dat deze aandeelhouders een slechte prijs voor hun aandelen krijgen ingeval van fusie, splitsing of omzetting. Stemmen zij niet door middel van een goedkeurend groepsbesluit in de zin van art. 2:231 lid 4 BW met deze statutenwijziging in, dan zijn zij aan de nadelige regeling niet gebonden (Kamerstukken II 2011/12, 32 426, nr. 24, p. 14).

163 Voor dit alles: Kamerstukken II 2011/12, 32 426, nr. 25, p. 7-8. Blijkens p. 8 van dit amendement is ten onrechte niet aan de voorgestelde wettekst van dit amendement toegevoegd: "De benoeming kan ook achterwege blijven indien de aandeelhouders hebben verklaard geen gebruik te maken van hun uittreedrecht."

164 Deze problematiek speelt niet alleen bij art. 2:218 lid 4 BW, maar ook bij art. 2:330a, 2:333h en 2:334ee1 BW

$165 \mathrm{Vgl}$ art. 2:195 lid 4 BW.

166 Vgl. Kamerstukken II 2010/11, 32 426, nr. 7, p. 6 (NV II).

167 Kamerstukken II 2010/11, 32 426, nr. 7, p. 4 (NV II). Een en ander geldt ook voor winstrechtloze aandelen.

168 Nagtegaal \& Snijder-Kuipers 2012, p. 245 
dat de schadeloosstelling op het moment van het verlijden van de akte van omzetting op de derdenrekening van de notaris zal moeten staan ten behoeve van de houders van de stemrechtloze aandelen. Kennelijk heeft de wetgever alleen aan een schadeloosstelling in geld gedacht. Dat neemt mijns inziens niet weg dat partijen in de fase waarin zij in onderhandeling zijn over de positie van de stemrechtloze aandeelhouder na omzetting andere opties ten dienste staan. In het kader van de omzetting van een BV in een NV noemde ik reeds de mogelijkheid van conversie van aandelen. Bij die mogelijkheid, maar ook bij de mogelijkheid van het winst- of participatiebewijs, blijft echter de lidmaatschapsverhouding bestaan. De stemrechtloze aandeelhouder heeft dan geen aanspraak op schadeloosstelling. Slechts indien de stemrechtloze aandeelhouder niet instemt met het besluit tot omzetting en de lidmaatschapsverhouding vervalt, komt hem de aanspraak op schadeloosstelling toe en bestaat die schadeloosstelling mijns inziens daarom slechts in geld.

Art. 2:181 lid 5 BW sluit toepassing van art. 2:231 lid 4 BW uit. Het gaat om de uitsluiting van het goedkeurende groepsbesluit van houders van stemrechtloze aandelen voor de statutenwijziging, die in het kader van de omzetting is vereist. Art. 2:18 lid $2 \mathrm{BW}$ stelt immers dat voor de omzetting van een rechtspersoon in een andere rechtspersoon onder meer vereist is een besluit tot omzetting en een besluit tot wijziging van de statuten. Daarmee 'wordt voorkomen dat de houders van stemrechtloze aandelen dubbele bescherming genieten. Met hen wordt onderhandeld over hun positie na de omzetting dan wel over schadeloosstelling en hun hoeft niet in een vergadering van houders van stemrechtloze aandelen goedkeuring gevraagd te worden voor de omzetting', aldus de wetgever. ${ }^{169}$ Deze uitsluiting is opgenomen, omdat het niet voor de hand ligt stemrechtloze aandeelhouders stemrecht te geven bij ingrijpende besluiten, zoals de omzetting van een BV in een andere rechtsvorm. Indien art. 2:231 lid 4 BW bij omzetting onverkort van toepassing zou zijn, heeft dat tot gevolg dat de stemrechtloze aandeelhouder onevenredig veel zeggenschap zou krijgen. Dat past niet bij de aard van zijn aandeelhouderschap. Het zou ook de verhoudingen tussen de aandeelhouders ingrijpend wijzigen. Bovendien zou het tot ongewenst gevolg hebben, gelijk het ontwerpartikel 2:228 lid $5 \mathrm{BW}$, dat bij de omzetting van een $\mathrm{BV}$ in een andere rechtsvorm altijd een besluit tot statutenwijziging zal plaatsvinden dat specifiek afbreuk doet aan enig recht van de houder van stemrechtloze aandelen, vooral als het niet de bedoeling is dat de houders van stemrechtloze aandelen in de nieuwe rechtspersoon wel stemrecht zouden krijgen, aldus de wetgever ten tijde van de behandeling van het wetsvoorstel in de Tweede Kamer. ${ }^{170}$

Ook in de Eerste Kamer is over deze bepaling gedebatteerd. ${ }^{171}$ Meer in het bijzonder is de vraag aan de orde gekomen waarom art. 2:195 lid 3, 2:216 lid 8,

169 Kamerstukken II 2010/11, 32 426, nr. 8, p. 14 (Nota van wijziging).

170 Kamerstukken II 2010/11, 32 426, nr. 7, p. 17 (NV II).

171 Zie Kamerstukken I 2011/12, 31058 en 32 426, nr. C, p. 17-18 (MvA I). 
2:226 lid 2, 2:228 leden 4 en 5, 2:242 lid 1, 2:252 lid 1 en 2:253 BW niet en art. 2:231 lid $4 \mathrm{BW}$ wél in geval van omzetting zijn uitgesloten. ${ }^{172}$ De minister antwoordde als volgt: "[Deze] (...) artikelen bieden aandeelhouders bescherming tegen wijziging van specifieke statutaire bepalingen die hun bijzondere rechten toekennen (Kamerstukken I 2011/12, 31 058, C, p. 18). Het is niet nodig of gewenst om deze bescherming te onthouden in het geval van een omzetting van een bv. De genoemde bepalingen bieden bescherming aan de desbetreffende (individuele of groep van) aandeelhouders doordat zij hun instemming kunnen onthouden aan onderdelen van de statutenwijziging zonder tegen de omzetting te stemmen. ${ }^{173}$ Dit sluit aan bij artikel 2:18 BW, dat stelt dat voor een omzetting naast een besluit tot omzetting ook een besluit tot statutenwijziging is vereist. Indien de eerder genoemde artikelen van toepassing blijven, dan kunnen wijzigingen in de statuten over de desbetreffende rechten en bevoegdheden slechts met instemming van de betrokken aandeelhouders doorgang vinden. Dat is niet anders dan bij statutenwijzigingen buiten omzetting. De uitsluiting van de bescherming van artikel 231 lid 4 is wel nodig, want deze voorkomt dubbele bescherming in twee situaties. Ten eerste de situatie die in het antwoord op de vorige vraag is beschreven, namelijk de dubbele bescherming van houders van stem- of winstrechtloze aandelen. Ten tweede wordt dubbele bescherming van minderheidsaandeelhouders voorkomen, die anders tweemaal zouden kunnen stemmen tegen de omzetting als geheel, namelijk zowel in de algemene vergadering als in een vergadering van hun groep van houders van aandelen van een bepaalde soort of aanduiding." ${ }^{174}$ Kort gezegd, komt het antwoord van de minister erop neer dat uitsluiting van art. 2:231 lid 4 BW dubbele bescherming van de stemrechtloze aandeelhouder bij een omzetting voorkomt. Een voorbeeld verduidelijkt dit. Op grond van art. 2:242 lid $1 \mathrm{BW}$ kan aan de vergadering van stemrechtloze aandeelhouders de bevoegdheid worden toegekend een bestuurder te benoemen. Ik verwijs naar paragraaf 6.2.3.3. Op een dergelijke statutaire regeling is art. 2:228 lid 4 derde volzin BW van toepassing. Indien een besluit tot wijziging van de statuten wordt genomen, inhoudende dat een bepaald orgaan anders dan de algemene vergadering een bestuurder kan benoemen, kan dat besluit slechts met algemene stemmen (unanimiteit) in een vergadering waarin het gehele geplaatste kapitaal vertegenwoordigd is worden genomen. Dat geldt ook

172 Zie Kamerstukken I 2011/12, 31 058, nr. D. p. 11-12.

Bij fusie en splitsing wordt ook de toepasselijkheid van art. 2:231 lid 4 BW uitgesloten. Zie respectievelijk art. 2:330 lid 2 en 2:334ee lid 2 BW. Diezelfde artikelleden vereisen echter naast het besluit tot fusie of splitsing van de algemene vergadering een voorafgaand of gelijktijdig goedkeurend besluit van elke groep houders van aandelen van een zelfde soort of aanduiding aan wier rechten de fusie of splitsing afbreuk doet. Met Nagtegaal \& Snijder-Kuiper 2012, p. 243 voetnoot 11, ben ik van mening dat art. 2:330 lid 2 en 2:334ee lid 2 BW beter zijn geformuleerd dan art. 2:231 lid 4 BW.

173 Erg duidelijk is deze zin niet. Immers, indien tegen de statutenwijziging wordt gestemd, wordt in feite ook tegen de omzetting - waartoe een statutenwijziging noodzakelijk is - gestemd. In gelijke zin: Nagtegaal \& Snijder-Kuipers 2012, p. 243.

174 Kamerstukken I 2011/12, 31 058, nr. E, p. 17-18 (Nadere MvA I). 
voor het ontnemen van die bevoegdheid. De achtergrond daarvan is dat een dergelijk besluit ingrijpende gevolgen heeft voor de zeggenschap van aandeelhouders, waartegen de unanimiteitsregel aldus bescherming biedt. ${ }^{175}$

Bij omzetting van een BV in een NV, waarbij aan de stemrechtloze aandeelhouders het benoemingsrecht van een bestuurder is toegekend, is het probleem afgezien dat de NV geen stemrechtloze aandelen kent - dat de NV een dergelijk benoemingsrecht niet kent. Dat zou een specifieke afbreuk van de rechten van stemrechtloze aandeelhouders inhouden, waartegen art. 2:231 lid 4 BW bescherming biedt. Art. 2:181 lid 5 BW sluit die bescherming echter uit, zodat de statuten in het kader van de omzetting kunnen worden gewijzigd. De stemrechtloze aandeelhouder ontleent reeds bescherming aan het bepaalde in art. 2:181 lid 3 BW. Hij kan met het besluit tot omzetting al dan niet instemmen. Doet hij dat niet, dan kan hij bij de vennootschap een verzoek tot schadeloosstelling indienen. Indien in art. 2:181 lid 5 BW de bescherming van art. 2:231 lid 4 BW niet uitgesloten zou zijn, zou dat tot gevolg hebben dat bij gebreke van een goedkeurend groepsbesluit van de stemrechtloze aandeelhouders ter zake van de statutenwijziging waarbij het benoemingsrecht van een bestuurder wordt ontnomen, de omzetting geen doorgang kan vinden. Art. 2:18 lid $2 \mathrm{BW}$ vereist immers naast een besluit tot omzetting ook een besluit tot statutenwijziging.

Art. 2:181 lid $6 \mathrm{BW}$ brengt tot uitdrukking dat voor de omzetting van een BV in een stichting of een vereniging de daarvoor noodzakelijke rechterlijke machtiging wordt geweigerd indien de belangen van de stemrechtloze aandeelhouder onvoldoende worden ontzien. De wetgever spreekt over een vangnet, namelijk in het geval de BV wel een rechterlijke machtiging verzoekt, maar geen regeling is getroffen voor de stemrechtloze aandeelhouder. In de parlementaire geschiedenis wordt daarbij verwezen naar de regeling van de schadeloosstelling. ${ }^{176}$

Naast het uittreedrecht en de schadeloosstelling wijst de wetgever erop dat voor eventuele gebreken in de procedure of andere nadelige gevolgen van een omzetting (maar ook ingeval van een fusie of splitsing) die niet met schadeloosstelling kunnen worden opgelost, een beroep kan worden gedaan op de geschillenregeling, het enquêterecht en de mogelijkheid om besluiten door de rechter te laten vernietigen. ${ }^{177}$

175 Kamerstukken II 2006/07, 31 058, nr. 3, p. 91 (MvT) en Kamerstukken I 2011/12, 31058 en 32 426, nr. C, p. 25 (MvA I).

176 Kamerstukken II 2010/11, 32 426, nr. 7, p. 19 (NV II) en Kamerstukken II 2010/11, 32 426, nr. 8, p. 13-14 (Nota van wijziging). Het ontwerpartikel is nadien gewijzigd, als gevolg waarvan rechterlijke tussenkomst ter zake van de benoeming van de deskundigen en het bepalen van de hoogte van de schadeloosstelling niet meer vereist is. Zie Kamerstukken II 2010/11, 32 426, nr. 25, p. 8. Dat neemt niet weg dat de rechter bij het verstrekken van de rechterlijke machtiging het belang van de stemrechtloze aandeelhouder moet betrekken en daarbij acht zal slaan of een schadeloosstelling is vastgesteld (of aangeboden), en zo ja, wat daarvan de hoogte is.

177 Kamerstukken II 2009/10, 32 426, nr. 3, p. 5 (MvT). 
Commentaar en aanbevelingen

In theorie lijkt de regeling van art. 2:181 BW goed van opzet. Partijen moeten tot overeenstemming komen over de positie van de stemrechtloze aandeelhouder in de rechtspersoon na omzetting. Komt men er niet uit, dan kan de stemrechtloze aandeelhouder schadeloosstelling verzoeken. Ook de overwegingen die de wetgever aan deze regeling ten grondslag legt, komen plausibel voor. Niettemin vraag ik me af of deze regeling in de praktijk werkbaar is. Beter gezegd, te verwachten is dat de regeling tot problemen kan leiden. Dat heeft er vooral mee te maken dat het stemrechtloze aandeel in de BV wegens het ontbreken van deze rechtsfiguur in de rechtspersoon na omzetting niet terugkomt. Ingeval van een omzetting van een BV in een NV kan wellicht tot een aandeel met enigszins gelijke rechten gekomen worden. Bij omzetting van een $\mathrm{BV}$ in een andere rechtspersoon lijkt mij dat bijzonder lastig.

Lastig is ook de vaststelling van de schadeloosstelling door de deskundigen. De wetgever geeft weliswaar een aanwijzing, namelijk dat de schadeloosstelling bepaald zal worden aan de hand van de nominale waarde van de aandelen en dat de schadeloosstelling daarnaast doorgaans nog een element van schadeloosstelling zal bevatten voor het verlies van dividendinkomsten of andere financiële aanspraken. Met de nominale waarde zal de deskundige nog wel uit de voeten kunnen, maar met het element voor verlies van dividendinkomsten wordt dat al moeilijker. De wetgever laat zich niet uit over de lengte van de (toekomstige) periode, nog daargelaten dat dividendinkomsten bijzonder lastig te bepalen zijn. Niet alleen zijn die inkomsten afhankelijk van de resultaten van de vennootschap, maar ook van het dividendbeleid van de vennootschap. Wordt de winst al dan niet gedeeltelijk gereserveerd, bijvoorbeeld wegens marktomstandigheden of noodzakelijke investeringen? Daarnaast speelt ook de uitkeringstest van art. 2:216 lid 3 BW een rol. Het bestuur moet het besluit tot uitkering goedkeuren.

Niet alleen speelt art. 2:216 BW een rol bij het vaststellen van de hoogte van de schadeloosstelling, maar ook bij het betalen van de schadeloosstelling zelf. Feitelijk is immers sprake van een uitkering waardoor het eigen vermogen wordt verminderd. Bij intrekking ex art. 2:208 BW wordt immers art. 2:216 lid 2 tot en met $4 \mathrm{BW}$ van overeenkomstige toepassing verklaard (art. 2:208 lid $6 \mathrm{BW}$ ). In art. 2:181 BW is echter art. 2:216 BW niet van overeenkomstige toepassing verklaard. ${ }^{178}$ Onduidelijk is of de stemrechtloze aandeelhouder in voorkomend geval gehouden is tot terugbetaling van de schadeloosstelling. Daartegen pleit dat de stemrechtloze aandelen zijn vervallen, maar dat is ingeval van intrekking ook het geval.

178 Ook in het advies d.d. 23 september 2010 van de Gecombineerde Commissie Vennootschapsrecht van de Nederlandse Orde van Advocaten en de Koninklijke Notariële Beroepsorganisatie inzake wetsvoorstel 32 426, aanpassing van de wetgeving aan en invoering van de Wet vereenvoudiging en flexibilisering bv-recht (Invoeringswet vereenvoudiging en flexibilisering bv-recht), p. 4, wordt dit probleem gesignaleerd. 
Ook in een andere situatie heeft de wetgever niet voorzien. De Gecombineerde Commissie Vennootschapsrecht heeft onder meer de vraag gesteld of de houders van stemrechtloze aandelen waarmee reeds overeenstemming over de hoogte van de schadeloosstelling was bereikt, in het geval dat voor andere houders van stemrechtloze aandelen van dezelfde soort of aanduiding de bepaling van die schadeloosstelling door de deskundige tot een hoger bedrag per aandeel leidt, ook op dat hogere bedrag aanspraak kunnen maken. De Gecombineerde Commissie Vennootschapsrecht meent mijns inziens terecht dat het antwoord daar op ' ja' is, tenzij een aandeelhouder uitdrukkelijk afziet van het recht dezelfde vergoeding te ontvangen als betaald wordt aan andere houders van aandelen van dezelfde soort. ${ }^{179}$ Ter voorkoming van problemen verdient het mijns inziens aanbeveling daarover in de minnelijke regeling een bepaling op te nemen.

Een opmerking over art. 2:181 lid 4 BW. Daarin wordt onder meer bepaald dat de benoeming van deskundigen achterwege kan blijven, indien de statuten of een overeenkomst waarbij de vennootschap en de desbetreffende aandeelhouders partij zijn, een duidelijke maatstaf bevatten aan de hand waarvan de schadeloosstelling zonder meer kan worden vastgesteld. In art. 2:192 lid 3 en 2:195 lid 4 BW is ten aanzien van prijsbepalingsregelingen, anders dan in art. 2:181 lid $4 \mathrm{BW}$, bepaald dat een dergelijke regeling niet tegen de wil van een aandeelhouder kan worden opgelegd. In de literatuur ${ }^{180}$ wordt mijns inziens terecht opgemerkt dat de prijsbepalingsregeling in de zin van art. 2:181 lid 4 BW specifiek op omzetting dient te zien, wil die regeling ingeval van omzetting toepassing kunnen vinden. Daarnaast zou naar analogie van art. 2:192 lid 3 en 2:195 lid 4 BW de statutaire prijsbepalingsregeling bij omzetting eerst van toepassing zijn nadat de aandeelhouder met die regeling heeft ingestemd. ${ }^{181}$

Een andere opmerking over art. 2:181 lid 4 BW. Dat artikellid bepaalt onder meer: "Indien tussen partijen op grond van de statuten of een overeenkomst waarbij de vennootschap en de desbetreffende aandeelhouders partij zijn, bepalingen over de vaststelling van de waarde van de aandelen of de vaststelling van de schadeloosstelling gelden, stellen de deskundigen hun bericht op met inachtneming daarvan (onderstreping RAW)." Niet duidelijk is waar de woorden 'de vaststelling van de waarde' naast 'de vaststelling van de schadeloosstelling' vandaan komen. Ik heb in de parlementaire geschiedenis daarvoor geen aanwijzing kunnen vinden, anders dan dat over de mogelijkheid van een statutaire regeling ter bepaling van de schadeloosstelling wordt opgemerkt, hetgeen ook op omzetting van toepassing is: "Wanneer de vennootschap bij de invoering van stem-of winstrechtloze aandelen wil voorkomen dat er in geval van een fusie of splitsing veel tijd en moeite gestoken

179 Advies d.d. 23 september 2010 van de Gecombineerde Commissie Vennootschapsrecht van de Nederlandse Orde van Advocaten en de Koninklijke Notariële Beroepsorganisatie inzake wetsvoorstel 32 426, aanpassing van de wetgeving aan en invoering van de Wet vereenvoudiging en flexibilisering bv-recht (Invoeringswet vereenvoudiging en flexibilisering bv-recht), p. 3. 180 Nagtegaal \& Snijder-Kuipers 2012, p. 245. Vgl. Van Eck 2013, p. 19 ingeval van fusie. 181 Vgl. Snijder-Kuipers 2012, p. 10. 
moet worden in het tot een vergelijk komen met de houders van deze aandelen over hun positie na de fusie of splitsing en met name over de hoogte van de schadeloosstelling, kan zij in de statuten een regeling opnemen om die schadeloosstelling te bepalen. Mocht in geval van een fusie of splitsing geen overeenstemming bereikt worden met deze aandeelhouders over hun positie na die fusie of splitsing, dan hoeft de procedure tot de vaststelling door de rechter van de hoogte van de schadeloosstelling slechts geringe tijd te vergen, omdat er dan een statutaire regeling bestaat waar de rechter (en indien nodig, de deskundigen) zich op kan (kunnen) baseren. De houder van stem- of winstrechtloze aandelen is bekend met die statuten of de overeenkomst, zodat hij weet hoe die schadeloosstelling te zijner tijd wordt vastgesteld." 182

De minster spreekt alleen over de vaststelling van de schadeloosstelling en niet over de vaststelling van de waarde van de aandelen. Het komt mij voor dat deze laatste woorden uit art. 2:181 lid 4 BW geschrapt moeten worden. Het gaat immers om een schadeloosstelling, omdat de stemrechtloze aandeelhouder ingeval van omzetting (maar ook bij fusie en splitsing) niet in een gelijke positie in de omgezette rechtspersoon kan terugkomen. Het is in dat geval zuiverder te spreken over de vaststelling van de schadeloosstelling dan over de vaststelling van de waarde van de aandelen. Een schadeloosstelling zou bovendien meer kunnen omvatten dan enkel de vaststelling van de waarde van de aandelen.

Zijn er alternatieven? Wat betreft de omzetting van een BV in een NV zou als eenvoudige oplossing gekozen kunnen worden voor de regel dat stemrechtloze aandelen in een $\mathrm{BV}$ tot aandelen met stemrecht in een $\mathrm{NV}$ verworden, ${ }^{183}$ waarbij de hoofdregel van art. 2:118 BW wordt gevolgd. Met deze route wordt het uittreedrecht omzeild. Wil men dat voorkomen (om de overeengekomen zeggenschaps- en financiële verhoudingen niet te wijzigen), dan is omzetting geen optie of moet men tegenstemmen. ${ }^{184}$ Wellicht dat tot een meer eenvoudige oplossing gekomen kan worden, indien de wetgever ook stemrechtloze aandelen in het NV-recht introduceert.

Met die introductie kan ook worden voorkomen dat als gevolg van het vervallen van de stemrechtloze aandelen bij de omzetting van een BV in een NV de voor de NV verplichte kapitaalgrens van $€ 45.000$ mogelijk niet wordt gehaald. Er zal dus bij deze omzetting en indien daarbij stemrechtloze aandelen vervallen rekening gehouden moeten worden dat ten tijde van de omzetting het geplaatste kapitaal ten minste $€ 45.000$ bedraagt. Met Timmermans ben ik van mening dat indien daaraan

182 Kamerstukken II 2010/11, 32 426, nr. 7, p. 6 (NV II). De geciteerde toelichting is gebaseerd op een eerder ontwerp van art. 2:181 lid 4 BW.

183 In het advies d.d. 23 september 2010 van de Gecombineerde Commissie Vennootschapsrecht van de Nederlandse Orde van Advocaten en de Koninklijke Notariële Beroepsorganisatie inzake wetsvoorstel 32 426, aanpassing van de wetgeving aan en invoering van de Wet vereenvoudiging en flexibilisering bv-recht (Invoeringswet vereenvoudiging en flexibilisering bv-recht), p. 4, wordt in dit kader over conversie gesproken.

184 In gelijke zin: Dortmond 2011 (2), p. 239 en Nagtegaal \& Snijder-Kuipers 2012, p. 244. 
niet voldaan wordt omzetting niet mogelijk is. De wettekst brengt dat echter niet tot uitdrukking. ${ }^{185}$

Art. 2:181 lid $3 \mathrm{BW}$ stelt dat de aandelen waarop het verzoek tot schadeloosstelling betrekking heeft op het moment waarop de omzetting van kracht wordt vervallen. Wat onder 'vervallen' verstaan wordt, volgt niet uit de parlementaire geschiedenis. Voor de hand ligt dat bij het van kracht worden van de omzetting door de BV een besluit tot intrekking van de stemrechtloze aandelen wordt genomen. ${ }^{186}$

\subsubsection{4 'Omzetting' (inbreng) van de BV in een personenvennootschap en andersom}

In deze paragraaf staan de gevolgen voor de stemrechtloze aandeelhouder bij omzetting van een BV in een personenvennootschap en andersom centraal. Onder personenvennootschappen worden verstaan de eenmanszaak, de vennootschap onder firma, de commanditaire vennootschap en de maatschap.

Indien een $\mathrm{BV}$ in een vennootschap onder firma omgezet wordt, is in juridische zin sprake van ontbinding van de BV in de zin van art. 2:19 BW. Een van de door art. 2:19 BW genoemde gevallen waarin de rechtspersoon, althans in dit geval de $\mathrm{BV}$, wordt ontbonden is een daartoe strekkend besluit van de algemene vergadering. Als gevolg van het besluit tot ontbinding moet worden vereffend. Gedurende de vereffening blijft de BV bestaan. De stemrechtloze aandeelhouder heeft ex art. 2:23b BW recht op het liquidatiesaldo, tenzij de statuten dat uitsluiten. Uit paragraaf 6.2.3.1 bleek reeds dat de stemrechtloze aandeelhouder met betrekking tot dit besluit in de algemene vergadering geen stemrecht heeft. In voorkomend geval kan de stemrechtloze aandeelhouder op grond van art. 2:8 jo. 2:15 lid 1 sub b BW vernietiging van het besluit tot ontbinding vorderen.

In de omgekeerde situatie, namelijk de omzetting van een vennootschap onder firma in een BV, is in juridische zin sprake van ontbinding van de vennootschap onder firma. Er wordt een besluit tot ontbinding van de vennootschap onder firma genomen, welke vennootschap wordt voorgezet als BV i.o. Vervolgens verplichten de vennoten zich tot oprichting van een BV. In deze voorovereenkomst worden tal van onderwerpen geregeld, zoals de inbreng, naam, plaats en doel van de vennootschap. Bij akte van oprichting wordt vervolgens de BV opgericht. Het is aan de vennoten van de vennootschap onder firma en de hen gegeven (contracts-)vrijheid bij of na oprichting van de BV te kiezen voor stemrechtloze aandelen in het kapitaal van die BV. Op gelijke wijze geldt een en ander ook voor de eenmanszaak, maatschap of commanditaire vennootschap.

185 Timmermans 2011, p. 54. Zie in het kader van de kapitaalbeschermingsregels bij de NV ook art. 2:72 lid 2 sub a BW.

186 In gelijke zin Timmermans 2011, p. 54. 
6.2.3.15 Fusie: de stemrechtloze aandeelhouder in de verdwijnende vennootschap

\section{Inleiding}

Een fusie is de rechtshandeling van twee of meer rechtspersonen waarbij een van deze het vermogen van de andere onder algemene titel verkrijgt of waarbij een nieuwe rechtspersoon die bij deze rechtshandeling door hen samen wordt opgericht, hun vermogen onder algemene titel verkrijgt (art. 2:309 BW). Op grond van art. 2:311 lid $2 \mathrm{BW}$ worden de aandeelhouders van de verdwijnende vennootschap aandeelhouder in de verkrijgende rechtspersoon. Art. 2:317 BW geeft een algemene regeling voor besluiten tot fusie, welk besluit in geval van een vennootschap wordt genomen door de algemene vergadering. Voor fusies van naamloze en besloten vennootschappen zijn onder meer art. 2:326, 2:330 en 2:330a BW van belang. Ook is te denken aan de driehoeksfusie van art. 2:333a BW en de grensoverschrijdende fusie van art. 2:333h BW.

In deze paragraaf besteed ik met name aandacht aan de fusie tussen een verdwijnende BV en een verkrijgende NV. De NV kent geen stemrechtloze aandelen. De vraag is wat in een dergelijke fusie de positie van de stemrechtloze aandeelhouder is. De wetgever verwoordt het kernachtig aldus: “(...) dat er in alle gevallen van fusie waarbij houders van stem- of winstrechtloze aandelen betrokken zijn, met deze houders onderhandeld moet worden over hun positie als aandeelhouder na de fusie. De uitkomst van deze onderhandelingen kan zijn dat er na de fusie een bv bestaat, waarin ze dezelfde positie als houder van stem- of winstrechtloze aandelen houden of dat hun aandelen worden geconverteerd naar aandelen met stem- of winstrecht. Het kan ook zijn dat beide partijen niet met elkaar verder willen of dat een van beide partijen niet met de ander verder wil, dan dient onderhandeld te worden over schadeloosstelling." 187

Op grond van art. 2:317 lid 4 BW kunnen de statuten een van lid 3 van dat artikel afwijkende regeling voor besluiten tot fusie geven. In voorkomend geval kan op die wijze de positie van de stemrechtloze aandeelhouder worden versterkt, bijvoorbeeld dat het besluit tot fusie de instemming van iedere stemrechtloze aandeelhouder of goedkeuring van de vergadering van stemrechtloze aandeelhouders vereist.

Fusie en schadeloosstelling

Art. 2:326 BW bepaalt dat het voorstel tot fusie, naast de in art. 2:312 BW genoemde gegevens onder meer vermeldt de gevolgen van de fusie voor de houders van stemrechtloze aandelen, de hoogte van de schadeloosstelling voor een aandeel bij toepassing van art. 2:330a BW en het totaal bedrag waarvoor ten hoogste met toepassing van art. 2:330a BW schadeloosstelling kan worden verzocht. ${ }^{188} \mathrm{Bij}$ de vermelding van de gevolgen voor de stemrechtloze aandeelhouders 'moet worden

187 Kamerstukken II 2010/11, 32 426, nr. 8, p. 15 (Nota van wijziging).

188 Volgens de parlementaire geschiedenis vormt art. 2:328 BW daarbij de grens. Zie Kamerstukken II 2011/12, 32 426, nr. 25, p. 8. 
vermeld of wordt voorgesteld deze aandelen te converteren in aandelen die de NV wel kent, waardoor de houders van de stemrechtloze aandelen ook aandeelhouders in de NV kunnen worden, of dat de aandeelhouders schadeloosstelling aangeboden zal worden voor het verlies van hun aandelen, waarbij het voorstel voor de omvang van dat bedrag in het fusievoorstel vermeld kan worden. Dit is ook van belang voor de aandeelhouders die over het fusie- of splitsingsvoorstel moeten besluiten. Zij zullen immers willen weten wat er gaat gebeuren met de houders van stemrechtloze aandelen: worden het gewone aandeelhouders, dan verwateren de rechten van de overige aandeelhouders', aldus de wetgever. ${ }^{189}$ Uit de parlementaire geschiedenis volgt voorts dat de achterliggende reden voor de vermelding van de gevolgen voor de stemrechtloze aandeelhouder in het fusievoorstel is, dat het bestuur van de vennootschap tijdig met deze aandeelhouder over de gevolgen van de fusie en de positie van die aandeelhouder na de fusie overleg gevoerd en onderhandeld heeft. De wetgever refereert daarbij aan de periode tussen de bekendmaking van de neerlegging van het fusievoorstel en het passeren van de notariële akte. Die periode is maximaal een half jaar (art. 2:318 en 2:334n BW). Die periode kan worden gebruikt voor onderhandelingen over de uiteindelijke schadeloosstelling als wordt geconcludeerd dat de stemrechtloze aandeelhouders de vennootschap zullen verlaten. Komen partijen daar onderling niet uit, dan stel(t)(len) de onafhankelijke deskundige(n) de schadeloosstelling vast. Door tijdig in overleg en onderhandeling te treden wordt voorkomen dat de schadeloosstellingsprocedure van art. 2:330a BW niet tot (te veel) vertraging leidt. De vennootschap heeft de vrijheid het onderhandelingsproces met de betrokken aandeelhouders op eigen wijze in te vullen, aldus de wetgever. ${ }^{190}$ De toelichting van de wetgever neemt naar mijn mening niet weg dat, omdat in het fusievoorstel de hoogte en het totaal bedrag van de schadeloosstelling moet worden opgenomen, de fusie vertraging kan oplopen. Ook meer dan de door de wetgever genoemde periode van een half jaar, zeker in het geval er alsnog deskundigen door de rechter moeten worden benoemd.

Wat precies over de gevolgen van de fusie in het fusievoorstel met betrekking tot de stemrechtloze aandeelhouder moet worden opgenomen, is mede afhankelijk van de stand van de onderhandelingen met deze aandeelhouder en of al duidelijk is of de vennootschap en de aandeelhouder het eens zijn over zijn positie na de fusie: is er voor hem als stemloze aandeelhouders plaats in een BV na de fusie? Wordt hij houder van aandelen met winst- en stemrecht in een verkrijgende $\mathrm{NV}$ of verlaat hij de BV met schadeloosstelling op grond van art. 2:330a BW? ${ }^{191}$

Art. 2:326 aanhef sub e BW brengt tot uitdrukking dat de hoogte van de schadeloosstelling in het fusievoorstel wordt vermeld. De vennootschap zal er dus voor moeten zorgen dat de hoogte van de schadeloosstelling voorafgaand aan de fusie is vastgesteld. De hoogte daarvan wordt zo nodig met inschakeling van

189 Kamerstukken II 2010/11, 32 426, nr. 7, p. 4 (NV II). Zie ook Van Eck 2013, p. 20.

190 Kamerstukken II 2010/11, 32 426, nr. 7, p. 4 (NV II).

191 Kamerstukken II 2010/11, 32 426, nr. 8, p. 15 (Nota van wijziging). 
deskundigen op grond van art. 2:330a lid 2 BW bepaald. ${ }^{192}$ Het eerder gesignaleerde probleem van vertraging wordt naar mijn mening niet ondervangen door op de voet van art. 2:330a lid 3 in afwijking van de daar genoemde hoofdregel in het fusievoorstel te bepalen dat de verkrijgende vennootschap de schadeloosstelling moet voldoen. Immers, het betalen van een schadeloosstelling is iets anders dan het vereiste van het in het fusievoorstel opnemen van de hoogte en het totaal bedrag van de schadeloosstelling. ${ }^{193}$ Daarnaast meen ik uit de wettekst van art. 2:330a lid 3 BW en de parlementaire geschiedenis ${ }^{194}$ daarbij te mogen afleiden dat het passeren van de fusieakte is gekoppeld aan de betaling van de schadeloosstelling.

Art. 2:330 lid $1 \mathrm{BW}$ stelt als hoofdregel dat voor het besluit tot fusie van de algemene vergadering in elk geval een meerderheid van ten minste twee derden is vereist, indien minder dan de helft van het geplaatste kapitaal ter vergadering is vertegenwoordigd. Op grond van art. 2:330 lid $2 \mathrm{BW}$ is een goedkeurend groepsbesluit vereist van de houders van stemrechtloze aandelen aan wier rechten in het kader van de fusie afbreuk wordt gedaan. De reden voor deze bescherming is dat de BV zelf ook een verkrijgende vennootschap kan zijn. Een fusie mag geen instrument zijn om een statutenwijziging te bewerkstelligen waardoor de beperkingen die de wet stelt ten aanzien van een besluit tot statutenwijziging in het kader van een fusie kunnen worden omzeild, aldus de wetgever. ${ }^{195}$ Daarnaast kunnen aan de vergadering van stemrechtloze aandeelhouders bijzondere bevoegdheden zijn toegekend, zoals de benoeming van een bestuurder of commissaris of een recht van instructie. ${ }^{196}$ In de literatuur worden gesteld dat bij afbreuk aan rechten kan worden gedacht aan een besluit tot fusie waarbij afbreuk wordt gedaan aan winst- of stemrechten. ${ }^{197}$ Naast het goedkeurende groepsbesluit op grond van art. 2:330 lid 2 BW is niet nog eenzelfde groepsbesluit door diezelfde aandeelhouders op grond van art. 2:231 lid 4 BW nodig. ${ }^{198}$ De wet noch de parlementaire geschiedenis laten zich uit over de vraag of voor het goedkeurende groepsbesluit bijzondere meerderheids- en

192 Kamerstukken II 2009/10, 32 426, nr. 3, p. 29 (MvT)

193 Anders: Timmermans 2011, p. 56.

194 Kamerstukken II 2011/12, 32 426, nr. 25, p. 9.

195 Kamerstukken II 2011/12, 32 426, nr. 26, p. 2

196 Kamerstukken II 2009/2010, 32 426, nr. 3, p. 30 (MvT).

197 Van Eck 2013, p. 22 en 23, met diverse voorbeelden waarin die afbreuk, onder verwijzing naar Roelofs 2012 (3), p. 13-14, aan winst- en stemrechten wordt uitgewerkt.

198 Kamerstukken II 2011/12, 32 426, nr. 26, p. 2-3. In een eerder ontwerp van art. 2:330a BW werd in lid 3 het goedkeurende groepsbesluit van de stemrechtloze aandeelhouders bij een besluit tot fusie buiten toepassing verklaard, zie Kamerstukken II 2009/10, 32 426, nr. 2, p. 9. De wetgever motiveerde dat als volgt: "Nu stemrechtloze of winstrechtloze aandeelhouders bescherming kunnen ontlenen aan de regeling voor schadeloosstelling, is er bij een fusie met een verkrijgende nv en een verdwijnende $b v$ met stemrechtloze of winstrechtloze aandelen geen reden voor aanvullende bescherming in de besluitvormingsregels. Daarom wordt artikel 330 lid 2, waarin is bepaald dat het fusiebesluit is onderworpen aan de goedkeuring van de houders van aandelen van een zelfde soort of aanduiding aan wier rechten de fusie afbreuk doet, buiten toepassing verklaard in $\rightarrow$ 
quorumeisen gelden. Daarom moet naar mijn mening worden aangenomen dat geen bijzondere eisen ten aanzien van de besluitvorming gelden. ${ }^{199}$

Door Roelofs en Van $\mathrm{Eck}^{200}$ wordt terecht opgemerkt dat art. 2:330 lid 2 BW geen rekening houdt met de mogelijkheid dat op grond van art. 2:331 lid $1 \mathrm{BW}$ een verkrijgende vennootschap bij bestuursbesluit tot fusie kan besluiten, tenzij de statuten anders bepalen. Zij menen, evenzeer terecht, dat het bestuur bevoegd blijft tot fusie te besluiten ingeval de fusie afbreuk zou doen aan enig recht van houders van aandelen van een bepaalde soort. Wel blijft een besluit in de zin van art. 2:330 lid 2 BW vereist.

Art. 2:330 lid 3 BW bepaalt dat de notulen van de algemene vergaderingen waarin tot fusie wordt besloten of waarin deze ingevolge lid 2 wordt goedgekeurd, worden opgemaakt bij notariële akte. Vanuit praktisch oogpunt verdient het aanbeveling de vergaderingen waarin deze besluiten worden genomen zoveel als mogelijk te combineren.

In afwijking van de genoemde hoofdregel van art. 2:311 BW kan de stemrechtloze aandeelhouder van de verdwijnende BV, indien hij geen aandeelhouder in de verkrijgende NV wordt, op grond van art. 2:330a BW een verzoek tot schadeloosstelling indienen. ${ }^{201}$ Wanneer de verkrijgende vennootschap, of bij toepassing van art. 2:333a BW de groepsmaatschappij die de aandelen toekent, geen besloten vennootschap is, kunnen houders van winstrechtloze aandelen die tegen het voorstel tot fusie hebben gestemd en houders van stemrechtloze aandelen bij de vennootschap een verzoek tot schadeloosstelling indienen. Het verzoek tot schadeloosstelling moet schriftelijk aan de vennootschap worden gedaan binnen één maand nadat zij aan de aandeelhouder heeft meegedeeld dat hij deze schadeloosstelling kan vragen. De mededeling geschiedt op dezelfde wijze als de oproeping tot een algemene vergadering. Het bedrag van de schadeloosstelling wordt vastgesteld door een of meer onafhankelijke deskundigen. De deskundigen brengen over de waardebepaling schriftelijk bericht uit, waarop art. 2:314 lid 2 BW van toepassing is. Indien tussen partijen op grond van de statuten of een overeenkomst waarbij de vennootschap en de desbetreffende aandeelhouders partij zijn, bepalingen over de vaststelling van de waarde van de aandelen of de vaststelling van de schadeloosstelling gelden, stellen de deskundigen hun bericht op met inachtneming daarvan. De benoeming van deskundigen kan achterwege blijven, indien de statuten of een overeenkomst waarbij de vennootschap en de desbetreffende aandeelhouders partij

artikel 330a lid 3." Zie Kamerstukken II 2009/10, 32 426, nr. 3, p. 30 (MvT). Datzelfde gold voor een besluit tot splitsing (Zie voor het eerdere ontwerp van art. 2:334ee1 lid 3 BW: Kamerstukken II 2009/10, 32 426, nr. 2, p. 10 en de toelichting daarop Kamerstukken II 2009/10, 32 426, nr. 3, p. 31 (MvT)). Zie ook Kamerstukken II 2010/11, 32 426, nr. 7, p. 17 (NV II).

199 In gelijke zin: H.E. Boschma \& J.N. Schutte-Veenstra, Tekst \& Commentaar Ondernemingsrecht en Effectenrecht, art. 2:330 BW, aant. 3, Deventer: Kluwer.

200 Roelofs 2012 (3), p. 14 en Van Eck 2013, p. 23. Zie ook art. 2:331 lid 4 BW. Dit geldt ook bij splitsing, zie art. 2:334ff lid 1 en 4 BW.

201 Kamerstukken II 2009/10, 32 426, nr. 3, p. 29 (MvT). 
zijn, een duidelijke maatstaf bevatten aan de hand waarvan de schadeloosstelling zonder meer kan worden vastgesteld. De notaris passeert de akte van fusie niet voordat de schadeloosstelling is betaald, tenzij de fuserende vennootschappen hebben besloten dat de verkrijgende vennootschap de schadeloosstelling moet voldoen. De aandelen waarop het verzoek betrekking heeft, vervallen op het moment waarop de fusie van kracht wordt, aldus art. 2:330a BW.

Art. 2:330a BW is in de wet opgenomen, omdat bij bepaalde vormen van fusie het toekennen van een aan gewone aandeelhouders gelijkwaardige positie aan houders van stemrechtloze aandelen van een verdwijnende BV niet goed mogelijk is. Dit probleem zal in eerste instantie door middel van onderhandeling, zoals hiervoor aangegeven, moeten worden opgelost. Onderdelen van die onderhandelingen zijn onder meer de waardering van aandelen en de aan de aandelen verbonden rechten. De wetgever acht het noodzakelijk die onderhandelingen te faciliteren door de uitweg van schadeloosstelling te bieden voor het geval er geen ruilverhouding tot stand kan komen. ${ }^{202}$ De stemrechtloze aandeelhouder is onvrijwillig in een positie terecht gekomen waar hij zelf geen invloed op heeft gehad. De vennootschap en de stemrechtloze aandeelhouder zullen eerst proberen tot een minnelijke regeling te komen voor het uittreden van die aandeelhouder. Het staat partijen vrij om in deze fase deskundigen in te schakelen die de hoogte van de schadeloosstelling vaststellen. ${ }^{203}$ Met andere woorden: indien de onderhandelingen niet tot resultaat leiden, biedt art. 2:330a BW de stemrechtloze aandeelhouder een uittreedrecht, in de zin van een schadeloosstelling. Dit uittreedrecht geldt alleen indien de verkrijgende vennootschap een naamloze vennootschap is. ${ }^{204}$ 'Voor eventuele gebreken in de procedure of andere nadelige gevolgen van een fusie tussen een NV en een BV die niet met schadeloosstelling kunnen worden opgelost, bevat de wet daarnaast de algemene waarborgen in de vorm van de geschillenregeling, het enquêterecht en de mogelijkheid om besluiten door de rechter te laten vernietigen', aldus de wetgever. $^{205}$

Art. 2:330a lid $1 \mathrm{BW}$ brengt tot uitdrukking dat de houders van stemrechtloze aandelen alleen een verzoek tot schadeloosstelling kunnen indienen indien de verkrijgende vennootschap geen BV is. Het uittreedrecht geldt aldus alleen indien de verkrijgende vennootschap een NV (en geen BV) is. Bij gebrek aan het stemrechtloze aandeel in het NV-recht, kan de stemrechtloze aandeelhouder in de verdwijnende BV geen stemrechtloze aandeelhouder in de NV worden. Indien de verkrijgende vennootschap een BV is, die geen stemrechtloze aandelen kent, geldt het uittreedrecht niet. ${ }^{206}$ Indien stemrechtloze aandelen in een verkrijgende BV

202 Kamerstukken II 2009/10, 32 426, nr. 3, p. 5 (MvT).

203 Kamerstukken II 2010/11, 32 426, nr. 7, p. 5-6 (NV II).

204 Kamerstukken II 2011/12, 32 426, nr. 25, p. 7.

205 Kamerstukken II 2009/10, 32 426, nr. 3, p. 5 (MvT).

206 Roelofs 2012 (3), p. 14. 
moeten worden toegekend, zal aldus eerst een statutenwijziging van de verkrijgende BV moeten plaatsvinden teneinde in die aandelen te voorzien. ${ }^{207}$

Het verzoek tot schadeloosstelling moet schriftelijk aan de vennootschap worden gedaan binnen een maand nadat de vennootschap de stemrechtloze aandeelhouder heeft medegedeeld dat hij om schadeloosstelling kan verzoeken. De mededeling van de vennootschap moet voldoen aan het bepaalde in art. 2:223 BW. Praktisch is deze mededeling en de schriftelijke waardebepaling door de deskundige, overeenkomstig art. 2:330a lid $2 \mathrm{BW}$, tegelijk met het voorstel tot fusie aan de stemrechtloze aandeelhouder te zenden. ${ }^{208}$

Art. 2:330a lid 2 BW geeft een regeling voor de wijze waarop de schadeloosstelling wordt bepaald. De hoogte daarvan zal aan de hand van de nominale waarde van de aandelen worden vastgesteld. Daarnaast zal de schadeloosstelling ook een element voor het verlies van dividendinkomsten, andere financiële aanspraken of voor het verlies van stemrecht bevatten. ${ }^{209}$

Art. 2:330a lid 2 BW biedt echter ook de mogelijkheid dat in de statuten of in een overeenkomst waarbij de vennootschap en de desbetreffende aandeelhouder(s) partij zijn, bepalingen over de vaststelling van de waarde van de aandelen of de vaststelling van de schadeloosstelling zijn opgenomen. Indien de statuten of de overeenkomst een duidelijke maatstaf bevat aan de hand waarvan de schadeloosstelling zonder meer kan worden vastgesteld, dan behoeven geen deskundigen te worden benoemd. Indien een duidelijke maatstaf ontbreekt, dan stellen de deskundigen hun bericht op met inachtneming van de bepalingen in de statuten of de overeenkomst over de vaststelling van de waarde van de aandelen of de vaststelling van de schadeloosstelling. In het kader van de omzetting merkte ik reeds op dat in de literatuur ${ }^{210}$ mijns inziens wordt terecht opgemerkt dat de prijsbepalingsregeling in de zin van art. 2:181 lid 4 BW specifiek op omzetting dient te zien, wil die regeling ingeval van omzetting toepassing kunnen vinden. Daarnaast zou naar analogie van art. 2:192 lid 3 en 2:195 lid 4 BW de statutaire prijsbepalingsregeling bij omzetting eerst van toepassing zijn nadat de aandeelhouder met die regeling heeft ingestemd. $^{211}$ Dit geldt mijns inziens in gelijke mate in het kader een prijsbepalingsregeling als bedoeld in art. 2:330a lid $2 \mathrm{BW}$.

De achtergrond van deze regeling is te voorkomen dat de vennootschap bij de invoering van stemrechtloze aandelen 'in geval van een fusie veel tijd en moeite moet steken om tot overeenstemming met de stemrechtloze aandeelhouders over hun positie na de fusie te komen, en met name over de hoogte van de schadeloosstelling. Mocht geen overeenstemming bereikt worden met de stemrechtloze aandeelhouders over hun positie na de fusie, dan hoeft de procedure tot de

207 Van Eck 2013, p. 18.

208 Roelofs 2012 (3), p. 14 en Van Eck 2013, p. 17-18. In gelijke zin ingeval van omzetting, zie Roelofs 2012 (2), p. 15.

209 Kamerstukken II 2010/11, 32 426, nr. 7, p. 4 (NV II).

210 Nagtegaal \& Snijder-Kuipers 2012, p. 245. Vgl. Van Eck 2013, p. 19 ingeval van fusie.

211 Vgl. Snijder-Kuipers 2012, p. 10. 
vaststelling door de rechter van de hoogte van de schadeloosstelling slechts geringe tijd te vergen, omdat er dan een statutaire regeling bestaat waarop de deskundigen zich kunnen baseren. De stemrechtloze aandeelhouder is bekend met die statuten of de overeenkomst, zodat hij weet hoe die schadeloosstelling te zijner tijd zal worden vastgesteld', aldus de wetgever. ${ }^{212}$

De deskundigen brengen over de waardebepaling schriftelijk bericht uit. Op deze berichtgeving is art. 2:314 lid $2 \mathrm{BW}$ van toepassing. Uit dat artikel en uit art. 2:326 BW volgt tevens dat het deskundigenbericht moet worden verkregen alvorens het besluit tot fusie kan worden genomen. Op deze wijze verkrijgt de stemrechtloze aandeelhouder inzicht in de gevolgen van het voorgenomen besluit tot fusie en kan hij een beredeneerde afweging maken. Het deskundigenbericht moet bij de oproep van de algemene vergadering waarin over het besluit tot fusie wordt beslist worden meegezonden. ${ }^{213}$ In het kader van art. 2:181 lid 4 BW merkte ik al op dat de regeling omtrent de deskundigen bij omzetting vragen oproept, welke vragen ook opkomen bij de regeling omtrent de deskundigen bij fusie. Ik volsta met verwijzing daarnaar. ${ }^{214}$

Art. 2:330a lid 3 BW brengt tot uitdrukking dat de schadeloosstelling ten behoeve van de stemrechtloze aandeelhouder op het moment van het verlijden van de fusieakte op de derdenrekening van de notaris moet staan. $^{215}$ Uit het artikellid volgt ook als hoofdregel dat op het moment dat de aandelen vervallen de schadeloosstelling moet zijn voldaan. Indien evenwel het fusievoorstel bepaalt dat de verkrijgende rechtspersoon de schadeloosstelling moet voldoen, behoeft de schadeloosstelling niet te zijn voldaan voordat de fusieakte wordt gepasseerd. Alleen de stemrechtloze aandelen waarvoor schadeloosstelling is verzocht, vervallen. ${ }^{216}$ Voor de stemrechtloze aandelen waarvoor geen schadeloosstelling wordt verzocht, worden ex art. 2:311 lid 2 BW aandelen toegekend in het kapitaal van de verkrijgende vennootschap, aldus de wetgever. ${ }^{217}$ De vraag is, gelijk als bij omzetting, wat voor soort aandelen de stemrechtloze aandeelhouder in de verdwijnende $\mathrm{BV}$ in de verkrijgende $\mathrm{NV}$ dan verkrijgt. ${ }^{218}$

212 Kamerstukken II 2010/11, 32 426, nr. 7, p. 6 (NV II). Deze toelichting is deels gebaseerd op een eerder ontwerp van art. 2:330a BW.

213 Kamerstukken II 2011/12, 32 426, nr. 25, p. 9 en 7-8. Bij de toelichting op art. 2:330a lid 2 BW wordt verwezen naar de toelichting op art. 2:181 lid 4 BW.

214 Zie ook Van Eck 2013, p. 19.

215 Kamerstukken II 2010/11, 32 426, nr. 7, p. 4 (NV II).

216 Koster 2011 stelt dat hierdoor een bijna volledige cash-out (de)merger toegestaan lijkt. Dat lijkt mij alleen het geval indien alle stemrechtloze aandeelhouders een schadeloosstelling toekomt. Zo niet, dan geldt art. 2:311 lid 2 BW. Overigens merkt Koster op dat een bijna volledige cash-out (de)merger vermoedelijk niet in overeenstemming met de bedoeling van de wetgever is gelet op het bepaalde in art. 2:325 lid 2 en 2:334x lid 2 BW.

217 Kamerstukken II 2011/12, 32 426, nr. 25, p. 9.

218 In gelijke zin in het geval van fusie Van Eck 2013, p. 18. Zie ook de suggestie van Dortmond 2011 (3), p. 508: In beginsel bepaalt de nominale waarde het aantal stemmen dat kan worden uitgebracht, tenzij gebruik wordt gemaakt van art. 2:118 lid 4 of lid 5 BW. 
Bij het vervallen van de aandelen gaat het om verval van rechtswege. ${ }^{219}$ Gelijk ik reeds opmerkte bij omzetting, is ook hier niet duidelijk wat de wetgever met 'vervallen' bedoelt.

\section{Driehoeksfusie}

Art. 2:333a BW geeft een regeling voor de driehoeksfusie. Een driehoeksfusie is een fusie waarbij een verdwijnende vennootschap met een verkrijgende vennootschap die deel uitmaakt van een concern fuseert, waarbij de aandeelhouders aandelen in de groepsmaatschappij van de verkrijgende vennootschap krijgen. Art. 2:333a BW bepaalt dat de akte van fusie kan bepalen dat de aandeelhouders van de verdwijnende vennootschappen aandeelhouder worden van een groepsmaatschappij van de verkrijgende vennootschap. Zij worden dan geen aandeelhouder van de verkrijgende vennootschap. Een dergelijke fusie is slechts mogelijk, indien de groepsmaatschappij alleen of samen met een andere groepsmaatschappij het gehele geplaatste kapitaal van de verkrijgende vennootschap verschaft. De art. 2:317 lid 1 tot en met 4, 2:330 en 2:331 BW zijn op het besluit van de groepsmaatschappij van overeenkomstige toepassing. De groepsmaatschappij die de aandelen toekent geldt naast de verkrijgende vennootschap als fuserende rechtspersoon. Op haar rusten de verplichtingen die op grond van art. 2:312 tot en met 2:329 en 2:330a lid 1 BW op een verkrijgende vennootschap rusten, met uitzondering van de verplichtingen ex art. 2:316, 2:317, 2:318 lid 4, 2:321 lid 2 en lid 4, 2:323, lid 7 BW. Art. 2:312 lid 2 onder b, 2:320, 2:325 lid 3, 2:326 lid 1 onder b en 2:330a lid 1 BW gelden alsdan niet voor de verkrijgende vennootschap.

Art. 2:333a lid 2 BW stelt als voorwaarde voor de driehoeksfusie dat de groepsmaatschappij - kort gezegd - het gehele geplaatste kapitaal van de verkrijgende vennootschap moet verschaffen. Onder meer het hiervoor besproken art. art: 2:317 lid 1 tot en met 4 en art. 2:330 BW zijn van overeenkomstige toepassing op het besluit tot fusie van de groepsmaatschappij. Voor de positie van de stemrechtloze aandeelhouder is vooral art. 2:333a lid 3 BW van belang, dat als uitgangspunt stelt dat de verplichtingen van de verkrijgende vennootschap worden opgelegd aan zowel de groepsmaatschappij die de aandelen uitreikt als aan de verkrijgende vennootschap. Art. 2:330a lid $1 \mathrm{BW}$ is een van die verplichtingen, die van toepassing is op de groepsmaatschappij. De schadeloosstelling voor houders van stemrechtloze aandelen van art. 2:330a BW is gerelateerd aan de toekenning van aandelen en geldt alleen voor de groepsmaatschappij. De verkrijgende vennootschap wordt in art. 2:333 lid 3 BW vrijgesteld van de verplichting als bedoeld in art. 2:330a lid $1 \mathrm{BW}^{220}$ De parlementaire geschiedenis bij art. 2:330a BW noemt de driehoeksfusie expliciet: "In geval van een driehoeksfusie is niet bepalend of de verkrijgende vennootschap een naamloze vennootschap of besloten vennootschap

219 Kamerstukken II 2010/11, 32 426, nr. 8, p. 15 (Nota van wijziging). 220 Kamerstukken II 2009/10, 32 426, nr. 3, p. 31 (MvT). 
is, maar of de groepsmaatschappij die bij toepassing van artikel 333 a de aandelen toekent een naamloze vennootschap [is]."221

Dortmond heeft terecht vraagtekens gesteld bij deze regeling. ${ }^{222}$ Indien de groepsmaatschappij een BV is, dan kunnen de stemrechtloze aandeelhouders van de verdwijnende vennootschap ook stemrechtloze aandelen verkrijgen in de groepsmaatschappij-BV. In dat geval zou een vrijstelling voor de schadeloosstelling voor de hand liggen. De wet voorziet daarin echter niet.

\section{Grensoverschrijdende fusie}

De grensoverschrijdende fusie wordt in art. 2:333b e.v. BW geregeld. ${ }^{223}$ Voor de positie van de stemrechtloze aandeelhouder is van belang dat een (verdwijnende) BV kan fuseren met een kapitaalvennootschap die opgericht is naar het recht van een andere lidstaat van de Europese Unie of de Europese Economische Ruimte (art. 2:333c lid 1 eerste volzin). De grensoverschrijdende driehoeksfusie wordt geregeld in art. 2:333c lid $3 \mathrm{BW}$. Ook bij een grensoverschrijdende fusie vinden (onder meer) de eerder besproken art. 2:311 lid 2, 2:312, 2:317 en 2:326 BW toepassing. Dat geldt ook voor art. 2:330 BW. In het tweede lid van dat artikel wordt art. 2:226 lid $2 \mathrm{BW}$ ten aanzien van een fusie van het hierna te bespreken art. 2:333h BW niet van toepassing verklaard. Reden daarvoor is dat het inherent aan een grensoverschrijdende ('outbound') fusie is, waarbij de verkrijgende vennootschap een buitenlandse vennootschap is, dat de plaats van vergadering in het buitenland zal liggen. ${ }^{224}$

In aanvulling op het bepaalde in art. 2:312 en 2:326 BW bepaalt art. 2:333d BW onder meer dat het gezamenlijke voorstel tot fusie een voorstel voor de hoogte van de schadeloosstelling voor een aandeel bij toepassing van art. 2:333h BW vermeldt. Lid 1 tot en met 3 van dat (laatste) artikel bepalen dat indien de verkrijgende vennootschap een vennootschap naar het recht van een andere lidstaat van de EU of de EER is, de aandeelhouder van een verdwijnende vennootschap die tegen het fusievoorstel heeft gestemd, en iedere houder van aandelen zonder stemrecht, binnen een maand na de datum van het besluit bij de verdwijnende vennootschap een verzoek tot schadeloosstelling kan indienen. Art. 2:330a BW geldt in dat geval niet. Het bedrag van de schadeloosstelling wordt vastgesteld door een of meer onafhankelijke deskundigen. De deskundigen brengen over de waardebepaling schriftelijk bericht uit, waarop art. 2:314 lid 2 BW van toepassing is. Indien tussen partijen op grond van de statuten of een overeenkomst waarbij de vennootschap en de desbetreffende aandeelhouders partij zijn, bepalingen over de vaststelling van de waarde van de aandelen of de vaststelling van de schadeloosstelling gelden, stellen de deskundigen hun bericht op met inachtneming daarvan. De benoeming van

221 Kamerstukken II 2011/12, 32 426, nr. 25, p. 9

222 Dortmond 2010, p. 524.

223 Zie hierover uitgebreid Van Boxel 2012 en Roelofs 2013.

224 Kamerstukken II 2011/12, 32 426, nr. 26, p. 2. 
deskundigen kan achterwege blijven, indien de statuten of een overeenkomst waarbij de vennootschap en de desbetreffende aandeelhouders partij zijn, een duidelijke maatstaf bevatten aan de hand waarvan de schadeloosstelling zonder meer kan worden vastgesteld. De aandelen waarop het verzoek betrekking heeft, vervallen op het moment dat de fusie van kracht wordt.

Art. 2:333h BW komt er ten aanzien van de positie van de stemrechtloze aandeelhouder erop neer dat, ingeval van fusie tussen een Nederlandse, verdwijnende BV en een verkrijgende vennootschap in een ander EU- of EER-land, de stemrechtloze aandeelhouder een maand na het besluit tot fusie van de verdwijnende vennootschap schadeloosstelling bij die verdwijnende vennootschap kan vragen. Art. 2:330a BW is in dit geval niet van toepassing. ${ }^{225}$ Daardoor wordt voorkomen dat er twee procedures tot bepaling van de schadeloosstelling gevoerd zouden moeten worden. ${ }^{226}$ Art. 2:333h lid $2 \mathrm{BW}$ kent daarvoor een aparte, aan art. 2:330a lid 2 BW gelijkluidende, regeling. Lid 3 van beide artikelen is wel afwijkend. Bij een grensoverschrijdende fusie is niet bepaald dat de notaris de fusieakte niet passeert voordat de schadeloosstelling is voldaan; daarvoor geldt een aparte regeling in art. 2:333i lid 3 en 4 BW.

In de literatuur ${ }^{227}$ wordt terecht opgemerkt dat het bij een grensoverschrijdende fusie ook goed mogelijk is dat de verkrijgende vennootschap stemrechtloze aandelen kent, zodat niet per definitie hoeft te worden voorzien in een schadeloosstelling voor de stemrechtloze aandeelhouder in de verdwijnende vennootschap. Een andere genoemde mogelijkheid is dat de stemrechtloze aandeelhouder een aandeel met volledig of beperkt stemrecht in de verkrijgende vennootschap krijgt toegekend. ${ }^{228}$ Niettemin biedt art. 2:333h BW deze aandeelhouder bescherming, die tegen zijn wil met het recht van een andere lidstaat te maken krijgt.

6.2.3.16 Splitsing en de positie van de stemrechtloze aandeelhouder

\section{Inleiding}

De regeling omtrent splitsing is in hoge mate gelijk aan die van fusie. In deze paragraaf zal ik met name stil staan bij de verschillen en de voor de positie van de stemrechtloze aandeelhouder relevante bepalingen ingeval van splitsing aanduiden. Voor het overige verwijs ik ter toelichting naar hetgeen ik in paragaaf 6.2.3.15 over de positie van de stemrechtloze aandeelhouder ingeval van fusie heb opgemerkt.

Onder 'splitsing' wordt verstaan 'zuivere splitsing' en 'afsplitsing'. Zuivere splitsing is de rechtshandeling waarbij het vermogen van een rechtspersoon die bij de splitsing ophoudt te bestaan onder algemene titel overeenkomstig de aan de akte

225 Bij een 'inbound' grensoverschrijdende fusie waarbij naast een verkrijgende Nederlandse NV ook een verdwijnende Nederlandse BV met stemrechtloze aandelen betrokken is, geldt art. 2:330a BW onverkort. Zie Roelofs 2013, p. 6.

226 Kamerstukken II 2011/12, 32 426, nr. 8, p. 16.

227 Van Boxel 2012, p. 637 en Roelofs 2013, p. 5

$228 \mathrm{Zie}$ in dit kader art. 2:312 lid 2 sub g BW. 
van splitsing gehechte beschrijving wordt verkregen door twee of meer andere rechtspersonen. Afsplitsing is de rechtshandeling waarbij het vermogen of een deel daarvan van een rechtspersoon die bij de splitsing niet ophoudt te bestaan onder algemene titel overeenkomstig de aan de akte van splitsing gehechte beschrijving wordt verkregen door een of meer andere rechtspersonen waarvan ten minste één lidmaatschapsrechten of aandelen in zijn kapitaal toekent aan de leden of aan aandeelhouders van de splitsende rechtspersoon of waarvan ten minste één bij de splitsing door de splitsende rechtspersoon wordt opgericht. ${ }^{229}$

Op grond van art. 2:334e lid $1 \mathrm{BW}$ worden de aandeelhouders van de splitsende rechtspersoon door de splitsing aandeelhouder in alle verkrijgende rechtspersonen. Art. $2: 334 \mathrm{e}$ lid 3 BW geeft een aantal uitzonderingen op deze regel. Voor de stemrechtloze aandeelhouder is de uitzondering genoemd onder d van belang, inhoudende dat art. 2:334e lid $1 \mathrm{BW}$ niet geldt indien art. 2:334ee1 BW van toepassing is. Dat (laatste) artikel regelt de schadeloosstelling voor de stemrechtloze aandeelhouder indien de verkrijgende vennootschap geen BV is. Art. 2:334m BW geeft een algemene regeling voor besluiten tot splitsing. Omdat deze bepaling, afgezien van het ontbreken van een zesde lid, gelijk is aan art. 2:317 BW betreffende het besluit tot fusie, ${ }^{230}$ verwijs ik naar paragraaf 6.2.3.15. Voor splitsing van een besloten vennootschap of een besloten vennootschap die in het kader van een splitsing wordt opgericht, zijn onder meer art. 2:334y, 2:334ee en 2:334ee1 BW van belang. Voorts is te denken aan de driehoeksplitsing van art. 2:334ii BW en de evenredige splitsing van art. 2:334hh BW.

Ook bij splitsing geldt dat op grond van art. 2:334m lid 4 BW de statuten een van lid 3 van dat artikel afwijkende regeling voor besluiten tot splitsing kan geven. In voorkomend geval kan op die wijze de positie van de stemrechtloze aandeelhouder worden versterkt, bijvoorbeeld dat het besluit tot splitsing de instemming of goedkeuring van iedere stemrechtloze aandeelhouder vereist.

\section{Splitsing en schadevergoeding}

Het voorstel tot splitsing moet de in art. 2:334f BW vermelde gegevens bevatten. In aanvulling daarop bepaalt art. 2:334y BW dat onder meer de gevolgen van de splitsing voor de houders van stemrechtloze aandelen, de hoogte van de schadeloosstelling voor een aandeel bij toepassing van art. 2:334ee1 BW en het totaal bedrag waarvoor ten hoogste met toepassing van art. 2:334ee1 BW schadeloosstelling kan worden verzocht, in het splitsingsvoorstel moeten worden vermeld. Deze bepaling komt overeen met de voor fusie gelijkluidende bepaling van art. 2:326 BW. De wetgever verwijst ook naar de toelichting op die laatste bepaling. ${ }^{231}$

229 Art. 2:334a lid 1, 2 en 3 BW

230 Kamerstukken II 2011/12, 32 426, nr. 26, p. 2.

231 Kamerstukken II 2009/10, 32 426, nr. 3, p. 31 (MvT). Per abuis bepaalt art. 2:334ee1 laatste volzin BW dat de aandelen waarop het verzoek tot schadeloosstelling betrekking heeft op het moment waarop de fusie van kracht wordt vervallen. Dat moet zijn op het moment waarop de splitsing van kracht wordt. 
Ten aanzien van het besluit tot splitsing geldt art. 2:334ee BW. Deze bepaling komt eveneens overeen met de voor fusie gelijkluidende bepaling van art. 2:330 BW. De wetgever verwijst ook hier naar de toelichting op die laatste bepaling. ${ }^{232}$ Ook geldt dat een goedkeurend groepsbesluit vereist is van de houders van stemrechtloze aandelen aan wier rechten in het kader van de splitsing afbreuk wordt gedaan. Naast dit groepsbesluit is niet nog eenzelfde groepsbesluit door diezelfde aandeelhouders op grond van art. 2:231 lid 4 BW nodig. ${ }^{233}$

In afwijking van de genoemde hoofdregel van art. 2:334e lid 1 BW kan de stemrechtloze aandeelhouder, indien hij geen aandeelhouder in de verkrijgende vennootschap - niet zijnde een BV - wordt, op grond van art. 2:334ee1 BW een verzoek tot schadeloosstelling indienen. ${ }^{234}$ Deze bepaling komt overeen met de voor fusie gelijkluidende bepaling van art. 2:330a BW. De wetgever licht toe: "Ingeval van splitsing of afsplitsing ontstaan verschillende verkrijgende rechtspersonen. Is ten minste één van die verkrijgende rechtspersonen een $n v$, dan ontstaat evenals bij fusie de situatie dat voor stemrechtloze (...) aandelen in een splitsende bv een goede ruilverhouding niet kan worden bepaald. Daarom wordt ook hier bepaald dat stemrechtloze (...) aandelen vervallen en dat de houders van die aandelen recht hebben op een schadeloosstelling als er geen overeenstemming is bereikt over de ruilverhouding. "235 Voor het overige verwijst de wetgever naar de toelichting op art. 2:330a BW. ${ }^{236}$ Uit art. 2:334ee1 lid $3 \mathrm{BW}$ volgt dat de verplichting tot betaling van de schadeloosstelling hoofdelijk op de verkrijgende

232 Kamerstukken II 2009/10, 32 426, nr. 3, p. 31 (MvT). Zie ook Kamerstukken II 2011/12, 32 426, nr. 26, p. 2.

233 Kamerstukken II 2011/12, 32 426, nr. 26, p. 2-3. In een eerder ontwerp van art. 2:330a BW werd in lid 3 het goedkeurende groepsbesluit van de stemrechtloze aandeelhouders bij een besluit tot fusie buiten toepassing verklaard, zie Kamerstukken II 2009/10, 32 426, nr. 2, p. 9. De wetgever motiveerde dat als volgt: "Nu stemrechtloze of winstrechtloze aandeelhouders bescherming kunnen ontlenen aan de regeling voor schadeloosstelling, is er bij een fusie met een verkrijgende nv en een verdwijnende bv met stemrechtloze of winstrechtloze aandelen geen reden voor aanvullende bescherming in de besluitvormingsregels. Daarom wordt artikel 330 lid 2, waarin is bepaald dat het fusiebesluit is onderworpen aan de goedkeuring van de houders van aandelen van een zelfde soort of aanduiding aan wier rechten de fusie afbreuk doet, buiten toepassing verklaard in artikel 330a lid 3." Zie Kamerstukken II 2009/10, 32 426, nr. 3, p. 30 (MvT). Datzelfde gold voor een besluit tot splitsing (Zie voor het eerdere ontwerp van art. 2:334ee1 lid 3 BW: Kamerstukken II 2009/10, 32 426, nr. 2, p. 10 en de toelichting daarop Kamerstukken II 2009/10, 32 426, nr. 3, p. 31 (MvT)). Zie ook Kamerstukken II 2010/11, 32 426, nr. 7 , p. 17 (NV II).

234 Kamerstukken II 2009/10, 32 426, nr. 3, p. 5 en 31 (MvT).

235 Kamerstukken II 2009/10, 32 426, nr. 3, p. 31 (MvT). De wetgever ging er ten tijde van het aangehaalde citaat vanuit dat alle stemrechtloze aandelen zouden vervallen. Blijkens de laatste volzin van art. 2:334ee1 BW vervallen slechts de stemrechtloze aandelen waarop het verzoek tot schadeloosstelling betrekking heeft.

236 Kamerstukken II 2009/10, 32 426, nr. 3, p. 31 (MvT). 
vennootschappen rust. ${ }^{237}$ Voor de stemrechtloze aandelen waarvoor geen schadeloosstelling wordt verzocht, worden ex art. 2:334e lid $1 \mathrm{BW}$ aandelen toegekend in het kapitaal van alle verkrijgende vennootschappen. De parlementaire geschiedenis bevat geen specifieke toelichting op dit punt.

Roelofs ${ }^{238}$ merkt mijns inziens terecht op dat ingeval van afsplitsing niet valt in te zien hoe de aandelen waarop het verzoek tot schadeloosstelling ziet ex art. 2:334ee1 lid 3 BW kunnen vervallen op het moment dat de afsplitsing van kracht wordt. Bij afsplitsing gaat immers het vermogen, of een deel daarvan, van een rechtspersoon, die bij de splitsing niet ophoudt te bestaan, onder algemene titel over op een andere rechtspersoon. De aandeelhouders van de afsplitsende rechtspersoon blijven aldus aandeelhouder in die rechtspersoon, terwijl de schadeloosstelling ziet op het niet verkrijgen van aandelen in de verkrijgende rechtspersoon.

\section{Ruziesplitsing ex art. 2:334cc $B W$}

De regeling voor schadeloosstelling van art. 2:334ee1 BW geldt ook voor een (zuivere) splitsing in de zin van art. 2:334cc BW, waarbij een deel van de aandeelhouders aandelen in de ene verkrijgende vennootschap verkrijgt en een ander deel aandelen in de andere vennootschap. In de praktijk wordt deze vorm van splitsing, als ruziesplitsing, bij onenigheid tussen aandeelhouders gebruikt. De wetgever licht toe: "Bij een dergelijke splitsing is het niet mogelijk om een goede oplossing te vinden voor de positie van stemrechtloze aandeelhouders, ook niet als de verkrijgende vennootschappen besloten vennootschappen zijn. Omdat op grond van art. 2:175 BW geldt dat er ten minste één aandeel met stemrecht bij een derde moet zijn geplaatst, kunnen de stemrechtloze aandeelhouders, in tegenstelling tot de aandeelhouders met stemrecht, niet worden ondergebracht in een afzonderlijke verkrijgende vennootschap." ${ }^{239}$ In de literatuur wordt gesteld dat niet valt in te zien waarom ingeval van een ruziesplitsing stemrechtloze aandeelhouders in de splitsende BV niet een gelijkwaardige positie in de verkrijgende (besloten) vennootschappen zouden kunnen krijgen. Eveneens terecht wordt opgemerkt dat de wetgever, gelet op de geciteerde passage, er kennelijk vanuit gaat dat alle stemrechtloze aandelen in een van de verkrijgende vennootschappen worden ondergebracht en de aandelen met stemrecht in de andere verkrijgende vennootschap. Ook dat hoeft niet per definitie het geval te zijn. Indien daarvan wel sprake is, kan dat op eenvoudige wijze worden opgelost. Bij splitsing kan de verkrijgende vennootschap

237 Kamerstukken II 2009/10, 32 426, nr. 3, p. 31 (MvT). Art. 2:334ee1 lid 3 laatste volzin BW bevat voorts nog een schrijffout: "De aandelen waarop het verzoek betrekking heeft, vervallen op het moment waarop de fusie (onderstreping RAW) van kracht wordt." Dat moet zijn splitsing.

238 Roelofs 2012 (3), p. 15.

239 Kamerstukken II 2009/10, 32 426, nr. 3, p. 32 (MvT). 
aandelen met stemrecht aan de (voormalige) stemrechtloze aandeelhouders uitgeven. Op deze wijze wordt voldaan aan het bepaalde in art. 2:175 BW. ${ }^{240}$

\section{Splitsing ex art. 2:334hh $B W$}

In art. 2:334hh BW worden twee vormen van vereenvoudigde splitsing geregeld. Het eerste lid ziet op de afsplitsing waarbij alle verkrijgende vennootschappen bij de splitsing worden opgericht en de splitsende rechtspersoon bij de splitsing enig aandeelhouder van de verkrijgende vennootschap wordt. In dat geval zijn art. 2:334f lid 4 eerste zin, 2:334w en 2:334y tot en met 2:334aa BW niet van toepassing. Het tweede lid betreft de evenredige splitsing, inhoudende dat alle verkrijgende vennootschappen bij de splitsing worden opgericht en de aandeelhouders van de splitsende vennootschap evenredig aan hun aandeel in de splitsende vennootschap aandeelhouder in de verkrijgende vennootschappen worden. In dat geval zijn art. 2:334g, 2:334i en 2:334y tot en met 2:334bb BW niet van toepassing. Ook bij deze vormen van splitsing geldt dat de stemrechtloze andeelhouder wordt beschermd door het vereiste van een goedkeurend groepsbesluit van de stemrechtloze aandeelhouders als bedoeld in art. 2:334ee lid $2 \mathrm{BW}$.

Zowel in het eerste als in het tweede lid van art. 2:334hh BW wordt onder meer art. 2:334y BW buiten toepassing verklaard. Dat laatste artikel bepaalt dat het splitsingsvoorstel onder meer vermeldt de gevolgen van de splitsing voor de houders van stemrechtloze aandelen, de hoogte van de schadeloosstelling voor een aandeel bij toepassing van art. 2:334ee1 $\mathrm{BW}$ en het totaal bedrag waarvoor ten hoogste met toepassing van art. 2:334ee1 BW schadeloosstelling kan worden verzocht. Bij een splitsing in de zin van art. 2:334hh BW heeft de stemrechtloze aandeelhouder aldus geen recht op schadeloosstelling. Dat is logisch, omdat er bij deze twee vormen van splitsing geen sprake is van een verdwijnende vennootschap.

Ten aanzien van de evenredige splitsing ligt een en ander iets genuanceerder. Indien de BV slechts een soort aandelen kent, spreekt het voor zich dat de aandeelhouders naar evenredigheid van hun aandelenbezit aandelen verkrijgen in alle verkrijgende vennootschappen. Indien de BV meerdere soorten aandelen kent, bijvoorbeeld ook stemrechtloze aandelen, is het antwoord minder voor zich sprekend. Roelofs \& Van Eck werpen terecht de vraag op of de aandelenstructuur van de verkrijgende vennootschappen identiek moet zijn aan die van de splitsende vennootschap, zodat de aandeelhouders niet alleen naar evenredigheid het kapitaal van de verkrijgende vennootschappen verschaffen, maar ook naar evenredigheid stemrecht hebben in de algemene vergadering en voor het overige naar evenredigheid alle bijzondere rechten, verbonden aan die (soort) aandelen hebben. ${ }^{241} \mathrm{Na}$ een

240 Dortmond 2010, p. 524; Lennarts \& Boschma 2010, p. 707 en Timmermans 2011, p. 56. Zie ook het advies d.d. 23 september 2010 van de Gecombineerde Commissie Vennootschapsrecht van de Nederlandse Orde van Advocaten en de Koninklijke Notariële Beroepsorganisatie inzake wetsvoorstel 32 426, aanpassing van de wetgeving aan en invoering van de Wet vereenvoudiging en flexibilisering bv-recht (Invoeringswet vereenvoudiging en flexibilisering bv-recht), p. 5.

241 Roelofs \& Van Eck 2011, p. 130 en Van Eck \& Roelofs 2012, p. 4-5. 
korte analyse komen zij tot de conclusie dat voor de toepassing van een evenredige splitsing niet vereist is dat bepaalde soorten aandelen ook bestaan in de verkrijgende vennootschappen. De achterliggende gedachte daarvan is dat wordt aangesloten bij de mate waarin aandeelhouders kapitaal verschaffen van de splitsende vennootschap en niet bij het bestaan van bepaalde soorten aandelen en de daaraan verbonden verschillende financiële of zeggenschapsrechten in het kapitaal van de splitsende vennootschap. Met andere woorden: aandelen van een bepaalde soort kunnen wel in de verkrijgende vennootschap terugkomen, maar aan die aandelen kunnen andere financiële en/of zeggenschapsrechten verbonden zijn dan de financiële en/of zeggenschapsrechten die aan de oorspronkelijke aandelen in de splitsende vennootschap verbonden waren. Als ik deze conclusie van Roelofs \& Van Eck volg, dan houdt dat voor de stemrechtloze aandeelhouder concreet in dat hij ingeval van een evenredige splitsing houder van een ander soort stemrechtloos aandeel kan worden. Beter gezegd: aan zijn aandeel kunnen andere financiële rechten verbonden zijn, bijvoorbeeld een beperkter winstrecht, dan aan zijn oorspronkelijke aandeel. Bij een evenredige splitsing met een splitsende BV met stemrechtloze aandelen en een verkrijgende BV ligt het naar mijn mening voor de hand dat gelijke stemrechtloze aandelen in de verkrijgende BV worden verkregen. Indien de verkrijgende rechtspersoon een $\mathrm{NV}$ is, lijkt een evenredige splitsing bij gebrek aan stemrechtloze aandelen in een NV niet mogelijk. ${ }^{242}$ Zoals gezegd, vindt de stemrechtloze aandeelhouder bescherming in het goedkeurende groepsbesluit van art. 2:334ee lid 2 BW.

\section{Driehoekssplitsing ex art. 2:334ii $\mathrm{BW}$}

Art. 2:334ii BW geeft een regeling voor de driehoekssplitsing. Een driehoekssplitsing is een splitsing, waarbij de verkrijgende vennootschap deel uitmaakt van een concern en de aandeelhouders van de splitsende vennootschap aandeelhouder worden van de groepsmaatschappij van de verkrijgende vennootschap. Art. 2:334ii BW bepaalt dat de akte van splitsing kan bepalen dat de aandeelhouders van de splitsende vennootschap aandeelhouder worden van een groepsmaatschappij van een verkrijgende vennootschap. Zij worden dan geen aandeelhouder van die verkrijgende vennootschap. Een driehoeksplitsing is slechts mogelijk, indien de groepsmaatschappij alleen of samen met een andere groepsmaatschappij het gehele geplaatste kapitaal van de verkrijgende vennootschap verschaft. Art. 2:334m lid 1 tot en met 4, 2:334ee en 2:334ff BW zijn op het besluit van de groepsmaatschappij van overeenkomstige toepassing. De groepsmaatschappij die de aandelen toekent geldt naast de verkrijgende vennootschap als partij bij de splitsing. Op haar rusten de verplichtingen die ex art. 2:334f tot en met 2:334dd en 2:334ee1 lid $1 \mathrm{BW}$ op een verkrijgende rechtspersoon rusten, met uitzondering van de verplichtingen ex art. 2:334k tot en met 2:334m en 2:334q lid 2 en 4 BW. De artikelen 2:334s, 2:334t en 2:334u lid 7 BW gelden niet voor de groepsmaatschappij. Art. 2:334f lid 2

242 In gelijke zin Roelofs 2012 (3), p. 16. 
onder b, 2:334x lid 3, 2:334y onder b en 2:334ee1 lid 1 BW gelden alsdan niet voor de verkrijgende vennootschap. Voor de toepassing van de art. 2:94b en 2:204b BW worden de verkrijging door de verkrijgende vennootschap en de toekenning van aandelen door de groepsmaatschappij beschouwd als werden zij door dezelfde vennootschap gedaan.

De regeling van de driehoekssplitsing is gelijkluidend an die van de driehoeksfusie in de zin van art. 2:333a BW. Voor de positie van de stemrechtloze aandeelhouder is vooral art. 2:334ii lid 3 BW van belang, dat als "uitgangspunt [stelt, toevoeging RAW] dat de verplichtingen van de verkrijgende vennootschap worden opgelegd zowel aan de groepsmaatschappij die de aandelen uitreikt als aan de verkrijgende vennootschap. In dit lid is artikel 334 eel toegevoegd aan de opsomming van artikelen die verplichtingen bevatten die op de groepsmaatschappij rusten. Van een aantal verplichtingen wordt de verkrijgende vennootschap vrijgesteld. Deze vrijstellingen gelden voor de verplichtingen die de toekenning van aandelen raken (...). Omdat de in artikel 334 eel geregelde schadeloosstelling voor houders van stemrechtloze (...) aandelen gerelateerd is aan de toekenning van aandelen (...), wordt de verkrijgende vennootschap in artikel 334ii lid 3 vrijgesteld van de verplichting als bedoeld in artikel 334 eel lid 1", aldus de wetgever. ${ }^{243}$ In de literatuur zijn terecht vraagtekens bij deze regeling gesteld. ${ }^{244}$ Indien de groepsmaatschappij een BV is, dan kunnen de stemrechtloze aandeelhouders van de splitsende vennootschap ook stemrechtloze aandelen verkrijgen in de groepsmaatschappij-BV. In dat geval zou een vrijstelling voor de schadeloosstelling voor de hand liggen.

\subsubsection{Enquêtebevoegdheid}

Op grond van het bepaalde in art. 2:345 jo. 2:346 BW kan de stemrechtloze aandeelhouder de OK schriftelijk verzoeken een of meer personen te benoemen tot het instellen van een onderzoek naar het beleid en de gang van zaken in de BV. Bij een $\mathrm{BV}$ met een geplaatst kapitaal van maximaal $€ 22,5$ miljoen kan op grond van art. 2:346 lid 1 aanhef onder $\mathrm{b}$ BW het enquêteverzoek worden ingediend door een of meer aandeelhouders die alleen of gezamenlijk ten minste een tiende gedeelte van het geplaatste kapitaal vertegenwoordigen of rechthebbenden zijn op een bedrag van aandelen daarvan tot een nominale waarde van $€ 225.000$ of zoveel minder als de statuten bepalen. ${ }^{245}$

243 Kamerstukken II 2009/10, 32 426, nr. 3, p. 32 (MvT).

244 Zie het advies d.d. 23 september 2010 van de Gecombineerde Commissie Vennootschapsrecht van de Nederlandse Orde van Advocaten en de Koninklijke Notariële Beroepsorganisatie inzake wetsvoorstel 32 426, aanpassing van de wetgeving aan en invoering van de Wet vereenvoudiging en flexibilisering bv-recht (Invoeringswet vereenvoudiging en flexibilisering bv-recht), p. 5 en Dortmond 2010, p. 524.

245 Kamerstukken II 2008/09, 31 058, nr. 3, p. 114 (MvT) en Kamerstukken II 2008/09, 31 058, nr. 6, p. 14 (NV II). Uitgaande van de Wet van 18 juni 2012 tot wijziging van boek 2 van het Burgerlijk $\rightarrow$ 
Art. 2:24d lid $2 \mathrm{BW}$ is in dit kader van belang. Op grond van die bepaling tellen de stemrechtloze aandelen bij de vraag of de verzoeker aan het criterium van art. 2:346 BW voldoet mee. De reden daarvoor is dat de wetgever het wenselijk vindt dat het enquêterecht voor alle aandeelhouders openstaat, waaronder de stemrechtloze aandeelhouder. ${ }^{246}$ Op het recht van enquête ga ik in paragraaf 8.8 nader in.

\subsubsection{Geschillenregeling}

De geschillenregeling kent een vordering tot uitstoting (art. 2:336 BW) en een vordering tot uittreding (art. 2:343 BW). De vordering tot uitstoting komt er - kort gezegd - op neer dat een aandeelhouder, die een derde van het kapitaal verschaft, van een aandeelhouder kan vorderen dat hij zijn aandelen overdraagt indien die (andere) aandeelhouder door zijn gedragingen het belang van de vennootschap zodanig schaadt, dat het voortduren van zijn aandeelhouderschap in redelijkheid niet kan worden geduld. De vordering tot uittreding houdt in dat de aandeelhouder die door gedragingen van één of meer mede-aandeelhouders zodanig in zijn rechten of belangen is geschaad dat het voortduren van zijn aandeelhouderschap in redelijkheid niet meer van hem kan worden gevergd, tegen die mede-aandeelhouders een vordering tot uittreding kan instellen, inhoudende dat zijn aandelen worden overgenomen.

Beide vorderingen staan, indien aan de overige voorwaarden die deze artikelen stellen is voldaan, open voor de stemrechtloze aandeelhouder. Ook ten aanzien van de geschillenregeling is art. 2:24d lid 2 BW van belang. Op grond van die bepaling tellen de stemrechtloze aandelen bij de vraag of de verzoeker aan het criterium van art. 2:336 lid $1 \mathrm{BW}$ voldoet mee. De reden daarvoor is dat de wetgever het wenselijk acht dat de vordering tot uitstoting voor alle aandeelhouders openstaat, waaronder de stemrechtloze aandeelhouder. ${ }^{247}$ Op de geschillenregeling ga ik in paragraaf 8.9 nader in

\subsubsection{Redelijkheid en billijkheid en vernietiging van besluiten}

De stemrechtloze aandeelhouder behoort tot de kring van betrokkenen als bedoeld in art. 2:8 BW. Hij heeft daarom op grond van art. 2:15 lid 1 aanhef, sub b BW het recht een besluit van een orgaan van de BV wegens strijd met de vennootschappelijke redelijkheid en billijkheid te vernietigen. Ik kom daarop in hoofdstuk 7 en 8 terug.

Wetboek in verband met de aanpassing van het recht van enquête (Kamerstukken 32 887, Stb. 2012, 274). Deze wet zal inwerking treden op 1 januari 2013 (Stb. 2012, 305). Bij een BV met een geplaatst kapitaal van meer dan $€ 22,5$ miljoen geldt op grond van art. 2:346 lid 1 sub c (nieuw) BW een percentage van één procent.

246 Kamerstukken II 2008/09, 31 058, nr. 6, p. 14 (NV II).

247 Kamerstukken II 2008/09, 31 058, nr. 6, p. 14-15 (NV II). 


\subsubsection{Slotopmerking}

In paragraaf 2.6 memoreerde ik dat de wetgever heeft gekozen voor een eenvoudige regeling van het stemrechtloze aandeel, althans dat getracht is te komen tot een eenvoudige regeling. ${ }^{248}$ Uit de bespreking van het stemrechtloze aandeel in paragraaf 4.2 en de bespreking van de rechten van de stemrechtloze aandeelhouder in paragraaf 6.2.3 volgt naar mijn mening dat van een eenvoudige regeling geen sprake is. In veel gevallen heeft de stemrechtloze aandeelhouder, behalve in de algemene vergadering, wel degelijk een vorm van zeggenschap. Het lijkt mij dat de wetgever aldus niet in zijn opzet van een eenvoudige regeling is geslaagd. De vraag is ook in hoeverre in de praktijk van het stemrechtloze aandeel gebruikt gemaakt zal worden. Vast staat dat de advisering over dit aandeel door de praktijkjurist meer van hem vergt.

\subsection{De houder van certificaten met en zonder vergaderrecht}

\subsubsection{Inleiding}

In deze paragraaf bespreek ik de houder van certificaten met en zonder vergaderrecht. Ik bespreek eerst de aard van de rechtsfiguur van certificering van aandelen (paragraaf 6.3.2). Vervolgens bespreek ik de aan certificaten van aandelen met en zonder vergaderrecht verbonden rechten (paragraaf 6.3.3).

\subsubsection{Aard van de rechtsfiguur}

In paragraaf 3.7.8 en 4.4 ging ik reeds in op de rechtsfiguur van certificering van aandelen. De aard van deze rechtsfiguur is als volgt. Door certificering wordt de juridische en economische eigendom van aandelen gesplitst. Het administratiekantoor is eigenaar van de aandelen in de BV en houdt die aandelen op grond van een beheersovereenkomst voor de certificaathouder. Er is sprake van een driehoeksverhouding, bestaande uit de verhouding (i) tussen de BV en het administratiekantoor, ${ }^{249}$ (ii) tussen het administratiekantoor en de certificaathouder ${ }^{250}$ en (iii) tussen de BV en de certificaathouder. ${ }^{251}$ Het is deze driehoeksverhouding die de interne verhoudingen vormgeven. Daarbij is vooral relevant of sprake is van certificaten met en zonder vergaderrecht. Andere relevante factoren zijn of sprake is van gehele of gedeeltelijke certificering van de aandelen in de BV en van royeerbare, beperkte royeerbare of niet-royeerbare certificaten.

248 Kamerstukken II 2006/07, 31 058, nr. 3, p. 12 (MvT).

249 Zie uitgebreid over deze rechtsverhouding Van den Ingh 1991, p. 263-267.

250 Zie uitgebreid over deze rechtsverhouding Van den Ingh 1991, p. 151-243.

251 Zie uitgebreid over deze rechtsverhouding Van den Ingh 1991, p. 245-262. 
Met de scheiding van de aan de aandelen verbonden financiële en zeggenschapsrechten vindt in zekere mate een inbreuk plaats op de dualistische structuur van de BV en komen wellicht principal-agent-problemen eerder om de hoek kijken. De certificaathouder is immers de werkelijke kapitaalverschaffer in de BV, doch de zeggenschapsrechten (waaronder het stemrecht) worden door het administratiekantoor, als aandeelhouder in de algemene vergadering van de vennootschap uitgeoefend. Het bestuur van het administratiekantoor vertegenwoordigt het administratiekantoor in de algemene vergadering. De zeggenschap komt daardoor bij een kleine groep van personen te liggen in plaats van bij iedere individuele certificaathouder. Deze problematiek klemt te meer, indien het bestuur van het administratiekantoor onder (grote) invloed staat van het bestuur van de vennootschap, bijvoorbeeld in het geval dat het bestuur van het administratiekantoor geheel of gedeeltelijk uit dezelfde bestuurder(s) bestaat als het bestuur van de vennootschap. ${ }^{252}$

Dit probleem kan ondervangen worden door in de doelomschrijving in de statuten van het administratiekantoor en in de administratievoorwaarden een norm op te nemen, waarnaar het bestuur van het administratiekantoor zich moet richten, in het bijzonder bij het uitoefenen van het stemrecht. Het administratiekantoor oefent immers namens de certificaathouders de aan de gecertificeerde aandelen verbonden rechten jegens de vennootschap uit. Die norm houdt bijvoorbeeld in dat het administratiekantoor de belangen van de certificaathouders behartigt. Ook komt het voor dat een andere norm wordt opgenomen, namelijk het behartigen van de belangen of continuilteit van de vennootschap en de met haar verbonden onderneming. ${ }^{253}$ In de literatuur wordt echter gesteld dat sprake is van een 'ondergrens'. Het administratiekantoor mag niet, ongeacht de vraag of, en zo ja welke norm opgenomen is in de statuten en in de administratievoorwaarden, de belangen van de certificaathouders onevenredig schaden. ${ }^{254}$

Bij schending van de norm door het administratiekantoor is sprake van een tekortkoming in de nakoming van een verbintenis. Ik verwijs naar paragraaf 6.3.3.2. Onder omstandigheden kunnen de bestuurders van het administratiekantoor uit hoofde van onrechtmatige daad worden aangesproken. ${ }^{255}$

252 Vgl. Noordraven 1988, p. 179 en Van den Ingh 1991, p. 198-202.

253 Asser/Maeijer, Van Solinge \& Nieuwe Weme 2-II* 2009, nr. 665. Voor de laatste norm in de doelomschrijving zie HR 1 juli 1988, NJ 1989, 226, m.nt. Ma (Drukker).

254 Van den Ingh 1991, p. 205 en Asser/Maeijer, Van Solinge \& Nieuwe Weme 2-II* 2009, nr. 665 255 Van den Ingh 1991, p. 206 en Asser/Maeijer, Van Solinge \& Nieuwe Weme 2-II* 2009, nr. 665. 


\subsubsection{Rechten van de certificaathouder}

\subsubsection{Algemeen}

Ten aanzien van de rechten van de certificaathouder moet in het kader van de genoemde driehoeksverhouding een onderscheid gemaakt worden tussen rechten van de certificaathouder jegens het administratiekantoor en rechten van de certificaathouder jegens de BV.

Ten aanzien van de rechten van de certificaathouder jegens het administratiekantoor zijn de statuten van het administratiekantoor en de beheersovereenkomst, belichaamd in de administratievoorwaarden, van belang. Bij de statuten kunnen aan de certificaathouders bepaalde (zeggenschaps-)rechten zijn toegekend. Bijvoorbeeld ten aanzien van het bestuur van het administratiekantoor, zoals de benoeming van een of meer bestuurders. ${ }^{256}$ Ook denkbaar is de bepaling dat het administratiekantoor bij belangrijke besluiten het stemrecht op de aandelen in de vennootschap slechts kan uitoefenen nadat de certificaathouders dit hebben goedgekeurd of dat daarvoor een gekwalificeerde meerderheid geldt. Bij 'belangrijke besluiten' kan worden gedacht aan onderwerpen als het wijzigen van de administratievoorwaarden, de doelomschrijving van het administratiekantoor of de samenstelling van het bestuur. Veelal worden deze rechten uitgeoefend door een orgaan van het administratiekantoor, zijnde de vergadering van certificaathouders. ${ }^{257}$

In de administratievoorwaarden zijn in de regel bepalingen opgenomen over het register van certificaathouders, de inzage in en het verkrijgen van een uittreksel in dat register, de levering en overgang van certificaten, de vergadering van certificaathouders, de oproeping van een dergelijke vergadering en het stemrecht in die vergadering, de administratie van de door het administratiekantoor in de vennootschap gehouden aandelen en de vervreemding van die aandelen, het doen van een voorstel door de certificaathouders over de wijze waarop het administratiekantoor het stemrecht uitoefent, het dividend en andere uitkeringen (in de regel inhoudende dat het administratiekantoor het dividend op de aandelen en andere uitkeringen van de vennootschap int en aan de certificaathouder voldoet), het overeenkomstige voorkeursrecht van certificaathouders bij uitgifte van nieuwe certificaten bij uitgifte van nieuwe aandelen door de vennootschap, de uitoefening van claimrechten, het wettelijk pandrecht van de certificaathouder op de aandelen in de vennootschap (bij certificaten met vergaderrecht), het verval van het recht op uitkering, decertificering, wijziging van de administratievoorwaarden, kosten aan de administratie verbonden en een geschillenregeling. ${ }^{258}$ De statuten van de vennootschap zijn van belang voor

256 Van den Ingh beschrijft diverse varianten van de bestuurssamenstelling: zie Van den Ingh 1991, p. 198-202.

257 Asser/Maeijer, Van Solinge \& Nieuwe Weme 2-II* 2009, nr. 663.

$258 \mathrm{Zie}$ voor een geval waarin aan de certificaathouders vergaande bevoegdheden zijn toegekend: Hof Amsterdam (OK) 7 augustus 2002, JOR 2002, 194 (De Hooge Bergsche Golfclub/De Rotte Bergen). 
het antwoord op de vraag of aan de certificaten vergaderrecht is verbonden (art. 2:227 lid $2 \mathrm{BW}$ ). Ik verwijs naar paragraaf 4.4.3.

Omdat sprake is van een contractuele verhouding tussen de certificaathouder en het administratiekantoor, zijn de redelijkheid en billijkheid van art. 6:2 en 6:248 BW in die verhouding van toepassing. In paragraaf $7.3 \mathrm{kom}$ ik daarop terug.

\begin{tabular}{|l|l|l|}
\hline & $\begin{array}{l}\text { Alle certificaathouders hebben jegens de BV de volgende } \\
\text { rechten }^{259}\end{array}$ & $\begin{array}{l}\text { BW Boek 2 } \\
\text { art. }\end{array}$ \\
\hline 1. & $\begin{array}{l}\text { het recht op inzage in de boeken en bescheiden en andere } \\
\text { gegevensdragers van de BV na haar ontbinding }\end{array}$ & 24 lid 4 \\
\hline 2. & het recht op gelijke behandeling & 201 lid 2 \\
\hline 3. & $\begin{array}{l}\text { het indienen van een enquêteverzoek ex art. 2:345 BW kan } \\
\text { bij een BV met een geplaatst kapitaal van maximaal } € 22,5 \\
\text { miljoen op grond van art. 2:346 lid 1 aanhef onder b BW } \\
\text { worden ingediend door een of meer certificaathouders die } \\
\text { gezamenlijk ten minste één tiende van het geplaatste } \\
\text { kapitaal vertegenwoordigen of rechthebbenden zijn op een } \\
\text { bedrag van certificaten daarvan tot een nominale waarde } \\
\text { van } € 225.000 \text { of zoveel minder als de statuten bepalen } \\
\mathrm{b}^{260}\end{array}$ \\
\hline 4. & $\begin{array}{l}\text { het recht op inzage in of een afschrift van een beperkte } \\
\text { balans en toelichting, indien de vennootschap geen winst } \\
\text { beoogt }\end{array}$ & $\begin{array}{l}396 \text { lid } 8 \text { jo. } \\
\text { lid 9 onder a }\end{array}$ \\
\hline
\end{tabular}

In aanvulling op deze rechten is het voor de rechten van de certificaathouder jegens de BV van belang of aan de certificaten vergaderrecht is verbonden. Indien dat het geval is, is sprake van een lidmaatschapsverhouding tussen de certificaathouder en de vennootschap. ${ }^{261}$

259 De in deze paragraaf weergegeven overzichten van rechten van houders van certificaat met en zonder vergaderrecht zijn deels ontleend aan Van den Ingh 1991, p. 245-246; Van den Ingh 2003 (1), p. 181-182; Van den Ingh 2003 (2), p. 2-3 en Portier 2008, p. 256-257.

260 Uitgaande van de Wet van 18 juni 2012 tot wijziging van boek 2 van het Burgerlijk Wetboek in verband met de aanpassing van het recht van enquête (Kamerstukken 32 887, Stb. 2012, 274). Deze wet zal inwerking treden op 1 januari 2013 (Stb. 2012, 305). Bij een BV met een geplaatst kapitaal van meer dan $€ 22,5$ miljoen geldt op grond van art. 2:346 lid 1 sub c (nieuw) BW een percentage van één procent.

261 Hamers 1996, p. 84-85 en de aldaar aangehaalde literatuur. Hamers komt tot de conclusie dat de heersende opvatting in de literatuur is dat houders van bewilligde certificaten in een lidmaatschapsverhouding tot de vennootschap staan. Ik zie niet in - naar terminologie van de flex-bv - waarom voor de certificaathouder met vergaderrecht tot een andere conclusie gekomen zou worden. Hamers 1996 , p. 87 , komt overigens ook tot de conclusie dat wanneer de vennootschap geen medewerking verleent aan de certificering onder omstandigheden toch een lidmaatschapsverhouding kan ontstaan tussen de vennootschap en de houder van een onbewilligd certificaat. 


\begin{tabular}{|c|c|c|}
\hline & $\begin{array}{l}\text { Alleen houders van certificaten met vergaderrecht } \\
\text { hebben de volgende rechten }\end{array}$ & $\begin{array}{l}\text { BW Boek } 2 \\
\text { art. }\end{array}$ \\
\hline 1. & $\begin{array}{l}\text { het instellen van een vordering tot vernietiging van be- } \\
\text { sluiten van een orgaan van de vennootschap }\end{array}$ & 15 \\
\hline 2. & $\begin{array}{l}\text { het recht (als vergadergerechtigde) ingeschreven te worden } \\
\text { in het aandeelhoudersregister }\end{array}$ & $194 \operatorname{lid} 1$ \\
\hline 3. & $\begin{array}{l}\text { het recht om niet een uittreksel uit het aandeelhouders- } \\
\text { register te verkrijgen met betrekking tot zijn certificaat }\end{array}$ & $194 \operatorname{lid} 4$ \\
\hline 4. & het recht van inzage in het aandeelhoudersregister & 194 lid 5 \\
\hline 5. & $\begin{array}{l}\text { het recht op inzage in de beschrijving van de inbreng op } \\
\text { aandelen anders dan in geld bij gelegenheid van de } \\
\text { oprichting }\end{array}$ & 204a lid 1 \\
\hline 6. & $\begin{array}{l}\text { het recht op inzage in de beschrijving van de inbreng op } \\
\text { aandelen anders dan in geld na oprichting }\end{array}$ & 204b lid 1 \\
\hline 7. & $\begin{array}{l}\text { het recht om kennis te nemen van de opgemaakte jaar- } \\
\text { rekening en het recht van instemming, zoals bedoeld in } \\
\text { art. 2:238 lid } 1 \mathrm{BW} \text {, met de vaststelling van de jaarrekening } \\
\text { door ondertekening van de jaarrekening door alle be- } \\
\text { stuurders en commissarissen, indien alle aandeelhouders } \\
\text { tevens bestuurder van de vennootschap zijn, welke vast- } \\
\text { stelling tevens tot kwijting aan de bestuurders en com- } \\
\text { missarissen strekt }\end{array}$ & $210 \operatorname{lid} 5^{262}$ \\
\hline 8. & $\begin{array}{l}\text { het recht de opgemaakte rekening, het jaarverslag en de in } \\
\text { art. 2:392 lid 1 BW genoemde gegevens te kunnen inzien } \\
\text { en het recht op een kosteloos afschrift van deze stukken }\end{array}$ & 212 \\
\hline 9. & $\begin{array}{l}\text { het verkrijgen van inlichtingen tijdens de algemene ver- } \\
\text { gadering }\end{array}$ & $217 \operatorname{lid} 2$ \\
\hline 10. & $\begin{array}{l}\text { het recht te verzoeken te worden gemachtigd om de } \\
\text { algemene vergadering bijeen te roepen }\end{array}$ & $\begin{array}{l}220 \text { lid } 2 \text { jo. } \\
\text { lid } 1\end{array}$ \\
\hline
\end{tabular}

262 Kamerstukken II 2006/07, 31 058, nr. 3, p. 76 (MvT) en Kamerstukken II 2010/11, 32 426, nr. 8, p. 15 (Nota van wijziging): "In het in artikel 210 lid 5 geschetste geval zijn alle aandeelhouders tevens bestuurder, zodat de kennisneming van de opgemaakte jaarrekening alleen betrekking heeft op de 'overige' vergadergerechtigden." Uit dit citaat volgt dat de stemrechtloze aandeelhouder dit recht niet heeft, omdat het art. 2:210 lid $5 \mathrm{BW}$ alleen van toepassing is indien die stemrechtloze aandeelhouder tevens bestuurder van de vennootschap is en er daarnaast overige vergadergerechtigden zijn. Zie ook Kamerstukken II 2008/09, 31 058, nr. 6, p. 39 (NV II) en Kamerstukken II 2008/ 09, 31058 , nr. 7, p. 18 (Nota van wijziging). 


\begin{tabular}{|c|c|c|}
\hline & $\begin{array}{l}\text { Alleen houders van certificaten met vergaderrecht } \\
\text { hebben de volgende rechten }\end{array}$ & $\begin{array}{l}\text { BW Boek } 2 \\
\text { art. }\end{array}$ \\
\hline 11. & $\begin{array}{l}\text { het recht de voorzieningenrechter te verzoeken te worden } \\
\text { gemachtigd er toe over te gaan om de bij art. 2:218 BW of } \\
\text { de statuten voorgeschreven algemene vergadering te doen } \\
\text { houden, indien zij die krachtens art. } 2: 219 \mathrm{BW} \text { tot de } \\
\text { bijeenroeping bevoegd zijn in gebreke zijn gebleven }\end{array}$ & $\begin{array}{l}222 \text { jo. } 220 \\
\text { lid } 2\end{array}$ \\
\hline 12. & $\begin{array}{l}\text { het recht door middel van een oproepingsbrief te worden } \\
\text { opgeroepen voor de algemene vergadering }\end{array}$ & 223 lid 1 \\
\hline 13. & $\begin{array}{l}\text { het recht - indien de certificaathouder hiermee instemt - } \\
\text { langs elektronische weg te worden opgeroepen voor de } \\
\text { algemene vergadering, tenzij de statuten anders bepalen }\end{array}$ & $223 \operatorname{lid} 2$ \\
\hline 14. & $\begin{array}{l}\text { het instemmingsrecht dat besluitvorming plaatsvindt ten } \\
\text { aanzien van onderwerpen waarvan de behandeling niet bij } \\
\text { de oproeping is aangekondigd met inachtneming van de } \\
\text { oproepingstermijn }\end{array}$ & $224 \operatorname{lid} 2$ \\
\hline 15. & $\begin{array}{l}\text { het recht schriftelijk de behandeling van een bepaald } \\
\text { onderwerp in de algemene vergadering te verzoeken }\end{array}$ & $\begin{array}{l}224 \mathrm{a} \text { lid } 2 \text { jo. } \\
\text { lid } 1\end{array}$ \\
\hline 16. & $\begin{array}{l}\text { het recht van instemming dat besluitvorming plaatsvindt, } \\
\text { omdat de oproeping of de wettelijke termijn van oproeping } \\
\text { van acht dagen niet in acht is genomen }\end{array}$ & 225 \\
\hline 17. & $\begin{array}{l}\text { het recht van instemming ten aanzien van een besluit tot } \\
\text { statutenwijziging, waarbij (na oprichting van de BV) een } \\
\text { statutaire plaats buiten Nederland voor het houden van een } \\
\text { algemene vergadering wordt aangewezen }\end{array}$ & 226 lid 2 \\
\hline 18. & $\begin{array}{l}\text { het recht van instemming de algemene vergadering op een } \\
\text { andere plaats te houden dan statutair voorgeschreven }\end{array}$ & $226 \operatorname{lid} 3$ \\
\hline 19. & $\begin{array}{l}\text { het recht de algemene vergadering bij te wonen en daarin } \\
\text { het woord te voeren }\end{array}$ & 227 lid 1 \\
\hline 20. & $\begin{array}{l}\text { het recht van instemming ten aanzien van een besluit tot } \\
\text { statutenwijziging dat tot gevolg heeft dat het vergaderrecht } \\
\text { aan één of meer certificaathouders wordt ontnomen }\end{array}$ & 227 lid 4 \\
\hline 21. & $\begin{array}{l}\text { het recht zich te doen vertegenwoordigen door een advo- } \\
\text { caat, notaris, registeraccountant of accountant-administra- } \\
\text { tieconsulent }\end{array}$ & 227 lid 5 \\
\hline 22. & $\begin{array}{l}\text { het recht op inzage in de aantekeningen die het bestuur } \\
\text { houdt van de besluiten in de algemene vergadering en } \\
\text { tegen ten hoogste de kostprijs hiervan een afschrift krijgen }\end{array}$ & 230 lid 4 \\
\hline
\end{tabular}




\begin{tabular}{|c|c|c|}
\hline & $\begin{array}{l}\text { Alleen houders van certificaten met vergaderrecht } \\
\text { hebben de volgende rechten }\end{array}$ & $\begin{array}{l}\text { BW Boek } 2 \\
\text { art. }\end{array}$ \\
\hline 23. & $\begin{array}{l}\text { het recht om kosteloos een afschrift te krijgen van het } \\
\text { voorstel tot wijziging van de statuten }\end{array}$ & $\begin{array}{l}233 \text { lid } 4 \text { jo. } \\
\text { lid } 3\end{array}$ \\
\hline 24. & $\begin{array}{l}\text { het recht om kosteloos een afschrift te krijgen van het } \\
\text { voorstel tot vermindering van het geplaatst kapitaal }\end{array}$ & $\begin{array}{l}208 \text { lid } 5 \text { jo. } \\
233 \text { lid } 3 \text { en } 4\end{array}$ \\
\hline 25. & $\begin{array}{l}\text { het recht van instemming indien de besluitvorming van } \\
\text { aandeelhouders op een andere wijze dan in een vergadering } \\
\text { geschiedt }\end{array}$ & 238 lid 1 \\
\hline 26. & $\begin{array}{l}\text { het recht op inzage in en een kosteloos afschrift van } \\
\text { stukken die in verband met een juridische fusie of een } \\
\text { juridische splitsing ten kantore van de vennootschap zijn } \\
\text { neergelegd }\end{array}$ & $\begin{array}{l}329 \text { jo. } 314 \\
\text { lid } 2 \text { en } 334 \text { dd } \\
\text { jo. } 334 \text { h lid } 2\end{array}$ \\
\hline
\end{tabular}

Volledigheidshalve ga ik in op de rechten van het administratiekantoor - hoewel geen kapitaalverschaffer zonder stemrecht - jegens de vennootschap. ${ }^{263}$ Als aandeelhouder (en vergadergerechtigde) heeft het dezelfde rechten als een 'gewone' aandeelhouder. Ik noem bijvoorbeeld het stemrecht op het aandeel, het recht op gelijke behandeling (art. 2:201 lid $2 \mathrm{BW}$ ) en het recht tot het indienen van een enquêteverzoek ex art. 2:345 BW door een of meer aandeelhouders die gezamenlijk ten minste een tiende van het geplaatste kapitaal vertegenwoordigen (art. 2:346 lid 1 sub b BW). ${ }^{264}$ Uiteraard heeft het administratiekantoor recht op uitkeringen, waaronder dividend (art. 2:216 BW) en recht op het liquidatiesaldo (art. 2:23b BW). Voor het overige verwijs ik naar het in paragraaf 3.7.3 gegeven overzicht van rechten die aan een gewone aandeelhouder toekomen.

Op een aantal rechten van certificaathouders in verband met de invoering van de flex-BV ga ik in de volgende paragrafen in. Dat betreft achtereenvolgens het stemrecht (paragraaf 6.3.3.2), het vergaderrecht (paragraaf 6.3.3.3) en het ontnemen daarvan (paragraaf 6.3.3.4), de besluitvorming buiten vergadering (paragraaf 6.3.3.5), het wettelijk pandrecht ex art. 3:259 BW (paragraaf 6.3.3.6), de royeerbaarheid van certificaten (paragraaf 6.3.3.7), de omzetting van de BV in een andere rechtspersoon (paragraaf 6.3.3.8), de 'omzetting' (inbreng) van de BV in een personenvennootschap of eenmanszaak (paragraaf 6.3.3.9), fusie (paragraaf 6.3.3.10), splitsing

263 Zie ook Van den Ingh 1991, p. 263-267.

264 Hof Amsterdam (OK) 9 maart 2000, JOR 2000, 99 (Te Pas/Willem III). Uitgaande van de Wet van 18 juni 2012 tot wijziging van boek 2 van het Burgerlijk Wetboek in verband met de aanpassing van het recht van enquête (Kamerstukken 32 887, Stb. 2012, 274). Deze wet zal inwerking treden op 1 januari 2013 (Stb. 2012, 305). Bij een BV met een geplaatst kapitaal van meer dan $€ 22,5$ miljoen geldt op grond van art. 2:346 lid 1 sub c (nieuw) BW een percentage van één procent. 
(paragraaf 6.3.3.11), het recht van enquête (paragraaf 6.3.3.12), de geschillenregeling (paragraaf 6.3.3.13) en, tot slot, de redelijkheid en billijkheid en vernietiging van besluiten (paragraaf 6.3.3.14). Voor het overgangsrecht in verband met de invoering van de flex-BV verwijs ik naar paragraaf 4.4.6.

\subsubsection{Het stemrecht}

Het stemrecht op de gecertificeerde aandelen wordt door het administratiekantoor uitgeoefend. In de literatuur wordt gesteld dat uit de titel van beheer in beginsel voortvloeit dat het administratiekantoor het belang van de certificaathouders voorop moet stellen. Bij het stemgedrag zal het administratiekantoor met de belangen op korte en lange termijn van de certificaathouders rekening moeten houden, ongeacht de normen die uit de statuten van het administratiekantoor en de administratievoorwaarden zouden voortvloeien. Deze belangen mogen niet onevenredig worden geschaad. Dat biedt een waarborg voor de bescherming van de belangen van certificaathouders. ${ }^{265}$ De statuten en de administratievoorwaarden zijn van belang om te bepalen in welke mate de certificaathouder invloed heeft op de besluitvorming in de algemene vergadering. Het administratiekantoor zal zich moeten richten naar de doelomschrijving, zoals opgenomen in de statuten. In de regel zal die doelomschrijving het belang van de certificaathouder omvatten of vooropstellen. Ook kan de doelomschrijving een norm voor stemgedrag inhouden. ${ }^{266}$ Daarnaast kunnen de administratievoorwaarden bepalen dat het administratiekantoor bij belangrijke besluiten het stemrecht op de aandelen in de vennootschap slechts kan uitoefenen nadat de certificaathouders zulks hebben goedgekeurd. De statuten en de administratievoorwaarden kunnen voorts regels geven over de verantwoordingsplicht van het administratiekantoor ten aanzien van het stemgedrag. Met andere woorden: de invloed van de certificaathouder op het stemgedrag van het administratiekantoor is afhankelijk van de omstandigheden van het geval en wordt bepaald door de inhoud van de statuten van het administratiekantoor en de administratievoorwaarden. Indien de certificaathouder vergadergerechtigd is, zal de invloed - zoals ik in paragraaf 6.3.3.3 zal bespreken - van de certificaathouder op de besluitvorming (verder) toenemen, zoals dat ook geldt voor de stemrechtloze aandeelhouder.

\subsubsection{Het vergaderrecht}

In paragraaf 4.4.3 besprak ik reeds het vergaderrecht als bedoeld in art. 2:227 BW. Onder het vergaderrecht wordt verstaan het recht om, in persoon of bij schriftelijk gevolmachtigde, de algemene vergadering bij te wonen en daar het woord te voeren. De statuten van de BV kunnen bepalen of er aan de certificaten vergaderrecht is

265 Van den Ingh 1991, p. 204-205; Brink 2004, p. 235 en Asser/Maeijer, Van Solinge \& Nieuwe Weme 2-II* 2009, nr. 665.

266 Asser/Maeijer, Van Solinge \& Nieuwe Weme 2-II* 2009, nr. 665. 
toegekend. De kenbaarheid van de vergadergerechtigden blijkt uit het aandeelhoudersregister. ${ }^{267}$ Dat geldt aldus ook voor de certificaathouder.

Of aan een certificaat vergaderrecht is verbonden, is niet enkel van belang vanwege dat ene recht. De wet koppelt aan de vergadergerechtigdheid tal van andere rechten, zoals uit het overzicht in paragraaf 6.3.3.1 blijkt. Het gaat bijvoorbeeld om het oproepingsrecht (art. 2:223 BW) en het recht kennis te nemen van oproepingsbrieven voor een algemene vergadering (art. 2:224 lid 1 BW), het recht om de voorzieningenrechter te verzoeken om een machtiging tot het bijeenroepen van een algemene vergadering (art. 2:220 BW) en besluitvorming in en buiten vergadering (respectievelijk lid 1 en 2 van art. 2:238 BW). Het vergaderrecht is dus van belang zowel voor het beïnvloeden van het besluitvormingsproces als voor de geldigheid van de besluitvorming. ${ }^{268}$ Niet inachtneming van deze rechten kan leiden tot nietigheid ex art. 2:14 BW of vernietigbaarheid ex art. 2:15 BW van besluiten. Daarmee is het vergaderrecht en de daaraan gekoppelde rechten een belangrijke factor die de interne verhoudingen van de certificaathouder als kapitaalverschaffer zonder stemrecht bepaald.

Op grond van art. 2:228 lid $2 \mathrm{BW}$ zijn statutaire regelingen die bepalen dat certificaten in het algemeen geen vergaderrecht hebben, dat alle certificaten vergaderrecht hebben of dat het vergaderrecht slechts toekomt aan bepaalde, in de statuten aangeduide certificaten, toegestaan. Uitgangspunt is dat de vennootschap zelf bepaalt of er certificaten met vergaderrecht worden toegelaten, en zo ja, aan welke certificaten dat vergaderrecht toekomt. Het zijn in beginsel de aandeelhouders die bepalen in hoeverre de besluitvorming in de algemene vergadering open staat voor anderen. ${ }^{269}$

Denkbaar is dat de statuten van de vennootschap bepalen dat de aan certificaten vergaderrecht verbonden kan worden. De vraag is dan of ingeval van certificering van aandelen het wettelijk pandrecht ontstaat. Naar mijn mening is dat gelet op de tekst van art. 2:227 lid 2 BW niet het geval. De statuten moeten daadwerkelijk het vergaderrecht aan de certificaten verbinden.

De laatste volzin van art. 2:227 lid 2 BW bepaalt dat de statuten kunnen bepalen dat het verbinden en ontnemen van vergaderrecht aan certificaten van aandelen geschiedt door een daartoe in de statuten aangewezen orgaan. Er zijn dus twee manieren om vergaderrecht aan certificaten te verbinden, te weten (i) toekenning bij statuten en (ii) toekenning door een orgaan, dat bij de statuten daartoe is aangewezen. ${ }^{270}$ Het orgaan dient een orgaan te zijn in de zin van art. 2:189a BW. Aldus kan de bevoegdheid tot het toekennen van vergaderrecht aan certificaten worden toegekend aan de vergadering van houders van aandelen van een bepaalde soort of aanduiding (waaronder dus ook de vergadering van stemrechtloze aandeelhouders),

267 Zie art. 2:194 lid 1 laatste volzin BW.

268 Vgl. Schwarz 1995, p. 204-205.

269 Kamerstukken II 2006/07, 31 058, nr. 3, p. 82 (MvT).

270 Kamerstukken II 2011/12, 32 426, nr. 13, p. 1. 
het bestuur, de raad van commissarissen en de gemeenschappelijke vergadering van het bestuur en de raad van commissarissen. Dat orgaan is in dat geval bevoegd om te besluiten dat aan een of meerdere certificaten vergaderrecht wordt verbonden of ontnomen. ${ }^{271}$

De mogelijkheid te bepalen dat het vergaderrecht slechts aan bepaalde, in de statuten aangeduide certificaten toekomt, maakt het tevens mogelijk een kwaliteitseis aan de certificaathouder te stellen. Bijvoorbeeld het zijn van werknemer ingeval van werknemerscertificaten. ${ }^{272}$ De statuten kunnen bepalen dat indien de arbeidsovereenkomst is geëindigd het orgaan het vergaderrecht aan het certificaat kan ontnemen. $^{273}$

Ten aanzien van het vergaderrecht is voorts van belang dat art. 2:196c BW bepaalt dat art. 2:196a en 2:196b BW van overeenkomstige toepassing zijn met betrekking tot de levering van een certificaat van een aandeel waaraan vergaderrecht is verbonden, met dien verstande dat de in art. 2:196b BW bedoelde overlegging of betekening geschiedt van een afschrift van de akte van levering. Dat houdt in dat het vergaderrecht eerst kan worden uitgeoefend nadat de BV de levering heeft erkend of nadat de akte van levering van het betreffende certificaat aan de vennootschap is betekend.

Zoals eerder opgemerkt, is een certificaat een vorderingsrecht op naam. Een dergelijk recht wordt geleverd op de wijze als bedoeld in art. 3:94 BW. Art. 2:196a lid 3 BW bepaalt dat indien de erkenning of betekening van de levering heeft plaatsgevonden zonder dat dit heeft geleid tot een daarop aansluitende wijziging in het register van aandeelhouders, deze levering noch aan de vennootschap noch aan anderen die te goeder trouw de in het aandeelhoudersregister ingeschreven persoon als aandeelhouder of eigenaar van een beperkt recht op een aandeel hebben beschouwd, kan worden tegengeworpen.

\subsubsection{Het ontnemen van het vergaderrecht aan het certificaat}

Het vergaderrecht kan aan het certificaat worden ontnomen. Art. 2:227 lid 4 BW bepaalt dat het aan certificaathouders bij statuten toegekende vergaderrecht slechts met instemming van die certificaathouder kan worden gewijzigd, tenzij bij het toekennen van het vergaderrecht de bevoegdheid tot wijziging uitdrukkelijk in de statuten was voorbehouden. ${ }^{274}$ In paragraaf 6.3.3.3 merkte ik op dat er twee

271 Kamerstukken II 2006/07, 31 058, nr. 3, p. 81-82 (MvT).

272 Daargelaten de vraag of het in alle gevallen verstandig is aan werknemers certificaten met vergaderrecht uit te geven. Het voorbeeld is ontleend aan Wouters 2011, p. 239.

273 In de administratievoorwaarden zal in de regel bepaald zijn dat de werknemer bij ontslag de door hem gehouden certificaten zal moeten aanbieden.

274 De mogelijkheid om de toekenning en ontneming van vergaderrecht ook mogelijk te maken door een besluit van een orgaan sluit aan bij de regeling voor stemrecht van pandhouders en vruchtgebruikers, waarbij de toekenning van stemrecht eveneens buiten de statuten om plaatsvindt (art. 2:197 lid 3 en 2:198 lid 3 BW), zie Kamerstukken II 2006/07, 31 058, nr. 3, p. 82 (MvT). 
manieren zijn om vergaderrecht aan certificaten te verbinden, te weten (i) toekenning bij statuten en (ii) toekenning door een orgaan, dat bij de statuten daartoe is aangewezen. Indien bij de toekenning van het vergaderrecht in de statuten bepaald is dat de regeling kan worden gewijzigd, is het instemmingsvereiste van de betrokken certificaathouder niet van toepassing. Er zijn aldus drie mogelijkheden het vergaderrecht aan het certificaat te ontnemen. Ten eerste, bij statuten is aan het certificaat vergaderrecht toegekend, maar het ontnemen van dat recht of wijziging daarvan is niet voorbehouden. De certificaathouder zal met het ontnemen van het vergaderrecht aan zijn certificaat moeten instemmen. Ten tweede, bij statuten is aan het certificaat vergaderrecht toegekend en het ontnemen van dat recht of wijziging daarvan is in dezelfde statutaire regeling voorbehouden. Het vergaderrecht kan op grond van de tenzij-clausule van art. 2:227 lid $4 \mathrm{BW}$ an het certificaat worden ontnomen (zonder dat daartoe instemming van de certificaathouder is vereist). ${ }^{275}$ Dat sluit ook aan bij de systematiek art. 2:232 BW, waarin is bepaald dat wijziging van een bepaling van de statuten, waarbij aan een ander dan aan aandeelhouders van de vennootschap als zodanig enig recht is toegekend, indien de gerechtigde in de wijziging niet toestemt, aan diens recht geen nadeel kan toebrengen, tenzij ten tijde van de toekenning van het recht de bevoegdheid tot wijziging bij die bepaling uitdrukkelijk was voorbehouden. Ten derde, de bevoegdheid tot het toekennen en ontnemen van vergaderrecht is toegekend aan een orgaan van de vennootschap in de zin van art. 2:189a BW. Dat orgaan kan zonder dat daartoe instemming van de certificaathouder is vereist het vergaderrecht aan het certificaat ontnemen: “(...) de vennootschap behoudt hierdoor flexibiliteit in het al dan niet toekennen, wijzigen en ontnemen van vergaderrecht. De certificaathouder weet dat hij voor de toekenning van vergaderrecht afhankelijk is van een besluit van een vennootschapsorgaan, en heeft dus geen statutair recht dat niet zonder diens toestemming kan worden gewijzigd." ${ }^{276}$ Daarbij ga ik ervan uit dat zowel de bevoegdheid tot het verbinden als de bevoegdheid tot het ontnemen van het vergaderrecht bij statuten aan het orgaan is toegekend. Deze derde mogelijkheid biedt de meeste flexibiliteit vanuit het oogpunt van de vennootschap en biedt tegelijkertijd de minste waarborgen voor de houder van een certificaat met vergaderrecht.

Theoretisch zou het toekennen aan een orgaan van de vennootschap van de bevoegdheid tot het verbinden van het vergaderrecht en de bevoegdheid tot het ontnemen van het vergaderrecht aan certificaten kunnen worden gesplitst. De parlementaire geschiedenis laat zich over een dergelijke splitsing echter niet uit. In dat geval laten zich meer dan de hiervoor geschetste drie mogelijkheden denken, waarbij in voorkomend geval bij het ontnemen van het vergaderrecht aan het

275 Kamerstukken II 2011/12, 32 426, nr. 13, p. 1. Daarmee is ook tegemoet gekomen aan kritiek op het oorspronkelijke ontwerp van art. 2:227 lid 4 BW. Van Veen 2008 (2), p. 5, pleitte voor meer flexibiliteit. Hij stelde dat bij de uitgifte van certificaten de wijzigingsbevoegdheid van art. 2:227 lid 4 BW reeds kan worden voorbehouden, zodat de instemmingseis toepassing mist.

276 Kamerstukken I 2011/12, 31058 en 32 426, nr. C, p. 7 (MvA I). 
certificaat alsnog instemming van de certificaathouder is vereist. De genoemde splitsing ligt echter niet voor de hand en goede statuten zullen de combinatie van het verbinden en het ontnemen van het vergaderrecht bij één orgaan (in)houden. In dat geval is er mijns inziens geen goede grond te veronderstellen dat bij een dergelijke, gecombineerde statutaire regeling de certificaathouder zou moeten instemmen met het besluit van het orgaan het vergaderrecht aan zijn certificaat te ontnemen. Immers, de bevoegdheid daartoe was de certificaathouder reeds bekend en ligt in de lijn met de tenzij-clausule van art. 2:227 lid 4 eerste volzin BW. ${ }^{277}$

Het ligt naar mijn mening niet voor de hand dat het ontnemen van het vergaderrecht ook mogelijk is voor bewilligde certificaten waaraan overeenkomstig art. V.2 lid 1 en 6 van het Overgangsrecht bij statutenwijziging vergaderrecht is toegekend en wiens houders op grond van datzelfde overgangsrecht als vergadergerechtigden in het aandeelhoudersregister zijn geregistreerd. Onder het oude recht bestond immers niet de mogelijkheid tot het ontnemen van het vergaderrecht aan bewilligde certificaten. Het zou ertoe leiden dat houders van deze certificaten in hun rechten worden aangetast. Wil de vennootschap toch in zijn algemeenheid in deze mogelijkheid voorzien, dan zullen deze 'oude' certificaathouders van deze mogelijkheid in de statuten moeten worden uitgezonderd. Wil de vennootschap ook ten aanzien van de 'oude' certificaathouders voorzien in de mogelijkheid tot het ontnemen van het vergaderrecht, dan zullen deze certificaathouders naar mijn mening volgens de hoofdregel van art. 2:227 lid 4 BW met een dergelijke statutenwijziging moeten instemmen. ${ }^{278}$

\subsubsection{Besluitvorming buiten vergadering}

In paragraaf 6.2.3.8 besprak ik de besluitvorming buiten vergadering ten aanzien van de stemrechtloze aandeelhouder. Ten aanzien van de certificaathouder met vergaderrecht geldt hetgeen in die paragraaf is opgemerkt op dezelfde wijze.

\subsubsection{Het wettelijk pandrecht ex art. 3:259 BW}

Op grond van art. 3:259 BW hebben de houders van certificaten met vergaderrecht een gezamenlijk, wettelijk pandrecht op de aandelen. ${ }^{279}$ Art. 3:259 lid 2 BW bepaalt onder meer dat indien de oorspronkelijke aandelen of schuldvorderingen op naam zijn gesteld en de certificaten zijn uitgegeven met medewerking van de uitgever van

277 In gelijke zin: Portengen 2007, p. 948; Portier 2008, p. 263 en Wouters 2011, p. 239. Anders: Nowak \& Van den Ingh 2007, p. 126. Van den Ingh heeft later zijn eerder ingenomen standpunt verlaten en zich aangesloten bij het standpunt van Portengen: zie Van den Ingh 2008, p. 8, noot 30.

278 In gelijke zin: Portier 2011, p. 51.

279 Voor een uitvoerige beschrijving van het pandrecht van certificaathouders onder het oude recht, welke beschrijving ook na invoering van de flex-BV relevant is, zie Van den Ingh 1991, p. 180-191 en Hamers 1996, p. 69-94. Zie ook Asser/Maeijer, Van Solinge \& Nieuwe Weme 2-II* 2009, nr. 667 en 668 . 
de oorspronkelijke aandelen of schuldvorderingen of er bij de statuten vergaderrecht verbonden is aan de certificaten van aandelen (onderstreping RAW), de certificaathouders tevens gezamenlijk een pandrecht op die aandelen of schuldvorderingen verkrijgen. Zijn de certificaten uitgegeven voor schuldvorderingen op naam zonder medewerking van de schuldenaar, dan verkrijgen de certificaathouders een zodanig pandrecht door mededeling van de uitgifte aan de schuldenaar. Art. 3:259 lid 3 BW geeft vervolgens een regeling op welke wijze dit pandrecht in voorkomend geval kan worden uitgeoefend. Kort gezegd, geeft het pandrecht ex art. 3:259 BW de houders van certificaten met vergaderrecht de bevoegdheid om bij niet-uitbetaling van de uitkeringen de aandelen overeenkomstig art. 3:259 lid 3 BW te doen verkopen en zich uit de opbrengst te voldoen. In een eerder stadium van de parlementaire behandeling van de wet overwoog de wetgever dat art. 3:259 BW een algemene regeling bevat die tevens ziet op certificaten van aandelen in een NV en op certificaten van schuldvorderingen en was de formulering van deze bepaling niet aangepast. Art. 2:227 BW heeft tot gevolg dat bij de toepassing van art. 3:259 BW ten aanzien van certificaten van aandelen in een BV slechts medewerking van de uitgever van de oorspronkelijke aandelen aangenomen kan worden, indien er sprake is van certificaten waaraan vergaderrecht in de zin van art. 2:227 BW is verbonden, aldus de wetgever. ${ }^{280}$ Later is de wetgever op het ongewijzigd laten van art. 3:259 BW teruggekomen en is aan de eerste volzin van lid 2 van art. 3:259 BW toegevoegd "of is er bij de statuten vergaderrecht verbonden aan de certificaten van aandelen". ${ }^{281}$ Reden voor deze toevoeging is dat in het BV-recht niet meer de bewilliging door de vennootschap van de uitgifte van de certificaten relevant is, maar het feit of de statuten vergaderrecht aan certificaten van aandelen toekennen. ${ }^{282}$ Ook hier speelt de problematiek van het overgangsrecht en de certificaathouder, zoals geschetst in paragraaf 4.4.6, een rol.

De vraag is of er met betrekking tot het wettelijk pandrecht een onderscheid moet worden gemaakt tussen certificaten waarbij het vergaderrecht bij de statuten is toegekend en certificaten waarbij het vergaderrecht door een orgaan is toegekend. Anders gezegd: de certificaten met vergaderrecht op grond van de eerste volzin van art. 2:227 lid $2 \mathrm{BW}$ en op grond van de laatste volzin van art. 2:227 lid $2 \mathrm{BW}$. Naar mijn mening moet een dergelijk onderscheid niet worden gemaakt. Uit de parlementaire geschiedenis blijkt niet dat de wetgever bedoeld heeft een dergelijk onderscheid te maken. Ik citeer: "Uitgangspunt van de voorgestelde regeling is dat de vennootschap zelf bepaalt of er certificaten met vergaderrecht worden toegelaten en zo ja, aan welke certificaten dat vergaderrecht toekomt. Het zijn

280 Kamerstukken II 2006/07, 31 058, nr. 3, p. 83 (MvT). Zie ook: Kamerstukken II 2009/10, 32 426, nr. 3, p. 6-7 (MvT) en Kamerstukken II 2010/11, 32 426, nr. 7, p. 7-8 (NV II).

281 In de Tweede Nota van Wijziging (Kamerstukken II 2011/12, 32 426, nr. 23, p. 2. Zie ook Gewijzigd voorstel van wet, Kamerstukken I 2011/12, 32 426, nr. A, p. 16), waarin wordt gesproken over een wijziging van art. 3:259 lid 3 BW. Dat moet op een verschrijving berusten en moet zijn art. 3:259 lid 2 BW.

282 Kamerstukken II 2011/12, 32 426, nr. 23, p. 3 (Tweede Nota van Wijziging). 
dus in beginsel de aandeelhouders die bepalen in hoeverre de besluitvorming in de algemene vergadering open staat voor anderen. (onderstreping RAW)". ${ }^{283}$ De woorden 'in beginsel de aandeelhouders' zien, mijns inziens, ten eerste op de eerste volzin van art. 2:227 lid 2 BW. De aandeelhouders gaan over de statuten en zij kunnen dus bij statuten vergaderrecht aan certificaten verbinden. ${ }^{284}$ Ten tweede zien die woorden, zo komt mij voor, ook op de laatste volzin van art. 2:227 lid 2 BW, namelijk dat een ander orgaan dan de algemene vergadering kan besluiten aan certificaten vergaderrecht te verbinden. Voor de hand ligt dat dit andere orgaan het bestuur van de vennootschap is. Die regeling behoeft een statutaire grondslag, waarvan het primaat bij de algemene vergadering ligt. Heeft de algemene vergadering tot een dergelijke statutaire regeling besloten, dan is feitelijk sprake van een delegatie van bevoegdheid. Waar de algemene vergadering op grond van de eerste volzin van art. 2:227 lid $2 \mathrm{BW}$ kan besluiten de statuten zodanig in te richten dat aan certificaten vergaderrecht toekomt, besluit zij op grond van de laatste volzin van art. 2:227 lid $2 \mathrm{BW}$ dat aan certificaten vergaderrecht kan worden toegekend, doch of, en zo ja wanneer, dat feitelijk - vanwege de delegatie van bevoegdheid - zal plaatsvinden, is afhankelijk van een ander orgaan. Dat orgaan is bovendien door de algemene vergadering in een statutaire regeling aangewezen.

Daarnaast volgt uit dit citaat uit de memorie van toelichting dat geen onderscheid wordt gemaakt tussen een eerste of laatste volzin van een art. 2:227 lid 2 BWsituatie. De wetgever noemt slechts art. 2:227 BW als geheel: "De nieuwe regeling in artikel 227 heeft tot gevolg dat men bij de toepassing van artikel 3:259 BW ten aanzien van certificaten van aandelen in een bv slechts medewerking van de uitgever van de oorspronkelijke aandelen zal kunnen aannemen, indien er sprake is van certificaten waaraan vergaderrecht in de zin van artikel 227 is verbonden." 285

Een andere vraag is of het ontnemen van het vergaderrecht aan de certificaten door een daartoe in de statuten aangewezen orgaan het wettelijk pandrecht doet vervallen. Mijns inziens luidt het antwoord op die vraag positief, gelijk het verbinden van het vergaderrecht aan het certificaat het wettelijk pandrecht doet ontstaan.

Het voorgaande vergt zorgvuldigheid in de vastlegging van de besluitvorming. Indien het bestuur op grond van een statutaire regeling als orgaan vergaderrecht aan certificaten mag toekennen en ontnemen, dan is het ter zake van de vastlegging van dat besluit gebonden aan het bepaalde in art. 2:230 lid 4 BW. Indien dat orgaan de vergadering van stemrechtloze aandeelhouders is, geldt die gebondenheid aan art. 2:230 lid 4 BW niet. Ik verwijs naar paragraaf 4.2.8. Ook het bijhouden van

283 Kamerstukken II 2006/07, 31 058, nr. 3, p. 82 (MvT).

284 Vgl. Schwarz 2012 (2), p. 216 in het kader van het overgangsrecht voor certificaathouders. Schwarz komt tot de conclusie dat de bevoegdheid tot erkenning van vergadergerechtigdheid van - onder het oude recht - houders van bewilligde certificaten naar - onder het nieuwe recht - houders van certificaten met vergaderrecht slechts aan de algemene vergadering toekomt.

285 Kamerstukken II 2006/07, 31 058, nr. 3, p. 83 (MvT). Zie ook Kamerstukken II 2011/12, 32 426, nr. 23, p. 3 (Tweede Nota van Wijziging). 
het aandeelhoudersregister zal in dit geval extra aandacht vergen. Op grond van art. 2:194 BW rust die verplichting op het bestuur van de vennootschap. Ik verwijs naar paragraaf 4.11. Indien het bestuur op grond van een statutaire regeling als orgaan vergaderrecht aan certificaten mag toekennen en ontnemen, mag worden verwacht dat het bij het besluit tot toekenning ook direct zorg draagt voor inschrijving van de certificaathouder als vergadergerechtigde en dat het bij het besluit tot ontneming die aantekening direct weer voor doorhaling zorg draagt.

\subsubsection{Royeerbaarheid van certificaten}

In paragraaf 4.4 .4 besprak ik wat verstaan wordt onder niet royeerbare, beperkt royeerbare en royeerbare certificaten. De vraag of certificaten al dan niet royeerbaar zijn, is relevant voor de verhouding van de houder van het certificaat tot de vennootschap. Afhankelijk van het antwoord op die vraag, kan de certificaathouder in voorkomend geval zijn certificaat omwisselen voor een aandeel, zodat zijn stemrecht 'herleeft'. In dat geval ziet de tot aandeelhouder geworden certificaathouder - weliswaar afhankelijk van de stemverhoudingen - zijn invloed op de besluitvorming in de algemene vergadering toenemen. Daarmee is de vraag of certificaten al dan niet royeerbaar zijn relevant voor de verhouding van de houder van het certificaat tot de vennootschap.

In paragraaf 4.4.4 stelde ik dat in de administratievoorwaarden kan worden bepaald of, en zo ja, onder welke voorwaarden, de certificaten tegen aandelen om te wisselen zijn. Wat is de situatie indien de administratievoorwaarden daarover zwijgen? In de literatuur zijn er twee opvattingen. De ene opvatting houdt in dat indien de administratievoorwaarden niets zeggen over de al dan niet (beperkte) royeerbaarheid de certificaten (onbeperkt) royeerbaar zijn. ${ }^{286}$ De andere opvatting is het spiegelbeeld daarvan. Laten de administratievoorwaarden zich niet over de al dan niet (beperkte) royeerbaarheid van de certificaten uit, dan zijn ze niet royeerbaar. $^{287}$ Deze opvatting gaat ervan uit dat de certificaathouder een vorderingsrecht op het administratiekantoor heeft tot royement van zijn certificaat, waartegenover het administratiekantoor het daarmee corresponderende aandeel aan de certificaathouder overdraagt. Dat recht is opgenomen in de administratievoorwaarden. Is daarover niets bepaald, dan bestaat dat recht derhalve niet. Niettemin kunnen het administratiekantoor en de certificaathouder alsnog anders overeenkomen. Dat houdt dan echter wel een wijziging van de bestaande contractuele verhouding in, waarvoor de algemene regels van het verbintenissenrecht gelden. Deze opvatting gaat naar mijn mening uit van de meest zuivere redenering. Ik sluit me daarom bij die opvatting aan.

286 Van den Ingh 1991, p. 78; Asser/Maeijer, Van Solinge \& Nieuwe Weme 2-II* 2009, nr. 662 en Dortmond 1990, p. 285.

287 J.B. Huizink, Groene Serie Rechtspersonen, art. 2:82 BW, aant. 8b, Deventer: Kluwer. 


\subsubsection{Omzetting van de BV in een andere rechtspersoon}

Ten aanzien van de positie van de certificaathouder bij omzetting van de BV in een andere rechtspersoon geldt het volgende. Op de omzetting is art. 2:18 BW van toepassing. Voor de omzetting is - kort gezegd - vereist (i) een besluit tot omzetting, (ii) een besluit tot wijziging van de statuten en (iii) een notariële akte tot omzetting die de nieuwe statuten van de omgezette rechtspersoon bevat. Niet alleen speelt deze vraag bij omzetting van de BV in een $\mathrm{NV}$, maar ook bij de omzetting van de BV in een andere rechtspersoon, bijvoorbeeld een stichting, coöperatie of vereniging. De houder van een certificaat van aandeel kan wegens het ontbreken van stemrecht immers geen invloed op het besluit tot omzetting uitoefenen. Art. 2:181 BW en 2:182 BW zijn blijkens de tekst van die artikelen op de houder van een certificaat niet van toepassing.

In de praktijk zal de omzetting van een BV in een NV vaker voorkomen dan de omzetting van de BV in een andere rechtspersoon dan de NV. In de literatuur wordt aangenomen dat het administratiekantoor bevoegd is het stemrecht uit te oefenen ten aanzien van het voorstel tot omzetting in een NV en de statutenwijziging in dat kader.

Niettemin zal het administratiekantoor de certificaathouder bij de besluitvorming moeten betrekken indien sprake is van afbreuk van de financiële rechten van de certificaathouders. ${ }^{288}$ Het administratiekantoor houdt de aandelen immers ten titel van beheer voor de certificaathouders. Het administratiekantoor zal in beginsel het belang van de certificaathouders moeten dienen. Een omzetting in een NV kan de verhouding tussen het administratiekantoor en de certificaathouders ingrijpend wijzigen. Het besluit tot omzetting en het daaropvolgende besluit tot statutenwijziging zijn belangrijke besluiten. In de literatuur is daarover opgemerkt dat afhankelijk van de inhoud van de statutenwijziging aan de certificaathouder een ontbindingsrecht ten aanzien van de administratievoorwaarden, althans de verhouding tussen de certificaathouder en het administratiekantoor, toekomt. ${ }^{289}$ In voorkomend geval doet het (bestuur van het) administratiekantoor er naar mijn mening goed aan de vergadering van certificaathouders te raadplegen - voor zover een dergelijke verplichting niet reeds in de administratievoorwaarden is opgenomen - en zowel het voorstel tot omzetting als de statutenwijzing in die vergadering in stemming te brengen, alvorens het administratiekantoor haar stem in de algemene vergadering uitbrengt. ${ }^{290}$ Dit klemt te meer, indien sprake is van certificaten met

288 Van den Ingh 1991, p. 208 en 243.

289 Van den Ingh 1991, p. 243.

290 Anders: Van den Ingh 1991, p. 243. Van den Ingh stelt dat het administratiekantoor zelfstandig kan stemmen over een besluit tot omzetting, maar dat dit ten aanzien van het besluit tot statutenwijziging anders kan zijn. Ik zie niet in waarom tussen deze twee besluiten een onderscheid gemaakt zou moeten worden. Beide besluiten gaan de certificaathouder aan. Juist over een belangrijk besluit als dat tot omzetting ligt raadpleging van de vergadering van certificaathouder in de rede alvorens het administratiekantoor haar stem in de algemene vergadering uitbrengt. 
vergaderrecht, welke na omzetting vergaderrecht moeten ontberen. Het administratiekantoor zal naar mijn mening met inachtneming van de uitslag van de stemming in de vergadering van certificaathouders voor dan wel tegen het besluit tot omzetting en statutenwijziging moeten stemmen, corresponderend met het aantal voor- en tegenstemmen in de vergadering van certificaathouders.

Ten aanzien van het aan het certificaat verbonden vergaderrecht kent de wet een specifieke regeling in art. 2:227 lid 4 BW. Slechts met instemming van de certificaathouder kunnen de statuten worden gewijzigd waarbij het vergaderrecht wordt ontnomen, tenzij deze bevoegdheid bij de toekenning van het vergaderrecht was voorbehouden. Alleen krachtens het BV-recht kan aan een certificaat vergaderrecht verbonden worden. Het NV-recht kent alleen bewilligde of niet-bewilligde certificaten. Indien een BV wordt omgezet in een NV en de NV de certificaten als bewilligde certificaten beschouwt, zal de in het kader van de omzetting noodzakelijke statutenwijziging in de regel de instemming van de certificaathouder hebben. Sterker, naar mijn mening is in dat geval de instemming van de certificaathouder niet vereist. ${ }^{291}$ Dat ligt anders indien de NV geen bewilligde certificaten kent of de certificaten met vergaderrecht als niet-bewilligd aanmerkt. In dat geval wordt het vergaderrecht aan het certificaat ontnomen en is op grond van art. 2:227 lid 4 BW de instemming van de certificaathouder vereist.

Overigens zal, gelet op de procedure zoals in art. 2:18 BW beschreven, de certificaathouder met vergaderrecht reeds bij de besluitvorming in de BV ten aanzien van de omzetting betrokken zijn. Voor de omzetting van een BV in een $\mathrm{NV}$ wijs ik volledigheidshalve op het bepaalde in art. 2:72 BW, inhoudende dat kort gezegd - het eigen vermogen van de vennootschap voor de omzetting ten minste overeenkwam met het gestorte en opgevraagde deel van het kapitaal.

\subsubsection{9 'Omzetting' (inbreng) van de BV in een personenvennootschap en andersom}

In deze paragraaf staan de gevolgen voor de certificaathouder bij omzetting van een $\mathrm{BV}$ in een personenvennootschap en andersom centraal. Onder personenvennootschappen wordt verstaan de eenmanszaak, de vennootschap onder firma, de commanditaire vennootschap en de maatschap.

Indien een BV wordt omgezet in een vennootschap onder firma is in juridische zin sprake van ontbinding van de BV in de zin van art. 2:19 BW. Een van de door art. 2:19 BW genoemde gevallen waarin de rechtspersoon, althans in dit geval de $\mathrm{BV}$, wordt ontbonden is een daartoe strekkend besluit van de algemene vergadering. Als gevolg van dat besluit moet worden vereffend. Gedurende de vereffening blijft de BV bestaan. Het administratiekantoor heeft ex art. 2:23b BW recht op het liquidatiesaldo, tenzij de statuten van de vennootschap zulks uitsluiten. In de regel

291 In gelijke zin: Nagtegaal \& Snijder-Kuipers 2012, p. 244. 
zal in de administratievoorwaarden bepaald zijn dat de uitkering van het liquidatiesaldo de certificaathouders ten goede komt. Het administratiekantoor oefent het stemrecht in de algemene vergadering uit. Het administratiekantoor houdt de aandelen immers ten titel van beheer voor de certificaathouders. Het administratiekantoor zal bij het uitbrengen van haar stem in beginsel het belang van de certificaathouders moeten dienen. Ook bij een besluit tot ontbinding zou ik willen bepleiten dat het administratiekantoor er goed aan doet over een dergelijk belangrijk besluit de vergadering van certificaathouder te radplegen - voor zover een dergelijke verplichting niet reeds in de administratievoorwaarden is opgenomen alvorens het administratiekantoor haar stem in de algemene vergadering uitbrengt. Het administratiekantoor zal naar mijn mening met inachtneming van de uitslag van de stemming in de vergadering van certificaathouders voor dan wel tegen het besluit tot ontbinding moeten stemmen, corresponderend met het aantal voor- en tegenstemmen in de vergadering van certificaathouders. Ook hier geldt dat, gelet op de procedure zoals in art. 2:19 BW beschreven, de certificaathouder met vergaderrecht reeds bij de besluitvorming in de BV ten aanzien van de ontbinding betrokken zal zijn.

In de omgekeerde situatie, namelijk de omzetting van een vennootschap onder firma in een BV, is in juridische zin sprake van ontbinding van de vennootschap onder firma. Er wordt een besluit tot ontbinding van de vennootschap onder firma genomen, welke vennootschap wordt voorgezet als BV i.o. Vervolgens verplichten de vennoten zich tot oprichting van een BV. In deze voorovereenkomst worden tal van onderwerpen geregeld, zoals de inbreng, naam, plaats en doel van de vennootschap. Bij akte van oprichting wordt vervolgens de BV opgericht. Het is aan de vennoten van de vennootschap onder firma en de hen gegeven (contracts)vrijheid bij of na oprichting van de BV te kiezen voor stemrechtloze aandelen in het kapitaal van die BV. Op gelijke wijze geldt een en ander ook voor de eenmanszaak, de maatschap of de commanditaire vennootschap.

\subsubsection{Fusie}

Op grond van art. 2:317 lid $1 \mathrm{BW}$ wordt het besluit tot fusie genomen door de algemene vergadering. Art. 2:317 lid $3 \mathrm{BW}$ geeft een nadere regeling ten aanzien van dat besluit. Een besluit tot fusie wordt genomen op dezelfde wijze als een besluit tot wijziging van de statuten. Vereist de wet voor een besluit tot statutenwijziging de instemming van alle aandeelhouders of bepaalde aandeelhouders, dan geldt dit ook voor het besluit tot fusie. Vereisen de statuten hiervoor goedkeuring, dan geldt dit ook voor het besluit tot fusie. Vereisen de statuten voor de wijziging van afzonderlijke bepalingen verschillende meerderheden, dan is voor een besluit tot fusie de grootste daarvan vereist, en sluiten de statuten wijziging van bepalingen uit, dan zijn de stemmen van alle stemgerechtigde leden of aandeelhouders vereist; een en ander tenzij die bepalingen na de fusie onverminderd zullen gelden. 
Art. 2:317 lid $3 \mathrm{BW}$ geldt niet indien de statuten een andere regeling voor besluiten tot fusie geven (art. 2:317 lid 4 BW).

Op welke wijze worden certificaathouders in geval van fusie beschermd? Art. 2:227 lid 4 BW bepaalt dat een statutaire regeling waarbij an certificaathouders vergaderrecht is toegekend slechts met instemming van de betrokken certificaathouders kan worden gewijzigd. Moeten certificaathouders met vergaderrecht in de verdwijnende vennootschap instemmen met het besluit tot fusie waarbij die certificaathouders in de verkrijgende vennootschap geen vergaderrecht toekomt? Een bevestigend antwoord op die vraag via de weg van art. 2:227 lid 4 BW is, zo komt mij voor, een te ruime interpretatie van dat artikel. Dat zou er namelijk op neerkomen dat de vergadergerechtigde certificaathouder in dat geval een vetorecht toekomt. Daarnaast geeft art. 2:317 lid 3 BW een specifieke regeling voor het nemen van het besluit tot fusie. Er wordt slechts gesproken over stemgerechtigde leden en aandeelhouders, niet over certificaathouders. Mijn conclusie is dan ook dat art. 2:227 lid $4 \mathrm{BW}$ ten aanzien van de certificaathouder niet in geval van fusie geldt. $^{292}$

Het administratiekantoor oefent namens de certificaathouders het stemrecht op de aandelen uit en zal aldus op de wijze als genoemd in art. 2:317 lid 1 BW in de algemene vergadering haar stem in de besluitvorming kunnen uitoefenen. Daarbij zal het administratiekantoor de belangen van de certificaathouders in acht moeten nemen. ${ }^{293}$

In de statuten van het administratiekantoor kan bepaald zijn dat het besluit tot fusie, of meer algemeen het besluit tot wijziging van de statuten, goedkeuring behoeft van de vergadering van certificaathouders. In dat geval zal de vergadering van certificaathouders het besluit tot fusie eveneens moeten goedkeuren. ${ }^{294}$

Het primaat ligt aldus bij het administratiekantoor, dat in de algemene vergadering voor of tegen het besluit tot fusie zal moeten stemmen. Van den Ingh en Schwarz ${ }^{295}$ zijn van mening dat het besluit tot fusie te zien is als een vervreemding van de aandelen door het administratiekantoor. Het administratiekantoor doet er goed aan over een dergelijk belangrijk besluit, gelijk bij besluiten over ontbinding en omzetting, de vergadering van certificaathouder te raadplegen - voor zover een dergelijke verplichting niet reeds in de administratievoorwaarden is opgenomen alvorens het administratiekantoor haar stem in de algemene vergadering uitbrengt. Het administratiekantoor zal naar mijn mening met inachtneming van de uitslag van de stemming in de vergadering van certificaathouders voor dan wel tegen het besluit tot fusie moeten stemmen, corresponderend met het aantal voor- en tegenstemmen in de vergadering van certificaathouders. Ook hier geldt dat, gelet op de procedure

292 In gelijke zin Dortmond 2011 (2), p. 239-240, die om andere redenen voor een enge interpretatie van art. 2:227 lid 4 BW pleit.

293 Schwarz 1992, p. 10.

294 Van den Ingh 1991, p. 242.

295 Van den Ingh 1991, p. 238 en Schwarz 1992, p. 10. Zie ook Voûte \& Vletter 2001, p. 136. 
zoals in art. 2:317 BW beschreven, de certificaathouder met vergaderrecht reeds bij de besluitvorming in de BV ten aanzien van de ontbinding betrokken zal zijn.

Wat is de positie van de houder van een certificaat met vergaderrecht in de verdwijnende vennootschap, indien de verkrijgende vennootschap geen of alleen certificaten van aandelen zonder vergaderrecht kent? De vergadergerechtigde certificaathouder heeft tal van andere rechten, ${ }^{296}$ waaronder het wettelijke pandrecht ex art. 3:259 BW. Tegen de omgekeerde situatie - van zonder naar met vergaderrecht - zal de certificaathouder in de regel geen bezwaar hebben. Onder het oude recht werd wel aangenomen dat wanneer sprake was van certificaten van aandelen die met medewerking van de verdwijnende vennootschap waren uitgegeven dat in beginsel leidt tot gelijke lidmaatschapsrechten jegens de verkrijgende vennootschap, tenzij de statuten van die laatste vennootschap bepaalden dat de vennootschap aan certificering geen medewerking verleent. Het belang van de certificaathouder komt in deze opvatting naar voren. ${ }^{297}$ Deze opvatting lijkt mij ook in het huidige BVrecht toepasbaar. Het huidige BV-recht kent voor de certificaathouder in geval van fusie geen specifieke beschermingsregels. Art. 2:216 lid 7, 2:231 lid 4 en art. 2:330 lid 2 BW bieden de certificaathouder geen bescherming. ${ }^{298} \mathrm{Hij}$ is immers geen aandeelhouder.

Hierbij past echter een nuancering, waarbij ik er vanuit ga dat het besluit tot fusie door de algemene vergadering is genomen. Ik ga daarbij tevens uit van een fusie tussen twee besloten vennootschappen. Voorstelbaar is dat in het fusievoorstel opgenomen is dat aan certificaten met vergaderrecht (in de verdwijnende vennootschap) in de verkrijgende vennootschap geen vergaderrecht toekomt. Indien de certificaathouder in de vergadering van certificaathouders voor het fusiebesluit stemt, zal hij zijn rechten verwerken en zal sprake zijn van een certificaat zonder vergaderrecht. ${ }^{299}$ Wat is de situatie indien de certificaathouder in de vergadering van certificaathouders tegen het fusiebesluit stemt? Van den Ingh en Schwarz hebben (onder het oude recht) bepleit dat het redelijk is dat de tegenstemmende certificaathouder een conversierecht toekomt, te meer indien de certificaathouder lidmaatschapsrechten in de verkrijgende vennootschap moet ontberen. Het conversierecht zou er in bestaan, dat de certificaathouder aandeelhouder wordt in de verkrijgende vennootschap. ${ }^{300}$ Ik zou Van den Ingh en Schwarz onder het nieuwe recht daarin niet willen volgen. Conversie zou betekenen dat de certificaathouder stemrecht zou krijgen. In de eerste plaats houdt dat een verbetering van de positie van de certificaathouder in, waarvoor mijns inziens op het eerste gezicht geen reden te bedenken is. In de tweede plaats, zal in het fusievoorstel opgenomen zijn dat aan certificaten met vergaderrecht (in de verdwijnende vennootschap) in de verkrijgende

296 Zie paragraaf 6.3.3.

297 Schwarz 1992, p. 10. Schwarz volgt hiermee P.J. Dortmond, Enige beschouwingen rondom aandelen (diss. Nijmegen), Deventer: Kluwer 1989, p. 141. Anders: Van den Ingh 1991, p. 240.

298 In gelijke zin Dortmond 2011 (2), p. 240.

299 In gelijke zin Schwarz 1992, p. 10.

300 Van den Ingh 1991, p. 239 en Schwarz 1992, p. 10 
vennootschap geen vergaderrecht toekomt. De wil van de (verkrijgende) vennootschap is er aldus op gericht de certificaathouder niet tot de kring van betrokkenen in de zin van art. 2:8 BW te laten behoren. ${ }^{301}$ Daarin past niet dat de certificaathouder dan vanwege een conversierecht aandeelhouder zou worden. Ook een conversierecht in een stemrechtloos aandeel in de verkrijgende vennootschap ligt naar mijn mening niet voor de hand, omdat de certificaathouder dan vergaderrecht verkrijgt terwijl dat niet de bedoeling was. In het fusievoorstel zal aandacht aan deze situatie moeten worden besteed. Een oplossing zou zijn dat de tegenstemmende certificaathouder een recht van schadevergoeding toekomt, ${ }^{302}$ gelijk aan de waarde van zijn certificaat met een eventuele 'bonus' voor het verlies van de positie in de vennootschap dan wel het vergaderrecht. De certificaathouder zou nog bescherming kunnen ontlenen aan het bepaalde in art. 2:8 jo. 2:15 BW. ${ }^{303}$ Het ligt echter niet voor de hand dat de rechter het genomen besluit tot fusie vernietigt op vordering van een of meer tegenstemmende certificaathouders. De rechter zal niet alleen het belang van die certificaathouder(s) in zijn overweging betrekken, maar bijvoorbeeld ook (i) de redenen waarom tot het fusiebesluit is gekomen, (ii) de belangen van de vennootschap en de andere bij de fusie betrokkenen en (iii) of, en zo ja in welke mate, in het fusievoorstel is voorzien in of rekening gehouden met de belangen van de tegenstemmende certificaathouder(s).

Tot slot, eveneens uitgaande van een fusie tussen twee besloten vennootschappen, meen ik dat het wettelijk pandrecht ex art. 3:259 BW vervalt, indien sprake is van certificaten met vergaderrecht in de verdwijnende vennootschap en certificaten zonder vergaderrecht in de verkrijgende vennootschap. ${ }^{304}$ Art. 3:259 lid 2 BW bepaalt immers "of is er bij de statuten vergaderrecht verbonden aan de certificaten van aandelen". Ik verwijs naar paragraaf 6.3.3.6.

\subsubsection{Splitsing}

Ten aanzien van het besluit tot splitsing geldt het bepaalde in art. 2:334m BW. Voor de positie van de certificaathouder in geval van splitsing geldt in gelijke mate hetgeen ik in paragraaf 6.3.3.10 heb opgemerkt ten aanzien van de certificaathouder in geval van fusie.

\subsubsection{Recht van enquête}

Op grond van het bepaalde in art. 2:345 jo. 2:346 BW kan de certificaathouder met en zonder vergaderrecht de OK schriftelijk verzoeken een of meer personen te

301 Zie paragraaf 7.4.2.

$302 \mathrm{Vgl}$. art. 3:320 BW.

303 Wellicht ook aan art. 2:323 lid 1 sub c BW. Voor splitsing art. 2:334u lid 1 sub c BW.

304 Onder het oude recht: in gelijke zin Schwarz 1992, p. 10. Anders: Van den Ingh 1991, p. 190. Van den Ingh baseert zich op art. 2:319 BW. Dat artikel ziet naar mijn mening niet op het wettelijk pandrecht ex art. 3:259 BW. Zie hierover Schwarz 1992, p. 10. 
benoemen tot het instellen van een onderzoek naar het beleid en de gang van zaken in de BV. Bij een BV met een geplaatst kapitaal van maximaal $€ 22,5$ miljoen kan op grond van art. 2:346 lid 1 aanhef onder b BW het enquêteverzoek worden ingediend door een of meer certificaathouders die alleen of gezamenlijk ten minste een tiende gedeelte van het geplaatste kapitaal vertegenwoordigen of rechthebbenden zijn op een bedrag van certificaten daarvan tot een nominale waarde van $€ 225.000$ of zoveel minder als de statuten bepalen. ${ }^{305}$ Op het recht van enquête ga ik in paragraaf 8.8 nader in.

\subsubsection{Geschillenregeling}

De geschillenregeling kent een vordering tot uitstoting (art. 2:336 BW) en een vordering tot uittreding (art. 2:343 BW). Deze vorderingen komen de certificaathouder niet toe. De vraag is of dat wenselijk is, te meer omdat de stemrechtloze aandeelhouder wel is toegelaten tot de geschillenregeling. De certificaathouder met vergaderrecht is immers nauw verwant aan de stemrechtloze aandeelhouder. Op dit thema ga ik in paragraaf 8.9 in.

\subsubsection{Redelijkheid en billijkheid en vernietiging van besluiten}

De houder van een certificaat met vergaderrecht behoort tot de kring van betrokkenen als bedoeld in art. 2:8 BW. Hij heeft daarom op grond van art. 2:15 lid 1 aanhef, sub $b$ BW het recht een besluit van een orgaan van de BV wegens strijd met de vennootschappelijke redelijkheid en billijkheid te vernietigen. De vraag of de houder van een certificaat zonder vergaderrecht behoort tot de kring van betrokkenen als bedoeld in art. 2:8 BW beantwoord ik in paragraaf 7.4.2. In paragraaf 8.6 geef ik antwoord op de vraag of de certificaathouder zonder vergaderrecht op grond van art. 2:15 BW het recht een besluit van een orgaan van de BV wegens strijd met de vennootschappelijke redelijkheid en billijkheid te vernietigen, althans een vordering daartoe in te stellen.

305 Uitgaande van de Wet van 18 juni 2012 tot wijziging van boek 2 van het Burgerlijk Wetboek in verband met de aanpassing van het recht van enquête (Kamerstukken 32 887, Stb. 2012, 274). Deze wet zal inwerking treden op 1 januari 2013 (Stb. 2012, 305). Bij een BV met een geplaatst kapitaal van meer dan $€ 22,5$ miljoen geldt op grond van art. 2:346 lid 1 sub c (nieuw) BW een percentage van één procent. 


\subsection{De aandeelhouder wiens stemrecht is overgedragen aan de vruchtgebruiker of de pandhouder}

\subsubsection{Inleiding}

In deze paragraaf bespreek ik de aandeelhouder wiens stemrecht is overgedragen aan de vruchtgebruiker of de pandhouder. Allereerst komt de aard van de rechtsfiguur aan de orde (paragraaf 6.4.2). Vervolgens bespreek ik de rechten en verplichtingen die aan deze rechtsfiguur zijn verbonden (paragraaf 6.4.3).

\subsubsection{Aard van de rechtsfiguur}

Voor de aandeelhouder wiens stemrecht is overgedragen aan de vruchtgebruiker of de pandhouder, geldt dat (nog steeds) sprake is van een lidmaatschapsverhouding tussen die aandeelhouder en de vennootschap. De overdracht van het stemrecht op grond van art. 2:197 lid 3 respectievelijk art. 2:198 lid 3 BW brengt daarin geen verandering.

\subsubsection{Rechten van de aandeelhouder wiens stemrecht is overgedragen aan de vruchtgebruiker of de pandhouder}

De aandeelhouder wiens stemrecht is overgedragen aan de vruchtgebruiker of de pandhouder heeft dezelfde rechten als de certificaathouder met vergaderrecht, zo volgt uit art. 2:197 lid 4 respectievelijk art. 2:198 lid 4 BW. Voor een overzicht van die rechten verwijs ik naar paragraaf 6.3.3.1. Daarnaast heeft de aandeelhouder wiens stemrecht is overgedragen aan de vruchtgebruiker of de pandhouder een voorkeursrecht op uit te geven aandelen ex art. 2:206a BW. Daarin verschilt hij van de stemrechtloze aandeelhouder, welke laatste aandeelhouder geen voorkeursrecht op uit te geven aandelen heeft. Ik verwijs naar art. 2:206a lid 2 onder c BW.

\subsection{De houder van een participatiebewijs}

\subsubsection{Inleiding}

In deze paragraaf bespreek ik de houder van een participatiebewijs. Allereerst komt de aard van de rechtsfiguur aan de orde (paragraaf 6.5.2). Vervolgens bespreek ik de rechten van de houder van een participatiebewijs (paragraaf 6.5.3). 


\subsubsection{Aard van de rechtsfiguur}

Participatiebewijzen worden tegen storting of inbreng verkregen en vertegenwoordigen kapitaal in de vennootschap. ${ }^{306}$ Participatiebewijzen worden daarom als financieringsinstrument van een onderneming gebruikt. Het eigen vermogen kan ermee worden vergroot. Bij uitgifte kan worden bepaald dat de vennootschap niet gehouden is de inbreng terug te betalen, anders dan bij ontbinding en liquidatie van de rechtspersoon. ${ }^{307}$

Aan een participatiebewijs zijn soms alle rechten die een aandeelhouder toekomen verbonden, behalve het stemrecht. Houders van participatiebewijzen hebben aanspraak op een deel van de winst en/of het liquidatiesaldo. Participatiebewijzen hebben een statutaire basis ${ }^{308}$ en een contractuele grondslag. ${ }^{309}$ Vanwege die grondslag geldt een grote vrijheid de participatievoorwaarden naar wens of behoefte in te richten. In de literatuur worden participatiebewijzen ook wel als statutaire winstrechten omschreven. ${ }^{310}$ Zoals betoogd, moet het participatiebewijs worden onderscheiden van het winstbewijs. ${ }^{311}$ In een BV zullen participatiebewijzen veelal op naam luiden, maar strikt noodzakelijk is dat niet. Participatiebewijzen kunnen ook aan toonder of aan order luiden. Gelet op het besloten karakter van de BV zal dat in de praktijk echter niet of nauwelijks voorkomen. Participatiebewijzen zijn vrij overdraagbaar, tenzij de participatievoorwaarden dat uitsluiten. ${ }^{312}$ Voor

306 Zie paragraaf 3.7.13.

307 Anders Van der Grinten 1991, p. 121-122.

308 Zie 2:23b lid 1 en 2:216 lid 1 BW.

309 Galavazi \& Van Wilsum 1988, p. 133, stellen dat een participatiebewijs zo kan worden ingericht dat feitelijk sprake is van een stemrechtloos aandeel en dat daarom veeleer sprake is van een vennootschapsrechtelijke verhouding dan van een contractuele verhouding tussen de vennootschap en de houder van een participatiebewijs.

310 Eisma 1991, p. 29; Ten Berg, p. 341; Asser/Maeijer, Van Solinge \& Nieuwe Weme 2-II* 2009, nr. 233; Slagter 2005, p. 278- 279 en Sanders \& Westbroek 2005, p. 100, waar de termen door elkaar worden gebruikt.

311 Zie paragraaf 3.7.9.

312 Het gaat daarbij om het beding tussen de houder van het participatiebewijs, als schuldeiser, en de vennootschap, als schuldenaar. Een dergelijke beding in de zin van art. 3:83 lid 2 BW sorteert goederenrechtelijk effect. Het gevolg is dat het participatiebewijs onoverdraagbaar is, zodat ieder overdracht in strijd met het beding ongeldig is. Het beding heeft absolute derdenwerking. Of de derde aan wie het certificaat is overgedragen op de hoogte was het beding, doet niet ter zake. Zie HR 17 januari 2003, LJN AF0168, NJ 2004, 281, m.nt. HJS, JOR 2003, 52, m.nt. M.H.E. Rongen (Oryx/ Van Eesteren) en Asser/Mijnssen, De Haan \& Van Dam 3-I, 2010, nr. 202. Van beschikkingsonbevoegdheid van de vervreemder is geen sprake, omdat aan het voorvereiste van overdraagbaarheid niet is voldaan, zie F.E.J. Beekhoven van de Boezem \& G.J.L. Bergervoet, Groene Serie Vermogensrecht, art. 3:83 BW, aant. 33, Deventer: Kluwer. Beekhoven van de Boezem \& Bergervoet onderscheiden twee mogelijkheden van werking dat aan het beding toekomt, namelijk (i) obligatoire werking en (ii) absolute derdenwerking, hetgeen een kwestie van uitleg van het beding is. Overigens leidt een en ander ook tot wanprestatie van de vervreemder jegens zijn wederpartij met wie het beding van onoverdraagbaarheid is overeengekomen. 
het onderscheid ten opzichte van het stemrechtloze aandeel verwijs ik naar paragraaf 4.7 .

\subsubsection{Rechten van de houder van een participatiebewijs}

\subsubsection{Algemeen}

Het participatiebewijs is als zodanig niet in de wet geregeld. Voor de rechten en verplichtingen zullen de participatievoorwaarden uitkomst moeten bieden. Hoewel het participatiebewijs niet in de wet geregeld is, geeft de wet niettemin een aantal aanknopingspunten voor en rechten aan de houder van een participatiebewijs. Omdat geen sprake is van een lidmaatschapsverhouding tussen de houder van een participatiebewijs en de vennootschap, staat die houder in een andere organisatorische verhouding tot de vennootschap. De houders van participatiebewijzen zijn geen orgaan van de vennootschap. ${ }^{313}$ Dat sluit echter niet uit dat die houders zich kunnen organiseren door het instellen van een vergadering van houders van participatiebewijzen, die algemeen bindende besluiten kan nemen en als zodanig als groep jegens de vennootschap positie kan innemen. ${ }^{314}$

In de regel zullen de participatievoorwaarden voornamelijk financiële rechten, en geen zeggenschapsrechten, aan de houder van een participatiebewijs toekennen. Het belangrijkste recht is het winstrecht. Voor de inhoud van dat recht moeten de participatievoorwaarden geraadpleegd worden. Als voorbeelden noem ik tevens bepalingen over de (storting van de) inbreng, op welke wijze de houder van het participatiebewijs deelt in de winst (bijvoorbeeld de hoogte en de al dan niet voorwaardelijkheid van de winstuitkering) en het liquidatieoverschot, inkoop en intrekking van het participatiebewijs, overdraagbaarheid, voorkeursrecht bij uitgifte van nieuwe participatiebewijzen, vergaderrecht, en wijziging van de participatievoorwaarden. Statutair of in de participatievoorwaarden kunnen aan de houders van een participatiebewijs bevoegdheden zijn toegekend, voor zover die bevoegdheden niet dwingendrechtelijk aan een orgaan van de vennootschap zijn toegekend. ${ }^{315}$

Een vraag die opkomt, is of de interne verhoudingen bij de houder van een participatiebewijs niet tevens worden geregeld door de vermogensrechtelijke redelijkheid en billijkheid van art. 6:2 en 6:248 BW. De houder van een participatiebewijs staat immers in een contractuele verhouding tot de vennootschap, zij het met een statutair anker. Op het antwoord op die vraag kom ik in paragraaf 7.3 terug.

313 Asser/Maeijer, Van Solinge \& Nieuwe Weme 2-II* 2009, nr. 233 en Prinsen 2004, p. 128. 314 Prinsen 2004, p. 128.

315 Asser/Maeijer, Van Solinge \& Nieuwe Weme 2-II* 2009, nr. 233 en Van der Grinten 1991, p. 126. Blanco Fernández \& Schwarz 1992, p. 290, noemen de rechten die aan houders van bewilligde certificaten toekomen, zoals het vergaderrecht. Van der Grinten 1991, p. 126 en Eisma 1991, p. 32, noemen ook het vergaderrecht. 
Het recht op winst op grond van een participatiebewijs moet worden onderscheiden van de zuivere contractuele winstrechten. Bij zuivere, contractuele winstrechten gaat het om een uitkering die ten laste van het resultaat van de vennootschap komt, zoals blijkt uit de winst- en verliesrekening. Het kan dan in dat geval gaan om loon, honorarium of bonusregelingen voor bestuurders, commissarissen en werknemers van de vennootschap. Met dergelijke uitkeringen is al bij het opmaken van de jaarrekening rekening gehouden en zijn reeds als kosten in het resultaat verwerkt. Zuivere, contractuele winstrechten moeten dus worden onderscheiden van winstrechten op grond van een participatiebewijs. In dat laatste geval gaat het om rechten op winst na vaststelling van de jaarrekening.

6.5.3.2 Uitgifte van het participatiebewijs en de grondslag voor de (winst)uitkering

De statutaire grondslag van het participatiebewijs komt tot uitdrukking in het recht op winst van de houder van een participatiebewijs. Art. 2:216 lid 1 BW bepaalt dat de algemene vergadering bevoegd is tot bestemming van de winst die door de vaststelling van de jaarrekening is bepaald en tot vaststelling van uitkeringen, voor zover het eigen vermogen groter is dan de reserves die krachtens de wet of de statuten moeten worden aangehouden. De literatuur is verdeeld over de vraag of voor de uitgifte van participatiebewijzen of de toekenning van rechten op winstuitkeringen een statutaire basis is vereist. Die discussie is gevoerd op basis van art. 2:216 lid 1 (oud) BW: "Voor zover bij de statuten niet anders is bepaald, komt de winst de aandeelhouders ten goede." In de praktijk weken de statuten van een BV vaak van dit uitgangspunt af door te bepalen dat de winst ter beschikking staat van de algemene vergadering. ${ }^{316}$

Op basis van de oude wettekst is verdedigd dat de uitgifte van een participatiebewijs geen statutaire basis behoeft, ${ }^{317}$ omdat de wet als hoofdregel stelde dat de winst aan de aandeelhouders ten goede komt, in de zin dat de winst aan de aandeelhouders, als kapitaalverschaffers van de vennootschap, wordt uitgekeerd. Wilde men van die hoofdregel afwijken, dan moesten de statuten in een andersluidende regeling voorzien. Voor de uitgifte van het participatiebewijs is een besluit van de algemene vergadering vereist, juist omdat de uitgifte daarvan van invloed is op (de hoogte van) de winstrechten van de aandeelhouders. Voor de uitkering van de winstrechten is gelet op het bepaalde in art. 2:216 lid $1 \mathrm{BW}$ wel een statutaire grondslag vereist. Het gaat om het onderscheid tussen uitkering van winst en de uitgifte van participatiebewijzen. De uitkering aan de participatiebewijshouder moet in de statuten verankerd zijn, aldus deze opvatting.

De andere opvatting is dat de uitgifte van participatiebewijzen wel een statutaire basis behoeft. Bij gebreke van een dergelijke statutaire voorziening zouden de

316 Kamerstukken II 2006/07, 31 058, nr. 3, p. 68 (MvT).

317 Blanco Fernández \& Schwarz 1992, p. 288-289 en Prinsen 2004, p. 130. 
houders van participatiebewijzen afhankelijk zijn van een jaarlijks door de algemene vergadering te nemen besluit tot winstuitkering aan de aandeelhouders. ${ }^{318}$ De vraag is vervolgens of de houder van het participatiebewijs op grond van de participatievoorwaarden, ondanks het ontbreken van een besluit of een negatief besluit tot uitkering, rechten jegens de vennootschap geldend kan maken. Het antwoord op die vraag is afhankelijk van de inhoud van de participatievoorwaarden en is sterk casuïstisch. Het spreekt voor zich dat de inhoud van de statuten en de participatievoorwaarden goed op elkaar moeten worden afgestemd. Ter vermijding van de weergegeven discussie is het naar mijn mening aan te bevelen de rechten van houders van participatiebewijzen statutair te verankeren. ${ }^{319}$

Ik sluit mij aan bij de opvatting dat voor de uitgifte van participatiebewijzen geen statutaire basis is vereist, welke opvatting onder het (nieuwe) BV-recht relevant blijft. Een extra argument daarvoor put ik uit de parlementaire geschiedenis bij art. 2:216 lid 1 BW: "Het voorgestelde lid 1 hanteert daarom als uitgangspunt dat de algemene vergadering bevoegd is tot bestemming van de winst en tot vaststelling van uitkeringen. (...) De algemene vergadering mag beslissen over de bestemming van de winst, hetzij door het te reserveren, hetzij door het uit te keren aan aandeelhouders (of anderen). Besluit de algemene vergadering om de door de vaststelling van de jaarrekening bepaalde winst (of een deel daarvan) te bestemmen voor uitkeringen, dan strekt dit besluit tot zowel bestemming als uitkering van de winst. Daarnaast is de algemene vergadering in het algemeen bevoegd om te besluiten tot het vaststellen van uitkeringen. Dit geldt niet alleen voor uitkeringen uit de winst, maar ook voor uitkeringen uit vrije reserves. ${ }^{320}$ Uit dit citaat volgt dat het bepaalde in art. 2:216 lid $1 \mathrm{BW}$ ziet op uitkering (bestemming van de winst en vaststelling van uitkeringen) en niet op de uitgifte. De tekst van art. 2:216 BW brengt dat - onder meer met de uitkeringstest van het derde lid - eens te meer tot uitdrukking. Naar mijn mening kan een en ander ook al worden afgeleid uit art. 2:216 (oud) BW.

In de literatuur wordt ook verschillend gedacht over de vraag op welk artikel de bevoegdheid tot uitgifte van participatiebewijzen is gebaseerd. Eisma gaat uit van art. 2:217 (oud) BW. ${ }^{321}$ Aan de algemene vergadering behoort, binnen de door de wet en de statuten gestelde grenzen, alle bevoegdheid, die niet aan het bestuur of aan anderen is toegekend. Blanco Fernández, Schwarz en Prinsen gaan uit van art. 2:216 (oud) BW. ${ }^{322}$ Met deze laatste schrijvers ben ik van mening dat art. 2:216 (oud en nieuw) BW de bevoegdheid tot uitgifte van participatiebewijzen geeft. De uitgifte van die bewijzen is immers direct van invloed op de winstaanspraken van de aandeelhouders. Blijkens de tweede volzin van art. 2:216 lid 1 BW kunnen de

318 Eisma 1991, p. 37-38 en Asser/Maeijer, Van Solinge \& Nieuwe Weme 2-II* 2009, nr. 233.

319 In gelijke zin Blanco Fernández \& Schwarz 1992, p. 289.

320 Kamerstukken II 2006/07, 31 058, nr. 3, p. 68-69 (MvT).

321 Eisma 1991, p. 38. Eisma gaat uit het corresponderende art. 2:107 BW voor de NV-bepalingen.

322 Blanco Fernández \& Schwarz 1992, p. 289 en Prinsen 2004, p. 131. 
statuten die bevoegdheid aan een ander orgaan toekennen, bijvoorbeeld aan het bestuur.

Bij de uitgifte van de participatiebewijzen zal het bestuur de vennootschap vertegenwoordigen. Ontbreekt een besluit tot uitgifte van de algemene vergadering (de delegatie van die bevoegdheid daargelaten) of is dat besluit nietig of vernietigbaar, dan is de vraag wat de status van de 'uitgegeven' participatiebewijzen is. Aan de rechtshandeling tot uitgifte van het participatiebewijs ontbreekt immers het constitutieve vereiste van een geldig besluit tot uitgifte van het participatiebewijs. De (rechtshandeling tot) uitgifte van het participatiebewijs komt dan in beginsel niet tot stand. Wordt het participatiebewijs niettemin uitgegeven, dan is de vraag of de houder van dat bewijs daaraan rechten mag ontlenen. In dat geval geldt het bepaalde in art. 2:16 lid $2 \mathrm{BW}$, eerste volzin, namelijk dat indien het besluit een rechtshandeling van de rechtspersoon is, die tot een wederpartij is gericht, of het een vereiste voor de geldigheid van een dergelijke rechtshandeling is, kan de nietigheid of vernietiging van het besluit niet aan die wederpartij worden tegengeworpen, indien deze het gebrek dat aan het besluit kleefde, kende noch behoefde te kennen. ${ }^{323}$ Met andere woorden: indien de wederpartij te goeder trouw was, kan het ontbreken van een geldig besluit tot uitgifte van het participatiebewijs hem niet worden tegengeworpen.

\subsubsection{Het recht op winst en/of uitkering}

Welke aanspraak op winst en/of uitkering de houder van een participatiebewijs heeft, blijkt uit de participatievoorwaarden. Zoals gezegd, biedt de contractsvrijheid een grote mate van vrijheid in inrichting en vormgeving van het recht op winst en uitkering.

Er kan bijvoorbeeld gedacht worden aan een vast bedrag op het nominale bedrag van het participatiebewijs, een bepaald percentage, al dan niet cumulatief, of een 'dividend' gelijk aan aandeelhouders. Ook is het mogelijk dat een bepaald deel van de winst eerst gereserveerd wordt of dat eerst uitkering aan de aandeelhouders wordt gedaan alvorens de houders van participatiebewijzen aan de beurt zijn. Samengevat geeft een participatiebewijs recht op een 'aandeel' in de winst.

Daarnaast kan het participatiebewijs recht geven op een uitkering uit de door de vennootschap aangehouden reserves. Art. 2:216 BW bepaalt dat de algemene vergadering onder meer bevoegd is tot het vaststellen van uitkeringen. Daaronder is niet alleen de winst begrepen, zoals die blijkt na vaststelling van de jaarrekening, doch ook uitkeringen ten laste van de reserves. Voor het doen van enige uitkering geldt dat het eigen vermogen groter moet zijn dan de reserves die krachtens de wet of de statuten moeten worden aangehouden. Daarnaast geldt de toets van art. 2:216 lid 2 BW en de eventuele aansprakelijkheid voortvloeiende uit art. 2:216 lid 3

323 Van der Grinten 1991, p. 124 en Prinsen 2004, p. 131. Vgl. Blanco Fernández \& Schwarz 1992, p. 289, r.k. 
BW. ${ }^{324}$ Voor deze aansprakelijkheid van de kapitaalverschaffer zonder stemrecht verwijs ik naar paragraaf 6.6.

Voor het overige geldt dat bij het besluit tot winstbestemming door de algemene vergadering rekening gehouden zal moeten worden met de belangen van de houders van participatiebewijzen en - in dat kader - de vennootschappelijke redelijkheid en billijkheid ex art. 2:8 $\mathrm{BW}^{325} \mathrm{Ik}$ kom daarop in paragraaf 7.5.4 terug.

\subsubsection{Het recht op liquidatieoverschot}

De statutaire grondslag van het participatiebewijs komt eveneens tot uitdrukking in het recht op het liquidatieoverschot. Art. 2:23b lid 1 eerste volzin BW bepaalt dat de vereffenaar hetgeen na de voldoening van de schuldeisers van het vermogen van de ontbonden rechtspersoon is overgebleven, in verhouding tot ieders recht overdraagt aan hen die krachtens de statuten daartoe zijn gerechtigd, of anders aan de leden of aandeelhouders. In de statuten zal dus bepaald moeten zijn dat de houder van een participatiebewijs recht heeft op het liquidatieoverschot. Ontbreekt een dergelijke bepaling, dan heeft de houder van een participatiebewijs geen recht op het liquidatieoverschot. Ook hier geldt een grote mate van vrijheid. In de literatuur wordt een vast bedrag, een breukdeel op het overschot, op gelijke voet met de aandeelhouders, bij voorrang op de aandeelhouders (of juist niet) genoemd. ${ }^{326}$

\subsubsection{Het vergaderrecht}

De houder van een participatiebewijs komt niet het wettelijk vergaderrecht ex art. 2:227 BW toe. Uit de tekst van art. 2:227 BW en de parlementaire geschiedenis blijkt niet dat ook aan anderen dan de in art. 2:227 BW genoemden bij de statuten vergaderrecht kan worden toegekend. Dat neemt niet weg dat de heersende opvatting in de literatuur onder het oude recht was dat aan de houder van een participatiebewijs vergaderrecht bij de statuten en bij overeenkomst kan worden toegekend. ${ }^{327}$ Voor de flex-BV geldt dat mijns inziens ook. Het ligt echter niet voor de hand de houder van een participatiebewijs, althans aan het participatiebewijs, vergaderrecht toe te kennen. Aan het wettelijk vergaderrecht ex art. 2:227 BW zijn immers tal van andere rechten gekoppeld. Ik verwijs naar het overzicht in

324 Kamerstukken II 2011/12, 32 426, nr. 21, p. 2: "Het wordt aan de vennootschap overgelaten op basis van welk document de uitkering wordt beoordeeld, waarbij het uiteraard voor de hand ligt dat bij de uitkering van winst in het kader van de vaststelling van de jaarrekening de vastgestelde jaarrekening als basis wordt gehanteerd."

325 Asser/Maeijer, Van Solinge \& Nieuwe Weme 2-II* 2009, nr. 233; Van der Grinten 1991, p. 127; Eisma 1991, p. 33; Blanco Fernández \& Schwarz 1992, p. 291-292 en Prinsen 2004, p. 133. HR 27 januari 1956, NJ 1956, 48 (Unipart/RDM) en HR 11 januari 1963, NJ 1964, 433, m.nt. G.J. Scholten (RCMA).

326 Van der Grinten 1991, p. 122-123; Eisma 1991, p. 31 en Prinsen 2004, p. 133.

327 Blanco Fernández \& Schwarz 1992, p. 290; Van der Grinten 1991, p. 126 en Eisma 1991, p. 32. 
paragraaf 6.3.3.1 ten aanzien van de certificaathouder met vergaderrecht. Het participatiebewijs met vergaderrecht vertoont in dat geval grote gelijkenis met het stemrechtloze aandeel en het certificaat met vergaderrecht. Indien niettemin aan (de houder van) een participatiebewijs vergaderrecht wordt toegekend, pleit ik voor zijn opname in het aandeelhoudersregister. Ik verwijs naar paragraaf 4.11.

\subsubsection{Het recht van instemming}

De houder van een participatiebewijs heeft geen zeggenschapsrechten. Om hem toch enige bescherming tegen afbreuk van zijn financiële rechten te bieden, geldt art. 2:232 BW. Dat artikel bepaalt dat wijziging van een bepaling van de statuten, waarbij aan een ander dan aan aandeelhouders van de vennootschap als zodanig enig recht toegekend is, indien de gerechtigde in de wijziging niet toestemt, aan diens recht geen nadeel kan toebrengen, tenzij ten tijde van de toekenning van het recht de bevoegdheid tot wijziging bij die bepaling uitdrukkelijk was voorbehouden. De hoofdregel is aldus dat de houder van een participatiebewijs moet instemmen met een statutenwijziging die nadeel aan zijn rechten toebrengt, tenzij de wijzigingsbevoegdheid bij de uitgifte van het participatiebewijs reeds is voorbehouden. $^{328}$ Stemt de houder van een participatiebewijs niet in, dan is de statutenwijziging niet op hem van toepassing. ${ }^{329}$ De statuten kunnen echter wel gewijzigd worden. Een besluit daartoe is wegens het ontbreken van instemming niet nietig. In de literatuur wordt verdedigd dat het artikel alleen ziet op financiële, statutaire rechten, maar een eenduidige opvatting is er niet. ${ }^{330}$ Voor het participatiebewijs is die discussie mijns inziens minder relevant, omdat aan de houder van een participatiebewijs in de regel slechts financiële rechten zijn toegekend. Ook in art. 2:232 BW komt de statutaire basis van het participatiebewijs tot uitdrukking.

\subsubsection{Het voorkeursrecht}

De houder van een participatiebewijs heeft geen voorkeursrecht op nieuw uit te geven participaties, tenzij de statuten dat bepalen. ${ }^{331}$ Omgekeerd geldt dat het wettelijk voorkeursrecht ex art. 2:206a BW niet van toepassing is. ${ }^{332}$ De aandeelhouder heeft aldus evenmin voorkeursrecht op uit te geven participaties, net zoals de houder van een participatiebewijs geen voorkeursrecht heeft op uit te geven aandelen.

328 Hier dient zich de parallel aan met het aan certificaathouders ontnemen van vergaderrecht, zie paragraaf 6.3.3.4.

329 Dortmond 2012 (2), p. 462.

330 Asser/Maeijer \& Van den Ingh 2-III 2000, nr. 542 en C.A. Schwarz, Groene Serie Rechtspersonen, art. 2:122 BW, aant. 2, Deventer: Kluwer. Anders: Van Schilfgaarde \& Winter 2009, p. 378.

331 Van der Grinten 1991, p. 123 en Prinsen 2004, p. 131. Prinsen 2004, p. 132, pleit voor een voorkeursrecht voor houders van participatiebewijzen.

332 Van der Grinten 1991, p. 124. Eisma 1991, p. 39. 


\subsubsection{Inkoop en intrekking}

De heersende opvatting in de literatuur onder het oude recht was dat participatiebewijzen kunnen worden ingekocht, waarbij door de verkrijging door de vennootschap de participatiebewijzen wegens vermenging teniet gaan. ${ }^{333}$ Daarbij is aansluiting gezocht bij art. 2:207 lid 2 sub c (oud) BW. Onder de flex-BV is dat naar mijn mening niet anders en zal moeten worden voldaan aan de eis die art. 2:207 lid 2 BW stelt. De vennootschap mag, behalve om niet, geen volgestorte eigen aandelen verkrijgen indien het eigen vermogen, verminderd met de verkrijgingsprijs, kleiner is dan de reserves die krachtens de wet of de statuten moeten worden aangehouden of indien het bestuur weet of redelijkerwijs behoort te voorzien dat de vennootschap na de verkrijging niet zal kunnen blijven voortgaan met het betalen van haar opeisbare schulden. Voor de vaststelling van het eigen vermogen en de reserves is de laatst vastgestelde jaarrekening bepalend.

In het verlengde van de vraag of inkoop van participatiebewijzen mogelijk is, ligt de vraag of participatiebewijzen kunnen worden ingetrokken. Participatiebewijzen hebben een contractuele grondslag. Er is sprake van een overeenkomst belichaamd in de participatievoorwaarden. Tenzij in die voorwaarden een intrekkingsbeding opgenomen is, kunnen participatiebewijzen mijns inziens slechts met instemming van de houder daarvan worden ingetrokken. ${ }^{334}$ Vanuit het oogpunt van de vennootschap verdient het daarom anbeveling de bevoegdheid tot intrekking in de participatievoorwaarden voor te behouden.

\subsubsection{Omzetting, fusie en splitsing}

Art. 2:320 BW geeft een regeling voor de houder van een participatiebewijs in de verdwijnende vennootschap ingeval van fusie. Het artikel bepaalt dat de houder van een participatiebewijs, niet zijnde lid of aandeelhouder, in de verdwijnende vennootschap een gelijkwaardig recht in de verkrijgende vennootschap of schadeloosstelling moet krijgen. De schadeloosstelling wordt bij gebreke van overeenstemming bepaald door een of meer onafhankelijke deskundigen, ten verzoeke van de meest gerede partij te benoemen door de voorzieningenrechter van de rechtbank van het arrondissement waarin de woonplaats van de verkrijgende rechtspersoon is gelegen.

Aan de houder van het participatiebewijs komt ingeval van fusie geen recht van verzet ex art. 2:316 BW toe. De houder van het participatiebewijs is immers geen schuldeiser. De wettekst roept een aantal vragen op: wat wordt verstaan onder gelijkwaardig recht? Indien geen gelijkwaardig recht gerealiseerd kan worden, is dan een combinatie van 'een recht' en schadeloosstelling mogelijk? Tussen wie moet overeenstemming worden bereikt? Ik neem aan tussen de houder van het

333 Asser/Maeijer, Van Solinge \& Nieuwe Weme 2-II* 2009, nr. 233; Eisma 1991, p. 39; Van der Grinten 1991, p. 126 en Prinsen 2004, p. 135.

334 In gelijke zin: Eisma 1991, p. 39. 
participatiebewijs en in ieder geval de verkrijgende vennootschap. De verkrijgende vennootschap zou naar mijn mening, gelijk bij art. 2:330a lid $3 \mathrm{BW}$, de schadeloosstelling aan de houder van een participatiebewijs moeten voldoen. Een bepaling daartoe ontbreekt in art. 2:320 BW.

Wat betreft de positie van de houder van een participatiebewijs ingeval van splitsing geldt art. 2:334p BW. Dat artikel heeft een nagenoeg met art. 2:320 BW gelijkluidende formulering. De houder van een participatiebewijs moet hetzij zodanige rechten in verkrijgende rechtspersonen krijgen, dat deze, waar toepasselijk samen met het recht dat hij jegens de splitsende rechtspersoon die blijft voortbestaan heeft, gelijkwaardig zijn aan zijn rechten voor de splitsing, hetzij schadeloosstelling krijgen. De wetgever stelt hierover: "Het is niet noodzakelijk dat de rechthebbende rechten in elke verkrijgende rechtspersoon krijgt. Vervangende rechten in een of meer verkrijgende rechtspersonen kunnen voldoende zijn, mits zij gelijkwaardig zijn aan het oorspronkelijke recht. Als de splitsende rechtspersoon na de splitsing voortbestaat, moet bij de waardering van de positie waarin de gerechtigde door de splitsing geraakt, ook het recht dat hij jegens de splitsende rechtspersoon heeft - en dat door de splitsing niet verloren gaat - worden betrokken."335 Aan de houder van het participatiebewijs komt, gelijk bij fusie, ingeval van splitsing geen recht van verzet ex art. 2:316 BW toe.

Zowel bij fusie als bij splitsing geldt dat de houder van een participatiebewijs recht heeft op inzage in en een kosteloos afschrift van stukken die in verband met een juridische fusie of een juridische splitsing ten kantore van de vennootschap zijn neergelegd (art. 2:314 lid 2 en art. 2:334h lid 2 BW).

Bij omzetting, fusie en splitsing geldt dat de vennootschappelijke redelijkheid en billijkheid jegens de houder van het participatiebewijs in acht genomen moet worden. Desgewenst kan door die houder vernietiging ex art. 2:15 lid 1 sub b BW van de besluiten daartoe gevorderd worden. Ingeval van omzetting kan de houder het participatiebewijs ook bescherming ontlenen aan het bepaalde in art. 2:232 jo. $2: 18 \mathrm{BW}$.

\subsubsection{Recht van enquête en geschillenregeling}

Aan de houder van een participatiebewijs komt geen recht van enquête toe, tenzij daartoe bij de statuten of bij overeenkomst met de rechtspersoon de bevoegdheid is toegekend (art. 2:346 lid 1 onder e BW). ${ }^{336}$ De geschillenregeling kent een vordering tot uitstoting (art. 2:336 BW) en een vordering tot uittreding (art. 2:343 BW). Deze vorderingen zijn echter rechten van aandeelhouders en komen naar hun aard aldus niet de houder van een participatiebewijs toe.

335 Kamerstukken I 1995/96, 24 702, nr. 3, p. 17 (MvT).

336 Uitgaande van de Wet van 18 juni 2012 tot wijziging van boek 2 van het Burgerlijk Wetboek in verband met de aanpassing van het recht van enquête (Kamerstukken 32 887, Stb. 2012, 274). Deze wet zal inwerking treden op 1 januari 2013 (Stb. 2012, 305). 


\subsubsection{Redelijkheid en billijkheid en vernietiging van besluiten}

De houder van een participatiebewijs is als betrokkene in de zin van art. 2:8 BW te beschouwen. Ik kom daarop in paragraaf 7.4.2 terug. Omdat de houder van een participatiebewijs tot de kring van betrokkenen als bedoeld in art. 2:8 BW behoort, heeft hij op grond van art. 2:15 lid 1 aanhef, sub b BW het recht een besluit van een orgaan van de BV wegens strijd met de vennootschappelijke redelijkheid en billijkheid te vernietigen. Ik kom daarop in paragraaf 8.6 terug.

\subsection{Aansprakelijkheid van de kapitaalverschaffers zonder stemrecht ex art. 2:216 lid $3 \mathrm{BW}$}

\section{Algemeen}

Op grond van art. 2:216 lid $1 \mathrm{BW}$ is de algemene vergadering bevoegd tot bestemming van de winst die door de vaststelling van de jaarrekening is bepaald en tot vaststelling van uitkeringen, voor zover het eigen vermogen groter is dan de reserves die krachtens de wet of de statuten moeten worden aangehouden. Een besluit dat strekt tot uitkering heeft geen gevolgen zolang het bestuur geen goedkeuring heeft verleend. Het bestuur weigert slechts ${ }^{337}$ de goedkeuring indien het weet of redelijkerwijs behoort te voorzien dat de vennootschap na de uitkering niet zal kunnen blijven voortgaan met het betalen van haar opeisbare schulden, zo volgt uit art. 2:216 lid $2 \mathrm{BW}$.

Art. 2:216 lid 3 BW regelt de aansprakelijkheid van aandeelhouders en andere winstgerechtigden. Het bepaalt onder meer dat degene die de uitkering ontving, terwijl hij wist of redelijkerwijs behoorde te voorzien dat de vennootschap na de uitkering niet zou kunnen voortgaan met het betalen van haar opeisbare schulden, gehouden is tot vergoeding van het tekort dat door de uitkering is ontstaan, ieder voor ten hoogste het bedrag of de waarde van de door hem ontvangen uitkering, met de wettelijke rente vanaf de dag van de uitkering. De aansprakelijkheid van art. 2:216 lid $3 \mathrm{BW}$ ziet niet op uitkeringen in de vorm van aandelen in het kapitaal van de vennootschap (stockdividend). Bij uitkering van bonusaandelen worden de aandelen volgestort vanuit de beschikbare reserves. De financiële positie van de vennootschap komt in dat geval niet in gevaar, omdat geen vermogen uit de vennootschap verdwijnt. ${ }^{338}$

Uit de parlementaire geschiedenis volgt dat de achterliggende gedachte bij de regeling voor uitkeringen is dat als de vennootschap in de situatie verkeert dat de betaling van de opeisbare schulden tegenover crediteuren onzeker wordt, de

337 Zie Kamerstukken II 2008/09, 31 058, nr. 6, p. 35 (NV II); Kamerstukken II 2008/09, 31 058, nr. 7, p. 16 (Nota van wijziging) en Kamerstukken I 2011/12, 31058 en 32 426, nr. C, p. 11-12 (MvA I). 338 Kamerstukken II 2006/07, 31 058, nr. 3, p. 76 (MvT). 
vorderingen van de crediteuren voorrang hebben boven de rechten van de aandeelhouders op uitkeringen uit het vermogen van de vennootschap. ${ }^{339}$ De wetgever licht nader toe: "Door te eisen dat de terugbetalingsplicht alleen geldt voor de ontvanger die wist of redelijkerwijs behoorde te voorzien dat de uitkering tot problemen zou leiden, wordt voor bestuurders een extra prikkel gecreëerd om de aandeelhouders en andere uitkeringsgerechtigden in zodanige mate te informeren dat ook zij op de hoogte zijn van de afwegingen bij de uitkeringstest." 340 Met andere woorden: de aansprakelijkheid is beperkt tot de ontvangers van uitkeringen die niet te goeder trouw waren. ${ }^{341}$ De wetgever stelt hierover: "De algemene vergadering wordt (...) in beginsel bevoegd tot bestemming van de winst en tot vaststelling van uitkeringen en is daarmee in beginsel ook verantwoordelijk voor het beleid dienaangaande. Omdat een $b v$ in de regel een beperkt aantal aandeelhouders kent, zullen zij in het algemeen nauw betrokken zijn bij de besluitvorming in de vennootschap. Het zou in die situatie niet gerechtvaardigd zijn om de sanctie van aansprakelijkheid volledig bij het bestuur te leggen, terwijl de aandeelhouders financieel zouden profiteren." 342

Uit de tekst van art. 2:216 lid 3 BW volgt niet jegens wie de aansprakelijkheid van ontvangers van uitkeringen geldt. De parlementaire geschiedenis maakt duidelijk dat sprake is van een aansprakelijkheid jegens de vennootschap. ${ }^{343}$ Uit de tekst van art. 2:216 lid $3 \mathrm{BW}$ volgt dat, indien een of meer bestuurders reeds hebben betaald uit hoofde van hun aansprakelijkheid, degene die de uitkering ontving terwijl hij niet te goeder trouw was, gehouden is om het bedrag terug te betalen aan de bestuurders. ${ }^{344}$ De aansprakelijke die de uitkering ontving, is niet bevoegd tot verrekening van zijn schuld aan de vennootschap met een eventuele vordering op de vennootschap, zo volgt uit de laatste volzin van art. 2:216 lid $3 \mathrm{BW}^{345}$ De bevoegdheid tot verrekening is niet uitgesloten ingeval de bestuurder regres neemt op de aandeelhouder. Een dergelijke verrekening gaat niet ten koste van schuldeisers van de vennootschap. De bestuurder heeft immers uit hoofde van zijn aansprakelijkheid het tekort dat door de uitkering is voldaan reeds aan de vennootschap voldaan. ${ }^{346}$ Van hoofdelijke aansprakelijkheid is gelet op de formulering van art. 2:216 lid $3 \mathrm{BW}$ naar mijn mening geen sprake. ${ }^{347}$

Wat betreft de omvang van de aansprakelijkheid kan het zo zijn dat de aansprakelijkheid van de aandeelhouder of winstgerechtigde verder gaat dan zijn

339 Kamerstukken II 2006/07, 31 058, nr. 3, p. 34 (MvT).

340 Kamerstukken II 2006/07, 31 058, nr. 3, p. 31 (MvT).

341 Kamerstukken II 2006/07, 31 058, nr. 3, p. 33 (MvT).

342 Kamerstukken II 2006/07, 31 058, nr. 3, p. 33-34 (MvT). Zie ook Kamerstukken II 2006/07, 31 058, nr. 3, p. 73 (MvT).

343 Kamerstukken II 2006/07, 31 058, nr. 3, p. 34 (MvT).

344 Zie ook Kamerstukken II 2006/07, 31 058, nr. 3, p. 31 en 73 (MvT).

345 Zie ook Kamerstukken II 2006/07, 31 058, nr. 3, p. 74 (MvT)

346 Kamerstukken I 2011/12, 31 058, nr. E, p. 13 (Nadere MvA I)

347 In gelijke zin: Groenland 2012, p. 30 
aandeel in het kapitaal in de BV. Voor de omvang van de aansprakelijkheid wordt immers aangesloten bij hetgeen de aandeelhouder aan dividend heeft ontvangen en niet bij de omvang van de deelname van de aandeelhouder in het kapitaal van de vennootschap. $^{348}$

De aansprakelijkheid is in tijd op twee manieren begrensd. Ten eerste, 'doordat aandeelhouders slechts aansprakelijk kunnen worden gesteld voor zover zij wisten of redelijkerwijs behoorden te weten dat de vennootschap na de uitkering in financiële problemen zou komen. Het gaat dus om wat redelijkerwijs voorzienbaar was ten tijde van de uitkering.' Ten tweede, gelden voor het instellen van de vordering jegens een aansprakelijke winstgerechtigde de algemene verjaringsregels van Boek 3 BW. ${ }^{349}$

In de literatuur is de vraag aan de orde gekomen op welk moment sprake moet zijn van goede trouw van de ontvanger van de uitkering. Is dat het moment waarop de algemene vergadering tot uitkering besluit, of is dat het moment waarop de winstgerechtigde de uitkering, nadat het besluit tot uitkering door het bestuur is goedgekeurd, de uitkering ontvangt? Ik ben het met Dortmond ${ }^{350}$ eens dat uit de parlementaire geschiedenis kan worden afgeleid dat er op het moment van het nemen van het besluit tot uitkering door de algemene vergadering sprake moet zijn van goede trouw. De wetgever licht toe: "Bestuurders hebben een raadgevende stem in de algemene vergadering (het voorgestelde artikel 227 lid 7). Ook bij besluitvorming buiten de algemene vergadering dienen de bestuurders voorafgaand aan de besluitvorming in de gelegenheid te worden gesteld om advies uit te brengen (het voorgestelde artikel 238 lid 1). Indien de algemene vergadering een besluit tot uitkering wil nemen en de bestuurders wisten of behoorden te weten dat de vennootschap daardoor niet zou kunnen voortgaan met het betalen van de opeisbare schulden, zullen de bestuurders in het kader van de raadgevende stem de algemene vergadering moeten waarschuwen. (...) Indien de algemene vergadering ondanks de waarschuwing van het bestuur het uitkeringsbesluit neemt, kunnen de bestuurders zich er in beginsel op beroepen dat zij hun taak behoorlijk hebben vervuld en is aansprakelijkheid op grond van artikel 9 niet aan de orde. De eventuele aansprakelijkheidsgevolgen berusten dan bij de leden van de algemene vergadering die het besluit nemen en bijvoorbeeld een winstuitkering ontvangen. (...) Indien het bestuur de financiële gevolgen van de uitkering daarentegen niet zorgvuldig onderzoekt en nalaat om de algemene vergadering te informeren over de schadelijke gevolgen van een voorgenomen besluit, dan zullen de bestuurders doorgaans op grond van artikel 9 en - in faillissementssituaties - artikel 248 kunnen worden aangesproken en kunnen de aandeelhouders zich in beginsel

348 Kamerstukken II 2008/09, 31 058, nr. 6, p. 31 (NV II)

349 Kamerstukken II 2008/09, 31 058, nr. 6, p. 31 (NV II).

350 Dortmond 2009 (2), p. 202 . De Kluiver 2006, p. 579, in dezelfde zin met betrekking tot een eerder ontwerp van art. 2:216 BW. 
beroepen op hun goede trouw. (onderstreping RAW), ${ }^{, 351}$ Uit het door mij onderstreepte deel van het citaat kan worden afgeleid dat het beoordelingsmoment van de goede trouw het moment is waarop de algemene vergadering het besluit tot uitkering neemt.

Welke kapitaalverschaffer zonder stemrecht kan aansprakelijk zijn?

Art. 2:216 lid 3 BW spreekt over 'degene die de uitkering ontving'. In de parlementaire geschiedenis wordt gesproken over 'aandeelhouders en andere uitkeringsgerechtigden'. Vanzelfsprekend vallen daaronder de stemrechtloze aandeelhouder en de aandeelhouder wiens stemrecht is overgedragen aan de vruchtgebruiker of pandhouder. Indien zij tijdens de algemene vergadering door het bestuur wegens de raadgevende stem zijn geïnformeerd over de schadelijke gevolgen van een voorgenomen besluit, kunnen zij zich niet beroepen op hun goede trouw. ${ }^{352}$ Ik kom hierop terug.

Ten aanzien van het certificaat van aandeel geldt dat het administratiekantoor als aandeelhouder uitkeringsgerechtigd is. In de administratievoorwaarden tussen het administratiekantoor en de certificaathouder zal in de regel zijn bepaald dat de uitkeringen die het administratiekantoor op de aandelen ontvangt aan de certificaathouders ten goede komen en na ontvangst daarvan omgaand aan de certificaathouders zullen worden uitgekeerd. Of een certificaathouder ex art. 2:216 lid 3 BW gehouden is tot terugbetaling van hetgeen hij ontvangen heeft, hangt naar mijn mening af van het antwoord op de vraag of sprake is van certificaten met of zonder vergaderrecht. Indien sprake is van een certificaat met vergaderrecht, dan is de houder van dat certificaat gerechtigd de algemene vergadering bij te wonen en daarin het woord te voeren. Hij zal ook worden opgeroepen en kennis (kunnen) nemen van de agenda van de algemene vergadering. Indien hij ter vergadering anwezig is, kan hij de raadgevende stem omtrent de uitkering van het bestuur aanhoren en daarover desgewenst vragen stellen. Zijn positie is aldus gelijk aan de stemrechtloze aandeelhouder en de aandeelhouder wiens stemrecht is overgedragen aan de vruchtgebruiker of pandhouder. Een punt verdient echter aandacht. Het is, zoals gesteld, het administratiekantoor dat de uitkering ontvangt. Als aandeelhouder zal zij worden angesproken tot vergoeding van het tekort dat door de uitkering is ontstaan. Omdat sprake is van een certificaat met vergaderrecht, zal het administratiekantoor verhaal kunnen halen bij de certificaathouder, althans zal daaromtrent een regeling in de administratievoorwaarden zijn of moeten worden opgenomen. Indien dat laatste niet het geval is, zal naar mijn mening een beroep kunnen worden gedaan op de aanvullende werking van de redelijkheid en billijkheid ex art. 6:248 lid $1 \mathrm{BW}^{353}$

351 Kamerstukken II 2008/09, 31 058, nr. 8, p. 3-4 (Tweede nota van wijziging).

352 In gelijke zin: Groenland 2012, p. 30 en Lennarts 2012, p. 185.

353 Vgl. Van den Ingh 1991, p. 157, noot 18. 
Ten aanzien van de houder van een certificaat zonder vergaderrecht geldt mijns inziens dat hij niet aansprakelijk kan zijn, althans dat hij zich kan beroepen op zijn goede trouw. De houder van een certificaat zonder vergaderrecht heeft niet het recht de algemene vergadering bij te wonen en daarin het woord te voeren. Als gevolg van het ontbreken van het vergaderrecht zal hij ook niet worden opgeroepen en zal hij geen kennis nemen van de agenda van de algemene vergadering. Hij is dan ook niet betrokken bij de besluitvorming in en het besluit tot uitkering van de algemene vergadering. Dit kan naar mijn mening anders zijn indien het bestuur van de vennootschap voorafgaand aan de besluitvorming in de algemene vergadering (lees: vóór de algemene vergadering en niet tijdens) over de uitkering ook de houder van een certificaat zonder vergaderrecht over de schadelijke gevolgen van een voorgenomen besluit informeert. Ik geef toe dat dit niet altijd voor de hand ligt bij certificaten zonder vergaderrecht, omdat het de vennootschap en haar bestuur niet bekend zal zijn dat gecertificeerd is en omdat er geen verplichting is de houder van een certificaat zonder vergaderrecht in het aandeelhoudersregister in te schrijven. Echter, niet in alle gevallen is het de vennootschap en haar bestuur onbekend dat gecertificeerd is. Te denken is aan werknemersparticipatie, waarbij juist certificaten zonder vergaderrecht worden uitgegeven om te voorkomen dat besluitvorming in de algemene vergadering bemoeilijkt wordt.

Kan de houder van een participatiebewijs als 'degene die de uitkering ontving' aansprakelijk zijn? In paragraaf 3.7.13 stelde ik dat het participatiebewijs een statutaire basis en een contractuele grondslag heeft. In de regel ontbeert de houder van een participatiebewijs echter het vergaderrecht. Hij heeft niet het recht de algemene vergadering bij te wonen en daarin het woord te voeren. Als gevolg van het ontbreken van het vergaderrecht zal ook niet worden opgeroepen en zal hij geen kennis nemen van de agenda van de algemene vergadering. Hij is dan ook niet betrokken bij de besluitvorming in en het besluit tot uitkering van de algemene vergadering. De houder van een participatiebewijs kan zich daarom mijns inziens beroepen op de goede trouw indien hij wordt aangesproken tot terugbetaling van het ontvangene. Dit is naar mijn mening anders indien het bestuur van de vennootschap voorafgaand aan de besluitvorming in de algemene vergadering (lees: vóór de algemene vergadering en niet tijdens) over de uitkering ook de houder van het participatiebewijs over de schadelijke gevolgen van een voorgenomen besluit informeert.

Er past evenwel een nuancering. Ik maakte die al bij de houder van het certificaat zonder vergaderrecht en de houder van het participatiebewijs. Het hiervoor aangehaalde citaat uit de parlementaire geschiedenis gaat in de eerste plaats uit van de raadgevende stem van bestuurders (en commissarissen) in - dus tijdens - de algemene vergadering. Het is goed mogelijk dat de vergadergerechtigde kapitaalverschaffers zonder stemrecht niet ter vergadering aanwezig zijn. Eerder stelde ik dat het beoordelingsmoment van de goede trouw het moment is waarop de algemene vergadering het besluit tot uitkering neemt. Afwezige, vergadergerechtigde kapitaalverschaffers zonder stemrecht kunnen daarom niet van de waarschuwingen op 
de hoogte zijn. Het gaat mij echter te ver te concluderen dat zij daarom niet aansprakelijk zouden zijn. De vergadergerechtigden zijn immers wel opgeroepen en hebben de agenda ontvangen. Dat zij de algemene vergadering niet bijwonen, is een omstandigheid die in hun risicosfeer ligt. ${ }^{354}$ De opvatting in de literatuur, waarbij ik mij aansluit, is dat het bestuur er verstandig aan doet tijdig vóór de algemene vergadering, bijvoorbeeld bij de oproep, te waarschuwen ten aanzien van de uitkeringstest en de financiële situatie van de vennootschap. Op deze wijze zijn alle uitkeringsgerechtigden op de hoogte dat de vennootschap na uitkering niet kan voortgaan met de betaling van haar opeisbare schulden. ${ }^{355}$

Ook een andere nuancering is denkbaar. De vergadergerechtigde kapitaalverschaffers zonder stemrecht zijn ter vergadering aanwezig. Het bestuur waarschuwt in het kader van haar raadgevende stem over de schadelijke gevolgen van het voorgenomen besluit tot uitkering. Niettemin besluiten de aandeelhouders (met stemrecht) tot uitkering. De vergadergerechtigde kapitaalverschaffers zonder stemrecht kunnen een dergelijk besluit wegens het ontbreken van stemrecht niet tegenhouden. ${ }^{356}$ Wat is in dat geval de positie van de aanwezige kapitaalverschaffer zonder stemrecht? De wetgever zegt slechts: "De eventuele aansprakelijkheidsgevolgen berusten (...) bij de leden van de algemene vergadering die het besluit nemen en bijvoorbeeld een winstuitkering ontvangen. ${ }^{357}$ Houdt dat in dat alleen degene die het besluit hebben genomen en een winstuitkering hebben ontvangen aansprakelijk zijn? Op grond van de wettekst van art. 2:216 lid 3 BW kies ik niet voor een dergelijke, beperkte opvatting. Art. 2:216 lid $3 \mathrm{BW}$ spreekt slechts over degene die de uitkering ontving en zegt niets over degene die het besluit tot uitkering nam. Ik concludeer dan ook dat de vergadergerechtigde kapitaalverschaffer zonder stemrecht, ook al kan hij geen stem uitbrengen over het te nemen besluit tot uitkering, aansprakelijk kan zijn.

Nog een laatste nuancering. Het is de vraag of het bestuur ex art. 2:216 lid 2 BW een besluit tot uitkering van de algemene vergadering ex art. 2:216 lid $1 \mathrm{BW}$ zal goedkeuren. Het ligt niet in de rede dat het bestuur wel in het kader van haar raadgevende stem een waarschuwing geeft en vervolgens (toch) het uitkeringsbesluit goedkeurt.

Bij besluitvorming buiten vergadering ten aanzien van een uitkering doet het bestuur er eveneens goed aan haar raadgevende stem in de zin van een waarschuwing tegen het voorgenomen besluit tot uitkering tijdig te laten horen op de wijze zoals hiervoor vermeld.

Een allerlaatste nuancering. Stel dat op grond van art. 2:216 lid 1 BW aan de vergadering van stemrechtloze aandeelhouders de bevoegdheid is toegekend de

354 Dortmond 2009 (2), p. 202, stelt vraagtekens bij deze problematiek.

355 Vgl. Buijn 2007, p. 358-369. Zie Ten Berg 2008 (2), p. 103; Bier 2008, p. 212 en Dortmond 2009

(2), p. 202.

356 De Kluiver 2006, p. 578 en Dortmond 2009, p. 202, spreken in dat kader van de aandeelhouder die niet aan het besluit heeft meegewerkt.

357 Kamerstukken II 2008/09, 31 058, nr. 8, p. 4 (Tweede nota van wijziging). 
winst te bestemmen en de uitkeringen vast te stellen. In de vergadering van stemrechtloze aandeelhouders heeft het bestuur van de vennootschap geen raadgevende stem. ${ }^{358}$ In dat geval kan het bestuur ook niet waarschuwen. Ik acht het dan mogelijk dat degene die de uitkering ontving zich op de goede trouw kan beroepen. Het ligt echter voor de hand dat indien aan de vergadering van stemrechtloze aandeelhouders de bevoegdheid is toegekend de winst te bestemmen en de uitkeringen vast te stellen statutair vastgelegd is dat in de vergadering van stemrechtloze aandeelhouders het bestuur van de vennootschap wel een raadgevende stem heeft.

\subsection{Het afzien van de uitoefening van het vergaderrecht}

Uit het voorgaande volgt dat de stemrechtloze aandeelhouder, de houder van een certificaat met vergaderrecht en de aandeelhouder wiens stemrecht is overgedragen aan de vruchtgebruiker of pandhouder vergaderrecht hebben.

De - wellicht slechts theoretische - vraag is of deze vergadergerechtigden vrijwillig afstand kunnen doen van het hen toekomende vergaderrecht. Allereerst is echter de vraag wat onder 'afstand van recht' moet worden verstaan. Afstand van recht is het prijsgeven van een recht. In het vermogensrecht gaat een verbintenis teniet door een overeenkomst van de schuldeisers met de schuldenaar, waarbij de schuldeiser van zijn vorderingsrecht afstand doet. ${ }^{359}$ Het vennootschapsrecht kent een dergelijke bepaling niet. Aandeelhouders staan in een lidmaatschapsverhouding tot de vennootschap, welke lidmaatschapsverhouding vorm of inhoud wordt gegeven door de aan het aandeel verbonden financiële en zeggenschapsrechten. Bovendien is Boek $2 \mathrm{BW}$ in hoge mate van dwingend recht, zo bepaalt art. 2:25 BW. In de statuten kan een afwijkende regeling worden opgenomen, voor zover uit de wet blijkt dat dit is toegestaan.

In paragraaf 3.6 stelde ik dat het aandeel een vermogensrecht in de zin van art. 3:6 $\mathrm{BW}$ is. Het aandeel kan worden overgedragen. De aan het aandeel verbonden financiële en zeggenschapsrechten zijn afhankelijke rechten in de zin van art. 3:7 BW. Zonder het aandeel kunnen deze rechten immers niet bestaan. Op grond van art. 3:82 BW volgen bij overdracht de aan het aandeel verbonden financiële en zeggenschapsrechten als afhankelijke rechten het aandeel. Zo kan bijvoorbeeld het stemrecht op een aandeel niet zelfstandig worden overgedragen. Dat geldt ook voor het recht op dividend. Wel is het mogelijk dat de aandeelhouder

358 Kamerstukken I 2011/12, 31 058, nr. E, p. 22 (Nadere MvA I).

359 Art. 6:160 BW. 
jegens de vennootschap afstand doet van zijn vorderingsrecht op dividend. Dat is afstand doen van een recht in de zin van art. 6:160 BW.

Met De Kluiver en Meinema ${ }^{360}$ ben ik van mening dat een onderscheid moet worden gemaakt tussen afstand doen van recht met goederenrechtelijke werking en afstand doen van recht met verbintenisrechtelijke werking en dat in het vennootschapsrecht slechts van de laatste categorie afstand kan worden gedaan. Onder 'afstand van recht' versta ik het vrijwillig prijsgeven ('afzien') van of het op een bepaalde wijze uitoefenen van een aan een aandeel verbonden recht op grond van een contractuele afspraak tussen de aandeelhouder aan de ene kant en de vennootschap en/of medeaandeelhouders aan de andere kant. Feitelijk gaat - anders dan in de vermogenrechtelijke pendant (zie art. 6:160 BW) - het recht niet teniet, zodat het niet geheel zuiver is te spreken van afstand van recht. Een voorbeeld van de verbintenisrechtelijke werking is de stemovereenkomst, waarbij de aandeelhouder zich jegens zijn mede-aandeelhouders heeft verbonden het aan zijn aandeel verbonden stemrecht op een bepaalde wijze uit te oefenen. Een ander voorbeeld is de overeenkomst tussen de aandeelhouder en de vennootschap, waarbij de aandeelhouder afstand doet van vorderingsrecht op het vastgestelde en opeisbare dividend.

De grens van een statutaire of contractuele afwijking wordt gevormd door art. 2:25 BW, art. 3:40 BW en de vennootschappelijke redelijkheid en billijkheid van art. 2:8 BW.

Terug naar de vraag of de stemrechtloze aandeelhouder, de houder van een certificaat met vergaderrecht en de aandeelhouder wiens stemrecht is overgedragen aan de vruchtgebruiker of pandhouder vrijwillig kunnen afzien van de uitoefening van hun vergaderrecht. Daarmee zouden zij, indien zulks mogelijk is, afstand doen van hun recht de algemene vergadering bij te wonen en daarin het woord te voeren. De wet noch de toelichting daarop laten zich hierover uit. Ik ben van mening dat vergadergerechtigden vrijwillig kunnen afzien van de uitoefening van hun vergaderrecht. ${ }^{361}$ Er bestaat geen belemmering voor, juist omdat de wet een statutaire mogelijkheid tot afwijking biedt ten aanzien van de certificaathouder met vergaderrecht. Art. 2:227 lid $4 \mathrm{BW}$ bepaalt immers dat de statutaire regeling waarbij aan certificaathouders vergaderrecht is toegekend met instemming van de certificaathouder kan worden gewijzigd, tenzij de bevoegdheid tot wijziging bij de toekenning van het vergaderrecht was voorbehouden. De laatste volzin van art. 2:227 lid 2 BW bepaalt dat de statuten kunnen bepalen dat het verbinden en ontnemen van vergaderrecht aan certificaten van aandelen geschiedt door een daartoe in de statuten aangewezen orgaan. Uit deze bepalingen volgt dat de algemene vergadering (of een ander orgaan) het vergaderrecht kan ontnemen, hetzij met instemming van de

360 De Kluiver \& Meinema 2002, p. 652; Meinema 2003, p. 48 en Meinema 2004, p. 38-39.

361 In gelijke zin: De Kluiver \& Meinema 2002, p. 653, over de certificaathouder. Meinema 2003, p. $52-$ 56 , in positieve zin over het afzien van de uitoefening van bepaalde aan de aandeelhouder toekomende rechten. Vgl. Van den Ingh 2003 (1), p. 184-185 en Van den Ingh 2003 (2), p. 5, over het afstand doen door de bewilligde certificaathouder van zijn vorderingsrecht tot vernietiging van besluiten. 
certificaathouder, hetzij omdat het recht van ontneming is voorbehouden bij de toekenning van het vergaderrecht. Hoewel deze regels slechts op certificaten zien, moet naar mijn mening wat een orgaan van de vennootschap kan ook de vergadergerechtigde zelf kunnen. Hij ontneemt zichzelf, door het vrijwillig afstand doen, het vergaderrecht. Beter gezegd: hij ziet af van de uitoefening van zijn vergaderrecht.

Ook om een andere reden kan mijns inziens door vergadergerechtigden vrijwillig worden afgezien hun vergaderrecht uit te oefenen. Algemeen aanvaard is dat aandeelhouders stemovereenkomsten kunnen sluiten, inhoudende dat een aandeelhouder op een bepaalde wijze stemt of zich van stemming onthoudt. Dat is een contractuele vorm van vrijwillig afstand doen van recht, zijnde een verbintenis op welke wijze de aandeelhouder het aan zijn aandeel verbonden recht uitoefent. De aandeelhouder beperkt de hem toekomende rechten, meer in het bijzonder de uitoefening van het hem toekomende stemrecht.

Kan ook afstand van het vergaderrecht worden gedaan voor een bepaalde periode en/of voor een of meerdere algemene vergaderingen? Dat is naar mijn mening mogelijk. Ik acht dat zelfs beter verdedigbaar dan de overeenkomst inhoudende dat de aandeelhouder voor onbepaalde tijd afstand doet van zijn recht de algemene vergadering bij te wonen en daarin het woord te voeren. In dat laatste geval raakt dat namelijk de grens van art. 2:25 en 3:40 BW, omdat bij een voor onbepaalde tijd afstand doen van de uitoefening van een aan een aandeel verbonden recht feitelijk sprake is van het daadwerkelijk afstand doen van een recht in de hiervoor genoemde goederenrechtelijke zin. Met andere woorden: het afzien van de uitoefening van het recht moet voldoende bepaalbaar zijn. ${ }^{362}$

Wat is het gevolg van het afzien van de uitoefening van het vergaderrecht? De wet koppelt aan de vergadergerechtigdheid tal van andere rechten. Het gaat bijvoorbeeld ook om het oproepingsrecht (art. 2:223 BW) en het recht kennis te nemen van oproepingsbrieven voor een algemene vergadering (art. 2:224 lid 1 BW), het recht om de voorzieningenrechter te verzoeken om een machtiging tot het bijeenroepen van een algemene vergadering (art. 2:220 BW) en besluitvorming in en buiten vergadering (respectievelijk lid 1 en 2 van art. 2:238 BW). Het vergaderrecht is dus van belang zowel voor het beïnvloeden van het besluitvormingsproces als voor de geldigheid van de besluitvorming. ${ }^{363}$ Niet inachtneming van deze rechten kan leiden tot nietigheid ex art. 2:14 BW of vernietigbaarheid ex art. 2:15 $\mathrm{BW}$ van besluiten. Indien de vergadergerechtigde afstand doet van het vergaderrecht, doet hij daarmee mijns inziens ook afstand van de aan het vergaderrecht gekoppelde rechten. ${ }^{364}$ Echter, juist omdat het afstand doen van het vergaderrecht vergaande gevolgen heeft, mag dat afstand doen van recht niet snel worden

362 In gelijke zin: De Kluiver \& Meinema 2002, p. 653; Meinema 2003, p. 54; Meinema 2004, p. 39 en Stokkermans \& Rensen 2012, p. 72.

363 Vgl. Schwarz 1995, p. 204-205.

364 Vgl. art. 6:160 BW. Door het afstand doen van recht gaan ook alle aan het vorderingsrecht verbonden nevenrechten, zoals pand, hypotheek, voorrechten en borgstellingen, teniet. 
aangenomen en zal dat in voorkomend geval goed moeten worden vastgelegd. Ik zou daarom niet zonder meer willen aannemen dat afstand van vergaderrecht stilzwijgend kan worden aangenomen.

Op grond van art. 2:225 BW kunnen, indien oproeping niet of niet tijdig heeft plaatsgevonden, slechts wettige besluiten worden genomen indien alle vergadergerechtigden ermee hebben ingestemd dat besluitvorming plaatsvindt. ${ }^{365} \mathrm{Er}$ is, zo komt mij voor, geen knip mogelijk tussen het afstand doen van vergaderrecht en het niet-afstand doen van het oproepingsrecht. Waarom zou een vergadergerechtigde wel opgeroepen willen worden voor de algemene vergadering, terwijl hij afstand heeft gedaan van zijn recht die algemene vergadering bij te wonen en daarin het woord te voeren (teneinde besluitvorming te beïnvloeden)? Het is of het een of het ander. Datzelfde geldt voor besluitvorming buiten vergadering op grond van art. 2:238 BW. Ook daarvoor geldt dat alle vergadergerechtigden met deze wijze van besluitvorming moeten instemmen. Het doen van afstand van vergaderrecht houdt naar mijn mening ook in dat de vergadergerechtigde ook afstand doet van zijn instemmingsrecht ter zake van besluitvorming buiten vergadering. Ook hier geldt: het is het een of het ander.

De vergadergerechtigde zal zowel jegens de vennootschap als jegens zijn medevergadergerechtigden moeten afzien van de uitoefening van zijn vergaderrecht, omdat de wet aan de vergadergerechtigdheid tal van andere rechten koppelt. Het vergaderrecht wordt uitgeoefend in de algemene vergadering. Dat is reden om jegens de mede-vergadergerechtigden afstand te doen. De reden om jegens de vennootschap afstand te doen, is bijvoorbeeld gelegen in het feit dat het bestuur van de vennootschap ex art. 2:219 BW bevoegd is de algemene vergadering bijeen te roepen.

Hiervoor stelde ik dat vergadergerechtigden vrijwillig kunnen afzien van de uitoefening van hun vergaderrecht. Ik scheerde de stemrechtloze aandeelhouder, de houder van een certificaat met vergaderrecht en de aandeelhouder wiens stemrecht is overgedragen aan de vruchtgebruiker of pandhouder over een kam. Is dat terecht? Een verschil zou gelegen kunnen zijn in het feit dat het in beginsel de aandeelhouders zijn die bepalen in hoeverre de besluitvorming in de algemene vergadering open staat voor anderen. Daarnaast is het uitgangspunt dat de vennootschap, althans de algemene vergadering, zelf bepaalt of er certificaten met vergaderrecht worden toegelaten, en zo ja, aan welke certificaten dat vergaderrecht toekomt. ${ }^{366} \mathrm{Ik}$ meen dat dit verschil niet essentieel is. Het gaat immers om het vrijwillig afzien van de uitoefening van het vergaderrecht door de vergadergerechtigde zelf.

365 En de bestuurders en commissarissen voorafgaand aan de besluitvorming in de gelegenheid zijn gesteld advies uit te brengen.

366 Kamerstukken II 2006/07, 31 058, nr. 3, p. 82 (MvT) 


\subsection{Samenvatting en conclusie}

In dit hoofdstuk stonden de rechten van de kapitaalverschaffers zonder stemrecht centraal.

De stemrechtloze aandeelhouder

Aan het stemrechtloze aandeel zijn alle rechten verbonden, behalve het stemrecht. In paragraaf 6.2.3.1 gaf ik een overzicht van de aan het stemrechtloze aandeel verbonden rechten. Het (gehele of gedeeltelijke) recht op winst en/of de reserves van de vennootschap is een belangrijk recht voor de stemrechtloze aandeelhouder. Op grond van het bepaalde in art. 2:216 BW is dat recht echter niet ongeclausuleerd. Eerst zal de algemene vergadering een besluit tot uitkering van de winst en/of reserves moeten nemen, welk besluit vervolgens moet worden goedgekeurd door het bestuur.

Aan de vergadering van stemrechtloze aandeelhouders kan op grond van art. 2:242, 2:244 en 2:245 BW de bevoegdheid worden toegekend een bestuurder te benoemen, te schorsen, te ontslaan en zijn bezoldiging vast te stellen, tenzij de benoeming van bestuurders geschiedt op grond van het (volledige) structuurregime. De ondergrens voor de benoeming is dat iedere aandeelhouder met stemrecht kan deelnemen aan de besluitvorming inzake de benoeming van ten minste één bestuurder. Er kunnen op grond van art. 2:244 BW meerdere organen bevoegd tot ontslag van een bestuurder zijn, doch niet ten aanzien van schorsing van een bestuurder. Door het benoemen van een eigen bestuurder kunnen de houders van stemrechtloze aandelen hun invloed in de vennootschap vergroten. Die bestuurder zal echter wel het vennootschappelijk belang in acht moeten nemen en niet alleen de achterban kunnen dienen. De toekenning en ontneming van bevoegdheid van de vergadering van stemrechtloze aandeelhouders een bestuurder te benoemen, te schorsen of te ontslaan kan slechts met unanimiteit in een vergadering waarin het gehele geplaatste kapitaal vertegenwoordigd is worden genomen. Bij een dergelijk besluit tot statutenwijziging wordt de stemrechtloze aandeelhouder beschermd door het bepaalde in art. 2:231 lid 4 BW. De statuten kunnen bepalen dat de vergadering van stemrechtloze aandeelhouders op grond van art. 2:243 lid 5 BW ook een bestuurder uit voordracht kan benoemen.

De regels van benoeming, schorsing en ontslag van commissarissen volgen in hoge mate de regels daaromtrent met betrekking tot de bestuurder. Ook deze bevoegdheden kunnen bij de statuten aan de vergadering van stemrechtloze aandeelhouders worden toegekend.

Uit art. 2:206a BW volgt dat de stemrechtloze aandeelhouder geen voorkeursrecht heeft op uit te geven aandelen van welke soort dan ook. Daarvan kan statutair worden afgeweken. Indien dat het geval is, komt het mij voor dat dit voorkeursrecht omzeild kan worden door gewone aandelen uit te geven en die aandelen vervolgens te certificeren en te plaatsen bij nieuwe kapitaalverschaffers zonder stemrecht. De 
stemrechtloze aandeelhouder kan in situaties omtrent het voorkeursrecht bescherming aan de vennootschappelijke redelijkheid en billijkheid ontlenen. De houder van gewone aandelen heeft geen voorkeursrecht op uit te geven stemrechtloze aandelen. De stemrechtloze aandeelhouder kan in het kader van de aanbiedingsregeling van art. 2:195 $\mathrm{BW}$ alleen reflecteren op aangeboden, stemrechtloze aandelen. Van deze hoofdregels kan bij de statuten worden afgeweken.

In een groot aantal gevallen wordt de stemrechtloze aandeelhouder beschermd. Ik verwijs naar het overzicht in paragraaf 6.2.3.6. Twee beschermingsregels verdienen bijzondere aandacht, namelijk art. 2:216 lid 8 en 2:231 lid 4 BW. Het instemmingsrecht van art. 2:216 lid $8 \mathrm{BW}$ moet naar mijn mening eng geïnterpreteerd worden. Het ziet op statutaire wijzigingen van het direct aan het aandeel verbonden financiële recht en niet op een statutaire wijziging die weliswaar afbreuk doet aan het recht op winst en/of reserves in de vennootschap, doch die indirect dat recht raken. Art. 2:231 lid 4 BW bepaalt voor de stemrechtloze aandeelhouders dat een besluit tot statutenwijziging dat specifiek afbreuk doet aan enig aan hen toekomend recht een goedkeurend besluit van deze groep van aandeelhouders vereist is. Het gaat daarbij om afbreuk van specifieke rechten verbonden aan deze aandelen en om een beperking van rechten, die ook verbonden zijn aan andere aandelen, doch welke beperking dan alleen geldt voor de bedoelde bepaalde aandelen en niet voor andere aandelen. De bevoegdheid tot wijziging kan ten tijde van de toekenning van het recht in de statuten worden voorbehouden op grond van de tenzij-clausule van art. 2:231 lid 4 BW. Naar mijn mening kan de statutaire regeling zo worden vormgegeven dat door een enkel besluit van de algemene vergadering dat recht kan worden geschrapt of gewijzigd. Het komt mij voor dat art. 2:231 lid 4 BW, gelet op het doel en strekking van deze bepaling, in de praktijk snel toepassing zal vinden.

Met besluitvorming buiten vergadering moet de stemrechtloze aandeelhouder instemmen. Het ontbreken van instemming maakt het in strijd daarmee genomen besluit naar mijn mening (slechts) vernietigbaar, gelet op de beoogde versoepeling van de besluitvorming buiten vergadering. Instemming hoeft niet schriftelijk en kan langs elektronische weg geschieden. Indien de stemrechtloze aandeelhouder weigert met besluitvorming buiten vergadering in te stemmen, zal er alsnog een algemene vergadering bijeengeroepen moeten worden. Ik ben van mening dat de vergadergerechtigde kapitaalverschaffers zonder stemrecht ten aanzien van de besluitvorming buiten vergadering ook achteraf daaraan hun instemming kunnen geven (expliciet) of kunnen doen blijken (impliciet) doordat die vergadergerechtigden geen bezwaar maken tegen de genomen besluiten. Mocht voorafgaande instemming ontbreken, dan verdient het aanbeveling die instemming achteraf alsnog expliciet te verkrijgen teneinde onzekerheid over de rechtsgeldigheid van buiten vergadering genomen besluiten te voorkomen. De rol van de vergadergerechtigde kapitaalverschaffer zonder stemrecht bij besluitvorming buiten vergadering lijkt mij gemarginaliseerd.

Een stemrechtloze aandeelhouder kan gebonden worden aan statutaire verplichtingen in de zin van art. 2:192 BW, maar dat hoeft niet het geval te zijn. Hij kan met 
de voorgestelde statutaire verplichting niet instemmen. Er is dan sprake van 'persoonsgebonden niet-gebondenheid', ongeacht of de stemrechtloze aandeelhouder na de statutenwijziging, waarbij de statutaire verplichting is ingevoerd, meer aandelen heeft verworven. Anders dan de wetgever meent, gaat deze persoonsgebonden niet-gebondenheid over bij opvolging onder algemene titel. Langs de weg van art. 2:192 BW kan naar mijn mening geen stemrechtloos aandeel gecreëerd worden.

Voor de toepassing van de uitkoopregeling van art. 2:201a BW wordt ook rekening gehouden met de stemrechtloze aandelen in een BV, zo bepaalt art. 2:24d lid 2 BW.

In de statuten van een BV kan worden opgenomen dat stemrechtloze aandelen in gewone aandelen geconverteerd kunnen worden. Daarbij kan bepaald zijn dat een bepaald orgaan bevoegd is te besluiten tot conversie of dat conversie van rechtswege zal plaatsvinden op een bepaald tijdstip of bij een bepaalde gebeurtenis. De stemrechtloze aandeelhouder verkrijgt als gevolg van deze conversie stemrecht in de algemene vergadering.

De stemrechtloze aandeelhouder wordt op grond van art. 2:181 lid $1 \mathrm{BW}$ ingeval van omzetting van een BV in een vereniging, coöperatie, of onderlinge waarborgmaatschappij lid van die rechtspersoon, tenzij hij een verzoek tot schadeloosstelling bij de vennootschap voor het verlies van zijn aandelen indient. Partijen zullen in eerste instantie moeten onderhandelen en overeenstemming moeten bereiken over de omvang van de rechten van de stemrechtloze aandeelhouder in de omgezette rechtspersoon. Art. 2:181 lid $3 \mathrm{BW}$ regelt het uittreedrecht van de stemrechtloze aandeelhouder indien de BV wordt omgezet in een NV. De NV kent geen stemrechtloze aandelen. De stemrechtloze aandeelhouder moet aldus bij omzetting aandeelhouder met winst- en (eventueel gering) stemrecht worden. Indien de stemrechtloze aandeelhouder niet met de omzetting instemt, kan hij schadeloosstelling verzoeken.

Het voorstel tot omzetting moet de schadeloosstelling, vastgesteld door een of meer deskundigen, vermelden. Het rapport van de deskundigen moet zijn uitgebracht voordat over de omzetting wordt besloten. De deskundigen moeten een tussen partijen op grond van de statuten of een overeenkomst geldende regeling omtrent de vaststelling van de waarde respecteren. De statutaire prijsbepalingsregeling of een soortgelijke regeling in een aandeelhoudersovereenkomst in de zin van art. 2:181 lid 4 derde volzin BW moet mijns inziens specifiek op omzetting zien, wil die regeling ingeval van omzetting toepassing kunnen vinden. De benoeming van deskundigen kan achterwege blijven indien (i) de schadeloosstelling zonder meer aan de hand van die regeling kan worden vastgesteld of (ii) de aandeelhouders hebben verklaard geen gebruik te maken van hun uittreedrecht. De schadeloosstelling zal worden bepaald aan de hand van de nominale waarde van de aandelen en zal een element van schadeloosstelling bevatten voor het verlies van dividendinkomsten of andere financiële aanspraken. Art. 2:181 lid 5 BW sluit 
toepassing van art. 2:231 lid 4 BW uit, omdat het niet voor de hand ligt stemrechtloze aandeelhouders stemrecht te geven bij ingrijpende besluiten, zoals omzetting. Daarmee wordt dubbele bescherming voorkomen. Art. 2:181 lid 6 BW brengt tot uitdrukking dat voor de omzetting van een BV in een stichting of een vereniging de daarvoor noodzakelijke rechterlijke machtiging wordt geweigerd indien de belangen van de stemrechtloze aandeelhouder onvoldoende worden ontzien.

Bij de regeling van de positie van de stemrechtloze aandeelhouder in geval van omzetting stel ik vraagtekens. Het is de vraag of de stemrechtloze aandeelhouder, gelet op de aard van de omgezette rechtspersoon, in een goede of vergelijkbare positie kan terugkeren. Kiest hij daar niet voor, dan is de vraag of de schadeloosstelling, althans de hoogte daarvan, op eenvoudige wijze kan worden vastgesteld.

Als eenvoudige oplossing voor de omzetting van een BV in een NV stel ik voor de regel dat stemrechtloze aandelen in een BV tot aandelen met stemrecht in een NV verworden, waarbij de hoofdregel van art. 2:118 BW wordt gevolgd. Wil men dat voorkomen (om de overeengekomen zeggenschaps- en financiële verhoudingen niet te wijzigen), dan is omzetting geen optie of moet men tegenstemmen. Een meer eenvoudige oplossing lijkt mij de introductie van stemrechtloze aandelen in de NV. Een ander punt van kritiek op de regeling omtrent de schadeloosstelling van art. 2:181 BW is dat niet duidelijk is wat onder vervallen van de stemrechtloze aandelen verstaan wordt. Mijns inziens ligt het voor de hand dat bij het van kracht worden van de omzetting door de BV een besluit tot intrekking van de stemrechtloze aandelen wordt genomen.

Indien een $\mathrm{BV}$ in een vennootschap onder firma omgezet wordt, is in juridische zin sprake van ontbinding van de BV in de zin van art. 2:19 BW. Als gevolg van het besluit tot ontbinding moet worden vereffend. De stemrechtloze aandeelhouder heeft ex art. 2:23b BW recht op het liquidatiesaldo, tenzij de statuten dit uitsluiten. In de omgekeerde situatie, namelijk de omzetting van een personenvennootschap in een $\mathrm{BV}$, is het aan de eigenaren van die personenvennootschap en de hen gegeven (contracts)vrijheid bij of na oprichting van de BV te kiezen voor stemrechtloze aandelen in het kapitaal van die BV.

De positie van de stemrechtloze aandeelhouder ingeval van fusie en splitsing lijkt in hoge mate op zijn positie ingeval van omzetting in een andere rechtspersoon. Art. 2:317 BW geeft een algemene regeling voor besluiten tot fusie. Voor fusies van NV's en BV's zijn onder meer art. 2:326, 2:330 en 2:330a BW van belang. Voor de stemrechtloze aandeelhouder en de rechtspraktijk is met name de fusie tussen een verdwijnende BV en een verkrijgende NV relevant. De NV kent geen stemrechtloze aandelen. Er zal met de stemrechtloze aandeelhouder onderhandeld moeten worden over zijn positie als aandeelhouder na de fusie. De uitkomst van deze onderhandelingen kan zijn dat er na de fusie een BV bestaat, waarin hij dezelfde positie als houder van stemrechtloze aandelen houdt of dat zijn aandelen worden geconverteerd naar aandelen met stem- of winstrecht. Het kan ook zijn dat beide partijen niet met elkaar verder willen of dat een van beide partijen niet met de ander verder wil. Er dient dan onderhandeld te worden over schadeloosstelling. De positie 
van de stemrechtloze aandeelhouder kan ex art. 2:317 lid 4 BW worden versterkt, bijvoorbeeld doordat het besluit tot fusie de instemming van iedere stemrechtloze aandeelhouder of goedkeuring van de vergadering van stemrechtloze aandeelhouders vereist.

Art. 2:330 lid $1 \mathrm{BW}$ geeft een hoofdregel voor het besluit tot fusie van de algemene vergadering. Daarnaast is op grond van art. 2:330 lid 2 BW een goedkeurend groepsbesluit vereist van de houders van stemrechtloze aandelen aan wier rechten in het kader van de fusie afbreuk wordt gedaan. De reden voor deze bescherming is dat de BV zelf ook een verkrijgende vennootschap kan zijn. Voorts kunnen aan de vergadering van stemrechtloze aandeelhouders bijzondere bevoegdheden zijn toegekend, zoals de benoeming van een bestuurder of commissaris of een recht van instructie. Naast het goedkeurende groepsbesluit op grond van art. 2:330 lid 2 BW is niet nog eenzelfde groepsbesluit door diezelfde aandeelhouders op grond van art. 2:231 lid 4 BW nodig. In afwijking van art. 2:311 BW kan de stemrechtloze aandeelhouder van de verdwijnende BV indien hij geen aandeelhouder in de verkrijgende NV wordt op grond van art. 2:330a BW een verzoek tot schadeloosstelling indienen. De regeling daartoe is gelijk aan die van omzetting.

Bij een driehoeksfusie in de zin van art. 2:333a BW rust de verplichting tot schadeloosstelling ex art. 2:330a BW op de groepsmaatschappij; de verkrijgende vennootschap is daarvan vrijgesteld. Indien de groepsmaatschappij een BV is, kunnen de stemrechtloze aandeelhouders van de verdwijnende vennootschap ook stemrechtloze aandelen verkrijgen in de groepsmaatschappij-BV.

Bij een grensoverschrijdende fusie ex art. 2:333h BW kan de stemrechtloze aandeelhouder een maand na het besluit tot fusie van de verdwijnende vennootschap schadeloosstelling bij die vennootschap vragen. Art. 2:330a BW is bij een grensoverschrijdende fusie niet van toepassing.

De regeling omtrent splitsing en de positie van de stemrechtloze aandeelhouder daarbij is in hoge mate gelijk aan die van fusie. Art. 2:334m BW geeft een algemene regeling voor besluiten tot splitsing. De positie van de stemrechtloze aandeelhouder kan ex art. 2:334m lid 4 BW worden versterkt, bijvoorbeeld doordat het besluit tot splitsing de instemming van iedere stemrechtloze aandeelhouder of goedkeuring van de vergadering van stemrechtloze aandeelhouders vereist. Voor splitsing van een besloten vennootschap of een besloten vennootschap die in het kader van een splitsing wordt opgericht, zijn onder meer 2:334ee en 2:334ee1 BW van belang. Dat (laatste) artikel regelt de schadeloosstelling voor de stemrechtloze aandeelhouder indien de verkrijgende vennootschap geen BV is. Deze bepalingen zijn de pendant van de toepasselijke bepalingen in geval van fusie (art. 2:330 en 2:330a BW). Eveneens geldt dat een goedkeurend groepsbesluit vereist is van de houders van stemrechtloze aandelen aan wier rechten in het kader van de splitsing afbreuk wordt gedaan. Art. 2:231 lid $4 \mathrm{BW}$ is in dit geval niet van toepassing.

In de literatuur wordt naar mijn mening terecht gesteld dat niet valt in te zien waarom ingeval van een ruziesplitsing ex art. 2:334cc BW stemrechtloze aandeelhouders in de splitsende BV niet een gelijkwaardige positie in de verkrijgende 
(besloten) vennootschappen zouden kunnen krijgen. Daarnaast gaat de wetgever er kennelijk en ten onrechte, zo wordt evenzeer terecht in de literatuur opgemerkt, vanuit dat alle stemrechtloze aandelen in een van de verkrijgende vennootschappen worden ondergebracht en de aandelen met stemrecht in de andere verkrijgende vennootschap. Ook dat hoeft niet per definitie het geval te zijn. Indien daarvan wel sprake is, kan dat op eenvoudige wijze worden opgelost. Bij splitsing kan de verkrijgende vennootschap aandelen met stemrecht aan de (voormalige) stemrechtloze aandeelhouders uitgeven.

Bij de vereenvoudigde splitsing van art. 2:334hh BW heeft de stemrechtloze aandeelhouder geen recht op schadeloosstelling. Er is immers geen sprake van een verdwijnende vennootschap. De stemrechtloze aandeelhouder kan in een evenredige splitsing ex art. 2:334hh lid 2 BW houder van een ander 'soort' stemrechtloos aandeel worden. Aan zijn aandeel kunnen andere financiële rechten verbonden zijn, bijvoorbeeld een beperkter winstrecht, dan aan zijn oorspronkelijke aandeel. Hij wordt beschermd door het goedkeurende groepsbesluit van art. 2:334ee lid 2 BW.

De regeling van de driehoekssplitsing van art. 2:334ii BW is gelijkluidend aan die van de driehoeksfusie in de zin van art. 2:333a BW. Voor de positie van de stemrechtloze aandeelhouder is art. 2:334ii lid 3 BW van belang, dat als uitgangspunt stelt dat de verplichtingen van de verkrijgende vennootschap worden opgelegd zowel aan de groepsmaatschappij die de aandelen uitreikt als aan de verkrijgende vennootschap. Omdat de in art. 2:334ee1 BW geregelde schadeloosstelling voor houders van stemrechtloze aandelen gerelateerd is aan de toekenning van aandelen, wordt de verkrijgende vennootschap in art. 2:334ii lid $3 \mathrm{BW}$ vrijgesteld van de verplichting als bedoeld in art. 2:334ee1 lid $1 \mathrm{BW}$. In de literatuur wordt hierover naar mijn mening terecht opgemerkt dat indien de groepsmaatschappij een BV is, de stemrechtloze aandeelhouders van de splitsende vennootschap ook stemrechtloze aandelen kunnen verkrijgen in de groepsmaatschappij-BV.

Naar mijn mening is de wetgever gelet op het voorgaande niet in zijn opzet geslaagd een eenvoudige regeling van het stemrechtloze aandeel te creëren.

De houder van certificaten met en zonder vergaderrecht

Door certificering wordt de juridische en economische eigendom van aandelen gesplitst. Het administratiekantoor is eigenaar van de aandelen in de BV en houdt die aandelen op grond van een beheersovereenkomst voor de certificaathouder. Er is sprake van een driehoeksverhouding, bestaande uit de verhouding (i) tussen de BV en het administratiekantoor, (ii) tussen het administratiekantoor en de certificaathouder en (iii) tussen de BV en de certificaathouder. Voor een overzicht van de aan het certificaat verbonden rechten in deze driehoeksverhouding verwijs ik naar paragraaf 6.3.3.1.

Het stemrecht op de gecertificeerde aandelen wordt door het administratiekantoor uitgeoefend. Bij het stemgedrag zal het administratiekantoor met de belangen van de certificaathouders op korte en lange termijn rekening moeten houden, ongeacht de 
normen die uit de statuten van het administratiekantoor en de administratievoorwaarden zouden voortvloeien. Deze belangen mogen niet onevenredig worden geschaad. De invloed van de certificaathouder op het stemgedrag van het administratiekantoor is afhankelijk van de omstandigheden van het geval en wordt bepaald door de inhoud van de statuten van het administratiekantoor en de administratievoorwaarden. Indien de certificaathouder vergadergerechtigd is, zal de invloed van de certificaathouder op de besluitvorming (verder) toenemen, zoals dat ook geldt voor de stemrechtloze aandeelhouder.

Voor de positie van de houder van een certificaat is bepalend of aan het certificaat vergaderrecht is toegekend. Het vergaderrecht en de daaraan gekoppelde rechten zijn van belang zowel voor het beïnvloeden van het besluitvormingsproces als voor de geldigheid van de besluitvorming. Het zijn belangrijke rechten voor deze certificaathouder. Op grond van art. 2:228 lid $2 \mathrm{BW}$ zijn statutaire regelingen die bepalen dat certificaten in het algemeen geen vergaderrecht hebben, dat alle certificaten vergaderrecht hebben of dat het vergaderrecht slechts toekomt aan bepaalde, in de statuten aangeduide certificaten, toegestaan. Uitgangspunt is dat de vennootschap, althans de algemene vergadering, zelf bepaalt of er certificaten met vergaderrecht worden toegelaten, en zo ja, aan welke certificaten dat vergaderrecht toekomt. Er zijn twee manieren om vergaderrecht aan certificaten te verbinden, te weten (i) toekenning bij statuten en (ii) toekenning door een orgaan, dat bij de statuten daartoe is aangewezen. Art. 2:227 lid 4 BW bepaalt dat het aan certificaathouders bij statuten toegekende vergaderrecht slechts met instemming van die certificaathouder kan worden gewijzigd, tenzij bij het toekennen van het vergaderrecht de bevoegdheid tot wijziging uitdrukkelijk in de statuten was voorbehouden. Er zijn drie mogelijkheden het vergaderrecht aan het certificaat te ontnemen. Ten eerste, bij statuten is aan het certificaat vergaderrecht toegekend, maar het ontnemen van dat recht of wijziging daarvan is niet voorbehouden. De certificaathouder zal met het ontnemen van het vergaderrecht aan zijn certificaat moeten instemmen. Ten tweede, bij statuten is aan het certificaat vergaderrecht toegekend en het ontnemen van dat recht of wijziging daarvan is in dezelfde statutaire regeling voorbehouden. Het vergaderrecht kan op grond van de tenzij-clausule van art. 2:227 lid 4 BW aan het certificaat worden ontnomen (zonder dat daartoe instemming van de certificaathouder is vereist). Ten derde, de bevoegdheid tot het toekennen en ontnemen van vergaderrecht is toegekend aan een orgaan van de vennootschap in de zin van art. 2:189a BW. Dat orgaan kan zonder dat daartoe instemming van de certificaathouder is vereist het vergaderrecht aan het certificaat ontnemen.

Bij besluitvorming buiten vergadering is de positie van de certificaathouder met vergaderrecht gelijk aan de positie van de stemrechtloze aandeelhouder. Met de certificaathouder zonder vergaderrecht hoeft bij besluitvorming buiten vergadering geen rekening gehouden te worden. Hij is immers niet vergadergerechtigd.

Aan de certificaathouder met vergaderrecht komt het wettelijke pandrecht ex art. 3:259 BW toe. Daarbij hoeft naar mijn mening geen onderscheid gemaakt te worden tussen certificaten waarbij het vergaderrecht bij de statuten en certificaten 
waarbij het vergaderrecht door een orgaan is toegekend. Het ontnemen van het vergaderrecht aan de certificaten door een daartoe in de statuten aangewezen orgaan doet het wettelijk pandrecht vervallen, gelijk het verbinden van het vergaderrecht aan het certificaat het wettelijk pandrecht doet ontstaan. Dit vergt (extra) zorgvuldigheid in de vastlegging van de besluitvorming en het bijhouden van het aandeelhoudersregister.

De vraag of certificaten al dan niet royeerbaar zijn, is ook relevant voor de verhouding van de houder van het certificaat tot de vennootschap. Afhankelijk van het antwoord op die vraag kan de certificaathouder zijn certificaat omwisselen voor een aandeel, zodat zijn stemrecht 'herleeft' en ziet hij - afhankelijk van de stemverhoudingen in de algemene vergadering - zijn invloed op de besluitvorming toenemen. Indien de administratievoorwaarden niet vermelden of certificaten royeerbaar zijn, moet naar mijn mening bij gebrek aan het vorderingsrecht daartoe ervan worden uitgegaan dat ze niet royeerbaar zijn.

Ten aanzien van de positie van de certificaathouder ingeval van omzetting van de $\mathrm{BV}$ in een personenvennootschap geldt in gelijke mate hetgeen ik in die situatie ten aanzien van de positie van de stemrechtloze aandeelhouder heb opgemerkt, zij het dat het administratiekantoor - als aandeelhouder - het stemrecht uitoefent ten aanzien van het besluit tot ontbinding. De certificaathouder met vergaderrecht zal vanwege dat vergaderrecht bij het besluitvormingsproces betrokken zijn. Indien een $\mathrm{BV}$ wordt omgezet in een NV en de NV de certificaten als bewilligde certificaten beschouwt, is naar mijn mening de instemming van de certificaathouder met vergaderrecht ten aanzien van de in het kader van de omzetting noodzakelijke statutenwijziging niet vereist. Indien de NV geen bewilligde certificaten kent of de certificaten met vergaderrecht als niet-bewilligd aanmerkt, wordt het vergaderrecht aan het certificaat ontnomen en is op grond van art. 2:227 lid 4 BW de instemming van de certificaathouder vereist.

Bij een besluit tot fusie ex art. 2:317 BW oefent het administratiekantoor namens de certificaathouders het stemrecht op de aandelen in de algemene vergadering uit. Daarbij zal het administratiekantoor de belangen van de certificaathouders in acht moeten nemen. In de statuten van het administratiekantoor kan bepaald zijn dat het besluit tot fusie, of meer algemeen het besluit tot wijziging van de statuten, goedkeuring behoeft van de vergadering van certificaathouders. Het administratiekantoor doet er naar mijn mening goed aan bij belangrijke besluiten als fusie, ontbinding en omzetting, de vergadering van certificaathouder te raadplegen - voor zover een dergelijke verplichting niet reeds in de administratievoorwaarden is opgenomen - alvorens het administratiekantoor haar stem in de algemene vergadering uitbrengt. Het administratiekantoor zal naar mijn mening met inachtneming van de uitslag van de stemming in de vergadering van certificaathouders voor dan wel tegen het besluit tot fusie moeten stemmen, corresponderend met het aantal voor- en tegenstemmen in de vergadering van certificaathouders. Ook hier geldt dat, gelet op de procedure zoals in art. 2:317 BW beschreven, de certificaathouder met vergaderrecht reeds bij de besluitvorming in de BV ten aanzien van de ontbinding betrokken 
zal zijn. Het komt mij voor dat art. 2:227 lid $4 \mathrm{BW}$ in geval van fusie en splitsing niet geldt. Evenmin bieden art. 2:216 lid 7 en 2:330 lid 2 BW de certificaathouder bescherming.

Bij een fusie tussen een verdwijnende vennootschap die certificaten met vergaderrecht kent en een verkrijgende vennootschap die geen of alleen certificaten zonder vergaderrecht kent, is de positie van de certificaathouder in de verdwijnende vennootschap naar mijn mening dat hij in beginsel gelijke lidmaatschapsrechten in de verkrijgende vennootschap moet verkrijgen.

Uitgaande van een fusie tussen twee besloten vennootschappen meen ik dat het wettelijk pandrecht ex art. 3:259 BW vervalt, indien sprake is van certificaten met vergaderrecht in de verdwijnende vennootschap en certificaten zonder vergaderrecht in de verkrijgende vennootschap.

De aandeelhouder wiens stemrecht is overgedragen aan de vruchtgebruiker of de pandhouder

Voor de aandeelhouder wiens stemrecht is overgedragen aan de vruchtgebruiker of de pandhouder geldt dat sprake is van een lidmaatschapsverhouding tussen die aandeelhouder en de vennootschap. Zij hebben dezelfde rechten als de certificaathouder met vergaderrecht, zo volgt uit respectievelijk art. 2:197 lid 4 en art. 2:198 lid 4 BW. Daarnaast hebben zij, anders dan de stemrechtloze aandeelhouder, ex art. 2:206a BW een voorkeursrecht op uit te geven aandelen.

\section{De houder van een participatiebewijs}

Het participatiebewijs is niet in de wet geregeld. Voor de rechten en verplichtingen zullen de participatievoorwaarden, waarvoor de contractsvrijheid geldt, uitkomst moeten bieden. Omdat geen sprake is van een lidmaatschapsverhouding tussen de houder van een participatiebewijs en de vennootschap, staat die houder in een andere organisatorische verhouding tot de vennootschap. De (vergadering van) houders van participatiebewijzen (is) zijn geen orgaan van de vennootschap. In de regel zullen de participatievoorwaarden voornamelijk financiële rechten, en geen zeggenschapsrechten, aan de houder van een participatiebewijs toekennen. Het belangrijkste recht is het winstrecht, en eventueel een recht op het liquidatieoverschot. Dat winstrecht heeft een statutaire grondslag. Voor de uitgifte van een participatiebewijs is naar mijn mening geen statutaire basis vereist. De houder van een participatiebewijs wordt tegen afbreuk van zijn financiële rechten door art. 2:232 BW beschermd. Hij moet instemmen met een statutenwijziging die nadeel aan zijn rechten toebrengt, tenzij de wijzigingsbevoegdheid bij de uitgifte van het participatiebewijs reeds is voorbehouden.

Participatiebewijzen kunnen door de vennootschap worden ingekocht. Daarbij zal moeten worden voldaan aan art. 2:207 lid 2 BW. Door de verkrijging gaan de participatiebewijzen wegens vermenging teniet. Tenzij in participatievoorwaarden een intrekkingsbeding opgenomen is, kunnen participatiebewijzen mijns inziens slechts met instemming van de houder daarvan worden ingetrokken. 
Art. 2:320 BW geeft een regeling voor de houder van een participatiebewijs in de verdwijnende vennootschap ingeval van fusie. Het artikel bepaalt dat de houder van een participatiebewijs in de verdwijnende vennootschap een gelijkwaardig recht in de verkrijgende vennootschap of schadeloosstelling moet krijgen. Wat betreft de positie van de houder van een participatiebewijs ingeval van splitsing geldt art. 2:334p BW. Dat artikel heeft een nagenoeg met art. 2:320 BW gelijkluidende formulering. Bij omzetting, fusie en splitsing geldt dat de vennootschappelijke redelijkheid en billijkheid jegens de houder van het participatiebewijs in acht genomen moet worden. Bij omzetting kan de houder van een participatiebewijs ook bescherming aan art. 2:232 BW ontlenen.

\section{Overige opmerkingen}

Op grond van art. 2:216 lid 3 BW kunnen de stemrechtloze aandeelhouder en de aandeelhouder wiens stemrecht is overgedragen aan de vruchtgebruiker of pandhouder aansprakelijk zijn voor de door hun ontvangen uitkeringen, ook al kunnen deze vergadergerechtigden geen stem uitbrengen over het te nemen besluit tot uitkering. Indien zij door het bestuur zijn geïnformeerd over de schadelijke gevolgen van een voorgenomen besluit, kunnen zij zich niet beroepen op hun goede trouw.

Of een certificaathouder ex art. 2:216 lid $3 \mathrm{BW}$ gehouden is tot terugbetaling van het ontvangene, hangt naar mijn mening ervan af of sprake is van certificaten met of zonder vergaderrecht. De certificaathouder met vergaderrecht zou ik gelijk willen stellen met de stemrechtloze aandeelhouder en de aandeelhouder wiens stemrecht is overgedragen aan de vruchtgebruiker of pandhouder. Het administratiekantoor zal, als uitkeringsgerechtigde aandeelhouder, verhaal kunnen halen bij deze certificaathouder. Daarover zal een regeling in de administratievoorwaarden zijn of moeten worden opgenomen. Indien dat laatste niet het geval is, zal naar mijn mening een beroep kunnen worden gedaan op de aanvullende werking van de redelijkheid en billijkheid ex art. 6:248 lid 1 BW. Ten aanzien van de houder van een certificaat zonder vergaderrecht geldt mijns inziens dat hij niet aansprakelijk kan zijn, althans dat hij zich kan beroepen op zijn goede trouw, tenzij het bestuur hem voorafgaand aan de besluitvorming over de schadelijke gevolgen van het besluit tot uitkering informeert.

De houder van een participatiebewijs kan zich mijns inziens beroepen op de goede trouw indien hij wordt aangesproken tot terugbetaling van het ontvangene, tenzij het bestuur van de vennootschap voorafgaand aan de besluitvorming in de algemene vergadering over de uitkering ook de houder van het participatiebewijs over de schadelijke gevolgen van een voorgenomen besluit informeert.

Afwezige, vergadergerechtigde kapitaalverschaffers zonder stemrecht kunnen niet van de waarschuwingen van het bestuur op de hoogte zijn. Deze vergadergerechtigden moeten worden opgeroepen en de agenda ontvangen. Het komt mij voor dat het niet bijwonen van de algemene vergadering een omstandigheid is die in hun risicosfeer ligt. 
De stemrechtloze aandeelhouder, de houder van een certificaat met vergaderrecht en de aandeelhouder wiens stemrecht is overgedragen aan de vruchtgebruiker of pandhouder kunnen mijns inziens (vrijwillig) afzien van de uitoefening van hun vergaderrecht, mits dat voldoende bepaalbaar is, bijvoorbeeld voor een bepaalde periode of voor een of meerdere algemene vergaderingen. Gelet op de vergaande gevolgen zou ik niet zonder meer willen aannemen dat het afzien van de uitoefening van vergaderrecht stilzwijgend kan worden aangenomen. Met het afzien van de uitoefening van vergaderrecht wordt ook afstand gedaan van de aan het vergaderrecht gekoppelde rechten, zoals het oproepingsrecht. Het afzien van de uitoefening van vergaderrecht houdt naar mijn mening ook in dat de vergadergerechtigde ook afstand doet van zijn instemmingsrecht ter zake van besluitvorming buiten vergadering. 


\section{Hoofdstuk 7}

\section{REDELIJKHEID EN BILLIJKHEID EN ZORGPLICHTEN IN DE BV}

\subsection{Inleiding}

In hoofdstuk 5 stonden de interne verhoudingen in de BV en het spanningsveld, waarin de kapitaalverschaffer zonder stemrecht zich bevindt, centraal. In hoofdstuk 6 stelde ik de rechten van de kapitaalverschaffers zonder stemrecht aan de orde. In dat hoofdstuk stond, feitelijk, hard law centraal. Dit hoofdstuk stelt soft law centraal, namelijk de open norm van de vennootschappelijke redelijkheid en billijkheid ex art. 2:8 BW.

Over de vennootschappelijke redelijkheid en billijkheid is in de juridische literatuur veel geschreven. ${ }^{1}$ Ook in de rechtspraak heeft art. 2:8 BW vele malen centraal gestaan en dat staat het nog steeds. Het doel van dit hoofdstuk is niet een uitputtende beschrijving daarvan te geven. Het doel van dit hoofdstuk is de vennootschappelijke redelijkheid en billijkheid te bezien vanuit de positie van de kapitaalverschaffer zonder stemrecht. Deze kapitaalverschaffer verschaft kapitaal aan de vennootschap, waartegenover hij stemrechtloze aandelen (of een vergelijkbare rechtsfiguur) verkrijgt. Aangezien hij geen stemrecht heeft is zijn formele invloed op de besluitvorming afwezig of beperkt. Hij is afhankelijk van het stemgedrag van en de besluitvorming door anderen, bijvoorbeeld het stemgedrag van de aandeelhouder in de algemene vergadering, de besluitvorming van die vergadering en de besluitvorming van het bestuur van de vennootschap. Dat stemgedrag en die besluitvorming kunnen gevolgen hebben voor de waarde van de onderneming en de waarde van - bijvoorbeeld - het stemrechtloze aandeel of andere rechtsfiguren zonder stemrecht. Daarnaast is het de vraag of het stemgedrag van en de besluitvorming door anderen gunstig is voor de kapitaalverschaffers zonder stemrecht, in die zin dat met de gerechtvaardigde belangen van die kapitaalverschaffers rekening wordt gehouden. In het verlengde daarvan ligt de vraag of aandeelhouders met stemrecht in de algemene vergadering rekening moeten houden met de gerechtvaardigde belangen van de kapitaalverschaffers

1 Zie alleen al de dissertatie van Koelemeijer (Koelemeijer 1999). Zie voor een overzicht ten aanzien van de vennootschappelijke redelijkheid en billijkheid: Asser/Maeijer, Van Solinge \& Nieuwe Weme 2-II* 2009, nr. 46 
zonder stemrecht. In zekere zin komt de vergelijking met de positie van minderheidsaandeelhouders naar voren, bijvoorbeeld in het kader van winstreservering of -uitkering.

De opbouw van dit hoofdstuk is als volgt. In paragraaf 7.2 ga ik in op de principal-agent theory in het kader van de vennootschappelijke redelijkheid en billijkheid. Vervolgens geef ik in paragraaf 7.3 een inleiding tot de vennootschappelijke redelijkheid en billijkheid. In paragraaf 7.4 bespreek ik welke kapitaalverschaffers zonder stemrecht tot de kring van betrokkenen in de zin van art. 2:8 BW behoren. Daarna onderzoek ik in paragraaf 7.5 de voor de kapitaalverschaffers zonder stemrecht relevante thema's in de vennootschappelijke redelijkheid en billijkheid. Paragraaf 7.6 vormt de samenvatting en conclusie van dit hoofdstuk.

\subsection{Principal-agent theory}

In paragraaf 5.2 besprak ik de principal-agent theory. Ik constateerde dat in het kader van dit onderzoek het eerste en het tweede agency problem van belang zijn. Bij het eerste probleem staat de kapitaalverschaffer zonder stemrecht als principaal in verhouding tot het bestuur van de vennootschap als agent. Die kapitaalverschaffer heeft geen stemrecht, zodat hij geen of minder mogelijkheden heeft om zich ervan te verzekeren dat het bestuur in zijn belang handelt. Het tweede agency problem is de verhouding tussen de meerderheids- en minderheidsaandeelhouders. Zoals ik reeds opmerkte, is in zekere zin de kapitaalverschaffer zonder stemrecht nog slechter af dan de minderheidsaandeelhouder. Wegens het gebrek aan stemrecht in de algemene vergadering kan de kapitaalverschaffer zonder stemrecht niet of in mindere mate dan de minderheidsaandeelhouder zich ervan verzekeren dat zijn belang wordt gediend. De economische gedachte achter de principal agent theory theorie is de agency costs te bestrijden. De theorie vindt haar juridische grondslag in de vennootschappelijke redelijkheid en billijkheid van art. 2:8 BW. De open norm van de vennootschappelijke redelijkheid en billijkheid en het aan de kapitaalverschaffers toegekende recht tot vernietiging van besluiten van een orgaan van een rechtspersoon wegens strijdigheid met die norm voorziet daardoor in bescherming van de principaal (art. 2:15 lid 1 sub b jo. 2:8 BW). ${ }^{2}$

\subsection{De vennootschappelijke redelijkheid en billijkheid}

In paragraaf 4.10 zijn de kapitaalverschaffers zonder stemrecht benoemd. Die kapitaalverschaffers staan in een verhouding tot de vennootschap, net zoals bijvoorbeeld het bestuur van de vennootschap in een bepaalde verhouding tot de vennootschap staat. Dat geldt bijvoorbeeld eveneens voor de aandeelhouders met stemrecht

2 De bescherming vloeit ook voort uit de in hoofdstuk 6 besproken rechten. 
of - indien een raad van commissarissen is ingesteld - de raad van commissarissen. Tot slot is ook tussen de kapitaalverschaffers onderling, al dan niet met stemrecht, sprake van een bepaalde verhouding. Deze verhoudingen zijn aan te duiden als interne verhoudingen, zoals ik in hoofdstuk 5 heb besproken. Op deze interne verhoudingen ziet de norm van art. 2:8 BW. ${ }^{3}$ In hoofdstuk 6 ging het vooral om de rechten en verplichtingen die door de wet en de statuten van de BV worden gegeven.

Naast de wet en de statuten geven de redelijkheid en billijkheid de interne verhoudingen vorm. Art. 2:8 BW geeft daarvoor een algemene regel. Een rechtspersoon en degenen die krachtens de wet en de statuten bij zijn organisatie zijn betrokken, moeten zich als zodanig jegens elkander gedragen naar hetgeen door redelijkheid en billijkheid wordt gevorderd. Een tussen hen krachtens wet, gewoonte, statuten, reglementen of besluit geldende regel is niet van toepassing voor zover dit in de gegeven omstandigheden naar maatstaven van redelijkheid en billijkheid onaanvaardbaar zou zijn. Art. 2:8 BW wordt ook wel de vennootschappelijke redelijkheid en billijkheid genoemd. Gelijk als in het vermogensrecht, ${ }^{4}$ kunnen de redelijkheid en billijkheid de interne verhoudingen van de vennootschap aanvullen (lid 1), maar ook beperken (lid 2). Aldus kunnen extra verplichtingen worden aangenomen of opgelegd, maar kan ook in voorkomende gevallen een regel krachtens wet, gewoonte, statuten, reglementen of besluit niet van toepassing zijn. Let wel, de toets van lid 1 is een andere dan die van lid 2. Wil sprake zijn van de aanvullende werking van de redelijkheid en billijkheid, dan is slechts vereist dat dit wordt gevorderd (lid 1). Bij de beperkende werking van de redelijkheid en billijkheid van lid 2 ligt dat echter anders. Daar geldt een strengere maatstaf. Een regel is niet van toepassing indien dat naar maatstaven van redelijkheid en billijkheid onaanvaardbaar zou zijn. Niettemin is lid 2 voor de invulling van de vennootschappelijke redelijkheid en billijkheid van belang. Lid 1 refereert aan de wet en de statuten, maar blijkens lid 2 wordt de redelijkheid en billijkheid ook ingevuld, of in dat geval beperkt, door gewoonte, reglementen of een besluit (vgl. art. 2:15 lid 1 sub c BW). Andere bronnen die de redelijkheid en billijkheid invullen kunnen een bestendig gehanteerde wijze van uitoefening van rechten en een overeenkomst zijn, zoals een aandeelhoudersovereenkomst of stemovereenkomst. ${ }^{5}$ Ook "maatschappelijk verantwoord ondernemen' kan de redelijkheid en billijkheid invullen. ${ }^{6}$ Het

3 De Monchy \& Timmerman 1991, p. 84; M.J.G.C. Raaijmakers 1991 (1), p. 213 en 219; Koelemeijer 1994, p. 714 en Koelemeijer 1999, p. 58. Zij meent dat een strikte scheiding tussen de interne en externe sfeer niet wenselijk is, p. 60; Verdam 1995, p. 227 en 234-235; Sanders \& Westbroek 2005, p. 276; Slagter 2005, p. 59; Van Schilfgaarde \& Winter 2009, p. 36 en 303; Olaerts 2007, p. 270; Asser/Maeijer, Van Solinge \& Nieuwe Weme 2-II* 2009, nr. 46 en J.B. Huizink, Groene Serie Rechtspersonen, art. 2:8 BW, aant. 2, en art. 2:15 BW, aant. 4, Deventer: Kluwer.

4 Art. 6:2 en 6:248 BW. Art. 2:8 BW wordt in de literatuur ook wel aangemerkt als een lex specialis van art. 6:2 en 6:248 BW. Zie Verdam 1995, p. 227.

5 Blanco Fernández 2002, p. 140 en M.J.G.C. Raaijmakers 1991 (1), p. 212-213.

6 Zie bijvoorbeeld: Steins Bisschop 2004, p. 79. 
eerste lid van art. 2:8 BW is blijkens de wettekst te beschouwen als een gedragsnorm. ${ }^{7}$ In het kader van de beperkende werking van de redelijkheid en billijkheid van art. 2:8 lid $2 \mathrm{BW}$ wordt in de literatuur wel aansluiting gezocht bij art. 3:13 BW, zijnde de misbruik van bevoegdheid. ${ }^{8}$

De Jongh onderscheidt vijf functies van de redelijkheid en billijkheid: (i) een interpreterende, (ii) een aanvullende, (iii) een corrigerende functie, (iv) een gedragsregulerende en (v) een stuwende functie. ${ }^{9}$ Met de laatste functie bedoelt hij dat de redelijkheid en billijkheid een bron kunnen zijn voor nieuwe wetgeving of soft law. Waar het in paragraaf 5.5.2 genoemde autonomiebeginsel ${ }^{10}$ met het billijkheidsbeginsel botst, ${ }^{11}$ is volgens De Jongh het evenredigheidsbeginsel het instrument om in de omstandigheden van het geval een redelijke verhouding te vinden tussen het autonomiebeginsel en het billijkheidsbeginsel. Een van beide, laatstgenoemde, beginselen zal in de gegeven omstandigheden moeten wijken voor het andere, zonder dat het andere beginsel als niet geldig wordt beschouwd. ${ }^{12}$

Anders dan in het vermogensrecht, is in het vennootschapsrecht (in de regel) geen sprake van contractuele verhoudingen, maar van lidmaatschapsverhoudingen. Daardoor kunnen de uitgangspunten voor de vermogensrechtelijke redelijkheid en billijkheid niet een op een worden overgenomen voor de vennootschappelijke redelijkheid en billijkheid. Dat neemt niet weg dat de toepassing van de redelijkheid en billijkheid ex art. 2:8 BW afhangt van de omstandigheden van het geval. Daarbij spelen de betrokken belangen een rol. ${ }^{13}$ De vermogensrechtelijke redelijkheid en billijkheid van art. 3:12, 6:2 en 6:248 BW mag echter niet uit het oog verloren worden, omdat die redelijkheid en billijkheid bij de houder van een certificaat met en zonder vergaderrecht en de houder van een participatiebewijs een rol spelen. Bij deze kapitaalverschaffers zonder stemrecht is immers sprake van een contractuele relatie. ${ }^{14}$ Bij de houder van een certificaat met en zonder vergaderrecht wordt die contractuele relatie gevormd door de beheerovereenkomst, uitmondend in de

7 Bulten 2011, p. 88.

8 Bulten 2011, p. 89-90

9 De Jongh 2011, p. 609-618.

10 Aandeelhouders mogen hun eigen belang tot uitgangspunt nemen bij de uitoefening van hun rechten.

11 Aandeelhouders houden rekening met de in het geding zijnde belangen van de vennootschap en van andere institutioneel betrokkenen.

12 Daarbij formuleert De Jongh 2011, p. 614 e.v., vier gezichtspunten als uitwerking van het evenredigheidsbeginsel, welke gezichtspunten behulpzaam kunnen zijn bij het oplossen van de botsing tussen het autonomie- en het billijkheidsbeginsel: (i) de mate waarin aandeelhouders met andere belangen rekening dienen te houden is afhankelijk van hun invloed en de mate waarin belangen van derden in het geding zijn, (ii) bij de uitoefening van hun rechten stemmen aandeelhouders het middel af op het beoogde doel, (iii) in een dialoog tussen aandeelhouders en bestuurders dienen aandeelhouders acht te slaan op het belang van vennootschap en onderneming, terwijl bestuurders de belangen van lange termijn aandeelhouders in aanmerking moeten nemen, en (iv) aandeelhouders geven zich rekenschap van tegenstrijdige belangen

13 J.B. Huizink, Groene Serie Rechtspersonen, art. 2:8 BW, aant. 2, Deventer: Kluwer.

14 Asser/Maeijer, Van Solinge \& Nieuwe Weme 2-II* 2009, nr. 663 en J.B. Huizink, Groene Serie Rechtspersonen, art. 2:8 BW, aant. 6, Deventer: Kluwer. 
administratievoorwaarden, met de STAK. Bij de houder van een participatiebewijs wordt de contractuele verhouding gevormd door de participatievoorwaarden. Omdat de houder van een certificaat met vergaderrecht tot de kring van betrokkenen in de zin van art. 2:8 BW behoort, geldt voor hem ook d(i)e vennootschappelijke redelijkheid en billijkheid. Er zal dus in voorkomend geval per rechtsfiguur zonder stemrecht moeten worden nagegaan om welke redelijkheid en billijkheid het gaat. ${ }^{15}$

Als algemeen uitgangspunt voor de toepassing van de (vennootschappelijke) redelijkheid en billijkheid geldt art. 3:12 BW. Dat artikel bepaalt dat bij de vaststelling van wat redelijkheid en billijkheid eisen rekening moet worden gehouden met algemeen erkende rechtsbeginselen, met de in Nederland levende rechtsovertuigingen en met de maatschappelijke en persoonlijke belangen, die bij het gegeven geval zijn betrokken. Via de schakelbepaling van art. 3:15 BW vindt art. 3:12 BW ook buiten het vermogensrecht toepassing, voor zover de aard van de rechtsbetrekking zich daartegen niet verzet. ${ }^{16}$ Ik memoreerde al het verschil tussen de lidmaatschapsverhouding en de contractuele verhouding. Reeds in het arrest Baris/Riezenkamp ${ }^{17}$ bepaalde de Hoge Raad dat "partijen, door in onderhandeling te treden over het sluiten van een overeenkomst, tot elkaar komen te staan in een bijzondere, door de goede trouw beheerste, rechtsverhouding, medebrengende, dat zij hun gedrag mede moeten laten bepalen door de gerechtvaardigde belangen van de wederpartij". In de literatuur wordt gesteld dat de redelijkheid en billijkheid de basis vormen voor de algemene beginselen van behoorlijk ondernemingsbestuur. Toetsing aan de redelijkheid en billijkheid houdt een marginale toetsing in. ${ }^{18}$

Art. 2:8 BW geeft geen concrete regels ter invulling van de vennootschappelijke redelijkheid en billijkheid. Zoals gesteld, is dat afhankelijk van de omstandigheden van het geval en de daarbij betrokken belangen. Het eerste lid van art. 2:8 BW is,

15 In gelijke zin: Stokkermans 2010, p. 180.

16 Brink 2004, p. 236, stelt met verwijzing naar art. 3:12 BW dat van de Nederlandse Corporate Governance Code, welke code alleen voor beursgenoteerde vennootschappen geldt, een zekere reflexwerking naar andere, niet-beursgenoteerde, vennootschappen kan uitgaan.

17 HR 15 november 1957, NJ 1958, 67, m.nt. Rutten (Baris/Riezenkamp).

18 De heersende leer is die van de marginale toetsing. Zie uitgebreid hierover: Koelemeijer 1999, p. 33 e.v. en de aldaar aangehaalde literatuur; De Monchy \& Timmerman 1991, p. 85-86; M.J.G.C. Raaijmakers 1991 (2), p. 1012; Mendel 1997, p. 211; Van den Ingh 2000, p. 205-206; Sanders \& Westbroek 2005, p. 276; Slagter 2005, p. 56; J.B. Huizink, Groene Serie Rechtspersonen, art. 2:15 BW, aant. 5, Deventer: Kluwer en Maeijer in zijn noot onder HR 17 mei 1991, NJ 1991, 645, m.nt. Ma (Lampe/Tonnema). Anders: Koelemeijer 1999, p. 36, 38 en 43. Zij stelt dat feitelijk sprake is van een integrale toetsing, doch dat niet te snel geoordeeld zal moeten worden dat een besluit in strijd met de vennootschappelijke redelijkheid en billijkheid is. In gelijke zin: Van Schilfgaarde \& Winter 2009, p. 302 en De Kluiver 2000, p. 234-235. Vgl. Assink 2007, p. 43-71. Zie ook HR 18 juni 1982, NJ 1983, 200, m.nt. Ma (De Vries/Elderveld) en HR 9 januari 1987, $N J$ 1987, 959, m.nt. Ma (Vecolac/Juliana). 
zoals gesteld, blijkens de wettekst te beschouwen als een gedragsnorm. ${ }^{19}$ De rechtspraak waarin art. 2:8 BW centraal staat, is sterk casuïstisch. ${ }^{20}$

Niettemin zijn er algemene uitgangspunten voor de invulling van de vennootschappelijke redelijkheid en billijkheid te formuleren. In paragaaf 5.3 besprak ik de beslotenheid van de BV en de aard of het karakter van de samenwerking in de BV. Die beslotenheid en dat karakter zijn een van de factoren die een rol spelen bij de invulling van de vennootschappelijke redelijkheid en billijkheid. ${ }^{21}$

In paragraaf 5.6 besprak ik de grens van het dienen van het eigen belang door de aandeelhouder. De vrijheid van de aandeelhouder zijn stemrecht uit te oefenen wordt begrensd door de norm van art. 2:8 BW. Het gaat daarbij om een afweging van alle betrokken belangen. Bij het stemgedrag over een winstuitkering zal de aandeelhouder met stemrecht ook de belangen van de kapitaalverschaffers zonder stemrecht, maar ook het belang van de vennootschap moeten betrekken. Doet hij dat niet, dan loopt hij het risico dat de rechter het besluit ex art. 2:15 lid 1 sub b BW vernietigt.

Handelen in strijd met de redelijkheid en billijkheid levert niet alleen het risico op dat het besluit van een orgaan van de vennootschap ex art. 2:15 lid 1 sub b BW wordt vernietigd. ${ }^{22}$ Een dergelijk handelen kan ook als wanbeleid worden aangemerkt. ${ }^{23}$ Als gevolg daarvan kunnen in een enquêteprocedure ex art. 2:359 BW voorzieningen worden getroffen. Ik wijs ook op de uitstotings- en uittredingsvordering van de geschillenregeling, respectievelijk art. 2:336 en 2:343 BW.

19 Verdam 1995, p. 219 en Bulten 2011, p. 88. Zie ook Pres. Rb. 's-Gravenhage 9 oktober 1987, KG 1987, 454 (Nevesbu), waarbij het ging om een tussen aandeelhouders gesloten samenwerking in de vorm van een joint venture BV.

20 Koelemeijer 1999, p. 29-30, is van mening dat de rechter zijn beslissing over hetgeen de redelijkheid en billijkheid vordert moet formuleren als een norm die in beginsel ook in andere gevallen toepassing kan vinden in het belang van de rechtsontwikkeling en de motivering van de beslissing. Dat komt de rechtsvinding ten goede.

21 M.J.G.C. Raaijmakers 1991 (1), p. 203 e.v., met betrekking tot de rechtsbetrekkingen tussen aandeelhouders in de 'quasi-vof'; Verdam 1995, p. 83 e.v. Op p. 229 merkt Verdam op dat het bestaan van een besloten verhouding bij de invulling van de redelijkheid en billijkheid in aanmerking genomen moet worden. Persoonlijke belangen omvatten ook de belangen van aandeelhouders, welke belangen de samenwerking in de vennootschap inkleuren. Koelemeijer 1999, p. 344-245. De Kluiver 2000, p. 239. Maeijer 2000, p. 287. Van den Ingh 2000, p. 208. Doorman 2002, p. 202, stelt dat de rechter het karakter van de vennootschap in zijn overwegingen kan betrekken, bijvoorbeeld bij een vennootschap die als een joint venture te beschouwen is. Rensen 2005, p. 45-46, noemt het karakter van de rechtspersoon (beursgenoteerde $\mathrm{BV}$, familie-BV, een vereniging), een handeling als een omzetting van een vof in een BV en het karakter van de samenwerking (bijvoorbeeld een joint venture) als factoren die de redelijkheid en billijkheid kunnen inkleuren. J.B. Huizink, Groene Serie Rechtspersonen, art. 2:8 BW, aant. 2, Deventer: Kluwer.

22 Zie ook art. 2:16 lid 2 BW.

23 HR 1 maart 2002, LJN AD9857, NJ 2002, 296, m.nt. Ma, JOR 2002, 79, m.nt. Van den Ingh (Zwagerman Beheer), r.o. 3.4. 
Uit de rechtspraak blijkt dat de gerechtvaardigde belangen van de bij de vennootschap betrokken personen en het besloten karakter van de BV dicht bij elkaar liggen. Zo volgt uit de Cromwilld/Versatel-beschikking ${ }^{24}$ dat de wijze waarop de bij de vennootschap betrokkenen met elkaar dienen om te gaan, mede moet worden beoordeeld tegen de achtergrond van de oorspronkelijke verhoudingen binnen de vennootschap, de wijze waarop de samenwerking tussen de betrokkenen tot stand gebracht en vorm gegeven is, en de achtergrond van de gerechtvaardigde belangen. Het miskennen daarvan door de vennootschap en de wijze waarop de vennootschap omgaat met of tekort doet aan gerechtvaardigde belangen van een betrokkene, kan een grond zijn tot het bevelen van een onderzoek. ${ }^{25}$ De minderheidsaandeelhouder kon in dit geval op grond van genoemde verhoudingen en samenwerking aanspraak maken op een andere gedragslijn van de vennootschap jegens haar dan in het algemeen van een vennootschap jegens minderheidsaandeelhouders en zelfs aandeelhouders in het algemeen gevergd kan worden. De samenwerking tussen de oorspronkelijke partijen heeft het karakter van een joint venture. De daaruit voor de minderheidsaandeelhouder voortvloeiende bijzondere anspraken kunnen haar niet zonder meer ontnomen worden enkel op de grond dat de besluitvorming naar regels van vennootschapsrecht in striktere zin op correcte wijze heeft plaatsgevonden. ${ }^{26}$ Gelet op deze beschikking, en met Verdam, ${ }^{27}$ ben ik van mening dat (onder meer) de aard van de samenwerking in de vennootschap en het besloten karakter van de BV de vennootschappelijke redelijkheid en billijkheid invullen.

Ik wijs ook op het Mante-arrest. ${ }^{28}$ Het ging in dat arrest om de nietigheid van een besluit van de algemene vergadering tot statutenwijziging wegens strijd met de redelijkheid en billijkheid. De Hoge Raad overwoog dat ook indien voldaan is aan alle formele vereisten, bij wet of statuten voor de wijze van oproeping van een aandeelhoudersvergadering gesteld, de eisen van redelijkheid en billijkheid die aandeelhouders jegens elkander in acht hebben te nemen onder omstandigheden kunnen medebrengen dat een aandeelhoudersvergadering niet overgaat tot het nemen van een besluit aangaande een onderwerp waarbij de belangen van bepaalde aandeelhouders in bijzondere mate zijn betrokken alvorens te hebben nagegaan of die aandeelhouders genoegzaam in de gelegenheid zijn gesteld aan de besluitvorming over dit hen in het bijzonder rakende onderwerp deel te nemen. Daarnaast overwoog de Hoge Raad "dat het (...) gaat om de nietigheid van een besluit (...) wegens strijd met een eis van redelijkheid en billijkheid jegens mede-aandeelhouders in acht te nemen en hierin bestaande dat, ook indien juist mocht zijn dat wet of statuten individuele oproeping van de aandeelhouders niet dwingend voorschreven, niettemin

24 Hof Amsterdam (OK) 20 mei 1999, NJ 2000, 199, JOR 2000, 72, m.nt. Blanco Fernández (Cromwilld/Verstatel).

25 r.o. 3.3

26 r.o. 3.4

27 Verdam 1995, p. 229.

28 HR 30 oktober 1964, NJ 1965, 107, m.nt. G.J. Scholten (Mante). 
de bijzondere omstandigheden van het geval tijdige verwittiging bepaaldelijk van die aandeelhouders wier belangen in het bijzonder door het te nemen besluit werden geraakt geboden deden zijn." Naast de aard van de samenwerking en het besloten karakter van de BV zullen aldus ook de gerechtvaardigde belangen van de betrokken aandeelhouders bij de invulling van de redelijkheid en billijkheid in aanmerking genomen moeten worden. ${ }^{29}$

Uit het Wijsmuller-arrest ${ }^{30}$ volgt dat de betekenis van een bepaling in de statuten van een rechtspersoon, voorschrijvende dat een besluit moet uitgaan van een orgaan van die rechtspersoon, in het geval waarin dat orgaan uit meer personen is samengesteld, in het bijzonder hierin gelegen is, dat het besluit tot stand komt als vrucht van onderling overleg van alle leden van dat orgaan die, na daartoe in de gelegenheid te zijn gesteld, aan dat overleg wensen deel te nemen. Kort gezegd: besluitvorming door een meerhoofdig orgaan moet op basis van vruchtbaar onderling overleg geschieden. In het verlengde van deze uitspraak ligt het Reynders/ McKinney-arrest, waarin overwogen werd dat de goede trouw, welke de verhouding tussen aandeelhouders beheerst, meebrengt dat indien een directeur/houder van vijftig procent van de aandelen van een vennootschap op een aandeelhoudersvergadering constateert dat zijn mede-directeur/houder van de overige vijftig procent van de aandelen ontbreekt, hij de vergadering voor wat betreft niet zeer dringende agendapunten verdaagt indien twijfel bestaat of de oproep voor de vergadering de betrokkene wel heeft bereikt. ${ }^{31}$ Ook hier speelde het besloten karakter dus een rol.

Koelemeijer ${ }^{32}$ schetst acht factoren die van invloed kunnen zijn op de belangenafweging door de rechter en die een rol spelen bij het bepalen van de eisen van de redelijkheid en billijkheid in een concreet geval, namelijk (i) hoedanigheid van de betrokkene(n) bij een belangenconflict, (ii) de invloed van de betrokkene(n) bij een belangenconflict, (iii) dubbelrollen of tegenstrijdig belang van de betrokkene(n) bij een belangenconflict, (iv) de aard en de inhoud van het besluit, (v) de gevolgen van het besluit of de gedraging van de betrokkene(n), (vi) de compensatie van de gevolgen van een besluit voor de betrokkene(n), (vii) het karakter van de vennootschap en (viii) de overeenkomst tussen de betrokkene(n).

De Kluiver komt tot een indeling van 'Fallgruppen' van criteria voor de beantwoording van de vraag of de redelijkheid en billijkheid een corrigerende functie kan vervullen. Deze Fallgruppen zijn: (i) wenire contra factum proprium (een inconsistent handelen zal als onredelijk en onbillijk geoordeeld kunnen worden, tenzij er sprake is van een bijzondere rechtvaardiging), (ii) wijziging van bevoegdheden, (iii) aard, inhoud van gevolgen van besluit, (iv) karakter van de

29 In gelijke zin Verdam 1995, p. 230.

30 HR 15 juli 1968, NJ 1969, 101, m.nt. G.J. Scholten (Wijsmuller)

31 Hof 's-Gravenhage 17 maart 1983, NJ 1984, 81 (Reynders/McKinney). Zie voor een kritische kanttekening bij dit arrest Blanco Fernández 2002, p. 136. Zie ook Rb. Arnhem 12 november 1942, NJ 1943, 846 en Rb. Breda 17 november 1942, NJ 1943, 463 (Astarte).

32 Koelemeijer 1999, p. 339. 
vennootschap en afspraken tussen betrokkenen en (v) de hoedanigheid en invloed van betrokkenen, waaronder begrepen een mogelijke dubbelrol en/of tegenstrijdig belang. ${ }^{33}$

\subsection{De kring van betrokkenen in de zin van art. 2:8 BW}

Art. 2:8 BW spreekt over 'een rechtspersoon en degenen die krachtens de wet en de statuten bij zijn organisatie zijn betrokken'. De Monchy \& Timmerman verstaan onder een persoon die krachtens de wet en de statuten bij de organisatie van de rechtspersoon is betrokken "een ieder die op grond van de wet of de statuten rechten of plichten heeft die door gedragingen, die zich binnen de sfeer van de rechtspersoon afspelen, rechtstreeks beïnvloed kunnen worden". ${ }^{34}$ De vraag rijst wie in het algemeen tot de kring van betrokkenen behoren. In het bijzonder is de vraag wie van de in paragraaf 4.10 genoemde kapitaalverschaffers zonder stemrecht tot de kring van betrokkenen in de zin van de vennootschappelijke redelijkheid en billijkheid behoren. Ik beantwoord eerst de eerste, algemene vraag.

\subsubsection{Algemeen}

De wetgever heeft voor een ruime kring van betrokkenen gekozen. ${ }^{35}$ In ieder geval behoren tot de kring van betrokkenen als bedoeld in art. 2:8 BW aandeelhouders, bestuurders en - indien van toepassing - commissarissen van de BV. Deze betrokkenen maken immers deel uit van de organen van de vennootschap, namelijk de algemene vergadering, het bestuur en - indien ingesteld - de raad van commissarissen. Houders van met medewerking van de vennootschap uitgegeven certificaten vallen ook onder de kring van betrokkenen, omdat zij 'rechten binnen het vennootschapsrechtelijk verband kunnen uitoefenen' en zij daardoor als bij de organisatie betrokken kunnen worden beschouwd. ${ }^{36}$

33 De Kluiver 2000, p. 238-239, geïnspireerd door Koelemeijer 1999 p. 339 e.v. en M.W. Hesselink, De redelijkheid en billijkheid in het Europese privaatrecht (diss. Utrecht), Deventer: Kluwer 1999, p. 56 e.v.

34 De Monchy \& Timmerman 1991, p. 49.

35 Kamerstukken II 1984/85, 17 725, nr. 7, p. 14-15 (MvA).

36 Kamerstukken II 1982/83, 17 725, nr. 1-3, p. 56 (MvT); De Monchy \& Timmerman 1991, p. 50; Van den Ingh 1991, p. 261; Koelemeijer 1999, p. 22; Blanco Fernández 2002, p. 129; Rensen 2005, p. 35; Stokkermans 2010, p. 179 en J.B. Huizink, Groene Serie Rechtspersonen, art. 2:8 BW, aant. 6, Deventer: Kluwer. De vennootschappelijke redelijkheid en billijkheid geldt ook in de verhouding tussen certificaathouder, certificaathouders onderling, STAK en bestuur van de STAK. Zie daarvoor Asser/Maeijer, Van Solinge \& Nieuwe Weme 2-II* 2009, nr. 633 met verwijzing naar jurisprudentie. 


\subsubsection{Welke kapitaalverschaffers zonder stemrecht behoren tot de kring van} betrokkenen?

Het antwoord op de tweede vraag, namelijk wie van de kapitaalverschaffers zonder stemrecht tot de kring van betrokkenen ex art. 2:8 BW behoort, is als volgt.

Het spreekt voor zich dat de stemrechtloze aandeelhouder, de aandeelhouder waarbij stemrecht is overgedragen aan de vruchtgebruiker of de pandhouder en de houder van certificaten met vergaderrecht tot de kring van betrokkenen behoren. ${ }^{37}$

Behoort de houder van certificaten zonder vergaderrecht ook tot die kring? De discussie onder het oude recht over de vraag wanneer van met of zonder medewerking van de vennootschap uitgegeven certificaten sprake is, speelt bij de beantwoording van deze vraag een rol.

De rechtbank Amsterdam heeft in haar vonnis van 25 augustus $2010^{38}$ overwogen dat tot de kring van de bij de vennootschap betrokkenen niet behoort de nietbewilligde certificaathouder: "Gezien de wettelijk vastgelegde beslotenheid van de aandeelhouderskring en het vereiste van duidelijkheid voor de vennootschap jegens wie zij de verplichtingen ingevolge artikel $2: 8 \mathrm{BW}$ in acht dient te nemen, heeft alleen die medewerking van de vennootschap tot gevolg dat de door artikel 2:8 $\mathrm{BW}$ bestreken kring van personen wordt uitgebreid, die als een op dat rechtsgevolg gerichte rechtshandeling van de vennootschap kan worden aangemerkt. Ingevolge de artikelen 3:33 jo 3:59 BW vereist aldus de door de vennootschap verleende medewerking, teneinde dat rechtsgevolg te bewerkstelligen, een daarop gerichte wil die zich door verklaring of gedraging van de vennootschap heeft geopenbaard. Dat is hier niet het geval. Immers, de statuten van de vennootschap schrijven voor dat aan de uitgifte van certificaten geen medewerking wordt verleend en uit de aanbiedingsbrieven aan Hofmans c.s. (de certificaathouders, toevoeging RAW) volgt dat hem uitdrukkelijk geen andere rechten worden verleend dan rechten die voortvloeien uit de certificaten zelf."

De rechtbank sluit zich aldus aan bij de enge opvatting in de literatuur en de Greenery-beschikking ${ }^{39}$ omtrent de vraag wanneer onder het oude recht sprake was van al dan niet bewilligde certificaten.

In de literatuur wordt verschillend gedacht over de vraag of de niet-bewilligde certificaathouder tot de kring van betrokkenen behoort. Nowak stelt in zijn JORnoot onder het genoemde vonnis van de rechtbank Amsterdam dat er geen principieel verschil is tussen de positie van de niet-bewilligde certificaathouder en de houder van een winstbewijs ingeval van een voor hen nadelig winstbesluit. ${ }^{40}$ Van Schilfgaarde stelt dat de vennootschappelijke redelijkheid en billijkheid in voorkomend geval niet a contrario maar naar analogie moet worden toegepast en dat de

37 Kamerstukken II 1982/83, 17 725, nr. 3, p. 56 (MvT).

38 Rb. Amsterdam 25 augustus 2008, LJN BN4965, r.o. 4.3 en JOR 2010, 301 m.nt. Nowak (CFS)

39 Hof Amsterdam (OK) 21 juni 2007, JOR 2007, 182 (Kalter/Greenery).

40 Zie onderdeel II van de noot. 
niet-bewilligde certificaathouder niet zonder meer buiten die norm valt. ${ }^{41}$ Huizink is van mening dat onder omstandigheden de niet-bewilligde certificaathouder tot de kring van betrokkenen als bedoeld in art. 2:8 BW behoort. Onder die omstandigheden behoort het geval dat de certificaathouder rechten aan zijn certificaat jegens de vennootschap kan ontlenen. ${ }^{42}$ Hamers koppelt het behoren tot de kring van betrokkenen aan het al dan niet in een lidmaatschapsverhouding tot de vennootschap staan van de certificaathouder. Hij concludeert onder meer dat houders van certificaten die met medewerking van de vennootschap zijn uitgegeven tot de kring van betrokkenen behoren. Niet-bewilligde certificaathouders vallen niet onder die kring, tenzij op een andere wijze een lidmaatschapsverhouding met de vennootschap gecreëerd is. ${ }^{43}$ Brink stelt dat houders van niet-bewilligde certificaten gerekend moeten worden tot de kring van betrokkenen, omdat zij deel uitmaken van de kring van belanghebbenden welke door art. 2:15 lid 3 sub a BW worden genoemd. ${ }^{44}$ Die laatste benadering komt mij als niet zuiver voor. Uitgaande van de opvatting dat houders van niet-bewilligde certificaten niet tot de kring van betrokkenen in de zin van art. 2:8 BW behoren, is de vraag of zij een vordering tot vernietiging van een besluit op grond van art. 2:15 lid 1 onder b BW kunnen instellen. Ik kom daarop in paragraaf 8.6 terug.

Terug naar de vraag of de houders van niet-bewilligde certificaten, en daarmee de houders van certificaten zonder vergaderrecht, tot de kring van betrokkenen behoren. Uit de rechtspraak blijkt dat de kring van betrokkenen in de zin van art. 2:8 $\mathrm{BW}$ ruim geïnterpreteerd kan worden. In het IKON-arrest ${ }^{45}$ is overwogen dat de Ondernemingsraad tot de kring van betrokkenen behoort. Maeijer is het met deze uitspraak niet eens. Hij stelt dat de Ondernemingsraad niet als een orgaan aan te merken is, zodat geen sprake is van behoren tot de kring van betrokkenen. Volgens Maeijer betekent dat echter niet dat de ondernemer en de Ondernemingsraad zich niet jegens elkaar hebben te gedragen naar hetgeen dat door redelijkheid en billijkheid wordt gevorderd. Dat kan echter niet op art. 2:7 BW (oud) worden gebaseerd. Ik volg het standpunt van Maeijer en zijn argumentatie. In het Geestelijk Leider-arrest ${ }^{46}$ ging het om de omlijning van het orgaanbegrip. Bij statuten van een stichting was een Geestelijk Leider, niet zijnde een bestuurder, voor het leven benoemd. Hij had de bevoegdheid zijn opvolger te benoemen, recht op inzage van

41 P. van Schilfgaarde, Losbl. Rechtspersonen, art. 2:7 (oud) BW, aant. 4 en 5, Deventer: Kluwer 1982. In dezelfde voorzichtige zin: Steins Bisschop 2004, p. 90-91

42 J.B. Huizink, Groene Serie Rechtspersonen, art. 2:8 BW, aant. 6, Deventer: Kluwer. Steins Bisschop 2004, p. 91, neemt ten aanzien daarvan aan 'dat daaronder bijvoorbeeld gerekend kan worden het recht om bepaalde financiële opbrengsten te ontvangen via het administratiekantoor dat in financiële zin transparant geacht moet worden jegens de certificaathouder.'

43 Hamers 1996, p. 88-89.

44 Brink 2004, p. 234

45 Hof Amsterdam (OK) 26 november 1987, NJ 1989, 271, m.nt. Ma (IKON).

46 HR 12 mei 2000, LJN AA 5779, NJ 2000, 439, JOR 2000, 145, m.nt. Blanco Fernández (Geestelijk Leider), zie met name r.o. 3.3. Zie over dit arrest in kritische zin: Schwarz 2000. Zie ook Van den Ingh 2002, p. 19-20 en 24. 
alle stukken en bescheiden van de stichting en het recht bindende adviezen aan het bestuur van de stichting te geven. De Hoge Raad sanctioneerde het oordeel van het hof dat deze positie van de Geestelijk Leider niet meebrengt dat het doel van de stichting onbereikbaar is en evenmin een blokkade vormt voor het functioneren van de stichting en haar bestuur. Art. 2:8 jo. 2:15 BW biedt waarborgen tegen het mogelijk machtsmisbruik van de Geestelijk Leider, aldus de Hoge Raad. Het arrest gaat uit van een ruim orgaanbegrip. Hoewel de Geestelijk Leider geen orgaan is, is hij wel bij de statuten benoemd en als zodanig krachtens de statuten bij de rechtspersoon betrokken. Ook uit het ASMI-arrest ${ }^{47}$ volgt een ruime opvatting van de kring van betrokkenen. Een stichting aan wie door de vennootschap op grond van een optieovereenkomst een recht tot het nemen van preferente aandelen in het aandelenkapitaal van de vennootschap toegekend is, behoort tot de kring van de betrokkenen. Het lijkt erop alsof de Hoge Raad de kring van betrokkenen uitbreidt tot (ook) degenen die anders dan krachtens de wet en de statuten bij de vennootschap betrokken zijn. Ook in de literatuur is deze opvatting te vinden. ${ }^{48}$

In de literatuur is echter ook nog een andere opvatting te vinden. Schwarz stelt dat houders van bewilligde certificaten in een lidmaatschapsbetrekking of organisatierechtelijke betrekking tot de vennootschap staan, dat hen binnen het bereik van art. 2:8 BW brengt. Houders van niet-bewilligde certificaten staan niet in een dergelijke betrekking tot de vennootschap. Wel zijn zij belanghebbenden en komen hen enkele rechten toe waarmee zij hun financiële belangen kunnen verdedigen, zoals het indienen van een enquêteverzoek. ${ }^{49}$ Stokkermans is van mening dat houders van niet-bewilligde certificaten, houders van participatie- en winstbewijzen, de Ondernemingsraad, werknemers en anderen die zich het belang van de vennootschap aantrekken of een eigen belang hebben, niet tot de kring van betrokkenen behoren. ${ }^{50}$ Stokkermans is het eens met het vonnis van de rechtbank Amsterdam van 25 augustus 2010. Hij ziet de institutioneel betrokkenen als degenen die bij de organisatie van de rechtspersoon betrokken zijn op grond van een bevoegdheid die door de rechtspersoon is toegekend, welke bevoegdheid door deze betrokkene is aanvaard. $^{51}$

Ten aanzien van het certificaat zonder vergaderrecht zijn er dus drie opvattingen. De eerste opvatting is dat de houder van dat certificaat niet tot de kring van

47 HR 9 juli 2010, LJN BM0976, NJ 2010, 544, m.nt. Van Schilfgaarde, JOR 2010, 228, m.nt. Van Ginneken (ASMI), r.o. 4.4.2.

48 Rensen 2005 , p. 40 , stelt dat naast de optiehouder ook de obligatiehouder tot de kring van betrokkenen in de zin van art. 2:8 BW behoort. Rensen stelt dat de omstandigheid dat de statuten van de vennootschap geen regeling over de positie van de obligatiehouder inhoudt niet weg neemt dat de obligatiehouder, evenals de optiehouder, is aan te merken als een bij de organisatie betrokkene in de zin van art. 2:8 BW.

49 Schwarz 1992, p. 6. In gelijke zin: De Monchy \& Timmerman 1991, p. 50.

50 Stokkermans 2010, p. 179. In gelijke zin: Wouters 2011, p. 238-239 met betrekking tot de nietbewilligde certificaathouder.

51 Stokkermans 2010, p. 179. 
betrokkenen behoort. De tweede opvatting is dat de houder van het certificaat zonder vergaderrecht wel tot de kring van betrokkenen behoort. Er lijkt in de literatuur een meerderheid voor deze opvatting te vinden. De derde opvatting is dat de houder van een certificaat zonder vergaderrecht weliswaar niet tot de kring van betrokkenen behoort, maar dat niettemin ex art. 2:15 lid 1 onder b BW wegens strijd met de vennootschappelijke redelijkheid en billijkheid vernietiging van het besluit door de houder van het certificaat zonder vergaderrecht kan worden gevorderd.

Laat ik eerst de vraag beantwoorden of de houder van een participatiebewijs tot de kring van betrokkenen in de zin van at. 2:8 BW behoort. Het antwoord op die vraag is blijkens de heersende opvatting in de literatuur ' $j a$ '. ${ }^{52}$ De houder van een participatiebewijs staat in een contractuele relatie tot de vennootschap. De grondslag voor de winstuitkering aan de houder van dat bewijs is art. 2:216 BW. Op grond van de hoofdregel van art. 2:232 BW kan zonder zijn instemming een statutenwijziging geen nadeel aan zijn rechten toebrengen. Dat neemt niet weg dat andere besluiten, anders dan een statutenwijziging, van invloed kunnen zijn op de winstrechten of winstuitkering van de houder van een participatiebewijs. In de rechtspraak zijn daarvan voorbeelden te vinden. Ik noem de arresten Baus/De Koedoe $I^{53}$ en Baus/ De Koedoe II. ${ }^{54}$ In deze arresten ging het om de vordering van tantième van een commissaris en strijd met de redelijkheid en billijkheid bij de vaststelling van de jaarrekening. Op grond van de jaarrekening werd de hoogte van het tantième vastgesteld. Bij het inroepen van de nietigheid van de jaarrekening moeten feiten en omstandigheden worden gesteld waaruit volgt dat de jaarrekening in strijd met de redelijkheid en billijkheid is vastgesteld. Ik noem ook het Unipart/RDM-arrest. ${ }^{55}$ Het ging in dat arrest om het beleid van het bestuur van zelffinanciering, waarbij een onderscheid tussen oneigenlijke en eigenlijke reserveringen werd gemaakt. Daardoor werd de winst verlaagd en de rechten van winstbewijshouders geraakt. In het RCMA-arrest ${ }^{56}$ ging het om een besluit tot herkapitalisatie door middel van bonusaandelen, genomen binnen het kader van de statuten waardoor ook de positie van de houders van winstbewijzen wordt bepaald, in de verhouding waarin aandeelhouders en houders van winstbewijzen delen in winst en liquidatiesaldo een wijziging ten nadele van de houders van winstbewijzen tot gevolg heeft. De

52 Galavazi \& Van Wilsum 1988, p. 133; De Monchy \& Timmerman 1991, p. 50; Eisma 1991, p. 33-34; Blanco Fernández 2002, p. 129; Prinsen 2004, p. 128; Slagter 2005, p. 58 en Asser/Maeijer, Van Solinge \& Nieuwe Weme 2-II* 2009, nr. 46 en 233. Van der Grinten 1991, p. 127, spreekt in dit kader over houders van winstbewijzen. Ik ga ervan uit dat ook hij van mening is dat jegens houders van participatiebewijzen de redelijkheid en billijkheid in acht genomen moet worden, omdat het winsten participatiebewijs verwante rechtsfiguren zijn. Anders: Stokkermans 2010, p. 179. Blanco Fernández \& Schwarz 1992, p. 291 (middenkolom), stellen dat afhankelijk van de inhoud van de statutaire regeling valt te zeggen of de houder van een participatiebewijs tot de kring van betrokken behoort. Zie ook Blanco Fernández 2002, p. 133.

53 HR 21 mei 1943, NJ 1943, 484 (Baus/De Koedoe I).

54 HR 31 januari 1947, NJ 1948, 115 (Baus/De Koedoe II).

55 HR 27 januari 1956, NJ 1956, 48, (Unipart/RDM).

56 HR 11 januari 1963, NJ 1964, 433, m.nt. G.J. Scholten (RCMA). 
Hoge Raad overwoog dat de vraag of een uitvoering van de overeenkomst tussen de vennootschap en de houders van winstbewijzen naar redelijkheid en billijkheid meebrengt dat maatregelen getroffen moeten worden om voor de houders van winstbewijzen de voor de uitgifte van de bonusaandelen bestaande toestand te herstellen, afhankelijk zal zijn van de omstandigheden van het geval. Uit deze arresten blijkt dat de vennootschap jegens de houders van winstbewijzen de redelijkheid en billijkheid in acht moet nemen en dat het bestuur van de vennootschap bij het nemen van besluiten de belangen van de winstbewijshouders in de besluitvorming moet betrekken en zo nodig maatregelen moet treffen.

De grens van de kring van betrokken ligt volgens lagere rechtspraak bij het volgende. Een bijzondere contractuele en/of familieverhouding leidt niet tot 'toetreding' tot de kring van betrokkenen. Daarnaast ziet art. 2:8 BW niet op situaties waarbij een niet tot de vennootschap betrokken persoon wel tot de kring van betrokkenen gaat behoren. ${ }^{57}$

Ik heb daarmee nog niet de vraag beantwoord of, naar mijn mening, de houder van een niet-bewilligd certificaat (onder het oude recht) en thans de houder van een certificaat zonder vergaderrecht tot de kring van betrokkenen behoort in de zin van art. 2:8 BW. Ik meen dat de houder van een certificaat zonder vergaderrecht niet tot die kring behoort. Anders dan onder het oude recht, kunnen de statuten van de BV op grond van art. 2:227 BW bepalen dat aan certificaten vergaderrecht is toegekend. Waar onder het oude recht discussie kon bestaan of certificaten met of zonder medewerking van de vennootschappen zijn uitgegeven, is die discussie er niet ten aanzien van certificaten die na invoering van de flex-BV zijn uitgegeven. De statuten zijn immers ten aanzien van het vergaderrecht leidend. De wil van de vennootschap is erop gericht aan de certificaten wel of niet vergaderrecht toe te kennen. ${ }^{58}$ Dit klemt te meer, omdat de wet aan de vergadergerechtigdheid tal van andere rechten koppelt. Ik verwijs naar paragraaf 6.3.3.3. Daarnaast maakt art. 2:227 lid $4 \mathrm{BW}$ het bovendien mogelijk het vergaderrecht te ontnemen. Ik verwijs naar paragraaf 6.3.3.4. Met andere woorden: de statuten bepalen dat de houder van het certificaat met vergaderrecht tot de kring van betrokkenen behoort, of dat de certificaathouder op meer afstand van de vennootschap wordt gezet, omdat het certificaat het vergaderrecht ontbeert.

Daarbij komt dat de wet aan het certificaat met vergaderrecht op grond van art. 3:259 BW een gezamenlijk pandrecht op de gecertificeerde aandelen aan de certificaathouders toekent. Dat is een ander gevolg van de wil van de vennootschap indien zij krachtens de statuten aan certificaten vergaderrecht toekent. De vennootschap beoogt zelf dat de houder van een certificaat met vergaderrecht dicht bij haar

$57 \mathrm{Rb}$. Rotterdam 25 november 1999, JOR 2000, 51.

58 Vgl. Kamerstukken II 2006/07, 31 058, nr. 3, p. 82 (MvT): "Uitgangspunt van de voorgestelde regeling is dat de vennootschap zelf bepaalt of er certificaten met vergaderrecht worden toegelaten en zo ja, aan welke certificaten dat vergaderrecht toekomt. Het zijn dus in beginsel de aandeelhouders die bepalen in hoeverre de besluitvorming in de algemene vergadering open staat voor anderen." 
staat of tot de kring van betrokkenen behoort. Daarmee neemt zij de 'last' van het zekerheidsrecht ten gunste van de gezamenlijke certificaathouders op haar gecertificeerde aandelen in haar kapitaal op zich. De wet kent aan de certificaathouder zonder vergaderrecht geen zekerheidsrecht ex art. 3:239 BW toe. Ware dat anders, dan zou langs die wettelijke weg de certificaathouder zonder vergaderrecht vanuit de vennootschap gezien ongewild tot de kring van betrokkenen gaan behoren, althans in voorkomend geval zou de vennootschap te maken kunnen krijgen met certificaathouders (zonder vergaderrecht) die hun gezamenlijk pandrecht uitwinnen. De wil van de vennootschap was daarop echter niet gericht. Zij heeft aan het certificaat niet krachtens de statuten vergaderrecht toegekend. Bovendien kan een aandeelhouder ook buiten medeweten van de vennootschap zijn aandelen certificeren, zodat ook om die reden certificaathouders zonder vergaderrecht niet tot de kring van betrokkenen behoren.

Waar ik in dit hoofdstuk over kapitaalverschaffers zonder stemrecht spreek, bedoel ik daarmee de kapitaalverschaffers zonder stemrecht die - mijns inziens - tot de kring van betrokkenen behoren, tenzij anders vermeld.

\subsection{Thema's in de vennootschappelijke redelijkheid en billijkheid}

\subsubsection{Inleiding}

De vennootschappelijke redelijkheid en billijkheid kan aan de hand van een aantal invalshoeken besproken worden. Zo kan de invalshoek van de interne verhoudingen worden genomen. Daarbij kan gedacht worden aan de verhoudingen tussen de aandeelhouders onderling met als klassiek thema de verhouding tussen meerderheids- en minderheidsaandeelhouders. Het gelijkheidsbeginsel speelt in deze verhouding bijvoorbeeld een rol. Een andere interne verhouding is de verhouding tussen het bestuur en de algemene vergadering. Als laatste noem ik de verhouding van de aandeelhouders tot de vennootschap. Een andere invalshoek is die van de wijze van besluitvorming door het bestuur en de algemene vergadering. Te denken valt daarbij in het eerste geval aan besluiten van het bestuur die voorafgaande goedkeuring van de algemene vergadering behoeven. In het tweede geval gaat het om voorgeschreven procedures om tot (rechtsgeldige) besluitvorming te komen, zoals oproepings- en agenderingsvereisten. Bij deze invalshoek gaat het om de formele aspecten van besluitvorming. Een volgende invalshoek is die van de materiële aspecten van de besluitvorming. Daarbij gaat het om de inhoud van het besluit zelf, bijvoorbeeld een besluit tot winstuitdeling. Ik noem een laatste invalshoek voor bespreking van de vennootschappelijke redelijkheid en billijkheid: thema's. Zo komt Stokkermans ${ }^{59}$ tot zes thema's: (i) voorgeschreven procedures, (ii) proportionaliteit, (iii) gelijkheid van aandeelhouders, (iv) tegenstrijdige belangen, (v) gewijzigde omstandigheden en (vi) onredelijk bezwarende bedingen.

59 Stokkermans 2008 (2), p. 118-129. 
In de rechtspraktijk en uit de te bespreken jurisprudentie blijkt dat het zelden gaat om slechts een invalshoek. Niettemin gaat het in de meeste gevallen om de uiteindelijke inhoud van het besluit. Zo speelde in het nog te bespreken Lampe/Tonnema-arrest ${ }^{60} \mathrm{de}$ verhouding tussen meerderheids- en minderheidsaandeelhouders een rol. De Hoge Raad sanctioneerde een besluit tot wijziging van de blokkeringsregeling van een aanbiedingsregeling in een goedkeuringsregeling, zodat de aandelen in Tonnema alsnog zonder medewerking van de minderheidsaandeelhouder Lampe aan een derde (Van Nelle) konden worden verkocht. Het ging in dit arrest aldus ook om de materiële aspecten van de besluitvorming. Een ander voorbeeld is het Janssen Pers-arrest. ${ }^{61}$ Het ging daarbij om een machtstrijd binnen de vennootschap. Een meerderheid van het bestuur van de STAK, die aandelen in Janssen Pers houdt, treedt als gevolg van een misverstand te vroeg af. De enig overgebleven bestuurder, P. Janssen, ziet zijn kans schoon en maakt gebruik van de onverwachts ontstane mogelijkheid de zeggenschap in de STAK en daarmee (indirect) in Janssen Pers te herkrijgen voordat het belang van Janssen Beheer in Janssen Pers overeenkomstig het genomen emissiebesluit een minderheidsbelang zou worden. P. Janssen wist dat Janssen Pers BV zich tegenover de nieuwe aandeelhouders tot uitgifte van aandelen had verbonden. De overeengekomen storting op die nieuwe aandelen had al enige maanden eerder plaatsgevonden. De Hoge Raad oordeelde, kort gezegd, dat de door P. Janssen met gebruikmaking van de vergissing van zijn medebestuurders bewerkstelligde besluiten indien al bevoegdelijk genomen wegens strijd met de eisen van redelijkheid en billijkheid aan vernietiging blootstonden.

Als laatste voorbeeld noem ik het vonnis in kort geding van de president van de rechtbank Roermond. ${ }^{62}$ De volgende casus speelde. Een (enig) bestuurder hield samen met zijn echtgenote 92 procent van de aandelen in een familievennootschap. In de loop der tijd had de bestuurder alle andere familieleden uitgekocht, behalve een familielid dat de andere acht procent van de aandelen hield. Voor deze aankopen heeft de bestuurder geld van de vennootschap geleend. De bestuurder had het plan om zijn schuld aan de vennootschap door middel van een aandelenemissie en vervolgens inkoop van aandelen door de vennootschap - tegen het dubbele bedrag dan waarvoor de aandelen waren uitgegeven - ongedaan te maken of te verkleinen. Er was dus sprake van een tegenstrijdig belang. Als gevolg van de constructie zou de bestuurder een verkapt dividend ontvangen en de minderheidsaandeelhouder niets. Wegens het gebrek aan informatie (ondanks verzoek daartoe en in strijd met het bepaalde in art. 2:217 BW) had de minderheidsaandeelhouder geen gebruik gemaakt van zijn voorkeursrecht. De uitgegeven aandelen waren niet volgestort, maar gedebiteerd in de rekening-courantverhouding tussen de bestuurder en de vennootschap. Er was aldus geen sprake van een reële volstorting en daarmee was

60 HR 17 mei 1991, NJ 1991, 645, m.nt. Ma (Lampe/Tonnema). Vgl. Pres. Rb. Utrecht 16 februari 1989, $K G 1989,156$.

61 HR 10 maart 1995, NJ 1995, 595, m.nt. Ma (Janssen Pers). Zie over dit arrest bijvoorbeeld Schwarz 1995 (1), p. 527 e.v. en De Kluiver 2000, p. 226-227 en 236

62 Pres. Rb. Roermond 27 januari 2000, JOR 2000, 73, m.nt. C.J. Groffen, KG 2000, 52. 
de verkrijging van de aandelen door de vennootschap nietig (art. 2:207 BW). Het inkoopbesluit betrof aldus persoonlijke motieven van de bestuurder en geen vennootschappelijk belang. De bestuurder ging er in financieel opzicht ongerechtvaardigd op vooruit, terwijl de vennootschap een groot geldbedrag verloor. Daarnaast zouden als gevolg van de constructie de door de minderheidsaandeelhouder gehouden aandelen in waarde dalen. De rechter concludeerde dan ook dat zowel in de hoedanigheid van bestuurder als van meerderheidsaandeelhouder sprake was van strijd met de vennootschappelijke redelijkheid en billijkheid.

Ik zal aan de hand van een aantal thema's de vennootschappelijke redelijkheid en billijkheid bespreken. Ik beperk mij tot thema's die, naar mijn mening, voor de kapitaalverschaffer zonder stemrecht die tot de kring van betrokkenen behoort relevant zijn. De te bespreken thema's zijn: (i) het gelijkheidsbeginsel (paragraaf 7.5.2), (ii) bescherming van minderheidsaandeelhouders (paragraaf 7.5.3), (iii) besluiten die de rechten op winst en/of reserves raken (paragraaf 7.5.4), (iv) de verhouding tussen aandeelhouders onderling (paragraaf 7.5.5), (v) de zorgplicht van (het bestuur van) de vennootschap jegens de kapitaalverschaffer zonder stemrecht (paragraaf 7.5.6), (vi) het recht op informatie van de kapitaalverschaffer zonder stemrecht (paragraaf 7.5.7) en (vii) de zorgplicht van de kapitaalverschaffer met (doorslaggevend) stemrecht jegens de kapitaalverschaffer zonder stemrecht (paragraaf 7.5.8). Ik heb voor deze thema's gekozen aan de hand de rechtspraak, de uitgangspunten van de flex-BV en de in de literatuur genoemde invalshoeken.

\subsubsection{Het gelijkheidsbeginsel}

Het gelijkheidsbeginsel wordt gezien als een uitwerking van de vennootschappelijke redelijkheid en billijkheid en als een van de elementaire beginselen van behoorlijk ondernemerschap. ${ }^{63}$ In art. 2:201 BW komt het gelijkheidsbeginsel tot uitdrukking. Tenzij bij de statuten anders is bepaald, zijn aan alle aandelen in verhouding tot hun bedrag gelijke rechten en verplichtingen verbonden. De vennootschap moet de aandeelhouders en de certificaathouders die zich in gelijke omstandigheden bevinden op dezelfde wijze behandelen. De statuten kunnen bepalen dat aan aandelen van een bepaalde soort of aanduiding bijzondere, statutaire zeggenschapsrechten in de vennootschap zijn verbonden.

Het eerste lid van art. 2:210 BW regelt de gelijke behandeling van aandelen. Die bepaling is van regelend recht, zo volgt uit de wettekst ("Voor zover bij de statuten

63 Asser/Maeijer, Van Solinge \& Nieuwe Weme 2-II* 2009, nr. 208 en sub 3.73-3.74 van de conclusie A-G Wesseling-van Gent bij HR 18 april 2003, LJN AF2161, NJ 2003, 286, m.nt. Ma, JOR 2003, 110, m.nt. Blanco Fernández (RNA) en de aldaar aangehaalde literatuur. Zie ook Van Schilfgaarde 1998, p. 22 en 26. Anders: G.T.M.J. Raaijmakers 2012, p. 40, ziet het gelijkheidsbeginsel weliswaar als een uitwerking van de norm van art. 2:8 BW, doch het gelijkheidsbeginsel heeft als norm een zelfstandige status gekregen. De uitleg van het gelijkheidsbeginsel als norm hoeft niet per definitie die van art. 2:8 BW te volgen. Zie verder over het gelijkheidsbeginsel bijvoorbeeld G.T.M.J. Raaijmakers 2012, p. 35 e.v. en, bij met name de beursvennootschap, Vletter-van Dort 2001. 
niet anders is bepaald"). ${ }^{64}$ Een statutaire regeling die van gelijke behandeling van aandelen afwijkt, kan onder omstandigheden in strijd met de vennootschappelijke redelijkheid en billijkheid zijn. ${ }^{65}$

In paragraaf 4.2.5 besprak ik het stemrechtloze aandeel met een beperkt recht op uitkering. Ik onderscheidde op die plaats acht soorten stemrechtloze aandelen. Onderscheid tussen aandelen van een verschillende soort of aanduiding is aldus toegestaan. Indien dat onderscheid bestaat, is geen sprake van schending van het gelijkheidsbeginsel in de zin van art. 2:210 lid $1 \mathrm{BW}$.

Het gelijkheidsbeginsel stond centraal in de eerder genoemde DSM-beschikking. ${ }^{66}$ Daarin overwoog de Hoge Raad: "De daarin opgenomen hoofdregel (art. 2:92 lid 1 $\mathrm{BW}$, toevoeging RAW) dat aan alle aandelen in verhouding tot hun bedrag gelijke rechten en verplichtingen zijn verbonden, is van regelend recht, nu daarvan in de statuten kan worden afgeweken. Uit de tekst en de strekking van deze bepaling volgt niet dat een statutaire afwijking van deze hoofdregel slechts mogelijk is met betrekking tot aandelen van een bepaalde soort. In het bijzonder schrijft art. 2:92 lid 1, gelezen in verband met het bepaalde in art. 2:105 BW, niet dwingend voor dat aan aandelen van dezelfde soort altijd in omvang gelijke aanspraken op dividend moeten zijn verbonden. Art. 2:92 lid 1 verzet zich daarom niet tegen een regeling in de statuten waarbij aan geregistreerde aandeelhouders onder bepaalde voorwaarden een financiële uitkering, bijvoorbeeld in de vorm van een aanvullend dividend, wordt toegekend, mits deze regeling geen schending oplevert van het in art. 2:92 lid 2 BW neergelegde gelijkheidsbeginsel." Met andere woorden: voor het creëren van een loyaliteitsdividend is het niet nodig een aparte soort aandelen uit te geven en een loyaliteitsdividend is als zodanig niet in strijd met het gelijkheidsbeginsel van art. 2:92 lid 2 BW. ${ }^{67}$ Op die laatste vraag heeft de Hoge Raad in het specifieke geval van DSM geen antwoord gegeven. ${ }^{68}$

64 Slagter 2005, p. 148 en Asser/Maeijer, Van Solinge \& Nieuwe Weme 2-II* 2009, nr. 207. HR 14 december 2007, LJN BB3523, NJ 2008, 105, m.nt. Ma, JOR 2008, 11, m.nt. A. Doorman (DSM).

65 Zie uitgebreid Doorman 2002, p. 199 e.v.

66 HR 14 december 2007, LJN BB3523, NJ 2008, 105, m.nt. Ma, JOR 2008, 11, m.nt. A. Doorman (DSM), r.o. 3.3. Zie verder over het loyaliteitsdividend (van DSM) bijvoorbeeld: Van Olffen 2006, p. 779 e.v.; Bier 2008 (2), p. 62 e.v.; Schild 2008, p. 30 e.v.; Van Veen 2008 (1), p. 23 e.v.; Hendriks \& Koelemeijer 2009, p. 181 e.v.; De Beurs 2011, p. 4 e.v.; Bier 2012 (2), p. 176-180; G.T.M.J. Raaijmakers 2012, p. 59-60 en Koelemeijer \& Hendriks 2012, p. 144 e.v.

67 De OK beschikte in tegengestelde zin, zie Hof Amsterdam (OK) 28 maart 2007, JOR 2007, 118, m.nt. Brink. A-G Timmerman stelde daarop cassatie in het belang der wet in, stellende dat het door DSM voorgestelde loyaliteitsdividend aan de houder van het aandeel is verbonden en niet behoort aan het aandeel zelf als samenstel van rechten en plichten. Ook in de literatuur zijn er opvattingen te vinden dat voor een loyaliteitsdividend een aparte soort aandelen vereist is, zie Bier 2003, p. 142 en 145; Bier 2008 (2), p. 63 (onder verwijzing naar literatuur, noot 5, 6 en 7) en 65. Anders bijvoorbeeld: Doorman 2002, p. 201; Van Olffen 2006, p. 780; Storm 2007, p. 474; Doorman in zijn noot onder het DSM-arrest: JOR 2008, 11, sub 12-14 en Stokkermans 2008 (1), p. 26.

68 Zie hierover Schild 2008, p. 34, met verwijzingen naar literatuur. 
Art. 2:92 BW is de pendant-bepaling van art. 2:201 BW voor de NV. Het is de vraag of het DSM-arrest, betreffende de naamloze vennootschap Koninklijke DSM N.V., wegens de invoering van de flex-BV voor de BV nog relevant is. Art. 2:216 lid 7 BW bepaalt immers dat bij de statuten kan worden bepaald dat aandelen van een bepaalde soort of aanduiding geen of slechts beperkt recht geven tot deling in de winst of reserves van de vennootschap. De wet biedt aldus uitdrukkelijk de mogelijkheid om met aandelen van een bepaalde soort of aanduiding van het bepaalde in art. 2:201 lid $1 \mathrm{BW}$ af te wijken. Met deze bepaling lijkt naar mijn mening het DSM-arrest voor het BV-recht achterhaald, althans niet relevant, te zijn. ${ }^{69}$ Het zou niet in het systeem van de wet passen dat voor de BV een loyaliteitsdividend op aandelen kan worden uitgekeerd zonder dat sprake is van aandelen van een bepaalde soort of aanduiding. ${ }^{70}$ Tegen deze opvatting pleit dat ook voor de invoering van de flex-BV het reeds mogelijk was verschillende soorten aandelen te creëren, het DSM-arrest en de opvattingen in de literatuur dat loyaliteitsdividend ook zonder soort aandelen gecreëerd kan worden. Niettemin meen ik dat, juist vanwege de flexibiliteit die de flex-BV biedt, het creëren van een recht op een loyaliteitsdividend door middel van een aparte soort aandelen de voorkeur verdient.

Ongeacht het antwoord op de vraag of in de flex-BV een aparte soort aandelen vereist is, zal bij invoering van een loyaliteitsdividend ten aanzien van de stemrechtloze aandeelhouder art. 2:231 lid $4 \mathrm{BW}$ in acht genomen moeten worden. Een goedkeurend besluit van de groep van stemrechtloze aandeelhouders is vereist.

Art. 2:201 lid 2 BW brengt dwingend rechtelijk tot uitdrukking dat aandeelhouders in gelijke omstandigheden gelijk moeten worden behandeld. Of sprake van gelijke omstandigheden is, zal het bestuur of de rechter per geval moeten beoordelen. ${ }^{71}$ Daarbij moeten alle relevante feiten en omstandigheden worden betrokken. ${ }^{72}$ De eerste vraag is wat in het voorliggende geval de relevante omstandigheden zijn. Indien dat vastgesteld is, is vervolgens de vraag of aandeelhouders zich in gelijke omstandigheden bevinden. ${ }^{73}$ Zo ja, dan zullen de aandeelhouders gelijk of naar evenredigheid van hun positie moeten worden behandeld. ${ }^{74}$

Het gelijkheidsbeginsel wordt niet geschonden indien de aandeelhouders zich niet in gelijke omstandigheden bevinden, of indien voor de ongelijke behandeling een redelijke en objectieve rechtvaardiging bestaat, zo volgt uit het Verenigde

69 Anders: H.E. Boschma \& J.N Schutte-Veenstra, Tekst \& Commentaar Burgerlijk Wetboek, art. 2:210 BW, aant. 2, Deventer: Kluwer.

70 Vgl. Bier 2008 (2), p. 65-66.

71 Kamerstukken II 1978/79, 15 304, nr. 3, p. 18 (MvT). Zie bijvoorbeeld Hof 's-Hertogenbosch 15 mei 1996, JOR 1996, 70 (Philips/VEB), r.o. 11.

72 G.T.M.J. Raaijmakers 2012, p. 44, die tevens van mening is dat de persoonlijke omstandigheden van de aandeelhouder betrokken moeten worden.

73 Zie bijvoorbeeld: Pres. Rb. Amsterdam 11 juni 1999, JOR 1999, 174, m.nt. Van Solinge (Leyinvest/ KBBVendex)

74 G.T.M.J. Raaijmakers 2012, p. 41 en 43. 
Bootlieden-arrest. ${ }^{75}$ Het ging in dat arrest om een herverdeling van het aandelenbezit wegens fiscale redenen, zodat iedere aandeelhouder ten minste vijf procent van de aandelen in de vennootschap zou houden. Daartoe werd tot uitgifte van aandelen besloten met uitsluiting of beperking van het voorkeursrecht en een enigszins ongelijke verdeling van de nieuw uit te geven aandelen. Vier aandeelhouders gingen van een vier procent naar een vijf procent-belang. De vijfde aandeelhouder moest ongeveer een procentpunt (van 19,25 procent naar 18,5 procent) van zijn belang inleveren. In feite werd in het arrest wegens de redelijke en objectieve rechtvaardiging aan het gelijkheidsbeginsel voorbij gegaan en was sprake van een belangenafweging. ${ }^{76}$ Bijzondere omstandigheden van het geval kunnen een redelijke en objectieve rechtvaardiging tot afwijking van het beginsel opleveren. ${ }^{77}$ Het gelijkheidsbeginsel is dus niet absoluut en vergt een belangenafweging. ${ }^{78}$

Het beginsel richt zich tot het bestuur van de vennootschap en de vennootschap zelf. $^{79} \mathrm{Bij}$ de belangenafweging heeft het bestuur een zekere discretionaire bevoegdheid en zal het ook het belang van de vennootschap in die afweging moeten betrekken. ${ }^{80}$ De aard van de vennootschap en de aard van de samenwerking zullen factoren zijn die daarbij een rol spelen. ${ }^{81}$

Tussen aandeelhouders van aandelen van dezelfde soort of aanduiding geldt het gelijkheidsbeginsel. ${ }^{82}$ Onderscheid tussen aandeelhouders van dezelfde soort of aanduiding is dus niet toegestaan. Het gelijkheidsbeginsel van art. 2:201 lid 2 BW geldt blijkens de memorie van toelichting ook voor certificaathouders. ${ }^{83} \mathrm{Ik}$ zie niet in waarom dat voor houders van certificaten met en zonder vergaderrecht in de flexBV anders zou zijn. ${ }^{84}$ Het gelijkheidsbeginsel van art. 2:201 lid 2 BW geldt mijns inziens ook voor de houders van participatiebewijzen. De grondslag daarvan is dan niet art. 2:201 lid $2 \mathrm{BW}$, maar de vennootschappelijke redelijkheid en billijkheid. ${ }^{85}$

Tot slot ga ik in op de verhouding tussen lid 1 en 2 van art. 2:201 BW. Tijdens de parlementaire behandeling van de NV-pendantbepaling is hierover door de minister opgemerkt dat een statutaire bepaling die lid 1 toestaat kan leiden tot verschillende

75 HR 31 december 1993, NJ 1994, 436, m.nt. Ma (Verenigde Bootlieden). Zie over dit arrest: Asser/ Maeijer, Van Solinge \& Nieuwe Weme 2-II* 2009, nr. 208; Vletter-van Dort 2001, p. 32-38; Doorman 2002, p. 202-205; Rensen 2005, p. 141 en G.T.M.J. Raaijmakers 2012, p. 48-53.

76 De Beurs 2011, p. 10 en 18.

77 G.T.M.J. Raaijmakers 2012, p. 50.

78 G.T.M.J. Raaijmakers 2012, p. 47.

79 Asser/Maeijer, Van Solinge \& Nieuwe Weme 2-II* 2009, nr. 208; Bartman 2002, p. 36 en G.T.M.J. Raaijmakers 2012, p. 44, 48 en 50.

80 G.T.M.J. Raaijmakers 2012, p. 48 en 50-52.

81 Vgl. paragraaf 5.3.2 en 5.3.3. Zie ook G.T.M.J. Raaijmakers 2012, p. 51.

82 Van Schilfgaarde 1998, p. 21. Pres. Rb. Amsterdam 20 december 2001, JOR 2002, 26 (Gorillapark), bekrachtigd door Hof Amsterdam (OK) 25 april 2002, JOR 2002, 128.

83 Kamerstukken II 1978/79, 15 304, nr. 3, p. 18 (MvT).

84 In gelijke zin: J.B. Huizink, Groene Serie Rechtspersonen, art. 2:92 BW, aant. 4a, Deventer: Kluwer.

85 Vgl. Van Schilfgaarde 1998, p. 22 en 26. 
omstandigheden in de zin van lid $2 .{ }^{86}$ Hoe moet dit worden uitgelegd? In de literatuur zijn twee opvattingen te vinden. De eerste opvatting gaat er vanuit dat indien in de statuten aandelen met een bepaalde soort of aanduiding zijn gecreëerd, de vennootschap jegens de diverse vergaderingen van deze aandelen van een bepaalde soort of aanduiding het gelijkheidsbeginsel niet in acht hoeft te nemen. Met andere woorden: alleen binnen de groep van houders van aandelen van een bepaalde soort of aanduiding moet de vennootschap het gelijkheidsbeginsel in acht nemen, in die zin dat aandeelhouders van aandelen van dezelfde soort of aanduiding gelijk worden behandeld. Op grond van de wet en de statuten is immers een onderscheid tussen soorten van aandelen mogelijk, zodat houders van verschillende soorten aandelen, vanwege deze statutaire basis, ongelijk mogen worden behandeld. De grens wordt gevormd door de vennootschappelijke redelijkheid en billijkheid, aldus deze opvatting. ${ }^{87}$ De tweede opvatting houdt in dat houders van verschillende soorten aandelen in zijn algemeenheid ongelijk behandeld mogen worden. In beginsel heeft iedere groep van aandeelhouders van een bepaalde soort of aanduiding een aparte status, die een afzonderlijke behandeling rechtvaardigt. Afhankelijk van de aard van het onderscheid tussen de verschillende groepen aandeelhouders en van de aard en de strekking van het betreffende onderwerp kan onderscheid tussen de verschillende groepen aandeelhouders worden opgeheven. ${ }^{88}$

Naar mijn mening is het verschil tussen deze opvattingen slechts academisch. Sterker, ik vraag me af of beide opvattingen niet op hetzelfde neerkomen, althans bij toetsing eenzelfde resultaat bereiken. Zowel de eerste als de tweede opvatting is niet absoluut en hebben een correctiemogelijkheid. In de eerste opvatting wordt de vennootschappelijke redelijkheid en billijkheid als correctiefactor genoemd, terwijl bij de correctiemogelijkheid van de tweede opvatting naar mijn mening omstandigheden worden genoemd die, afhankelijk van de omstandigheden van het geval, betrokken moeten worden bij de beoordeling van de corrigerende werking van de vennootschappelijke redelijkheid en billijkheid.

\subsubsection{Bescherming van minderheidsaandeelhouders}

In het kader van de invoering van de flex-BV heeft de wetgever oog gehad voor de positie van de minderheidsaandeelhouder en die positie als volgt omschreven: "De grotere vrijheid van inrichting heeft als gevolg dat bijzondere aandacht dient te worden besteed aan de positie van minderheidsaandeelhouders. Zij lopen het risico dat de meerderheid als gevolg van de grotere vrijheid van inrichting de minderheid benadeelt. De wet biedt daarom een aantal minimumwaarborgen voor de bescherming van de minderheidsaandeelhouder. Anderzijds mag de bescherming van de minderheidsaandeelhouder niet ten koste gaan van de flexibilisering die met dit

86 Kamerstukken II 1979/80, 15 304, nr. 6, p. 18

87 Van Schilfgaarde 1998, p. 20 en 28 en Van Olffen 2006, p. 782.

88 Doorman 2002, p. 200; Van Veen 2008 (1), p. 25 en G.T.M.J. Raaijmakers 2012, p. 45. 
wetsvoorstel wordt nagestreefd. Het is inherent aan de besluitvorming in een algemene vergadering dat de minderheidsaandeelhouder zich in beginsel moet schikken in de besluitvorming door de meerderheid. Hierbij is van belang dat aandeelhouders zich in algemene zin in hun onderlinge verhoudingen moeten laten leiden door de redelijkheid en billijkheid (artikel 8). Slechts voor die gevallen waarin het risico bestaat dat het meerderheidsbelang wordt misbruikt of waar essentiële rechten van aandeelhouders in het geding zijn, ligt specifieke wettelijke bescherming van de minderheidsaandeelhouder in de rede." 89

Van Olffen omschrijft de minderheidsaandeelhouder als 'een persoon die gegeven het aantal stemmen verbonden aan de door hem gehouden aandelen in een vennootschap niet in staat is besluitvorming in de algemene vergadering te blokkeren'. ${ }^{90}$ Een met de positie van de minderheidsaandeelhouder vergelijkbare kapitaalverschaffer is de kapitaalverschaffer zonder stemrecht. Aan de ene kant brengt de positie van de minderheidsaandeelhouder mee dat hij hem onwelgevallige besluiten tegen zich moet laten gelden. Dat geldt ook voor de stemrechtloze aandeelhouder. Aan de andere kant mag de meerderheidsaandeelhouder zijn macht niet misbruiken. Strijdigheid met de vennootschappelijke redelijkheid en billijkheid, die de lidmaatschapsverhoudingen tussen aandeelhouders beheersen, ligt in dat geval op de loer. Van der Grinten waarschuwde reeds voor de onderlinge verhoudingen tussen aandeelhouders met en zonder stemrecht. ${ }^{91}$ De Commissie Vennootschapsrecht heeft erop gewezen dat het ontbreken van stemrecht aan het stemrechtloze aandeel kan leiden tot onevenwichtigheid in de zeggenschapsverhoudingen in de algemene vergadering. In die vergadering kan over allerlei kwesties besloten worden die bij oprichting van de BV niet waren voorzien. Het gevolg daarvan zou kunnen zijn een grotere druk op de rechterlijke macht, omdat de stemrechtloze aandeelhouder zich eerder in de knel voelt komen. Die aandeelhouder zou eerder geneigd zijn vernietiging van een besluit van de algemene vergadering wegens strijd met de vennootschappelijke redelijkheid en billijkheid te vorderen dan wel een enquête te verzoeken of een vordering tot uittreding in te stellen. ${ }^{92}$

De meerderheidsaandeelhouder moet bij het uitbrengen van zijn stem ook rekening houden met de redelijke belangen van de minderheidsaandeelhouder. ${ }^{93}$ Indien de meerderheidsaandeelhouder tevens (enig) bestuurder van de vennootschap

89 Kamerstukken II 2006/07, 31 058, nr. 3, p. 3-4 (MvT).

90 Van Olffen 2012, p. 374

91 Van der Grinten 1971 (1), p. 303.

92 Advies van de Commissie vennootschapsrecht over het wetsvoorstel inzake de vereenvoudiging en flexibilisering van het b.v.-recht d.d. 23 november 2006, p. 12, te vinden op http://www.rijksoverheid.nl/onderwerpen/flexibele-BV.

93 Zie bijvoorbeeld Hof Amsterdam (OK) 3 november 2000, JOR 2001, 3; Hof Amsterdam (OK) 30 november 2000, JOR 2001, 4, m.nt. Van den Ingh (Zwagerman); Hof Amsterdam (OK) 22 december 2000, JOR 2001, 32; Hof Amsterdam (OK) 18 januari 2001, JOR 2001, 34, m.nt. Brink (VIBA); Hof Amsterdam (OK) 23 januari 2001, JOR 2001, 56; Hof Amsterdam (OK) 4 juli 2001, JOR 2001, 149, $\rightarrow$ 
is, geldt die zorgplicht eens te meer. Zo overwoog de OK in de De Bruin/De Haskerbeschikking ${ }^{94}$ dat op het bestuur van De Hasker rust "jegens De Bruin Beheer als aandeelhouder niet bestuurder een bijzondere zorgplicht, in - met name - die zin dat het bestuur voldoende openheid dient te betrachten door het verschaffen van gegevens waarop de derde aandeelhouder als zodanig geen recht heeft en dat dient te worden voorkomen dat vermenging van belangen van De Hasker met die van haar bestuur onderscheidenlijk haar meerderheidsaandeelhouder(s) - al of niet ten koste van haar minderheidsaandeelhouder - plaatsvindt. Deze bijzondere zorgplicht weegt des te zwaarder in een geval als het onderhavige, waarin twee van de drie aandeelhouders tevens bestuurder zijn van De Hasker." Voor de kapitaalverschaffer met stemrecht geldt dat ten opzichte van de kapitaalverschaffer zonder stemrecht mijns inziens in gelijke mate.

Om tot normen of zorgplichten ${ }^{95}$ die ten opzichte van de kapitaalverschaffer zonder stemrecht in acht genomen moeten worden te komen, sta ik eerst stil bij de vraag of, en zo ja, welke normen of zorgplichten er ten opzichte van minderheidsaandeelhouders gelden en op welke wijze dergelijke aandeelhouders worden beschermd.

Een bekend arrest is het Lampe/Tonnema-arrest. ${ }^{96}$ De casus is als volgt. Lampe bezat minder dan vijf procent van de aandelen in het kapitaal van Tonnema BV. De meerderheid van de aandeelhouders wenste de aandelen aan een derde te verkopen; naar later bleek aan Van Nelle Holding NV. Deze meerderheid had zich verenigd met de criteria van een verkoop aan die derde, doch kende de plannen van Van Nelle Holding NV niet, zo maak ik op uit het arrest. Lampe heeft zich daartegen verzet, onder meer stellende dat daarmee het karakter van het familiebedrijf verloren zou gaan en dat hij een hogere prijs voor de aandelen zou bieden, dan wel dat via hem een hogere prijs verkregen zou kunnen worden. Lampe beriep zich onder meer op de in de statuten opgenomen blokkeringsregeling in de vorm van een aanbiedingsregeling. Bij

m.nt. Brink (HBG) en HR 1 maart 2002, LJN AD9857, NJ 2002, 296, m.nt. Ma, JOR 2002, 79, m.nt. Van den Ingh (Zwagerman Beheer). De omgekeerde situatie kan zich ook voor doen, zie Pres. Rb. Amsterdam 20 december 2001, JOR 2002, 26 (Gorillapark), bekrachtigd door Hof Amsterdam (OK) 25 april 2002, JOR 2002, 128: de minderheidsaandeelhouder wordt bevolen zich te gedragen conform een niet door die minderheidsaandeelhouder aanvaarde wijziging in de aandeelhoudersovereenkomst. De minderheidsaandeelhouder handelt in strijd met de redelijkheid en billijkheid door een voor haar gunstiger regeling af te dwingen. Zie voor literatuur bijvoorbeeld Van den Ingh 2000, p. 203 e.v., ten aanzien van het stemgedrag van aandeelhouders.

94 Hof Amsterdam (OK) 17 december 2007, JOR 2008, 35, r.o. 3.4.

95 Zie Huizink 2010, p. 8-9 en Van Olffen 2012, p. 376-378 over de - al dan niet bestaande - nuances tussen 'zorgplichten', 'zorgvuldigheidsplicht' en 'bijzondere zorgvuldigheidsverplichting'.

96 HR 17 mei 1991, NJ 1991, 645, m.nt. Ma (Lampe/Tonnema), met name r.o. 3.4 van het arrest. Vgl. Pres. Rb. Utrecht 16 februari 1989, $K G$ 1989, 156. Zie ook M.J.G.C. Raaijmakers 1991 (2), Koelemeijer 1999, p. 43 en 159 e.v., Bartman \& Dorresteijn 2009, p. 117. Tonnema BV was de fabrikant van KING-pepermunt. Zie voor de geschiedenis van het familiebedrijf Tonnema: J. de Jager, De KING-familie, geschiedenis van een pepermuntje, Leeuwarden: Friese Pers Boekerij, 2010. Met name p. 103 e.v. geven inzicht in de achtergrond die leidde tot het Lampe/Tonnema-arrest. 
besluit van de algemene vergadering is de anbiedingsregeling gewijzigd in een goedkeuringsregeling. De overdracht van aandelen behoefde als gevolg van die statutenwijziging goedkeuring van de algemene vergadering. Goedkeuring volgde. Volgens Lampe is het besluit tot wijziging van de aanbiedingsregeling in de goedkeuringsregeling in strijd met de vennootschappelijke redelijkheid en billijkheid genomen. ${ }^{97}$ Vervolgens zijn de aandelen, behalve die van Lampe, alsnog aan Van Nelle Holding NV verkocht en geleverd. Later heeft Lampe op grond van de toegewezen vordering tot uitkoop ex art. 2:201a BW zijn aandelen aan Van Nelle Holding NV geleverd.

De Hoge Raad overwoog dat Lampe vanaf de aanvang van zijn aandeelhouderschap rekening had te houden met de mogelijkheid van wijziging van de aanbiedingsregeling bij meerderheidsbesluit. Dat argument vind ik weinig overtuigend, omdat het er niet om gaat waarmee Lampe rekening behoefde te houden bij aanvang van zijn aandeelhouderschap. Een van de stellingen van Lampe was dat het besluit tot wijziging van de aanbiedingsregeling in de goedkeuringsregeling in strijd met de vennootschappelijke redelijk en billijkheid is genomen. Dat besluit is ruim $n a$ aanvang van het aandeelhouderschap van Lampe genomen en die toets was aan de orde in de procedure. ${ }^{98}$

De Hoge Raad spreekt niet van een zorgplicht, maar overweegt dat in de overwegingen van het hof ligt besloten dat het hof het belang van Lampe bij het in stand blijven van zijn uit de aanbiedingsregeling voortvloeiende rechten heeft afgewogen tegen de belangen van de overgrote meerderheid van de aandeelhouders en van de onderneming, welke afweging ten nadele van Lampe is uitgevallen. Het beroep van Lampe dat de wijziging van de blokkeringsregeling in strijd is met de jegens hem in acht te nemen vennootschappelijke redelijkheid en billijkheid gaat daarom niet op. Het besluit tot de statutenwijziging is daarom niet vernietigbaar.

De Hoge Raad ziet het door Lampe genoemde argument van de 'familievennootschap' niet als een bijzondere omstandigheid. Wellicht omdat de wijziging van de blokkeringsregeling alle aandeelhouders raakte om verkoop aan een derde mogelijk te maken. Daarnaast ging Lampe er door de wijziging in financiële zin niet op achteruit. Na uitkoop ex art. 2:201a BW ontving Lampe dezelfde prijs voor zijn aandelen van Van Nelle Holding N.V. als de aandeelhouders die reeds met de verkoop hadden ingestemd. Een andere reden om het familiebedrijf in dit geval niet als een bijzondere omstandigheid te zien was wellicht gelegen in het feit dat de aandelen, mede door vererving, over een aantal takken van de families van de oorspronkelijke oprichters versnipperd waren. Van een persoonsgebonden samenwerking en de beslotenheid van de BV was derhalve geen sprake meer.

97 Vrij vertaald: het veranderen van de spelregels tijdens de wedstrijd.

98 Bovendien miskent de Hoge Raad de familieverhoudingen in de Tonnema-affaire. Lampe had zijn aandelen als (minderjarig) kind van zijn moeder gekregen. Zie J. de Jager, De KING-familie, geschiedenis van een pepermuntje, Leeuwarden: Friese Pers Boekerij 2010, p. 116 en 131. 
In hoofdstuk 5 besprak ik de beslotenheid van de BV en het karakter van samenwerking in die rechtsvorm. Lampe heeft in zijn cassatiemiddel onder meer betoogd dat de statutenwijziging de kern van het samenwerkingsverband tussen de aandeelhouders onderling en de familievennootschap, die Tonnema BV destijds was, raakt. ${ }^{99}$ De Hoge Raad volgt echter de motivering van het hof en overweegt "dat het hof het belang van Lampe bij het in stand blijven van zijn uit de aanbiedingsregeling voortvloeiende rechten heeft afgewogen tegen de belangen van de overgrote meerderheid van de aandeelhouders en van de onderneming, welke afweging ten nadele van Lampe is uitgevallen." Daarmee is geen rechtsregel geschonden aldus de Hoge Raad. ${ }^{100}$ Lampe kon zich aldus niet tegen het meerderheidsbesluit verzetten. Overigens had Lampe zich reeds voordat het besluit tot het wijzigen van de blokkeringsregeling zou worden genomen tevergeefs verzet. ${ }^{101}$ Deze overweging ten aanzien van de belangenafweging is de kern van het arrest. Zonder uitputtend te willen zijn, noem ik een aantal reacties in de literatuur op het arrest. Ieder vanuit een andere invalshoek. Timmerman merkt op dat het begrijpelijk is dat de belangen van Lampe minder zwaar hebben gewogen dan de andere bij de verkoop betrokken belangen. De statutenwijziging maakte de verkoop van Tonnema BV mogelijk, welke verkoop gewenst was door het bestuur, de ondernemingsraad, de vakorganisaties en de overgrote meerderheid van de aandeelhouders. Lampe heeft kennelijk niet duidelijk kunnen maken wat zijn plannen waren, aldus Timmerman. ${ }^{102}$ In de conclusie van zijn analyse van het Lampe/Tonnema-arrest stelt Schwarz dat indien de meerderheid van de aandelen in een hand zou zijn geweest, het belang van de minderheidsaandeelhouder zwaarder had moeten wegen. De wijziging van de aanbiedingsregeling in een goedkeuringsregeling zou in die situatie als misbruik van meerderheidsmacht kunnen worden gekenschetst. De keuze van de minderheidsaandeelhouder zou dan zijn beperkt tot het al dan niet overnemen van alle aandelen. Bij weigering daarvan zou verkoop aan een derde mogelijk zijn. ${ }^{103}$ Koelemeijer ${ }^{104}$ leidt, onder verwijzing naar het Janssen Persarrest $^{105}$ en het Vecolac/Juliana-arrest, ${ }^{106}$ uit het Lampe/Tonnema-arrest af dat in het kader van de belangenafweging een besluit waarbij een recht van een aandeelhouder ongedaan wordt gemaakt gerechtvaardigd kan zijn en dat afhankelijk van de

99 Cassatiemiddel, sub 6.

100 r.o. 3.4. Het is met name deze overweging dat Koelemeijer 1999, p. 43, stelt dat de toetsing aan de redelijkheid en billijkheid geen marginale toetsing is, maar dat sprake is van een belangafweging. Maeijer stelt in zijn $N J$-noot onder het arrest dat uit de overweging van de Hoge Raad volgt 'dat het bereikte toetsingsresultaat herkenbaar op een afweging van de in het geding zijnde belangen is gebaseerd.' Zie ook noot 18 .

101 Pres. Rb. Leeuwarden 3 februari 1988, KG 1988, 200.

102 Timmerman 1991, p. 190.

103 Schwarz 1994, p. 464. Zie ook Bakker 2011, p. 41-42

104 Koelemeijer 1999, p. 44.

105 HR 10 maart 1995, NJ 1995, 595, m.nt. Ma (Janssen Pers).

106 HR 9 januari 1987, NJ 1987, 959, m.nt. Ma (Vecolac/Juliana). 
omstandigheden van het geval een dergelijke afweging ook tot een ander resultaat kan leiden.

Ook in het Zwagerman Beheer-arrest ${ }^{107}$ stonden minderheidsaandeelhouders en familieverhoudingen centraal. De Hoge Raag overweegt: “(...) De Ondernemingskamer is klaarblijkelijk uitgegaan van de in art. 2:8 $\mathrm{BW}$ neergelegde regel dat de vennootschap en degenen die krachtens de wet en de statuten bij haar organisatie zijn betrokken, zich als zodanig jegens elkander moeten gedragen naar hetgeen door de redelijkheid en billijkheid wordt gevorderd. Uit deze regel vloeit onder meer voort dat de vennootschap zorgvuldigheid moet betrachten met betrekking tot de belangen van al haar aandeelhouders. De uitwerking van de zorgvuldigheidsplicht zal mede afhankelijk zijn van de omstandigheden van het geval, waarbij zoals de Ondernemingskamer heeft gedaan, in aanmerking mag worden genomen dat het gaat om minderheidsaandeelhouders tegenover meerderheidsaandeelhouders en om familierechtelijke verhoudingen tussen de bij de vennootschap betrokken personen. Onder deze omstandigheden, die zich hier voordoen, kan eerder dan in andere gevallen sprake zijn van de mogelijkheid van een vermenging van de belangen van de vennootschap en van sommige van deze personen, zodat er reden is daarop attent te zijn en met de nodige zorgvuldigheid te voorkomen dat ontoelaatbare verstrengeling van belangen ontstaat. Aldus verstaan geeft het bestreden oordeel van de Ondernemingskamer niet blijk van een onjuiste rechtsopvatting."

De vraag is waarom in het Lampe/Tonnema-arrest geen en in het Zwagerman Beheer-arrest wel rekening met de familieverhoudingen gehouden wordt. In het Zwagerman Beheer-arrest was sprake van (ernstige) belangenverstrengeling en was geen openheid van zaken door de vennootschap jegens de minderheidsaandeelhouders betracht. Bij belangenverstrengeling klemt het niet betrachten van openheid van zaken te meer. In het Lampe/Tonnema-arrest was - in ieder geval op het eerste gezicht ${ }^{108}$ - de belangenverstrengeling niet aan de orde. Daarnaast was in die casus, anders dan in het Zwagerman Beheer-arrest waarbij er twee minderheidsaandeelhouders waren, sprake van een over diverse familietakken versnipperd aandelenbezit.

In het reeds genoemde Vecolac/Juliana-arrest ${ }^{109}$ overwoog de Hoge Raad: "dat de beide bestreden besluiten tezamen een vorm van samenwerking in het leven roepen welke zodanig ver gaat en van die krachtens de oude statuten van Vecolac zo

107 HR 1 maart 2002, LJN AD9857, NJ 2002, 296, m.nt. Ma, JOR 2002, 79, m.nt. Van den Ingh (Zwagerman Beheer), r.o. 3.4. (vervolg op Hof Amsterdam (OK) 30 november 2000, JOR 2001, 4, m.nt. Van den Ingh). Zie ook Asser/Maeijer, Van Solinge \& Nieuwe Weme 2-II* 2009, nr. 667. In lijn daarmee ligt: HR 29 september 2006, NJ 2006, 639, m.nt. Ma, JOR 2007, 62 (The Mill Resort); Hof Amsterdam (OK) 31 augustus 2001, JOR 2001, 208 (De Merwede Holding) en Hof Amsterdam (OK) 6 juni 2011, LJN BQ9757, JOR 2011, 282, m.nt. Blanco Fernández (Jeezet/Synpact), r.o. 3.24.

108 J. de Jager, De KING-familie, geschiedenis van een pepermuntje, Leeuwarden: Friese Pers Boekerij, 2010, p. 103 e.v. doet anders vermoeden

109 HR 9 januari 1987, $N J$ 1987, 959, m.nt. Ma (Vecolac/Juliana), r.o. 3.4. 
wezenlijk verschilt, dat zij, welk gewicht ook toekomt aan de belangen welke de meerderheid met die samenwerking beoogde te dienen, naar eisen van redelijkheid en billijkheid aan een zich daartegen verzettende minderheid niet had mogen zijn opgelegd." Maeijer formuleert het in zijn noot onder het arrest als volgt: "De belangen van een minderheid kunnen zo overwegend zijn dat zij moeten worden ontzien door een meerderheid: ongeacht het gewicht van de belangen die deze meerderheid beoogt te dienen. Ook dan is er van een belangenafweging sprake: zij het dat het belang van de minderheid aanstonds de doorslag zal geven." 110

De hiervoor besproken arresten leren dat, afhankelijk van de omstandigheden van het geval, sprake kan zijn van een zorgplicht van meerderheidsaandeelhouders jegens minderheidsaandeelhouders, welke zorgplicht is gebaseerd op art. 2:8 BW. Relevante omstandigheden zijn de aard van de samenwerking, de beslotenheid van de BV en familieverhoudingen. ${ }^{111}$ Telkens zullen de belangen van alle aandeelhouders en de vennootschap in acht genomen moeten worden en de vraag beantwoord moeten worden of die belangen niet onevenredig worden geschaad. Indien deze relevante omstandigheden zich voordoen, kan eerder sprake zijn van belangenverstrengeling. Er geldt dan een verhoogde zorgplicht. Anders gezegd: men moet extra alert zijn. Niet per definitie is in dat geval sprake van een ontoelaatbare belangenverstrengeling. Voor het antwoord op de vraag of sprake is van een ontoelaatbare belangenverstrengeling en onevenredige schending van belangen is de mate van openheid en informatieverstrekking van belang.

Deze regels van bescherming van minderheidsaandeelhouders gelden naar mijn mening op gelijke wijze ten aanzien van de stemrechtloze aandeelhouders en andere kapitaalverschaffers zonder stemrecht die tot de kring van betrokkenen behoren. Het feit dat de stemrechtloze aandeelhouder geen stemrecht heeft, is mijns inziens geen reden om te spreken over een verhoogde zorgplicht jegens de stemrechtloze aandeelhouder of andere kapitaalverschaffers zonder stemrecht. Wel zullen de belangen van die kapitaalverschaffers op grond van de angehaalde jurisprudentie in acht moeten worden genomen. Naast de genoemde relevante omstandigheden kan bij de invulling van de zorgplicht gekeken worden naar de vennootschappelijke structuur, de mate waarin de kapitaalverschaffer zonder stemrecht kapitaal verschaft en de mate waarin die kapitaalverschaffer, ondanks het ontbreken van stemrecht, zeggenschap in de vennootschap heeft, zoals bijvoorbeeld het recht tot benoemen van bestuurder(s) of commissaris(sen). De uitkomst van de invulling van die zorgplicht zal gelet op de verschillende aard van de rechtsfiguren zonder stemrecht, waarvan de houders tot de kring van betrokkenen behoren, telkens anders uitvallen. Daarvoor zijn geen algemene regels te geven, omdat de concrete inhoud van de zorgplicht sterk afhankelijk is van de omstandigheden van het geval.

110 Sub 5.

111 In gelijke zin Van Olffen 2012, p. 375 en 378. 


\subsubsection{Besluiten die de rechten op winst en/of reserves raken}

\subsubsection{Inleiding}

Bij invoering van de flex-BV en de introductie van het stemrechtloze aandeel in die BV heeft de wetgever als uitgangspunt genomen dat de stemrechtloze aandeelhouders met name beschermd dienen te worden tegen afbreuk van hun winstrechten. ${ }^{112}$ Bij gebrek aan stemrecht in de algemene vergadering zijn voornamelijk de aan het stemrechtloze aandeel verbonden financiële rechten van belang. De financiële rechten vormen een 'wezenlijk onderdeel van het aandeelhouderschap'. ${ }^{113}$ Art. 2:216 BW geeft de stemrechtloze aandeelhouder recht op dividend, althans in beginsel recht op uitkering daarvan. In paragraaf 6.2.3.6 besprak ik de wettelijke beschermingsregels voor de stemrechtloze aandeelhouder indien aan zijn rechten in de winst en/of reserves afbreuk wordt gedaan. Voor de specifieke wettelijke regels ter bescherming van de overige kapitaalverschaffers zonder stemrecht tegen afbreuk van hun rechten op winst en/of reserves verwijs ik naar hoofdstuk 6.

In deze paragraaf staat centraal een besluit van de algemene vergadering op grond van het bepaalde in art. 2:216 BW waarbij de winst geheel of gedeeltelijk wordt gereserveerd, terwijl de stemrechtloze aandeelhouder uitkering van de gehele winst wenst. In paragraaf 7.5.4.2 werk ik dit thema uit. Een besluit tot reservering van de winst is een besluit dat direct de financiële rechten van de stemrechtloze aandeelhouder raakt. Andere besluiten, die ik aanmerk als indirecte besluiten, raken echter ook de winstrechten van de stemrechtloze aandeelhouder. Ik denk daarbij met name aan besluiten van de algemene vergadering omtrent de bezoldiging van bestuurders (art. 2:245 BW) en van commissarissen (art. 2:255 BW). Dat thema werk ik uit in paragraaf 7.5.4.3. In paragraaf 7.5.4.4 bespreek ik de overige besluiten van de algemene vergadering of het bestuur die de rechten op winst en/of de reserves van de kapitaalverschaffer zonder stemrecht raken.

\subsubsection{Winstreservering ${ }^{114}$}

Indien de stemrechtloze aandeelhouder geen dividend op zijn aandeel ontvangt, ontbeert hij rendement op dat aandeel. Het niet uitkeren van winst kan een eenvoudige reden hebben. De vennootschap maakt geen winst; er valt niets uit te keren. In het geval dat de vennootschap wel winst maakt, doch die winst wordt bij besluit van de algemene vergadering gereserveerd, is geen sprake van rendement. Er kan gesteld worden dat de winst toegevoegd wordt aan de reserves van de

112 Kamerstukken II 2008/09, 31 058, nr. 6, p. 39.

113 Kamerstukken II 2006/07, 31 058, nr. 3, p. 75 (MvT).

114 Zie uitgebreid over dit thema: Koelemeijer 1999, p. 169-192, met rechtsvergelijking tussen Duits, Frans en Engels recht. 
vennootschap, zodat de intrinsieke waarde van het aandeel stijgt. Het is echter de vraag of de reserves niet verdampen, of de toevoeging van de winst aan de reserves leidt tot een hogere winst in het jaar daarna en of die hogere winst vervolgens als dividend wordt uitgekeerd. Met andere woorden: de stemrechtloze aandeelhouder verkeert in onzekerheid. In de tussentijd kan de stemrechtloze aandeelhouder het ontbeerde dividend niet rendabel maken. Daarbij komt dat de stemrechtloze aandeelhouder zijn aandelen niet zomaar aan een derde kan verkopen. Vanwege het besloten karakter van de BV geldt als hoofdregel de aanbiedingsregeling ex art. 2:195 BW. Dit klemt te meer, omdat de stemrechtloze aandeelhouder voor het genieten van winst uit de resultaten van de vennootschap uitsluitend op het uit te keren dividend zal zijn aangewezen. ${ }^{115}$

Art. 2:216 lid 1 BW bepaalt dat de algemene vergadering bevoegd is tot bestemming van de winst die door de vaststelling van de jaarrekening is bepaald en tot vaststelling van uitkeringen, voor zover het eigen vermogen groter is dan de reserves die krachtens de wet of de statuten moeten worden aangehouden. De statuten kunnen de bevoegdheden tot bestemming van de winst die door de vaststelling van de jaarrekening is bepaald en tot vaststelling van uitkeringen beperken of toekennen aan een ander orgaan. Onder een beperking valt bijvoorbeeld dat de statuten bepalen dat de winst rechtstreeks ten goede komt aan de aandeelhouders of dat een deel van de winst toekomt aan bepaalde personen (statutair winstrecht). Een andere mogelijkheid is dat de statuten voorschrijven dat de winst onder bepaalde omstandigheden wordt gereserveerd. Indien de statuten de bevoegdheid tot bestemming van winst of de vaststelling van uitkeringen toekennen aan een ander orgaan, ${ }^{116}$ moet sprake zijn van een orgaan in de zin van art. 2:189a BW. ${ }^{117}$ In het geval waarin de statuten bepalen dat de winst die blijkt uit de jaarrekening toekomt aan de aandeelhouders, dient het besluit tot vaststelling van de jaarrekening te worden beschouwd als het besluit dat strekt tot uitkering. Dat besluit vereist goedkeuring van het bestuur, alvorens rechtsgeldig kan worden overgegaan tot betaalbaarstelling van de uitkering. ${ }^{118}$

In deze paragraaf ga ik uit van de hoofdregel dat de genoemde bevoegdheden aan de algemene vergadering toekomen en dat van een voornoemde beperking of toekenning aan een ander orgaan, meer in het bijzonder aan de vergadering van stemrechtloze aandeelhouders, ${ }^{119}$ geen sprake is.

De OK verwoordt de algemene regels omtrent het uitkeren en het reserveren van winst in de Jeezet/Synpact-beschikking als volgt: "In beginsel hebben de aandeelhouders zonder meer recht op uitkering van de in een boekjaar gerealiseerde winst.

115 In gelijke zin Koelemeijer 1999, p. 170 en Bier 2003, p. 69, noot 192. Vgl. Hof 's-Gravenhage 1 oktober 1982, NJ 1983, 393 (Van Rees/Smits).

116 Koelemeijer 2012, p. 44, bepleit dat alleen de algemene vergadering bevoegd is de winst te bestemmen.

117 Kamerstukken II 2006/07, 31 058, nr. 3, p. 69 (MvT).

118 Kamerstukken I 2011/12, 31 058, nr. E, p. 14 (Nadere MvA).

119 Zie paragraaf 4.2.7. 
Dit is anders indien de statuten bepalen dat de winst ter beschikking staat van een vennootschapsorgaan, bijvoorbeeld van de algemene vergadering van aandeelhouders. In dat geval dient de algemene vergadering van aandeelhouders een besluit tot winstbestemming te nemen; zij kan besluiten tot (gehele of gedeeltelijke) reservering of tot (gehele of gedeeltelijke) uitkering. De algemene vergadering van aandeelhouders dient bij het nemen van het besluit tot winstbestemming de redelijkheid en billijkheid in het oog te houden. Het belang van een (minderheids)aandeelhouder bij uitkering van dividend dient zorgvuldig te worden afgewogen tegen het belang van de vennootschap en de wens van de andere aandeelhouder(s) om de winst (geheel of gedeeltelijk) aan de reserves toe te voegen. In beginsel dient de winst aan de aandeelhouders te worden uitgekeerd, tenzij het vennootschappelijk belang vereist dat tot (gehele of gedeeltelijke) reservering van de winst wordt overgegaan. Het gedurende een onbepaalde tijd handhaven van een beleid waarbij alle winst wordt gereserveerd zal in het algemeen niet gerechtvaardigd zijn. Het dividendbeleid dient kenbaar te zijn voor de aandeelhouders en te worden gemotiveerd." 120

Uit deze overweging komt naar voren dat niet alleen de vennootschappelijke redelijkheid en billijkheid, maar ook het vennootschappelijke belang, een rol speelt bij het antwoord op de vraag of een besluit tot reservering van de winst moet worden vernietigd. ${ }^{121}$ Bij toetsing van dat besluit gaat het om een afweging van de hiervoor genoemde belangen. ${ }^{122}$ Ten aanzien van het vennootschappelijk belang ingeval van winstreservering wordt in de literatuur een aantal factoren genoemd die dat belang kan invullen: de grootte van de onderneming, de positie van de vennootschap binnen een groep van vennootschappen, de bedrijfseconomische en financiële positie (waaronder de liquiditeit) van de vennootschap, de algemene toestand van de marktsector of branche waarin de onderneming opereert, de prognoses van die sector of branche, de toekomstige verplichtingen van de vennootschap en de plannen van de vennootschap. ${ }^{123}$

De overweging van de OK in de Jeezet/Synpact-beschikking is gebaseerd op een aantal arresten over winstreservering. Ik noem de belangrijkste.

Uit het Van Rees/Smits-arrest, ${ }^{124}$ waarbij sprake was van een familievennootschap, volgt dat het besluit van de algemene vergadering de restantwinst zodanig te verdelen, dat de minderheidsaandeelhouders, die voor het genieten van winst uit de resultaten van de vennootschap uitsluitend op het uit te keren dividend zijn aangewezen, zelfs niet een redelijke rente verkregen voor het door hen geïnvesteerde kapitaal, alle omstandigheden in aanmerking nemende in redelijkheid niet genomen had kunnen

120 Hof Amsterdam (OK) 6 juni 2011, LJN BQ9757, JOR 2011, 282, m.nt. Blanco Fernández (Jeezet/ Synpact), r.o. 3.10.

121 In gelijke zin: Bier 2003, p. 71.

122 Koelemeijer 1999, p. 170

123 Koelemeijer 1999, p. 171; Bier 2003, p. 72 en Bier 2012 (2), p. 195

124 Hof 's-Gravenhage 1 oktober 1982, NJ 1983, 393 (Van Rees/Smits). 
worden. Daarbij speelde een rol dat de directeur-meerderheidsaandeelhouder door het bestreden besluit zijn tantième (relatief) zag stijgen.

Uit het Sluis-arrest ${ }^{125}$ volgt dat van gegronde redenen om aan een juist beleid te twijfelen in de zin van art. 2:350 lid $1 \mathrm{BW}$ onder omstandigheden niet alleen sprake kan zijn indien (i) de vennootschap gedurende een aantal jaren, zonder dat het belang van de vennootschap zulks rechtvaardigt, geen of een in verhouding tot de winst slechts gering dividend uitkeert, (ii) de vennootschap op grond van een statutaire bepaling gedurende een reeks van jaren de door haar gemaakte winsten niet of slechts in geringe mate bij wege van dividend aan de aandeelhouders uitkeert zonder dat zulks (nog langer) door het vennootschappelijke belang gerechtvaardigd wordt, en (iii) de vennootschap niet aan wijziging van die statutaire bepaling wenst mede te werken. Ook in de Kerstens-beschikking werd geoordeeld dat het onnodig structureel reserveren van winst een gegronde reden kan vormen om aan een juist beleid te twijfelen. ${ }^{126}$

Het Hof Arnhem volgde in het Uniwest-arrest ${ }^{127}$ de lijn die de Hoge Raad in het Sluis-arrest heeft uitgezet. In het Uniwest-arrest werd een besluit tot het reserveren van de winst vernietigd en werd de vennootschap veroordeeld tot het betalen van dividend. ${ }^{128}$ In de casus van het arrest frustreerde een meerderheidsaandeelhouder een besluit tot uitkering van de winst. De winst werd over een tweetal jaren geheel

125 HR 9 juli 1990, LJN AC0960, NJ 1991, 51, m.nt. Ma (Sluis). Maeijer vraagt zich in sub 4 van zijn noot onder dit arrest af of het enquêterecht de aangewezen weg is om op te komen tegen het in strijd met de redelijkheid en billijkheid blokkeren van een besluit tot statutenwijziging door een groep aandeelhouders. Het gaat immers om gedrag van aandeelhouders. Niet om (wan)beleid van de vennootschap, aldus Maeijer. Anders, zo meen ik te mogen opmaken: Van den Ingh 2000, p. 206. IJsselmuiden 1990, p. 316, is van mening dat het enquêterecht niet de juiste voorzieningen biedt om de beknelde aandeelhouder tegemoet te kunnen komen en een redelijk dividendbeleid te bereiken. Zie ook Slagter 1991, p. 161 en IJsselmuiden 1995, p. 52. Volgens IJsselmuiden is de enige oplossing de gedwongen uittreding in de zin van art. 2:343 BW. Anders: Bier 2003, p. 71-76, acht het enquêterecht juist een goed middel om tot een beter, toekomstig dividendbeleid te komen, ook voor de minderheidsaandeelhouder.

126 Hof Amsterdam (OK) 15 september 1994, NJ 1995, 540 (Kerstens). Zie voor het vervolg Hof Amsterdam (OK) 9 mei 1996, JOR 1996, 57.

127 Hof Arnhem 26 mei 1992, NJ 1993, 182 m.nt. Ma (Uniwest). Vgl. Hof 's-Gravenhage 1 oktober 1982, NJ 1983, 393 (Van Rees/Smits). Zie voor de uitspraak in eerste aanleg: Rb. Zutphen 17 januari 1991: Winter 1991 en Slagter 1991.

128 r.o. 13. De veroordeling tot betaalbaarstelling is door Maeijer in zijn noot onder het arrest instemmend begroet. In gelijke zin bijvoorbeeld: HR 21 mei 1943, NJ 1943, 484 (Baus/De Koedoe I); Slagter 1991, p. 162; Th.S. IJsselmuiden, TVVS 1995, 7, p. 196 (sub 2) en Van den Ingh 2000, p. 213, die echter opmerkt dat een dergelijke veroordeling niet executeerbaar is. Anders: Winter 1991, p. 248; Koelemeijer 1999, p. 190-191 en Bier 2003, p. 76-77. Koelemeijer ziet een rol weggelegd voor de rechter, meer in het bijzonder de $\mathrm{OK}$, die als deskundige instantie de bevoegdheid heeft om over de uitkering van winst te besluiten (enigszins anders geformuleerd op p. 192).

Op vorige, reeds vaststaande besluiten, als gevolg van het niet tijdig aanvechten daarvan, tot reservering kan niet worden teruggekomen, zie r.o. 10 van het hof. Men dient dus tijdig ex art. 2:15 lid 5 BW tegen een dergelijk besluit op te komen. In gelijke zin: Bier 2003, p. 71 en Bos 2005, p. 145, voetnoot 74. 
gereserveerd. De meerderheidsaandeelhouder was van mening dat zijn medeaandeelhouders, tevens ex-werknemers, concurrerende handelingen door middel van een nieuwe onderneming verrichtten. Het hof overwoog dat die handelingen zich niet afspeelden 'in de sfeer van de rechtspersoon als bedoeld in art. 2:8 BW' ${ }^{129}$ Daarnaast overwoog het hof dat indien de aan de concurrerende aandeelhouders verweten gedragingen tot financieel nadeel voor de vennootschap zouden hebben geleid, die aandeelhouders daarvan ook zelf nadeel zouden hebben ondervonden. Een dergelijk nadeel kan slechts worden opgelost via een vordering tot schadevergoeding en niet door vaststelling van een lager dividend dan waarop aandeelhouders in redelijkheid aanspraak kunnen maken, aldus het hof. ${ }^{130}$

In de Sirvana/EMBA-beschikking ${ }^{131}$ overwoog de OK: "De vraag of het belang van Sirvana bij uitkering van dividend voldoende is meegewogen, moet worden beantwoord aan de hand van de omstandigheden van het geval, waarbij met name zal moeten worden afgewogen of EMBA in redelijkheid heeft kunnen oordelen dat het passeren van het dividend over de boekjaren 1997 tot en met 2002 noodzakelijk was in het belang van de bedrijfsvoering van haar desbetreffende dochtervennootschappen onderscheidenlijk teneinde de balansverhoudingen (liquiditeit en solvabiliteit) van haarzelf of die desbetreffende dochtervennootschappen op een aanvaardbaar peil te brengen of te houden. Het gedurende een onbepaalde tijd handhaven van een reserveringsbeleid zal in het algemeen niet gerechtvaardigd zijn."

Uit de laatste volzin van deze overweging volgt dat het voor onbepaalde tijd handhaven van een reserveringsbeleid niet zonder meer ongerechtvaardigd is. Dat blijkt ook uit de uitspraak van de OK van 2 november 1995 inzake Van Uden's Scheepvaart- en Agentuurmaatschappij. ${ }^{132}$ In deze uitspraak was sprake van een excessieve winst over een boekjaar. Van Uden keerde jaarlijks vijftien procent dividend uit. Ondanks de extra winst vond er geen verhoging van het dividend plaats. Volgens de OK was er vanwege het vennootschappelijk belang geen grond om aan de juistheid van het beleid te twijfelen. Dat belang zag er volgens Van Uden in haar wens een buffer aan liquide middelen aan te houden. Een dergelijke buffer hield de vennootschap door de jaren heen aan. Daarnaast was sprake van een herstructurering, zodat er geen ruimte was voor een aanzienlijke uitkering aan de

129 r.o. 3. Slagter 1991, p. 161, r.k., toont zich kritisch over de overweging. Zie ook HR 19 oktober 1990, NJ 1991, 21, m.nt. Ma (Akkoca).

130 r.o. 4.

131 Hof Amsterdam (OK) 15 maart 2005, JOR 2005, 88 (Sirvana/EMBA), r.o. 3.23. Het tegen deze beschikking gerichte cassatieberoep werd op grond van art. 81 RO verworpen, zie HR 1 september 2006, JOR 2006, 262 (Sirvana/EMBA).

132 Hof Amsterdam 2 november 1995, TVVS 1996, 4, p. 117-119, m.nt. IJsselmuiden, JOR 1996 nulnummer, rekestnr. 377/95, p. 16 e.v. (Van Uden's Scheepvaart- en Agentuurmaatschappij). IJsselmuiden is in sub 3.3 van zijn noot onder het arrest kritisch ten aanzien van het vermeende vennootschappelijke belang wegens belangenverstrengeling. 
aandeelhouders. De liquide middelen waren voorts nodig voor de noodzakelijke investeringen.

Het al dan niet uitkeren van dividend speelt niet alleen in de relatie tussen meerderheidsaandeelhouders en minderheidsaandeelhouders. Ook in de relatie tussen houders van verschillende soorten aandelen kan dit thema zich voor doen. Zo overwoog de rechtbank Leeuwarden op 25 augustus 2010 onder verwijzing naar het Sluis-arrest en het Uniwest-arrest in haar vonnis: "Naar het oordeel van de rechtbank is het door de algemene vergadering van aandeelhouders van ABS genomen besluit om ter zake van het jaar 2007 wél dividend uit te keren aan de cumulatief preferente aandeelhouder - tevens zijnde de bestuurder van ABS-maar niet aan de gewone aandeelhouders (waaronder Gjaltema) in strijd met de redelijkheid en billijkheid die door artikel 2:8 BW wordt geëist, en heeft Gjaltema terecht de nietigheid van dit besluit ingeroepen op grond van artikel 2:15 lid 1 onder $b$ BW. ABS heeft onvoldoende onderbouwd gesteld dat het uitkeren van dividend aan de gewone aandeelhouders op grond van de financiële positie van ABS, haar bedrijfsresultaten en vooruitzichten niet gerechtvaardigd was."

Ook de Poststate Beheer-beschikking ${ }^{134}$ sluit aan bij de hiervoor genoemde rechtspraak. Het zijn van een familievennootschap was in deze beschikking een extra element. Vier broers en zussen hielden allen aandelen in Poststate Beheer. Een broer hield een meerderheidsbelang van zeventig procent en was enig bestuurder van de vennootschap. Er was geruime tijd geen dividend uitgekeerd, voor welk reserveringsbeleid geen goede bedrijfseconomische grond bestond. Het besluit tot winstreservering was niet deugdelijk aan de minderheidsaandeelhouders toegelicht of gemotiveerd. Evenmin voldeed de vennootschap aan een rechtmatig verzoek tot het verstrekken van informatie van een van de minderheidsaandeelhouders. De OK concludeerde dat er gegronde redenen zijn om te twijfelen aan een juist beleid en gelastte een onderzoek.

Tot slot noem ik het VEB/KLM-Air France-arrest. ${ }^{135}$ In de statuten is aan de vergadering van houders van prioriteitsaandelen het recht toegekend eerst een bedrag van de winst te reserveren. ${ }^{136}$ Aldus geschiedde: 90,7 procent van in de vastgestelde jaarrekening vastgestelde winst werd door de prioriteit bij besluit gereserveerd. De minderheidsaandeelhouders kwamen tegen dit besluit op. Zij vonden dat een hoger dividend moest worden uitgekeerd en dat er in redelijkheid geen verdedigbare argumenten waren voor het besluit van de prioriteit. Het hof Amsterdam overwoog: "Het hof neemt tot uitgangspunt dat, overeenkomstig de statuten van KLM, haar vergadering van houders van prioriteitsaandelen, bij het nemen van het in dit geding bestreden besluit tot reservering, een afweging diende

$133 L J N$ BN5188, r.o. 4.9.

134 Hof Amsterdam (OK) 29 juni 2010, ARO 2010, 104 (Poststate Beheer).

135 Hof Amsterdam 15 november 2011, JOR 2012, 6, m.nt. Vroom (VEB/KLM-Air France), vervolg op Rb. Amsterdam 1 september 2010, LJN BN5569, JOR 2010, 303, m.nt. Kuster. Zie over het vonnis van de rechtbank bijvoorbeeld Bier 2011, p. 28 e.v.

136 Vgl. art. 2:216 lid 1 BW. 
te maken, met inachtneming van alle, haar destijds bekende, feiten en omstandigheden, tussen alle met haar besluit gemoeide (en voor haar kenbare) belangen van de vennootschap, van de daaraan verbonden onderneming en van belanghebbenden, waaronder het belang van de minderheidsaandeelhouders bij een redelijk dividend. Daarbij moet de vergadering van houders van prioriteitsaandelen en haar algemene vergadering van aandeelhouders een ruime mate van beoordelingsvrijheid worden toegekend. Dit brengt mee dat het besluit tot reservering van de winst en, als gevolg daarvan, de vaststelling van het dividend, niet met een beroep op de eisen van redelijkheid en billijkheid kan worden aangetast op de enkele grond dat over de juistheid van het besluit in gemoede verschillend kan worden gedacht, of met het betoog dat in enig opzicht beter te verantwoorden en wellicht voor de minderheidsaandeelhouders wenselijker alternatieven voorhanden waren. Het besluitvormingsproces over dit soort aangelegenheden zou anders kunnen verzanden in langdurige discussies tussen de (organen van) de vennootschap en haar aandeelhouders (en door hen in de arm genomen deskundigen), nu in die besluitvorming vele aspecten van financiële appreciatie een rol kunnen spelen en uiteenlopende opvattingen denkbaar zijn betreffende de te volgen koers van de onderneming, de vooruitzichten en de te nemen risico's. De belangen van de vennootschap, de daaraan verbonden onderneming en belanghebbenden in het algemeen zouden slecht gediend zijn met zulke discussies tussen bepaalde "stakeholders" en (de organen van) de vennootschap."137

Het eerste deel van deze overweging sluit aan bij de lijn van de hiervoor besproken uitspraken. Het tweede deel van de overweging ziet op de vraag in hoeverre een besluit tot winstreservering moet worden gemotiveerd. Dat een dergelijk besluit moet worden gemotiveerd, spreekt mijns inziens voor zich en volgt reeds uit de literatuur ${ }^{138}$ en de genoemde Jeezet/Synpact-beschikking. De motivering maakt het mogelijk het besluit en de overwegingen om tot dat besluit te komen te toetsen, althans daarin inzicht te verkrijgen. Indien dat inzicht door de algemene vergadering niet is gegeven, kan de minderheidsaandeelhouder betogen dat er kennelijk bij het nemen van het bestreden besluit zijn gerechtvaardigde belangen niet zijn betrokken. Bier stelt zelfs dat een ongemotiveerd besluit al reden genoeg moet zijn het besluit te vernietigen. ${ }^{139}$ Indien dat inzicht wel gegeven is, kan de vennootschap betogen dat in de besluitvorming die gerechtvaardigde belangen zijn betrokken, doch dat wegens het gemotiveerde, verdedigbare en gerechtvaardige vennootschappelijke belang de winst, al dan niet gedeeltelijk, is gereserveerd. ${ }^{140}$ Het VEB/KLM-Air France-arrest leert dat de

137 r.o. 3.26 .

138 Bier 2003, p. 81 .

139 Bier 2003, p. 81.

$140 \mathrm{Zie}$ voor een geval waarin zonder een deugdelijke motivering daartoe de winst jarenlang is gereserveerd en aan een minderheidsaandeelhouder geruime tijd geen informatie is verstrekt: $\mathrm{Rb}$. Rotterdam 28 maart 2012, LJN BW0672. 
motivering of redelijke onderbouwing in zeer beperkte zin wordt getoetst om uitvoerige discussies te voorkomen. ${ }^{141}$

Schönau stelt in haar commentaar op het arrest dat een zekere discussie bij het nemen van een besluit tot reservering onvermijdelijk is en dat het hof kennelijk bedoeld heeft te zeggen dat het niet in het belang van de vennootschap is dat de rechter in de beleidsvrijheid van het ter zake bevoegde orgaan treedt. ${ }^{142}$ Dat lijkt mij een juiste aanvulling op de hiervoor geciteerde overweging van het hof.

Koelemeijer gaat in haar commentaar nog verder. Zij stelt dat het hof lijkt te oordelen dat "de minderheidsaandeelhouder volledig wordt uitgesloten van het besluitvormingsproces en daarmee van de vraag of er wordt uitgekeerd, en zo ja, wat de hoogte daarvan zou moeten zijn." Daarnaast stelt zij dat het arrest niet in lijn is met de eerder genoemde rechtspraak, inhoudende dat de winst in beginsel aan de aandeelhouders moet worden uitgekeerd, tenzij het vennootschappelijk belang vereist dat tot gehele of gedeeltelijke reservering besloten moet worden. ${ }^{143}$ Dat laatste lijkt mij juist. Ik verwijs naar de hierna te formuleren regels met betrekking tot de besluitvorming rond winstreservering.

In haar noot onder het VEB/KLM-Air France-arrest merkt Bier ${ }^{144}$ terecht op dat procederen tijd kost en dat tegen de tijd dat een besluit tot reservering wordt vernietigd, al dan niet bij een in kracht van gewijsde gegane uitspraak, de omstandigheden zodanig veranderd kunnen zijn dat de vennootschap niet meer in de positie is uitkering te doen, althans dat die uitkering wegens het vennootschappelijk belang niet meer gerechtvaardigd is. Te denken valt aan economische omstandigheden, strategiewijziging, liquiditeitsbehoefte en dergelijke.

In het besproken Uniwest-arrest werd een besluit tot het reserveren van de winst vernietigd en werd de vennootschap veroordeeld tot het betalen van dividend. ${ }^{145}$ Deze situatie speelt vooral indien de stemrechtloze aandeelhouder van mening is dat teveel gereserveerd en te weinig winst uitgekeerd is. Mijns inziens past de rechter terughoudendheid bij een dergelijke veroordeling. Feitelijk zou eerst na vernietiging van het besluit tot reservering een nieuw besluit tot uitkering genomen moeten worden. ${ }^{146}$ Het gaat mij te ver dat dit nieuwe besluit zonder meer een besluit tot uitkering is. Er zal opnieuw op grond van art. 2:8 BW en het vennootschappelijk belang een belangenafweging moeten plaatsvinden. Ook zullen aandeelhouders en bestuurders, gelet op de uitkeringstest van art. 2:216 lid 2 BW en eventuele aansprakelijkheid van bestuurders en aandeelhouders op grond van art. 2:216 lid $3 \mathrm{BW}$, mijns inziens niet lichtvaardig tot een nieuw besluit tot uitkering en

141 In gelijke zin Vroom in zijn JOR-noot onder het arrest. Hij stelt dat 'die motivering slechts (uiterst) marginaal wordt getoetst.'

142 Schönau 2012, p. 19.

143 Koelemeijer 2012, p. 42.

144 Bier 2012 (1), p. 92

$145 \mathrm{Vgl}$. art. 3:300 BW.

146 In gelijke zin: Van den Ingh 2000, p. 213. 
goedkeuringsbesluit van het besluit tot uitkering kunnen of moeten komen. Dat maakt de positie van de aandeelhouders, waaronder de stemrechtloze aandeelhouder, die met succes tegen het besluit tot reservering opgekomen zijn niet benijdenswaardig. ${ }^{147}$ Op grond van de nieuwe, gewijzigde omstandigheden kan immers wederom tot een besluit tot (gedeeltelijke) reservering gekomen worden. Steun voor mijn opvatting vind ik in de parlementaire geschiedenis: "De gecombineerde commissie heeft aandacht gevraagd voor het tijdstip waarop het bestuur de in het voorgestelde artikel 216 bedoelde goedkeuring van een uitkering moet verlenen. Omdat de uitkeringstest een beoordeling inhoudt van de financiële positie van de vennootschap ten tijde van de uitkering, is het van belang dat het bestuur de goedkeuring zo dicht mogelijk voor de datum van de daadwerkelijke uitkering verleent. Is er enige tijd verstreken tussen het besluit van de algemene vergadering tot vaststelling van de uitkering en de daadwerkelijke uitkering, dan zal het bestuur bij gewijzigde financiële omstandigheden die in de weg staan aan een uitkering de goedkeuring moeten weigeren en dus niet overgaan tot uitkering van de bedragen. Het besluit van de algemene vergadering heeft dan door het ontbreken van de goedkeuring van het bestuur geen gevolgen." Hoewel het citaat niet ziet op de situatie dat sprake is van een rechterlijke vernietiging en veroordeling tot betaling van dividend, makkt deze overweging in de parlementaire geschiedenis wel duidelijk dat indien enige tijd verstreken is tussen het besluit tot uitkering van de algemene vergadering en de daadwerkelijke uitkering het bestuur in het kader van de goedkeuring van het uitkeringsbesluit opnieuw naar de financiële omstandigheden van de vennootschap moet kijken.

Ook om een andere reden past de rechter mijns inziens terughoudendheid. Die reden ligt in het verlengde van het hiervoor gestelde, namelijk dat de rechter te veel op de stoel van het bestuur gaat zitten, ${ }^{148}$ juist gelet op de reeds genoemde uitkeringstest van art. 2:216 lid 2 BW. Dit klemt te meer, indien in afwijking van de hoofdregel van art. 2:216 lid $1 \mathrm{BW}$ de statuten de bevoegdheid tot bestemming van de winst en tot vaststelling van uitkeringen aan het bestuur hebben toegekend. Los van deze afwijking van de hoofdregel zal de rechter allereerst op aandeelhoudersniveau een besluit moeten nemen in welke mate de winst al dan niet gereserveerd of uitgekeerd zal worden (en in de regel een hogere uitkering, omdat de stemrechtloze aandeelhouder ageert tegen het feit dat hij niets of te weinig winst heeft uitgekeerd gekregen). De tweede stap die de rechter zal moeten nemen, is op bestuursniveau, te weten de uitkeringstest van art. 2:216 lid $2 \mathrm{BW}$. De rechter zal in de regel niet beschikken over de gegevens en informatie teneinde te beoordelen of de vennootschap na de uitkering niet zal kunnen blijven voortgaan met het betalen van haar opeisbare schulden, althans of dat redelijkerwijs te voorzien is. Ook al beschikt de rechter wel over de gegevens en informatie teneinde de toets van dat criterium te doen, wat is dan de situatie indien de vennootschap vervolgens op grond

147 In gelijke zin: Bier 2012 (1), p. 93.

148 Vgl. Bier 2012 (2), p. 201. 
van de rechtelijke uitspraak over gaat tot betaalbaarstelling van de uitkering en de vennootschap na deze uitkering binnen een jaar alsnog niet kan voortgaan met het betalen van haar opeisbare schulden? Zijn de bestuurders in dat geval op grond van art. 2:216 lid 3 BW hoofdelijk verbonden voor het tekort dat door de uitkering is ontstaan? Geldt een gelijke aansprakelijkheid, eveneens op grond van art. 2:216 lid 3 BW, in dit geval ook voor degene die de uitkering ontving? Een ander, meer praktisch, punt is dat de rechter op het moment van het doen van zijn uitspraak in de regel niet over de meest actuele gegevens en informatie van de vennootschap zal beschikken. Er kan in de tussentijd sprake zijn van een gewijzigde financiële situatie of (andere) omstandigheden met betrekking tot de vennootschap en de door haar gedreven onderneming.

Uit het voorgaande volgt mijns inziens dat de rechter er goed aan doet in zijn uitspraak geen besluit tot uitkering op te nemen, maar - afhankelijk van de statuten van de vennootschap - de algemene vergadering of het bestuur op draagt een nieuw besluit te nemen. ${ }^{149}$ Zoals gesteld, zal mijn inziens opnieuw op grond van art. 2:8 BW en het vennootschappelijk belang een belangenafweging moeten plaatsvinden, hetgeen niet per definitie tot een besluit tot uitkering of een hogere uitkering zal (kunnen) leiden. Daarnaast zal de uitkeringstest van art. 2:216 lid 2 BW in acht genomen moeten worden.

Concluderend: Bier heeft in haar noot onder het VEB/KLM-Air France-arrest de regels ten aanzien van de besluitvorming rond winstreservering fraai samengevat. ${ }^{150}$ Vertaald naar de flex-BV en de stemrechtloze aandeelhouder zouden, met dank aan Bier, die regels als volgt kunnen luiden:

1. Krachtens de hoofdregel van art. 2:216 lid $1 \mathrm{BW}$ is de algemene vergadering bevoegd tot bestemming van de winst die door de vaststelling van de jaarrekening is bepaald en tot vaststelling van uitkeringen, voor zover het eigen vermogen groter is dan de reserves die krachtens de wet of de statuten moeten worden aangehouden;

2. De algemene vergadering moet bij het nemen van het besluit tot winstbestemming, te weten (gehele of gedeeltelijke) reservering of (gehele of gedeeltelijke) uitkering, de redelijkheid en billijkheid in acht nemen;

3. In beginsel dient de winst aan (de stemrechtloze) aandeelhouder te worden uitgekeerd, tenzij het vennootschappelijk belang vereist dat de winst geheel of gedeeltelijk wordt gereserveerd. De norm van art. 2:8 BW brengt mee, dat

149 Bier 2012 (2), p. 201, stelt dat de rechter het bestuur kan opdragen een gemotiveerd voorstel omtrent een (nieuw) besluit tot uitkering te doen, welk voorstel goedkeuring van de rechter behoeft en na goedkeuring in de plaats treedt van het eerder vernietigde besluit. Mijn bezwaar daartegen is dat ook in dat geval de rechter te veel op de stoel van de aandeelhouders en het bestuur zit en dat daarmee het aansprakelijkheidsrisico van art. 2:216 lid 3 BW niet weggenomen wordt. Een tot betaling van het tekort dat door de uitkering aangesproken bestuurder kan mijns inziens niet stellen dat hem vanwege de goedkeuring van de rechter geen blaam treft.

150 Zie Bier 2012 (1), p. 91. 
meerderheidsaandeelhouders/aandeelhouders met stemrecht/bestuurders rekening moeten houden met de belangen van de stemrechtloze aandeelhouder. Tot deze belangen dient te worden gerekend het belang dat de stemrechtloze aandeelhouder heeft om een redelijke vergoeding (in de vorm van dividend) te ontvangen voor zijn financiële betrokkenheid bij de vennootschap. Het belang van een stemrechtloze aandeelhouder bij uitkering van dividend moet zorgvuldig worden afgewogen tegen het belang van de vennootschap en de wens van de andere aandeelhouder(s) (met stemrecht) om de winst (geheel of gedeeltelijk) aan de reserves toe te voegen;

4. Het gedurende onbepaalde tijd handhaven van een reserveringsbeleid waarbij alle of een groot deel van de winst wordt gereserveerd zonder dat het belang van de vennootschap dit rechtvaardigt, kan ten opzichte van de stemrechtloze aandeelhouder in strijd zijn met art. 2:8 BW;

5. Afhankelijk van de omstandigheden hoeft het niet onredelijk te zijn dat aan bepaalde motieven voor winstreservering, zoals het belang van de bedrijfsvoering teneinde de balansverhoudingen (liquiditeit en solvabiliteit) op een aanvaardbaar peil te brengen of te houden, een groter gewicht wordt toegekend aan het belang van de vennootschap dan aan het belang en de wens van de stemrechtloze aandeelhouder bij dividenduitkeringen;

6. De motieven om tot reservering van winst over te gaan moeten uitdrukkelijk en gemotiveerd aan de stemrechtloze aandeelhouder kenbaar worden gemaakt.

Ik zou deze regels tevens willen volgen voor de andere kapitaalverschaffers zonder stemrecht die tot de kring van betrokkenen behoren, voor zover de aard van de rechtsfiguur zich daartegen niet verzet.

\subsubsection{Besluiten omtrent de bezoldiging van bestuurders en commissarissen}

Uit art. 2:245 BW volgt dat de bezoldiging van de bestuurders van de vennootschap wordt vastgesteld door de algemene vergadering, tenzij de statuten anders bepalen. Voor de bezoldiging van commissarissen geldt dezelfde hoofdregel (art. 2:255 BW). Een statutaire afwijking is echter uitgesloten. Onder de bezoldiging kan zowel een vaste als een variabele beloning vallen. Het spreekt voor zich dat de hoogte van de bezoldiging van invloed is op de hoogte van de winst van de vennootschap. De bezoldiging wordt immers op de winst- en verliesrekening van de vennootschap als kostenpost opgenomen. De kapitaalverschaffer zonder stemrecht kan vanwege het ontbreken van het stemrecht aan zijn rechtsfiguur geen beslissende invloed op de besluitvorming over het bepaalde in art. 2:245 en/of 2:255 BW uitoefenen.

Voor dit thema is een aantal arresten van belang. In de arresten Baus/De Koedoe I en Baus/De Koedoe II $^{151}$ stelde een winstgerechtigde commissaris de winstuitkeringen

151 HR 21 mei 1943, NJ 1943, 484 (Baus/De Koedoe I) en HR 31 januari 1947, NJ 1948, 115 (Baus/De Koedoe II). 
aan de bestuurder van de vennootschap aan de orde. In het Baus/De Koedoe I-arrest overwoog de Hoge Raad dat een winstgerechtigde van de vennootschap gebonden is aan de vaststelling van de winst door de algemene vergadering, tenzij deze vaststelling, die deel uitmaakt van de uitvoering van de overeenkomst met de winstgerechtigde, is geschied in strijd met de goede trouw. Het is in strijd met de goede trouw indien de vennootschap bij die vaststelling een gedragslijn heeft gevolgd, die onder de gegeven omstandigheden geen redelijk handelende vennootschap ten opzichte van haar winstgerechtigde kan volgen. Wanneer daarvan sprake is, kan de winstgerechtigde de nietigheid van de winstvaststelling vorderen. Indien die nietigheid door de rechter is aanvaard, behoeft de vennootschap niet opnieuw de winst vast te stellen, maar vordert de redelijkheid in het algemeen dat de rechter kan bepalen in hoeverre de vastgestelde winst ten opzichte van de desbetreffende winstgerechtigde verandering behoort te ondergaan, aldus de Hoge Raad. Uit het Baus/De Koedoe II-arrest volgt dat in dit kader slechts sprake is van een marginale toetsing door de rechter.

In het Schuurmans/Amsterdamse Ballast Maatschappij-arrest ${ }^{152}$ overwoog de Hoge Raad dat bij de beantwoording van de vraag, of de winstvaststelling in strijd was met de tegenover de tantièmist in acht te nemen goede trouw, mede in aanmerking genomen mag worden de omstandigheid dat de bestuurder zelf, omdat hij de gevolgde reserveringspolitiek in het belang van het bedrijf oordeelde, als directeur daarmede heeft ingestemd.

Een mooi voorbeeld uit meer recente rechtspraak vormt de beschikking van de OK inzake Mojo Works/Mojo Theater, ${ }^{153}$ meer in het bijzonder r.o. 3.5: "Mojo Theater heeft gesteld dat Visser zichzelf weliswaar zonder besluit van de algemene vergadering van aandeelhouders een salarisverhoging heeft toegekend, maar dat deze verhoging marktconform is en dat de ava die salarisverhoging op 30 september 2011 met terugwerkende kracht heeft goedgekeurd. Naar het oordeel van de Ondernemingskamer heeft Mojo Theater met dit standpunt het bezwaar van Mojo Works niet ondervangen. Vooropgesteld moet worden, dat het Visser niet vrij stond zonder besluit van de algemene vergadering van aandeelhouders zijn salaris te verhogen. Door dit toch te doen heeft hij gehandeld in strijd met het voorschrift van artikel 12 lid 6 en van artikel 14 lid 3 van de statuten. Met de stelling van Mojo Theater dat het besluit tot salarisverhoging toch altijd genomen zou zijn omdat Visser als (indirect) meerderheidsaandeelhouder een doorslaggevende stem heeft, stelt zij in feite dat degë̈nformeerde - opvatting van de minderheidsaandeelhouder voor de meerderheidsaandeelhouder niet relevant is en miskent zij het belang van zorgvuldige besluitvorming op basis van informatie aan en gedachtewisseling door de vergadering. Deze miskenning is des te ernstiger omdat de belangen van Visser als bestuurder niet parallel met die van de vennootschap liepen. Voorts valt mede in het licht van de tegenvallende resultaten van Mojo Theater in 2009 (te weten een netto verlies van $€$ 538.899,76) een salarisverhoging van $€ 92.399,80$ ten opzichte van het salaris dat Visser in 2008

152 HR 9 januari 1953, NJ 1953, 460 (Schuurmans/Amsterdamse Ballast Maatschappij). 153 Hof Amsterdam (OK) 20 februari 2012, LJN BV7334 (Mojo Works/Mojo Theater). 
verdiende - zonder nadere toelichting die ontbreekt - niet goed te rechtvaardigen. Dit klemt te meer nu Visser tijdens de algemene vergadering van aandeelhouders op 30 september 2011 zijn standpunt dat de salarisverhoging marktconform zou zijn niet heeft toegelicht. Ook in deze procedure heeft Colour of the Dreams verzuimd dit aan de hand van concrete gegevens toe te lichten. De Ondernemingskamer overweegt tot slot dat, ondanks de hierboven onder 2.9 aangehaalde mededeling van Visser bij e-mail van 19 mei 2010, de salarisverhoging in 2009 en 2010 volledig is uitbetaald."

Uit de rechtspraak volgt dat de algemene vergadering bij het vaststellen van de bezoldiging van bestuurders en commissarissen jegens winstgerechtigden de vennootschappelijke redelijkheid en billijkheid in acht moet nemen. Ik meen dat in de gestelde regel 'winstgerechtigden' als kapitaalverschaffers zonder stemrecht gelezen kan worden. Gelijk als in de casus van de genoemde arresten, hebben zij geen stemrecht, zodat zij tijdens de algemene vergadering niet tegen een voorgenomen, nadelig besluit kunnen opkomen. In de genoemde arresten was sprake van een contractuele gerechtigdheid tot de winst. De houder van een participatiebewijs is contractueel gerechtigd tot de winst. De stemrechtloze aandeelhouder, de houder van een certificaat met vergaderrecht en de houder van een aandeel waarbij het stemrecht is overgedragen aan de vruchtgebruiker of pandhouder staan in een lidmaatschapsverhouding tot de vennootschap. Het verschil tussen de contractuele verhouding of de lidmaatschapverhouding lijkt mij echter niet essentieel. In paragraaf 7.4.2 heb ik betoogd alle kapitaalverschaffers zonder stemrecht, behalve de houder van een certificaat zonder vergaderrecht, tot de kring van betrokkenen in de zin van art. 2:8 BW behoren. Voor hen geldt dus dat de algemene vergadering bij het vaststellen van de bezoldiging van bestuurders en commissarissen de vennootschappelijke redelijkheid en billijkheid in acht moet nemen. Op de bescherming van de certificaathouder zonder vergaderrecht kom ik in hoofdstuk 8 terug.

\subsubsection{Overige besluiten die de rechten op winst en/of de reserves aantasten}

Niet alleen een besluit over winstreservering of een besluit over de bezoldiging van een bestuurder of commissaris kan invloed hebben op de hoogte van de financiële aanspraken van de kapitaalverschaffer zonder stemrecht. Tal van andere besluiten van de algemene vergadering of het bestuur kunnen dat ook hebben. In het algemeen wordt de stemrechtloze aandeelhouder beschermd door het bepaalde in art. 2:216 lid 8 en art. 2:231 lid 4 BW. Ik verwijs naar paragraaf 6.2.3.7. Ik verwijs voorts naar het in paragraaf 6.2.3.6 gegeven overzicht van beschermingregels voor de stemrechtloze aandeelhouder in meer bijzondere situaties.

Voor de overige kapitaalverschaffers zonder stemrecht, de aandeelhouder wiens stemrecht is overgedragen aan de vruchtgebruiker of pandhouder en de certificaathouder met of zonder vergaderrecht, gelden de beschermingsregels van de stemrechtloze aandeelhouder niet. Zij zullen het in de regel moeten doen met de 
kapstokbescherming van art. 2:8 jo. 2:15 BW. Voor de houder van een participatiebewijs geldt nog de bescherming van art. 2:232 BW.

In de rechtspraak zijn voorbeelden te vinden van besluiten die de rechten op winst van kapitaalverschaffers zonder stemrecht aantasten. In het Unipart/RDM-arrest ${ }^{154}$ ging het om het beleid van het bestuur van zelffinanciering, waarbij een onderscheid tussen oneigenlijke en eigenlijke reserveringen werd gemaakt. Daardoor werd de winst verlaagd en de rechten van winstbewijshouders geraakt. De grens tussen oneigenlijke en eigenlijke reserveringen was echter niet altijd even scherp te trekken. De besluitvorming daarover werd overgelaten aan de directie. Uit het arrest volgt dat de directie daarbij de vennootschappelijke redelijkheid en billijkheid jegens de houders van oprichtersbewijzen in acht moet nemen. Het besluit van de directie kon wegens de financiële staat van RDM na de Tweede Wereldoorlog en het vennootschappelijke belang echter de toets der kritiek doorstaan.

In het RCMA-arrest ${ }^{155}$ ging het om een besluit van bestuurders en commissarissen van een NV tot uitgifte van bonusaandelen in het kader van herkapitalisatie. De statuten van de NV verzetten zich niet tegen een dergelijk besluit. Als gevolg daarvan werd in de verhouding waarin de aandeelhouders en houders van winstbewijzen in de winst en het liquidatiesaldo van de NV deelden ten nadele van de houders van winstbewijzen gewijzigd. De Hoge Raad overwoog dat dit niet uitsluit dat de NV, door het achterwege laten van maatregelen welke de invloed van het besluit op de positie van de houders van de winstbewijzen konden opheffen, tegenover die houders wanprestatie kan hebben gepleegd. Uit het enkele feit dat die invloed ongunstig was, vloeit niet zonder meer de verplichting tot het treffen van dergelijke maatregelen. De vraag of een uitvoering van de overeenkomst tussen de vennootschap en de houders van winstbewijzen naar redelijkheid en billijkheid meebrengt dat de daartoe bevoegde vennootschapsorganen maatregelen moeten treffen teneinde voor de houders van de winstbewijzen de vóór de herkapitalisatie bestaande toestand te herstellen, zal afhankelijk zijn van de in elk bijzonder geval bestaande omstandigheden, zoals de voor de verhouding tussen aandeelhouders en houders van winstbewijzen met betrekking tot hun aandelen in winst en liquidatiesaldo oorspronkelijk gekozen opzet, de ontwikkeling van die verhouding en de herkomst van de reserves, waardoor de bij de herkapitalisatie uitgegeven bonusaandelen zijn gedekt, aldus de Hoge Raad. Uit het arrest volgt dat de stelplicht en bewijslast van de genoemde omstandigheden op de houders van de winstbewijzen rust.

Een ander voorbeeld is de Lenda/Muntal-beschikking. ${ }^{156}$ Het ging daarbij om een beheersvergoeding die onzakelijk hoog en ten laste van de vennootschap Muntal BV werd uitgekeerd. Die vergoeding deed volgens de OK onvoldoende recht aan

154 HR 27 januari 1956, NJ 1956, 48, (Unipart/RDM).

155 HR 11 januari 1963, NJ 1964, 433, m.nt. G.J. Scholten (RCMA). Zie ook Hof Amsterdam (OK) 3 maart 1999, JOR 1999, 87 (Gucci), r.o. 3.3 en Hof Amsterdam (OK) 11 maart 1999, NJ 1999, 351, JOR 1999, 89, m.nt. Brink (Breevast), r.o. 4.16.

156 Hof Amsterdam (OK) 30 maart 2011, LJN BQ1776, JOR 2011, 217 (Lenda/Muntal), r.o. 3.3. 
het vennootschappelijk belang en het belang van de minderheidscertificaathouder. Daarnaast was Muntal BV ernstig tekortgeschoten in haar informatieverplichtingen, was sprake van het risico van benadeling van de vennootschap en de minderheidscertificaathouder. De OK concludeerde tot wanbeleid. Bijzonder aan deze beschikking is de volgende overweging van de OK: "(...) De beheersvergoeding, zoals deze in de jaarrekeningen van de vennootschap tot uitdrukking is gekomen, heeft fiscaal en commercieel gevolgen gehad in de verhouding tot derden. Het belang van de vennootschap dat hierop niet - althans niet reeds nu - wordt teruggekomen, weegt zwaarder dan het belang van verzoeker om daarop betrekking hebbende besluiten te vernietigen. Het belang van verzoeker kan naar het oordeel van de OK wél meebrengen dat bij een eventuele - op zichzelf wenselijk voorkomende - overdracht van diens certificaten voor doeleinden van vaststelling van een redelijke overnameprijs met enige terugwerkende kracht (te denken is aan een periode van omstreeks vijf jaar) wordt uitgegaan van een zakelijk verantwoorde beheersvergoeding (met inachtneming van het effect van de vennootschapsbelasting). (...)",157

Uit het voorgaande volgt dat, voor zover er geen specifieke beschermingsregel geldt, de kapitaalverschaffers zonder stemrecht, die tot de kring van betrokkenen behoren, ingeval van besluiten van de algemene vergadering of het bestuur die hun rechten op winst en/of reserves aantasten, bescherming kunnen ontlenen aan de vennootschappelijke redelijkheid en billijkheid.

\subsubsection{Verhouding tussen aandeelhouders onderling}

In het verlengde van de reeds besproken thema's ligt de verhouding tussen aandeelhouders onderling, meer in het bijzonder de relatie meerderheids- en minderheidsaandeelhouder. Enerzijds brengt de positie van de minderheidsaandeelhouder met zich mee dat hij hem onwelgevallige besluiten tegen zich moet laten gelden. Anderzijds mag de meerderheidsaandeelhouder zijn macht niet misbruiken. Strijdigheid met de vennootschappelijke redelijkheid en billijkheid, die de lidmaatschapsverhoudingen tussen aandeelhouders beheersen, ligt in dat geval op de loer. De meerderheidsaandeelhouder moet bij het uitbrengen van zijn stem ook rekening houden met de redelijke belangen van de minderheidsaandeelhouder. ${ }^{158}$ Het

157 r.o. 3.8 .

158 Zie bijvoorbeeld Hof Amsterdam (OK) 3 november 2000, JOR 2001, 3; Hof Amsterdam (OK) 30 november 2000, JOR 2001, 4, m.nt. Van den Ingh (Zwagerman); Hof Amsterdam (OK) 22 december 2000, JOR 2001, 32; Hof Amsterdam (OK) 18 januari 2001, JOR 2001, 34, m.nt. Brink (VIBA); Hof Amsterdam (OK) 23 januari 2001, JOR 2001, 56; Hof Amsterdam (OK) 4 juli 2001, JOR 2001, 149, m.nt. Brink (HBG) en HR 1 maart 2002, NJ 2002, 96, m.nt. Ma, JOR 2002, 79, m.nt. Van den Ingh (Zwagerman Beheer). De omgekeerde situatie kan zich ook voor doen, zie Pres. Rb. Amsterdam 20 december 2001, JOR 2002, 26 (Gorillapark), bekrachtigd door Hof Amsterdam (OK) 25 april 2002, JOR 2002, 128: de minderheidsaandeelhouder wordt bevolen zich te gedragen conform een niet $\rightarrow$ 
voorgaande gaat ook op voor de verhouding tussen aandeelhouders met en zonder stemrecht.

Uit het Wijsmuller-arrest ${ }^{159}$ volgt, kort gezegd, dat de besluitvorming door een meerhoofdig orgaan op basis van vruchtbaar onderling overleg moet geschieden. De aandeelhouders met en zonder stemrecht hebben jegens elkaar de verplichting tot onderling overleg. ${ }^{160}$ Voor dat doel beschikken zij immers over vergaderrecht.

Van den Ingh stelt dat naarmate de participatie van de aandeelhouder in de vennootschap groter is, die aandeelhouder eerder oog moet hebben voor de belangen van anderen. Aan die gekwalificeerde aandeelhouder worden hoge eisen gesteld. Hij zal overleg met zijn mede-aandeelhouders en de vennootschap moeten voeren. Daarnaast stelt Van den Ingh dat van de tegenstemmende, gekwalificeerde aandeelhouder mag worden verwacht dat hij met een tegenvoorstel komt. ${ }^{161}$

De aard van de samenwerking en het karakter van de vennootschap kan ook een factor van belang zijn. Zo overwoog de OK in de Cromwilld/Versatel- beschikking: ${ }^{162}$ “(...) dat juist het joint venture karakter van de samenwerking tussen de oorspronkelijke partijen meebrengt dat ook op Cromwilld de verplichting rust naar best vermogen het totstandbrengen van een gemeenschappelijk gedragen beleid te bevorderen, ook al wijken haar inzichten - al of niet op onderdelen - af van de andere partijen bij de joint venture, en staat het haar niet, althans niet zonder meer of steeds vrij in de eerste plaats haar eigen belangen voorop te stellen."

In de rechtspraak zijn vele voorbeelden te vinden over de verhouding meerderheids- en minderheidsaandeelhouder en machtstrijd. Ik noem er enkele. In 1942 overwoog de Hoge Raad al: "Behoudens hier niet ter zake doende beperkingen hebben aandeelhouders het recht vrijelijk te beslissen, wien zij als directeur wenschen te benoemen. Mocht door de meerderheid van aandeelhouders een persoon zijn benoemd, die ten eenenmale de geschiktheid mist om als directeur op te treden, dan kan eerst dan van misbruik van meerderheidsmacht, welke aan de minderheid het recht zou geven vanwege strijd met de goede trouw of met de openbare orde en goede zeden de nietigheid van het besluit in te roepen sprake zijn, indien deze benoeming zoude zijn geschied met den opzet, hetzij om zichzelf of een derde onbillijk te bevoordeelen, hetzij om de vennootschap of een derde te schaden." 163

door die minderheidsaandeelhouder aanvaarde wijziging in de aandeelhoudersovereenkomst. De minderheidsaandeelhouder handelt in strijd met de redelijkheid en billijkheid door een voor haar gunstiger regeling af te dwingen. Zie voor literatuur bijvoorbeeld Van den Ingh 2000, p. 203 e.v. en Huizink 2000, p. 280.

159 HR 15 juli 1968, NJ 1969, 101, m.nt. G.J. Scholten (Wijsmuller).

160 Zie over dit thema ook Schwarz 1995 (2), p. 201 e.v.

161 Van den Ingh 2000, p. 208 en Rb. Roermond 17 mei 1973, NJ 1974, 57.

162 Hof Amsterdam (OK) 20 mei 1999, NJ 2000, 199, JOR 2000, 72, m.nt. Blanco Fernández (Cromwilld/Versatel), r.o. 3.6.

163 HR 13 februari 1942, NJ 1942, 360 
Ook het eerder genoemde Mante-arrest ${ }^{164}$ kan in de verhouding meerderheidsen minderheidsaandeelhouder worden geplaatst. Het ging in dat arrest om de nietigheid van een besluit van de algemene vergadering tot statutenwijziging wegens strijd met de redelijkheid en billijkheid. De Hoge Raad overwoog dat ook indien voldaan is aan alle formele vereisten, bij wet of statuten voor de wijze van oproeping van een aandeelhoudersvergadering gesteld, de eisen van redelijkheid en billijkheid die aandeelhouders jegens elkander in acht hebben te nemen onder omstandigheden kunnen medebrengen dat een aandeelhoudersvergadering niet overgaat tot het nemen van een besluit aangaande een onderwerp waarbij de belangen van bepaalde aandeelhouders in bijzondere mate zijn betrokken alvorens te hebben nagegaan of die aandeelhouders genoegzaam in de gelegenheid zijn gesteld aan de besluitvorming over dit hen in het bijzonder rakende onderwerp deel te nemen. Met andere woorden: de meerderheidsaandeelhouder kon bij afwezigheid van de minderheidsaandeelhouder niet zonder meer beslissen, te meer omdat het besluit tot statutenwijzing ook (de gerechtvaardigde belangen van) die minderheidsaandeelhouder raakte.

In lagere rechtspraak werd het voorstel van het bestuur van de vennootschap aan de algemene vergadering om het voorkeursrecht van een minderheidsaandeelhouder bij de aandelenemissie uit te sluiten gezien als een middel om de door de minderheidsaandeelhouder ingestelde geschillenregeling te frustreren. Zowel het voorstel als het besluit tot een dergelijke emissie onder uitsluiting van het voorkeursrecht van de minderheidsaandeelhouder werd in strijd met de vennootschappelijke redelijkheid en billijkheid geacht. ${ }^{165}$

In de Robot Medical/MCEG-beschikking ${ }^{166}$ plaatst de OK het misbruik van meerderheidsmacht in het kader van de beginselen van behoorlijk ondernemerschap. Het gaat in deze beschikking over een impasse in het bestuur tussen vader en zoon, die tevens middellijk ieder vijftig procent van de aandelen houden in een privékliniek voor esthetische geneeskunde. Als gevolg van die impasse is onrust ontstaan onder meer onder de aan de kliniek verbonden artsen. Een fraaie overweging uit die beschikking is: “(...) Het gebruik maken van meerderheidsmacht om een einde te maken aan conflicten in (de onderneming van) de vennootschap door degene die over deze meerderheidsmacht beschikt in dier voege dat hij door dat gebruik maken een situatie in het leven zal kunnen en willen roepen die - slechts - overeenstemt met zijn eigen opvattingen omtrent hetgeen in (de onderneming van) de vennootschap dient te geschieden, geven immers op zichzelf en zonder méér noch blijk van het vermogen in het licht van beginselen van behoorlijk ondernemerschap meerderheidsmacht aan te wenden op een wijze die alle in aanmerking te nemen belangen in de beschouwing betrekt noch van inzicht aangaande de wijze waarop conflicten zoals die zich in het onderhavige geval voordoen redelijkerwijze kunnen

164 HR 30 oktober 1964, NJ 1965, 107, m.nt. G.J. Scholten (Mante).

165 Pres. Rb. Haarlem 8 mei 1990, $K G$ 1990, 247, r.o. 3.2.

166 Hof Amsterdam (OK) 25 februari 2000, JOR 2000, 75, m.nt. Josephus Jitta (Robot Medical/MCEG). 
worden opgelost. Dat geldt althans zeker waar het betreft een onderneming van een aard en met een organisatie als de onderhavige. Aldus versterken bedoeld gebruik willen maken van meerderheidsmacht en daarmee de hier besproken stellingname van Senior het oordeel dat er gegronde redenen zijn om aan een juist beleid van de vennootschap te twijfelen." 167

Ook in het eerder besproken Zwagerman Beheer-arrest ${ }^{168}$ stonden meerderheidsen minderheidsaandeelhouders centraal. De Hoge Raag overweegt dat de uitwerking van de zorgvuldigheidplicht van art. 2:8 BW mede afhankelijk zal zijn van de omstandigheden van het geval, waarbij "in aanmerking mag worden genomen dat het gaat om minderheidsaandeelhouders tegenover meerderheidsaandeelhouders en om familierechtelijke verhoudingen tussen de bij de vennootschap betrokken personen. Onder deze omstandigheden (...) kan eerder dan in andere gevallen sprake zijn van de mogelijkheid van een vermenging van de belangen van de vennootschap en van sommige van deze personen, zodat er reden is daarop attent te zijn en met de nodige zorgvuldigheid te voorkomen dat ontoelaatbare verstrengeling van belangen ontstaat." De besloten verhoudingen, tot uitdrukking komend in de familieverhoudingen, waren in dit arrest een extra omstandigheid. Dat geldt bijvoorbeeld ook voor joint venture verhoudingen. ${ }^{169}$ Zowel bij familieverhoudingen als bij een joint venture gaat het om loyaliteit en vertrouwen. ${ }^{170}$

Het The Mill Resort-arres ${ }^{171}$ ligt in het verlengde van het Zwagerman Beheerarrest. Hoewel het in dat arrest over stemrecht in een vereniging van appartementseigenaren gaat, vindt de relevante overweging van de Hoge Raad ook in het BVrecht toepassing. De Hoge Raad overweegt ${ }^{172}$ dat - mede gelet op het feit dat degene die de meerderheid van de stemmen heeft, gelieerd is aan de contractpartij het oordeel van het hof dat het besluit van de vereniging tot het sluiten van een managementovereenkomst met een hogere managementfee dan in de markt gebruikelijk geen strijd oplevert met de jegens de overige appartementseigenaren in acht te nemen eisen van redelijkheid en billijkheid, zonder nadere motivering onbegrijpelijk is. Het besluit om een geldleningsovereenkomst aan te gaan met een partij die is gelieerd aan degene die de meerderheid van de stemmen heeft, kan in strijd zijn met de eisen van de redelijkheid en billijkheid dan wel tot stand zijn

167 r.o. 3.6 .

168 HR 1 maart 2002, LJN AD9857, NJ 2002, 296, m.nt. Ma, JOR 2002, 79, m.nt. Van den Ingh (Zwagerman Beheer), r.o. 3.4. (vervolg op Hof Amsterdam (OK) 30 november 2000, JOR 2001, 4, m.nt. Van den Ingh). Zie ook Asser/Maeijer, Van Solinge \& Nieuwe Weme 2-II* 2009, nr. 667. In lijn daarmee ligt: HR 29 september 2006, NJ 2006, 639, m.nt. Ma, JOR 2007, 62 (The Mill Resort) en Hof Amsterdam (OK) 6 juni 2011, LJN BQ9757, JOR 2011, 282, m.nt. Blanco Fernández (Jeezet/ Synpact), r.o. 3.24 .

169 Hof Amsterdam (OK) 20 mei 1999, NJ 2000, 199, JOR 2000, 72, m.nt. Blanco Fernández (Cromwilld/Verstatel).

170 In gelijke zin: Hendriks \& Koelemeijer 2009, p. 185.

171 HR 29 september 2006, LJN AY5697, NJ 2006, 639, m.nt. Ma, JOR 2007, 62 (The Mill Resort). 172 r.o. 3.4 en 3.5 . 
gekomen door misbruik van meerderheidsmacht, indien komt vast te staan dat de overeengekomen rente hoger is dan de gebruikelijke marktrente.

Tot slot noem ik het vonnis van de rechtbank Amsterdam van 6 februari 2002 over de juridische fusie van Vendex KBB. ${ }^{173}$ Samengevat komt het oordeel van de rechtbank erop neer dat in de gegeven omstandigheden meerderheidsaandeelhouder Vendex, tevens degene die feitelijk de zeggenschap over KBB als verdwijnende vennootschap had, met de belangen van de minderheidsaandeelhouder Leyinvest bij de voorgenomen fusie rekening diende te houden op dezelfde wijze als een onafhankelijk bestuur van een fuserende vennootschap de belangen van haar aandeelhouders dient te behartigen. Vendex mocht zich niet laten leiden door haar belang als meerderheidsaandeelhouder van KBB bij de ruilverhouding, maar als fusiepartner. De rechtbank vernietigde het fusiebesluit, onder meer omdat geen 'redelijk oordelend aandeelhouder' tot het onderhavige fusiebesluit had kunnen komen.

\subsubsection{De zorgplicht van (het bestuur van) de vennootschap jegens de kapitaalverschaffer zonder stemrecht}

Uit de rechtspraak volgt dat de vennootschap een bijzondere zorgplicht heeft ten opzichte van haar minderheidsaandeelhouders. ${ }^{174}$ In de VIBA-beschikking ${ }^{175}$ overwoog de OK onder meer: "Waar reeds in het algemeen geldt dat een vennootschap tegenover haar minderheidsaandeelhouders de nodige zorgvuldigheid in acht dient te nemen brengt bedoeld risico in het onderhavige geval met zich dat de vennootschap een verhoogde zorgplicht heeft mogelijke verstrengeling van belangen van de vennootschap met die van een haar controlerend aandeelhouder te voorkomen alsmede - in verband daarmee - dat naar behoren opening van zaken wordt gegeven."

Niet alleen heeft de vennootschap een bijzondere zorgplicht jegens haar minderheidsaandeelhouders; die zorgplicht heeft de vennootschap ook jegens certificaathouders, zo volgt bijvoorbeeld uit de De Hooge Bergsche Golfclub/De Rotte Bergen-beschikking. ${ }^{176}$ Het ging in deze beschikking om certificaathouders in een vennootschap, welke vennootschap een golfbaan exploiteert. De OK overwoog: “(...) De certificaathouders zijn niet alleen economisch gerechtigd in het kapitaal van de vennootschap en uit dien hoofde bij haar beleid en gang van zaken

173 Rb. Amsterdam 6 februari 2002, JOR 2002, 61 (Vendex KBB)

174 HR 1 maart 2002, LJN AD9857, NJ 2002, 296, m.nt. Ma, JOR 2002, 79, m.nt. Van den Ingh (Zwagerman Beheer), r.o. 3.4. (vervolg op Hof Amsterdam (OK) 30 november 2000, JOR 2001, 4, m.nt. Van den Ingh). Zie ook Asser/Maeijer, Van Solinge \& Nieuwe Weme 2-II* 2009, nr. 667.

175 Hof Amsterdam (OK) 18 januari 2001, JOR 2001, 34, m.nt. Brink (VIBA), r.o. 3.3. In gelijke zin Hof Amsterdam (OK) 21 juni 2001, JOR 2001, 184 (Wildschut/EMO), r.o. 3.3 en Hof Amsterdam (OK) 17 december 2007, JOR 2008, 35 (De Bruin/De Hasker).

176 Hof Amsterdam (OK) 7 augustus 2002, JOR 2002, 194 (De Hooge Bergsche Golfclub/De Rotte Bergen). 
betrokken, te meer nog nu de certificaten met medewerking van de vennootschap zijn uitgegeven, zij hebben daarnaast ingevolge artikel 15 van de Administratievoorwaarden de bevoegdheid de Stichting - in haar hoedanigheid van aandeelhoudster van de vennootschap - te instrueren hoe zij haar stem in de algemene vergadering van aandeelhouders van de vennootschap dient uit te oefenen en ingevolge de statuten van de vennootschap voorts nog het recht een algemene vergadering van aandeelhouders van de vennootschap bijeen te - doen - roepen. Behalve ingevolge deze vennootschapsrechtelijke betrokkenheid staan zij bovendien in een bijzondere verhouding tot de vennootschap doordat zij in vergaande mate betrokken zijn bij en belang hebben bij de wijze waarop de bedrijfsmatige activiteiten van de vennootschap worden uitgeoefend. De weigering van de vennootschap de door de certificaathouders gewenste algemene vergadering van aandeelhouders te doen plaatsvinden is een ernstige miskenning van de rechten en belangen alsmede van de positie van haar certificaathouders." certificaathouders aan de vennootschap verweten - hiervoor in 3.4 vermelde feitelijke gedragingen van de vennootschap (waarvan de Ondernemingskamer het aannemelijk acht dat zij zich hebben voorgedaan) geven blijk van het niet in acht nemen van de door de vennootschap jegens haar certificaathouders, mede gezien hun hiervoor vermelde bijzondere rechten en belangen, in acht te nemen zorgvuldigheid. (...)". ${ }^{178}$ De OK concludeert dat er gegronde redenen zijn om aan een juist beleid van de vennootschap te twijfelen, zodat het doen van een onderzoek gerechtvaardigd is.

De zorgplicht van de vennootschap jegens certificaathouders volgt ook uit de Lenda/Muntal-beschikking van de OK. ${ }^{179}$ Het ging om een situatie waarin een van de certificaathouders indirect bestuurder is en de andere certificaathouder niet bij het bestuur van de vennootschap betrokken is. In dat geval rust op de vennootschap een bijzondere zorgplicht jegens die laatste certificaathouder om een zo groot mogelijke openheid te betrachten, zeker ingeval van (mogelijk) tegenstrijdige belangen. Indien niet duidelijk is wat de voorwaarden van een transactie zijn, mogelijk sprake is van tegenstrijdig belang en het bestuur niet voldoet aan herhaalde verzoeken om informatie, voldoet het bestuur niet aan haar zorgplicht. Onder meer deze omstandigheden leverden volgens het hof gegronde redenen op om aan de juistheid van het beleid te twijfelen, zodat een enquête is gelast. Uit de Langen/Flora Beheerbeschikking volgt dat een vergelijkbare zorgvuldigheidsplicht ook geldt voor de STAK jegens haar minderheidscertificaathouders. ${ }^{180}$

De jurisprudentie over de zorgplicht van (het bestuur van) de vennootschap jegens minderheidsaandeelhouders en certificaathouders van, met name, de OK is

177 r.o. 3.5 .

178 r.o. 3.6 .

179 Hof Amsterdam (OK) 30 maart 2011, LJN BQ1776, JOR 2011, 217 (Lenda/Muntal), r.o. 3.3. Uit de uitspraak leid ik af dat sprake is van met medewerking van de vennootschap uitgegeven certificaten. 180 Hof Amsterdam (OK) 23 juli 2001, JOR 2001, 204 (Langen/Flora Beheer), r.o. 3.2. 
sterk casuïstisch. In tal van omstandigheden wordt deze zorgplicht aangenomen. Vaak is sprake, zoals uit de hiervoor aangehaalde jurisprudentie blijkt, van een samenloop van omstandigheden, bijvoorbeeld een meerderheid-minderheid-situatie, een belangentegenstelling of -verstrengeling en het (in het kader daarvan) niet of onvoldoende informatie verschaffen of het niet of niet in voldoende mate betrachten van openheid. Indien het bestuur van de vennootschap geconfronteerd wordt met een meerderheidsaandeelhouder dan kan het bestuur teneinde aan haar zorgplicht jegens de kapitaalverschaffer zonder stemrecht te voldoen in voorkomend geval vernietiging van het besluit vorderen dan wel een enquêteverzoek indienen. ${ }^{181}$

Tot slot wijs ik er op dat niet alleen op het bestuur van de vennootschap een zorgplicht jegens de minderheidsaandeelhouder rust. Uit de beschikking van de OK van 7 mei 2008 volgt dat ook de raad van commissarissen een bijzondere zorgplicht jegens minderheidsaandeelhouders heeft: "De aan een raad van commissarissen in het vennootschappelijke belang opgedragen taak brengt onder meer mee dat de raad van commissarissen, indien een minderheidsaandeelhouder bevreesd is dat de jegens hem door de organen van de vennootschap en bij de vennootschap betrokken belanghebbenden in acht te nemen bijzondere zorgplicht wordt of zal worden geschonden en daarover zorgen uit en vragen stelt, serieus dient om te gaan met en in te gaan op die zorgen en die vragen. Een raad van commissarissen dient in zo'n geval datgene te doen wat in redelijkheid van hem kan worden verwacht om de bezorgdheid bij de minderheidsaandeelhouder weg te nemen." 182

Ik meen dat de in de jurisprudentie ontwikkelde zorgplicht van (het bestuur van) de vennootschap jegens minderheidsaandeelhouders en certificaathouders ook voor de kapitaalverschaffers zonder stemrecht, die tot de kring van betrokkenen behoren, geldt. Zoals ik reeds betoogde, is de positie van de kapitaalverschaffer zonder stemrecht in veel gevallen te vergelijken met de positie van de minderheidsaandeelhouder.

\subsubsection{Het recht op informatie van de kapitaalverschaffers zonder stemrecht}

\section{Inleiding}

De zorgplicht van het bestuur van de vennootschap jegens de kapitaalverschaffers zonder stemrecht, die tot de kring van betrokkenen behoren, plaats ik in het thema van informatieverschaffing aan die kapitaalverschaffers. In paragraaf 7.5.1 stelde ik dat in de jurisprudentie vaak sprake is van een samenloop van omstandigheden, bijvoorbeeld een meerderheid-minderheid-situatie, een belangentegenstelling of -verstrengeling en het (in het kader daarvan) niet, of onvoldoende, geven van informatie of het niet, of niet in voldoende mate, betrachten van openheid. In het kader van de principal-agent theory, in paragraaf 5.2, refereerde ik aan de informatieasymmetrie. Het bestuur van de vennootschap heeft veelal een informatievoorsprong op de aandeelhouders. Het

181 Vgl. Bartman 2002, p. 44.

182 Hof Amsterdam (OK) 7 mei 2008, JOR 2008, 195, r.o. 3.5. 
verkrijgen van inzicht in de gang van zaken van de vennootschap is voor de (minderheids)aandeelhouder een rechtmatig belang. ${ }^{183}$ Ik geef een aantal voorbeelden uit de rechtspraak.

In de Linders/Hofstee-beschikking ${ }^{184}$ overwoog de OK: "Bij een tegenstrijdig belang is het van grote betekenis dat de te onderscheiden belangen op zorgvuldige wijze gescheiden worden gehouden. Het betrachten van een zo groot mogelijke openheid is daarvoor een waarborg. (...) In een geval als het onderhavige waarin de ondernemingsleiding voor de voorgenomen transactie - zij het onverplicht - de goedkeuring heeft willen verkrijgen van de algemene vergadering van aandeelhouders, dient aan aandeelhouders tijdig die informatie te worden verstrekt die zij redelijkerwijs voor het vormen van een verantwoord oordeel over die transactie nodig hebben. Dit kan met zich brengen dat de te verstrekken informatie niet slechts mondeling doch ook schriftelijk wordt gegeven. De redelijkheid en billijkheid die ten aanzien van aandeelhouders in acht moet worden genomen kan daartoe verplichten."

Uit de eerder besproken Van Uden's Scheepvaart- en Agentuurmaatschappijbeschikking ${ }^{185}$ volgt (ook) dat het bestaan van belangentegenstellingen meebrengt, in het bijzonder voor degene bij wie de zeggenschap in de vennootschap is geconcentreerd, dat hij degenen aan wiens belangen zijn eigen belangen tegengesteld (kunnen) zijn, zo uitvoering mogelijk informeert en aan hen een zo groot mogelijke opening van zaken biedt, ook om zo de schijn te voorkomen dat hij zijn eigen belang heeft behartigd ten koste van hun belangen. De grens van deze informatieplicht ligt daar waar de belangen van de vennootschap in gevaar zouden kunnen komen, zodat geheimhouding is geboden.

In de Zwagerman Beheer-beschikking ${ }^{186}$ overwoog de OK dat een vennootschap jegens haar minderheidsaandeelhouders een bijzondere zorgvuldigheid in acht dient te nemen. De vennootschap dient "in het bijzonder te voorkomen dat verstrengeling van haar belangen met die van haar directie en/of haar meerderheidsaandeelhouder (s) - al dan niet ten koste van haar minderheidsaandeelhouders - plaatsvindt. Ook dient zij naar behoren opening van zaken te geven. Deze algemene zorgvuldigheidsplicht weegt des te zwaarder in een geval als het onderhavige, waarin onder meer sprake is van familierechtelijke verhoudingen tussen diverse betrokkenen." Van den Ingh merkt in zijn noot onder deze beschikking op dat het door de OK erkende recht op informatie mogelijk gebaseerd is op de vennootschappelijke redelijkheid en billijkheid en het gelijkheidsbeginsel. Daarmee past bij beursvennootschappen meer terughoudendheid dan bij familievennootschappen, aldus Van den Ingh. ${ }^{187}$

183 Hof Amsterdam (OK) 21 september 1978, NJ 1979, 403, m.nt. Ma.

184 Hof Amsterdam (OK) 26 mei 1983, NJ 1984, 481, m.nt. Ma (Linders/Hofstee), r.o. 4

185 Hof Amsterdam (OK) 2 november 1995, TVVS 1996-4, p. 119-120, m.nt. IJsselmuiden, JOR 1996 0-nummer, rekestnr. 377/95, p. 16 e.v. (Van Uden's Scheepvaart- en Agentuurmaatschappij), r.o. 4.5.

186 Hof Amsterdam (OK) 30 november 2000, JOR 2001, 4, m.nt. Van den Ingh (Zwagerman Beheer), r.o. 3.1. 187 sub 2, tweede alinea. 
In de Dialoc ID Holdings-beschikking overwoog de OK "dat (het bestuur van) een vennootschap tegenover haar minderheidsaandeelhouder(s) een bijzondere zorgvuldigheid in acht dient te nemen en deze (n) in ruime mate en op controleerbare wijze inzicht dient te verschaffen indien transacties worden aangegaan waarvan op voorhand niet zonder meer duidelijk is dat zij in het belang van de vennootschap zijn onderscheidenlijk die onder op het eerste gezicht niet voor de hand liggende voorwaarden worden aangegaan of tot voor de vennootschap nadelige gevolgen hebben geleid dan wel het risico van belangenvermenging in zich bergen." 188

Uit de hiervoor genoemde rechtspraak volgt dat op (het bestuur van) de vennootschap een zorgplicht rust de minderheidsaandeelhouder in voorkomend geval correct en tijdig te informeren. Zoals ik reeds betoogde, is de positie van de kapitaalverschaffer zonder stemrecht in veel gevallen te vergelijken met de positie van de minderheidsaandeelhouder. De vraag rijst of de kapitaalverschaffer zonder stemrecht, die tot de kring van betrokkenen behoort, een recht op informatie heeft, zowel tijdens als buiten de algemene vergadering. Voordat ik antwoord op die vraag geef, bespreek ik eerst het recht op informatie van de individuele, gewone aandeelhouder tijdens en buiten de algemene vergadering. Daarover is in de literatuur reeds veel geschreven, zodat ik alleen op de hoofdlijnen en de heersende opvattingen in ga. ${ }^{189} \mathrm{Ik}$ laat een contractueel recht op informatieverschaffing, bijvoorbeeld op grond van een aandeelhoudersovereenkomst, ${ }^{190}$ buiten beschouwing. Ook laat ik een zwaarwichtig belang van de vennootschap tegen informatieverschaffing onbesproken, omdat niet waarschijnlijk is dat zulks specifiek voor de kapitaalverschaffer zonder stemrecht zal gelden.

Recht op informatie van individuele aandeelhouder tijdens de algemene vergadering Art. 2:217 lid 2 BW bepaalt dat het bestuur en de raad van commissarissen de algemene vergadering alle verlangde inlichtingen verschaffen, tenzij een zwaarwichtig belang van de vennootschap zich daartegen verzet. Ook dit artikel is een uitwerking van de dualistische structuur van de BV en de principal-agent theory. De aandeelhouders verschaffen kapitaal, waarmee het bestuur onderneemt. De aandeelhouders hebben aldus belang bij het verkrijgen van inlichtingen. Door het verschaffen van informatie legt het bestuur over het gevoerde beleid verantwoording aan de algemene vergadering af, zijnde de economisch eigenaren van de vennootschap en de door haar gedreven onderneming. ${ }^{191}$ De algemene vergadering is door middel van de haar toekomende rechten op grond van de verschafte informatie in

188 Hof Amsterdam (OK) 28 februari 2007, JOR 2007, 141, m.nt. E. Schmieman (Dialoc ID Holdings), r.o. 3.8. Zie ook Hof Amsterdam (OK) 22 mei 2002, JOR 2002, 188 (Mega Electra Groep Amsterdam).

189 Zie bijvoorbeeld Vletter-van Dort 2001; Deraedt 2001, p. 165 e.v.; Van der Korst 2007, p. 161-186; Schoenmaker-Tijsseling 2011, p. 83 e.v. en Vletter-van Dort 2012, p. 209 e.v.

190 Of een andere overeenkomst of omstandigheid: zie Pres. Rb. Amsterdam 11 juni 1999, JOR 1999, 174, m.nt. Van Solinge (Leyinvest/KBBVendex).

191 Kamerstukken II 1969/70, 10 751, nr. 3, p. 18 (MvT) en C.A. Schwarz, Groene Serie Rechtspersonen, art. 2:107 BW, aant. 5, Deventer: Kluwer. 
staat zeggenschap uit te oefenen, bijvoorbeeld de vaststelling van de jaarrekening, het benoemen of ontslaan van bestuurders of een besluit tot statutenwijziging. De inlichtingen zullen door de algemene vergadering veelal worden gevraagd in het kader van het vaststellen van de jaarrekening. Het recht op inlichtingen ziet op alle inlichtingen over de financiële positie en de resultaten en de operationele situatie van de vennootschap, maar ook ten aanzien van de interne structuur van de vennootschap. ${ }^{192}$ De achterliggende gedachte daarvan is dat de algemene vergadering op die wijze tot een 'voldoende gefundeerde besluitvorming' kan komen. ${ }^{193}$ De informatieverstrekking tijdens de algemene vergadering dient dus zowel de aan het aandeel verbonden financiële rechten als de zeggenschapsrechten. Tussen deze twee soorten rechten bestaat in het kader van de informatievoorziening aldus een wisselwerking.

Art. 2:217 lid 2 BW bevat geen formaliteiten of regels over de wijze waarop het recht op informatie tijdens de algemene vergadering door de aandeelhouder kan of moet worden uitgeoefend. Uit de parlementaire geschiedenis ${ }^{194}$ en het ASMI-arrest ${ }^{195}$ volgt dat het bestuur en de raad van commissarissen gehouden zijn aan de algemene vergadering, behoudens zwaarwichtige redenen, alle verlangde inlichtingen te verschaffen. Iedere aandeelhouder heeft voorts ter vergadering zelfstandig het recht vragen te stellen en de vennootschap dient die vragen te beantwoorden.

Bij het uitoefenen van dat recht zal de aandeelhouder de vennootschappelijke redelijkheid en billijkheid in acht moeten nemen. Zijn vragen moeten zien op het gevoerde beleid en hij zal de orderegels van de vergadering in acht moeten nemen, hetgeen ook geldt voor de beantwoording van de vragen door het bestuur of de raad van commissarissen. ${ }^{196}$ Van de aandeelhouder mag een zakelijke opstelling worden verwacht. De aandeelhouder hoeft zich daarbij niet te beperken tot alleen de punten die op de agenda zijn vermeld. Veelal zijn vragen te herleiden tot een agendapunt als 'financiële verslaglegging', 'jaarrekening' of 'decharge'. Vaak is ook een 'rondvraag' als agendapunt opgenomen. ${ }^{197}$ Het bestuur en de raad van commissarissen hebben niet slechts een reactieve informatieplicht, maar in voorkomend geval ook een spontane informatieplicht. ${ }^{198}$

192 Van der Korst 2007, p. 163-164

193 Asser/Maeijer, Van Solinge \& Nieuwe Weme 2-II* 2009, nr. 327, naar aanleiding van de VIBAbeschikking: HR 21 februari 2003, LJN AF1797, NJ 2003, 181, JOR 2003, 58, m.nt. M. Brink (VIBA). Anders: Schoenmaker-Tijsseling 2011, p. 85.

194 Kamerstukken II 2008/09, 31 476, nr. 3, p. 15 (MvT)

195 HR 9 juli 2010, LJN BM0976, NJ 2010, 544, m.nt. Van Schilfgaarde, JOR 2010, 228, m.nt. Van Ginneken (ASMI)

196 C.A. Schwarz, Groene Serie Rechtspersonen, art. 2:107 BW, aant. 5, Deventer: Kluwer. Kamerstukken II 2008/09, 31 746, nr. 3, p. 16 (MvT); Deraedt 2001, p. 165; Vletter-van Dort 2001, p. 6668; Slagter 2005, p. 292; Schoenmaker-Tijsseling 2011, p. 87 en Vletter-van Dort 2012, p. 211

197 HR 9 juli 2010, LJN BM0976, NJ 2010, 544, m.nt. Van Schilfgaarde, JOR 2010, 228, m.nt. Van Ginneken (ASMI). Vletter-van Dort 2001, p. 86. Zie voor een overzicht van standpunten in de literatuur Schoenmaker-Tijsseling 2011, p. 87-88.

198 Schoenmaker-Tijsseling 2011, p. 85-86, komt tot deze conclusie onder verwijzing naar rechtspraak en literatuur. Zie ook Van der Korst 2007, p. 167-170. 
Uit de wettekst volgt dat de verplichting tot het verschaffen van informatie een verplichting van het bestuur (en de raad van commissarissen) als orgaan van de vennootschap is. Op een individuele bestuurder rust deze verplichting niet. De wet geeft niet aan wat de sanctie is op overtreding van deze verplichting. Te denken valt echter aan schorsing, ontslag of aansprakelijkheid van de bestuurder ex art. 2:9 BW. Ook kan het niet afdoende verstrekken van informatie in een enquêteprocedure leiden tot het oordeel dat sprake is van gegronde redenen om aan een juist beleid te twijfelen of tot de vaststelling dat sprake is van wanbeleid. ${ }^{199}$

Recht op informatie van individuele aandeelhouder buiten de algemene vergadering De vraag is vervolgens of ook buiten de algemene vergadering informatieverschaffing aan individuele aandeelhouders of een vertegenwoordiging van aandeelhouders kan plaatsvinden. Het antwoord daarop is als volgt. Uit de tekst van art. 2:217 lid 2 BW volgt dat het recht op informatie een recht is dat aan de algemene vergadering als orgaan toekomt en niet aan een individuele aandeelhouder. Wel kunnen individuele aandeelhouders ter vergadering om inlichtingen verzoeken. Dat verzoek zal ter vergadering moeten worden behandeld en de verlangde informatie zal ook ter vergadering moeten worden verstrekt. ${ }^{200}$

In het ASMI-arrest ${ }^{201}$ formuleert de Hoge Raad het in r.o. 4.6 als volgt: "Het bestuur en de RvC zijn gehouden aan de AvA, behoudens zwaarwichtige redenen, alle verlangde inlichtingen te verschaffen (art. 2:107 lid 2 BW). Iedere aandeelhouder heeft voorts ter vergadering zelfstandig het recht vragen te stellenongeacht of deze betrekking hebben op punten die op de agenda zijn vermeld - en de vennootschap dient die vragen te beantwoorden (art. 9 lid 1 en 2 EG-Richtlijn nr. 2007/36 van 11 juli 2007 betreffende de uitoefening van bepaalde rechten van aandeelhouders in beursgenoteerde vennootschappen, PbEU 2007, L 184/17). Daarbuiten hebben aandeelhouders geen recht op het verstrekken van door hen afzonderlijk verlangde informatie. Het recht op nadere inlichtingen is een recht van de AvA als orgaan van de vennootschap, verleend met het oog op vennootschappelijke rekening en verantwoording. (...)". De Hoge Raad volgde de conclusie van A-G Timmerman. ${ }^{202}$ De Hoge Raad is resoluut in zijn bewoordingen. Buiten de algemene vergadering bestaat voor aandeelhouders geen recht op inlichtingen. A-G Timmerman is in zijn conclusie onder het arrest iets minder resoluut. Hij wil uitzonderingen niet bij voorbaat uitsluiten, maar kan geen situatie bedenken waarin

199 Zie Asser/Maeijer, Van Solinge \& Nieuwe Weme 2-II* 2009, nr. 328.

200 Maeijer 2000, p. 287; Slagter 2005, p. 292; Sanders \& Westbroek 2005, p. 133 en Asser/Maeijer, Van Solinge \& Nieuwe Weme 2-II* 2009, nr. 327. Kamerstukken II 2008/09, 31 746, nr. 3, p. 15-16 en 22 (MvT). Zie ook Pres. Rb. 's-Hertogenbosch 5 augustus 1999, JOR 1999, 202. In andere zin: Van Schilfgaarde \& Winter 2009, p. 217.

201 HR 9 juli 2010, LJN BM0976, NJ 2010, 544, m.nt. Van Schilfgaarde, JOR 2010, 228, m.nt. Van Ginneken (ASMI). Zie ook Pres. Rb. Amsterdam 15 juni 1988, $K G$ 1988, 276, r.o. 5.

202 Die conclusie is zeer lezenswaardig en genuanceerd. Sub 3.6.1 tot en met 3.6.11 gaan over het recht op informatie. 
toch een individueel informatierecht van een aandeelhouder buiten de algemene vergadering bestaat. Indien toch sprake is van een individueel informatierecht, past zeer terughoudende toepassing. De verplichting tot het verstrekken van informatie zou dan voortvloeien uit een zorgvuldigheidsverplichting. ${ }^{203}$

In de literatuur is ook een aantal opvattingen te vinden gelijk aan het ASMIarrest. Slagter en Asser/Maeijer, Van Solinge \& Nieuwe Weme zijn van mening dat buiten de algemene vergadering voor individuele aandeelhouders geen recht op inlichtingen bestaat, omdat het beginsel van gelijke behandeling van aandeelhouders hierdoor zou worden aangetast. ${ }^{204}$ Ook De Groot \& Bakker en Vletter-van Dort behoren tot deze stroming. ${ }^{205}$

Voorstanders zijn Koelemeijer, Van Schilfgaarde \& Winter, De Monchy \& Timmerman $^{206}$ en Schoenmaker-Tijsseling. ${ }^{207} \mathrm{Zij}$ stellen dat de individuele aandeelhouder onder omstandigheden op grond van art. 2:8 BW bepaalde voor hem van belang zijnde inlichtingen buiten vergadering kan verkrijgen. Het gelijkheidsbeginsel van art. 2:201 lid 2 BW speelt daarbij een rol, aldus Van Schilfgaarde \& Winter. Schwarz en Deraedt sluiten zich bij deze mening aan en stellen dat de individuele aandeelhouder op ieder moment inlichtingen kan vragen. De wettelijke bevoegdheid daartoe heeft hij slechts tijdens de algemene vergadering. ${ }^{208}$ Begrijp ik het goed,

203 Zie sub 3.6.7 van de concl. A-G.

204 Slagter 2005, p. 292 en 308; Asser/Maeijer, Van Solinge \& Nieuwe Weme 2-II* 2009, nr. 327, spreekt van 'terughoudendheid'. Zie ook Pres. Rb. Amsterdam 27 juli 1999, JOR 1999, 178, m.nt. Nieuwe Weme (VEB/Otra). In zijn noot onder dit vonnis meent Nieuwe Weme dat 'indien het recht op informatie wordt gegrond op art. 2:8 BW de vennootschap in ieder geval wel in rechte zal kunnen worden aangesproken'. Slagter 2005, p. 292, noot 20, spreekt niettemin van 'een pleitbare stelling: de verhouding tussen de veel wetende meerderheidsaandeelhouder en de weinig wetende minderheidsaandeelhouder kan meebrengen dat het bestuur extra informatie moet verstrekken en het bestuur zich niet snel kan verschuilen achter de escape-clausule van art. 2:217 lid 2 slot BW.'

205 De Groot \& Bakker 2011, p. 261 en 262 en Vletter-van Dort 2012, p. 215. Niettemin stellen De Groot \& Bakker 2011, p. 254, dat 'het in bepaalde omstandigheden denkbaar is dat art. 2:8 BW een verplichting voor het bestuur en de raad van commissarissen met zich mee brengt de algemene vergadering, althans alle aandeelhouders, spontaan en direct te informeren met het oog op een adequate behartiging van de aan hun aandeelhouderschap verbonden zeggenschapsrechten en/of vermogensrechtelijke belangen.' Vletter-van Dort 2001, p. 84, was eerst de opvatting toegedaan dat onder omstandigheden een rechtspersoon op grond van de redelijkheid en billijkheid gehouden kan zijn bepaalde inlichtingen te verstrekken aan een individuele aandeelhouder buiten vergadering.

206 Timmerman is blijkens zijn (latere) conclusie bij het ASMI-arrest (toch) tegen. Zie sub 3.6.6 van die conclusie. Ik meen echter te kunnen afleiden dat deze opvatting alleen op de beursgenoteerde NV ziet.

207 De Monchy \& Timmerman 1991, p. 51; Koelemeijer 1999, p. 93 en 95; Van Schilfgaarde \& Winter 2009, p. 217 en Schoenmaker-Tijsseling 2001, p. 88.

208 C.A. Schwarz, Groene Serie Rechtspersonen, art. 2:107 BW, aant. 5, Deventer: Kluwer. Deraedt 2001, p. 165. Zie ook Rb. Utrecht 29 juli 1998, JOR 1999, 58. Het ging in dit vonnis om het recht op informatie van leden van een coöperatie, r.o. 4.3: "Iets anders is dat individuele leden onder omstandigheden op grond van artikel 2:8 BW bepaalde voor hen van belang zijnde inlichtingen kunnen verkrijgen, eventueel ook buiten vergadering. Hun aanspraak heeft echter niet dezelfde kracht als die van de ALV als zodanig." 
dan houden de opvattingen van Schwarz en Deraedt het midden tussen (i) de opvatting dat buiten de algemene vergadering voor aandeelhouders geen recht op inlichtingen bestaat en (ii) de opvatting dat de individuele aandeelhouder onder omstandigheden op grond van art. 2:8 BW bepaalde voor hem van belang zijnde inlichtingen buiten vergadering kan verkrijgen. Hoewel Slagter de eerste opvatting voorstaat, maakt hij niettemin een uitzondering voor de grootaandeelhouder die nadere gegevens van de vennootschap nodig heeft voor het opstellen van de eigen jaarrekening. De vennootschap is in dat geval verplicht, ook buiten de algemene vergadering, die gegevens te verschaffen. ${ }^{209}$

Het hiervoor aangehaalde ASMI-arrest heeft de vraag, of de individuele aandeelhouder buiten de algemene vergadering een recht op informatie heeft, negatief beantwoord. Daarentegen overwoog de OK in de Butôt-beschikking ${ }^{210}$ dat onder bijzondere omstandigheden het bestuur ook buiten het verband van de algemene vergadering in beginsel verlangde informatie moet verschaffen. Het ging in deze beschikking om economisch rechthebbenden op certificaten, welke rechthebbenden deelgenoten zijn geworden in een nalatenschap. Zij wensten zich een oordeel te vormen over de financiële situatie van de vennootschap (een familiebedrijf), waarvan zij kapitaalverschaffer waren geworden. De OK beschouwde dat als een bijzondere omstandigheid, die een uitzondering op de hoofdregel 'dat het informatierecht van de kapitaalverschaffer echter niet zo ver gaat dat het bestuur ook buiten het verband van de algemene vergadering aan aandeelhouders te allen tijde en zonder meer alle verlangde informatie dient te verschaffen'. In de latere Jeezet/ Synpact-beschikking ${ }^{211}$ heeft de OK het recht op informatie buiten de algemene vergadering herhaald. De OK overwoog dat: “(...) in het algemeen ten aanzien van het informatierecht van aandeelhouders (...) de hoofdregel is dat het bestuur van een vennootschap haar aandeelhouders door middel van de jaarrekening informeert en dat de aandeelhouders in de algemene vergadering van aandeelhouders aan het bestuur informatie kunnen vragen en dat het bestuur in beginsel gehouden is deze informatie te verschaffen. Buiten de algemene vergadering van aandeelhouders hebben de aandeelhouders in beginsel geen recht op het verkrijgen van de bedoelde informatie. Van deze hoofdregel dient - onder meer - te worden afgeweken in een situatie als de onderhavige, waarin sprake is van een besloten vennootschap met een joint venture-karakter met drie aandeelhouders van wie er twee gezamenlijk optrekken en de meerderheid van de stemrechten in de algemene

209 Slagter 2005, p. 308

210 Hof Amsterdam (OK) 17 februari 2009, JOR 2009, 129, m.nt. G. van Solinge (Butôt), r.o. 3.7. Tegen deze beschikking is cassatie ingesteld. Zie HR 10 september 2010, LJN BM6077, NJ 2010, 665, m.nt. P. van Schilfgaarde en S. Perrick, JOR 2010, 337, m.nt. M. Brink (Butôt). In cassatie werd echter niet met een middel opgekomen tegen de overweging dat onder bijzondere omstandigheden het bestuur ook buiten het verband van de algemene vergadering in beginsel verlangde informatie moet verschaffen.

211 Hof Amsterdam (OK) 6 juni 2011, LJN BQ9757, JOR 2011, 282, m.nt. Blanco Fernández (Jeezet/ Synpact). 
vergadering van aandeelhouders vertegenwoordigen en die tevens in het bestuur van de vennootschap voorzien. In dat geval rust er op het bestuur van de vennootschap een bijzondere zorgplicht jegens de minderheidsaandeelhouder die geen bestuurder is en dient jegens hem meer openheid te worden betracht met betrekking tot de informatie waarop een aandeelhouder als zodanig geen recht heeft. Dit geldt in het bijzonder indien sprake is van (mogelijke) belangenverstrengeling." 212 Terecht merkt Blanco Fernández in zijn noot onder deze beschikking op dat de overweging van de OK vragen oproept. Afgezien van de eenpersoons-BV heeft vrijwel iedere BV gelet op het besloten karakter slechts een beperkt aantal aandeelhouders en, kennelijk in de visie van de OK, een joint venture-karakter. De door de OK genoemde afwijking van de hoofdregel is dan een hoofdregel geworden, zodat iedere individuele aandeelhouder in een BV recht op informatie heeft. Daarnaast is niet duidelijk wat de OK bedoelt met de woorden "onder meer". Kennelijk zijn er nog meer uitzonderingen op de hoofdregel mogelijk.

Ook een eerdere uitspraak van de President van de rechtbank Groningen laat de mogelijkheid open dat op grond van de vennootschappelijke redelijkheid en billijkheid de vennootschap haar aandeelhouders vooraf en buiten vergadering informeert. $^{213}$ Ik lees dat ook in de Mojo Works/Mojo Theater-beschikking, ${ }^{214}$ waarin de $\mathrm{OK}$ in r.o. 3.7 onder meer overweegt: "Gelet op de omstandigheden van het geval, waaronder het feit dat de meerderheidsaandeelhouder Colour of the Dream in de persoon van Visser wel geacht kon worden op de hoogte te zijn geweest van de ontwikkeling in de resultaten, had het naar het oordeel van de Ondernemingskamer op de weg van Mojo Theater weg gelegen om - al dan niet in een algemene vergadering van aandeelhouders - ook de minderheidsaandeelhouder Mojo Works reeds in de loop van 2009 - en niet achteraf in mei 2010 - van die ontwikkeling op de hoogte te stellen."

Het ASMI-arrest is van latere datum dan de hiervoor besproken Butôt-beschikking van de OK, maar van een eerdere datum dan de Jeezet/Synpact-beschikking. Ik meen dat het ASMI-arrest ruimte laat onder bijzondere omstandigheden, zoals die in de Jeezet/Synpact-beschikking gegeven, van de hoofdregel te blijven afwijken. De

212 r.o. 3.24 .

213 Pres. Rb. Groningen 11 september 1996, KG 1996, 326, r.o. 7. Zie ook Rb. Utrecht 29 juli 1998, JOR 1999, 58. De rechtbank overwoog in r.o. 4.3: “(...) Bij de n.v. en de b.v. bepaalt de wet in de artikelen 2:107/217 lid 2 BW dat het bestuur aan de algemene vergadering inlichtingen moet verschaffen, tenzij een zwaarwichtig belang van de vennootschap zich daartegen verzet. Een gelijksoortige bepaling voor de coöperatie geeft de wet niet. Het recht van de algemene vergadering op inlichtingen van het bestuur kan bij de coöperatie worden gebaseerd op artikel 2:8 jo. 2:48 BW. Het bestuur is verplicht de inlichtingen te verschaffen aan de algemene vergadering als zodanig, dus niet zonder meer aan de individuele leden. Iets anders is dat individuele leden onder omstandigheden op grond van artikel 2:8 BW bepaalde voor hen van belang zijnde inlichtingen kunnen verkrijgen, eventueel ook buiten vergadering. Hun aanspraak heeft echter niet dezelfde kracht als die van de ALV als zodanig."

214 Hof Amsterdam (OK) 20 februari 2012, LJN BV7334 (Mojo Works/Mojo Theater). 
grondslag daarvoor is de vennootschappelijke redelijkheid en billijkheid. ${ }^{215}$ Bovendien ging het in het ASMI-arrest om een beursgenoteerde NV, waarbij transparantie, gelijke en gelijktijdige informatievoorziening in het algemeen en van aandeelhouders in het bijzonder, gelet op die notering, van prominent belang zijn. Ik kan mij voorstellen dat dit voor de Hoge Raad reden is geweest in absolute zin te overwegen dat buiten de algemene vergadering aandeelhouders geen recht op het verstrekken van door hen afzonderlijk verlangde informatie hebben, te meer omdat de Hoge Raad verwijst naar art. 9 lid 1 en 2 EG-Richtlijn nr. 2007/36 van 11 juli 2007 betreffende de uitoefening van bepaalde rechten van aandeelhouders in beursgenoteerde vennootschappen. Ook de conclusie van A-G Timmerman onder het arrest lijkt de insteek van de beursgenoteerde vennootschap te hebben. ${ }^{216}$ Voor de BV ligt dat anders. De regels voor beursgenoteerde vennootschappen gelden niet. Bovendien kan vanuit praktisch oogpunt gelet op de in de regel beperkte kring van aandeelhouders eerder en makkelijker voldaan kan worden aan de verplichting van de vennootschap tot transparantie jegens en tot gelijke en gelijktijdige informatievoorziening van haar aandeelhouders.

Recht op informatie van de kapitaalverschaffers zonder stemrecht ter vergadering De vraag is of het recht op informatie ex art. 2:217 lid 2 BW voor alle kapitaalverschaffers zonder stemrecht geldt. Voor de stemrechtloze aandeelhouder zou ik die vraag, zoals gezegd, positief willen beantwoorden. Die andeelhouder maakt immers deel uit van de algemene vergadering. Hij kan op grond van het aan het stemrechtloze aandeel verbonden vergaderrecht de algemene vergadering bijwonen en daarin het woord voeren. Datzelfde positieve antwoord geldt voor de houder van certificaten met vergaderrecht $\mathrm{t}^{217}$ en de aandeelhouder die vanwege de overdracht van zijn stemrecht aan de vruchtgebruiker of pandhouder geen stemrecht heeft. Ik verwijs naar art. 2:227 lid $2 \mathrm{BW}$. Voor houders van certificaten zonder vergaderrecht zou ik de vraag negatief willen beantwoorden. ${ }^{218} \mathrm{Zij}$ behoren niet tot de kring van

215 Zie ook Vzr. Rb. Leeuwarden 15 april 2009, LJN BI3631, JOR 2009, 187, m.nt. T.S. Jansen, r.o. 4.5: "Onder bijzondere omstandigheden kan de individuele aandeelhouder buiten de AVA om verzoeken doen en vragen stellen. Waar DZ Software c.s. echter hebben nagelaten aan te geven welke bijzondere omstandigheden dat in dit geval zijn, naast de hiervoor verworpene, kunnen zij niet buiten de AVA om dergelijke verzoeken doen en vragen stellen." De verworpen omstandigheden betroffen het verschil van mening tussen partijen over de vraag of de gevraagde informatie wegens onwil niet is verstrekt, het in het kader daarvan al dan niet als een nodeloze exercitie beschouwen van het houden van een algemene vergadering en, indien informatieverstrekking wel zou hebben plaatsgevonden, of de informatie in voldoende mate van gedetailleerdheid zou zijn verstrekt.

216 Zie sub 3.6.6 van de concl. A-G.

217 C.A. Schwarz, Groene Serie Rechtspersonen, art. 2:107 BW, aant. 5, Deventer: Kluwer. Onder het oude recht volgde dat reeds uit lagere rechtspraak: Pres. Rb. 's-Hertogenbosch 5 augustus 1999, JOR 1999,202 . Uit deze uitspraak leid ik af dat sprake is van met medewerking van de vennootschap uitgegeven certificaten. Het ter beschikking stellen van informatie zal ingeval van certificaten van aandelen via de STAK, als aandeelhouder, geschieden. Zie Brink 2004, p. 236.

218 Zie ook Hof Amsterdam (OK) 5 april 2012, LJN BW4144, ARO 2012, 55 (Zadeko). 
betrokkenen van art. 2:8 BW. Zij hebben bovendien geen vergaderrecht en kunnen aldus niet de algemene vergadering bijwonen, aan welke vergadering of de individuele vergadergerechtigde ter vergadering het recht op informatie toekomt. Die conclusie geldt mijns inziens ook voor de houder van een participatiebewijs, tenzij in de participatievoorwaarden ten aanzien van het vergaderrecht anders overeengekomen is.

Recht op informatie van de kapitaalverschaffers zonder stemrecht buiten vergadering Het komt mij voor dat bij wege van uitzondering de stemrechtloze aandeelhouder, de houder van certificaten met vergaderrecht en de aandeelhouder die vanwege de overdracht van zijn stemrecht aan de vruchtgebruiker of pandhouder geen stemrecht heeft wegens bijzondere omstandigheden op grond van de vennootschappelijke redelijkheid en billijkheid een recht op informatie (buiten vergadering) hebben. Het ASMI-arrest laat daarvoor mijns inziens ruimte. Wegens het bepaalde in art. 2:201 lid 2 BW zal daarmee echter terughoudend moeten worden omgegaan. De bijzondere omstandigheden zijn met name aan de orde bij transacties (i) met een mogelijk tegenstrijdig belang of belangenverstrengeling, (ii) strijdig met het vennootschappelijk belang en (iii) die onder op het eerste gezicht niet voor de hand liggende voorwaarden worden aangegaan. De bijzondere omstandigheden klemmen te meer in geval van een familievennootschap.

Mijns inziens pleit nog een andere overweging voor het recht op informatie in vorenbedoelde zin, van de kapitaalverschaffers zonder stemrecht buiten vergadering. Een bank, als verstrekker van vreemd vermogen, heeft in de regel in de met de BV gesloten kredietovereenkomst of de daarop toepasselijke algemene bankvoorwaarden van kredietverlening bedongen dat de kredietnemer de bank ongevraagd en omgaand in een aantal gevallen of gebeurtenissen op de hoogte stelt of informeert. Het aantal gevallen is vaak zeer groot en ziet op situaties waarin de vennootschap het krediet mogelijk niet meer zou kunnen terugbetalen of het teniet gaan of de waardevermindering van aan de bank verleende zekerheden. Te denken valt ook aan besluiten of gevallen die de vennootschap en de door haar gedreven onderneming raken, zoals ontbinding, faillietverklaring, aanvraag van surseance van betaling, inkoop van eigen aandelen, beslaglegging, verkoop van activa, verandering in zeggenschap(sverhoudingen) en dergelijke. Het nalaten te voldoen aan die verplichting kan tot opzegging van het krediet en opeising van het openstaande saldo door de bank leiden. De gevallen of gebeurtenissen zijn vergelijkbaar met de bijzondere omstandigheden waarin de kapitaalverschaffer zonder stemrecht op grond van de vennootschappelijke redelijkheid en billijkheid een recht op informatie buiten de algemene vergadering heeft. De bank heeft daarmee een feitelijk sterkere positie dan de kapitaalverschaffer zonder stemrecht. Die kapitaalverschaffer kan immers zijn inbreng niet opeisen. De vennootschap is niet tot terugbetaling verplicht. ${ }^{219}$ Hoewel in de relatie tussen de bank en de vennootschap sprake is

$219 \mathrm{Bij}$ het participatiebewijs kan in de participatievoorwaarden daarvan worden afgeweken. 
van een in het kader van een contractuele verhouding bedongen verplichting, is er mijns inziens geen reden te bedenken voor dit verschil. Indien op de vennootschap een gelijke verplichting tot het informeren van de kapitaalverschaffer zonder stemrecht zou rusten als de verplichting die de vennootschap jegens de bank zou hebben, blijft de kapitaalverschaffer zonder stemrecht ten opzichte van de bank op achterstand staan. De bank kan immers haar krediet opeisen en de verleende zekerheden uitwinnen. De kapitaalverschaffer zonder stemrecht kan zijn inbreng niet opvorderen. Zekerheden heeft hij niet. Hem staat slechts de dure en langdurige gang naar de rechter te wachten. Daarbij komt dat de bank bedongen zal hebben dat de vennootschap haar periodiek op de hoogte stelt van de jaar-, halfjaar-, kwartaalen/of maandcijfers en prognoses. Met andere woorden: (het bestuur van) de vennootschap zal in het algemeen niet direct schade lijden indien zij - onder de genoemde omstandigheden en met terughoudendheid - ook buiten vergadering haar kapitaalverschaffers zonder stemrecht wel zou informeren.

\subsubsection{De zorgplicht van de kapitaalverschaffer met (doorslaggevend) stemrecht jegens de kapitaalverschaffer zonder stemrecht}

In het verlengde van hetgeen ik in paragaaf 7.5.5 ten aanzien van de verhouding tussen aandeelhouders onderling heb betoogd, zou ik een zorgplicht van de kapitaalverschaffer met (doorslaggevend) stemrecht jegens de kapitaalverschaffer zonder stemrecht, die tot de kring van betrokkenen behoort, willen aannemen. Assink heeft een aantal regels geformuleerd, mede aan de hand van de hiervoor besproken jurisprudentie, ten aanzien van verantwoord gedrag van aandeelhouders, die een substantieel aandelenbelang in de vennootschap houden, waarbij de aan die aandelen verbonden stemrechten voorzienbaar en potentieel doorslaggevend zijn in de besluitvorming van de algemene vergadering. ${ }^{220}$ Het komt mij voor dat deze regels goed toepasbaar zijn in de relatie tussen de kapitaalverschaffer met stemrecht en de kapitaalverschaffer zonder stemrecht, die tot de kring van betrokkenen behoort, meer in het bijzonder indien een of meerdere kapitaalverschaffers met stemrecht tezamen een doorslaggevende stem in de algemene vergadering hebben. Van den Ingh spreekt in dit kader van de gekwalificeerde aandeelhouder. ${ }^{221}$ Vertaald naar die situatie kunnen de regels van Assink als volgt worden geformuleerd. Van de kapitaalverschaffer met (potentieel) doorslaggevend stemrecht mag worden verlangd dat hij zich voorafgaand aan de algemene vergadering adequaat informeert. De informatie ziet op het voorliggende besluit zelf en de visie van het

220 Assink 2009, p. 106 e.v. Zie ook Van den Ingh 2000, p. 203 e.v.

221 Van den Ingh 2000, p. 207-208. Van den Ingh merkt over wie de gekwalificeerde aandeelhouder is op: "De vraag wie daaronder valt, is net zo lastig te beantwoorden als de vraag wanneer iemand beslissende zeggenschap heeft. Naast juridische factoren, zoals de inhoud van de statuten en eventuele aandeelhoudersovereenkomsten, spelen bij deze vragen ook feitelijke elementen een rol, zoals de mate van (overige) betrokkenheid bij de vennootschap en de mate waarin aandeelhouders de AVA plegen bij te wonen." 
bestuur en, indien ingesteld, van de raad van commissarissen op de voorgenomen besluitvorming. ${ }^{222}$ Ook zal hij zich bij de uitoefening van zijn (doorslaggevend) stemrecht adequaat moeten informeren over (i) de kenbare gevolgen van zijn stemgedrag voor de vennootschap en (ii) de kenbare gevolgen voor en de gerechtvaardigde belangen van de kapitaalverschaffers zonder stemrecht, die tot de kring van betrokkenen in de zin van art. 2:8 BW behoren.

In de hiervoor besproken jurisprudentie kwam ook het persoonlijke belang van de meerderheidsaandeelhouder en eventuele belangenverstrengeling aan de orde, te meer wanneer sprake is van een meerderheidsaandeelhouder die de vennootschap ook op bestuursniveau (feitelijk) controleert. In dat geval klemmen de hiervoor geformuleerde regels eens te meer. De kapitaalverschaffer met (doorslaggevend) stemrecht zal bij de aanwezigheid van een persoonlijk belang dat tegenstrijdig is aan de belangen van de vennootschap en de kapitaalverschaffers zonder stemrecht extra alert moeten zijn. Hij zal bij de uitoefening van zijn stemrecht (i) rekening moeten houden met de gerechtvaardigde belangen van de kapitaalverschaffers zonder stemrecht, $^{223}$ (ii) transparantie ten aanzien van het voorgenomen besluit of de voorgenomen transactie moeten betrachten en (iii) moeten voorkomen dat sprake is van bevoordeling ten koste van de vennootschap en/of de kapitaalverschaffers zonder stemrecht. Op de kapitaalverschaffer met (doorslaggevend) stemrecht rust een bijzondere zorgplicht, inhoudende dat hij zijn eigen belang niet boven dat van de vennootschap en de minderheidsaandeelhouders mag stellen, zo volgt uit de rechtspraak. ${ }^{224}$ Die bijzondere zorgplicht geldt mijns inziens ook jegens de kapitaalverschaffers zonder stemrecht, die tot de kring van betrokkenen behoren.

De kapitaalverschaffer met (doorslaggevend) stemrecht overtreedt de grens van het toelaatbare indien hij bij de uitoefening van zijn stemrecht de belangen van de vennootschap en/of de kapitaalverschaffers zonder stemrecht, die tot de kring van betrokkenen behoren, onevenredig schaadt, bijvoorbeeld als de continuïteit van de onderneming wordt bedreigd. ${ }^{225}$ Indien de kapitaalverschaffer met (doorslaggevend)

222 HR 10 maart 1995, NJ 1995, 595, m.nt. Ma (Janssen Pers), r.o. 3.5.1.

223 Zie bijvoorbeeld Pres. Rb. Middelburg 14 april 1998, JOR 2000, 25, r.o. 3.1.2: “(...) Gelet op de problemen mag van Sandieson, zonder miskenning van haar belangen als aandeelhouder, niettemin, mede gezien de voor haar uit de samenwerkingsovereenkomst voortvloeiende verplichting de belangen van alle aandeelhouders na te streven en gezien de verantwoordelijkheid die zij als aandeelhouder mede draagt voor de belangen van andere belanghebbenden bij de vennootschap zoals werknemers, een constructieve benadering van mogelijke oplossingen worden verwacht."

224 Zie bijvoorbeeld, naast eerder genoemde jurisprudentie, Hof Amsterdam (OK) 14 januari 1993 , NJ 1993, 460 (VEB/KMZM), r.o. 5; Hof Amsterdam (OK) 17 april 1997, NJ 1997, 672 (Bobel), r.o. 3.1 onder b en r.o. 3.2.; Hof Amsterdam (OK) 22 september 2003, JOR 2003, 280 (Eendebak/ Schiphol Service); Hof Amsterdam (OK) 3 februari 2004, JOR 2004, 101 (Headscanning Patent), r.o. 3.6. en Hof Amsterdam (OK) 3 mei 2006, JOR 2006, 211 (Bonne Route Holding), r.o. 3.8 en 3.11. Zie ook Hendriks \& Koelemeijer 2009, p. 186.

225 Vgl. Van den Ingh 2000, p. 205 en 207; Assink 2009, p. 109; HR 30 juni 1944, NJ 1944, 465 (Wennex) en art. 3:13 BW. Niet rekening houden met het belang van de vennootschap kan onder omstandigheden tot uitstoting ex art. 2:336 BW leiden. 
stemrecht het niet eens is met het door het bestuur van de vennootschap gevoerde beleid en een koerswijziging wenst, zal (i) hij constructief overleg met het bestuur en de andere aandeelhouders moeten voeren (in of buiten de algemene vergadering), ${ }^{226}$ (ii) daarbij transparant moeten handelen en (iii) zijn beweegredenen voor de koerswijziging kenbaar moeten maken aan zowel het bestuur als de kapitaalverschaffers zonder stemrecht. ${ }^{227}$ Daarnaast stelt Van den Ingh dat van de tegenstemmende, gekwalificeerde aandeelhouder mag worden verwacht dat hij met een tegenvoorstel komt. $^{228}$ Volgt de kapitaalverschaffer met (doorslaggevend) stemrecht deze regels, dan acht ik de kans dat de kapitaalverschaffer zonder stemrecht slaagt in zijn vordering tot vernietiging van een besluit of in zijn enquêteverzoek aanzienlijk kleiner.

\subsection{Samenvatting en conclusie}

In dit hoofdstuk stonden de redelijkheid en billijkheid en zorgplichten in de BV, meer in het bijzonder ten aanzien van de kapitaalverschaffer zonder stemrecht, centraal. De norm van de vennootschappelijke redelijkheid en billijkheid van art. 2:8 BW is een open norm. De interne verhoudingen in de BV worden naast de wet en de statuten door deze norm inhoud gegeven.

De redelijkheid en billijkheid kunnen deze interne verhoudingen onder meer aanvullen of corrigeren. Uit de rechtspraak zijn algemene uitgangspunten te distilleren die deze open norm invulling geven. Koelemeijer ${ }^{229}$ schetst acht factoren die van invloed kunnen zijn op de belangenafweging door de rechter en die een rol spelen bij het bepalen van de eisen van de redelijkheid en billijkheid in een concreet geval, namelijk (i) hoedanigheid van de betrokkene(n) bij een belangenconflict, (ii) de invloed van de betrokkene(n) bij een belangenconflict, (iii) dubbelrollen of tegenstrijdig belang van de betrokkene(n) bij een belangenconflict, (iv) de aard en de inhoud van het besluit, (v) de gevolgen van het besluit of de gedraging van de betrokkene(n), (vi) de compensatie van de gevolgen van een besluit voor de betrokkene(n), (vii) het karakter van de vennootschap en (viii) de overeenkomst tussen de betrokkene(n). Toetsing aan de redelijkheid en billijkheid houdt een marginale toetsing in, zo luidt de heersende opvatting in de literatuur.

Van de kapitaalverschaffers zonder stemrecht behoren naar mijn mening de stemrechtloze aandeelhouder, de houder van certificaten van aandelen met vergaderrecht, de aandeelhouder wiens stemrecht is overgedragen aan de vruchtgebruiker of pandhouder en de houder van een participatiebewijs tot de kring van betrokkenen in de zin van art. 2:8 BW. De houder van certificaten van aandelen zonder vergaderrecht schaar ik niet onder de kring van betrokkenen, omdat de wil van de

\footnotetext{
226 Van den Ingh 2000, p. 208.

227 Vgl. Assink 2009, p. 110.

228 Van den Ingh 2000, p. 208 en Rb. Roermond 17 mei 1973, NJ 1974, 57.

229 Koelemeijer 1999, p. 339.
} 
vennootschap niet op die betrokkenheid is gericht. De statuten hebben aan de certificaten immers geen vergaderrecht toegekend.

Een aantal thema's in de vennootschappelijke redelijkheid en billijkheid is voor de kapitaalverschaffer zonder stemrecht die tot de kring van betrokkenen behoort in het bijzonder van belang. Deze thema's zijn: (i) het gelijkheidsbeginsel, (ii) bescherming van minderheidsaandeelhouders, (iii) besluiten die de rechten op winst en/of reserves raken, (iv) de verhouding tussen aandeelhouders onderling, (v) de zorgplicht van (het bestuur van) de vennootschap jegens de kapitaalverschaffer zonder stemrecht, (vi) het recht op informatie van de kapitaalverschaffer zonder stemrecht en (vii) de zorgplicht van de kapitaalverschaffer met (doorslaggevend) stemrecht jegens de kapitaalverschaffer zonder stemrecht. Uit de rechtspraak blijkt dat deze thema's vaak door elkaar heen lopen.

Ten aanzien van het gelijkheidsbeginsel geldt dat onderscheid tussen aandelen van een verschillende soort of aanduiding is toegestaan. Dat geldt ook voor stemrechtloze aandelen. Indien dat onderscheid bestaat, is geen sprake van schending van het gelijkheidsbeginsel in de zin van art. 2:201 lid 1 BW. Onderscheid tussen aandeelhouders van dezelfde soort of aanduiding is niet toegestaan. Het gelijkheidsbeginsel van art. 2:201 lid 2 BW geldt naar mijn mening ook voor certificaathouders met en zonder vergaderrecht en houders van participatiebewijzen. Ten aanzien van die laatsten geldt dat de grondslag daarvoor art. 2:8 $\mathrm{BW}$ is.

Uit de rechtspraak volgt dat afhankelijk van de omstandigheden van het geval sprake kan zijn van een zorgplicht van meerderheidsaandeelhouders jegens minderheidsaandeelhouders. Relevante omstandigheden zijn de aard van de samenwerking, de beslotenheid van de BV en familieverhoudingen. De belangen van alle aandeelhouders en de vennootschap zullen in acht genomen moeten worden. Daarbij zal de vraag beantwoord moeten worden of die belangen niet onevenredig worden geschaad. Indien deze relevante omstandigheden zich voordoen, kan eerder sprake zijn van belangenverstrengeling. Er geldt dan een verhoogde zorgplicht. Voor het antwoord op de vraag of sprake is van een ontoelaatbare belangenverstrengeling en onevenredige schending van belangen is de mate van openheid en informatieverstrekking van belang. Deze regels van bescherming van minderheidsaandeelhouders gelden naar mijn mening op gelijke wijze ten aanzien van de kapitaalverschaffers zonder stemrecht die tot de kring van betrokkenen behoren. Naast de genoemde relevante omstandigheden kan bij de invulling van de zorgplicht gekeken worden naar de vennootschappelijke structuur, de mate waarin de kapitaalverschaffer zonder stemrecht kapitaal verschaft en de mate waarin die kapitaalverschaffer, ondanks het ontbreken van stemrecht, zeggenschap in de vennootschap heeft, zoals bijvoorbeeld het recht tot benoemen van bestuurder(s) of commissaris(sen).

Ten aanzien van de besluiten die de rechten op winst en/of reserves raken, kunnen voor de kapitaalverschaffers zonder stemrecht, die tot de kring van betrokkenen behoren, drie relevante deelthema's worden onderscheiden: (i) winstreservering, (ii) besluiten omtrent de bezoldiging van bestuurders en commissarissen en (iii) overige besluiten die de rechten op winst en/of de reserves aantasten. Voor de besluitvorming 
rond winstreservering zou ik de door Bier ${ }^{230}$ ten aanzien daarvan geformuleerde regels ook voor de kapitaalverschaffers zonder stemrecht willen volgen, voor zover de aard van de rechtsfiguur zonder stemrecht zich daartegen niet verzet. ${ }^{231}$ Uit de rechtspraak volgt dat de algemene vergadering bij het vaststellen van de bezoldiging van bestuurders en commissarissen jegens winstgerechtigden de vennootschappelijke redelijkheid en billijkheid in acht moet nemen. Ik meen dat in de gestelde regel 'winstgerechtigden' als kapitaalverschaffers zonder stemrecht gelezen kan worden, mits zij tot de kring van betrokkenen behoren. Voor zover er geen specifieke beschermingsregel geldt, kunnen de kapitaalverschaffers zonder stemrecht die tot de kring van betrokkenen behoren ingeval van besluiten van de algemene vergadering of het bestuur die hun rechten op winst en/of reserves aantasten bescherming ontlenen aan de vennootschappelijke redelijkheid en billijkheid.

Voor de verhouding tussen aandeelhouders onderling, meer in het bijzonder de relatie meerderheids- en minderheidsaandeelhouder, geldt enerzijds dat de positie van de minderheidsaandeelhouder met zich brengt dat hij hem onwelgevallige besluiten tegen zich moet laten gelden. Anderzijds mag de meerderheidsaandeelhouder zijn macht niet misbruiken. De meerderheidsaandeelhouder moet bij het uitbrengen van zijn stem ook rekening houden met de redelijke belangen van de minderheidsaandeelhouder. Het voorgaande gaat mijns inziens ook op voor de verhouding tussen aandeelhouders met andere kapitaalverschaffers zonder stemrecht die tot de kring van betrokkenen behoren.

Ik meen dat de in de jurisprudentie ontwikkelde zorgplicht van (het bestuur van) de vennootschap jegens minderheidsaandeelhouders en certificaathouders ook voor de kapitaalverschaffers zonder stemrecht die tot de kring van betrokkenen behoren geldt. De inhoud van die zorgplicht is afhankelijk van de omstandigheden van het geval en de aard van de rechtsfiguur zonder stemrecht.

Het recht op informatie ex art. 2:217 lid 2 BW komt mijns inziens toe aan de stemrechtloze aandeelhouder, de houder van certificaten met vergaderrecht en de aandeelhouder die vanwege de overdracht van zijn stemrecht aan de vruchtgebruiker of pandhouder geen stemrecht heeft. Dat geldt niet voor de houder van certificaten zonder vergaderrecht. Hem ontbeert immers vergaderrecht. Evenmin kan de houder van een participatiebewijs rechten aan art. 2:217 lid $2 \mathrm{BW}$ ontlenen, tenzij in de participatievoorwaarden anders overeengekomen is.

Het komt mij voor dat de vergadergerechtigde kapitaalverschaffers zonder stemrecht als uitzondering wegens bijzondere omstandigheden op grond van de vennootschappelijke redelijkheid en billijkheid een recht op informatie (buiten vergadering) hebben. Het ASMI-arrest laat daarvoor mijns inziens ruimte. Wegens het bepaalde in art. 2:201 lid $2 \mathrm{BW}$ zal daarmee echter terughoudend moeten worden omgegaan. De bijzondere omstandigheden zijn met name gelegen bij transacties (i) met een mogelijk tegenstrijdig belang of belangenverstrengeling,

230 Zie Bier 2012 (1), p. 91.

$231 \mathrm{Zie}$ voor deze regels paragraaf 7.5.4.2, slot. 
(ii) strijdig met het vennootschappelijk belang en (iii) die onder op het eerste gezicht niet voor de hand liggende voorwaarden worden aangegaan. De bijzondere omstandigheden klemmen te meer in geval van een familievennootschap.

Van de kapitaalverschaffer met (potentieel) doorslaggevend stemrecht mag worden verlangd dat hij zich voorafgaand aan de algemene vergadering adequaat informeert. De informatie ziet op het voorliggende besluit zelf en de visie van het bestuur en, indien ingesteld, van de raad van commissarissen op de voorgenomen besluitvorming. Ook zal hij zich bij de uitoefening van zijn (doorslaggevend) stemrecht adequaat moeten informeren over (i) de kenbare gevolgen van zijn stemgedrag voor de vennootschap en (ii) de kenbare gevolgen voor en de gerechtvaardigde belangen van de kapitaalverschaffers zonder stemrecht, die tot de kring van betrokkenen in de zin van art. 2:8 BW behoren.

De kapitaalverschaffer met (doorslaggevend) stemrecht zal bij de aanwezigheid van een persoonlijk belang dat tegenstrijdig is aan de belangen van de vennootschap en de kapitaalverschaffers zonder stemrecht, die tot de kring van betrokkenen behoren, extra alert moeten zijn. Op de kapitaalverschaffer met (doorslaggevend) stemrecht rust een bijzondere zorgplicht, inhoudende dat hij zijn eigen belang niet boven dat van de vennootschap en de kapitaalverschaffers zonder stemrecht mag stellen. De kapitaalverschaffer met (doorslaggevend) stemrecht overtreedt de grens van het toelaatbare indien hij bij de uitoefening van zijn stemrecht de belangen van de vennootschap en/of de kapitaalverschaffers zonder stemrecht, die tot de kring van betrokkenen behoren, onevenredig schaadt. 



\section{Hoofdstuk 8}

\section{RECHTSVORDERINGEN VAN DE KAPITAALVERSCHAFFER ZONDER STEMRECHT}

\subsection{Inleiding}

In dit hoofdstuk staan de middelen van de kapitaalverschaffers zonder stemrecht om hun rechten af te dwingen centraal. Anders gezegd: het gaat om de hen toekomende rechtsvorderingen. Onder het begrip 'rechtsvordering' wordt verstaan de in rechte ingestelde eis om de materiële aanspraak af te dwingen. Aan dit materiële, subjectieve recht is het recht verbonden om de aanspraak af te dwingen door middel van het instellen van een rechtsvordering. ${ }^{1}$ Het kan daarbij gaan om een conventionele of een reconventionele vordering in een dagvaardingsprocedure, maar ook op een verzoek in het kader van een verzoekschriftprocedure.

De Commissie Vennootschapsrecht heeft erop gewezen dat het ontbreken van stemrecht aan het stemrechtloze aandeel kan leiden tot onevenwichtigheid in de zeggenschapsverhoudingen in de algemene vergadering. In die vergadering kan over allerlei kwesties besloten worden die bij oprichting van de BV niet waren voorzien. Het gevolg daarvan zou kunnen zijn een grotere druk op de rechterlijke macht, omdat de stemrechtloze aandeelhouder zich eerder in de knel voelt komen. Die aandeelhouder zou eerder geneigd zijn vernietiging van een besluit van de algemene vergadering wegens strijd met de vennootschappelijke redelijkheid en billijkheid te vorderen dan wel een enquête verzoeken of een vordering tot uittreding in te stellen. ${ }^{2}$

Het doel van de kapitaalverschaffer zonder stemrecht bij het gebruik van zijn rechtsvorderingen of de aanzegging daartoe is in de eerste plaats het te zijner gunste beïnvloeden van de besluitvorming. Middelen daartoe zijn het agenderingsrecht (paragraaf 8.2), het verzoek tot het bijeenroepen van een algemene vergadering (paragraaf 8.3), het verzoek tot het geven van inlichtingen (paragraaf 8.4) en de vordering tot medewerking tot het nemen van een besluit (paragraaf 8.5 ). In de

1 P.A. Stein \& A.S. Rueb, Compendium Burgerlijk Procesrecht, Deventer: Kluwer 2007, p. 4 en Snijder in sub 4b van zijn noot onder HR 25 januari 1991, NJ 1992, 172, m.nt. H.J. Snijders (Van Berkel/Tribosa).

2 Advies van de Commissie vennootschapsrecht over het wetsvoorstel inzake de vereenvoudiging en flexibilisering van het b.v.-recht d.d. 23 november 2006, p. 12, te vinden op http://www.rijksoverheid.nl/onderwerpen/flexibele-BV. 
tweede plaats is het doel van de kapitaalverschaffer zonder stemrecht genomen besluiten aan te vechten ter handhaving of verbetering van zijn rechtspositie. Middelen daartoe zijn de vordering tot vernietiging van art. 2:15 BW wegens strijd met de vennootschappelijke redelijkheid en billijkheid (paragraaf 8.6) en het enquêterecht (paragraaf 8.8). Daarnaast bestaat de mogelijkheid in kort geding een gebod of verbod te vorderen indien sprake is van (een dreiging van) schending van de zorgplicht jegens de kapitaalverschaffer zonder stemrecht (paragraaf 8.7). Een andere, mogelijke rechtsvordering die de kapitaalverschaffer zonder stemrecht ten dienste staat is de geschillenregeling (paragraaf 8.9).

In de genoemde paragrafen zal worden onderzocht wie van de kapitaalverschaffers zonder stemrecht welke rechtsvordering toekomt. Ik beperk mij slechts tot die vraag. Ik zal daarom niet de rechtsvordering zelf bespreken, anders dan ter inleiding. In de literatuur is over deze rechtsvorderingen reeds veel en veelvuldig geschreven.

Het antwoord op de vraag wie van de kapitaalverschaffers zonder stemrecht welke rechtsvordering toekomt, leidt tot een aantal knelpunten in de rechtspositie van de betreffende kapitaalverschaffer zonder stemrecht, meer in het bijzonder in de rechtspositie van de stemrechtloze aandeelhouder. De vraag is of deze rechtsvorderingen de stemrechtloze aandeelhouder voldoende soelaas bieden. Daarom stel ik in paragraaf 8.10 aan de orde of het stemrecht op het stemrechtloze aandeel zou moeten 'herleven'. In paragraaf 8.11 bespreek ik welke middelen, anders dan rechtsvorderingen, de stemrechtloze aandeelhouder ten dienste zouden kunnen staan om zijn rechtspositie te versterken.

Tot slot kom ik in paragraaf 8.12 tot een samenvatting en conclusie.

\subsection{Agenderingsrecht}

\section{Aard van het middel}

Art. 2:224 BW stelt dat de oproep voor de algemene vergadering de te behandelen onderwerpen vermeldt. Art. 2:224a BW bepaalt dat een onderwerp, waarvan de behandeling schriftelijk is verzocht door een of meer houders van aandelen die alleen of gezamenlijk ten minste een honderdste gedeelte van het geplaatste kapitaal vertegenwoordigen, wordt opgenomen in de oproeping of op dezelfde wijze aangekondigd indien de vennootschap het verzoek niet later dan op de dertigste dag voor die van de vergadering heeft ontvangen en mits geen zwaarwichtig belang van de vennootschap zich daartegen verzet. In de statuten kan het vereiste gedeelte van het kapitaal lager worden gesteld en de termijn voor indiening van het verzoek worden verkort.

Welke kapitaalverschaffer zonder stemrecht komt het agenderingsrecht toe? Uit art. 2:224a lid $1 \mathrm{BW}$ volgt dat het agenderingsrecht toekomt aan een of meer houders van aandelen die alleen of gezamenlijk ten minste een honderdste gedeelte van het geplaatste kapitaal vertegenwoordigen. Op grond van art. 2:24d lid 2 BW tellen stemrechtloze aandelen bij het bepalen van deze één procent-drempel mee. 
De wettekst spreekt van 'aandeelhouders', zodat het agenderingsrecht toekomt aan de stemrechtloze aandeelhouder ${ }^{3}$ en de houder van aandelen waarvan het stemrecht is overgedragen aan de vruchtgebruiker of pandhouder. ${ }^{4}$

Uit art. 2:224a lid $2 \mathrm{BW}$ volgt dat de certificaathouder zonder vergaderrecht buiten spel staat. Voor de toepassing van art. 2:224a BW worden overige vergadergerechtigden ${ }^{5}$ met aandeelhouders gelijk gesteld. De certificaathouder met vergaderrecht komt het agenderingsrecht wel toe. ${ }^{6}$

De houder van een participatiebewijs komt het agenderingsrecht niet toe, tenzij de participatievoorwaarden anders bepalen. Dat laatste lijkt mij niet voor de hand liggen, omdat deze kapitaalverschaffer in de regel op meer afstand van de vennootschap staat dan de vergadergerechtigde kapitaalverschaffers zonder stemrecht. De conclusie is dan ook dat alleen vergadergerechtigden agenderingsgerechtigd zijn.

Art. 2:224a BW is van dwingend recht voor de stemrechtloze aandeelhouder, de houder van aandelen waarvan het stemrecht is overgedragen aan de vruchtgebruiker of pandhouder en de houder van certificaten met vergaderrecht. Ten aanzien van deze kapitaalverschaffers zonder stemrecht kan het agenderingsrecht niet worden uitgesloten. $^{7}$

Afwijzing agenderingsverzoek

Indien het verzoek tot agendering wordt afgewezen, staat de agenderingsgerechtigde een aantal middelen ten dienste. ${ }^{8}$ Allereerst kan het besluit tot afwijzing worden aangevochten op de voet van art. 2:8 jo. 2:15 lid 1 sub b BW. Daarnaast kan gebruik worden gemaakt van het recht op inlichtingen in de zin van art. 2:217 lid 2 BW. Indien het verzoek zonder (deugdelijke) motivering is afgewezen, kan de agenderingsgerechtigde tijdens de algemene vergadering een toelichting daarop vragen. Ook kan de agenderingsgerechtigde in kort geding vorderen dat het bestuur wordt bevolen alsnog het aangedragen agendapunt op de agenda te plaatsen en te verbieden dat de algemene vergadering zal plaatsvinden zonder het aangedragen agendapunt, een en ander op straffe van verbeurte van een dwangsom. In de literatuur wordt tevens de mogelijkheid genoemd de bestuurder op grond van onbehoorlijk bestuur of onrechtmatige daad an te spreken. ${ }^{9}$ Tot slot kan gedacht worden aan een enquêteverzoek, stellende dat een niet gemotiveerde of onterechte afwijzing van het agenderingsverzoek door het bestuur een gegronde reden is om aan een juist beleid te twijfelen.

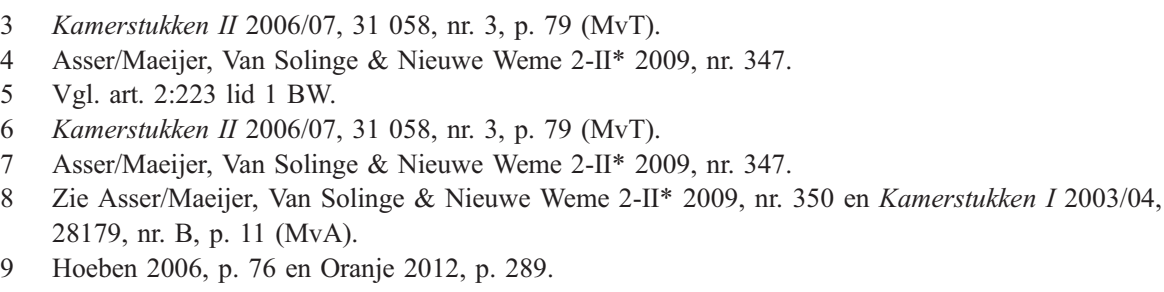




\section{Beschouwing}

Allereerst rijst de vraag wat het agenderingsrecht de vergadergerechtigde brengt. Het antwoord daarop is dat hij door middel van zijn vergaderrecht tijdens de algemene vergadering kan trachten de besluitvorming over het door hem naar voren gebrachte agendapunt te zijnen gunste te beïnvloeden. Feit blijft echter dat hij niet stemgerechtigd is. Mocht de kapitaalverschaffer zonder stemrecht met agenderingsrecht 'overstemd' worden, dan staat hem nog vernietiging van het besluit ex art. 2:8 jo. 2:15 lid 1 sub b BW ter beschikking.

Een volgende vraag is of de één procent-drempel voor de agenderingsgerechtigde een knelpunt is. Dat lijkt mij niet. Eén procent is geen hoge drempel. Daarnaast volgt uit de laatste volzin van art. 2:224a lid $1 \mathrm{BW}$ dat in de statuten kan worden bepaald de drempel lager te stellen.

Tot slot heeft de houder van een participatiebewijs, zijnde een kapitaalverschaffer zonder stemrecht en zonder agenderingsrecht, het recht te vorderen dat het hem onwelgevallige besluit ex art. 2:8 jo. 2:15 lid 1 sub b BW wordt vernietigd. In paragraaf 8.6 zal ik betogen dat de houder van een certificaat zonder vergaderrecht dit recht niet toekomt.

\subsection{Verzoek tot bijeenroepen algemene vergadering}

\section{Aard van het middel}

Art. 2:220 BW bepaalt dat een of meer houders van aandelen die alleen of gezamenlijk ten minste een honderdste gedeelte van het geplaatste kapitaal vertegenwoordigen aan het bestuur en aan de raad van commissarissen schriftelijk en onder nauwkeurige opgave van de te behandelen onderwerpen het verzoek kunnen richten een algemene vergadering bijeen te roepen. Het bestuur en de raad van commissarissen - daartoe in dit geval gelijkelijk bevoegd - treffen de nodige maatregelen, opdat de algemene vergadering binnen vier weken na het verzoek kan worden gehouden, tenzij een zwaarwichtig belang van de vennootschap zich daartegen verzet. In de statuten kan het vereiste gedeelte van het kapitaal lager worden gesteld en de termijn waarbinnen de algemene vergadering moet worden gehouden worden verkort.

Onder het oude recht bedroeg de drempel voor het verzoek tot bijeenroepen van een algemene vergadering tien procent. De wetgever heeft de verlaging van deze drempel tot één procent als volgt toegelicht: "De expertgroep heeft aanbevolen artikel 220 te wijzigen, door te bepalen dat individuele aandeelhouders zonder rechterlijke tussenkomst om een vergadering kunnen verzoeken. Deze aanbeveling is overgenomen, met dien verstande dat het recht wordt toegekend aan een of meer aandeelhouders die alleen of gezamenlijk ten minste een honderdste deel van het geplaatste kapitaal vertegenwoordigen. De positie van minderheidsaandeelhouders wordt hiermee versterkt. Op advies van de commissie vennootschapsrecht is bij de uitwerking aangesloten bij het agenderingsrecht in artikel 224a, waarvoor ook een 
grens geldt van een honderdste van het geplaatste kapitaal. In de onderlinge verhouding tussen artikel $224 a$ en het voorgestelde artikel 220 is het wenselijk dat de drempel voor het bijeenroepen van een vergadering en het agenderen van een onderwerp gelijk is." ${ }^{\prime 10}$

Welke kapitaalverschaffer zonder stemrecht komt het bijeenroepingsrecht van art. 2:220 BW toe?

Uit art. 2:220 lid $1 \mathrm{BW}$ volgt dat het bijeenroepingsrecht toekomt aan een of meer houders van aandelen die alleen of gezamenlijk ten minste een honderdste gedeelte van het geplaatste kapitaal vertegenwoordigen. Op grond van art. 2:24d lid 2 BW tellen stemrechtloze aandelen bij het bepalen van deze één procent-drempel mee.

De wettekst spreekt van 'aandeelhouders', zodat het bijeenroepingsrecht toekomt aan de stemrechtloze aandeelhouder ${ }^{11}$ en de houder van aandelen waarvan het stemrecht is overgedragen aan de vruchtgebruiker of pandhouder. ${ }^{12}$

Art. 2:220 lid $2 \mathrm{BW}$ bepaalt dat met houders van aandelen in de zin van het artikel gelijk worden gesteld anderen aan wie het vergaderrecht toekomt, zoals de houder van certificaten met vergaderrecht. ${ }^{13}$ De houder van certificaten zonder vergaderrecht heeft het bijeenroepingsrecht niet. Datzelfde geldt voor de houder van een participatiebewijs. Ook hem komt het agenderingsrecht niet toe, tenzij de participatievoorwaarden anders bepalen. Dat laatste lijkt mij niet voor de hand liggen, omdat de houder in de regel wat verder van de vennootschap af staat. De logische conclusie is dan ook dat alleen vergadergerechtigden bijeenroepingsgerechtigd zijn.

Art. 2:220 BW is van dwingend recht voor de stemrechtloze aandeelhouder, de houder van aandelen waarvan het stemrecht is overgedragen aan de vruchtgebruiker of pandhouder en de houder van certificaten met vergaderrecht. Ten aanzien van deze kapitaalverschaffers zonder stemrecht kan het bijeenroepingsrecht niet worden uitgesloten.

\section{Afwijzing bijeenroepingsverzoek}

De laatste volzin van art. 2:220 BW bepaalt dat indien het bestuur en de raad van commissarissen geen uitvoering geven aan het verzoek, de bijeenroepingsgerechtigden op hun verzoek door de voorzieningenrechter van de rechtbank gemachtigd kunnen worden tot de bijeenroeping van de algemene vergadering.

Uit art. 2:221 BW volgt dat de voorzieningenrechter van de rechtbank, ${ }^{14}$ na verhoor of oproeping van de vennootschap, de verzochte machtiging verleent,

10 Kamerstukken II 2006/07, 31 058, nr. 3, p. 77 (MvT).

11 Kamerstukken II 2006/07, 31 058, nr. 3, p. $77-78$ (MvT) en Kamerstukken II 2008/09, 31 058, nr. 6, p. 14 (NV II)

12 Asser/Maeijer, Van Solinge \& Nieuwe Weme 2-II* 2009, nr. 335.

13 Kamerstukken II 2006/07, 31 058, nr. 3, p. 82 (MvT) en Kamerstukken II 2008/09, 31 058, nr. 6, p. 14 (NV II). Asser/Maeijer, Van Solinge \& Nieuwe Weme 2-II* 2009, nr. 335.

14 Ten aanzien van de relatieve bevoegdheid geldt art. $995 \mathrm{Rv}$ 
indien de verzoekers summierlijk hebben doen blijken, dat de in art. 2:220 BW gestelde voorwaarden zijn vervuld, en dat zij een redelijk belang hebben bij het houden van de vergadering. De voorzieningenrechter wijst het verzoek af, indien een zwaarwichtig belang van de vennootschap zich tegen het houden van een algemene vergadering verzet. Indien de voorzieningenrechter de verzochte machtiging verleent, stelt hij de vorm en de termijnen voor de oproeping tot de algemene vergadering vast. Bij deze oproeping wordt vermeld dat zij krachtens rechterlijke machtiging geschiedt. De op deze wijze gedane oproeping is rechtsgeldig, ook indien mocht blijken dat de machtiging ten onrechte was verleend. Tegen de beschikking van de voorzieningenrechter kan alleen cassatie in het belang der wet worden ingesteld.

\section{Beschouwing}

Allereerst rijst de vraag wat het bijeenroepingsrecht de vergadergerechtigde brengt. Het antwoord daarop is dat hij door middel van zijn vergaderrecht tijdens de algemene vergadering kan trachten de besluitvorming te zijnen gunste te beïnvloeden. Feit blijft echter dat hij niet stemgerechtigd is. Mocht de kapitaalverschaffer zonder stemrecht 'overstemd' worden, dan staat hem nog vernietiging van het besluit ex art. 2:8 jo. 2:15 lid 1 sub b BW ter beschikking.

Een volgende vraag is of de één procent-drempel voor de bijeenroepingsgerechtigde een knelpunt is. Dat lijkt mij niet. Eén procent is geen hoge drempel. Daarnaast volgt uit de een na laatste volzin van art. 2:220 lid 1 BW dat in de statuten kan worden bepaald de drempel lager te stellen.

Tot slot heeft de houder van een participatiebewijs, zijnde de kapitaalverschaffer zonder stemrecht en zonder bijeenroepingsrecht, het recht te vorderen dat het hem onwelgevallige besluit ex art. 2:8 jo. 2:15 lid 1 sub b BW wordt vernietigd. In paragraaf $8.6 \mathrm{zal}$ ik betogen dat de houder van een certificaat zonder vergaderrecht dit recht niet toekomt.

\subsection{Afdwingen van het recht van inlichtingen}

Inleiding

In paragraaf 7.5.7 concludeerde ik dat de stemrechtloze aandeelhouder, de houder van een aandeel wiens stemrecht is overgedragen aan de vruchtgebruiker of pandhouder en de houder van een certificaat met vergaderrecht tijdens de algemene vergadering een recht op informatie hebben. Ik concludeerde ook dat, als uitzondering op de hoofdregel, alle kapitaalverschaffers zonder stemrecht wegens bijzondere omstandigheden op grond van de vennootschappelijke redelijkheid en billijkheid een recht op informatie buiten vergadering hebben. Gelet op die laatste, uitzonderlijke situatie ga ik in deze paragraaf slechts in op de vraag: welke rechtsmiddelen hebben de stemrechtloze aandeelhouder, de houder van een aandeel wiens stemrecht is overgedragen aan de vruchtgebruiker of pandhouder en de 
houder van een certificaat met vergaderrecht indien tijdens de algemene vergadering zijn recht op informatie is geschonden? ${ }^{15}$

Welke rechtsmiddelen?

a. art. 2:217 lid $2 \mathrm{BW}$

Een vordering tot het verstrekken van informatie zal tegen de vennootschap zelf moeten worden ingesteld. Het is echter het bestuur (of de raad van commissarissen) die de informatie uiteindelijk verschaft. ${ }^{16}$ De grondslag van de vordering is art. 2:217 lid 2 BW. ${ }^{17}$ In de literatuur wordt gesteld dat de enkele vordering tot het verstrekken van informatie niet voldoende is. Er moeten bijkomende en bijzondere omstandigheden aanwezig zijn. ${ }^{18}$ Naar mijn mening komt de vordering tot het verstrekken van informatie alleen de vergadergerechtigde kapitaalverschaffers zonder stemrecht toe. ${ }^{19}$ Uit de literatuur en rechtspraak blijkt dat deze kapitaalverschaffers eerst tijdens de algemene vergadering tevergeefs om informatie moeten hebben gevraagd, anders ontbreekt belang bij hun vordering. ${ }^{20}$

b. $\quad$ art. $843 \mathrm{a} \mathrm{Rv}$

Naast een vordering tot het verstrekken van informatie op grond van art. 2:217 lid 2 BW kan gedacht worden aan een vordering tot inzage ex art. 843a Rv. ${ }^{21}$ Art. 843a lid $1 \mathrm{Rv}$ bepaalt dat hij die daarbij rechtmatig belang heeft, op zijn kosten inzage, afschrift of uittreksel kan vorderen van bepaalde bescheiden aangaande een rechtsbetrekking waarin hij of zijn rechtsvoorgangers partij zijn, van degene die deze bescheiden te zijner beschikking of onder zijn berusting heeft. Onder bescheiden worden mede verstaan: op een gegevensdrager aangebrachte gegevens. Ook ten

15 Ik laat ook buiten beschouwing de vordering tot nakoming van een contractuele verplichting tot het verstrekken van informatie, bijvoorbeeld op grond van een aandeelhoudersovereenkomst.

16 Asser/Maeijer, Van Solinge \& Nieuwe Weme 2-II* 2009, nr. 327 onder d; Van der Korst 2007, p. 175-176; Vletter-van Dort 2001, p. 93 en p. 95-98; De Groot \& Bakker 2011, p. 253-254 en Vletter-van Dort 2012, p. 217. Zie ook Pres. Rb. Amsterdam 27 juli 1999, JOR 1999, 178, m.nt. Nieuwe Weme (VEB/Otra) en Pres. Rb. Amsterdam 22 mei 2000, JOR 2000, 129 (World Online).

17 Zie voor vorderingen tot het verstrekken van informatie buiten art. 2:217 BW: Van der Korst 2007, p. 174-186.

18 Van der Korst 2007, p. 176 en de op die pagina in voetnoot 104 genoemde jurisprudentie; De Groot \& Bakker 2011, p. 253 en Vletter-van Dort 2012, p. 218.

19 Vgl. Vletter-van Dort 2001, p. 100. Zij concludeert tot een bevoegdheid van de individuele aandeelhouder, en niet slechts de algemene vergadering als collectief, tot het instellen van de vordering. In gelijke zin De Groot \& Bakker 2011, p. 253

20 Art. 3:303 BW. Pres. Rb. Amsterdam 22 mei 2000, JOR 2000, 129 (World Online). Vzr. Rb. Leeuwarden 15 april 2009, LJN BI3631, JOR 2009, 187, m.nt. T.S. Jansen, r.o. 4.4. De Groot \& Bakker 2011, p. 254.

21 Zie uitgebreid over dit artikel: J. Ekelmans, De exhibitieplicht (diss. Groningen), Deventer: Kluwer 2010; J.R. Sijmonsma, Het inzagerecht, Artikel 843 a van het Wetboek van Burgerlijke Rechtsvordering (diss. Maastricht), Deventer: Kluwer 2010 en T.S. Jansen, 'Verboden te vissen, maar vragen mag. Art. 843a Rv in de ondernemingsrechtpraktijk', TOP 2009-3, p. 89-94. 
aanzien van de grondslag geldt naar mijn mening dat de exhibitieplicht van art. 843a Rv alleen de vergadergerechtigde kapitaalverschaffers zonder stemrecht toekomt. ${ }^{22}$ Ter zake van het rechtmatig belang moet het gaan om een tijdens de algemene vergadering geschonden informatierecht. Doel van de vordering is om deze informatie alsnog te verschaffen aan deze kapitaalverschaffers zonder stemrecht, maar - gelet op het gelijkheidsbeginsel - ook aan andere vergadergerechtigde kapitaalverschaffers. Ook geldt hier dat de vordering jegens de vennootschap zal moeten worden ingesteld en dat het bestuur of de raad van commissarissen de informatie bij toewijzing zal moeten verschaffen. ${ }^{23}$

c. voorlopig getuigenverhoor

Het Perrier/Marceau-arrest ${ }^{24}$ is een voorbeeld van het verkrijgen van informatie van de vennootschap door een minderheidsaandeelhouder buiten de mogelijkheden van Boek 2 BW om. Marceau hield 3,45 procent van de aandelen in Perrier en was voornemens een rechtsvordering tegen Perrier in te stellen. In dat kader had zij belang om via een voorlopig getuigenverhoor informatie te verkrijgen. Als minderheidsaandeelhouder werd Marceau als belanghebbende aangemerkt en werd het verzoek tot het houden van een voorlopig getuigenverhoor ingewilligd.

Het verzoek tot het houden van een voorlopig getuigenverhoor ex art. $186 \mathrm{Rv}$ kan worden afgewezen indien sprake is van misbruik van bevoegdheid. Daarvan is onder meer sprake indien de verzoeker wegens de onevenredigheid van de over en weer betrokken belangen in redelijkheid niet tot toepassing van die bevoegdheid kan worden toegelaten. Een andere afwijzingsgrond is strijd met de goede procesorde of een ander zwaarwichtig belang. Een laatste afwijzingsgrond is dat er geen belang bij het verzoek is. ${ }^{25}$

De vergadergerechtigde kapitaalverschaffer zonder stemrecht kan naar mijn mening in voorkomend geval een voorlopig getuigenverhoor verzoeken indien hij tijdens de algemene vergadering tevergeefs om informatie heeft gevraagd. Die laatste voorwaarde sluit aan bij hetgeen in de literatuur wordt gesteld, namelijk dat de individuele aandeelhouder het collectieve geschonden informatierecht tijdens de algemene vergadering zal moeten benadrukken teneinde te voorkomen dat wegens

22 Vgl. Vletter-van Dort 2001, p. 100. Zij concludeert tot een bevoegdheid van de individuele aandeelhouder, en niet slechts de algemene vergadering als collectief, tot het instellen van de vordering. In gelijke zin De Groot \& Bakker 2011, p. 253.

23 In gelijke zin: De Groot \& Bakker 2011, p. 258-259.

24 HR 20 oktober 1995, NJ 1996, 120, m.nt. Ma (Perrier/Marceau). Zie hierover ook Vletter-van Dort 2001, p. 229 e.v.

25 Zie sub 2 van de $N J$-noot van Maeijer onder HR 20 oktober 1995, NJ 1996, 120, m.nt. Ma (Perrier/ Marceau). HR 6 februari 1987, NJ 1988, 1, m.nt. W.H. Heemskerk (Slingerland/Amsterdam); HR 19 februari 1993, NJ 1994, 345, m.nt. H.J. Snijders (Van de Ven/Pierik); HR 11 februari 2005, LJN AR6809, NJ 2005, 442 (Frog People Mover/Floriade) en HR 21 november 2008, LJN BF3938, NJ 2008, 608 (Udo/Renault Nissan). Art. 3:303 BW. 
gebrek aan eigen belang van de verzoekende aandeelhouders het verzoek wordt afgewezen. ${ }^{26}$

\section{d. enquêterecht}

Is het enquêterecht een middel voor de vergadergerechtigde kapitaalverschaffer zonder stemrecht om de tijdens de algemene vergadering tevergeefs verzochte informatie alsnog te verkrijgen? Uit hoofdstuk 7 volgt dat een onderdeel van de zorgplicht jegens de kapitaalverschaffer zonder stemrecht is het hen tijdig, voldoende en correct van informatie voorzien. Ik verwijs naar paragraaf 7.5.6 en 7.5.7. Daarbij past de kanttekening dat uit de HBG-beschikking ${ }^{27}$ volgt dat de eenmalige, gebrekkige wijze waarop het bestuur en de raad van commissarissen de algemene vergadering hebben geïnformeerd nog geen wanbeleid oplevert. Er was in die beschikking geen sprake van herhaaldelijk en stelselmatig tekort schieten op dit punt. Weliswaar kan ook een enkele gedraging wanbeleid opleveren, met name indien die gedraging tot voor de onderneming zeer schadelijke gevolgen heeft geleid. ${ }^{28}$ In de HBG-beschikking was geen sprake van zeer schadelijke gevolgen, doch van het ontstaan van misverstanden en een vertrouwensbreuk met de aandeelhouders. De VIBA-beschikking ${ }^{29}$ ligt in lijn met het voorgaande. Het onvoldoende verstrekken van informatie kan niet als wanbeleid worden aangemerkt indien het, zoals in de VIBA-beschikking, niet opzettelijk is gebeurd en slechts heeft geleid tot de mogelijkheid dat bij een deel van de aandeelhouders de onterechte indruk bleef bestaan dat sprake was van onaanvaardbare belangenverstrengeling.

Tegen deze achtergrond is het de vraag of de vergadergerechtigde kapitaalverschaffer zonder stemrecht het enquêterecht kan gebruiken om de informatie te vergaren die hem tijdens de algemene vergadering is onthouden. Het antwoord daarop luidt mijns inziens ontkennend. Ik verwijs daarbij naar de Meefout/Meepobeschikking. ${ }^{30}$ Daarin overwoog de OK dat een verzoek ex art. 843a Rv niet in het stelsel van het enquêterecht past. Of anders gezegd: indien een onderzoek ex art. 2:345 lid $1 \mathrm{BW}$ bevolen is, is er geen plaats voor een verzoek ex art. 843a Rv. De wet voorziet door middel van het recht van enquête in een aparte rechtsgang voor het instellen van een onderzoek naar het beleid en de gang van zaken van een rechtspersoon. Dat onderzoek is de kern van het enquêterecht. De OK kan in aansluiting op het verslag van het onderzoek voorzieningen treffen indien uit het verslag van wanbeleid van de rechtspersoon is gebleken. Een verzoek ex art. 843a $\mathrm{Rv}$ zou het stelstel van het enquêterecht op onaanvaardbare wijze doorkruisen, indien naast het onderzoek naar het beleid en de gang van zaken van een rechtspersoon een partij zelfstandig onderzoek kan (laten) doen naar feiten of

26 De Groot \& Bakker 2011, p. 262.

27 HR 21 februari 2003, LJN AF1486, NJ 2003, 182, m.nt. Ma, JOR 2003, 57, m.nt. M.P. Nieuwe Weme (HBG), r.o. 6.8.2.

28 HR 10 januari 1990, NJ 1990, 466, m.nt. Ma (Ogem II)

29 HR 21 februari 2003, LJN AF1797, NJ 2003, 181, JOR 2003, 58, m.nt. M. Brink (VIBA), r.o. 3.4.3.

30 Hof Amsterdam (OK) 27 juni 2007, JOR 2007, 268, m.nt. Van der Korst (Meefout/Meepo). 
omstandigheden die van belang (kunnen) zijn voor de beoordeling van het beleid en de gang van zaken van een rechtspersoon. De OK ziet het onderzoek op grond van art. 2:345 lid $1 \mathrm{BW}$ als een lex specialis van het bepaalde in art. 843a Rv. De uitkomsten van een inzage op grond van art. 843a Rv kunnen niet als grondslag dienen voor een door de OK te nemen beslissing ex art. 2:354, 2:355 en 2:356 BW. Deze beslissingen kunnen slechts gebaseerd zijn op het verslag van de door de OK benoemde onderzoeker, aldus de OK. ${ }^{31}$ Met andere woorden: het enquêterecht moet voor het doel gebruikt worden, waarvoor het in de wet is opgenomen. Het enquêterecht kan niet louter gebruikt worden om informatie te verkrijgen in het kader van een eigen onderzoek van de verzoeker.

In de literatuur ${ }^{32}$ wordt terecht op grond van de Skygate-beschikking ${ }^{33}$ verdedigd dat, indien de toestand van de vennootschap of het belang van het onderzoek dat vergt, de vennootschap op grond van een onmiddellijke voorziening gelast kan worden de aandeelhouder de tijdens de algemene vergadering onthouden informatie te verschaffen. In dat geval gaat het dus om de toestand van de vennootschap of het belang van het onderzoek - en niet het belang van de aandeelhouder - die of dat de verstrekking van de informatie aan de aandeelhouder rechtvaardigt. Ik zou deze lijn voor de vergadergerechtigde kapitaalverschaffer zonder stemrecht willen overnemen.

\section{e. $\operatorname{art.} 3: 15 \mathrm{j} \mathrm{BW}$}

Art. 3:15j BW bepaalt onder meer dat openlegging van tot een administratie behorende boeken, bescheiden en andere gegevensdragers kunnen, voorzover zij daarbij een rechtstreeks en voldoende belang hebben, vorderen vennoten, ten aanzien van de boekhouding van de vennootschap, en schuldeisers in het geval van faillissement of toepassing van de schuldsaneringsregeling natuurlijke personen, ten aanzien van de boekhouding van de failliet of degene ten aanzien van wie de schuldsaneringsregeling van toepassing is.

In de literatuur zijn de meningen verdeeld over de vraag of art. 3:15j BW een grondslag kan zijn voor de vordering tot informatieverstrekking indien daarom tijdens de algemene vergadering tevergeefs is gevraagd. ${ }^{34}$ Op grond van de wetsgeschiedenis $^{35}$ moet worden uitgegaan van het niet-limitatieve karakter van art. 3:15j BW. Ook het ASMI-arrest ${ }^{36}$ staat er mijns inziens niet aan in de weg dat

31 r.o. 3.4 en 3.5. Gelijke bewoordingen zijn de vinden in Hof Amsterdam (OK) 9 januari 2004, NJ 2004, 168, JOR 2004, 72, m.nt. Brink (Laurus), r.o. 3.4 en HR 27 september 2000, LJN AA7245, NJ 2000, 653, JOR 2000, 217, m.nt. Brink (Gucci), r.o. 4.2. Zie ook Rb. Breda 4 november 2003, JOR 2004, 97, m.nt. Brink.

32 De Groot \& Bakker 2011, p. 256.

33 HR 19 oktober 2001, NJ 2002, 92, m.nt Ma, JOR 2002, 5, m.nt. Van den Ingh (Skygate), r.o. 3.6.

34 Tegen: De Groot \& Bakker 2011, p. 260-261. Zie ook Van der Korst 2007, p. 91. Voor: Van Veersen 2006, p. 9 en Wijers \& Haasjes 2006, p. 52.

35 Kamerstukken II 2000/01, 27 284, nr. 3, p. 8-9 (MvT).

36 HR 9 juli 2010, LJN BM0976, NJ 2010, 544, m.nt. Van Schilfgaarde, JOR 2010, 228, m.nt. Van Ginneken (ASMI). 
de vergadergerechtigde kapitaalverschaffer zonder stemrecht op grond van art. 3:15j BW openlegging kan vorderen indien tijdens de algemene vergadering zijn recht op informatie is geschonden.

\section{f. art. 22 en $162 \mathrm{Rv}$}

Art. $22 \mathrm{Rv}$ geeft een algemeen voorschrift voor procedures en bepaalt onder meer dat de rechter in alle gevallen en in elke stand van de procedure partijen of een van hen kan bevelen bepaalde stellingen toe te lichten of bepaalde, op de zaak betrekking hebbende bescheiden over te leggen. In het kader van het bewijsrecht kan de rechter op grond van art. $162 \mathrm{Rv}$ in de loop van een geding, op verzoek of ambtshalve, aan partijen of aan een van hen de openlegging bevelen van de boeken, bescheiden en geschriften, die zij ingevolge de wet moeten houden, maken of bewaren. Beide bepalingen drukken de discretionaire bevoegdheid van de rechter uit. In de literatuur wordt mijns inziens terecht gesteld dat deze artikelen de aandeelhouder slechts te hulp kan schieten indien de informatieverstrekking tijdens de algemene vergadering en het vergeefse verzoek daartoe van de aandeelhouder onderwerp van geschil, of beter: de procedure, is. Gelet op de discretionaire bevoegdheid van de rechter is het echter de vraag of deze artikelen de aandeelhouder daadwerkelijk te hulp kunnen schieten. ${ }^{37}$ Ik meen dat het voorgaande in gelijke mate op gaat voor de vergadergerechtigde kapitaalverschaffer zonder stemrecht.

\subsection{Vordering tot medewerking tot het nemen van een besluit}

\section{Aard van het middel}

In de literatuur wordt de mogelijkheid geopperd dat de vennootschap onder omstandigheden op grond van de aanvullende werking van de vennootschappelijke redelijkheid en billijkheid van een grootaandeelhouder vordert dat die aandeelhouder meewerkt tot het nemen van een besluit, bijvoorbeeld de vaststelling van de jaarrekening na eerdere weigering daartoe. ${ }^{38}$

In het vonnis van de rechtbank Roermond van 17 mei $1973^{39}$ ging het om een grootaandeelhouder in een NV. Hij stemde tegen de vaststelling van de jaarrekening zonder concreet aan te geven in hoeverre die jaarstukken naar zijn mening gewijzigd moesten worden. Daarmee verhinderde hij de vaststelling van de, al dan niet gewijzigde, jaarstukken. De rechtbank acht dat in strijd met de vennootschappelijke redelijkheid en billijkheid, zowel jegens de andere aandeelhouders als jegens de vennootschap. De rechtbank oordeelde bovendien dat de grootaandeelhouder zich niet rechtsgeldig tegen de vaststelling van de jaarrekening heeft verzet, zodat deze is vastgesteld. Daarnaast veroordeelde de rechtbank de grootaandeelhouder tijdens de

37 De Groot \& Bakker 2011, p. 259-260.

38 De Monchy \& Timmerman 1991, p. 51.

39 Rb. Roermond 17 mei 1973, NJ 1974, 57. 
eerstkomende algemene vergadering aan de andere aandeelhouders gemotiveerd kenbaar te maken waarom hij niet kan instemmen met de vaststelling, al dan niet in gewijzigde vorm, van de jaarrekeningen van andere boekjaren, bij gebreke waarvan de grootaandeelhouder wordt geacht zich van stemming over die andere jaarrekeningen te hebben onthouden. Tot slot oordeelde de rechtbank dat de grootaandeelhouder, zolang hij over de meerderheid van het geplaatste aandelenkapitaal beschikt en de jaarvergaderingen bijwoont, gehouden is gemotiveerd te verklaren over de door het bestuur opgemaakte jaarstukken en aan de vaststelling van die - al dan niet gewijzigde - jaarstukken mede te werken, bij gebreke waarvan hij geacht wordt zich van stemming over die jaarstukken te hebben onthouden.

Uit het eerder besproken Van Rees/Smits-arrest ${ }^{40}$ volgt dat het besluit van de algemene vergadering de restantwinst zodanig te verdelen, dat de minderheidsaandeelhouders, die voor het genieten van winst uit de resultaten van de vennootschap uitsluitend op het uit te keren dividend zijn aangewezen, zelfs niet een redelijke rente verkregen voor het door hen geïnvesteerde kapitaal, alle omstandigheden in aanmerking nemende, in redelijkheid niet genomen had kunnen worden. Er volgde dan ook vernietiging van het besluit. De rechtbank overwoog dat het haar niet vrijstaat de bevoegdheid tot bestemming van de winst naar zich toe te trekken, zodat de algemene vergadering met inachtneming van het vonnis van de rechtbank een nieuw besluit diende te nemen. Het hof nam deze drempel echter wel, althans op een andere wijze, en wees de gewijzigde eis van de minderheidsaandeelhouders toe. Die gewijzigde eis hield in dat de algemene vergadering diende te beslissen dat uit de algemene reserves alsnog een bedrag van $f 49.200$ onder de aandeelhouders zal worden verdeeld. Het hof achtte de aanwezige dividendreserve daartoe voldoende en overwoog dat een verhoging van het dividend van $f 15.000$ tot $f 64.200$, met inachtneming van de beslissingsvrijheid die de algemene vergadering verder heeft, als een minimum moet worden aangemerkt.

Concluderend: uit de literatuur en rechtspraak volgt dat onder omstandigheden een vordering tot medewerking tot het nemen van een besluit (succesvol) kan worden ingesteld.

Welke kapitaalverschaffer zonder stemrecht komt de vordering tot medewerking tot het nemen van een besluit toe?

Naar mijn mening komt de vordering tot medewerking tot het nemen van een besluit toe aan alle kapitaalverschaffers zonder stemrecht, uitgezonderd de houder van certificaten zonder vergaderrecht. Hij behoort immers niet tot de kring van betrokkenen in de zin van art. 2:8 BW. De grondslag voor de vordering is de vennootschappelijke redelijkheid en billijkheid.

40 Hof 's-Gravenhage 1 oktober 1982, NJ 1983, 393 (Van Rees/Smits). 
Knelpunten

Ik ben van mening dat de rechter met de nodige terughoudendheid de vordering tot medewerking tot het nemen van een besluit moet beoordelen. Uit de twee besproken uitspraken blijkt immers dat sprake is van bijzondere omstandigheden. In het vonnis van de rechtbank Roermond van 17 mei 1973 ging het om een grootaandeelhouder die ongemotiveerd misbruik maakte van zijn meerderheidspositie. In het Van Rees/ Smits-arrest oordeelde het hof dat de algemene reserves een verhoging van het dividend toelieten. Daarbij was sprake van een familievennootschap en speelde een rol dat de directeur-meerderheidsaandeelhouder door het bestreden besluit zijn tantième (relatief) zag stijgen. Die terughoudendheid klemt te meer ingeval van een vordering tot medewerking van een besluit tot uitkering van (een hoger) dividend. Ik verwijs naar hetgeen ik in paragraaf 7.5.4.2 ter zake van winstreservering heb betoogd.

\subsection{Vernietiging van besluiten ex art. 2:15 lid 1 onder b jo. 2:8 BW}

\section{Aard van het middel}

In hoofdstuk 7 besprak ik de vennootschappelijke redelijkheid en billijkheid in relatie tot de kapitaalverschaffers zonder stemrecht. Een rechtspersoon en degenen die krachtens de wet en de statuten bij zijn organisatie zijn betrokken, moeten zich als zodanig jegens elkander gedragen naar hetgeen door redelijkheid en billijkheid wordt gevorderd. Een tussen hen krachtens wet, gewoonte, statuten, reglementen of besluit geldende regel is niet van toepassing voor zover dit in de gegeven omstandigheden naar maatstaven van redelijkheid en billijkheid onaanvaardbaar zou zijn, zo bepaalt art. 2:8 BW. De vennootschappelijke redelijkheid en billijkheid kunnen de interne verhoudingen van de vennootschap aanvullen, maar ook beperken. Aldus kunnen extra verplichtingen worden aangenomen of opgelegd, maar kan ook in voorkomende gevallen een regel krachtens wet, gewoonte, statuten, reglementen of besluit niet van toepassing zijn. Het artikel wordt ook wel als 'kapstok' gezien voor de bescherming van de minderheidsaandeelhouder in de flex-BV. ${ }^{41}$

Art. 2:15 lid 1 onder b BW bepaalt dat een besluit van een orgaan van een rechtspersoon vernietigbaar is wegens strijd met de vennootschappelijke redelijkheid en billijkheid.

Toetsing aan de redelijkheid en billijkheid houdt een marginale toetsing in. ${ }^{42}$ De rechter zal het orgaan dat het besluit heeft genomen de nodige ruimte laten. Vaak worden in besluitvorming belangen tegen elkaar afgewogen, welke belangen de rechter in zijn oordeel zal moeten betrekken en afwegen. De te stellen vraag is of het orgaan als redelijk handelend orgaan met afweging van alle betrokken belangen in

41 Portengen \& Groenland 2007, p. 251.

42 Zie paragraaf 7.3 en voetnoot 18 van hoofdstuk 7. 
redelijkheid tot het besluit kon komen. ${ }^{43}$ Daarbij zal het betreffende orgaan als verweer vaak het vennootschappelijke belang betrekken. ${ }^{44}$ Een besluit kan inhoudelijk in strijd met de redelijkheid en billijkheid zijn, maar ook wegens de wijze waarop dat besluit tot stand is gekomen. ${ }^{45}$

Art. 2:15 lid 3 onder a BW bepaalt dat vernietiging geschiedt door een uitspraak van de rechtbank van de woonplaats van de rechtspersoon op een vordering tegen de rechtspersoon van iemand die een redelijk belang heeft bij de naleving van de verplichting die niet is nagekomen. Wat wordt verstaan onder redelijk belang? In het Lampe/Videoworks-arrest ${ }^{46}$ oordeelde de Hoge Raad dat een ontslagen directeur in zijn kwaliteit van aandeelhouder in het algemeen niet geacht moet worden steeds een redelijk belang te hebben bij vernietiging van een besluit dat in strijd met wet of statuten tot stand is gekomen. Degene die een beroep op vernietiging doet, moet een eigen belang hebben dat is of dreigt te worden geschaad. Hij moet daarbij aan zijn stelplicht voldoen en bij gemotiveerde betwisting zal hij dat belang moeten bewijzen. Ontbreekt het redelijk belang, dan heeft de vordering tot vernietiging geen kans. ${ }^{47}$ Deze lijn kan naar mijn mening worden gevolgd voor een vordering tot vernietiging van een besluit gebaseerd op strijd met de vennootschappelijke redelijkheid en billijkheid. ${ }^{48}$

De bevoegdheid om vernietiging van het besluit te vorderen, vervalt een jaar na het einde van de dag, waarop hetzij aan het besluit voldoende bekendheid is gegeven, hetzij de belanghebbende van het besluit kennis heeft genomen of daarvan is verwittigd, zo bepaalt art. 2:15 lid $5 \mathrm{BW}$. Vernietiging is niet mogelijk bij wijze van verweer, indien de termijn van een jaar is verstreken. Wel zou in dat geval een beroep gedaan kunnen worden op art. 2:8 lid $2 \mathrm{BW}^{49}$ Daarnaast zou het enquêterecht te hulp kunnen schieten. Ingeval van wanbeleid kan de OK besluiten vernietigen. De OK is niet aan de verjaringstermijn gebonden. ${ }^{50}$ Ook kan gedacht worden aan een vordering tot nakoming van een zorgplicht gebaseerd op de redelijkheid en billijkheid. ${ }^{51}$

Welke kapitaalverschaffer zonder stemrecht komt de vordering tot vernietiging van besluiten ex art. 2:15 jo. 2:8 $\mathrm{BW}$ toe?

Art. 2:15 lid 3 onder a BW bepaalt dat op een vordering tegen de rechtspersoon van iemand die een redelijk belang heeft bij de naleving van de verplichting die niet is nagekomen de vernietiging geschiedt door een uitspraak van de rechtbank van de

43 Vgl. De Monchy \& Timmerman 1991, p. 85

44 Zie bijvoorbeeld HR 1 april 1949, NJ 1949, 465, m.nt. Ph.A.N.H. (Doetinchemse IJzergieterij).

45 Zie bijvoorbeeld HR 30 oktober 1964, NJ 1965, 107, m.nt. G.J. Scholten (Mante).

46 HR 31 mei 1996, NJ 1996, 694, m.nt. Ma (Lampe/Videoworks).

47 Vgl. art. 3:303 jo. 3:326 BW. Zie ook Van den Ingh 1991, p. 262 en HR 19 mei 1989, NJ 1989, 652 (Dekker/Lucas).

48 Zie ook De Monchy \& Timmerman 1991, p. 89.

49 Sanders \& Westbroek 2005, p. 280. Rensen 2005, p. 114.

50 Zie bijvoorbeeld Maeijer in zijn $N J$-noot onder Hof Amsterdam (OK) 22 december 1983, NJ 1985, 383, m.nt. Ma (Ogem) en Van den Ingh 1991, p. 262.

51 Stokkermans 2010, p. 179. 
woonplaats van de rechtspersoon. Onder 'iemand die een redelijk belang heeft' behoort in ieder geval degene die tot de kring van betrokkenen in de zin van art. 2:8 BW behoort. In paragraaf 7.4.2 concludeerde ik dat de stemrechtloze aandeelhouder, de aandeelhouder waarbij stemrecht is overgedragen aan de vruchtgebruiker of de pandhouder, de houder van certificaten met vergaderrecht en de houder van een participatiebewijs tot de kring van betrokkenen behoren. Deze kapitaalverschaffers zonder stemrecht komt de vordering tot vernietiging van besluiten ex art. 2:15 lid 1 onder $\mathrm{b}$ BW toe. ${ }^{52}$ In dezelfde paragraaf 7.4.2 concludeerde ik dat houders van certificaten zonder vergaderrecht niet tot de kring van betrokkenen in de zin van art. 2:8 BW behoren.

Uitgaande van die laatste opvatting, is de vraag of deze certificaathouders een vordering tot vernietiging van een besluit op grond van art. 2:15 lid 1 onder b BW kunnen instellen. De meningen in de literatuur onder het oude recht waren ten aanzien van de niet-bewilligde certificaathouder verdeeld. De voorstanders ${ }^{53}$ gaan ervan uit dat houders van niet-bewilligde certificaten 'een redelijk en vooral financieel belang hebben bij de naleving van de verplichtingen die in het bijzonder jegens aandeelhouders voortvloeien uit de wet, de statuten of de redelijkheid en billijkheid'. Daarbij wordt in deze opvatting vooral gedacht aan een besluit tot winstbestemming en uitkering. De tegenstanders ${ }^{54}$ stellen zich op het standpunt dat de niet-bewilligde certificaathouder niet tot de kring van betrokkenen behoort en dat hem daarom geen vordering tot vernietiging van een besluit wegens schending van de vennootschappelijke redelijkheid en billijkheid toekomt.

In haar vonnis van 25 augustus 2010 van de rechtbank Amsterdam ${ }^{55}$ ging het over besluiten tot herstructurering van het aandelenkapitaal van een vennootschap als gevolg waarvan de verkoopopbrengst van de certificaten, als gevolg van achterstelling en omvang van het rendement op (andere) aandelen, lager zou zijn. Hofman c.s., als certificaathouders, maakten bezwaar. De rechtbank overwoog ten aanzien van de vraag of de niet-bewilligde certificaathouder gerechtigd is de vordering tot vernietiging van een besluit ex art. 2:15 lid 1 onder b BW in te stellen als volgt:

52 Zie voor het participatiebewijs bijvoorbeeld De Monchy \& Timmerman 1991, p. 85; Slagter 2005, p. 65 en Sanders \& Westbroek 2005, p. 280. Anders ten aanzien van het participatiebewijs: Stokkermans 2010, p. 180. Stokkermans is van mening dat uit het Unipart-arrest en uit het RCMA-arrest niet kan worden afgeleid dat de Hoge Raad is toegekomen aan een beoordeling van de ontvankelijkheid van deze (vermeende) belanghebbenden. Naar mijn mening is de opvatting van Stokkermans onjuist, omdat participatiebewijzen een statutaire grondslag moeten hebben. Zie ook De Monchy \& Timmerman 1991, p. 50.

53 Asser/Maeijer, Van Solinge \& Nieuwe Weme 2-II* 2009, nr. 671; De Kluiver 1991, p. 69; Slagter 2005, p. 65; Sanders \& Westbroek 2005, p. 280 en Nowak in sub 3 van zijn noot onder Rb. Amsterdam 25 augustus 2010, LJN BN4965, JOR 2010, 301, m.nt. Nowak (CFS). Slagter en Sanders \& Westbroek maken tekstueel geen onderscheid in bewilligde en niet-bewilligde certificaten.

54 Van den Ingh 1991, p. 262; Stokkermans 2010, p. 180 en 182 en Wouters 2011, p. 239.

55 Rb. Amsterdam 25 augustus 2010, LJN BN4965, JOR 2010, 301, m.nt. Nowak (CFS). Zie over dit vonnis uitgebreid: Stokkermans 2010, p. 177 e.v. 
"4.3. Bij de beoordeling komt het aan op de vraag of [eiser sub 1$]$ c.s. behoort tot de kring van de bij de vennootschap betrokkenen die krachtens artikel 2:8 BW zich als zodanig jegens elkaar dienen te gedragen naar hetgeen door de redelijkheid en billijkheid wordt gevorderd. Als hij daar niet toe behoort, is immers gegeven dat hij ook geen belang heeft bij naleving van die verplichting, in de zin van artikel 2:15 lid 3 aanhef en onder a BW, omdat die verplichting dan jegens [eiser sub 1$]$ c.s. niet bestaat. Tot de in artikel 2:8 BW bedoelde kring van de krachtens de wet en de statuten betrokkenen behoren ondermeer houders van met medewerking van de vennootschap uitgegeven certificaten. Deze houders zijn immers krachtens de wet bij de organisatie van de vennootschap betrokken, ondermeer ingevolge de artikelen 2:220 lid $2 \mathrm{BW}$ (recht op het bijeenroepen van een algemene vergadering) en 3:259 lid $2 \mathrm{BW}$ (gezamenlijk pandrecht op de onderliggende aandelen). Of [eiser sub 1] c.s. nu, zoals hij stelt, behoort tot deze krachtens de wet bij de vennootschap betrokkenen, is afhankelijk van de medewerking die de vennootschap aan de uitgifte van de door hem gehouden certificaten heeft verleend. Gezien de wettelijk vastgelegde beslotenheid van de aandeelhouderskring en het vereiste van duidelijkheid voor de vennootschap jegens wie zij de verplichtingen ingevolge artikel 2:8 BW in acht dient te nemen, heeft alleen die medewerking van de vennootschap tot gevolg dat de door artikel 2:8 BW bestreken kring van personen wordt uitgebreid, die als een op dat rechtsgevolg gerichte rechtshandeling van de vennootschap kan worden aangemerkt. Ingevolge de artikelen 3:33 jo 3:59 BW vereist aldus de door de vennootschap verleende medewerking, teneinde dat rechtsgevolg te bewerkstelligen, een daarop gerichte wil die zich door verklaring of gedraging van de vennootschap heeft geopenbaard. Dat is hier niet het geval. Immers, de statuten van de vennootschap schrijven voor dat aan de uitgifte van certificaten geen medewerking wordt verleend en uit de aanbiedingsbrieven aan [eiser sub 1] c.s. volgt dat hem uitdrukkelijk geen andere rechten worden verleend dan rechten die voortvloeien uit de certificaten zelf (r.o. 2.3 hiervoor). [eiser sub 1] c.s. heeft dit ook aanvaard.

4.4. Het voorgaande leidt tot de slotsom dat [eiser sub 1] c.s. niet behoort tot degenen die krachtens wet of statuten bij de organisatie van CFS zijn betrokken. Dat, zoals hij stelt, de gewraakte besluiten jegens hem naar wijze van totstandkoming of inhoud strijdig zouden zijn met de redelijkheid en billijkheid maakt dan ook niet dat sprake is van een schending van de in artikel 2:8 BW neergelegde norm, en kan derhalve geen grond opleveren voor vernietiging als bedoeld in artikel 2:15 lid 1 sub $b$ BW."

De rechtbank voegt er nog aan toe dat niet uitgesloten kan worden dat het nemen van de besluiten onder omstandigheden onrechtmatig geoordeeld moet worden. Een daarop gebaseerde vordering tot schadevergoeding was echter niet ingesteld. ${ }^{56}$

56 r.o. 4.5 . 
De benadering van de tegenstanders en de rechtbank Amsterdam in haar vonnis van 25 augustus $2010 \mathrm{komt}$ mij als de meest zuivere voor, omdat deze benadering uitgaat van de kring van betrokkenen van art. 2:8 BW en de wil en verklaring van de vennootschap.

Deze benadering zou ik ook willen volgen voor de houder van certificaten zonder vergaderrecht. Ingevolge art. 2:227 lid $2 \mathrm{BW}$ kunnen slechts de statuten vergaderrecht aan certificaten verbinden. Dat sluit aan op de hiervoor aangehaalde overweging van de rechtbank Amsterdam: "Ingevolge de artikelen 3:33 jo 3:59 BW vereist aldus de door de vennootschap verleende medewerking, teneinde dat rechtsgevolg te bewerkstelligen, een daarop gerichte wil die zich door verklaring of gedraging van de vennootschap heeft geopenbaard." Kort gezegd, de vennootschap, althans de algemene vergadering, verbindt aan de certificaten geen vergaderrecht. Er heeft geen 'toekenning en aanvaarding van bevoegdheden tussen de vennootschap en de certificaathouder' plaatsgevonden. ${ }^{57}$ Daarmee heeft zij ook beoogd dat deze certificaathouder niet tot de kring van betrokkenen in de zin van art. 2:8 BW behoort. De vennootschap heeft ook niet gewild dat de houder van een certificaat zonder vergaderrecht invloed op de besluitvorming kan uitoefenen. Deze certificaathouder moet dan ook niet de mogelijkheid hebben genomen besluiten te vernietigen. Ook vanuit oogpunt van rechtszekerheid verdient het de voorkeur dat de vennootschap niet achteraf geconfronteerd wordt met een vordering tot vernietiging van een besluit door iemand waarvan zij zelf heeft bepaald dat die niet tot haar kring van betrokkenen behoort.

Concluderend stel ik mij dan ook op het standpunt dat de certificaathouder zonder vergaderrecht niet het recht toekomt besluiten te vernietigen wegens strijd met de vennootschappelijke redelijkheid en billijkheid. ${ }^{58}$ Dat neemt niet weg dat in voorkomend geval deze certificaathouder een vordering tot schadevergoeding op grond van onrechtmatige daad kan toekomen, indien zijn gerechtvaardigde belangen door besluitvorming in de BV zouden worden geschaad.

Gevolgen van de vernietiging

Art. 2:16 BW bepaalt onder meer dat de onherroepelijke uitspraak, waarbij het bestreden besluit is vernietigd, voor een ieder bindend is indien de rechtspersoon partij in het geding is geweest. Het door de rechter vernietigde besluit, maakt dat besluit ongeldig. De uitspraak heeft naar haar aard te gelden ten opzichte van een ieder en niet alleen ten opzichte van degene die de vernietiging heeft verzocht. Voor deze algemene werking is tussenkomst van de burgerlijke rechter noodzakelijk. ${ }^{59}$

57 Stokkermans 2010, p. 179

58 Al ben ik met Steins Bisschop 2004, p. 97, van mening dat deze conclusie 'licht verwarrend' kan zijn.

59 HR 10 november 2006, LJN AY4033, NJ 2007, 561, m.nt. H.J. Snijders, JOR 2007, 5, m.nt. P. Sanders (Groenselect), r.o. 3.5. 
Schending van het bepaalde in art. 2:8 BW en vernietiging van een besluit ex art. 2:15 BW op grond daarvan brengt in de regel ook onrechtmatigheid met zich mee. Daarnaast kan ook sprake zijn van een tekortkoming in de contractuele relatie met de vennootschap. ${ }^{60}$

Ten aanzien van de houder van een stemrechtloos aandeel, de houder van een certificaat met vergaderrecht en de houder van een aandeel waarvan het stemrecht is overgedragen aan de vruchtgebruiker of pandhouder ben ik van mening dat bij schending jegens hen van de vennootschappelijke redelijkheid en billijkheid in de regel sprake is van een onrechtmatige daad. De houders van deze rechtsfiguren staan zonder twijfel in een lidmaatschapverhouding en niet (ook) in een contractuele verhouding tot de vennootschap, tenzij sprake is van een aandeelhoudersovereenkomst waarbij ook de vennootschap partij is. Ten aanzien van de houder van een participatiebewijs concludeerde ik in paragraaf 6.5.3.1 dat sprake is van een contractuele verhouding tot de vennootschap, zij het met een statutaire basis. Schending van de vennootschappelijke redelijkheid en billijkheid jegens de houder van een participatiebewijs - hij behoort immers tot de kring van betrokkenen in de zin van art. 2:8 BW - levert daarom naar mijn mening een toerekenbare tekortkoming op. De houder van een certificaat zonder vergaderrecht behoort niet tot de kring van betrokkenen in de zin van art. 2:8 BW. In voorkomend geval zal hij naar mijn mening een vordering tot schadevergoeding op grond van onrechtmatige daad kunnen instellen. ${ }^{61}$

\subsection{Gebod of verbod in kort geding}

In spoedeisende zaken kan de kapitaalverschaffer zonder stemrecht in kort geding op grond van art. $254 \mathrm{Rv}$ een onmiddellijke voorziening bij voorraad vorderen. De grondslag voor een dergelijke vordering is de onrechtmatige daad, zijnde een inbreuk op een recht en een doen of nalaten in strijd met een wettelijke plicht of met hetgeen volgens ongeschreven recht in het maatschappelijk verkeer betaamt, meer in het bijzonder strijd met de vennootschappelijke redelijkheid en billijkheid.

Te denken valt aan een voorgenomen besluit van het bestuur of de algemene vergadering dat de gerechtvaardigde belangen van de kapitaalverschaffer zonder stemrecht raakt. In dat geval kan de kapitaalverschaffer zonder stemrecht in kort geding een verbod tot het nemen van dat besluit vorderen, op straffe van verbeurte van een dwangsom. Ook is denkbaar dat het bestuur of de algemene vergadering

60 Verdam 1995, p. 232-233 en Stokkermans 2010, p. 180.

61 In gelijke zin Van den Ingh 1991, p. 262. Stokkermans 2010, p. 180, ziet onder omstandigheden daarnaast de mogelijkheid van een op art. 6:2 BW gebaseerde vordering van de houder van een certificaat zonder vergaderrecht via de bepalingen van lastgeving (7:414 en 7:419-421 BW) 
nalaat een besluit te nemen, in welk geval een gebod tot het nemen van een bepaald besluit in kort geding gevorderd kan worden. ${ }^{62}$

De tekst van art. $254 \mathrm{Rv}$ brengt tot uitdrukking dat de voorzieningenrechter in kort geding een afweging van de in het geding zijn de belangen maakt ('gelet op de belangen van partijen'). Dat maakt dat het belang van de kapitaalverschaffer zonder stemrecht niet prevaleert. De voorzieningenrechter zal in zijn overwegingen dan ook de gerechtvaardigde belangen van anderen, die bij het geding betrokken zijn, betrekken. Ook zal hij oog moeten hebben voor het vennootschappelijk belang. Het komt mij voor dat de kapitaalverschaffer zonder stemrecht die tot de kring van betrokkenen behoort eerder een in rechte te respecteren belang heeft dan de certificaathouder zonder vergaderrecht.

Daarnaast heeft de kort geding procedure een bijzonder karakter. Niet altijd zullen de feiten en de juridische merites van de zaak in kort geding uitgekristalliseerd zijn. Dat kan leiden tot behoedzaamheid bij toewijzing van de vordering of afwijzing op de voet van art. $256 \mathrm{Rv}$. Het oordeel van de rechter is voorlopig en ook de voorziening heeft een voorlopig karakter. De rechter in kort geding zal in zijn oordeel vaak betrekken wat de verwachte uitkomst in een bodemprocedure zal zijn. Zijn beslissing en de juridische grondslag daarvan zal in de regel daarop vooruitlopen. Voorts zal de voorzieningenrechter een afweging maken wat de gevolgen zouden zijn van het verlenen van de gevorderde voorziening en de gevolgen van de weigering daarvan.

Dit alles maakt dat het maar de vraag is of de kapitaalverschaffer zonder stemrecht in alle gevallen baat bij het gebod of verbod in kort geding zal hebben.

\subsection{Enquêterecht}

Aard van het middel

Art. 2:345 lid $1 \mathrm{BW}$ bepaalt onder meer dat op schriftelijk verzoek van degenen die krachtens art. 2:346 en 2:347 BW daartoe bevoegd zijn, de OK een of meer personen kan benoemen tot het instellen van een onderzoek naar het beleid en de gang van zaken van een rechtspersoon, hetzij in de gehele omvang daarvan, hetzij met betrekking tot een gedeelte of een bepaald tijdvak. Zoals uit hoofdstuk 7 volgt, passeren in het enqueterecht vele onderwerpen de revue, bijvoorbeeld het verstrekken van onvoldoende informatie, een impasse in de besluitvorming, belangenverstrengeling of tegenstrijdige belangen, (onredelijke) dividendpolitiek en het onvoldoende rekening houden met de belangen van minderheidsaandeelhouders of certificaathouders. In hoofdstuk 7 zijn deze onderwerpen aan de orde gekomen en volgde dat deze onderwerpen ook voor de kapitaalverschaffer zonder stemrecht relevant kunnen zijn.

62 Zie art. 3:296 BW. 
Welke kapitaalverschaffer zonder stemrecht komt het recht van enquête toe? Per 1 januari 2013 zal het enquêterecht worden gewijzigd. ${ }^{63}$ Er wordt een onderscheid gemaakt tussen kleine vennootschappen en grote of beursgenoteerde vennootschappen. De grens van dat onderscheid ligt bij een geplaatst kapitaal van $€ 22,5$ miljoen. Tot het indienen van een enquêteverzoek bij kleine vennootschappen geldt indien het betreft een naamloze vennootschap of besloten vennootschap met beperkte aansprakelijkheid met een geplaatst kapitaal van maximaal $€ 22,5$ miljoen: een of meer houders van aandelen of van certificaten van aandelen, die alleen of gezamenlijk ten minste een tiende gedeelte van het geplaatste kapitaal vertegenwoordigen of rechthebbenden zijn op een bedrag van aandelen of certificaten daarvan tot een nominale waarde van $€ 225.000$ of zoveel minder als de statuten bepalen (art. 2:346 lid 1 sub b BW). Tot het indienen van een enquêteverzoek bij grote of beursgenoteerde vennootschappen geldt: indien het betreft een naamloze vennootschap of besloten vennootschap met beperkte aansprakelijkheid met een geplaatst kapitaal van meer dan $€ 22,5$ miljoen: een of meer houders van aandelen of van certificaten van aandelen, die alleen of gezamenlijk ten minste een honderdste gedeelte van het geplaatste kapitaal vertegenwoordigen of, indien de aandelen of certificaten zijn toegelaten tot de handel op een gereglementeerde markt of een multilaterale handelsfaciliteit, als bedoeld in artikel 1:1 van de Wet op het financieel toezicht of een met een gereglementeerde markt of multilaterale handelsfaciliteit vergelijkbaar systeem uit een staat die geen lidstaat is, ten minste een waarde vertegenwoordigen van $€ 20$ miljoen volgens de slotkoers op de laatste handelsdag voor indiening van het verzoek, of zoveel minder als de statuten bepalen (art. 2:346 lid 1 sub c BW).

Met andere woorden: voor kleine BV's is de kapitaaleis ongewijzigd gebleven. ${ }^{64}$ Niettemin kan in de statuten een lagere eis worden opgenomen ("of zoveel minder als de statuten bepalen"). Aan de ontvankelijkheidsvereisten van art. 2:346 BW moet zijn voldaan op het moment van indiening van het verzoek. ${ }^{65}$ De beoordeling van de ontvankelijkheid op grond van de kapitaaleis vindt alleen in eerste aanleg plaats. $^{66}$

Het gewijzigde enquêterecht voorziet ook in de mogelijkheid dat de rechtspersoon (als bedoeld in art. 2:344 $\mathrm{BW}$ ) zelf een verzoek tot enquête indient (art. 2:346 lid 1 sub d BW). Als reden noemt de wetgever dat er behoefte kan zijn aan een onderzoek indien sprake is van een patstelling in de algemene

63 Wet van 18 juni 2012 tot wijziging van boek 2 van het Burgerlijk Wetboek in verband met de aanpassing van het recht van enquête (Kamerstukken 32 887, Stb. 2012, 274), inwerkingtreding op 1 januari 2013 (Stb. 2012, 305).

64 Kamerstukken II 2010/11, 32 887, nr. 3, p. 27 (MvT). Zie ook Kamerstukken II 2011/12, 32 887, nr. 6, p. 13 (NV II).

65 Hof Amsterdam (OK) 22 december 1983, NJ 1985, 383, m.nt. Ma (Ogem).

66 HR 30 maart 2012, LJN BV1435, NJ 2012, 423, m.nt. P. van Schilfgaarde, JOR 2012, 142, m.nt. Winters (Hermes c.s./ASMI). Bij de toetsing van de ontvankelijkheid is cassatie gaat het er ingevolge art. 426 lid $1 \mathrm{Rv}$ om of de verzoeker in de procedure voor de $\mathrm{OK}$ is verschenen, r.o. 4.1.2. 
vergadering, waardoor wezenlijke besluiten niet kunnen worden genomen, of een patstelling tussen het bestuur en de algemene vergadering die beide een wezenlijk verschillend beleid voorstaan als gevolg waarvan het belang van de vennootschap in het geding zou kunnen komen. Ook het gedrag van een individuele aandeelhouder kan aanleiding geven voor een enquête indien dat gedrag de gang van zaken binnen de vennootschap voldoende sterk raakt. Daaronder valt ook gedrag buiten de (jaarlijkse) algemene vergadering. Ook het gedrag van een vorig bestuur of een ander orgaan van de rechtspersoon kan onder het enquêteverzoek vallen. De wetgever voegt er nog aan toe dat het oordeel van de OK over een bepaald aandeelhoudersbesluit, het gedrag van de algemene vergadering of een individuele aandeelhouder, geen antwoord geeft op de aansprakelijkheidsvraag. Dat zal in een aparte procedure, waarbij het gedrag van de desbetreffende andeelhouder centraal staat, moeten worden vastgesteld. In die procedure is onder meer relevant de omvang van het kapitaalbelang en het stemgedrag, de vraag of de aandeelhouder handelt binnen de grenzen van de redelijkheid en billijkheid en de vraag of hij handelt als feitelijke beleidsbepaler. ${ }^{67}$

De mogelijkheid dat de rechtspersoon een enquêteverzoek kan indienen is naar mijn mening een verbetering van de rechtspositie van de kapitaalverschaffer zonder stemrecht.

Daarnaast zijn op grond van art. 2:346 lid 1 sub e BW degenen, aan wie daartoe bij de statuten of bij overeenkomst met de rechtspersoon de bevoegdheid is toegekend bevoegd een verzoek tot enquête in te dienen. ${ }^{68}$

Art. 2:346 BW spreekt van 'aandeelhouders', zodat het enquêterecht toekomt aan de stemrechtloze aandeelhouder ${ }^{69}$ en de houder van aandelen waarvan het stemrecht is overgedragen aan de vruchtgebruiker of pandhouder. ${ }^{70}$ Op grond van art. 2:24d lid 2 BW tellen stemrechtloze aandelen bij het bepalen van de genoemde drempel of kapitaaleis mee.

Het enquêterecht komt ook toe aan houders van certificaten van aandelen, ongeacht of aan de certificaten vergaderrecht is toegekend. ${ }^{71}$ De economisch rechthebbende op certificaten wordt gelijkgesteld met de certificaathouder ex

67 Voor dit alles: Kamerstukken II 2010/11, 32 887, nr. 3, p. 15-16 (MvT).

68 Zie Asser/Maeijer, Van Solinge \& Nieuwe Weme 2-II* 2009, nr. 744. Door de Wet van 18 juni 2012 tot wijziging van boek 2 van het Burgerlijk Wetboek in verband met de aanpassing van het recht van enquête (Kamerstukken 32 887, Stb. 2012, 274) zal art. 2:346 aanhef sub c BW naar art. 2:346 lid 1 sub e BW worden verplaatst. Deze wet zal inwerking treden op 1 januari 2013 (Stb. 2012, 305).

69 Kamerstukken II 2006/07, 31 058, nr. 3, p. 114 (MvT) en Kamerstukken II 2008/09, 31 058, nr. 6, p. 14 (NV II).

70 Geerts 2004, p. 55.

71 De heersende opvatting in de literatuur onder het oude recht was dat de bevoegdheid tot het indienen van een enquêteverzoek ook toekomt aan de houder van niet-bewilligde certificaten. Zie Van Zeben 1977, p. 1476-1477; Van den Ingh 1991, p. 247-256; Geerts 2004, p. 56; P.G.F.A. Geerts, Groene Serie Rechtspersonen, art. 2:346 BW, aant. 2.1, Deventer: Kluwer; Sanders \& Westbroek 2005, p. 313; Asser/Maeijer, Van Solinge \& Nieuwe Weme 2-II* 2009, nr. 671 en 738 en $\rightarrow$ 
art. 2:346 aanhef sub b BW. ${ }^{72}$ Houders van certificaten van aandelen die behoren tot een onverdeelde nalatenschap hebben als kapitaalverschaffer een eigen economisch belang bij de certificaten. Zij zijn gelijk te stellen met de in art. 2:346 lid 1 onder b BW bedoelde certificaathouders en zijn derhalve bevoegd tot het indienen van een enquêteverzoek. ${ }^{73}$

De strekking van het enquêterecht brengt mee dat bij de toepassing daarvan het uiteindelijk vooral aankomt op de economische werkelijkheid. ${ }^{74}$ De economische werkelijkheid of gerechtigdheid komt ook tot uitdrukking in de Chinese Workerbeschikking: aandeelhouders in een buitenlandse moedervennootschap kunnen onder omstandigheden worden aangemerkt als economisch gerechtigden in een Nederlandse dochtervennootschap. ${ }^{75}$

De grens van de economische werkelijkheid is het hebben van economisch belang op grond van een trustverhouding. Dat is onvoldoende om voor de toepassing van het enquêterecht gelijk te worden gesteld met economisch rechthebbende voor wier rekening en risico de aandelen worden gehouden. ${ }^{76}$

Aan de houder van een participatiebewijs komt geen recht van enquête toe. Op grond van art. 2:346 aanhef onder c BW acht ik het echter mogelijk dat aan hem daartoe bij de statuten of bij overeenkomst met de rechtspersoon de bevoegdheid wordt toegekend. ${ }^{77}$ Daarbij zal dan wel aan de kapitaaleis voldaan moeten zijn, omdat anders de houder van een participatiebewijs in een gunstiger positie komt te verkeren dan de andere kapitaalverschaffers zonder stemrecht.

Daarnaast acht ik het mogelijk dat de houder van een participatiebewijs zich volgens art. 282 lid $1 \mathrm{Rv}$ als belanghebbende in de enquêteprocedure voegt. Steun voor deze opvatting ontleen ik aan de parlementaire geschiedenis en enkele uitspraken. De parlementaire geschiedenis verwoordt het ter toelichting op art. 429h lid 1 (oud) BW aldus: “(...) Iedere belanghebbende is bevoegd een verweerschrift in te dienen, onverschillig of hij ingevolgde artikel $429 f$ is opgeroepen of

Kamerstukken II 2010/11, 32 887, nr. 3, p. 28 (MvT). Dat geldt aldus ook na invoering van de flex-BV voor de houder van certificaten zonder vergaderrecht. Anders: Van den Ingh 2008, p. 8, is er 'minder gelukkig' mee dat de certificaathouder zonder vergaderrecht ook het recht van enquête toekomt. Zie ook Van den Ingh, 2004, p. 227 (en eerder in andere zin Van den Ingh 1991, p. 254-256).

72 HR 6 juni 2003, LJN AF9440, NJ 2003, 486, m.nt. Ma, JOR 2003, 161, m.nt. Josephus Jitta (Scheipar), Hof Amsterdam (OK) 17 februari 2009, JOR 2009, 19, m.nt. G. van Solinge (Butôt).

73 HR 10 september 2010, LJN BM6077, NJ 2010, 665, m.nt. P. van Schilfgaarde en S. Perrick, JOR 2010, 337, m.nt. M. Brink (Butôt), r.o. 3.6.3.

74 HR 4 februari 2005, LJN AR8899, NJ 2005, 127, m.nt. Ma, JOR 2005, 58, m.nt. Van den Ingh (Landis), r.o. 3.3.4

75 Hof Amsterdam (OK) 7 februari 2012, LJN BV7329, JOR 2012, 143, m.nt. A. Doorman, r.o. 3.5 en 3.6 .

76 HR 8 april 2011, LJN BP4943, NJ 2011, 338, m.nt. P. van Schilfgaarde, JOR 2011, 178, m.nt. A. Doorman (vervolg op Hof Amsterdam (OK) 5 november 2009, JOR 2010, 10, m.nt. Doorman).

77 Geerts 2004, p. 87-88, is terughoudend de kring van enquêtegerechtigden uit te breiden. De bevoegdheid dient toe te komen aan een beperkte kring van belanghebbenden, die nauw bij de vennootschap betrokken is. Daarmee wordt (ook) voorkomen dat de toegang tot de OK dichtslibt. 
niet. Ook de niet opgeroepene behoort in de gelegenheid te worden gesteld zich te doen horen; misschien heeft de oorspronkelijk verzoeker niet alle belanghebbenden genoemd of zijn de belanghebbenden niet allen bekend. Vrees dat nu ieder die zich als belanghebbende aandient aan de behandeling zou kunnen deelnemen behoeft niet te bestaan, want bij twijfel aan werkelijk belang is het laatste woord aan de rechter ook zonder uitdrukkelijke wetsbepaling." het burgerlijk procesrecht werd opgemerkt 'dat onder 'belanghebbende' valt te verstaan: een ieder die, anders dan als verzoeker, als concrete belanghebbende bij de procedure betrokken kan worden: de potentiële wederpartij van de verzoeker derhalve'. ${ }^{79}$

Titel 3 van het Wetboek van Burgerlijke Rechtsvordering geeft geen omschrijving of definitie van 'belanghebbende'. In zijn arrest van 25 oktober $1991^{80}$ overwoog de Hoge Raad: "Wie tot de belanghebbenden in de zin van deze bepaling zijn te rekenen, is in de wet niet in het algemeen aangegeven, maar moet voor ieder type verzoekschriftprocedure uit de aard van de procedure en de daarmee verband houdende wetsbepalingen worden afgeleid. In de onderhavige zaak gaat het om een beschikking tot goedkeuring van een besluit tot fusie van een stichting als bedoeld in art. 2:317 lid $5 \mathrm{BW}$. Een persoon die behoort tot de kring van de bij de stichting betrokkenen, zoals een oprichter of iemand die ten tijde van de totstandkoming van het fusiebesluit deel uitmaakt van een van de organen van de stichting, moet in beginsel als belanghebbende worden aangemerkt. Een niet tot deze kring behorende persoon kan slechts dan als belanghebbende in de zin van art. 429n lid 2 hoger beroep tegen een zodanige beschikking instellen wanneer de goedkeuring van het fusiebesluit zou leiden tot een specifiek en concreet nadeel voor hem in zijn betrekkingen tot de stichting."

Maeijer stelt in zijn $N J$-noot onder dit arrest dat de Hoge Raad bij zijn benadering van het begrip 'belanghebbende' in dit arrest aansluit bij de door hem ontwikkelde 'kringenleer' naar aanleiding van het begrip belanghebbende in art. $999 \mathrm{Rv}^{81}$ De Hoge Raad maakt in dat laatste geval onderscheid tussen de kring van de bij de onderneming betrokkenen wier belang wordt verondersteld en een overige groep van mogelijke belanghebbenden die een specifiek en concreet nadeel moeten stellen en bij wie een dergelijk nadeel moet blijken. In de literatuur is betoogd dat de belanghebbende een eigen recht of eigen belang ${ }^{82}$ moet hebben om als belanghebbende in een procedure te mogen opkomen voor dat eigen recht of belang. Dat sluit aan bij het bepaalde in art. 3:303 BW, inhoudende dat zonder voldoende belang niemand een rechtsvordering toekomt.

78 Kamerstukken II 1963/64, 7753, nr. 3, p. 7 (MvT).

79 Kamerstukken II 1999/2000, 26 885, nr. 3, p. 59 (MvT)

80 HR 25 oktober 1991, NJ 1992, 149, m.nt. Ma, r.o. 4.2.

81 In gelijke zin: Leijten 2002, p. 66.

82 Boekman 1996, p. 10-11; Asser 1997, p. 59-61 en Leijten 2002, p. 67 en 69-70. Boekman stelt dat het eigen belang van de belanghebbende bestaat uit hoofde van zijn functie of omdat een eigen recht van de belanghebbende geschonden dreigt te worden. 
De 'belang-benadering' komt ook terug in de Scheipar-beschikking. ${ }^{83}$ Deze beschikking ziet op een enquêteprocedure. De Hoge Raad sluit aan bij haar eerdere overweging in het hiervoor aangehaalde arrest van 25 oktober 1991 en voegt in haar overweging toe: "Bij de beantwoording van de vraag of iemand belanghebbende is, zal een rol spelen in hoeverre deze door de uitkomst van de desbetreffende procedure zodanig in een eigen belang kan worden getroffen dat deze daarin behoort te mogen opkomen ter bescherming van dat belang of in hoeverre deze anderszins zo nauw betrokken is of is geweest bij het onderwerp dat in de procedure word behandeld, dat daarin een belang is gelegen om in de procedure te verschijnen." 84 In de daaropvolgende rechtsoverweging concretiseert de Hoge Raad dit criterium voor de voormalig bestuurder van de vennootschap: "Gelet op de zoeven vermelde maatstaf en op het doel van een enquêteprocedure, moet worden aangenomen dat de voormalige bestuurder van de rechtspersoon die volgens het daartoe ingediende verzoek onderworpen dreigt te worden aan een onderzoek naar het in het verleden mede door deze bestuurder gevoerde beleid en de gang van zaken in de rechtspersoon, als belanghebbende kan worden aangemerkt. Deze bestuurder zal immers voor de periode die hem aangaat voor dat beleid verantwoordelijk kunnen worden gehouden. Er is geen reden om te dezer zake verschil te maken tussen de eerste fase van de enquêteprocedure waarin moet worden beoordeeld of er gegronde redenen zijn om aan een juist beleid te twijfelen, en de tweede fase waarin moet worden beoordeeld of van wanbeleid sprake is geweest en welke gevolgen daaraan eventueel moeten worden verbonden." 85 Met andere woorden: het gaat om feitelijke betrokkenheid van de belanghebbende. ${ }^{86}$

In paragraaf 7.4.2 concludeerde ik dat de houder van een participatiebewijs tot de kring van betrokkenen behoort in de zin van art. 2:8 BW, zodat naar mijn mening op grond van dit arrest en de aangehaalde meningen in de literatuur ook de houder van een participatiebewijs als een belanghebbende in de zin van art. $282 \mathrm{Rv}$ te beschouwen is en aldus langs die weg gerechtigd is een enquêteverzoek in te dienen.

De belanghebbende kan op grond van art. 282 lid 4 Rv een zelfstandig verzoek indienen, mits dit betrekking heeft op het onderwerp van het oorspronkelijke verzoek.

\section{Knelpunten}

a. de kapitaaleis

Uit het voorgaande volgt dat de stemrechtloze aandeelhouder, de aandeelhouder wiens stemrecht overgedragen is aan de vruchtgebruiker of pandhouder en de

83 HR 6 juni 2003, LJN AF9440, NJ 2003, 486, m.nt. Ma, JOR 2003, 161, m.nt. Josephus Jitta (Scheipar).

84 r.o. 3.3.2.

85 r.o. 3.3 .3 .

86 Zie hierover ook sub 2.7 tot en met 2.10 van de conclusie A-G onder HR 6 juni 2003, LJN AF9440, NJ 2003, 486, m.nt. Ma, JOR 2003, 161, m.nt. Josephus Jitta (Scheipar). Het begrip 'feitelijke betrokkenheid' komt ook naar voren in Kamerstukken II 1999/2000, 26 885, nr. 3, p. 59 (MvT). 
houder van een certificaat met of zonder vergaderrecht aan een kapitaaleis moeten voldoen voor het indienen van een enquêteverzoek. De vraag is of die kapitaaleis een belemmering is in de bescherming van deze kapitaalverschaffers zonder stemrecht. Mijns inziens is dat niet het geval. Ten eerste omdat het enquêterecht met ingang van 1 januari 2013 de mogelijkheid kent dat de rechtspersoon ook zelf een verzoek tot enquête kan indienen, bijvoorbeeld bij een patstelling in een orgaan van de vennootschap, een patstelling in de besluitvorming of gedrag van een individuele aandeelhouder, welk gedrag de gang van zaken binnen de vennootschap voldoende sterk raakt.

Ten tweede, de kapitaalverschaffer zonder stemrecht die niet aan de voorwaarden van art. 2:346 BW voldoet, kan zich op grond van art. 282 lid $1 \mathrm{Rv}$ als belanghebbende in de enquêteprocedure voegen. ${ }^{87}$ Ten derde kan de OK op grond van art. 279 lid 1 laatste volzin $\mathrm{Rv}$ ook ambtshalve de desbetreffende kapitaalverschaffer als belanghebbende oproepen. Ik verwijs naar de eerder besproken Scheipar-beschikking.

Ten vierde, op grond van de E-Traction-beschikking ${ }^{88}$ bestaat voor iedere belanghebbende de mogelijkheid ex art. 282 lid $4 \mathrm{Rv}$ in de enquêteprocedure een zelfstandig verzoek in te dienen, mits dit betrekking heeft op het onderwerp van het oorspronkelijke verzoek. De Hoge Raad overweegt: "Een verzoek om een onmiddellijke voorziening als bedoeld in art. 2:349a lid 2 of 2:355 lid 3 BW voldoet in beginsel aan deze laatste eis en kan dus ook door andere belanghebbenden worden gedaan dan de indieners van het enquêteverzoek of van het in art. 2:355 lid $1 \mathrm{BW}$ genoemde verzoek tot het treffen van de in art. 2:356 BW genoemde voorzieningen. De omstandigheid dat de tekst van de wet alleen de indieners van deze verzoeken noemt bij de mogelijkheid tot het doen van het verzoek om een onmiddellijke voorziening, is onvoldoende grond voor een wetsuitleg in andere zin. Er is geen genoegzame reden om aan andere belanghebbenden, in afwijking van art. 282 lid 4 $R v$., deze mogelijkheid te onthouden. Aan het onthouden van die mogelijkheid aan hen kleeft bovendien het bezwaar dat zij voor een voorlopige voorziening zouden zijn aangewezen op een kort geding, hetgeen leidt tot dubbele procedures en het risico in zich draagt van tegenstrijdige uitspraken." 89

87 Hof Amsterdam (OK) 27 mei 1999, NJ 1999, 487, JOR 1999, 121, m.nt. L.L.M. Prinsen (Gucci), r.o. 3.4. Van den Ingh 2004, p. 229, wijst daarbij op de door Maeijer ontwikkelde kringenleer. Hij stelt dat in beginsel de bewilligde certificaathouder als belanghebbende geldt en dat de niet-bewilligde certificaathouder, die niet tot de kring van betrokkenen ex art. 2:8 BW behoort, zal moeten aantonen dat hij een specifiek en concreet nadeel heeft geleden of dreigt te lijden. Geerts 2004, p. 253, stelt dat gelet op de ruime definitie van het begrip 'belanghebbende' in de Scheipar-beschikking iedere certificaathouder als belanghebbende te beschouwen is. Zie ook Leijten 2002, p. 66-67.

88 HR 23 maart 2012, LJN BV1056, NJ 2012, 393, m.nt. P. van Schilfgaarde, JOR 2012, 141, m.nt. M.W. Josephus Jitta en T. Barkhuysen (E-Traction).

89 r.o. 4.1.3. Bij wijziging van het enquêterecht per 1 januari 2013 is niet voorzien in wijziging van art. 2:355 lid $1 \mathrm{BW}$, zodat de overweging van de Hoge Raad ook na 1 januari 2013 relevant blijft. 
b. de aard van de maatregel in een enquêteprocedure

In het enquêterecht staat het beleid van en de gang van zaken binnen de vennootschap centraal. Het is een fundamenteel andere procedure dan de procedure met betrekking tot de vordering tot vernietiging van een besluit ex art. 2:15 jo. 2:8 BW. Niettemin kan ook de OK in voorkomend geval op grond van art. 2:356 BW besluiten vernietigen. ${ }^{90}$ De enquêteprocedure biedt echter geen mogelijkheid tot overdracht van aandelen. ${ }^{91}$

Bij de kapitaalverschaffers zonder stemrecht staan vooral de financiële rechten, die aan hun rechtsfiguur zijn verbonden, centraal. Ik concentreer mij daarom op de vraag of de enquêteprocedure een probaat middel is om in de bescherming van deze rechten te voorzien. ${ }^{92}$ Het gaat daarbij om de situatie dat de (enquêtegerechtigde) kapitaalverschaffer zonder stemrecht van mening is dat te weinig uitgekeerd is als gevolg van een al dan niet gedeeltelijke reservering van de winst. Ten aanzien van het besluit tot winstreservering verwijs ik naar paragraaf 7.5.4.2. Op die plaats betoogde ik dat indien het besluit tot het reserveren van winst wordt vernietigd, de rechter er goed aan doet in zijn uitspraak geen besluit tot uitkering op te nemen, maar - afhankelijk van de statuten van de vennootschap - de algemene vergadering of het bestuur op draagt een nieuw besluit te nemen. Zoals gesteld, zal mijns inziens opnieuw op grond van art. 2:8 BW en het vennootschappelijk belang een belangenafweging moeten plaatsvinden, hetgeen niet per definitie tot een besluit tot uitkering of een hogere uitkering zal (kunnen) of hoeft (te) leiden. Daarnaast zal de uitkeringstest van art. 2:216 $\mathrm{BW}$ in acht genomen moeten worden. In deze nieuwe besluitvorming omtrent uitkering zal voor de bestuurder(s) en voor de uitkeringsgerechtigden ook de aansprakelijkheid op grond van art. 2:216 lid 3 BW een rol spelen. Voor die aansprakelijkheid is het moment waarop de uitkering wordt voldaan bepalend..$^{33}$ Dat moment is aldus per definitie later dan het moment waarop het besluit tot reservering is genomen en het moment waarop de rechter dat laatste besluit heeft vernietigd. Wel zal het een en ander ertoe kunnen leiden dat besluitvorming zorgvuldiger en beter gemotiveerd geschiedt, waarbij extra aandacht zal worden besteed aan de positie van de kapitaalverschaffer zonder stemrecht en de motivering van de rechter om tot vernietiging van het besluit tot reservering te komen. $^{94}$

90 Vernietiging van besluiten kan niet als voorlopige voorziening in de zin van art. 2:349a lid 2 BW worden verzocht. Zie Geerts 2004, p. 266.

91 Bulten 2011, p. 326-327, pleit voor en beveelt aan de toevoeging van de gedwongen aandelenoverdracht aan de voorzieningen van art. 2:356 BW.

92 Zie in meer algemene zin over de certificaathouder en het enquêterecht: Van den Ingh 2004, meer in het bijzonder p. 230-231, en Van den Ingh 2008, in het bijzonder p. 9.

93 Kamerstukken I 2011/12, 31058 en 32 426, nr. C, p. 14 (MvA I).

94 Bier spreekt in dit kader van een 'zorgvuldiger dividendbeleid' of 'betere dividendpolitiek'. Bier 2003, p. 74 en 75 . 
Concluderend: het enquêterecht is voor de enquêtegerechtigde kapitaalverschaffer zonder stemrecht niet zonder meer een probaat middel om zijn rechtspositie te beschermen.

\subsection{Geschillenregeling ${ }^{95}$}

De geschillenregeling bestaat uit de vordering tot gedwongen overdracht of uitstoting (art. 2:336 BW) en de vordering tot uittreding (art. 2:343 BW). Het doel of resultaat van de geschillenregeling is aldus de overdracht van aandelen.

\section{Aard van het middel}

a. de vordering tot gedwongen overdracht of uitstoting

Art. 2:336 lid $1 \mathrm{BW}$ bepaalt dat een of meer houders van aandelen die alleen of gezamenlijk ten minste een derde van het geplaatste kapitaal verschaffen, van een aandeelhouder die door zijn gedragingen het belang van de vennootschap zodanig schaadt of heeft geschaad, dat het voortduren van zijn aandeelhouderschap in redelijkheid niet kan worden geduld, in rechte kunnen vorderen dat hij zijn aandelen overeenkomstig art. 2:341 BW overdraagt. Dit wordt ook wel de vordering tot gedwongen overdracht of uitstoting genoemd.

De grondslag van de vordering tot uitstoting ${ }^{96}$ is dat de gedaagde aandeelhouder door zijn gedrag het gedrag van de vennootschap schaadt of heeft geschaad. ${ }^{97}$ Gedragingen die wel schadelijk zijn voor de goede naam en faam van de vennootschap, maar die niet direct verband houden met het functioneren van de aandeelhouder binnen de vennootschap, zijn daartoe niet voldoende. Datzelfde geldt voor het enkele hinderlijke of zelfs onaanvaardbare gedrag van een aandeelhouder. Het gaat aldus om gedragingen van de aandeelhouder - in die hoedanigheid ${ }^{98}-$ die

95 Zie uitgebreid over de geschillenregeling: Bulten 2011. De minister heeft aangekondigd dat in 2012 de voorbereidingen zullen worden gestart voor een aanvullende herziening van de geschillenregeling en een wetsontwerp ter consultatie aan te bieden. Zie Kamerstukken I 2011/12, 31 058, nr. E, p. 2 (Nadere MvA).

96 Zie hierover uitgebreid Bulten 2011, p. 57-68.

97 Kamerstukken II 2006/07, 31 058, nr. 3, p. 17 (MvT): uitstoting is ook mogelijk wegens gedragingen die ten tijde van het instellen van de vordering in het verleden liggen.

98 Hof Amsterdam (OK) 27 oktober 1994, NJ 1996, 167 (Muller/Muts); Rb. Amsterdam 28 maart 2001, JOR 2001, 110 (Hoffmann/Hoffmann) en - in vervolg - Hof Amsterdam (OK) 10 april 2003, JOR 2003, 144, m.nt. Bulten (Hoffmann/Hoffmann). Asser/Maeijer, Van Solinge \& Nieuwe Weme 2-II* 2009, nr. 707, zijn van mening dat deze enge uitleg van het criterium niet gehandhaafd moet blijven. De toets zou moeten zijn: schaadt het gedrag van de aandeelhouders het belang van de vennootschap zodanig, dat het handhaven als aandeelhouder niet langer mogelijk is? Zie ook Bulten in haar JORnoot onder het eerder genoemde Hoffman-arrest. De minister spreekt over 'de beperkte gronden waarop aandeelhouders kunnen worden uitgestoten' als knelpunt in de geschillenregeling, zie Kamerstukken II 2006/07, 31 058, nr. 3, p. 17 (MvT) 
ertoe leiden dat het functioneren van de vennootschap in gevaar wordt gebracht, omdat de besluitvorming wordt verlamd. ${ }^{99}$

b. de vordering tot uittreding

Art. 2:343 lid $1 \mathrm{BW}$ bepaalt onder meer dat de aandeelhouder die door gedragingen van één of meer mede-aandeelhouders zodanig in zijn rechten of belangen is geschaad $^{100}$ dat het voortduren van zijn andeelhouderschap in redelijkheid niet meer van hem kan worden gevergd, tegen die mede-aandeelhouders een vordering tot uittreding kan instellen, inhoudende dat zijn aandelen overeenkomstig art. 2:343a lid 1, 2 en 3 BW worden overgenomen. Dit wordt ook wel de vordering tot uittreding genoemd. ${ }^{101}$ De vordering tot uittreding kan ook worden ingesteld tegen de vennootschap op grond van gedragingen van één of meer mede-aandeelhouders of van de vennootschap zelf. Indien de vordering tegen de vennootschap wordt toegewezen, dan is de vennootschap verplicht tot overneming. ${ }^{102}$

De grondslag van de vordering tot uittreding ${ }^{103}$ is de gedraging van een aandeelhouder, waardoor de andere aandeelhouder zodanig in zijn recht of belangen wordt geschaad dat het voortduren van het aandeelhouderschap van de ene aandeelhouder in redelijkheid niet kan worden gevergd. De mede-aandeelhouder zit in een benarde situatie of is bekneld. De vordering tot uittreding kan een einde maken aan deze positie. De wettekst brengt tot uitdrukking dat het om het belang van de aandeelhouder gaat. Anders dan bij de vordering tot uitstoting gaat het dus niet om schending van het vennootschappelijk belang. Dat neemt niet weg dat ook de vennootschap ermee gediend kan zijn dat aan de benarde situatie een einde komt. Noch de omstandigheid dat gedragingen als bedoeld in art. 2:343 BW tevens het

99 Kamerstukken II 1984/85, 18 905, nr. 3, p. 15-17 (MvT).

100 Met invoering van de flex-BV zijn de woorden 'wordt geschaad' gewijzigd in 'is geschaad'. Daarmee wordt tot uitdrukking gebracht dat uittreding ook mogelijk is wegens gedragingen die ten tijde van de vordering inmiddels in het verleden liggen. Zie Kamerstukken II 2006/07, 31 058, nr. 3, p. $108(\mathrm{MvT})$

101 Zie uitgebreid over het uittredingsrecht van de minderheidsaandeelhouder: P.P. de Vries, Exit rights of minority shareholders in a private limited company (diss. Groningen), Deventer: Kluwer 2010.

102 Kamerstukken II 2006/07, 31 058, nr. 3, p. 108 (MvT). Met invoering van de flex-BV is het mogelijk geworden de vordering tot uittreding in te stellen tegen de vennootschap op grond van gedragingen van één of meer mede-aandeelhouders of van de vennootschap zelf. Daarmee komt de wetgever terug op haar eerdere standpunt dat indien sprake is van wanbeheer de enquêteprocedure moet worden gevolgd (Kamerstukken II 1984/85, 18 905, nr. 3, p. 26 (MvT). “Waar de mogelijkheden van een enquêteprocedure en de uittredingsregeling elkaar ook in andere omstandigheden niet steeds uitsluiten, bestaat er onvoldoende grond om aan die beperking thans nog vast te houden.", aldus de wetgever ten tijde van de parlementaire behandeling van het wetsvoorstel van de flex-BV. Is de vordering ingesteld tegen de vennootschap, dan zal wel rekening moeten worden gehouden met de beperkingen die zijn gesteld aan verkrijging door de vennootschap van eigen aandelen. Zie art. 2:207 BW.

103 Zie hierover uitgebreid Bulten 2011, p. 69-82. Bulten komt uiteindelijk tot de conclusie dat zowel voor de vordering tot uitstoting als de vordering tot uittreding eenzelfde grond gehanteerd zou moeten worden, gebaseerd op art. 2:8 BW. Zie Bulten 2011, p. 92-93. De minister heeft deze aanbeveling niet overgenomen, zie Kamerstukken II 2008/09, 31 058, nr. 6, p. 23 (NV II). 
belang van de vennootschap schaden en mogelijk aanleiding geven tot een vordering ingevolge art. 2:336 BW, noch de omstandigheid dat een andere aandeelhouder dan eiser ook schade heeft ondervonden, staan aan toepasselijkheid van art. 2:343 BW in de weg. ${ }^{104}$ Het kan gaan om allerlei gedragingen van een mede-aandeelhouder, die ertoe leiden dat de andere aandeelhouder 'benard' raakt. ${ }^{105}$ Die gedragingen hoeven geen verband te houden met het aandeelhouderschap. Het gaat om alle gedragingen, van welke aard dan ook, die kunnen leiden tot benardheid. ${ }^{106}$ Daarbij behoeft op zich nog geen sprake te zijn van misdragingen van de mede-aandeelhouders. ${ }^{107}$ Het kan ook gaan om een minderheid van aandeelhouders die door de meerderheid in een onhoudbare situatie wordt gebracht. ${ }^{108}$

Blijkens art. 2:338 lid 3 BW kunnen de vordering tot uitstoting en de vordering tot uitreding ook bij wege van voorlopige voorziening worden ingesteld.

Welke kapitaalverschaffer zonder stemrecht komen de vorderingen uit hoofde van de geschillenregeling toe? ${ }^{109}$

a. de vordering tot gedwongen overdracht of uitstoting

Uit art. 2:336 lid $1 \mathrm{BW}$ volgt dat de vordering tot gedwongen overdracht toekomt aan een of meer houders van aandelen die alleen of gezamenlijk ten minste een derde van het geplaatste kapitaal verschaffen. Op grond van art. 2:24d lid 2 BW tellen stemrechtloze aandelen bij het bepalen van deze drempel mee. De wettekst spreekt van aandeelhouders, zodat de vordering toekomt aan de stemrechtloze aandeelhouder. ${ }^{110}$ De vordering komt ook toe aan de houder van aandelen waarvan het stemrecht is overgedragen aan de vruchtgebruiker of pandhouder. De vordering komt niet toe aan de certificaathouder en evenmin aan de houder van een participatiebewijs. Op grond van art. 2:336 lid 2 BW kan het administratiekantoor de vordering tot uitstoting slechts instellen indien de certificaathouders daarmee tevoren hebben ingestemd. Ontbreekt deze instemming, dan is het niet-ontvankelijk. Het administratiekantoor dat aandelen houdt waarvan ook anderen dan de vennootschap of een dochtermaatschappij certificaten houden, kan de vordering wel instellen, maar alleen voor de aandelen waarvan de certificaten door die anderen worden gehouden. Dit vloeit voort uit de woorden 'indien en voor zover' in art. 2:336 lid 2 tweede volzin BW. ${ }^{111}$

104 Hof Amsterdam (OK) 16 mei 1991, NJ 1992, 203 (Van Baarsen/Van Vliet).

105 Zie voor een overzicht van gedragingen Asser/Maeijer, Van Solinge \& Nieuwe Weme 2-II* 2009, nr. 709

106 Hof Amsterdam (OK) 22 oktober 1992, NJ 1993, 411 (Van Eyk/Nootebos).

107 Vgl. Hof Amsterdam (OK) 20 november 1997, NJ 1998, 392 (Hooymans).

108 Hof Amsterdam (OK) 24 februari 1994, NJ 1995, 354

109 Zie uitvoering over de processuele positie van de certificaathouder: Van der Sangen 2001, p. 113 e.v.

110 Kamerstukken II 2008/09, 31 058, nr. 6, p. 14-15 (NV II).

111 Kamerstukken II 1984/85, 18 905, nr. 3, p. 17 (MvT). 
b. de vordering tot uittreding

Uit art. 2:343 lid $1 \mathrm{BW}$ volgt dat de vordering tot uittreding toekomt aan de aandeelhouder. Daaronder is mede begrepen de stemrechtloze aandeelhouder en de houder van aandelen waarvan het stemrecht is overgedragen aan de vruchtgebruiker of pandhouder. Anders dan bij de vordering tot uitstoting wordt daarbij geen kapitaaleis gesteld. De vordering komt niet toe aan de certificaathouder en evenmin aan de houder van een participatiebewijs. De vordering tot uittreding kan ook worden ingesteld tegen de vennootschap op grond van gedragingen van één of meer mede-aandeelhouders of van de vennootschap zelf.

\section{Knelpunten}

a. vordering tot uitstoting

Zoals gesteld, komt de certificaathouder niet de vordering tot uitstoting toe. De wetgever merkt daarover op dat zij de positie van de certificaathouder te zeer vindt verschillen van die van een gewone aandeelhouder. ${ }^{112}$ Kennelijk is dat een verwijzing naar de memorie van toelichting bij invoering van de geschillenregeling. Destijds noemde de wetgever als argument de certificaathouder de vordering tot uittreding te onthouden dat de certificaathouder geen stemrecht in de vennootschap heeft, zodat het niet kan gaan om geschillen tussen aandeelhouders. ${ }^{113}$ Ik zie geen goede reden waarom de stemrechtloze aandeelhouder wel en de houder van een certificaat met vergaderrecht niet de vordering tot uitstoting toekomt. Het certificaat met vergaderrecht toont grote gelijkenis met het stemrechtloze aandeel; zo hebben beide geen stemrecht. Er is naar mijn mening geen rechtvaardiging voor dit verschil te vinden, te meer omdat de certificaathouder met en zonder vergaderrecht wel bij voldoende kapitaalbelang enquêtegerechtigd zijn. Bovendien kan, anders dan het enquêterecht, de geschillenregeling overdracht van aandelen bewerkstelligen en zo een geschil of impasse tot een definitief einde brengen. Vooral in familievennootschappen, joint ventures of andere (meer) besloten verhoudingen kan de geschillenregeling de certificaathouder met vergaderrecht haar nut bewijzen. ${ }^{114}$

112 Kamerstukken II 2006/07, 31 058, nr. 3, p. 22 (MvT).

113 Kamerstukken II 1984/85, 18 905, nr. 3, p. 15 (MvT).

114 In gelijke zin Bulten 2011, p. 148. Zie p. 149-150 hoe de geschillenregeling ten aanzien van de bewilligde certificaathouder dan vorm zou kunnen krijgen.

Andere voorstanders: Leijten 2000, p. 2-3, wijst er op dat de geschillenregeling niet alleen het belang van de eisende aandeelhouder(s) en van de vennootschap dient, maar ook het algemeen belang. Leijten verwijst daarbij naar HR 8 december 1993, NJ 1994, 273 (Van den Berg). Van der Sangen 2001, p. 117.

Tegenstanders: Van den Ingh 2008, p. 9, sluit zich aan bij de opvatting van de minister en stelt dat conflicten tussen certificaathouders zich niet zo vaak zullen voordoen als tussen aandeelhouders. Bij aandeelhouders gaan het vaak om geschillen ten aanzien van de uitoefening van het stemrecht, welk stemrecht de certificaathouder ontbeert. Soerjatin 2006, p. 217, stelt dat de certificaathouder een geheel andere positie bekleedt dat de aandeelhouder. Zij wijst op de mogelijkheid in de statuten $\rightarrow$ 
Een ander knelpunt zou de kapitaaleis kunnen zijn, die art. 2:336 BW stelt. De vordering tot uitstoting kan slechts worden ingesteld door een of meer houders van aandelen die alleen of gezamenlijk ten minste een derde van het geplaatste kapitaal verschaffen. Met Bulten ${ }^{115}$ ben ik eens dat er geen goede reden voor deze drempel is te bedenken. Zowel bij het agenderingsrecht als bij het bijeenroepingsrecht geldt een drempel van een honderdste. In het enquêterecht geldt voor de kleine BV een drempel van tien procent. Het enquêterecht kan diep ingrijpen in de vennootschap en haar structuur. Ook de toewijzing van de vordering tot uitstoting heeft ingrijpende gevolgen. Een aandeelhouder moet als gevolg daarvan zijn aandelen overdragen. Ook de grondslag van de uitstotingsvordering is in zekere zin te vergelijken met de grondslag van een enquêteverzoek. Niet valt in te zien waarom in de geschillenregeling bij de vordering tot uitstoting een hogere kapitaaleis geldt dan in het enquêterecht voor de kleine BV. Ik pleit er dan ook voor de kapitaaleis voor de vordering tot uitstoting gelijk te trekken met de kapitaaleis als bedoeld in art. 2:346 lid 1 onder b BW, zijnde ten minste een tiende gedeelte van het geplaatste kapitaal.

b. vordering tot uittreding

Ten aanzien van de vordering tot uittreding en de positie van de houder van een certificaat met vergaderrecht geldt mijns inziens hetgeen ik ten aanzien van die positie bij de vordering tot uitstoting heb gesteld: ook de houder van een certificaat met vergaderrecht moet de vordering tot uittreding toekomen.

De houder van een certificaat zonder vergaderrecht behoort niet tot de kring van betrokkenen, zodat ik aan hem niet de vordering tot uitstoting en de vordering tot uittreding zou willen laten toekomen.

\subsection{Herleven van stemrecht?}

Inleiding

Uit het voorgaande bleek dat de belangrijkste middelen van de kapitaalverschaffer zonder stemrecht het vernietigen van een besluit ex art. 2:15 BW en het verzoek tot het instellen van een enquête ex art. 2:345 BW, gecombineerd met het verzoek tot voorlopige voorzieningen ex art. 2:349a BW, zijn. Ondanks een eventueel voor de kapitaalverschaffer zonder stemrecht in die procedures te verkrijgen positief resultaat, is echter sprake van handelen achteraf. Het leed is vaak al geschied, dat wil zeggen dat bijvoorbeeld het besluit reeds in strijd met de vennootschappelijke

en de administratievoorwaarden te voorzien in uittreedmogelijkheden voor certificaathouders. Asser/ Maeijer, Van Solinge \& Nieuwe Weme 2-II* 2009, nr. 706, stellen dat 'de certificaathouder niet een uitstotingsvordering toekomt, omdat hij, evenals de vennootschap, geen problemen kan ondervinden van de gedragingen van mede-aandeelhouders'

115 Bulten 2011, p. 100-101. 
redelijkheid en billijkheid is genomen. De kapitaalverschaffer zonder stemrecht kan, gelet op de hem ten dienste staande instrumenten, niet anders doen dan reactief in plaats van proactief handelen. Dat reactief handelen gaat bovendien gepaard met de nodige tijd en kosten.

Voorafgaande aan de besluitvorming kan de vergadergerechtigde kapitaalverschaffer zonder stemrecht door middel van het recht tot het bijeenroepen van een algemene vergadering en het agenderingsrecht de besluitvorming trachten te beïnvloeden. Op het moment van besluitvorming kan hij de besluitvorming beïnvloeden door de uitoefening van zijn vergaderrecht.

Beperk ik mij tot de nieuwe rechtsfiguur van het stemrechtloze aandeel, dan biedt de wet diverse waarborgen ter bescherming van de rechten van die aandeelhouder. Uit paragraaf 6.2.3.6 volgt dat zestien regels de stemrechtloze aandeelhouder bescherming bieden. De belangrijkste beschermingsregels voor de stemrechtloze aandeelhouder zijn die van art. 2:216 lid 8 en 2:231 lid 4 BW. Uitgangspunt van de wetgever is immers dat de stemrechtloze aandeelhouder voornamelijk moet worden beschermd tegen afbreuk van de aan zijn aandeel verbonden financiële rechten. ${ }^{116}$ In paragraaf 6.2.3.7 betoogde ik echter dat art. 2:216 lid 8 en 2:231 lid 4 BW eng moeten worden uitgelegd.

Het voorgaande doet de vraag rijzen of het stemrecht op het stemrechtloze aandeel in bepaalde gevallen moet herleven.

Moet het stemrecht op het stemrechtloze aandeel in bepaalde gevallen herleven? Alvorens ik antwoord op deze vraag geef, maak ik eerst een opmerking. De vraag is in feite niet goed geformuleerd. Art. 2:228 lid 5 BW bepaalt immers dat aan het stemrechtloze aandeel in de algemene vergadering geen stemrecht is verbonden. Wat niet is, kan dus ook niet herleven. Beter geformuleerd, is de vraag of in bepaalde gevallen aan het stemrechtloze aandeel in afwijking van de hoofdregel van art. 2:228 lid $5 \mathrm{BW}$ stemrecht in de algemene vergadering toekomt.

In de literatuur is bepleit stemrechtloze aandelen een, al dan niet cumulatief, laag preferent winstdelende aanspraak te geven. Het accent komt bij een stemrechtloos aandeel te liggen op de vermogenswaarde van het aandeel. De preferente dividend aanspraak zou in die gedachte een compensatie bieden voor het ontbreken van zeggenschap. Gelet op het accent op de vermogenswaarde van het aandeel, zou bij aantasting daarvan het stemrecht moeten herleven. ${ }^{117}$ Bijvoorbeeld in het geval dat het preferente dividend niet wordt uitgekeerd. Het stemrecht zou op verzoek van de aandeelhouder herleven en blijven bestaan tot het moment waarop de totale (cumulatieve) preferente aanspraak aan de stemrechtloze aandeelhouder is uitgekeerd. Indien in een periode van drie jaar onvoldoende preferent dividend is uitgekeerd, zou het stemrecht van rechtswege moeten ontstaan. Aan het automatisch

116 Kamerstukken II 2008/09, 31 058, nr. 6, p. 39.

117 Faasen 1989, p. 501; Schwarz 1990, p. 9-10 en Van den Nieuwenhuijzen 2008, p. 22. Zie voor een variant hierop: Stokkermans 2008 (1), p. 30, 1.k. Anders: Portier 2008, p. 240. 
verbinden van stemrecht zou geen behoefte zijn, aldus Schwarz. ${ }^{118}$ In deze visie is sprake van een voorwaardelijk stemrechtloos aandeel. De wetgever heeft gekozen, zo stelt zij, voor een eenvoudige regeling van het stemrechtloze aandeel. Anders dan in de literatuur bepleit, is daaraan geen (cumulatief) preferent dividend verbonden. ${ }^{119}$ In paragraaf 6.2.4 concludeerde ik dat de wetgever niet in zijn opzet van een eenvoudige regeling is geslaagd.

Vooral een besluit tot winstreservering kan de financiële rechten van de stemrechtloze aandeelhouder raken. Indachtig het eerder besproken Sluis-arres ${ }^{120}$ en met inachtneming van de in paragraaf 7.5.4.2 geformuleerde regels ten aanzien van winstreservering en de positie van de stemrechtloze aandeelhouder, zou aan art. 2:228 lid 5 BW de volgende formulering kunnen worden toegevoegd. Ik sluit daarbij aan bij de hiervoor in de literatuur aangehaalde overwegingen en het Sluis-arrest:

"Het stemrecht op het stemrechtloze aandeel ontstaat op schriftelijk verzoek van de stemrechtloze aandeelhouder van rechtswege, indien de vennootschap (i) gedurende drie opvolgende jaren geen of een in verhouding tot de winst slechts gering dividend uitkeert en (ii) op grond van een statutaire bepaling gedurende drie opvolgende jaren de door haar gemaakte winsten niet of slechts in geringe mate bij wege van dividend aan de aandeelhouders uitkeert, tenzij het belang van de vennootschap zulks rechtvaardigt."

De tenzij-clausule brengt tot uitdrukking dat de bewijslast niet op de stemrechtloze aandeel, maar op de aandeelhouder met stemrecht, die samen met de stemrechtloze aandeelhouder wiens stemrecht herleeft een besluit tot winstuitkering zal moeten nemen, en de vennootschap, die indien tot winstuitkering wordt besloten dat besluit zal moeten uitvoeren. Tevens sluit de voorgestelde bepaling aan bij de regels omtrent uitkering als bedoeld in art. 2:216 BW en zullen los van de voorgestelde bepaling deze regels gelden. Op grond van deze bepaling is sprake van conversie van het stemrechtloze aandeel in een gewoon aandeel (met inachtneming van de eventuele beperkte gerechtigdheid tot winst en/of de reserves). Dit is te vergelijken met royeerbare of beperkte royeerbare certificaten van aandelen. Bij dergelijke certificaten kan de certificaathouder op zijn verzoek of onder de voorwaarden, zoals beschreven in de administratievoorwaarden, zijn certificaten voor aandelen inwisselen. In dat geval verschiet deze kapitaalverschaffer zonder stemrecht van kleur en wordt hij een aandeelhouder met stemrecht.

\section{Knelpunten}

Met deze voorgestelde bepaling wordt echter niet ondervangen het probleem van kapitaalverwatering indien de vennootschap gewone aandelen uitgeeft, op welke

118 Schwarz 1990, p. 11-14

119 Dat neemt niet weg dat dergelijke aandelen wel kunnen worden uitgegeven, zie art. 2:201 lid 1 jo. 2:206a lid 2 BW

120 HR 9 juli 1990, LJN AC0960, NJ 1991, 51, m.nt. Ma (Sluis). 
aandelen de stemrechtloze aandeelhouder op grond van art. 2:206a BW geen voorkeursrecht kan uitoefenen. Ik verwijs naar paragraaf 6.2.3.5. Deze voorgestelde bepaling biedt evenmin bescherming in gevallen die buiten de, door mij voorgestane, enge interpretatie van art. 2:216 lid 8 en 2:231 lid 4 BW vallen.

Het praktische probleem is dus dat de voorgestelde bepaling niet aan het doel voldoet, terwijl het bovendien de vraag is of het mogelijk is een zodanige bepaling te formuleren die voorziet in 'herleven' van stemrecht ingeval dat de aan het stemrechtloze aandeel verbonden financiële rechten worden geraakt. Dat lijkt mij ondoenlijk, omdat de situatie waarin het stemrecht zou moeten herleven sterk afhankelijk is van de omstandigheden van het geval. De wet kan niet voorzien in dergelijke casuïstiek. Juist daarvoor biedt de algemene norm van de vennootschappelijke redelijkheid en billijkheid bescherming.

Een ander praktisch bezwaar tegen het 'herleven' van het stemrecht op het stemrechtloze aandeel is dat, indien het wel mogelijk zou zijn het herleven van stemrecht in casuïstiek te bevatten, de regeling van het stemrechtloze aandeel nog minder 'eenvoudig' wordt, dan zij met haar zestien beschermingsregels - verdeeld in types van goedkeuring, instemming en vrijstelling - al is. Dat komt de rechtszekerheid niet ten goede. Bovendien neemt de aantrekkelijkheid van het stemrechtloze aandeel door het woud aan (dwingendrechtelijke) regels af. De rechtsfiguur van certificering van aandelen biedt dan meer vrijheid en mogelijkheden. Te denken valt aan certificaten met en zonder vergaderrecht, deelcertificering, (beperkte) royeerbaarheid en de contractsvrijheid van de administratievoorwaarden.

Een volgend bezwaar is dat de wet reeds voorziet in de mogelijkheid tot versterking van de positie van de stemrechtloze aandeelhouder. Direct gerelateerd aan de financiële rechten van het stemrechtloze aandeel zijn dat de mogelijkheid dat de statuten van de vennootschap in afwijking van de hoofdregel van art. 2:216 lid $1 \mathrm{BW}$ bepalen dat de vergadering van houders van stemrechtloze aandelen bevoegd is tot bestemming van de winst die door vaststelling van de jaarrekening is bepaald en tot vaststelling van uitkeringen, althans dat de vergadering van houders van stemrechtloze aandelen voorafgaande goedkeuring dient te verlenen. Op grond van art. 2:210 lid 7 BW kunnen de statuten bovendien bepalen dat de vergadering van houders van stemrechtloze aandelen de bevoegdheid heeft te bepalen welk deel van het resultaat van het boekjaar wordt gereserveerd of hoe het verlies wordt verwerkt. Daarnaast kan de positie van de stemrechtloze aandeelhouder worden versterkt door in de statuten van de BV erin te voorzien dat aan de vergadering van houders van stemrechtloze aandelen de bevoegdheid tot uitgifte van aandelen en het voorkeursrecht op andere dan stemrechtloze aandelen toekomt. Indirect gerelateerd aan de financiële rechten van het stemrechtloze aandeel kan de positie van de stemrechtloze aandeelhouder worden versterkt door in de statuten van de BV erin te voorzien dat aan de vergadering van houders van stemrechtloze aandelen de bevoegdheid tot het verbinden of ontnemen van vergaderrechten aan certificaten, het recht van benoeming en ontslag van bestuurders en/of commissarissen de bevoegdheid tot voorafgaande goedkeuring 
van bestuurbesluiten ex art. 2:239 lid 3 BW en de bevoegdheid tot het geven van instructies aan het bestuur ex art. 2:239 lid 4 BW toekomt.

Ik kom dan ook tot de conclusie dat het 'herleven' van het stemrecht op het stemrechtloze aandeel niet aan te bevelen is.

\subsection{Restcategorie van middelen, niet zijnde rechtsvorderingen}

In het voorgaande werden de rechtsvorderingen besproken die de kapitaalverschaffers zonder stemrecht ten dienste staan ter bescherming van hun rechtspositie. Welke middelen zijn er, naast deze rechtsvorderingen, ter bescherming of verbetering van de positie van de stemrechtloze aandeelhouder? Ik onderscheid daarbij statutaire en buiten-statutaire middelen.

De positie van de stemrechtloze aandeelhouder kan worden versterkt door in de statuten van de BV erin te voorzien dat:

1. de vergadering van houders van stemrechtloze aandelen bevoegd is tot bestemming van de winst die door vaststelling van de jaarrekening is bepaald en tot vaststelling van uitkeringen, althans dat de vergadering van houders van stemrechtloze aandelen voorafgaande goedkeuring dient te verlenen;

2. de vergadering van houders van stemrechtloze aandelen bevoegd is te bepalen welk deel van het resultaat van het boekjaar wordt gereserveerd of hoe het verlies wordt verwerkt;

3. de vergadering van houders van stemrechtloze aandelen bevoegd is tot uitgifte van aandelen;

4. houders van stemrechtloze aandelen een voorkeursrecht op uit te geven aandelen toekomt;

5. de vergadering van houders van stemrechtloze aandelen bevoegd is tot het verbinden of ontnemen van vergaderrechten aan certificaten;

6. de vergadering van houders van stemrechtloze aandelen bevoegd is tot benoeming, schorsing en ontslag van bestuurders en/of commissarissen;

7. de vergadering van houders van stemrechtloze aandelen bevoegd is tot het geven van instructies aan het bestuur.

Buiten-statutair kan de positie van de stemrechtloze aandeelhouder worden versterkt door middel van een aandeelhoudersovereenkomst, waarin bijvoorbeeld bepalingen omtrent dividendbeleid zijn opgenomen. Handelen de aandeelhouders met stemrecht in strijd daarmee, dan is sprake van een tekortkoming, waarvan in rechte nakoming kan worden gevorderd. De bepalingen omtrent het dividendbeleid zouden kunnen worden versterkt met een boetebeding, zodat in voorkomend geval ook ${ }^{121}$ daarvan nakoming kan worden gevorderd. Te denken valt ook aan bepalingen in een aandeelhoudersovereenkomst waarbij het bestuur buiten de algemene vergadering

121 Het bepaalde in art. 6:92 lid 1 BW zal dan weg gecontracteerd moeten worden. 
om verplicht is tot informatieverstrekking. Deze niet-limitatieve voorbeelden maken dat aandeelhouders met stemrecht en het bestuur ook langs contractuele weg gedwongen worden de belangen van de stemrechtloze aandeelhouders in acht te nemen.

\subsection{Samenvatting en conclusie}

In dit hoofdstuk stonden de middelen van de kapitaalverschaffers zonder stemrecht om hun rechten af te dwingen of hun rechtspositie te verbeteren centraal.

Het agenderingsrecht van art. 2:224a lid $1 \mathrm{BW}$ komt toe aan de stemrechtloze aandeelhouder, de houder van aandelen waarvan het stemrecht is overgedragen aan de vruchtgebruiker of pandhouder en de houder van een certificaat van aandeel met vergaderrecht. Voor alle agenderingsgerechtigde kapitaalverschaffers zonder stemrecht geldt dat zij aan de kapitaaleis moeten voldoen. Het agenderingsrecht komt niet toe aan de certificaathouder zonder vergaderrecht en evenmin aan de houder van een participatiebewijs. De conclusie is dan ook dat alleen vergadergerechtigden agenderingsgerechtigd zijn. Diezelfde conclusie geldt voor het bijeenroepingsrecht van art. 2:220 lid 2 BW. Alleen vergadergerechtigden zijn bijeenroepingsgerechtigd.

Er staat de vergadergerechtigde kapitaalverschaffer zonder stemrecht een aantal rechtsmiddelen ten dienste indien tijdens de algemene vergadering zijn recht op informatie is geschonden. Voorwaarde is wel dat deze kapitaalverschaffer zonder stemrecht tevergeefs tijdens de algemene vergadering om informatie of inlichtingen heeft gevraagd. Van de in paragraaf 8.4 besproken middelen om het recht van inlichtingen af te dwingen lijken een vordering gebaseerd op art. 2:217 lid $2 \mathrm{BW}$, de exhibitieplicht van art. $843 \mathrm{Rv}$, het voorlopig getuigenverhoor en het enquêterecht het meest effectief. Wat betreft het enquêterecht past in dit kader de kanttekening dat slechts indien de toestand van de vennootschap of het belang van het onderzoek dat vergt, de vennootschap op grond van een onmiddellijke voorziening gelast kan worden de aandeelhouder de tijdens de algemene vergadering onthouden informatie te verschaffen.

Een ander middel is de vordering tot medewerking tot het nemen van een besluit. Deze vordering komt naar mijn mening toe aan alle kapitaalverschaffers zonder stemrecht, uitgezonderd de houder van certificaten zonder vergaderrecht. Deze laatste behoort immers niet tot de kring van betrokkenen in de zin van art. 2:8 BW. De grondslag voor de vordering is de vennootschappelijke redelijkheid en billijkheid. Daarnaast ben ik van mening dat de rechter met de nodige terughoudendheid de vordering tot medewerking tot het nemen van een besluit moet beoordelen.

De kapitaalverschaffers zonder stemrecht die tot de kring van betrokkenen in de zin van art. 2:8 BW behoren, zijnde de stemrechtloze aandeelhouder, de aandeelhouder waarbij stemrecht is overgedragen aan de vruchtgebruiker of de pandhouder, de houder van certificaten met vergaderrecht en de houder van een participatiebewijs, komen de vordering tot vernietiging van besluiten ex art. 2:15 lid 1 onder $b$ 
BW toe. De houder van certificaten zonder vergaderrecht komt deze vordering naar mijn mening niet toe. De vennootschap heeft niet gewild dat deze certificaathouder (s) invloed op de besluitvorming kan (kunnen) uitoefenen. De wil en verklaring van de vennootschap is daarop niet gericht, omdat de statuten aan die certificaten geen vergaderrecht toekennen.

In spoedeisende zaken kan de kapitaalverschaffer zonder stemrecht in kort geding op grond van art. $254 \mathrm{Rv}$ een onmiddellijke voorziening bij voorraad vorderen. De grondslag voor een dergelijke vordering kan zijn strijdigheid met de vennootschappelijke redelijkheid en billijkheid. Te denken valt aan een verbod van een voorgenomen besluit van het bestuur of de algemene vergadering dat de gerechtvaardigde belangen van de kapitaalverschaffer zonder stemrecht raakt, of juist een gebod indien nagelaten wordt een besluit te nemen. Gelet op de aard van de procedure en het voorlopige karakter van de op te leggen maatregel is het naar mijn mening de vraag of de kapitaalverschaffer zonder stemrecht in alle gevallen baat bij het gebod of verbod in kort geding zal hebben. Het komt mij bovendien voor dat de kapitaalverschaffer zonder stemrecht die tot de kring van betrokkenen behoort eerder een in rechte te respecteren belang heeft dan de certificaathouder zonder vergaderrecht.

Het recht van enquête komt aan alle kapitaalverschaffers zonder stemrecht toe (mits zij aan de kapitaaleis voldoen), uitgezonderd de houder van een participatiebewijs. Op grond van art. 2:346 lid 1 onder e $\mathrm{BW}^{122}$ acht ik het echter mogelijk dat de houder van een participatiebewijs bij de statuten of bij overeenkomst met de rechtspersoon de enquêtebevoegdheid wordt toegekend. Daarbij zal aan de kapitaaleis voldaan moeten zijn, omdat anders de houder van een participatiebewijs in een gunstiger positie komt te verkeren dan de andere kapitaalverschaffers zonder stemrecht. Daarnaast acht ik het mogelijk dat de houder van een participatiebewijs zich ex art. 282 lid $1 \mathrm{Rv}$ als belanghebbende in de enquêteprocedure voegt.

Het komt mij voor dat de kapitaaleis bij een enquêteverzoek geen belemmering is in de bescherming van de kapitaalverschaffers zonder stemrecht. Ook de rechtspersoon zelf kan een verzoek tot enquête indienen. De kapitaalverschaffer zonder stemrecht die niet aan de kapitaaleis voldoet, kan zich als belanghebbende in de enquêteprocedure voegen. Bovendien kan de OK ook ambtshalve de kapitaalverschaffer als belanghebbende oproepen. Daarnaast bestaat voor iedere belanghebbende de mogelijkheid een zelfstandig verzoek in te dienen, mits dit betrekking heeft op het onderwerp van het oorspronkelijke enquêteverzoek.

De vraag of het enquêterecht een probaat middel is ter bescherming van de aan de rechtsfiguren zonder stemrecht verbonden financiële rechten, kan niet zonder meer en overtuigend met 'ja' worden beantwoord. Wel zal de uitkomst van de enquêteprocedure ertoe kunnen leiden dat besluitvorming met betrekking tot

122 Uitgaande van de Wet van 18 juni 2012 tot wijziging van boek 2 van het Burgerlijk Wetboek in verband met de aanpassing van het recht van enquête (Kamerstukken 32 887, Stb. 2012, 274). Deze wet zal inwerking treden op 1 januari 2013 (Stb. 2012, 305). 
uitkeringen zorgvuldiger en beter gemotiveerd geschiedt, waarbij extra aandacht zal worden besteed aan de positie van de kapitaalverschaffer zonder stemrecht en de motivering van de rechter om tot vernietiging van het besluit tot reservering te komen.

De vordering tot gedwongen overdracht of uitstoting in de geschillenregeling komt toe aan de stemrechtloze aandeelhouder en de houder van aandelen waarvan het stemrecht is overgedragen aan de vruchtgebruiker of pandhouder, mits aan de kapitaaleis van art. 2:336 $\mathrm{BW}$ is voldaan. De vordering komt niet toe aan de certificaathouder en evenmin aan de houder van een participatiebewijs. De vordering tot uittreding ex art. 2:343 BW komt eveneens toe aan de stemrechtloze aandeelhouder en de houder van aandelen waarvan het stemrecht is overgedragen aan de vruchtgebruiker of pandhouder, doch niet aan de certificaathouder en evenmin aan de houder van een participatiebewijs.

Een knelpunt in de regeling van de vordering tot uitstoting en de vordering tot uittreding is dat deze vorderingen niet toekomen aan de certificaathouder. Ik zie geen goede reden waarom de stemrechtloze aandeelhouder wel en de houder van een certificaat met vergaderrecht niet deze vorderingen toekomt, terwijl de certificaathouder enquêtegerechtigd is. Een (ander) knelpunt in de regeling van de vordering tot uitstoting is de kapitaaleis van ten minste een derde van het geplaatste kapitaal, die art. 2:336 BW stelt. Daarvoor is evenmin een goede reden te bedenken. Ik pleit er voor die kapitaaleis gelijk te trekken met de kapitaaleis voor het indienen van een enquêteverzoek als bedoeld in art. 2:346 lid 1 onder b BW, zijnde ten minste een tiende gedeelte van het geplaatste kapitaal. De houder van een certificaat zonder vergaderrecht behoort niet tot de kring van betrokkenen, zodat ik aan hem niet de vordering tot uitstoting en de vordering tot uittreding zou willen laten toekomen.

In paragraaf $8.10 \mathrm{kwam} \mathrm{ik}$ tot de conclusie dat het stemrecht op stemrechtloze aandelen in voorkomend geval niet moet 'herleven'. Het lijkt mij wegens de casuïstiek ondoenlijk een bepaling te formuleren die in de situatie voorziet dat het stemrecht herleeft ingeval de aan het stemrechtloze aandeel verbonden financiële rechten worden geraakt. De algemene norm van de vennootschappelijke redelijkheid en billijkheid biedt daarvoor reeds bescherming. Daarnaast zou de regeling van het stemrechtloze aandeel nog minder 'eenvoudig' worden, dan zij met haar zestien beschermingsregels - verdeeld in types van goedkeuring, instemming en vrijstelling al is en maakt een degelijke regeling het stemrechtloze aandeel voor de praktijk minder aantrekkelijk. Bovendien voorziet de wet reeds in de mogelijkheid tot versterking van de positie van de stemrechtloze aandeelhouder.

Tot slot betoogde ik in paragraaf 8.11 dat zowel statutair als buiten-statutair de rechtspositie van de stemrechtloze aandeelhouder kan worden versterkt. Voor de mogelijkheden daartoe verwijs ik naar hetgeen ik in die paragraaf heb opgemerkt. 
Hoofdstuk 9

SAMENVATTING, CONCLUSIES EN AANBEVELINGEN

\section{$9.1 \quad$ Inleiding}

Met de invoering per 1 oktober 2012 van de Wet vereenvoudiging en flexibilisering $\mathrm{BV}$-recht en de Invoeringswet vereenvoudiging en flexibilisering BV-recht is in het Nederlandse BV-recht het stemrechtloze aandeel geïntroduceerd. Dat is de aanleiding voor mijn onderzoek geweest. Daaraan ging een pleidooi voor dat aandeel gedurende een periode van circa veertig jaren vooraf. De wetgever kon niet om de behoefte heen die in de praktijk aan dat aandeel bestond. In algemene zin dwongen Europese ontwikkelingen, op grond van jurisprudentie en wegens de concurrentiepositie van de Nederlandse BV, tot flexibilisering van het BV-recht. Ik verwijs naar hoofdstuk 2.

In hoofdstuk 3 inventariseerde ik soorten aandelen en verwante stukken. Uit de inventarisatie van soorten aandelen en verwante stukken volgt dat de rechtsfiguren zonder stemrecht in de BV (kunnen) zijn: (i) het stemrechtloze aandeel, (ii) certificaten van aandelen (met of zonder vergaderrecht), (iii) het aandeel waarbij het stemrecht is overgedragen aan de vruchtgebruiker, (iv) het aandeel waarbij het stemrecht is overgedragen aan de pandhouder en (v) het participatiebewijs. De houder van een van deze rechtsfiguren is te beschouwen als een 'kapitalverschaffer zonder stemrecht'. Mijn onderzoek richtte zich op deze kapitaalverschaffer.

In paragraaf 9.2 geef ik als conclusie antwoord op de in hoofdstuk 1 geformuleerde vragen. Deze vragen zijn:

1. Wat is de verhouding van de kapitaalverschaffer zonder stemrecht tot:

a. de vennootschap;

b. het bestuur van de vennootschap;

c. andere kapitaalverschaffers van de vennootschap met stemrecht in de algemene vergadering?

2. Door welke rechten, verplichtingen en normen worden die verhoudingen ingevuld?

3. Hoe kan de kapitaalverschaffer zonder stemrecht invloed op die verhoudingen uitoefenen en zijn rechten waarborgen? 
Vervolgens geef ik in paragraaf 9.3 een aantal aanbevelingen tot verbetering van de wet. In paragraaf 9.4 sluit ik af met verwachtingen en een slotopmerking.

\subsection{Conclusies}

\subsubsection{Wat is de verhouding van de kapitaalverschaffer zonder stemrecht tot de vennootschap, haar bestuur en de kapitaalverschaffers van de vennootschap met stemrecht?}

\section{Aard van de rechtsfiguur zonder stemrecht}

Het antwoord op de vraag wat de verhouding van de kapitaalverschaffer zonder stemrecht tot de vennootschap, haar bestuur en de kapitaalverschaffers van de vennootschap met stemrecht is, wordt in de eerste plaats bepaald door de aard van de rechtsfiguur zonder stemrecht. In hoofdstuk 4 besprak ik deze rechtsfiguren.

Het stemrechtloze aandeel wordt geregeld in art. 2:228 lid 5 BW. Ik zou dat aandeel als volgt willen definiëren: 'het stemrechtloze aandeel is een vermogensrecht op naam, in de vorm van een aandeel uitgegeven door de BV, dat kapitaal in een $B V$ vertegenwoordigt, waaraan de rechten volgens de wet en de statuten van de BV zijn verbonden, waaronder het recht - al dan niet beperkt - op winst en/of reserves van die $\mathrm{BV}$, doch aan welk aandeel geen stemrecht in de algemene vergadering is verbonden'. Stemrechtloze aandelen zijn aandelen van een bepaalde soort of aanduiding.

Op grond van art. 2:216 lid $7 \mathrm{BW}$ kunnen verschillende soorten stemrechtloze aandelen worden gecreëerd die geheel of gedeeltelijk recht geven op winst en/of reserves, of een combinatie daarvan.

De vergadering van houders van stemrechtloze andelen is een orgaan van de vennootschap in de zin van art. 2:189a BW. Dat maakt het mogelijk aan dat orgaan bepaalde bevoegdheden toe te kennen, zoals de benoeming van een bestuurder en/of commissaris. Houders van stemrechtloze aandelen hebben in 'hun' vergadering stemrecht. Bestuurders en commissarissen hebben in de vergadering van stemrechtloze aandeelhouders geen raadgevende stem. Het komt mij echter voor dat uit de eisen van de vennootschappelijke redelijkheid en billijkheid kan voortvloeien dat de vergadering van houders van stemrechtloze aandelen, indien haar als orgaan statutaire bevoegdheden zijn toegekend, bij (belangrijke) besluiten de bestuurders (en commissarissen) in de gelegenheid stelt hun raadgevende stem te doen horen, te meer indien de bestuurders niet tevens aandeelhouders zijn.

De hoofdregel van art. 2:24d lid $1 \mathrm{BW}$ is dat stemrechtloze aandelen bij de vaststelling in hoeverre de leden of aandeelhouders stemmen, aanwezig of vertegenwoordigd zijn, of in hoeverre het aandelenkapitaal verschaft wordt of vertegenwoordigd is, niet meetellen. Art. 2:24d lid 2 BW formuleert voor de daarin genoemde artikelen de uitzondering. 
Op grond van deze hoofdregel tellen stemrechtloze aandelen bij de bepaling of sprake is van een dochtermaatschappij in de zin van art. 2:24a BW niet mee. Datzelfde geldt voor de bepaling of sprake is van een groepsmaatschappij als bedoeld in art. 2:24b BW. Ik meen dat de hoofdregel van art. 2:24d lid $1 \mathrm{BW}$ niet consistent is, omdat op grond van art. 2:242 jo. 2:244 en 2:252 jo. 2:254 BW de bevoegdheid tot benoeming en ontslaan van bestuurders en commissarissen aan de vergadering van stemrechtloze aandeelhouders kan worden toegekend. Vele variaties van 'dochtermaatschappij' zijn mogelijk, indien de benoeming van bestuurders toekomt aan diverse soorten aandelen. Een dergelijke toekenning van bevoegdheid is een omstandigheid die mijns inziens ook bij de feitelijke invulling van het criterium van 'centrale leiding' bij het bepalen of sprake is van een groep of groepsmaatschappij moet worden betrokken.

De uitzonderingsregel van art. 2:24d lid 2 BW bepaalt dat stemrechtloze aandelen bij de toepassing van art. 2:24c BW meetellen bij de vaststelling van de aanwezigheid van een deelneming. Daarmee wordt volgens de wetgever voorkomen dat vennootschappen stemrechtloze aandelen zouden gebruiken om te ontkomen aan de verplichting informatie over die deelnemingen in de financiële verslaggeving op te nemen. Art. 2:24d lid 2 BW komt er op neer dat bij de bepaling of sprake is van een afhankelijke maatschappij in de zin van art. 2:63a, 2:152 en art. 2:262 BW tevens rekening gehouden moet worden met de stemrechtloze aandelen in die BV. Mij dunkt dat dit ertoe kan leiden dat, indien een vennootschap stemrechtloze aandelen in een andere vennootschap houdt, de structuurregeling van toepassing is, terwijl die stemrechtloze aandeelhouder geen zeggenschap kan uitoefenen over de afhankelijke maatschappij.

Familievennootschappen waarbij stemrechtloze aandelen uitgegeven zijn, kunnen opteren voor het verzwakte structuurregime van art. 2:265a BW, mits aan het vereiste van 'onderlinge regeling tot samenwerking' en aan de overige vereisten van art. 2:265a BW is voldaan.

Bij de introductie van het stemrechtloze aandeel heeft de wetgever bij een aantal wettelijke bepalingen kennelijk niet nagedacht wat de gevolgen daarvan zijn. Het betreft het begrip 'meerderheid der aandelen' in de zin van art. 1:88 lid $5 \mathrm{BW}$, het begrip 'uiteindelijk belanghebbende' in de Wwft en Wtt, de woorden 'ten minste de helft van het geplaatste kapitaal' in art. 43 Fw en het begrip 'in overwegende mate bij machte' als bedoeld in art. 1:141 lid 4 BW.

De invoering van stemrechtloze aandelen leidt niet tot overgangsrechtelijke problemen.

De rechtsfiguur van certificering van aandelen is te vergelijken met het stemrechtloze aandeel. Door certificering wordt de juridische en economische eigendom van de aandelen gesplitst. De aandelen worden overgedragen aan en gehouden door een administratiekantoor. Het AK beheert de aandelen en geeft de certificaten uit aan de certificaathouder(s). De rechtsverhouding tussen het administratiekantoor en de certificaathouder(s) is een beheerovereenkomst, die belichaamd wordt in de administratievoorwaarden. Tussen het administratiekantoor als aandeelhouder en de 
vennootschap gelden de wet en de statuten, zodat sprake is van een wettelijke en statutaire basis. Het administratiekantoor heeft als aandeelhouder in beginsel de aan de aandelen verbonden zeggenschapsrechten, terwijl de certificaathouder de financiële rechten van het aandeel heeft, zoals het recht op dividend. Er kan onderscheid worden gemaakt tussen royeerbare, beperkt royeerbare en niet-royeerbare certificaten. In de flex-BV is het onder het oude recht bestaande onderscheid tussen met of zonder medewerking van de vennootschap uitgegeven certificaten verdwenen. Het gaat in de flex-BV om de vraag of bij de statuten aan certificaten vergaderrecht in de zin van art. 2:227 BW is verbonden. Uitgangspunt is dat de vennootschap zelf bepaalt of er certificaten met vergaderrecht worden toegelaten, en zo ja, aan welke certificaten dat vergaderrecht toekomt. De hoofdregel van art. 2:227 lid 4 BW bepaalt dat het aan certificaathouders toegekende vergaderrecht slechts met instemming van die certificaathouder kan worden gewijzigd. Op grond van art. 2:227 lid 2 BW zijn statutaire regelingen mogelijk, die bepalen dat (i) certificaten in het algemeen geen vergaderrecht hebben, (ii) alle certificaten vergaderrecht hebben of (iii) het vergaderrecht slechts toekomt aan bepaalde, in de statuten aangeduide certificaten. De wet koppelt aan het vergaderrecht talloze andere rechten, zoals bijvoorbeeld het recht om kennis te nemen van oproepingsbrieven voor een algemene vergadering (art. 2:224 lid 1 BW) en het recht om de voorzieningenrechter te verzoeken om een machtiging tot het bijeenroepen van een algemene vergadering (art. 2:220 BW).

Art. 2:227 BW heeft tot gevolg dat bij de toepassing van art. 3:259 BW ten aanzien van certificaten van aandelen in een BV slechts medewerking van de uitgever van de oorspronkelijke aandelen aangenomen kan worden, indien er sprake is van certificaten waaraan statutair vergaderrecht is verbonden.

Voor certificaathouders zijn in algemene zin art. 68a en 69 Overgangswet NBW relevant. Daarnaast geven art. V.2 lid 1 en 6 van het Overgangsrecht specifieke regels. De vennootschap, althans haar bestuur, moet zo snel mogelijk, doch uiterlijk 1 oktober 2013 de vergadergerechtigde certificaathouder in het aandeelhoudersregister vermelden. Is het aandeelhoudersregister een maand vóór de datum van de eerste algemene vergadering na het tijdstip van inwerkingtreding van de wet nog niet overeenkomstig art. 2:194 lid 1 laatste volzin BW voltooid, dan zijn art. 2:223 lid 2 en 3 (oud) BW van toepassing. Houders van certificaten die met medewerking van de vennootschap uitgegeven zijn, kunnen de vennootschap schriftelijk verzoeken hen als vergadergerechtigden in het aandeelhoudersregister in te schrijven. Indien het bestuur dit verzoek afwijst, kunnen de houders van deze certificaten de rechtbank verzoeken het bestuur op te dragen hen als vergadergerechtigden in te schrijven. Zijn er voor het tijdstip van inwerkingtreding van de wet met medewerking van de vennootschap certificaten van haar aandelen uitgegeven, dan dient de vennootschap bij de eerstvolgende statutenwijziging vergaderrecht te verbinden aan deze certificaten overeenkomstig art. 2:227 lid 2 BW. Tot het moment van die statutenwijziging worden onder certificaten waaraan bij de statuten vergaderrecht is verbonden tevens verstaan certificaten die voor inwerkingtreding van de wet over 
vergaderrecht beschikten en die in het aandeelhoudersregister zijn opgenomen en mogen de vergadergerechtigde certificaathouders de aan hen toekomende rechten uitoefenen.

Het vruchtgebruik op aandelen is geregeld in art. 2:197 BW. Het pandrecht op aandelen is geregeld in art. 2:198 BW. De hoofdregel van beide regelingen is dat de aandeelhouder het stemrecht heeft op de aandelen waarop het vruchtgebruik of het pandrecht is gevestigd. Op grond van art. 2:197 lid 3 BW, respectievelijk art. 2:198 lid $3 \mathrm{BW}$, wordt de aandeelhouder stemrechtloos indien het stemrecht bij de vestiging van het vruchtgebruik, respectievelijk het pandrecht, aan de vruchtgebruiker, respectievelijk de pandhouder, is overgedragen of indien die overdracht nadien schriftelijk tussen de aandeelhouder en de vruchtgebruiker, respectievelijk de pandhouder, is overeengekomen. Art. 2:196a BW is daarbij van overeenkomstige toepassing verklaard. De vruchtgebruiker, respectievelijk de pandhouder, moet iemand zijn aan wie de aandelen vrij kunnen worden overgedragen. Als dat laatste niet het geval is, moet - kort gezegd - zowel de regeling over de overdracht van het stemrecht als de overdracht van het stemrecht zelf door de algemene vergadering worden goedgekeurd. Art. 2:197 lid 4 BW, respectievelijk art. 2:198 lid 4 BW, bepaalt dat de aandeelhouder die vanwege een vruchtgebruik, respectievelijk pandrecht, geen stemrecht heeft, de rechten heeft die door de wet zijn toegekend aan de houders van certificaten van aandelen waaraan vergaderrecht is verbonden. Uit art. 2:227 lid 2 BW volgt dat de aandeelhouder die vanwege een vruchtgebruik of pandrecht geen stemrecht heeft, wel vergaderrecht heeft. De inwerkingtreding van de flex-BV doet aan een reeds rechtsgeldig gevestigd vruchtgebruik of pandrecht op aandelen, waarbij de aandeelhouder zijn stemrecht aan de vruchtgebruiker of pandhouder heeft overgedragen, niet af.

Participatiebewijzen worden tegen storting of inbreng verkregen en vertegenwoordigen kapitaal in de vennootschap. Aan een participatiebewijs zijn soms alle rechten die een aandeelhouder toekomen verbonden, behalve het stemrecht. Houders van participatiebewijzen hebben aanspraak op een deel van de winst en/of het liquidatiesaldo. Participatiebewijzen hebben een statutaire basis en een contractuele grondslag. De rechtsverhouding tussen de houder van het participatiebewijs en de vennootschap wordt ingevuld door de participatievoorwaarden. De inwerkingtreding van de flex-BV doet aan de rechtsgeldigheid van reeds uitgegeven participatiebewijzen niet af.

\section{Interne verhoudingen in de $B V$}

Niet alleen de aard van de rechtsfiguur zonder stemrecht bepaalt de verhouding van de kapitaalverschaffer zonder stemrecht tot de vennootschap, haar bestuur en de kapitaalverschaffers van de vennootschap met stemrecht. Ook de interne verhoudingen in de BV spelen daarbij een rol. In hoofdstuk 5 besprak ik deze verhoudingen. Het gaat daarbij om de onderlinge betrekkingen tussen de kapitaalverschaffer en de algemene vergadering, het bestuur van de vennootschap of de vennootschap. Deze betrekkingen geven het spanningsveld weer, waarin de kapitaalverschaffer zonder 
stemrecht zich bevindt. Deze verhoudingen kunnen vanuit de rechtseconomie benaderd worden door de principal-agent theory. De kapitaalverschaffers zonder stemrecht moeten zich ervan kunnen verzekeren dat ook hun belang door de diverse actoren in het vennootschappelijk verband wordt gediend. In de flex-BV blijft de beslotenheid een van de factoren die de interne verhoudingen bepaalt. Datzelfde geldt voor de aard van de samenwerking in of door middel van de BV. Beide factoren, doch niet uitsluitend deze factoren, vullen de (rechts)normen in de interne verhoudingen in. Het vennootschappelijk belang dient als richtsnoer voor het handelen van het bestuur en de raad van commissarissen van de BV. De wetgever lijkt uit te gaan van de gecombineerde opvatting van het vennootschappelijk belang.

Het bestuur is autonoom in de uitoefening van zijn taak en bevoegdheden. De dualistische structuur is in de flex-BV gehandhaafd. De algemene vergadering kan een statutaire instructiebevoegdheid jegens het bestuur hebben. De instructiebevoegdheid is een inbreuk op de dualistische structuur en de autonomie van het bestuur.

De statuten kunnen bepalen dat het bestuur zich dient te gedragen naar de aanwijzingen van een ander orgaan van de vennootschap. Het bestuur is gehouden de aanwijzingen op te volgen, tenzij deze in strijd zijn met het belang van de vennootschap en de met haar verbonden onderneming. Daaronder valt ook het gerechtvaardigde belang van de kapitaalverschaffer zonder stemrecht. Op grond van het orgaanbegrip van art. 2:189a BW kan ook aan de vergadering van stemrechtloze aandeelhouders instructiebevoegdheid toekomen. Naar mijn mening kan aan meerdere organen een statutaire instructiebevoegdheid ex art. 2:239 lid 4 BW worden toegekend.

De vrijheid van de aandeelhouder zijn stemrecht uit te oefenen wordt begrensd door de norm van art. 2:8 BW en het vennootschappelijk belang. Zijn stemgedrag zal aan die norm getoetst (kunnen) worden.

III. De rechten van de kapitaalverschaffers zonder stemrecht

Naast de aard van de rechtsfiguur en de interne verhoudingen in de BV bepalen de rechten van de kapitaalverschaffers zonder stemrecht de verhouding van de kapitaalverschaffer zonder stemrecht tot de vennootschap, haar bestuur en de kapitaalverschaffers van de vennootschap met stemrecht. In hoofdstuk 6 besprak ik deze rechten.

Het stemrechtloze aandeel

Aan het stemrechtloze aandeel zijn alle rechten verbonden, behalve het stemrecht. In paragraaf 6.2.3.1 gaf ik een overzicht van de aan het stemrechtloze aandeel verbonden rechten. Het (geheel of gedeeltelijke) recht op winst en/of de reserves van de vennootschap is een belangrijk recht voor de stemrechtloze aandeelhouder. Op grond van het bepaalde in art. 2:216 BW is dat recht op uitkering echter niet ongeclausuleerd.

Aan de vergadering van stemrechtloze aandeelhouders kan op grond van art. 2:242, 2:244 en 2:245 BW de bevoegdheid worden toegekend een bestuurder te benoemen, te schorsen, te ontslaan en zijn bezoldiging vast te stellen, tenzij de benoeming van bestuurders geschiedt op grond van het (volledige) structuurregime. 
De ondergrens voor de benoeming is dat iedere aandeelhouder met stemrecht kan deelnemen aan de besluitvorming inzake de benoeming van ten minste één bestuurder. Er kunnen op grond van art. 2:244 BW meerdere organen bevoegd zijn tot ontslag van een bestuurder. Door het benoemen van een eigen bestuurder kunnen de houders van stemrechtloze aandelen hun invloed in de vennootschap vergroten. Die bestuurder zal echter wel het vennootschappelijk belang in acht moeten nemen en niet alleen de achterban kunnen dienen. De toekenning en ontneming van bevoegdheid van de vergadering van stemrechtloze aandeelhouders een bestuurder te benoemen te schorsen of te ontslaan kan slechts met unanimiteit in een vergadering waarin het gehele geplaatste kapitaal vertegenwoordigd is worden genomen. Bij een dergelijk besluit tot statutenwijziging wordt de stemrechtloze aandeelhouder beschermd door het bepaalde in art. 2:231 lid 4 BW. De statuten kunnen bepalen dat de vergadering van stemrechtloze aandeelhouders op grond van art. 2:243 lid 5 BW ook een bestuurder uit voordracht kan benoemen.

De regels van benoeming, schorsing en ontslag van commissarissen volgen in hoge mate de regels daaromtrent met betrekking tot de bestuurder. Ook deze bevoegdheden kunnen bij de statuten aan de vergadering van stemrechtloze aandeelhouders worden toegekend.

Uit art. 2:206a BW volgt dat de stemrechtloze aandeelhouder geen voorkeursrecht heeft op uit te geven aandelen van welke soort dan ook. Daarvan kan statutair worden afgeweken. Indien dat het geval is, komt het mij voor dat dit voorkeursrecht omzeild kan worden door gewone aandelen uit te geven en die aandelen vervolgens te certificeren en te plaatsen bij nieuwe kapitaalverschaffers zonder stemrecht. De stemrechtloze aandeelhouder kan in situaties omtrent het voorkeursrecht bescherming aan de vennootschappelijke redelijkheid en billijkheid ontlenen. De houder van gewone aandelen heeft geen voorkeursrecht op uit te geven stemrechtloze aandelen. De stemrechtloze aandeelhouder kan in het kader van de aanbiedingsregeling van art. 2:195 $\mathrm{BW}$ alleen reflecteren op aangeboden, stemrechtloze aandelen. Van deze hoofdregels kan bij de statuten worden afgeweken.

In een groot aantal gevallen wordt de stemrechtloze aandeelhouder beschermd. Ik verwijs naar het overzicht in paragraaf 6.2.3.6. Twee beschermingsregels verdienen bijzondere aandacht, namelijk art. 2:216 lid 8 en 2:231 lid 4 BW. Het instemmingsrecht van art. 2:216 lid $8 \mathrm{BW}$ moet naar mijn mening eng geïnterpreteerd worden. Het ziet op statutaire wijzigingen van het direct aan het aandeel verbonden financiële recht en niet op een statutaire wijziging die weliswaar afbreuk doet aan het recht op winst en/of reserves in de vennootschap, doch die indirect dat recht raken. Art. 2:231 lid 4 BW bepaalt voor de stemrechtloze aandeelhouders dat een besluit tot statutenwijziging dat specifiek afbreuk doet aan enig aan hen toekomend recht een goedkeurend besluit van deze groep van aandeelhouders vereist is. Het gaat daarbij om afbreuk van specifieke rechten verbonden aan deze aandelen en om een beperking van rechten, die ook verbonden zijn aan andere aandelen, doch welke beperking dan alleen geldt voor de bedoelde bepaalde aandelen en niet voor andere aandelen. De bevoegdheid tot wijziging kan ten tijde van de toekenning van het 
recht in de statuten worden voorbehouden op grond van de tenzij-clausule van art. 2:231 lid 4 BW. Naar mijn mening kan de statutaire regeling zo worden vormgegeven dat door een enkel besluit van de algemene vergadering dat recht kan worden geschrapt of gewijzigd. Het komt mij voor dat art. 2:231 lid 4 BW, gelet op het doel en strekking van deze bepaling, in de praktijk snel toepassing zal vinden.

Met besluitvorming buiten vergadering moet de stemrechtloze aandeelhouder instemmen. Het ontbreken van instemming maakt het in strijd daarmee genomen besluit naar mijn mening (slechts) vernietigbaar, gelet op de beoogde versoepeling van de besluitvorming buiten vergadering. Instemming hoeft niet uitdrukkelijk en kan langs elektronische weg geschieden. De rol van de vergadergerechtigde kapitaalverschaffer zonder stemrecht bij besluitvorming buiten vergadering lijkt mij gemarginaliseerd.

Een stemrechtloze aandeelhouder kan gebonden worden aan statutaire verplichtingen in de zin van art. 2:192 BW, maar dat hoeft niet het geval te zijn. Hij kan met de voorgestelde statutaire verplichting niet instemmen. Er is dan sprake van 'persoonsgebonden niet-gebondenheid', ongeacht of de stemrechtloze aandeelhouder na de statutenwijziging, waarbij de statutaire verplichting is ingevoerd, meer aandelen heeft verworven.

Voor de toepassing van de uitkoopregeling van art. 2:201a BW wordt ook rekening gehouden met de stemrechtloze aandelen in een BV, zo bepaalt art. 2:24d lid 2 BW.

In de statuten van een BV kan worden opgenomen dat stemrechtloze aandelen in gewone aandelen geconverteerd kunnen worden. De stemrechtloze aandeelhouder verkrijgt als gevolg van die conversie stemrecht in de algemene vergadering.

De stemrechtloze aandeelhouder wordt op grond van art. 2:181 lid 1 BW ingeval van omzetting van een $\mathrm{BV}$ in een vereniging, coöperatie, of onderlinge waarborgmaatschappij lid van die rechtspersoon, tenzij hij een verzoek tot schadeloosstelling bij de vennootschap voor het verlies van zijn aandelen indient. Partijen zullen in eerste instantie moeten onderhandelen en overeenstemming moeten bereiken over de omvang van de rechten van de stemrechtloze aandeelhouder in de omgezette rechtspersoon. Art. 2:181 lid $3 \mathrm{BW}$ regelt het uittreedrecht van de stemrechtloze aandeelhouder indien de BV wordt omgezet in een NV. De NV kent geen stemrechtloze aandelen. De stemrechtloze aandeelhouder moet aldus bij omzetting aandeelhouder met winst- en (eventueel gering) stemrecht worden. Indien de stemrechtloze aandeelhouder niet met de omzetting instemt, kan hij schadeloosstelling verzoeken.

Art. 2:181 lid 4 BW geeft een regeling voor de schadeloosstelling die in het voorstel tot omzetting moet zijn opgenomen. De statutaire prijsbepalingsregeling of een soortgelijke regeling in een aandeelhoudersovereenkomst in de zin van art. 2:181 lid 4 derde volzin BW moet mijns inziens specifiek op omzetting zien, wil die regeling ingeval van omzetting toepassing kunnen vinden. Art. 2:181 lid 5 BW sluit toepassing van art. 2:231 lid 4 BW uit, omdat het niet voor de hand ligt stemrechtloze aandeelhouders stemrecht te geven bij ingrijpende besluiten. Daarmee wordt dubbele bescherming voorkomen. Art. 2:181 lid $6 \mathrm{BW}$ brengt tot uitdrukking 
dat voor de omzetting van een BV in een stichting of een vereniging de daarvoor noodzakelijke rechterlijke machtiging wordt geweigerd indien de belangen van de stemrechtloze aandeelhouder onvoldoende worden ontzien.

Bij de regeling van de positie van de stemrechtloze aandeelhouder in geval van omzetting stel ik vraagtekens. Het is de vraag of de stemrechtloze aandeelhouder, gelet op de aard van de omgezette rechtspersoon, in een goede of vergelijkbare positie kan terugkeren. Kiest hij daar niet voor, dan is de vraag of de schadeloosstelling, althans de hoogte daarvan, op eenvoudige wijze kan worden vastgesteld.

Een ander punt van kritiek is dat niet duidelijk is wat onder vervallen van de stemrechtloze aandelen verstaan wordt. Mijns inziens ligt het voor de hand dat bij het van kracht worden van de omzetting door de BV een besluit tot intrekking van de stemrechtloze aandelen wordt genomen.

Indien een BV wordt omgezet in een vennootschap onder firma is in juridische zin sprake van ontbinding van de BV. De stemrechtloze aandeelhouder heeft ex art. 2:23b BW recht op het liquidatiesaldo, tenzij de statuten dit uitsluiten. In de situatie van omzetting van een personenvennootschap in een $\mathrm{BV}$, is het aan de eigenaren van die personenvennootschap en de hen gegeven (contracts)vrijheid bij of na oprichting van de BV te kiezen voor stemrechtloze aandelen in het kapitaal van die BV.

De positie van de stemrechtloze aandeelhouder ingeval van fusie en splitsing lijkt in hoge mate op zijn positie ingeval van omzetting in een andere rechtspersoon. Voor de stemrechtloze aandeelhouder en de rechtspraktijk is met name de fusie tussen een verdwijnende BV en een verkrijgende NV relevant. De NV kent geen stemrechtloze aandelen. Er zal met de stemrechtloze aandeelhouder onderhandeld moeten worden over zijn positie als aandeelhouder na de fusie. De uitkomst van deze onderhandelingen kan zijn dat er na de fusie een BV bestaat, waarin hij dezelfde positie als houder van stemrechtloze aandelen houdt of dat zijn aandelen worden geconverteerd naar aandelen met stem- of winstrecht. Het kan ook zijn dat beide partijen niet met elkaar verder willen of dat een van beide partijen niet met de ander verder wil. Er zal dan onderhandeld moeten worden over schadeloosstelling. De positie van de stemrechtloze aandeelhouder kan ex art. 2:317 lid 4 BW worden versterkt, bijvoorbeeld doordat het besluit tot fusie de instemming van iedere stemrechtloze aandeelhouder of goedkeuring van de vergadering van stemrechtloze aandeelhouders vereist.

Art. 2:330 lid 1 BW geeft een hoofdregel voor het besluit tot fusie van de algemene vergadering. Daarnaast is op grond van art. 2:330 lid 2 BW een goedkeurend groepsbesluit vereist van de houders van stemrechtloze aandelen aan wier rechten in het kader van de fusie afbreuk wordt gedaan. De reden voor deze bescherming is dat de BV zelf ook een verkrijgende vennootschap kan zijn. Voorts kunnen aan de vergadering van stemrechtloze aandeelhouders bijzondere bevoegdheden zijn toegekend. Art. 2:231 lid 4 BW is in dit geval niet van toepassing. In afwijking van art. 2:311 BW kan de stemrechtloze aandeelhouder van de verdwijnende BV, indien hij geen aandeelhouder in de verkrijgende NV wordt, op grond 
van art. 2:330a BW een verzoek tot schadeloosstelling indienen. De regeling daartoe is gelijk aan die van omzetting.

Bij een driehoeksfusie in de zin van art. 2:333a BW rust de verplichting tot schadeloosstelling ex art. 2:330a BW op de groepsmaatschappij; de verkrijgende vennootschap is daarvan vrijgesteld. Indien de groepsmaatschappij een BV is, kunnen de stemrechtloze aandeelhouders van de verdwijnende vennootschap ook stemrechtloze aandelen verkrijgen in de groepsmaatschappij-BV.

In geval van een grensoverschrijdende fusie ex art. 2:333h BW kan de stemrechtloze aandeelhouder een maand na het besluit tot fusie van de verdwijnende vennootschap schadeloosstelling bij die vennootschap vragen. Art. 2:330a BW is bij een grensoverschrijdende fusie niet van toepassing.

De regeling omtrent splitsing en de positie van de stemrechtloze aandeelhouder daarbij is in hoge mate gelijk aan die van fusie. Art. 2:334m BW geeft een algemene regeling voor besluiten tot splitsing. Ook bij splitsing geldt dat op grond van art. 2:334m lid 4 BW de statuten een van lid 3 van dat artikel afwijkende regeling voor besluiten tot splitsing kunnen geven, zodat de positie van de stemrechtloze aandeelhouder kan worden versterkt. Voor splitsing van een besloten vennootschap of een besloten vennootschap die in het kader van een splitsing wordt opgericht, zijn onder meer art. 2:334ee en 2:334eel BW van belang. Dat (laatste) artikel regelt de schadeloosstelling voor de stemrechtloze aandeelhouder indien de verkrijgende vennootschap geen BV is. Deze bepalingen zijn de pendant van de toepasselijke bepalingen in geval van fusie (art. 2:330 en 2:330a BW). Eveneens geldt dat een goedkeurend groepsbesluit vereist is van de houders van stemrechtloze aandelen aan wier rechten in het kader van de splitsing afbreuk wordt gedaan. Ook in dit geval is art. 2:231 lid 4 BW niet van toepassing.

In de literatuur wordt naar mijn mening terecht gesteld dat niet valt in te zien waarom ingeval van een ruziesplitsing ex art. 2:334cc BW stemrechtloze aandeelhouders in de splitsende BV niet een gelijkwaardige positie in de verkrijgende (besloten) vennootschappen zouden kunnen krijgen. Daarnaast gaat de wetgever er kennelijk en ten onrechte, zo wordt evenzeer terecht in de literatuur opgemerkt, vanuit dat alle stemrechtloze aandelen in een van de verkrijgende vennootschappen worden ondergebracht en de aandelen met stemrecht in de andere verkrijgende vennootschap. Ook dat hoeft niet per definitie het geval te zijn. Indien daarvan wel sprake is, kan dat op eenvoudige wijze worden opgelost. Bij splitsing kan de verkrijgende vennootschap aandelen met stemrecht aan de (voormalige) stemrechtloze aandeelhouders uitgeven.

Bij de vereenvoudigde splitsing van art. 2:334hh BW heeft de stemrechtloze aandeelhouder geen recht op schadeloosstelling. Er is immers geen sprake van een verdwijnende vennootschap. De stemrechtloze aandeelhouder kan bij een evenredige splitsing ex art. 2:334hh lid $2 \mathrm{BW}$ houder van een ander 'soort' stemrechtloos aandeel worden. Aan zijn aandeel kunnen andere financiële rechten verbonden zijn, bijvoorbeeld een beperkter winstrecht, dan aan zijn oorspronkelijke aandeel. Hij wordt beschermd door het goedkeurende groepsbesluit van art. 2:334ee lid 2 BW. 
De regeling van de driehoekssplitsing van art. 2:334ii BW is gelijkluidend aan die van de driehoeksfusie in de zin van art. 2:333a BW. Voor de positie van de stemrechtloze aandeelhouder is art. 2:334ii lid 3 BW van belang, dat als uitgangspunt stelt dat de verplichtingen van de verkrijgende vennootschap worden opgelegd zowel aan de groepsmaatschappij die de aandelen uitreikt als aan de verkrijgende vennootschap. Omdat de in art. 2:334ee1 BW geregelde schadeloosstelling voor houders van stemrechtloze aandelen gerelateerd is aan de toekenning van aandelen, wordt de verkrijgende vennootschap in art. 2:334ii lid $3 \mathrm{BW}$ vrijgesteld van de verplichting als bedoeld in art. 2:334ee1 lid $1 \mathrm{BW}$. In de literatuur wordt hierover naar mijn mening terecht opgemerkt dat indien de groepsmaatschappij een BV is, de stemrechtloze aandeelhouders van de splitsende vennootschap ook stemrechtloze aandelen kunnen verkrijgen in de groepsmaatschappij-BV.

Uit het voorgaande volgt naar mijn mening dat de wetgever niet is geslaagd in zijn opzet van een eenvoudige regeling van het stemrechtloze aandeel.

Het certificaat van aandeel met en zonder vergaderrecht

Door certificering wordt de juridische en economische eigendom van aandelen gesplitst. Voor een overzicht van de aan het certificaat verbonden rechten in de driehoeksverhouding tussen de certificaathouder-administratiekantoor-BV verwijs ik naar paragraaf 6.3.3.1.

In de literatuur wordt gesteld dat uit de titel van beheer in beginsel voortvloeit dat het administratiekantoor bij de uitoefening van het stemrecht met de belangen van de certificaathouders op korte en lange termijn rekening moet houden, ongeacht de normen die uit de statuten van het administratiekantoor en de administratievoorwaarden zouden voortvloeien. Deze belangen mogen niet onevenredig worden geschaad. De invloed van de certificaathouder op het stemgedrag van het administratiekantoor is afhankelijk van de omstandigheden van het geval en wordt bepaald door de inhoud van de statuten van het administratiekantoor en de administratievoorwaarden. Indien de certificaathouder vergadergerechtigd is, zal de invloed van de certificaathouder op de besluitvorming (verder) toenemen, zoals dat ook geldt voor de stemrechtloze aandeelhouder.

Voor de positie van de houder van een certificaat is bepalend of aan het certificaat vergaderrecht is toegekend. Het vergaderrecht en de daaraan gekoppelde rechten zijn van belang zowel voor het beïnvloeden van het besluitvormingsproces als voor de geldigheid van de besluitvorming. Het zijn belangrijke rechten voor deze certificaathouder. Op grond van art. 2:228 lid 2 BW zijn statutaire regelingen die bepalen dat certificaten in het algemeen geen vergaderrecht hebben, dat alle certificaten vergaderrecht hebben of dat het vergaderrecht slechts toekomt aan bepaalde, in de statuten aangeduide certificaten, toegestaan. Uitgangspunt is dat de vennootschap, althans de algemene vergadering, zelf bepaalt of er certificaten met vergaderrecht worden toegelaten, en zo ja, aan welke certificaten dat vergaderrecht toekomt. Er zijn twee manieren om vergaderrecht aan certificaten te verbinden, te weten (i) toekenning bij statuten en (ii) toekenning door een orgaan, dat bij de 
statuten daartoe is aangewezen. Art. 2:227 lid 4 BW bepaalt dat het aan certificaathouders bij statuten toegekende vergaderrecht slechts met instemming van die certificaathouder kan worden gewijzigd, tenzij bij het toekennen van het vergaderrecht de bevoegdheid tot wijziging uitdrukkelijk in de statuten was voorbehouden. Er zijn drie mogelijkheden het vergaderrecht aan het certificaat te ontnemen. Ten eerste, bij statuten is aan het certificaat vergaderrecht toegekend, maar het ontnemen van dat recht of wijziging daarvan is niet voorbehouden. De certificaathouder zal met het ontnemen van het vergaderrecht aan zijn certificaat moeten instemmen. Ten tweede, bij statuten is aan het certificaat vergaderrecht toegekend en het ontnemen van dat recht of wijziging daarvan is in dezelfde statutaire regeling voorbehouden. Het vergaderrecht kan op grond van de tenzij-clausule van art. 2:227 lid 4 BW aan het certificaat worden ontnomen (zonder dat daartoe instemming van de certificaathouder is vereist). Ten derde, de bevoegdheid tot het toekennen en ontnemen van vergaderrecht is toegekend aan een orgaan van de vennootschap in de zin van art. 2:189a BW. Dat orgaan kan zonder dat daartoe instemming van de certificaathouder is vereist het vergaderrecht aan het certificaat ontnemen.

Bij besluitvorming buiten vergadering is de positie van de certificaathouder met vergaderrecht gelijk aan de positie van de stemrechtloze aandeelhouder. Met de certificaathouder zonder vergaderrecht hoeft bij besluitvorming buiten vergadering geen rekening gehouden te worden. Hij is immers niet vergadergerechtigd.

Aan de certificaathouder met vergaderrecht komt het wettelijke pandrecht ex art. 3:259 BW toe. Daarbij hoeft naar mijn mening geen onderscheid gemaakt te worden tussen certificaten waarbij het vergaderrecht bij de statuten en certificaten waarbij het vergaderrecht door een orgaan is toegekend. Het ontnemen van het vergaderrecht aan de certificaten door een daartoe in de statuten aangewezen orgaan doet het wettelijk pandrecht vervallen, gelijk het verbinden van het vergaderrecht aan het certificaat het wettelijk pandrecht doet ontstaan.

De vraag of certificaten al dan niet royeerbaar zijn, is ook relevant voor de verhouding van de houder van het certificaat tot de vennootschap. Afhankelijk van het antwoord op die vraag kan de certificaathouder zijn certificaat omwisselen voor een aandeel, zodat zijn stemrecht 'herleeft' en ziet hij - afhankelijk van de stemverhoudingen in de algemene vergadering - zijn invloed op de besluitvorming toenemen. Indien de administratievoorwaarden niet vermelden of certificaten royeerbaar zijn, moet naar mijn mening ervan worden uitgegaan dat ze niet royeerbaar zijn.

Voor de positie van de certificaathouder ingeval van omzetting van de BV in een personenvennootschap geldt hetzelfde als voor de positie van de stemrechtloze aandeelhouder, zij het dat het administratiekantoor - als aandeelhouder - het stemrecht uitoefent ten aanzien van het besluit tot ontbinding. De certificaathouder met vergaderrecht zal vanwege dat vergaderrecht bij het besluitvormingsproces betrokken zijn. Indien een BV wordt omgezet in een NV en de NV de certificaten als bewilligde certificaten beschouwt, is naar mijn mening de instemming van de certificaathouder met vergaderrecht ten aanzien van de in het kader van de omzetting noodzakelijke 
statutenwijziging niet vereist. Indien de NV geen bewilligde certificaten kent of de certificaten met vergaderrecht als niet-bewilligd aanmerkt, wordt het vergaderrecht aan het certificaat ontnomen en is op grond van art. 2:227 lid 4 BW de instemming van de certificaathouder vereist.

Bij een besluit tot fusie ex art. 2:317 BW oefent het administratiekantoor namens de certificaathouders het stemrecht op de aandelen in de algemene vergadering uit. Daarbij zal het administratiekantoor de belangen van de certificaathouders in acht moeten nemen. In de statuten van het administratiekantoor kan bepaald zijn dat het besluit tot fusie, of meer algemeen het besluit tot wijziging van de statuten, goedkeuring behoeft van de vergadering van certificaathouders. Het administratiekantoor doet er naar mijn mening goed aan bij belangrijke besluiten als fusie, ontbinding en omzetting, de vergadering van certificaathouder te raadplegen - voor zover een dergelijke verplichting niet reeds in de administratievoorwaarden is opgenomen - alvorens het administratiekantoor haar stem in de algemene vergadering uitbrengt. Het administratiekantoor zal naar mijn mening met inachtneming van de uitslag van de stemming in de vergadering van certificaathouders voor dan wel tegen het besluit tot fusie moeten stemmen, corresponderend met het aantal voor- en tegenstemmen in de vergadering van certificaathouders. Ook hier geldt dat, gelet op de procedure zoals in art. 2:317 BW beschreven, de certificaathouder met vergaderrecht reeds bij de besluitvorming in de BV ten aanzien van de ontbinding betrokken zal zijn. Het komt mij voor dat art. 2:227 lid 4 BW in geval van fusie en splitsing niet geldt. Evenmin bieden art. 2:216 lid 7 en 2:330 lid 2 BW de certificaathouder bescherming.

Bij een fusie tussen een verdwijnende vennootschap die certificaten met vergaderrecht kent en een verkrijgende vennootschap die geen of alleen certificaten zonder vergaderrecht kent, is de positie van de certificaathouder in de verdwijnende vennootschap naar mijn mening dat hij in beginsel gelijke lidmaatschapsrechten in de verkrijgende vennootschap moet verkrijgen.

Uitgaande van een fusie tussen twee BV's meen ik dat het wettelijk pandrecht ex art. 3:259 BW vervalt, indien sprake is van certificaten met vergaderrecht in de verdwijnende vennootschap en certificaten zonder vergaderrecht in de verkrijgende vennootschap.

De aandeelhouder wiens stemrecht is overgedragen aan de vruchtgebruiker of de pandhouder

Voor de aandeelhouder wiens stemrecht is overgedragen aan de vruchtgebruiker of de pandhouder geldt dat sprake is van een lidmaatschapsverhouding tussen die aandeelhouder en de vennootschap. Zij hebben dezelfde rechten als de certificaathouder met vergaderrecht, zo volgt uit respectievelijk art. 2:197 lid 4 en art. 2:198 lid 4 BW. Daarnaast hebben zij, anders dan de stemrechtloze aandeelhouder, ex art. 2:206a BW een voorkeursrecht op uit te geven aandelen. 
De houder van een participatiebewijs

Het participatiebewijs is niet in de wet geregeld. Voor de rechten en verplichtingen zullen de participatievoorwaarden, waarvoor de contractsvrijheid geldt, uitkomst moeten bieden. Omdat geen sprake is van een lidmaatschapsverhouding tussen de houder van een participatiebewijs en de vennootschap, staat die houder in een andere organisatorische verhouding tot de vennootschap. De (vergadering van) houders van participatiebewijzen (is) zijn geen orgaan van de vennootschap. In de regel zullen de participatievoorwaarden voornamelijk financiële rechten, en geen zeggenschapsrechten, aan de houder van een participatiebewijs toekennen. Het belangrijkste recht is het winstrecht, en eventueel een recht op het liquidatieoverschot. Dat winstrecht heeft een statutaire grondslag. Voor de uitgifte van een participatiebewijs is naar mijn mening geen statutaire basis vereist. De houder van een participatiebewijs wordt tegen afbreuk van zijn financiële rechten door art. 2:232 BW beschermd. Hij moet instemmen met een statutenwijziging die nadeel aan zijn rechten toebrengt, tenzij de wijzigingsbevoegdheid bij de uitgifte van het participatiebewijs reeds is voorbehouden.

Participatiebewijzen kunnen door de vennootschap worden ingekocht. Daarbij zal moeten worden voldaan aan de eis van art. 2:207 lid 2 BW. Door deze verkrijging gaan de participatiebewijzen wegens vermenging teniet. Tenzij in de participatievoorwaarden een intrekkingsbeding opgenomen is, kunnen participatiebewijzen mijns inziens slechts met instemming van de houder daarvan worden ingetrokken.

Art. 2:320 BW geeft een regeling voor de houder van een participatiebewijs in de verdwijnende vennootschap ingeval van fusie. Het artikel bepaalt dat de houder van een participatiebewijs in de verdwijnende vennootschap een gelijkwaardig recht in de verkrijgende vennootschap of schadeloosstelling moet krijgen. Wat betreft de positie van de houder van een participatiebewijs ingeval van splitsing geldt art. 2:334p BW. Dat artikel heeft een nagenoeg met art. 2:320 BW gelijkluidende formulering. Bij omzetting, fusie en splitsing geldt dat de vennootschappelijke redelijkheid en billijkheid jegens de houder van het participatiebewijs in acht genomen moet worden. Bij omzetting kan de houder van een participatiebewijs ook bescherming aan art. 2:232 BW ontlenen.

\section{Overige opmerkingen}

Op grond van art. 2:216 lid 3 BW kunnen de stemrechtloze aandeelhouder en de aandeelhouder wiens stemrecht is overgedragen aan de vruchtgebruiker of pandhouder aansprakelijk zijn voor de door hen ontvangen uitkeringen, ook al kunnen deze vergadergerechtigden geen stem uitbrengen over het te nemen besluit tot uitkering. Indien zij door het bestuur zijn geïnformeerd over de schadelijke gevolgen van een voorgenomen besluit, kunnen zij zich niet beroepen op hun goede trouw.

Of een certificaathouder ex art. 2:216 lid $3 \mathrm{BW}$ gehouden is tot terugbetaling van het ontvangene, hangt naar mijn mening af van het antwoord op de vraag of sprake 
is van certificaten met of zonder vergaderrecht. De certificaathouder met vergaderrecht zou ik gelijk willen stellen met de stemrechtloze aandeelhouder en de aandeelhouder wiens stemrecht is overgedragen aan de vruchtgebruiker of pandhouder. Het administratiekantoor zal, als uitkeringsgerechtigde aandeelhouder, verhaal kunnen halen bij deze certificaathouder. Daarover zal een regeling in de administratievoorwaarden zijn of moeten worden opgenomen. Indien dat laatste niet het geval is, zal naar mijn mening een beroep kunnen worden gedaan op de aanvullende werking van de redelijkheid en billijkheid ex art. 6:248 lid 1 BW. Ten aanzien van de houder van een certificaat zonder vergaderrecht geldt mijns inziens dat hij niet aansprakelijk kan zijn, althans dat hij zich kan beroepen op zijn goede trouw, tenzij het bestuur hem voorafgaand aan de besluitvorming over de schadelijke gevolgen van het besluit tot uitkering informeert.

De houder van een participatiebewijs kan zich mijns inziens beroepen op de goede trouw indien hij wordt aangesproken tot terugbetaling van het ontvangene, tenzij het bestuur van de vennootschap voorafgaand aan de besluitvorming in de algemene vergadering over de uitkering ook de houder van het participatiebewijs over de schadelijke gevolgen van een voorgenomen besluit informeert.

Afwezige, vergadergerechtigde kapitaalverschaffers zonder stemrecht kunnen niet van de waarschuwingen van het bestuur op de hoogte zijn. Deze vergadergerechtigden moeten worden opgeroepen en hebben de agenda ontvangen. Het komt mij voor dat het niet bijwonen van de algemene vergadering een omstandigheid is die in hun risicosfeer ligt.

De stemrechtloze aandeelhouder, de houder van een certificaat met vergaderrecht en de aandeelhouder wiens stemrecht is overgedragen aan de vruchtgebruiker of pandhouder kunnen mijns inziens (vrijwillig) afzien van de uitoefening van hun vergaderrecht, mits dat voldoende bepaalbaar is, bijvoorbeeld voor een bepaalde periode of voor een of meerdere algemene vergaderingen. Gelet op de vergaande gevolgen zou ik niet zonder meer willen aannemen dat het afzien van de uitoefening van vergaderrecht stilzwijgend kan worden aangenomen. Met het afzien van de uitoefening van vergaderrecht wordt ook afstand gedaan van de aan het vergaderrecht gekoppelde rechten, zoals het oproepingsrecht. Het afzien van de uitoefening van vergaderrecht houdt naar mijn mening ook in dat de vergadergerechtigde ook afstand doet van zijn instemmingsrecht ter zake van besluitvorming buiten vergadering.

\subsubsection{Door welke rechtsnormen wordt de verhouding van de kapitaalverschaffer zonder stemrecht tot de vennootschap, haar bestuur en de kapitaalverschaffers van de vennootschap met stemrecht ingevuld?}

In hoofdstuk 7 gaf ik antwoord op de vraag door welke rechtsnormen de verhouding van de kapitaalverschaffer zonder stemrecht tot de vennootschap, haar bestuur en de kapitaalverschaffers van de vennootschap met stemrecht wordt ingevuld. Deze interne verhoudingen in de BV worden, naast de wet en de statuten door de open norm van de vennootschappelijke redelijkheid en billijkheid inhoud gegeven. De 
vennootschappelijke redelijkheid en billijkheid kunnen deze interne verhoudingen onder meer aanvullen of corrigeren.

Uit de rechtspraak zijn algemene uitgangspunten te distilleren die deze open norm invulling geven. Koelemeijer ${ }^{1}$ schetst acht factoren die van invloed kunnen zijn op de belangenafweging door de rechter en die een rol spelen bij het bepalen van de eisen van de redelijkheid en billijkheid in een concreet geval, namelijk (i) hoedanigheid van de betrokkene(n) bij een belangenconflict, (ii) de invloed van de betrokkene(n) bij een belangenconflict, (iii) dubbelrollen of tegenstrijdig belang van de betrokkene(n) bij een belangenconflict, (iv) de aard en de inhoud van het besluit, (v) de gevolgen van het besluit of de gedraging van de betrokkene(n), (vi) de compensatie van de gevolgen van een besluit voor de betrokkene(n), (vii) het karakter van de vennootschap en (viii) de overeenkomst tussen de betrokkene(n). Toetsing aan de redelijkheid en billijkheid houdt een marginale toetsing in, zo luidt de heersende opvatting in de literatuur.

Van de kapitaalverschaffers zonder stemrecht behoren naar mijn mening de stemrechtloze aandeelhouder, de houder van certificaten van aandelen met vergaderrecht, de aandeelhouder wiens stemrecht is overgedragen aan de vruchtgebruiker of pandhouder en de houder van een participatiebewijs tot de kring van betrokkenen in de zin van art. 2:8 BW. De houder van certificaten van aandelen zonder vergaderrecht schaar ik niet onder de kring van betrokkenen, omdat de wil van de vennootschap niet op die betrokkenheid is gericht. De statuten kennen aan deze certificaten geen vergaderrecht toe.

Een aantal thema's in de vennootschappelijke redelijkheid en billijkheid is voor de kapitaalverschaffer zonder stemrecht die tot de kring van betrokkenen behoort in het bijzonder van belang. Deze thema's zijn: (i) het gelijkheidsbeginsel, (ii) bescherming van minderheidsaandeelhouders, (iii) besluiten die de rechten op winst en/of reserves raken, (iv) de verhouding tussen aandeelhouders onderling, (v) de zorgplicht van (het bestuur van) de vennootschap jegens de kapitaalverschaffer zonder stemrecht, (vi) het recht op informatie van de kapitaalverschaffer zonder stemrecht en (vii) de zorgplicht van de kapitaalverschaffer met (doorslaggevend) stemrecht jegens de kapitaalverschaffer zonder stemrecht. Uit de rechtspraak blijkt dat deze thema's vaak door elkaar heen lopen.

Voor het gelijkheidsbeginsel geldt dat onderscheid tussen aandelen van een verschillende soort of aanduiding is toegestaan, hetgeen ook ten aanzien van stemrechtloze aandelen geldt. Indien dat onderscheid bestaat, is geen sprake van schending van het gelijkheidsbeginsel in de zin van art. 2:201 lid $1 \mathrm{BW}$. Onderscheid tussen aandeelhouders van dezelfde soort of aanduiding is niet toegestaan. Het gelijkheidsbeginsel van art. 2:201 lid 2 BW geldt naar mijn mening ook voor certificaathouders met en zonder vergaderrecht en houders van participatiebewijzen. Ten aanzien van die laatsten geldt dat de grondslag daarvoor art. 2:8 $\mathrm{BW}$ is.

1 Koelemeijer 1999, p. 339. 
Uit de rechtspraak volgt dat afhankelijk van de omstandigheden van het geval sprake kan zijn van een zorgplicht van meerderheidsaandeelhouders jegens minderheidsaandeelhouders. Relevante omstandigheden zijn de aard van de samenwerking, de beslotenheid van de BV en familieverhoudingen. De belangen van alle aandeelhouders en de vennootschap zullen in acht genomen moeten worden. De vraag moet beantwoord worden of die belangen niet onevenredig worden geschaad. Indien deze relevante omstandigheden zich voordoen, kan eerder sprake zijn van belangenverstrengeling. Er geldt dan een verhoogde zorgplicht. Voor het antwoord op de vraag of sprake is van een ontoelaatbare belangenverstrengeling en onevenredige schending van belangen, is de mate van openheid en informatieverstrekking van belang. Deze regels van bescherming van minderheidsaandeelhouders gelden naar mijn mening op gelijke wijze ten aanzien van de kapitaalverschaffers zonder stemrecht die tot de kring van betrokkenen behoren. Naast de genoemde relevante omstandigheden kan bij de invulling van de zorgplicht gekeken worden naar de vennootschappelijke structuur, de mate waarin de kapitaalverschaffer zonder stemrecht kapitaal verschaft en de mate waarin die kapitaalverschaffer, ondanks het ontbreken van stemrecht, zeggenschap in de vennootschap heeft, zoals bijvoorbeeld het recht tot benoemen van bestuurder(s) of commissaris(sen).

Wat betreft de besluiten die de rechten op winst en/of reserves raken, kunnen voor de kapitaalverschaffers zonder stemrecht, die tot de kring van betrokkenen behoren, drie relevante deelthema's worden onderscheiden: (i) winstreservering, (ii) besluiten omtrent de bezoldiging van bestuurders en commissarissen en (iii) overige besluiten die de rechten op winst en/of de reserves aantasten. Voor de besluitvorming rond winstreservering zou ik de door Bier $^{2}$ ten aanzien daarvan geformuleerde regels ook voor de kapitaalverschaffers zonder stemrecht willen volgen, voor zover de aard van de rechtsfiguur zonder stemrecht zich daartegen niet verzet. ${ }^{3}$ Uit de rechtspraak volgt dat de algemene vergadering bij het vaststellen van de bezoldiging van bestuurders en commissarissen jegens winstgerechtigden de vennootschappelijke redelijkheid en billijkheid in acht moet nemen. Ik meen dat in de gestelde regel 'winstgerechtigden' als kapitaalverschaffers zonder stemrecht gelezen kan worden, mits zij tot de kring van betrokkenen behoren. Voor zover er geen specifieke beschermingsregel geldt, kunnen de kapitaalverschaffers zonder stemrecht, die tot de kring van betrokkenen behoren, ingeval van besluiten van de algemene vergadering of het bestuur die hun rechten op winst en/of reserves aantasten bescherming ontlenen aan de vennootschappelijke redelijkheid en billijkheid.

Voor de verhouding tussen aandeelhouders onderling, meer in het bijzonder de relatie meerderheids- en minderheidsaandeelhouder, geldt enerzijds dat de positie van de minderheidsaandeelhouder met zich brengt dat hij hem onwelgevallige besluiten tegen zich moet laten gelden. Anderzijds mag de meerderheidsaandeelhouder zijn macht niet misbruiken. De meerderheidsaandeelhouder moet bij het

Zie Bier 2012 (1), p. 91.

3 Zie voor deze regels paragraaf 7.5.4.2, slot. 
uitbrengen van zijn stem ook rekening houden met de redelijke belangen van de minderheidsaandeelhouder. Het voorgaande gaat mijns inziens ook op voor de verhouding tussen aandeelhouders met andere kapitaalverschaffers zonder stemrecht die tot de kring van betrokkenen behoren.

Ik meen dat de in de jurisprudentie ontwikkelde zorgplicht van (het bestuur van) de vennootschap jegens minderheidsaandeelhouders en certificaathouders ook voor de kapitaalverschaffers zonder stemrecht, die tot de kring van betrokkenen behoren, geldt. De inhoud van die zorgplicht is afhankelijk van de omstandigheden van het geval en de aard van de rechtsfiguur zonder stemrecht.

Het recht op informatie ex art. 2:217 lid 2 BW komt mijns inziens toe aan de stemrechtloze aandeelhouder, de houder van certificaten met vergaderrecht en de aandeelhouder die vanwege de overdracht van zijn stemrecht aan de vruchtgebruiker of pandhouder geen stemrecht heeft. Dat geldt niet voor de houder van certificaten zonder vergaderrecht. Hem ontbeert immers vergaderrecht. Evenmin kan de houder van een participatiebewijs rechten aan art. 2:217 lid 2 BW ontlenen, tenzij in de participatievoorwaarden anders overeengekomen is.

Het komt mij voor dat de kapitaalverschaffer zonder stemrecht die tot de kring van betrokkenen behoort als uitzondering op de hoofdregel van art. 2:217 lid 2 BW wegens bijzondere omstandigheden op grond van de vennootschappelijke redelijkheid en billijkheid een recht op informatie (buiten vergadering) heeft. Het ASMIarrest laat daarvoor mijns inziens ruimte. Wegens het bepaalde in art. 2:201 lid 2 BW zal daarmee echter terughoudend moeten worden omgegaan. De bijzondere omstandigheden zijn met name gelegen bij transacties (i) met een mogelijk tegenstrijdig belang of belangenverstrengeling, (ii) strijdig met het vennootschappelijk belang en (iii) die onder op het eerste gezicht niet voor de hand liggende voorwaarden worden aangegaan. De bijzondere omstandigheden klemmen te meer in geval van een familievennootschap.

Van de kapitaalverschaffer met (potentieel) doorslaggevend stemrecht mag worden verlangd dat hij zich voorafgaand aan de algemene vergadering adequaat informeert. Hij zal zich bij de uitoefening van zijn (doorslaggevend) stemrecht adequaat moeten informeren over (i) de kenbare gevolgen van zijn stemgedrag voor de vennootschap en (ii) de kenbare gevolgen voor en de gerechtvaardigde belangen van de kapitaalverschaffers zonder stemrecht, die tot de kring van betrokkenen in de zin van art. 2:8 BW behoren.

De kapitaalverschaffer met (doorslaggevend) stemrecht zal bij de aanwezigheid van een persoonlijk belang dat tegenstrijdig is aan de belangen van de vennootschap en de kapitaalverschaffers zonder stemrecht, die tot de kring van betrokkenen behoren, extra alert moeten zijn. Op de kapitaalverschaffer met (doorslaggevend) stemrecht rust een bijzondere zorgplicht, inhoudende dat hij zijn eigen belang niet boven dat van de vennootschap en de kapitaalverschaffers zonder stemrecht mag stellen. De kapitaalverschaffer met (doorslaggevend) stemrecht overtreedt de grens van het toelaatbare indien hij bij de uitoefening van zijn stemrecht de belangen van 
de vennootschap en/of de kapitaalverschaffers zonder stemrecht, die tot de kring van betrokkenen behoren, onevenredig schaadt.

\subsubsection{Hoe kan de kapitaalverschaffer zonder stemrecht op de interne verhoudingen in de BV invloed uitoefenen en zijn rechten waarborgen?}

Hoofdstuk 8 beantwoordt de derde hoofdvraag: hoe kan de kapitaalverschaffer zonder stemrecht invloed op de interne verhoudingen in de BV uitoefenen en zijn rechten waarborgen? Er zijn diverse middelen voor de kapitaalverschaffers zonder stemrecht om hun rechten af te dwingen of hun rechtspositie te verbeteren.

Het agenderingsrecht van art. 2:224a lid $1 \mathrm{BW}$ komt toe aan de stemrechtloze aandeelhouder, de houder van aandelen waarvan het stemrecht is overgedragen aan de vruchtgebruiker of pandhouder en de houder van een certificaat van aandeel met vergaderrecht. Voor alle agenderingsgerechtigde kapitaalverschaffers zonder stemrecht geldt dat zij aan de kapitaaleis moeten voldoen. Het agenderingsrecht komt niet toe aan de certificaathouder zonder vergaderrecht en evenmin aan de houder van een participatiebewijs. De conclusie is dan ook dat alleen vergadergerechtigden agenderingsgerechtigd zijn. Diezelfde conclusie geldt voor het bijeenroepingsrecht van art. 2:220 lid 2 BW. Alleen vergadergerechtigden zijn bijeenroepingsgerechtigd.

Er staat de vergadergerechtigde kapitaalverschaffer zonder stemrecht een aantal rechtsmiddelen ten dienste indien tijdens de algemene vergadering zijn recht op informatie is geschonden. Voorwaarde is dat deze kapitaalverschaffer zonder stemrecht tevergeefs tijdens de algemene vergadering om informatie of inlichtingen heeft gevraagd. Van de in paragraaf 8.4 besproken middelen om het recht van inlichtingen af te dwingen lijken een vordering gebaseerd op art. 2:217 lid 2 BW, de exhibitieplicht van art. $843 \mathrm{Rv}$, het voorlopig getuigenverhoor en het enquêterecht het meest effectief. Voor het enquêterecht geldt als beperking dat slechts indien de toestand van de vennootschap of het belang van het onderzoek dat vergt de vennootschap op grond van een onmiddellijke voorziening gelast kan worden de aandeelhouder de tijdens de algemene vergadering onthouden informatie te verschaffen.

Een ander middel is de vordering tot medewerking tot het nemen van een besluit. Deze vordering komt naar mijn mening toe aan alle kapitaalverschaffers zonder stemrecht, uitgezonderd de houder van certificaten zonder vergaderrecht. Deze laatste behoort immers niet tot de kring van betrokkenen in de zin van art. 2:8 BW. De grondslag van de vordering is de vennootschappelijke redelijkheid en billijkheid. Ik ben van mening dat de rechter met terughoudendheid deze vordering moet beoordelen.

De kapitaalverschaffer zonder stemrecht die tot de kring van betrokkenen in de zin van art. 2:8 BW behoort, komt de vordering tot vernietiging van besluiten ex art. 2:15 lid 1 onder b BW toe. De houder van certificaten zonder vergaderrecht komt deze vordering naar mijn mening niet toe. De vennootschap heeft niet gewild dat deze certificaathouder(s) invloed op de besluitvorming kan uitoefenen. De statuten kennen deze certificaten geen vergaderrecht toe. 
In spoedeisende zaken kan voornamelijk de kapitaalverschaffer zonder stemrecht die tot de kring van betrokkenen behoort in kort geding een onmiddellijke voorziening bij voorraad vorderen. De grondslag van een dergelijke vordering kan strijdigheid met de vennootschappelijke redelijkheid en billijkheid zijn. Gelet op de aard van de procedure en het voorlopige karakter van de op te leggen maatregel is naar mijn mening de uitkomst van deze procedure voor de kapitaalverschaffer zonder stemrecht onzeker.

Het recht van enquête komt alle kapitaalverschaffers zonder stemrecht toe (mits zij aan de kapitaaleis voldoen), uitgezonderd de houder van een participatiebewijs. Op grond van art. 2:346 lid 1 onder e $\mathrm{BW}^{4}$ acht ik het echter mogelijk dat de houder van een participatiebewijs bij de statuten of bij overeenkomst met de rechtspersoon de enquêtebevoegdheid wordt toegekend. Daarbij zal aan de kapitaaleis voldaan moeten zijn, omdat anders de houder van een participatiebewijs in een gunstiger positie komt te verkeren dan de andere kapitaalverschaffers zonder stemrecht. Daarnaast acht ik het mogelijk dat de houder van een participatiebewijs zich ex art. 282 lid $1 \mathrm{Rv}$ als belanghebbende in de enquêteprocedure voegt.

De kapitaalverschaffer zonder stemrecht die niet aan de kapitaaleis voldoet, kan zich als belanghebbende in de enquêteprocedure voegen. Bovendien kan de OK ook ambtshalve de kapitaalverschaffer als belanghebbende oproepen. Daarnaast bestaat voor iedere belanghebbende de mogelijkheid een zelfstandig verzoek in te dienen, mits dit betrekking heeft op het onderwerp van het oorspronkelijke enquêteverzoek. De kapitaalverschaffer zonder stemrecht kan ook baat hebben bij de situatie dat de rechtspersoon zelf een verzoek tot enquête indient.

De vraag of het enquêterecht een probaat middel is ter bescherming van de aan de rechtsfiguren zonder stemrecht verbonden financiële rechten, kan niet zonder meer met 'ja' worden beantwoord. Wel zal de uitkomst van de enquêteprocedure ertoe kunnen leiden dat besluitvorming met betrekking tot uitkeringen zorgvuldiger en beter gemotiveerd geschiedt, waarbij extra aandacht zal worden besteed aan de positie van de kapitaalverschaffer zonder stemrecht en de motivering van de rechter om tot vernietiging van het besluit tot reservering te komen.

De vordering tot gedwongen overdracht of uitstoting in de geschillenregeling komt toe aan de stemrechtloze aandeelhouder en de houder van aandelen waarvan het stemrecht is overgedragen aan de vruchtgebruiker of pandhouder, mits aan de kapitaaleis van art. 2:336 BW is voldaan. De vordering komt niet toe aan de certificaathouder en evenmin aan de houder van een participatiebewijs. De vordering tot uittreding ex art. 2:343 BW komt eveneens toe aan de stemrechtloze aandeelhouder en de houder van aandelen waarvan het stemrecht is overgedragen aan de vruchtgebruiker of pandhouder, doch niet aan de certificaathouder en evenmin aan de houder van een participatiebewijs.

4 Uitgaande van de Wet van 18 juni 2012 tot wijziging van boek 2 van het Burgerlijk Wetboek in verband met de aanpassing van het recht van enquête (Kamerstukken 32 887, Stb. 2012, 274). Deze wet zal inwerking treden op 1 januari 2013 (Stb. 2012, 305). 
Een knelpunt in de regeling van de vordering tot uitstoting en de vordering tot uittreding is dat deze vorderingen niet toekomen aan de certificaathouder. Ik zie geen goede reden waarom de stemrechtloze aandeelhouder wel en de houder van een certificaat met vergaderrecht niet deze vorderingen toekomt, terwijl de certificaathouder enquêtegerechtigd is. Een (ander) knelpunt in de regeling van de vordering tot uitstoting is de kapitaaleis van ten minste een derde van het geplaatste kapitaal, die art. 2:336 BW stelt. Daarvoor is evenmin een goede reden te bedenken. Ik pleit er voor die kapitaaleis gelijk te trekken met de kapitaaleis voor het indienen van een enquêteverzoek ex art. 2:346 lid 1 onder b BW, zijnde ten minste een tiende gedeelte van het geplaatste kapitaal. De houder van een certificaat zonder vergaderrecht behoort niet tot de kring van betrokkenen, zodat ik aan hem niet de vordering tot uitstoting en de vordering tot uittreding zou willen laten toekomen.

In paragraaf $8.10 \mathrm{kwam}$ ik tot de conclusie dat het stemrecht op stemrechtloze aandelen in voorkomend geval niet moet 'herleven'. Dat zou op praktische bezwaren stuiten. Bovendien biedt de wet de stemrechtloze aandeelhouder reeds voldoende bescherming dan wel mogelijkheden zijn positie te versterken.

Tot slot betoogde ik in paragraaf 8.11 dat zowel statutair als buiten-statutair de rechtspositie van de stemrechtloze aandeelhouder kan worden versterkt.

\subsection{Aanbevelingen tot wijziging of interpretatie van de wet}

Uit dit onderzoek volgt enige kritiek op de wijze waarop de wetgever het stemrechtloze aandeel en de rechten van de houder van dat aandeel heeft vormgegeven. In deze paragraaf doe ik aanbevelingen tot wijziging of interpretatie van de wet.

Voor aanbevelingen voor de rechtspraktijk verwijs ik naar Bijlagen 3, 4 en 5. Zij zien vooral op de voor- en nadelen van de diverse rechtsfiguren zonder stemrecht en aandachtspunten bij het gebruik van deze rechtsfiguren, bijvoorbeeld in het kader van structurering van vennootschappen. Ik beperk mij daarbij tot het stemrechtloze aandeel (Bijlage 3), het certificaat van aandeel (Bijlage 4) en het participatiebewijs (Bijlage 5). De rechtsfiguren van pandrecht of vruchtgebruik op aandelen worden in de praktijk in andere situaties gebruikt en zien niet op de keuze tussen (het gebruik van) het stemrechtloze aandeel, het certificaat van aandeel of het participatiebewijs. 
Mijn belangrijkste aanbevelingen tot verbetering of interpretatie van de wet zijn:

\begin{tabular}{|c|c|c|}
\hline & Aanbevelingen tot wijziging of interpretatie van de wet & Paragraaf \\
\hline 1. & $\begin{array}{l}\text { Het opnemen in de wet van een wettelijke definitie van het } \\
\text { stemrechtloze aandeel, luidende als volgt: "Het stemrechtloze } \\
\text { aandeel is een vermogensrecht op naam, in de vorm van een } \\
\text { aandeel uitgegeven door de BV, dat kapitaal in een BV } \\
\text { vertegenwoordigt, waaraan de rechten volgens de wet en de } \\
\text { statuten van de BV zijn verbonden, waaronder het recht - al } \\
\text { dan niet beperkt - op winst en/of reserves van die BV, doch } \\
\text { aan welk aandeel geen stemrecht in de algemene vergadering } \\
\text { is verbonden." }\end{array}$ & 4.2 .4 \\
\hline 2. & $\begin{array}{l}\text { Het wijzigen van de tweede volzin van art. } 2: 228 \text { lid } 5 \text { BW in: } \\
\text { "Een dergelijke regeling kan slechts worden getroffen ten } \\
\text { aanzien van alle aandelen van een bepaalde soort of aandui- } \\
\text { ding waarvan alle aandeelhouders instemmen, dan wel ten } \\
\text { aanzien van alle aandelen van een bepaalde soort of aan- } \\
\text { duiding die niet zijn geplaatst." }\end{array}$ & 4.2 .2 \\
\hline 3. & $\begin{array}{l}\text { Art. 2:228 lid } 5 \text { laatste volzin BW kan beter als volgt worden } \\
\text { geformuleerd: "Ten aanzien van stemrechtloze aandelen kan } \\
\text { niet op grond van art. } 216 \text { lid } 7 \text { worden bepaald dat zij geen } \\
\text { enkel recht geven tot deling in de winst of de reserves van de } \\
\text { vennootschap." }\end{array}$ & 4.2 .5 \\
\hline 4. & $\begin{array}{l}\text { Aan art. } 2: 178 \text { lid } 1 \mathrm{BW} \text { moeten de woorden "van een } \\
\text { bepaalde aanduiding" worden toegevoegd. }\end{array}$ & 4.2 .6 \\
\hline 5. & $\begin{array}{l}\text { Het bestuur van de vennootschap moet wettelijk verplicht } \\
\text { worden schriftelijk aantekening te houden van besluiten van } \\
\text { de vergadering van stemrechtloze aandeelhouders. }\end{array}$ & 4.2 .8 \\
\hline 6. & $\begin{array}{l}\text { Het zou wettelijk verplicht moeten worden dat notulen worden } \\
\text { opgemaakt van de vergadering van houders van stemrechtloze } \\
\text { aandelen en de algemene vergadering. Dat komt de toetsing } \\
\text { van de besluiten en de besluitvorming ten goede. }\end{array}$ & 4.2 .8 \\
\hline
\end{tabular}




\begin{tabular}{|l|l|l|}
\hline & Aanbevelingen tot wijziging of interpretatie van de wet & Paragraaf \\
\hline 7. & $\begin{array}{l}\text { Met de invoering van het stemrechtloze aandeel is niet duidelijk } \\
\text { wat onder het begrip 'de meerderheid der aandelen' in de zin } \\
\text { van art. 1:88 lid 5 BW moet worden verstaan. Dat begrip wordt } \\
\text { ingevuld door het formele criterium van de vennootschaps- } \\
\text { structuur en het materiële criterium van de combinatie van } \\
\text { zeggenschap en financieel belang. Voor de invulling van het } \\
\text { financiële belang van het materiële criterium zou ik een pro- } \\
\text { portionele minimumgrens van tien procent in het kapitaal van de } \\
\text { BV aan door de handelend bestuurder te houden stemrechtloze } \\
\text { aandelen willen stellen. }\end{array}$ & \\
\hline 8. & $\begin{array}{l}\text { Onder het begrip 'uiteindelijk belanghebbende' in de Wwft en } \\
\text { Wtt moet (ook) worden verstaan de stemrechtloze aandeel- } \\
\text { houder met een zodanig kapitaalsbelang dat hij ten minste 25 } \\
\text { procent van het geplaatste kapitaal in de BV houdt. Via zijn } \\
\text { aandeelhouderschap heeft hij immers een meer dan substan- } \\
\text { tieel, financieel belang in de (doel)vennootschap. Dat die } \\
\text { stemrechtloze aandeelhouder het stemrecht ontbeert, doet } \\
\text { daaraan niet af. }\end{array}$ & 4.3 .9 \\
\hline 9. & $\begin{array}{l}\text { Gelet op de achtergrond en de strekking van art. 43 Fw, meer in } \\
\text { het bijzonder de in dat artikel opgenomen bewijsvermoedens, } \\
\text { pleit ik ervoor in situaties als bedoeld in art. 43 lid 1 sub 4 onder } \\
\text { c en sub 5 onder c en d Fw onder de woorden 'ten minste de } \\
\text { helft van het geplaatste kapitaal' ook te verstaan de stemrecht- } \\
\text { loze aandeelhouder met een zodanig kapitaalsbelang dat hij ten } \\
\text { minste de helft van het geplaatste kapitaal in de BV houdt. }\end{array}$ & \\
\hline 10. & $\begin{array}{l}\text { Het begrip 'in overwegende mate bij machte' als bedoeld in } \\
\text { art. 1:141 lid 4 BW moet worden uitgelegd als een feitelijk } \\
\text { zeggenschapscriterium. Dat criterium lijkt in de flex-BV we- } \\
\text { gens de introductie van het stemrechtloze aandeel niet goed } \\
\text { hanteerbaar. Daardoor kan willekeur ontstaan. Indien tussen } \\
\text { echtelieden een periodiek verrekenbeding is overeengekomen, } \\
\text { dat mede winst uit onderneming omvat terwijl een van de } \\
\text { echtgenoten stemrechtloze aandelen in een BV houdt, zouden } \\
\text { de ingehouden winsten, nar evenredigheid van het aandelen- } \\
\text { bezit, in de verrekening betrokken moeten worden. }\end{array}$ & 4.3 .11 \\
\hline
\end{tabular}




\begin{tabular}{|c|c|c|}
\hline & Aanbevelingen tot wijziging of interpretatie van de wet & Paragraaf \\
\hline 11. & $\begin{array}{l}\text { Art. V.2 lid } 1 \text { eerste volzin van het Overgangsrecht moet } \\
\text { luiden dat het bestuur van de vennootschap voldoet aan het } \\
\text { bepaalde in art. 2:194 lid } 1 \text { laatste volzin BW conform de } \\
\text { verplichting van dat laatste artikel dat het bestuur van de } \\
\text { vennootschap het aandeelhoudersregister bijhoudt. }\end{array}$ & 4.4 .6 .3 \\
\hline 12. & $\begin{array}{l}\text { Art. V.2 lid } 1 \text { laatste volzin van het Overgangsrecht moet } \\
\text { bepalen dat inschrijving van de certificaathouder als verga- } \\
\text { dergerechtigde in het aandeelhoudersregister op last van de } \\
\text { rechter of voorzieningenrechter tot gevolg heeft dat certifi- } \\
\text { caathoudersrechten ontstaan. }\end{array}$ & 4.4 .6 .3 \\
\hline 13. & $\begin{array}{l}\text { Art. V.2 lid } 6 \text { van het Overgangsrecht moet luiden dat "de } \\
\text { vennootschap bij de eerstvolgende statutenwijziging verga- } \\
\text { derrecht [dient] te verbinden aan deze certificaten overeen- } \\
\text { komstig artikel } 227 \text { lid 2". Blijkens art. 2:227 lid } 2 \text { BW wordt } \\
\text { immers vergaderrecht aan certificaten verbonden en niet aan } \\
\text { de houders van certificaten. }\end{array}$ & 4.4 .6 .3 \\
\hline 14. & $\begin{array}{l}\text { Aan de eerste volzin van art. V.2 lid } 1 \text { van het Overgangsrecht } \\
\text { moet na de punt worden toegevoegd: "Indien sprake is van } \\
\text { houders van certificaten van aandelen, welke certificaten } \\
\text { voor inwerkingtreding van de wet met medewerking van de } \\
\text { vennootschap zijn uitgegeven en de vennootschap en haar } \\
\text { organen zulks hebben erkend of dienovereenkomstig hebben } \\
\text { gehandeld, voldoet het bestuur van de vennootschap omgaand na } \\
\text { inwerkingtreding van de wet aan artikel } 194 \text { lid 1, laatste volzin." }\end{array}$ & 4.4 .6 .3 \\
\hline 15. & $\begin{array}{l}\text { Aan de eerste volzin van art. V.2 lid } 1 \text { van het Overgangsrecht } \\
\text { moet tevens na de punt worden toegevoegd: "Indien sprake is } \\
\text { van houders van certificaten van aandelen waaraan verga- } \\
\text { derrecht is verbonden, welke certificaten na inwerkingtreding } \\
\text { van de wet zijn uitgegeven, voldoet het bestuur van de } \\
\text { vennootschap omgaand na uitgifte van die certificaten aan } \\
\text { artikel } 194 \text { lid 1, laatste volzin." }\end{array}$ & 4.4 .6 .3 \\
\hline 16. & $\begin{array}{l}\text { Houders van participatiebewijzen met vergaderrecht moeten in } \\
\text { het aandeelhoudersregister worden opgenomen. }\end{array}$ & 4.11 \\
\hline 17. & $\begin{array}{l}\text { Ter bescherming van de vergadergerechtigde kapitaalver- } \\
\text { schaffer zonder stemrecht zou de wetgever aan art. 2:238 lid } 1 \\
\text { BW het woord 'voorafgaand' moeten toevoegen. }\end{array}$ & 6.2 .3 .8 \\
\hline
\end{tabular}




\begin{tabular}{|l|l|l|}
\hline & Aanbevelingen tot wijziging of interpretatie van de wet & Paragraaf \\
\hline 18. & $\begin{array}{l}\text { Wegens gebrek aan toegevoegde waarde kunnen de woorden } \\
\text { 'vaststelling van de waarde van de aandelen' in art. 2:181 lid 4 } \\
\text { BW worden geschrapt. }\end{array}$ & 6.2 .3 .13 \\
\hline 19. & $\begin{array}{l}\text { Als eenvoudige oplossing voor de omzetting van een BV in } \\
\text { een NV stel ik voor de regel dat stemrechtloze aandelen in een } \\
\text { BV tot aandelen met stemrecht in een NV verworden. }\end{array}$ & 6.2 .3 .13 \\
\hline 20. & $\begin{array}{l}\text { Een meer eenvoudige oplossing voor de omzetting van een } \\
\text { BV in een NV lijkt mij de introductie van stemrechtloze } \\
\text { aandelen in de NV. }\end{array}$ & 6.2 .3 .13 \\
\hline 21. & $\begin{array}{l}\text { Indien bij een driehoeksfusie of driehoeksplitsing de groeps- } \\
\text { maatschappij een BV is, kunnen de stemrechtloze aandeel- } \\
\text { houders van de verdwijnende vennootschap ook stemrechtloze } \\
\text { aandelen verkrijgen in de groepsmaatschappij-BV. De wet zou } \\
\text { in dat geval in een vrijstelling voor de schadeloosstelling } \\
\text { moeten voorzien. }\end{array}$ & 6.2 .3 .15 en \\
\hline 22. & $\begin{array}{l}\text { Aan de certificaathouder met vergaderrecht moet de vordering } \\
\text { tot uitstoting en de vordering tot uittreding in de geschillen- } \\
\text { regeling toekomen. Ik pleit er bovendien voor de kapitaaleis van } \\
\text { art. 2:336 BW gelijk te trekken met de kapitaaleis voor het } \\
\text { indienen van een enquêteverzoek ex art. 2:346 lid 1 onder b BW, } \\
\text { zijnde ten minste een tiende gedeelte van het geplaatste kapitaal. }\end{array}$ & 8.9 \\
\hline
\end{tabular}

\section{$9.4 \quad$ Verwachtingen en tot slot}

Met de Commissie Vennootschapsrecht ben ik van mening dat het ontbreken van stemrecht aan het stemrechtloze aandeel kan leiden tot onevenwichtigheid in de zeggenschapsverhoudingen in de algemene vergadering. In die vergadering kan over allerlei kwesties besloten worden die bij oprichting van de BV niet waren voorzien. Het gevolg daarvan zou kunnen zijn een grotere druk op de rechterlijke macht, omdat de stemrechtloze aandeelhouder zich in de knel voelt komen. Die aandeelhouder zou wellicht eerder geneigd zijn vernietiging van een besluit van de algemene vergadering of van het bestuur wegens strijd met de vennootschappelijke redelijkheid en billijkheid ex art. 2:8 BW te vorderen dan wel een enquête te verzoeken of een vordering tot uittreding in te stellen. ${ }^{5}$

5 Advies van de Commissie vennootschapsrecht over het wetsvoorstel inzake de vereenvoudiging en flexibilisering van het b.v.-recht d.d. 23 november 2006, p. 12, te vinden op http://www.rijksoverheid.nl/onderwerpen/flexibele-BV. In meer algemene zin ook Timmerman 2004, p. 30 en Stokkermans 2008 (2), p. 118. 
De vrijheid van inrichting van een BV en haar statuten is met de invoering van de flex-BV vergroot. Meer vrijheid schept ook meer verantwoordelijkheid voor allen die bij de BV zijn betrokken, meer in het bijzonder jegens de kapitaalverschaffer zonder stemrecht. Richt ik mij tot de stemrechtloze aandeelhouder, dan kan hij met de geschetste, wettelijke instrumenten echter ook voor zichzelf opkomen en de interne verhoudingen beïnvloeden. Zijn mogelijkheden worden nog eens vergroot indien mijn aanbevelingen tot verbetering van de wet door de wetgever worden overgenomen.

Tot slot een algemene opmerking. De citeertitel van de wet luidt: 'Wet vereenvoudiging en flexibilisering bv-recht'. Het moge duidelijk zijn dat het nieuwe BVrecht wel meer flexibel wordt, maar - indien van alle mogelijkheden gebruikt gemaakt wordt - beslist niet eenvoudiger. 
III

SUMMARY, CONCLUSIONS AND RECOMMENDATIONS

\subsection{Introduction}

On the introduction of the Act on simplification and greater flexibility of private companies with limited liability (BV) (Wet vereenvoudiging en flexibilisering $B V$ recht) and the Implementation act on simplification and greater flexibility of private limited companies on 1 October 2012, Dutch law was introduced to shares without voting rights. This was the reason for my research. Forty years of arguments in favour of this class of share had preceded it. The legislator could not get around the need for this class of share. In general, developments in Europe, based on case law and for reasons of the competitive position of the Dutch BV, forced Dutch law governing private limited companies to become more flexible. I refer to Chapter 2.

In Chapter 3, I surveyed the classes of shares and related legal concepts. Based on my inventory of classes of shares and related legal concepts, I have concluded that the legal concepts without voting rights in the BV may be: (i) shares without voting rights, (ii) depositary receipts (with or without the right to attend general meetings), (iii) shares whereby the right to vote has been transferred to the usufructuary, (iv) shares whereby the right to vote has been transferred to the pledgee, and (v) certificates. The holder of any of these legal concepts may be seen as a 'provider of capital without the right to vote'. I have focused my research on this provider of capital.

In section 9.2, my conclusion is an answer to the questions I formulated in Chapter 1. These questions are:

1. What is the relationship between the provider of capital without the right to vote and:

a. the company;

b. the management board of the company;

c. other providers of capital of the company with the right to vote in the general meeting?

2. Which are the rights, obligations and standards that govern these relationships?

3. How can the provider of capital without the right to vote influence these relationships and safeguard his rights? 
In section 9.3, I will offer some recommendations for improvement of the law. In section 9.4, I conclude with expectations and a final remark.

\subsection{Conclusions}

9.2.1 What is the relationship between the provider of capital without the right to vote and the company, its management board and the company's providers of capital with voting rights?

I. Nature of the legal concept without voting rights

The answer to the question of the relationship between the provider of capital without the right to vote and the company, its management board and the company's providers of capital with voting rights is determined first and foremost by the nature of the legal concept without voting rights. These legal concepts were discussed in Chapter 4.

Shares without the right to vote are regulated in Article 2:228, paragraph 5 of the Dutch Civil Code (CC). My definition of said shares would be: 'a share without voting rights is a registered property right, in the shape of a share issued by the private company with limited liability, that represents capital in that private company, to which the rights are statutorily and according to the articles of association of the private company attached, including the right - limited or not to profits and/or reserves of same private company, to which share, however, no right is attached to cast a vote in the general meeting'. Shares without voting rights are shares of a particular class or indication.

Based on Article 2:216, paragraph 7 CC, several classes of shares may be created which give entitlement to profits and/or reserves, or a combination thereof.

The meeting of shareholders without voting rights is a corporate body pursuant to Article 2:189a CC. This enables this body to have certain powers to be attached to it, including the appointment of managing directors and/or members of the supervisory board. Holders of shares without voting rights have the right to cast their vote in 'their' meeting. Managing directors and supervisory board members do not have an advisory vote in the meeting of the shareholders without voting rights. In my opinion, however, the requirements of corporate reasonableness and fairness may give rise to the managing directors (and supervisory board members) being given the opportunity to cast their advisory vote when (important) decisions need to be made, all the more when managing directors are not shareholders at the same time, by the meeting of shareholders without voting rights, if it, in its capacity as a body, has been assigned such powers by the articles of association.

The main rule of Article 2:24d, paragraph $1 \mathrm{CC}$ is that when determining the extent to which the members or shareholders vote, are present or represented, or to which the share capital is contributed or represented shares without voting rights are not taken into account. Exceptions to this main rule are formulated in Article 2:24d, 
paragraph $2 \mathrm{CC}$. Based on this main rule, when determining whether a company is a subsidiary in the sense of Article 2:24a CC shares without voting rights are not taken into account. The same applies in the determination of a group company as referred to in Article 2:24b CC. In my opinion, the main rule of Article 2:24d, paragraph $1 \mathrm{CC}$ is inconsistent, because based on Article 2:242 CC in conjunction with Articles 2:244 and 2:252 CC in conjunction with Article 2:254 CC, the authority to appoint and dismiss managing directors and supervisory board members may be vested in the meeting of shareholders without voting rights. If the appointment of managing directors is vested in several classes of shares, many varieties of subsidiaries are possible. Such vesting of authority is a circumstance which in my opinion should be included in the content of the 'central management' criterion when determining whether a group or group company is involved.

The exception in Article 2:24d, paragraph $2 \mathrm{CC}$ provides that in the application of Article 2:24c CC shares without voting rights are to be taken into account when determining the presence of a participation. According to the legislator, this prevents companies from using shares without voting rights to evade the obligation to include information on such participations in the financial reports. Article 2:24d, paragraph $2 \mathrm{CC}$ states that when determining whether there is a dependent company as referred to in Article 2:63a, 2:152 and Article 2:262 CC the shares without voting rights should also be taken into account in such private limited company. In the situation where a company holds shares without voting rights in another company, I think this may lead to the structure regime becoming applicable, while such shareholder without voting rights cannot exercise voting powers on the dependent company.

Family companies for which shares without voting rights were issued, may opt for the mitigated structure regime as referred to in Article 2:265a CC, provided the requirement of 'mutual agreement to cooperate' and the other requirements of Article 2:265a CC have been met.

The legislator, when introducing shares without voting rights has apparently not realized the implications for several legal provisions of the introduction of such shares. It concerns the concepts 'majority of the shares' as referred to in Article 1:88, paragraph $5 \mathrm{CC}$; 'ultimate beneficial owner' in the Wet ter voorkoming van witwassen en financieren van terrorisme (Prevention of Money Laundering and Financing of Terrorism Act) and the Wet toezicht trustkantoren (Supervision of Trust Offices Act); the words 'at least half of the issued capital' in Article 43 of the Faillissementswet (Bankruptcy Act), and the concept 'predominantly able' as referred to in Article 1:141, paragraph 4 CC.

The implementation of shares without voting rights does not lead to problems with transitional rules.

The legal concept of depositary receipts for shares is similar to shares without voting rights. By certification the legal and economic rights of the shares are divided. The shares are transferred to and held by a depositary or administrative office. The depositary or administrative office administrates the shares and issues the depositary receipts to the holder(s) of such depositary receipts. The legal 
relationship between the administrative office and the holder(s) of depositary receipts is an administrative agreement, embodied in the administration provisions. The relationship between the administrative office and the company is governed by the law and by the articles of association, which means its basis is legal and in accordance with the articles of association. As a shareholder, the administrative office has the control rights initially attached to the shares, while the holders of depositary receipts have the financial rights, such as the right to dividend. Distinction may be made between exchangeable and non-exchangeable depositary receipts, and depositary receipts with limited exchangeability. The distinction between depositary receipts issued with or without cooperation by the company in the former situation has disappeared in the 'flex- $B V$ '. In the flex- $B V$ the question is whether in the articles of association the right to attend general meetings as referred to in Article 2:227 CC is attached to the depositary receipts. The basic assumption is that the company itself determines whether depositary receipts with voting rights are admitted and if so, in which depositary receipts such right to attend general meetings is vested. The main rule of Article 2:227, paragraph $4 \mathrm{CC}$ provides that the right to attend meetings vested in holders of depositary receipts may only be amended with the consent of such holder. Based on Article 2:227, paragraph 2 CC provisions in the articles of association are possible providing that (i) depositary receipts generally do not have the right to attend general meetings, (ii) all depositary receipts have the right to attend general meetings, or (iii) the right to attend meetings is only vested in certain depositary receipts indicated in the articles of association. Several other rights are statutorily connected with the right to attend meetings, such as the right to be informed of notices convening a general meeting (Article 2:224, paragraph $1 \mathrm{CC}$ ), and the right to request the authority to convene a general meeting by a preliminary relief judge (Article 2:220 CC).

The implications of Article 2:227 CC are that when applying Article 3:259 CC to share certificates in a public limited company, only the cooperation of the issuer of the original shares may be accepted if the articles of association provide that the right to attend general meetings is vested in the depositary receipts.

In general terms, Articles 68a and 69 Overgangswet NBW (Transitional law New Dutch Civil Code) are relevant to depositary receipt holders. In addition, Article V.2, paragraphs 1 and 6 of the Overgangsrecht (transitional law of the Implementation act on simplification and greater flexibility of private limited companies) provide specific rules. The company, or at least its management board, should register the depositary receipt holder with the right to attend general meetings in its shareholders' register as soon as possible, but no later than 1 October 2013. After the law has taken effect, if the shareholders' register has not been completed one month prior to the date of the first general meeting pursuant to Article 2:194, paragraph 1, last complete sentence CC, then Article 2:223, paragraphs 2 and 3 (old) CC apply. Holders of depositary receipts issued with the cooperation of the company may request in writing that the company registers them in the shareholders' register as having the right to attend general meetings. If this request is denied by the 
management board, the depositary receipt holders may request the court to order the management board to register them as having the right to attend general meetings. If depositary receipts of the company's shares were issued with the cooperation of the company before the moment of the law taking effect, then the company must attach the right to attend general meetings to these depositary receipts in the first amendment of the articles of association, pursuant to Article 2:227, paragraph 2 CC. Until the moment of such amendment of the articles of association, depositary receipts with the right to attend general meetings shall, according to the articles of association, also mean depositary receipts which prior to the law taking effect had the right to attend general meetings attached to them and which are included in the shareholders' register, and the holders of depositary receipts with the right to attend general meetings may exercise their rights.

The right of usufruct on shares is regulated in Article 2:197 CC. The right of pledge on shares is regulated in Article 2:198 CC. The main rule of both regulations is that the shareholder has the right to vote on the shares on which the right of usufruct or the right of pledge is established. Based on Article 2:197, paragraph 3 CC, and Article 2:198, paragraph $3 \mathrm{CC}$, respectively, the shareholder loses his right to vote if the voting right is transferred at the time of establishment of the right of usufruct or the right of pledge, respectively, to the usufructuary or the pledgee, respectively, or if such transfer is agreed in writing afterwards between the shareholder and the usufructuary or the pledgee, respectively. Article 2:196a CC is declared applicable, mutatis mutandis. The usufructuary or the pledgee, respectively, must be a person to whom the shares may be transferred freely. If such is not the case, both the regulation on the transfer of the right to vote and the transfer of the right to vote itself should - to put it briefly - be approved by the general meeting. Article 2:197, paragraph $4 \mathrm{CC}$ and Article 2:198, paragraph 4 CC, respectively, provide that the shareholder who does not have the right to vote due to usufruct or pledge, respectively, does have the rights assigned by law to the holders of depositary receipts of shares to which the right to attend meetings is attached. Article 2:22, paragraph $2 \mathrm{CC}$ stipulates that the shareholder who has no right to vote due to a usufruct or a pledge does have the right to attend general meetings. The coming into force of the flex- $B V$ does not alter a legally valid, already established usufruct or pledge on shares, in which the shareholder has transferred his right to vote to the usufructuary or pledgee.

Participation certificates are acquired by payment or contribution and represent capital in the company. Sometimes all rights attached to shares are vested in a participation certificate, except the right to vote. Holders of participation certificates are entitled to part of the profits and/or the liquidation balance (distributions). Participation certificates have a basis in the articles of association and in contracts. The legal relationship between the holder of a participation certificate and the company is regulated by the participation certificate provisions. The coming into force of the flex- $B V$ does not alter the validity of already issued participation certificates. 
II. Internal relationships in the $B V$

The relationship between the provider of capital without voting rights and the company, its management board and the company's providers of capital with voting rights is not solely determined by the nature of the legal concept without voting rights. The internal relationships within the BV also have their role. These relationships were discussed in Chapter 5. These are the mutual relationships between the provider of capital and the general meeting, the management board of the company or the company itself. These relationships reflect the area of tension in which the provider of capital without voting rights finds himself. From an economy and law perspective, these relationships may be analysed with the principal-agent theory. The providers of capital without voting rights must be able to ensure that their interests are also served by the several actors in the corporate context. In the flex- $B V$, its closed or private nature remains one of the factors governing the internal relationships. The same is applicable to the nature of the cooperation in or through the BV. Both factors, but not only these factors, determine the (legal) standards in the internal relationships. The interest of the company acts as a guideline for the acts of the company's management board and supervisory board. The legislator seems to take its departure from the combined views on corporate interests.

The management board is autonomous in the exercise of its duties and powers. The dualistic structure is maintained in the flex- $B V$. According to the articles of association, the general meeting can have the power to instruct the management board. This power is a breach of the dualistic structure and the autonomy of the management board.

The articles of association may provide that the management board must act in accordance with the instructions of another body of the company. The management board must follow such instructions, unless they are contrary to the interests of the company and its undertaking. This also includes the legitimate interests of the provider of capital without voting rights. Based on the concept of 'body' in Article 2:189a CC, instructional powers may also be vested in the general meeting of shareholders without voting rights. In my opinion, instructional powers according to the articles of association may be vested in several bodies, pursuant to Article 2:239, paragraph 4 CC.

The freedom of the shareholder to exercise his voting rights is limited by the standard of Article 2:8 CC and the interests of the company. His voting behaviour shall or may be tested against this standard.

\section{The rights of providers of capital without voting rights}

In addition to the nature of the legal concept and the internal relationships in the BV, the rights of the providers of capital without voting rights determine the relations between the provider of capital without voting rights and the company, its management board and the company's providers of capital with voting rights. These rights were discussed in Chapter 6. 
Shares without voting rights

All rights are attached to the shares without voting rights, except the right to vote in the general meeting. Section 6.2.3.1 shows an overview of the rights attached to shares without voting rights. The (whole or partial) right to profits and/or the reserves (distributions) of the company is an important right for the shareholder without voting rights. However, according to Article 2:216 CC, this right is not unconditional.

In the general meeting of shareholders without voting rights the power to appoint, suspend and dismiss a managing director and to determine his remuneration may be vested pursuant to Articles 2:242, 2:244, and 2:245 CC, unless the appointment of managing directors is done on the basis of the (full) structure regime. The bottom limit for the appointment is that every shareholder with voting rights may participate in the decision making in respect of the appointment of at least one managing director. Pursuant to Article 2:244 CC several bodies may be authorized to dismiss a managing director. Shareholders without voting rights may enlarge their influence in the company by appointing a managing director of their own. Such managing director will have to take the corporate interests into account and not just the interests of his supporters. The assignation and deprivation of the power by the meeting of the shareholders without voting rights to appoint, suspend or dismiss a managing director may only be done in unanimity during a meeting in which the issued capital is represented in its entirety. In such a resolution to amend the articles of association, the shareholder without voting rights is protected by the provisions in Article 2:231, paragraph $4 \mathrm{CC}$. The articles of association may provide that the meeting of the shareholders without voting rights may also appoint a managing director on nomination, pursuant to Article 2:243, paragraph 5 CC.

The rules governing the appointment, suspension and dismissal of supervisory board members follow to a high degree such rules in respect to managing directors. These powers may also be vested in the meeting of the shareholders without voting rights by the articles of association.

Article 2:206a CC stipulates that the shareholder without voting rights does not have a pre-emption right in respect of an issue of shares of any class. The articles of association may derogate from that. If that is the case, then such pre-emption right may, in my opinion, be circumvented by issuing ordinary shares and subsequently certifying them and issuing them with new providers of capital without voting rights. In situations concerning a pre-emption right in respect of an issue of shares, shareholders without voting rights may derive protection from corporate reasonableness and fairness. The holder of ordinary shares has no pre-emption right in respect of an issue of shares without voting rights. Shareholders without voting rights may, as part of the right of first refusal provision in Article 2:195 CC, only consider offered shares without voting rights. The articles of association may derogate from these main rules.

In many cases, shareholders without voting rights are protected. I refer to the overview in section 6.2.3.6. Two of these protection rules call for special attention, 
Articles 2:216, paragraph 8 and 2:231, paragraph 4 CC. In my opinion, the right of consent as referred to in Article 2:216, paragraph $8 \mathrm{CC}$ calls for a narrow interpretation. It regards amendments to the articles of association affecting the financial rights directly attached to those shares rather than an amendment to the articles of association affecting the right to profits and/or reserves (distributions) in the company, but nonetheless affecting such financial rights attached to those shares indirectly. Article 2:231, paragraph $4 \mathrm{CC}$ provides that for shareholders without voting rights a resolution to amend the articles of association that specifically affects any of their rights requires a consenting resolution from this group of shareholders. It concerns affecting specific rights attached to these shares and a limitation of rights which are also attached to other shares, but whose limitation then only applies to the specific shares referred to rather than to other shares. The right to amendment may be reserved at the time of the assignation of the rights in the articles of association pursuant to the unless-clause in Article 2:231, paragraph 4 CC. In my opinion, the article of association can be formulated so that a single resolution of the general meeting can amend or remove such right. To my mind, Article 2:231, paragraph 4 $\mathrm{CC}$ will quickly be applicable in practice, considering the purpose and content of the provision.

Shareholders without voting rights must consent to decision making outside a general meeting. The absence of consent renders the decision contrary to it (only) voidable, in my opinion, considering the intended liberalization of the decision making outside the general meeting. Consent is not necessarily explicit and may be given electronically. In decision making outside a general meeting the role of the provider of capital with the right to attend general meetings but without the right to vote appears marginal to me.

Shareholders without voting rights may be bound to obligations under the articles of association as provided in Article 2:192 CC, but not necessarily so. They have the option not to consent to the proposed obligation under the articles of association. Then it is a matter of 'being personally not bound' (persoonsgebonden nietgebondenheid), whether or not the shareholder without voting rights has acquired more shares after the amendment of the articles of association, by which the obligations were introduced.

For the application of the buy-out provision in Article 2:201a CC the shares without voting rights in a BV are also taken into account, as provided in Article 2:24d, paragraph $2 \mathrm{CC}$.

The articles of association of a BV may include a provision that shares without voting rights may be converted to ordinary shares. As a result of such conversion, the shareholder without voting rights gains the right to vote in the general meeting.

Based on Article 2:181, paragraph $1 \mathrm{CC}$, in case of conversion of a BV to an association, a cooperative, or a mutual insurance society, the shareholder without voting rights becomes a member of such legal person, unless he files a request to the company for compensation of his loss of the shares. At first instance, the parties will have to negotiate an agreement on the scope of the rights of the shareholders without 
voting rights in the converted legal person. Article 2:181, paragraph $3 \mathrm{CC}$ provides the withdrawal right of the shareholder without voting rights if the private company with limited liability $(B V)$ is converted to a (public) company limited by shares $(N V)$. Shares without voting rights are not part of any NV. In a conversion, the shareholder without voting rights must therefore become a shareholder with a right to profits and a (perhaps small) right to vote in the general meeting. If the shareholder without voting rights does not consent to the conversion, he may request compensation.

Article 2:181, paragraph $4 \mathrm{CC}$ contains a provision for the compensation which must be included in the proposal for the conversion. The share valuation provision, the compensation provision or a similar provision in a shareholders' agreement or in the articles of association as referred to in Article 2:181, paragraph 4, third sentence CC must regard conversion specifically, in my opinion, if said provision should be applicable in case of conversion. Article 2:181, paragraph $5 \mathrm{CC}$ excludes the application of Article 2:231, paragraph $4 \mathrm{CC}$, because it does not speak for itself to grant voting rights to shareholders without voting rights when far-reaching decisions need to be made. Double protection is thereby prevented. Article 2:181, paragraph 6 $\mathrm{CC}$ states that the judicial authorization required for the conversion of a $\mathrm{BV}$ to a foundation or an association shall be denied if the interests of the shareholders without voting rights have not sufficiently been considered.

I question the regulation of the position of the shareholders without voting rights in the case of conversion. It is uncertain whether shareholders without voting rights will be able to return in a comparable position, considering the nature of the converted legal person. If such shareholder does not choose to do so, then it is doubtful whether the amount of compensation can easily be established.

Another point of criticism is that it is unclear what 'shares cease to exist' means. To me, it speaks for itself that at the same time as the conversion takes effect, the BV decides to revoke the shares without voting rights.

If a BV is converted to a general partnership (vennootschap onder firma) the BV is legally dissolved. Pursuant to Article 2:23b CC the shareholders without voting rights are entitled to the liquidation balance, unless such is excluded by the articles of association. In the situation where a partnership (personenvennootschap) is converted to a BV, during or after the incorporation the owners of such partnership are free to choose to have shares without voting rights in the capital of the BV.

In case of merger and division the position of the shareholders without voting rights is to a great extent comparable to their position in case of conversion to another legal person. The merger between a BV ceasing to exist and an acquiring $\mathrm{NV}$ are especially relevant to the shareholders without voting rights and to the legal practice. Shares without voting rights are not part of any NV. Negotiations will have to be conducted with the shareholders without voting rights on their position as shareholders after the merger. After the merger, such negotiations may result in a $\mathrm{BV}$ in which their position as shareholders without voting rights is the same, or they may result in conversion of their shares to shares with voting rights or with rights to 
profits. Both parties may also decide to part ways or either party may decide not to wish to continue with the other party. In that case, compensation will need to be negotiated. The position of the shareholders without voting rights can be strengthened pursuant to Article 2:317, paragraph $4 \mathrm{CC}$, for instance because the merger resolution requires the consent of every shareholder without voting rights or the approval of the general meeting of shareholders without voting rights.

Article 2:330, paragraph $1 \mathrm{CC}$ contains a main rule for the merger resolution of the general meeting. In addition, pursuant to Article 2:330, paragraph $2 \mathrm{CC}$ an approving resolution is required of each group of holders of shares without voting rights whose rights are affected by the merger. The reason for such protection is that the BV itself may also be an acquiring company. Moreover, special powers may have been assigned to the meeting of shareholders without voting rights. In that case, Article 2:231, paragraph $4 \mathrm{CC}$ does not apply. In derogation from Article 2:311 CC the shareholder without voting rights of the BV ceasing to exist may file a request for compensation, if he is not a shareholder in the acquiring $\mathrm{NV}$, pursuant to Article 2:330a CC. The regulation therefor is the same as for conversion.

In a triangular merger as referred to in Article 2:333a CC the obligation to compensation pursuant to Article 2:330a CC lies with the group company; the acquiring company is exempt. If the group company is a BV, shares without voting rights in the group company-BV can also be acquired by the shareholders without voting rights of the company ceasing to exist.

In case of cross-border mergers pursuant to Article 2:333h CC the shareholder without voting rights of the company ceasing to exist may request compensation from that company, up to a month after the merger resolution. Article 2:330a CC does not apply to cross-border mergers.

The regulation concerning division and the related position of the shareholders without voting rights is to a great extent comparable to the regulation concerning merger. Article 2:334m CC contains general regulation for division resolutions. For divisions, pursuant to Article 2:334m, paragraph $4 \mathrm{CC}$ the articles of association may, in derogation from paragraph 3 of said Article, also contain a regulation for division resolutions, so that the position of the shareholders without voting rights may be strengthened. Among others, Articles 2:334ee and 2:334ee1 CC are relevant to the division of a private limited company or of a private limited company being incorporated as part of a division. The latter Article stipulates the compensation for shareholders without voting rights if the acquiring company is not a BV. These provisions are the counterparts of the applicable provisions in case of merger (Articles 2:330 and 2:330a CC). Also, an approving group resolution is required from the shareholders without voting rights whose rights are affected by the division. In that case, Article 2:231, paragraph $4 \mathrm{CC}$ does not apply either.

The literature states, in my opinion aptly, that it is inexplicable that in case of a contentious division (ruziesplitsing) pursuant to Article 2:334cc CC shareholders without voting rights in the dividing BV should not be given an equivalent position in the acquiring (limited) companies. Moreover, the legislator apparently and 
mistakenly, as is equally aptly stated in the literature, presupposes that all shares without voting rights are placed under one of the acquiring companies and all other shares in the other acquiring company. That is also not necessarily the case. If it is, this situation can easily be resolved. In a division, the acquiring company may issue shares with voting rights to the (former) shareholders without voting rights.

In the simplified division of Article 2:334hh CC the shareholder without voting rights has no right to compensation. After all, there is no company ceasing to exist. In a proportionate division, pursuant to Article 2:334hh CC the shareholders without voting rights may become the holders of a different 'class' of share without voting rights. Other financial rights may be attached to such shares than to the original shares, for instance a more limited right to profits. They are protected by the approving group resolution of Article 2:334ee, paragraph $2 \mathrm{CC}$.

The provision of the triangular division pursuant to Article $2: 334 \mathrm{ii} \mathrm{CC}$ is identical to the triangular merger provision as referred to in Article 2:333a CC. For the position of the shareholders without voting rights Article 2:334ii, paragraph $3 \mathrm{CC}$ is relevant, whose basis is that the obligations of the acquiring company are imposed upon the group company issuing the shares as well as upon the acquiring company. As the compensation provided in Article 2:334ee1 CC for holders of shares without voting rights is related to the assignation of shares, the acquiring company in Article 2:334ii, paragraph $3 \mathrm{CC}$ is exempted from the obligation as referred to in Article 2:334ee1, paragraph $1 \mathrm{CC}$. It is, in my opinion aptly, stated in the literature on this matter that if the group company is a $\mathrm{BV}$, the shareholders without voting rights of the dividing company may also acquire shares without voting rights in the group company-BV.

It is my opinion that from the foregoing follows that the legislator has not succeeded in formulating a simple regulation concerning shares without voting rights.

Depositary receipts of shares with and without the right to attend general meetings By certification the legal and economic rights of the shares are divided. An overview of the rights attached to depositary receipts in the triangular relationship between the holder of the depositary receipt, the administrative office and the BV is found in section 6.3.3.1.

The literature states that the administrative title leads to the basic assumption that the administrative office has to take the short-term and long-term interests of the holders of depositary receipts into account in exercising their right to vote in the general meeting, irrespective of the standards arising from the articles of association of the administrative office and of its administrative provisions. These interests may not be disproportionately affected. The influence of the holders of depositary receipts on the voting behaviour of the administrative office depends on each separate case and is determined by the content of the articles of association of the administrative office and its administrative provisions. If the holders of depositary 
receipts have the right to attend general meetings, their influence on the decision making shall increase (further), as is also the case for shareholders without voting rights.

The assignation of the right to attend general meetings determines the position of the holders of depositary receipts. The right to attend general meetings and the associated rights are relevant both to their influence on the decision making and to the validity of the decision making. These are important rights for these holders of depositary receipts. Based on Article 2:228, paragraph $2 \mathrm{CC}$ provisions in the articles of association are allowed providing that depositary receipts generally do not have the right to attend general meetings; that all depositary receipts have the right to attend general meetings; or that the right to attend general meetings is only vested in certain depositary receipts indicated in the articles of association. The basic assumption is that the company, or at least its general meeting, determines whether depositary receipts with the right to attend general meetings are admitted and if so, in which depositary receipts such right to attend general meetings is vested. There are two ways to attach the right to attend general meetings to depositary receipts, namely (i) assignation by articles of association, and (ii) assignation by a body to which this power is assigned in the articles of association. Article 2:227, paragraph $4 \mathrm{CC}$ stipulates that the right to attend general meetings assigned to holders of depositary receipts by the articles of association may only be amended with the consent of such holders of depositary receipts, unless the power to amend was explicitly reserved in the articles of association with the assignation of the right to attend general meetings. Depriving depositary receipts of the right to attend general meetings can be done in three ways. Firstly, in articles of association the right to attend meetings is attached to the depositary receipt, but deprivation or amendment of that right has not been reserved. The holder of depositary receipts will have to consent to depriving his depositary receipt of the right to attend general meetings. Secondly, in articles of association the right to attend meetings is attached to the depositary receipt, and deprivation or amendment of that right has been reserved in the same provision of the articles of association. The depositary receipt may be deprived of the right to attend general meetings pursuant to the unless-clause in Article 2:227, paragraph $4 \mathrm{CC}$ (without consent from the holder of the depositary receipt for such deprivation being required). Thirdly, the power to assign and deprive the right to attend general meetings is assigned to a body of the company as referred to in Article 2:189a CC. Such body may deprive the depositary receipt of its right to attend general meetings without consent from the holder of the depositary receipt.

In decision making outside the general meeting the position of holders of depositary receipts with the right to attend general meetings is equal to the position of shareholders without voting rights. In decision making outside the general meeting the depositary receipt holder without the right to attend general meetings does not have to be taken into account. After all, he does not have the right to attend general meetings. 
The legal right of pledge is vested in the holder of a depositary receipt, pursuant to Article 3:259 CC. In my opinion, no distinction needs to be made between depositary receipts whereby the right to attend general meetings has been assigned by the articles of association and whereby such right has been assigned by a body. The deprivation of the right to attend general meetings from the depositary receipts by a body appointed to do this by the articles of association causes the legal right to pledge to cease to exist, just as the attachment of the right to attend general meetings to the depositary receipt causes the legal right of pledge to come into existence.

The question whether depositary receipts are exchangeable or not is also relevant to the relationship between the holder of such depositary receipt and the company. Depending on the answer to that question, the depositary receipt holder may exchange his depositary receipt for a share, so that his right to vote 'is resurrected' and he will see - depending on the balance of votes in the general meeting - an increase in his influence on the decision making. If in the administrative provisions the exchangeability of depositary receipts is not mentioned, my opinion is that the basic assumption should be that they are not exchangeable.

In case of conversion of the BV to a partnership, the position of the depositary receipt holder is the same as that of the shareholder without voting rights, except that the administrative office - as a shareholder - exercises its voting right on the dissolution resolution. The depositary receipt holder with the right to attend general meetings shall be involved in the decision making process due to this right to attend general meetings. If a $\mathrm{BV}$ is converted to an $\mathrm{NV}$ and the $\mathrm{NV}$ considers the depositary receipts as having been issued with the cooperation of the company, then the consent of the depositary receipt holder with the right to attend general meetings is, in my opinion, not required in respect of the necessary amendment of the articles of association as part of the conversion. If depositary receipts issued with the cooperation of the company are not part of the NV or if the NV regards them as issued without cooperation, the depositary receipt is then deprived of the right to attend general meetings and, pursuant to Article 2:227, paragraph $4 \mathrm{CC}$ the consent of the holder of the depositary receipt is required.

In a merger resolution pursuant to Article 2:317 $\mathrm{CC}$ the administrative office exercises the right to vote on the shares in the general meeting on behalf of the holders of depositary receipts. The administrative office will thereby have to take the interests of the holders of depositary receipts into account. The articles of association of the administrative office may provide that the merger resolution, or more generally the resolution to amendment of the articles of association, requires approval by the meeting of depositary receipt holders. In important resolutions, such as mergers, dissolutions and conversions, the administrative office should, in my opinion, consult the holders of depositary receipts - insofar as such an obligation is not yet included in the administrative provisions - before casting its vote in the general meeting. The administrative office will have to vote for or against the merger resolution, taking into account the results of the vote in the meeting of the depositary receipt holders, corresponding to the number of votes for and 
against in the meeting of the depositary receipt holders. Considering the procedure as described in Article 2:317 CC, the holders of depositary receipts with the right to attend general meetings shall also in this case be involved in the decision making in the BV in respect to the dissolution. I think Article 2:227, paragraph $4 \mathrm{CC}$ does not apply in case of merger and division. Nor do Articles 2:216, paragraph 7 and 2:330, paragraph $2 \mathrm{CC}$ offer protection to the holders of depositary receipts.

In a merger between a company ceasing to exist with depositary receipts with the right to attend general meetings and an acquiring company without depositary receipts or only with depositary receipts without the right to attend general meetings, the position of depositary receipt holders in the company ceasing to exist is in my opinion that they should in principle be given identical membership rights in the acquiring company.

In a merger of two BVs I think that the legal right of pledge pursuant to Article 3:259 CC becomes invalid if there are depositary receipts with the right to attend general meetings in the company ceasing to exist and depositary receipts without the right to attend general meetings in the acquiring company.

The shareholder whose right to vote is transferred to the usufructuary or the pledgee

The shareholder whose right to vote is transferred to the usufructuary or the pledgee has a membership relationship with the company. They share the same rights as depositary receipt holders with the right to attend general meetings, as stipulated by Articles 2:197, paragraph 4 and 2:198, paragraph 4 CC, respectively. In addition, pursuant to Article 2:206a CC they have a pre-emption right in respect to an issue of shares, as opposed shareholders without voting rights.

\section{Participation certificate holders}

Participation certificates are not legally provided for. For the relevant rights and obligations the participation provisions, which have contractual freedom, will have to form the solution. As there is no membership relation between the holder of a participation certificate and the company, such holder has a different organizational relationship with the company. The (meeting of) holders of participation certificates (is) are not a body of the company. Generally speaking, the participation provisions will mainly assign financial rights, not control rights, to the holders of participation certificates. The most important right is the right to profits, and perhaps a right to liquidation surplus (distributions). Such right to profits is based in the articles of association. In my opinion, a basis in articles of association is not required for the issue of participation certificates. The holder of a participation certificate is protected by Article 2:232 CC when the rights attached to his participation certificate are affected. He must consent to an amendment of the articles of association affecting his rights, unless the power of amendment has already been reserved at the issuing of the participation certificate. 
Participation certificates may be (re)purchased by the company. In doing so, the requirement of Article 2:207, paragraph $2 \mathrm{CC}$ will have to be met. Participation certificates cease to exist by such (re)purchase, due to intermixture. Unless a withdrawal clause has been included in the participation provisions, to my mind, participation certificates may only be withdrawn with the consent of its holder.

Article 2:320 CC contains a provision for the holder of a participation certificate in the company ceasing to exist in case of a merger. This Article stipulates that the holder of a participation certificate in the company ceasing to exist shall receive an equivalent right in the acquiring company, or a compensation. Regarding the position of the holder of a participation certificate in case of a division, Article 2:334p CC applies. This article is almost identical to Article 2:320 CC. For conversions, mergers and divisions it is stipulated that corporate reasonableness and fairness towards the holder of the participation certificate must be observed. In conversions, the holder of a participation certificate may also derive protection from Article 2:232 CC.

Other remarks

Based on Article 2:216, paragraph $3 \mathrm{CC}$ the shareholder without voting rights and the shareholder whose voting rights have been transferred to the usufructuary or the pledgee can be liable for distributions received by them, even if these holders of the right to vote in general meetings may not cast their votes on the distribution resolution. If they were informed by the management board on the possibility of adverse effects of any intended resolution, they may not invoke their good faith.

Whether the holder of a depositary receipt pursuant to Article 2:216, paragraph 3 $\mathrm{CC}$ is obliged to repay what he has received, in my opinion depends on the answer to the question whether the depositary receipt does or does not have the right to attend general meetings attached to it. I think the holder of a depositary receipt with the right to attend general meetings should be put on a par with the shareholder without voting rights and the shareholder whose voting right has been transferred to the usufructuary or the pledgee. As a beneficiary shareholder, the administrative office will be able to seek recourse from such holder of a depositary receipt. A relevant provision will be or will have to be included in the administrative provisions. If the latter is not the case, I think the suppletive effect of the reasonableness and fairness pursuant to Article 6:248, paragraph $1 \mathrm{CC}$ can be invoked. In my opinion, the holder of a depositary receipt without the right to attend general meetings cannot be liable, at least that he can invoke his good faith, unless the management board informs him on adverse effects of the resolution of distributions prior to the passing of that resolution.

The holder of a participation certificate can invoke good faith if he is being held liable for reimbursement of what he has received, unless the management board of the company also informs the holder of a participation certificate of the adverse effects of an intended resolution prior to the decision making in the general meeting on such distributions. 
Absent providers of capital with the right to attend general meetings but without the right to vote cannot be informed about the warnings of the management board. Such providers of capital with the right to attend general meetings should receive a convening notice as well as the meeting's agenda. It seems to me that not attending the general meeting is a risk to providers of capital in that respect.

The shareholder without voting rights, the holder of a depositary receipt with the right to attend general meetings and the shareholder whose right to vote has been transferred to a usufructuary or a pledgee can (voluntarily) decide not to exercise their right to attend general meetings, provided that it is sufficiently definable, for instance for a certain period of time, or for several general meetings. Considering the far-reaching consequences, I would not just like to assume that deciding not to exercise one's right to attend general meetings can be assumed by implication. Deciding not to exercise the right to attend general meetings also means waiving the rights attached to such right to attend general meetings, such as the right to convene general meetings. Deciding not to exercise the right to attend general meetings in my opinion also means that the person with the right to attend general meetings waives his right to consent in respect of decision making outside the general meeting.

\subsubsection{Which are the legal standards governing the relationship between the provider of capital without the right to vote and the company, its management board and the company's providers of capital with voting rights?}

In Chapter 7, I answered the question which legal standards govern the relationship between the provider of capital without the right to vote and the company, its management board and the company's providers of capital with voting rights. In addition to the law and the articles of association, these internal relationships within the BV are also governed by the open standard of corporate reasonableness and fairness. Corporate reasonableness and fairness can for instance complement or correct these internal relationships.

This open standard derives its substance from general principles distilled from jurisdiction. Koelemeijer ${ }^{1}$ outlines eight factors which may influence the judge's balancing of interests and which may play a role in defining the requirements for reasonableness and fairness in concrete cases, namely (i) the capacity of the party (parties) involved in a conflict of interests, (ii) the influence of the party (parties) involved in a conflict of interests, (iii) dual roles or contrary interest of the party (parties) involved in a conflict of interests, (iv) the nature and content of the decision, (v) the consequences of the decision or the behaviour of the party (parties) involved, (vi) the compensation for the consequences of a decision to the party (parties) involved, (vii) the nature of the company, and (viii) the agreement between

1 Koelemeijer 1999, p. 339. 
the party (parties) involved. The prevailing sentiment in the literature is that testing against reasonableness and fairness is marginal. I do not regard holders of depositary receipts of shares without the right to attend general meetings as belonging to the circle of stakeholders, because the will of the company is not aimed at this type of involvement. The articles of association do not attach the right to attend general meetings to such depositary receipts.

Several themes in corporate reasonableness and fairness are of particular importance to the provider of capital without voting rights who belongs to the circle of stakeholders. These themes are: (i) the principle of equality, (ii) the protection of minority shareholders, (iii) resolutions affecting the rights to profits and/or reserves, (iv) the mutual relations between shareholders, (v) the duty of care by (the management board of) the company towards the provider of capital without voting rights, (vi) the right to information of the provider of capital without voting rights, and (vii) the duty of care by the provider of capital with (decisive) voting rights towards the provider of capital without voting rights. It is evident from jurisdiction that these themes are often intermixed.

As far as the principle of equality is concerned, a distinction between shares of different classes or indications is allowed, which also holds true for shares without voting rights. If such distinction exists, then there is no breach of the principle of equality as referred to in Article 2:201, paragraph $1 \mathrm{CC}$. Making a distinction between holders of shares of the same class or indication is not permitted. The principle of equality as referred to in Article 2:201, paragraph 2 CC in my opinion also applies to holders of depositary receipts with and without the right to attend general meetings and to holders of participation certificates. For the latter, the basis therefor is Article 2:8 CC.

The jurisdiction states that depending on the circumstances of the case, there can be a duty of care by holders of majority shares towards holders of minority shares. Relevant circumstances are the nature of the cooperation, the closed or private nature of the BV and family relations. The interests of all shareholders and the company will have to be taken into account. The question is whether these interests are not affected proportionately. If such relevant circumstances occur, there may rather be a case of conflict of interest. In that case, there is a higher duty of care. In answering the question whether there is an inadmissible conflict of interests and disproportionate breach of interests, the extent of openness and supply of information is relevant. These rules to protect holders of minority shares to my mind apply equally to the providers of capital without voting rights belonging to the circle of stakeholders. In addition to said relevant circumstances, for the interpretation of the duty of care the corporate structure should be considered, the extent to which the provider of capital without voting rights provides capital and the extent to which such provider of capital has control in the company, despite the absence of voting rights, such as the right to appoint managing director(s) or supervisory board member(s). 
As far as the decisions affecting the rights to profits and/or reserves are concerned, three relevant themes can be distinguished for the providers of capital without voting rights belonging to the circle of stakeholders: (i) reserving of profits, (ii) resolutions on the remuneration of managing directors and supervisory board members, and (iii) other resolutions affecting the rights to profits and/or reserves. For the decision making regarding profit reservation, I would like to follow the rules formulated by $\mathrm{Bier}^{2}$ in respect thereof for the providers of capital without voting rights as well, insofar as the nature of the legal concept without voting rights is not contrary to it. ${ }^{3}$ Case law stipulates that the general meeting must observe reasonableness and fairness towards those with rights to profits in establishing the remuneration of managing directors and supervisory board members. It is my opinion that in said rule 'those with rights to profits' may also be read as providers of capital without voting rights, provided that they belong the circle of stakeholders. Insofar as no specific protection provision is applicable, the providers of capital without voting rights belonging to the circle of stakeholders may derive protection from corporate reasonableness and fairness in case of resolutions by the general meeting affecting their rights to profits and/or reserves (distributions).

As far as the mutual relations between shareholders are concerned, and more specifically the relationship between holders of minority and majority shares, on the one hand the position of the holder of minority shares implies that he has to accept resolutions that are disagreeable to him. On the other hand, the holder of majority shares may not abuse his power. The majority shareholder must also take the reasonable interests of the minority shareholder into account when casting his vote in the general meeting. The foregoing also applies to the relationship between shareholders and other providers of capital without voting rights belonging to the circle of stakeholders.

I think that the duty of care developed in case law by (the management board of) the company towards minority shareholders and holders of depositary receipts also applies to the providers of capital without voting rights belonging to the circle of stakeholders. The interpretation of such duty of care depends on the circumstances of the case and the nature of the legal concept without voting rights.

The right to information pursuant to Article 2:217, paragraph $2 \mathrm{CC}$ in my opinion belongs to the shareholder without voting rights, the holder of depositary receipts with the right to attend general meetings and the shareholder who has no voting rights because they have been transferred to the usufructuary or pledgee. This does not apply to the holder of depositary receipts without the right to attend general meetings. After all, he has no right to attend general meetings. Nor can the holder of a participation certificate derive rights from Article 2:217, paragraph $2 \mathrm{CC}$, unless the participation provisions provide otherwise.

See Bier 2012 (1), p. 91.

3 See section 7.5.4.2, end for these rules. 
It seems to me that the provider of capital without voting rights belonging to the circle of stakeholders, in exception to the main rule of Article 2:217, paragraph $2 \mathrm{CC}$, due to special circumstances has a right to information (outside the general meeting), based on corporate reasonableness and fairness. In my opinion, the ASMI ruling leaves some scope for discussion. However, because of the provisions of Article 2:201, paragraph $2 \mathrm{CC}$ this will have to be treated with reservation. The special circumstances are mainly to be found in transactions (i) with a potential contrary interest or a conflict of interests, (ii) contrary to corporate interests, and (iii) entered into under circumstances that do not speak for themselves at first sight. The special circumstances are all the more consequential in case of a family company.

The provider of capital with (potentially) decisive voting rights may be required to inform himself adequately prior to the general meeting. In exercising his right to cast his (decisive) vote, he will have to inform himself adequately on (i) the knowable consequences of his voting behaviour to the company, and (ii) the knowable consequences to and the legitimate interests of the providers of capital without voting rights belonging to the circle of stakeholders as referred to in Article 2:8 CC.

The provider of capital with (decisive) voting rights will have to be particularly watchful in the presence of a personal interest conflicting with the interests of the company and of the providers of capital without voting rights belonging to the circle of stakeholders. The provider of capital with (decisive) voting rights is encumbered with a special duty of care, namely that he must not put his own interest before that of the company and of the providers of capital without voting rights. The provider of capital with (decisive) voting rights exceeds the bounds of the admissible if, in exercising his right to vote, he damages the interests of the company and/or of the providers of capital without voting rights belonging to the circle of stakeholders disproportionately.

\subsubsection{How can the provider of capital without the right to vote influence internal relationships within the $B V$ and safeguard his rights?}

Chapter 8 answers the third main question: How can the provider of capital without the right to vote influence internal relationships within the BV and safeguard his rights? Providers of capital without voting rights have several means to enforce their rights or to improve their legal position.

The right to have issues placed on the agenda of the general meeting pursuant to Article 2:224a, paragraph $1 \mathrm{CC}$ falls to the shareholder without voting rights, the holder of shares whose right to vote has been transferred to the usufructuary or pledgee and the holder of a depositary receipt of a share with the right to attend general meetings. All providers of capital who have the right to have issues placed on the agenda but without voting rights must meet the capital requirements. The right to have issues placed on the agenda does not fall to the holder of a depositary receipt without the right to attend general meetings, nor to the holder of a participation certificate. The conclusion is, therefore, that only those with the right 
to attend general meetings have the right to have issues placed on the agenda. The same conclusion applies to the convening right pursuant to Article 2:220, paragraph 2 CC. Only those who have the right to attend general meetings have convening rights.

The provider of capital with the right to attend general meetings but without voting rights has recourse to a number of legal remedies if his right to information is breached during the general meeting. Such applies provided that the provider of capital without voting rights has asked for information during the general meeting, but to no avail. Of the remedies discussed in section 8.4 to enforce the right to information a claim based on Article 2:217, paragraph $2 \mathrm{CC}$, the obligation to provide exhibits pursuant to Article 843 Code of Civil Procedure, provisional examination of a witness and the right of inquiry seem the most effective. The right of inquiry has as its limitation that only if the condition of the company or the interest of the inquiry so require, the company can be ordered based on an immediate relief to provide the shareholder with the information that was withheld from him during the general meeting.

Another remedy is the action for cooperation in order to pass a resolution. In my opinion, all providers of capital without voting rights are entitled to such action, except the holder of depositary receipts without the right to attend general meetings. The latter does not after all belong to the circle of stakeholders as referred to in Article 2:8 CC. The basis of such action is corporate reasonableness and fairness. It is my opinion that the court should rule on such action with restraint.

The action to nullify resolutions pursuant to Article 2:15, paragraph 1 sub (b) CC falls to the provider of capital without voting rights belonging to the circle of stakeholders as referred to in Article 2:8 CC. In my opinion, the holder of depositary receipts without the right to attend general meetings is not entitled to such action. It was never the company's intention that these depositary receipt holders should have any influence on the decision making. The articles of association do not attach the right to attend general meetings to such depositary receipts.

In urgent cases, primarily the provider of capital without voting rights belonging to the circle of stakeholders can request immediate relief on grounds of urgency in preliminary relief proceedings. The grounds for such a request may be a conflict with the principles of corporate reasonableness and fairness. Considering the nature of the procedure and the preliminary character of the order to be imposed, the outcome of this procedure is uncertain for the provider of capital without voting rights.

The right of inquiry falls to all providers of capital without voting rights (provided they meet the capital requirements), except the holders of participation certificates. Based on Article 2:346, paragraph $1 \mathrm{sub}$ (e) $\mathrm{CC},{ }^{4}$ however, I consider it possible that the right of inquiry will be attached to the holder of a participation certificate by the articles of association or by agreement with the legal person.

4 Based on the 18 June 2012 Act to amend Book 2 of the Civil Code in connection with the adaptation of the right of inquiry. Kamerstukken (Parliamentary papers) 32887 , Staatsblad (Dutch Bulletin of Acts and Decrees) 2012, 274). This law will come into effect on 1 January 2013 (Staatsblad 2012, 305). 
Moreover, the capital requirement will have to be met, because the holder of a participation certificate will otherwise have a more favourable position than the other providers of capital without voting rights. In addition, I consider it possible that the holder of a participation certificate will join the inquiry procedure as an interested party pursuant to Article 282, paragraph 1 Code of Civil Procedure. The provider of capital without voting rights, who does not meet the capital requirement, can join the inquiry procedure as an interested party. Moreover, the Enterprise Division of the Amsterdam Court of Appeal (Ondernemingskamer) can also officially call up the provider of capital as interested party. In addition, every interested party has the opportunity to submit an independent request, provided it is connected with the subject of the original inquiry request. The provider of capital without voting rights can also profit from the situation in which the legal person itself submits an inquiry request.

The question whether the right of inquiry is effective as a means to protect the financial rights attached to the legal concepts without voting rights, cannot simply be answered affirmatively. However, the outcome of the inquiry procedure may very well lead to a more careful and better motivated decision making process regarding distributions, whereby special attention will be given to the position of the provider of capital without voting rights and to the reasoning by the court to nullify the resolution for reservation.

The action for expulsion in the statutory dispute resolution falls to the shareholder without voting rights and the holder of shares whose right to vote has been transferred to the usufructuary or pledgee, provided the capital requirement pursuant to Article 2:336 CC has been met. The action does not fall to the holder of a depositary receipt, nor to the holder of a participation certificate. The action for resignation pursuant to Article 2:343 CC also falls to the shareholder without voting rights and the holder of shares whose right to vote has been transferred to the usufructuary or the pledgee, but not to the depositary receipt holder, nor to the holder of a participation certificate.

A sticking point in the statutory dispute resolution of the action for expulsion and the action for resignation is that the depositary receipt holder is not entitled to these actions. I fail to see a good reason why the shareholder without voting rights and the depositary receipt holder with the right to attend general meetings should not be entitled to these actions, while the depositary receipt holder has the right of inquiry. Another sticking point in the statutory dispute resolution of the action for expulsion is the capital requirement of at least one third of the issued capital provided by Article 2:336 CC. I cannot think of a good reason for this, either. I argue in favour of levelling up said capital requirement to the capital requirement for submitting a request for inquiry based on Article 2:346, paragraph $1 \mathrm{sub}$ (b) $\mathrm{CC}$, to wit at least one tenth of the issued capital. The holder of a depositary receipt without the right to attend general meetings does not belong to the circle of stakeholders, so that I would not like him to be entitled to the action for expulsion and the action for resignation. 
In section 8.10 I reached the conclusion that the voting right on shares without voting rights should not be 'resurrected', should the case arise. That would meet with practical obstacles. Moreover, the law provides the shareholder without voting rights with sufficient protection as it is, or with sufficient means to strengthen his position.

Finally, I argued in section 8.11 that the legal position of the shareholder without voting rights can be strengthened, both in and outside the articles of association.

\subsection{Recommendations for amendment or interpretation of the law}

As a result of my research, I have a few points of criticism for the manner in which the legislator has modelled shares without voting rights and the rights of the holders of such shares. In this section, I put forward recommendations for the improvement or the interpretation of the law.

For recommendations regarding the legal practice I refer to Appendices 3, 4, and 5. These are primarily regarding the pros and cons of the different legal concepts without voting rights and points of interest for the use of these legal concepts, for instance as part of the structuralization of companies. My recommendations are limited to shares without voting rights (Appendix 3), depositary receipts of shares (Appendix 4) and participation certificates (Appendix 5). The legal concepts of the right to usufruct or pledge on shares are used in different situations in practice and do not concern the choice between (the use of) shares without voting rights, depositary receipts of shares or participation certificates. 
My principal recommendations for the improvement or the interpretation of the law are:

\begin{tabular}{|c|c|c|}
\hline & Recommendations for amendment or interpretation of the law & Section \\
\hline 1. & $\begin{array}{l}\text { Including a statutory definition of shares without voting rights, } \\
\text { as follows: 'A share without voting rights is a registered } \\
\text { property right, in the shape of a share issued by the private } \\
\text { company with limited liability, that represents capital in that } \\
\text { private company, to which the rights are statutorily and } \\
\text { according to the articles of association of the private company } \\
\text { attached, including the right-limited or not - to profits and/or } \\
\text { reserves of same private company, to which share, however, no } \\
\text { right is attached to cast a vote in the general meeting'. }\end{array}$ & 4.2 .4 \\
\hline 2. & $\begin{array}{l}\text { Changing the second sentence of Article } 2: 228 \text {, paragraph } 5 \text { CC } \\
\text { to: "Such an arrangement can only be made with regard to all } \\
\text { shares of a specific class or indication of which all shareholders } \\
\text { have given their consent, or with regard to all shares of a } \\
\text { specific class or indication that have not been issued." }\end{array}$ & 4.2 .2 \\
\hline 3. & $\begin{array}{l}\text { A better formulation of Article } 2: 228 \text {, paragraph } 5 \text {, last sentence } \\
\text { CC could be: "With regard to shares without voting rights it } \\
\text { may not be stipulated on the basis of Article } 216 \text {, paragraph } 7 \\
\text { that those shares provide no right whatsoever to participate in } \\
\text { the distribution of profits or reserves of the company." }\end{array}$ & 4.2 .5 \\
\hline 4. & $\begin{array}{l}\text { The words "of a specific indication" should be added to Article } \\
2: 178 \text {, paragraph } 1 \text { CC. }\end{array}$ & 4.2 .6 \\
\hline 5. & $\begin{array}{l}\text { The management board of the company should be legally } \\
\text { required to record the resolutions of the meeting of the } \\
\text { shareholders without voting rights in writing. }\end{array}$ & 4.2 .8 \\
\hline 6. & $\begin{array}{l}\text { Drawing up minutes of the meeting of shareholders without } \\
\text { voting rights and of the general meeting should be a legal } \\
\text { requirement. This will be beneficial to the testing of the } \\
\text { resolutions and the decision making. }\end{array}$ & 4.2 .8 \\
\hline
\end{tabular}




\begin{tabular}{|c|c|c|}
\hline & Recommendations for amendment or interpretation of the law & Section \\
\hline 7. & $\begin{array}{l}\text { One of the results of the introduction of shares without voting } \\
\text { rights is that it is unclear how the concept 'the majority of } \\
\text { shares' as referred to in Article } 1: 88 \text {, paragraph } 5 \mathrm{CC} \text { should be } \\
\text { interpreted. This concept is defined by the formal criterion of } \\
\text { the company structure and the material criterion of the combi- } \\
\text { nation of control and financial interest. With regard to the } \\
\text { financial interest component of the material criterion I would } \\
\text { like to propose a proportionate minimum limit of ten per cent in } \\
\text { the capital of the BV to the number of shares without voting } \\
\text { rights held by the acting director. }\end{array}$ & 4.3 .8 \\
\hline 8. & $\begin{array}{l}\text { The concept 'ultimate beneficial owner' in the Wet ter voor- } \\
\text { koming van witwassen en financieren van terrorisme (Preven- } \\
\text { tion of Money Laundering and Financing of Terrorism Act) and } \\
\text { the Wet toezicht trustkantoren (Supervision of Trust Offices } \\
\text { Act) should (also) include the shareholder without voting rights } \\
\text { with such a capital interest that he holds at least } 25 \text { per cent of } \\
\text { the issued capital in the BV. After all, by being a shareholder he } \\
\text { has a more than substantial financial interest in the (target) } \\
\text { company. This is not altered by the fact that said shareholder } \\
\text { has no voting rights. }\end{array}$ & 4.3 .9 \\
\hline 9. & $\begin{array}{l}\text { Considering the background and purpose of Article } 43 \text { Faillis- } \\
\text { sementswet (Bankruptcy Act) and more particularly the eviden- } \\
\text { tiary presumption included in that Article, in situations as referred } \\
\text { to in Article 43, paragraph } 1 \text { sub (4) under (c) and sub (5) under } \\
\text { (c) and (d) Faillissementswet I argue in favour of regarding the } \\
\text { words 'at least half of the issued capital' also to include the } \\
\text { shareholder without voting rights with such a capital interest that } \\
\text { he holds at least half of the issued capital in the BV. }\end{array}$ & 4.3 .10 \\
\hline 10. & $\begin{array}{l}\text { The concept 'predominantly able' as referred to in Article } 1: 141 \text {, } \\
\text { paragraph } 4 \text { CC should be interpreted as a factual control } \\
\text { criterion. In the flex- } B V \text {, this criterion does not seem easily } \\
\text { applicable due to the introduction of the share without voting } \\
\text { rights. This gives rise to arbitrariness. If spouses have agreed } \\
\text { upon a regular set-off clause which includes profits from business } \\
\text { activities while one of the spouses owns shares without voting } \\
\text { rights in a BV, retained earnings in proportion to the share } \\
\text { ownership should be taken into account in the settlement. }\end{array}$ & 4.3 .11 \\
\hline
\end{tabular}




\begin{tabular}{|c|c|c|}
\hline & Recommendations for amendment or interpretation of the law & Section \\
\hline 11. & $\begin{array}{l}\text { Article V.2, paragraph } 1 \text { first sentence of the Overgangsrecht } \\
\text { should read that the management board of the company } \\
\text { complies with the provisions of Article } 2: 194 \text {, paragraph } 1 \text { last } \\
\text { sentence CC in accordance with the obligation of the latter } \\
\text { Article that the management board of the company maintains } \\
\text { the shareholders' register. }\end{array}$ & 4.4 .6 .3 \\
\hline 12. & $\begin{array}{l}\text { Article V.2, paragraph } 1 \text { last sentence of the Overgangsrecht } \\
\text { should stipulate that registration by order of the court or the } \\
\text { provisional relief court of the holder of depositary receipts in } \\
\text { the shareholders' register as having the right to attend general } \\
\text { meetings gives rise to depositary receipt holder's rights. }\end{array}$ & 4.4 .6 .3 \\
\hline 13. & $\begin{array}{l}\text { Article V.2, paragraph } 6 \text { Overgangsrecht should read that "at } \\
\text { the next amendment of the articles of association, the company } \\
\text { [must] attach the right to attend general meetings to these } \\
\text { depositary receipts pursuant to Article } 227 \text {, paragraph } 2 \text { ". } \\
\text { According to Article } 2: 227 \text {, paragraph } 2 \text { CC the right to attend } \\
\text { general meetings is after all attached to depositary receipts } \\
\text { rather than to the holders of depositary receipts. }\end{array}$ & 4.4 .6 .3 \\
\hline 14. & $\begin{array}{l}\text { After the first sentence of Article V.2, paragraph } 1 \text { Over- } \\
\text { gangsrecht the following should be added after the full stop: "If } \\
\text { there are holders of depositary receipts of shares, which have } \\
\text { been issued with the cooperation of the company prior to the } \\
\text { law taking effect and the company and its bodies have recog- } \\
\text { nized such or have acted accordingly, the management board of } \\
\text { the company immediately after the law coming into effect } \\
\text { complies with Article 194, paragraph 1, last sentence." }\end{array}$ & 4.4 .6 .3 \\
\hline 15. & $\begin{array}{l}\text { After the first sentence of Article V.2, paragraph } 1 \text { Overgangs- } \\
\text { recht the following should be added after the full stop as well: "If } \\
\text { there are holders of depositary receipts of shares to which the } \\
\text { right to attend general meetings has been attached, which } \\
\text { depositary receipts were issued after the law came into force, the } \\
\text { management of the company after the issue of such depositary } \\
\text { receipts complies with Article 194, paragraph 1, last sentence." }\end{array}$ & 4.4 .6 .3 \\
\hline 16. & $\begin{array}{l}\text { Holders of participation certificates with the right to attend general } \\
\text { meetings should be registered in the shareholders' register. }\end{array}$ & 4.11 \\
\hline 17. & $\begin{array}{l}\text { For the protection of the provider of capital with the right to } \\
\text { attend general meetings but without the right to vote the } \\
\text { legislator should add the words 'in advance' to Article } 2: 238 \text {, } \\
\text { paragraph } 1 \mathrm{CC} \text {. }\end{array}$ & 6.2 .3 .8 \\
\hline
\end{tabular}




\begin{tabular}{|c|c|c|}
\hline & Recommendations for amendment or interpretation of the law & Section \\
\hline 18. & $\begin{array}{l}\text { Due to a lack of added value the words 'assessment of the value } \\
\text { of the shares' in Article 2:181, paragraph } 4 \text { CC may be } \\
\text { scrapped. }\end{array}$ & 6.2.3.13 \\
\hline 19. & $\begin{array}{l}\text { As a simple solution to the conversion of a BV to an NV I put } \\
\text { forward the rule that shares without voting rights in a BV } \\
\text { become shares with voting rights in the NV. }\end{array}$ & 6.2.3.13 \\
\hline 20. & $\begin{array}{l}\text { An even simpler solution for the conversion of a BV to an NV } \\
\text { is in my opinion the introduction of shares without voting rights } \\
\text { in the NV. }\end{array}$ & 6.2.3.13 \\
\hline 21. & $\begin{array}{l}\text { If in a triangular merger or a triangular division the group } \\
\text { company is a BV, shares without voting rights in the group } \\
\text { company-BV can also be acquired by the shareholders without } \\
\text { voting rights of the company ceasing to exist. In such cases the } \\
\text { law should provide for an exemption from compensation. }\end{array}$ & $\begin{array}{l}6.2 .3 .15 \\
\text { and } \\
6.2 .3 .16\end{array}$ \\
\hline 22. & $\begin{array}{l}\text { Holders of depositary receipts with the right to attend general } \\
\text { meetings should be entitled to the action for expulsion and the } \\
\text { action for resignation in the statutory dispute resolution. I also } \\
\text { argue in favour of levelling up the capital requirement in Article } \\
2: 336 \text { CC to the capital requirement for submitting a request for } \\
\text { inquiry based on Article } 2: 346 \text {, paragraph } 1 \text { sub (b) CC, to wit } \\
\text { at least one tenth of the issued capital. }\end{array}$ & 8.9 \\
\hline
\end{tabular}

\subsection{Expectations and afterword}

I agree with the Commissie Vennootschapsrecht (Company Law Committee) that the lack of the right to vote on the share without voting rights may lead to instability in the balance of power in the general meeting. All sorts of issues can be decided in the general meeting which were not anticipated at the establishment of the BV. This could lead to greater pressure on the judiciary because the shareholder without voting rights feels cornered. Such a shareholder might lean towards nullification of resolutions of the general meeting or the management board based on a conflict with the principle of corporate reasonableness and fairness pursuant to Article 2:8 CC or towards requesting an inquiry or demanding a resignation. ${ }^{5}$ The introduction of the flex- $B V$ has increased the freedom in setting up a $\mathrm{BV}$ and its articles of association. More freedom creates more responsibility for everyone involved with the $\mathrm{BV}$, and

5 Advice of the Commissie vennootschapsrecht on the legislative proposal concerning simplification and greater flexibility of private companies with limited liability (BV) of 23 November 2006, p. 12, to be found here: http://www.rijksoverheid.nl/onderwerpen/flexibele-BV. In more general terms also Timmerman 2004, p. 30 and Stokkermans 2008 (2), p. 118. 
more particularly towards the provider of capital without voting rights. Thinking about the shareholder without voting rights, the legal instruments I have outlined enable him to assert himself and to influence the internal relationships. His opportunities will increase even further if my recommendations for the improvement of the law are adopted by the legislator.

In conclusion, I would like to make a general remark. The short title of the law is: 'Act on simplification and greater flexibility of private companies with limited liability (BV)'. I think it is quite obvious that the new Private Company law will be more flexible, but - if all the possibilities that the law has to offer will be used - it will definitely not be simpler. 



\section{BIJLAGE 1: AAN GEWONE AANDELEN VERBONDEN RECHTEN}

Bij de opsomming van de rechten van aandeelhouders kan een driedeling worden gemaakt tussen rechten die aan een individuele aandeelhouder toekomen, rechten die aan een groep van aandeelhouders toekomen en rechten die aan de algemene vergadering toekomen. Ik beperk mij bij deze opsomming tot de BV en hoofdlijnen:

\begin{tabular}{|c|c|c|}
\hline & Rechten van een individuele aandeelhouder & BW Boek 2 art. \\
\hline 1. & $\begin{array}{l}\text { Het instellen van een vordering tot vernietiging van } \\
\text { besluiten van een orgaan van de vennootschap }\end{array}$ & 15 \\
\hline 2. & $\begin{array}{l}\text { Het recht op het liquidatiesaldo na ontbinding en } \\
\text { vereffening van de vennootschap }\end{array}$ & $23 b$ \\
\hline 3. & $\begin{array}{l}\text { Het recht op inzage in de boeken en bescheiden en } \\
\text { andere gegevensdragers van de BV na haar ontbinding }\end{array}$ & $24 \operatorname{lid} 4$ \\
\hline 4. & Het recht op gelijke behandeling & 201 lid 2 \\
\hline 5. & $\begin{array}{l}\text { Het uitoefenen van het voorkeursrecht op uit te geven } \\
\text { aandelen, tenzij sprake is van een stemrechtloos } \\
\text { aandeel }\end{array}$ & $206 \mathrm{a}$ \\
\hline 6. & Het recht op winst en uitkeringen & 216 \\
\hline 7. & $\begin{array}{l}\text { Het verkrijgen van inlichtingen tijdens de algemene } \\
\text { vergadering }\end{array}$ & 217 lid 2 \\
\hline 8. & $\begin{array}{l}\text { Het bijeenroepen van de algemene vergadering na } \\
\text { machtiging daartoe door de voorzieningenrechter } \\
\text { ingeval het bestuur daartoe in gebreke blijft }\end{array}$ & 222 \\
\hline 9. & $\begin{array}{l}\text { Het bijwonen van de algemene vergadering en } \\
\text { daarin het woord voeren (het vergaderrecht) }\end{array}$ & 227 \\
\hline 10. & $\begin{array}{l}\text { Het uitoefenen van stemrecht tijdens de algemene } \\
\text { vergadering }\end{array}$ & 227 jo. 228 \\
\hline 11. & $\begin{array}{l}\text { Het instellen van de vordering tot overdracht van de } \\
\text { aandelen van zijn mede-aandeelhouder }\end{array}$ & 343 \\
\hline
\end{tabular}


Bijlage 1: Aan gewone aandelen verbonden rechten

\begin{tabular}{|l|l|l|}
\hline & Rechten van een individuele aandeelhouder & BW Boek 2 art. \\
\hline 12. & $\begin{array}{l}\text { Het instellen van een vordering tot nakoming jegens } \\
\text { de vennootschap van de plicht een accountant op- } \\
\text { dracht te verlenen tot onderzoek van de jaarrekening }\end{array}$ & 393 lid 8 jo. lid 1 \\
\hline 13. & $\begin{array}{l}\text { Het recht op inzage in of een afschrift van een } \\
\text { beperkte balans en toelichting }\end{array}$ & 396 lid 8 jo. lid 9 \\
\hline 14. & $\begin{array}{l}\text { Het indienen van een verzoek tot een voorlopig } \\
\text { getuigenverhoor }\end{array}$ & - \\
\hline
\end{tabular}

\begin{tabular}{|l|l|l|}
\hline & $\begin{array}{l}\text { Rechten die aan een of meer aandeelhouders } \\
\text { toekomen }\end{array}$ & BW Boek 2 art. \\
\hline 1. & $\begin{array}{l}\text { Het bijeenroepen van een buitengewone algemene } \\
\text { vergadering na machtiging daartoe door de voor- } \\
\text { zieningenrechter door een of meer aandeelhouders } \\
\text { die gezamenlijk ten minste een honderdste gedeelte } \\
\text { van het geplaatste kapitaal vertegenwoordigen }\end{array}$ & 220 \\
\hline 2. & $\begin{array}{l}\text { Het recht schriftelijk de behandeling van een be- } \\
\text { paald onderwerp in de algemene vergadering te } \\
\text { verzoeken door een of meer aandeelhouders die } \\
\text { gezamenlijk ten minste een honderdste van het } \\
\text { geplaatste kapitaal vertegenwoordigen }\end{array}$ & $224 \mathrm{a}$ \\
\hline 3. & $\begin{array}{l}\text { Het instellen van de vordering tot overdracht van de } \\
\text { aandelen jegens een mede-aandeelhouder door een } \\
\text { of meer aandeelhouders die gezamenlijk ten minste } \\
\text { een derde van het geplaatste kapitaal vertegen- } \\
\text { woordigen indien die mede-aandeelhouder het } \\
\text { belang van de vennootschap schaadt }\end{array}$ & 336 \\
\hline 4. & $\begin{array}{l}\text { Het indienen van een enqueteverzoek ex art. 2:345 } \\
\text { BW bij een BV met een geplaatst kapitaal van } \\
\text { maximaal } € 22,5 \text { miljoen door een of meer aandeel- } \\
\text { houders die alleen of gezamenlijk ten minste een } \\
\text { tiende gedeelte van het geplaatste kapitaal vertegen- } \\
\text { woordigen of rechthebbenden zijn op een bedrag van } \\
\text { aandelen daarvan tot een nominale waarde van } \\
€ 225.000 \text { of zoveel minder als de statuten bepalen }\end{array}$ & 346 lid 1 sub b \\
\hline
\end{tabular}

1 HR 20 oktober 1995, NJ 1996, 120 (Perrier/Marceau) en Hof 's-Gravenhage 22 mei 2008, LJN BD2349, JOR 2008, 223 (Verhoeff c.s./KPNQwest).

2 Uitgaande van de Wet van 18 juni 2012 tot wijziging van boek 2 van het Burgerlijk Wetboek in verband met de aanpassing van het recht van enquête (Kamerstukken 32 887, Stb. 2012, 274). Deze wet zal inwerking treden op 1 januari 2013 (Stb. 2012, 305). Bij een BV met een geplaatst kapitaal van meer dan $€ 22,5$ miljoen geldt op grond van art. 2:346 lid 1 sub c (nieuw) BW een percentage van 1 procent. 
Bijlage 1: Aan gewone aandelen verbonden rechten

\begin{tabular}{|l|l|l|}
\hline & Rechten van de algemene vergadering & \\
\hline 1. & $\begin{array}{l}\text { Het besluiten tot omzetting in een andere } \\
\text { rechtsvorm }\end{array}$ & 18 \\
\hline 2. & Het besluiten tot ontbinden van de vennootschap & 19 lid 1 sub a \\
\hline 3. & Het besluiten tot een emissie van aandelen & 206 \\
\hline 4. & Het besluiten tot kapitaalvermindering & 208 \\
\hline 5. & Het jaarlijks vaststellen van de jaarrekening & 210 lid 3 \\
\hline 6. & Het bestemmen van de winst & 216 \\
\hline 7. & Het besluiten tot het wijzigen van de statuten & 231 \\
\hline 8. & Het benoemen van bestuurders & 242 \\
\hline 9. & Het schorsen en ontslaan van bestuurders & 244 \\
\hline 10. & Het vaststellen van de bezoldiging van bestuurders & 245 \\
\hline 11. & Het benoemen van commissarissen & 252 \\
\hline 12. & Het schorsen en ontslaan van commissarissen & 254 \\
\hline 13. & $\begin{array}{l}\text { Het vaststellen van de bezoldiging van } \\
\text { commissarissen }\end{array}$ & 255 \\
\hline 14. & Het besluiten tot fusie of splitsing & $\begin{array}{l}317 \text { en } 334 \mathrm{~m} \text { lid } 1 \\
\text { en } 3\end{array}$ \\
\hline
\end{tabular}

3 Voor de structuurvennootschap in de zin van art. 2:263 e.v. BW wijkt een en ander echter af. In een structuurvennootschap worden bijvoorbeeld de bestuurders op grond van het bepaalde in art. 2:272 door de raad van commissarissen benoemd en zijn de besluiten van het bestuur als genoemd in art. 2:274 BW aan de goedkeuring van de raad van commissarissen onderworpen. 



\title{
BIJLAGE 2: WETTEKSTEN BOEK 2 OUD BW
}

\author{
Art. 2:175 lid 1 (oud) BW
}

De besloten vennootschap met beperkte aansprakelijkheid is een rechtspersoon met een in aandelen verdeeld maatschappelijk kapitaal. Aandeelbewijzen worden niet uitgegeven; de aandelen zijn niet vrij overdraagbaar. Een aandeelhouder is niet persoonlijk aansprakelijk voor hetgeen in naam van de vennootschap wordt verricht en is niet gehouden boven het bedrag dat op zijn aandelen behoort te worden gestort in de verliezen van de vennootschap bij te dragen.

\section{Art. 2:195 (oud) BW}

1. Een aandeelhouder kan, voor zover de statuten deze bevoegdheid niet beperken of uitsluiten, een of meer van zijn aandelen vrijelijk overdragen aan zijn echtgenoot of geregistreerde partner, aan zijn bloed- en aanverwanten, in de rechte lijn onbeperkt en in de zijlijn in de tweede graad, aan een medeaandeelhouder en aan de vennootschap. De kring van personen aan wie de aandeelhouder een of meer van zijn aandelen vrijelijk kan overdragen, kan bij de statuten worden uitgebreid tot zijn bloed- en aanverwanten in de zijlijn, of sommigen van hen, in de derde en vierde graad.

2. Voor iedere andere overdracht dan die welke ingevolge het vorige lid vrijelijk kan geschieden, dienen de statuten een blokkeringsregeling te bevatten.

3. De overdracht krachtens legaat geldt voor de toepassing van de blokkeringsregeling als een overdracht door de erflater.

4. Deze blokkeringsregeling dient zodanig te zijn dat de aandeelhouder voor de overdracht, wil zij geldig zijn, de goedkeuring behoeft van een bij de statuten daartoe aangewezen orgaan der vennootschap. De overdracht moet plaatsvinden binnen drie maanden nadat de goedkeuring is verleend. De goedkeuring wordt geacht te zijn verleend indien het orgaan der vennootschap dat met de beslissing is belast niet gelijktijdig met de weigering van de goedkeuring aan de verzoeker opgave doet van een of meer gegadigden die bereid zijn al de aandelen waarop het verzoek om goedkeuring betrekking heeft tegen contante betaling te kopen. 
5. Het vierde lid vindt geen toepassing, voor zover de statuten een blokkeringsregeling bevatten, volgens welke de aandeelhouder die een of meer aandelen wil vervreemden, deze eerst moet aanbieden aan zijn mede-aandeelhouders. Deze regeling kan voorts inhouden dat, zo de mede-aandeelhouders het aanbod niet aanvaarden, het aanbod moet geschieden aan andere gegadigden, angewezen door een bij de statuten daarmede belast orgaan der vennootschap. De aanbieder blijft bevoegd zijn aanbod in te trekken, mits dit geschiedt binnen een maand nadat hem bekend is aan welke gegadigden hij al de aandelen waarop het aanbod betrekking heeft kan verkopen en tegen welke prijs. Indien vaststaat dat niet al de aandelen waarop het aanbod betrekking heeft tegen contante betaling worden gekocht, zal de aanbieder de aandelen binnen drie maanden na die vaststelling vrijelijk mogen overdragen.

6. De blokkeringsregeling dient zodanig te zijn dat de aandeelhouder, indien hij dit verlangt, van degenen die als gegadigden in de zin van het vierde lid worden opgegeven of aan wie ingevolge de blokkeringsregeling als bedoeld in het vijfde lid moet worden aangeboden een prijs ontvangt, gelijk aan de waarde van zijn aandeel of aandelen, vastgesteld door een of meer onafhankelijke deskundigen.

7. De vennootschap zelf kan slechts met de instemming van de aandeelhouder ingevolge het vierde of het vijfde lid gegadigde zijn.

8. Beperking van de overdraagbaarheid van de aandelen kan niet zodanig geschieden, dat die overdracht onmogelijk of uiterst bezwaarlijk wordt gemaakt. Hetzelfde geldt voor toedeling van aandelen uit een gemeenschap.

9. Bepalingen in de statuten omtrent overdraagbaarheid van aandelen gelden niet, indien de houder krachtens de wet tot overdracht van zijn aandeel aan een eerdere houder verplicht is.

Art. 2:195a (oud) BW

1. De statuten kunnen bepalen dat in gevallen, in de statuten omschreven, de aandeelhouder gehouden is zijn aandelen aan te bieden en over te dragen. De statuten kunnen daarbij bepalen dat zolang de aandeelhouder zijn verplichtingen tot aanbieding of overdracht niet nakomt, zijn stemrecht, zijn recht op deelname aan de algemene vergadering en zijn recht op uitkeringen is opgeschort.

2. De statuten kunnen bepalen dat indien een aandeelhouder niet binnen een bepaalde redelijke termijn zijn statutaire verplichtingen tot aanbieding en overdracht van zijn aandelen is nagekomen, de vennootschap onherroepelijk gevolmachtigd is de aandelen aan te bieden en over te dragen. Wanneer er geen gegadigden zijn aan wie de aandeelhouder al zijn aandelen zal kunnen overdragen volgens een regeling in de statuten, ontbreekt de volmacht en is de aandeelhouder onherroepelijk van het bepaalde in lid 1 ontheven.

3. De regeling dient zodanig te zijn dat de aandeelhouder die dit verlangt een prijs ontvangt, gelijk aan de waarde van zijn aandeel of aandelen, vastgesteld door een of meer onafhankelijke deskundigen. 


\section{Art. 2:195b (oud) BW}

1. De statuten kunnen bepalen dat van de aandeelhouder die niet of niet langer aan in de statuten gestelde eisen voldoet het stemrecht, het recht op deelname aan de algemene vergadering en het recht op uitkeringen is opgeschort.

2. Indien de aandeelhouder een of meer van de in lid 1 genoemde rechten niet kan uitoefenen en de aandeelhouder niet gehouden is zijn aandelen aan te bieden en over te dragen, is hij onherroepelijk van de in de statuten gestelde eisen ontheven wanneer de vennootschap niet binnen drie maanden na een verzoek daartoe van de aandeelhouder gegadigden heeft aangewezen aan wie hij al zijn aandelen zal kunnen overdragen volgens een regeling in de statuten.

3. De regeling dient zodanig te zijn dat de aandeelhouder die dit verlangt een prijs ontvangt, gelijk aan de waarde van zijn aandeel of aandelen, vastgesteld door een of meer onafhankelijke deskundigen. 

BIJLAGE 3: VOOR- EN NADELEN VAN HET STEMRECHTLOZE AANDEEL EN AANBEVELINGEN

\begin{tabular}{|l|l|}
\hline Voordelen & Nadelen \\
\hline $\begin{array}{l}\text { Het is een internationaal bekende } \\
\text { rechtsfiguur. }\end{array}$ & $\begin{array}{l}\text { Niet alle aandelen in de BV kunnen } \\
\text { stemrechtloze aandelen zijn (zie } \\
\text { art. 2:175 lid 1 BW). Er moet ten } \\
\text { minste een aandeel met stemrecht uit- } \\
\text { staan bij een ander dan de vennoot- } \\
\text { schap of een dochtervennootschap. Het } \\
\text { aandeel met stemrecht kan een } \\
\text { winstrechtloos aandeel zijn. Dit } \\
\text { aandeel kan bijvoorbeeld worden ge- } \\
\text { plaatst bij de bestuurder van de ven- } \\
\text { nootschap of een administratiekantoor. }\end{array}$ \\
\hline $\begin{array}{l}\text { De introductie van een stemrechtloos } \\
\text { aandeel binnen een vennootschap is } \\
\text { eenvoudig en kostenbesparend. Bij } \\
\text { oprichting van een BV kan worden } \\
\text { volstaan met de uitgifte van stemrecht- } \\
\text { loze aandelen, die in de statuten zijn } \\
\text { aangemerkt als aandelen van een } \\
\text { bepaalde soort of aanduiding. } \\
\text { sprake van is een (rechtstreekse) lidmaat- } \\
\text { schapsverhouding met de vennootschap } \\
\text { en geen sprake van een - meer } \\
\text { ingewikkelde - driehoeksverhouding, } \\
\text { zoals bij certificering het geval is. }\end{array}$ & $\begin{array}{l}\text { Het feit dat er geen stemrecht aan het } \\
\text { aandeel verbonden is, is 'definitief'. } \\
\text { Het stemrecht herleeft niet indien de } \\
\text { belangen van de stemrechtloze } \\
\text { aandeelhouder worden geschaad. }\end{array}$ \\
\hline
\end{tabular}

1 Met die beperking dat er ten minste een aandeel met stemrecht moet uitstaan bij een ander dan de vennootschap of een dochtervennootschap (zie het eerste nadeel). 
Bijlage 3: Voor-en nadelen van het stemrechtloze aandeel en aanbevelingen

\begin{tabular}{|c|c|}
\hline Voordelen & Nadelen \\
\hline $\begin{array}{l}\text { Aan het aandeel is geen stemrecht } \\
\text { verbonden. Bij certificering is sprake } \\
\text { van verschuiving van de zeggenschap. } \\
\text { Via het bestuur van de STAK heeft de } \\
\text { certificaathouder in voorkomend geval } \\
\text { wel enige vorm van zeggenschap. }\end{array}$ & $\begin{array}{l}\text { Hoewel aan het aandeel geen stem- } \\
\text { recht is verbonden, is er wel verga- } \\
\text { derrecht aan verbonden. Het } \\
\text { vergaderrecht kan niet worden uitge- } \\
\text { sloten of ontnomen. Dat kan besluit- } \\
\text { vorming moeilijker maken. Houders } \\
\text { van stemrechtloze aandelen moeten } \\
\text { bijvoorbeeld worden opgeroepen voor } \\
\text { de algemene vergadering. Daarnaast } \\
\text { biedt het vergaderrecht toegang tot de } \\
\text { algemene vergadering, zodat het } \\
\text { besluitvormingsproces tijdens de } \\
\text { algemene vergadering kan worden } \\
\text { beïnvloed. Met besluitvorming buiten } \\
\text { vergadering moeten zij instemmen. }\end{array}$ \\
\hline $\begin{array}{l}\text { Het stemrechtloze aandeel is vooral } \\
\text { toepasbaar in situaties waarin slechts } \\
\text { financiële deelname in de BV is vereist } \\
\text { zonder de stemverhoudingen aan te } \\
\text { tasten, bijvoorbeeld in familieven- } \\
\text { nootschappen, bij bedrijfsopvolging, } \\
\text { bij werknemersparticipaties, bij deel- } \\
\text { name door banken, private equity en } \\
\text { andere financieringsmaatschappijen, } \\
\text { bij internationale (houdster)structuren } \\
\text { of bij joint ventures. Er is dan geen } \\
\text { sprake van verwatering van stemrecht. }\end{array}$ & $\begin{array}{l}\text { De (beschermings)regels van het } \\
\text { stemrechtloze aandeel zijn van dwin- } \\
\text { gend recht. Dat maakt deze rechtsfi- } \\
\text { guur minder flexibel dan certificaten } \\
\text { van aandelen. }\end{array}$ \\
\hline $\begin{array}{l}\text { De stemrechtloze aandeelhouder heeft } \\
\text { een vordering tot uittreding ex art. } \\
\text { 2:343 BW en een vordering tot uitsto- } \\
\text { ting ex art. } 2: 336 \mathrm{BW} \text {. De certificaat- } \\
\text { houder ontbeert deze vorderingen. }\end{array}$ & \\
\hline
\end{tabular}




\section{Aanbevelingen voor de praktijk}

1. Indien gewenst, het versterken van de positie van de stemrechtloze aandeelhouder (zie paragraaf 8.11).

2. Bij gebruik van het stemrechtloze aandeel zal er rekening mee moeten worden gehouden dat (eerder) sprake kan zijn van een aanmerkelijk belang. ${ }^{2}$

3. Indien in een $\mathrm{BV}$ verschillende soorten stemrechtloze aandelen ${ }^{3}$ bestaan, verdient het aanbeveling die soorten van een aparte aanduiding te voorzien (zie paragraaf 4.2.6).

2 HR 16 december 2011, LJN BU8233, r.o. 3.3.4: "Dit een en ander beziende is de Hoge Raad van oordeel dat sprake is van verschillende soorten aandelen niet alleen indien sprake is van een bijzondere gerechtigdheid tot een vermogensbestanddeel of een reserve van de vennootschap (zoals het geval is bij letteraandelen met een eigen dividendreserve), maar ook indien tussen verschillende soorten aandelen uitsluitend een verschil bestaat met betrekking tot de beshuitvorming omtrent uitkeringen van winst of vermogen van de vennootschap." Zie ook Kamerstukken I 2011/12, 31058 en 32 426, nr. C. p. 2-4; De Kort 2012, p. 12 e.v. en Mol-Verver 2012, p. 6 e.v.

3 Zie paragraaf 4.2 .5 

VII

BIJLAGE 4: VOOR- EN NADELEN VAN HET CERTIFICAAT VAN AANDEEL EN AANBEVELINGEN

\begin{tabular}{|c|c|}
\hline Voordelen & Nadelen \\
\hline $\begin{array}{l}\text { In een BV kan sprake zijn van certifi- } \\
\text { caten met en zonder vergaderrecht. }\end{array}$ & $\begin{array}{l}\text { In het buitenland is het een relatief } \\
\text { onbekende rechtsfiguur. }\end{array}$ \\
\hline $\begin{array}{l}\text { Aan certificaten kan het vergaderrecht } \\
\text { worden onthouden. Bij bijvoorbeeld } \\
\text { werknemersparticipatie, of een } \\
\text { (andere) grote groep van participanten } \\
\text { in de BV kan dat een voordeel zijn om } \\
\text { te voorkomen dat het besluitvor- } \\
\text { mingsproces van de aandeelhouders } \\
\text { bemoeilijkt wordt. Houders van certi- } \\
\text { ficaten van aandelen met vergaderrecht } \\
\text { moeten bijvoorbeeld worden opgeroe- } \\
\text { pen voor de algemene vergadering. } \\
\text { Daarnaast biedt het vergaderrecht } \\
\text { toegang tot de algemene vergadering, } \\
\text { zodat het besluitvormingsproces } \\
\text { tijdens de algemene vergadering kan } \\
\text { worden beïnvloed. Met besluitvorming } \\
\text { buiten vergadering moeten zij } \\
\text { instemmen. }\end{array}$ & $\begin{array}{l}\text { De kosten van het opzetten en in stand } \\
\text { houden van de voor certificering } \\
\text { benodigde structuur zijn hoger dan de } \\
\text { uitgifte van stemrechtloze aandelen. Er } \\
\text { zal een administratiekantoor moeten } \\
\text { worden opgericht en administratie- } \\
\text { voorwaarden moeten worden } \\
\text { opgesteld. Ook moeten de aandelen } \\
\text { notarieel aan het administratiekantoor } \\
\text { worden overgedragen, tenzij bij } \\
\text { oprichting van de BV de aandelen } \\
\text { reeds bij het administratiekantoor zijn } \\
\text { geplaatst. Daarnaast is sprake van } \\
\text { jaarlijkse administratie- en accoun- } \\
\text { tantskosten. }\end{array}$ \\
\hline $\begin{array}{l}\text { Aan certificaten kan het vergaderrecht } \\
\text { worden ontnomen indien aan het be- } \\
\text { paalde van art. 2:227 lid } 4 \text { BW is } \\
\text { voldaan. Dat biedt meer flexibiliteit } \\
\text { dan het stemrechtloze aandeel, waar- } \\
\text { aan het vergaderrecht per definitie ge- } \\
\text { koppeld is en blijft. }\end{array}$ & $\begin{array}{l}\text { Indien vergaderrecht aan het certificaat } \\
\text { is verbonden, kan dat besluitvorming } \\
\text { bemoeilijken. }\end{array}$ \\
\hline
\end{tabular}

1 Kodde 2005, p. 583; Ten Berg 2007, p. 343, voetnoot 32; Portier 2008, p. 234 en Van Engelen 2011, p. 122. 
Bijlage 4: Voor- en nadelen van het certificaat van aandeel en aanbevelingen

\begin{tabular}{|l|l|}
\hline Voordelen & Nadelen \\
\hline $\begin{array}{l}\text { Het certificaat van aandeel kan roy- } \\
\text { eerbaar worden gemaakt, onder de } \\
\text { voorwaarden zoals in de administra- } \\
\text { tievoorwaarden genoemd. Het stem- } \\
\text { recht op het certificaat kan aldus } \\
\text { 'herleven'. Onder omstandigheden kan } \\
\text { dat gewenst zijn, bijvoorbeeld in het } \\
\text { geval dat de kapitaalverschaffer een } \\
\text { grotere invloed wenst te hebben. }\end{array}$ & $\begin{array}{l}\text { Vanuit het oogpunt van de kapitaal- } \\
\text { verschaffer kan een nadeel zijn de } \\
\text { bepaling van niet-royeerbaarheid van } \\
\text { de certificaten of de bepaling in de } \\
\text { administratievoorwaarden dat het ad- } \\
\text { ministratiekantoor een verzoek tot de- } \\
\text { certificering altijd mag afwijzen. }\end{array}$ \\
\hline $\begin{array}{l}\text { In de administratievoorwaarden kun- } \\
\text { nen aanvullende bepalingen worden } \\
\text { opgenomen over de overdraagbaarheid } \\
\text { (beperking of uitsluiting) en verplich- } \\
\text { ting tot aanbieding van de certificaten. }\end{array}$ & $\begin{array}{l}\text { Aan de rechtsfiguur van certificering is } \\
\text { altijd stemrecht verbonden. Het stem- } \\
\text { recht berust bij het administratiekantoor } \\
\text { als aandeelhouder. De certificaathouder } \\
\text { heeft geen stemrecht. Er vindt als ge- } \\
\text { volg van de certificering een verschui- } \\
\text { ving van het stemrecht plaats. }\end{array}$ \\
\hline $\begin{array}{l}\text { Anders dan bij stemrechtloze aandelen, } \\
\text { kunnen bij certificering alle aandelen } \\
\text { (met stem- én winstrecht) worden } \\
\text { gecertificeerd. De beperking van } \\
\text { art. 2:175 BW geldt dan niet. }\end{array}$ & \\
\hline $\begin{array}{l}\text { Aan de certificaathouder kan indirecte } \\
\text { zeggenschap worden gegeven. Afhan- } \\
\text { kelijk van de statuten van het adminis- } \\
\text { tratiekantoor en de inhoud van de } \\
\text { administratievoorwaarden zal het } \\
\text { bestuur van het administratiekantoor in } \\
\text { meer of in mindere mate met het belang } \\
\text { van de certificaathouder rekening moe- } \\
\text { ten houden. Ook kan worden bepaald } \\
\text { dat het bestuur van het administratie- } \\
\text { kantoor voor bepaalde besluiten voor- } \\
\text { afgaande toestemming nodig heeft van } \\
\text { de vergadering van certificaathouders. }\end{array}$ & \\
\hline
\end{tabular}

2 Zie Van den Ingh 2008, p. 10, met betrekking tot de vraag of een dergelijk beding naar maatstaven van redelijkheid en billijkheid onaanvaardbaar is. In Hof Amsterdam 26 januari 1995, KG 1995, 192 (Kluft Distrifood) is een vordering tot decertificering toegewezen. In dat arrest waren alle certificaten in één hand en kwam daardoor de ratio van certificering te ontvallen. Zie over dit arrest De Bontridder 1995, p. 44 e.v. 
Bijlage 4: Voor-en nadelen van het certificaat van aandeel en aanbevelingen

\begin{tabular}{|l|l|}
\hline Voordelen & Nadelen \\
\hline Ten opzichte van het stemrechtloze & \\
aandeel biedt certificering vanwege de & \\
driehoeksverhouding meer mogelijk- & \\
heden tot flexibiliteit in en inrichting & \\
van de verhoudingen. & \\
\hline Certificering kan de voorkeur boven & \\
het stemrechtloze aandeel hebben. In & \\
de statuten van het administratiekan- & \\
toor kan een regeling worden opgeno- & \\
men over een toekomstig bestuurder & \\
indien de huidige bestuurder defun- & \\
geert. Bij bedrijfsopvolging kan dat & \\
relevant zijn. Vader wil zijn onderne- & \\
ming aan zijn kinderen overdragen, & \\
maar hij wenst niet dat de kinderen & \\
zeggenschap in de onderneming krij- & \\
gen, omdat zij als ondernemer niet & \\
geschikt zijn hem op te volgen. In de & \\
statuten van het administratiekantoor & \\
kan dan op voorhand een extern be- & \\
stuurder worden benoemd in het geval & \\
vader defungeert. & \\
\hline De houder van een certificaat zonder & \\
vergaderrecht behoort naar mijn me- & \\
ning niet tot de kring van betrokkenen & \\
in de zin van art. 2:8 BW en kan geen & \\
vordering tot vernietiging ex art. 2:15 & \\
lid 1 onder b BW instellen. Vanuit het & \\
oogpunt van de vennootschap staat hij & \\
verder van die vennootschap af. & \\
\hline
\end{tabular}


Bijlage 4: Voor- en nadelen van het certificaat van aandeel en aanbevelingen

\begin{tabular}{|c|c|c|}
\hline & Aanbevelingen voor de praktijk & Paragraaf \\
\hline 1. & $\begin{array}{l}\text { Indien de bevoegdheid tot het toekennen en ontnemen } \\
\text { van vergaderrecht ex art. } 2: 227 \text { lid } 4 \mathrm{BW} \text { is toegekend } \\
\text { aan een orgaan van de vennootschap in de zin van art. } \\
2: 189 \text { a BW, kan dat orgaan zonder dat daartoe instem- } \\
\text { ming van de certificaathouder is vereist het vergader- } \\
\text { recht aan het certificaat ontnemen. Dit biedt de meeste } \\
\text { flexibiliteit vanuit het oogpunt van de vennootschap en } \\
\text { biedt tegelijkertijd de minste waarborgen voor de hou- } \\
\text { der van een certificaat met vergaderrecht. }\end{array}$ & 6.3.3.4 \\
\hline 2. & $\begin{array}{l}\text { Afhankelijk van het belang dat de certificaathouder } \\
\text { (via de STAK) in het kapitaal van de vennootschap } \\
\text { vertegenwoordigd, de aard van het te nemen besluit in } \\
\text { de algemene vergadering of door het bestuur van de } \\
\text { vennootschap, het kenbare belang van de vennootschap } \\
\text { en het kenbare belang van de betreffende certificaat- } \\
\text { houder, doen de vennootschap en haar organen er } \\
\text { verstandig aan de certificaathouder gedurende de } \\
\text { mogelijke discussie in het kader van het overgangsrecht } \\
\text { over de vraag of de certificaathouder wel of niet } \\
\text { vergaderrecht toekomt bij de besluitvorming, voor } \\
\text { zover rechtens vereist, te betrekken. }\end{array}$ & 4.4.6.3 \\
\hline
\end{tabular}


VIII

BIJLAGE 5: VOOR- EN NADELEN VAN HET PARTICIPATIEBEWIJS EN AANBEVELINGEN

\begin{tabular}{|c|c|}
\hline $\begin{array}{l}\text { Voordelen } \\
\text { (vanuit het gezichtspunt van de } \\
\text { vennootschap) }\end{array}$ & Nadelen \\
\hline $\begin{array}{l}\text { Het participatiebewijs is een zeer fle- } \\
\text { xibel instrument, vanwege de statutaire } \\
\text { basis en de contractuele grondslag. De } \\
\text { contractuele grondslag is uitgewerkt in } \\
\text { de participatievoorwaarden, waarvoor } \\
\text { de contractsvrijheid binnen de grenzen } \\
\text { van de vennootschappelijke redelijk- } \\
\text { heid en billijkheid geldt. Voor de BV } \\
\text { kan deze flexibiliteit een voordeel zijn. } \\
\text { Zo kan in de participatievoorwaarden } \\
\text { worden bepaald dat (slechts) een } \\
\text { voorwaardelijk recht op een deel van } \\
\text { de winst bestaat. Ook kan de over- } \\
\text { draagbaarheid van het participatiebe- } \\
\text { wijs worden beperkt of uitgesloten. }\end{array}$ & $\begin{array}{l}\text { De flexibiliteit van het participatiebe- } \\
\text { wijs (vanuit het gezichtpunt van de } \\
\text { houder van het participatiebewijs). } \\
\text { De rechten van de houder van het } \\
\text { participatiebewijs kunnen aanzienlijk } \\
\text { worden beperkt. }\end{array}$ \\
\hline \multirow[t]{2}{*}{$\begin{array}{l}\text { In de regel komt de houder van een } \\
\text { participatiebewijs geen stem-, verga- } \\
\text { der-, informatierecht of recht van } \\
\text { enquête toe. }\end{array}$} & $\begin{array}{l}\text { De houder van een participatiebewijs } \\
\text { behoort tot de kring van betrokkenen } \\
\text { in de zin van art. } 2: 8 \text { BW en kan aldus } \\
\text { een vordering tot vernietiging ex } \\
\text { art. } 2: 15 \text { lid } 1 \text { onder b BW instellen } \\
\text { (vanuit het gezichtpunt van de } \\
\text { vennootschap). }\end{array}$ \\
\hline & $\begin{array}{l}\text { De houder van een participatiebewijs } \\
\text { komt geen stem-, vergader-, informa- } \\
\text { tierecht of recht van enquête toe } \\
\text { (vanuit het gezichtpunt van de houder } \\
\text { van het participatiebewijs). }\end{array}$ \\
\hline
\end{tabular}


Bijlage 5: Voor-en nadelen van het participatiebewijs en aanbevelingen

\begin{tabular}{|l|l|}
\hline $\begin{array}{l}\text { Voordelen } \\
\text { (vanuit het gezichtspunt van de } \\
\text { vennootschap) }\end{array}$ & Nadelen \\
\hline & $\begin{array}{l}\text { De waarde van een participatiebewijs } \\
\text { zal in de regel niet gelijk opgaan met } \\
\text { de waarde van een (stemrechtloos) } \\
\text { aandeel in de BV. }\end{array}$ \\
\hline
\end{tabular}

Het is afhankelijk van de omstandigheden van het geval, meer in het bijzonder de inrichting van de participatievoorwaarden, wat de exacte voor- en nadelen (zullen) zijn.

\begin{tabular}{|l|l|l|}
\hline 1. & Aanbevelingen voor de praktijk & Paragraaf \\
\hline 1. & $\begin{array}{l}\text { Participatiebewijzen kunnen voor werknemers- } \\
\text { participaties worden gebruikt }{ }^{3}, \text { zeker in geval reeds } \\
\text { certificaten met vergaderrecht of stemrechtloze } \\
\text { aandelen bestaan en niet gewenst is dat aan werknemers } \\
\text { vergaderrecht toekomt. Met de invoering van het } \\
\text { stemrechtloze aandeel behoort de weergegeven discus- } \\
\text { sie met betrekking tot de toelaatbaarheid van } \\
\text { participatiebewijzen, die materieel kunnen worden } \\
\text { ingericht als een stemrechtloos aandeel, tot het } \\
\text { verleden. }\end{array}$ & \\
\hline 2. & $\begin{array}{l}\text { Ter vermijding van discussie is het naar mijn mening } \\
\text { aan te bevelen de rechten van houders van } \\
\text { participatiebewijzen statutair te verankeren. }\end{array}$ & 6.5 .3 .2 \\
\hline 3. & $\begin{array}{l}\text { Vanuit het oogpunt van de vennootschap verdient het } \\
\text { aanbeveling de bevoegdheid tot intrekking in de } \\
\text { participatievoorwaarden voor te behouden. }\end{array}$ & 6.5 .3 .8 \\
\hline
\end{tabular}

3 Uittien \& Alleman 2010, p. 308 en Van Engelen 2011, p. 122. Sanders \& Westbroek 2005, p. 100101 zijn kritisch over het gebruik van participatiebewijzen.

4 Ik ben van mening dat - ook vóór de invoering van het stemrechtloze aandeel - dit toelaatbaar is. 
IX

\section{LIJST VAN GERAADPLEEGDE EN AANGEHAALDE LITERATUUR}

\section{Albicher \& Van Mierlo 2005}

H.M.A. Albicher \& J.J.M. van Mierlo, 'Eerste tranche ambtelijk voorontwerp nieuw BV-recht: inventarisatie naar aanleiding van de consultatieronde', $T v O B$ 2005-4, p. $122-128$.

\section{Asser 1997}

W.D.H. Asser, 'Het partijbegrip en binding van uitspraken in vennootschappelijke procedures', in: P. van Schilfgaarde, S.C.J.J. Kortmann, H.J.M.N. Honée e.a. (red.), Rechtspleging in het ondernemingsrecht, Deventer: Kluwer, 1997, p. 57-74.

\section{Asser/Maeijer, Van Solinge \& Nieuwe Weme 2-II* 2009}

G. van Solinge \& M.P. Nieuwe Weme, Mr C. Asser's Handleiding tot de beoefening van het Nederlands burgerlijk recht, Rechtspersonenrecht, De naamloze en besloten vennootschap, deel 2-II* (voorheen deel 2-III), Deventer: Kluwer 2009 (verwezen wordt naar nr.).

Asser/Maeijer, Van Solinge \& Nieuwe Weme 2-IIA 2013

G. van Solinge \& M.P. Nieuwe Weme, Mr C. Asser's Handleiding tot de beoefening van het Nederlands burgerlijk recht, Rechtspersonenrecht, De naamloze en besloten vennootschap, deel 2-IIA NV en BV-Oprichting, vermogen en aandelen, Deventer: Kluwer 2013 (verwezen wordt naar nr.).

\section{Assink 2007}

B.F. Assink, Rechterlijke toetsing van bestuurlijk gedrag (diss. Rotterdam), Deventer: Kluwer 2007.

\section{Assink 2009}

B.F. Assink, 'Facetten van verantwoordelijkheid in hedendaags ondernemingsbestuur', in: Ondernemingsbestuur en risicobeheersing op de drempel van een nieuw decennium: een ondernemingsrechtelijke analyse (preadvies van de Vereeniging 'Handelsrecht' 2009), Deventer: Kluwer 2009, p. 5-200. 


\section{Assink 2010}

B.F. Assink, De Januskop van het ondernemingsrecht. Over faciliëring en regulering van ondernemerschap (oratie Rotterdam), Deventer: Kluwer 2010.

\section{Baert 1999}

P. Baert, 'Certificering van vennootschapseffecten: bij de Noorderburen over het muurtje kijken', TRV 1999, p. 127-151.

\section{Bakker 2011}

S.T.E. Bakker, 'Aandeelhouders: rekening houden met de vennootschap?', $V \& O$ 2011-2, p. 39-42.

\section{Barneveld 2009}

J. Barneveld, 'PCM \& private equity - Over de rol van het vennootschappelijk belang bij vermogensonttrekkingen', WPNR 2009, 6791, p. 230-238.

\section{Bartman 2002}

S.M. Bartman, 'Minderheidsaandeelhouders: tussen exit en zorgplicht', in: L. Timmerman e.a., Concernverhoudingen, Voordrachten en discussieverslag van het gelijknamige congres op vrijdag 9 en zaterdag 10 november 2001, Serie vanwege het Van der Heijden Instituut, deel 69, Deventer: Kluwer, 2002, p. 29-45.

\section{Bartman \& Dorresteijn 2009}

S.M. Bartman \& A.F.M. Dorresteijn, Van het concern, Deventer: Kluwer 2009.

\section{Bartman \& De Groot 2012}

S.M. Bartman \& C. de Groot, 'De aanwijzingsbevoegdheid van de algemene vergadering van aandeelhouders, een lastig leerstuk', in: P.J. van der Korst, R. Abma \& G.T.M.J. Raaijmakers (red.), Handboek onderneming en aandeelhouder, Deventer: Kluwer 2012, p. 247-274.

Ten Berg 2007

J.A.M. ten Berg, 'Aandelen in de bv-nieuwe stijl: stemrecht en stortingsplicht', Ondernemingsrecht 2007-9, p. 338-350.

\section{Ten Berg 2008 (1)}

J.A.M. ten Berg, 'De flexibele BV en de bescherming van haar crediteuren', JBN 2008-7/8, p. 7-9.

Ten Berg 2008 (2)

J.A.M. ten Berg, 'De kapitaalbescherming op de helling', $O \& F$ 2008-3, p. 88-108. 


\section{Ten Berg 2012}

J.A.M. ten Berg, '(Af)stemming in de Flex-BV', Ondernemingsrecht 2012-14, p. 614-622.

\section{De Beurs 2011}

S.F. de Beurs, 'Loyaliteitsdividend bij beursvennootschappen; gerechtvaardigd?', $O \& F$ 2011-2, p. 4-23.

\section{Bier 2003}

B. Bier, Uitkeringen aan aandeelhouders (diss. Rotterdam), Deventer: Kluwer 2003.

\section{Bier 2008 (1)}

B. Bier, 'Kapitaal en kapitaalbescherming', in: Het nieuwe BV-recht voor de praktijk (preadvies KNB 2008), Den Haag: Sdu Uitgevers 2008, p. 169-219.

\section{Bier 2008 (2)}

B. Bier, 'Loyaal aan soorten aandelen', TOP 2008-2, p. 62-66.

\section{Bier 2011}

B. Bier, 'Winstreservering en minderheidsaandeelhouders na openbaar bod', Ondernemingsrecht 2011-1, p. 28-32.

Bier 2012 (1)

B. Bier, 'Winstreservering en minderheidsaandeelhouders na openbaar bod', Ondernemingsrecht 2012-2, p. 88-93.

\section{Bier 2012 (2)}

B. Bier, 'Betekent winstrecht ook recht op winst?' in: P.J. van der Korst, R. Abma \& G.T.M.J. Raaijmakers (red.), Handboek onderneming en aandeelhouder, Deventer: Kluwer 2012, p. 163-208.

\section{Blanco Fernández \& Schwarz 1992}

J.M. Blanco Fernández \& C.A. Schwarz, 'Enkele opmerkingen over het participatiebewijs', WPNR 1992, 6045, p. 287-293.

\section{Blanco Fernández 2002}

J.M. Blanco Fernández, 'Het toepassingsbereik van artikel 2:8 BW', in: S.C.J.J. Kortmann e.a. (red.), Onderneming en 10 jaar Nieuw Burgerlijk Recht, Serie Onderneming en Recht, deel 24, Deventer: Kluwer 2002, p. 125-142.

\section{Bloemsma 1973}

M.P. Bloemsma, 'Beschermingsconstructies', TVVS 1973-9, p. 225-230. 


\section{Blom 1992}

F.W.C. Blom, 'Stemrechtloze aandelen kunnen wel constructief zijn', De NV, 1992, p. 205.

\section{Boekman 1996}

S. Boekman, De verzoekschriftprocedure, Zwolle: W.E.J. Tjeenk Willink 1996.

\section{Bon \& Cornelisse 2008}

W. Bon \& R.P.C. Cornelisse, 'Aandelen kunnen feitelijk [fiscaal] niet functioneren als vreemd vermogen', WFR 2008, 6751, p. 137-143.

\section{Bonnier 2006}

M.W. Bonnier, 'Vereenvoudiging en Flexibilisering van het BV recht', JBN 2006-19, p. 3-7.

\section{De Bontridder 1995}

M.J.J. de Bontridder, 'Decertificering van niet-royeerbare certificaten', V\&O 1995-4, p. 44-46.

\section{Den Boogert 1992}

M.W. den Boogert, 'Boekbespreking' (bespreking van: C.A. Schwarz, Aandelen zonder stemrecht (oratie Maastricht), Zwolle: W.E.J. Tjeenk Willink 1990), WPNR 1992, 6031, p. 12-13.

\section{Bos 2005}

E.C. Bos, Vruchtgebruik op aandelen. Over de grenzen van goederenrecht, erfrecht en vennootschapsrecht (diss. Maastricht), Serie vanwege het Van der Heijden Instituut, deel 84, Deventer: Kluwer 2005.

\section{Boschma \& Kuijers-Tollenaar 2013}

H.E. Boschma \& G.K. Kuijers-Tollenaar, 'De bevoegdheidsverdeling in de Flex-BV: AV of BGA?', WPNR 2013, 6962, p. 101-108.

\section{Bosse 2008}

W. Bosse, 'De flexibele BV; oprichting, aandelen zonder stemrecht en zonder winstrecht', JBN 2008-5, p. 3-7.

Bosse 2011 (1)

W. Bosse, 'Invoeringswet vereenvoudiging en flexibilisering bv-recht (I)', WPNR 2011, 6871, p. 71-74. 


\section{Bosse 2011 (2)}

W. Bosse, 'Invoeringswet vereenvoudiging en flexibilisering bv-recht (II, slot)', WPNR 2011, 6872, p. 95-98.

Bosse 2012 (1)

W. Bosse, 'De flex-bv (deel 1)', ftV 2012-3, p. 5-13.

Bosse 2012 (2)

W. Bosse, 'De flex-bv (deel 2)', ftV 2012-4, p. 5-11.

Van Boxel 2012

H.J.M.M. van Boxel, '(In)flexibiliteit over de grens', Ondernemingsrecht 2012-14, p. $637-645$.

\section{Van den Braak 2006}

S.M. van den Braak, 'Vestigingsvrijheid en misbruik van de (buitenlandse) vennootschap', Ondernemingsrecht 2006-5, p. 174-181.

\section{Breedveld-de Voogd 2010}

C.G. Breedveld-de Voogd, 'Toestemming van echtgenote ook niet nodig als aandelen zijn gecertificeerd', $J B N$ 2010-12, p. 12-14.

\section{Brink 2004}

M. Brink, 'De gecertificeerde structuur-NV en -BV', $T v O B$ 2004-5, p. 233-237.

Buijn 2007

F.K. Buijn, 'Onzekere winstuitkeringen', Ondernemingsrecht 2007-9, p. 356-360.

\section{Buijs 1995}

D.C. Buijs, 'Stemrechtloze aandelen', in: P. van Schilfgaarde e.a., Knelpunten in de vennootschapswetgeving, Deventer: Kluwer 1995, p. 53-61.

Bulten 2011

C.D.J. Bulten, De geschillenregeling ten gronde (diss. Nijmegen), Deventer: Kluwer 2011.

\section{Burgers 1987}

H.Th.M. Burgers, 'Aandelen zonder stemrecht en aandelen beperkt stemrecht', TVVS 1987, p. 276-278. 


\section{Cahen 1970}

J.L.P. Cahen, 'De invloed van de belangenverbreding op het handelen van de aandeelhouder', in: Honderd jaar rechtsleven. De Nederlandse Juristen-vereniging 1870-1970, Zwolle: Tjeenk Willink 1970, p. 71-84.

\section{Van Daelen \& Huybens 2010}

M.M.A. van Daelen \& J.H. Huybens, 'Europese ontwikkelingen en (de hervorming van) het BV-recht in verschillende lidstaten', $T v O B$ 2010-4, p. 99-117.

\section{Delfos-Roy 1997}

Y.L.L.A.M. Delfos-Roy, Informatieverstrekking en informatievergaring in het kader van de toezichthoudende en raadgevende taak van de Raad van Commissarissen (diss. Leiden), Deventer: Kluwer 1997.

\section{Demirtas \& Daverschot 2010}

Y. Demirtas \& M.K. Daverschot, 'Scheiding van zeggenschapsrechten en vermogensrechten bij registergoederen', $V \& O$ 2010-5, p. 101-104.

\section{Deraedt 2001}

P.G. Deraedt, 'De verstrekking van inlichtingen aan een individuele aandeelhouder', $V \& O$ 2001-10, p. 165-167.

\section{Doorman 2001}

A. Doorman, 'Wie mag hoeden over de belangen van de minderheidsaandeelhouders?', Ondernemingsrecht 2001-14, p. 428-432.

\section{Doorman 2002}

A. Doorman, 'Het buigzame gelijkheidbeginsel', Ondernemingsrecht 2002-7, p. 199-206.

\section{Dortmond 1990}

P.J. Dortmond, 'Naschrift', De NV 1990-11/12, p. 285.

\section{Dortmond 2003}

P.J. Dortmond, 'Extra verplichtingen voor aandeelhouders', Ondernemingsrecht 2003-9, p. 333-336.

\section{Dortmond 2007}

P.J. Dortmond, 'Flexibel aandeelhouderschap', Ondernemingsrecht 2007-9, p. 350-355. 


\section{Dortmond 2009 (1)}

P.J. Dortmond, 'Wijzigingen in het wetsontwerp flexibilisering bv-recht', Ondernemingsrecht 2009-1, p. 33-37.

Dortmond 2009 (2)

P.J. Dortmond, 'De tweede nota van wijziging bij het wetsvoorstel flexibilisering BV-recht', Ondernemingsrecht 2009-4, p. 200-203.

\section{Dortmond 2010}

P.J. Dortmond, 'Rechten van stemrechtloze aandelen in de invoeringswet flexibilisering BV-recht', Ondernemingsrecht 2010-13, p. 521-525.

Dortmond 2011 (1)

P.J. Dortmond, 'Specifiek afbreuk aan enig recht', Ondernemingsrecht 2011-1, p. 21-23.

\section{Dortmond 2011 (2)}

P.J. Dortmond, 'Winstrechtloze aandelen bij de omzetting van een bv in een nv', Ondernemingsrecht 2011-6, p. 238-240.

Dortmond 2011 (3)

P.J. Dortmond, 'Amendementen bij de invoeringswet flexibilisering BV-recht', Ondernemingsrecht 2011-14, p. 507-513.

\section{Dortmond 2012 (1)}

P.J. Dortmond, 'Memorie van antwoord Eerste Kamer flexibilisering bv-recht', Ondernemingsrecht 2012-5, p. 198-201.

Dortmond 2012 (2)

P.J. Dortmond, 'Wet flexibilisering BV-recht aangenomen', Ondernemingsrecht 2012-10/11, p. 460-462.

\section{Van Duuren 2002}

T.P. van Duuren, De joint venture-vennootschap, Een persoonsgebonden kapitaalvennootschap, Den Haag: Boom Juridische uitgevers 2002.

\section{Van Duuren 2004}

T.P. van Duuren, 'De positie van de Nederlandse BV ten opzichte van haar buitenlandse equivalenten en de Europese B.V.', Ondernemingsrecht 2004-1, p. 4-10. 


\section{Van Duuren 2006 (1)}

T.P. van Duuren, 'De structuur en interne organisatie van de flexibele BV', in: De vereenvoudigde $B V$ (Verslag van de vergadering van de Vereeniging 'Handelsrecht'), Deventer: Kluwer 2006, p. 9-14.

\section{Van Duuren 2006 (2)}

T.P. van Duuren, 'De structuur en interne organisatie van de flexibele BV', in: De vereenvoudigde BV (Preadvies van de Vereeniging 'Handelsrecht' 2006), Deventer: Kluwer 2006, p. 3-32.

Van Duuren 2007

T.P. van Duuren, 'Joint ventures in het nieuwe BV-recht', TOP 2007-6, p. 243-247.

\section{Van Eck \& Roelofs 2012}

G.C. van Eck \& E.R. Roelofs, 'De evenredige splitsing in de zin van artikel 2:334hh, lid 2 BW', JBN 2012-1, p. 3-6.

\section{Van Eck 2013}

G.C. van Eck, 'Fusie van de flex-BV', TvOB 2013-1, p. 17-23.

\section{Eijsbouts 2010}

A.J.A.J. Eijsbouts, 'Elementaire beginselen van Maatschappelijk Verantwoord Ondernemen', in: Maatschappelijk Verantwoord Ondernemen (Handelingen Nederlandse Juristen-Vereniging 2010-1), Deventer: Kluwer 2010, p. 39-119.

\section{Eijsbouts 2011}

A.J.A.J. Eijsbouts, Corporate responsibility, beyond voluntarism. Regulatory options to reinfoce the licence to operate (oratie Maastricht), Maastricht: Océ Business Services 2011, ISBN 978-905-681-3734.

\section{Eijsbouts \& Kemp 2012}

A.J.A.J. Eijsbouts \& B. Kemp, 'Over maatschappelijk verantwoord ondernemen, waardecreatie, ondernemingsrecht en vennootschappelijk belang', $T v O B$ 2012-5, p. $120-132$.

\section{Eisma 1991}

S.E. Eisma, 'Tussen aandeel en schuldbrief: participatiebewijzen', in L. Timmerman e.a., Ondernemingsrechtelijke contracten, Verslag van een congres gehouden op 8 en 9 maart 1991 georganiseerd door het Instituut voor Ondernemingsrecht Rijksuniversiteit Groningen, Deventer: Kluwer 1991, p. 27-41. 


\section{Eisma \& De Keijzer 1994}

S.E. Eisma \& J.Th.A. de Keijzer, Aandelen zonder stemrecht, Nibe-bankjuridische reeks, nr. 21, Amsterdam 1994.

Eisma e.a. 2002

S.E. Eisma, Leerboek effectenrecht, Nijmegen: Ars Aequi Libri 2002.

\section{Van Engelen 2011}

S.M. van Engelen, 'Werknemersparticipatie: certificaten of winstbewijzen; straks stemrechtloze aandelen?', $V \& O$ 2011-6, p. 120-122.

\section{Faasen 1989}

R. Faasen, 'Aandelen zonder stemrecht, een rechtsvergelijkend onderzoek', in: D. Kokkini-Iatridou \& E.W. Grosheide, Eenvormig en vergelijkend privaatrecht 1989, Lelystad: Vermande 1989, p. 455-501.

\section{Fleming 2004}

J. Fleming, 'Verslag van het vijftiende congres van het Instituut voor Ondernemingsrecht: de vereenvoudiging van het BV-recht', Ondernemingsrecht 2004-14, p. $537-544$.

\section{Galavazi \& Van Wilsum 1988}

J.J.H.M. Galavazi \& H. van Wilsum, 'In Nederland nu ook Non-Voting Shares?', De NV 1988-4, p. 130-136.

\section{Geerts 2004}

P.G.F.A. Geerts, Enkele formele aspecten van het enquêterecht (diss. Groningen), Deventer: Kluwer 2004.

\section{Van Geffen 2004}

C.J.A. van Geffen, 'De grens tussen eigen en vreemd vermogen', Ondernemingsrecht 2004-6, p. 207-211.

\section{Van Gendt 2011}

S.C. van Gendt, 'Certificering in Wetsvoorstel Flex-BV - gevolgen voor de praktijk’, $O \& F$ 2011-3, p. 30-37.

\section{Van Ginneken \& Timmerman 2011}

M.J. van Ginneken \& L. Timmerman, 'De betekenis van het evenredigheidsbeginsel voor het ondernemingsrecht', Ondernemingsrecht 2011-17, p. 601-607. 
Van der Grinten 1971 (1)

W.C.L. van der Grinten, 'De aandeelhoudersvergadering en de NV', in: Uit het recht, Rechtsgeleerde opstellen aangeboden aan Mr. P.J. Verdam, Deventer: Kluwer 1971, p. 295-305.

\section{Van der Grinten 1971 (2)}

W.C.L. van der Grinten, 'Boekbespreking' (bespreking van: G. Suetens Bourgeois, De verhouding meerderheid-minderheid in de naamloze vennootschap, GentLeuven: Wetenschappelijke Uitgeverij E. Story Scientia), De NV 1971-48, p. 107.

Van der Grinten 1991

W.C.L. van der Grinten, 'Winstbewijzen als financieringsmethode', in: J.M.M. Maeijer, L.H. Slijkhuis \& R.J.C. van Helden (red.), De Bankier als Jurist. Tegen wil en dank (Langman-bundel), Deventer: Kluwer 1991, p. 121-129.

\section{Groenewald 2004}

Th. Groenewald, 'Risico's bij tracking stock', Ondernemingsrecht 2004-6, p. 194-200.

\section{Van Groeningen 1989}

E.J.J.C. van Groeningen, 'Bescherming tegen overvallen: zakelijk nodig', De NV 1989-6, p. 139-143.

\section{Groenland 2010}

I.C.P. Groenland, 'Invoeringswet Flexibilisering BV-recht', JBN 2010-11, p. 12-16.

\section{Groenland 2012}

I.C.P. Groenland, 'Uitkeren aan aandeelhouders, (hoe) kunnen we dat doen?', $O \& F$ 2012-4, p. 17-36.

\section{De Groot \& Bakker 2011}

J.W. de Groot \& P.S. Bakker, 'Remedies voor de ontoereikend geïnformeerde aandeelhouder', in: M. Holtzer, A.F.J.A. Leijten \& D.J. Oranje (red.), Geschriften vanwege de Vereniging Corporate Litigation 2010-2011, p. 251-263.

\section{Grundmann-van de Krol 2004}

C.M. Grundmann-van de Krol, 'Wennen aan een nieuw effectenbegrip: enkele vraagpunten', Ondernemingsrecht 2004-11, p. 432-436.

\section{Hamers 1996}

J.J.A. Hamers, Verpanding van aandelen en de beslotenheid van kapitaalvennootschappen (diss. Maastricht), Serie Monografieën vanwege het Van der Heijden Instituut, deel 49, Deventer: Kluwer 1996. 


\section{Hammerstein 2011}

A. Hammerstein, 'Het evenredigheidsbeginsel als leidraad', Ondernemingrecht 2011-17, p. 599-600.

Heijstek 2006

J.T.J. Heijstek, 'Inkoop en pandrecht rondom decertificering', JBN 2006-52, p. 4-6.

\section{Heikens 2008}

H.A. Heikens, 'De 'stem' van de stemrechtloze aandeelhouder', TvOB 2008-5, p. 131-136.

\section{Hendriks \& Koelemeijer 2009}

R.W.F. Hendriks \& M. Koelemeijer, 'Loyaliteitsdividend: naar loyale aandeelhouders?', in: P. Essers, G. Raaijmakers, G. van der Sangen, A. Verdam \& E. Vermeulen (red.), Met Recht, Deventer: Kluwer 2009, p. 181-191

\section{Van den Heuvel 2011}

P.P.A.H. van den Heuvel, 'De Flex-BV; flexibel stemrecht en aandelen zonder stemrecht', $T \nu O B$ 2011-3, p. 73-81.

\section{Hoeben 2006}

S.J.M. Hoeben, 'Het agenderingsrecht van kapitaalverschaffers van naamloze vennootschappen', $V \& O 2006-4$, p. 74-77.

\section{Honée 1984}

H.J.M.N. Honée, 'Het toestemmingsvereiste en de echtgenootgrootaandeelhouder (art. 88 boek 1 BW)', in: E.A.A. Luijten \& W.C.L van der Grinten (red.), Een Kapitein, twee schepen: bundel opstellen aangeboden aan Prof. Mr. E.A.A. Luijten ter gelegenheid van zijn zilveren ambtsjubileum aan de K.U. Nijmegen op 28 september 1984 (Luijten-bundel), Zwolle: Tjeenk Willink, 1984, p. 89-97.

\section{Van Hövell tot Westervlier 2011}

A.F.J. van Hövell tot Westervlier, 'De rechtsgeldigheid van een prijsbepalingsregeling bij een aanbiedingsplicht in de statuten of aandeelhoudersovereenkomst, naar huidig en komend recht', $V \& O$ 2011-12, p. 242-246.

\section{Huizink 2000}

J.B. Huizink, 'De structuurregeling bij geprivatiseerde ondernemingen', WPNR 2000,6399 , p. $279-280$.

\section{Huizink 2001}

J.B. Huizink, 'Bewilligde of niet-bewilligde certificaten', WPNR 2001, 6554, p. 693-694. 


\section{Huizink 2010}

J.B. Huizink, 'Zorgplichten in het concern', $O \& F$ 2010-4, p. 5-28.

\section{IJsselmuiden 1990}

Th.S. IJsselmuiden, annotatie bij HR 9 juli 1990 (Sluis), TVVS 1990-12, p. 314-316.

\section{IJsselmuiden 1995}

Th.S. IJsselmuiden, annotatie bij Hof Amsterdam (OK) 15 september 1994 (Kerstens), TVVS 1995-2, p. 51-52.

\section{Van den Ingh 1991}

F.J.P. van den Ingh, Certificering en certificaat van aandeel bij de besloten vennootschap (diss. Nijmegen), Serie Monografieën vanwege het Van der Heijden Instituut, deel 35, Deventer: Kluwer 1991.

\section{Van den Ingh 1992}

F.J.P. van den Ingh, 'Een andere kijk op enkele problemen bij certificering van aandelen', TVVS 1992-3, p. 77-78 (reactie op Schwarz 1992).

\section{Van den Ingh 1994}

F.J.P. van den Ingh, 'De positie van minderheidsaandeelhouders', Dossier Onderneming \& Financiering 1994-18, p. 42-46.

\section{Van den Ingh 2000}

F.J.P. van den Ingh, 'Het stemgedrag van aandeelhouders', in: $A-T-D$, Opstellen aangeboden aan prof. mr. P. van Schilfgaarde, Deventer: Kluwer 2000, p. 203-213.

\section{Van den Ingh 2002}

F.J.P. van den Ingh, 'De bevelstructuur in de vennootschap', in L. Timmerman e.a., Concernverhoudingen, Serie vanwege het Van der Heijden Instituut, deel 69, Deventer: Kluwer 2002, p. 13-27.

\section{Van den Ingh 2003 (1)}

F.J.P. van den Ingh, 'Met medewerking uitgegeven certificaten', $S V \& V$ 2003-5, p. 181-185.

Van den Ingh 2003 (2)

F.J.P. van den Ingh, 'Medewerking bij certificering van aandelen', $O \& F$ 2003-57, p. 2-6.

\section{Van den Ingh 2004}

F.J.P. van den Ingh, 'Certificaathouder en enquêterecht', TvOB 2004-5, p. 226-232. 


\section{Van den Ingh 2008}

F.J.P. van den Ingh, 'Certificering van aandelen', WPNR 2008, 6737, p. 3-10.

\section{Janssen 2011}

M.A.J.G. Janssen, 'Borgtocht en artikel 1:88, lid 5 BW', ORP 2011-2, p. 31-35.

\section{De Jongh 2011}

J.M. de Jongh, 'Redelijkheid en billijkheid en het evenredigheidsbeginsel, in het bijzonder in de verhouding van aandeelhouders tot bestuur', Ondernemingsrecht 2011-17, p. 608-618.

\section{De Jongh 2012}

J.M. de Jongh, 'Oligarchie in thema en variaties. Zeggenschap van aandeelhouders vóór 1900', in: P.J. van der Korst, R. Abma \& G.T.M.J. Raaijmakers (red.), Handboek onderneming en aandeelhouder, Deventer: Kluwer 2012, p. 3-33.

\section{Kaemingk 2012}

H.L. Kaemingk, 'Aandeelhouderswaarde als ondernemingsstrategie? Enkele beschouwingen over private equity fondsen als aandeelhouders van Nederlandse ondernemingen', in: P.J. van der Korst, R. Abma \& G.T.M.J. Raaijmakers (red.), Handboek onderneming en aandeelhouder, Deventer: Kluwer 2012, p. 477-511.

\section{De Kluiver 1991}

H.J. de Kluiver, 'Toelating van betrokkenen bij rechtspersonen; een verkenning op de scheidslijn tussen rechtspersonen- en verbintenissenrecht (II en slot)', $S \& V$ 1991-3, p. 63-70.

\section{De Kluiver 1994}

H.J. de Kluiver, 'Het vennootschapsrecht dient te worden versoepeld ... verscherpt', TVVS 1994-7, p. 174-179.

De Kluiver 2000

H.J. de Kluiver, 'Goede trouw en rechtspersoonlijkheid', in: A-T-D, Opstellen aangeboden aan prof. mr. P. van Schilfgaarde, Deventer: Kluwer 2000, p. 225-240.

\section{De Kluiver 2005}

H.J. de Kluiver, 'Familievennootschappen en (nieuw) vennootschapsrecht', WPNR 2005,6647, p. $985-993$.

\section{De Kluiver 2006}

H.J. de Kluiver, 'Vermogensbescherming bij de BV: modernisering in internationaal perspectief', WPNR 2006, 6676, p. 571-580. 


\section{De Kluiver 2008}

H.J. de Kluiver, 'Het nieuwe BV-recht voor de praktijk', WPNR 2008, 6768, p. 687-693.

\section{De Kluiver \& Meinema 2002}

H.J. de Kluiver \& M. Meinema, 'Dwingend vennootschapsrecht na de Wet herziening preventief toezicht en de mogelijkheden van statutaire of contractuele afwijking en aanvulling', WPNR 2002, 6503, p. 648-659.

\section{Kodde 2005}

K. Kodde, 'De Private Equity Buy Out Transactie: structurering van de equity, aandeelhouders- en verkoopafspraken', Ondernemingsrecht 2005-17, p. 581-589.

\section{Koelemeijer 1994}

M. Koelemeijer, 'Redelijkheid en billijkheid in het vennootschapsrecht. Gebruik van corporate opportunities: een (on)geoorloofde gedraging van bestuurders?', WPNR 1994, 6154, p. 714-719.

\section{Koelemeijer 1999}

M. Koelemeijer, Redelijkheid en billijkheid in kapitaalvennootschappen (diss. Maastricht), Deventer: Kluwer 1999.

\section{Koelemeijer 2012}

M. Koelemeijer, 'Minderheidsaandeelhouders revisited: les uit Air France-KLM', TvOB 2012-2, p. 41-44.

\section{Koelemeijer \& Hendriks 2012}

M. Koelemeijer \& R.W.F. Hendriks, 'Loyaliteitsdividend: naar loyale aandeelhouders?', TvOB 2012-5, p. 144-148.

\section{Van der Korst 2007}

P.J. van der Korst, Bedrijfsgeheimen en transparantieverplichtingen (diss. Nijmegen), Deventer: Kluwer 2007.

\section{Van der Korst 2010}

P.J. van der Korst, 'Aanwijzingsbevoegdheid en instructiemacht in concernverhoudingen’, TOP 2010-7, p. 270-275.

\section{Van der Korst 2011}

P.J. van der Korst, 'Kwaliteitseisen voor aandeelhouders, nu en straks', ftV 2011-4, p. 3-4. 


\section{De Kort 2012}

J.W.J. de Kort, 'Soortaandelen in het aanmerkelijkbelang-regime, HR 16 december 2011', ftV 2012-4, p. 12-15.

\section{Koster 2006}

H. Koster, 'Stemrecht ontwikkelingen', Ondernemingsrecht 2006-12, p. 434-435.

\section{Koster 2011}

H. Koster, 'Over stemrechtloze aandelen en cash out (de)mergers in Nederland', Ondernemingsrecht 2011-13, p. 474-475.

\section{Koster 2012}

H. Koster, 'Flexibeler regeling zeggenschapsrechten bij vruchtgebruik en pandrecht op aandelen', $T v O B$ 2012-6, p. 208-213.

\section{Kraakman e.a. 2009}

R. Kraakman e.a., The anatomy of Corporate Law, A Comparative and Functional Approach, Oxford: Oxford University Press 2009.

\section{Van der Krans 2005}

A. van der Krans, 'Sense and Simplicity', $O \& F$ 2005-65, p. 3-10.

\section{Van der Kroon 2007}

J.T. van der Kroon, 'Flexibeler BV-recht: minder formaliteiten en vrijere verhoudingen tussen de aandeelhouders', $V \& O$ 2007-1, p. 11-13

\section{Leemrijse 2005}

J.J.C.A. Leemrijse, 'De Eerste Tranche van het vereenvoudigd BV-recht', $T v O B$ 2005-2, p. 39-46.

\section{Leijten 2000}

A.F.J.A. Leijten, 'Geschillen tussen aandeelhouders', in: A.F.J.A. Leijten, L. Timmerman, J.H.M. Willems e.a., Conflicten rondom de rechtspersoon, Serie Monografieën vanwege het Van der Heijden Instituut, deel 62, Deventer: Kluwer 2000 .

\section{Leijten 2002}

A.F.J.A. Leijten, 'De positie van de derde in het enquêterecht', in: G. van Solinge \& M. Holtzer (red.), Geschriften vanwege de Vereniging Corporate Litigation 20012002, Deventer: Kluwer 2002, p. 65-77. 


\section{Lennarts \& Boschma 2010}

M.L. Lennarts \& H.E. Boschma, 'Een nieuwe stap voorwaarts in de richting van de Flex-BV: het wetsvoorstel Invoeringswet vereenvoudiging en flexibilisering BV-recht', WPNR 2010, 6857, p. 704-715.

\section{Lennarts 2012}

M.L. Lennarts, 'Het nieuwe art. 2:216 BW: de goedkeuringsbevoegdheid van het bestuur en het daaraan verbonden aansprakelijkheidsrisico', TvOB 2012-6, p. $179-187$.

\section{Maeijer 1984}

J.M.M. Maeijer, 'De corrigerende werking van de goede trouw, in het bijzonder binnen rechtspersonen', in E.A.A. Luijten e.a. (red.), Goed en trouw (Van der Grinten-bundel), Zwolle: Tjeenk Willink 1984, p. 31-44.

\section{Maeijer 1990}

J.M.M. Maeijer, 'Bespreking van: M.M. Mendel, Het vennootschappelijk belang. Mede in concernverband beschouwd (oratie Leiden)', RMThemis 1990-9, p. $465-468$.

\section{Maeijer 2000}

J.M.M. Maeijer, 'Deelrechtsorde, redelijkheid en billijkheid, en vennootschappelijk belang', in: $A-T-D$, Opstellen aangeboden aan prof. mr. P. van Schilfgaarde, Deventer: Kluwer 2000, p. 281-289.

\section{Marcusse \& Mulder ten Kate 2001}

M.F. Marcusse \& B. Mulder ten Kate, 'Aandelen zonder stemrecht?', V\&O 2001-9, p. $148-150$.

\section{Marges 2006}

S.M. Marges, 'De toekomst van het BV-recht', $f t V$ 2006, p. 20-28.

\section{Meijers 2004}

V.A.E.M. Meijers. 'Reactie op "Bewilliging van certificaten van aandelen", (H.J. Portengen \& I.C.P Groenland, 'Bewilliging van certificaten van aandelen', WPNR 2003, 6559, p. 947-952), WPNR 2004, 6566, p. 141-143.

\section{Meinema 2003}

M. Meinema, Dwingend recht voor de besloten vennootschap. Een beschouwing over de contractsvrijheid van aandeelhouders in rechtsvergelijkend perspectief (diss. Maastricht), Deventer: Kluwer 2003. 


\section{Meinema 2004}

M. Meinema, 'Artikel 2:25 BW en de afstand van (vennootschaps)recht', Ondernemingsrecht 2004-1/2, p. 36-40.

\section{Mendel 1989}

M.M. Mendel, Het vennootschappelijk belang. Mede in concernverband beschouwd (oratie Leiden), Deventer: Kluwer 1989.

\section{Mendel 1997}

M.M. Mendel, 'Stemrecht, minderheidsaandeelhouders en ongelijkheidscompensatie', in: L. Betten e.a. (red.), Ongelijkheidscompensatie als roode draad in het recht. Liber Amicorum voor prof. mr. M.G. Rood, Deventer: Kluwer 1997, p. 207-215.

\section{Moerland 2002}

P.W. Moerland, 'Heeft de certificering van aandelen nog toekomst', Ondernemingsrecht 2002-10, p. 280-285.

\section{Mol 2012}

S. Mol, 'Grenzen aan een LBO', Ondernemingsrecht 2012-3, p. 109-116.

\section{Mol-Verver 2012}

S.J. Mol-Verver, 'Ruimte in het aanmerkelijk belang door arrest inzake soort begrip', FBN 2012-3, p. 6-9.

\section{De Monchy \& Timmerman 1991}

C.W. de Monchy \& L. Timmerman, De nieuwe algemene bepalingen van boek 2 $B W$ (Preadvies van de Vereeniging 'Handelsrecht' 1991), Zwolle: Tjeenk Willink 1991.

\section{Van Mourik 1983}

M.J.A. van Mourik, 'Aanpassing en herziening van Boek $1 \mathrm{BW}$ ter gelegenheid van de invoering van de Boeken 3-6 van het nieuw BW', WPNR 1983, 5640, p. 101-106.

\section{Van Mourik 2011}

M.J.A. van Mourik, 'Groot-aandeelhouder en periodiek verrekenbeding', WPNR 2011,6902 , p. $840-846$.

\section{Van den Munckhof 2011}

E.J.H. van den Munckhof, 'Stemrecht- en winstrechtloze aandelen. De implicaties voor art. 1:88 lid 5 Burgerlijk Wetboek', WPNR 2011, 6907, p. 950-953. 


\section{Van den Munckhof 2012}

E.J.H. van den Munckhof, Naschrift op 'Stemrecht- en winstrechtloze aandelen. De implicaties voor art. 1:88 lid 5 Burgerlijk Wetboek', WPNR 2012, 6920, p. 191.

\section{Nagtegaal \& Snijder-Kuipers 2012}

C.R. Nagtegaal \& B. Snijder-Kuipers, 'Omzetting van de BV na inwerkingtreding van de Wet flex-bv', TOP 2012-6, p. 242-246.

\section{Van den Nieuwenhuijzen 2008}

M.C.A. van den Nieuwenhuijzen, 'Aandelen zonder stemrecht en aandelen met flexibel stemrecht in de flex-BV', WPNR 2008, 6737, p. 17-25.

\section{De Nijs Bik 2002}

W.W. de Nijs Bik, 'De structuurregeling met mate', Ondernemingsrecht 2002-3/4, p. $96-100$.

\section{De Nijs Bik 2004}

W.W. de Nijs Bik, De nieuwe structuurregeling, Deventer: Kluwer 2004.

\section{Noordraven 1988}

G. Noordraven, 'De zeggenschap van verschaffers van risicodragend kapitaal', in: Van vennootschappelijk belang. Opstellen aangeboden aan Prof. Mr. J.M.M. Maeijer, Zwolle: W.E.J. Tjeenk Willink 1988, p. 171-183.

\section{Nowak \& Van den Ingh 2005}

R.G.J. Nowak \& F.J.P. van den Ingh, 'Het voorontwerp flexibilisering BV-recht (eerste tranche)', Ondernemingsrecht 2005-5, p. 161-166.

\section{Nowak \& Van den Ingh 2007}

R.G.J. Nowak \& F.J.P. van den Ingh, 'Besluitvorming in het wetsvoorstel flex-BV', TvOB 2007-4, p. 122-133.

\section{Olaerts 2007}

M. Olaerts, Vennootschappelijke beleidsbepaling in geval van financiële moeilijkheden; de positie van de bestuurders en aandeelhouders (diss. Maastricht), Antwerpen: Intersentia 2007.

\section{Van Olffen 1997}

M. van Olffen, 'Conversie van aandelen', WPNR 1997, 6253, p. 49-52.

\section{Van Olffen 2006}

M. van Olffen, 'Loyaliteitsaandelen', WPNR 2006, 6687, p. 779-784. 


\section{Van Olffen 2012}

M. van Olffen, 'Meerderheidsaandeelhouders versus minderheidsaandeelhouders, een bijzondere zorg(vuldigheids)plicht? Zwagerman revisited', in: P.J. van der Korst, R. Abma \& G.T.M.J. Raaijmakers (red.), Handboek onderneming en aandeelhouder, Deventer: Kluwer 2012, p. 367-379.

\section{Oranje 2008 (1)}

F.J. Oranje, 'Orgaanstructuur en bevoegdheden' in: Het nieuwe BV-recht voor de praktijk (preadvies KNB 2008), Den Haag: Sdu Uitgevers 2008, p. 21-105.

Oranje 2008 (2)

F.J. Oranje, 'De Flex-BV: orgaanstructuur en bevoegdheden', JBN 2008-6, p. 6-11.

\section{Oranje 2012}

F.J. Oranje, 'Convocatie- en agenderingsrecht van aandeelhouders. Toegevoegde waarde in het systeem van checks and balances tussen bestuur en aandeelhouders?', in: P.J. van der Korst, R. Abma \& G.T.M.J. Raaijmakers (red.), Handboek onderneming en aandeelhouder, Deventer: Kluwer 2012, p. 275-304.

\section{Perrick 1993}

S. Perrick, 'De onherroepelijke volmacht in het vennootschapsrecht', in: B.J. Asscher \& U.W. Bentinck (red.), Kabaal in Holland (Asscher-bundel), Arnhem: Gouda Quint 1993, p. 89-92.

\section{Van der Ploeg 1990}

T.J. van der Ploeg, Boekbespreking van Schwarz 1990, TVVS 1990-10, p. 267-268.

\section{Portengen \& Groenland 2003}

H.J. Portengen \& I.C.P Groenland, 'Bewilliging van certificaten van aandelen', WPNR 2003, 6559, p. 947-952.

\section{Portengen \& De Groot 2004}

H.J. Portengen \& K.E. Groot, 'Conversie van aandelen', Ondernemingsrecht 20046, p. 200-207.

\section{Portengen 2006}

H.J. Portengen, 'Naar contractsvrijheid voor de BV en haar statutaire inrichting (?!)', in: De vereenvoudigde BV (Preadvies van de Vereeniging 'Handelsrecht' 2006), Deventer: Kluwer 2006, p. 33-112.

\section{Portengen 2007}

H.J. Portengen, 'Interne verhoudingen - flex BV', WPNR 2007, 6731, p. 940-949. 


\section{Portengen \& Groenland 2007}

H.J. Portengen \& I.C.P Groenland, 'Minderheidsbescherming in het nieuwe BVrecht', TOP 2007-6, p. 248-251.

\section{Portier 2008}

G.M. Portier, 'Stemrecht en certificering', in: Het nieuwe BV-recht voor de praktijk (preadvies KNB 2008), Den Haag: Sdu Uitgevers 2008, p. 221-268.

\section{Portier 2011}

G.M. Portier, 'Flex-bv: overgangsregeling certificering, zo werkt het (niet)', WPNR 2011, 6870, p. 47-52.

\section{Prinsen 2004}

J.J. Prinsen, Converteerbare obligaties. Omzetting van schuld in eigen vermogen (diss. Nijmegen), Deventer: Kluwer 2004.

\section{Prinsen 2011}

J.J. Prinsen, 'Corporate governance op de grens van een nieuw decennium. Verhoudingen tussen bestuur, commissarissen en aandeelhouders van de beursvennootschap', $O \& F$ 2011-1, p. 29-53.

Quist 2010 (1)

P.H.N. Quist, 'Het omkatten van certificaten (I)', WPNR 2010, 6858, p. 727-729.

Quist 2010 (2)

P.H.N. Quist, 'Het omkatten van certificaten (II, slot)', WPNR 2010, 6859, p. 748-749.

\section{Quist 2010 (3)}

P.H.N. Quist, 'Topmodel met alle opties. Een preview van de flex-bv', TOP 2010-3, p. 94-99.

\section{Quist 2012}

P.H.N. Quist, 'Topmodel met alle opties (II). Een facelift voor de flex-bv', TOP 2012-1, p. 37-45.

\section{G.T.M.J. Raaijmakers 2012}

G.T.M.J. Raaijmakers, 'Gelijke behandeling van aandeelhouders en beleggers', in: P.J. van der Korst, R. Abma \& G.T.M.J. Raaijmakers (red.), Handboek onderneming en aandeelhouder, Deventer: Kluwer 2012, p. 35-73. 


\section{M.J.G.C. Raaijmakers 1991 (1)}

M.J.G.C. Raaijmakers, 'Over de rechtsbetrekking van aandeelhouders in een "quasiVof", in: In het nu, wat worden zal. Opstellen aangeboden aan prof. mr. H.C.F. Schoordijk, Deventer: Kluwer 1991, p. 203-221.

\section{M.J.G.C. Raaijmakers 1991 (2)}

M.J.G.C. Raaijmakers, 'Besluit van aandeelhouders tot statutenwijziging in strijd met de redelijkheid en billijkheid?', AA 1991-11, p. 1009-1015.

\section{M.J.G.C. Raaijmakers 1994}

M.J.G.C. Raaijmakers, "'Besloten" vennootschappen: quasi-nv of quasi-vof?, Enkele rechtsvergelijkende notities', $A A$ 1994-5, p. 340-348.

\section{Raaijmakers \& Van der Sangen 2011}

M.J.G.C. Raaijmakers \& G.J.H. van der Sangen, 'De positie van de directeurgrootaandeelhouder in het nieuwe BV-recht', TVOB 2011-4, p. 90-96.

\section{Raaijmakers \& Van der Sangen 2012}

M.J.G.C. Raaijmakers \& G.J.H. van der Sangen, 'De directeur-grootaandeelhouder in het nieuwe BV-recht', in: P.J. van der Korst, R. Abma \& G.T.M.J. Raaijmakers (red.), Handboek onderneming en aandeelhouder, Deventer: Kluwer 2012, p. 513-543.

\section{Rapport van de Expertgroep}

Het rapport Vereenvoudiging en flexibilisering van het Nederlandse BV-recht van 6 mei 2004 van de expertgroep in het najaar van 2003 ingesteld door de minister van Justitie en de staatssecretaris van Economische Zaken onder voorzitterschap van prof. mr. H.J. de Kluiver, te raadplegen op http://www.rijksoverheid.nl/onderwerpen/flexibele-bv. en opgenomen in F.J.P. van den Ingh en R.G.J. Nowak (red.), Vereenvoudiging en flexibilisering BV-recht, deel 1: De pre-parlementaire geschiedenis, Deventer: Kluwer 2006, p. 171 e.v.

\section{Rensen 2005}

G.J.C. Rensen, Extra-verplichtingen van leden en aandeelhouders (diss. Nijmegen), Serie vanwege het Van der Heijden Instituut, deel 83, Deventer: Kluwer 2005.

\section{Rietkerk 1992}

G. Rietkerk, 'Stemrechtloze aandelen', De NV 1992-5, p. 101.

\section{Rietvelt 2011}

L.E. Rietvelt, 'Certificering: weer geen bewilliging', $J B N$ 2011-11, p. 12-15. 


\section{Roelofs \& Van Eck 2011}

E.R. Roelofs \& G.C. van Eck, 'Toepassing van de evenredige splitsing in de praktijk', TvOB 2011-6, p. 127-133.

\section{Roelofs 2012 (1)}

E.R. Roelofs, 'Wijzigingen in de Wet op de formeel buitenlandse vennootschappen ten gevolge van de flexibilisering van het BV-recht', $J B N$ 2012-6, p. 12-14.

\section{Roelofs 2012 (2)}

E.R. Roelofs, 'De omzetting van een 'Flex-BV”, JBN 2012-10, p. 12-16.

\section{Roelofs 2012 (3)}

E.R. Roelofs, 'Wijzigingen in de fusie- en splitsingswetgeving ten gevolge van de Flex-BV', JBN 2012-11, p. 12-16.

\section{Roelofs 2013}

E.R. Roelofs, 'De gevolgen van de Flex-BV voor de schadeloosstelling bij grensoverschrijdende fusie', $J B N$ 2013-1, p. 3-6.

\section{Roest 2005}

J. Roest, 'Familievennootschap en structuurregeling', WPNR 2005, 6647, p. 993-999.

\section{Roest 2012}

J. Roest, 'De gevolgen van de Wet flexibilisering BV-recht voor de relatie vennootschap-aandeelhouder', in: P.J. van der Korst, R. Abma \& G.T.M.J. Raaijmakers (red.), Handboek onderneming en aandeelhouder, Deventer: Kluwer 2012, p. $75-111$.

\section{Sanders \& Westbroek 2005}

P. Sanders en W. Westbroek, BV en NV, Deventer: Kluwer 2005.

\section{Van der Sangen 2001}

G.J.H. van der Sangen, 'De positie van de Stichting Administratiekantoor en zijn certificaathouders in de geschillenregeling', $S \& V$ 2001-6, p. 113-117.

\section{Van der Sangen 2003}

G.J.H. van der Sangen, 'Aandeelhoudersovereenkomsten in besloten verhoudingen’, $S V \& V$ 2003-1, p. 32-42.

\section{Van der Sangen \& Raaijmakers 2004}

G.J.H. van der Sangen \& M.J.G.C. Raaijmakers, 'Modernisering van het BV-recht en crediteurenbescherming', $T v O B$ 2004-6, p. 247-257. 


\section{Van der Sangen 2008}

G.J.H. van der Sangen, 'Bescherming van minderheidsaandeelhouders bij de flexBV', TvOB 2008-1, p. 1-9.

\section{Schild 2008}

A.J.P. Schild, 'Het loyaliteitsdividend van DSM en de onmiddellijke voorzieningen van de ondernemingskamer', $M v V$ 2008-2, p. 30-37.

\section{Van Schilfgaarde 1988}

P. van Schilfgaarde, 'Beursovername en beschermingsconstructies', in: J.M.M. Maeijer e.a., Verslag van het congres “Aandelen”, Deventer: Kluwer 1988, p. 19-36.

\section{Van Schilfgaarde 1998}

P. van Schilfgaarde, 'Gelijke behandeling van aandeelhouders', in: P.C. van den Hoek, P. van Schilfgaarde, H.J.M.N. Honée e.a., Corporate Governance voor juristen, Deventer: Kluwer 1998.

\section{Van Schilfgaarde \& Winter 2006}

P. van Schilfgaarde \& J. Winter, Van de BV en de NV, Deventer: Kluwer 2006

Van Schilfgaarde \& Winter 2009

P. van Schilfgaarde \& J. Winter, Van de BV en de NV, Deventer: Kluwer 2009.

\section{Schoenmaker-Tijsseling 2011}

E. Schoenmaker-Tijsseling, 'Het recht van een individuele aandeelhouder op informatie', $T v O B$ 2011-4, p. 83-89.

\section{Schoonbrood 2012}

J.D.M. Schoonbrood, 'Overgangsrecht Wet vereenvoudiging en flexibilisering bvrecht en Wet bestuur en toezicht', WPNR 2012, 6933, p. 423-437.

\section{Schönau 2012}

M. Schönau, 'Winstreservering door meerderheidsaandeelhouders en de grenzen van artikel 2:8 BW', $V \& O 2012-1$, p. 16-19.

\section{Schrama 2012}

H.K. Schrama, 'Aandeelhouders en het vennootschappelijk belang', $V \& O$ 2012-6, p. 101-106.

\section{Schuit 2008}

S.R. Schuit, 'Over corporatisme en corporate governance', in: M. Pheijffer en F. van Eenennaam e.a., Commissaris van nu. Gevaarlijke gedachten voor commissarissen, Assen: Koninklijke van Gorcum 2008, p. 225-238. 


\section{Schwarz 1986}

C.A. Schwarz, Blokkering van aandelen (diss. Leiden), Serie Monografieën vanwege het Van der Heijden Instituut, deel 27, Deventer: Kluwer 1986.

\section{Schwarz 1990}

C.A. Schwarz, Aandelen zonder stemrecht (oratie Maastricht), Zwolle: W.E.J. Tjeenk Willink 1990.

\section{Schwarz 1992}

C.A. Schwarz, 'Enkele vragen bij certificering van aandelen', TVVS 1992-1, p. 6-11.

\section{Schwarz 1994}

C.A. Schwarz, 'Boekbespreking' (bespreking van: B.C.M. Waaijer, Statuten en statutenwijziging (diss. Nijmegen), Deventer: Kluwer 1993), WPNR 1994, 6142, p. $462-464$.

\section{Schwarz 1995 (1)}

C.A. Schwarz, 'Goede raad is duur; motiveringsplicht, hoorrecht en raadgevende stem bij ontslag van bestuurders', WPNR 1995, 6190, p. 527-531.

\section{Schwarz 1995 (2)}

C.A. Schwarz, 'De invloed van vergadergerechtigden zonder stemrecht op besluitvorming in de aandeelhoudersvergadering', in: P.H.M. Gerver, J.G. Kuijl, A.J.H. Pleysier \& R.T.G. Verstraaten (red.), Heden verschenen voor mij... (Liber Amicorum A.L.M. Soons), Arnhem: Gouda Quint 1995, p. 201-208.

\section{Schwarz 2000}

C.A. Schwarz, 'Stichting Moskee Al Firdaus' (rubriek privaatrecht actueel), WPNR 2000, 6408, p. 471-472.

\section{Schwarz 2002}

C.A. Schwarz, 'Certificering van aandelen als onderlinge regeling tot samenwerking tussen aandeelhouders? Toepasselijkheid van het structuurmodel op de besloten (naamloze) vennootschap in de voorstellen tot wijziging van de structuurregeling', $S \& V$ 2002-2, p. 44-51.

\section{Schwarz 2004}

C.A. Schwarz, 'Certificering als beschermingsconstructie; bruikbaarheid in een veranderend tijdsgewricht', $T v O B$ 2004-5, p. 220-225.

\section{Schwarz 2012 (1)}

C.A. Schwarz, 'Bescherming van minderheidsaandeelhouders bij beklemmende statutenwijziging naar komend BV-recht', TvOB 2012-2, p. 52-59. 
Schwarz 2012 (2)

C.A. Schwarz, 'De invoering van het nieuwe BV-recht en de noodzaak tot studie en aanpassing van de statuten', $T v O B$ 2012-6, p. 214-219.

\section{Seubring 2010}

E. Seubring, 'Wetsvoorstel Invoeringswet Flex-BV: een eerste signalering, $V \& O$ 2010-10, p. 186-191.

\section{Slagter 1977}

W.J. Slagter, 'Boekbespreking' (bespreking van Uit het recht. Rechtsgeleerde opstellen aangeboden aan mr. P.J. Verdam, Deventer: Kluwer 1971), TVVS/Ondernemingsrecht 1977-4, p. 127-128.

\section{Slagter 1988}

W.J. Slagter, Macht en onmacht van de aandeelhouder (diësrede Erasmus Universiteit Rotterdam), Deventer: Kluwer 1988.

\section{Slagter 1991}

W.J. Slagter, Vordering tot uitkering van dividend (Rechtspraak, Vennootschapsrecht, bespreking van Rb. Zutphen 17 januari 1991 (Uniwest)), TVVS 1991-91, p. $160-162$.

\section{Slagter 2004}

W.J. Slagter, 'De lidmaatschapsverhouding als grondslag van het rechtspersonenrecht', Ondernemingsrecht 2004-11, p. 424-428.

Slagter 2005

W.J. Slagter, Compendium Ondernemingsrecht, Deventer: Kluwer 2005.

Slagter 2008

W.J. Slagter, Sdu Commentaar Ondernemingsrecht, art. 2:8 BW, Den Haag: Sdu Uitgevers 2008.

\section{Snijder-Kuipers 2012}

B. Snijder-Kuipers, 'Flexibeler waardebepaling van aandelen na invoering Flex-BV', JBN 2012-11, p. 8-11.

Smeets 2005

S.P. Smeets, 'Hoe flexibel wordt Nederland in vergelijking met Delaware?', $V \& O$ 2005-5, p. 86-88. 


\section{Soerjatin 2006}

E.M. Soerjatin, 'Voorontwerp van de nieuwe geschillenregeling: extreme makeover, the legal edition', in M. Holtzer, A.F.J.A. Leijten \& D.J. Oranje (red.), Geschriften vanwege de Vereniging Corporate Litigation 2005-2006, Deventer: Kluwer 2006, p. 203-217.

\section{Van Solinge \& Van Boxel 2008}

G. van Solinge \& H.J.M.M. van Boxel, 'Bescherming van minderheidsaandeelhouders bij een grensoverschrijdende fusie', WPNR 2008, 6776, p. 885-896.

Van der Steenstraten 2010

F. van der Steenstraten, 'Wetvoorstel flexibilisering BV-recht; de laatste stand van zaken', $V \& O$ 2010-2, p. 30-32.

\section{Steins Bisschop 2004}

B.T.M. Steins Bisschop, Maatschappelijk verantwoord ondernemen en het ondernemingsrecht, Den Haag: Boom Juridische uitgevers 2004.

\section{Steins Bisschop 2010}

B.T.M. Steins Bisschop, 'Globalization: selected developments in corporate law', in: M. Faure, A. van der Walt, Globalization and Private Law. The way forward, Celtenham: Edward Elgar Publishing 2010, p. 211-254.

\section{Stelling 2001}

K. Stelling, 'Reactie op 'Bewilligde of niet-bewilligde certificaten' van prof. mr. J.B. Huizink in WPNR 2001, 6454, p. 972-973', WPNR 2001, 6465 met naschrift J.B. Huizink, p. 972-974.

\section{Stienstra 2005}

E.C. Stienstra, 'Vennootschappelijk belang', $V \& O$ 2005-2, p. 22-26.

Stokkermans 2008 (1)

Chr.M. Stokkermans, 'Verdeling van winst en reserves in het nieuwe BV-recht', $V \& O 2008-2$, p. 26-31.

\section{Stokkermans 2008 (2)}

Chr.M. Stokkermans, 'Beslotenheid en extraverbintenissen', in: Het nieuwe BVrecht voor de praktijk (preadvies KNB 2008), Den Haag: Sdu Uitgevers 2008, p. 107-167.

\section{Stokkermans 2008 (3)}

Chr.M. Stokkermans, 'Extra-verplichtingen en statutaire overdrachtsbeperkingen', WPNR 2008, 6741, p. 111-120. 
Lijst van geraadpleegde en aangehaalde literatuur

\section{Stokkermans 2010}

Chr.M. Stokkermans, 'Vernietiging van besluiten', $V \& O$ 2010-10, p. 177-182.

\section{Stokkermans \& Rensen 2012}

Chr.M. Stokkermans \& G.J.C. Rensen, 'Invoering flex-BV; een nieuw statutair speelveld', TOP 2012-2, p. 68-72.

\section{Storm 2007}

P.M. Storm, 'Rechtspraak, enquêterecht, loyaliteitsdividend DSM', Ondernemingsrecht 2007-12, p. 471-474.

\section{Timmerman 1975}

L. Timmerman, 'De beslotenheid nader beschouwd', TVVS 1975, p. 241-250.

\section{Timmerman 1991}

L. Timmerman, 'Is een besluit tot wijziging van de statutaire blokkeringsregeling in strijd met de redelijkheid en billijkheid?', commentaar bij HR 17 mei 1991 (Lampe/ Tonnema), TVVS 1991-7, p. 189-191.

\section{Timmerman 1992}

L. Timmerman, 'Is versoepeling van het Nederlandse n.v./b.v.-recht wenselijk?, TVVS 1992-92, p. 163-168.

\section{Timmerman 2004}

L. Timmerman, 'Een BV zonder bestuur en zonder aandeelhoudersvergadering', Ondernemingsrecht 2004-1, p. 27-30.

Timmerman 2009 (1)

L. Timmerman, 'Grondslagen van geldend ondernemingsrecht', Ondernemingsrecht 2009-1, p. 4-13.

\section{Timmerman 2009 (2)}

L. Timmerman, 'Vrijheid alleen is niet genoeg, een reactie', Ondernemingsrecht 2009-1, p. 24-27.

\section{Timmermans 2011}

R.A.F. Timmermans, 'Omzetting, fusie en splitsing van een bv met stemrechtloze en winstrechtloze aandelen', WPNR 2011, 6870, p. 53-56.

\section{Treurniet 1959}

W.C. Treurniet, 'Wat niet in het bijvoegsel staat (De stemovereenkomst)', De NV 1959, p. 163-166. 


\section{Treurniet 1968}

W.C. Treurniet, 'Titel III, Kapitaal, aandelen en rechten der aandeelhouders, obligaties', De NV 1968 (special over de Europese NV), p. 204.

\section{Van Uchelen-Schipper 2012}

M.J. van Uchelen-Schipper, Naschrift op 'Stemrecht- en winstrechtloze aandelen. De implicaties voor art. 1:88 lid 5 Burgerlijk Wetboek' van Van den Munckhof 2011, WPNR 2012, 6920, p. 189-190.

\section{Uittien \& Alleman 2010}

H. Uittien \& S.A. Alleman, 'Managementparticipatie bij private equity investeringen (I), Over 'alignment of interests' en 'conflict of interests', TOP 2010-8, p. 306-310.

\section{Vaessen 2012}

R.T.L. Vaessen, 'Het einde van certificering in zicht? De invloed van de introductie van stemrechtloze aandelen op deze vertrouwde rechtsfiguur', TvOB 2012-4, p. $105-110$.

\section{Van Veen 2005}

W.J.M. van Veen, 'Bedrijfsopvolging bij kapitaalvennootschappen; vennootschappelijke aspecten', in: Bedrijfsopvolging. Civielrechtelijke en fiscaalrechtelijke aspecten. (Preadvies KNB 2005), Den Haag: Sdu Uitgevers 2005, p. 307-361.

\section{Van Veen 2007}

W.J.M. van Veen, 'Statutaire verbintenissen, verplichtingen tot uittreden en het ontnemen van aan aandelen verbonden rechten volgens het ontwerp inzake de Flex-BV', WPNR 2007, 6731, p. 950-958.

Van Veen 2008 (1)

W.J.M. van Veen, 'Loyaliteitsdividend en het gelijkheidsbeginsel', $B b$ 2008-3, p. 23-27.

\section{Van Veen 2008 (2)}

W.J.M. van Veen, 'Beslotenheid en certificaathouders van de flexibele BV', $J B N$ 2008-12, p. 3-5.

\section{Van Veen 2009}

W.J.M. van Veen, 'Gewijzigde regeling eisen voor het aandeelhouderschap en bescherming stemrechtloze aandeelhouders in het ontwerp flex-BV', WPNR 2009, 6801, p. 467-473. 


\section{Van Veen 2010}

W.J.M. van Veen, 'Statutaire eisen en -verbintenissen: één pot nat?', Ondernemingsrecht 2010-15, p. 613-617.

\section{Van Veersen 2006}

J.A.C. van Veersen, 'Exhibitieplicht ex art. 3:15j BW; een ondergeschoven kindje', $V \& O$ 2006-1, p. 6-10.

\section{Verburgh 2006}

M. Verburgh, "Verslag van de vergadering van de Vereeniging "Handelsrecht" over "De vereenvoudigde BV"', Ondernemingsrecht 2006-17, p. 617-622.

\section{Verburgt \& Van der Korst 2012}

B. Verburgt \& P. van der Korst, 'Uitkeringen aan aandeelhouders bij de flex-bv', $f t V$ 2012-3, p. 14-20.

\section{Verdam 1995}

A.F. Verdam, Corporate opportunities. Over de toeëigening door functionarissen van aan de vennootschap toebehorende business opportunities (diss. Tilburg), Zwolle: W.E.J. Tjeenk Willink 1995.

\section{Verdam 2013}

A.F. Verdam, 'Het vennootschappelijk belang: méér dan 'enlightened shareholder value', Ondernemingsrecht 2013-3, p. 93-101.

\section{Vermeulen 2006}

E.P.M. Vermeulen, 'De plaats en de inrichting van een nieuw BV-recht in een innovatieve economie', in: De vereenvoudigde BV (Preadvies van de Vereeniging 'Handelsrecht' 2006), Deventer: Kluwer 2006, p. 113-180.

\section{Verslag Expertmeeting}

Verslag van de op 16 december 2005 gehouden Expertmeeting inzake het BV-recht, te raadplegen op http://www.rijksoverheid.nl/onderwerpen/flexibele-bv.

\section{Vletter-van Dort 2001}

H.M. Vletter-van Dort, Gelijke behandeling van beleggers bij informatieverstrekking (diss. Utrecht), Deventer: Kluwer 2001.

\section{Vletter-van Dort 2012}

H.M. Vletter-van Dort, 'Informatierechten van de aandeelhoudersvergadering en de individuele aandeelhouder: een update', in: P.J. van der Korst, R. Abma \& G.T.M.J. Raaijmakers (red.), Handboek onderneming en aandeelhouder, Deventer: Kluwer 2012 , p. 209-245. 


\section{Voogd 1989}

R.P. Voogd, Statutaire beschermingsmiddelen bij beursvennootschappen (diss. Nijmegen), Serie vanwege het Van der Heijden Instituut, deel 32, Deventer: Kluwer 1989.

\section{Voogd 1993}

R.P. Voogd, 'Certificering', in: A.G. Lubbers \& W. Westbroek (red.), Vennootschapsrecht in EG-perspectief (KNB-bundel), Deventer: Kluwer 1993, p. 23-35.

\section{Voûte 1991}

A. Voûte, Aandelen voor werknemers. Motivatie door participatie (diss. Nijmegen), Deventer: Kluwer 1991.

\section{Voûte \& Vletter 2001}

A. Voûte \& W.S. Vletter, 'De juridische fusie en de certificaathouder: lessen uit Ahrend-Samas', Ondernemingsrecht 2001-5, p. 134-136.

\section{Waal 2003}

E.A. Waal, 'Toestemming vereist?', $N b B W$ 2003-10, p. 160-163.

\section{Wachter 1988}

B. Wachter, interventie, in: Harmonisatie van vennootschaps- en effectenrecht, Symposium KUB, Deventer: Kluwer 1998, p. 136-139.

\section{Wijers \& Haasjes 2006}

W.P. Wijers \& A.J. Haasjes, 'Exhibitie in het (ondernemings)recht', $O \& F$ 2006-71, p. $49-62$.

\section{Willemars 2011}

I.D.J. Willemars, 'De flex-BV, groepsverhoudingen en het structuurregime', $T v O B$ 2011-6, p. 134-138.

\section{Winter 1991}

J.W. Winter, Recente rechtspraak, annotatie bij Rb. Zutphen 17 januari 1991 (Uniwest Group BV), WPNR 1991, 6001, p. 246-248.

\section{Winter 2007}

J. Winter, 'Level playing fields forever', in: H. Beckman, H.L. Kaemingk, Ch. Honée (e.a.), De nieuwe macht van de kapitaalverschaffer, Deventer: Kluwer 2007, p. 121-138. 


\section{Wolf $2011(1)$}

R.A. Wolf, 'De 'meerderheid der aandelen' in artikel 1:88 lid 5 BW en het stemrechtloze aandeel in de Flex-BV', TvOB 2011-4, p. 97-102.

\section{Wolf 2011 (2)}

R.A. Wolf, 'Enkele wettelijke bepalingen gezien in het licht van het stemrechtloze aandeel', TvOB 2011-6, p. 139-145.

\section{Wolf 2012}

R.A. Wolf, Reactie op 'Stemrecht- en winstrechtloze aandelen. De implicaties voor art. 1:88 lid 5 Burgerlijk Wetboek' van Van den Munckhof 2011, WPNR 2012, 6920 , p. $186-188$

\section{Wouters 2011}

R.J. Wouters, 'Certificering onder het nieuwe BV-recht: werkt het zo (wel) voor de praktijk?', TOP 2011-6, p. 236-242.

\section{Zaman \& Oostwouder 2001}

D.F.M.M. Zaman \& W.J. Oostwouder, 'Over certificaten mét en aandelen zónder stemrecht', Ondernemingsrecht 2001-15, p. 442-450.

\section{Zaman 2004 (1)}

D.F.M.M. Zaman, 'Vereenvoudiging en flexibilisering van het BV-recht', $T v O B$ 2004-3, p. 115-120.

\section{Zaman 2004 (2)}

D.F.M.M. Zaman, 'Certificering en modernisering van het ondernemingsrecht- en vennootschapsrecht', $T v O B$ 2004-5, p. 215-219.

\section{Zaman 2008}

D.F.M.M. Zaman, 'De Flex-BV', JBN 2008-4, p. 8-12.

Zaman \& Groenland 2009

D.F.M.M. Zaman en I.C.P. Groenland, 'Tussen contract en instituut: waar zweeft de Flex-BV?’, TvOB 2009-6, p. 168-173.

\section{Van Zeben 1969}

C.J. van Zeben, Parlementaire Geschiedenis van het Nieuwe Burgerlijk Wetboek, Invoeringswet Boek 1, Personen- en Familierecht, Deventer: Kluwer 1969. 
Van Zeben \& Du Pon 1977

C.J. van Zeben \& J.W. du Pon, Parlementaire Geschiedenis van het Nieuwe Burgerlijk Wetboek, Invoeringswet Boek 2, Rechtspersonen, Deventer: Kluwer 1977.

\section{Zonnenberg 2009}

L.H.M. Zonnenberg, Het verrekenbeding (diss. Heerlen), Deventer: Kluwer 2009. 


\title{
LIJST VAN GERAADPLEEGDE EN AANGEHAALDE PARLEMENTAIRE EN OVERIGE STUKKEN
}

\author{
A. Parlementaire stukken
}

I

Wet van 18 juni 2012 tot wijziging van Boek 2 van het Burgerlijk Wetboek in verband met de aanpassing van de regeling voor besloten vennootschappen met beperkte aansprakelijkheid (Wet vereenvoudiging en flexibilisering bv-recht). Kamerstukken 31 058. Stb. 2012, 299. Inwerking getreden op 1 oktober 2012.

1. Kamerstukken II 2006/07, 31 058, nr. 1 (Koninklijke boodschap)

2. Kamerstukken II 2006/07, 31 058, nr. 2 (Voorstel van wet)

3. Kamerstukken II 2006/07, 31 058, nr. 3 (Memorie van Toelichting)

4. Kamerstukken II 2006/07, 31 058, nr. 4 (Advies Raad van State en nader rapport)

5. Kamerstukken II 2007/08, 31 058, nr. 5 (Verslag)

6. Kamerstukken II 2008/09, 31 058, nr. 6 (Nota naar aanleiding van het verslag)

7. Kamerstukken II 2008/09, 31 058, nr. 7 (Nota van wijziging)

8. Kamerstukken II 2008/09, 31 058, nr. 8 (Tweede nota van wijziging)

9. Kamerstukken II 2009/10, 31 058, nr. 11 (Verslag van een wetgevingsoverleg)

10. Kamerstukken II 2009/10, 31 058, nr. 16

11. Kamerstukken II 2009/10, 31058 , nr. 17

12. Kamerstukken II 2009/10, 31 058, nr. 20

13. Kamerstukken II 2009/10, 31 058, nr. 21

14. Kamerstukken II 2009/10, 31 058, nr. 22 (Verslag van een wetgevingsoverleg)

15. Kamerstukken II 2009/10, 31058 , nr. 23

16. Kamerstukken II 2009/10, 31 058, nr. 28 (Brief van de Minister van Justitie)

17. Kamerstukken I 2009/10, 31 058, nr. A (Gewijzigd voorstel van wet)

18. Kamerstukken I 2011/12, 31 058, nr. B (Voorlopig verslag)

19. Kamerstukken I 2011/12, 31 058, nr. C (Memorie van antwoord)

20. Kamerstukken I 2011/12, 31 058, nr. D (Nader voorlopig verslag)

21. Kamerstukken I 2011/12, 31 058, nr. E (Nadere memorie van antwoord) 
II

Wet van 18 juni 2012 tot aanpassing van de wetgeving aan en invoering van de Wet vereenvoudiging en flexibilisering bv-recht (Invoeringswet vereenvoudiging en flexibilisering bv-recht). Kamerstukken 32426 (vermeld voor zover relevant voor het onderzoek). Stb. 2012, 300. Inwerking getreden op 1 oktober 2012.

1. Kamerstukken II 2009/10, 32 426, nr. 1 (Koninklijke boodschap)

2. Kamerstukken II 2009/10, 32 426, nr. 2 (Voorstel van wet)

3. Kamerstukken II 2009/10, 32 426, nr. 3 (Memorie van toelichting)

4. Kamerstukken II 2009/10, 32 426, nr. 4 (Nader rapport)

5. Kamerstukken II 2010/11, 32 426, nr. 6 (Verslag)

6. Kamerstukken II 2010/11, 32 426, nr. 7 (Nota naar aanleiding van het verslag)

7. Kamerstukken II 2010/11, 32 426, nr. 8 (Nota van wijziging)

8. Kamerstukken II 2011/12, 32 426, nr. 11 (Amendement)

9. Kamerstukken II 2011/12, 32 426, nr. 13 (Amendement)

10. Kamerstukken II 2011/12, 32 426, nr. 14 (Amendement)

11. Kamerstukken II 2011/12, 32 426, nr. 15 (Amendement)

12. Kamerstukken II 2011/12, 32 426, nr. 16 (Amendement)

13. Kamerstukken II 2011/12, 32 426, nr. 20 (Amendement)

14. Kamerstukken II 2011/12, 32 426, nr. 21 (Amendement)

15. Kamerstukken II 2011/12, 32 426, nr. 22 (Brief van de Minister van Veiligheid en Justitie)

16. Kamerstukken II 2011/12, 32 426, nr. 23 (Tweede nota van wijziging)

17. Kamerstukken II 2011/12, 32 426, nr. 24 (Verslag wetgevingsoverleg)

18. Kamerstukken II 2011/12, 32 426, nr. 25 (Gewijzigd amendement)

19. Kamerstukken II 2011/12, 32 426, nr. 26 (Gewijzigd amendement)

20. Kamerstukken II 2011/12, 32 426, nr. 27 (Gewijzigd amendement)

21. Kamerstukken II 2011/12, 32 426, nr. 28 (Gewijzigd amendement)

22. Kamerstukken I 2011/12, 32 426, nr. A (Gewijzigd voorstel van wet)

23. Kamerstukken I 2011/12, 32 426, nr. B (Voorlopig verslag)

24. Kamerstukken I 2011/12, 32 426, nr. C (Memorie van antwoord)

III

Besluit van 29 juni 2012 tot vaststelling van het tijdstip van inwerkingtreding van de Wet vereenvoudiging en flexibilisering bv-recht en de Invoeringswet vereenvoudiging en flexibilisering bv-recht. Stb. 2012, 301. 
B. Overige stukken

1. Het rapport Vereenvoudiging en flexibilisering van het Nederlandse BV-recht van 6 mei 2004 van de expertgroep in het najaar van 2003 ingesteld door de minister van Justitie en de staatssecretaris van Economische Zaken onder voorzitterschap van prof. mr. H.J. de Kluiver;

2. Verslag van de Expertmeeting inzake het bv-recht d.d. 16 december 2005;

3. Advies d.d. 30 maart 2005 van de Gecombineerde Commissie Vennootschapsrecht van de Nederlandse Orde van Advocaten en de Koninklijke Notariële Beroepsorganisatie 'Eerste tranche ambtelijk voorontwerp Vereenvoudiging en Flexibilisering van het BV-recht, Orgaanstructuur en bevoegdheden, aandelen en certificaten';

4. Advies d.d. 30 september 2005 van de Gecombineerde Commissie Vennootschapsrecht van de Nederlandse Orde van Advocaten en de Koninklijke Notariële Beroepsorganisatie 'Tweede tranche ambtelijk voorontwerp Vereenvoudiging en Flexibilisering van het BV-recht, Beslotenheid en geschillenregeling';

5. Advies d.d. 2 juni 2006 van de Gecombineerde Commissie Vennootschapsrecht van de Nederlandse Orde van Advocaten en de Koninklijke Notariële Beroepsorganisatie 'Derde tranche ambtelijk voorontwerp Vereenvoudiging en Flexibilisering van het BV-recht, Kapitaal en Schuldeisersbescherming';

6. Advies d.d. 23 november 2006 van de Commissie vennootschapsrecht over het wetsvoorstel inzake de vereenvoudiging en flexibilisering van het bv-recht;

7. Advies d.d. 20 september 2007 van de Gecombineerde Commissie Vennootschapsrecht van de Nederlandse Orde van Advocaten en de Koninklijke Notariële Beroepsorganisatie inzake Wetsvoorstel Wijziging van Boek 2 van het Burgerlijk Wetboek in verband met de aanpassing van de regeling voor besloten vennootschappen met beperkte aansprakelijkheid (Wet vereenvoudiging en Flexibilisering BV-recht, Kamerstukken 31 058);

8. Advies d.d. 23 september 2010 van de Gecombineerde Commissie Vennootschapsrecht van de Nederlandse Orde van Advocaten en de Koninklijke Notariële Beroepsorganisatie inzake wetsvoorstel 32 426, aanpassing van de wetgeving aan en invoering van de Wet vereenvoudiging en flexibilisering bvrecht (Invoeringswet vereenvoudiging en flexibilisering bv-recht);

9. stukken uit het dossier de flexibele bv, te raadplegen op http://www.rijksoverheid.nl/onderwerpen/flexibele-bv, waaronder het ambtelijk voorontwerp 'Vereenvoudiging en Flexibilisering van het BV-recht', eerste, tweede en derde tranche met memorie van toelichting en de reacties daarop vanuit de wetenschap en de rechtspraktijk en van andere belanghebbenden. 



\section{RECHTSPRAAK}

(onderverdeeld per instantie in chronologische volgorde)

\section{Hof van Justitie van de Europese Gemeenschappen}

HvJ EG 9 maart 1999, nr. C-212/97, NJ 2000, 48, m.nt. P. Vlas, JOR 1999, 117

(Centros)

HvJ EG 30 september 2003, nr. C-167/01, NJ 2004, 394, JOR 2003, 249

(Inspire Art)

HvJ EG 12 juli 2012, nr. C-378/10, JOR 2012, 285, m.nt. Vossestein (Vale)

\section{Hoge Raad}

HR 13 februari 1942, NJ 1942, 360

HR 21 mei 1943, NJ 1943, 484 (Baus/De Koedoe I)

HR 30 juni 1944, NJ 1944, 465 (Wennex)

HR 31 januari 1947, NJ 1948, 115 (Baus/De Koedoe II)

HR 1 april 1949, NJ 1949, 465, m.nt. Ph.A.N.H. (Doetinchemse IJzergieterij)

HR 9 januari 1953, NJ 1953, 460 (Schuurmans/Amsterdamse Ballast Maatschappij)

HR 21 januari 1955, NJ 1959, 43, m.nt. HB (Forumbank)

HR 27 januari 1956, NJ 1956, 48 (Unipart/RDM)

HR 15 november 1957, NJ 1958, 67, m.nt. Rutten (Baris/Riezenkamp)

HR 23 mei 1958, NJ 1958, 458 (Pierlot/Kreemer)

HR 13 november 1959, NJ 1960, 472 (Distilleerderij Melchers)

HR 19 februari 1960, NJ 1960, 473, m.nt. HB (Aurora)

HR 11 januari 1963, NJ 1964, 433, m.nt. G.J. Scholten (RCMA)

HR 30 oktober 1964, NJ 1965, 107, m.nt. G.J. Scholten (Mante)

HR 15 juli 1968, NJ 1969, 101, m.nt. G.J. Scholten (Wijsmuller)

HR 19 maart 1975, NJ 1976, 267, m.nt. Wachter (Westertoren/HVA)

HR 18 juni 1982, $N J$ 1983, 200, m.nt. Ma (De Vries/Elderveld)

HR 9 januari 1987, NJ 1987, 959, m.nt. Ma (Vecolac/Juliana)

HR 6 februari 1987, NJ 1988, 1, m.nt. W.H. Heemskerk (Slingerland/

Amsterdam)

HR 1 juli 1988, NJ 1989, 226, m.nt. Ma (Drukker)

HR 19 mei 1989, NJ 1989, 652 (Dekker/Lucas)

HR 10 januari 1990, NJ 1990, 466, m.nt. Ma (Ogem II)

HR 9 juli 1990, $N J$ 1991, 51, m.nt. Ma (Sluis)

HR 19 oktober 1990, NJ 1991, 21, m.nt. Ma (Akkoca) 
HR 17 mei 1991, NJ 1991, 645, m.nt. Ma (Lampe/Tonnema)

HR 25 oktober 1991, NJ 1992, 149, m.nt. Ma

HR 19 februari 1993, NJ 1994, 345, m.nt. H.J. Snijders (Van de Ven/Pierik)

HR 31 december 1993, NJ 1994, 436, m.nt. Ma (Verenigde Bootlieden)

HR 2 december 1994, NJ 1995, 288, m.nt. Ma (Poot/ABP)

HR 10 maart 1995, NJ 1995, 595, m.nt. Ma (Janssen Pers)

HR 19 mei 1995, NJ 1996, 119, m.nt. WMK (Keereweer/Sogelease)

HR 20 oktober 1995, NJ 1996, 120, m.nt. Ma (Perrier/Marceau)

HR 31 mei 1996, NJ 1996, 694, m.nt. Ma (Lampe/Videoworks)

HR 20 september 1996, NJ 1997, 149, JOR 1996, 119 (Playland)

HR 14 april 2000, LJN AA5526, NJ 2000, 689, m.nt. WMK en JOR 2000, 113

(Soetelieve/Stienstra)

HR 12 mei 2000, LJN AA 5779, NJ 2000, 439, JOR 2000, 145, m.nt. Blanco

Fernández (Geestelijk Leider)

HR 27 september 2000, LJN AA7245, NJ 2000, 653, JOR 2000, 217, m.nt.

Brink (Gucci)

HR 19 oktober 2001, NJ 2002, 92, m.nt. Ma, JOR 2002, 5, m.nt. Van den Ingh (Skygate)

HR 21 december 2001, LJN AD4499, NJ 2005, 96, m.nt. S.C.J.J. Kortmann, JOR 2002, 38, m.nt. Faber en Bartman (SOBI/Hurks)

HR 1 maart 2002, LJN AD9857, NJ 2002, 296, m.nt. Ma, JOR 2002, 79, m.nt. Van den Ingh (Zwagerman Beheer)

HR 17 januari 2003, LJN AF0168, NJ 2004, 281, m.nt. HJS, JOR 2003, 52, m.nt. M.H.E. Rongen (Oryx/Van Eesteren)

HR 21 februari 2003, LJN AF1797, NJ 2003, 181, JOR 2003, 58, m.nt.

M. Brink (VIBA)

HR 21 februari 2003, LJN AF1486, NJ 2003, 182, m.nt. Ma, JOR 2003, 57, m.nt. M.P. Nieuwe Weme (HBG)

HR 18 april 2003, LJN AF2161, NJ 2003, 286, m.nt. Ma, JOR 2003, 110, m.nt. Blanco Fernández (RNA)

HR 6 juni 2003, LJN AF9440, NJ 2003, 486, m.nt. Ma, JOR 2003, 161, m.nt. Josephus Jitta (Scheipar)

HR 11 juli 2003, LJN AF7513, NJ 2004, 173, m.nt. WMK, JOR 2003, 223, m.nt. Verdaas (Kelders/Fortis)

HR 4 februari 2005, LJN AR8899, NJ 2005, 127, m.nt. Ma, JOR 2005, 58, m.nt. Van den Ingh (Landis)

HR 11 februari 2005, LJN AR6809, NJ 2005, 442 (Frog People Mover/Floriade) HR 20 januari 2006, LJN AU5681, NJ 2006, 79, JOR 2006, 195, m.nt. Verdaas (Fortis/Van der Zee)

HR 29 september 2006, LJN AY5697, NJ 2006, 639, m.nt. Ma, JOR 2007, 62 (The Mill Resort)

HR 10 november 2006, LJN AY4033, NJ 2007, 561 m.nt. H.J. Snijders,

JOR 2007, 5 m.nt. P. Sanders (Groenselect) 
HR 4 mei 2007, LJN AZ7621 (Pelshouderij)

HR 13 juli 2007, LJN BA7972, NJ 2007, 434, m.nt. Ma, JOR 2007, 178, m.nt. Nieuwe Weme (ABN AMRO)

HR 14 december 2007, LJN BB3523, NJ 2008, 105, m.nt. Ma, JOR 2008, 11, m.nt. Doorman (DSM)

HR 20 juni 2008, LJN BC4959, NJ 2009, 21, m.nt. Ma en Snijders, JOR 2008, 206, m.nt. Borrius

HR 21 november 2008, LJN BF3938, NJ 2008, 608 (Udo/Renault Nissan)

HR 22 december 2009, JOR 2010, 40, m.nt. Nowak (Hay Group/Schneider) HR 9 juli 2010, LJN BM0976, NJ 2010, 544, m.nt. Van Schilfgaarde, JOR 2010, 228, m.nt. Van Ginneken (ASMI)

HR 10 september 2010, LJN BM6077, NJ 2010, 665, m.nt. P. van Schilfgaarde en S. Perrick, JOR 2010, 337, m.nt. M. Brink (Butôt)

HR 8 oktober 2010, LJN BN1402, NJ 2011, 30, m.nt. L.C.A. Verstappen, JOR 2010, 367, JIN 2010, 863, m.nt. G.C. Vergouwen en I. Boekhorst HR 8 april 2011, LJN BP4943, NJ 2011, 338, m.nt. P. van Schilfgaarde, JOR 2011, 178, m.nt. A. Doorman

HR 18 november 2011, LJN BQ2860

HR 16 december 2011, LJN BU8233

HR 23 maart 2012, LJN BV1056, NJ 2012, 393, m.nt. P. van Schilfgaarde, JOR 2012, 141, m.nt. M.W. Josephus Jitta en T. Barkhuysen (E-Traction) HR 30 maart 2012, LJN BV1435, NJ 2012, 423, m.nt. P. van Schilfgaarde, JOR 2012, 142, m.nt. Winters (Hermes c.s./ASMI)

\section{Gerechtshof}

Hof Amsterdam (OK) 21 september 1978, NJ 1979, 403, m.nt. Ma Hof 's-Gravenhage 1 oktober 1982, NJ 1983, 393 (Van Rees/Smits) Hof 's-Gravenhage 17 maart 1983, NJ 1984, 81 (Reynders/McKinney) Hof Amsterdam (OK) 26 mei 1983, NJ 1984, 481, m.nt. Ma (Linders/Hofstee) Hof Amsterdam (OK) 22 december 1983, NJ 1985, 383, m.nt. Ma (Ogem) Hof Amsterdam (OK) 26 november 1987, NJ 1989, 271, m.nt. Ma (IKON) Hof Amsterdam 18 mei 1989, NJ 1990, 591

Hof Amsterdam (OK) 16 mei 1991, NJ 1992, 203 (Van Baarsen/Van Vliet) Hof Arnhem 26 mei 1992, NJ 1993, 182, m.nt. Ma (Uniwest) Hof Amsterdam (OK) 22 oktober 1992, NJ 1993, 411 (Van Eyk/Nootebos) Hof Amsterdam (OK) 14 januari 1993, NJ 1993, 460 (VEB/KMZM) Hof Amsterdam (OK) 24 februari 1994, NJ 1995, 354 Hof Amsterdam (OK) 15 september 1994, NJ 1995, 540 (Kerstens) Hof Amsterdam (OK) 27 oktober 1994, NJ 1996, 167 (Muller/Muts) Hof Amsterdam 26 januari 1995, KG 1995, 192 (Kluft Distrifood) Hof Amsterdam 2 november 1995, TVVS 1996, 4, p. 117-119, m.nt. IJsselmuiden, JOR 1996 nulnummer, rekestnr. 377/95, p. 16 e.v. (Van Uden's Scheepvaart- en Agentuurmaatschappij) 
Hof 's-Hertogenbosch 15 mei 1996, JOR 1996, 70 (Philips/VEB)

Hof Amsterdam (OK) 17 april 1997, NJ 1997, 672 (Bobel)

Hof Amsterdam 6 november 1997, JOR 1998, 95, m.nt. C.J. Groffen

Hof Amsterdam (OK) 20 november 1997, NJ 1998, 392 (Hooymans)

Hof Amsterdam (OK) 3 maart 1999, JOR 1999, 87 (Gucci)

Hof Amsterdam (OK) 11 maart 1999, NJ 1999, 351, JOR 1999, 89, m.nt. Brink (Breevast)

Hof Amsterdam (OK) 20 mei 1999, NJ 2000, 199, JOR 2000, 72, m.nt. Blanco

Fernández (Cromwilld/Verstatel)

Hof Amsterdam (OK) 27 mei 1999, NJ 1999, 487, JOR 1999, 121, m.nt.

L.L.M. Prinsen (Gucci)

Hof Amsterdam (OK) 25 februari 2000, JOR 2000, 75, m.nt. Josephus Jitta

(Robot Medical/MCEG)

Hof Amsterdam (OK) 9 maart 2000, JOR 2000, 99 (Te Pas/Willem III)

Hof Amsterdam (OK) 3 november 2000, JOR 2001, 3

Hof Amsterdam (OK) 30 november 2000, JOR 2001, 4, m.nt. Van den Ingh

(Zwagerman)

Hof Amsterdam (OK) 22 december 2000, JOR 2001, 32

Hof Amsterdam (OK) 18 januari 2001, JOR 2001, 34, m.nt. Brink (VIBA)

Hof Amsterdam (OK) 23 januari 2001, JOR 2001, 56

Hof Amsterdam (OK) 21 juni 2001, JOR 2001, 184 (Wildschut/EMO)

Hof Amsterdam (OK) 4 juli 2001, JOR 2001, 149, m.nt. Brink (HBG)

Hof Amsterdam (OK) 23 juli 2001, JOR 2001, 204 (Langen/Flora Beheer)

Hof Amsterdam (OK) 31 augustus 2001, JOR 2001, 208 (De Merwede

Holding)

Hof Amsterdam 13 december 2001, NJ 2004, 145

Hof Amsterdam (OK) 25 april 2002, JOR 2002, 128 (Gorillapark)

Hof Amsterdam (OK) 8 mei 2002, JOR 2002, 112, m.nt. Blanco Fernández

(Broadnet)

Hof Amsterdam (OK) 22 mei 2002, JOR 2002, 188 (Mega Electra Groep

Amsterdam)

Hof Amsterdam (OK) 7 augustus 2002, JOR 2002, 194 (De Hooge Bergsche

Golfclub/De Rotte Bergen)

Hof Arnhem 8 oktober 2002, NJ 2003, 444, JOR 2003, 187, m.nt. A.J. Verdaas

(Ledegang/Roordink Bedrijfswagens)

Hof Amsterdam (OK) 10 april 2003, JOR 2003, 144, m.nt. Bulten (Hoffmann/

Hoffmann)

Hof Amsterdam (OK) 22 september 2003, JOR 2003, 280 (Eendebak/Schiphol

Service)

Hof Amsterdam (OK) 9 januari 2004, NJ 2004, 168, JOR 2004, 72, m.nt.

Brinkx (Laurus)

Hof Amsterdam (OK) 3 februari 2004, JOR 2004, 101 (Headscanning Patent)

Hof Amsterdam (OK) 15 maart 2005, JOR 2005, 88 (Sirvana/EMBA) 
Hof Amsterdam (OK) 3 mei 2006, JOR 2006, 211 (Bonne Route Holding) Hof Amsterdam (OK) 17 januari 2007, LJN AZ6440, JOR 2007, 42, m.nt. Blanco Fernández (Stork)

Hof Amsterdam (OK) 28 februari 2007, JOR 2007, 141, m.nt. E. Schmieman (Dialoc ID Holdings)

Hof Amsterdam (OK) 28 maart 2007, JOR 2007, 118, m.nt. Brink (DSM) Hof Amsterdam (OK) 21 juni 2007, JOR 2007, 182 (Kalter/The Greenery) Hof Amsterdam (OK) 27 juni 2007, JOR 2007, 268, m.nt. Van der Korst (Meefout/Meepo)

Hof Amsterdam (OK) 17 december 2007, JOR 2008, 35 (De Bruin/De Hasker) Hof Amsterdam (OK) 10 januari 2008, JOR 2008, 39, m.nt. Brink (PCM I) Hof Amsterdam (OK) 7 mei 2008, JOR 2008, 195

Hof 's-Gravenhage 22 mei 2008, LJN BD2349, JOR 2008, 223

(Verhoeff c.s./KPNQwest)

Hof Amsterdam (OK) 10 december 2008, JOR 2009, 38 (AHAM)

Hof Amsterdam (OK) 17 februari 2009, JOR 2009, 129, m.nt. G. van Solinge (Butôt)

Hof Amsterdam (OK) 27 mei 2010, LJN BM5928, JOR 2010, 189, m.nt. T.M. Stevens (PCM II)

Hof Amsterdam (OK) 29 juni 2010, ARO 2010, 104 (Poststate Beheer) Hof 's-Hertogenbosch 11 januari 2011, LJN BP1015, JOR 2012, 191 Hof Amsterdam (OK) 30 maart 2011, LJN BQ1776, JOR 2011, 217 (Lenda/Muntal)

Hof Amsterdam (OK) 6 juni 2011, LJN BQ9757, JOR 2011, 282, m.nt. Blanco Fernández (Jeezet/Synpact)

Hof Amsterdam 15 november 2011, JOR 2012, 6, m.nt. Vroom (VEB/KLM-Air France)

Hof Amsterdam (OK) 20 februari 2012, LJN BV7334 (Mojo Works/ Mojo Theater)

Hof Amsterdam (OK) 5 april 2012, LJN BW4144, ARO 2012, 55 (Zadeko)

\section{Rechtbank}

Rb. Arnhem 12 november 1942, NJ 1943, 846

Rb. Breda 17 november 1942, NJ 1943, 463 (Astarte)

Rb. Roermond 17 mei 1973, NJ 1974, 57

Pres. Rb. 's-Gravenhage 9 oktober 1987, KG 1987, 454 (Nevesbu)

Rb. Leeuwarden 12 november 1987, NJ 1988, 699 (Dirkse/Interpolacel)

Pres. Rb. Leeuwarden 3 februari 1988, $K G$ 1988, 200

Pres. Rb. Amsterdam 15 juni 1988, KG 1988, 276

Pres. Rb. Utrecht 16 februari 1989, $K G$ 1989, 156

Pres. Rb. Haarlem 8 mei 1990, KG 1990, 247

Pres. Rb. Assen 17 december 1993, KG 1994, 90

Pres. Rb. Groningen 11 september 1996, KG 1996, 326 
Rb. Utrecht 18 september 1996, JOR 1996, 116

Pres. Rb. Middelburg 14 april 1998, JOR 2000, 25

Rb. Utrecht 29 juli 1998, JOR 1999, 58

Pres. Rb. Amsterdam 11 juni 1999, JOR 1999, 174, m.nt. Van Solinge

(Leyinvest/KBBVendex)

Pres. Rb. Amsterdam 27 juli 1999, JOR 1999, 178, m.nt. Nieuwe Weme

(VEB/Otra)

Rb. Rotterdam 25 november 1999, JOR 2000, 51

Pres. Rb. Roermond 27 januari 2000, JOR 2000, 73, m.nt. C.J. Groffen, KG 2000, 52

Rb. Utrecht 15 maart 2000, JOR 2000, 233 m.nt. Van den Ingh (Unirobe/

Geense Beheer)

Pres. Rb. Amsterdam 22 mei 2000, JOR 2000, 129 (World Online)

Rb. Amsterdam 28 maart 2001, JOR 2001, 110 (Hoffmann/Hoffmann)

Pres. Rb. Amsterdam 20 december 2001, JOR 2002, 26 (Gorillapark)

Rb. Amsterdam 6 februari 2002, JOR 2002, 61 (Vendex KBB)

Vzr. Rb. 's-Gravenhage 7 augustus 2002, JOR 2002, 173, m.nt. Van den Ingh (Wittke/NEM)

Rb. 's-Gravenhage 26 februari 2003, JOR 2003, 188, m.nt. A.J. Verdaas

Rb. Rotterdam 26 maart 2003, JOR 2003, 189, m.nt. A.J. Verdaas

Rb. Utrecht 2 april 2003, LJN AF6970, NJ 2003, 353, JOR 2003, 190, m.nt.

A.J. Verdaas

Rb. Amsterdam 16 april 2003, JOR 2003, 191, m.nt. A.J. Verdaas

Rb. Breda 4 november 2003, JOR 2004, 97, m.nt. Brink

$\mathrm{Rb}$. Zwolle 23 juni 2004, LJN AP4551

Rb. Almelo 21 februari 2007, JOR 2007, 130, m.nt. A. Steneker

Vzr. Rb. Leeuwarden 15 april 2009, LJN BI3631, JOR 2009, 187, m.nt.

T.S. Jansen

Rb. Amsterdam 25 augustus 2010, LJN BN4965, JOR 2010, 301, m.nt.

Nowak (CFS)

$\mathrm{Rb}$. Leeuwarden 25 augustus 2010, $L J N$ BN5188

Rb. Amsterdam 1 september 2010, LJN BN5569, JOR 2010, 303, m.nt.

Kuster (VEB/KLM-Air France)

Rb. Dordrecht 8 december 2010, LJN BO7043, JOR 2011, 64, m.nt.

A.J. Verdaas

Rb. 's-Hertogenbosch 18 januari 2012, LJN BV2015, JOR 2012, 367

Rb. Rotterdam 28 maart 2012, LJN BW0672 
XII

OVER DE PROMOVENDUS

Rogier Anton Wolf is op 2 augustus 1973 te Alphen aan den Rijn geboren.

Van 1985 tot en met 1991 heeft hij Voorbereidend Wetenschappelijk Onderwijs (VWO) gevolgd aan het Rijnlands Lyceum te Oegstgeest. Van 1991 tot en met 1997 studeerde hij Nederlands recht aan de Faculteit der Rechtsgeleerdheid van de Universiteit Leiden, alwaar hij in 1997 in de civielrechtelijke afstudeerrichting is afgestudeerd. Bovendien heeft hij tijdens zijn studie een aantal ondernemingsrechtelijke keuzevakken, deels aan de Libera Università Internazionale degli Studi Sociali (LUISS Guido Carli) te Rome (Italië), behaald. In 2008 rondde hij cum laude de post academische specialisatieopleiding Bedrijfsoverdracht in het $M K B$ van de Grotius Academie af.

Rogier Wolf is sinds 1999 advocaat. Hij heeft een ondernemingsrechtelijke praktijk en is thans als partner verbonden aan TeekensKarstens advocaten notarissen (www.tk.nl).

Rogier Wolf heeft zijn onderzoek, waarvan dit proefschrift de resultante is, in samenwerking met het Institute for Corporate Law, Governance and Innovation Policies (ICGI) van de Faculteit der Rechtsgeleerdheid van de Universiteit Maastricht verricht (www.maastrichtuniversity.nl/icgi). 

Serie vanwege het Van der Heijden Instituut te Nijmegen onder redactie van prof. mr. G. van Solinge, prof. mr. M. van Olffen, prof. mr. M.P. Nieuwe Weme en prof. mr. C.D.J. Bulten.

1. Mr. W.J.M. Noldus, Ongeldigheid van besluiten in de naamloze vennootschap (1969)

2. Mr. P.A.L.M. van der Velden, De vereniging-rechtspersoon en haar leden (1969)

3. Mr. P.R. Smits, De externe gebondenheid van het vennootschapsvermogen (1969)

4. Mr. J.A.Th.J.M. Duynstee, Beschouwingen over de stichting naar Nederlands privaatrecht (1970)

5. Mr. J.H.F.J. Cremers, Prioriteitsaandelen (1971)

6. Mr. M.M. Mendel, Het statutaire doel van de naamloze vennootschap (1971)

7. Prof. mr. W.C.L. van der Grinten, mr. W. Westbroek, prof. mr. J.M.M. Maeijer en prof. mr. P. Sanders, Het nieuwe vennootschapsrecht (1972)

8. Mr. A.M. Brenninkmeijer, Stemovereenkomsten van aandeelhouders (1973)

9. Prof. mr. W.C.L. van der Grinten, prof. mr. J.M.M. Maeijer, mr. S.J.H. Huijben en mr. A.G. Lubbers, De nieuwe structuur van de grote NV en BV (1973)

10. Prof. mr. C.Æ. Uniken Venema, Misbruik van voorwetenschap (1974)

11. Mr. A. Plate, Niet volgestorte aandelen (1974)

12. Mr. P.W.H.M. Francissen en mr. J.M. Jansen, Statuten van de grote NV en BV (1975)

13. Prof. mr. J.M.M. Maeijer, prof. dr. W. Albeda, prof. mr. W.C.L. van der Grinten en prof. drs. H.W. Lambers, Problemen bij fusie van NV en BV (1975)

14. Mr. M.J.G.C. Raaijmakers, Joint ventures (1976)

15. Mr. P.W.H.M. Francissen en mr. P.F.M. van Lierop, De ondernemingsraad (1977)

16. Prof. mr. J.M.M. Maeijer en prof. mr. J. Ronse, De vertegenwoordiging van rechtspersonen naar Nederlands en Belgisch recht (1978)

17. Mr. T.J. van der Ploeg, Het Burgerlijk Recht en de vrijwillige organisaties. Beschouwingen n.a.v. de regeling van de vereniging en de stichting in Boek 2 BW (1978)

18. Prof. mr. J.M.M. Maeijer, mr. W. Westbroek, prof. mr. W.C.L. van der Grinten en mr. Y. Scholten, Het vennootschapsrecht en de Tweede EEG-Richtlijn (1979)

19. Mr. H.J.M.N. Honée, De benoeming van commissarissen bij grote vennootschappen (1979)

20. Prof. drs. J.W. Schoonderbeek, prof. dr. W. van Bruinessen, prof. mr. J.M.M. Maeijer, prof. mr. W.C.L. van der Grinten, mr. W.J.M. Gitmans, De jaarrekening en de Vierde EEG-Richtlijn (1981) 
21. Mr. H.J.M.N. Honée, Concernrecht en medezeggenschapsregelingen (1981)

22. Prof. mr. J.M.M. Maeijer, prof. mr. W.C.L. van der Grinten, prof. mr. H.J.M. N. Honée, mr. A.G. van Solinge, mr. G.M.J. Ackermans, Ondernemingsraad en Vennootschap (1982)

23. Mr. dr. P. Vlas, Rechtspersonen in het internationaal privaatrecht (1982)

24. Mr. F.K. Buijn, De oprichting van de NV en de BV (1984)

25. Prof. dr. M. Lutter, mr. W. Westbroek, prof. mr. H.J.M.N. Honée, prof. mr. J. M.M. Maeijer, mr. G.M.J. Ackermans, De besloten vennootschap (1985)

26. Prof. mr. H.J.M.N. Honée, Contacten tussen commissarissen en ondernemingsraad (1986)

27. Mr. C.A. Schwarz, Blokkering van aandelen (1986)

28. Mr. J. Lievens, prof. mr. H.J.M.N. Honée, prof. mr. W.C.L. van der Grinten, prof. mr. J.M.M. Maeijer, prof. mr. P. van Schilfgaarde, mr. drs. H. Langman, mr. J. Bloemarts, mr. G. Noordraven, mw. mr. M.J. Zeldenrust-Visch, Financiële kruisverbanden en andere aspecten van concernfinanciering (1987)

29. Mr. Th.C.M. Hendriks-Jansen, Vermogensbescherming en persoonlijke aansprakelijkheid bij de besloten vennootschap (1988)

30. Misbruik van voorwetenschap. Uitgave op initiatief van Actioma, Juridisch Faculteitsblad Katholieke Universiteit Nijmegen, ter gelegenheid van zijn 10-jarig bestaan (1989)

31. Mr. P.J. Dortmond, Enige beschouwingen rondom aandelen (1989)

32. Mr. R.P. Voogd, Statutaire beschermingsmiddelen bij beursvennootschappen (1989)

33. Mr. M.P. van Achterberg, De juridische definitie van het economische verschijnsel concern (1989)

34. Dr. K. Geens, prof. mr. W.C.L. van der Grinten, mr. R.P. Voogd, mr. A.G. van Solinge, mr. H.J.M.N. Honée, prof. mr. P.J. Dortmond, prof. mr. J.H.V. Stuyck, mr. J.A.W. Schreurs, Beschermingsconstructies (1990)

35. Mr. F.J.P. van den Ingh, Certificering en certificaat van aandeel bij de besloten vennootschap (1991)

36. Mr. G. Noordraven, De regeling van de Überschuldung (1991)

37. Prof. mr. J.M.M. Maeijer, prof. mr. drs. H. Beckman, prof. mr. S.C.J.J. Kortmann, mr. F.H.A. Arisz, mr. M.E. Engelaar, Aansprakelijkheid en draagplicht van bestuurders, commissarissen en accountants; verzekeringsaspecten (1991)

38. Mr. A. Voûte, Aandelen voor werknemers (1991)

39. Mr. H.J.M.N. Honée, prof. mr. P.J. Dortmond, mr. H.J. de Bijll Nachenius, dr. H.O.C.R. Ruding, mr. M.W. den Boogert, mr. C.W.A. Timmermans, prof. mr. H.M.N. Schonis, mw. mr. M.E. Engelaar, mr. J.A.W. Schreurs, Grensoverschrijdende samenwerking van ondernemingen (1992)

40. Mr. D.R. Doorenbos, Financieel strafrecht (1992)

41. Mr. B.C.M. Waaijer, Statuten en statutenwijziging (1993) 
42. Mr. L.G.H.J. Houwen, mr. drs. A.P. Schoonbrood-Wessels, mr. J.A.W. Schreurs, Aansprakelijkheid in concernverhoudingen (1993)

43. Mr. F.J.P. van den Ingh, prof. mr. S.C.J.J. Kortmann, drs. M.J.M. Buiting, mr. N.E.D. Faber, mr. R.W.Th. Norbruis, mr. J.W. van der Staay, Converteerbare obligaties en aandelen (1993)

44. Mr. Gerard van Solinge, Grensoverschrijdende juridische fusie (1994)

45. Mr. R.J.C. van Helden, mr. O.L.O. de Witt Wijnen, mr. A.G. van Solinge, prof. mr. P.J. Dortmond, prof. mr. J.M.M. Maeijer, mr. H.J.M.N. Honée, mr. E. Boswinkel, mw. mr. J. Roest, Problemen rondom de algemene vergadering (1994)

46. Mr. M.E. Schreurs-Engelaar, Organen van de coöperatie (1995)

47. Prof. mr. J.M.M. Maeijer, prof. mr. H.M.N. Schonis, prof. dr. A.H.M. Daniels, prof. dr. P.H.J. Essers, Fiscale en civielrechtelijke aspecten van de commanditaire vennootschap (1996)

48. Mr. J. Roest, Medezeggenschap van werknemers bij financieel-economische besluiten (1996)

49. Mr. J.J.A. Hamers, Verpanding van aandelen en de beslotenheid van kapitaalvennootschappen (1996)

50. Prof. mr. J.R. Schaafsma, prof. mr. S. Perrick, mr. D.H. Cross, prof. mr. L. Timmerman, mr. F.G.B. Graaf, prof. mr. J.M.M. Maeijer, mr. H.M.L. Dings, mw. mr. J. Roest, Ontwikkelingen in het effectenverkeersrecht (1996)

51. Preadvies voor de Vereniging voor Effectenrecht 1994, Civielrechtelijke gevolgen van handelen in strijd met effectenregelgeving, prof. mr. W.C.L. van der Grinten, prof. mr. S.C.J.J. Kortmann, prof. mr. S. Perrick (1996)

52. Mr. drs. C.M. Grundmann-van de Krol, mr. F.J.P. van den Ingh, Parlementaire Geschiedenis van de Wet toezicht effectenverkeer 1995 (1996)

53. Mr. M.A. Blom, Prospectusaansprakelijkheid van de lead manager (1996)

54. Mr. J.W. Bellingwout, Zetelverplaatsing van rechtspersonen (1996)

55. Preadvies voor de Vereniging voor Effectenrecht 1996, Bewaring en eigendom van effecten, mr. W.A.K. Rank, mr. E.M. van Ardenne-Stachiw, mr. Ch. W. le Rûtte (1997)

56. Mr. Y.L.L.A.M. Delfos-Roy, Informatieverstrekking en informatievergaring in het kader van de toezichthoudende en raadgevende taak van de Raad van Commissarissen (1997)

57. Maeijers belangstellingen. Prof. mr. F.J.P. van den Ingh, prof. mr. C.A. Schwarz, prof. mr. H.J.M.N. Honée, prof. mr. P. van Schilfgaarde, prof. mr. M.M. Mendel, prof. mr. M.J.G.C. Raaijmakers, prof. mr. T.J. van der Ploeg, prof. mr. A.L. Mohr, prof. dr. W. van Gerven, prof. dr. K. Geens, prof. mr. J. M.M. Maeijer (1997)

58. Lustrumbundel Vereniging voor Effectenrecht 1997, De opkomst van een rechtsgebied, mr. R.I.V.F. Bertrams, mr. S.A. Boele, mr. D.H. Cross, prof. mr. S.E. Eisma, mr. C.M. Grundmann-van de Krol, mr. W. de Jong, mr. A.F.J.A. Leijten, mr. A. Nederveen, prof. mr. M.J.G.C. Raaijmakers, prof. mr. W.A.K. 
Rank, mr. V.P.G. de Serière, prof. mr. W.J. Slagter, prof. mr. L. Timmerman, mr. L.J.K. Vincent (1997)

59. Prof. mr. F.J.P. van den Ingh, prof. mr. G. van Solinge, prof. mr. J.M.M. Maeijer, Drie Nijmeegse redes, Beschouwingen over financiering, enquêterecht en privatisering (1998)

60. Mr. H.M.L. Dings, De commissie van aandeelhouders bij structuurvennootschappen (1998)

61. Preadviezen voor de Vereniging voor Effectenrecht 1999, Aspecten van toezicht, Beschouwingen over het toezicht op de financiële sector, mr. H.G. van Everdingen, mr. drs. C.M. Grundmann-van de Krol, mr. H.J. Sachse (1999)

62. Conflicten rondom de rechtspersoon, mr. A.F.J.A. Leijten, prof. mr. L. Timmerman, mr. J.H.M. Willems, mr. R.A.A. Duk, prof. mr. G. van Solinge, prof. mr. P.J. Dortmond, mr. O.L.O. de Witt Wijnen (2000)

63. Preadviezen voor de Vereniging voor Effectenrecht 2000, Beleggingsinstellingen nader belicht, mr. drs. N.V. Ponsen, mr. P. Klemann (2000)

64. Prof. mr. M. van Olffen, Beschermingsmaatregelen in de 21e eeuw (2000)

65. Voorkennis, toezicht en boetes in nieuwe financiële wetgeving, mr. D.R. Doorenbos, prof. mr. N.S.J. Koeman, mr. A.W.H. Docters van Leeuwen, mr. A.J. Macro, mr. H.J. Sachse, drs. ing. C. Maas, mr. D.J.R. Lemstra (2000)

66. Preadviezen voor de Vereniging voor Effectenrecht 2001, Effectenverkeer via internet. Een tussenstand vanuit effectenrechtelijk perspectief, drs. E.F. Feitsma, mr. V.N.G. van Leeuwen, mr. L.A.G. Moelker, mr. W. de Jong (2001)

67. Verspreide Geschriften van E.J.J. van der Heijden. Verzameld door C.J.H. Jansen en G. van Solinge (2001)

68. Geschriften vanwege de Vereniging Corporate Litigation 2001-2002, onder redactie van prof. mr. G. van Solinge en mr. M. Holtzer (2002)

69. Concernverhoudingen, prof. mr. L. Timmerman. prof. mr. F.J.P. van den Ingh, mr. S.M. Bartman, mr. L.G. Verburg, mr. M.L. Lennarts, prof. mr. M.J.A. van Mourik, mr. D.R. Doorenbos, prof. mr. M. van Olffen (2002)

70. Preadvies voor de Vereniging voor Effectenrecht 2002, De afwikkeling van grensoverschrijdende effectentransacties, mr. B.M. van Beek en mr. D. van Bruggen (2002)

71. Lustrumbundel Vereniging voor Effectenrecht 2002, Een bewezen bestaansrecht (2002)

72. Geschriften vanwege de Vereniging Corporate Litigation 2002-2003, onder redactie van prof. mr. G. van Solinge en mr. M. Holtzer (2003)

73. Mr. M.S. Koppert-van Beek, Handelen namens een op te richten vennootschap (2003)

74. Personenvennootschappen, prof. mr. G. van Solinge, prof. mr. P.J. Dortmond, prof. mr. J.M.M. Maeijer, mr. J.A.M. ten Berg, prof. mr. M. van Olffen, prof. mr. M.J.A. van Mourik, prof. mr. A.L. Mohr en prof. mr. H.M.N. Schonis (2003) 
75. Geschriften vanwege de Vereniging Corporate Litigation 2003-2004, onder redactie van prof. mr. G. van Solinge en mr. M. Holtzer (2004)

76. De werknemer in het ondernemingsrecht, prof. mr. L. Timmerman, prof. mr. G. van Solinge, mr. P.A.M. Witteveen, prof. mr. L.C.J. Sprengers, mr. G.N.H. Kemperink, mr. D.C. Buijs, mr. R.M. Beltzer, mr. F.B.J. Grapperhaus, prof. mr. I.P. Asscher-Vonk, mr. R.A.A. Duk (2004)

77. Verspreide Geschriften van W.C.L. van der Grinten. Verzameld en ingeleid door C.J.H. Jansen, S.C.J.J. Kortmann en G. van Solinge (2004)

78. Mr. J.M. Blanco Fernández, mr. M. Holtzer, prof. mr. G. van Solinge, Richtlijnen voor de onderzoeker in enquêteprocedures (2004)

79. Mr. J.J. Prinsen, Converteerbare obligaties (2004)

80. Mr. M.P. Nieuwe Weme, Het verplicht bod op effecten (2004)

81. Preadvies voor de Vereniging voor Effectenrecht 2004. Voorstel van Wet op het financieel toezicht, mr. J.M. van Dijk en mr. H.V. Oppelaar (2004)

82. Geschriften vanwege de Vereniging Corporate Litigation 2004-2005, onder redactie van prof. mr. G. van Solinge, mr. M. Holtzer en mr. A.F.J.A. Leijten (2005)

83. Mr. G.J.C. Rensen, Extra-verplichtingen van leden en aandeelhouders (2005)

84. Mr. E.C. Bos, Vruchtgebruik op aandelen (2005)

85. Prof. mr. F.J.P. van den Ingh, mr. R.G.J. Nowak, Vereenvoudiging en flexibilisering BV-recht, deel I. De pre-parlementaire geschiedenis (2006)

86. Mr. R.G.J. Nowak, A.M. Mennens, Vereenvoudiging en flexibilisering BV-recht, deel II. De parlementaire geschiedenis (2012)

87. Geschriften vanwege de Vereniging Corporate Litigation 2005-2006, onder redactie van mr. M. Holtzer, mr. A.F.J.A. Leijten en mr. D.J. Oranje (2006)

88. De financiering van de onderneming, prof. $\mathrm{mr}$. G. van Solinge, prof. mr. H. Beckman, prof. mr. F.J.P. van den Ingh, prof. mr. H.J. de Kluiver, mr. R.J. Abendroth, prof. mr. H.M.N. Schonis, prof. mr. M. van Olffen, mr. V.P.G. de Serière, prof. dr. R.J.M. Dassen RA (2006)

89. Mr. H. ten Voorde, Deponering, publicatie en verzet (2006)

90. Preadvies voor de Vereniging voor Effectenrecht 2006, De geïnformeerde consument, mr. F.M.A. 't Hart en prof. mr. C.E. Du Perron (2006)

91. Mr. drs. B.J. de Jong, prof. mr. drs. M.P. Nieuwe Weme, Publicatie van de jaarrekening (2006)

92. Mr. P.J. van der Korst, Bedrijfsgeheimen en transparantieplichten (2007)

93. Geschriften vanwege de Vereniging Corporate Litigation 2006-2007, onder redactie van mr. M. Holtzer, mr. A.F.J.A. Leijten en mr. D.J. Oranje (2007)

94. Mr. J.M. Blanco Fernández, prof. mr. M. van Olffen, Rechtsvorm en gebruik van LLP's en LLC's (2007)

95. Lustrumbundel Vereniging voor Effectenrecht 2007, Bouwen en bezinning (2007)

96. Mr. P.J. van der Korst, prof. mr. M.P. Nieuwe Weme, prof. mr. G. van Solinge, Delegatie van emissiebevoegdheid (2008) 
97. Geschriften vanwege de Vereniging Corporate Litigation 2007-2008, onder redactie van mr. M. Holtzer, mr. A.F.J.A. Leijten en mr. D.J. Oranje (2008)

98. Flexibele rechtsvormen, prof. mr. J.M.M. Maeijer, prof. mr. H.J. De Kluiver, prof. mr. D.F.M.M. Zaman, mr. J.M. Blanco Fernández, prof. mr. P.J. Dortmond, prof. mr. A.L. Mohr, mr. J.H.M. Willems, prof. mr. M. van Olffen (2008)

99. Geschriften vanwege de Vereniging Corporate Litigation 2008-2009, onder redactie van mr. M. Holtzer, mr. A.F.J.A. Leijten en mr. D.J. Oranje (2009)

100. Verspreide geschriften van J.M.M. Maeijer. Verzameld en ingeleid door C.D.J. Bulten, C.J.H. Jansen en G. van Solinge (2009)

101. Preadvies voor de Vereniging voor Effectenrecht 2009, Financieel toezicht in bestuursrecht en privaatrecht, A.H. Scheltema en M. Scheltema (2009)

102. Willems' wegen, Opstellen aangeboden aan prof. mr. J.H.M. Willems ter gelegenheid van zijn terugtreden als voorzitter van de Ondernemingskamer van het Gerechtshof te Amsterdam, onder redactie van mr. K.M. van Hassel en prof. mr. M.P. Nieuwe Weme (2010)

103. B.J. de Jong, Schade door misleiding op de effectenmarkt (2010)

104. Geschriften vanwege de Vereniging Corporate Litigation 2009-2010, onder redactie van mr. M. Holtzer, mr. A.F.J.A. Leijten en mr. D.J. Oranje (2010)

105. Geschillen in de vennootschap, prof. mr. G. van Solinge, prof. mr. H.J. de Kluiver, mr. M.W. Josephus Jitta, mr. P.D. Olden, prof. mr. S.C.J.J. Kortmann, prof. mr. C.J.M. Klaassen, prof. mr. M.J. Kroeze, prof. mr. M.W. den Boogert, mr. drs. A.R.J. Croiset van Uchelen, mr. P.N. Wakkie, prof. mr. J.H.M. Willems (2010)

106. Preadvies voor de Vereniging voor Effectenrecht 2010, Oneerlijke handelspraktijken en handhaving van consumentenbescherming in de financiële sector, mr. C.W.M. Lieverse, prof. mr. J.G.J. Rinkes (2010)

107. G.T.J. Hoff, Openbaarmaking van koersgevoelige informatie (2011)

108. C.D.J. Bulten, De geschillenregeling ten gronde (2011)

109. H.J.M.M. van Boxel, Grensoverschrijdende fusies van kapitaalvennootschappen naar Nederlands recht (2011)

110. Geschriften vanwege de Vereniging Corporate Litigation 2010-2011, onder redactie van mr. M. Holtzer, mr. A.F.J.A. Leijten en mr. D.J. Oranje (2011)

111. Preadvies voor de Vereniging voor Effectenrecht 2011, Regulering van de otcderivatenmarkten in de EU en de VS, mr. F.G.B. Graaf en mr. R.A. Stegeman (2011)

112. Geschriften vanwege de Vereniging Corporate Litigation 2011-2012, onder redactie van mr. M. Holtzer, mr. A.F.J.A. Leijten en mr. D.J. Oranje (2012)

113. Lustrumbundel Vereniging voor effectenrecht 2012, Gedurfde essays over financieel toezichtrecht (2012) 
114. Relativering van rechtspersoonlijkheid, prof. mr. G. van Solinge, prof. mr. C.D.J. Bulten, prof. mr. M.J. Kroeze, mr. D.A.M.H.W. Strik, prof. mr. S.C.J.J. Kortmann, prof. mr. M. van Olffen, prof. mr. H-J de Kluiver, mr. D.F. Lunsingh Scheurleer, mr. J.H. Lemstra (2012)

115. Geschriften vanwege de Vereniging Corporate Litigation 2012-2013, onder redactie van mr. M. Holtzer, mr. A.F.J.A. Leijten en mr. D.J. Oranje (2013)

116. R.A. Wolf, De kapitaalverschaffer zonder stemrecht in de BV (2013) 
